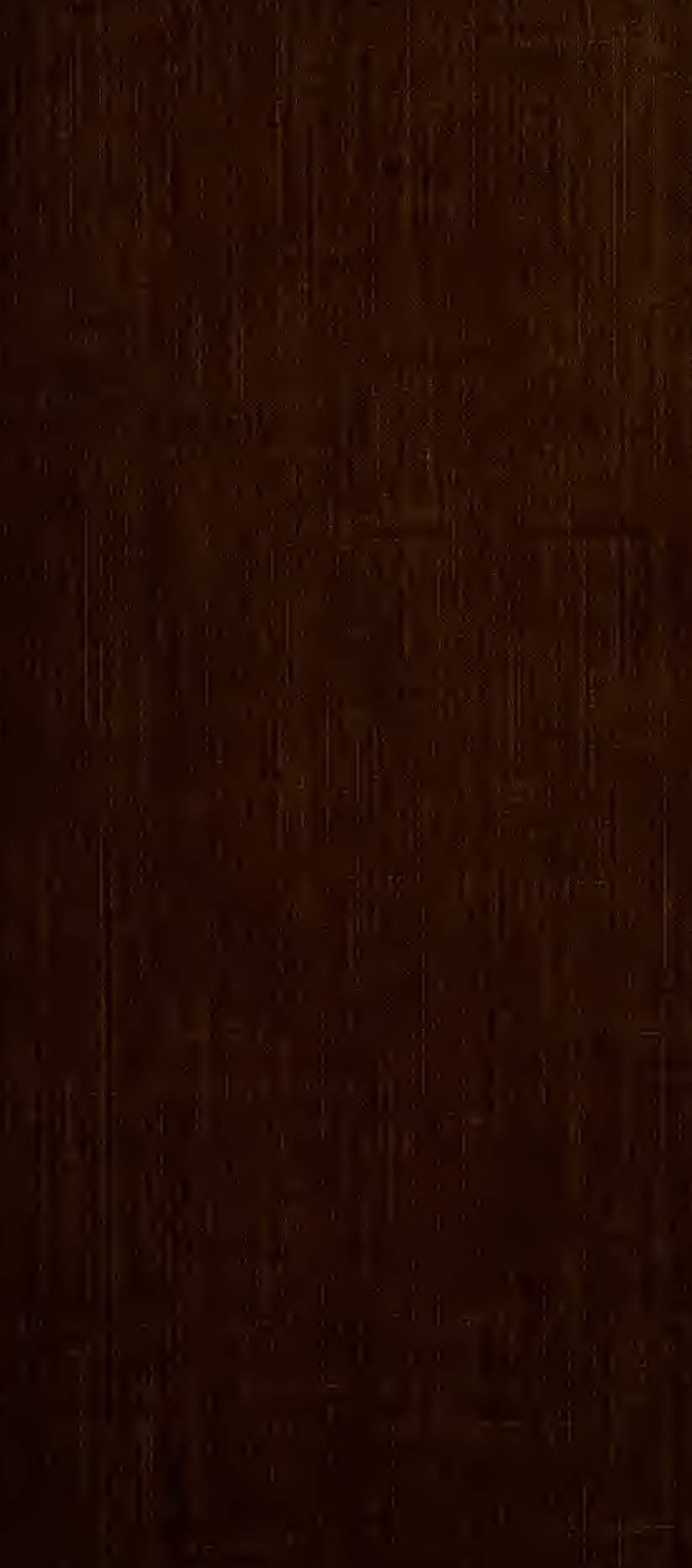




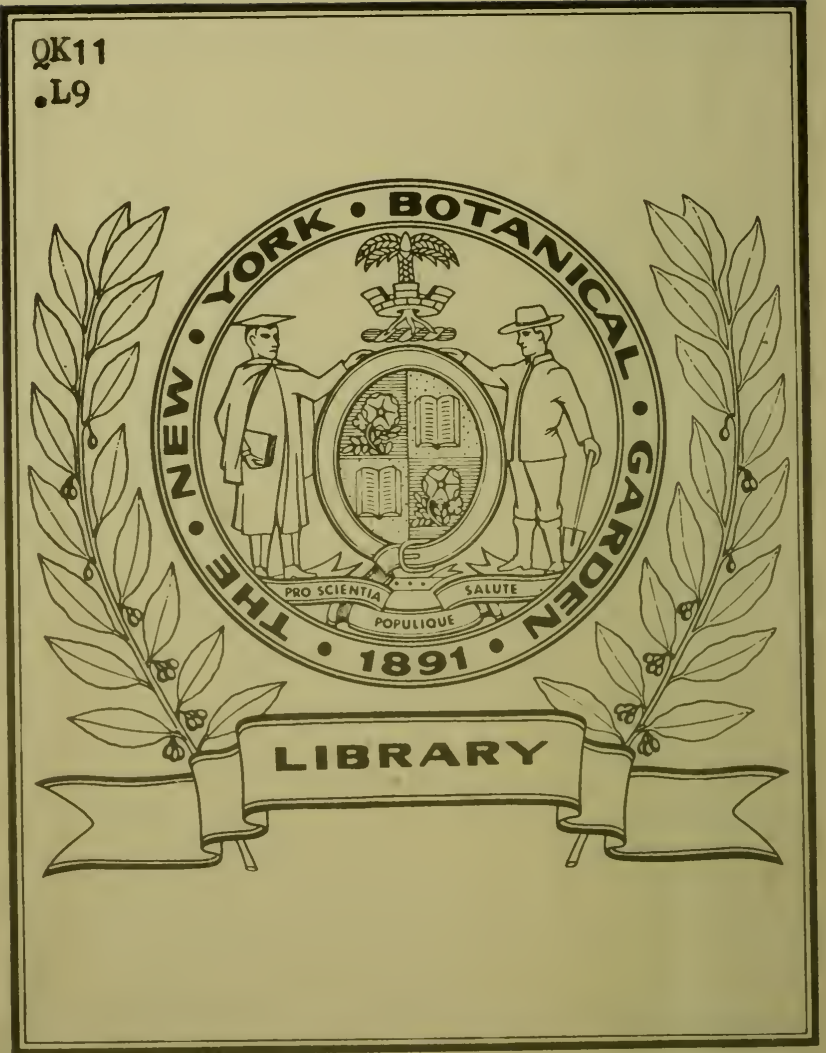






\title{
PLANT NAMES
}

\section{WITH A VIEW TO A}

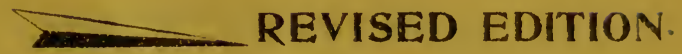

\section{$* 2 * * *$}

The Author of "Plant Names and Synonyms" requests that any one who finds omitted from the list of popular synonyms any name in actual use in any part of the United States, shall communicate such omission to him at once, at the address below. Do not delay because it is only a single name, or beeause the name is misapplied. If possible state in what region the name is known to be in use. Any other corrections that should be made in names or in statements of fact will be gratefully received.

\section{A. B. LYONS.}

\author{
Laboratory of \\ NELSON, BAKER \& CO., \\ DETROIT, MICH.
}





\section{PLANT NAMES}

\section{SCIENTIFIC AND POPULAR}

INCLUDING IN THE CASE OF EACH PLANT

$\longrightarrow$ THE-

\section{CORRECT BOTANICAL NAME}

IN ACCORDANCE WITH THE REFORMED NOMENCLATURE,

TOGETHER WITH BOTANICAL AND

\section{POPULAR SYNONYMS}

AND VERNACULAR GERMAN, FREYCH AND SPANISH NAMES. THE LIST COMPRISES ALL IMPORTANT MEDICINAL PLANTS WITH THEIR PHARMACOPOEIAL NAMES, THE PRINCIPAL FOOD PLANTS OF THE WORLD AND ALL OTHERS OF ANY ECOYOMIC IMYORTANCE, GIVING ESPECIAL PROMINENCE TO TIIOSE: WHICH ARE IXDIGEYOCS IX TIIE UNITED STATES.

COMPILED FROM THE MOST AUTHENTIC SOURCES $-\mathrm{BY}-$

A. B. LYONS, M. D.

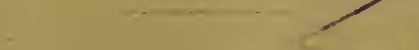

SEN YORK

DETIRIT.

NELSON, BAKER \& ('O., P'UBLIN)

1900. 


\section{$Q K 11$ \\ . L9}

Entered according to act of Congress in the year 1900 By A. B. Lyors, M. D.

In the Office of the Librarian of Congress at Washington, D. C. 


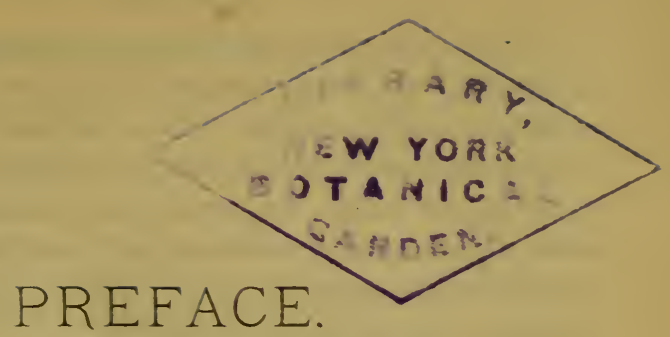

Plant smonom Every plant is supposed to have a "correct" botanical name, and can have only one such. As a matter of fact there are few plants that have not been orer and orer rechristened by scientific botanists, each one maintaining that his is its only really "correct" designation. Out of the endless confusion there is at last emerging order and uniformity.

At the Botanical Congress held at Paris in 1867 the principle was definitely adopted that the scientific designation of a plant should be in every case the name first applied to it (with suitable definition and description). provided that name had not been previously applied to another plant. This rule has necessitated many elanges in the current nomenclature. The names adopted in this book have been brought as far as possible into accordance with the reformed nomenclature. In the case of our indigenous plants, the names giren by Britton and Brown in their recently published "Flora of the Northern States and Canada, hare been adopted with very few exceptions as conforming to the new rules. The attempt has been made to adhere to the principle also in the case of exotic plants, but it has not been alwars possible to eonsult original authorities. In a number of instances where the new rule requires changes in name which hare undoubtedly been already made by botanists, but for which authority could not be found, my own name appears as authority, indieating that the responsibility is mine.

It has been my endearor to make the list of popular sprnonyms as complete and at the same time as authentic as posible. It has not been diffieult to gather popular names of the plants of Europe, particularly of Great Britain. In our own country popular names are used in a very haphazard manner, and there has never been any attempt to gather all the names adopted in different localities. From the most reliable soures of information at my command I hare gleaned a large number of the current popular name- 
Book names, such as those adopted by botanists for the various species of a genus, hardly come within the scope of this work, although some such are given. Where there are several plants belonging to one genus, there is likely to be a good deal of interchanging of popular names. In general, however, each name is considered to belong properly to some one species and should be restricted thereto, and in a book of synonyms like this, names must be given as though this were the actual practice.

Although aside from the main purpose of this work, I have indicated the origin and meaning of many popular names, and I have also given as far as possible, the etymologies of the Latin generic names.

The principle of double credit for authority of botanical names has been applied whenever practicable. It has not been possible always to ascertain which was the earlier of two specific names. In such cases only the single credit is given.

Synonyms under the various genera are in the true sense synonyms only when followed by authority. Synonyns "in part" are generic names that, for reasons good or bad, have been applied by botanists to some of the plants of the genus in question.

In the English names, the orthography of the Century Dictionary has been given the preference, alternative forms being, however, also recognized, those now obsolete often in parenthesis.

I have endeavored to include in this enumeration: 1st. All the more important plants used medicinally in our country, including many which are practically obsolete yet may be sometimes asked for in drug stores. 2nd. Plants of economic value, especially those furnishing important food stuffs. Pasture grasses, however, and many forage plants, as well as the multitude of plants cultivated in gardens and greenhouses for ornament, I have been compelled by limit of space to omit. 3rd. Plants indigenous to any part of the United States. The name of every genus of flowering plants known to occur in North America, north of Mexico is given, with a brief description and statement of its geographical distribution. Only genera of grasses and of sedges are excepted, this omission giving room to include those of ferns and Lycopods. In each case a statement is made of the number of species found "in U. S." which must be understood to include also those of British America, the number being generally that of the species included in the catalogue recently (1898) published by $\mathrm{A}$. A. Heller, of North American plants North of Mexico. 
The book should thus be of interest and value to every one interested in American botany. It is, however, more especially intended to meet the practical needs of the retail druggist, who is often called upon to supply some root, bark or herb of which only an unfamiliar popular name is known to the customer. For the benefit of the druggist also the pharmacopoeial names are given of all drugs official in the United States, Great Britain, Germany and France, and also the unofficial Latin as well as the vernacular German, French and Spanish names of the several drugs or plants. Medicinal properties are also succinctly stated.

The greatest care has been taken to render the book accurate in its scientific information and complete and authentic in itssynonomy. A copious index serves as a key to this mass of information, enabling the reader to turn instantly to the desired jaragraph.

Laboratory of NELSON, BAKER \& (O).

JANUARY, 1900. 


\section{EXPLANATION OF ABBREVIATIONS AND \\ SYMBOLS.}

Adv. Adventive.

Br. British Pharmacopoeia.

Cort. Cortex.

Cult. Cultivated.

Fol. Folia.

Fr. French name.

Ger. German name.

H. Herb.

(Kew) Name given preference in Index Kewensis.

P. G. German Pharmacopoeia.

Nat. Naturalized.

R. Radix.

Rh. Rhizome.

Sp. Spanish name.

sp. Species.

Syn. Synonym or Synonyms.

U.S. United States. (i. e. N. America, North of Mexico).

U. S. P. United Sțates Pharmacopoeia.

* Name better applied to another plant.

$\dagger$ Name improperly applied to this plant.

† A rerbal corruption.

\& Book name, found in manuals of Botany, ete.

|| Obsolete, vulgar or provincial name. 


\section{PLANT NAMES AND- SYNONYMS.}

1. ABÁMA, Adans. 1763. Bog Asphodel. - Melanthaceæ. The ancient Greek name. Syn. Narthecium, Juss. 1789. Small perennial herbs. Four known species, northern Hemisphere; 2 in U. S.

a. A. Americána (Ker) Morong (Narthecium Americana Ker, N. ossifragum var. Americanum Gray). Southern New Jersey. American Bog Asphodel, Bastard or Lancashire Asphodel, Moor-grass, Rosa-Solis*.

2. ÁBIES, Juss. - - Fir. - $\quad$ - Pinacer.

The ancient Greek name. Syn. Pinus, Picea, in part. Evergreen trees, mountains and high latitudes of north temperate zone. About 20 species; 12 in U. S.

a. A. Ábies (L. ) Rusby (Pinus Abies L., P. excelsa Lam., P. Picea Du Roi, Picea excelsa Link). Northern Europe and Asia, also in Alps. Norway Spruce, Spruce Fir, Galipot tree; Ger. Fichte; Fr. Pesse, Épicéa, Faux Sapin (Codex). The resinous exudate is known as frankincense; from this is prepared Burgundy Pitch; Pix Burdundica U. S. P., Br., Resina pini burgundica, Pix alba; Ger. Burgunder Harz, Burgunder Pech; Fr. Poix de Bourgogne, Poix des Vosges, Poix jaune (Codex). Stimulant, vulnerary, revulsive, etc. Leaf buds and shoots used in making spruce beer.

b. A. balsámea (L.) Mill. (Pinus balsamea L.). British America. south to Virginia and Minnesota. Balsam Fir, Balm of Gilead Fir, Balsam tree, American Silver Fir, Fir Pine, Blister Pine, Single Spruce*. Oleoresin from the bark: Canada Balsam, Balsam of Fir; Terebinthina canadensis, U.S. P., Br., Balsamum Canadense; Ger. Canadischer Terpentin; Fr. Baume du ('anada (Codex), Térébinthine du Canada. Terebinthinate, expectorant, etc.

c. A. Fráseri (Pursh) Lindl. (Pinus Fraseri Pursh). Virginia to Tennessee. Fraser's Balsam Fir, Southern Balsam Fir, Mountain Balsam-tree, Balsam, She-balsam, Double Spruce*. Oleoresin resembles that of (b) and is sometimes substituted therefor. 
d. A. magnífica Murray. California Magnificent Firs, Califoruia Silver Fir, Red Fir, Queen-of-the Sierras. The largest of all Firs. A valuable timber tree. The shasta Fir and Grolden Fir are rarieties of this species.

e. A. nóbilis Lind. Washington and Oregon. Noble Fir, Larch.t

f. A. Pícea (L.) Lyons (Pinus Picea L., Pinus pectinata Lam., P. Abies DuRoi, A. alba Mill., A. pectinata D.C. (Kew.), A. excelsa Link., not Poir). Europe. Silver Fir, European silver Fir, Silver Pine, Strassburg Yine, Tanne; Ger. l'eisstanne, Edeltanne; Fr. Sapin argenté. Pesinous exudate, Strassburg Turpentine; Terebinthina argentoratensis; Fr. Térébenthine d' Alsace, des Vosges ou de Strasbourg, Térébenthine au citron (Codex). Kesembles Venice turpentine.

3. ABRÓNIA, Juss. - Abronia. - Nyctaginacea. From Greek, "graceful,"' of the flowers. Syn. Cycloptera, Tricratus, in part. Annual or perennial herbs, some ornamental. About 15 species; 12 in U. S., mostly western.

4. ÁBRUS, L. Abrus, Indian Licorice, etc. Papilionaceae. From Greek, "graceful," of the seeds. Syn. Zaga, in part. Shrubby climbers or sub-shrubs. About 5 species, tropical regions.

a. A. precatórius L. (Glycine Abrus L., A. minor Desv.). India, cult. in most tropical countries. Indian Licorice (Liquorice), Wild Licorice, Red-bean rine; Ger. Indisches Suissholz; Fr. Liane à réglisse. Réglisse indienne, Herbe à beau-père. Seeds, Jequirity (Brazil), Quequiri, Crab's-eyes, Jumble-beads, John(row beans, Love-peas, Black-eyed Susan; Semen abri; Ger. Paternostererbsen; Fr. Pois d' Amérique. Irritant, used in treatment of ophthalmia. Root, a poor substitute for licorice root.

j. ABÚTA, Aubl. False Pareira Brava. Menispermacex. From vernacular Brazilian name. Syn. Auelasma, Miers. Shrubby climbers with coriaceous leaves. About 8 species, tropical America.

a. A. amára Aublet. (The Index Kewensis makes this a synonym of Aristolochia glaucescens H. B. K. ). Brazil. Reputed source of Yellow I'areira brara.

b. A. ruféscens Aublet. Brazil. White Pareira brava, Butua (vernacular).

(j. A BÚTILON, Ciaertn. ( Abutilaea). Abutilon. Malvacene. Name given by Arabian Aricenna, d. 1037. Herbs, shrubs or even trees. About 90 species, mostly tropical and sub-tropical; 18 in U. S., mostly south-western.

a. A. Ibútilon (I.) Rusby (A. Avicenna (iaertn.). Southern Asia, nat. in U. S. and widely elsewhere. Velvet-leaf, Indian Mallow, American Jute, Butter-weed, Butter-print, Button- 
weed, Cotton-weed, American Hemp*, Indian Hemp*; Mormonweed, lie-marker, Pie-print, Sheep-weed, Velvet-weed. Plant, especially flowers, mucilaginous like. Ilthaea.

b. A. Indicum Don, India, and other species have similar properties.

7. ACÁCIA, Adans. Acacia, Wattle (Australia). Mimosaceae. The Greek name, meaning "thorny." 'Trees and shrubs. About 4.50 species, mostly sub-tropical, especially of Africa and Australia; 16 in $\mathrm{L}$. S.

a. A. Arábica (Lam.) Willd. (Mimosa Arabica Lam. The species probably includes also .1. Adansonii Guil. \& Per., A. Nilutica Delile and $A$. vera Willd.). India to Senegambia. Egrptian Gum A rabic tree, Egyptian Thorn. Vernacular names are Kikar and Babur. Bark, (Babul, Babulah or Baboot bark) astringent, used in tanning as are the rods (nebneb). The tree is the probable source of gum Mogador, called also Morocco and Barbary gum. See (k.) The tree produces also lac. ree Croton aromaticus.

b. A. Cáteclıu (L. f.) Willd. (Mimosa Catechu L. f.) East Indies and ('eylon. nat. in Jamaica. ('atechu tree. Fixtract prepared from the rood is the Catechu of medicine aud the cutch of taunery also called cashoo and gambir *; Cstechu L.S. P., P. G., Terra japonica, Cutechu nigrum: ('ier. Katechu, I'egukatechu; Fr. Cachou de Pégu, ('ashcuttie (Codex). A powerful astringent.

c. A. decúrrens Willd. Australia. Black Wattle-tree. Bark astringent, used in tanning and for making a variety of cutch or terra japonica. The tree yields also a fair quality of gum, (Australian gum, Wattle gum).

d. A. Farnesiána Wrilld. (A. Indica Desv.). Tropical and subtropical America, Texas to California, also cult. in Europe. ('assie, Lassia-flower tree, Sponge tree, Huisache (Texas), Matitas (Mexico.), Kalú (Hawaii), Opopanax*.' Flovers, much used in perfumery. Shrub also yields gum.

e. A. stenocárpa Hochst. Ibyssinia and Nubia. Source of Suakin or Savakin gum, called also suak, Talha and Talea gum.

f. A. Gréggii A. Gray. Texas to Mexico. One of the plant which yields lac. See ('roton aromaticus.

g. A. homalıphýlla Cunninghan. Australia. Myall., Violetwood. Irood fragrant. used for tobacco-pipes, ete.

h. A. Lórrida Willd. South Africa. Doorn-boom (i. e. Thorntree) Karra-doorn, Karoo Thorn. Source of the Cape gum. Bark used in tanning.

i. A. Melanóxylon R. Br. Southeastern Australia. Black-wood tree, Light wood*. Wood raluable for cabinet work. 
j. A. pycnántha Benth. Australia. Golden Wattle. Bark yields a fine quality of cutch.

k. A Sénegal Willd (A. Verek Guil. \& Per.) Kordofan to the Senegal. Gum Arabic tree, Acacia. Gummy exudate of this and other species is gum acacia or gum Arabic; Acacia, U. S. P., Acaciae Gummi, Br., Gummi arabicum, Gummi mimosae, P. G.; Ger. Arabisches Gummi, Mimosen-gummi; Fr. Gomme arabique vraie (Codex); Sp. Goma arabiga., Mucilaginous, demulcent.

1. A. Súma (Roxb.) Kurz (Mimosa Suma Roxb., A. Catechu W. \& A., not Willd.). Southern India. Source of part of the Catechu of commerce. Other species of Acacia yielding gum are (m.) A. Ehrenbergiána Hayne, Arabia and upper Egypt, Seyah; (n.) A. Séyal Delile (A. fistula Schweinf.), Thirsty Thorn and (o.) A. tórtilis Hayne called Seyal or Seyaleh. Commercial varieties of gum are Hashabi or Kordofan pum, Sennaar or Sennari gum, Gedda or Jidda gum and gum Tor or Turic, besides those already mentioned. The finest selected white gum is known as Turkey gum.

8. ACAÉNA, L. - Acaena. - Rosaceae. Syn. Ancistrum, Forst. Herbs, some shrubby. About 40 species, New World, especially S. America, to Australia; 1 in U. S.

9. ACALÝPHA, L. Three-seeded Mercury. Euphorbiaceæ. Greek name of a Nettle. Syn. Cupameni, Adans. Herbs or shrubs. About 230 species, mostly tropical and sub-tropical; 9 in U. S.

a. A. Virgínica L. Ontario and eastern U. S. Mercury-weed, Virginia Three-seeded Mercury? and diuretic.

10. ACAMPTOPÁPPUS, A. Gray. - - Compositæ. From Greek, "rigid pappus." Syn. Aplopappus, (Haplopappus) in part. Low desert shrubs. Two known species, both in southwestern U. S.

11. ACANTHóchiton, Torr. Acanthochiton. Amaranthaceæ. From Greek, "Thorny Cloak." Dioecious herb, one species. Texas to Arizona.

12. ACANTHOMíNTHA, A. Gray. Acanthomintha. Labiatx. From Greek, "thorny Mint." Low annuals. Two known species, Pacific Coast, L. S.

13. ACANThóscyphus, Small. - - Polygonaceæ. From Greek, "thorny cup. 1 in U. S.

14. ACANTHOSPÉriUM, Schrank. - - Compositæ. From Greek, "thorny seed." Syn. Centrospermum, H. B. K. Diffuse annuals with bur-like fruit. About 5 species, tropical regions; 2 nat. in U. S. 
15. ACÁNTHUS.L.

Acanthus.

Acanthacex.

Ancient Greek name of any thorny or prickly plant, applied later particularly to this genus. Robust herbs with ornamental foliage. About 15 species, Mediterranean region.

a. A. móllis L. Southern Europe. Acanthus, Branc-ursine, Bear's breech, Culberdill $\|$, Sedocke $\|$.

16. ÁCER, L. - Maple. - Aceraceae. [Sapindaceæ.] The Latin name, from "pointed" lobes of the leaves. Syn. Negundo, in part. Trees and shrubs. About 100 species, North temperate zone; 15 in U. S.

a. A. nígrum Michx. (A. saccharinum, var nigrum T. \& Gr.) Ontario to Alabama, west to Louisiana and Minnesota. Black Sugar Maple, Black Maple, Hard Maple. Sap rich in sugar.

b. A. Negúndo L. (Negundo aceroides Moench, N. Negundo (L.) Karst.). Ontario te Mexico, but rare near Atlantic coast. Ash-leaved Maple, Box Elder, Cut-leaved or Red River Maple, Black Ash*, IIaple Ash, Water Ash, Sugar Maple*.

c. A. Penusylránicum L. (A. striatum Du Roi). Nova Scotia, south to Tennessee. Striped or Goose-foot Maple, Northern Maple, Moosewood, False or Striped Dogwood, Whistle-wood.

d. A. Pseudo-Plátanus L. Europe and western Asia, cult. in U. S. Sycamore Maple, Succamoret, Spurious or Mock Planetree, Whistle-wood.

e. A. ríbrum L. Canada to Florida and Texas. Red, Scarlet or Water Maple, Swamp Maple; White, Hard or Shoe-peg Maple, also Soft Maple*.

f. A. saccharínum L. (A. dasycarpum Erhr., A. eriocarpum Michx. ). Canada to Florida, west to Indian Territory and Dakota. Silver or Silver-leaf Maple, Soft or White Maple; Creek, River, Swamp or Water Maple, Red Maple*. Sap yields comparatively little sugar.

g. A. Sáccharum Marsh (A. saccharinum Wang, not L., A. barbatum Michx. ). Canada to Florida, west to Texas and Nebraska. Sugar Maple, Rock Maple, Sugar Tree, Black Maple. Sap the source of most of the maple sugar.

h. A. spicátum Lam, (A. montanum Ait.). Canada to N. Carolina, west to Minnesota. Mountain Maple; Low, Moose, Swamp or Water Maple.

17. ACERÁTES, Ell. 1817. Milk-weed*. Asclepiadaceae. From Gireek, "hornless," of the corona. Syn. P'olyotus, Nutt., 1835., Asclepias in part. Milky perennial herbs, resembling Asclepias. Seven species, North $\mathrm{America} ; 5$ in U. S.

18. ACHILLÉA, L. - Yarrow, Milfoil. - Composita. Greek name, the plant with which "Achilles" healed Telephus. Herbs, mostly perennial, with numerous small flowerheads. About 75 species, mostly of Old World; 3 nat. in I. S. 
it. A. Millefólium L. Europe and Asia, naturalized in U. S. Yarrow, (Yarroway, Yerrow) Milfoil, Thousand-leaf, Thousandleaved Clover, Green-arrow, Camil †, Cammock*, Dog-daisy ('xordolobo, Nosebleed, Bloodwort, C'arpenter's-grase, Sanguinary, Soldiers' Woundwort, Old-man's-pepper, Tansy†; Ger. Schafgarbe, Schafgrippe, Gachelkraut, Feldgarbe; Fr. Millefeuille, Herbe aux Charpentiers. The flowering plant or flowers, Summitates (Flores) millefolii s. Achiller. Stiuulant tonic, vulnerary, astringent, diuretic.

b. A. moscháta, Jacq. (Ptarmica moschata DC., ) Switzerland. Iva; Ger. Iva, Genippkräuter; Fr. Génépi blane. The plant, Herba ivae, H. genippi veri, stimulant, antispasmodic.

c. A. nóbilis L. Central and Southern Europe. Noble Yarrow; Ger Edelgarbe, Edelschafgarbe. Considered more active than common Yarrow.

d. A. Ptármica I. Europe and Asia, nat. in U. S. Sneezewort (Neesewort), White Tansy, Sneezewort Yarrow or Tansy, Goosetongue; Wild, Europeau or Bastard Pellitory, Fair-maid-ofFrance, Seven-year's-love; Ger. Bertramgarbe, B rtramskraut; Fr. Herbe à Éternuer. Root sternutatory, acrid, sialagogue. [Other European species used like A. Millefolium are (e.) A. agerátum L., Maudlin Tansy, (f.) A. atráta L., Iva, (g.) A. nána L., Dwarf Iva.]

19. ÁCHLYS, DC: _- Achlys. - Berberidacere. From Greek, "mist.', Scapose herbs. Two known species, one in Japan; 1 in U. S.

20. 'ÍCHRAS. L. - - Sapodilla. - - Sapotaceae. Greek name of a wild Pear. A tree. One species only.

a. A. Sapóta L. (Sapota Achras Mill.) Tropical America. Sapodilla, Sapodilla Plum, Naseberry. Bark, (Jamaica bark, ) astringent, febrifuge. Seeds aperient, diuretic. 'The tree is said to yield also chicle gum. See Yimusops.

21. ACHROÁNTHES, Raf. 1S08. Adder's-mouth. Orchidaceae. From Greek "green flowered." Syn. Microstylis, Nutt, 1818. Low perennials with racemes of small flowers. About 40 species; 4 in U. S.

22. A(HYRACHAÉNA. Schauer. Achyrachaena. Compositæ. From Greek, "chaffy fruited." Annual herb, the rather large heads nearly rayless. One species, California.

23. A CLEISÁNTHUS, A. Gray. Acleisanthus. Nyctaginacere. From Greek, with "flowers not enclosed." Herbs, some shrubby. About 6 species, warmer region $\mathrm{N}$. America; 5 in southwestern U. S.

24. ACNÍD A, L. - Water-hemp. - Amaranthaceae.

From Greek, "stingless." Syn. Amaranthus, iu part. Annual herbs resembling Amaranth. About 5 species, all of Eastern N. America and West Indies. 
25. ACONíTUM, L. Monkshood, Wrolfsbane, etc. Ranunculaceae. The ancient Greek name. Ornamental, but poisonous perennial herbs resembling Delphinium. About 18 species, mountainous regions of north temperate zone; 7 in $\mathrm{L} . \mathrm{S}$.

a. A. Anthóra Lin. Europe. Yellow IIelmet-flower. Iloot bitter, tonic.

b. A. Chinénse Siebold and (c.) A. Japónicum Thunberg, yield respectively the Chinese and Japanese Aconite roots. (d.) $A$. Físcheri Kieich. of Japan is, howerer, more active than either of these.

e. A. férox Wallich ( $\Lambda$. virosum Don). Himalaya mountains. Indian Aconite, Bish, Bishma, Bikh-root; Fr. Aconit féroce (Codex). Root even more active than that of (i.)

f. A. heterophýllum Wallich. Himalaya mountains. Atis. Root tonic, febrifuge, not acrid.

g. A. Lycóctonum L. Europe. Great Yellow Wolfsbane, Badger's-bane, Bear's-bane, Hare's-bane, Beast-bane. Leaves used as a pot herb in Lapland.

h. A. palmátum Don. India. Root, called Bishma or Bikhma, bitter, not acrid.

i. A. Napéllus L. (A. variabile Hayne, A. vulgare DC:). Moun tains of Europe and Asia. Aconite, Monkshood, Monkeył, Wolfsbane, Friars'-cap, Friars'-cowl, Cuckoo's-cap, Face-in-hood, Jacob's-chariot, Blue-rocket, Old-wires-mutehes\|, Mousebane, Wolfroot; Ger. Eisenhut, Sturmhut; Fr. Aconit Napel (Codex). The tuberous ront, Aconitum. U. S. P., Aconiti radix Br., Tubera aconiti, P. G. Arterial and nervous sedative, anodyne. The principal alkaloid, aconitine, is one of the most active poisons known. Leaves, Aconiti folia, Br., much inferior in activity to the tubers.

j. A. reclinátum A. Gray. Virginia to Georgia. Trailing Wolfsbane or Monkshood.

k. A. uncinátum L. Pennsylvania to Georgia, west to Wisconsin. Wild Monkshood or Wolfsbane.

26. ÁCORUS, I. - Sweet Flag. _ _ Iraceae. The Greek name. Reed-like plants with thick root-stocks. Only 2 species, 1 of Japan, the other of north temperate zone.

a. A. Cálamıs L. Europe, Asia and N. Ameriea. Siweet Flag, Calanus, Calmus (New Jersey), Sweet Cane, Sweet Grass, Sweet Myrtle, Sweet Rush, Sweet Sedge, Sweet Segg, Sweet root, Cinnamon Sedge, Myrtle Flag, Myrtle Grass, Myrtle Sedge, Beewort; Ger. Kalmus; Fr. Acore vrai, (Codex), Acore odorant; Sp. Ital. Calamo aromatico. The Rhizome, Calamus, I. S. P.: Rhizoma Calani, P. G., Radix acori, Rad. calımi aromatici. Aromatic, stimulant, carminative. 
27. ACRóstTICHUM, L. Acrostichum. Polypodiaceae.

From Greek, meaning not evident. Syn. Chrysodium, in part. A large evergreen fern. One species. Marshes in tropieal regions (Florida).

28. ICTAÉA. L. Baneberry, Cohosh. Ranunculaceae. Greek name of the Elder. Perennial herbs with compound leares. Four species, north temperate zone; 3 in U. S.

a. A. álba (L.) Mill. (A. spicata var. alba L.). British America, south to Georgia and Missouri. White Cohosh, White Baneberry, Herb Christopher, Rattlesnake-lierb, Necklace-weed, Ilue Cohosh, White-beads, White Grapewort, White-berry, Snakeroot*. Rhizome of this and the two following species acrid, emeto-cathartic, parasiticide.

b. A. rúbra (Ait.) WVilld. (A. spicata var. rubra Ait.) Canada and northeastern U. S. Red Cohosh, Red Bane-berry, Coral-andpearl. Poison-berry, Red-berry, Red-berry Snakeroot, Snakeberry, Toad-root, Herb Christopher, Rattlesnake-herb.

c. A. spicáta L. Europe and Asia. Baneberry, Herb Christopher, Grapewort, Rattlesnake-herb, Scalbegres\|; Ger. Christophswurz, Wolfswurz; Fr. Racine de Saint Christophe.

29. A (YINÓLEPIS, A. Gray. Actinolepis. Compositæ. From Greek, "ray scile." Syn. Eriophyllum, in part. Low winter-annuals. Five known species, all of California.

30. ACTINOSPÉRMUM, Ell. 1824. Aetinospermum. Compositae From Greek, "ray seed." Syn. Baldwina, Nutt. 1818 [not Baldwinia, Raf. 1818, although this name has been commonly applied.] Annual or perennial herbs with large yellow-rayed flower heads. Two species, both of southeastern U. S.

:1. ÁCUAN, Med. Theod., 1786 . Mimosa. Mimosacer. Vernacular name. Syn. Desmanthus, Willd. 1806 and Darlingtonia, DC. 1825. Perennial herbs or Mimosa-like shrubs. About 12 species. all but one of New World; 10 of Mexican border, U. S.

3ะ. ADANSÓNIA, L. Baobab, etc. Bombacer (Malvacea). Named for Michal Adanson, French naturalist, d. 1806. Syn. Baobab, Adans., Ophelus, Lour. Trees. Three known species, Old World.

a. A. digitáta L. Tropical Africa, nat. in East and West Indies. Baobab, Calabash-tree, African Cream-of-tartar tree, Ethiopian Sour-gourd tree. Fruit, Monkey-bread, Bread-nut, Sour -gourd; Ger. Affenbrod; Fr. Pain des Singes. Acidulous, refrigerant as in the following species. Bark reputed febrifuge.

b. A. Gregórii F. Muell. Australia. Gouty-stem tree, Australian Babab or Sour-gourd tree.

๔. A. Madagascariénsis Bail. Madagascar. Fruit is c.ılled Creanof-tartar fruil. 
33. ACÍN11A, Medic., 1786. Bowstring IIemp. Haemodoracea Syn. Sansevieria, (Kew.) Thunb. 1794 (Sansiviera). Herbaceous plants, the leaves yielding a hemp-like fibre. About 12 species, East Indies and $\Lambda$ frica.

a. A. Roxburghiána (Schult.) Lyons (Sansevieria Roxburghiana sichult.) India. Moorva, Marool, Bow-string Hemp.

34. A DÉLIA, I'. Br. $1756 . \quad$ - Adelia. - Oleaceae. From Greek, "inconspicuons". Syn. Forestiera, P'oir. 1811. Shrubs or small trees. About 15 speeies, new world; 9 in U. S.

3.j. IIENANTHÉliA, I. Red Sandalwoodt, etc. Papilionaceae. From Greck. "gland-anthered." Syyn. Stachychrysum, Trees or sliruhs. About 5 species, tropical regions, (ild World.

a. A. paronína L. East Indies. False Red Sandalwood. Scarlet seeds nsed as weights, like those of Abrus.

36. ADENOCAÚLON, Hook. Adenocaulon. Compositae. From Greek, "gland-stem". Perennial herbs with small heads of tubular flowers. Three species, one each of Asia, S. America and N. America (U. S.)

37. A DENOSTÉCIA, Bentl. Adenostegia. Scrophulariaceae. From Greek, "gland sheath." Syn. Cordylanthus, in part. annual herbs. About 16 species, Pacific coast, U. S.

3.9. A DEYóSTOMA, Hook and Arn. Adenostoma. Rosaceae. From Greek, "gland mouth." Unarmed evergreen shrubs with small flowers in panicled racemes. Two species, Pacific border U. S.

39. AIHÁTOIA, Nees. Malabar-nut. Acanthaceae. From vernacular, Malabar. Syn. Davernoya, E. Meyer, Justicia in part. Shrubs. About 6 species, tropical regions.

a. A. Adhátoda (L.) Lyons (Justicia Adhatoda L., A. vasica Nees.) India. Malabar nut. Fruit, also leaves and root, antispasmodic, febrifuge, ecbolic.

40. Ai)Í́N'TU, L. - Maidenhair. - Polypodiaceae. The ('reck name, "incapable of being wet." Delicate ferns. 80 or 90 species, mostly of tropical America; 5 in U. S.

a. A. Capillus-Véneris L. Warm parts of U. S. and of both hemispheres. Venus'-hair, Maidenhair, European Maidenhair Black Maidenhair (tree), Lady's-hair, Dudder-grass, Ger. Frauen-haar, Venushaar; Fr. Capillaire de Montpelier (Codex); Sp. Culantrillo. Plant slightly astringent, expectorant.

b. A. pedátum L. Canada and Northern U. S., also Alaska and western Asia. Maidenhair, American Maidenhair, IIair Fern, Rock Fern; (ier. Nordamerikanisches Frauenhaar; Fr. Capillaire du Canada (Codex). Properties of (a). Other species indigenous to those regions are employed similarly in Mexico and S. America. 
41. ADÍCEA, Raf. 1815. Clearweed, Coolweed, etc. Urticaceae. Name unexplained. Syn. Pilea, Lindl. 1S21. Annual or perennial stingless herbs. About 150 species, chiefly tropical; 2 in U.S.

a. A. púmila (L.) Raf. (Pilea pumila A. Gray). Canada and Eastern U. S. Clearweed, Coolweed, Richweed, Stingless Nettle.

42. ADLÚMIA, Raf. Climbing Fumitory. Papaveraceae. Named for John Adlum, gardener, of Washington. A delicate climber, one species only.

a. A. fungósa (Ait.) Greene (Fumaria fungosa Ait., A. cirrhosa Raf.) Canada and $\mathrm{N}$. Carolina, west to Kansas. Climbing Fumitory, Mountain-fringe, Wood-fringe, Alleghany-fringe, Alleghany-vine, Canary-vine, Cypress-vine, Fairy-creeper.

43. ADÓLPHÍA, Meissn. - Adolphia. - Rliamnaceae. Syn. Ceanothus, Colletia, Colubrina, in part. Shrubs allied to Colubrina. Two known species, Southwestern U. S.

44. ADÓNIS, L. Pheasant's-eye. Ranunculaceae. The Greek name; plant fabled to have sprung from the blood of Adonis. Ornamental annual or perennial herbs. About 6 species, temperate Asia and Europe; 1 nat. U. S. Syn.; Ger. Adonisröschen; Fr. Adonide.

a. A. aestrális L. Europe and Asia, Summer Pheasant's-eye.

b. A. ámuıa L. 1753 (A. autunnalis L. 1763.) Southern Europe. Cult. in gardens and adv. U. S. Corn Pheasant's-eye, Red Morocco, Red Mathas, Adonis-flower, Bird's-eye, Purple or Red Camomile, Love-lies-bleeding*, Passeflower; Fr. Rose à rubie.

c. A. veruális L. Europe and Asia, Vernal Pheasant's-eye, False Hellebore, Bird's-eye, Ox-eye. The Herb, as of preceding species, is a cardiac tonic resembling digitalis in action.

45. ADOPOGON, Neck. 1790. Dwarf Dandelion, Goat's-beard. Cichoreaceae.

From Greek, "handsome beard." Syn. Krigia, Schreb. 1791, also Cynthia, Hyposeris, in part. Dandelion-like annuals or perennials. Five species, all of U.S.

46. ADÓXA, I. Musk-root, Mosehatel. Adoxaceac. From Greek, "without glory." Herb with tuberous root, one species.

a. A. moschatellína L. Aretic Europe Asia and N. America (U. S.) Musk-root, Moschatel. ()ther names are Hollow-root, Musk, Musk C'rowfoot, Musk Wood-Crowfoot, Bulbous Funitory, Gloryless.

47. AÉGLE, Correa.

Bengal Quince.

Rutaceac.

Name from Greek mythology, one of the Hesperides. Thorny aromatic trees. About 4 ' species, tropical Asia and Africa. 
a. 1. Mármelos (L.) Correa (C'rataeva Jarmelos L., C. religiosa Ainsl., Feronia pellucida Roth.) India. Indian Bael (Bhel, Bel), Bengal Quince, Golden Apple; Ger. Bengalische Quitte; Fr. C'oing du Bengale. The dried half-ripe fivit, Belæ fructus, $\mathrm{Br}$, , astringent.

48. AEGOPÓDIUM, I. Gout-weed. Umbelliferae. The Greek name, "goat's foot." One or two species, natives of Europe and Asia.

a. A. Podagrária L. Europe, adv. in northeastern U. S. Goutweed, Goutwort, Goat-weed, Herb Gerard, Wild or English Masterwort, Ax-weed, Ash-weed, White-ash herb, Ground Ash, Aiseweed, Dwarf or Bishop's Elder, Dog Elder, Bishop' s-weed, Garden-plague, Wild Alder $\nmid, J$ ack-jump-about. Plant reputed antiscorbutic and diuretic.

49. AESCHYNÓMENE, L. Joint-Vetch. Papilionaceae. From Greek, "ashamed," from sensitiveness of leaves. Syn. Hedysarum, in part. Herbs or shrubs with yellow flowers. About 55 species, warm regions; 2 in $\mathrm{U}$. S.

50. AÉSCULUS, L. - Horse-Chestnut. - Hippocastanacere. Latin name of Italian Oak. Syn. Hippocastanum. Trees or shrubs with digitate leaves. About 15 species, America and Asia; 7 in U. S.

a. A. glábra Willd. Michigan to Alabama, west to Indian Territory. Ohio Buckeye, Fetid Buckeye, American Horse-Chestnut. Wood used for artificial limbs, etc.

b. A. Hippocástanum L. (H. vulgare Gaertn.). Asia, nat. and cult. in Europe and U. S. Horse-Chestnut, Bongay, Konkertree; Ger. Rosskastanie; Fr. Chataignier d' Inde; Sp. Castaño de Indias. Bark, Cortex hippocastani, Lort. castaneæ equinæ; Tonic, antiperiodic, antiseptic. Seeds (called by children conquerors, konkers or oblionkers) sternutatory, reputed narcotic.

c. A. octándra Marsh. (A. lutea Wang., A. flava Ait.). Pennsylvania to Georgia, west to Texas and Iowa. Yellow or Large Buckeye, Sweet or Big Buckeye.

d. A. Pária L. Southeastern U. S. Red or Little Buckeye, Redflowered Buckeye, Fish-poison.

51. AÉTHUSA, L. - Fool's Parsley. - Umbellifera. Greek name, "burning," of the taste. Annual herb resembling Conium, a single species.

a. A. Cynápium L. Europe and Asia, adv. in U. S. Fool's Parsley, Ass-parsley, False or 'Iog's Parsley, Fool's Cicely, Dill*, Dog-poison, Small or Lesser Hemlock; Ger. Hundspetersilie, Gartenschierling; Fr. Ethuse, Petite ciguë, Ache des chiens. Plant not poisonous, as reputed. 
j2. AFZÉLIA, J. G. Gmel. 1796. Afzelia. Serophulariacear. Named for Adam Afzelius, Swedish botanist, d. 1812. Syn. Seymeria, Pursh 1814, Gerardia, in part. Stout, yellow-flowered herbs. About 10 species, $\mathrm{X}$. America and Madagascar; 6 in $\mathrm{U}$. S.

a. A. macrophýlla (Nutt.) Kze. East central U. S. Mullen Forglore.

53. AGÁRICUS, L. Mushroom, Toadstool. Hymenomycetes. Syn. Toad's-cap, Toad's-hat, Toad's-meat, Frog-stool. The name Toadstool applies properly to fungi of this genus. but is popularly extended to poisonous fungi generally. The genus includes many species of edible Mushrooms.

a. A. campéstris L. Cosmopolitan. Mushroom, (Masheroom) Edible Mushroom, Kedgup Mushroom, Button Mnshroom. 'To this and other species, are giren the names Fairies'-table, Pisky-stool, White-caps. Fungus esculent.

54. AGÁSTACHE, Clayt. 1762. ¿ Giant Hrssop. Labiatae. From Greek, "many-spiked". Syn. Vleckia, Raf. 1808, Lophanthus, Benth. 1829 [not Adans. 1763.] Tall perennial herbs. Four species, all of U. S.

a. A. anethiodóra (Nutt.) Brit. (Lophanthus anisatus Benth., Hyssopus anethiodorus Nutt.) Illinois to Nebraska and northward. Fragrant Giant Hyssop. Anise Hyssop.

ј.). Áfrathis, Salisb. 1807. - Wax Pine. - Pinaceae. Syn. Dammara, Lam. 1786, but this name is otherwise applied. Large trees with leathery leares. About 10 species, East Indies to New Zealand.

a. A. anstrális (Lamb.) Steud. (Dammara australis Lamb.). New Zealand. Kauri Pine. Source of Kauri resin, ( New Zealand or Kauri Copal, Kauri gum). A magniticent tree furnishing exceedingly valuable timber.

b. A. Loranthifólia Salisb. (A. Dammara Rich., Dammara alba Rumph., D. orientalis Lamb. ). East Indies. Amboyna Pine, Tamniar tree, Agath Dammar. Resinous exudate. Dammara resin (Damar resin, Damar gum), which is obtained also from (c.) A. oráta (C. Moore) Lyons, (D. ovata C. Moore) of New Caledonia and (d.) A. robústa (C. Moore) Lyons, (D. robusta C. Moore) of Queensland.

56. Afíre, L. Agave, False Aloe. Amaryllidaceae. From Greek, "noble." Herbs with fleshy radical leares and tall scapes. About 140 species, all American; $1 S$ in U. S.

a. A. Americána L. Tropical America. American Aloe, Century-plant. Fresh juice saccharine, laxative, antiscorbutic.

b. A. Ixtli Karw. Yucatan, "cult. in tropical countries. Sisal -hemp plant; Chelem, or Sacci of the Mexicans. Fibre of this and of other large species, a substitute for hemp, called Sisal -hemp, henequen or henequin. 
c. A. Mexicána Lam. Mexico. Maguey plant. This and perhaps other species, yield the Mexican pulque, which is simply the fermented juice, and mezcal, distilled from the same.

d. A. Virgínica L. Southern L. S., False Aloe, Rattlesnake's Master, Virginian Agave. Root bitter, carminative.

57. AFERATCM, L. - Ageratum. - Compositae. Greek name of an aromatic plant, "not growing old.' 'Syn. Cœlestina, in part. Herbs with numerous small flower-heads. About 10 species, America, chiefly tropical; 3 in U. S.

a. A. conyzoídes L. (A. Mexicanum Hort.). Tropical America and cult. for ornament. Generally known as Agerátum.

jS. AGÓSERIS, Raf. 1817. False Dandelion, etc. Cichoriaceae. From Greek, "'head Succory." Syn. Troximon, Nutt. 1813 [not Gærtn. 1791]. Herbs mostly with radical leaves and dandelion-like flowers. About 25 species, $\mathrm{X}$. and S. America, 23 in U. S.

๑). AGRIMóNIA, L. - Agrimony. - Rosaceae. The Latin name, perhaps transposed from Argemone. Perennial herbs with pinnate leaves and racemes of small yellow flowers. About 15 species, north temperate zone and Andes; 7 in $\mathrm{C}$. S.

a. A. Eupatória L. Europe. Agrimony (Egremoine, Egramounde, Hemony) European Agrimony, Cockle-bur*, Clire』, Garclive\|, Goosechite\|, Fererfewt, Harrest-lice, Lirerwort*, . Stickwort, White or Wild Tansy*; Ger. Leberklette, Odermennig, Heil-aller-Welt; Fr. Aigrimoine (Codex), Eupatoire des Grecs. The flowering herb, H. agrimoniae, H. lappulæ hepaticæ. Astringent, antiscorbutic, taenicide.

b. A. hirsúta (Muhl.) Bicknell (A. Eupatoria var. hirsuta Muhl.). Canada and Northeastern U. S., also California. Tall Hairy Agrimony?, Beggarticks, Stick-seed, Stick-weed, Cockle-bur*. These names with synonyms of (a.) are applied also to other indigenous species, which hare in general the properties of (a)

(60). AGROPÝR0X, J. Gaertn. Wheat Grass. Gramineae. From Greek, "field wheat." Syn. Triticum, in part. About 32 species; 22 in U. S.

a. A. répens (L.) Beauv. (Triticum repens L.). Europe, Northern Asia, nat. in U. S. Couch-grass; Cooch-, Cutch-or Scutch -grass; Quitch-, Quick-, Twitch-, or Squitch-grass, C'ouch Wheat, Sheep's-cheese, Quickens, Wickens, Wick, W itch-grass; Ger. Queckenwurzel, Graswurzel; Fr. Chiendent officinal, Petit Chiendent (Codex); Sp. Grama. The rhizome, Iriticum, U. S. P., Rhizona (Radix) graminis. Emollient, diuretic, lithontriptic, antiphlogistic.

\footnotetext{
61. AfrROSTÉMMA, L. Corn Cockle. Caryophyllaceae. From Greek, "ield garland." Coarse annual herbs with showy flowers. Two species, Europe and Asia.
} 
2. A. Githágo L. (Lychnis Githago Lam.). Europe, nat. in U.S. Corn Cockle, Corn Campion, Corn Pink, Corn Rose, Mullen Pink, Old-maid's Pink, Crown-of-the-field.

62. AILÁNTHUS, Desf. Tree-of-heaven. Simarubaceac. From vernacular, Malacca, meaning "tree-ot-heaven." Trees with pinnate leaves. Four species, China to Australia.

a. A. excélsa Roxb. India. Bark, bitter, tonic, febrifuge.

b. A. glandulósa Desf. China, cult. in U.S. as a shade tree. Ailanthus, Tree-of-heaven, Chinese Sumach, False Varnish-tree, Devil's-walkingstick, Heavenward tree, 'Tree-of-the-gods; Ger. Götter'Jaum; Fr. Vernis de Japon. Bark (of tree and of root) bitter, stomachic, tonic, antidysenteric, taenicide.

c. A. Malabárica DC. East Indies. Gum resin used as incense and as a remedy for dysentery.

63. ÁJUGA, L. - Bugle, Ground-Pine*. - Labiatae. Syn. Teucrium, in part. Annual or perennial herbs. About 40 species, Old World; nat. in U. S.

a. A. Chamaépitys (L.) Schreb. (Teucrium Chamæpitys L.). Europe. Ground-pine*, Field Cypress, Cypressł, Forget-me -not*, Ground Ivy; Ger. Günsel, Feldcupresse; Fr. Ivette, Chamæpitys (Codex); Sp. Pinillo olorroso. The flowering tops aromatic, aperient, tonic.

b. A. Íva (L.) Schreb. (Teucrium Iva L.) Europe. French Ground-pine, Herb-ivy, Herb-eve, Gout Ivy, Ground Ivy; Ger. Bisamgünsel; Fr. Ivette musquée (Codex). Flowering top: aromatic, tonic, febrifuge.

c. A. réptans L. Europe, nat. in eastern U. S. Bugle, Commnn or Brown Bugle, Carpenter-herb, Middle-comfrey, Middle -consound (i. e. consolida or healing), Sicklewort, Dead-men 's -bellows, Helfringwort, Wild Mint; Ger. Goldner Günsel; Fr. Bugle (Codex). Plant nildly astringent, vulnerary.

d. A. pyramidális L. Europe. Mountain Bugle, Upright Bugloss. Properties of (c.)

64. ALBÍzZIA, Courdou. - Albizzia. - Mimosaceac. Name from Albizzi, a noble family of Tuscany. Syn. Besenna, Acacia, in part. Trees and shrubs, natives of tropical Asia and Africa.

a. A. anthelmíntica (Baill.) Courd. (Acacia anthelmintica Baill., Besenna anthelmintica Rich.). Abyssinia. Mesenna, (Musenna, Mussena), Busenna, Bisinna; Fr. Moussena. Buussena (Codex). Bark taenicide.

65. ALCHEvíLLA, L. - Lady's-mantle. - Rosaceae. Name of uncertain origin, probably "alchemist's" plant. Herbs with small greenish flowers. About 35 species, Old World and Western America; 3 in $\mathrm{C}$. S. 
a. A. arrénsis (L.) Scop. (Aphanes arvensis L.). Europe, nat. in U. S. Parsley-piert, Field Lady's-mantle, Bowel-hive, Colicwort, Argentill, Breakstone, Parsley-breakstone, Parsley-vlix, Fire-grass; Fr. Perce-pierre, Petit pied-de-lion des champs. Plant formerly used in strangury.

b. A. vulgáris L. Europe, nat. in U. S. Lady's-mantle, Ladies'mantle, Dew-cup, Bear's-foot, Duck's-foot, Lamb's-foot, Lion'sfoot (Padelion, Pedelyon), Great Sanicle, Syudaw; Ger. Helft, Frauenmantel; Fr. Alchemille.

66. ALCHórNEA, Swz. Alcornoque. Euphorbiaceae. Trees or shrubs. About 30 species, warmer regions of both hemispheres.

a. A. latifólia Swz. South America and West Indies. Alcornoque. Bark bitter, tonic.

67. ÁLETES, Coult. \& Rose. - Umbelliferae. From Greek, "miller". Herb. One species, western U. S.

68. ALETRIS, L. Stargrass, etc. Liliaceae (Haemodoraceæ). From Greek, "miller," alluding to mealy pubescence. Perennial scapose herbs with racemes of small flowers. About 8 species, eastern N. America and Asia; 2 in U. S.

a. A. farinósa L. Ontario and eastern U.S. Unicorn-root, Colicroot, True Unicorn-root, Unicorn-plant, Unicorn's-horn, Mealy Starwort, Starwort, Star-grass, False Star-grass, Star-root, Blazing-star*, Ague-grass, Ague-root, Aloe-root, Crow-corn, Devil's-bit*, Huskwort; Ger. Einhornwurzel, Mehlige Aletris; Fr. Alétris farineux. Rhizome bitter, tonic, stomachic.

69. ALEÚRITES, Forst. Candlenut, etc. Euphorbiaceae. From Greek, "mealy," alluding to the scurfy pubescence. Trees. About 5 species, tropical regions of Old World and Oceanica, See also Croton.

a. A. Molnccána (L.) Willd. (Jatropha Moluccana L., A. triloba Forst., Juglans ( 'amirum Lour. ). East Indies and Islands of the Pacitic. Candlenut, Indian or Tahiti Walnut, Belgaum or Country Walnut, Spanish Walnut, Lumbang-nut, Kukui of Hawaiian Islands; Ger. Kerzennussbaum, Firnissbaum. Kernels yield a drying oil, Kekune oil, Lumbang oil, Artists' oil.

70. ALHÁGI, Forst. Persian Manna-tree. Papilionaceae. The Arabic name of the plant. Spiny shrubs, perhaps only one species, Mediterranean basin to India, Manna of Sinai.

a. A. camelórum Fisher. Western Asia. Persian Manna tree. The saccharine exudate is Persian Manna.

71. ALÍGERA, Suksdorf. - Aligera. - Valerianaceac. From Latin, "winged". Syn. Valerianella, in part. Herbs, eight species in western U. S. 
72. ALÍSMA, L. - Water Plantain. - Alismaceae. From Greek, "salt loving". Aquatic or marsh herbs. About 10 species, 2 in U. S.

a. A. Plantago-aquática L. Europe, Asia and N. America. Water Plantain, Mad-dog weed, Deil's-spoons, Great 'Thrumwort; Ger. Fröschlötfel, W asserwegerich; Fr. Plantain d' eau, Pain de grenouilles. Leaves acrid, counter-irritant, reputed vuluerary and lithontriptic.

73. ALKíNNA, Tausch. - Alkanet. - Boraginaceae. Name Arabic, the same word as Henna. Syn. Anchusa, in part. Perennial herbs. About 40 species, Mediterranean region.

a. A. Vinctória (L.) Tausch. (Anchusa tinctoria L.). Westeru Asia and southeastern Europe. Alkanet. Orcanette, Dyer's Alkanet, Anchusa, Spanish Bugloss; Ger. Alkanndwurzel, Ankerwurzel; Fr. Orcanette (Codex). Root, Radix alkanne (spuriæ), yields a red dye.

74. AlLIÁRIA, Adans. - Hedge Garlic. - Cruciferae. From Latin, "garlicy". Syn. Erysimum, Sisymbrium, in part. White-flowered biennial or perennial herbs. About 5 species, Europe and Asia; 1 nat. in U. S.

a. A. Alliária (L.) Brit. (Erysimum Alliaria L., Sisymbrium Alliaria Scop., Alliaria officinalis Andrz.). Europe and northern Asia, nat. in U. S. Hedge Garlic, Garlic Mustard, Garlic wort, Cardiackeł, English Treacle, (i. e. Theriac), Poor-man'streacle, Poor-man's-mustard, Leek Cress, Jack-by-the-hedge, Penny-hedge, Sauce-alone, Swarms; Ger. Knoblauchkraut; l'r. Alliaire Commune. Plant antiscorbutic.

75. ALLIÓNIA, Loefl. 1758. Umbrella-wort. Nyctaginaceae. Named for C. Allioni, Italian botanist, d. 1804. Syn. Oxybaphus, L'Her. 1797. Herbs. About 20 species, mostly American; 9 in U. S.

a. A. hirsuita Pursh (O. hirsutus Choisy). Texas to Minnesota and northward. Hairy Umbrella-wortg. Musk.

76. ÁLLIUN, L. Onion, Leek, Garlic, etc. Liliaceac. Latiu name of Garlic. Bulbous h+rbs with intolerable odor (alliaceous). About 275 species; 59 in U. S. Medicinal properties of all species similar to those of $(\mathrm{e})$.

a. A. Ascalónicum L. Commonly cultivated. Shallot, Seallion, Cibol; Ger. Schallotte; Fr. Échalote. Bulb esculent.

b. A. Canadénse L. Eastern U.S. Meadow Garlic, Wild Garlic.

c. A. Cépa L. Universally cultivated. Onion; Ger. Zwiebel, Zipolle, Bolle; Fr. Oignon Commun (Codex). Bulb esculent.

d. A. Pórrum L. Commonly cultivated. Leek, French Leek, Ollick, Scallion*; Ger. Lauch; Fr. Porreau. 
e. A. satírum L. (Porrum sativum (L.) Reich.) Commonly cultivated. Garlic (Garlete), Clown's treacle, Poor-man's treacle (treacle, an antidote to venemous bites, the same as theriac); Ger. Kinoblauch, Gartenlauch; Fr. Ail (Codex). Bulb, Allium U. S. P.. Bulbus Allii, Radix allii sativi. Esculent, antispasmodic, diuretic, emollient, anthelmintic.

f. A. Schoenuprásum L. Northern U. S., Europe and Asia, also commoniy cult. Chives (Cives, Civet, Sithes, Siethes, Syves, Sweth), Rush Girlic, Clive Garlic, Shore Onion; Ger. Schnittlauch; Fr. Civette. Leaves used in salads, etc.

g. A. tricóccum Ait. Canada to N. Carolina, west to Minnesota. Wild Leek, Three-seeded Leek $\xi$.

h. A. ursínum L. Europe. Bear's Garlic, Ramsons (originally Ram's-horns) Ramps, (Ramsden, Rams, Roms) Buckrams, Devil's-posy, Hog's-garlic, Wild Leek, Gypsy Onions.

i. A. Victoriális L. Central Europe and Asia. Allerman's-root; Ger. Allermannsharnisch (langer). Bulb, Bulbus victorialis (longus), antispasmodic.

j. A. vineále L. Europe. nat. in eastern U. S. Wild Garlic, Field Garlic, Crow Garlic, Cow Garlic, Crow Onion.

77. AlLOCíRYA, Greene. Allocarya. Boraginacege. From Greek, "dıfferent nuts." Syn. Krynitzkia, Eritrichium, in part. Insignificant annuals. About 27 species in western U. S.

78. ALLÓTPOPA, Gray. Allotropa. Monotropaceap. From Greek, "diversely turned", (compare Monotropa). A leafless parasite. One species, California.

79. ÁLNUS, Gaertn. - Alder. - Betulaceae. The Latin name, from Celtic. Syn. Betula, in part. Trees or shrubs. About 15 species, northern hemisphere and Indes; 10 in U. S.

a. A. glutinósa (L.) Medic. (B. Alnus var. glutinosa L.) Europe and Northern Asia. European Alder (Aller, Eller, Aul, Owler, Howler, Hollard, Orl), Dog-tree (North England), Black Alder, Irish Mahogany; Ger. Eilenbaum, Schwarzerle, Eller; Fr. Aune noir; Sp. Aile. Bark astringent, febrifuge.

b. A. rugósa (Du Roi) K. Koch. (A. serrulata Willd.). Eastern U. S. Tag-alder, Smooth Alder, Green or Common Alder, American Alder, Red or Speckled Alder. Bark alterative, emetic, astringent.

so. íLOE, L.

Aloe.

Liliaceae.

The Greek name. Scapose herbs. About 60 species, warmer regions, especially of Africa. 
a. A. Abyssínica Lam. 'Northeastern Africa. The probable source of Jafferabad Aloes.

b. A. férox Mill. South Africa. Inspissated juice of the leaves of this, also of $(\mathrm{g})$ and $(\mathrm{k})$, Cape Aloes, Alce Capensis. U. S. P., 1870, Aloe, P. G., Aloe lucida; Fr. Aloès du Cap (Codex, in which, however, this species is marked with an interrogation point). Other South African species from which Aloes is derived are (c) A. Africána Mill. (P. G. and Codex), (d) A. arboréscens Mill., (e) A. Commelyni Willd., (f) A. linguifórmis L. (Codex), (g) A. Língna Willd (Gasteria Lingua Link.), (h) A. perfoliáta L. (Codex) and (i) A. purpuráscens Haworth. Laxative, cathartic.

j. A. Pérryi Baker. Socotra. Source of Socotrine Aloes, Aloe Socotrina, U. S. P., Br.; Ger. Aloe Sucotrina; Fr. Aloès Sucotrin. This has long been regarded as the best rariety of Aloes but the yield of aloin is small.

k. A. spicáta L. South Africa. One of the chief sources of Cape Aloes (Codex). See (b).

1. A. Succotrfna Lam. (A. vera Mill., Not L. Probably includes A. officinalis Forsk. and A. rubescens DC.). Eastern Africa. Source of the Moka and the common Socotrine Aloes (F. von Mueller).

m. A. véra $(\mathrm{L}$. ) Webb. (A. perfoliata var. vera L., A. vulgaris Lam., A. Barbadensis Mill. Includes A. Indica Royle and A. littoralis Koenig.) India to northwestern Africa, nat. in West Indies. Source of Barbadoes Aloes, Hepatfe Aloes and Curaçao Aloes; Aloe Barbadense. U. S. P., Br.; Ger. Barbados Aloe, Curassao Aloe; Fr. Aloès des Barbades, de la Jamaique ou des Antilles (Codex), Aloès hépatique. Laxative, cathartic.

81. ALÓPHLA, B. \& H. - Alophila. - Iridaceae. Herbs; 2 species in $\mathrm{U}$. S.

82. ALPÍYIA, L. - Galangal. - Zingiberaceae. Syn. Galanga, in part. Herbs from branching rhizomes, flowers ornamental. About 40 species, warmer regions of Asia to Australia. See Kæmpferia.

a. A. Galángal Willd (Galanga officinalis Salisb.). Java. Greater Galangal. Properties of (b) but feebler.

b. A. officinárum Hance. Southern China. Galangal, Smaller Galangal, Galangale, Galanga, East India Catarrh-root, C'hinese Ginger; (xer. Galgant; Fr. Galanga officinal, Galanga de la Chine (Codex). Rhizome, Rhizoma Galangæ P. G., Radix galangæ minoris; aromatic, carminative, stomachic.

S3. A LSÍNE, L. 1753. Chickweed, Starwort, etc. Caryophyllaceæ. From Greek, "grove", indicating the habitat. Syn. Stellaria, L. 1753; Cerastium, in part. Small annual weeds. About 75 species; 25 in U.S. 
a. A. aquática (L.) Brit. (Cerastium aquaticum L., Stellaria aquatica Scop.) Europe, Adv. in U. S. Water Mouse-ear Chickweed, Water Chickweed.

b. A. Holóstea (L.) Brit. Europe and northern Asia, adv. in U. S. Greater Stitchwort or Starwort, Adder's-meat, Allbone, Easter-bell, Lady's-lint, Snake-grass, Snake-flower, Snap-jack, Snappers, Star-flower, Thunder-Hower, White-bird.

c. A. média L. (Stellaria media Cyr.). Europe, northern Asia and N. America, and widely nat. Common Chickweed, Chickenweed, Satin-flower, Tongue-grass, White-bird, Winter-weed. Formerly reputed refrigerant, demulcent and alterative.

d. A. púbera (Michx.) Brit. (Stellaria pubera Michx.) Eastern U. S. ; Pennsylvania, southward. Great Chickweed, Star Chickweed.

84. ALSÓPHILA, R. Br. Tree-fern. Polypodiaceae. From Greek, "grove loving." Tree ferns. About 50 species, tropical and subtropical regions.

a. A. lúrida Hook. Java. The capillary chaff from this and allied species is the paku-kidang or pakoe-kidang used as a styptic in surgery. See Balantium and Cibotium.

55. AlstónIA, R. Br. Alstonia, Dita. Apocynaceae. Named for Dr. Alston, botanist of Edinburgh. Syn. Echites, in part. Trees or shrubs with a milky juice. About 20 species, tropical regions of Old World.

a. A. constrícta F. Muell. Australia. Alstonia bark, Australian Fever-bark, Bitter-bark, Native Quinine. Properties of (b).

b. A. scholáris (L.) R. Br. (Echites scholaris L.) East Indies; Philippines to Australia. Dita, Devil's-tree, Pali-mara (Bombay). Bark, Dita bark; Ger. Ditarinde; Fr. Écorce de Dita (Codex); Bitter, antiperiodic.

c. A. spectábilis R. Br. Java. Source of Poele-bark, more active than the foregoing.

\$6. ALTERNANTHÉRA, Forsk.

Amaranthaceae.

From Latin, "with alternate anthers" Dwarf tufted plants, some with variegated foliage, (commonly known as Achyranthesf). About 20 species, Australia and tropical America; 2 in U. S.

87. ALTHAÉA, L. Mallow*, Hollyhock, etc. Malvaceae. The Greek name, "'healing." syn. Alcea, in part. Mucilaginous herbs. About 15 species, Old World; 1 nat. in U. S.

a. A. officinális L. Europe and Asia, sparingly nat. in U. S. Marsh-mallow, White Mallow, Mortification-root, Sweat-weed, Wymote; Ger. Althee, Eibisch; Fr. Guimauve (Codex); Sp. Altea, Malvavisco. Root, Althaea. U. S. P.; Radix Althaeæ P. G., Rad. bismalvæ, Rad. malvavisci v. hibisci. Mucilaginous, demulcent. Leaves and flowers are also official in French Codex. 
b. A. rósea (L.) Cavanilles (Alcea rosea L.). Levant, cult. in gardens. Hollyhock (Holly Oakt, Holy Hokeł, Hollikocket, Hollekł, Hock, Hockholler), Althea Rose; Ger. Stockrose. Stockmalve; Fr. Rose tremiere, Passerose. Floners, Flores malvae arboreae, mucilaginous, emollient.

88. ALÝSSUM, L.

Alyssum.

Cruciferat. The Greek name, signifying perhaps "curing blindness.", Srin. Clypeola. in part. Low annual or perennial herbs. About 100 species, Old World; 1 nat. in U. S. See also Koniga.

a. A. alyssoídes (L.) Gouan. (Clypeola alyisoides L. 175̃3, A. calycinum L. 1762). Europe, adv. in U. S. Yellow or Small Alyssum, Heal-bite, Heal-dog.

89. ALæXIA, Banks. - Alyxia. - Apoeynacer. Shrubs or small trees. About 40 species, tropical Asia to Australia.

a. A. olirafórmis Gaud. Hawaiian Islands. Maile. The fragrant Myrtle-like leaves used for festal wreaths (leis). The MIaire of 'Tahite is an allied species.

b. A. stelláta R. \& S. East Indies. Bark used like Canella.

90. AMANítA, Pers.

Hymenomycetes, Agaricini.

Greek name of a fungus. Mushrooms of a poisonous or suspicious character, some, however,'edible. About 50 species, especially of Europe and S. America.

a. A. museária (L.) Pers. (Agaricus muscarius L.). Europe, mostly under pine trees. Fly Agaric, Flybane, Fly Fungus, Bug Agaric, Poisonous Mushroom; Ger. Fliegenschwamm, Fliegenpilz; Fr. Agaric mouche, Fausse oronge. Fungus used to control night sweats.

b. A. pha:loídes Fries. Europe and U. S. Death-cup. The most poisonous of all Mushrooms.

91. AMARíNTHUS, L. (Amarantus)

Amaranthacex. The Greek name, "unfading". Syn. Euxolus, Amblogyne, in part. Coarse anmuals, mostly weeds, a few ornamental. About 50 species, cosmopolitan; 30 in U. S. including nat. species. The ornamental species are known as Amaranth, the weeds as Pigweed.

a. A. caudátus L. India, cult. in gardens. Prince's-feather*, Cat's-tail, Floramor, Flower-gentle, Love-lies-bleeding*, I'assevelours, Velvet-flower, Thrumwort, many of these names applied also to $(b)$ and $(d)$.

b. A. Gangéticus L. (including A. nelancholicus L.). Easteru Asia, cult. in gardens. The variety melancholicus is called Love-lies-bleeding, Lovely-bleeding and Nun's Whipping-post, Var. tricolor is Joseph's-coat (of many colors). Plant used by Chinese as a pot herb. 
c. A. graécizans L. 1753 (A. alba L. 1763). Tropical America, nat. in U. S. Tumbleweed, Pigweed.

d. A. hýbridus L. (Includes A. hypochondriacus L. and A. chlorostachys Willd.). Tropical America, cult. in gardens. Slender Pigweed?, Green or Red Amaranth (varieties), Pigweed, Amaranth, Careless, Pilewort, Balder-herb. The cultivated variety is called also Prince's feather*,Floramor, Flower-gentle, Red Coxcomb, Lovely-bleeding, etc. Plant mildly astringent.

e. A. retrofléxus L. Tropical America, nat. in U. S. Common or Rough Pigweed, Red-root*, Beet-root.

92. AMAR ĹLLIS, L. Belladonna Lily. Amaryllidaceæ. Greek proper name, "sparkling" or "twinkling". Syn. Belladonna. A scapose bulbous plant with lily-like flowers. One species, south Africa.

a. A. Belladónna L. (Belladonna purpurascens Sweet). South Africa and cult. for ornament. Belladonna Lily.

93. AMBLYóLEPIS, DC. Amblyolepis. Compositre. From Greek, "blunt-scaled". A comarin-scented anuual. One species, Texas.

94. AMBLYOPÁPPUS, Hook. \& Arn. From Greek, witl "obtuse pappus". Syn. Aromia, Infantea. Low annuals. About 4 species; 1 nat. in California.

95. AMBRÓSIA, L. Ragweed. Ambrosiaceae (Compositæ). The Greek name, Ambrosia, the fabled food of the immortals. Coarse rank weeds. About 12 species, mostly American; 8 or 9 in U. S.

a. A. artemisiafólia L. Eastern U. S. to British Columbia and Mexico. Ragweed, Common Ragweed, Hogweed, Roman Wormwood, Wild 'Tansy, Stammerwort, Black-weed, Bitterweed, Tassel-weed, Stick-weed, Carrot-weed, Bastard Wormwood. The pollen is accused of causing hay asthma.

b. A. trífida L. Ontario to Florida and Colorado. Tall Ambrosia, Great Ragweed, Giant Ragweed, Horse-cane, Horse-weed, Bitter-weed, Rich-weed, Wild Hemp, Buffalo-weed. Plant, like foregoing, astringent, detergent, antiphlogistic, etc.

96. ANELÁNCHIER, Medic. June-berry, etc. Pomacer. The Savoy name of the Medlar. Syn. Aronia, Mespilus, Pyrus, Cratægus, in part. Shrubs or trees with berry-like, edible fruit (pomes). $\quad \Lambda$ bout 12 species, north temperate zone; 10 in U. S.

a. A. alnifólia Nutt., Michigan to California and British Columbia. Northwestern June- or Service-berry, Pigeon-berry.

b. A Botrápium (L. fil.) DC. Canada and eastern U. S. Shadbush, Swamp Sugar-pear, Grape Pear. 
c. A. Canadénsis (L.) Medic. (Mespilus Canadensis L., Crataegus racemosa Lam. ). Canada to Florida and Louisiana. Juneberry, Service-berry, May Cherry, called also Sugar-berry, Sugar Pear, Sugar Plum, Indian Cherry, Sand Cherry*, May Pear, Juice Pear, Indian Pear, Bilberry*, Shad-bush, Service tree, Boxwood, Dogwood*.

97. AMMÁNyIA, L. Ammannia. Lythracese. Named for Johann Ammann, German botanist, d. 1741. Annual herbs. About 30 species; 4 in U. S.

a. A. Koéhuei Britton. New Jersey to Florida. Tooth-cup.

98. Á MмI, L. - Bishop's-weed. - Umbellifera. Greek name of an African Umbelliferous plant. Herbs resembling Daucus. About 12 species, mostly of Mediterranean region. See Ptychotis.

a. A. Visnága Lam. Southern Europe, northern Africa and the Orient. Tooth-pick plant, (visnaga is Spanish for tooth-pick), Bishop's-weed, El Kellah; Fr. Herbe aux cure-dents, Herbe aux gencives. Seeds diuretic, anodyne.

99. AMMODÉNIA, J. G. Gmel.1769. Sandwort. Caryophyllacex. From Greek, "sand loving". Syn. Honkenya, Ehrh. 1788. Fleshy maritime herbs. Two species, north temperate zone; 2 in U. S.

a. A. peploídes (L. ) Rupr. (Arenaria peploides L.). Europe, Asia and N. America, south to N. Jersey. Sea-beach Sandwort, Sea Chickweed, Sea Purslane, Sea Pimpernel.

100. AMMOSELÍNUM, T. \& Gr. Sand Parsley. Umbelliferæ. From Greek, "sand parsley". Low annuals. Two species, both of Mexican border, U. S.

101. Aı́́MUM, L. Cardamom*, etc. Zingiberaceae. Greek name of some Eastern spice plant. Herbarenus plants from creeping rootstocks. Tropical regions of Old World. See Elettaria.

a. A. angustifólium Sonnérat. Madagascar. Probable source of Madagascar Cardamom.

b. A. Cardamómmm L. East Indies and Siam. Fruits constitute Round Cardamom or Cluster Cardamom; Fr. Amome en grappes (Codex), used in southern Europe.

c. A. globósum Lour. China. Fruits are the Chinese Cardamon or Round Chinese Cardamom.

d. A. Granum-paradísi Afz. Sierra Leone. Seeds of this and of several other species have been known as Grains of Paradise, Grana paradisi. See $(g)$. 
e. A. Koraríma Pareira. Eastern Africa. The plant, not yet described, yielding Korarima Cardamon, Korarima, Heil, Guráji spice, Habhal-habashi, Heel-habashee; Cardamomum majus (true).

f. A. Háximum Roxb. Java. Fruits are Java Cardamom.

g. A. Meloguéta Roscoe. Western Africa. Seeds Melegueta Pepper (Piper Melagueta), Grains of Paradice (grana paradisi), Paradise seed, Gruinea grains; pungent, now used only in veterinary medicine and in sophisticating liquors.

h. A. subulátum Roxb. India. Fruits are the winged Bengal Cardamom, Morung Elachi or Buro Elachi. [The similar Nepal Cardamom is derived from an undetermined species of Amomum.]

i. A. Xanthioídes Wallich. Further India. Fruits are known in England as Bastard or Wild Cardamom of Siam; Xanthioid Cardamom.

102. AMOREÚXIA, Moç. \& Sess. Amoreuxia. Bixaceae. Syn. Euryanthe, in part. Shrubs with showy flowers. About 3 species, warmer regions of New World; 1 in U. S.

103. AMÓRPHA, L. False Indigo. Papilionaceae. From Greek, "anomalous", the flowers having but one petal. Shrubs with spiked violet, blue or white flowers. About 10 species, all of U. S. (and Mexico.)

a. A. canéscens Pursh. Prairie region. Lead plant, Shoe-strings, Wild Tea.

b. A. Pruticósa L. Florida to Colorado and Manitoba. False or Bastard Indigo, River Lucust. Forwerly a source of indigo.

104. AMPÉLANUS, Brit. 1894. Sand-vine. Asclepiadaceae. From Greek, "vine-like". Syn. Enslenia, Nutt. 1818, [not Raf. 1817]. Herbaceous twining vines. Three species, New World; 2 in U. S.

105. AMPELÓPSIS, Michx. 1803. Ampelopsis. Vitacex. From Greek, "resembling the grape-vine". Syn. Cissus Pers. 1805 (not L. 1753). Wroody climbers or shrubs. About 15 species, mostly of Old World; 2 in U. S. See Parthenocissus.

a. A. arbórea (L.) Rusby (Vitis arborea L., V. bipinnata T. \& Gr., Cissus stans Pers.). Southeastern U. S. to Cuba. Pepper-vine, Pinnate-leaved Ampelopsis?.

106. AMPELOSÍCYOS, Thou. 1807 . From Greek, "grape-vine" and "cucumber". Syn. Telfairia, Hook. 1827, Joliffia, Boj. 1827, also impelosycios. Shrubby climbers. Two species, tropical Africa. 
a. A. scándens Thou. (T. pedata Hook., J. Africana Delile). Zanzibar. Seeds edible; yield a bland fixed oil.

107. AMPHĹ́CHYRIS, DC. Amphiachyris. Composita. From Greek, "chaff all around". Syn. Brachyris, in part. Small herbs. Two species, both of U. S.

108. AMPHIÁNTHUS, Torr. Amphianthus. Seroplulariaceae. From Greek, a flower being produced both at base and apex of stem. Minute aquatic annual. A single species, Georgia.

109. AMSÍXKIA, Lehm. Amsinckia. Boraginaceae. Named for William Amsinck of Hamburg. Syn. Benthamia, Lithospermum, in part. Rough-hispid annuals. About 10 species, New World; 6 in U. S., Pacific border.

110. AMSÓNIA, Walt. - Amsonia. - Apocynacege. Named for Charles Amson of South Carolina. Perennial herbs with blue or bluish flowers. About 8 species, $\mathrm{N}$. America and eastern Asia; 6 in U. S.

111. AM ÝGIDLUS, L. Almond, Peach, etc. Drupaceae. Greek name of "almond". Syn. Prunus, Persica, in part. Trees, mostly with fleshy fruits. About 8 species, Asia and N. America; 2 in U. S.

2. A. commúnis L. (Prunus Amygdalus Baill.). Western Asia, now cult. in all subtropical countries. Almond tree; Ger. Mandelbaum; Fr. Amandier. There are two varieties, amara and dulcis of De Candolle, the former yielding Bitter Almonds, the latter Sweet Almonds, Malaga Almonds, - Jordan Almonds (a large variety), Paper-shell Almonds (with thin shell). Fruit of the former is smygdala smara, U. S. P., Br. Amygdalæ amarae P. G., Semen amygdali amarum; Ger. Bittere Mandeln; Fr. Amandes amères (Codex); Sp. Almendras amargas. Sedative, containing potentially hydrocyanic acid. Fruit of the latter is Amygdala dulcis, U. S. P., Br., Amygdalæ dulces, P. G., Semen amygdali dulce; Ger. Süsse Mandeln; Fr. Amandes douces (C'odex), Sp. Alnendras dulces. Esculent, emollient, yield a bland fixed oil.

b. A. Pérsica L. (Prunus Persica Stokes, Persica vulgaris DC. ). Southeastern Asia, now widely cultivated. Introduced from Persia, hence the name Persica (malum persicum). Peach; Ger. Pfirsch; Fr. Pêcher; Sp. Melocoton Lurazno. Var. necturina Maxim (Persica Necturina Steud., A. glabra Auct.) is the Nectarine; var. platycárpa Gray is the Peen-to or Flat Peach of the southern U. S. Leaves and kernels contain potentially hydrocyanic acid; sedative, vermifuge. [In some varieties the kernels are sweet.]

112. AMYRIS, L. Torch-wood, Candlewood. Rutaceae. Greek name, perhaps connected with "nyrrh". Trees and shrubs. About 12 species, warmer regions of New World; 2 in $\mathrm{U}$. S. 
113. ANACíMPTIs, Rich. Anacamptis.

Orehidaceae.

Fron Greek, "bent backwards". Syn. Orehis, in part. European terrestrial orchids. About 3 species.

a. A. pyramidális Richard. Europe. Tubers eonstitute one variety of salep. See Orchis.

114. ANACÁRDIUM, Rottb. Cashew. Anacardiaceae. From Greek, "heart-like". Syn. Cassuvium, in part. Shrubs or trees. About 8 species, tropical America. See Semecarpus.

a. A. occidentále L. (C'assuvium pomiferum Lam.). Tropical America. ('ashew-nut tree, West Indian Cashew; Ger. Westindische Anacardien, ('ashunuss; Fr. Acajou à pommes; Sp. Anacardo. Rind of finit acrid, vesicant. Kernels when roasted edible.

115. AYACYCLUS, L. - Pellitory. - Compositae. Herbs with flower-heads of medium size. About 10 species. Mediterranean region.

a. A. officinárum Hayne. Germany. German Pellitory; Ger. Deutsche Bertramwurzel, Zahnwurzel, Speichelwurzel; Fr. Pyrèthre conımun. Root, Radix pyrethri germanici, Rad. dentariæ, Counter-irritant, sternutatory.

b. A. Pyréthrum (L. ) DC. (Anthemis Pyrethrum I., Matricaria Pyrethrum Baill.). Northwestern Africa. Pellitory, Pellitory of Spain, Spanish Camomile, Alexander's-foot, Bertram, Longwort. Root Pyretiorum. U. S. P., Pyrethri radix, Br., Rad. pyrethri romani; Ger. Römische Bertramwurzel; Fr. Pyrèthre officinal (Codex), Pyrèthre vrai (roman). Salivaire; Sp. Peritre. Sternutatory, sialagogne, counter-irritant.

116. ANAGáLLIs, L. Pimpernel. Primulaceae. From Greek, "delightful". Annual or perennial weeds. About 15 species, all but one of Old World; 1 nat. in U. S.

a. A. arrénsis L. Europe, nat. in L. S. and widely elsewhere. Red Pimpernel, Srarlet Pimpernel, Red Chickweed or Chickenweed, Burnet Rose, Bird's-eye, Bird's-tongue, Eye-bright, John-go-to-bed-at-noon, Orange-lily Pernel, Poor-man's-weather-glass, Shepherd's-calender, Sliepherd's-clock (or-watch), Shepherd's-delight, Shepherd's-sundial, Shepherd's-warning, Sun-flower*, Tom I'impernowl, Waywort, Wink-a-peep, Wincopipe (Bacon); Ger. (Gauchheil, Rothe Miere, Collmarkraut; Fr. Mouron rouge. Plant acrid, containing Saponin. [Blue Pimpernel is a variety, $A$. arvensis corulea (Lam.) Ledeb.]

117. AVAMÍRTA, Colebr. Cocculus Indicue. Menispermacex. Syn. Menispermum, Cocculus, in part. A slurubby climber. One species, Old World. 
a. A. Cócculus (L.) Wight \& Arn. (M. Cocculus L. . M. lacuncsum Lam. A. paniculata Colebr., Cocculus suberosus DC.). East Indies and Hindustan. Fruit, Cocculus Indicus, Indian Cocculus or Cockle, Fish-berries, India-berries, Oriental-berries, Levant-nut; Ger. Kockelskörner, Fischkörner, Tollkörner; Fr. Coque du Levant (Codex). Source of Picrotoxinum, U. S. P., Br., powerful poison; parasiticide.

118. ANAMÓMIS, Griseb. Anamomis. Myrtaceae. Syn. Luma, H. B. K., also Eugenia and Myrtus, in part. Trees. About 3 species, warmer regions of New World; 1 in U. S.

119. ANÁNAS, Adans. - Pine-apple. - Bromeliaceae. From vernacular, S. America. Syn. Ananassa Lindl. Bromelia, in part. Suffrutescent plants with a fleshy compound fruit. About, 6 species, tropical America.

a. A. Anánas (L.) Lyons (B. Ananas L., A. sativa Schult., Ananassa sativa Lind.). South America and cult. in all tropical countries. Pine Apple, Pine*; Ger. Ananas, Kronananas; Fr. Pomme d' ananas, Pain de sucre. Unripe fruit, astringent, diuretic, anthelmintic. Ripe fruit contains a peptonizing ferment; esculent.

120. ANÁNTHERIX, Nutt. Anantherix. Asclepiadaceae. From Greek, "awnless". Syn. Acerates, in part. Perennial herb. A single species, Georgia to Florida.

121. ANÁPHALIS, DC. Life-ererlasting. Compositae. Greek name of some Composite plant. Syn. Gnaphalium, Antennaria, in part. Woolly herbs resembling Gnaphalium. About 30 species, north temperate zone; 1 in U. S.

a. A. margaritácea (L.) Benth. \& Hook. (G. margaritaceum L., Antennaria margaritacea Hook.). Northern Asia and N. America, south to N. Carolina, Kansas and California. Pearly Everlasting, Large-flowered Everlasting, Life-everlasting*,Livelong, Ever-white, Cotton-weed, Indian-posy, Lady-never-fade, Ladies' Tobacco, Moonshine, None-so-pretty*, Old-sow, Poverty-weed*, Silver-button, Silver-leaf. Plant, aromatic, antiseptic, vulnerary.

122. ANASTÁTICA. L. Rose of Jericho. Cruciferae. From Greek, "resurrection" plant. Annual herb. One species, Mediterranean region.

a. A. Hierochúntica L. Deserts of Syria, Arabia and northern Africa. Rose of Jericho, Resurrection-plant; Fr. Jérose hygrometrique.

123. ANCHIÉTEA, St. Hil. Anchietea. Violacere. Named for P. Anchietea, Brazilian botanist. Syn. Noisettia, in part. Shrubby climbers. About 4 species, S. America.

a. A. salutáris St. Hil. (N. pyrifolia Mart.). Brazil. Root emeto-cathartic, alterative. 
124. ANCHÚ:SA, L.

ANCHÚs A, L. - Alkanet. - Boraginaceae. World.

a. A. officinális L. Europe. Bugloss (from Greek, meaning oxtongue), Ox-tongue, Garden Alkanet or Orcanet; Ger. Ochsenzungenkraut; Fr. Buglosse (Codex, which includes also (b) A. Itálica L., Italian or Small Bugloss. ). Plant demulcent, diaphoretic.

125. A NCISTROCÁRPHUS, Gray. Ancistrocarphus. Compositre. From Greek, "fishhook chaff"'. Syn. Stylocline, in part. Low canescent annual with small glomerate flower-heads. One species, California.

\section{ANDA. See JOANNESIA.}

\section{ANDIRA. See VOUACAPOUA.}

126. ANDRÁCHNE, L. Andrachne. Euphorbiaceae. Syn. Lepidanthus, in part. Herbs or shrubby plants with small axillary flowers. About 10 species; 1 in $\mathrm{U}$. $\mathrm{s}$.

127. ANDROGRÁPHIS, Wall. Andrographis. Acanthaceae. Syn. Justicia, in part. Herbs, some suffrutescent. About 20 species, tropical Asia.

a. A. paniculáta Nees. (J. paniculata Burm.). India. Kariyat, Creyat. Herb bitter, tonic.

128. ANIDRÓNEDA, L. Wild Rosemary. Ericaceae. Name from Greek mythology A small evergreen shrub with acid foliage. One species, (U.S.)

a. A. Polifólia L. Northern Europe, Asia and N. America, south to New Jersey and Michigan. Wild or Marsh Rosemary, Marsh Holy-rose, Mloorwort. Plant reputed poisonous.

129. ANDROPÓGON, L. Beard-grass. Gramineae. From Greek, "man beard", the staminate flowers having awns. Syn. Vetiveria, in part. Tall grasses. About 150 species; 36 in U. S.

a. A. Cálamus Royle. Central India. The Sweet Calamus of the ancients. Source of the Ginger-grass oil of Nemaur (F. von Mueller).

b. A. citrátus DC. India. Lemon-grass, Verbena-grass. From this and some allied species are distilled the oils used in perfumery as grass oil, oil of verbena, oil of spikenard (Mueller).

c. A. Nárdus L. India. Nard-grass, Spikenard*. Source of Citronella oil, called also by names under $(b)$. 
d. A. Schoenảnthus L. (A. pachnodes Trin., A. Martini Roxb.). india. Ginger-grass, Lemon-grass*, Camel's-hay, Indian Ger:tnium. Source of Siri oil, called also Turkish oil of Geranium, Rusa oil, Roshé or Rosé oil, Idris-yaghi (Turkey), used for adulterating oil of rose. An allied speeies, also yielding oil, is (e) A. Ivaraucusa Roxb.

f. A. squarrósa I. (A. muricatus Retz. A. odorata Virey, V. arundinacea Griseb.). Indiat, widely distributed in tropical countries. Kuskus grass, Vetiver; Fr. Chiendent des Indes. Roots, properly called vetiver, also kuskus, nsed for making the fragrant mats called tatties. Source of Tetiver oil, used in perfumery.

130. ANDRósACE, L. Androsace. Primulareae. From Greek, "man's shield". Low herbs with tufted basal leaves. About 50 species, northern hemisphere; 6 in U. S.

131. ANDROSTÉPHIUM, Torr. Androstephium. Liliaceae. From Greek, "man's crown', the filaments forming a crown. Syn. Milla, in part. Scapose herbs from a tuberous root. Two species, both of U. S.

a. A. coerúleum (Scheele) Greene (M. coerulea Scheele, A. violaceum Torr.). Kansas to Texas. Babies'-breath.

133. ANÉMIA, Swz. (Aneinia). Flowering Fern*. Achizaraceac. From Greek, "without covering", Aneimia being the more correct form. Small ferns with fertile portions of fronds contracted into semblance of a spicate inflorescence. About 15 species; 2 in U. S.

133. ANEMÓNE, L.

Anémone.

Ramunculacege.

The (ireek name, meaning "wind" flower. Perennial herbs with palmately divided leaves. About 100 species, temperate and sub-arctic regions; $20 \mathrm{in} \mathrm{U}$. $\mathrm{S}$.

a. A. Canadénsis L. 1768 (A. Pennsylvanica L. 1771). British America, south to Pennsylvania and Colorado. Canada Anemone\%, Pennsylvanian Anemone, Round-leaved or Roundheaded Anemone, White-flowered Anemone or Crowfoot $†$.

b. A. Caroliniána Walt. Georgia to Texas, north to Nebraska. Carolina Anemone?, Purple Anemone, May-flower, Wood-flower.

c. A. Coronária, L. Levant and cult. in gardens. Garden Anemone. Properties of $(\mathrm{g})$. [The garden Anemoncs are varieties of this species, also of (d) A. horténsis Thor., perhaps not specifically distinet, and of (e) A. Japónica Sieb. \& Zucc.]

f. A. multífida Poir (A. Hudsoniana Richards). British America, south to Michigan and Colorado. Red Wind-flower, Cut-leaved Anemone?. 
g. A. nemorósa Michx. Europe. Wood Anemone (Anemony Aulmoneyst, Fnemyt, Neminy), Wind-tlower, Bow-bells, Cowslipt, Wood Crowfoot, Cuckoo-flower*, Cuckoo-spit*, Darngrass, Drops-of-snow, Gallant, Granny's-nighteap, Wild Jessaminet, Moon-flower*, Smellboxes, Soldiers; Ger. Weisser IVallhahnentuss; Fr. Anémone des bois, Anémone sylvie (codex). Plrant acrid, containing anemonin, used like Pulsatilla. [In siberia (h) A. ranumculoíl's L. and (i) A. sylvés. tris I. are also used].

j. I. quinquefólia L. (A. nemorosa var. quinquefolia Gray). (anada to Georgia, west to Rocky Mountains. American Wood Anemone, Wind-flower, May-flower, Snow-drops*, Thimble-weedt, also synonyms of $(g)$ with which the species has heen eonfounded.

k. I. Virginiána L. Canada and northeastern U. S. Tall Anemone, Virginian Anemone\%, Thinble weed.

1:34. ANÉ'THUM, L. - Dill. - U'mbelliferae. The Greek name of Anise or Dill. Syn. Peucedanum, in mart. Herbs, perhaps better retained in Pencedanum. Abont 3 species, Europe and Asia.

a. 1. gravéolens L. (P. graveolens, B. \& H. ). Asia Minor, now widely cult. Dill, Garden Dill, Dilly, Anet, the Anise of Scripture; Ger. Dill; Fr. Inette ('́olex), Fenouil puant; Sp. Eneldo. Fruit, Anethi fructus Br., aromatic, carminative.

135.). ANGÉLICA， L. $1753 . \quad$ Angelica. Umbelliferae. Named from its supposed magical rirtues. Syn. Archangelica, Hottim. 1814. Tall perennial herbs with compound leaves. About 30 species, northern hemisphere and New Zealand; 8 in . U. S.

¿. A. Archangélica L. (A. officinalis Moench. Archangelica officinalis Ioffin. ). Northern Europe and Asia. European dngeliea, (Jeelico+, Aunt Jerichosł). Garden Angelica, Angelica, Archangel, Bellyache root, Ait-skeiters", Skytes\|, Holy Ghost, (iround-ash*, Ground-clder*, Hemlock†, Jack-jump-about; Fr. Angélique officinale (Codex). Root, Radix angelicae; (ier. Angelicawurzel, Heilegegeistwurzel, Engelwurz, aromatic, carminative.

b. A. atropurpírea L. (A. triquinata Michx., Archangelica atropurpureat Hoffim. ). Ontario to Delaware and west to Minnesota. Angelica, American Angelica. Great or Purple-stemmed Angelica, High or Purple Angelica, Masterwort*, also nost of the strnonyms of (a). Root and seed, aromatic, carminative.

‘. A. sylvéstris L. Europe. Wild Angelica (of Europe), Goutweed*, Ground-ash.

1. A. Villósa (Walt.) B. S. P. ( A. hirsuta Muhl.). Southeastern U. S. Smaller Angelica, Southern Angelica, Hairy or Pubescent Angelica\%. l’roperties of (b). 
136. ANGRAÉCUN, Thou.

Angreecum.

Orchidaceae. Syn. Aerobion, Spreng. Epiphytes. About 15 species, tropical regions, especially of Madagascar and Africa.

a. A. frágrans Thou. Madagascar. Faham or Faam Tea, /sle of Bourbon Tea; Fr. Faham (Codex). Léares fragrant, expectorant, stomachic.

\section{ANHALÓNIUM. See LOPHOPHORA.}

137. ANISACÁNTHUS, Nees. Anisacanthus. Acanthaceae. From Greek, "unequal Acanthus". Syn. Drejera, Birnbaumia, in part. Shrubby plants. About 6 species, Mexico and its borders; 3 in U. S.

138. ANisocírPUS, Nutt. Anisocarpus. Compositae. From Greek, "unequal fruited". Syn. Madia, in part. Herbs. About 5 species, Pacitic Coast, U. S.

139. ANIsóconı, Tor. \& Gr. Anisocoma. Cichoriaceae. From Greek, "with unequal hairs", alluding to the pappus. Syn. Pterostephanus, Kellogg. Low scapose annual. One species, California to Nevada.

140. ANÓNA, L. (Annona) Custard-apple, etc. Anonaceae. From vernacular Malay name, Menona. Trees or shrubs with fleshy, sometimes edible, fruits.

a. A. Cherimólia Mill. (A. tripetala Ait.). Peru, cult. in tropical countries. Cherimoyer, Cherimolia. Fruit esculent.

b. A. muricáta L. West Indies. Sour-sop; Fr. Corassol épineux Corassol grand, Cachiman épineux. Fruit acid, not highly valued. Seeds astringent. Leaves vulnerary.

c. A. palústris L. West Indies and tropical Africa. Alligatorapple, Cork-wood tree. Wood spongy, used for corks. Fruit reputed poisonous.

d. A. reticuláta $\mathrm{L}$. West Indies. Custard-apple, Bullock's-heart, Sugar-apple; Fr. Petit Corassol, Mamilier. Fruit esculent, highly esteemed. Juice of tree acrid.

e. A. squamósa L. East Indies. Sweet-sop, Sugar-apple, Oriental Custard-apple, Cachiman; Fr. Atocire, Pomme-canelle, Atte. Seeds parasiticide. Unripe fruit astringent.

141. ÁNODA, Cav. Anoda. Malvaceae. Herbs. About 15 species, warmer regions of America; 7 in southwestern U. S.

142. ÁxOGRA, Spach. Erening Primrose. Onagraceae. Name a transliteration of Onagra. Syn. Oenothera, in part. Herbs with showy white or pink flowers. About 10 species, N. America; 9 in U. S. 
143. ANREDERA, Juss.

Anredera.

Chenopodiaceae. U. S.

Herbaceous climber. One species, West Indies to southeastern

144. ANTEXNÁRIA, Gaertn. Everlasting. Compositae. Named from likeness of pappus to "antennæ" of an insect.

- Syn. Gnaphalium, in part. Perennial woolly herbs. About 36 species, north temperate zone and South America; 23 in U. S. 'T he plants are mildly bitter and aromatic, and are esteemed vulnerary.

a. A. dioíra (L.) Gaertn. (Gnaphalium dioicum L.). Northern Europe, Asia and N. America, south to New Mexico and California. Mountain Cudweed, Mountain or Moor Everlasting, Cat's-ear, Cat's foot, Cat's-paws, Cotton-weed; Ger. Weisse oder Rothe Katzenpfötchen ( 1 mmortellen); Fr. Pied de chat (Codex). Fiover-leads, Flores gnaphalii, Flores pedis cati.

b. A. plantaginifólia (L.) Richards (G. plantaginifolium L., A Parlinii Fernald). Canada and eastern U. S. Plantain leaf Everlasting or Cud-weed, Mouse-ear Everlasting; Spring, Early or Pearly Everlasting, Pussy-toes, Dog-toes, Four-toes, White Plantain, Ladies' Tobacco, Indian or Woman's Tobacco, Love's-test, Pinı ushion, Poverty-weed.

145. ÁxTHEMIs, L. Camomile, etc. Compositae. The Greek name of Camomile. Syn. Maruta, (hamomilla, in part. Herbs with pinnatified or dissected leaves and rather large flower-heads. About 100 species, Old World; 5 nat. in U. S.

a. A. arvénsis L. Europe, nat. in U. S. Corn Camomile (Chamomile), Field Camomile.

b. A. Cótula L. (Maruta Cotula DC. ). Europe and northern Asia, nat. in U. S. and widely elswhere: May weed, Dog's Camomile, Fetid or Stinking Camomile, Fetid May-weed, Bald-eyebrow, Balderbræ + , Balders, ('higger-weed, Dog or Horse Daisy, Pig-sty or Poison Daisy, Dillweed, Dillidillweed, Dog-fennel, Dog-tinkel, Dog-banner, Dog-binder, Dog Camoryne, Fieldwort, Flowan, Hog-fennel, Jay-weed, Madder", Maden-weed. (i. e. Mayweed), Maise, Marg, Mathes, Morgan, Murg; Ger. Stinkkamillen.

c. A. nóbilis L. (C. nobilis Godr.). Europe, cult. in (ireat Britain, Germany, France and Belgium, cult. and adv. in L. S. Garden, English, White or Low Camomile ('hamomile, Camomine, Camovyne $\ddagger$, Camil), Scotch Camonile ( form with"single" flowers), Roman Camomile (form with "double" flowers), Ground-apple, Whig-plant; Ger. Römische Kamille; Fr. Canomille romaine (Codex); Sp. Manzanilla romana. Fiowcr-heads, Anthomis. U. S. P., Anthemidis flores, Br., Flores Chamonillæ romanæ, stimulant tonic, stomachic, nauseant. See Matricaria.

146. ANTHÉRIIUM, L. Anthericum. Liliaceae. Syn. Phalangium, in part. Scapose herbs with fleshy fasciculate roots. About 60 species, mostly of Europe, Africa and Australia, a few American; 2 in U. S. 
147. ANThoxínthuM, L. Vernal-Grass. Gramineae. From Greek, "yellow flowered". About 5 species, Europe; 2 nat. in U. S.

a. A. odorátuu L. Europe, nat. in U. S. Sweet Vernal-grass, Sweet-seented Grass, Spring-grass, Pig-grass, Prim-grass. Plant fragrant, abounding in coumarin.

148. ANTHRíscus, Hoffm. Chervil. Umbelliferae. Greek name of an umbelliferous plant, perhaps (a). Syn. Cerefolium, Chaerophyllum, Seandix, in part. Parsley-like herbs. About 10 species, Old World; 3 nat. in U. S.

a. A. Anthríscus (L.) Karst. (Chaerophyllum Anthriscus I., A. vulgaris Bernh.). Europe. Bur-chervil, Hemlock-chervil, Rough Chervil. Plant distinctly poisonous.

b. A. C'erefólium (L.) Hoffin. (Scandix Cerefolium L., ('haerophylInm sativum Lam.). Europe, sparingly nat. in eastern I'. 's. Garden Chervil, Chervil (Chevorell), Beaked Parsley; (ier. Keruel, Gartenkerhel; Fr. Cerfeuil. Plint, Herba cerefolii $₫$. chaerophylli, deobstruent, diuretic. Youngleares used in silads, ete.

c. A. sylvéstris (L.) Hoffn. Europe. Wild Chervil, Wild Cicely, Wild Caraway, Ass-parsley, Cow-chervil, Cow-weed, Cow-mumble, Cow-parsley, Coney-parsley, Devil's-parsley, Kettle-dock, Orehard-weed, Rabbit's-meat, Rat's-bane, Sweet-ash, Whiteweed. [Probably many of these synonyms belong more properly to (a)].

149. ANTHÝlLIs, L. Kidney-Veteh, etc. Papilionaceane. Herbs or shrubs. About 20 species, Old World.

a. A. Vulnerária, L. Europe, western Asia and northern Africa. Kidney-veteh, Woundwort, Saumchwort, Cat's-claws, C'rawnels, Crow's-foot, Jupiter's-beard, Lady's-fingers, Lamb's-toes. Plant styptic, vulnerary. A fodder plant for sheep.

150. ANTIÁRIS, Lesch. Sack-tree, ete. Artocarpaceap. From vernacular, Java. Syn. Lepurandra, in part. Trees. About 6 species, tropical Asia to Australia.

a. A. saccidora, Dalz. (Lepurandra saceidora Nimmo, perhaps not distinct from the following). Western India. Sack-tree. Inner bark used for sacks.

b. A. toxicária, Lesch. Java. Upas-tree. Gum-resinous exudutc, upis antiar, nsed in Java as an arrow poison. See Strrchonoc Tiente.

151. ANTikRHíxUM, I. snapdragon. Scrophulariaceae. From Greek, "snout like". Annual or perennial herbs with showy flowers. Abont 40 species, Europe, Asia and western $X$. America; 18 in U. S. 
a. A. május L. Europe, cult. in gardens. Snapdragon, Great snapdragon, Dog's-mouth, Dragon's-mouth. Lion's-mouth, 'Tiger's-mouth, Toad's-mouth, Rabbit's-mouth, Bunny-mouth, Bunny-rabbit, Rabbits, Bull-dog, Catchfly, Calf-snout, Lion's. snap; Ger. Löwenmaul (grosses); Fr. Mutlier, Gueule de loup, Grueule de lion.

152. ANÝ('HIA, Michx. Forked Chickweed. Caryophyllaceate. From Greek, "whitlow" weed. Syn. Buinalis, Queria, in part. Insignificant herbs. Two species, both of $\mathrm{U}$. S.

153. APARGÍDIUM, Tor. \&Gr. Apargidium. Cichoriaceate. From G'reek, "resembling Apargia". Syn. Leontodon, in part. Scapose herb. One species, Pacific coast of U. S.

154. APHANíSMA, Nutt. Aphanisma. Chenopodiaceae. From Greek, "di-appearing". Syn. Cryptanthus, in part. Herb. A single species, California.

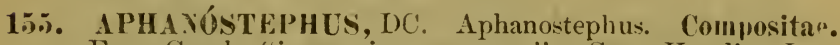
From Greek, "ineonspicuous crown". Syn. Keerlia, Leucopsidium, in part, Canescent herbs. Abont 5 species, Mexico and adjacent region; 4 in $\mathrm{U}$. S.

156. APIÁsTRUM. Nutt. Apiastrum. Cmbelliferae. From Greek, "false Celery". Syn. Leptocaulis, Apium, in part. Annual herb: Two species, both of $\mathrm{U}$. S.

15\%. ÁPIOS, Noench. Ground-nut. Papilionaceae. From Greek, "pear", alluding to shape of tubers. Syn. Glycine, in part. Twining perennials, some with tuberous rootstocks. Four species, 3 of 'Asia; 1 in L. S.

a. A. Ápios (L.) Mac M. (Glycine Apios L., A. tuberosa Moench). Eastern U. S. and Canada. (rround-nut, Indian Potato, Daknta Potato, Pig Potato, Potato P'ea, Ground Yea, Trailing Pea, White-apple, Traveler's-delight. 'Tubers edible.

1j8. ÁPILI, I. Parsley, Celery. Umbelliferae. Latin name of some umbelliferous plant. Syn. Carum, Sison, Heliosciadiun, Petroselinum, in part. Herbs with pinnately compound or dissected leares. About 15 species, 4 indigenous or nat. in $\mathrm{C}$. S.

a. A. gravéolens L. Europe, now everywhere cult. Celery (Salary + ), Celeriac (turnip-rooted variety), smallage, Smallache, Ache*, Marsh Parsley, March, Merch, Wild Parsley, Mile; Ger. Sellerie, Eppich; Fr. Ache des marais (Codex) Ache Céleri; Sp. Apio Silvestro. Fruit, Fructus apii, and root; nervine, antispasmodic, reputed aphrodisiac. Blanched lectes esculent.

b. A. Petroselínum L. (Carum Petroselinum B. \& H. (Kew), I'. sativum Hoffm.). Europe, now everywhere cult. Parsley, Common or Garden Parsley, Ache (pronounced Aitch), March; (ier. Petersilie, Petersilge; Fr. Persil (Codex); Sp. Peregil. Frnit, Fructus (Semen) petroselini, Fructus apii hortensis; source of Apiol. Emmenagogue, carminative, diuretic. The rnot is sometinies also used. 
159. APLÉCTRUM, Nutt. Adam-and-Eve. Orchidaceae. From Greek, "without spur". A scapose herb, the corm producing each season a new one by an oftset, hence the popular name. One species, U. S.

a. A. spicátum (Walt.) B. S. P. (A rethusa spicata Walt., Aplectrum hyemále Nutt., Cymbidium hyemale Wills.). Ontario to Georgia and California. Adam-and-Eve, Putty-root. Corm mucilaginous.

160. APócYYur, L. :- Dogbane. - Apocynaceae. Greek name of a poisonous plant, "dog-bane". Perennial smooth herbs with pink or white flowers in cymes. About 8 species, north temperate zone; 5 in U. S.

a. A. androsaemifólium L. British America, south to Georgia and Arizona. Dog-bane, Bitter-root, Bitter or Spreading Dogbane (Dogsbane), Catchfly*, Flytrap, Colic-root*, Honey-bloom, Milk Ipecac, Wild Ipecac, Indian Hemp*, Milkweed\%, Wandering Milkweed, Rheumati-m-weed, Western W'all-flower, Ger. Kolikwurzel.' Root emeto-cathartic, diaphoretic, alterative.

b. A. cannábinum L. British America and throughout most of U. S. Canadian Hemp, American or Black Indian Iíemp, Indian Hemp*, Amy-root, Bowńnan's-root*, Bitter-root*, Indian Physic, Rheumatisn-weed, Milk-weed*, Wild Cotton; Ger. Indianischer Hanf, Canadischer Hanf, Hundskohl; Fr. Chınvre du Canada. Root emeto-cathartic, diaphoretic, expectorant.

c. A. hypericifólium Ait. (A. cannabium var. hypericifolium Gray). British America south to Ohio and New Mexico. St. John's Dogbane?, Clasping-leared Dogbane?. Often confounded with (b) which it closely resembles.

161. APODANTHÉRA, Arn. Apodanthera. Cucurbitaceae. Peremnial herbs, About 14 species, tropical America; 1 in U.S.

162. APODÁNTHES, Poit. Apodanthes. Cytinaceae. U. S.

Minute parasites. About 10 species, widely distributed; 1 in

163. APTÉRIA, Nutt. Apteria. Burmannicese. From Greek, "leafless". Slender, practically leafless plants. Three or four species described, probably merely varieties of a single one. North America; 1 in U. S.

164. APONOGÉTON, L.1781. (Amogeton, Apogeton ). Naiadaceae. Syn. Ouvirandra, Thou. 1809. Water plants with fleshy farinaceous rhizomes. About 20 species, Asia, Africa and Australia. Ouvirandra includes the species with fenestrated leares.

a. A. Penestrále Hook. (O. fenestralis Poir.). Madagascar, Lattice-leaf, Lattice plant, Lace-leaf, Water-yam. Leares a mere skeleton. Fleshy tubers esculent. 
165. AQULLLÁRIA, Lam.

Alne-wood.

Thymeliaceae.

From vernacular name, erroneously translated "eagle wood" Syn. Agallochum, Aloexylum. Trees. About 3 species, China to East Indies.

a. A. Agállocha Roxb. (Aloexylum Agallochum Lour.). Cochin China, Assim and ajoining regions. The fragrant wood is lignaloes, the Aloes of Scripture (Lign-aloes=lignum aloes, aloes-wood) also called (alambac, Agal-wood (i. e. Agallochum wood), Aloe-wood, Aggur, Tuggur or Agila-wood, whence by confusion with Latin aquila, Eagle-wood.

166. AQUILÉGIA, L. Rolumbine. Ranuneulaceae. Frum Latin, "eagle-like", the spurs resembling talons. Perennial her's with fantastic-shaped showy flowers. About 20 species, north temperate zone; 15 in U. S. The species are acrid and the following are reputed diuretic, diaphoretic and emnienagogue.

a. A. Canadénsis L. Canada and eastern U. S. Wild Columbine, Red Columbine, Bells, Chuckies, Honer-suckle*, Jack-in-trousers, Rock-lily, Meeting-houses. Planted in gardens for ornament, as are other indigenous species.

b. A. vulgáris L. Europe. Cult. in gardens and adv. in U. S. European Columbine, Garden Columbine, (Colourbineł, Cullavine, (urranbine), Bluebell\%*, Blue-starry, Boots-and-shoes, Capon's-feather, Capon's-tail, Cock's-foot, C'ulverwort, Dove'sfoot, Granny's-nightcap, Hawk-feet, Hen-and-chickens*, Lady'sshoes, Lady's-slippers*, Snapdragon*, Sowdwort, Two facesunder-a hat; Ger. Glockenblume, Ackelei; Fr. Colombine.

167. ÍRABIS, L. Rock Cress, Wall ('ress. Cluriferae. The Greek name, "Arabian plant". Syn. Turritis, L., also Sisymbrium, Cardamine, in part. Annual or perennial cresslike herbs. About 80 species, mostlý of northern hemisphere; 48 in U. S.

a. A. alpína L. Sub-arctic Europe, Asia and N. America, also cult. in gardens. Alpine Rock-cress, Alpine Molewort, Bishop's-wig, Dusty-husband, March-and-May, May, Snowdri't, Snow-on-the-mountain, Sweet-Alice, White-Alison, White-rock.

b. A. Canadénsis L. Canada and northeastern U. S., south to Texas. Sickle-pod.

c. A. glábra (L.) Bernh. (T. glabra L., A. perfoliata Lam.). Northern Europe, Asia and N. America. Tower Mustard, Tower Cress.

d. A. Iyráta L. (C. spathulata Michx.). Canada and northeastern U. S., also in Japan. Lyre-leaved Rock-cress. Plant, as in some other species, pungent, anti-scorbutic.

168. ÁRACHIS, L. - Peanut. - Papilionaceae. Greek name of some leguminous plant. Low herbs with subterranean legumes. About 7 species, tropical $A$ nierica. 
a. A. Jypogaéa L. Tropical America, widely eult. Peanut, Gonber or Gouber (Negrues of sonthern States), (xround Pea, Ground-nut, Earth-nut, Yer-nutł, Haụh-nut, Manila-nut; Ger. Erdnuss; Fr. Pintache de terre. Seeds e-culent; yield a valuable fixed oil called in India Katchung oil.

169. AR\⿻ríLLCS, Neck. Aragallus. Papilionacear. Syn. Oxytropis, Astragalus, in part. Herhs or sub-shrubs: related to Oxytropis. About 20 species, all of wtstern $\mathrm{C} . S$.

170. ARÁLIA, L. - Aralia. - Araliacear. Name of unknown origin. Syn. Fatsia, in part. Perennial aromatic herbs, shrubs or trees. About 27 species. N. America and $A$ ia $; 6$ in $\mathrm{C}$. S.

a. A. Califórnica Wats. Pacific Coast of L.S. California Syikenard. Like (e), but larger.

b. A. Líspida Vent. Northeastern L. S. to Labrador and Minne sota. Dwarf Elder, Wild Elder, Bristly Sarsaparilla, Britılestem, Rough or Brittle-stem Sarsaparilla, Pigeon berry. Burk diuretic, alterative.

c. A. Indicaúlis L. Tortheastern C. s. to Manitola and Missouri. American Sarsaparilla, Wild or False Sarsaparilla, Virginian Sarsaparilla, Small Spikenard, Kabbit's-root. Shot-bush, Wrild Licorice: Ger. Nackte Aralie; Fr. Aralie á tige nue, Petit nard. Rhizome of this and of (e), formerly called Nardns Americanus, alterative, stimulant, diuretic.

d. A. papyrifera Hook. (more correctly Fatsia papyrifera (Hook.) Dec. \& Planch.). Formosa. The white pith, cut in sheets, is the ('hinese rice paper.

e. A. racemósa L. Northeastern L. S. to New Brumswick and Minnesota. Spikenard, American Spikenard, Spignet, Spiceberry, Indian-root, l'etty-morrel, Life-of-Man, old-man's-root; Ger. Amerikanische Nard; Fr. Nard Américain. See (c).

f. A. spinósa L. Gulf States to New York. Ilercules'-club, Toothache-tree, Wild Orange, Spikenard-tree, Pick-tree, Shotbush, Pigeon-tree, Sea Ash, Angelica tree, Southeru Prickly Hlder, Southern Prickly Asht; (ier. DornigeA ralie; Fr. A ralic épineuse. Bark acrid, alterative, antiarthritic.

171. ARAUCÁRIA, - Araucaria. - Pinacear. Lo'ty evergreen trees. About 8 species, walm region;, S. America to Australia.

a. A. Pxcélsa R. Br. Norfolk Island. Norfolk Island Pine. Timber used for ship building.

b. A. imluricáta Pavon. Chili and Patagonia. Arancaria, Monkey-puzzle. The most hardy of the Araucarias. Timber valuable. Seeds constitute the chief food of the aborigines in some regions. 
172. ÁRBUTUs, L. - Arbutus.

The clacsical Ericace. chiefly of western $A$ sia and N. America; 3 in U. S.

a. A. Menziésii Pursh. Pacific coast, U. S. California Madroño or Madroña. See 176 (d).

b. A. Unédo L. Mediterranean region. European Strawberry tree, Arbute tree, Arbeset, Apple-of-Cain, Cane-Apple; Ger. Erdbeerbaum; Fr. Arbousier (Codex), Olonier, Frasier en arbre. Root and leares astringent. From the berries a spirit is distilled.

c. A. Xalapénsis H. B. K. (Arctostaphylos Oxacana DC.).

- Mexico and southwestern U. S. Mexican Madroño or Madroña. Leares have the action of U va Ursi.

173. ARC'TERÍNTHIS, Greene. Areteranthis. Ranunculaceæ. From Greek, "northern spring-flower". One species in U.S.

174. ÁRCTIUM, L. - Burdock. - Compositæ. The Greek name, "bearish", i. e. rough. Syn. Lappa, in part. C'oarse biennial herbs, forming troublesome weeds. About 6 species, Europe and Asia; 3 nat. in U. S.

a. A. Láppa L. (L. major Gaertn.). Europe and Asia, nat. in U. S. and widely elsewhere. Burdock, Great Burdock, Bazzies, Bachelor's-buttons*, Beggar's-buttons, Billy-Buttons, Bourholnı, Clive, Clotbur* (Clote-bur, Clit-bur), C'ockle-bur* (Cockly-bur, ('rocklety-bur, Cuckoldy-bur), Cuckold-dock, ('ucklemoors, Cuckoo-button, Harebur, Hurr-bur, Hardock, Hoar-dock, Stick-button, Thistle*, Turkey-bur; Gier. Klettenwurzel; Fr. Bardane, (Codex) Glouteron; Sp. Bardana. See (b).

b. A. mímus Schk. (Lappa minor DC., A. Lappa var. minus A. Gray). Europe and Asia, nat. in U. S. and widely elsewhere. Lesser Burdock, Common Burdock (of U. S.). Generally confounded with (a) and called by the same names. Both are included in A. officinalis Allioni and Lappa rulgaris Neilr. Root of both species, Lappa U. S. P., Radix bardunæ, and fruit, , Fructus lappæ, Semen bardanæ; alterative, deobstruent.

17.5. ARCTOMÉCON, Torr. Arctomecon. Paparerareae. From Greek, "northern Poppy". Herbs. Three species in western U. S.

176. ARCTOSTÁPHYLOS, Adans. Bear-berry. Ericaceae. From Greek, "bear's grape". Evergreen shrubs or small trees. About 25 species, mostly of western $N$. America; 21 in U. S.

a. A. glaúca Lindl. California. Great-berried Manzanita. Leares employed like those of (f), as are also those of the Mexican species: (b). A. mucrocífera DC., (c) A. Polifólia Kunth and (d) A. tomentósa Dougl., the last being known as Madroño or Madroña. See Arbutus (a) and (c). 
e. A. púngens H. B. K. California. Common Manzanita, this name being applied to the several shrubby Californian species.

f. A. Uva Úrsi (L.) Spreng. (Arbutus Uva Ursi L., A. officinalis Wimmer). Northern Europe. Asia and N. America, south to New Jersey, Colorado and C'alifornia. Bearberry, Red Bearberry, Bear's Grapę, Uva Ursi, Universe-vineł, Bear`s Bilberry, Bear's Whortleberry, Brawlins, Burren Myrtle, Upland or Mountain Cranberry, Creashak, Crowberry, Kinnikinnic, Killikinic, Meal-berry, MIountain Box, Rock-berry, Sagachomi, Rapper dandies (the fruit); Ger. Bärentraube; Fr. Ura Ursi, Busserole, Raisin d'ours (Codex); Sp. Gayuba. Lerres, Uva Ursi. U. S. P., Uvæ ursi folia, Br., Ful. aretostaphyli; astringent diuretic.

177. ARÉCA, L. - Betel-nut. - Sabalaceac. From vernacular name, East Indies. Palms with solid nutlike fruit. About 25 species, tropical Asia and East Indies.

a. A. Cátechı L. East Indies. Betel-nut Palm, Areca-nut Palm, Pinang. Seeds, Areca, Br., Semen arece; Ger. Arekanuss, Betelnuss; Fr. Noix d'arec. Trnicide, masticatory.

178. ARÉNGA, Labil. Sugar Palm. Sabalıerae. From vernacular name. Syn. Saguerus, in part. Palms. About 5 species, tropical Asia to Australia.

a. A. saccharífera Labil. (Saguerus Rumphii Roxb., S. saccharifer Blume, S. Gamuto Hout. ). East Indies. Areng Palm, Sugar Palm; Condiar, Lontar or Lantar Palm. Tree yields Sago, also Palm wine (toddy) and Palm sugar (jaggery).

179. ARETHÚSA, L. Arethusa. Orchilaceae. Dedicated to the nymph Arethusa. Ornamental bulbous plants. Two species, one in Japan, one in U. S.

a. A. bulbósa L. Canada to N. Carolina, west to Minnesota. Arethusa, Dragon's-mouth, Wild Pink.

180. ARGEMóne, L. Prickly Poppy. Papareraceae. Greek name of a Poppy, from that of an eye-disease it was supposed to cure. Prickly herbs with yellow latex and showy Howers. About 8 species, all of southern U. S. and Mlexico.

a. A. álba Lestib. (A. albiflora Hornem.). South-central U. S. White Prickly-poppy, White or Prairie Poppy-thistle. Plant acrid, emeto-cathartic, narcotic; oil from seeds purgative.

b. A. Mexicána L. Tropical America, adv. in southern U. S. Mexican Prickly-poppy, Mexican Poppy, Jamaica Yellow Thistle, Yellow Poppy-thistle or Flowering-thistle, Thorn Poppy, Bird-in-the-bush, Devil's-tig. Properties of $(a)$.

181. ARISAÉMA, Mart. Indian Turnip. Aracease. From Greek, "arum-like". Syn. Arum, in part. Perennial herbs with acrid, starchy corms. About 50 sipecies, mostly of Asia; 3 in U. S. 
a. A. Dracóntinm (L.) Schott. (Arum Draeontium L.). Canada and eastern U. S. Green-dragon, Dragon-root. Yroperties of (b).

b. A. triphýllum (L.) Torr. (Arum triphytlum L., Arisæma atrorubens Blume). Canada and eastern U. S. Indian Turnip, Jack-in-the-pulpit, Wake-robin, Three-leaved Arum, Wild Pepper, Dragon Turnip, Brown-dragon, Devil's-ear; Marsh-, Swamp-, Wild-, M-adow- or Pepper-turnip, Starchwort, Bogonion, Priest's-pintl, Lords-and-Ladies, (Some other synonyms of Arum maculatum are also sometimes applied to this plant.); Ger. Indianische Aronswurz, Zehrwurz, Dreiblättriger Aron; Fr. Gonet à trois feuilles; Sp. Aro. Corm, Arum, Radix (Tubera) ari indici; acrid, carminative, expectorant.

182. ARISTOLÓCHL, L. Birthwort, Heartwort. Aristolochia-

The Greek name, "favoring child-birth". Svn. Endodeca, in part. Perennial herbs or vines with strangely-shaped flowers. About 180 species; 11 in U. S. See Corydalis.

a. A. lónga L. Sonthern Europe. Long Birthwort; Ger. Langer Osterluzei, Lange Hohlwurzel. Rhizome alterative, believed to facilitate parturition.

b. A. macrophýlla Lam. (A. Sipho L'Her). Pennsylvania to Georgia and Kansas. Dutchman's-pipe, Pipe-vine, Big Sarsaparilla, Wild Ginger*.

c. A. Pistolóchia L. Southern Europe. French or Spanish Birthwort; Ger. Französischer Osterluzei, Netzblatthohlwurzel. Rhizome, Rad. pistolochiae, Rad. aristolochiae polyrrhizæ. Properties and uses of $(\mathrm{a})$.

d. A. reticuláta Nutt. Louisiana and Texas. Snake-root, Southern Serpentaria. Rhizome, Serpentaria U. S. P., in part, Serpentariæ rhizoma Br., in part. See (f).

e. A. rotúnila L. Southern Europe. Round Birthwort, Somerwort; Ger. Runder Osterluzei, Rund-Hohlwurzel, Gebärmutterswurzel. Properties of (a).

f. A. Serpentária L. (Endodeca Serpentaria Klotsch). New York to Michigan and southwards. Serpentaria, Virginia Snakeroot, Snakeweed, (Snagrel, Sangrel, Sangree root), Serpentary, Pelican-Hower; (ier. Virginische Schlangenwurzel; Fr. Serpentaire de Virginie (Codex), Vipérine de Virginie; Sp. Serpentaria de Virginia. Rhizome and roots, Serpentaria U. S. P., Serpentariæ rhizonı, Br., Rad. serpentariae (virginianæ), Rad. colubrina v. viperina. Stimulant tonic, diaphoretic, alterative.

183. ÁRNICı, L. - Arnica. - Compositae. The classical name, perhaps a corruption of "Ptarmica": Syn. Doronicum, in part. Herbs, mostly with yellow flowers. About 25 species, northern hemisphere; 22 in U. S. 
a. A. montána L. (D. Arnica R. Br.). Northern Europe, Asia and N. America. Arnica, Leopard's-bane, Wolf's-bane, Mountain Tobacco; Ger. Wohlverleih, Arnika, Fallk aut, Gems. blume, Blutblume; Fr. Arnici (Codex), Arnique. Flowers, Arnicae flores, U. S. P., rhisome and rootlets, srnicae radix, U.S. P., Arnica rhizoma, Br. Lertes, Fulia Arnice, Herba doronici germanici. Irritant, nauseant, narcotic, vulnerary.

Indigenous species, having probably similar properties are (b) A. alpina Olin, (c) A. acaúlis (Walt.) B. S. P. (A. nudicaulis Eil. ) and (d) A. Chamissónis Less. (A. mollis Hook.).

184. ARNóSERIS, Gaertn. Lamb-Succory. Cichoriaceae. From Greek, "Iamb succory'? Syn. Hyposeris, in part. Herb. One species.

a. A. mínima (L.) Dumort. (Hyposeris minima L., A. pnsilla, (Gaertn.). Western Europe, adv. in U. S. Lamb-succory, Dwarf Swine's or Hog's Succory, Dwarf Nipplewort.

18.j. ARónIA, Pers. Choke-berry, Choke Pear. Pomaceae. Name from "Aria", the Beam-tree. Syn. Mespilus, Pvrus, in part. Shrubs with berry-like pomes. 'Two species, both in T.S.

a. I. arbutifólia (L.) Ell. (P. arbutifolia L.). Canada and eastern U. S. Red Choke-berry or Choke-pear, Dog-berry tree. Fruit excessively astringent.

1S6. ARRACÁCIA. Bancr. 1826 (Arracacha). Umbelliferae. Syn. Telea DC. 1830 . Herbs, with fleshy aromatic root: About 12 species, all American; 7 in sonth western $L$. S.

19\%. ARTEMÍSIA, L. Wormwood, Sage-brush. Compositue. Named for Artemisia, wife of Mausolus. Syn. Absinthium. in part. Aromatic bitter herbs or small shrubs. About 200 -pecies, northern hemisphere and S. America; 50 in U. S.

a. A. Abrótanum L. Southern Europe and western Asia; cult. ind adv. in U. S. Southernwood, Abrotanum (Apple-rienniet, Averoyne + ), Boy's-love, Kis-me-quick-and-go, Lad-savour, Mraiden's-ruin, Maid's-love, Old-man, Smelling-wood, Sinvenwood, Sweet-Benjamin; Ger. Eberraute, Eherreiskraut, Gertwurz, Stabwnrzel; Fr. Aurone Mâle, Citronelle (Codex); Šl. Abrotano. Plant, Herba abrotani, aromatic, bitter; odor lemon-like.

b. A. Absínthium L. (Absinthium vulgare Lam.). North Africa, Lurope and northern Asia, cult. and adv. in U. S. Wormwood, (Warmot, Wormit, Werenod) Absinthium, Mad srwort. IIingwort, Old-woman; Ger. Wermuth, Alsei, Wnrmod; Fr: Absinthe (grande), Aluyne (Corlex); Sp. Ajenjos. Thps and lertes, Absinthium, U.S. P., Summitates absinthii; stimulant tonic, anthelmintic, narentic.

c. A. Abyssínica Oliv. Abyssinia. Tshuking, Zerechtit. I'/unt aromatic bitter. 
1. 1. Címa Herg. Orient. Sice $(\mathrm{m})$.

e. A. Bracínculns L. Sonthern Europe and Asia, also widely cult. Tarragon (i. e. I)ragon), Biting-dragon; Ger. Dragunbeifuss. Kaisersalut; Fr. Sp. Estragon. Plant ani-e-scented, used as a condiment.

f. 1. filifólia Torr. Nebraska to Texas and Utah. Silvery Wormwood, Wormwood Sage. locally known as Southernwood.

g. A. Prígida Wild. Minnesota to Idiaho, south to'Texas. Mountain Sage, Pasture Sage-brush, Wild sage, Wormwood Sage, Siermalviat. Plent aromatic, bitter, diaphoretic, febrifuge.

1. A. glaciális L. Switzerland. Silky Wormwood. This species, also (i) A. mustellína Vill. and (j) A. spicráı Wulf., both of the swiss Alps, is used in the preparation of absinthe. Flourering plant, Herba absinthii alpini, Herba genippi albi; (ier. Weisser (renipp; Fr. Genipi rrai (Codex); stimulant, bitter, tonic.

k. A. gnaphalódes Nutt (A. Ludoviciana var. gnaphalodes T. \& (ir.). Texas to western Ontario and westward. Western Mugwort, Prairie or Cudweed MIngwort, Western Sage. Fruit of this also of (1) A. dracumculoilles Pursh, used as food by Indiuns.

m. 1. Míxa D( . China. Hoxa plant. From the leaves are prepared Chinese moxa, used formerly as a cautery.

11. I. pauciflóril (Leteh.) Weber (A. maritima var. pauciflora Ledeb., A. Lercheana. Kar. \& Kir. A. maritima var. Stechmanniana Besser). Western Asia. This plant rather than (d), as formerly supposed, yields the Levant worm-seed. The unexpanded flowers; Levant, Aleppo or Alevandria Wormseed; San ronic-, T. S. P., Flores (v. Anthodia) cinæ, Semen cinae, Semen contra s. sanctum s. santonici; Ger. Wurmsamen, Zittwersamen, (inablüthen; Fr. Semen contra, Semencine, Barbotine (Codex); Sp. Yantónica. Anthelmintic. Source of iantonin.

ค. 1. Póntiea L. Snuthern Europe to Central Asia. Roman Wormwood; Ger. Römischer oder Pontischer Wermuth; Fr. Absinthe P'ontique on petite ( ('odex). Properties of (b).

1. A. tridentáta Nutt. Nebraska to Colorado and westward. Sage-brush, Common Sage-brush, Sage-wood, MIountain Sage. This and other species, as $(q)$ A. arbúseula Nutt. and (r) A. trifida Nint., Dwarf Sage-brush, have properties of $(\mathrm{g})$.

s. A. vulgáris L. Europe, northern Africa and Asia, nat. in U. S. Mugwort, (Muggert, Mogford), Common Mugwort, Apple-pie, Bulwand, Fat-hen*, Felnn-herb, Green Ginger, Mugweed, Motherwort, Smotherwond, Sailor's Tubaces, Wormwood*; Ger. Beifuns, Jungfernkraut, Weiberkraut; Fr. Armoise (Codex), Couronne de Saint-jean; Sp. Artemisa. Herb, Herba artemisia, emmenagogue, antispasnodic. Root tonic, antispasmodic. 
188. ARTOCÁ RPUS, Forst. Breadfruit, etc. Artocarpaceae. From Greek, "bread fruit". Syn. Iridaps, Polyphema, Soccus, Rademachia, in part. Trees. About 60 specie, warmer regions of Old World.

a. A. incísa L. (A. communis Forst., Iridaps Rima Commers, Soccus granosus Rumpl., Rademachia incisa Thunb.). East Indies to Polynesia, cult. in all tropical countries. Breadfruit tree, Bread-tree; Fr. Rima, Arbre à pain. Fruit esculent.

b. A. integrifólia L. (Soccus major Rumph., Polyphema cauliflorum Lour. ). East Indies. Jack-tree, Jaca- or Jak-tree. Fruit, Jack-fruit, esculent.

189. ÁRUM, S. - - Arum. - - Aracere. The ancient Greek name. Acrid herbs. About 45 species, Europe and Asia.

a. A. maculátum L. Europe. Spotted Arum (Aron, Auron), Adder's-root; Bobbins, Buckram, Cocky-baby, Cuckoo-babies, Cuckoo-pint, Dragon-root, Great (also Small) Dragon, Friar'scowl, Gaglee, Bloody-man's-finger, Kings-and-queens, Lordsand-ladies, Lamb-lakins, Lily-grass, Mandrake*, Nightingales, Parson-and-clerk, Poison-berry, Quakers, Sago-plant, Schoolmasters, Snake's-meat, Starch-roọt, Wake-robin, Wild Lily; Ger. Pfaffenpint, Gefleckter Aronstab, Aronwurz, Zehrwurz; Fr. Arum, Gouet, Pied-de-veau (Codex). Rhizome (Corm), Rhizoma (Tubera) ari, Rad. dracontii minoris; Acrid, carminative, expectorant. Source of Portland Arrow-root.

190. ARÚNCUS, “Adans. Groat's-beard. Rosaceae. The classical name. Syn. Spiræa, in part. Tall perennial herbs with flowers in panicled spikes. Two species, 1 in Japan, 1 circumpolar and in U. S.

191. ARUNDINÁRIA, Michx. Small Cane. Gramineae. Name Latin, "reed like". Bamboo-like grasses. About 24 species; 3 in U. S. See Bambusa $(j)$ and $(k)$.

a. A. macrospérma Michx. Southeastern U. S. Cancbrake. Culms used for fishing-rods, etc.

192. ARÚND0, L. - - Reed. - - Gramineap. Latin name of "reed" (properly Harundo). Tall reedy grasses. About 35 species; 1 in U. S.

a. A. Dónax I. Mediterranean region. Reed, Spanish Cane; Fr. Canne de Provence, Grand roseau (Codex). Rhizome diuretic, emmenagogue.

193. ASAGRAÉA, Lindl. 1839 (Asa Graya). Liliaceae. Named for the distinguished American botanist, Asa Gray. Syn. Schœnocaulon Gray, 1848, Skoinolon Raf.; Sabadilla, Helonias, Veratrum, in part. Scapose bulbous herbs. About 5 species, Florida to Venezuela; 2 in U. S. 
a. A. officinális (Ch. \& Sch.) Lindl. (Veratrum officinale Ch. \& Sch., Schoenocaulon officinale Gray, Helonias officinalis Don, Sabadilla officinarum Brandt). Mexico to Venezuela. Ceradilla, Sabadilla, Indian Barley-caustic. Seeds, Sabadilla Br.; Ger. Sabadillsamen, Laüsekörner, Laüsesamen; Fr. Cévadille (Codex); Sp. Cebadilla; source of veratrine; insecticide.

194. ÁSARUM, L. Asarabacca, etc. Aristolochiaceae. The classical name. Stemlers perennials with aromatic rhizomes. About 18 species, north temperate zone; 13 in U. S.

a. A. Canadénse L. Canada to N. Carolina and Kansas. Canada Snakeroot, Wild Ginger, Indian Ginger, False Coltsfoot, Vermont or Heart Snakeroot, Black or Coltsfoot Snakeroot, Colicroơt, Cat's-foot, Broad-leared Asarabacca; G'er. Canadische Schlangenwurz, Indischer Ingwer; Fr. Asaret; Sp. Azaro. Rhizome, Asarum, U. S. P., Rad. asari canadensis; aromatie, carminative, diaphoretic; in large doses, irritant. Other American species having similar properties are (b) A. arifólium Michx., Virginia to Alabama, Halberd-leaved Asarum, (c) A. caudátum Lindl., California, (d) A. micránthum (Schuttlw.) Small, Virginia and N. Carolina, Large-flowered Asarum and (e) A. Virgínicum L., Virginia to Georgia, Virginia Asarum, Southern Wild Ginger, all three of these being called also Heart-leaf.

f. A. Europáeum L. Europe. Asarabacca, European Snakeroot, Foalfoot, Hazelwort, Public-house plant, Wild Nard; Ger. Haselwurz, Wilder Nard; Fr. Asarum, Cabaret (Codex). Rhizome, Pad. asari, Rad. nardi rusticæ (v. silvestris); Emetocathartic, sternutatory.

g. A. Siebóldii Miq. Japan. To-sai-shin. Rhizome aromatic, pungent.

195. ASCLÉPIAS, L. Silkweed, Milkweed. Asclepiadaceae. Greek name of a plant dedicated to Esculapius. Perennial herbs, mostly with white milk-sap. About 85 species, mostly of New World; 49 in U. S. The species are called also Swallowwort.

a. A. Curassávica L. Tropical America. Bastard Ipecacuanha or Ipecac, Blood-flower, Blood-weed, Red-head. In Central America called Cancerillo or Ponchishuiz. Herb and root, irritant, emetic, alterative.

b. A. incarnáta L. Canada to Tennessee and Kansas. White Indian Hemp, Swamp Milkweed, Flesh-colored Swallowwort or Asclepias, Rose-colored Silkweed, Rose or Swamp Silkweed, Water Nerve-root; Ger. Fleischfarbige Schwal benwurzel; Fr. Asclépiade incarnate. Root cardiac tonic, diuretic, anthelmintic.

c. A. Syríaca L. (A. Cornuti Dec.). Canada to N. Carolina and Kansas. Silkwreed, Common Silkweed or Milkweed, Silky Swallow wort, Virginian Silk, Wild Cotton; Ger Seidenpflanze; Fr. Asclépiade à la soie, Herbe à la ouate. Root diuretic, diaphoretic, sedative. Milk sap vulnerary. 
d. A. tuberósa L. Ontario to Florida, west to Arizona and Minnesota. Pleurisy-root, Butterfly-weed, Canada-root, Indian Posy, Orange-root, Orange Swallowwort, Tuber-root, Whiteroot, Wind-root, Yellow or Orange Milkweed; Ger. Knollige Schwalbenwurzel; Fr. Asclépiade tubereuse. Root, Asclepias, U. S. P.; diaphoretic, expectorant, carminative, in large doses emeto-cathartic.

106. ASCLEPIODÓRA. Gray. Milkweed. Asclepiadaceae. From Greek, "gift of Aesculapias". Syn. Anantherix, Asclepias, in part. Milky herbs resembling Asclepias. Five or six species, N. America; 2 in U. S.

197. ÁSCYRUM, L. St. Peter's-wort. Hypericaceae. From Greek, "not rough", Small smooth shrubby. plants resembling Hypericum. About 6 species, $N$. America; 5 in U. S., mostly southern.

a. A. hypericoídes L. 1753 (A. Crux-Andreæ L. 1763). Eastern U. S. St. Andrew's-cross. Root resolvent.

198. ASÍMINA, Adans. - Papaw. - Anonaceae. From aboriginal name, Assimin. Syn. Anona (Annona),

in part. Small trees or shrubs, some with edible fruits. About 8 species, all of U. S. and Mexico.

a. A. triloba (L.) Dunal (Anona triloba L.). New York to Michigan and southward. Papaw, Pawpaw, North American Papaw, Custard-apple, False Banana, Fetid-shrub; Fr. Asiminier. Fruit edible. Seeds enretic.

199. ASPÁRAGUS, L. Asparagus. Convallariaceae. The ancient Greek name of Persian origin. Perennial herbs with foliage consisting of minute branchlets. About 100 species, Old World.

a. A. officinális L. Europe, everywhere cult. as a food-plant. Asparagus, (Sparagus, Sperage) Sparrow-grass + , Grass, Paddock-cheese; Ger. Spargel; Fr. Asperge (Codex); Sp. Esparraguera. Shoots, Asparagi turiones, used as fond. Rhizome, Radix asparagi, Rad. atticis, like the shoots, actively diuretic, cardiac stimulant.

b. A. scáber Brign. (A. amarus DC., A. marinus Reich.). Southern Europe. Bitter Asparagus. Properties of (a). "Johnson's Syrup" was made from this plant.

200. ASPERÚG0, L. German Madwort. Boraginaceae. From Latin, "rough". A small rough-hispid herb. One species.

a. A. procúmbens L. Europe and Asia, adv. in L. S. German Madwort, Catch-weed, Great Goose-grass, Small Wild Bugloss. Plant diaphoretic, vulnerary.

201. ASPÉRULA, L. Woodruff, etc. From Latin, "roughish". Perennial herbs with whorled leaves. About 80 species, Old World. 
a. A. cynánchica L. Europe to Asia Minor. Quinsywort, Squinancy, Herb-of-vine, Sheplerd's Bedstraw. Plant formerly used externally in quinsy.

b. A. odoráta L. Europe, adv. in U. S. Sweet Woodruff (Woodrip, Woodrowel, Woodrowe), Sweet Hairhoof, Sweet-grass, Hay-plant, Mugwet, Mugget, Rock-weed, Star-grass; Ger. Waldmeister, Herzfreude, Sternleberkraut; Fr. Aspérule. Herb, Herba asperulæ, H. matrisilvæ, H. hepaticæ stellatæ, H. cordialis; contains coumarin; diuretic, deobstruent, hepatic stimulant.

202. ASPICÁRPA, Rich. Aspicarpa. Malpighiaceae. From Greek, "shield fruit". Low shrubs. About 5 species, Mexico and its borders; 2 in U. S.

203. ASPIDOSPÉRMA, Mart. \& Zucc. Quebracho. Apocynacea. From Greek, "shield seed". Trees. About 55 species, S. America.

a. A. Quebrácho-blanco Schlecht. Argentine Republic. Quebracho (i. e. axe-breaking), Quebracho blanco. Bark, Aspidosperma, U. S. P.. Cortex aspidospermatis quebracho. Tonic, antispasmodic, especially in asthma.

204. ASPLÉNIUM, L. Spleenwort. Polypodiaceae. A cosmopolitan genus of ferns of about 350 species; 21 in U. S. The following have been used in place of Adiantum, q. $\nabla$.

a. A. Adiantum-nígrum L. Europe, Asia and Oceanica. Black Maiden-hair, Black-oak Fern, Petty Fern.

b. A. Filix-foémina L. Europe, Asia and N. America, (Common in U. S.). Female Fern, Lady Fern, Backache Brake.

c. A. Ruta-murária L. Europe and widely distributed (Eastern U. S. ). White Maidenhair, Wall-rue spleenwort, Stone-rue, Rue Fern, Tentwort, Wall-pie.

d. A. Trichómanes L. Widely distributed (U.S.). Maidenhair Spleenwort, English Maidenhair, Waterwort.

205. ASTÉPHANUS, R. Br. Astephanus. Asclepiadaceae. From Greek, "crownless", alluding to the stamens. Undershrubs or climbers. About 30 species, warmer regions of Africa and America; 1 in U. S.

206. ÁSTER, L.

Aster.

Compositae.

The Greek name, "star"-flower. Perennial, rarely annual, herbs, the characteristic wild flower of late fall. About 250) species, most abundant in $\mathrm{N}$. America; 125 in $\mathrm{U}$. S. The Indian name is It-brings-the-frost. Local names in America are Frost-flower, Grood-bye-summer, Daisy (Ohio). The following among the common species of the eastern U. S. have special names, but these are not restricted in popular usage to the respective species. 
a. A. cordifólius L. Blue Wood-aster, Bee-weed, Tongue.

b. A. dumósus L. Rice-button Aster.

c. A. ericoídes L. White Heath-aster, White Rosemary, Dogfennel*, Mare's-tail, Michaelmas Daisy*, Scrub-brush.

d. A. hirsuticaúlis Lind. Old-field Sweet, Old Virginia Stick -weed, White-devil, Wire-weed.

e. A. Lowrieánus Porter. Bee-weed, Blue-devil.

f. A. multiflórus Ait. White or Dense-flowered Wreath-aster, Fall-flower.

g. A. Nora-Ángliæ L., New England Aster, Michaelmas Daisy*.

h. A. puníceus L. Red-stalk or Purple-stem Aster, Early Purple Aster; Cocash, Meadow Scabish, Swan-weed, Squaw-weed** Root stimulant, diaphoretic, antispasmodic.

i. A. Tradescánti L. Michaelmas Daisy, Blue Camomile, Blue Daisy.

207. ASTÍLBE, Hamilton. Astilbe. Saxifragaceae. From Greek, "without brightness". Perennial herbs with large decompound leaves, About 7 species, N. America and eastern Asia; 1 in U. S.

a. A. biternáta (Vent.) Brit. (Tiarella biternata Vent. A. decaudra D. Don ). Sontheastern U. S. False Goat's-beard.

208. ASTRÁGALUS, L. Milk-vetch, etc. Papilionacer. Greek name of a leguminous plant. Herbs or nore or less shrubby Vetch-like plants. About 1000 species, most abundant in northern Asia; 300 in U. S.

a. A. Baéticus L. Southern Europe. Swedish Coffee; Ger. Stragalkaffee. Seeds, a substitute for coffee.

b. A. crassicárpus Nutt. (A. caryocarpus Ker, A. carnosus Pursh). iranitoba to Texas and Colorado. Ground Plum, Buffalo Apple, Buffalo Bean, Buffialo Pea. Fleshy legumes edible. See (o).

c. A. crotaláriae (Benth.) A. Gray. California. California Loco -weed, Loco-plant, Crazy-weed. Plant poisonous to istock. See $(p)$.

d. A. exscápus L. Europe. Root mucilaginous, diuretic.

e. A. glycyphýllos L, Europe and northern Asia. Wild Licorice (Liquorice), Licorice Vetch. Leaves and seeds have a sweet taste, diuretic. 
f. A. gúmmifer Labil. Syria. Tragacanth shrub, Goat's-thorn. Gummy exudate, Tragacanth, not to be pronounced trajacanth; Syrian Tragacanth, Guat's-thorn gum , Hog-gum, Tragacant ha, U. S. P., Br., Gummi tragacantha; Ger. 'Traganth, Fr. Gomme adragante (Codex); Sp. Goma tragacanta. Demulcent. Gum tragacanth is produced also by $(\mathrm{g})$ A. adscéndens Bois. \& Hsk., Persia; (h) A. brachyeályx Fischer, Central Asia; (i) A. Créticus Lam., Greece; (j) A. cylléneus Bois. \& Held.; (k) A. microcéphalus Willd., Asia Ninor; (1) A. pyenócladus Bois. \& Hsk., Persia; (m) A. stromátodes Bunge, Syria; (n) A. vérus Olivier, Persia.

o. A. Mexicánus A. DC. (A. trichocalyx Nutt., [not Trautr.). Illinois to Nebraska and 'Texas. Ground Plum, Prairie Apple. Fleshy legumes edible. See (b).

p. A. mollíssimus Torr. Nebraska to Texas. Texas Loco-weed, Loco plant, Woolly Loco-weed, Crazy-weed, Rattle-weed. This as well as (c) and some other species produce in horses and other animals peculiar intoxicating effects. See also Spiesia Lamberti.

209. ASTRÁNTIA, L. - Astrantia. - Umbelliferae. Herbs. About 10 species, Europe and western Asia.

a. A. májor L. Europe. Black Sanicle, Imperial Masterwort, Black or Bastard Hellebore; Fr. Radiaire, Sanicle femelle. Root, Rad. imperatoriae nigræ; aromatic, alterative, astringent.

210. ASTROCÁRYUM, G. W. Meyer. Astrocaryum. Sabalacez. From Greek, "star fig". Thorny palms. About 35̄ species, tropical America.

a. A. vulgáre Mart. S. America. Fruit, source of Tucun oil.

211. ATAÉNIA, Endl. Ataenia. Umbelliferae. From Greek, "without fillet". Syn. Carum, in part. Herbs. Three species in U. S.

a. A. Gaírdneri H. \& A. (C. Gairdneri Benth.). Wyoming to Washington and California. Tuberous roots, called yamp, used by the Indians for food, as are those of the Californian (b) A. Kellógii (A. Gray) Greene (C. Kelloggii Gray).

212. ATHAMáNTA, L. Candia Carrot. Umbelliferae. Syn. Libanotis, in part. Herbs. About 18 species, Europe and Asia.

a. A. Creténsis L. (Libanotis hirsuta Roehl.). Mediterranean region. Cretan Carrot, Candia Carrot; Fr. Daucus de Crète (Codex). Seed aromatic, carminative, diuretic.

213. ATHEROSPÉRMA, Labil. Sassafras*. Monimiaceæ. Aromatic trees. Four species, Australia to S. America.

a. A. moschátum Labil. Australia and Tasmania. Tasmanian Sassafras tree. Bark tonic, astringent, aromatic with nutmeglike odor. See Doryphora. 
814. ATHÝsANUS, Greene. From Greek, "without fringe". Slender annual. One species, California.

215. ATRÁCTYLIS, L.

Ancient Greek plant name. Herbs. About 20 species, Mediterranean region to China.

a. A. gummífera L. Southern Europe. Fr. Chaméléon blanc. Exudate sold in Greece as pseudo-mastich or acantho-mastich.

216. ATRÁGENE, L. Virgin's-bower* Ranunculaceae. Greek name for some vine. Syn. Clematis, in part. Perennial climbers with showy flowers. About 4 species, northern U. S.

a. A. Americána Sims (C. verticillaris DC.). British America south to Virginia and Minnesota. Purple Virgin's-bower, Mountain or Whorl-leaved Clematis.

217. ATRICHóSERIS, A. Gray. From Greek, "bald Succory". Oue species in western U. S.

218. ÁTRIPLEX, L. Orach, Salt-bush. Chenopodiaceae. The ancient Greek name, "not nourishing". Syn. Calligonum, in part. Plants resembling Chenopodium, many growing in saline soil and so valuable as fodder plants. About 130 species, cosmopolitan; 56 in U. S.

2. A. canéscens (Pursh) James (C. canescens Pursh). S. Dakota to Mexico and California. Bushy Atriplex, Cenizo.

b. A. halimoídes Lind., (c) A. Muélleri Benth. and (d) A. nummulária Lind. are among the most valuable "Salt-bushes" of Australia.

e. A. hastáta L. Europe and northeastern N. America. Halberd-leaved Orach\&, Lamb`s-quarters, Fat-hen, Hard-iron. Plant sometimes used as a pot herb.

f. A. horténsis L. Asia and cult., especially in Europe. Garden Orach (Orache, Orage, Arach, Areche), Mountain Spinach, Bonny-dame, Butter-leaves; Fr. Arroche. Plant used as Spinach; seeds emetic.

219. ÁtroPA, L. - Belladonna, ete. - Solanacere. Name from tbat of one of the Fates of Greek mythology. Poisonous herbs. About 4 species, Europe, Asia and $\mathrm{S}$. America.

a. A. Belladónna L. Southern Europe to central Asia. Deadly Nightshade, Belladonna (i. e. beautiful lady, perhaps from effect on the pupil of the eye), Banewort, Death's-herb, Doft-berry, Dway-berry, Dwale, Great Morel, Jacob's-ladder*, Manicou, Mad, Mekilwort, Poison Black Cherry, Sleeping Nightshade; Ger. Tollkirsche, Wolfskirche, Tollkraut; Fr. Belladone (Codex), Morelle furieuse. Leares, Belladonnæ folia. U. S. P., Br; Folia belladonnæ, P. G. Root, Belladonnæ radix.U. S. P., Br. Deliriant narcotic, mydriatic, anodyne. Contains atropine. 
200. ATTÍLEA, H. B. K. Cohune Palm, etc. Sabalaceae Named for Attalus, king of Pergamum. Tall palms. About 30 species, tropical America.

i. A. Cohńme Mart. Honduras. Cohune, Cahoun or Corazo Palm. Fruit yields a fixed oil.

b. A. funífera Mart. Brazil. Bast Palm, Broom Palm, Pissaba. Seed, Coquilla-nut, used in turnery. Leaf stalks furnish fibre for cordage, known as Monkey-grass or Yara-grass.

201. A VÉXA L. - - Oat. - - Gramineae. The ancient Latin name. About 50 species, mostly Old World; 6 in $\mathrm{C}$. S.

a. A. satíva L. Widely cultivated as a cereal. Common Oats, (Awts, Woats, Wocks, Wots, Yaits, Yetts) Aits (Scotland) Hafer-corn, Haver, Haws; Ger. Hafer; Fr. Avoine (Codex). Seed esculent. Medicinal properties probably mythical.

222. AVERRHÓA, L. Tree-Sorrel. Oxalidacene. Named for Averrhoes, Arabian naturalist. d. 1198. Small trees with Ash-like foliage and edible fruit. Two known species, China.

a. A. Bilímbi L. China, cult. in East Indies. Bilimbi tree (Bilimbing, Bilimby, Blimbing), Cucumber-tree. Fruit acid, used for pickles, confections, etc.

b. A. Carámbola L. China, cult. in East Indies. Carambola tree, Caramba. Fruit used for tarts, etc.

223. AVICÉNIIA, L. Mangrove* * Verbenaceae. Named for the Arabian Avicenna. Littoral trees with habit of Rhizophora. Two species; 1 in U. S.

a. A. nítida Jacq. Florida, West Indies to east Africa. Black Mangrove, Olive Mangrove, Blackwood, Courida. Bark agtringent, used in tanning.

b. A. officinális L. New Zeland to Australia. White Mangrove, Manawa of the Maoris.

224. AYÉNIA, Lœfl. (Dayenia) - - Sterculiaceze. Herbs or shrubs. About 16 species, warmer regions of New World; 2 in U.S.

225. AZÁLEA, L. Azalea, Honeysuckle*. Ericaceae. From Greek, "arid". Syn. Rhododendron, in part. Shrubs with large showy flowers. About 40 species, Asia and N. America; 6 in U. S.

a. A. nudiflóra L. (Rhododendron nudiflorum Torr.). Eastern U. S. to Texas. Wild Honeysuckle, Purple or Early Honeysuckle, Purple or Pink Azalea, Election Pink, Swamp Pink, Pinkster-flower. A parasitic fungus on it is known as Swamp Apple, May Apple, Honeysuckle Apple, Swamp Cheeses. 
b. A. viscósa L. (Rlododendron viscosum Torr.). Eastern U. S. to Texas. Swamp Pink, Meadow Pink, Swamp Honeysuckle, White or Clammy Honeysuckle, Clammy Azalea, Spring-bloom. Var. glauca Michx. is Cinnamon Honeysuckle. [Other indigenous species are (c) 1 . arboréscens Pursh, Tree or Smooth Azalea, Smooth Honeysuckle; (d) A. canéscens Michx., Mountain or Hoary Azalea; (e) A. lútea L., Flame Azalea, Yellow Honeysuckle.]

226. BÁCCHARIS, L. Baccharis, Groundsel. Compositae. Greek name of an aromatic plant. Diœcious shrubs with small flower heads. About 275 species, all American; 20 in U. S.

a. B. Lalimifólia L. Eastern and southern U. S. near sea-board, also West Indies. Groundsel tree, Groundsel bush, Pencil-tree, Cotton-seed tree, Plowman's Spikenard. Plant aromatic, demulcent.

b. B. piluláris DC: California. Kidney-root. Plant, diuretic.

227. BAÉRIA, Fisch. \& Mey. Baeria. Compositae. Named for Karl Ernst von Baer, Russian naturalist. Syn. Dichreta, Burrielia, in part. Mostly annual, with yellow flowers. About 23 species, all of California.

228. BÁHIA, Lag. - Bahia. - Compositae. Named for J. F. Bahi, Spanish botanist. Syn. Trichophyllum, in part. Herbs or sub-shrubs with yellow flowers. About 16 species, all American; 12 in U. S.

229. BAILÉYA, Harv. \& Gray. - Baileya. Compositae. Named for Jacob Whitman Bailey, Imerican microscopist. Floccose-woolly herbs. : Three species, southwestern U. S.

230. BALLÓTA, L. Black Horehound, etc. Labiatae. The ancient Greek name, "rejected", i. e. by cittle. Perennial hairy herbs, some shrubby. About 25 species, Old World; 1 nat. in U. S.

a. B. nígra, L. (B. fotida Lam.). Europe, adv. in U. S. Black Horehound, Hairhound, Black Archangel, Dunny Nettle; Fetid, Stinking or Bastard Horehound, Henbit, Stinking-Roger; Ger. Schwarzer Andorn, Gemeine Ballote; Fr. Marube noir, Marube fétide. Flowering herb, H. ballotæ, H. marubii nigri v. fœtidi, antispasmodic, anthelmintic.

231. BAISAMORHÍZA, Hook. Balsam root. Compositae. From Greek, "balsam root". Syn. Kalliactis, Espeletia, Buphthalmum, Helianthus, in part. Perennials with fleshy balsamic roots. Ten species, all of western U. S.

a. B. sagittáta (Pursh) Nutt. (Buphthalmum sagittatum Pursh, E. sagittata Nutt. Includes also B. helianthoides Nutt.). Colorado and northwestward. Roots of this and some other species, notably (b) B. incána Nutt. used as food by the aborigines. 
232. BAMBÚSA, Schb. (Bambos, Bambus).Bamboo. Gramineae. From vernacular, East Indies. Gigantic grasses. About 80 species, natives of warm countries.

a. B. vulgáris Schrad. India, now nat. in all tropical countries. Common Bamboo. Uses innumerable.

The following are among the numerous species known as Bamboo; (b) B. arundinácea Willd., Thorny Bamboo of India; (c) B. áspera Schult. (120 ft.), East Indies; (d) B. Brandísii Munro (120 ft.), Tenasserim and Pegu; (e) B. Balcóoa Roxb. ( $70 \mathrm{ft}$.), Bengal to Assam; (f) B. polymórpha Munro (80 ft.), Burma; (g) B. spinósa Roxb. (100) ft.), Bengal; (h) B. Túlda Roxb. (70 ft.), Bengal to Burma.

Bamboos belonging to other genera are (i) Anthrosty lídium excélsum Giriseb. (80 ft.), West Indies; (j) Arundinaria acumináta Munro (20 ft.), Mexico; ( $\mathrm{k}$ ) Arundinária tesseláta Munro, (20 ft.), S. Africa (see also 191); (1) Cephalostáchyum pergrácile Munro (40 ft.), Burma; (m) Chús(quea simplicifióra Munro ( $80 \mathrm{ft}$.), Panama; (n) Dendrocálamus Hamiltóni Nees (60 ft.), Himalayas; (o) Gigantóchloa heterostáchya Munro (30 ft. ), Malacea; (p) Guádua refrácta Munro (30 ft.), Brazil; (q) Meróstachys Clausséni Munro, ( $>$ ft. ), Brazil; ( $r$ ) Nástus Bourbónicus Ǵmel. (50 ft.), Bourbon, (s) Oxytenanthéra Abyssínica Munro (50 ft.), Abyssinia to Angola; (t) Phyllóstacliys uígra Munro, (25 ft.), China and Japan; (u) Planótia nóbilis Munro, New Granada, (v) Pseudostachyum polymórphum Munro (very tall), Himalayas, (w) Sclizostáchyum Blúmei Nees, Java.

233. BÁPHIA, Afzel. Camwood.

Trees. About 10 species, all African.

Papilionaceae.

a. B. nítida Lodd. Western Africa. Camwood, Barwood. Wood yields a red dye.

234. BAPTÍSIA, Vent. Wild Indigo. Papilionaceae. From Greek, a "dye" plant. Syn. Sophora, Podalyria, Crotalaria, in part. Perennial herbs with showy yellow, white or blue flowers. About 16 species, all of eastern and southern U. S. and Mexico.

a. B. austrális (L.) R. Br. (S. australis L.). Southeastern U. S. Blue, Wild or Faise Indigo, Blue Rattle-bush.

b. B. tinctória (L.) R. Br. (S. tinctoria L., P. tinctoria Michx.) Ontario to Minnesota and Louisiana. Yellow or American Indigo, Indigo-weed, Yellow or Indigo Broom, Clover Broom, Broom Clover, Horse-fly weed, Shoo-fly, Rattle-bush; Ger. Baptisie, Wilder Indigo, Pferdfliegenstrauch; Fr. Indigo sauvage. Root alterative, emeto-cathartic, antiseptic.

235. BARBÁREA, R. Br. Winter Cress. Cruciferae. Dedicated to St. Barbara. Syn. Erysimum, in part. Biennial or perennial herbs with yellow flowers. About 10 species, 3 nat. in U. S. 
a. B. Barbárea (L.) MacM. (E. Barbarea L., B. vulgaris R. Br.) Europe and northern Asia, nat. in U. S. Winter-cress, Landcress, Herb Barbara, Cassabully, Bitter or Rocket Cress, French or Normandy Cress, St. Barbara's Cress, Yellow Rocket, Winter or Wound Rocket, Yellow Scurvy-grass, Hedge Mustard, St. Barbara's herb; Ger. Winterkresse, Winterbrunnenkresse; Fr. Herbe de Ste. Barbe. Plant antiscorbutic, sometimes used for salad.

b. B. praécox (J. E. Sm.) R. Br. (E. præcox. J. E. Sm.). Europe, adv. in U. S. Early Winter-cress, Belle Isle Cress, Land Cress. Properties of (a).

236. BARóSMA, Willd. 1809 (Baryosma). Buchu. Rutaceae. From Greek, of "heavy odor". Syn. Bucco, Wendl., 1808, Parapetalifera, Wendl. 1808, Diosma, in part. Strong-scented evergreen shrubs. About 15 species, southern Africa.

a. B. betulína (Thunb.) Bart. \& Wend. (D. betulina Thunb., D. crenata DC., Bucco betulina R. \& Sch.). Southern Africa. Buchu, Short Buchu; Ger. Bukko; Fr. Buchu, Bucen (Codex). Leaves (of this and the following), Buchu, U. S. P., Buchu folia, Br.,Fol. barosmæ v. diosmæ v. buchu v. bucco. Stimulant diuretic, stomachic.

b. B. crenuláia (L.) Hook. (D. crenulata L., B. crenata Kze. D. odorata DC., D. latifolia Lodd.). Southern Africa. Same names and properties as (a).

c. B. serratifólia (Curt.) Willd. (D. serratifolia Curt.). Longleaf Buchu, Long Buchu. Properties of (a), but containing less volatile oil.

237. BAR'TĹ'TTIA, A. Gray. Bartlettia. Compositae. Named for J. R. Bartlett, Commissioner Mexican Boundary Survey. Slender winter annual with yellow Howers. One species, Mexican border of U. S.

238. BA RTónia, Muhl. Bartonia. Gentianaceae. Named for Prof. B. S. Barton, of Philadelphia, d. 1815. Syn. Centaurella, Saginat, in part. Slender, almost leafless annuals or biennials. Two or three species, eastern U. S.

a. B. Virgínica (L.) B. S. P. (Sagina Virginica L., B. tenella Willd.). Eastern U. S. Yellow Bartonia, Screwstem.

239. BÁRTSIA, L. Bartsia. Scrophulariaceae. Named for John Bartsch, Prussian botanist, d. 1738. Perennial herbs, some parasitic. About 6 species, northern hemisphere; 1 in U. $S$.

240. BÁSSIA, Koenig. Mahwa, etc. Sapotaceae. Named for Ferdinand Bassi, Italian botanist, d. 1774. Syn. Butyrospermum, Illipe, in part. Trees. About 25 species, India and East Indies.

a. B. butyrácea Roxb. India. Indian Butter-tree, Phulwara. Seeds yield a tallow-like fat, Fulwa butter. 
b. B. latifólia Roxb. (Illipe latifolia Muell.). Bengal. Mahwa tree (Mahwah), Mohwa tree. Fleshy flouers saccharine, used as food. Seeds yield Mahwa butter.

c. B. longifólia L. East Indies. Illupi, Elloopa, Meetru. Flowers esculent. Seeds yield elloopa oil. Bark astringent, antipruritic.

d. B. Párkii G. Don. (Butyrospernum Parkii Kotschy (Kew), the preferable name). Tropical Africa. Shea tree, African Butter tree. Sceds yield a solid fat called Shea butter, Galam butter or Bambuk butter.

241. BÁTIS, I. Jamaica Saltwort or Samphire. Batidaceae. Maritime shrub, probably a single species, $N$. America to Philippine Islands (U. S.).

242. BATRÁCHIUM, S. F. (iray. Water Crowfoot. Ranunculaceae.

From Greek, "frog plant", alluding to the habitat. Syn. Ranunculus, in part. Aquatic herbs with white flowers. About 20 species; 4 in U. S.

a. B. trichophýllum (Chaix) Bossch. (R. trichophyllus Chaix, R. aquatilis var. trichophyllus Gray). Northern Europe, Asia and N. America, south to North C'arolina and California. White Water-crowfoot, Green Eel-grass, Pickerel-weed*, Water Milfoil*.

243. BAUHÍNIA, L. St. Thomas' tree, etc. Caesalpinaceae. Named for the brothers Jean and Gaspard Bauhin, Swiss botanists, d. 1613 and 1624, the suggestion coming from the two-lobed leaves. Woody climbers, shrubs or trees. About J80 species, tropical regions.

a. B. tomentósa L. India and tropical Africa. St. Thomas tree (flowers spotted with the martyr's blood). Buds and leaves used in dysentery.

b. B. variegáta L. China and East Indies. Mountain Ebony. Bark astringent.

244. BÉBBIA, Greene. - Pebbia. - Compositae. Named for M. S. Webb, American botanist, nineteenth Century. Syn. Carphephorus, in part. Suffruticose herb with fragrant golden-yellow blossoms. One species, southwestern U. S.

245. BEGóNIA, L. Begonia, Elephant's-ear. Begoniaceae. Named for Gov. Begon of San Domingo, 17th C'entury. Ornamental herbs with oblique leaves, flowers commonly waxlike and rose-colored. Many species cult. in gardens.

246. BEJÁRLA, Mutis (Befaria). Bejaria. Ericaceae. Named for Prof. Bejar, botanist of Cadiz. Shrubs. About 20 species, New World, mostly of $S$. America; 1 in U. S. 
247. BeLLíNIA, Roem. \& Schult. Bellinia.. Solanaceae. One species in U. S. (Heller).

248. BÉLLIS, L. - - Daisy. - - Compositae. The Latin name, "pretty". Low herbs. About 25 species, northern hemisphere and S. America; 1 in U. S.

a. B. perémnis L. Europe and Asia, adv. in U. S. Garden Daisy (Dazeg), English or European Daisy, Dicky Daisy, Dog. Daisy (north England), Childing Daisy, Bairnwort, Banwort, Bennert, Bone-flower, Bonewort, Bruise-wort, Consound, Catposy\|, Cockiloorie\|, Gowan (Scotland), Ewe Gowan, May Gowan, Gowlan, Hen-and-chickens, Maple-flower, Margaret; Ger. Masliebenblume; Fr. Marguerite. Leaves formerly reputed vulnerary.

249. BELOPHÉRONE, Nees. Belopherone. Acanthaceae. From Greek, "pointed dart". Syn. Jacobinia, Sericographis, in part. Shrubby plants with red flowers. About 40 species, tropical America; 1 in California.

250. BÉXZOIN, Fabric. 1763. Spice-bnsh. Lauraceae. Name from gum benzoin. Syu. Euosmus, Nutt. 1818; Laurus, Lindera in part. Aromatic shrubs or trees. About 7 species, N. America and Asia; 2 in U. S.

a. B. Bénzoin (L.) Coulter (Laurus Benzoin L., Lindera Benzoin Blume, B. odoriferum Nees.). Ontario to N. Carolina and Kansas. Spice-bush, Benjamin-bush, Wild Allspice, Feverbush, Spice-wood, Snap wood; Ger. Benzoelorbeer; Fr. Laurierbenzoin; Bark and twigs, stinnlant, diaphoretic, febrifuge, anthelnintic. Fruit carminative, condiment.

b. B. melissæfólium (Walt.) Nees. (Laurus melissæfolia Walt., Lindera mellissæfolia Blume). Missouri to Florida. Hairy Spice-bush, Spice-wood, Jove's-fruit.

251. BÉRBERIS, L.

Barberry.

Berberidaceae. Latin name, from Arabic. Shrubs with vellow wood and often spiny leaves. About 75 species, north temperate zone and S. America; 14 in U. S.

a. B. aristáta Roxb. India. Indian Barberry, Ruswut, Rusat. Root bark used as a tonic, as is that of (b) B. Asiática Roxb. and of (c) B. Lýcium Royle.

d. B. Aquifólium Pursh. (Berberis repens Lindl., Malıonia repens Don.). Rocky Mountains. U. S. and British Columbia. Oregon Grape, Rocky Mountain Grape, Holly-leaved Barberry, California Barberry, Trailing Mahonia. [According to some botanists B. repens is a distinct and smaller species. (d) B. nervósa Pursh. is probably not distinguished from these by collectors of the roots.] Root (sometimes called Graperoot) bitter tonic, alterative. 
e. B. rulgáris L. Europe and Western Asia, nat. in U. S. Barberry; Common European or Garden Barberry, Barbaraune, Guild-tree, Jaundice-berry, Pepperidge-bush (England), Piperidge (corrupted from Berberis) Peprage, Sow-berry, Wood-sow, Wood-sour, Wood-sore; Ger. Berberitze, Saurach; Fr. Berberis, Épine-vinette (Codex), Vinettier; Sp. Berberos. Bark of root tonic, aperient; contaius berberine, as in other species. Leaves: antiscorbutic. Fruit, called Rilts, refrigerant, esculent.

25.. BERCHÉMIA, Teck. Supple-jack. Rhamnacege. Name unexplained, Climbing or erect shrubs. About 15 species, all but one of Asia and tropical Africa; 1 in U. S.

253. BÉRGLA, L. - Bergia. - Elatinaceae. Named for P. J. Bergius, Swedish naturalist, d, 1790. Unimportant herbs, some suffrutescent. About 15 species, mostly Old World; 1 in U. S.

254. BERGÍNIA, Harvey. Berginia. Acanthaceae. Named for M. Pergin of Dublin. A low shrubby plant. One species, southwestern U. S.

25๊. BERLANI)IÉRA; DC. Berlandiera. ('ompositae. Named for J. Berlaudier, Swiss botanist. Perennial woolly herbs with rather large flower-heads (yellow). About 5 species, Mexican border; 4 in U. S.

256. BERYÁRDIA, Houst. Bernardia. Euphorbiaceae. Shrubs or herbs. About 30 species, warner regions of New World; 1 in U. S.

257. BERTHOLLÉTIA, Humb. \& Bonp.

Lecythidaceae.

Named for Claude Louis Berthollet, French chemist, d. 1822. Syn. Bertholetia. Tall trees. One or two species, S. America.

a. B. excélsa Humb. \& Bonp. Northern S. America. Juvia tree, Castanhiero de Para. Seeds, Brazil-nuts, Para-nuts, Cream-nuts, Nigger-toes, Castana-nuts; Fr. Chataigne du Brésil; esculent, abounding in oil.

258. BÉRULA, Hoffm. Water-Parsnip. Umbelliferæ. From Latin name of water-cress. Syn. Sium, in part. One species.

a. B. Précta (Huds.) Coville (S. erectum Huds., S. angustifolium L. ). Northern Europe, Asia and N. America, south to Illinois. and California. Cut-leaved or Lesser Water-parsnip, Narrowleaved or Creeping Water-parsnip.

259. BÉTA, L. - - Beet. - - Chenopodiacea. The Latin name. Herbs with fleshy roots. About 15 species, Europe, temperate Asia and Africa.

a. B. vulgáris L. Southern Europe, now generally cultivated. Beet, Beet-radish, Beetrave, Beetraw, Beetrie (Scotland), var. nacrorrhiza is Mangel-wurzel. (There are many named. 
varieties, those used for manufacture of sugar being distinguished as Sugar beets); Ger. Runkelrübe, Zuckerrübe, Fr. Bettarave. Fleshy roots esculent, rich in sugar. Leares used as a pot herb. [The wild B. maritima L., now regarded as the same species, is called Wild Spinach.]

260. BETÓNICA, L. - Betony. - Labiatae. The Latin name of Wood Betony. Syn. Stachys, in part. Herbs resembling Stachys. About 12 species, Europe and Asia.

a. B. officinális L. (Stachys Betonica Benth.). Southern Europe, adr. U. S. Wood Betony, Bishop's-wort, Herb Christopher*, Wild Hop, Lousewort; Ger. Zehrkraut, Betonie; Fr. Betoine (Codex). The blossoming plant, Herba betonica, $\mathrm{H}$. veronicæ purpureæ, formerly reputed febrifuge, etc.

961. BÉTULA, L. - - Birch. - - Betulaceae. The ancient Latin name. Trees, some with white papery cortex. About 35 species, north temperate and arctic zones; 9 in $\mathrm{U} . \mathrm{S}$.

a. B. álba L. Northern Asia and Europe. White Birch, European White Birch, Lady Birch?. Birke, Make-peace, Ribbon-tree: Ger. Birke; Fr. Bouleau. Source of Birch Tar or daggett, used in making Russian leather. Empyreumatic oil, Oleun rusci, Oleum betulinum v. moscovitum, antiseptic and vulnerary.

b. B. lénta L. Ontario to Florida. Sweet Birch, Cherry Birch, Black Birch, Spice Birch, River or Mahogany Birch, Moun-. tain Mahogany. Branches and foliage yield an oil, sold as oil of wintergreen.

c. B. papyrífera Marsh. (B. papyracea Ait.). British America and northern U. S. Canoe Birch, Paper Birch, American White Birch, Silver Birch, Bolean Birch, Spool-wood. Bark used for many purposes.

Other indigenous species are (d) B. Iútea Michx. f., Yellow Birch; Gray, Silver or Swamp Birch; (e) B. nígra L., River Birch; Red, Black or Water Birch; (f) B. occidenális Hook., Western Red Birch; Black, Cherry, Gray, Sweet or Water Birch of the far west; (g) B. populifólia Marsh (B. alba var. populifolia spach), the true American White Birch; Gray, Pin, Porerty or Old-field Birch, (a smaller tree than (c); (h) B. púmila L., Low Birch, also called Tag Aldert.

262. BICUCÚLLA, Adans. 1763. Ear-drops. Fumariaceae. From Latin, "double hooded". Syn. Diclytra, Borck. 1797, (Dielytra), Dicentra, Bernh. 1833 ; Fumaria, Corydalis, in part. Herbs with dissected leaves and racemes of showy flowers. About 14 species, $\mathbf{T}$. America and western Asia; 8 in U. S.

a. B. Canadénsis (Goldie) Millsp. (C. Canadensis Goldie, Diclytra Canadensis DC., Dicentra Canadensis Walp., C. formosa Auct. not DC: .). Ontario to Kentucky and Missouri. Turkey Corn, Squirrel Corn, Turkey Pea, Staggerweed, Colic-weed, Wild Hyacinth, Diclytra, Fumitory. Tubers, Corydalis, tonic*, diuretic, alterative. 
b. B. cucullária (L.) Millsp. (Diclytra cucullaria DC. Dielytra cucullaria T. \& G., Dicentra cucullaria Torr.). Northern U. S. Dutchman's-breeches, Little-boy's-breeches, Kitten'sbreeches, Breeches-flower Indian-boys-and-girls, Monkshood*, White Ear-drop, Soldier's Cap, Colic-weed*\%, Boys-and-girls.

c. B. exímia (Ker.) Millsp. (Fumaria eximia Ker, Dicentra eximia Torr. ). New York to Georgia. Wild Bleeding-heart, Staggerweed, Turkey-corn.

d. B. formósa (DC) Howell. (C. formosa DC.). Pacific coast of U. S. California Bleeding-heart.

263. BídeNS, D. Beggar-ticks, etc. Compositae. From Latin, "two toothed", of the achenes. Syn. Diodonta, Coreopsis, Helianthust, in part. Coarse herbs, the achenes armed with barbed awns. About 60 species, widely distributed; 20 in U. S.

a. B. aristósa (Michx.) Brit. (C. aristosa Michx. B. aristata Muhl.) and other showy species of eastern U. S., as (b) B. coronáta (L.) Fisch., (c) B. trichospérma (Michx.) Brit., originally referred to Coreopsis, are called Tickseed Sunflower.

d. B. Béckii Torr. Canada to New Jersey and Missouri. Water Marigold.

e B. bipinnáta L. Eastern U. S. to Nebraska and Mexico, nat. in Europe. Spanish-needles. Root and seed emmenagogue, expectorant, used in hay asthma.

f. B. cérnua L. Northern Europe, Asia and N. America. Simaller or Nodding Bar-marigold, Baclin, Double-tooth, Pitch forks, Water Agrimony.

g. B. Prondósa L. Canada and eastern to central L.S. Common Beggar-ticks, Stick-tight, Beggar-lice, Cow-lice, Harvest-lice, Cuckles, Cuckold, Devil's-pitchforks, Rayless Marigold, Common Bur-marigold. Most of these names are applied to other similar species.

h. B. laévis (L.) B. S. P. (II. laeris L., B. chrysanthemoides Michx.). Widely distributed in N. America. Brook Sunflower, Large or Smooth Bur-marigold.

i. B. tripartíta L. Europe. Swamp Peggar-ticks, Agrimony Water-hemp, Water Agrimony; Ger. Gelber Wasserhanf, Wasserdürrwurz, Fr. Chanvre aquatique. Properties of (e).

264. BIFÓRA, Hoffn.

Bifora.

Umbelliferae. Syn. Atrema, in part. Herbs. About 5 species, nortl temperate zone; 1 in U. S.

265. BIGNóNIA L. - Bignonia - Bignoniaceae. Named for Abbe Bignon, librarian to Louis XV. Woody climbers with showy flowers. About 150 species, all American; 1 in U. S. 
a. B. alliácea Lam. Guiana and West Indies. Garlic shrub. Fr. Liane à l'ail.

b. B. crucígera L. (B. capreolata L.). Virginia and Illinois to Florida. Tendrilled Trumpet-flowerל, Cross-vine, Quarter-vine. Root alterative, detergent.

c. B. nodósa Manso, of Brazil is one of many plants known as Caroba. See Jacaranda.

266. BÍXA, L. - - Arnotta. - - Bixareae. Shrubs with showy flowers and prickly capsules. One or two species, South America.

a. B. Orellána L. Tropical America, and commonly cult. in tropical countries. Arnotta tree. Fruit yields the coloring matter called Arnotta (Annatto, Annota, Anotto), Orellana, Orleana; Ger. Orlean; Fr. Rocou, Terra de la Nourelle-Orleana; Sp. Achiotillo.

267. BLÉCHNUM, Presl. Blechnum. Polypodiaceae. The ancient Greek name. Ferns. About 40 species, New World to Australia; 1 in U. S.

265. BLENYOSPÉRM. Less. Blennosperma. Compositae. From Greek, "mucus seed". Syn. Aphalus, Coniothele. Low annuals. Two species, one of C'hili, one of C'alifornia.

269. BLEPHARIPÁPPUS, Hook. Blepharipappus. Compositæ. From Greek, "eye-lash" and "pappus". Syn. Layia, Ptilonella, in part. Annual herbs with mostly showy Howers (white or yellow). About 17 species, Pacific border of $\mathrm{C}$. S.

270. BLEPHÍLIA, Raf. Ohio Horsemint. Labiatae. From Greek, "eye-lash", alluding to ciliate calyx-teeth. Syn. Monarda, in part. Perennial herbs of mint-like odor. Two species, eastern U. S.

271. BLÉTIA, R. \& P.

Bletia.

Orchidaceae.

Terrestrial orchids, often highly ornamental. About 80 species, warmer regions of New World; 1 in $\mathrm{U}$. S.

272. BLÍGHIA, Koenig. Blighia. Sapindaceae. Named for Capt. Bligh of H. M. S. Bounty. Syn. Akea, Akeesia; Cupania, in part. Trees. Two species, referred by many botanists to Cupania; tropical Africa.

a. B. sápida Koenig (C. sapida Voigt, Akea solitaria Stokes, Akeesia Africana Tussac). Western Africa, cult. in tropical countries. Akee tree. Fruit acidulous, edible.

273. BLITCM, L. Strawberry Blite. Chenopodiaceae. The Greek name of a salad plant. Syn. Chenopodium, in part. A pigweed-like plant with fleshy red fruit. One species. 
a. B. capitátum L. (C. capitatum Asch.). Northern Europe, Asia and N. America, south to Colorado. Strawberry Spinach, Indian Strawberry, Indian-paint. Plant used as a pot herb.

274. BLOOMÉRIA, Kellogg. Bloomeria. Liliaceae. Scapose herbs from a small corm. Four species in southwestern U. S.

275. BLÚMEA, DC. - Blumea. - Compositae. Named for Karl Ludwig Blume, botanist of Holland, d. 1862. Balsamic or aromatic plants, more than 100 species, mostly of tropical Asia.

a. B. balsamífera DC. China and Burma. Vernacular name Nigai. Plant yields Ngai Camphor.

276. BOEHMÉRIA, Jacq. Ramie, etc. Urticaceae. Named for G. R. Boehmer, German botanist, d. 1803. Herbs, shrubs or trees. About 50 species, mostly tropical; 1 in U. S.

a. B. nírea Gaud. Eastern Asia. Ramie, Rheea. Stems yield a strong white fibre from which the Chinese grass-cloth is made.

27. BOERHAíVIA, L. (Boerhavia). _ - Nyctaginaceae. Named for Hermann Boerhaave, Dutch naturalist, d. 1729. Herbs. About 40 species, warmer regions of Old and New World; 17 in U. S.

278. BOISDUVÁLIA, Spach. Boisduvalia. Onagraceae. Syn. Oenothera, in part. Herbs. About 10 species, New World; 6 in U. S.

279. BOLÁNDRA, A. Gray. Bolandra. Saxifragaceae. Herbs. Two known species, Pacific coast, U. S.

280. BóLDU, Adans. 1763 (Boldea, Boldus). Monimiaceae. From vernacular name, Chili. Syn. Peumus, Mol. 1782, Ruizzia, R. \& P. 1794, Boldoa, Endl. not Cav. Fıagrant evergreen shrub. One species.

a. B. Bóldus (Mol.) Lyons (Peumus Boldus Mol., R. fragrans R. \& Pav., P. fragrans, Pers., Boldea fragrans, C. Gay). Chili. Boldo, Boldoa, Boldu; Fr. Boldo (Codex). Leaves tonic, antispasmodic, used for relief of catarrhal conditions.

281. B0LÉLIA, Raf. $1832 . \quad$ Bolelia. Lobeliaceae. A transliteration of Lobelia. Syn. Downingia, 'Torr. 1856. Herbs. About 15 species, New World; 12 in southwestern U. S.

282. BOLTóniA, L. Her. Boltonia. Compositae. Named for James Bolton, English botanist, 18th Century. Perennial herbs, with white, pink or purple flowers. Four or five species, all of U. S.

283. BOMÁREA, Mirb. Bomarea. Amaryllidaceae. Named for Valmont de Bomare, French naturalist, 18th Century. Twining plants. About 70 species, S. America and Mexico. 
a. B. édulis, IIe: Tropical America. Tubers esculent.

884. BORÁG0, L. - Borage. - Boraginaceae. The Latin name, "rough bairy". Hairy herbs with showy hlue flowers. About 17 species, Mediterrane:un region.

a. B. offeinális L. Levant, cult. in gardens and adv. in L. S. Borage, Burrage, Bee-bread, Cool-tankard, Lang-de-beef, Starflower; Ger. Borasch, Boretsch; Fr. Bourrache (Codex); Sp. Borraja. Herb emollient, diuretic, febrifuge.

285. BoRássus, L. Palmyra Palm. Sabalaceae. From Greek name of palm fruit. Tall large Palms, two principal species, one of Asia one of Africa.

a. B. flabéllifer L. (B. flabelliformis Murr.). Southeastern Asia. Palmyra Palm, Fan Palm, Toddy Palm. Sap yields palm wine (toddy) and palm sugar (jaggery, whence Latin saccharum). Young seedlings esculent.

286. BORBÓNIA, L. Borbonia. Papilionaceae. Shrubs or suffrutescent herbs. About 30 species, mostly of southern Africa.

a. B cordáta L. S. Africa. Leaves used for tea.

287. BORRÍCHIA, Adans. Sea Ox-eye. Compositae. Named for Olaf Borrick. Danish botanist. Syn. Buphthalmum, in part. Fleshy littoral shrubs. A bout 5 species, tropical America; 2 in U. S.

a. B. frutéscens (L.) DC. (Buphthalmum frutescens L.). South eastern U. S. and West Indies. Sea Ox-eye, Jamaica Samphire. See Batis.

288. BOSCHNIÁKIA, C. A. Meyer. Boschniakia. Orohanchaceæ. Scaly herbs. Five known species, eastern Asia, Japan and N. America; 3 in U. S.

a. B. strobilácea Gray. California. Squirrel's-grandfather.

289. BOSWÉLLIA, Roxb. Boswellia. Burseraceae. Named for John Boswell of Edinburgh. Trees. About 10 species, southern Asia and eastern Africa.

a. B. Cartérii Birdw., and probably other species of Arabia and Somali-land, yield the gum resin, Olibanum or Frankincense, Gummi-resina Olibanum, Thus; Ger. Weihrauch; Fr. Encens, Oliban (Codex); Sp. Incienso. Balsamic, antiseptic, vulnerary.

b. B. Frereána Birdw. Somali-land. Gum-revin, African or Oriental Elemi, Lubân Mayeti (Mati); used as a masticatory.

c. B. papyrífera Hochst. Abyssinia. Gum resin resembles that of $(a)$.

d. B. serráta Roxb. (B. thurifera Coleb.). India. Salai tree. Gum-resin, Indian Olibanum, Gum Thus, Male incense, probably the frankincense of the ancients; used in India for incense. 
290. BOTRÝCHLH, Swz. Grape-fern. Ophioglossacea. From Greek word for a "cluster of grapes". Syn, Usmundat, in part. Small fleshy ferns. About 12 species; 9 in U. S.

a. B. Lunária (L.) Swz. (O. Lumaria L.). Northern Europe, Asia and $\mathrm{X}$. America. Moonwort, Moon Fern, Lunary, Plentage, Cnshoe-the-horse, the first three of these names being sometimes extended to other species.

b. B. Virginiánum (L.) Siwz. (O). Virginiana L., B. gracile Pursh.). Northern Europe, Asia and $\mathbf{N}$. America. Virginia Grape-fern?, Rattlesnake Fern, Indicator (Virginia), Hemlockleaved Moonwort?.

291. BOÚCHEA, Cham. Bouchea. Verbenaceae. Named for Charles and Peter Bouché, gardeners of Berlin. Herbs, some shrubby. About 20 species, mostly African, a few in America and Asia; 3 in southwestern U. S.

292. BOCCHÉTIA, DC. Bouchetia. Solanaceae. Named for D. Bouchet, French botanist. Low perennial herb, a single species, Texas to Brazil.

293. BOURDÓXIA, Greene. Bourdonia. Compositae. Syn. Keerlia. Two species in western U. S.

294. BOURRÉRIA, P. Br. (Beurreria). Boraginaceae. Named for a Nuremberg apothecary, Bourrer. Syn. Crematomia, Miers, Ehretia, Pittonia, in part. Trees and shrubs. About 25 species, tropical America; 2 in U. $\mathrm{S}$.

995. BOUVÍRDIA, Salisb. Bouvardia. Rubiaceae. Name for Dr. Bouvard of the Jardin du Roi, Paris. Ornamental shrubs. About 50 species, tropical America; 2 in U. S.

296. BOWDÍCHIA, H. B. K. Bowdichia. Papilionaceae. Named for J. E. Bowdich, traveler in west Africa. Syn. Sebipira, Mart. Trees. Two species, S. America.

a. B. virgilioídes $H$. B. K., Brazil. Alcornoco, Alcornoque. Bark tonic, febrifuge. See 334 (a).

297. BOWLÉSIA, R. \& P. Bowlesia. Umbelliferae. Herbs. About 20 species, mostly of S. America; 1 in U. S.

29S. BRABÉJUM, L. Kafir Chestnut. Proteaceae. Syn. Brabyla. Shrubs. One species, south Africa.

a. B. stellatifólium L. South Africa. Kafir Chestnut, Wild Chestnut, Wild Almond. Seeds esculent, a substitute for coffee.

299. BRACHYÁCTIS, Ledeb. Rayless Aster. Compositae. From Greek, "short rayed". Syn. Tripolium, Aster, in part. Smooth, somewhat fleshy herbs. About 7 species, $\mathbf{N}$. Anerica and northern Asia; 1 in U. S.

300. I3RACHYCHAÉTA, T. \& Gr. False Golden-rod. Compositæ. From Greek, "short bristled", of the pappus. Syn. Solidago, in part. One species, eastern U. S. 
301. BRA DBÚRYA, Raf. 1817. Butterfly-Pea. Papilionaceae. Named for John Bradbury, explorer in America early in 19th Century. Syn. Centrosema, Benth. 1838, Clitoria, in part. Vines with showy flowers. About 30 species, all American; 2 in $\mathrm{U}$. S.

802. BRASÉNIA, Schreb. Water-shield. Nymphaaceæ. Name unexplained. Syn. Hydropeltis, Menyanthes, in part. Aquatic plant with small peltate leaves. One species.

a. B. purpúrea (Michx.) Casp. (H. purpurea Michx., B. Schreberi J. F. Gmel. (Kew), B. peltata Pursh.). Nova Scotia to Mexico and California, also in Asia and Australia. Watershield, Water-target, Water-jelly, Deer-foot, Frog-leaf, Little Lily-pad, Little Water-lily, Water-leaf. Leaves astringent. Roots farinaceous.

303. BRÁSSICA, L. Cabbage, etc. Cruciferae. The Latin name of Cabbage. Syn. Sinapis, in part, Annual, biennial or perennial herbs. About 80 species, Old World.

a. B. arvénsis (L.) B. S. P. (B. Sinapistrum Boiss. (Kew), S. arrensis L.). Europe, adv, in U. S. Charlock (Carlock, Carlick, Kerlock, Curlock), Wild Mustard, Corn Mustard, Corn or Field Kale, Bastard Rocket, Chadlock (Kedlock, Kellock, Kilk), Kraut-weed, Crowd-weed $\ddagger$, Runch, Warlock, Yellowflower. Seeds like those of (d) but smaller.

b. B. campéstris L. Europe. Wild or Common Navew, Wild Navette, Nape, Bargeman's Cabbage, Colza, Summer Rape. Of this species it is believed that B. Nápus L., which yields the various kinds of Turnip (Cole-rape) are only varieties. Tuberous roots, in cultivation, esculent, antiscorbutic. Seeds, Rape seed, Cole-seed, Bird-seed; yield Rape or Colza oil; Ger. Rüböl, Rapsöl, Kohlsaatsöl; Fr. Huile de navette, Huile de Colza.

c. B. júncea (L.) Coss. (S. juncea L.). Southern Russia, adv. in U. S. Sarepta Mustard, Russian Mustard, Indian Mustard. Properties of $(d)$.

d. B. nígra (L. ) Koch (S. nigra L., B. sinapioides Roth.). Europe and Asia, nat. in U. S. Black Mustard, Red Mustard, Cadlock, Kerlock, Senore, Scurvy. Seed, Sinapis nigra, U. S. P., Sinapis nigræ Semina, Br., Sem. Sinapis P. G., Semen sinapeos; Ger. Senf, Schwarzer Senfsamen; Fr. Moutarde noire (Codex);Sp. Mostaza negra; Irritant, emetic, revulsive, counterirritant, also used as a condiment.

e. B. olerácea L. Europe, now universally cultivated. Cabbage, Colewort, Collard $\ddagger$, (southern U. S.) Colletł; in the wild state, Sea-Cabbage or Sea Kale, also Coolstock, Ragged Jack. Under cultivation has developed the varieties known as Cauliflower, Broccoli, Borecole (Bowkail), Brussels Sprouts, Kohl rabi; Ger. Kohl; Fr. Chou. Leaves (heads, buds, etc.), esculent.

304. BRA UNÉRIA, Neck.1790. Purple Cone-flower.Composita. Named for Jacob Brauner, German botanist, 18th Century. Syn. Echinacea, Moench. 1794, Rudbeckia, in part. Robust herbs with thick black roots. Two species, both of U. S. 
2. B. pállida (Nutt.) Britton. (Rudbeckia pallida Nutt., Echinacea angustifolia DC.). Alabama to Texas and northwestward. Pale-purple Cone-flower, Comb (Dakota), Echinacea, Sampsonroot. Root alterative; remedy for snake-bite, hydrophobia, etc.

b. B. purpúrea (L.) Brit. (Fichinacea purpurea Moench., Rudbeckia purpurea L.) Virginia to Illinois and Louisiana. Black Sampson, Hedgehog Cone-flower, Purple Cone-flower, Red Sun-flower, Comb-flower. Properties of No. 1.

305. BRÁY A, Sternb. \& Hoppe. Braya. Cruciferae. Perennial scapose herbs. About 15 species, Arctic and Alpine regions; 2 in $\mathrm{U}$. S.

306. BRAZÓRIA, Eng. \& Gray. Brazoria. Labiatae. Named from the river Brazos in Texas. Syn. Physostegia, in part. Low annuals. Two known species, both of Texas.

307. BREVOÓRTIA, Wood. Brevoortia. Liliaceae. Scapose herb with showy umbellate flowers. A single species, California.

2. B. renústa Greene (B. coccinea, Wats., B. Ida-Maia Wood. California. Vegetable Fire-cracker, Crimson Satin-flower.

308. BREWÉRIA, R. Br. Breweria. Convolvulaceae. Named for Samuel Brewer, a correspondent of Dillen. Syn. Stylisma, Bonamia, Convolvulus, in part. Procumbent herbs. About 30 species, warm regions; 7 in $\mathrm{U}$. S.

309. BRINTóNIA, Greene. Brintonia. Compositae. Syn. Solidago, in part. Herb, allied to Golden-rod. One species in western $\mathrm{U}$. S.

310. BRITTONÁMRA, Brittonamra. Papilionaceae. Syn. Cracca, in part. Herbs. Two species in western U.S.

311. BRODIAÉA, Sm. California Hyacinth. Liliaceae. Scapose herbs from a coated bulb. About 20 species, New World; 8 in southwestern U. S.

312. BROMÉLIA, L. Bromelia. Bromeliacene. Named for Adolph Bromel, Swedish botanist, d. 1705 . Fiber plants. About 30 species, S. America.

a. B. Pínguin L. West Indies. Pinguin, Pen-gwyn. Fruit acidulous, refrigerant, anthelmintic. A hedge plant.

313. BRónUS, L. Brome-Grass, Chess. Graminex. Greek name of a kind of Oats. About 40 species; 23 in U.S.

a. B. secalínus L. Europe and Asia, nat. in U. S. Chess, Cheat, Cheat-grass, Smooth Rye-brome.

314. BRoNGNiárTIA, H. B. K. Brongniartia. Papilionaceæ. Named for Adolph Brongniart, French botanist. Shrubs. About 20 species, mostly of Mexico; 1 in U. $\mathrm{S}$. 
315. BRÓSIMUM, Swz. 1788. Cow-tree, etc. Artocarpaceac. From Greek, "esculent". Syn. Piratinera Aubl. 1775 ("witb false characters", B. \& H. ), Galactodendron H. B. K., in part. Trees with milky sap. About 8 species, tropical America.

2. B. Alicástrum Swz. West Indies. Seeds, called in Jamaiea bread-nuts, esculent. Milk juice acrid.

b. B. Galactodéndron D. Don (G. utile Kunth.). Tropical America. Cow tree, Milk tree, Palo de vaca, Arbol de léche. Milk juice resembles cow's milk. See Clusia.

316. BROUSSONÉTIA, L'Her. Paper Mulberry. Moraceae. Named for M. Broussonet, French naturalist, d. 1807 . Syn. Morus, in part. Trees with fibrous bark. About 7 species, eastern Asia and Oceanica.

2. B. papyrifera (L.) Vent. (M. papyrifera L.). Acia and Oceanica, nat. in U. S. Paper Mulberry, Tahiti Mulberry, Cut-paper. Inner bark made into paper in Japan and into bark cloth (kapa, tapa) in the islands of the Pacific. 317. BRUNFÉLSIA, L. Solanace:ıe.
Named for Otto Brunfels, botanist of Metz, 16th Century. Shrubs or small trees. About 35 species, tropical America.

a. B. Hopeána Benth. (Franciscea uniflora Pohl.). Braxil. Manaca (one of several plants so called), called also Manacín, Camganiba, Geratacáca, Mercurio-vegetal (vegetable nercury). Root antiarthritic, alterative.

318. BRUNYÍCHIA, Banks. Brunnichia. Polygonacere. Named for M. T. Brunnich, Norwegian naturalist. Syn. Rajania, in part. Shrubby climber. Two species, one of Africa, 1 in U. S.

319. BRYÁNTHUS, S. G. Gmel. Bryanthus. Ericaceae. From Greek, "luxuriant-bloom". "Syn. Menziesia. . Low shrubs. About 6 species, Arctic and north temperate zones; 4 in U. S.

320. BRYóNIA, L. Bryony, White-vine, etc. Cucurbitaceae. The ancient Greek name. Syn. Corallocarpus, in part. Climbing perennial herbs. About 15 species, warmer regions of Old World.

a. B. álba L. Eastern Europe and western Asia. White Bryony (also called Black Bryony, from color of berries, but not to be confounded with 'Tamus communis q. v.), Tetter-berry, Whitevine, Wood-vine, Wild-vine.

b. B. dioíca L. Europe. Red Bryony, Common Bryony, Cowbind, Cow's-lick, Devil's Turnip, False Mandrake, Hedge Grape, Murrain-berry, Snake-berry, White-vine, Wild Hop; Ger. Zaunrübe, Gichtrübe, Stickwurz, Hundskurbis; Fr. Bryone blanche (Codex), Couleuvrée; Sp. Brionia. Root of this and of (a), Bryonia, U. S. P., Radix bryonia, Rad. vitis albre, 
Rad. uræ anguinæ. Hydragogue cathartic, irritant, rubefacient. [In Africa the allied (c) Kedróstis nána Cogn. (B. Africanum Thunb.) is used in the same manner].

d. B. epigaéa Rottl. (Corallocarpus epigæa Hook. f., the preferable name). Java. Root alterative, cathartic, anthelmintic.

321. BRYOPHÝLLUM, Salisb. Air-plant. Crassulaceae. From Greek, "budding leaf". Syn. Crassuvium, in part.

a. B. calycínum Salisb. Madagascar, Mauritius, etc. Air-plant, Life-plant. Leares vulnerary.

322. BÚCERAS, P. Br. 1756, not Hall, 1785. Combretaceæ. From Greek, "ox horn". Syn. Bucida, L. 1759, Terminalia, L. 1767 (Kew), Myrobalanus, Gaertn. 1791, Catappa, Pentaptera, in part. Trees or shrubs. About 90 species, tropical regions, especially of Old W orld.

2. B. angustifólius (Jacq.) Lyons (T. angustifolia Jacq., T. Benzoin L. fils, Catappa B-nzoin Gaertn.). Mauritins. Incense tree. Exudate constitutes false benzoin, used as incense.

b. B. Bellírica (Gaertn.) Lyons (T. Bellerica Roxb. (Kew), M. Bellirica Gaertn. ). East Indies. Dired fruits, Round Myrobalans, Pelleric Afyrobalans, Myrobalani rotundae s. bellerice; Ger. Runde Myrobalanen. Properties of (d).

c. B. Catáppa (L.) Lyons (T. Catappa L. (Kew), B. Bucida Crantz, Bucida Buceras Sieber, not L.). India and tropical regions generally. Umbrella tree, Malabar Almond, Country Almond (W. Indies), Kamani (Hawaii). Seeds almond-like; yield a bland fixed oil.

d. B. Chebúla (Retz) Lyons (T. Chebula Retz, M. Chebula Gaertn., Bucida comintana Blanco). India. Harra. Dried fruits are chebulic myrobalans, the yellow from the mature, the black from the blasted fruit; Ink-nuts, Harr-nuts, Myrobalani indicae s. nigrae; Ger. Indische oder schwarze Myrobalanen, astringent with cathartic properties like rhubarb: also used for tanning and for making ink. Chebula is a conserve made from the fruits.

323. BÚCHNERA, L. Blue-hearts. Scrophulariaceae. Named for J. G. Buchner. Hispid or scabrous herbs. About 30 species, tropical or sub-tropical; 4 in U. S.

324. BUCKIÉYA, Torr. Buckleya. Santalacę. Syn. Darbya, A. Gray. Shrubs. Two species, 1 in Japan, 1 in U. S.

a. B. lanuginósa (Michx.) Pers. (Sideroxylon lannginosum Michx.). Southeastern U. S. Woolly Buckthorn, Black $\mathrm{Haw}^{*}$, Gum-elastic.

b. B. Iycioídes (L.) Pers. (Sideroxylon lycioides L.). Southeastern U. S. Southern Buckthorn, Carolina Buckthorn, Bumelia, Chittim-wood, Coma, Iron-wood, Mock Orange. 
c. B. retúsa Swz. West Indies. Bastard Balata or Bully Tree.

325. BUDDLÉIA, Houst. Buddleia. Loganiaceae. Trees, shrubs or herbs. About 100 species, India, South Africa and America; 6 in U. S.

326. BUMÉLIA, Swz. Buckthorn*. Sapotaceae. Greek name of a species of Ash, "ox Ash". Syn. Sideroxylon, in part. Shrubs and trees, often thorny. About 30 species, all American; 6 in U. S.

\section{BUNIUM. See CONOPODIUM.}

327. BUPLEÚRUM, L. Hare's-ear, etc. Umbelliferae. The Greek name, "ox-ribbed". Herbs with entire clasping or perfoliate leaves. About 65 species; 1 in U. S.

a. B. rotundifólium L. Europe and western Asia, nat. in U. S. Hare's-ear, Thorough-wax or Thoroughwort, (i. e. perfoliate). Buplever?, Modesty; Ger. Durchwachskraut, Hasenohr; Fr. Oreille de lièvre. Herb and seed formerly regarded medicinal.

328. BURMÁNNIA, L. Burnannia. Burmanniacex. Named for Johann Burmann, Dutch botanist. 18th Century. Syn. Tripterella, in part. Herbs with perianth three-winged. About 25 species, warm and tropical regions; 2 in $\mathrm{U}$. S.

329. BÚRSA, Weber, 1780 . Shepherd's-purse. Cruciferæx. From middle Latin, a "purse". Syn. Capsella, Medic. 1792, Thlaspi, in part. Inconspicuous annuals. About 4 species, northern hemisphere; 1 nat. in U. S.

a. B. Bursa-pastóris (L.) Brit. (Thlaspi Bursa-pastoris L., C. Bursa-pastoris Medic.). Eur pe, nat. in U. S. and widely elsewhere. Shepherd's-purse, Blind-weed, Case-weed, Casseweed, Clappedepouch\|, Cocowort, Fat-hen*, 'Lady s-purse, Mother's-heart, Pepper-and-shot, Pepper-plant, Y'Yick-pocket, Pick-purse, Poor-man's-pharmacetty, Shovel-weed, Toothwort*, Toywort, Ward-seed. Wind-flower", Witches'-pouches; Ger. Hirtentäschlein, Hirtentäschel, Säckelkraut, Gänsekresse; Fr. Bourse à pasteur, Molette. Herb, Herba capsellæ, H. bursæpastoris; astringent, emmenagogue, diuretic.

330. BÚRSERA, L: - Bursera. - Burseraceac. Named for Joachim Burser, German botanist, 17th Century. Syn. Elaphrium, Icica, in part. Trees or shrubs, natives of tropical America; 2 in U. S. See also Canarium, Elaphrium and Protium.

a. B. gummífera L. Tropical America. Jamaica or West Indiau Birch, Gumbo-limbo tree; Fr. (iommart. Source of Cachibou or Chibou resin, resembling Caranna. [According to King's Dispensatory (1899) oil of Mexican Lignalues is derived from (b) B. Delpachiana].

331. BÚTEA, Koenig. 1795. Bastard Teak. Papilionaceae. Named for John, Earl of Bute, d. 1792. Syn. Plaso, Adans, 1763. Trees or shrubby climbers with showy flowers. About 5 species, southeastern Asia. 
a. B. Prondósa Roxb. India to Burma. Dhak tree, Pulas or Palas tree, Bastard Teak. Inspissated sap, Bengal or Palas Kino, Butea gum; astringent, resembling true kino. Seeds source of Moodooga oil (anthelmintic). The tree yields also lac. See Croton aromatica.

332. BUTNÉRIA, Duham 1755.

Calycanthaceae. Syn. Calycanthus L. 1759, Buettneria, Byttneria. Ornamental shrubs. Three species, all of U. S.

ג. B. fértilis (Walt.) Kearney (C. fertilis Walt., C. lævigatus Willd., C. glaucus Willd.). Pennsylvania to Georgia. Smooth Strawberry-shrub?, Bubby-bush, Sweet-scented shrub, Spice-bush*. Root, leaves and bark, antiperiodic. Fruit reputed poisonous to sheep.

b. B. flórida (L.) Kearney (C floridus L.). Virginia to Mississippi. Carolina Allspice, Sweet-scented shrub, Hairy Strawberry-shrub?, Strawberry-bush, Spice-bush*, Sweet-Betsies, Florida Allspicef. Bark aromatic.

c. B. occidentális (H. \&. A. ) Greene (C. occidentalis, H. \& A.). Pacific border of U. S. California Spice-bush.

\section{BUTYROSPERMUM. See BASSIA.}

333. BÚXUS, L. - - Box. - . Buxaceae. The ancient (ireek name. Evergreen trees or shrubs. About 20 species, Europe, Asia, Africa and West Indies.

a. B. sempérvirens L. Europe and Asia, also cult. in gardens. Box tree, Bush-tree, Dudgeon. Leaves cathartic. Wo dd diaphoretic, alterative; also much used for engraving.

334. BYRS0NíMA, Rich. Locust-berry. Malpighiaceae. Shrubs or trees. About 80 species, tropical America; 1 in U. S.

a. B. spicáta Rich. (B. coriacea DC.). West Indies and S. America. Locust-berry. Bark, called in Braxil Muruxi bark, used in tanning. The bark of several other species is used for the same purpose under the name of Alcornoque bark.

335. CABÓMBA, Aubl. Water-shield. Nymphaeaceae. Vernacular name, Guiana. Aquatic plants with floating peltate leaves. About 5 species, tropical America; 1 in U. S.

336. CACALIÓPSIs, Gray. Cacaliopsis. Compòsitae. From Greek, "resembling Cacalia". Floccose-woolly perennial. One species, Pacific border of U. S.

337. CÁCTUS, L. $1753 . \quad$ - Cactus. _ Cactaceae. Greek name of some thorny plant. Syn. Mammillaria, Haw. 1812. Fleshy leafless plants, armed with spines. About 300 species, warm and tropical America; 23 in U. S. None known to have active properties. See Cereus and Opuntia. 
338. CAESALPÍNIA, L. Sappan, etc. Cresalpinacere. Named for Andreas Caesalpinus, Italian botanist, d. 1603. Syn. Guilandina, Libidibia, in part. Trees or shrubs. Ahout 50 species, tropical; 3 in U. S. See Guilandina.

a. C. coriária Willd. (Libidibia coriaria Schlecht.). West Indies and S. America. Pods known as Divi-divi, Libi-divi, Libidibi or Muatta-pana; Fructus coriaria; astringent, used for tanning.

b. C. echináta Lam. (Guilandina echinata Spreng.) Brazil. One of several species yielding the Brazil wood (true), Pernambucowood, Nicaragua-wood, Hypernic-wood, Lima-wood, and Peachwood of commerce, used in dyeing.

c. C. Sáppan L. East Indies. Source of Sappan-wood, Sampfenwood, Bukkum or Wukkum of India, used in dyeing.

339. CAJUPÚTI, Adans. $1763 . \quad$ Cajuput. Myrtaceae. From vernacular. Syn. Melaleuca, L. 176i, Myrtoleucodendron, Rumph. Aromatic shrubs or trees with showy flowers. About 100 species, chiefly of Australia.

a. C. ericifólia (Sm.) Lyons (Melaleuca ericifolia Sm.). Australia. Australian Cajuput (Cajeput) tree. Leaces yield an oil very similar to Cajuput oil.

b. C. riridiflóra (Gaertn.) Lyons (Melaleuca viridiflora Gaertn., II. Leucadendron L., (Kew.). Includes M. Cajuputi Roxb.). East Indian Islands to India and Australia. (ajuput tree. Leares yield a volatile oil, Oleum Cajuputi, U. S. P. which is stimulant, analgesic, stomachic, etc.

340. CAKíLE, Gaertn. Sea Rocket. Cruciferae. The old Arabic name. Syn. Bunias, in part. Fleshy-ktemmed herbs with 2-jointed siliques. About 3 species, sea and lake shores, Europe and N. America; 2 in U. S.

341. CÁLAMUS, L. Rattan Palı. Sabalacene. The Greek name of a Reed. Syn. Rotang. Slender-stemmed plants. About 80 species, tropical regions, Old World.

a. C. rudéntum Lour., (b) C. rérus Lour., (c) C. viminális Reinw. and some other species furnish the canes or rattans of commerce. From (d) C. Scipiónum Lour. are obtained the Malacca walking-canes.

342. CalaNdrísia, H. B. K. Calandrinia. Portulacaceae. Annual or perennial herbs, some with showy flowers. About 120 species, mostly of Chili and Australia; 5 in U. S.

343. CALCEOLÁRIA, Loefl. 1758. Calceolaria. Violacex. From Latin, "slipper like". Syn. Ionidium, Vent. 1803; Viola, in part. Herbs, nostly of tropical America; 2 in U. S.

a, C. Ipecacuánha (Vent.) Lyons [I. Ipecacuanha Vent. (Kew)]. Brazil. White Ipecac, Poaya. Root emetic. 
b. C. verticilláta (Ort.) Kze. (V. verticillata Ort., I. polygalæofolium Vent. (Kew), I. lineare Torr.). Kansas to Colorade and Mexico. Nodding or Whorl-leaved Violet. Properties and uses of $(\mathbf{a})$.

344. CALÉNDULA, L. - Marigold. - Compositae. From Latin, "monthly" blooming. Herbs with showy yellow flowers. About 25 species, Mediterranean region.

2. C. officinális L. (Caltha officinalis Moench.). Southern Europe and the Levant, cult. in gardens. Garden Marigold, Pot Marigold (Mally-gowl), Mary-bud, Gold-bloom, Golding, Gowlan, Holigold, Jackanapes-on-horseback, Rods-gold, Ruddes, Sunflower*; Ger. Ringelblume, Todtenblume, Warzenkraut; Fr. Souci, Fleur de tous les mois. Florets, Calendula. U. S. P., Flores calendulae; Vulnerary, anti-emetic. The blossoming plant, Herba calendulæ, H. calthæ sativæ, H. verrucariæ; vulnerary, formerly believed to remove warts.

345. CÁLLA, L. - Calla, Water Arum. . Araceac. An ancient plant name. . Acrid bog herb. One species.

a. C. palństris L. Northern Europe, Asia and N. America. Water Arum, Wild Calla, Faverole, Female-dragon, Waterdragon, Swamp-robin.

346. CALLIÁNIDA, Benth. 1840. Calliandra. Mimosacrap. From Greek, "beautiful stamen". Syn. Anneslia, Salisb. 1807, not Anneslea, Wall. 1829. Ornamental shrubs, a few herbs or trees. About 80 species, New World; 5 in U. S. [The antiperiodic Panbotano bark of Mexico is derired from C. Houstoni (King's Disp.)].

347. CALLICÁRPA, L. - Callicarpa. Verbenaceae. From Greek, "beautiful fruit". Shrubs. About 25 species, warmer regions, chiefly of Asia; 1 in U. S.

a C. Americána L. Virginia to Florida and Texas. French Mulberry, Bermuda Mulberry, Sour-bush.

348. CAILÍRRHOE, Nutt. 1821. Poppy Mallow. Malvaceae. Name from Greek mythology. Syn. Nuttallia, Barton, 1822; Malva, Sida, in part. Herbs with showy flowers. About 7 species, central and southern U. S. and northern Mexico.

349. CALLÍTRIS, Vent. Sandarac. - Pinaceae. Syn. Thuja, in part. Trees or shrubs. About 18 species, Africa to Australia.

a. C. quadriválvis Vent. (T. articulata Vahl.). Northwester Africa. Alerce, Sandarac tree, Arar-tree. Resinous exudate, Sandarac. Gum Sandarac, Juniper resin, Gum Juniper; Sandaraca; Ger. Sandarak; Fr. Sandaraque (Codex); Terebinthinate, styptic, also used for varnishes, etc. Wood ornamental, called Citron-wood, Panther-wood, Tiger-wood, Arar-wood.

350. CALLÚNA, Salisb.

Heather, etc.

Ericaceae. Syn. Erica, in part. A low evergreen shrub. One species. 
a. C. vulgáris (L.) Salisb. (E. vulgaris L.). Europe, nat. in New England. Heather, Dog-heather, He-heather, Dog-, Ling-, Red- or Small Heath, Scotch Heather (U. S.), Broom*, Besom, Busam, Bent, Bream, Grig, Black or Crow Ling, Moor. Plant reputed sudorific, diuretic, etc.

351. CALOCHóRTUS, Pursh. Mariposa Lily. Liliaeeae. From Greek, "beautiful lily". Herbs with coated corms and showy flowers; among the most beautiful of American wild flowers. About 40 species, southwestern U. S. and Mexica.

a. C. álbus Doug. California. Lily-bell.

b. C. pulchéllus Doug. California. Golden Lily-bell.

c. C. renústus Benth. California. Mariposa Lily, Butterfly Lily, Wild or Butterfly Tulip, Pretty-grass, nanes not confined to this species.

352. CALÓPHANES, Don, 1833. Calophanes. Acanthaceae. From Greek, of "beautiful appearance". Syn. Dyschoriste, Nees, 1832. Perennial herbs or shrubs with blue or purple flowers. About 30 species, warmer regions; 5 in U. S.

353. CALOPHÝLLUM, L. Tacamahac. Clusiaceae. From Greek, 'beautiful leaf'. Large trees with parallel veined leaves. About 60 species, tropical, mostly of Old World.

2. C. Inophýllum L. East Indies and Oceanica. Tacamahac tree, Poon tree, Kamani (Polynesia). Resinous exudate, East Indian or Oriental Tacamahac, Resina Tacamahaca; Ger. Takamahak, Takmak; terebinthinate. Seeds yield a fixed oil, Bitter oil, Domba oil, Poon-seed oil, Weandee, used in rheumatism.

b. C. Tacamaháca Willd. Madagascar tơ East Indies. Also yields Tacamahac.

354. CALótroPIS, R. Br. Mudar. Asclepiadaceae. Syn. Asclepias in part. Shrubs or trees. Three species, Asia and Africa.

a. C. gigántea (L.) Dryand. (A. gigantea L.). India. Bowstring Hemp*. Called in northern India Mudar, Madar or Ak, in southern India Yercum. Bark of root, Mudar bark, Radix mudaris, Rad. calotropis; alterative, diaphoretic, emetic.

b. C. prócera (Ait.) Dryand. (A. procera Ait., C. Hamiltoni Wight). India. westward to Africa. French Jasmine. Yields also Mudar bark.

355. CÁLTHA, L. Marsh Marigold. Ranunculaceat. The Latin name of Marigold. Marsh plants with buttercup -like flowers. About 10 species, high latitudes of both hemispheres; 5 in U. S.

a. C. palústris L. Ontario to S. Carolina, west to Iowa. Marsh Marigold, Meadow Buttercup*, Cowslip (U. S.), Bull-flower, 
Great Butter-flower, Capers, Coltsfoot*, Cow-lily, Cowslop, Spring Cowslip, Crowfoott, Crazy-Bet, Drunkards, Gools, Meadow Gowan, Open or Water Gowan, Meadow-bouts, Mayblob, Mire-blob, Horse-blo', Water-blob, King-cups*, Palsywort, Soldier's-buttons, Swamp-robin, Water-dragon, Watergoggles. Plant used as a pot herb.

356. CALYCADÉNIA, DC. Calycadenia. Compositae. From Greek, "cup gland". Syn. Hemizonia, in part. Aunual herbs with linear leares. About 17 species, southeastern U.S.

357. CALYCOCÁRPUM, Nutt. Cup-seed. Menispermaceae. From Greek, "cup fruit". Syn. Menispermum, in part. Herbaceous climber. One species, southwestern U. S.

358. CALYCósERIS, Gray. Calycoseris. Cichoriaceae. From Greek, "cup Succory". Winter-annuals with showy flowers. Two species, southwestern U. S. and Mexico.

359. CALÝPSO, Salisb. - Calypso. - Orchidaceae. Dedicated to Calypso, of Greek mythology. Syn. Cypripedium, in part. Bog orchid. One species, (U. S.)

a. C. bulbósa (L.) Oakes (Cyp. bulbosum L., Cal. borealis Salisb.). Northern Europe, Asia and N. America. Calypso.

360. CALYPTRÍDIUM, Nutt. Calyptridium. Portulacaceae. From Greek, "veil" or "quiver". Succulent annuals. Four species, southwestern U. S.

361. CAMÉLINA, Crantz. False Flax. Cruciftrae. From Greek, "low flax". Syn. Myagrum, in part. Annual herbs. About 5 species, Europe and Asia; 2 nat. in U. S.

a. C. satíva (I.) Crantz (M. sativum L.). Europe, nat. in U.S. Gold-of-pleasure, Wild or False Flax, Dutch Flax, Camline, Cheat, Madwort, Myagrum; Ger. Leindotter. Seeds, Dodderseed, Siberian Oil-seed, yield German Sesame oil.

362. CAMPÁNULA, L. Bell-flower. Campanulacene. From Latin, "little bell"' Herbs, some ornamental. About 250 species, northern hemisphere; 18 in U. S.

a. C. Rapúnculus L. Europe. Rampion. Tuberous roots esculent.

b. C. rotundifólia L. Northern Europe, Asia and N. America, south to Illinois, Arizona and California. Harebell (England, also Hair-bell, Air-bell), Bluebell (Scotland), Round-leaved Bellwort? (a misnomer), Blaewort, Blaver, Blue-blauers, Blue bottle*, Gowk's-tlumbs, Heath-bell, Witches'-bell, Lady'sor Witches'- thimble; Ger. Glockenblume, Fr. Campanule.

Noteworthy European species are (c). C. glomeráta L., Dane's-blood, Canterbury-bells*; (d) C. latifólia L., Great Bell-flower, Coventry-bells, White Foxglovet; (e) C. médium L., Canterbury-bells, Marian, Mercury's-violet; (f) C. Trachélium L., Throatwort, Haskwort, Blue Foxglovet, Canterbury-or Coventry-bells. 
363. CAMPTOSÓRCS, Link. Walking-fern. Polypodiaceac. From Greek, "bent sori". Small ferns. Two species, one of Asia, one in N. America (U. S.).

364. CANáYGA, Rumph. not Aubl. Ylang-ylang. Anonaceae. From vernacular name. Syn. Unona, Lvaria, in part. Trees or shrubs. Three species, East Indies.

a. C. odoríta (Lam.) Hook. f. (Traria odorata Lam., Unona odorata Dunal). East Indies. Ylang-ylang. Flowers source of oil of ylang-ylang or cananga.

36. CANíRIUM, L - Elemi. - Burseraceae. Balsanic trees. About 90 species, tropical Asia and Africa.

a. C. commune L. East Indies. Probably from this species is derived the resinous exudate, Elemi (Br. 1885), Manila Elemi, Resina (Gummi) Elemi; Fr. Élémi (Codex); Sp. Goma de limon. Terebinthinate, vulnerary. Fruit, Java Almond, cathartic.

b. C. stríctum Roxb. Southern India. Source of Black Dammar resin.

366. CANAVíLI, Adans. (Canavalia, DC.). Papilionaceae. Shrubby climbers. About 18 species, tropical regions; 2 in U. S.

367. CánBYA, Parry. - Canbya. - Papaveraceae. Named for the American botanist Canby. Herbs. Two known species, California.

368. CANÉLLA, P. Br. 1756 Canella. Canellaceae. From French, Canelle, "cinuamon". Syn. Winterania L. 1759. Aromatic shrubs. Two known species, tropical America.

2. C. Winterána (L.) Gaertn. (W. Canella L., C. alba Murray). Florida and West Indies. Canella, White or Wild Cinnamon, Bahama White-wood. Bark, False Winter's bark, Cortex canellæ, Cort. winteranus spurius, Costus dulcis; Ger. Weisser Kaneel, Weisser Zimmt; Fr. Canelle blanche (Codex). Sp. Canella blanca. Stimulant tonic, used as a condiment.

369. CíNMA, L. Indian-shot, etc. Cannacese (Marantacea). From Latin, "reed" or "cane". Robust ornamental herbs from tleshy rhizomes. About 80 species, tropical regions especially of New World.

2. C. édulis Ker. Peru and Brazil, cult. in West Indies. Achiras. Fecula from rhizomes, Canna starch or arrowroot, Amylum cannæ, U. S. P. 1870, Toulema (tous-les-mois); Ger. Cannastärke; Fr. Fecule de tolemane. A similar starch is obtained from other species, as (b) C. coccínea Mill. (C. rubra Willd.).

e. C. Indica L. Widely distributed in the tropics. Indian-shot, China-shot, Common Canna or Tous-les-mois. Many other species are now cultivated as ornamental plants. 
370. CíxYABIS, L.

Hemip.

Moraceae.

The classical name. Robust herb. ()ne species, central Asia.

a. (. satíra L. (including C. Indica Lam.). Asia, now widely cult. and nat. Hemp, Common Hemp, Hemp-weed, Gallowgrais, Neck-weed, Nick-weed, St. Andrews-lace, Tristram'sknot, Red-root*, Welsh Parsley. (Staminate plants popularly called Female Hemp (Femble, Fimble), Barren Hemp; pistillate plants, Male, Carl or ('hurl Hemp, thus reversing the sexes); Ger. Hant; Fr. Chanvre (Codex), Chènevis. An important fibre plant. Seeds yield oil. Flowering tops of the Anericangrown plant were formerly (U. S. P. 1880) official as Cannabis Americana, American Cannabis, American Hemp. Flowering tops of the pistillate plant grown in the East Indies; Cannabis Indica U. S. P., Br., Herba camnabis indicie, Indian Cannabis, Indian Hemp, Gunjah, Ganjah, Guaza; a form used as an intoxicant in the East is Bhang, Siddhi, Hashish or Halish (Fr. Haschisch, Codex); an impure resin is Charas or Churrus (('harrus, Cherrus). Antispasmodic, narcotic. Seeds; Semen v. Fructus cannabis; Ger. Hanfsamen, Hanfkörner; demulcent.

371. CANótI, Torr. - Canotia - Simarubacea. Leafless spiny shrub, formerly referred to Rosaceae, Rutaceæ, etc. One species, Mexico and southwestern U. S.

372. CAPYOÍDES, Adans. 1763. Corydalis. Papareraceae. From Greek, "smoke-like". Syn. Neckeria, Scop. 1777; Corydalis, Vent. 1803. Delicate erect or climbing herbs. About 110 species, north temperate zone and $\mathrm{S}$. Africa; 7 in U.S.

a. C. fabáceum (Pers.) Lyons (Cor. fabacea Pers., Cor. solida Sw. Cor. digitata Pers.). Europe. Solid Birthwort. Tubers, Tubera corydalis solidæ, Rad. aristolochire solidæ; Ger. Feste (Volle) Osterleiwurzel; formerly reputed emmenagogue and eutocic.

b. C. fiávulum (Raf.) Kze. Ontario to Minnesota, south to Louisiana. Pale Corydalis. Colic-weed*.

c. C. tuberósum (DC.) Lyons (Cor. tuberosa DC., Cor. bulbosa Pers., Cor. cava Schweig., Cor. solida Moench.). Europe. Bulbous Fumitory, Round Birthwort, Holewort. Tubers, Tubera corydalis cavæ, Rad. aristolochiæ cavæ v. fabaceæ; Ger. Hohlwurzel, Donnerwurzel; Fr. Fumeterre bulbeuse; reputed emmenagogue, anthelmintic.

373 CAPYÓREA, Raf. Capnorea. Hydrophyllaceae. Syn. Hesperochiron, Wats. Scapose herbs. Three known species, southwestern U. S.

374. CÁPPARIS, L. - Caper. - Capparidaceae. The ancient Greek name. Shrubs with showy flowers. About 150 species, warm and tropical regions.

a. C. aphyilla Roth. (C. Sodada, R. Br.). Africa. Fruit used like pepper. 
b. C. cynophallóphora L. and (c) C. ferrigínea L. (Mustardshrub) of the West Indies have root-bar:s that are vesicating and diuretic; plants anthelmintic.

c. C. spinósa L. Mediterranean region to central Asia. Caper bush, Hyssop of Scripture; Ger. Kiapper; Fr. Câprier; Sp. Alcaparro. Buds, called capers, pungent, antiscorbutic.

375. CAPRÁRIA, L. Capraria. Scrophulariaceae. From Latin, "goat-weed". Herbs or undershrubs, warmer regions of Africa and America; 1 in U. S.

376. CAPRíOLA, Adans. 1763. Bermuda Grass. Gramineae. From Latin, (food for the) "wild goat". Syn. Cynodon, Rich. $1805 . \quad$ Matted grasses, 4 species; 1 nat. in U. S.

a. C. Dáctylon (L. ) Kze. (Panicum Dactylon L., Cynodon Dactylon Pers. ). Naturalized in U. S. from Europe and widely distributed. Bermuda Grass, Scutch or Scotch Grass, Dog's-tooth. Grass, Indian Couch-grass, Bahama Grass. Stolons, Radix graminis dactyli, used in Europe like Couch-grass.

377. CÁPSICUM, L. Red Pepper, Pod Pepper. Solanaceae. From Latin. "box", alluding to the fruit. Herbs with pungent fruit. About 25 species, warmer regions of both hemispheres.

a. C. ánnuum L. S. America, now universally cult. in many varieties, some of which have been described as species, as $\mathbf{C}$. lóngum Fing. C. gróssum Willd. and C. cordifórme Mill. Garden Pepper, Pod Pepper, Red Pepper, Spanish Pepper, Goat's Pepper, Chili Pepper, Chillies, Guinea Pepper*, Bird Pepper*;.Ger. Spanischer Pfeffer, Türkischer Pfeffer, Guinea Pfeffer, Taschenpfeffer, Schotenpfeffer; Fr. Piment des jardins, Poivre de Guinée (Codex), Piment rouge, Capsique; Sp. Chile, Pimiento. Fruit of this and other species, Red Pepper, Cayenne Pepper, Paprica; Fructus capsici, Piper hispanicum. The German Pharmacopœeia recognizes C. annuum and C. longum. Properties of (b).

b. C. fastigiátum Bl. (C. minimum, Roxb. not Mill.) S. America, now widely cult. Cayenne Pepper. Fruit known in eommerce as African Pepper, Bird Pepper, in Great Britain as Guinea Pepper and Chillies; Capsicum. U. S. P., Capsici fructus Br. Piper cajannense; Ger. Cajennepfeffer; Fr. Piment de Cayenne (Codex). [The only species admitted by the U. S. and British Pharmacopoeias.] Stimulant, stomachic, revulsive, rubefacient.

c. C. frutéscens L. (C. crassum Willd.) S. America. The fruit of this species, smaller than that of (b), is also called Cayenne pepper and is equally active.

378. CARAPA, Aubl. Crab-tree, etc. Meliaceae. Vernacular name, Guiana. Syn. Xylocarpus, in part. Trees. About 5 species, tropical America and Africa.

a. C. Guianénsis Aubl. (X.Carapa Spreng.). Guiana. Andiroba. or Carapa tree, Crabwood tree. Bark febrifuge. Seeds yield Carapa oil, Carap or Crab oil, Andiroba oil. 
b. C. prócera DC. (C. Touloucouna Guil. \& Per.). Senegal. Kundah tree (Touloucouna, Tallicouna). Seeds, Mote nuts, yield Kundah (Tallicouna, Tulucuna, Callicoonah, Coundi, Kounda) oil, which is bitter, cathartic and anthelmintic.

379. CARDÁMINE, L. Bitter Cress. Cruciferae. Greek name of a Cress, "heart-strengthening". Herbs. About 100 species, temperate regions; 29 in U. S.

a. C. amára L. Europe and northern Asia. Bitter Cress.

b. C. hirsúta L. Europe and Asia, nat. in U. S. Hairy Bittercress, Small Bitter-cress, Lamb's Cress, Land Cress.

c. C. praténsis L. Northern Europe, Asia and N. America (U.S. ). Cuckoo-flower (Flos cuculi), Cuckoo-spit, Meadow or Small Bitter-cress, Bonny-bird-een, Headache*, May-flower, Lady's Smock (Shakespere), Smick-smock, Milkmaids, Spink; Ger. Wiesenkresse, Cukukskraut; Fr. Cresson des prés. Herb, Herba nasturtii pratensis. Like the preceding, anti-scorbutic, deobstruent.

d. C. purpúrea (Torr.) Brit. (A rabis rhomboidea var. purpurea Torr.), C. Douglassii (Torr.) Brit.). Canada, south to Maryland and Wisconsin. Purple Cress, Spring Cress, Mountain Water-cress.

e. C. rotundifólia Michx. New Jersey to Ohio and south to N. Carolina. American Water-cress, Round-leared Water-cress, Mountain Water-cress.

380. CARDIOSPÉRMUM, L. Heart-seed. Sapindaceae. From Greek, "heart seed". Herbaceous vines. About 20 species, warm and temperate regions; 3 in U. S.

a. C. Halicácabum L. South America and cult. in gardens. Balloon-vine, Heart-seed 3 , Heart Pea, Indian-heart, Wintercherry*, Puff-ball†. Root reputed laxative and diuretic.

381. CÁRDUUS, L. Thistle, Tassel-bur. Compositae. The ancient Latin name, whence our word "card" (for wool etc.). Syn. Cnicus, Cirsium, Serratula, in part. Robust prickly herbs. About 250 species, northern hemisphere; 56 in U. S.

a. C. arvéusis (L.) Robs. (S. arvensis L., Cn. arvensis Hoffm. (Kew), Cir. arvensis Scop. ). Europe, nat. in U. S. and elsewhere. Canada Thistle, Boar-, Corn-, Creeping-, Cursed-, Dog-, Hard-, Prickly- (Pricky-), Sharp- or Way Thistle, Dashel, Dodger. A pernicious weed.

b. C. lanceolátum L. (Cn. lanceolatus Willd. (Kew), Cir. lanceolatum Scop.). Europe, nat. in U. S. Common Thistle, Bull Thistle, Scotch Thistle, Bur Thistle (Scotland); BankBell-, Bird-, Blue-, Boar-, Buck-, Button-, Horse-, Plume-, Roadside- or Spear Thistle. The emblem of Scotland.

c. C. nútans L. Asia and Europe, adv. in U. S. Musk Thistle, Plumeless Thistle, Queen Ann's Thistle, Bank or Buck This tle, wrongly called Scotch Thistle. 
382. CÁREX, L.

Sedge.

Crperaceae.

Classical name of uncertain origin. Grass-like Sedges. More than 1000 species; about 350 in U. S.

a. C. arenária L. Europe, adv. in U. S. Sand Sedge, Sand-star, Sea Sedge, Red Couch-grass, Sea-bent, Sea Bent-grass, Stare, German Sarsaparilla; Ger. Sandriedgras, Sandsegge, Rothe Quecke; Fr. Laiche. Rhizome; Rhizoma earicis, Rad. sarsaparillæ germanicæ. Properties of Sarsaparilla.

383. CÁRICA, L. Papaw. Caricaceae (Papayaceae). Latin name of "fig". Syn. Papaya, Tourn. Shrubby or arborescent plants, generally with simple stem. About 20 species, tropical America; 1 in U. S.

a. C. Papáya L. (P. Carica Gaertn., P. rulgaris DC.). Tropical America, cult. in all tropical countries. Papaw (Pawpaw), Papaya, Melon tree, Custard Apple†, Mamæiro; Ger. Melonenbaum, Papaybaum. Milky juice of unripe fruit, Succus papayæ, has properties like those of pepsin.

384. CARlíNa, L. Carline Thistle. Compositae. Named for Charlemagne, whose army found in the plant a remedy for the plague. Thistle-like plants, natives of Europe.

a. C. acaúlis L. (A variety of this is C. caulescens Lam.). Europe. Carline Thistle, Ground Thistle; Ger. Sonnendistel, Eberwurz, Rosswurzel; Fr. Chardon doré, Carline. Root, Rad. carlinæ v. cardopatiæ, diaphoretic, diuretic, emmenagogue. Fleshy receptacle of this and of (b) C. acanthifólia All., esculent.

385. CARLOWRÍGHTIA, Gray. Carlowrightia. Acanthaceae. Named for Charles Wright, American botanist. Undershrubs. Three known species, southwestern U. S.

386. CarminátIA, Moc. Carminatia. Compositae. Named for Prof. B. Carminati of Pavia. Herb with rather small heads of whitish flowers, Mexico and southwestern U. S.

387. CARPENTÉRIA, Torr. Carpenteria. Saxipragaceae. Undershrub with large white flowers. A single species, California.

388. CARPhÉPHoRUS, Cass. Carphephorus. Compositae. From Greek, "chaff bearing". Syn. Liatris, in part. Perennial herbs, some suffrutescent. About 8 species, North America; 4 in U. $\mathrm{S}$.

389. CARPHOCHAÉtA. Gray. Carphochæa. Compositae. From Greek, "chaff bristle". Perennial herbs, some suffrutescent. Three known species, Mexico and its borders; 1 in U. S.

390. CARPÍNUS, L.

Hornbeam.

Betulaceae.

The ancient Latin name. Trees or shrubs. About 12 species, northern hemisphere; 1 in $U$. S. 
a. C. Caroliniána Walt. (C'. Americana Michx.). Eastern U. S. American Hornbeam, Blue Beech, Water Beech, Iron-wood, Hurst- or Horst- beech, Horse Beech.

391. CÁRTHAMUS, L.

Safflower.

Compositae. The Latin name, from Arabic, "pigment". Herbs. Two or more species, Old World.

a. C. tinctórius L. India, cult. extensively in Europe, Asia and Africa. Saftlower, Dyer's Saffron, African Saffron, American or Thistle Saffron, False or Bastard Saffron, Parrot's Corn; Ger. Farbersatlor, Falscher Safran, Deutscher Safran; Fr. Carthame; Sp. Cartamo, Azafrancillo, Alazor. Florets; Flores carthami, C'arthamus; diaphoretic, resembling camomile. [The South African Carmendik, used as a stomachic bitter, is from a related plant.]

392. CÁRUM, L.

Caraway, etc.

Umbelliferae.

The ancient Greek name. Syn. Bulbocastanum, Bunium, in part. Herbs. About 50 species, temperate and warm regions; 1 in U. S. See also Apium, Atænia, Conopodium, Ptychotis.

a. C. Bulbocástanum Koch, (B. Linnæi Schur.). Mediterranean region. Tubers and leares esculent. Fruit a condiment.

b. C. Cárui L. (also written C. Carvi). Northern Asia and Europe, adv. in U. S. Caraway, Carvies, Saxifraget. Fruit; Carum. U. S. P., Carui Fructus, Br., Semen carvi; Ger. Kümmelsamen, Kümmel, Garbe; Fr. Carui (Codex), Cumin des prés; Sp. Alcaravea; aromatic, carminative, used chiefly as a flavor and condiment.

c. C. ferulæfólium Bois. (Bunium ferulæfolium Desf.). (yprus and Candia. Topana. Tubers edible.

393. CARÝOCAR, - Guiana Butternut. - Rhizobolaceae. From Greek, "head nut", from size of fruit. Syn. Pekea, in part. Trees producing edible nuts. About 10 species, S. America.

a. C. butyrósum Willd. (Pekea butyrosa Aubl.), Pekea tree and (b) C. nucíferum L., Souari (Suwarrow) tree, both of Guiana, yield oily nuts called South American or Guiana Butternuts.

394. CARYóTA, L.

Toddy Palm, etc.

From Greek, "nut" palm. Tall palms. About 12 species, East Indies and southeast Asia.

a. C. úreus L. Ceylon and India. Ceylon Toddy Palm, JaggeryPalm, Bastard Sago-Palm. Sap yields palm wine (toddy) and palm sugar (jaggery). Stem yields sago; See Borassus.

395. CASIMIRÓA, La Llare. Zapote. Aurantiaceae. Trees. Two known species, tropical N. America.

a. C. édulis Llav. \& Lex. Mexico. Zapote. Fruit edible but soporific. Seeds poisonous. 
396. CÁSSIA, L. - Cassia. - Crsalpinacere. Ancient Greek plant name, from Hebrew. Syn. Senua, in part. Herbs, shrubs and even trees. About 275 species, warm and temperate regions, especially tropical America; about 30 in U. S. See Cathartocarpus.

a. C. Ábsus L. India to Egypt. Absus Seed. The seeds of this and of (b) C. auriculáta L. of India are used like those of Abrus in ophthalmia.

c. C. acutifólia Delile (C. lanceolata Nectoux, C. Senna var.b. L., C. orientalis Pers., C. lenitiva Bisch., Senna acutifolia Link.). Egypt to Kordofan. Alexandria Seuna, Tripoli Senna; Ger. Alexandrinische Senna, Palt-Senna; Fr. Séné de la Palte, d' Égypte, d'Alexandrie (Codex). Leares of this and of (d); Senna U. S. P., Seuna Alexandrina, Br., Folia sennæ; Ger. Sennesblätter; Fr. Feuilles de séné; cathartic.

d. C. angustifólia Vahl. (C. elongata Lemaire, C. lanceolata W. \& Arn., C. acutifolia Nees., C. medica, Forsk., C. mediciualis Bisch, Senna officinalis Roxb., S. angustifolia Batka). India westward to Somali coast. Tinnivelly Senna, India Senna. Leares, Senna Indica, Br. The East India or Bombay senua is less carefully prepared, and still inferior is the Arabian or Mecca senna, also sold as Bombay senna, all derived from this species; Ger. Indische Senna; Fr. Séné de Tinnevelly (Codex).

e. C. Marylándica L. (Senna Marylandica Link.). New England to Nebraska and south to the Gulf. Wild Senna, American Senna, Locust-plant. Leaves have been used instead of true senna, but are inferior.

f. C. níctitans L. Maine to Indiana and south to Texas. Wild Sensitive-plant, Sensitive Pea. [The larger (g) C. Chamæcrísta L. of the same region is called Partridge Pea, Dwarf Cassia, Prairie Senna or Larger Sensitive-pea.

h. C. obováta Colladon (C. Senna Forskal, C. obtusa Roxb. C. obtusata Hayne, Senna obovata Link.). Arabia and northern and eastern Africa. Soudan Senna, Syrian or Aleppo Senna. The leaves are sometimes mixed with those of Alexandria senna.

i. C. occidentális L. Widely diffused in tropical countries. Coffee Senna, Stinking Cassia, Styptic weed. Roasted seeds are Negro Coffee, Mogdad Coffee, Magotty-boy Bean; Ger. MogdadKaffee; Fr. Café chilen; a substitute for coffee.

j. C. Tóra L. (C. obtusifolia L.). Southern U. S. and widely diffused in tropical countries. Low Senna, Sickle Senna.

397. CASSIÓPE, D. Don. Moss-plant, Moss-bush. Ericaceæ. Name from Greek mythology, like that of the related Andromeda. Syn. Andromeda, in part. Evergreen heath-like or moss-like shrubs. About 10 species, high north latitudes; 5 in U. S. and British America. 
398. CÁSSYTHA, L. - Cassytha. - Lauraceae. Slender, apparently leafless vines. About 15 species, mostly Australian; 1 in U. $\dot{\mathrm{S}}$.

399. CaSTÁLIA, Salinb. Pond Lily, etc. Nymphæaceæ. Named from the famed spring on Parnassus. Syn. Nymphæa, in part. Aquatic plants with Magnolia-like flowers. About 25 species; 7 in U. S.

a. C. álba (L.) Lyons (Nymphaea alba L. C. speciosa Salisb.). Europe. European White Water-lily or Pond-lily, Water-blob\|, Water-can; Fr. Nénuphar blanc (Codex). Ǩoot alterative, astringent.

b. C. odoríta (Dryand.) Woodv. \& Wood. (Nymphaea odorata Dryand., C. pudica Salisb.). Nova Scotia to Manitoba and south to the Gulf. Sweet-scented White Water-lily, White Pond-lily, Water-nymph., Wa'er Cabbage, Toad Lily. [The same names except the first are given to the very similar but larger and scentless (c) C. tuberósa (Paine) Greene, northern U. S. to Nebraska.] Root astringent, demulcent.

400. CaSTÁNEA, Adans. - Chestnut. - Fagaceæ. Latin name, from a city in Thessaly. Trees or shrubs with edible nuts enclosed in a prickly bur. Four or five species, northern hemisphere; 3 in U. S.

a. C. dentáta (Marsh) Borkh. (C. vesca var. Americana Michx., C. Americana, Raf.). (Ontario to Michigan and Tennessee. American Chestnut, Chestnut, Prickly-bur, Sardinian-nut; Ger. Kastanienbaum; Fr. Châtaignier, Marronier; Sp. Castaño. Leaves sedative, used in whooping cough. Bark astringent, tonic, febrifuge. Fruit esculent.

b. C. púmila (L.) Mill. (Fagus pumila L.). New Jersey to Indiana and southwards. Chinkapin (Chincapin, Chinquapin), Dwarf Chestnut.

c. C. Castánea (L.) Lyons (Fagus Castanea L., C. sativa Mill. (Kew), C. vesca Gaertn., C. vulgaris Lam. ). Asia and Europe. European Chestnut, Spanish Ches:nut, Chastey, Bur, Frenchnut, Meat-nut, Stover-nut. Properties of (a).

401. CaSTAXóPSIS, Spach. Oak Chestnut. Fagaceae. From Greek, "chestnut-like". Trees producing edible nuts. About 20 species, mostly of tropical Asia, 1 in U. S.

a. C. chrysophýlla A. DC. California. Californian Oak-chestnut, California Ćhinkapin.

402. CASTÉLA, Turp. - Castela. - Simarubaceæ. Shrubs. About 10 species, tropical America; 1 in U. S.

403. CASTILLÉJA, Mutis. Painted-cup. Scrophulariaceæ. Named for Castill. jo, Spanish botanist. Syn. Bartsia, in part. Herbs, flower-spikes often with colored bracts. About 40 species, mostly of New World; 30 in U.S. 
a. C. coccínea. (L.) Spreng. (B. coccinea L.). Ontario to Texas. Scarlet Yainted-cup, Indian Paint-brush, Bloody-warrior, RedIndians, Election-posies, Prairie-fire, Wickakee. (These names given also to other species having red bracts.)

404. CASTÍLLOA, Cervant. Castilloa. Artocarpaceae. From Spanish, "Castilian". Trees. About 3 species, tropical America.

a. C. elástica Cervantes and (b) C. Markhamiána Collins, both of Mexico, yield india rubber. See Hevea.

405. CASUARÍNA, L. Australian Oak, Beefwood. Casuarinacea. From Latin, "cassowary tree", alluding to the plumy foliage. Leafless trees, looking like arboreous Equisetums. About 30 species, Australia to East Indies. In Australia called "oaks", several of the species "she-oaks", one "he-oak".

a. C. equisetifólia L. (C. Indica Pers.). Southern Asia to Australia and Polynesia. Iron-wood (South Sea Islands), Swamp Oak (Australia), Tna (Fiji Islands, where formerly the wood was used for cannibal forks). Bark of this and other species astı ingent. Woud hard and durable.

406. CATÁLPA, Scop. - Catalpa. - Bignoniaceae. Vernacular Indian name. Syn. Bignonia, in part. 'Trees or shrubs with showy Howers. About 10 species, 2 in Asia, the rest American; 2 in U. $\mathrm{S}$.

a. C. Catálpa (L.) Karst. (C. bignonioides Walt. (Kew), B. Catalpa L., C. syringæfolia Sims.). Southeastern U. S. Catalpa tree, Indian Bean, Bean tree, Snoking-bean, Cigar tree, Indian-cigar, Candle tree, Catawba tree*. Fruit antispasmodic, cardiac; sedative. Bark anthelmintic, alterative.

b. C. speciósa Warder (C. cordifolia Duham). Illinois to Arkansas. Hardy or Weatern Catalpa, Catawba tree, Larger Indianbean, Cigar tree, Shawnee-wood. Properties of (a).

407. CATESBAÉA, L. Lily-thorn.

Rubiaceae. Named for Mark Catesby, English naturalist, d. 1749. Shrubs. About 10 species, mostly of West Indies; 1 in U. S.

408. CÁTHA, Forsk. (not G. Don). Khat. Celastraceae. From the Arabic name. Syn. Celastrus, in part. A small shrub. One species.

a. C. édulis Forsk. (Celastrus edulis Vahl.). Arabia and eastern Africa. Leaves Khat, Kât, Cat, Cafta, Arabian or Abysoinian Tea, used like Chinese tea.

409. CATHARTOCÁRPUS, Pers. $1805 . \quad$ Caesalpinaceae. Fiom Greek, "purging fruit". Syu. Bactyrilobium, Fistula, Cassia, in part. Trees with huge legumes, the seeds embedded in pulp. Tropical regions.

a. C. grándis (L. fils) Pers. (Cassia grandis L. fils (Kew), Cassia Brasiliana Lam., Casia mollis Vahl.). South America. Horse Cassia. Properties of (b). 
b. C. Fístula (L.) Pers. (Cassia Fistula L., Bactyrilobium Fistula Willd.). Southern Asia, now cult. widely in tropical regions. Golden-shower tree, Purging Cassia tree, P'uddingstick tree, Pudding-pipe tree, Iru nstick tree, Tree highly ornamental. Fruit; ù ssia Fistula, U. S. P.,(Cassire P'ulpa Br.), Purgıng (assia, Fructus cassiæ fistulæ; (ier. Rohrkassie, Köhrenkassie, Purgirkassie; Fr. Casse officinale (Codex) Casse en batons; Sp. Caña tistula; Laxative, mildly cathartic.

c. C. moschátus G. Don (Cassia moschata Kunth.). Panama. Fruit resembles that of (b.) but is lighter colored and somewhat astringent.

410. CaTóPsis, Griseb. Catopsis. Bromeliaceae. Herbs. About 3 species, tropical America; 1 in U. S.

411. CAÚCALIS, L. Hedge Parsley. Umbelliferae. The (ireek name. Syn. 'Tordylium, Torilis, in part. Annual herbs. About 20 species, northern hemisphere.

a. C. Anthríseus (L.) Huds. (Tord. Anthriscus L., Torilis Anthriscus Bernh. ). Europe, adv. in U. S. Erect Hedge-parsley, Rough C'hervil, Hemlock Chervil, Scabby-head, Rough Cicely, Hogweed, Lady's-needlework.

412. CaUláxthus, S. Wats. Caulanthus. Cruciferae. From Greek, "stem flower". Herbs. Seven known species, all of California and vicinity.

413. CAULOPIÝLLUM, Michx. Blue Cohosh. Berberilaceae. From Greek, "stem leaf". Syn. Leontice, in part. A glaucous herb with a single compound leaf. One species.

a. C. thalictroídes (L.) Michx. (L. thalictroides L.). Canada to N: Carolina, Missouri and Nebraska, also in Japan. Blue Cohosh, Pappouse-root, Squaw-root, Blueberry-root, Blue Ginseng, Yellow Ginseng. Rhizome and roots; Caulophyllum, U. S. P.; demulcent, antispasmodic, emmenagogue, dinretic.

414. CaYaPónia, Silv. Manso 1836.

Cucurbitaceae. Syn. Trianosperma, Mart. 1843; Bryonia, in part. Herbaceous climbers. About $6 \overline{5}$ species, nostly of tropical America; 2 in U. S.

a. C. Americána (Lam.) Cogn. (B. Americana Lam.). West Indies. Properties of Bryonia dioica, q. v.

b. C. fleifólia Cogn. (T. ficifolia Cogn.). Brazil. Tayuya. Root alterative, emetic.

415. CEAXóTHUS, L. Red-root, etc. Rhamnaceae. Greek name of a kind of thistle. Shrubs with white or blue panicled Howers. About 50 species, all of U.S. and northern Mexico. 
a. C. Americánus L. Ontario to Manitoba and south to the Gulf. Red root, New Jersey 'Tea, Jersey Tea, Walpole Tea, Mountainsweet, Wild Snowball, Sprangles; Grr. Seckelblume; Fr. Céanothe. Root, astringent, alterative. Leaves used formerly as a substitute for Chinese tea.

b. C. coerúleus Lagasca (C. azureus Desf.). Mexico. The plant is there used as a febrifuge.

c. C. thyrsiflórus Esch. California. California Lilac, Blue Myrtle.

416. CÉBATHA, Forsk. 1775. Cebatha. Menispermareae. An Arabic name. Syn. Cocculus, DC. 1818; Menispermum, in part. Diøecious vines. About 10 species, mostly tropical; 2 in U. S.

a. C. Carolína (L.) Britton (M. Carolinum L., Cocculus Carolinus DC. ). Southeastern U. S. Carolina or Red-berried Moons'ed.

417. CÉDRELA, P. Br. Spanish Cedar. Cedrelaceae. From Greek, "cedar fir". Syn. Cedrust, in part. Trees. About 15 species, tropical Asia and America.

a. C. odoráta L. (C. Cedro Loefl., Cedrus odorata Mill.). West Indies. Jamaica Red Cedar, Spanish Cedar; Honduras, Barbadoes, Havana or West Indian C'edar, Sweet scented Cedar. Bark aromatic, febrifuge. Wood fragrant; source of Cerlar-wood oil.

b. C. Toóna Roxb. (C. australis F. Muell., perhaps a distinct species). Malacca to Australia. Toon tree, Indian or East Indian Mahogany, Singapore Cedar, Australian Red Cedar. Gummy exudate, Ćedar gum, resembles Acacia.

418. CEDRONÉLLA, Riv. Cedronella. Iabiatae. Syn. Dracocephalum, in part. Herbs. About 9 species, N. America, Canary Islands and Japan.

a. C. Mexicána Benth. and (b) C. pállida Lindl. of Mexico are used as substitutes for Melissa.

c. C. triphýlla Mœnch. (D. Canariense L.). Canary Islands. Balm of Gilead*, Sweet Balm. Herb aromatic, diaphoretic.

419. CÉDRUS, Mill. Cedar of Lebanon. Pinaceae. The classical name. Syn. Abies, Pinus, in part. A spreading evergreen tree with fragrant wood. One species, Asia and Africa.

a. C. Cédrus (L.) Lyons (Pinus Cedrus L., C. Libani Barrel (Kew ), C. Libanotica Link, A. Cedrus Poir.). Syria. Cedar of Lebanon. Source of Lebanon Manna. A variety of this species is the magnificient Deodar Cedar of the Himalayas, C. Deodara Loud.

420. CEÍBA, Medic. 1787. Silk-cotton tree. Bombacere. Vernacular name. Syn. Eriodendron DC.; Bombax, in part. Trees. About 8 species, all but one of tropical America. 
a. C. pentándra Gaertn. (Bom'sax Ceiba Auct., Eriodendron anfractuosum DC: ). Tropical Asia and Africa. Silk-cotton tree, Cotton-tree, God-tree, Cabbage-wood.

421. CElástruS, L. Staff-tree. Celastraceae. Greek name of an evergreen tree. Shrubs, mostly climbing. About 30 species, mostly of Old World; 1 in U. S.

a. C. scándens L. Ontario to Manitoba and south to N. Carolina and New Mexico. False Bittersweet, Climbing or Shrulbby Bittersweet, Wax-work, Staff-tree, Staff-vine, Fevertwig, Yellow-root, Climbing Orange-root, Koxbury W'ax-work, Jacob's Ladder*; Ger. Celaster; Fr. C'elastre. Bark emetic, discutient, anti-syphilitic.

422. CÉLTIS, L. - Nettle-tree. - Ulmaceæ. The ancient Latin name. Trees or shrubs. About 60 species, mostly of Old World; 2 in U. S.

a. C. occidentális L. (C. pumila Pursh.). Canada to Louisiana and Kansas. Hackberry. Sugar-berry, American Nettle-tree, Beaver-wood, Bastard Elm, False Elm, Juniper-treeł, Hoop Asht, Rim Ash†, One-berry. Fruit edıble.

b. C. austrális L. Europe. European Nettle-berry. Probably the lotus of the ancients, the food of the lotus-eaters.

423. CENTAÚREA, L. Blue-bottle, etc. Compositae. Greek name, plant of the Centaurs. Syn. Calcitrapa, Cyanus, Plectocephalus, in part. Herbs or sub-shrubs. About 350 species, mostly of Old World; 1 indigenous in U. S.

a. C. Americána Nutt. (P. Americanus Don.). South-central U.S. to Mexico. American Star-thistle.

b. C. Calcítrapa L. (Calcitrapa Calcitrapa (L.) Hill). Europe, adv. in U.S. Star Thistle, Caltrops, Maize-thorn, Mouse-thorn, Knapweed*; Ger. Sterndistel; Fr. Chardon étoilé. Plant tonic, irritant, nauseant.

c. C. Cýanus L. (Cyanus Cyanus (L.) Hill). Europe, cult. in gardens and nat. in U. S. Blue-bottle, Corn Blue-bottle, Cornflower, Bachelor's buttons, Blue-blow, Blue-bonnets, Blue-caps, Blue Poppy, Blawırt, Blarer, Break-your-spectacles, Brushes, Corn-binks, Corn-bottle*, Corn Centaury, French Pink, Hurtsickle, Knapweed*, Witches'-bells, Witches'-thimbles; (rer. Kornblume; Fr. Bluet, Barbeau (Codex), Casse-lunette. Florets, mildly astringent, used in collyria.

d. C. nígra L. Europe, adv. in U. S. Black Knapweed, Knapweed, Knobweed, Horse-knobs, Bachelor's-buttons*, Buttonweed, Black soap, Blue-tops, Bole-weeed, Bull-weed, Bundweed, Centaury, Club-weed, Crop-weed, Dur-bottle, Drumstick, How-weed, Hurt-sickle, Iron-head, Iron-weed, Lady's-cushion, Loggerhearls, Matfelon, Mater-filon, Tar-bottle, Tassel, Sweeps. Root tonic, alterative. 
424. CENTÉLLA, L. Marsh Pennywort. Umbelliferae. From Latin, "little prickle". Syn. Hydrocotyle, in part. Herbs or sub-shrubs. About 20 species, mostly of south Africa; 1 in U. S.

a. C. Asiática (L.) Urban (H. Asiatica L. (Kew), H. repanda Pers.). Maryland to Florida and Texas and widely distributed in tropical countries. Indian Pennywort, Ovate-leaved Marsh Pennywort, Thick-leaved Pennywort; Ger. Asiatischer Wassernabel; Fr. Hydrocotyle (Codex), Bevilacqua; Sp. Hidrocotila. Plant, Herba hydrocotyles asiaticae, alterative, narcotic, used in cutaneous diseases.

425. CENTROMÁDIA, Greene. Centromadia. Compositae. From Latin, "prickly Madia". Syn. Hemizonia, in part.

- Resinous annuals. About 6 species, California.

426. CENTÚNCULUS, L. Chaffiveed, etc. Primulaceae. Latin dim. of cento, a "patch". Low annuals. Three species, America and Australia; 2 in U. S.

a. C. mínimus L. Europe and North and South America. Chaffweed, False or Bastard Pimperel.

\section{CEPHAELIS. See URAGOGA.}

427. CEPHALANTHÉRA, Rich. Cephalanthera. Orchidaceae. From Greek, "head antlıer". Terrestrial orchids. About 10 species, temperate regions; 1 in U. S.

428. 'EPHALÁNTHUS, L. , Button-bush. Rubiacere. From Greek, "head flower". Shrubs or small trees. About 6 species, Asia and America; 1 in U. S.

a. C. occidentális L. Canada to Florida and California. Buttonbush, Button tree, Buttonwood shrub, Box*, Crouper-bush, Crane-willow, Honey-ball, Little Snowball, Mountain Globeflower, Pin-ball, Pond or Swamp Dogwood, River-bush, Swamp-wood. Bark tonic, alterative.

429. CERANTHÉRA, Ell. Ceranthera. Labiatae. From Greek, "horn anther". Fragrant annuals. Two known species, southeastern U. S.

430. CERÁSTIUM, L. Chickweed. Caryophyllaceae. From Greek, "horn" alluding to the capsules. Herbs with flowers in dichotomous cymes. About 50 species, mostly of temperate zone, about 6 in U.S.

431. CERATíOLA, Michx. Ceratiola. Empetraceae. A heath-like shrub, one species only, S. Carolina.

432. CERATÓNIA, L. St. John's-bread. Papilionaceac. From Greek, "horn"-podded. A small tree, one species only. 
a. C. Silíqua L. Mediterranean Basin. Carob tree, Locust tree. St. John's-bread, Honey-bread, Sweet-pod, Locust Bean. [ [ Locust because the food of John the Baptist, a name now applierl to other leguminums trees]. Ger. Johannisbrod, Soodbrod,Karobe; iFr. Caroube (Codex) Carouge; Sp. Algarruba de Valenca, Garmbo(from Arabic). Legumes, Fructus ceratonice, Siliqua dulcis; demulcent, rich in sugar, the "husks" of the parable. Seeds. the original karat weight. See Abrus and Adenanthera.

433. CERATOPHÝLLUM, L. Hornwort. Ceratophyllaceae. From Greek, "horn-leaf', Aquatic plants. Une or two species, cosmopolitan.

a. C. demérsum L. Cosmopolitan, common in U.S. Hornwort, Horn-weed, Morass-weed. Plant reputed emollient.

434. CERATóPTERIS, Brongn. Water-fern. Polypodiaceae. From Greek, "horn frond". Syn. Elbocarpus, Parkeria. Small aquatic fern. One species only, in all sub-tropical cuuntries, (U. S.)

435. CERCÍDIUM, Tul. Cercidium. Caesalpinaceae. Latin, from Cercis, the Judas tree. Syn. Parkinsonia, in part. Trees or shrubs. About 5 species, all American; 3 in southwestern U. S.

436. CÉRCIS, L. - Judas-tree. - Caesalpinaceae. The classical name. Syn. Siliquastrum, Medic. Shrubs or small trees. About 6 species, northern hemisphere; 3 in U. S.

a. C. Canadénsis L. (S. Canarense Medic., S. cordatum Moench.). Ontario and eastern U. S. American Judas-tree, Red-bud, Red Judas-tree, Salad-tree; Fr. Bouton rouge, Gainier. Buds have been used in salads and pickles.

b. C. Siliquástrum L. (S. Arbor-Judae Medic.). Europe. European Judas-tree, Love-tree; Ger. Judasbaum, Fr. Arbre de Judée.

437. CERCOCÁ RPUS, H. B. K. Mountain Mahogany. Rosaceae. From Greek, "tailed fruit". Shrubs or small trees. About 6 species, southwestern U. S. and Mexico.

a. C. ledifólius Nutt. Sierra Nevada Mountains. California Mountain Mahogany.

438. CÉREUS, Miller. - Cereus. - Cactaceae. Syn. Cactus, in part. A genus of more than 200 species, tropical regions, New World.

a. C. grandiflórus (L.) Mill. (Cactus grandiflorus L.). Tropical America. Night-bloming Cereus; Ger. Königen der Nacht; Fr. Cierge à grandes fleurs. Plant, especially flowers, cardiac sedative. [Several other species have been employed, notably (b) C. Bonplándii Parm., Brazil and (c) C. MeDonaldii Hook., Honduras.]

d. C. trianguláris Mill. Central America to West Indies. Strawberry Pear. Fruit edible. 
439. CeróxyloN, Humb \& Bonp. Wax Palm. Sabalaceae. From Greek, "wax-tree". T'all palms. About 8 species, South America.

a. C. Andícolum Humb. New Granada reaching nearly the snow line. Wax Palm. Trunk covered with a vegetable wax used for candles.

440. CÉSTRUM, L. - Cestrum. - Solanaceae. Shrubs or small trees. Upward of 100 species, tropical America; 2 in U. S.

441. CÉTER.ICH, Wild. Scale Fern. Polypodiaceae. Old Greek name, of eastern origin. A small genus of coriaceous ferns with chaffy fronds.

a. C. Céterach (L.) Lyons (Asplenium Ceterach L., C. officinarum Willd. ). Europe to India. Milt-waste, Scale Fern, Scaly Fern, Ceterach. Fronds demulcent.

442. CETRáRIA. Ach. - Lichenes (Parmeliacei). Lichens.

a. C. Islándica Acharius (Lichen Islandicus L., Parmelia Islandica Sprengel.). Northern Asia. Europe and N. America. I celand Moss. Plant, etraria, U. S. P., Lichen islandicus; Ger. Isländisches Moos, Isländische Flechte, Kramperlthee, Krampelthee; Fr. Lichen d' Islande (Codex) Mousse d'Islande; Sp. Liquen islandico; Mucilaginous, demulcent.

443. CEVálliA, Lag. - Cevallia. - Loasaceae. Herb. One species, Texas and New Mexico.

444. CHaENáCTIS, DC. Chænactis. Compositae. From Greek, "gaping ray". Herbs, rarely suffrutescent. About 25 species, California and adjacent regions.

445. CHAEROPHÝLLUM, L. Chervil. Umbelliferae. From Greek, "fragrant leaf". Herbs. About 30 species, north temperate zone and N. Africa; 3 in U. S. See Anthriscus.

446. CHAETADÉLPHIA, Gray. Chaetadelphia. Cichoriaceae. From Greek; the "bristles" of the pappus being 5-adelphous. Perennial herb. One species, Nevada.

447. CHa ETб́CHLOA, Scribn. Millet. Gramineae. From Greek, "bristle gra-s". Syn. Setaria, Ixophorus, Panicum, in part. Grasses with spike-like panicles. About 10 species; 4 in U. S.

a. C. Itálica (L.) Scribn. (P. Italicum L., S. Italica R. \& S., I. Italicus Nash). Europe, originally from 4 sia, now widely cult. Italian Millet, Hungarian Grass; German, Golden or Hungarian Millet. Grain used for food.

448. CHAETOPÁPPA, DC. Chaetopappa. Compositae. From Greek, "bristle pappus". Syn. Distasis, in part. Slender herbs. Three species, southwestern U. S. 
449. CHÁLCAS, L. 1767. - Curry-leaf. - Rutaceae. Syn. Murraya, L. 1771 (Kew); Bergera, in part. Trees or shrubs. About 8 species, tropical Asia to Australia and Oceanica.

a. C. Koenígii (L.) Kurz. (M. Koenigii Spreng (Kew), B. Koenigii L.). India. Curry-leaf tree. Leaves aromatic. Seeds yield Simbolee oil.

450. CHAMAEBÁTIA, Benth. Chamæbatia. Rosareae. From Greek, "ground bush". Syn. Spiræa, in part. Shrub with foliage of Milfoil and agreeable fragrance. One species, California.

451. CHAMAEBATIírIA, Maxim. Chamaebatiaria. Rusaceae. Named Irom resemblance to preceding. Syn. Spiræa, in part. One species, California.

452. CHAMAECÍSTUS, Oeder. 1761. Alpine Azalea. Ericaceae. From Greek, "ground C'estus". Syn. Loiseleuria, Desv. 1813; Azalea, in part. Low shrub. One species, circumpolar (U. S.).

a. C. procúmbens (L.) Kz. (A. procumbens L., C. serpyllifolia S. F. Gray). Northern Europe, Asia and N. America. Alpine or Trailing Azalea.

453. CHAMAECÝ ParIS, Spach. White Cedar. Pinaceae. From Greek, "ground Cypress". Syn. Cupressus, Thuya, in part. Evergreen trees, resembling Thuya. About 7 species, $\mathrm{N}$. America and Japan; 3 in U. S.

a. C. thyoídes (L.) B. S. P. (Cup. thyoides L. (Kew), T. sphæroidalis Rich.). Southeastern U. S. Southern White Cedar, Post Cedar, Swamp Cedar, Juniper*. [The Alaska Cedar and Port Oxford Cedar of the Pacific coast are also of this genus.]

454. CHAMA EDÁPHNE, Moench 1794. Cassandra. Ericaceae. From (ireek, "ground Daphne". Syn. Cassindra, D. Don. 1834; Andromeda, in part. Small shrub with aspect of Vaccinium. One species, circumpolar (U. S. ).

a. C. calyculáta (L.) Moench (Cass. calyculata D. Don (Kew), A. calyculata L. ). Northern Europe, Asia and N. America. Leather-leaf, Dwarf Cassandra.

455. CHAMAELÍRIUM, Willd. Blazing-star. Melanthaceæ. From Greek, "ground Lily". Syn. Helonias, Veratrum, in part. Herb from tuberous rootstock. One species, $\mathbf{N}$. America.

a. C. lúteum (L.) A. Gray (V. luteum L., H. dioica Pursh, C. Carolinianum Willd.). Ontario and eastern U. S. Helonias, False Unicorn-root. Blazing-star, Drooping Starwort, Devil'sbit, Unic rn-root, Unicorn's-horn, Red-seed. Rhizome tonic, diuretic, anthelmintic.

456. CHAMAENÉRION, Adans. Willow-herb. Onagraceae. From Greek, "ground Rose-bay". Syn. Epilobium, in part. Perennial herbs with showy flowers. About 4 species, north temperate zune; 2 in $\mathrm{U}$. $\mathrm{S}$. 
a. C. angustifólium (L.) Scop. (E. angustifolium L., E. spicatum Lam.). British America, south to N. Carolina, Arizona and California. Great Willow-herb, Spiked or French Willowherb, Purple Fire-weed, Fire-weed*, Fire-top, Burnt-weed, Wickup, Indian Wicopy, Herb-wickopy, Purple Rocket, Rosebay, Bay Willow, Flowering Willow; Blooming, French or Persian Willow, Blooming Sally, Sally-bloom, Pigweed*.

45̆7. CHAMAÉRHOD0S, Bunge. Chamaerhodos. Rosaceae. From Greek, "ground Rose", Small sub-shrubs. About 6 species, northern Asia and N. America; 1 in U. S.

458. CHAMAESÁRACHA, Gray. Chamaesaracha. Solanaceae. From Greek, "ground Saracha". Perennial herbs or subshrubs. About 6 species, N. America; 4 in U. S.

459. CHA PMÁNNIA, T. \& Gr. Chapmannia. Papilionaceae. Named for Dr. A. W. Chapman, American botanist. Viscid herb. One species, Florida.

460. CHÁVICA, Miq. Long Pepper, etc. Piperaceae. From vernacular name. Syn. Piper, in part. Herbs or shrubs resembling Piper. About 40 species, tropical regions, Old World.

a. C. Bétle (L.) Miq. (P. Betle L.). India, cult. in tropical countries. Betel Pepper. Leaves, Betel-leaves, sialagogue, stimulant; chewed with the betel-nut. (The leaves of (b) C. Siriboa (L.) Miq. are also used).

c. C. lóngum (L.) Miq. (P. longum L., C. Roxburghii Miq.) India, Ceylon and Philippines. Long Pepper, resembling the preceding.

d. C. officinárum Miq. (P. officinarum DC., P. Chaba Hunter). Java. Long Pepper, Elephant Pepper. Fruit spikes, Piper longum, Spadices piperis longi, Spad. chavicae; Ger. Langer Pfeffer; Fr. Poivre long (Codex); condiment, counter-irritant, antiperiodic.

461. CHEILÁNTHES, Swz. Lip-Fern. Polypodiaceæ. From Greek, "lip flower", alluding to the lipped indusium. Small rock-loving ferns. About 65 species; 21 in U. S.

a. C. gracíllima D. C. Eaton. Pacific slope of U. S. Lace Fern, a name applied also to the species of Hymenophyllum and to other finely cut ferns.

462. CHELIDÓxIUM, L. Celandine. Papaveraceae. The Greek name, meaning "swallowwort". Herb with yellow sap. One species.

a. C. május L. (including C. minus L.). Europe, nat. in U. S. Celandine (Saladine), Garden or Greater Celaudine, Cock-foot, Devil's-milk*, Felonwort, Jacob's-ladder*, Kill-wait, Swallowwort*, Tetterwort, Wart-flower, Wart-weed, Wartwort, Wretweed; Ger. Schellkraut, Schöllkraut; Fr. Chélidoine, Herbe \& l'hirondelle; Sp. Celidonia mayor. Herb; Chelidonium, U. S. P., H. chelidonii; irritant, cathartic, anthelmintic. 
463. CHELÓNE, L. Turtle-head, etc. Scrophulariaceae.

From Greek, "tortoise". Perennial herbs. Four species, all of U. S.

a. C. glábra L. Canada and eastern U. S. Balmony, Turtlehead,Turtle-bloom, Bitter-herb, Cod-head, Fish-mouth, Shellflower*, Salt-rheum weed, Snake-head. Plant laxative, chologogue, anthelmintic.

464. CHENOPÓDIUM, L. Goosefoot, Pigweed. Chenopodiaceae. From Greek, "goose foot'. Herbs, occasionally shrubby. About 60 species, widely distributed; 22 in U. S.

a. C. álbum L. Europe and Asia, nat. in U. S. Lamb's-quarters, Pigweed, Bacon-weed, Dirty-Dick, Fat-hen, Frost-blite, Meals, Mails, Melge, Miles, Mutton-tops, Muck-weed, Rag-jag, White Goosefoot?, Wild Spinach; Ger. Weisser Gänsefuss; Fr. Ansérine sauvage. Used as a pot herb.

b. C. ambrosioídes L. Canada and U. S., nat. from tropical America. Mexican Tea, Spanish Tea, Jerusalem Tea, Jesuit Tea*, Ambrosia; Ger. Wohlreichender Gänsefuss, Mexikanisclies Traubenkraut; Fr. Ambroise de Mexique (Codex). Herb, $H$. chenopodii ambrosioides ( $\mathrm{v}$. ambrosiaci), tonic, nervine, emmenagogue.

c. C. anthelmúnticum L. (C. ambrosioides var. anthelminticum A. Gray). Europe, nat. in U. S. Wormseed, American Wormseed, Jerusalem-oak. Fruit; Chenopodium. U. S. P.; Ger. Amerikanischer Wurmsamen; Fr. Ansérine vermifuge (Codex); Sp. Epazote. Anthelmintic, source of oil of wormseed.

d. C. Bonus-Hénricus L. Europe, ads. in U. S. Good King Henry, All-good, Blite; English, False or Wild Mercury, Markerrył, Mercury-dockan, Mercury Goosefoot, Perennial Goosefoot?. Fat-hen, Roman plant, Shoemaker's-heels, Smeardock, Smiddy-leaves; Wild Spinach; Ger. Guter Heinrich; Fr. Bon Henri; Sp. Zeñiglo. Plant reputed vulnerary.

e. C. Bótrys L. Europe and Asia, nat. in U. S. Jerusalem-oak, Ambrose, Feather Geranium, Turnpike Geranium, Hind-heal; Ger. Traubenkraut; Fr. Chénopode à grappes. Plant aromatic, resembling (b).

f. C. hýbridum I. Europe and X. America (U. S.). Mapleleaved Goosefoot or Pigweed, Hog's-bane, Sowbane; Swine'sbane, Nightshade*.

g. C. rúbrum L. Northern Europe, Asia and N. America. Red Goosefoot or Pigweed, French Spinach, Fat-hen, Swine'sbane.

h. C. Quínoa Willd. Peru and Chili. Quinoa (Quinua), Pettyrice. Seeds used like buckwheat.

i. C. Vulvária L. Europe. Fetid Goosefoot, Stinking Goosefoot or Motherwort, Dirty-John, Notchweed; Ger. Stinkender Melde; Fr. Vulvaire (Codex), Ansérine puante. Plant antispasmodic, nervine. 
465. Снilópsis, D. Don. Desert Willow. Bignoniaceae. Ornamental shrub. One species, U. S. and Mexico.

466. СНiмá PHILA, Pursh 1814. Wintergreen, etc. Pyrolaceae. From Greek, "winter-loving". Syn. Psera, Raf. 1819; Pyrola, in part. Evergreen herbs. About 6 species, northeast Asia and N. America; 3 in U. S.

a. C. maculáta (L.) Pursh (Pyrola maculata L.). Ontario to Georgia, west to Minnesota. Spotted Wintergreen, Spotted Pipsissewa, Spotted Piperidge, Dragon's-tongue, Ratsbane, Rheumatism-root, Wild Arsenic, also many of the :ynonyms of $(\mathrm{b})$.

b. C. umbelláta (L.) Nutt. (Pyrola umbellata L., Pseva umbellata (L.) O. Kze., C. corymbosa Pursh). Europe, Asia and N. America, Maine to Georgia, west to California. Pipsissewa, Prince's-pine, Bitter Wintergreen, Bittersweet*, Ground Holly, King's-cure, Love-in-winter, Noble-pine, Pine Tulip, Pyrola, Rheumatism-weed; Ger. Doldenblüthiges Harnk raut, Wintergrïn; Fr. Pyrole ombellée. Leaves; Chımaphila, U. S. P., diuretic, tonic, astringent.

467. CHIOcóCCA, P. Br. Snowberry. Rubiaceae. From Greek, "snıw berry". Shrubs. About 12 species, mostly of tropical America; 1 in U. S.

a. C. racemósa Jacq. Tropical America to Florida. Cahinca; Snowberry, Cluster-flowered Snowberry? David's-root. Root, Radix caincæ (cahincæ); Ger. Käinkawurzel; diuretic, hydragogue. [Similar properties are attributed to the Brazilian (b) C. brachiáta R. \& P. (C. densifolia Mart., C. anguifuga Mart.), Cainana, Caninana, Brazilian Snakeroot, Rad. caincae brasiliensis, Rad. serpentariae brasiliensis].

468. СHIÓ(GENES, Salisb. Creeping Snowberry. Vacciniaceae. From Greek, "snow born". Syn. Vaccinium, in part. Creeping evergreen plant. One species, N. America and Japan.

a. C. hispídula (L.) T. \& Gr. (V. hispidulum L., C. serpyllifolia Salisb., C. Japonica A. Gray). British America, south to N. Carolina and Michigan. Creeping Snowberry, Ivory Plum, Maidenhairt, Moxie-berry, Mountain Partridge-berry, Running Birch, White Cranberry, White Pollum, White Tea-berry, White Wintergreen. Berries have flavor of gaultheria.

469. CHIONÁNTHUS, L. Fringe-tree. Oleaceae. From Greek, "snow flower". Shrubs or small trees. Three species, China and N. America; 1 in U. S.

a. C. Virgínica L. Delaware to Florida and Texas. Fringe-tree, American Fringe-tree, American Fringe, White Fringe, Flowering Ash, Gray-beard tree, Old-man's-beard, White Ash*, Poison Ash, Shavings, Snow-flower?. Root bark tonic, febrifuge, laxative, reputed narcotic.

470. CH IONÓPHILA, Benth. Chionophila. Scrophulariaceae. From Greek, "snow loving". A low herb. One species, high in the Rocky Mountains (U. S.). 
471. CHLORÓGALUM, Kunth.

Soap-bulb.

Liliaceae.

From Greek, "yellow milk". Syn. Phalangium, in part. Bulbous herbs. About 4 species, western U. S.

a. C. pomeridiánum (Ker) Kunth. (Phalangium pomeridianum Sweet). California. California Soap-root. Soap-bulb, Soapplant, Soap-apple (the bulb), Amole. Bulb formerly used as a detergent.

472. CHLORÓPHORA, Gaud. Fustic tree. Moraceae. From Greek, "yellow bearing". Syn. Maclura, in part. Trees with milky sap. Two species, tropical Africa and America.

a. C. tinctória Gaud. (Maclura tinctoria D. Don). West Indies and tropical America. Fustic-tree. Wood, Old Fustic, Yellowwood, Cuba-wood, used for dyeing. See Cotinus.

473. CHOÍSYA, H. B. K. Choisya. Rutaceae. Named for Jacques Deny Choisy, Swiss botanist, d. 1859. Shrub with ternate leaves. One species, Mexico and southwestern U. S.

474. CHONDRÍLLA, L. Gum Succory. Cichoriaceae. From Greek, "lump", alluding to exudate on stems. Perennial herbs, leaves mostly basal. About 18 species, Old World.

a. C. júncea L. Europe, sparingly naturalized in U. S. Gum Succory, Devil's-grass, Hog-bite, Naked-weed, Skeleton-weed.

47.. CHONDRODÉNDRON, R. \& Pav.

Menispermaceae. From Greek, "cartilage tree"' (incorrectly spelled Chondodendron): Syn. Botryopsis, Cocculus, in part. Shrubby climbers. About 7 species, South America.

a. C. tomentósum R. \& Pav. (Cocculus Chondrodendron DC., B. platyphylla Miers). Brazil and Peru. Abutuit, Pareira brava. Root; Pareira, U. S. P., Pareirae radix, Br., Rad. pareirae (bravae); Ger. Grieswurzel, Pareirawurzel; Fr. Sp. Butua; diuretic.

476. CHONDRÓPHORA, Raf. Rayless Golden-rod. Compositae. From Greek, "cartilage bearing"'. Syn. Chrysocoma, Bigelovia, in part. Perennial herb with aspect of a depauperated Golden-rod. One species, eastern U. S. 477. CHÓNDRUS, Lyngb.
From Greek, "cartilage" or "gelatine". Syn. Sphaerococcus, Fucus, in part. Dull purple or green seaweeds.

a. C. críspus (L.) Lyngbye (F. crispus L., S. crispus Agardh). Northern Atlantic Ocean. Irish Mloss, Carrageen (Carigeen, Carrigeen, Carragheen), Killeen, Pig-wrack, Pearl Moss; Ger. Knorpeltang, Perlnoos, Irländisches IInos; Fr. Carragaheen, Carrageen, Mousse perlée (Codex); Sp. Caragaheen. The whole plant; Chondrus. U S. P., Fucus crispus, Fucus irlandicus; demulcent, mucilaginous. 
478. CHORIZÁNTHE, R. Br. Chorizanthe. Polygonaceae. Herbs or sub-shrubs. About 50 species, chiefly of Chili and California; 34 in U. S.

479. CHROSPÉRMA, Raf. 1825. Fly Poison, etc. Melanthaceae. From Greek, "color seed". Syn. Amianthium A. Gray, 1837; Melanthium, Zygadenus, in part. A lily-like bulbous plant. One species (U. S.).

a. C. muscaetóxicum (Walt.) Kze. (M. muscaetoxicum Walt., Z. muscaetoxicum Regel (Kew), A. muscaetoxicum A. Gray). Long Island to Florida and Arkansas. Fly poison, Crowpoison, Fall-poison. Bulb insecticide.

480. CHRYSACTÍNIA, Gray. Chrysactinia. Compositae. From Greek, "golden rayed". Resinous-aromatic sub-shrub. One species, Mexican border of U. S.

481. CHRYSÁMPHORA, Grn. Pitcher-plant*. Sarraceniaceae. From Greek, "golden rase". Syn. Darlingtonia, Torr., not DC. Plant resembles Sarracenia. One species, California.

a. C. Califórnica (Torr.) Greene (D. Californica Torr.). California Pitcher-plant, California Side-saddle flower.

482. CHRYSÁNTHENUM, L. Chrysanthemum. Compositae. From Greek, "golden flower". Syn. Balsamita, Leucanthemum, Matricaria, Pyrethrum, Tanacetum, in part. Annual or perennial herbs. About 100 species, northern hemisphere; 8 in U. S. (indigenous or naturalized).

a. C. Balsámita L. (P. Balsamita Willd., T. Balsamita L., B. suaveolens Pers., P. Tanacetum DC. ). Europe and Asia, cult. in gardeus and adv. in U. S. Costmary, Cost (from Latin costus), Alecost ( so named from its former use in brewing), Alecoast, Cock Mint, Lavendert, Maudlin (i. e. Magdeline), Mint Geranium; Ger. Frauenminze, Balsamkraut, Marienblatt; Fr. Balsamite odorante, Baume-coq, Menthe-coq, Coq des jardins (Codex). Herb; H. balsamitæ, H. menthæ saracenicæ v. romanæ; aromatic, emmenagogue, resembling Tanacetum.

b. C. cárneum Weber (P. carneum Bieber.) and (c) C. rósenm Weber (P. roseum Bibers.). Both species referred in Index Kewensis to C. coccineum Willd. Persia to Caucasus mountains. Flowers, Flores pyrethri (rosei v. persici), Pulvis insecticidus persicus; Persian insect-powder, Buhach; Ger. Persische Bertramblüthen; Fr. Pyrèthre du Caucase (Codex), Chamomile de Perse; insecticide. [The Dalmatian insect-powder, from flowers of Pyrethrum cinerariaefolium Trev., is nuch inferior in activity.]

d. C. Prutéscens L. Canary Islands, cult. in gardens. Marguerite (of gardens), Paris Daisy.

e. C. Leucánthemum L. (L. vulgare Lam.). Europe and Asia, nat. in eastern U. S. Ox-eye Daisy, Common Field Daisy (of U. S. ); Bull-, Bulls-eye-, Butter-, Big-, Devil's-, Dog-, Golden-, 
Great-, Horse-, Maudlin- (Magdalene), Midsummer-, Moon-, Poor-land- or White Daisy; Dog-blow (Nora Scotia), Dutch Morgan, Horse-Gowan, Kellup-weed, Herb Margaret, Marguerite, Maudlinwort, Moon-flower, Moon-penny, Great White Ox-eye, Pismire, Poverty-weed, Sheriff-weed, White-weed.

f. C. Parthéuium (L.) Pers. (M. Parthenium.L., P. Parthenium Smith, T. Parthenium Schulz). Europe, cult. in gardens and adv. in U. S. Feverfew, (Featherfew, Fetter-foe), Febrifuge plant, Wild Camomile, Pellitory, Bertram, Whitewort; Ger. Mutterkraut; Fr. Matricaire (Codex). Herb bitter, tonic, febrifuge, anthelmintic.

g. C. segétum L. (P. segetum Moench.). Furope. Corn Marigold, Field or Wild Marigold (of England), Golden-flower, Ýllow Ox-eye.

h. C. Sinénse Sabine and (i) C. Indicum 'L. of Japan, especially the former, are the well-known garden Chrysanthemums.

4S3. CHRYSOBÁLAYUS, L. Cocoa Plum. Drupaceae. From Greek, "golden date". Shrubs or trees. About 8 species, sub-tropical America and Africa; 2 in U. S.

a. C. Ícaco L. West Indies and Florida. Cocoa Plum. Leares and roots astringent; Fr. Prune-coton, Prune des anses. Fruit edible.

b. C. oblongifólius Michx. Florida to Alabama. Gopher-root.

484. CHRYSÓGONUM, L. Chrysogonum. Compositae. From Greek, "golden knee". Perennial herb witl yellow flowers. One species, southeastern U. S.

485. CHRYSÓMA, T. \& Gr. Chrysoma. Compositae. Syn. Aplopappus, Bigeloria, in part. Perennial herbs resembling Solidago. About 14 species, southwestern U. S.

486. CHRYSOPHÝLLCM, L. Star-apple. Sapotaceae. From Greek, 'golden leaf"' Syn. Cainito, in part. See Lucuma. Trees with milky juice. About 60 species, tropical regions; 1 in $\mathrm{U}$. S.

a. C. Cainíto L. (Cainito pomiferum Tuss.). West Indies. Starapple, Cainito. Fruit esculent.

487. CHRYSOPLÉNIUM, L. Golden Saxifrage. Saxifragaceae. From Greek, "golden spleen". Small semi-aquatic herbs. About 15 species, north temperate zone and S. America; 4 in U. S.

a. C. Americánum Schw. British America and northern U. S. Water-carpet, Golden Saxifrage. [In Europe some species are used as salad, called Rock-cress; Ger. Goldmilz; Fr. C'resson de roches].

488. CHRYSÓPSIS, Nutt. 1818. Golden Aster. Compositae. From Greek, of "golden appearance". Syn. Diplogon, Raf. 1818. [not Poiret 1811], also Inula, Amellus, Diplopappus, in part. Perennial herbs. About 35 species, U. S. and Mexico. 
a. C. graminifólia (Michx.) Nutt. (I. graminifolia Michx.) Southeastern U. S. Grass-leaved Golden-aster, Golden-star, Silver Aster, Silver-grass, Silk-grass, Scurvy-grass.

b. C. villósus (Pursh) Nutt. (A. villosus Pursh.). Alabama to Nebraska and British Columbia. Hairy Golden-aster or Rosinwood.

489. CHRYSOTHÁMNUS, Nutt. Chrysothamnus. Compositae. From Greek, "golden bush". Syn. Linosyris, Aplopappus, Bigelovia, in part. Low shrubs with numerous small flowerheads (yellow). About 30 species, all of U. S., mostly western.

a. C. nauseósus (Pursh) Brit. New Mexico to California and British Columbia. Fetid Rayless-Goldenrod?, Rabbit-brush.

490. CHYLISMA, Small. Chylisma. Onagraceae. Syn. Oenothera, in part. Herbs. Seven species in U.S.

491. CHYTRACÚLIA, P. Br. 1756. Chytraculia. Myrtaceae. Syn. Calyptranthes Sw. 1788; Eugenia, in part. Shrubs or trees. About 90 species, New World; 1 in U.S.

492. CIBÓTIUI, Kaulf. Tree-fern. Arboreous ferns. About 10 species, tropical regions.

a. C. Bárometz J. Sm. (b) C. glaucéscens Kze. and (c) C. Djambiánum Hassk. of Sumatra yield penghawar djambi the "golden moss" of the Chinese, consisting of chaffy hairs from base of stipes; Pililiv. Paleæ cibotii; Ger. Farnhaar. In Mexico a similar product called Ocopetate or cola de mono is obtained from (d) C. Schiédei Schlecht., and in the Hawaiian Islands the more silky pulu is obtained from (e) C. Menziésii Hook. and (f) C. glaúcum H. \& A. These are used in surgery as haemostatics, the last named a material for stuffing cushions, etc. The shaggy caudex of (a) was the Tartarian lamb (agnus scythicus) of early travelers, to which magical virtues were attributed. See also Alsophila and Dicksonia.

493. CíCER, L. - Chick Pea. - Papilionacer. The Latin name. Syn. Nochetta, S. G. Gmel. Herbs. About 10 species, Mediterranean region to central Asia.

a. C. arietínum L. (N. oleracea S. G. Gmel., C. sativum Schkur.). Southern Europe and the Orient. Chick Pea, Egyptian Pea, Coffee Pea. Called in Italy Cece, in Spain, Garbanzos; in India, Gram. One of the most important of food plants.

494. CICHÓRIUM, L. - Chicory. - Cichoriaceae. Classical name from the Arabic. Herbs with cauline leaves very small. About 10 species, Old World.

a. C. Endívia L. Southern Europe and Asia, widely cult. Garden Endive, Endive, Garden Succory, Chicken's-meat. Blanched tops used like Celery. 
b. C. Intybus L. Europe, Asia and northem Africa, nat. in U. S., (also cult.). Chicory, Wild Succory, Blue Daisy, Bluesailors, Bachelor's-buttons*, Bunk; Ger. Endivie, Cichorie; Fr. Chicorée saurage (Codex). Root; Rad. cichorii; bitter, used as a substitute for coffee.

495. CICÚTA, L Water Hemlock, etc. Umbeliifera. The ancient Latin name. Syn. Cicutaria, in part. Perennial herbs. About 8 species, north temperate zone and Mexico; 7 in U.S.

a. C. bulbífera L. Canada and northeastern U. S. Bulb-bearing Water-hemlock.

b. C. maculáta L. (C. virosa var. maculata Coult. \& Rose.). Ontario and eastern U. S., west to $\mathrm{N}$. Mexicu. American Water-hemlock, Musquash-root, Beaver-poison, Childrens-' bane, Death-of-man, Musquash-poison, Poison Hemlock**, Poison Snakeweed, Spotted Parsley, Wild Parsnip, Wild Hemlock (not to be confounded with Conium maculatum q. v.). Properties of (c).

c. C. virósa L. (Cicutaria aquatica Lam.). Northern Europe and Asia. European Water-hemlock, Brook-tongue, Cowbane, Deathin, with many of the synonyms of (b); Ger. Wasserschierling, Giftwütherich; Fr. Ciguë vireuse; Sp. Cicuta virulenta. Plant, especially the ront, poisonous; reputed alterative and local anodyne.

496. CIENFUEGósIA, Cav. 1787. Cienfuegosia. Malraceae. Syn. Fugosia, Juss. 1789, Cienfuegia, Willd. 1800. Shrubby plants with habit of Hibiscus. About 16 species, tropical America, Africa and Australia; 2 in U. S.

497. CIMICÍfUGA, L. Black Cohosh. Ranunculaceae. From Latin, "bug-banisher". Syn. Thalictrodes (1739). Actaea, Macrotys, Botraphis, in part. Tall perennial herbs. About 10 species, N. America, Asia and eastern Europe; 7 in U. S.

a. C. racemósa (L.) Nutt. (A. racemosa L., C. serpentaria Pursh. iI. actaeoides Raf., B. actaeoides Raf. T. racemosum O. Kze.). Ontario to Georgia, west to Minnesota and Wisconsin. Black Cohosh, Black Snakeroot, Bugbane, Bugwort, Rattlesnake'sroot, Rattle-root, Rattle-weed, Rattle-top, Rich-weed, Squawroot; Ger. Klapperschlangenwurzel, Schwarze Schlangenwurzel; Fr. Actée à grappes. Rhizome and roots; Cimicifuga, U. S. P., Rad. cimicifugæ, Rad. acteæ, Rad. christophorianæ; alterative, antispasmodic, anti-rheumatic, emmenagogue.

498. CINCHÓNA, L. (Quinquina, Kinkina). Rubiaceae. Named for the countess of Chinchon, cured of malarial fever by the bark in 1638 . Trees. About 50 species, Peru, north to Venezuela, in the Cordilleras. The more valuable species are now cultivated in Java, India and Jamaica. 
a. C. Calisáya Weddell (C. Weddelliana O. Kze. To this species are also referred C. Ledgeriána Moens. and perhaps C. Hasskarliána Miq.). Peru to New Granada. Bark; Cinchona, U. S. P. (in part). Cinchona flava U.S. P. 1880, Cinchonie flavæ cortex, Cort. chinæ calisayæ, Cort. chinæ regiæ; Yellow Cinchona Bark, Calisaya Bark, Yellow Peruvian Bark; Ger. Kalisayachina, Kalisaya-rinde, Königschina; Fr. Quinquina jaune royale, Quinquina Calisaya (Codex); Sp. Quina Calisaya. Tonic, antiperiodic, particularly rich in quinine.

b. C. cordifólia Mutis. Bolivia. Yields the hard Carthagena Bark or West Pitaya Bark, which is rich in alkaloids.

c. C. micrántha Ruiz. \& Pav. (C. Pavoniana O. Kze.). Bolivia and Peru. Source of Lima Bark and in part of the Gray and Huanuco Barks; Fr. Quinquina gris Huanuco (Codex.)

d. C. nítida Ruiz. \& Par. (Perhaps belongs to C. Favoniana O. Kze.). Peru and Equador. Source of part of the Gray and Huanuco, and some of the Loxa Bark.

e. C. officinális L. (C. Condaminea Humb. Probably includes C. lancifolia Mutis. and C. Pitayensis Wedd., both of which yielded formerly Pitaya Bark. ). Eequador and Peru. Source especially of Loxa Bark, Crown Bark and Brown Peruvian Bark. Bark; Cinchona, U. S. P., in part; Cinchona pallida, Cortex cinchonae pallidae, Cort. chinae fuscus v. griseus, China fusca v. grisea v. pallida v. cinerea; Pale Peruvian Bark; Ger. Braune Chinarinde, Graue Chinarinde, Kronchina; Fr. Quinquina gris de Loxa, (Codex); Sp. Quina gris de Loja, Quina Charhuarguera. Properties of (a).

f. C. succirúbra Paron. Peru and Ecquador. Bark; Cinchona rubra, U. S. P., Cinchonæ rubræ Cortex, Br., Cortex chinæe (ruber) P. G., C'hina rubra; Red Cinchona, Red Peruvian Bark, Red Bark; Ger. Rothe Chinariude; Fr. Quinquina rouge (Codex); Sp, Quina roja. Properties of (a).

499. CINXAMODÉNDRON, Endl. False Canella. Canellaceae. From Greek, "cinnamon tree". "Syn. Canella, in part. Trees. About 3 species, tropical America.

a. C. axilláre Endl. (Canella axillaris Mart.). Brazil. Paratudo (i. e. Heal-all) aromatico. Bark pungent, aromatic.

b. C. corticósum Miers. Jamaica. Jamaica Canella. Bark of this and of (c) C. macrántlum Baill. of Puerto Rico, are used like Canella and often sold as Canella, also as Winter's Bark; see Drimys.

500. CINYAMÓMUM, L. Cinnamon, Camphor, etc. Lauraceae. The classical name. Syn. Laurus, Camphora, in part. Trees with ribbed leaves. About 100 species, warmer regions, India to Australia.

a. C. aromáticum Nees (L. Cassia Nees, C. Cassia Blume (Kew), not Burm. ). Southern China. Cassia, Chinese Cinnamon. Bark of the shoots of this and some. other species grown in China; 
Cinnamomum Cassia, U. S. P., Cortex Cinnamomi, P. G., Cort. cinnamomi cassiae v. chinensis, Cassia cinnamomea, Cinnamomum chinense, Cassia lignea; Cassia bark, C'assia Cinnamon; Ger. Zimmtkassie, Chinesischer Zimmt, Kaneel, Zimmt; Fr. C'anelle de China; Sp. Canella; aromatic, carminative, astringent, condiment. Among other species yielding Cassia Bark is probably (c) C. Burminni Blume of Java and Sumatra. Cassia Bark is the source of the oil of Cinnamon of the U. S. P.

b. C. Cámphora (L. ) T. Nees \& Eberm. (Laurus Camphora L., Camphora officinarum C. Bauhin). Southeastern Asia, Japan, Formosa and cult. elsewhere in tropical countries. Camphor tree, Camphor Laurel. Source of ('amphor, a concrete volatile oil (ketone) obtained by sublimation from the wood; Camphora, U. S. P.; Ger. Kampfer; Fr. Camphre; Sp. Alcanfor; nervous sedative, small doses stimulant.

d. C. Zeylánicum Nees. (Kew) (L. Cassia Burm. J768, L. Cinnamomum L., probably the oldest name but possibly applied to a different plant). Ceylon, Borneo and Cochin ('hina. Bark; Cinnamomurn Zeylanicum, U. S. P., Cinnamomi Cortex, Br., Cort. cinnamoni zeylanici, Cinnamomum acutum v. verum; Ceylon Cinnamon, True Cinnamon, Cinnamon bark; Ger. Zeylonzimmt, Feiner Zimmt, Echter Zimmt; Fr. Canelle de Ceylan (Codex). Properties of (b), but flavor much superior. Source of the oil of Cinnamon of the British and French Pharmacopœias.

e. C. Culílaban (L.) Lyons, Blume (Laurus Culilaban L., C. Culilawan Blume, C. Culitlawan Nees.). Moluccas. Culilawan Bark, Clove Bark. Bark aromatic, clove-like in flavor.

f. C. Loureírii Nees. (Laurus Cinnamomum Lour. not L.). Cochin China. The unripe fruits of this and other species are Clavelli cassiae v. cinnamomi, Flores cassiae; Cassia Buds; Ger. Zimmtblüthen, Kaneelblüthen, Zimmtnägelchen. Properties of $(b)$.

g. C. Támala Nees (Laurus Tamala Buch. L. Cassia Roxb.). India. Yields a coarse kind of Cassia bark, Cortex malabathri. From this and other species are obtained Cassia leaves, Folia malabathri, not now much used. Properties of (b).

h. C. sp. indet. Annam. Bark; Cinnamomum Saigonicum, U. S. P., Cortex cinnamomi saigonici; Saigon Cinnamon; Ger. Saigonzimmt; Fr. Canelle de Saigon. Properties of (b) but generally richer in essential oil and therefore preferable.

501. CIRCAÉA, L. Enchanter's Nightshade. Onagraceae. Named after Circe, the enchantress. Perennial herbs. About 5 species, northern hemisphere; 3 in U. S.

a. C. Lutetiána L. Canada to Georgia, west to Missouri. Common Enchanter's Nightshade, Bindweed Nightshade, Wild Mandrake. 
502. Císsus, L. (not Pers.).

Cissus.

Vitaceae. Ancient Greek name of Ivy. Syn. Vitis, in part. Shrubby climbers, mostly of warmer regions; 3 in U. S.

a. C. ácida L. Tropical America to Florida. Sorrel vine.

503. cÍsTUS, L. Gum Cistus, Rock Rose. Cistacene. Ancient Greek plant name. Handsome shrubs. About 40 species, Mediterranean region.

a. C. Cyprínus Lam., Cyprus; (b) C. Ladaníferus L., Spain and Portugal, and (c) C. polymórphus Willk. (including C. Creticus L. ), Crete, Rose of Crete; yield the resinous exudate called Labdanum or Ladanum, Resina ladanum, aromatic, emmenagogue, stimulant.

504. CITHARÉXYLU, Mill. Citharexylum. Verbenaceae. Shrubs or trees. About 40 species, warmer regions, New World; 2 in U. S.

505. CITRÚLLUS, Forsk. 1775. Melon, etc. Cucurbitaceae. From Latin name of Lemon. Svn. Colocynthis, 'Tournf. 1735; Cucurbita, Cucunis, in part. Herbaceous vines. About 4 species, warmer regions of Old World.

a. C. Citrúllus (L.) Karst. (Cucurbita Citrullus L., Cit. vulgaris Schrad.). Native of Asia, everywhere cult. Water melon. Fruit, especially seeds, diuretic; seeds, formerly called cold seeds, emollient. See Cucumis aud Cucurbita.

b. C. Colocynthis (L.) Schrad. (Cucumis Colocynthis, L., Colocynthis vulgaris Schrad.). Asia, Africa and southern kurope. Colocynth, Bitter Apple, Bitter Gourd, Bitter Cucumber. The decorticated fruit; volocynth:s, U. S. P., Fructus colocynthidis, Poma colocynthidis; Ger. Koloquinten; Fr. Coloquinthe (Codex); Sp. Coloquintide. (The pulp only is official in the British P'harmacopoeia); Bitter, cholagogue, cathartic.

506. Cítrius, L. Citron, Orange, etc. Aurantiaceae. The classical name of "citron". Thorny trees with aromatic foliage and generally acid fruit. About 20 species, reduced by some to 5, tropical Asia to Australia.

a. C. ácida Pers. and (b) C. ácris Mill., both perhaps referable to (k). Lime, Sour Lime. Fruit, exceedingly acid, antiscorbutic. See $(h)$.

c. C. amára (L.) Lyons (C. Aurantium var. amara L., C. Aurantiaca var. Bigaradia Brandis, C. Aurantium var. vulgaris W. \& A., C. vulgaris Risso, C. Bigaradia Loisel. ). India, nat. in Florida and other tropical countries. Bitter (range, Seville Orange, Wild Orange, Ger. Pomeranzenbaum; Fr. Bigaradier. Rind of fruit; Aur ntii A mari Cortex, U. S. P. Aurantii Cortex recens and Aurantii Cortex siccatus, Br., Cort. aurantii fructus v. pomorum, Cort. aurantiorum; Bitter Orangepeel; Ger. Pomeranzenschale; Fr. Écorce d'oringe amère, Écorce de Curaçao(Codex); bitter, nsed for flavor, source of oil of Orange. Unripe fruit yields oil of Neroli petit-grain. Flowers, Flores naphr, yield oil of Neroli petale, and by distillation orange-flower water. 
d. C. Aurántium L. (C. dulcis Pers.), generally regarded as a variety of (c) improved by eultivation. Sweet Orange. Among the numerous varieties may be mentioned the Blood Orange, with red juice, the seedless Navel Orange and the aromatic Curaçao Orange, incorreetly written Curaçoa. Rind of fruit; Aurantii dulcis Cortex, U. S. P., used as a flavoring agent. Fruit esculent.

e. C. Bergámia Risso \& Poit. (C. Aurantium var. Bergamia WV. \& A.). Probably to be referred to ( $k$ ), perhaps a hybrid. Southern Italy. Berganıt Orange or Lemon. Rind of firuit, source of oil of Bergamot.

f. C. Cédra Gallesio. Probably referable to ( $k$ ). Citron (Cedrat), Cedrate, Adam's Apple. The thick rind made into a confection. One variety yields oil of Cedra (Cedrate).

g. C. Decumána Murr. Eastern Asia, cult in all sub-tropical countries. Shaddock, Pomeln, Pompelmos. Varieties are known as Grape-fruit and Forbidden-fruit. Fruit acid, esculent.

h. C. Limétta Risso. Probably referable to (k). Sweet Lime, Sweet or Pear Lemon (According to F. von Mueller C. Limetta is the true Lime, the Sweet Lime being C. Aumia Risso.). Fruit esculent.

i. C. Limónium Risso (C. medica var. b. L.), Referable to (k). Lemon. Rind of fruit; Limonis Cortex, U. S. P., Br., Cort. fructus citri, Flavedo citri, used as a flavor; source of oil of Lemon. Juice of ripe fruit, Limonis succus, U. S. P., Suceus citri recens; acid, antiscorbutic. Fruit, Lemon; Ger. Citrone, Limonie; Fr. Citron, Limon (Codex), acid, refrigerant, antiscorbutic.

k. C. médica L. Southern Asia. Cult. in many varieties (see above) in sub-tropical countries. Citron, in the comprehensive sense of the word.

1. C. nóbilis Lour. Regarded by some as a variety of (c). Japan and China. Mandarin or Chinese Orange, Kid-glove Orange, Tangerine, Oonshin. Fruit esculent.

„07. CLADOTHÁNINUS, Bong. 1833. Cladothamnus. Ericaceae. From Greek, "branch bush". Syn. Tolmiaea, Hook. 1834. Shrubs. Two species, northwestern U. S.

508. CLí́dothrix, Nutt. Cladothrix. Amaranthaceae. From Greek, "branching-haired". Syn. Achyranthes, in part. Stellate-pubescent herbs. Abont 4 species, southwestern U. S. and Mexico.

509. CLAIRÁSTIS, Raf. Yellow-wood. Papilimaceae. From Greek, "brittle-branched"'. Syn. Virgilia, in part. Trees with showy white flowers. Two species, one of China; 1 in U. S. 
a. C. Ińtea (Michx.) Koch (Virgilia lutea Michx., C. fragrans Raf., 1824, C. tinctoria Raf., 1825). Kentucky, Tennessee and N. Carolina. Kentucky Yellow-wood, American Yellow-wood, Yellow Locust, Gopher-wood, Yellow Ash, American Fustic. Wood yields a yellow dye.

510. CLÁPPIA, Gray.

Clappia.

Conipositae. Named for Dr. A. Clapp, American botanical author. Perennial herb, with fleshy terete leaves. One species, southwestern U. S.

511. ClárkIA, Pursh (Clarckia).

Onagraceae. Annual herbs with purple or rose-colored flowers. About 6 species; Pacific coast of N. America (U. S. ).

512. CLÁVICEPS, Ergot. Pyrenomycetes. From Latin, "club head". Syn. Cordiceps. Parasitic on fruit of various grasses.

a. C. purpúrea (Fries) Tulasne (Cordiceps purpurea Fries). Parasitic on Rye. Ergot, Spurred Rye, Smut of Rye, Cockspur Rye, Mother of Rye, Hornseed. Sclerotium of the fungus; Ergota, U. S. P., Br.; Secale cornutum, Clavus isecalinus, Mater secalis; Ger. Roggenmutter, Mutterkorn, Zapfenkorn, Hungerkorn; Fr. Ergot de Seigle (Codex), Seigle ergoté (noir), Blé cornu; Sp. Cuernecillo (Tizon) de Centeno; ecbolic, hremostatic.

513. CLAYTónIA, L. Spring-beauty. Portulacaceae. Named for John Clayton, American botanist, d. 1773. Syn. Montia, in part. Succulent herbs. About 25 species, mostly of $\mathrm{N}$. America; 20 in U. S.

a. C. Caroliniána Michx. and (b) C. Virgínica L., of the eastern U. S. are called Spring-beanty, Good-morning-Spring, Grassflower,May-flower, Wild Potato. The related (c) C. lanceoláta Pursh. of the west is called also Pigeon-root.

d. C. Chamíssoi Ledeb. Western U. S. Chamisso's Claytonia, Toad-lily.

e. C. perfoliáta Donn. (M. perfoliata Greene). British Columbia to Mexico. Indian Lettuce, Spanish Lettuce. Plant used as a pot herb.

514. CLÉNATIS, L. Virgin's-bower. Ranunculaceae. The Greek name of some climbing plant. Vines or perennial herbs with persistent plumose styles. About 100 species, 25 in U. S. The plants are acrid and many have been used as vesicants and counter-irritants.

a. C. críspa L. (C. cylindrica Sims). Southeastern U. S. Marsh Clematis, Curl-flowered Clematis, Bluebell rine, Blue Jessamine (Jasmine).

b. C. Flámmula L. Southern Europe and northern Africa. Sweet-scented Virgin's-bower. 
c. C. Virginiána L. Canada to Georgia and Kansas. Common Virgin's-bower of northern U. Ș., Devil's-darning-needle, Devil's-hair, Love-vine, Traveler's-joy, Woodbine*.

d. C. vitálba L. Europe. Virgin's-bower, Traveler's-joy, Bindwith, Crocodile, Gray-beard, Love-bind, Love-entangled, Ladies'-bower, Maiden's-honesty, Old-man's-beard, Old-man'swoozard, Robin-Hood's-fetter, Smoke-wood, Snow-in-harvest, Withy-wind, White-vine; Fr. Herbe aux gueux (used by beggars to cause ulcers).

Of indigenous species, (e) C. ocliroleúca dit. is called Curly-head, (f) C. ligusticifólia Nutt., Western Virgin'sbower, Wind-flower; (g) C. Símsii Sweet, also (h) C. Viórua L. are called Leather-flower.

515. CLEÓNE, L. Cleome, Spider-flower. Capparidaceae. An old Greek plant name. Herbs or sub-shrubs, many ornamental. About 75 species, mostly tropical, especially American and African; 7 in $\mathrm{U}$. S.

516. CLEOMÉLLA, DC. Cleomella. Capparidaceae. Diminutive of Cleome. Annual glabrous herbs with yellow flowers. About 10 species, all of Mexico, and adjacent territory; 8 in $\mathrm{U}$. S.

517. CLERIÓNTIA, Gaud. Oha-wai. Lobeliaceae. Shrubs, some arborescent. About 11 species, all of Hawaiian Islands.

a. C. macrocárpa Gaud. (C. Kakeana Meyen). Hawaiian Islands. Oha-wai. Fruit esculent, although insipid.

518. CLÉTHRA, L. Sweet Pepper-Bush, etc. Clethraceae. From Greek name of Alder, the foliage being similar. Shrubs or small trees. About 30 species, America and Japan; 2 in U. S.

a. C. alnifólia L. Maine to Florida. Sweet Pepper-bush, Spiked Alder, White-bush.

519. CLIFTóNIA, Banks 1805. Buckwheat tree. Cyrillaceae. Syn. Mylocaryum, Willd. 1809. Shrub. One species, southern U. S.

a. C. monophýlla (Lam.) Sarg. (C. nitida Gaertn. (Kew), C. ligustrina Sims, M. ligustrinum, Willd.). Georgia and Gulf States. Titi, Buckwheat tree, Ironwood*.

520. CLINOPÓDIUM, L. $1753 . \quad$ Calamint, etc. Labiatae. From Greek, "bed foot". Syn. Calamintha, Moench. 1794; Thymus, Melissa, in part. [Some botanists refer the species to Satureia L.] Herbs or sub-shrubs. About 50 species, north temperate zone; 15 in U. S.

a. C. Ácinos (L.) Kze. (T. Acinos L., M. Acinos Benth., Cal. Acinos DC. ). Europe, adv. in U.S. Basil Thyme (i. e. royal Thyme), Basil Balm, Mother of Thyme, Poly-mountain. 
b. C. Calamíntlıa (L.) Kze. (M. Calamintha L., Cal. officinalis Moench). Europe and Asia, cult. in gardens. Calamint (i. e. excellent Mint), Calamint Balm, Cap-mint, Mountain Mint.

c. C. Népeta (L.) Kze. (M. Nepeta L., Cal. Nepeta Link. \& Hoff.). Europe and Asia, nat. in U.S. Field Balm, Basil Thyme, Field or Lesser Calamint.

d. C. vulyáre L. (M. Clinopodium Benth., Cal. Clinopodium DC.). Europe, Asia and North America, south to W. Virginia and Colorado. Field Basil, Wild Basil, Stone Basil, Basilweed, Bed's-foot, Dog-mint, Horse or Field Thyme, Mother of Thyme*, Poly-mountain*. Like the preceding species, stimulant, diaphoretic.

521. CLINTónIA, Raf. Clintonia. Convallariaceae. Named for Gov. DeWritt Clinton of N. Y., d. 1828. Syn. Dracaena, in part. Unpretentious scapose herbs. About 6 species, N. America and Asia; 4 in U. S.

a. C. boreális (Ait.) Raf. (D. borealis Ait.). Canada to N. Carolina, west to Miunesota. Yellow Clintonia, Bear-tongue, Cowtongue, Dog-berry, Heal-all, Clinton's Lily, Northern Lily, Wild Lily-of-the-valley.

522. CLITóRIA, L. Butterfly Pea, etc. Papilionaceàe. From Latin, "clitoris", anatomical term. Woody vines or suffrutescent herbs. About 30 species, warm and temperate regions; 1 in $\mathrm{U}$. S. [The root of the orvamental C. teruatea L. (Ternatea vulgaris H. B. K.) is used in India as an emetic and catharic.]

523. CLÚSIA, L. Monkey Apple, etc. Guttiferaceae. Named for Clusius (C. de l'Escluse) French botanist. Trees or shrubs. Abrut 65 species, tropical America; 1 in U. S. [The Cow tree of Venezuela has been referred to this genus.]

a. C. fláva Jacq. West Indies to Florida. Monkey Apple, Mountain Mango, Wild Fig. Resinous exudate used like pitch.

524. CNEORÍDIUM, Hook. f. Cneoridium. Rutaceae. Latin, from Cneorum, the name of an allied genus. Shrub. One species, California.

525. CNÍCUS, L. Blessed Thistle. Greek name of Carthamus, early transferred to Thistles. Syn. Centaurea, Calcitrapa, in part. Thistle-like herb. One species.

a. C. benedíctus L. 1753 (Centaurea benedicta L. 1763, Cal. lanuginosa Lam. ). Southern Europe, adv. in L. S. Blessed Thistle, Our Lady's Thistle, St. Benedict's Thistle, Bitter Thistle, Holy Thistle, Cursed Thistle, Spotted Thistle, Spotted Cardus. Blessed Cardus; Ger. Spinnendistel, Bitterdistel, Heilige Distel; Fr. Chardon bénit (Codex); Sp. Cardo Santo. Leaves and flowering tops; Herba cardui benedicti; Ger. Cardobenediktenkraut, Cardenbenedict, Bernhardinerkraut, Bitter tonic with irritant properties. 
526. CoccóloBis, P. Br. (Coccoloba L.).

Polygonaceae.

From (xrreek, "berry pod". Shrubs or trees, many producing edible herry-like fruits. About 80 species, tropical America; 2 in U.S.

a. C. laurifólia (Jacq.) Sarg. (Coccoloba Floridana Meisn., C. parvifolia Nutt.). Southern Florida. Pigeon Plum.

b. C. uvífera (L.) Sarg. (Coccoloba uvifera L.). West Indies, Florida. Sea-side Grape, Lobe-berry, Sea-grape, Grape tree, Mangrove*. Fruit edible. Tree yields Jamaica, West Indian or Caracas Kino, an extract from the wood and bark. Astringent.

527. COCHLEÁRIA, L. Scurry-grass, etc. Cruciferae. From Greek, "spoon"-shaped of the leares. Maritime herbs. About 25 species, north temperate zone; 5 in U. S. See Roripa.

a. C. officinális L. (C. oblongifolia DC.). Aretic Europe, Asia and N. America. Scurvy-grass. Scurvy-weed, Scrubby-grass, Spoonwort; Ger. Löffelkraut, Skorbutkrant; Fr. Cochléaria, (Codex), Herbe au scorbut. Fresh herb, Herba cochleariæ, antiscorbutic; used as a salad.

528. COCHLOSPÉRMUM, Kunth. Kutera. Bixaceae. From Greek, "snail seed". Shrubs or small trees with palmately lobed leaves. About 15 species, tropical Asia, Africa and America.

a. C. Gossýpium DC. India. Source of Hogg Gun, Kntera or Kathira, resembling gum tragacanth. See IIoronobea.

529. Cócos, L. - Cocoa Palm. - Sabalaceae. Ancient Greek name of a Palm. Tall, graceful palms. About 35 species, mostly American; 1 in U. S.

a. C. aculeáta Jacq. (Acrocomia sclerocarpa Mart.). Tropical America. Fruit source of macaja butter, resembling palm oil.

b. C. nucifera L. Found in all tropical countries. Cocoa Palm, Cocoanut tree; Ger. Kokospalm; Fr. Cocotier; famed for the number and variety of its useful products, which include material for mats, fibre for ropes (coir), palm wine (toddy) and palm sugar. Fruit yields cocoanut oil; Oleum cocois, Oleum cocos; Cocoanut butter; Ger. Kokosnussöl Kokosbutter, Kokosöl; Fr. Beurre de coco; used in manufacture of soap, of hair dressings, etc. Pulp of fruit used in India and Abyssinia as a taenicide.

530. Coelopleúrun, Ledeb. Coelopleurun. Umbelliferae. From Greek, "hollow ribbed". Syn. Archangelica, Angelica, in part. Herbs. Two known species, western U. S.

531. CófFEA, L. - - Coffee. - - Rubiaceae. From Arabic name of the beverage "coffee". Shrubs or small trees. About 60 species, tropical regions of both hemispheres. 
a. C. Arábica L. Tropical Africa, especially Abyssinia, but now cult. in all tropical countries. Coffee tree; Ger. Kaffeebaum; Seeds, Semen coffeæ, Coffee; Ger. Ḱaffee, Kaffeebohnen; Fr. Café (Codex); stimulant, nervine.

๖32. CóIX, L. - Job's-tears. - Gramineae. Syn. Lithagrostis, Gaertn. Robust grasses with bony fruits. About 6 species, tropical Asia.

a. C. Lachryma-Jóbi L. (C. Lachryma L., L. Lachryma-Jobi Gaertn.). East Indies and Japan, cult. in gardens. The bony "seeds" are called Job's-tear's and are reputed diuretic and lithontriptic.

533. CóLA, Schott \& Endl. 1823. Cola. Sterculiaceae. From vernacular name. Syn. Bichea, Stokes 1812 . Lunanea, DC. 1825, Colaria, Raf. 1824; Sterculia, in part. Trees. About 12 species, tropical Africa.

a. C. acumináta (Beauv.) Schott (S. acuminata Beauv., Bichea solitaria Stokes, Lunanea Bichy DC.). Tropical Africa, nat. in WTest Indies. Kola-nut tree. Seeds, Kola-nut, Cola-nut, Female Cola, Soudan Coffee*, Guru (Gourou, Gooroo), Bichy or Bissy-bissy (W. Indies), Ombéné; Ger. Kolanuss; Fr. Noix de Kola, Noix de gourou, Café du Soudan; Sp. Nuez de Cola (Kola); contains caffeine and theobromine. Properties resembling those of coffee.

„34. CóLCHICUM, L. Meadow Saffron. Liliaceae. Greek name of a poisonous bulbous plant ("Colchis", the land of sorcery.). Ornamental scapose herbs. About 45 species, Mediterranean region to central Asia.

a. C. autumnále L. Central and southern Europe. Colchicum, Meadow Saffron, Autumn Crocus; Autumn, Fog, Meadow or Michaelmas Crocus, Purple Crocus, Rams, Son-before-thefather, Naked Ladies, Upstart; Ger. Herbstzeitlose, Wiesensafran; Fr. Colchique (Codex), Safran bâtard; Sp. Colchico. Corm; Colchici radix, U. S. P., Colchici cormus, Br.. Bulbus v. Tuber colchici, Colchicum root; Ger. Colchicumzwiebel, Zeitlosenwurzel; Fr. Bulbe de Colchique. Seeds; Colchici Semen U. S. P., Colchici semina, Br.; Irritant, evacuant, antiarthritic.

b. C. variegátum L. Southern Europe and Levant. Chequerflower. From this or more probably some other species come the corms known in the orient as hermodactyls.

535. COLDÉNIA, L. - Coldenia. - Boraginaceae. Named for Dr. C. Colden, Colonial Lieut.-Governor of N. Y., 18th Century. Herbs. About 12 species, mostly of New World; 6 in southwestern U. S.

536. COLEÓGYNE, Torr. Coleogyne. Rosaceae. From Greek, "sheath style". Shrub. A single species, California. 
537. Coleosív'HUS, Cass. 1817. Coleosanthus. Compositae. From Greek, "sheath flower". Syn. Brickellia, Ell. 1824, Eupatorium, in part. Herbs or shrubs. About 60 species, 36 in U. S.

j38. COLLíSSI, Nutt. Collinsia. Scrophulariaceae. Named for Zacchaeus Collins, botanist of Philadelphia, d. 1831. Herbs. About 25 species, $\mathrm{N}$. America; 22 in U. S., mostly of California.

a. C. Vérua Nutt. New York to Wiscousin and Indian Territory. Blue-eyed Mary, Innocence, Broad-leaved Collinsia.

539. COLLINSÓNIA, L. Horse-balm, etc. Labiatae. Named for Peter Collinson, English botanist, d. 1768 . Syn. Hypogon, in part. Rank-growing aromatic herbs. Two or three species, eastern N. America; 1 in U. S.

a. C. anisáta Sims (H. anisatum Raf.). Southeastern U. S. Anise-root.

b. C. Canadénsis L. Ontario to Florida and west to Kansas and Wisconsin. Horse-balm, Stone-root, Citronella, Rich-weed. Rich-leaf, Horse-weed, Ox-balm, Heal-all*, Knob-root, Knobgrass, Knob-weed, Hard-hack*, Knot-root; Ger. Collinsonie; Fr. Guérit-tout, Baume de cheval. Root diuretic, diaphoretic, expectorant. Leaves vulnerary

540. COLLónIA, Nutt. Collomia. Polemoniaceae. From Greek, "glutinous", of the seeds. Syn. Gilia, in part. Herbs, mostly annual. About 15 species, western $\mathrm{N}$. America; 9 in U. S.

541. COLOCÁSIA, Schott. Taro, Cocco, etc. Araceae. Greek name of an Egyptian water plant. Syn. Arum, Caladium, in part. Acrid herbs from thickened rhizomes. About 5 species, tropical Asia, one widely distributed.

a. C. Colocásia (L.) Lyons (A. Colocasia L., C. antiquorum Schott, especially the variety esculéntr, C. esculenta (L.) Schott, A. esculentum L., Cal. esculentum Vent.). - Tropical Asia, cult. in most tropical countries. Fleshy rhizomes acrid when uncooked, abounding in starch, when cooked a palatable and nourishing food, the Taro (Kalo) of the Pacific Islands, where it is the chief food of the natives. In the West Indies called Cocco, Cocue, Tanya, in West Indies and Africa also Eddoes (Eddas, Edders), in China Yu-tao, in Japan Sato-imo, in Central America Oto. Another name is Kialkas. Leaves (luau) used as a pot herb. Plant much cultivated in U. S. for ornament.

542. COLOGÁNIA, Kunth. Cologauia. Papilionaceae. Herbaceous climbers. About 12 species, New World, especially Mexico; 4 in U. S.

543. COLÓPTERA, Coult. \& Rose. Coloptera. Umbelliferae. Herbs. Three species in western U. S. 
544. COLUBRíNA, Rich. Puerto Rico Bark. Rhamnaceae.

From Latin, "serpent". Small trees or shrubs. About $1 \tilde{}$ species, warmer regions, both hemispheres; 3 in U. S.

a., C. reclináta Brongn. [Ceanothus reclinatus L'Her. (Kew.)]. West Indies. Puerto Rico Bark; Fr. Écorce costière, Sp. Palo mabi. Bark of this species, as well as of the West Indian (b) C. ferruginósa Brongn. and (c) C. ferméntum Rich., used as a substitute for hops.

545. ColúteA, L. Bladder-Senna. Papilionaceae. Greek name of a leguminous tree, "pod bearing". Shrubs. About 10 species, southern Europe to central Asia.

a. C. arboréscens L. Southern Europe. Bladder Senna, Bastard Senna; Ger. Falsche Senna; Fr. Baguenaudier, Séué indigène; Sp. Espanta-lobos. Leares cathartic; smoke therefrom errhine.

546. COMÁxDR ג, Nutt. Bastard Toad-flax. Santalaceae. From Greek, "hair anthered". Syn. Thesium, in part. Perennial herbs, parasitic on roots. About four species, one in Europe; 3 in U. S.

a. C. umbelláta (L.) Nutt. (T. umbellatum L.). British America south to Georgia, Arizona and California. Bastard Toadflax.

547. CÓMARUM, L. Marsh Cinquefoil. Rosaceae. Greek name of Arbutus. Syn. Potentilla, in part. Perennial bog-herb, a single species, north temperate zone (U. S.).

a. C. palústre L. (Potentilla palustris Scop., P. comarum Nestl.). Northern Europe, Asia and $\mathrm{X}$. America, south to New Jersey, Iowa and California. Marsh Cinquefoil, Purple Cinquefoil, Marsh Fire-finger, Purple Marsh-locks, Purplewort, Cow-berry, Bog Strawberry. Plant astringent.

548. COMBRÉTUY, L. Butter tree, etc. Combretaceae. Shrubby climbers or small trees. About 120 species, tropical regions, Asia, Africa and America.

a. C. butyrósum Tul. (C. butyraceum, Carnel.). S. Africa. Butter tree. Fruit vields a butter-like fat, chiquito, used by the Kafirs as food.

549. COMMELÍNA, L.

Day-flower.

Commelinaceae.

Named for J., G. and K. Commelin, Dutch botanists of 17 th and 18 th centuries. Herbs. About 95 species, warm or temperate regions; 8 in $\mathrm{U}$. $\mathrm{S}$.

550. COMMíPHORA, Jacq.1797. Myrrh, etc. Burseracere. From Greek, "gum bearing". Syn. Balsamea, Gled. 1782, Niouttout, Adans. 1759, Balsamodendron, Kunth, 1824; Amyris, Heudelotia, in part. Balsamic trees or shrubs. About 40 species, tropical Asia and Africa. 
a. C. Africána Endl. (Balsamea Africana Baill. Balsamodendron Africanum Arn., H. Africana Rich.). Western Africa. Resinous exudate, African Bdellium; Fr. Bdellium d'Afrique (Codex); vulnerary, expectorant, emmenagogue.

b. C. Múkul Engl. (Balsamea Mukul Baill., Balsamodendron Mukul Hook.). India. Exudate is East Indian Bdellium, produced also by other species, notably (c) C. Agállocha Engl. (A. Commiphora Roxb.).

d. C. Mýrrha (Nees) Engl. (Balsamea Myrrha Baill., Balsamodendron Myrrha Nees.). Arabia and eastern Africa. Resinous exudate; Mryrrha, U. S. P., Br., P. G., Gummi-resina (Gummi) Myrrha; Myrrh; Ger. Fr. Myrrhe (Codex); Sp. Mirra; vulnerary, tonic, emmenagogue.

e. C. Opobálsamum (Forst.) Engl. (Amyris Opobalsamum Forst., Balsamea Meccanensis Gled., Balsamodendron Gileadense DC., B. Ehrenbergianum Berg., B. Opobalsamum Kunth.). Abyssinia and southward. Balm-of-Gilead tree. Resinous exudate, Balm of Gilead (true), Balm or Balsam of Syria, Mecca Balsam; Balsamum gileadense, Opobalsamum (verum), Balsamum meccæ v. judiacum; Fr. Baume blanc, Baume de la Mecque; balsamic, vulnerary.

5อ1. COMPTóNIA, Banks. Sweet Fern. Myricaceae. Named for Bishop Henry Compton, d. 1713. Syn. Liquidambart, Myrica, in part. A small aromatic shrub. One species.

a. C. peregrína (L.) Coulter (L. peregrina L., M. asplenifolia L., C. asplenifolia Gaertn., M. Comptonia DC. ). Canada and northeastern U.S. Sweet Fern, Fern-gale, Fern bush, Meadow Fern,Shrubby Fern, Canada Sweet-gale, Spleenwort bush, Sweetbush, Sweet Ferry; Fr. Liquidambar à feuilles de céterach. Leaves and tops astringent, aromatic, carminative.

552. CoxÁNTHUS, S. Wats. Conanthus. Hydrophyllaceae. From Greek, "cone flower". Herbs. About 15 species in western U. S.

553. COXDília, Cav. Black Ironwood. Rhamnaceae. Shrubs. About 9 species, New World; 3 in U. S.

a. C. microphýlla Cav. Chili and Argentina. Piquillin. Fruit edible.

554. CONiOSELIYUM, Hoffm. Hemlock Parsley. Umbelliferae. From Greek, "hemlock-parsley". Herbs. About 4 species, all of $\mathrm{N}$. America; 1 in U. S.

55ร. CoxíUM, L. Poison Hemlock. Umbelliferae. The ancient Greek name of Hemlock. Herbs. Two species, one of Europe and Asia, one of Africa.

a. C. maculátum L. Europe and Asia, nat. in U. S. Poison Hemlock, (Humlock, Humly); St. Bennet's Herb, Spotted Parsley, Bad-man's-oatmeal, Heck-how, Poison Snakeweed* or 
Snakeroot, Wode-whistle, Cashes, Bunk, Poison Parsley, Spotted Cowbane (often confounded with Cicuta maculata); Ger. Gefleckter Schierling; Fr. Ciguë officinale, Grande Ciguë (Codex); Sp. Cicuta mayor. Fruit; Conium, U. S. P., Conii fructus Br.; Conium-seed, Hemlock-fruits. Leaves; Conii folia, Br., Herba conii, H. cicutæ (majoris). Sedative, anodyne, discutient; active principle coniine.

556. CONÓBEA, Aubl. Conobea. Scrophulariaceae. Vernacular name, Guiana. Syn. Capraria, in part. Herbs. Ábout 8 species, all American; 2 in U. S.

557. CONOCÁRPUS, L. Button tree. Combretaceae. From Greek, "cone fruited". Trees and shrubs, tropical America; 1. in U. S.

a. C. eréctus L. West Indies to Florida. Buttonwood, Button tree, Zaragoza Mangrove.

558. CONóPHOLIS, Wallr. Squaw-root, etc. Orobanchaceae. From Greek, "scaly cone". Parasitic scaly herbs. Two species; U. S. and Mexico.

a. C. Americána (L.f.) Wallr. (Orobanche Americana L. f.). Maine to Michigan and south to Florida. Squaw-root, Squawdrops, Cancer-root, Earth-club, American Broom-rape, Clapwort. Improperly called Beech-drops, as it grows in Oak woods. Plant astringent.

559. CONOPÓDIUM, Koch. 1824. Earth-nut. Umbelliferae. Syn. Bulbocastanum Lag. 1821; Bunium, Carum, in part. Herbs. About 12 species, Spain to Turkestan.

a. C. denudátum (DC) Koch. (B. flexuosum With.,Bulbocastanum majus Lag., Carum flexuosum Fries, Bunium denudatum DC. ). Western Europe. Earth Chestnut. Tubers edible, called Kipper-nuts, Earth-nuts, Yer-nuts+, Jur-nutsł, Ar-nutsł, Pignuts, Hawknuts, Grunnut $\ddagger$, Truflle†. See Carum.

560. CONRADÍXA, Gray. Conradina. Labiatae. Named for Solomon W. Conrad, botanist of Philadelphia. Canescent herb. One species, Alabama to Florida.

561. CONRÍngIA, Heist. (Gorinkia). Hare's-ear. Cruciferae. Named for Prof. H. Conring, of Helmstädt, d. 1681. Syn. Brassica, Erysimum, in part. Herbs. About 7 species, Europe and western Asia.

a. C. orientális (L.) Dumort (B. orientalis L., B. perfoliata Lam., E. orientale R. Br.). Europe, nat. in U. S. Hare's-ear, Treacle Mustard.

562. CONVALLÁRIA, L. Lily of the Valley. Convallariaceae. From Latin, "valley flower". Perennial herb. One species.

a. C. majális L. (C. latifolia Lam.). Northern Europe, Asia and N. America (Allegheny mountains). Lily of the valley, Conval-lily, May or Park Lily, Wood Lily, May-blossom, Liricon- 
fancy ${ }_{+}^{+}$, Valleys; Ger. Maiblume, Maiglocken; Fr. Muguet (Codex); Sp. Liris de los valles. Rhizome and rootlets; Convallaria, U. S. P.; cardiac tonic, like Digitalis. Flowers and leares are also used.

568. CoNvólvULUS, L. Bind-weed. Convolvulaceae. From Latin, "twiuing". Syn. ('alystegia, Volvulus, in part. Trailing or twining vines. About $1 \% 5$ species, widely distributed; 16 in U. S., including naturalized species.

a. C. arvénsis L. Europe and Asia, nat. in U. S. Small Bindweed, Bear-bind, Hedge-bells, Bell-bind, Corn-lily, Corn-bind, Lap-love, Sheep-blue, Wind, With-wind.

b. C. Scammónium L. (Calystegia Scammonia Pritz.). Southern Europe and the Levant. Scammony plant. Root; Scammoniæ radix, Br. Dried latex; Scammonium, U. S. P., Br.; Gummi-resina Scammonium, Diagrydium; Scammony; Ger. Scammonium, Scammon; Fr. Scammonée d'Alep (Codex). Cathartic, hydragogue. [The best quality is called virgin scammony. The Aleppo is considered better than the Smyrna scammony].

c. C. Sépium L. [Cal. Sepium R. Br. (Kew)]. Europe, Asia and N. America, south to N. Carolina and Utah. Hedge Bindweed, Bracted or Great Bindweed, Bell-bind, Greater Bearbind, Creeper, Hedge-bells, Hedge-lily, Lily-bind, Ladies' nightcap, Rutland-beauty, Woodbind, Woodbine*, German Scammonyt.

d. C. spithamaéns L. (Cal. spithamæa Paleste (Kew), V. spithamæus Kze.). British America and eastern U. S. Upright Bindweed, Dwarf Morning-glory, Bracted Bindweed.

564. COOPÉRIA, Herb. Prairie Lily. Amaryllidaceae. Named for Daniel Cooper of London, d. 1842. Scapose herbs from bulbs. Two species, southern U. S. and Mexico.

565. COPAÍVA, Jacq. 1760 . Copaiba. Caesalpinaceae. From vernacular name. Syn. Copaiba, Adans. 1763, (Mill. 173y), Copaifera, L. 1762. Trees or shrubs. About 12 species, tropical S. America and Africa.

a. C. Langsdórfii (Desf.) O. Kze. (Copaifera Langsdorfii Desf.). Brazil. Oleoresin from this and other species, Ccpaiba, U. S. P., Br., Balsamum Copaivæ, P. G., Balsam of Copaiba (Copaiva, Capivi); Ger. Copaivabalsam; Fr..Copalm (Codex), Baume de Copalm; Sp. Balsamo di Copaive. Antiseptic, diuretic, balsamic.

Other species yielding balsam of Copaiba are (b) C. coriácea (Mart.) Lyons (Copaifera coriacea Mart.), Brazil; (c) C. Gnianénsis (Desf.) Lyons (Copaifera Guianensis Desf.), Guiana to Brazil; (d) C. officinális (L.) Lyons (Copaifera officinalis L., C. Jacquini Desf.), Venezuela, New Grenada and W. Indies.

566. COPERNíCIA, Mart. 1837. Wax Palm. Sabalaceae. Named in honor of Copernicus. Syn. Chrysophylla, Blume 
1836, not Chrysophyllum L. 1752; Corypha, in part. Fan palms of medium size. About 6 species, tropical America.

a. C. cerífera (Ar.) Mart. (Cor. cerifera Arruda). Brazil. Brazilian Wax Palm. Young leaves coated with a vegetable wax, Carnauba wax, used for candles, etc. Root alterative, like Sarsaparilla.

567. CÓPTIS, Salisb. Gold-thread. Ranunculaceae. From Greek, "cut leaved". Syn. Helleborus, Isopyrum, in part. Herbs. About 9 species, north temperate zone; 5 in U. S.

a. C. Teéta Wallich. India. Mishmee Bitter, Chinese Goldthread. Properties of (b).

b. C. trifólia (L.) Salisb. (H. trifolius L., H. trilobus Lam., H. pumilus Salisb. I. trifolium Brit.). British America, south to Maryland and Minnesota. Gold-thread, Canker-root, Mouthroot, Yellow-root; Ger. Gelbe Niesswurz, Kleinste Niesswurz; Fr. Coptide. Root Bitter tonic. Contains berberine.

568. CORALLORHÍzA, R. Br. Coral-root. Orchidaceae. From Greek, "coral-root". Syn. Cymbidium. Scapose herbs with coral-like roots. About 15 species, north temperate zone; 8 in U. S.

a. C. olontorhízon (Willd.) Nutt. (Cymbidium odontorhizon Willd.). Massachusetts to Florida and west to Missouri. Small-flowered Coral-root, Small or Late Coral-root, Crawleyroot, Crawley, Chickens'-toes, Dragon's-claw, Turkey-claw, Fever-root; most of these names also applied to other species. Root diaphoretic, febrifuge. [The roots of other species are no doubt collected as crawley-root, notably of (b) (C. multiflóra Nutt.].

569. CórCHORUS, L. Jew's Mallow, Jute. Tiliaceae. Greek name of a plant with bitter taste. Herbs and small shrubs. About 50 species, warmer regions of Old and $\mathrm{New}$ World; 2 in U. S.

a. C. capsuláris L. India and widely naturalized. Jute plant. Fiber, jute, used for gunny-bags, carpets, etc.

b. C. olitórins L. India and cult. in most sub-tropical countries. Jew's Mallow. Shoots used as a pot herb. Fiber forms part of the jute of commerce.

\section{CORDIA, See VARRONIA.}

570. CORÉMA, Don. 1826. Broom Crowberry. Empetraceae. From Greek word for "broom". Syn. Uakesia, Tuckerm. 1842; Empetrum, in part. Low shrubs. Two species, one of Europe, one of northeastern U. S.

a. C. Conrádii Torr. Newfoundland to New Jersey near the coast. Plymouth Crowberry, Conrad's Broom Urowberry\&, Brown Crowberry, Crakeberry*, Poverty-grass. 
571. COREÓPSIS, L. Tickseed Sunflower.

From Greek, "bug like", of the achenia. Syn. Calliopsis, in part. Iferbs, mostly with showy flowers. About 50 species, America, S. Africa and Australia; 25 in U. S.

a. C. tinctória Nutt. Central U.S. and cult. in gardens. Golden Coreopsis, Wild Flax*, Nuttall's weed.

572. CORETHRóGYNE, DC. Corethrogyne. Compositae. From Greek, "broom style" Aster-like perennials. About 6 species, all of California.

573. CORÍ́NDRUM, L. Coriander. Umbelliferae. Classical name from the bug-like smell. Herb. Probably a single species.

a. C. satívum L. Asia, cult. and adv. in U. S. Coriander (Coliander). The fruit; Coriandrum. U. S. P.; Coriandri fructus, Br., Semen coriandri; Coriander seed, Coriander; Ger. Koriandersamen, Fr. Coriandre (Codex); Sp. Cilantro, Culantro. Aromatic, carminative, condiment. Source of oil of coriander.

574. CORIÁRIA, L. Tanner's Sumac. Coriariaceae. From Latin, "tanner's" shrub. Poisonous shrubs. About 10 species, warmer regions of Old and New World.

a. C. myrtifólia L. (C. tinctoria Dulac.). Southern Europe and northern Africa. Tanner's Sumac, Currier's Sumac, Ger. Gerberstrauch; Fr. Redoul, Sumac des corroyeurs. Fruit poisonous. Leares have been used to adulterate Senna.

b. C. sarmentósa Forst. New Zeland. Wine-berry shrub, Tutu (vernacular), Toot plant. Seeds poisonous, but wine is made from the juice of the fruit. Source of the New Zealand tootpoison.

575. CORISPÉRMUM, L. Bug-seed, Tick-seed. Chenopodiaceae. From Greek, "bug seed". Herbs. About 10 species, circumpolar; 1 in U. S., viz. (a) C. hyssopifólium L., Bug-weed, Tumbleweed.

576. CóRNUS, L. Cornel, Dogwood. The Latin name, "horny", from hardness of the wood. Shrubs or trees. About 2.5 species, north temperate zone, Mexico and P'eru; 20 in U. S.

a. C. alternifólia L. fils. Canada and northeastern U. S. Blue or Purple Dogwood, Green Osier, Umbrella treet.

b. C. Amónum Mill. (C. sericea L.). Ontario and eastern U. S. Silky Cornel, Blue-berried Cornel, Kinnikinic (Killikinic), Female or Swamp Dogwood, Red-brush, Red Osier, Red-rod, Red Willowt. Rose Willowt, Squaw-bush; Ger. Sumpfkornel; Fr. Cornouiller soyeux. Bark bitter, expectorant, nauseant. 
c. C. Canalénsis L. British America, south to New Jersey, Minnesota and California. Low or Dwa rf Cornel, Bunch-berry, Bunch Plum, Cracker-berry, Small Fowering-cornel. V'ery similar to this is the arctic (d) C. Suécica L., called Plantof-gluttony and Dwarf Honeysucklet.

e. C. círcináta L'Her. (C. rugosa Laur., possibly the older name). Canada and northeastern U. S. Round-leared Cornel or Dogwood, Green Osier. Bark bitter, astringent, febrifuge.

f. C. flórida L. Ontario and eastern U. S. Flowering Dogwood, Dogwood; American, Virginia or Florida Dogwood, Boxwood; New England, American or Falve Box-wood, American Cornelian tree; Flowering, Florida or White Cornel, Indian Arrow-wood, Nature's-mistake; Ger. Grossblüthige Kornel, Hornbaum; Fr. Cornouiller à grandes fleurs. Bark of root; Cornus, U. S. P., Dogwood bark; bitter, tonic, febrifuge. [The Flowering Dogwood of California and British Columbia is the larger tree $(\mathrm{g})$ C. occillentális ( $\mathrm{T}$. \& $\mathrm{G}_{\text {. }}$ ) C'oville (C. Nuttallii Audubon)].

h. C. Mas L. (C. mascula L.). Europe and northern Asia. Cornelian Cherry, Male Cornel, Cornelian tree, Redwood of Turkey; Ger. Kornelkirsche, Dürlitze, Herlitze; Fr. Cornouiller. Flowers astringent. Fruit edible but austere.

i. C. stolonifera Michx. British America, south to Kentucky, Arizona and California. Red Osier Cornel or Dogwood, Redbrush, Dogberry tree, Gutter tree, Kinnikinic, Killikinic, Waxberry Cornel. [Similar to this is (j) C. sanguínea L., the common Dogwood of Europe.]

577. CoRoníLLA, L. - Axseed. - Papilionaceae. Latin diminutive, a little crown. Syn. Emerus, Mill., Scorpius, Medic. Herbs. About 25 species, Europe, Asia and N. Africa.

a. C. scurpioídes (Medic.) Koch (S. scorpioides Medic.). Europe. Coronilla. Plant cardiac tonic, like Digitalis. [(b) C. Émerus L. (E. Caesalpinia Medic.), Europe, is Scorpion Senna; (c) C. vária L., Europe, adv. in U. S., is Axseed, Axwort, Hive-vine.

578. CorónOPUS, Gaertn. 1791. Wart Cress. Cruciferae. From Greek, "crow foot", alluding to dissected leaves. Syn. Senebiera, DC. 1799; Cochlearia, in part. Diffuse herbs. About 6 species, warm and temperate regions.

a. C. Corónopus (L.) Karst. (Coch. Coronopus L., S. Coronopus Poir. ), Europe, adv. in U. S. Wart Cress, Wartwort, Swine's Cress, Sow-grass, Buck's-horn, Herb Ivy*, Wild Scurvy-grass. Plant anti-scorbutic.

579. CóRYLUS, L. Hazel, Filbert. Betulaceae. Ancient Greek name, from "helmet"-like involucre. Shrubs or small trees. About 7 species, northern hemisphere; 2 (or 3 ) in U.S. 
a. C. Americána Walt., Canada and eastern U. S. and (b) C. rostráta Ait., British America south to Georgia and Oregon (a variety in California), are the American Hazelnut bushes, the latter the Beaked Hazel. (c) C. Avelláma L. (C. maxima Mill.), Europe and Asia, is the European Hazel (Hezzle, Haul, Halse) or Filbert (Filberd, Filbeard, Hhilbert), Beard tree, Halenut, Nuttal tree, Nut-bush, Nutre, Woodnut, (varieties known as Full-beards, Cob-nuts, Cosford and Downton Filberts, Barcelona Nuts); Ger. Hasel; Fr. Noisetier. Seeds of all species rield hazel-nut oil. Spiculce from involucre of (b) used like those of Mucuna.

580. CórYPHA, L. Talipot Palm. Sabalaceae. From Greek, "tall". Fan-leaved Palms. About 7 species, tropical Asia.

a. C. nubraculífera L. Ceylon and India. Talipot Palm (Taliput, Talipat), Basket Palm, Shreetalum, Smeetalum. Leaves used for umbrellas, as a substitute for paper, etc.

ss1. CoscínIUM, Colebr. Columbo-wood. Menispermaceae. Syn. Menispermum, in part. Shrubs. About 4 species, tropical Asia.

a. C. fenestrátum (Gaertn.) Colebr. (M. fenestratum Gaertn.). Ceylon. Columbo-wood, False Calumba. Wood, bark and root, bitter tonic.

582. Cósmos, Cav. (Cosmus, Cosmea). From Greek "Ormament", Compositae. species, Mexico and adjacent region; 3 in U. S.

583. CótINUS, Adans. Smoke-tree. Anacardiaceae. Greek name of the Oleaster. Syn. Rhus, in part. Shrubs or small trees. One species of Europe and Asia, one of America.

a. C. cotinoídes (Nutt.) Brit. (R. cotinoides Nutt. 1838, C. Americanus Nutt. 1849.). American Smoke-tree, Wild Smoke-tree, Chittam-wood, Yellow-wood. Also other synonyms from the following.

b. C. Cótinus (L.) Karst. (R. Cotinus L., C. coriaria Duham). Europe and Asia. Venice Sumac (Sumach), Venetian Sumac, Smoke-tree, Smoke-plant, False Fringe-tree, Purple Fringe, Wig-tree, Feather-tree, Aaron's-beard. W'od, called young Fustic and Zante-wood, yields a yellow dye.

584. CotoneísTER, Medic. Fire Thorn. Pomaceae. From Latin, "star quince". Syn. Crataegus, Mespilus, in part. Ornamental shrubs or small trees. About 20 species, Old World.

a. C. Pyracántha (L.) Spach. (Crataegus Pyracantha Medic. (Kew), M. Pyracantha L.). Evergreen Thorn, Fire Thorn, Pyracanth, Christ's Thorn*, Egyptian Thorn*.

585. Có'TULA, L. - Cotula. - Compositae. Diminutive of cota, classical name of a composite plant. Herbs. About 40 species, widely distributed; 2 in U. S. 

586. COTYLÉDON, L. Narelwort. Crassulaceae.
Ancient Greek name of a plant with "cup-like" leaves. Syn. Umbilicus. Herbs or shrubs. About 75 species, Old World and N. America; 15 in U. S.

a. C. Umbilícus L. (C. umbilicata Lam., U. pendulinus DC.). Europe. Navelwort, Pennywort, Penny-leaves, Penny-pies, Penny-plates, Wall Pennywort, Cups-and-sancers, Hipwort, Kidneywort, Milk-the-cows, Pancakes; Ger. Nabelkraut; Fr. Cotylet, Nombril de Vénus. Leares mucilaginous, vulnerary.

587. COURSÉTIA, DC. Coursetia. Papilionaceae. Trees or shrubs. About 10 species, warmer regions of America; 2 in U. S.

588. CovílLEA, Vail. Creosote bush. Zygophyllaceae. Syn. Larrea, Car. Evergreen heavy-scented shrubs. About 5 species, mostly of S. America; 1 in U. S.

a. C. divaricáta (Cav.) Vail (L. Mexicana Moric.). Southern Colorado to California and Mexicn. Creosote bush, Tar-weed. Plant alterative, antisyphilitic. One source of lac. See Croton aromaticus.

589. CoWÁNIA, Don. - Cowania. - Rosaceàe. Named for Mr. Cowan, explorer in Mexico and Peru. Shrubs. About 3 species, Mexico and southwestern U. S.

590. CRÁCCA, L. 1753. Goat's Rue, etc. Papilionaceae. Latin name of a Vetch. Syn. Tephrosia, Pers. 1807; Galega in part. Herbs, sometimes shrubby. About 120 species, warm and tropical regions; 14 in U. S.

a. C. Apolínea (Delile) Lyons (T. Apolinea Link. (Kew), G. Apolinea Delile). Southern Europe. Egyptian Indigo. Leaves an adulterant of senna, also a source of indigo.

b. C. piscatória (Sol.) Lyons (G. piscatoria Sol., G. littoralis Forst., T. purpurea Pers. (Kew), T. piscatoria Hilleb., T. leptostachya DC.). Fish-poison, Auhuhu, Hola (Hawaii). Tropical regions generally. Plant has narcotic properties; used medicinally in India and to stupefy fish in Islands of Pacitic.

c. C. toxicária (Pers) Lyons (T. toxicaria Pers.). Africa, nat. in West Indies. Fish-poison. Properties of (b).

d. C. Virginiána L. 1753 (Galega Virginiana L. 1763, Tephrosia Virginiana Pers.). Southern New England to Florida and west to Minnesota and northern Mexico. Cat-gut, Hoary Pea, Groat's Rue, Devil's-shoestrings, Wild Sweet Pea, Turkey Pea, Rabbit Pea; Ger., Fr. Téphrosie. Leaves and root, laxative, tonic, vermifuge.

591. CRASSÍNA, Scepin, 1758 Zinnia. Compositae. Named from Paul Crassus, Italian botanist, 16th century. Syn. Zinnia, L. 1759. Herbs, some species shrubby. About 12 species, $\mathbf{N}$. America; 5 in U. S. [The garden Zinnia is C. élegans (Jacq.) Lyons, of Mexico.] 
592. CRATAÉGUS, L.

Hawthorn.

Pomaceae. Greek name of a kind of thorn having "tough" wood. Syn. Mespilus, in part. 'Thorny shrubs or small trees. About 50 species, north temperate zone, Mexico and S. America; 23 in U. S.

a. C. Oxyacántha L. Europe and Asia, nat. in U. S. English Hawthorn (Haythorn, Hathorn), Haw-tree, Hedge-thorn, White or May Thorn, May-bush, May Quick-set, Wick, Wickens; var. praecox is the Glastonbury Thorn; Ger. Hagedorn; Fr. Aubépine. Fruit called haws, whence the name Hawthorn.

Of American species, the more noteworthy are (b) C. aestivális (Walt. ) 'T. and Gr., May Haw, Apple Haw of southern states (fruit used for jellies); (c) C. coccínea L., Scarlet Thorn or Hawthorn, White or Red Thorn*; (d) C. cordáta (Mill.) Ait. (M. cordata Mill., C. populifolia Walt.), Washington Thorn, American Hedge-thorn; (e) C. Crusgálli L., Cockspur Thorn, Newcastle Thorn, Pin Thorn; (f) C. tomentósa L., Pear Thorn, Black Thorn, Common or White Thorn, Pear Haw; (g) C. uniflóra Moench (C. parvifolia Ait.), Dwarf Thorn, suited for low hedges. Fruit of sereral species called red haws, occasionally thorn-plums or thorn-apples.

593. CRATAÉVA, L. 1759. Garlic Pear. Capparidaceae. Named for Crataevus, ancient Greek herbalist. Syn. Tapia, Adans, 1763. Shrubs or trees. About 18 species, tropical regions.

a. C. gynándra L. Jamaica. Garlic Pear. Bark of root epispastic.

594. CRÉPIS, L. - Hawk's-beard. - Cichoriaceae. From Greek, "sandal". Herbs resembling Hieracium. About 180 species, northern hemisphere; 23 in U. S.

595. CRESCÉNTIA, L. Calabash tree. Bignoniaceae. U. S.

Shrubs or trees. About 15 species, tropical America; 1 in

a. C. Cújete L. (C. acuminata H. B. K., C. angustifolia Willd. C. Cujute Auct.). Tropical America. Calabash tree. Fruit calabash-like.

596. CRÉSSA, L. - Cressa. - Convolrulaceae. From Greek, "Cretan". Low perennial herbs with small flowers. Two known species, widely diffused, both in U.S.

597. CRÍNUM, L. Lily*. Amaryllidaceae. Greek name of a Lily. Ornamental bulbous plants with lilylike blossoms. About 60 species, warmer regions Old and $\mathrm{New}$ World; 1 in U. S.

598. CRISTALÉLLA, Nutt. Cristatella. Capparidaceae. Latin dim. of cristata, "crested". Viscid herbs. Two species, both of south-central U. S. 
599. CRÍtHMCM. L. - Samphire. - Umbelliferae.

A succulent herb. One species, Uld World.

a. C. marítimum L. Coasts of Europe. Samphire (Sampere, Semper, originally Sampier from the French, Saint Pierre, i. e. St. Yeter; the Latin name was Petrus, meaning a rock plant, with no reference to the Apostle Peter), ('amphire, Crest-marine, Pasper, Peter's Cress, Rock-semper, Sea Fennel. Leares used for pickles, etc.

600. CROCÍnIUM, Honk. Crocidium. Compositae. From Greek, "woolly, alluding to axils of leaves. Small winter-annual with golden yellow flowers. One species, northern California and northward.

601. CRÓClS, L. - - Saffron. - - Iridaceae. The ancient Greek name. Ornamental herbs with tuberous roots. About 70 species, Mediterranean region to central Asia.

a. C. Satívus L. (C. officinalis Martyn). Western Asia, cult. in southern Europe. Saftron, Autumnal Crocus, Spanish Saffron. Saffron raised in Pennsylrania is locally known as American Saffron, a name elsewhere applied to Carthamus, q. r. Stigmas; Crocus, U. S. P., Br., Stigmata Croci, Saffion; Ger. Fr. Safran (Codex); Sp. Azafran; aromatic, diaphoretic, emmenagogue. (b.) C. serótinus Salisb. (C. odorus Bivona). of southern fiurope also yields Saffron.

602. CRoóyIA, Torr. Croomia. Roxburghiaceae. Herbs. Two species, one of Japan, one of Florida.

603. CROsSópterrx. Fenzl. Crossopteryx. Rubiaceae. From Greek, "tassel wing". Trees with bitter bark. One or two species, Africa.

a. C. febrifuga Benth. (C. Kotschyana Fenz.). Tropical Africa. Bark febrifuge, containing a bitter alkaloid.

604. CrossosóxA, Nutt. Crossosoma. Ranunculaceae. Sub-shrubs. Two known species, California.

605. ('ROTAlárIA, L. Rattle-box. Papilionaceae. From Greek, "rattle" (pod.) Herbs, sometimes shrubby. About 250 species, mostly tropical; 9 in U. S.

a. C. júncea L. Sonthern Asia, nat. in Australia, etc. Yields a strong tibre called Bengal, Bombay, Madras or Sumn hemp. A raluable fodder plant. Several ot her species yield useful fibres, notably (b) 1: Búrhia Hamilton of Afghanistan, and (c) C. retúsa L., East.Indies, nat. in Brazil.

d. C. sagittális L. Eastern U. S. to Mexico. Rattle-box, Wild Pea, Loco-weed*. See Astragalus $(c)$ and $(p)$, also Spiesia.

606. CRótOx, L. - Croton. - Euphorbiaceae. Greek name of Ricinus, both words meaning a "tick". Syn. Aleurites, Clutia, Tiglium, in part. Herbs or shrubs. About 600 species, warm and temperate regions; 25 in U. S. 
a. C. aromáticus L. (A. laccifera Willd. C. lacciferus L.). India. Lac tree. One of the trees yielding shellac, a resinous exudute caused by the puncture of an insect; Lac (Seed-lac, grain-lac, stick-lac, etc.); Lacca, Resina lacca; Ger. Lack, Gummilack; Fr. Laque, Gomme lacque; Sp. Gorna laca. See Butea, Covillea, Erythrina, Ficus and Schleichera.

b. C. Elutéria (L.) Bennett (Clutia Eluteria L.). Bahamas. Sweetwood tree. Bark; Cascarilla, U. S. P., Br., Cortex cascarillæ, Cort. eluteriae v. thuris; Ger. Kaskarillrinde, Kaskarille; Fr. Cascarille officinale (Codex), Ghacrille, Écorce Éleuthérienne; Sp. Cascarilla; stimulant tonic. [The bark of (c) C. Cas'arilla (L.) Bennett (Clutia Cascarilla L.) may be sometimes sold as Cascarilla bark.]

d. C. Malámbo Karst. Venezuela. Source of Malambo bark. Properties of (b).

e. C. monothógynus Michx. Southern U. S. and Mexico. Prairie Tea.

f. C. níreus Jacq. (C. Pseudo-China Schlecht.). Mexico. Source of Copalchi bark; bitter, nervine, antiperiodic.

g. C. parána Hamilton. [Perhaps not distinct from $(\mathrm{h})]$. Seeds, Tilly-seeds', purgative.

h. C. Tíglium L. (T. officinale Klotsch). East Indies. Crotonoil plant. Seeds Molucca grains, Croton seeds; Semen tiglii v. crotonıs, Grana tiglii; Ger. Granatill, Purgirkörner; Fr. Croton tiglium, Graine de Tilly ou des Moluques (Codex), Petits pignons d' Inde; Sp. Grana tiglio; purgative. Source of Cleum Tiglii, U. S. P., Oleum Crotonis, Br., P. G; Croton oil; Ger. Crotonöl, Granadillöl.

607. CRÚSEA, Cham. \& Sch. (not Rich.). Crusea. Rubiaceae. Named for Prof. IV. Cruse of Koenigsburg. Herbs. About 10 species, mostly of Mexico and Central America; 3 in U. S.

608. CRYPTÁNTHE, Lehm. 1832. Cryptanthe. Boraginaceae. From Greek, "hidden flower". Syn. Krynitzkia, F. \& M. 1841. Low annuals. About 50 species, America; 46 in U. S.

609. CRYPTOCÁRYA, R. Br. (Cryptocaria). Lauraceae. From Greek, "hidden nut". Trees. About 45 species, tropical regions.

a. C. moscháta Nees. \& Mart. Brazil. Brazilian Nutmeg tree. Fruit aromatic, resembling true nutmeg.

610. Cryptográmina, R. Br. Rock Brake. Polypodiaceae. From Greek, "hidden writing", alluding to the conctaled sporangia. Small ferns. Two species, one in boreal Europe and Asia, one in northern U.S.

\section{CUBÉBA, Raf. - Cubeb. - Piperaceae.} From vernacular, Persia or India. Syn. Piper (Kew), in part. About 20 species, tropical Asia and Africa. 
a. C. Cubéba (L. f.) Lyons (P. Cubeba L. f., C. officinalis Miq.). Java and adjacent Islands. Cubeb plant, Cubeb Pepper. Unripe fruit; Cubeba. U. S. P., Cubebae fructus, Br., Baccae cubebae, Piper caudatum; Cubeb, Cubebs, Tailed Pepper, Java Pepper; Ger. Kubeben, Schwindelkörner, Schwanzpfeffer; Fr. Cubèbe, Poivre à queue (Codex); Sp. Cubebas; stimulant, expectorant, diuretic, balsamic.

Other species yielding very similar fruits are (b) C. Lówong Miq. (Piper Lowong Bl.); (c) C. Wallíchii Miq. (Piper ribesoides Wallich) and (d) C. crássipes Miq. (Piper crassipes Korthals). The fruit of (e) C. canína Miq. (Piper caninum Bl. ) is smaller; that of (f) C. Clísii Miq. (Piper Clusii C. DC.) of western Africa resembles Cubeb in appearance but contains piperine instead of cubebin; called African Black Pepper, Cubeb Pepper, Ashantee or Guinea Pepper, Guinea or African Cubeb.

612. CUBÉLIUM, Raf. 1824. Green Violet. Violaceae. From Greek mythological character, Cybele. Syn. Solea, Spreng. 1813 [not Spreng. 1800]. Herb with inconspicuous flowers. A single species, Canada and northeastern U. S.

613. CÚCUMIS, L. Cucumber, Melon. Cucurbitaceae. Latin name of Cucumber, whence also the English word Cucumber. Syn. Melo, Bryonia, in part. Herbaceous vines. About 30 species, chiefly of tropical Asia and Africa.

a. C. Mélo L. (M. vulgaris Cogn., M. sativus Sagaret.). Central Asia, now universally cult. Melon, Musk-melon (i. e. Muscat Melon), Cantaloupe (Cantaleup), Nutmeg Melon, Abdalavi (Egypt), Conomon (Japan). Var. flexuosus L. is the Serpent Melon or Snake Cucumber; var. Dúdaim L. (C. odoratissimus Moench), Vegetable Pomegranate. Queen Anne's Pocket Melon, Smelly-million $\|$; var. Chito Morr. is Vegetable Orange, Lemon or Apple, Vine Peach. Fruit esculent. Seeds (cold seeds) emollient. See $614(d)$.

b. C. myriocárpus Naud. S. Africa. Cacur. Pulp of fruit emetic, cathartic, resembling colocynth.

c. C. satívus L. Central and southern Asia, now universally cult. Cucumber, Gherkin, Gerkin (the young fruit or a small-fruited variety); Ger. Gurke; Fr. Concombre (Codex); Sp. Cohombro. Juice of fruit, also seeds (cold seeds), emollient. See 614 (d).

d. C. trígonus Rottb. (B. callosa Roxb.). India. Fruit bitter, purgative. Seeds anthelmintic.

614. CUCÚRBITA, L. Pumplkin, etc. Cucurbitaceae. Ancient Latin name of Gourd, whence also the English word Gourd. Syn. Cucumis, in part. Herbaceous vines. About 10 species; 6 in U. S.

a. C. foetidíssima H. B. K. (C. perennis A. Gray, Cucumis perennis James). Nebraska to Texas, Mexico and California. Missouri Gourd, Calabazilla, Wild Pumpkin, Chili Cojote. 
b. C. máxima Duchesne. Tropical Asia, widely cult. Squash, (formerly Squanter-squash, from Indian Askutasquash), Vineapple\|l, Winter Squash, Turban Squash, Large Gourd or Pompion of England, V'egetable-marrow, Varieties are the Hubbard, Boston Marrow, etc. Fr. Courge potiron (Codex). Fruit esculent.

c. C. moscháta Duchesne. Tropical Asia, widely cult. Crookneck Squash; China, Cushaw or Canada Crook-neck, Winter Crook-neck Squash. Fruit esculent.

d. C. Pépo L. North America, widely cult. Pumpkin (of America), Pompion. The type is the common Field or Yellow Pumpkin. Among the varieties are the Scallop Squashes, the Summer Crook-neck or Warty Squashes and some of the ornamental Gourds. Fruit generally esculent, although of coarse fibre. Seeds; Pepc, U. S. P., Semen peponis, Semina cucurbitæ, Pumpkin seeds, Ger. Kürbissamen, Kürbiskörner, Graumontsamen; Fr. Semences de potirons; taenicide, emollient (One of the four "cold seeds", the others being those of melon, cucumber and gourd).

615. CUMÍNUM, $\mathrm{L}$.

Cumin.

Umbelliferae.

The ancient Greek name. Herb with aromatic fruit. One species.

a. C. Cymínum L. (C. odorum Salisb.). Northern Africa, cult. in southern Europe, etc. Cumin (Cummin), Sweet Cumin. Fruit, Fructus cumini (cymini), Semen cumini; Ger. Haferkümmel, Kramkümmel, Mutterkümmel, Pfefferkümmel, Römischer Kümmel; Fr. Cumin (Codex); Sp. Comino; carminative, resembling caraway.

616. CUNíl A, L. - Stone-mint, etc. - Labiatae. The Latin name of an Origanum. Sym. Hedyosmos, Satureia, in part. Herbs or low shrubs. About 15 species, all American; 1 in U. S.

a. C. origanoídes (L.) Britton (S. origanoides L. 1753, Cunila Mariana L. 1759 , H. origanoides Kze.). New York to Ohio and south to Florida. American Dittany, Stone Mint, Sweet Horse-mint, Mountain Dittany, Wild Basil, High Pennyroyal, Maryland Cunila. Herb diaphoretic.

617. CUPRÉSSUS, L, Cypress.

Pinaceae. The ancient Greek name, whence the English word Cypress. Evergreen trees. About 12 species, temperate regions, Europe, Asia and North America; 5 in U. S.

a. C. macrocárpa Hartweg. California. Monterey Cypress.

b. C. sempérvirens L. Persia and the Levant. Cypress tree, Oriental or European Cypress.

618. CÚRCAS, Adans. Purging-nut. Euphorbiaceae. Syn. Jatropha, in part. Herbs or shrubs, tropical America. 
a. C. púrgans Adans. (C. Adansonii Endl., Jatropha Curcas L.). West Indies and S. America. Purging-nut tree. Seeds; Curcas, Semen ricini majoris, Sem. curcadis, Sem. ficus infernalis, Nuces catharticae americanæ; Physic-nut, Barbados-nut, Purging-nut; Ger. Schwarze Brechnüsse, Grosse Purgirnüsse, Grosse Ricinussamen. Seeds and oil expressed therefrom powerfully cathartic. Leaves galactagogue. (b) C. multífidus (L.) Endl. (Jatropha multifida L.), South America, has similar properties.

619. CURCÚMA, L. - Turmeric. Marantaceae. From Arabic name of Saffron. Syn. Amomum, in part. Herbaceous plants from fleshy rhizomes. About 35 species, warmer regions of Old World to Oceanica.

a. C. angustifólia Roxb. East Indies. Rhizomes of this and some other species yield East Indian Arrow-root, Tikor. See Maranta.

b. C. aromática Salisb. (C. Zedoaria Roxb.). East Indies. Round Zedoary; Fr. Zédoarie ronde (Codex). Properties of (e).

c. C. lónga L. (A. Curcuma Jacq.; includes C. rotunda L.), India, cult. in many tropical countries. Turmeric plant. Indian Saffron, Huldee (India). Rhizome, Rhizoma (Radix) curcumae; Turmeric (i. e. terra meriti), Curcuma; Ger. Kurkuma, Gilbwurzel, Gelber Ingwer, Gelbsuchtwurzel; Fr. Curcuma long et rond (Codex); aromatic, condiment; yields a yellow dye. (d) C. viridiflóra. Roxb. also yields turmeric.

e. C. Zedoária Rosc. (A. Zedoaria Willd., C. Zerumbet Roxb., A. Zerumbet Koenig). East Indies. Zedoary. Rhizome; Zedoaria, Rhizoma (Radix) zedoariae; Ger. Zarnabac, Zittwerwurzel, Langer 'Zittwer, Giftheil; Fr. Zédoaire longue. Pungent, closely resembling ginger in properties and use.

620. CÚSCUTA, L. - Dodder. - Cuscutaceae. Latin from the Arabic name. Leafless white or yellow parasitic vines. About 100 species; 25 in U. S.

a. C. Epílinum Weihe. Europe, nat. in U. S. Flax Dodder (Dother), Flax-drop, Flax-vine. Names applied to the various species are Beggar-weed, Bind, Hale-, Hell- or Hairy- bind, Hell-weed, Hail-weed, Hair-weed, Devil's-guts, Fordboh, Lovevine, Podder, Scald-weed, Scold, Strangle-tare, Strangle-weed.

b. C. Epíthymum Murr. (C. Trifolii Bab.). Europe, adv. in U. S. Thyme Dodder, Clover Dodder, Lesser or Lucerne Dodder. (The Dodders generally are named from their hostplants, as Smartweed Dodder, Hazel Dodder, etc.

621. CUSPÁRIA, Humb. $1814 . \quad$ Angostura. Kutaceae. Syn. Bonplandia, Willd. 1802 not Cav. 1800, Angostura, R. \& S. 1819; Galipea, in part. Shrubs or small trees. About 30 species, tropical America. 
a. C. Augostúra (Rich.) Lyons (B. Angostura Rich, G. Cusparıa St. Hil., G. febrifuga Bail. G. officinalis Hancock, C. febrifuga Humb. (Kew), B. trifoliata Willd.). Northern S. America. Bark Cuspariae cortex, Br. Angustura, Cortex angusturae; Angostura or Angustura bark, Carony bark; Ger. Angusturarinde; Fr. Angusture vraie (Codex); bitter, tonic, stomachic.

622. (YYATHÉ, Sm. Tree-fern. Polypodiaceae. From Greek, "cup", alluding to the indusium. Syn. Folypodiumt, in part. Arborescent ferns. About 25 species, natives of tropical regions.

a. C. medulláris (Forst.) Swz. (P. medullare Forst.). New Zealand. Medullary substance of caudex edible.

623. CÝCAS, L. Fern Palm, Sago Palm*. Cycadacene. Greek name of a Palm. Palm-like plants. About 20 species, tropical Australia, Asia and Polynesia.

a. C. circinális L. Malabar. Malabar Sago Palm or Fern Palm, Madu-nut. Trunk yields sago, as in the true Sago Palms. (b) C. revolúta Thunb. of Japan and other species also yield Sago. Both species are cult. as house plants.

624. CYCLADÉYIA, Benth. Cycladenia. Apocynaceae. From Greek, "ring gland". Low perennial herbs. One or two species, California.:

625. CÝClaMEN, L. Cyclamen, Sow-bread. Primulaceae. The ancient Greek name. Stemless perennials from tuberous rhizomes. About 12 species, Mediterranean region to central Asia.

a. C. Europaéum L. Southern Europe. Sow-bread, Swine-bread, Ground-bread, Bleeding-nun; Ger. Erdscheibe, Erdbrod, Schweinbrod; Fr. Pain de porceau, Arthanite; Sp. Pan de puerco. Tuber drastic cathartic, emetic.

626. CYCLoLóma, Moq. Tumble weed. Chenopodiaceae. From Greek, "circle border", alluding to calyx. A pigweedlike herb (Winged Pigweed $\zeta$ ). One species, U. S.

627. CYCLÓPIA, Vent. Bush Tea. Papilionaceae. Named for the Crclops of mythology. Shrubs. About 10 species, South Africa.

a. C. galeoídes DC., (b) C. latifólia DC., (c) C. sessiliflóra Eckl. \& Zeyh., (d) C. subternáta Vog. (C. intermedia E. Meyen, C. Vogelii Harv.) and other species, yield the Bush tea of S. Africa, African Tea; Ger. Honigthee, Birsthee, Capthee, Buschthee, used as a beverage; expectorant, diaphoretic.

628. CYDÓNIA, Mill. 1752. Quince. Pomaceae. Latin name, from Cydonia, a town in Crete. Syn. Pyrus, Sorbus, in part. Shrubs or small trees. Europe and Asia.

a. C. Cydónia (L) Lyons (P. Cydonia L. (Kew), C. vulgaris Pers., C. Europaea Savi. S. Cydonia Cranz). Asia and Europe, widely cult. Quince tree. Probably the golden ap- 
ples of the Hesperides; Ger. Quittenbaum; Fr. Cognassier, Fruit; Fructus (Poma) cydoniae; Ger. Quitten; Fr. Coing ( Codex); Sp. Membrillo, Portuguese Marmelo, whence our word marmalade; esculent, astringent. Seeds; Cydonium, Semen cydoniae, Quince seed; Ger. Quittensamen, Quittenkörner; Fr. Semences (Pépins) de coing; mucilaginous, demulcent. [The ornamental Japanese Quince is (b) C. Japónica (Thunb.) Pers.]

629. CYMBALÁRIA, Medic. Kenilworth Ivy. Scrophulariaceae. From Greek, "cymbal". Syn. Antirrhinum, Linaria, in part. Creeping or spreading herbs. About 10 species, Old World.

a. C. Cymbalária (L.) Wettst. (H. Cymbalaria L., L. Cymbalaria Mill.). Europe, adv. in U. S. Kenilworth Ivy, Coliseum Ivy, Ivy-leaved Toad-flax, Wandering Jew, Ivy-weed, Aaron's-beard, Mother-of-thousands, Oxford-weed, Pedlar'sbasket, Pennywort, Climbing or Roving Sailor, Rabbits.

630. CYNÁNCHUM, L. 1753. Swallowwort*. Asclepiadaceae. From Greek, "dog-strangling". Syn. Vincetoxicum, Moench 1794 (not Walt. 1788), Asclepias, in part. Mostly perennial vines. About 100 species, Old and New Worlds; 3 in U. S.

a. C. acútum L. (C. Monspeliacum L.). Europe and Asia. French or Montpelier Scammony, from the milk sap of this plant, has been used in place of true scammony.

b. C. Vincetóxicum (L.) Pers. ( $\mathrm{V}^{\top}$. officinale Moench (Kew), A. Vincetoxicum I.). Europe. Swallowwort, White Swallowwort, German Contrayerva, Tame-poison; Ger. Schwalbenwurz, Giftwende, Giftwurz, Gottesgabwurz; Fr. Asclépiade, Domptevenin (Codex), Hirundinaire. Root, Rad. vincetoxici v. hirundinariae v. asclepiadis; emetic, cathartic, diuretic, sudorific.

631. CÍNARA, L. - Artichoke. - Compositae. The classical name. Thistle-like herbs. About 8 species, Mediterranean region.

a. C. Cardúnculus L. Southern Europe, and widely cult. Cardoon. Blanched leaf stalks esculent. Flowers used in France to coagulate milk.

b. C. Scólymus L. Southern Europe, northern Africa, and widely cult. Artichoke, Bur Artichoke. Fleshy scales of flower heads edible when freed from the bristles or "choke". The "chard" or blanched central leaf stalk is also eaten. Artichoke is reputed a blood purifier, diuretic and cholagogue.

632. CYNóC'TONUM, J. G. Gmel. $1791 . \quad$ Loganiaceae. From Greek, "dog slaying". Syn. Mitreola R. Br. 1810; Ophiorhiza, in part. Herbs. About 5 species; 1 in U. S.

633. CYNoGLóssuM, L. Hound's-tongue. Boraginaceae. From Greek, "dog's-tongue". Herbs with bur-like fruits. About 75 species; 5 in U. S. 
a. C. officinále L. Europe, widely nat. in U. S. Hound's-tongue, Gypsy-flower, Dog's-tongue, Dog-bur, Canadian Bur, Sheeplice, Tory-weed, Rose-noble; Ger. Hundszunge, Venusfinger; Fr. Cynoglosse (Codex), Langue de chien. Root and herb sedative, lenitive, expectorant.

b. C. Virgínicum L. Canada to Florida and Kansas. Wild Comfrey, Dog-bur.

634. CYNOSCIÁIIUM, DC. Cynosciadium. Umbelliferae. From Greek, "dog celery". Small annuals. Two species, both of southern U. S.

635. CYPÉRUS, L. Galingale, Cypress-grass. Cyperaceae. The ancient Greek name. Syn. Pycreus, Papyrus, in part. Sedges with umbellate or capitate inflorescence. About 650 species; 77 in U. S.

a. C. articulátus L. Tropical regions. Adrue, Guinea Rush. Rhizome anti-emetic, carminative.

b. C. esculéntus L. A widely distributed species, sometimes a troublesome weed. Nut-grass. Tubers, Earth-nut, Earth or Ground Almond, Rush-nut, Chufa; Fr. Souchet comestible, Amandes de terre; edible, rich in oil of agreeable flavor for salad oil; roasted, a substitute for coffee. The American (c) C. phymatódes Muhl. is referred by some to this species, but its tubers are very small.

d. C. lóngus L. (C. officinalis T. Nees.) Europe. English Galingale (Galangal), Sweet Cyperus. Rhizome, Cypress-root, tonic, stomachic. [(e) C. olorátus L. (Pycreus polystachys Beauv.) of India has similar properties in a more marked degree.]

f. C. Papýrus L. (Papyrus antiquorum Willd.). Northeastern Africa to Syria. Papyrus Sedge, Papyrus, Bullrush of Egypt. Anciently known as Biblus, whence our word Bible. Formerly used as we now use paper, that word being derived from Papyrus. [Similar but much smaller is the Umbrella plant (g) C. alternifólius L., a common house plant. ]

h. C. vaginátus $\mathrm{R}$. Br. (C. textilis F. Muell.). Australia and S. Africa. A valuable fibre plant, used for making ropes, mats, etc. In China (i) C. tegétum Roxb. and in Hawaii (j) C. laevigátus L., Ehuawa, is cultivated for the same uses.

636. CYPRIPÉDIUM, L. Ladies'-slipper. Orchidaceae. From Greek, "Venus' buskin". Perennial herbs with showy flowers. About 40 species, temperate and tropical regions; 11 in U. S.

a. C. acaúle Ait. Canada and northeastern U. S. Stemless Ladies'-slipper, Pink or Purple Ladies'-slipper, Camel's-foot, Whip-poor-will's-shoe. Other names applied indiscriminately to our native species, except (b), are Moccasin-flower, Indianmoccasin, American or Wild Valerian, Nerve-root, Noah's-ark, Indian-shoe, Squirrel-shoes, Venus'-shoe, Ducks, Old-goose, Two-lips. 
b. C. arietínum R. Br. Canada and northeastern U. S. Ram'shead Ladies'-slipper, Ram's-head.

c. C. cándidum Willd. New York to Minnesota and Missouri. Small White Ladies'-slipper.

d. C. hirsútum Mill. (C. pubescens Willd.). Nova Scotia south to Alabama and west to Nebraska and Missouri. Yellow Ladies'-slipper, Y'ellow Moccasin-flower, Yenus'-shoe, Y'enus'cup, Yellow Indian-shoe, American Valerian, Nerre-root, Male Nervine, Yellow Noak's-ark, Yellows, Monkey-flower, Umbil-root, Yellow Umbil (Umble or Umbel); Ger. Gelbfrauenshuhwurz; Fr. Cypripède jaune, Valériane americaine. Rhizome and rootlets (of this and the following species); Cypripedium. U. S. P., Rhizoma cypripedii, Ladies'-slipper; antispasmodic, nervine.

e. C. parviflórum Salisb. British America to Georgia, Missouri and Oregon. Small Yellow Ladies'-slipper. Synonyms and properties of $(d)$, the two species being closely similar.

f. C. regínae Walt. (C. spectabile Salisb., C. album Ait.). Nova Scotia to Georgia and Minnesota. Showy Ladies'slipper, Female Nervine, Pink Moccasin-flower.

637. CYRÍLLA, Gard. Leatherwood, etc. Cyrillaceae. Named for D. Cyrillo, Italian physician. Shrubs or small trees. Two species, southern U. S. and tropical America.

a. C. racemiflóra Walt. Southeastern U. S. Southern Leatherwood, Burn-wood, Ironwood, He-Huckleberry, White or Red Titi.

638. CYRTOPÓDIUM, R. Br. Cyrtopodium. Orchidaceıe. From Greek, "curved foot". Fleshy-stemmed orchids, very showy. About 28 species, tropical America; 2 in U. S.

639. CYRTORHÝYCHA, Nutt. Buttercup. Ranunculaceae. From Greek, "curved beak". Syn. Kanunculus, in part. Herb resembling Ranunculus. One species, central U. S.

640. CYSTÓPTERIS, Bernh. Brittle Fern. Polypodiaceae. From Greek, "bladder fern", referring to inflated indusium. Rock ferns. About 5 species; 3 in U. S.

a. C. frágiịs (L.) Bernh. (P. fragile L.). Cosmopolitan. Brittle Fern, Bottle Fern, White-oak Fern.

641. CÝTISUS, L. - Broom. - Papilionaceae. Ancient Greek name of a leguminous plant. Syn. Genista, Laburnum, Sarothamnus, Spartium, in part. Shrubs, often spiny. About 45 species, Old World.

a. C. Labńrnum L. (L. anagyroides Medic. (Kew), L. vulgare Presl. ). Southern Europe. Laburnum, Bean-trefoil, Goldenchain, Golden-shower, He-Broom, False Ebony, Ebony of the Alps; Ger. Goldregen, Bohnenbaum; Fr. Faux Ébénier, Cytise. Seeds sedative, soporific, narcoto-acrid, aperient. 
b. C. Seopáriıs (L.) Link. (Spar. Scoparium L., Sar. Scoparius Koch, G. Scoparia Lam.). Northern Asia, Europe. adv. in U. S. Broom; Green, Scotch or Irish Broom, Hag-weed, Bannal, Besom; Ger. Besenkraut, Besenginster, Pfriemenkraut; Fr. Genêt á balais. Tops; Scoparius. U. S. P., Scoparii cacunina, Br.; sedative, diuretic. In Germany the flowers also, Flores genistae, Fl. spartii scoparii, are used.

642. DALIBÁRDA, L. - Dewdrop. - Rosaceae. Named for T. F. Dalibard, French botanist, 18th Century. A downy tufted herb. One species, northeastern U. S. and Canada.

643. DAMАSÓNIUM, Juss. Damasonium. Alismaceae. Syn. Actinocarpus, in part. Aquatic herbs. About 4 species; 1 in U. S.

644. DÁPHNE, L. Spurge Laurel. Thymeliaceae. Ancient Greek name, from the Nymph Daphne. Evergreen shrubs. About 40 species, Europe and Asia.

a. D. Gnídium L. Southern Europe. Spurge Flax, Mezereon; Fr. Garou, Sainbois (Codex). See (c).

b. D. Iauréola L. Central Europe. Spurge Laurel, Dwarf Bay, Copse or Wood Laurel, Lady Laurel, Fox-poison, Mezereon, Sturdy Lowries. Șee (c).

c. D. Mezéreum L. Northern Asia and Europe, adv. in U. S. Mezereon, Mysterious plant+, Dwarf Bay, Daffadowndilly*, Magell, Paradise plant, Spurge Flax, Spurge Olive, Wild Pepper; Ger. Kellerhals, Seidelbast; Fr. Mézéréon, Bois gentil (Codex); Sp. Macereon, Torviso. Bark of all three species; Mezereon. U. S. P., Mezerei cortex, Br., Cort. thymelere v. coccognidii; acrid, irritant, alterative. Fruit, German Pepper, has been used to adulterate black pepper.

645. DAPHNÓPSIS, Mart. \& Zucc. Daphnopsis. Thymeliaceae. From Greek, "Daphne-like". Syn. Daphne, in part. Shrubs. About 15 species, tropical America.

a. D. Salicifólia Meissn. (Daphne salicifolia Kuntl.). Mexico. Leaves epispastic.

646. DASYLÍRION, Zucc.

Dasylirion.

Liliaceae. From Greek, "dense (flowered) lily". Plants with woody stem. About 19 species, Mexico and adjacent regions; 2 in U.S.

647. DASÝs'TOMA, Raf. False Foxglove. Scrophulariaceae. From Greek, "dense (bearded) mouth". Syn. Gerardia, Rhinanthus, in part. liather robust herbs with showy yellow flowers. Six species, all of eastern $\mathrm{N}$. America; 5 in U.. S..

a. 1). Pediculária (L.) Benth. (G. Pedicularia L.). Canada and eastern U. S. Fern-leaved False Foxglove, Bushy Gerardia, Lousewort, American Foxglove, Ferer-weed. 
b. D. Virgínicus (L.) Brit. (R. Virginicas L., G. quercifolia Pursh, D. quercifolia Benth.). Eastern U. S. Smooth or Oak-leared False Foxglove, Golden Oak.

648. DATÍSCA, L. - Datisca. - Datiscaceae. Syn. Tricerastes, Presl. Annual herbs. Two known species, one in Asia, one in California.

649. DATÚRA, L. Thorn-apple, etc. Solanaceae. From vernacular, Hindustan(?). Syn. Brugmansia, in part. Robust herbs with showy flowers, some tropical species shrubs. About 20 species; 6 in U. S. including those naturalized.

a. D. arbórea L. (B. arborea Steud.). Tropical America, cuIt. for ornament in California. Brugmansia, Floribunda, Floripondał.

b. D. Stramónium L. Asia, now a cosmopolitan weed. Stramonium, Thorn-apple, Jamestown-weed, Jimson-weed, Jamestown Lily, Devil's-apple, Devil's-trumpet, Mad-apple, Apple of Peru, Stink-weed, Stink, Fire-weed, Dewtry; Ger. Stechapfel, Dornapfel; Fr. Stramoine, Pomme épineuse (Codex); Sp. Estramonio, Toloache. Leaves; Stramorii folia, U. S. P., Br., Herba stramonii, Herba daturae. Seeds; Stramonii semen, U. S. P., Br., Semina stramonii v. daturae; sedative anodyne, deliriant.

c. D. Tátula L. [probably only a variety of (b)]. South America, nat. in U. S. Purple Thorn-apple, Purple Stramonium. Very similar to the last and having identical properties. Sereral other species are used as narcotics, notably (d) D. fastuósa L. (D. alba Nees) of India; (e) D. Métel L., Africa and southern Asia, and (f) D. sanguímea Ruiz et Pav. of Peru, from the seeds of which an intoxicating drink is prepared.

650. DAUbextóniA, DC. Daubentonia. Papilionaceae. Named for M. Daubenton, French botanist. Syn. Sesbania, in part. Small shrubs with quadrangular pods. About 4 species, sub-tropical America; 1 in U. S.

651. DAÚCUS, L. - Carrot. - Umbelliferae. The ancient Greek name. Annual or biennial herbs with dissected compound leaves. About 25 species; 1 in U. S.

a. D. Caróta L. Northern Asia and Europe, widely nat. and cult. Carrot. The wild plant is called Wild Carrot, Bee's-nest or Bird's-nest plant, Devil's-plague, Dawke, Fiddle, Hill-trot, Lace-flower, Nirrot, Rantipole; Ger. Möhre, Gelbe Rübe; Fr. Carotte (Codex); Sp. Zannahoria. Fruit of wild plant, Fructus carotae v. dauci, diuretic, emmenagogue. Root vulnerary, esculent.

652. DÉCOD0N, J. F. Gmel. (Decadon).

Lythraceae. From Greek, "ten toothed", of the calyx. Syn. Nessaea, Lythrum, in part. Aquatic herb. One species. 
a. D. verticillátus (L.) Ell. (L. verticillatum L., N. verticillata $H$. B. K.). Eastern U. S. and Canada. Swamp Loose-strife, Swamp Willow-herb, Wild Oleander, Peat-weed, Slink-weed.

653. DECUMÁRIA, L. Decumaria. Saxifragaceae. From Latin, "ten parted"'. Woody climber. One species, southeastern U. S.

654. DEINÁNDRA, Greene. Deinandra. Compositae. From Greek, "terrible man". Syn. Hemizonia, in part. Herbs. Six known species, southwestern U. S.

655. DELABÉCHEA, Lindl. Bottle tree. Stereuliaceae. Named for Sir ${ }^{\circ}$ H. T. De la Bêche, geologist, 19th Century. Syn. Sterculia, in part. An Australian tree with trunk bulged in barrel form. One species; (a) D. rupéstris Lindl. (S. rupestris Benth.), Australia.

656. DELPHÍNIUM, L. Larkspur. Ranunculaceae. Latin "dolphin-like", of the flower. Syn. Staphisagria, in part. Erect herbs with showy blue, red or white flowers. About 60 species, north temperate zone; 46 in U. S.

a. D. Ajácis L. Southern Europe and cult. in gardens. The common Larkspur of country gardens. Properties of (c).

b. I). Caroliniánum Walt. (D. azureum Michx.). Prairies of Central U. S. Azure, Blue, Carolina or Prairie Larkspur.

c. 1). Consólida L. Central Europe, cult. in gardens and adv. in U. S. Field Larkspur, Knight's-spur, Lark-heel, Lark's-claw, Staggerweed, King's Consound; 'ier. Rettersporn, Lerchenklaue, Hornkuim nel; Fr. Pied d'alouette Leaves, flowers and seeds; Herba, Flores, Semen consolidae (regalis), v. calcitrippae; acrid, irritant, emeto-cathartic, alterative. [The seeds were official as Delphinium, U. S. P., 1870.]

d. D. Staphiságria L. (S. macrocarpa Spach., D. officinale Wenderoth). Mediterranean basin. Lousewort. Seeds; Staphisagria, U. S. P., Staphisagriae semina, Br., Sem. staphidis agriae, Sem. pedicularis; Stavesacre seed; Ger. Stephanskörner, Stafadriansamen, Läusekörner, Läusepfeffer, Rattenpfeffer; Fr. Staphisaigre (Codex); Sp. Estafisagria, Albarraz; used as a parasiticide.

e. D. trolliifólium A. Gr. California. Cow-poison.

f. D. urceolátum Jacq. (D. exaltatum Ait. ). Pennsylvania to Alabama, west to Nebraska, also cult. in gardens. Tall Larkspur. This and our other numerous species have properties of $(\mathbf{c})$.

657. DÉNDRIUI, Desv. 1813. Sand Myrtle. Ericaceae. From Greek, "tree like". Syn. Leiophyllum Pers. 1805, not Erhr. 1780. Shrubs. Two known species, eastern U. S.

658. DENDrovécon, Benth.; Tree Poppy. Papareraceae. From Greek, "tree poppy". Shrubby plants. Two species, California. 
65.9. DENDRóPHYLAX, Reichb. Dendrophylax. Orchidaceae. From Greek, "tree guard". Leafless epiphytes. Two species, West Indies; 1 in U. S.

660. DENTÁRIA, L. Toothwort, Pepper-root. Cruciferae. From Latin, "toothed", of the rootstocks. Syn. Cardamine (Kew), in part. Perennial herbs from scaly or toothed rootstocks. About 16 species, all of $\mathrm{U}$. S.

a. D. diphýlla Michx. (C. diphylla Wood). Canada and northeastern U. S. Two-leaved Toothwort or Tooth-root, Pepperroot, Crinkle-root, Trickle. Root of this and other species, antiscorbutic, resembling horseradish.

b. D. laciniáta Muhl. Canada and eastern U. S. Cut-leaved Toothwort or Pepper-root, Crow-toe, Crow-foot*.

661. DERÍNGA, Adans. 1763. Honewort. Umbelliferae. Syn. Cryptotaenia, DC. 1829. Yerennial herb. One specios, eastern U. S.

662. DIA MóRPHA, Nutt. Diamorpha. Crassulaceae. From Greek, “doubly anomalous'. Low herb. One species, southeastern U. S.

663. DIANTHÉRA, L. Water-willow, Acantlıceae. From Greek, "doubly anthered". Herbs. About 100 species, mostly tropical America; 5 in U. S.

664. DIÁNTHUS, L. Pink, Carnation, etc. Caryoplyyllaceae. Greek, "the flower of Zeus." Syn. Tunica, in part. Herbs, mostly perennial. About 200 species, Old World, 1 in boreal America. Sereral species cult. in gardens, notably, (a) D. Caryopliyllus L., Carnation, Carnation or Clove Gilliflower, Clove Pink, Picotee, Grenadine, etc., (b) D. barbátus L., Sweet William, Bunch Pink, French Pink, Blooming-down, London-pride, London-tuft, Snowflake, Sweet-John, Tolmeiner; (c) D. prólifer L. [T. prolifera Scop. (Kew)], C'hilding or Proliferous Pink; (d) D. plumárius L., Common Pink of old gardens, Grass Yink.

665. DLAPÉDIUM, Konig. 1806. Diapedium. Acanthaceae. From Greek, "over plains" (?). Syn. Dicliptera (Kew), Juss.1807; Justicia, in part. Herbs. About 00 species, warmer regions; 4 in $\mathrm{U}$. $\mathrm{S}$.

666. DIAPÉNSIA, L. Diapensia. Diapensiaceae. Evergreen sub-shrubs. Two species, one of Himalayas, one circumpolar (northern U. S.).

667. DICHAETÓPHORA, Gray. Dichaetophora. Compositae. From Greek, "bearing two bristles". Syn. Boltonia, in part. A Daisy-like winter annual. One species, Texas.

668. DICHÓNIRA, Forst. Dichondra. Convolvulaceae. From Greek, "two kerneled". Syn. Sibthorpia, in part. Round-leaved prostrate or creeping herbs. About 5 species, warm regions, 2 in $\mathrm{U}$. S. 
669. DICKsóxIA, L'Her.

Dicksonia.

Polypodiaceae.

Named for James Dickson, English botanist, d. 1822. Syn. Balantium, in part. Large Ferns, tropical species often arborescent. About 50 species; 1 in U. S.

a. D. chrysótricha Moore (B. chrysotrichum Hassk.). Java. Capillary chaff from base of stipes is Paku-kidang or Pakoekidang, used in surgery as a styptic, see Alsophila, and Cibotium.

670. DICóRIA, T. \& Gr. Dicoria.

Compositae. From Greek, "two bugs", alluding to appearance of akenes. Herbs. Two known species, Arizona to California.

671. DICRAyocárPUs, Gray. Dicranocarpus. Compositae. From Greek, "pitchfork fruit". An inconspicuous annual herb. One species, Texas.

672. DICR AÚRUS, Hook. f. Dicraurus. Amaranthaceae. Herb. One species, Texas.

678. DICTÁMNUs, L. - Dittany. The classical name from Mt. Dicte Strong-scentere. with showy flowers. One species.

a. D. álbus L. (D. Fraxinella Pers.). Europe. White Fraxinella, European or Bastard Dittany, Dittander, Garden Ginger. Root; Rad. dictamni albae, Rad. fraxinellae; Ger. Weisse Diptamwurzel, Escherwurzel, Aeschenwurzel, Spechtwurzel; antispasmodic, diuretic.

674. DICYPÉLLIUM, Nees. Clove-bark tree. Lauraceae. From Greek, "two goblets". Syn. Persea, Licaria, in part. Aromatic tree. One species.

a. D. caryophyllátum Nees. (P. caryophyllata Mart.. L. Guianensis Aubl., apparently the oldest name.). Brazil. Clove Bark tree; Ger. Cravobaum, Nelkenzimmtbaum. Bark; Clovebark, Clove Cinnamon, Cassia caryophyllata, Cortex caryophyllati; resembles cinnamon. The wood, called rose-wood, yields oil of Licaria or of Lign-aloes, used in perfumery. See also Aquilaria.

675. DÍDIPLIS, Raf. Water Purslane.

Lythraceae. From Greek, "twice double". Aquatic or "amphibious" herb. One species, U. S. Closely related to the Old World genus Peplis.

676. DIERVíLLA,Moench. Bush Honey-suckle. Caprifoliaceae. Named for Dr. Dierville of Canada. Syn. Lonicera, in part. Shrubs, related to Weigela. Three species; all of U. S.

a. D. Diervílla (L.) MacM. (L. Diervilla L., D. trifida Moench., D. Canadensis Willd.). Canada and northeastern U. S. Bush Honey-suckle, Gravel-weed, Life-of-man. Root, leares and twigs, diuretic, astringent, alterative.

677. IDGITÁLIS, L. Foxglore. Scrophulariaceae. From Latin, (glove) "finger". Robust herbs with showy flowers in racemes. About 20 species, Europe and Asia. 
a. D. purpúrea L. (D. tomentosa Link \& Hoffm. ). Europe, cult. in gardens and adv. in U. S. Purple Foxglove, Foxglove, (originally Folk's-glove), Thimbles, Fairy-cap, Fairy-fingers, Fairy-thimbles, Fairy-bells, Dog's-finger, Finger-flower, Ladies'glove, Lady-fingers, Ladies'-thimble. Pop-dock, Flap-dock, Flop-dock, Lion's-mouth, Rabbit's-flower, Cottagers, 'Throatwort, Scotch Mercury; Ger. Fingerhut; Fr. Digitale (Codex), Digitale Pourprée, Grande Digitale; Sp. Dedalera. Leaves; Digitalis, U. S. P., Digitalis Folia, Br., Folia digitalis, P. G., Herba digitalis; cardiac sedative, diuretic.

678. DIÓCLEA, H. B. K. Dioclea. Papilionaceae. From Greek, "troublesome". Shrubs or climbers. About 25 species, mostly of tropical America, two in Asia; 1 in U. S.

679. DIONAÉA, Ellis. Venus' Flytrap. Sarraceniaceae. Dedicated to Dione of Greek mythology. Herb with sensitive foliage. One species, found only in southern U. S.

a. D. muscípula Ellis (D. sensitiva Salisb.). Pine barrens of $\mathrm{N}$. and S. C'arolina. Venus' Flytrap; Ger. Venus die Fliegenfängerin; Fr. Attrappe-mouche. An insectivorous plant.

680. DIOSCORÉA, L. - Yam. - Dioscoreaceae. Named for ancient Greek naturalist Dioscorides. Twining vines from thick rootstocks. About 160 species, mostly tropical; 1 in U. S.

Among the species cultivated for their esculent fleshy rootstocks are (a) D. aculeáta L., India to Oceanica, the Kaawi Yam; (b) D. aláta L., India and South Sea Islands, the Uvi Yam, White Negro Yam(weighing sometimes 100 pounds);(c) D. glábr’a Roxb. (D. Batatas, Decaisne), India and China, the Chinese Yam; (d) D. Japónica Thunb., Japan, where it is much cultivated; (e) D. sátiva L., widely distributed; Common Yam, inferior to the above.

f. D. villósa $\mathrm{L}$. Ontario to Florida and west to Texas and Minnesota. Wild Yam, Colic-root, Rheumatism-root, Devil's-bones. Rhizome diaphoretic, expectorant, uterine tonic. [The contorted root-stocks known as False Wild Yam, according to King's Dispensatory (1899) are from D. villosa var. glabra].

681. DIOSPÝk0S, L. Ebony, Date Plum. Ebenaceae. From Greek, "Zeus' wheat", so named by Pliny. Trees or shrubs. About 160 species, especially of Asia; 2 in U. S.

a. D. Ébenum Koenig. Ceylon. Ebony. This species yields the best ebony, but the wood of many other species, in India, Africa, Mauritius and Madagascar, is almost equally hard and black.

b. I. Káki L. f. China and Japan. Japanese Persimmon or Date Plum. The best native fruit of Japan.

c. D. Lótus L. Eastern Asia. Common Date Plum, Lotus tree. Fruit edible but small. 
d. D. obtusifólia Willd. Mexico. Zapote prieto, Zapote negro; Bark and leaves astringent, tonic.

e. D. Virginiána L. Rhode Island to Florida and west to Texas and Kansas. Common Persimmon (Parsimon), Seeded Plum, Winter Plum, Possum-wood, Lotus-tree, Jove's-fruit, North American Ebony; Ger. Amerikanische Dattelpflaume; Fr. Plaqueminier de Virginie. Fruit, Virginian Date-plum?, esculent. Unripe fruit a powerful astringent. In India (f) $\mathbf{D}$. Embryópteris Pers., called Giaub, is also used as an astringent.

682. DÍPHOLIS, DC. - Bully-tree*.

Sapotaceae. From Greek, "double scale". Syn. Bumelia, in part. Shrubs or trees. About 3 species, West Indies; 1 in S. Florida.

683. DIPHYLLÉIA, Michx. Umbrella-leaf. Berberidaceae. From Greek, "double leaf". Herbs resembling Podophyllum, with cymose flowers. Two species, one of Japan, one of southeastern U. S.

684. DÍPlaCUS, Nutt. Diplacus. Scrophulariaceae. Syn. Mimulus, in part. Glutinous evergreen sub-shrubs with solitary showy flowers, New World; 10 in U. S.

685. DIPLOTÁXIS, DC. Rocket, Crossweed. Cruciferae. From Greek, "double ranked", of the seeds. Syn. Sisymbrium, Brassica, in part. Herbs resembling Mustard. About 30 species, Old World; 2 adv. in U. S.

a. D. murális (L.) DC. (S. murale L.). Europe, adv. in U. S. Sand Rocket, Cross-weed, Flix-weed.

686. DÍPSACUS, L. . Teasel. . Dipsaceae. The Greek name, "thirst plant". Robust herbs with flowers in dense spiny heads. About 15 species, Old World; 2 nat. in U. S.

a. D. Fullónum L. Europe; adv. in U. S. Probably only a variety of (b). Fuller's Teasel, Fuller's Thistle, Fuller's-weed, Draper's Teasel, Clothier's-brush, with other synonyms of (b). Hearls used to raise a "nap" in cloth.

b. D. sylvéstris Mill. (D. Fullonum L. in part). Europe and northern Asia, nat. in U. S. Teasel; Wild, Common or Card Teasel, Card Thistle, Indian Thistle, Church-brooms, Gypsycombs, Hutton-weed, Prickly-bark, Prický-bark, Shepherd'sstaff;, Tassel, Venus'-bath, Venus'-cup, Wood-brooms. Ront diuretic, diaphoretic, stomachic.

687. DIPTEROCÁRPUS, Gaertn.

Dipterocarpaceae. From Greek, "two-winged fruit". Resinous trees with leathery leaves. About 45 species, south eastern Asia and East Indies.

a. D. alátus Roxb., (b) D. incánus Roxb. (D. costatus Gaertn.), (c) D. turbinátus Gaertn. (D. laevis Hamilton), and other species of India and the East Indies, yield the oleoresin called Gurjun balsam or Wood oil, Balsamum pterocarpi, Balsamum Gurjun (s. gurjunicum), resembling copaiba, especially useful in treating leprosy. 
688. DÍPTERYX, Schreb. 1791. Tonka Bean. Papilionaceae. From Greek, "two winged". Syn. Coumarouna Aubl. 1775, in part. Trees. About 10 species, tropical America.

a. D. odoráta Willd. (Coumarouna odorata Aublet). Guiana. Seeds; Semen tonco, Faba tonco; 'Tonka-bean, Tonga- $\ddagger$ or Tonquin- $\ddagger$ bean, Coumarouma-bean, Snuff-bean; Ger. Tonkabohnen; Fr. Tonka [Fêve] (Codex); Sp. Haba tonka; rich in coumarin, used for flavoring and in perfumery.

b. D. oppositifólia Willd. (Coumarouna oppositifolia Aublet). Cayenne. English Tonka Bean. Seeds smaller and less fragrant than thise of (a).

689. DÍRCA, L. . Leatherwood.

Thymeliaceae. Name from a fountain in Thebes. Shrubs with fibrous bark. Two species, both of U. S.

a. D. palústris L. Ontario to Florida and west to Minnesota. Leather-wood, Leather-bush, Mnnse-wood, Swamp-wood, Leaver-wood, Lever-wood, American Mezereon, Rope-bark, Wickup, Wicopy. Bark irritant, emetic.

690. DÍSPORUM, Salisb. 1812. Disporum. Convallariaceae. From Greek, "two ovuled". Syn. Prosartes, Don 1840; Streptopus, in part. Perennial herbs. About. 15 species, N. America and Asia; 8 in U.S., mostly western.

691. DÍSTASIS, DC. - Distasis. - Compositae. Syn. Chaetopappa, in part. Herb. One species, southwestern U. S.

692. DITÁXIS, Vahl.

Ditaxis.

Euphorb:aceae. From Greek, "two ranked", of the stamens. Syn. Aphora, Argyrothanmia, in part. Perennial herbs. About 20 species, temperate and tropical regions; 9 in U.S.

693. DonecátheoN, L. Shooting-star, etc. Primulaceae. From Greek, "twelve gods". An old Greek plant-name. Scapose perennial herbs. Abont 18 species, N. America and northeastern Asia; 15 in U. S., mostly western.

a. J). Meádia L. Pennsylvania to Georgia and west to Texas and Manitoba. Shooting-star, American Cowslip, Mosquito-bells, Pride of Ohio, . Indian-chief, Johnny-jump, Rooster-heads.

694. IODONAÉA, L.

Dodozaea.

Sapindaceae.

Trees or shrubs. About 45 species, tropical regions, especially of Australia; 1 in U. S.

695. DOELLINGÉrIA, Nees. White Aster. Compositae. Named for Th. Dollinger, botanical explorer. Syn. Diplopappus, Aster, in part. Perennial herbs resembling Aster. Four species, all of U. S.

696. JÓNDIA, Adans. 1763. Blite, Sea-Blite. Chenopodiaceae. Named for J. Dondi, Italian naturalist, 17th Century. Syu. Suaeda, Forsk. 1775; Salsola, C'henopodium, in part. Thickleared herbs or low shrubs. About 50 species, widely distributed; 11 in U. S. 
697. JORÉMA, D. Don. Ammoniac plant. Umbelliferae. From Greek, "gift". Syn. Peucedanum, in part. Herbs. About 5 species, west-central Asia.

a. D. Ammoníacum Don. (P. Ammoniacum H. Br.). Persia. Gum-resinous exudate of this and perhaps other species; Ammoniacum, U. S. P., Br.; Gummi-resina ammoniacum, Gurn Ammoniac; Ger. Ammoniak-gummi; Fr. Gomme ammoniaque (Codex); stimulant, expectorant, antispasmodic, rubefacient.

b. D. Aúcheri Bois. Western Persia. Zuh of the Kurds. Yields also gum ammoniac. [From (c) 1). robústum Loftus, a different gum is produced].

698. DORSTÉNIA, L. Contrayerva. Artocarpaceae. Named for T. Dorsten, German botanist, d. 1552. Herbs. About 40 species, tropical America.

a. D. Brasiliénsis Lam. Wrest Indies, Central America, south to Peru; (b) 1). Contrayérva L. Brazil. Root of both is known as Contrayerva (i. e. antidotal remedy); Ger. Bezoarwurzel, Giftwurzel; Fr. Contrayerve; stimulant tonic, antidote to snake poison; (c) D. Jrakéna L., (d) I). Cayápia Vell. (D. opifera Mart.) and (e) D. tubicína R. \& P., yield similar roots.

699. DORÝPHORA, Endl. Sassafras tree. Monimiaceae. From Greek, "spice bearing". Syn. Doratophora, Lem. An aromatic tree. One species, Australia. See Atherosperna.

a. D. Sássafras Endl. Anstralia. Sassafras tree. Leares and bark have anise-like odor, carminative.

700. DOUGLÍSIA, Lindl. Douglasia. Primulaceae. Named for Darid Douglas, botanical explorer. Herbs. About 5 species, one in Europe; 4 in northwestern U. S.

701. DOVYÁLIS, E. Meyer. Kei Apple.

Syn. Aberia, in part. Shrubs or trees. About 10 species, southeru and western Africa.

a. D. Cáffra (Harv. \& Sond.) Lyons (A beria Caffra Harv. \& Sond.). Southern Africa. Kei Apple, Kai Apple. Fruit acid, used for pickles and preserves.

702. IRÁBA, L. Whitlow-grass, Nailwort. Cruciferae. The Greek name of a Lepidium. Tufted herbs. About 150 species, north temperate and arctic regions and S. America; 42 in U. S. See Erophila.

703. IURACAÉNA, L. (Drakaina). Dragon tree. Liliaceae. Shrubby or arborescent plants. Syn. Draco, in part. About 50 species, warmer regions, Old World.

a. D. Dráeo L. (Draco dragonalis Crantz). Canary Islands. Dragon 'Tree. Exudate is a variety of I ragon's-blood. [(b) D. Ombet Kotschy, of Socotra, yields a similar product, brought to Arabia uuder the name of Katir.] 
704. DRACOCÉPHALUM, L. Dragon-head. Labiatae.

From Greek, "dragon-head". Perennial herbs. About 35 species, northern hemisphere; 1 in U. S.

705. DRAPÉRIA, Torr. Draperia. Hydrophyllaceae. Named for Prof. John William Draper of New York. Syn. Nama, in part. Low perennial herb. One species, California.

706. DRÍMYS, Forst. Winter's-bark. Magnoliaceae. Syn. Tasmannia, Wintera, in part. Trees. About 12 species, S. America and Australasia.

a. D. Wínteri Forst. (Wintera aromatica Murray). The species is now regarded as including D. Mexicana Sessé, D. Chilensis DC. and D. Granatensis L. f. South America. Winter's Bark, Magellan Canella, Winter's Cinnamon, Pepper-tree*. Burk; Cortex winteranus, Cort. magellanicus v. antiscorbuticus; Ger. Echte Winterrinde, Winterszimmt; F. Écorce de Winter (Codex), Canella de Magellan; Sp. Corteza Winterana; aromatic, stimulant. [One variety of Coto bark has been traced to D. Granatensis, which is the variety official as Winter's bark in the French Codex. The Australian (b) D. axilláris Forst. and (c) D. aromática (R. Br.) F. Muell. (T. aromatica R. Br., D. lanceolata Baill.) have spicy barks. The fruit of the latter is used like pepper.]

707. DRÓSERA, L. - Sundew. - Droseraceae. From Greek, "dewey". Insectivorous bog herbs. About 110 species, especially abundant in Australia; 7 in U. S.

a. D. rotundifólia L. Europe, Asia and N. America, south to Florida and California. Round leaved Sundew, Common Sundew, Dew-plant*, Eye-bright*, Lustwort, Moor-grass, Moorwort, Red-rot, Rosa-solis, Ros-solis, Youthwort; Ger. Sonnenthau, Edler Wiederthon, Sinnthan, Yungfernblüthe; Fr. Rosée du Soleil. Plant, Herba rorellae, H. droserae v. roris solis; expectorant, diuretic. [(b)I). longifólia L. (D. Anglica Huds. ), Europe and U. S., Long-leaved Sundew, has been also employed.]

708. DRÝAS, L. Mountain Avens. Rosaceae. From Latin, "wood-nymph". Low alpine or arctic subshrubs. Three species, circumpolar, (U. S.). [(a)D. octopétala L. is sometimes called Wood Betony.]

709. DRYMÁRIA, Willd. Drymaria. Caryophyllaceae. Herbs. About 35 species, mostly of warmer regions of New World; 6 in U. S.

710. DRYOBÁLAYOPS, Gaertn. - Dipterocarpaceae. From Greek, "tree", "acorn" and "appearance". A stately tree. One species, East Indies.

a. D. aromática Gaertn. (D. Camphora Coleb.). Sumatra and Borneo. Source of Sumatra or Borneo Camphor, also of the Borneo oil of Camphor. 
711. DRYOPÉTALOX, Gray. (Dryopetalum). Herb. One species, New Mexico.

Cruciferae.

712. DRYÓPTERIS, Adans. 1763. Shield Fern. Polypodiaceae. From Greek, "oak fern", alluding to forest habitat. Syn. Aspidium Swz. 1800; Polystichum, Nephrodium, Acrostichum $†$, Polypodiumt, in part. About 350 species; 27 in U. S.

a. D. acrostichoídes (Michx.) Kze. (N. acrostichoides Michx., Asp. acrostichoides Swz.). Canada and eastern U.S. Christmas Fern, Holly Fern.

b. D. Fílix-Mas (L.) Schott (Polypodium Filix-Mas, L., Asp. Filix-Mas, Swz., Polystichum Filix-Mas, Roth.). Almost cosmopolitan (northern U. S.). Male Fern, Male Shield-fern, Basket Fern, Bear's-paw root, Knotty Brake, Sweet Brake; Ger. Wurmfarn, Waldfarn, Johanniswurzel; Fr. Fougère male (Codex); Sp. Helecho macho. Rhizome of this and of (c); Aspidium, U. S. P., Filix-Mas, Br., Rhizoma filicis, Rad. filicis (maris); anthelmintic, taenicide.

c. D. marginális (L.) A. Gray (Polypodium marginale L., Asp. marginale Swz., N. marginale Michx.). British America, south to Alabama and Arkansas. Evergreen Wood-fern, Marginal-fruited Shield-fern?

d. D. spinulósa (Retz.) Kze. (Polypodium spinulosum Retz., Asp. spinulosum Swz.). Northern Europe, Asia and N. America. Common Wood-fern.

e. D. Thelýpteris (L.) A. Gray (Acros. Thelypteris L., Asp. Thelypteris Swz.). Europe, Asia and N. America (eastern U. S. ). Marsh Shield-fern, Fragrant Meadow-fern, Quill Fern, Female Fern*; Marsh, Meadow or Swamp Fern.

713. IRÝPETES, Vahl. Drypetes. Euphorbiaceae. Syn. Xylosma, in part. Trees or shrubs. About 8 species, warmer regions of New World; 3 in U. S.

2. D. crócea Poit. ( $\mathrm{X}$. nitidum Gray). West Indies to Florida and S. America. Guiana Plum, White-woodr.

714. DUBOÍSIA, R. Br. Pituri, etc. Solanaceae. Named for F. N. A. Dubois, French botanist, d. 1824 . Shrubs. About 3 species, Australia and adjacent islands.

a. 1. Hopwoódii F. Muell. Australia. Pituri (Pitury, Pitchuri, Pedgery, Bedgery). Leaves contain an alkaloid, piturine, different in action from duboisine.

b. D. myoporoídes R. Br. Eastern Australia and New Caledonia. Corkwood Elm, Orungurabie, Ngmoo, Duboisia. Leaves contain a mydriatic alkaloid, duboisine (hyoscyamine.)

715. IUCHÉSNEA, J. E. Sm. Mock Strawberry. Rosaceae. Named for A. N. Duchesne, French botanist. Syn. Fragaria, in part. Perennial herbs resembling Fragaria but with insipid fruit. Two species, southern Asia; 1 nat. in U. S., (a) $\mathbf{D}$. Índica (Andr.) Focke, called also Indian or Yellow Strawberry. 
716. DULÁCIA, Vell. 1825. Muira-puama. Olacaceae. Syn. Liriosma, Poepp \& Endl. 1842. Shrubs and small trees. About 12 species, S. America.

a. 1). ováta (Miers) Lyons (Liriosma ovata Miers.). Brazil. Muira-puama. A tree with fragrant wood. Root aphrodisiac.

717. DUPíTYA, Vell. 1825. Pipewort. Eriocaulaceae. Named for M. Dupaty. Syn. Paepalanthus, Mart. 1830. Herbs. About 215 species, mostly of tropical America; 1 in U. S.

718. DURÁNTA, L. - Duranta. - Verbenaceae. Named for Castor Durantes, botanical writer of 16 th Century. Herbs, often thorny. About 8 species, mostly of America; 1 in U. S.

719. DÚRI0, Adans. - Durian. - Sterculiaceae. From the vernacular name. Trees. About 7 species, fiast Indies.

a. D. zibethínus Murr. (D. stercoraceus Noronha). East Indies. Durian. Fruit esculent, delicious in flavor but of intolerable odor.

720. DYś́nIA, Car. (Dyssodia). Fetid Marigold. Composi iae. From Greek, "ill smelling". Syn. Tagetes, Boebera, in part. Strong-smelling herbs with small flower-heads. About 15 species, mostly of Mexico; 3 in U. S.

a. D. pappósa (Vent.) A. S. Hitchcock (T. papposa Vent., B. chrysanthemoides Willd.). Ohio to Nebraska, south to Mexico. Prairie-dog weed, Fetid Marigold, False Dog-fennel.

721. Eastwó́dia, Brandegee. Eastwoodia. Compositae. Herbs. One species in U. S.

722. EATONÉLLA, Gray. Eatonella. Compositae. Named for Prof. D. C. Eaton, American botanist. Floccose woolly annual. One species, California.

723. ECaSTAPHÝLLUM, P.Br. Ecastaphrllum Papilionaceae. U. S.

Shrubs. About 7 species, Africa and tropical America; 1 in

724. ECBÁLLIUM, A. Rich. (Ecbalium). Cucurbitaceae. From Greek, "squirting". Syn. Momordica, in part. Herbaceous vine. One species.

a. E. Elatérium (L.) A. Rich. (M. Elaterium L., E. officinale Nees, E. agreste Reich., E. cordifolium Moench). Southern Europe. Squirting Cucumber, Wild Balsam-apple, Wild Cucumber; Ger. Eselsgurke, Springgurke, Eselskürbiss, Spritzgurke; Fr. Concombre sauvage (Uodex) Concombre purgatif d' âne; Sp. Cohambrilla amargo. Fruit; Ecballii fructus, Br., Cucumis asininus, v. agrestis; Purgative, source of Elaterinum, U. S. P., Br., Elaterin, a crystallizable neutral principle. 
725. ECHINOCÁCTUS, Link \& Otto. Echinocactus. Cactaceae. From Greek, "hedgehog Cactus". About 200 species, warm dry regions of New World; 25 in U. S.

726. ECHIxocÉREUS, Engelm. Echinocereus. Cactaceae. From Greek, "hedgehog Cereus". About 45 species, warm and dry regions of $\mathrm{New}$ World; 29 in U. S.

727. ECHINónoRUS, Rich. Bur-head. Alismaceae. Syn. Sagittaria, Alisma, in part. Aquatic or marsh herbs. About 15 species, mostly American; 3 in U. S.

728. ECHINóPANAX, Dec. \& Pl. Devil's-club. Araliaceae. From Greek, "hedgehog Panax". Syn. Fatsia, in part. A prickly shrub. One species, northwestern U. S.

729. ECHIX́PEPOx, Naud. Echinopepon. Cucurbitaceae. From Greek, "hedgehog Melon". Syn. Echinocystis, in part. Herbaceous vines, warmer regions N. America; 2 in U. S.

730. ECHITES, P. Br. Sarannah-flower, etc. Apocynaceae. Syn. Prestonia, in part. Shrubby climbers, many ornamental. About 10) species, tropical America; 4 in U. S.

a. E. acumináta R. \& Pav. S. America. Cundurango de plátano. Bark alterative.

b. E. hirsíta R. \& Par. [Prestonia hirsuta Muell (Kew)]. South America. Cundurango de paloma. Bark alterative.

731. ÉCHIUM, L. Viper's Bugloss, etc. Boraginaceae. From Greek, "viper". Hairy herbs with rather showy blue flowers. About 30 species, Old World.

a. E. vulgáre L. Europe and Asia, nat. in U. S. Viper's Buglose, Blue-weed, Blue Thistle, Blue-derils, Blue-stem, Blue Cat'stail, Viper's-grass, Viper's-herb, Snake-flower, Adderswort; Ger. Natterkopf; Fr. Vipérine. Plant diuretic, expectorant.

732. ECLÍPTA, L. - Eclipta. - Compositae. From Greek, "wanting" (a pappus). Syn. Verbesina, in part. Inconspicuous herbs with small heads of whitish flowers. About 5 species, tropical; 1 nat. in U. S.

733. EDWíxIA, Heller. Edwinia. Saxifragaceae. Syn. Jamesia, T. \& Gr. Low shrub. One species in southcentral U. S.

734. EHRÉTIA, L. - Ehretia. - Boraginaceae. Named for $\mathrm{G}$. D. Ehret, botanical painter, 18th Century. Trees or shrubs. About 50 species, mostly tropical; 1 in $U$. S.

735. ELAEÍGYUS, L. Silver-berry. Elaeagnaceae. From Greek, "sacred olive". Shrubs or trees. About 20 species, Europe, Asia, Australia and $\mathrm{N}$. America; 1 in U. S.

a. E. argéntea Fursh. British America, south to Minnesota and Utah. Silver-berry. Fruit edible. (b) E. horténsis Bibers., Southern Europe to China, Trebizonde Date, and (c) E. umbellátus Thunb., Japan, yield also edible fruit. 
736. ELAÉIS, Jacq. - Oil Palm. - Sabalaceae. Greek name of Olive tree. Low palms. About 6 species, mostly of S. America, one African.

a. E. Guineénsis Jacq. Western Africa, cult. in Brazil. Oil Palm, African Oil-palm. Fruit, source of palm oil, largely used for making soap.

737. ELAPHÓMYCES, Fries. Hart's Truffle. Tuberaceae. From Greek, "hart fungus". Syn. Lycoperdont, Scleroderma, in part. Underground fungi, resembling puff-balls.

a. E. cervínum (L.) Lyous (L. cervinum L., S. cervinum Pers., E. granulatus Fries). Europe. Hart's Truffle, Hart's-balls, Deer-balls, Rut-of-harts, Lycoperdon nuts, Puff-ball†; Ger. Hirschbrunst, Hirschtruftle; Fr. Truffe de cerf. Fungus, Fungus (Boletus) cervinus, formerly reputed aphrodisiac.

738. ELÁPHRIUM, Jacq. Mexican Elemi. Burseraceae. Syn. Bursera (Kew), in part. Trees or shrubs, tropical America.

a. E. elemíferum Royle(B. elemifera J. Hook. ). Mexico. Resinous exudate, Mexican Copal, Mexican Elemi. See Canarium.

739. ELATíNE, L. Waterwort, Mud Purslane. Elatinaceae. Greek plant name, meaning "fir like". Small berbs with minute flowers. About 9 species, temperate and warm regions; 4 in U. S.

740. ELATINoÍDES, Wettst.1891.Toad-flax.Scrophulariaceae. From Greek, "resembling Elatine". Syn. Elatine, Moench 1794, not L. 1753; Antirrhinum, Linaria, in part. Annual herbs. About 25 species, Old World.

a. E. Elatíne (L.) Wettst. (A. Elatine L., L. Elatine Mill.). Asia and Europe, nat. in U. S. Sharp-pointed Fluellin or Toad-flax, Canker-root. Cancerwort.

b. E. spúria (L.) Wettst. (A. spurium L., L. spuria Mill.). Round-leaved Toad-flax, Cancerwort, Female Fluellin.

741. ELEPHÁNTOPUS, L. Elephant's-foot. Compositae. From Greek, "elephant's-foot" or "ivory foot". Perennial herbs. About 15 species; 3 in U. S.

a. E. tomentósus L. Southeastern U. S. Tobacco-weed, Devil'sgrandmother.

742. ELETTÁRIA, Maton 1811. Cardamom. Zingiberaceae. Syn. Cardamomum Salisb. 1812 (Noronha, 1790); Amomum, Alpinia, Matonia, Reanalmia, in part. Herbs from a thick rhizome. About 10 species, Eist Indies, especially Java.

a. E. répens (Sonn.)Baill. (Am. repens Sonnerat, E. Cardamomum, Maton, (Kew), Alp. Cardamomum Roxb. Am. Cardamomum White, not Am. Cardamon L., M. Cardamomum Smith, R. Cardamomum Roscoe). Hindustan. Fruit; Cardamomum. U. S. P., Cardamomi semina Br., Fructus (semen ) cardamomi 
(minoris), Cardamom seed, Cardamom-fruits, commercially divided into "shorts", "short-longs", "mediums" and "longs", also distinguished as Malabar, Aleppy and Madras cardamoms; Ger. Kardamom, Kleiner Kardamom; Fr. Cardamome du Nalabar, [petit et moyen] (Codex); Sp. Cardamomo menor; aromatic, carminative. [(b) E. májor Smith, Ceylon, perhaps only a variety of (a), yields the Ceylon or long cardamoms; Fr. Cardamome de Ceylan, Grand Cardamome (Codex)]. See Amomum.

743. ELLIÓTTí, Muhl. Ëlliottia. Ericaceae. Named for Stephen Elliott, American botanist. Shrubs. Three known species, eastern Asia and N. America; 1 in southeastern U. S.

744. EMBÉLIA, Burm. $1768 . \quad$ Embelia. Myrsinaceae. Syn. Ribesioides, L. 1744, Samara, L. 1771, not Sw. 1788. Shrubs. About 20 species, tropical Asia and Africa.

a. E. Ríbes Burm. (S. Ribes, Benth \& Hook.). India. Embelia. Fruit highly aromatic, alteratire, anthelmintic, adulterant of black pepper.

745. EMIENíNTHE, Benth. Emmenanthe. Hydrophyllaceae. From Greek, "abiding flower". Annual herbs with yellow or

746. EMÓRYA, Torr. Emorya. Loganiaceae. Named for Gen. W. H. Emory (Mexican Boundary Survey). Shrubs with fragrant flowers. One species, Texas.

747. ÉMPETRUM, L. Crow-berry. Empetraceae. From Greek, "rock plant". Sub-shrubs. Two species, one in high n,orthern latitudes, the other of S. America; 1 in U. S.

a. E. nígrum L. Northern Europe, Asia and N. America, south to New England, Michigan and California. Black Crow-berry, Heath-berry, Heath, Black-berried Heath, Monox Heather, Crake-berry, Curlew-berry, Crow-pea, Wire Ling. Berries edible, used for dyeing.

748. EXCÉLIA, Adans. - Encelia. - Compositae. Named for Christopher Encel. Herbs or undershrubs with rather sliowy yellow flowers. About 25 species, Mexico and adjacent regions; 11 in U. S.

749. ENCEPHALÁRTOS, Lehm. Kafir-bread. Cycadaceae. From Greek, "bread pith". Palm-like plants with short cylindrical or spherical trunks. About 20 species, South Africa.

a. E. Cáffer Miq. (E. Cycadis Sweet). South Africa. Hottentot Breadfruit, Kafir Bread. Farinaceous pith esculent.

750. ENGELMíxNIA, T. \& Gr. Engelmannia. Compositae. Named for Dr. Geo. Engelmann, botanist, St. Louis. Perennial herb. One species, southern U. S. and Mexico. 
751. ÉNTADA, Adans. $1763 . \quad$ Sea Bean. Minosaceae. Syn. Gigalobium P. Br. 1756; Mimosa, in part. Shrubby climbers. About 12 species, mostly of Africa and tropical Americs,

a. E. scándens (L.) Benth. (M. scandens L.). East and West Indies. Sea Bean, Gogo (Philippines), Gandoo (Java), Faba marina. Plant acrid, containing saponin.

752. ÉPHEDRA, L. ^ Joint Fir. * Gnetaceae. From Greek, "upon a seat". Shrubs, almost leafless. About 25 species, temperate regions; 7 in U. $\mathrm{S}$.

a. E. antisyphilítica C. A. Meyer. Joint Fir, Mountain Rush, Shrubby Horsetail. The branches of this and other species of the western U. S. known as Teamster's Tea. Astringent, antisyphilitic. [From a Japanese species, perhaps (b) E. monospérma S. G. Gmel. (E. monostachya Turcz.), is procured a mydriatic alkaloid ephedrine.] .

753. EPIDÉNDRUM, L. Tree-orchis.

Orchidaceae.

From Greek, "upon a tree", i. e. epiphytic. Epiphytes with a tuberous or creeping rhizome. More than 300 species, chiefly of S. America; 8 in U. S.

754. EPIGAÉA, L.

Trailing Arbutus.

Ericaceae.

From Greek, "trailing". Evergreen prostrate shrubs. Two species, one in Japan, one in U. S.

a. E. répens L. Florida to Michigan and northward. Trailing Arbutus, Gravel-plant, May-flower, Shad-flower, Ground Laurel, Mountain Pink, Winter Pink, Crocus ( $N$. Carolina). Leaves astringent, diuretic, like those of Uva Ursi.

75.. EPILÓBIUM, L. Willow-herb.

Onagraceae. From Greek, "upon a pod"' Herbs, sometimes shrubby. About 65 species, especially of temperate zones; 40 in U. S.

a. E. hirsútum L. Europe, adv. in U. S. Great or Hairy Willowherb, Codlins-and-cream (so called from its acidulous odor), Fiddle-grass, Apple-pie, Cherry-pie, Grooseberry-pie.

b. E. palístre L. Europe, Asia and N. America. Marsh or Swamp Willow-herb, Wickup. See Chamaenerion.

756. EPIPÁCTIS. Adans. Heleborine. Orehidaceae. The ancient Greek name. Syn. Serapias, in part. Herbs with leafy stem and racemose flowers. About 10 species; 2 in U. S.

a. E. viridiflóra (Hoffm.) Reichb. (S. viridiflora Hoffm. E. Helleborine Gray, not L. ). Europe, and in eastern U. S. (rare). Helleborine, Bastard Hellebore, naines given also to the European (b) E. lateriflóra L., which this resembles.

757. EPIPRÉMINUM, Schott.

(Tonga).

Araceae. Syn. Rhaphidophora, in part. Shrubby climbers with aerial roots. About 8 species, East Indies to Polynesia. 
a. E. mirábile Schott. (R. Vitiensis Schott.). Fiji Islanda. Said to be one of the constituents of the Fiji drug called Tonga.

758. EQUISÉTUM, L.

Horsetail, etc.

Equisetaceae. Ancient Latin name, "horse bristle", or "equal bristled". Plants of a primitive type. About 25 species; 14 in U. S.

a. E. arvénse L. Northern Europe, Asia and X. America, south to Virginia and California. Field Horsetail, Bottle-brush, Cat's-tail, Horse-pipe; Ger. Kleiner Schachtelhalm, Zinnkraut, Schenerkraut, Dubock, Pferdschwanz. Plant, H. equiseti (minoris), diuretic.

b. E. hyemále L. Europe, Asia and N. America, including U. S. Common Scouring-rush. The following names apply to this and other rough species; Dutch Rush, Gun-bright, Horse-pipe, Pewterwort, Polishing Rush, Rough Horsetail, Shave-grass; Ger. Tischlerschachtelhalm, Polir-schachtelhalm. Stems, H. equeseti majoris, diuretic.

c. E. palústre L. Europe and northern N. America, south to New York and Arizona. Marsh Horsetail, Cat-whiistles, Marsh Reed, Paddock-pipes, Snake-pipes Toad-pipes, Tad-pipes, the latter names also applied to other species.

759. ERÁNTHIS, Salisb. Winter Aconite. Raunnculaceae. From Greek, "flower of spring". Syn. Cammarum, Helleborus, in part. Herbs from tuberous rootstocks. About 5 species, Europe and Asia.

a. E. hyemális (L.) Salisb. (H. hyemalis L., C. hyemale (L.) Greene, Heller's catalogue). Europe, cult. and adv. in U. S. Winter Aconite, Winter Hellebore, Christmas-flower, Wolf'sbane.

760. ERECHTÍTES, Raf. Fire-weed. Compositae. Ancient Greek name of groundsel, "rending". Syn. Senecio, in part. Herbs. About 12 species, America and Australasia; 1 in U.S.

a. E. hieracifólia (L.) Raf. (S. hieracifolius L.). British America to Nebraska, Louisiana and Mexico, also S. America. Fire-weed, Pilewort. Herb, emollient, astringent.

761. EREMIÁSTRUM, Gray. Eremiastrum. Compositae. From Greek, "desert Aster". Small winter annuals. Two species, Arizona to California.

762. EREMínULA, Greene. Ereminula. Compositae. Syn. Dimeresia, Gray. Herb. One species in Oregon.

763. EREMOCÁRPUS, Benth. Eremocarpus. Euphorbiaceae. From Greek, "solitary fruited". Rank-smelling herb. One species, California.

a. E. setígerus Benth. California. Ginger-leaf. Plant, carminative, febrifuge. 
764. EREMOCÁRYA, Greene. Eremocarya. Boraginaceae. From Greek, "desert nut". Syn. Krynitzkia, in part. Herbs. Two species in western U. S.

765. ÉRICA, L. - Heath, Heather. - Ericaceae. The ancient Greek name. Small shrubs. About 400 species, Old World, especially S. Africa.

a. E. arbórea L. Mediterranean region. Tree Heath. Wood used for brier-root pipes.

b. E. cinérea L. Europe, adv. in U. S. Scotch Heath or Heather, Bell Ling, Carline Heather, Cat-Heather, Crow Ling, Black Heath, She-Heather.

c. E. Tétralix L. Europe. Small Heath,Father-of-heath; Bell, Besom or Broom Heath, Honey-bottle, Carlin or Ringe Heather.

766. ERICAMÉRIA, Gray. Ericameria. Compositae. Syn. Aplopappus, in part. Evergreen undershrubs with heath-like foliage and yellow flowers. About 10 species, southwestern U.S.

763. ERIGENÍA, Nutt. Harbinger-of-spring. Umbelliferae. From Greek, "spring born". Syn. Sison, in part. Perennial herb. One species, U. S.

a. E. bulbósa (Michx.) Nutt.(S. bulbosum Michx.). Canada and northeastern U. S. Harbinger-of-spring, Pepper-and-salt, Turkey-pea*.

768. ERÍGER0N, L. - Erigeron. - Compositae. From Greek, "early old". Syn. Astert, Doronicumt, in part. Herbs. About 130 species, most abundant in New World; more than 100 in U. S.

a. E. ánnuus (L.) Pers. (A. annuus L.). Canada to Virginia and Missouri. Sweet Scabious (U. S. ), Daisy-Fleabane, Lace-button.

b. E. Philadélphicus L. Throughout North America. Philadelphia Fleabane, Sweet Scabious*, Skevish, Daisy-Fleabane, Daisy*.

c. E. pulchéllus Michx. (E. bellidifolius Muhl.). Ontario to Florida and west to Minnesota. Robin's Plantain, Poor Robin's Plantain, Robert's Plantain, Rose-Betty, Blue SpringDaisy.

d. E. púmilus Nutt. Utah to Nebraska and northward. Low Erigeron, Daisy (of western plains).

e. E. ramósus (Walt.) B. S. P. (D. ramosum Walt., E. strigosus Muhl.). Canada to Florida and Texas. Common Daisy-Fleabane.

769. ERIOBÓTRYA, Lind.

Loquat.

Pomaceae. Syn. Photinia, MIespilus, in part. Shrubs or trees. About. 10 species, southern and eastern Asia. 
a. E. Japonica (Thunb.) Lind. (M. Japonica Thunb., P. Eriobotrya J. Hook.). China and Japan. Loquat (China), Lukwati, Dukwat, Loquat Plum, Japan Plum (southern U. S.), Japanese Medlar, Biwa (Bywa, Pipa), Kuskuhe (Japan). Fruit esculent.

770. ERIOCÁRPUM, Nutt.

Eriocarpum.

Compositae. From Greek, "woolly fruit". Syn. Aplopappus and Amellus, in part. Herbs and shrubs. Ábout 10 species, all American; 9 in U. S.

771. ERIOCAÚLON, L. Pipewort. Eriocanlaceae. From Greek, "woolly stem". Syn. Nasmythia, in part. Aquatic or bog herbs with heads of minute flowers. About 110 species, tropical and warm regions; 5 in U. S.

772. ERIODÍCTYON, Benth. (Eriodyction). Hydrophyllaceae. From Greek, "woolly net". Syn. Wigandia, in part. Balsamic shrubs. Three species, California to Arizona.

a. E. Califórnicum (H. \& A.) Greene (W. Californica H. \& A., E. glutinosum Benth.). California to northern Mexico. Yerba Santa, Consumptive's-weed, Bear's-weed, Mountain Balm, Gum plant, Tar-weed*. Leaves; Eriodictyon, U. S. P.; expectorant; masks bitterness of quinine.

773. ERIÓGONUM, Michx. Eriogonum. Polygonaceae. From Greek, "wool joint". Herbs, some suffruticose. About 200 species, western N. America; 167 in U. S. The name Wild Buckwheat is given to some species.

77. ERIÓPHORUM, L. Cotton-grass. Cyperaceae. From Greek, "wool bearing". Bog sedges, the flower-heads conspicious with the bristles forming the perianth. About 15 species, north temperate zone; 10 in U. S.

a. E. vaginátum L. Northern Europe, Asia and N. America. Sheathed Cotton-grass? Davy-whiteyeads, Hare's-tail, Rush or Cotton-grass. Other names not confined to this species, are Cotton Rush, Draw-Ling, Flors-seave, Moor-pawm (i. e. palm), Mo:s-crop, Pull-Ling.

75. EROPHÝLLUM, Lag. Erophyllum. Compositae. From Greek, "woolly leaf". Mostly floccose herbs, some shrubby. About 20 species, southwestern U. S. and Mexico.

776. ERÍTHALIS, L. - Erithalis. - Rubiaceae. Ancient Greek plant-name. Shrubs. About 5 species, West Indies; 1 in Florida.

77. ERÓDIUM, L'Her. Stork's-bill, etc. Geraniaceae. From Greek, "heron". Syn. Geranium, in part. Herbs. About 60 species, widely distributed; 3 native in U. S.

a. E. Cicutárium (L.)L'Her. (G. Cicutarium L.). Europe and Asia, widely nat. in U. S. Common Stork's-bill, Hemlock Stork's-bill or Heron's-bill, Pin Clover, Pin-weed, I'in-grass, Pine-needle, Pink-needle, Powk-needle, Stick-pile, Alfilaria [Alfilarilla, Filaree] (California). Plant astringent, diuretic. 
b. E. moschátum Willd. Europe, adv. in U. S. Musky Heron'sbill, Covey, Sweet Covey, Muscovy Musk, Ground-needle, Pick-needle, Pink-needle. Plant diaphoretic.

778. ERóPHILA, DC. 1821 . Whitlow-grass. Cruciferae. From Greek, "spring loving". Syn. Gansblum, Adans. 1763; Draba, in part. Herbs. About 6 species, Europe to Asia Minor.

a. E. vérna (L.) E. Meyer (D. verna L., E. Draba Schimp. \& Spen., E. vulgaris DC.). Europe, nat. in U. S. Vernal Whitlow-grass, Faverel, Nailwort, Shad-flower, White-blow.

779. ERYóDEA, Swz. - - Ernodea. - Rubiaceae. From Greek, "'sprouting" or "'branching". Procumbent shrub. One species, Florida.

780. ERTÉI A, Adans. 1763.

Ertela.

Rutaceae. Syn. Monnieria L. 1759, Moniera Loefl. 1758 (not Monniera or Moniera, B. Juss. 1756), Aubletia, Rich. 1807 . Herbs. About 2 species, S. America; (a) E. trifólia (L.) Lyons (Monnieria trifolia L., A. trifolia Rich.). One of the Brazilian plants known as Jaborandi.

781. ERÝYGIUM, L. Eryngo, Briery Thistle, etc. Umbelliferae. Ancient Greek name of a thistle-like plant. Herbs with prickly leaves. About 150 species, widely distributed; 27 in U. S.

a. E. aquáticum L. (E. yuccefolium Michx.). New Jersey to Florida and Texas. Water Eryngo, Rattlesnake's-master, Button Snakeroot, Corn Snakeroot, Rattlesnake Flag, Rattlesnakeweed. Root acrid-aromatic, diaphoretic, expectorant, emetic. [Other species are credited with similar properties.]

b. E. campéstre L. Europe. Field Eryngo, Hundred-headed Thistle, Fever-weed; Ger. Mannstreu, Brachdistel, Krausdistel; Fr. Chardon, Roland, Panicaut (Codex). Root diuretic.

c. E. marítimum L. Europe. Sea Holly, Sea Hulrer, Sea Eryngo. Fleshy roots formerly candied, aromatic, expectorant, diuretic.

782. ERÝSLMUM, L. Errsimum, etc. Cruciferae. Greek name of hedge-mustard. Syn. Cheiranthus (adopted in Heller's catalogue). Herbs. About 100 species, north temperate zone, especially Old World; 18 in U. S.

a. E. ásperum DC. (E. lanceolatum Pursh, E. Arkansanum Nutt., C. Arkansanus (Nutt.) Greene). Ohio to Texas and northwest to Pacific Coast. Western Wallflower, Yellow Phlox, Orange Mustard, Prairie Rocket.

b. E. cheiranthoídes L. Europe and British America, south to Pennsylvania. Treacle Mustard, Wormaseed Mustard, Treacle Wormseed, Tarrify. Plant anthelmintic, stomachic. 
783. ERYTHRAÉA, Neck.

Centaury.

Gentianaceae. From Greek, "red", the color of the flowers in some species. Syn. Gentiana, Cicendia, Schultesia, in part. Bitter herbs. About 50 species; 10 indig. in U. S., mostly in the west. ·

a. E. Ceniaúrium (L.) Pers. (G. Centaurium L.). Europe, adv. in U. S. Lesser Centaury, European Centaury (Sanctuary $\ddagger$ ), Bitter-herb, Bloodwort, Christ's-ladder, Felt rike, Feverfew*, Earth-gall, Mountain Flax; Ger. Tausendguldenkraut, Rother Aurin; Fr. Petite Centaurée (Codex); Sp. Centaura menor. Herb; H. centaurii (minoris); bitter tonic.

b. E. Chilénsis Pers., (c) E. strícta Schlecht, (d) E. Jorullénsis Kunth [S. stenophylla Mart. (Kew)] and perhaps other species of S. America and Mexico are called Canchalagua; properties of (a).

784. ERYTHRÍNA, L. Coral tree. Papilionaceae. From Greek, "red" the color of the seeds. Trees or shrubs with showy crimson or scarlet blossoms and red seeds. About 45 species, tropical or sub-tropical; 2 in U. S.

a. E. Corallodéndron L. Brazil. Coral-tree. Bark anodyne, expectorant. Leaves diuretic, laxatire.

b. E. Mulúngn Mart. Brazil. Bark hypnotic, anodyne.

7S5. ERYTHRÓNIUM, L. Adder's-tongue, etc. Liliaceae. Greek name of a plant having "red" flowers. Two-leaved herbs from a corm. About 14 species, mostly of N. America; 13 in U. S.

a. E. álbidum Nutt. Ontario to Tennessee and Texas. White Adder's-tongue, Spring Lily. To this and other species are applied many of the synonyms under (b).

b. E. Americánum Ker. (E. angustatum Raf., E. bracteatum Bigel. ). Canada and eastern U. S. Yellow or Common Adder's-tongue, Adder's-leaf, Adder's Violet, Dog's-tooth Violet, Deer's-tongue, Lamb's-tongue, Rattlesnake's Violet, Scrofularoot, Trout Lily, Trout-flower, Yellow-bells, Yellow Lily, Yellow Snake-leaf, Yellow'Snowdrop. Plant reputed alterative, emetic.

786. ERYTHROPHLOÉCH, Afzel. Sassy-bark. Mimosaceae. Syn. Fillaea, in part. Trees. About 5 species, tropical Africa, Asia and tustralia.

a. E. Guineénse Don. (E. ordale Bolle, E. judiciale Procter, F. suaveolens Guil. et Perrot.). Central and west Africa. Red Water-tree. Bark, Sassy-bark, Saucy-bark, Mancona-bark; Ger. Manconarinde; Fr. Ëcorce de Mançone. Used in Africa as an ordeal- and arrow-poison; narcotic, emeto-cathartic, diaphoretic, febrifuge.

787. ERYTHRÓXYLON, L. Coca. Erythroxylaceae. From Greek, "red wood". Shrubs and trees. A Aloout 70 species, tropical America, a few in Africa and Asia. 
a. E. Cóca Lam. Peru, Bolivia, etc. Coca, Cuca, Hayo, Ipado, Spadic. (Principal varieties, Huanaco frum Bolivia and Truxillo from Peru, the latter derived from E. Coca var. Spruceanum Burck.). Leares: Coca, U. S. P., Erythroxylon, U. S. 1880; Cocae Folia, Br., Fol. erythroxyli (cocæ.); Ger. Cocablätter; Fr. Coca (Codex), Feuilles de Coca; Local anaesthetic, stimulaut, nervine. Source of cocaine.

788. ESCHSCHólTzIA, Cham. California Poppy.Papaveraceae. Named for T. F. van Eschscholtz, German naturalist, d. 1831. Highly ornamental herbs with dissected leaves and yellow flowers. About 20 species, California.

789. ESEYBÉCKIA, H. B. K. Brazilian Angostura. Rutaceae. Syn. Evodia, in part. Trees. About 17 species, tropical regions, New World.

a. E. Pebrífuga Juss. (Evodia febrifuga St. Hil.). Brazil. Brazilian Angostura. Bark bitter tonic; contains, besides esenbeckine, an alkaloid (quinovine) analagous to quinine, found also in some cinchona barks.

790. EUCALYPTUS, L'Hér. Gum tree. Myrtaceap. From Greek, "well veiled". Trees with thick leathery leaves. About 150 species, Australia and neighboring islands, many furnishing very hard, tough and durable timber.

a. E. amygdalína Labill. Southeast Australia. Brown Peppermint-tree, White Peppermint-tree, Giant Gum-tree, Swamp Gum-tree, Australian Nountain Ash. [The tallest of trees, unless it be the giant Sequoias of California. One has been measured which was $471 \mathrm{ft}$. high. Yields more volatile oil than any other species, but containing no eucalyptol.]

b. E. corynocályx F. Muell. South Australia. Sugar Gum-tree. Foliage sweetish, browsed on by cattle and sheep.

c. E. glóbulus Labill. Victoria and Tasmania. Blue Gum-tree (incorrectly written Blue-gun tree); Ger. Vielchenbaum. Leaves; Eucalyptus, U. S. P., Folia eucalypti; Ger. Eucalyptusblätter; Fr. (Feuilles d') Eucalyptus (Codex); antiseptic, astringent, febrifuge [The tree is much planted in Italy, Algeria and elsewhere to dispel malaria. The volatile oil is official, although the yield of oil is much smaller than in (a).]

d. E. Leucóxylon F. Muell.(E. sideroxylon A. Cunn.). Victoria, etc. Iron bark tree. Bark very rich in kino tannin. Wood stronger even than hickory.

e. E. rostráta Schlecht. Southern and central Australia. Redgum tree. Exudate; Eucalypti Gummi Br., Australian or Botany Bay Kino, called also Red Gum, astringent, like Malabar Kino. Other species yielding kino are (f) E. corymbósa Sm., Bloodwood tree, (g) E. calopliylla R. Br. and $(\mathrm{h})$ E. piperíta Sm., Peppermint tree. 
i. E. viminális Labill. Southeast Australia. Manna Gum-tree. Exudate Australian Manna, which is also obtained occasionally from (j) E. goniocályx F. Muell., and (k) E. Gúnni J. Hooker, Cider tree.

Other Eucalypts worthy of note are (1) E. cornúta Labill., Yate tree; $(\mathrm{m})$ E. diversícolor F. Muell., Karri tree; (n) E.' gomphiocéphala DC., 'Tooart tree; (o) E. Iongifólia Link., Woolly-butt tree; (p) E. margináta Sm., Jarrah, Australian or Bastard Mahogany (timber resists teredo); $(q)$ E. microcorys F. Muell., Tallow-wood tree, Stringy-bark tree; (r) E. oblí(jua L'Her., Messmate tree (the Common Stringy-bark tree of Tasmania); (s) E. odoráta Behr., Peppermint tree (of south Australia); (t) E. oleósa F. Muell., Mallee tree (very rich in volatile oil); (u) E. piluláris Sm., Black-butt tree, Mountain Ash; ( v) E. polyanthema Schauer, Red Box tree, Australian Lignum Vitae; (w) E. populifólia Hook., Bembil, Shiningleaved Box Eucalyptus; (x) E. purctáta DC., Leather-jacket, Hickory Eucalyptus; (y) E. resinífera Sm., Red or Forest Mahogany (erroneously named as source of Australian Kino); (z) E. robústa Sm., Swamp or White Mahogany; (aa) E. salúbris F. Muell., Gimlet-wood. Fluted Gum-tree; (bb) E. Sieberiána F. Muell., (E. virgata, Sieber), Mountain Ash, in Tasmania called Gum-top or Iron-bark tree; (cc) E. Stuartiána F. Muell., Apple-scented Gum-tree; (dd) E. terminális F. Muell., Bloodwood tree (of northern Australia). [Honey produced from the flowers of Eucalyptus possesses active medicinal properties, antipyretic, antiseptic, etc.]

791. EUCÉPHALUS, Nutt. Aster. Compositae. From Greek, with "fine (flower) heads". Syn. Aster, in part. Herbs resembling Aster. About 10 species, all of U. S.

792. EUCHARÍDIUM, Fisch. \& Mey. Eucharidium.Onagraceae. Annual herbs with red flowers. Two species, California.

793. ECCHEUMA, Agardh. Agar-Agar. Gelidiaceae. Sea weeds allied to Gelidium q. v. About 18 species, warmer seas.

a. E. gelátina Agardh, (b) E. spinósum Agardh. Indian Ocean. Macassar or Celebes Agar-agar, Jelly plant. The source (in part) of Japanese or Chinese gelatin or isinglass. Used as a culture medium by bacteriologists. See Gelidium and Sphaerococcus.

791. EUCYÍDE, Zucc. - Eucnide. - Loasaceae. From Greek, "nettle sure". Syn. Mentzelia, in part. Herbs. Three known species, all of southwestern U. S.

795. EUCRÝPTA, Gray. Eucrypta. Hydrophyllaceae. From Greek, "well concealed". Syn. Ellisia, in part. Herbs. Three species, southwestern U. S.

796. EUGÉNIA, Micheli. Clove-tree, etc. Myrtaceae. Named for Prince Eugene of Saroy, d. 1730. Syn. Caryophyllus, Calyptranthes, Syzygium, Myrtus, in part. Trees and shrubs. More than 500 species, tropical regions, Old and New World; 7 in U. S. See Jambos. 
a. E. aromática (L.) O.Kze., not Berg. (Caryophillus aromaticus L., M. Caryophullus Spreng., M. caryophyllata Thunb.). Molucca Islands, cult. in many tropical countries. Clove-tree; Ger. Gewürznelkenbaurn; Fr. Giroflier. Flower buds, Cloves; Caryophyllus, U. S. P., Caryophyllum, Br., Caryophylli, P. G., Caryophylli aromatici; Ger. Gewürznelken, Gewürznägelein; Fr. Girofle (Codex), Clous aromatiques; Sp. Clavos de especia; carminative, comnter-irritant, much used as a condiment. Source of oil of cloves. Flower stalks, Clove stalks; Festucae (Fusti) caryophyllorum; Ger. Nelkenstiele, Nelkenholz; Fr. Griffe de girofle. Fruit, Mother Cloves; Anthophylli; Ger. Mutternelken; Fr. Mères de girofles, Clous matrices.

(b) E. Chéruen Mol. (E. Chekan DC., M. Cheken Spreng.). Chili. Cheken, Chekan, Chequen. Leaves aromatic, astringent.

c. E. Jambolána Lam. (S. Jambolanum DC., Cal. Jambolana Willd.). East Indies and Oceanica. Fruit esculent. Seeds used in diabetes mellitus.

Several species of Eugenia produce edible fruits, notably; (d) E. cordifólia Wight, Ceylon; (e) E. Hállii Berg., Bolivia: (f) E. mabaeoídes Wight, Ceylon; $(\mathrm{g})$ E. Nhánica Cambes., Brazil; (h) E. pyriformis Cambes., the Uvalho do Campo of Brazil, and (i) E. revolúta Wight, Ceylon.

Species found in Florida and the West Indies are, (j) E. buxifólia (Swz.) Willd., Spanish Stopper, Gurgeon Stopper; (k) E. montícola (Swz.) DC., White Stopper, with edible fruit; (1) E. prócera (Swz.) Poir., Stopper; (m) E. Gárberi Sarg., Red Stopper.

797. EÚLOBUS, Nutt. - Eulobus. - Onagraceae. From Greek, "well podded". A slender annual. One species, California.

798. EULÓPHIA, R. Br. Eulophia. Orchidaceae. From Greek, "well crested'. Epiphytal or terrestria. orchids. About 80 species, tropical Asia, America and especially southern Africa.

a. E. campéstris Wall., and (b) E. herbácea Lind. Central Asia. Tubers were formerly imported as salep.

799. EÚLOPHUS, Nutt. Eulophus. Umbelliferae. From Greek, "well plumed". Perennial herbs from tuberous. roots. About 5 species, all of U. S., mostly western.

800. EUNÁNUS, Gray. Eunanus. Scrophulariacea. From Greek, "dwarf". Syn. Mimulus, in part. Low viscid or glandular-pubescent annuals. About 26 species, California to Utah.

801. EUÓxYMUS, L. (Evonymus). Wahoo, etc. Celastracea. Ancient Greek name, meaning "honored" or "lucky". Shrubs. About 65 species, north temperate zone; 6 in U. S.

a. E. Americánus L. New York to Florida and west to Texas. Strawberry bush, Strawberry shrub, Burning-bush, Fish-wood. 
b. E. atropurpúreus Jacq. Ontario and eastern U. S., west to Montana. Wahoo (Waahoo, Wauhoo, Whahoo), Burningbush, Bursting-heart, Indian Arrow-wood, Strawberry tree or bush, American Spindle-tree, Bitter Asht. Bark of rool; Enopymus, U. S. P., Cort. euonymi; bitter, tonic, laxative, cholagogue.

c. E. Europaéus L. Europe, adv. in U. S. Spindle-tree, Arrowbeam, Butcher's-prick tree, Cat tree, Gaiter tree, Gatten, Gatteridge, Louse-berry tree; the tough wood called Peg-wood, Prick-timber, Prick-wood, Skewer-wood, Dog-wood*, Wit'hwood; Ger. Spillbaum, Spindelbaum, Pfaffenhütchen; Fr. Fusain, Bonnet de prêtre. Seeds emetic, purgative, insecticide.

802. EUPATÓRIUM, L. Thoroughwort, etc. Compositae. Greek name of Agrimony, after Mithridates surnamed Eupator. Syn. Artemisiat, Conoclinium, in part. Perennial herbs with small flower heads. About 575 species, mostly of warmer regions; 46 in $\mathrm{U}$. $\mathrm{S}$.

a. E. ageratoíles L. f. Canada to Georgia and west to Nebraska and Lonisiana. White Snake-root, White Sanicle, Indian Sanicle, Deerwort Boneset, Poolwort, Pool-root, Rich-weed, Squaw-weed, Stevia. Root aromatic, diuretic, vulnerary.

b. E. aromáticum L. Massachusetts to Florida. Smaller White Snake-root, Wild Hoarhound, Pool-root, Poolwort. Root aromatic, diuretic, anti-spasmodic.

c. E. cannábinum L. Europe. Hemp Agrimony, Bastard or Dutch Agrimony, Water Agrimony, Bastard Ḧemp, Hempweed, W'ater-Hemp, Raspberries-and-cream, Sweet-smelling Trefoilt, Water-maudlin, Andurion $\ddagger$; Ger. Wasserdost, Hirschklee, Wasserhanf.

d. E. capillifólium (Lam.) Small (A. capillifolia Lam., E. foeniculoides Walt. E. foeniculaceum Willd.). Virginia to Florida and West Indies. Dog Fennel, Hog-weed.

e. E, coelestínum L. (Conocliniunı coelestinum DC.). NewJersey to Florida and Texas. Mist-flower, Blue Boneset. Plant anti-spasmodic, expectorant.

f. E. glutinósum Lam. S. America. One of several plants known as Matico or Yerba del soldado (Soldier's herb.) See Piper angustifolium.

g. E. lencólepis T. \& G. New Jersey to Florida and Louisiana. Justice-weed, White-bracted Thoroughwort. The name Justice-weed is applied also to $(h)$ E. hyssopifólium L., Massachusetts to Texas.

i. E. perfoliátum I. (E. connatum Michx.). (anada to Florida and west to Texas and Nebraska. Boneset, Common Thoroughwort, Thorough-stem, Thorough-wax, Thorow-wax or 'Through- 
wax (i. e. "growing through" or perfoliate), Indian Sage, Wild Sage, Ague-weed, Crosswort, Feverwort, Vegetable Antimony, Sweating-plant; Ger. Durchwachsdost, Durchwachsener Wrasserdost oder Wasserhanf;Fr.Eupatoire perfoliée, Herbe à fièvre, Herbe parfaite; Sp. Eupatorio. Leaves and flowering tops, Eupatorium U. S. P., Herba eupatorii perfoliati; bitter, tonic, febrifuge, diaphoretic.

j. E. purpúreum L. (E. trifoliatum L.). British America, south to Florida and Utah. Queen-of-the-meadow, Joe-Pye weed, Gravel-root, Indian Gravel-root, King-of-the-meadow, Marsh Milk-weed, Motherwort, Nigger-weed, Quillwort*, Purple Boneset; Slunkweed, Tall Boneset, Trumpet-weed. Root diuretic, astringent. Closely related to this is ( $\mathrm{k}$ ) E. maculátum L. Virginia to New York. Spotted Joe-Pye weed, Spotted Boneset, Spotted Eyebright.

1. E. rotundifólium L. Eastern U. S. Wild Hoarhound, Roundleaved Thoroughwort.

m. E. triplinérve Tahl. (E. Aya-pana Vent.). Brazil. Aya-pana, Nyapana; Ger. Heilsamer Wasserdost; Fr. Aya-pana (Codex). Leaves diaphoretic, diuretic, antidote to snake-poison. Plant rich in tannin.

n. E. rerbenaefólium Michx. (E. pilosum Walt., E. teucrifolium Willd.). Eastern U. S. Rough Thoroughwort or Boneset, Vervain Thoroughwort, Wild Hoarhound.

s03. EUPHórBIA, L. Spurge. Eupliorbiaceae. Greek name of an African plant, named for Euphorbos, King Juba's physician. Syn. Tithymalus, in part. Herbs or shrubs. About 700 species, warmer parts of temperate zones; 118 in U. S.

a. E. corolláta L. Canada and eastern U. S. Flowering Spurge, Blooming or Large-flowering Spurge, Apple-root, Bowman'sroot, Emetic-root, Milk Ipecac, Milkweed*, Milk Purslane or Pursley, Snake-milk, Purging-root, White Purslane, IVild Hippo (Hipp). Root of this and of (f); Euphorbia, U. S. P. 18S0; Emeto-cathartic, diaphoretic, irritant.

b. E. Cyparíssias L. Europe, adv. in U. S. Cypress Spurge, Cypress*, Balsam Spurge, Bonaparte's-crown, Graveyard-weed, Irish Moss*, Kiss-me-quick, Quacksalver's Spurge, Tree Moss, Welcome-to-our-house.

c. E. Ésula L. Europe, adv. in U. S. Leafy Spurge, Faitour'sgrass, Tithymal.

d. E. Helioscópia L. Europe, nat. in U. S. Sun Spurge, Wart Spurge, Wart-weed, Wart-grass, Wartwort, Cat's-milk, Churnstaff, Deril's-milk, Mouse-milk, Mad-woman's-milk, Wolf'smilk, Little-good (Scotland), Saturday's-pepper, Seven-sisters, Sun-weed, Turnsole*. Juice acrid, formerly used to cure warts.

e. E. heterodóxa Muell. Brazil. Juice, leite d' Alveloz (Alveloz milk), acrid, escharotic; applied to caucroids, etc. 
f. E. Ipecacuánha L. Atlantic border of U. S. Ipecac Spurge, American or Carolina Ipecac, Milk or Spurge Ipecac, White or Wild Ipecac, Wild Hippo, Black Spurge. See (a). :

g. E. Láthyris L. (T. Lathyris Scop.). Europe, nat. in U. S. Caper Spurge, Caper bush, Wild Caper, Catapuce (Chaucer), Garden or Myrtle Spurge, Gopher plant, Anti-gopher plant, Mole plant, Mole tree, Springwort, Wolf's-milk; Fr. Epurge (Codex). Seeds Sem. cataputiae minoris, Sem. lathyridis majoris, Grana regia majora; Ger. Kleine Springkörner, K̇leine Purgirkörner; drastic cathartic. Yields an oil resembling Croton oil.

h. E. maculáta L. Throughout most of N. America. Spotted or Blotched Spurge, Black Spurge, Spotted Purslane (Fursley), Black or Milk Purslane, Milkweed*, Spotted Eyebright.

i. E. margináta Pursh. Minnesota to Texas. Variegated or White-margined Spurge, Mountain-snow, Snow-on-the-mountain.

j. E. nútans Lag. (E. hypericifolia A. Gray, not L., E. Preslii Guss.). Large Spotted-spurge, Upright Spotted or Blotcled Spurge, with other synonyms of $(\mathrm{h})$.

k. ${ }_{\mathbf{z}}^{\mathrm{s}}$ E. Péplus L. Europe, adv. in U. S. Pretty Spurge, Devil'smilk, Seven-sisters, Wart-weed.

1. E. pilulífera L. India, Australia and widely distributed in tropical countries. Pill-bearing Spurge. Plant reputed a specific in asthma.

m. E. prostráta Ait. Arizona. Prostrate Spurge, Swallowwort, Gallindrinera. Reputed an infallible cure for snake bites.

n. E. resinífera Berg. Morocco. Gum resin; Euphorbium P. G., Gummi v. Resina euphorbium; Ger. Euphorbium; Fr. Gommeresine d'Eupnorbe (Codex); Sp. Euforbio; drastic cathartic, sternutatory, chiefly used as a counter-irritant.

S04. EUPHRÁSIA, L. Eyebright. Serophulariaceae. From Greek, "delight" or "good cheer". Low parasitic herbs. About 110 species, temperate and cooler regions; 3 in U. S.

a. E. officinális L. Europe. Eyebright, Eyewort, Euphrasy;Ger. Augentrost; Fr. Euphraise; Sp. Eufrasia. Plant astringent; formerly used in ophthalmia.

805. EURÓTIA, Adans. Eurotia. Chenopodiaceae. From Greek, "hoary" or "mouldy". Syn. Diotis, in part. Herbs or low shrubs. Two species, one of Euro-Asia, one of western N. America, viz. (a) E. lanáta (Pursh) Moq., called White Sage and Winter-fat.

806. EURYTAÉNIA, T. \& Gr., (Eurytenia). Umbelliferae. From Greek, "well filleted". Herb. One species, southwestern U. S. 
807. EUSTÓMA, Salisb. Canada-pest. Gentianaceae. From Greek, "open mouthed". Syn. Lisianthus, in part. Glaucous annual herbs. Two species, southern U. S. and Mexico. (a) E. Russellianum (L.) Griseb. is called Canadapest.

80S. EUTÉRPE, Gaertn.

Assai Palm.

Sabalaceae.

Dedicated to the muse, Euterpe. Slender graceful palms. About 20 species, South America.

a. F. édulis Mart. Brazil. Assai Palm. Fruit esculent, used for preparing assai, an important article of food in Pará.

809. EUTHAMÍA, Nutt. Fragrant Golden-rod. Compositae. From Greek, "closely crowded", of the flower-heads. Syn. Chrysocoma, Solidago, in part. Perennial herbs with corymbed heads. Four species, all of U. S.

a. E. Caroliniána (L.) Greene. Eastern U. S. Slender Fragrant Golden-rod, Quobsque-weed.

b. E. graminifólia (L.) Nutt. (S. lanceolata L.). Canada and eastern U. S. Flat-top, Fragrant or Bushy Golden-rod.

810. EUTRÉMA, R. Br. - Eutrema. - C'ruciferae. Perennial herbs. About 10 species, Aretic and Alpine regions, chiefly of northern hemisphere; 4 in U. S.

811. EVónIA, - - Evodia. - - Rutaceae. Small trees or shrubs. About 30 species, Australiz and East Indian Islands. See Esenbeckia.

a. E. rutaecárpa Hook. f. \& Thouars. Japan. Unripe fruits and stems purgative, emmenagogue.

\$12. Evólyulus, L. Evolvulus. Conrolrulaceae. From Latin, "unrolling". Herbs, erect or diffuse. About 85 species, tropical and sub-tropical; $S$ in U. S. mostly southern.

818. EXC0ECírIA, L. Excœcaria. Euphorbiaceae. From Latin, "blinding", alluding to acrid quality of the juice. Shrubs or small trees. About 50 species, India and tropical America. See Stillingia.

a. E. Agállocha L. India to Polynesia. Formerly erroneously believed to be source of lign aloes. Milk juice, Tiger's-milk, acrid, escharotic. See Aquilaria.

814. EXÍDIUI, Fries. Jew's-ear. Helvellaceae. Syn. Peziza, Hirneola, in part. Cup-like saprophytic fungi.

a. E. Auricula-Júdae Fries (P. Auricula I., H. Auricula-Judae Auct. ). Europe. Jew's-ear Fungus, Jew's-ear, Elder Fungus; Ger. Hollunderschwamm, Judasohr. The entire fungus, Fungus sambuci, Auricula Judae; emollient, formerly reputed hydragogue. 
815. EXOGÓNIUM, Choisy.

Jalap.

Convolvulaceae. Syn. Ipomoea, Convolvulus, in part. Perennial, more or less shrubby twiners. About 15 species, tropical America.

a. E. Púrga (Wend.) Lind. (C. Purga Wend., I. Purga Hayne, I. Schiedeana Zucc., not Ham., I. Jalapa Schiede \& Deppe, not L., E. Jalapa Baill., E. dumosum Benth. ). Mexico and cult. in India and Jamaica. Jalap, True Jalap. Tubers; Jalapa. U. S. P., Br., Tubera jalapae, P. G., Rad. jalapae; Ger. Jalapenknollen, Jalape, Jalappenwurzel; Fr. Jalap tubéreux ou officinal (Codex); Sp. Jalapa; hydragogue cathartic.

Several allied species yield purgative tubers, notably (b) E. Jalapa (L.) Hayne (Conv. Jalapa L., not I. Jalapa Pursh) of Mexico, and in Brazil roots known as Purga, Batata Purgante, Jalapinha, Jeticucú and Emburerembo, some of these from allied genera. The Mexican Mechoacan root (Rad. mechoacanna) is also from an allied plant. See Ipomoea, (1) and $(n)$.

816. EXOSTÉMA, Rich. (Exostemma).

Rubiaceae.

From Greek, "with exserted stamens". Syn. Cinchona, in part. Trees or shrubs. About 30 species, tropical America; 1 in U. S.

a. E. Caribaéim (Jacq.) R. \& S. (C. Caribaea Jacq.). Florida and West Indies. Prince-wood, Seaside Beech. Bark, Caribaean or Caribbee Bark, bitter, febrifuge, emetic. The following West Indian species have similar properties and uses; (b) E. brachycárpum R. \& Sch., Jamaica Bark, (c) E. floribúndum R. \& Sch., St. Lucia Bark, Caribaean Bark.

817. EXóTHEA, Macfay. Ink-wood. Sapindaceae. From Greek, "expelled". Syn. Hypelate. Melicocca, in part. Tree with very hard and heavy wood. Onespecies; (a) E. paniculáta (Juss.) Radlk., West Indies to Florida, Inkwood, Ironwood.

818. EYSENHÁRDTIA, H. B. K. 1823.

Papilionaceae.

Named for Prof. C. W. Eysenhardt of Königsberg. Syn. Vibırquia, Ortega 1798 . Shrubs or small trees. Four species, southern U. S. and Mexico.

819. FabIáxa, Ruiz. \& Pav. Pichi. Shrubs. About 15 species, natives of $\mathrm{S}$. America.

a. F. imbricáta R. \& Par. Chili. Pichi, Fabiana. Leafy twigs bitter, tonic, terebinthinate diuretic.

820. FaGóxIA, L. Fagonia. Zygophyllaceae. Herbs. Two or three very variable species, widely distributed; 1 in U. S.

821. FAGOPÝrUM, Gaertn. Buckwheat. Polygonacer. From Greek, "beech-wheat", the grain resembling a beechnut. Buckwheat means also beech-wheat. Syn. Polygonum, in part. Herbs, annual or perennial. About 6 species, Europe and Asia; 2 nat. in U. S. 
a. F. Fagopýrum (L.) Karst. (Polygonum Fagophyrum L., F. esculentum Moench.). Eastern Europe and western Asia, cult. in temperate regions. Buckwheat, Brank, Crap, Indian Wheat, Heath Corn, Saracen's Corn; Ger. Buchweizen; Fr. Sarrasin, Blé noir. Seeds esculent. Several other species are cultivated for their seeds, notably (b) E. cymósum Meissner, the Chinese Perennial Buckwheat, and (c) F. Tatáricum (L.) Gaertn., Tatary (Tartary) Buckwheat, Rough Buckwheat, cult. in U. S.

822. FÁGUS, L. - - - Beech. - - Fagaceae. Classical name, derived from Greek, "to eat". Trees, some of great size. About 10 species, temperate zones; 1 in U. S.

a. F. Americána Sweet (F. ferruginea dit.). Canada to Florida and west to Texas and Wisconsin. American Beech, Red Beech, White Beech, Beech-nut tree. Seeds edible.

b. F. sylvática L. Europe and northern Asia. European Beech, White Beech. Seeds esculent; yield a fixed oil, Oleum fagi, Beech oil; Ger. Buchelöl, Bucheckeröl; Fr. Huile de faines, suitable for liniments, etc.

823. FALCÁTA, Gmel. 1796. Hog Pea-nut. Papilionaceae. From Latin, "sickle like" referring to the "keel". Syn. Amphicarpa, Ell. 1817; Glycine, in part. Twining vines, some producing subterranean fruit. About 7 species, eastern Asia and N. America; 2 in U. S.

a. F. comósa (L.) Kze. (G. comosa L. 1753, A. Tmonoica (L. 1763) Ell. Amphicarpaea monoica Nutt.). Hog Pea-nut, Wild Pea-nut, Pea-vine.

824. FALLÚGIA, Endl. - Fallugia. - Rosaceae. Shrub. One species, Mexico and southwestern U. S.

FATSLA. See ${ }_{i}^{x}$ RALIA, (d).

825. FENDLÉRA, Engelm. \& Gr. Fendlera. Saxifragaceae. Named for the American botanist, Fendler.' Shrubs. Two known species, southwestern U. S.

826. FERóNIA, Corr. Elephant Apple. Aurantiaceae. From name of an old Italian deity. A large tree. One species only, India.

a. F. elephántum Correa. India. Elephant Apple, Wood Apple. Leaves of anise-like odor, carminative. Fruits edible; tree yields Feronia gum, or East Indian gum Arabic.

897. FERREÍREA, Allem. Ferreirea. Papilionaceae. Syn. Andira, in part. Tree. One species; (a) F. spectábilis Allemao (A. spectabilis Saldanha). Brazil. Exudate, Resina d' angelim pedra, astringent, resembling Kino. 
828. FÉRULA, L.

Asafetida, etc.

Umbelliferae.

Ancient Latin name of Fennel, meaning a "walking stick". Syn. Angelica $\dagger$, Euryangium, Narthex, Scordosma, Sumbulus, in part. Robust herbs. About 80 species, west-central Asia.

a. F. alliácea Boiss. Northeastern Persia. Source of an inferior variety of asafetida.

b. F. Poétida (Bunge) Regel (S. foetidum Bunge, F. Scordosma Bent. \& Trim., Assafœetida Boiss., not Willd., F. Narthex Willd., not Boiss.). Turkestan, Bokhara and western Afghanistan. Gum resin; Asafetida, Asafoetida, U. S. P., Br., Gummi-resina asafoetida, Asafœetida; Ger. Stinkasant, Teufelsdreck; Fr. Asa fotida (Codex); has been called cibus deorum (food of the gods) and stercus diaboli (devil's dung); antispasmodic, carminative, stimulant. Leares eaten as salad.

c. F. galbanífiua Bois. \& Buhse (including F. erubescens Boiss. and F. gummosa Boiss.) Persia. Gum resin; Galbanum, Br. (also P. G. and Codex), Gummi-resina galbanum, Gummi galbanun; Ger. Galban, Mutterharz; Sp Galbano; stimulant to mucous membranes. (Other species yield a similar product, notably (d) F. rubricaúlis Boiss. and (e) F. Scháir Borszczon).

f. F. Nárthex Boiss. (F. assafoetida Willd., N. assafœetida Falc.). Persia to Afghanistan. Source of some of the asafetida from Afghanistan.

g. F. Pérsica Willd. not Sims or Bunge. Persia. Source of the gum resin Sagapenum, resembling Galbanum.

h. F. Súmbul Hook. f. (E. Sumbul Kauffm. Sum. moschatus . Reinsch, A. moschata Wiggers). Central Asia. Musk-root, Sumbul. Root; Sumbul, U. S. P., Sumbul radix, Br.; Ger. Sumbulwurzel, Moschuswurzel; Fr. Racine de Sumbul; antispasmodic, nervine.

i. F. Tingitána L. Northern Africa. Source of African Ammoniac, formerly known as Silphium. See Dorema and Thapsia.

829. FEVÍLLEA, L. Fevillea. Cucurbitaceae. Vines climbing by tendrils, with gourd-like fruit. About 6 species, tropical America.

a. F. cordifólia L., not Vell. Jamaica. Sequa, Cacoon Antidote. Seeds emeto-cathartic. [The oily seeds of a Peruvian species known as Abilla are used for candles or torches].

830. FICÁRIA, Huds. Pilewort Buttercup. Ranunculaceae. From Latin, "fig", like, alluding to the root tubercles. Syn. Ranunculus, in part. Perennial herbs resembling Ranunculus. About 4 species, Old Wrorld.

a. F. Ficária (L.) Karst. (R. Ficaria L., F. ranunculoides Moench). Europe, adv. in L. S. Lesser Celandine, Crain, Golden-cup, Golden-guineas, Herb-of-grace, Pilewort, Pilewort Buttercup, Wordsworth's flower; (ier. Feigenranunkel; Fr. Petite chélidoine. Plant formerly believed to cure hemorrhoids. 
831. Fícus, Tourn. - - Fig. - - Moraceae. The ancient Latin name, probably from Hebrew, "feg". Syn. Urostigma, in part. Trees or shrubs. About 650 species, warm and tropical regions; 3 in $\mathrm{U}$. S.

a. F. Cárica L. Western Asia, cult. in all sub-tropical and tropical countries. Fig tree; Ger. Feigenbaum; Fr. Figuier. The dried fruit (more correctly the fleshy receptacle with included fruits), Ficus, U.S. P., Br. - Fructus caricæ, Caricæ, Ficus passa; Fici; Ger. Feigen; Fr. Figue (Codex); Sp. Higo. The Turkey or Smyrna figs (caricie pingues) are much larger than the Greek or Dalmatian figs (carice minores); esculent, laxative, used for cataplasms, formerly roasted as a substitute for coffee.

b. F. elástica Roxb. (Urostigma elastica Miq.). East Indies, a conmon shade tree in tropical countries. India-rubber tree. The india rubber of commerce is, however, derived chiefly from other trees. See Hevea, Manihot, Castilloa and Urceola.

c. F. Índica L. India. Banyan tree: Indian Fig. (The Banyan of Lord Howe's Island, which exceeds this in size, is (d) F. colnmiáris, Moore \& Muell.)

e. F. religiósa L. India. Sacred Fig. Pipul tree (Pipal, Pippul, Peepul), Bo tree. One of many trees yielding lac; (f) F. Benghalénsis L. and $(\mathrm{g})$ F. Tsjéla Hamilton, as well as $\mathrm{F}$. Indica (above), also produce lac. See Croton (a).

h. F. pedunculáta Willd. West Indies to Florida. Jamaica Cherry.

i. F. Sycamórus L. Mediterranean region. Sycamore tree, Pharaoh's Fig, the Fig tree of Scripture. Fruit esculent.

832. FILÁ(x0, L. Filago, Everlasting. Compositae. From Latin, filum, a "thread". Syn. Erax, Diaperia, in part. White-woolly annuals. About 12 species, New and Old World; 4 in U. S. . (In Heller's catalogue the species are referred to Erax.) See Gifola.

\$33. FILIPÉxDULA, L. Filipendula. Rosaceae. Syn. Spiraea, in part. Suffrutescent plants, north temperate zone; 2 in U. S. Syn. Fillyfindillan†, Lady's-ruffles.

\$34. FLA VÉRIA, Juss. " Flaveria. Compositae. From Latin favus, "yellow". Syn. Milleria, in part. Herbs with small densely clustered heads. About 7 species, warmer regions of America, 4 in U. S.

\$3ร̆. FLINDÉRSIA, R. Br. Leopard tree. Meliaceae. Srn. Elæodendront, in part. Trees or shrubs. About 12 species, Australia to New Caledonia.

a. F. maculósa (Lind.) F. von Muell. (E. maculosum Lind.). Australia Leopard-tree, Spotted-tree. Gummy exudate resembles Acacia and is used in a similar way. 
836. FLOÉRKIA, Willd. False Mermaid. Limnanthaceae. Named for H. G. Floerke, German botanist d. 1835 . Marsh annual. A single species, north America; U. S. throughout.

837. FlorestíxA, Cass. Florestina. Compositae. Probably from a personal name. Syn. Stevia, in part. Hoary herbs. Two species, Mexico to Texas; 1 in U. S.

838. FLOURÉNSIA, DC. Flourensia. Compositae. Named for Dr. M. J. P. Flourens. Shrubby resinous plants. About 3 species, Mexico and southwestern U. S.

839. FOExícCLUM, Adans. Fennel. Umbelliferae. Latin name, diminutive from foenum, "hay". Syn. Anethum, Meum, in part. Biennial or perennial herbs with dissected leaves. About 4 species, Old World; 1 adv. in U. S.

a. F. Foenículım (L.) Karst. (Anethum Fueniculum L., F. vulgare Gaertn., F. capillaceum Gilib., F. officinale All., ITeum Foniculum Spreng. ). Southern Europe and Western Asia, and widely cult. Fennel (Finkel, Fingel, Spingel), Large Fennel, Giant Fennel, Dill*; Ger. Fenchel; Fr. Fenouil. Fruit; Foeniculum, U. S. P., Fœniculi fructus, Br., Semen fœniculi; Fennel-seed, Fennel-fruit. Commercial varieties are Saxon or German fennel-seed and the Roman or Italian which is larger and comes from the variety known as Sweet Fennel, F. dúlce DC., Fenouil doux of the Codex; aromatic, carminative, stomachic. Source of oil of Fennel. 'The root also is occasionally used in Europe.

840. FOTHERGíLLA, Murr. Witch Alder. Hamamelidaceae. Named for Dr. John Fothergill, English naturalist, d. 1780. Syn. Hamamelis, in part. A small shrub, one species, (a) F. Carolína (L.) Britton, Eastern U. S., called Witch Alder or Dwarf Alder.

841. FOCQUIÉRIA, H. B. K. Candlewood. Tamariscaceae. Syn. Fouquiera, Spreng. Thorny shrubs or trees. About 3 species, Mexico and adjacent territory; 1 in C. S.

842. FRAGÁRIA, L. - Strawberry. - Rosaceae. Latin name, perhaps from "fragrance" of the fruit. Peren-

nial herbs, spreading by runners. About 15 species, north temperate zone and S. America; 7 in U. S.

a. F. Americána (Porter) Britton (F. vesca var. Americana Porter). Canada to New Jersey and west to Oregon, in the woods. American Wood Strawberry. Fruit (i. e. fleshy receptacle) of this as of all the species esculent.

b. F. Canadénsis Michx. British America, south to New York, in fields and meadows. Northern Wild Strawberry, Mountain Strawberry.

c. F. Chilénsis Duchesue. Chili and northward to Oregon. Cinili Strawberry, (one of the most prolific species in cultivation). 
d. F. résca L. (F. vulgaris Erhr.) Europe, nat. in eastern U. S.

- European Wood Strawberry, Sheep-nose, Sow-tit. The parent species of many cultivated varieties; Ger. Erdbeere; Fr. Fraisier (Codex).

e. F. Virginiána Duchesne (F. vesca Walt.). Canada to Florida and west to Louisiana, Arizona and S. Dakota. Virginia Strawberry, Scarlet Strawberry, Common Field Strawberry. Parent species of many cultivated varieties.

843. FRANKÉNIA, L. (Franca, Franka). Frankeniaceae. Named for Prof. Johann Franke, of Upsala, d. 1661. Syn. Franca, Micheli 1763. Heath-like herbs or sub-shrubs. About 30 species, widely distributed in temperate regions; 3 in U. S.

a. F. grandifólia Cham. \& Schlecht. (Franca grandifolia Esch.). California in salt marshes, Yerba Reuma. Herb astringent.

844. FRÁSERA, Walt. American Calumba. Gentianaceae. Named for John Fraser, English botanical collector, d.1817. Robust herbs with flowers in terminal panicles. About 13 species, all of the U. S., mostly western.

a. F. Carolinénsis Walt. (F. Walteri Michx.). Canada to Georgia and west to Wisconsin. American Columbo, Indian Lettuce, Yellow Gentian, Pyramid-plant, Pyramid-flower, Ground Centaury, Meadow-pride. Root; Radix colombo americanæ; Ger. Amerikanische Colombowurzel; Fr. Racine de Colombo de Mariette (d'Amérique); bitter tonic resembling Calumba. Fresh root emeto-cathartic.

845. FríxinUS, L. - - Ash. - - Oleaceae. The ancient Latin name. Syn. Ornus, in part. Trees, generally with pinnate leares. About 40 species; 16 in U. S. Ger. Esche; Fr. Frêne; Sp. Fresco.

a. F. Americána L. (F. alba Marsh., F. epiptera Michx., F. Caroliniana Wang., not Mill. ). Canada and eastern U. S. American White Ash, White Ash, Cane Ash, Ash. Bark of this and other species febrifuge; leares laxative, anti-arthritic. Wood tough, elastic.

b. F. excélsior L. Europe. European Ash; Fr. Frêne (Codex). Some manna is obtained from this species in southern Europe. Bark and leares used as in (a).

c. F. nígra Marsh. (F. sambucifolia Lam.). Canada and northwestern U. S. Black Ash, Hoop Ash, Swamp or Water Ash, Basket Ash.

d. F. Órnus L. (Ornus Europœa Pers.). Europe and the Levant. Manna Ash, Flowering Ash, European Manna tree. Erudate; Manna, U. S. P.; Fr. Manne (Codex); laxative. (The species probably includes F. rotundifolia Lam.). Additional American species are (e) F. Caroliniána Mill. (F. platycarpa Michx.), Water Ash, Carolina Ash, Pop or Poppy Ash; (f) F. lanceoláta Borck ( $F$. viridis Michx.), Green Ash, Blue or Swamp Ash; (g) F. Penusylvánica Marsh ( $\mathrm{F}$. pubescens Lam.), Red Ash, Black Ash ${ }^{*}$, and (h) F. quadranguláta Michx. (F. quadrangularis Lodd.), Blue Ash. 
846. FREMONTODÉNDRON, COV.

Cheiranthodendraceae. From Greek, "Fremont's tree", in honor of Col. Fremont. Syn. Fremontia, Torr. 1854 not 1845; Cheiranthodendron, in part. Shrub bearing a profusion of yellow flowers. One species, California.

a. F. Califórnicum (Torr.) Coville (Fremontia Californica Tor., C. Californicum Baill.). California Slippery EIm. Inner bark used for poultices, etc.

847. FRITILLÁRIA, L. Guinea-hen flower. L:liaceae. From Latin fritillus, a "dice box". Bulbous herbs. About 50 species, north temperate zone; 9 in U. S.

a. F. liliácea Lindl. California. Green Lily. [Cult. in gardens are (b) F. imperiális L., Crown-imperial and (c) F. meleágris L. of Europe, Guinea-hen flower, Checkered Daffodil, Snake's-head, Weeping-widow, Widow-wail.]

d. F. rerticilláta Willd., not Bieb. nor Wall. (F. Thunbergii Miq.). Siberia. Bai-mo. Seeds anti-rheumatic.

848. FROELÍCHIA, Moench. Frølichia. Amaranthaceae. Named for J. A. Froelich, German botanist. Syn. Oplotheca, in part. Woolly or silky herbs. About 12 species, all American; 4 in U. S.

849. FÚCUS, L. Seaweed, Kelpware. Fucaceae. From the Greek name of "seaweed". Syn. Cystoseira, Halidrys, Sargassum, in part. Social seaweeds with flat or compressed forked fronds.

a. F. nátans L. (Sargassum bacciferum Agardh). Atlantic Ocean. Gulf weed.

b. F. vesiculósus $\mathrm{L}$. North Atlantic and north Pacific Oceans. Bladder-wrack, Kelpware, Black-tang, Cut-weed, Bladder Fucus, Lady-wrack, Sea-wrack, Sea Oak. The entire plant; Quercus marinus; Ger. Blasentang, Höckertang, Seeeiche; Fr. Varech vésiculeux (Codex); reputed to reduce obesity. (c) F. serrátus L. and (d) F. siliquósus L. (Cystoseira siliquosa Agardh, Halidrys siliquosa Lyngbye) are also used and are authorized by the Codex.

850. FUMÁRIA, L. - Fumitory. - Papareraceae. Old Latin name, "smoky". Herbs with dissected leaves. About 35 species, Old World.

a. F. officinális L. Europe, adv. in U.S. Fumitory, Hedge Fumitory, Earth-smoke?, Beggary, Wax-dolls; Ger. Erdrauch, Feldraute; Fr. Fumeterre (Codex); Sp. Hiel de tierra, Pajarilla. Fresh juice of the plant, alterative, discutient.

851. FÚNKIA, Spreng. 1817 . Day-Lily. $\begin{aligned} & \text { Liliaceae. } \\ & \text { Named for H. Funck, German botanist. Syn. Saussurea, }\end{aligned}$ Named for H. Funck, German botanist. Syn. Saussurea,
alisb. 1807 (without description), Niobe, Salisb. 1812, Hosta, Tratt. 1812, not Jacq. 1797. Perennial scapose herbs from woody rhizomes. About 6 species, China and Japan; (a) $\mathbf{F}$. ováta Spreng. (S. cœrulea Salisb.), Blue Day-lily; (b) F. subeordáta Spreng. ( N. cordifolia Salisb., H. Japonica Tratt.)

White Day-lily, Plantain Lily. 
852. FURCRAÉA, V'ent. 1793.

Amaryllidaceae. Syn. Fourcroya, Spreng $181 \bar{\gamma}$. Plants resembling Agave. About 18 species, trispical America: (a) F. gigántea Vent. (F. viridis Hemsley), of Central America resembles Sisal Hemp, its leaves yielding a similar fibre.

S58. FÚSANUS, R. Br. Quandong nut.

Trees or shrubs, natives of S. Africa and Australia.

a. F. acuminátus R. Br. (Santalum Preissianum Miq.). Australia. Quandong-nut, Quandang, Native Peach. Both fruit and kernel esculent and highly esteemed.

854. GAERTNÉRIA, Med. 1785. Grertneria. Ambrosiaceae. Named for Joseph Giertner, German botanist, d. 1791. Syn. Franseria, Cav. 1793; Ambrosia, in part. Hispid or tomentose herbs. About 15 species, America; 12 in U. S.

855. GaILLÁRDIA, Foug. Blanket-flower. Compositae. Named for M. Graillard, French botanist. Syn. Mgassizia, in part. Herbs with large flower heads, the rays occasionally wanting. About 12 specier, New World; $11^{\circ}$ in U. S. and Mexico.

856. Galíctia, P. Br. Milk Pear. Papilionaceae. From Greek, "milky", alluding to the sap. Herbaceous or shrubby plants, generally climbing or prostrate. About 50 species, warmer regions, e-pecially of America; 14 in U. S., mostly southwestern.

s57. GaLíNTHUS, L. Snowdrop. Amaryllidaceae. From Greek, "milk flower". Srapose herbs from a coated bulb. Three species, Europe and western Asia.

a. G. níralis L. Europe. Snowdrop, Fair-maids, Fair-maids-ofFebruary.

s5s. GíldX, L. Galax, Beetle-weed. Diapensiaceae. From Greek, "milk", but the name seems not appropriate. Scapose perennial, with densely racemed small flowers. A single species; (a) G. aphylla L., southern L. S., called also Galaxy+ and Colt's-foot.

959. GALEDCPA, Lam. 1786 Kurung. Papilionaceae. Syn. Pongamia, Vent., 1803; Dalbergia, in part. A tree. One species, tropical Asia to Australia.

a. (x. Póngam Raeusch (P. glabra Vent., D) arborea Roxb. G. Indica Lam., perhaps the oldest name). India to Australia and Fiji Islands. Seeds source of Kurung (Kurunj) or Poona oil.

860. GALÉGA, L. Goat's Rue.

Papiliouaceae. From Greek, "milk producing". Smooth perennial herbs. About 6 species, southern Europe and western Asia.

a. G. officinális L. Mediterranean region to central Europe. Goat's Rue; Ger. Geisraute, Pestilenzkraut; Fr. Rue de chèrre. Herb, Herba rute caprariæe, diaphoretic, anthelnintic, antispasmodic. 
861. GALEÓPSIS, L.

Hemp Nettle.

"wersel herbs. About 6 species, Old World.

Annual

a. (x. Tetrálhit L. (G. grandiflora suter., (̇. camnabina Willd.). Europe and Asia, nat. in U. S. Hemp Nettle, -Hemp Deadnettle, Bee Nettle, Dog Nettle, Blind Nettle, Flowering Nettle, Nettle Hemp, Wild or Bastard Hemp, Gilidewort, Ironwort, Holy-rope; Ger. Hanfnessel, Hohlzahn; Fr. ('hanvre hâtard, Galeopside. Herb tonic, antiperiodic.

b. (t. ochroleńca Lam. (G. grandiflora Roth., (i. cannabina l'ollich). Europe. Pale-vellow Hemp-nettle. Herb; Herba (Summitates) galeopsidis; (ier. Blankenheimer 'Thee, Lieber'sche Kräuter, Gesundheitskräuter; a popular remedy (in Germany) for coughs, etc.

862. GALINSÓ(XA, R. \& P. Cialinog:al. Compositae. Named for M. M. Galinsoga of Madrid. JIerths with small flower heads. About $\bar{s}$ species, all American; 2 in U. $\mathrm{S}$.

863. GÁLIUM, L. Bedstraw, (learers, etc. Rubiaceae. Greek name of (i) which has the property of coagulating "milk". Syn. (ruciata, in part. Herbs often armed, mostly with whorled leaves. Abont 225 species; 50 in L. S. Synonyms are Airif, Geckdor, (iull-grass, (iye, Stickleback, .Tivers, Witherspail.

a. G. Aparíne L. Europe, nat. in L. S. (leavers (Clivers), Cleaverwort, Goose-grass, Gosling-grass, Gosling-weed, Airif, Hairif, Beggar-lice, Bur-head, Catch-weed, Cling-rascal, Claver-grass, Gallion, Gravel-grass, Grip, Grip-grass, Love-man, Maid's-hair, Yig-tail, Pertimugget, Poor-Robin, Snatch-weed, Stick-a-back, Stickle-back, Sweet-hearts, Turkey-grass, Wild Hedge-burs, Wild Rosemaryt; (ier. Klebkraut; Fr. (irateron, Rièbel. Herb diuretic, discutient. Other rough species like (b) G. aspréllum Michx. are also callerl ('leavers, Catch-weed, etc.

c. G. cireaézans Miclıx. Canada and eastern L. s. Wild Licorice, Cross Cleavers. Leaves have a sweet taste, as do those of (d) G. lanceolátum Torr. of northeastern L. S. and Canada. Torrey's Wild Licorice.

e. G. Cruciáta Scop. (G. cruciatum Sm., (: hirsuta Fourr.). Europe and northern Asia. Maywort, Golden Crosswort, Golden Mugwet (Muguet) or Mugweed, Honeywort.

f. G. Moilúgo L. (G. album Mill.). Europe, nat. in I. S. Greater Wild Madder, Great or White I Iedge-bedstraw, Babies'breath, Infant's-breath, Whip-tongue; Ger. Waldstroh; Fr. Caille-lait blanc (Codex). Flowering tops antispasmodic.

g. G. tinctórium L. (G. trifidum var. latifolium Torr., (i. obtusum Bigel. ). Canada to N. Carolina, west to Arizona. Smaller Wild Madder, Dyer's Cleavers. Root of this as of (f) yields a red dye. 
h. G. triflórum Michx. Northern Europe, Asia and N. America, south to Alabaina and California. Sweet-scented or Fragrant Bedstraw. Leaves contain coumarin as in Asperula (b.)

i. G. vérum L. (G. luteum L., G. floridum Salisb. ). Europe, Asia, nat. in U. S. Yellow Bedstraw, Our-lady's Bedstraw, Ladies' or Yellow Cleavers, Bedflower, Brum, Cheese-rennet, Runnet, Curdwort, Keeslip, Fleawort, Maid's-hair; Ger. Megerkraut, Liebfrauenstroh, Labkraut; Fr. Caille-lait jaune (Codex); Sp. Cuajalache. Herb diuretic; coagulates milk.

864. GALPÍNSIA, Brit. 1894. Galpinsia. Onagraceae. Anagram of Salpingia. Syn. Salpingia, Raimann 1893, not Salpinga DC.; Oenothera, in part. Perennial herbs, some shrubby, with yellow flowers. About 4 species, Mexico and adjacent regions; 3 in U. S.

865. GALVÉZIA, Juss. 1789. Galvezia. Scrophulariaceae. Syn. Galvesia, J. F. Gmel. 1791, Agassizia, Chav. 1830. Herbs or sub-shrubs. About 3 species, New World; 1 in U. S.

866. GARBÉRIA, Gray. Garberia. Compositae. Named for Dr. A. P. Garber, the rediscoverer. Syn. Liatris, Leptoclinium, in part. Shrub with numerous rather small flower-heads. One species, Florida.

867. GARCÍNIA, L. Mangosteen, etc.

Clusiaceae. Named for Laurent Garcin, French botanist, d. 1752. Syn. Mangostana, Brindonia, Hebradendron, in part. Trees with yellow milk sap. About 40 species, tropical Asia, Africa and East Indian Islands.

a. G. Hanbúrii Hook f. var. pedicellata Hanb. perhaps a distinct species, (G. pictoria Roxb., G. Gutta Wight, G. elliptica Wall., G. Cambogioides Royle, H. Cambogioides Graham), elosely related to G. Morella Desr. Farther India. Gum resin; Cambogia. U. S. P., Br., Gambogia, U. S. P. 1870, Gamboge; Gummi-resina guttæ v. gutti, Gutta gamba, Cambodia; Ger. Gutti, Gummi-gutt; Fr. Gomme-gutte (Codex); Sp. Goma guta, Guta gamba; irritant, hydragogue.

b. G. Índica Choisy (G. purpurea Roxb., B. Indica Du Petit-Th.). India. Seeds used in curries; source of Kokum butter or concrete oil of Mangosteen.

c. G. Mangostána L. (M. Garcinia Gaertn.) ). East Indies, cult. in all tropical countries. Mangosteen (Mangostan, Mangostine). Fruit esculent. Rind of fruit, Cort. mangostanæ, erroneously called Mango fruit; astringent, as is also the bark of the tree.

868. GARDÉNIA, Ellis. Cape Jasmine. Rubiaceae. Named for Alexander Garden of S. Carolina, d. 1791. Trees or shrubs. Abont 60 species, tropical Asia and Africa.

a. G. campanuláta Roxb. India to Burma. Fruit cathartic, anthelmintic; (b) G. édulis F. Muell. is the Australian Breadfruit; (c) G. jasminoídes Ellis. (including G. florida L. and G. radicans Thunb.) from China is the well known Cape Jasmine (Jessamine). 
s69. GÁRRYA, Dougl. California Fever-bush. Cornaceae. Evergreen shrubs with coriaceous leares. About 14 species, warmer regions of New World, 7 in southwestern U. S.

a. G. Fremónti Torr. California. California Fever-bush, Skunkbush. Leaves cholagogue, tonic.

S70. GAULTHÉRIA, L. 1751. (Gualtheria).

Ericaceae.

Named for Dr. Gaulthier of Quebec. Syn. Brossæa L. 1737. Shrubs with evergreen leaves. About 100 species, mostly of S. America, a few of $\mathrm{N}$. America and Asia; 4 in U'S.

a. G. híspida R. Br. Australia to New Zealand. Wax-cluster.

b. G. procúmbens L. (Brossaea procumbens (L.) O. Kze.). Canada and northeastern U. S. Wintergreen, Creeping or Spring Wintergreen, Aromatic or Spicy Wintergreen, Teaberry, Partridge-herry, Box-berry, Checkerberry, Chicken-berry, Spice-berry, Deerberry, Ground-berry, Grouse-berry, Hillberry, Ivy-berry, Redberry Tea, Canadian Tea, Mountain Tea, Chinks, Drunkards, Red Pollom, Ivory Plum, Rapperdandies; Fr. Gaulthérie Couchée (Codex). Leaves; Folia gaultheriæ; Ger. Canadischer Thee, Bergthee; Fr. Feuilles de gaulthérie (de palommier), Thé du Canada, Thè de terreneuve; astringent, aromatic; source of Oleum Gaultheriae, U. S. P., Oil of Wintergreen. See Betula lenta.

c. G. Shállon Pursh. Northwestern U. S. and British Columbia. Shallon, Salal. Fruit esculent as is that of (d) G. Myrsinites Hook. of the same region.

S71. GAÚRA, L. Wild Honeysuckle*.

Onagraceae.

From Greek, "superb", although the name is not very well applied. Herbs with pink or red flowers. About 18 species, N. America; 14 in U. S.

872. GAURÉLLA, Small. Spotted Primrose. Onagraceae. Latin, diminutive of Gaura. Syn. Oenothera, in part. Diffuse perennial herb. One species, Nebraska to New Mexico.

873. GAYLUSSÁCIA, H.B.K. 1818. Huckleberry. Vacciniaceae. Named for the French chemist Gay-Lussac. Syn. Adnaria, Raf. 1817?; Vaccinium, in part. Low shrubs, our species producing edible fruits. About 40 species, all American; 7 in U. S. The species of the northeastern states are (a) $G$. brachycera (Michx.) A. Gr. (V. brachycerum Michx., V. buxifolium Salisb., not Hook. f.), Box Huckleberry (Whortleberry); (b) G. dumósa (Andr.) T. \& Gr. (V. dumosum Andr.), Dwarf or Bush Huckleberry; (c) G. Prondósa (L.) T. \& Gr. (V. frondosum L. ), Blue-tangle, Tangleberry, Dangleberry, Blue Huckleberry; (d) G. resinósa (Ait.) T. \& Gr. (V'. resinosum Ait. ), Black or High-bush Huckleberry, Blacksnaps, Crackers.

874. GA YÓPHYTUM, A. Juss. Gayophytum. Onagraceae. Slender annual herbs. About 10 species, New World; 6 in U. S. 
87.). (iEISSOSPÉRMUM. Allem. Dis.

A pocynaceae.

From Greek, "bordered seed". Trees with hoary-pubescent leaves. About + species, south America; (a) G. Vellósii Alem. (G. laeve Miers) of Brazil is Pao Pareira. Baric bitter, antiperiodic.

s76. (iELASINE, Herb.

Gelasine.

Iridaceae.

Bulbous herbs. One or two species, New World; 1 in southern U. S.

877. GELÍIIUI, Lan.

A gar-agar.

Gelidiaceae.

Syn. Cornea, Stackh. S.eaweeds abounding in gelose. See Encheuma.

a. (†. córneum Lam. Coasts of C'hina. One of severa' seaweeds from which the ('hinese edible bird's nests are made. This together with (b) Gloiopéltis ténax J. Agardh, as well as species of Eucheuma and Sphaerococcus constitute Agar-agar.

\$7. GELSÉMIUM, Juss. Yellow Jasmine. Loganiaceae. From Italian name of "Jasmine". Syn. Lisianthus, Bignoniat, in part. Twining woody vines with showy yellow flowers. Two species, one of eastern Asia, one of $\mathrm{U}$. S.

a. (r. sempérvirens (L.) Ait. f. (B. sempervirens L., G. nitidum Michx., L. sempervirens Miller, Anonymos sempervirens Walt., G. lucidum Poiret). Virginia to Florida, Texas and south to Guatemala. Yellow Jasmine or Jessamine, Carolina Jessamine, Carolina IVild Woodbine, Evening Trumpet-flower; Ger. Gelber Jasmin, Jasminbignonie, Immergrüne Trompetenblume, Giftjasmin, Gelsemie; Fr. Gelsemium (Codex), Jasmin sauvage; Sp. Gelsemio. Rhizome and roots; Gelsemium. U. S. P., Gelsemii radix, Br.; antispasmodic, arterial and nervous seda. tive.

\$79. GEMMÍYGIA, Fabr. 1759. Blackberry Lily. Iridaceae. Syn. Belamcanda, Adans., 1763; Pardanthus, Ker. 1805; Ixia, in part. Rather robust herb with fruit resembling in appearance a blackberry. One species, eastern Asia, nat. in I. S. (a) (H. Chinénsis (L.) Kze. (Ixia Chinensis L.); Blackberry Lily, Leopard-flower, Dwarf Tiger-lily.

sxo. GÉXIPA, L. - Frenip tree. - Rubiaceae. Tame from vernacular, West Indies. Trees with succulent fruit. About 10 species, mostly of tropical America; 1 in U. S.

a. (x. Americána L. S. America. Genip tree, Genipap (vernacular Genipapo), in Surinam called Marmalade-box. Fruit (large as an orange) esculent. The Seven-year Apple from(b) (1. Clusiaefólia Griseb., West Indies to Florida, is not edible.

si1. (KExist A, L. Broon, Whin. Papilionaceae. Latin name (from C'eltic gen a "bush), applied originally to Spartium junceum L. From this comes Fr. genêt and hence Plantagenet (Plante à genêt). Shrubs, some thorny, with showy yellow flowers. About so species, temperate regions of uld World. 
a. G. linctoria L. (including G. pubescens L. and (i. lueida Kittel). Europe and northern Asia, nat. in L. S. Iyer's Broom, Dye-weed, Green-weed, Alleluia, Base Broom, ( $i$ reen Hroom, Dyer's Furze, Dyer's Whin, Groonwood, Woad-waxen, Woodwax, Wood-waxen, Waxen-woad, Widow-wisse, Wudwise; Ger. Färberginster, Gillbkraut, Gilösen. Herb, H. geniste (tinctoriæ), H. cytisogenistæ; diuretic, cathartic, formerly used to produce the famous Kendal green.

882, GENTIÁNA, L. - Gentian. - Gentianaceae. Named for King Gentius of Illyria. Bitter herbs with showy blue, purple, yellow or white flowers. About 300 species, north temperate and Arctic zones and S. America; to in U. S.; Ger. Enzian; Fr. Gentiane; Sp. Genciana.

a. G. criníta Froel. Ontario to Georgia and west to Iowa and Minnesota. Fringed Gentian, Larger Fringed (ientian.

b. G. Ińtea L. Southern and central Europe. Yellow Gientian, Pale Gentian, Bitter-root, Bitterwort, Felwort. Root; Gentiana, U. S. P., Gentianæ radix., Br., R. gentianæ P. G., R. gentianæ rubrae v. luteæ $v$. majoris; Ger. Enzianwurzel, Bitterwurzel, Rother Enzian; Fr. Gentiane (Codex), Racine de gentiane jaune; bitter, tonic. [The smaller roots also of $(c)$ G. Panuónica Scopoli, Austria; (d) G. punctáta I., Alps to the Balkans, and (e) G. purpúrea L., Alps, Carpathian Mountains and Norway, are collected with those of $(i$. lutea, and are recognized in some of the European pharmacopoeias.]

f. G. quinquefólia L. (G. quinqueflora Lam.). Five flowered Gentian, Stiff Gentian, Ague-weed, Gall-weed, Blue lientian. Plant bitter, tonic.

g. G. Saponária L. (G. Catesbæi Walt., not of Elliott). ()ntario to Florida and west to Louisiana and Minnesota. Soapwort Gentian; Marsh or Rough Gentian, Calathian Violet, Harvestbells. (This and other species are used under various names such as American Gentian, Blue or Southern Gentian, Sarnpson Snakeroot for the same uses as the European Gentian.)

Other species of indigenous gentians are (h) (t. acuta Michx. (perhaps only a variety of the Old World G. Amerella L.), Northern (Yentian, Baldmoney (Bawdmoney), Bastard Gentian:

(i) (x. Andréwsii Griseb. (G. alba Muhl.), Closed or Blind Gentian, Cloistered-heart, Barrel Gentian, Bottle Gentian; (j) G. detónsa Rottb. (G. serrata Gunner), Smaller Fringed Gentian; (k) G. Ellióttii Chapm. (G. Catesbrei Ell., not of Walt., G. scaberrima Kusnezow), Elliott's Gintian; (1) G. flávida A. Gray (G. alba A. Gray 1848 not Mubl. 1S1s), Yellowish Gentian; (m) G. Porphyrio J. F. Gmel. ( $(x$. purpurea Walt. not L., G. angustifolia Michx.), One-flowered Gentian; (n) G. villósa L. (G. ochroleuca Froel.), Striped Gentian, Straw Colored or Marsh Gentian. [There has been much confusion in the nomenclature, scientific as well as popular of our gentians.]

883. GERÁNIUM, L. Geranium, Cranesbill. (ieraniaceae.

From Greek, "crane", alluding to beak of fruit, an ancient plant name. Perennial herbs. About 175 species, temperate regions; 21 in $\mathrm{U}$. $\mathrm{S}$. 
a. G. maculátum L. Canada and eastern U. S., south to Georgia. Cranesbill, Spotted or Wild Cranesbill, Storksbill, Spotted or Wild Geranium, Alum-root, Alum-bloom, Chocolate-flower, Crowfoot*, Dove-foot, Old-maid's-night-cap, Shame-face; Ger. Fleckstorchschnabel; Fr. Bec-de-grue tacheté, Geranium maculé, Pied-de-corneille; Sp. Geranio. Rhizome; Geranium, U. S. P., astringent.

b. G. Robertiánum L. Canada to New Jersey, west to Missouri and Manitoba, also in Europe, Asia and northern Africa. Herb Robert, Fox Geranium, Mountain Geranium, Deathcome-quickly, Dragon's-blood*, Red-Robin, Red-bird, Redbird's-eye, Redshanks, Rock-weed, Sailor' s-knot, Stinking Cranesbill, Wren's-flower, Jenny-wren; Ger. Ruprechtskraut, Bockstorchschnabel; Fr. Herbe à Robert. Herb astringent, discutient, diuretic.

884. GERÁRDIA, L. Gerardia. Scrophulariaceae. Named for John Gerarde, author of the Herbal, d. 1612. Herbaceous or suffruticose plants with showy flowers. About 40 species, New World; 20 in U. S. See also Dasystoma.

885. GÉUI, L. - Avens. - Rosaceae. The ancient Latin name. Syn. Stylipus, in part. Perennial herbs with yellow, white, rarely purple flowers. About 40 species, mostly in north temperate zone; 17 in U. S.

a. G. ciliátım Pursh (G. triflorum Pursh.). British America and northern U. S. Long-plumed Purple Arens, Johnny-smoker, Prairie-smoke.

b. G. rivále L. Northern Europe, Asia and N. America, south to Pennsylvania and Colorado. Water Arens, Purple or Drooping A rens, Evans-root, Chocolate-root, Indian Chocolate, Cureall, Maidenhair*, Throat-root. Rhizome and rootlets; Rad. caryophyllatæ ayuaticæ, Rad. benedictæ sylvestris; Ger. Sumpfnelkenwurzel, Wasserbenediktenwurzel; Fr. Racine de benoite aquatique; astringent, tonic, stomachic.

c. G. stríctum Ait. (G. Canadense Murr., not Jacq.). British America, south to New Jersey and Arizona. Yellow Avens, Yellow Bennet. Black-bur (local U. S.).

d. G. urbánum L. (G. caryophyllatum Pers.). Europe. European Arens (Avance, Evans), Bennet, Herb Bennet or Bennett, Blessed herb, Clove-root, City Avens, Yellow or Wood Avens, Goldy-harefoot, London-basket, Star-of-the-earth; Ger. Nelkenwurz, Benedictenwurz; Fr. Benoite (Codex). Rhizome; Rad. (Rhizoma) caryophyllatæ, Rad. gei. Properties of (b).

e. G. Virginiánum L. Canada and northeastern U. S. Rough Avens White Avens, Red-root, Throat-root, Chocolate-root, (this name applied to other species having a similarly colored root), American Bennet. These names apply equally, except the first to (f) G. Canadénse Jacq. (G. album Gmel. (Kew), G. Carolinianum Walt.), which is properly American White Avens. Properties of (b). 
886. GífOLA, Cass.

Cotton Rose, etc.

Compositae.

Anagram of Filago. Syn. Filago, Gnaphalium, in part. White-woolly herbs, resembling Filago. About 10 species, warm and temperate regions; 5 in U. S. [Heller catalogues the species as Filago.]

a. G. Germánica (L.) Dumort (Filago Germanica L.). Europe, nat. in U. S. Cotton Rose, Chafe-weed, Cudweed, Childing Cudweed, Down-weed, Herb Christopher*, Hoarwort, Owl's-crown; formerly called Herba impia. Plant reputed vulnerary.

887. GIGARTÍNA, Stackh. Sea Moss. Gigarïineae. Syn. Sphærococcus, Mastocarpus, in part. Seaweeds related to Chondrus. About 50 species, widely distributed.

a. G. mamillósa Greville (S. mamillosus Argardh, M. mamillosus Kutzing). Coasts of north Atlantic. Irish Moss, in part. Plant; Chondrus, U. S. P., in part. See Chondrus crispus.

88s. GílLI, R. \& P. • Gilia. - Polemoniaceae. Named for Philip Gil, Spanish botanist. Syn. Cantua, Collomia, in part. Herbs, some ornamental. About 75 species, New World; 63 in U. S.

889. GíNKG0, L. 1771. Maidenhair tree. Taxaceae. Vernacular Japanese name. Syn. Salisburia, Sm. 1797. A tree with leaves resembling frondlets of an Adiantum.

a. G. bilóba L. (S. adiantifolia Sm.). China and Japan, and often planted as a shade tree. Gingko tree, (Ginkgo, Gingo), Maidenhair tree; Chinese name Yin-hing (i. e. Silver Apricot). Seeds, called by the Chinese Pa-koo, almond-like, esculent yield a fixed oil. 890. GITHóPSIS, Nutt.
Inconspicuons annuals. Two species, both of California.

891. GLADÍOLUS, L. Sword-lily; Iridaceae. From Latin, dim. of gladius, a "sword"; Herbs from fleshy corms. About 90 species, Africa and the Mediterranean region.

a.G. édulis Burchell. Sonth Africa. Corms edible, tasting like chestnuts when roasted.

b. G. palústris Gaudin (G. Boucheanus Schlecht.). Sword-lily, Round Ramson, Round Mandrake, Corn Flag; Ger. Runder Allermannsharnisch, Siegmarswurz. Corms, Bulbi victorialis rotundi, Bulbi gladioli; vulnerary.

892. GLAÚCIUM, Juss. Horned Poppy. „Papaveraceae. Name from Greek, alluding to "glancous", foliage. Syn. Chelidonium, in part. Glaucous herbs with yellow latex. About $\hat{6}$ species, mostly of Mediterranean region.

a. G. Glańcinm (L.) Karst. (Chelidonium Glaucium L., Gr. flavum Crantz (Kew), G. luteum Scop.). Southern Europe, adv. in U. S. Yellow Horned Poppy, Yellow Sea Poppy, Horn Poppy, Bruise-root, Bruisewort, Spatmore, Squatmore, Sea Celandine; Ger. Hornmohn; Fr. Pavot cornu. Fresh plant or juice of plant purgative, hydragogue; (b) G. corniculátum Curtius has similar properties. 
893. GLAÚX, L. Sea Milkwort, etc. Primulaceae. The ancient name of Milk-vetch, meaning "sea green". Small but rather pretty herbs of salt marshes. Two species, one of north temperate zone, one of S. America.

a. (4. marítima L. Northern Europe, Asia and N. America. Sea Milkwort, Black Saltwort, Sea Trifoly; Ger. Milchkraut; Fr. Gilauce.

s94. GLECHÓMA, L. - Ground Ivy. - Labiatae. Ancient Greek name of a Labiate plant. Syn Nepeta, in part. Creeping herbs. About 6 species, Old World.

a. (i. hellerácea L. (Nepeta Glechoma Benth., N. hederacea B. S. P.). Europe, widely nat. in U. S. Ground Ivy, Field Balm, Gill-over-the-ground, Alehoof or Tanhoof (so called from use in brewing), Cat's-foot, Cat's-paw, Creeping-Charlie, Crowvictuals, Gill-ale, Gill-go-by-the-ground, Gill-run, Hay-hove, Hay-maids, Hedge-maids, Hove, Robın-run-away, Robin-runin-the-hedge; Ger. Gundelreben; Fr. Lierre terrestre (Codex). Her $b$ formerly reputed stimulant tonic, etc.

895. GLEDÍTSIA, L. 1742. (Gleditschia). Caesalpinaceae. Named for J. D. Gleditsch, German botanist, d. 1786 . Syn. Melilobus, Mitch. 1748. Thorny trees. About 5 species, N. America and Asia; 2 in U. S.

a. (4. aquática Marsh. (G. monosperma Walt. (Kew), G. Carolinensis Lam.). Indiana and southward, west to Missouri. Water Locust, Swamp Locust.

b. G. triacánthos L. (G. spinosa Marsh. G. brachycarpa, Pursh., G. Meliloba Walt., (k. heterophylla Raf.). Michigan to Georgia, west to Texas and Kansas. Honey Locust, Sweet Locust, Thorn or Black Locust, Honey, Honey-shucks, Sweetbean, Three-thorned Acacia. Pods contain a saccharine pulp.

\$96. GLÍNUS, Löfl. - Glinus. Syn. Mollugo, in part. Herbs, rarely shrubby. About 6 species; tropical and subtropical regions; 1 in U. S.

99. GLOBULÁRIA, L. Globularia. Globulariaceae. From Latin, a "little ball". Herbs or shrubs. About 15 species, Mediterranean region.

a. (x. Álypum L. (G. virgata Salisb.). Southern Europe. Wild Senna, European Wild Senna. Leaves used as a substitute for true senna.

\$9๙. GLOSSOPÉTALON, Gray. (Glossopetalum). Sapindaceae. From Greek, "tongue" and "petal". Spiny shrub. One species, U. S. and Mexico.

8!99. (YIOT'TÍDIUM, Benth. Glottidium. Papilionaceae. From Greek, "throat-like". Syn. Sesbania, in part. Herbs with pinnate leaves. One species in southern U. S. 
900. GLYCINE, L. Soy Bean, etc.

Papilionaceae. Syn. Dolichos, Soja, in part. Herbs, mostly climbing or prostrate. About 16 species, tropical Asia, Africa and Australia.

a. G. híspida Maxim. (S. hispida Moench). China and Japan. Soy Bean, Sahuca Bean, White Gram, called in Japan Miso. Seeds esculent, used for preparation of Japanese Soy (Sooja); (b) G. Sója (L.) S. \& Z. (D. Soja L.). is said to be a distinct species, but probably used in the same manner (Mueller).

901. GLYCósMA, Nutt. Glycosma. Úmbelliferae. From Greek, "sweet smelling". Syn. Osmorrhiza, Myrrhis, in part. Herbs with anisate odor. Two species, southwestern U. S.

902. GLYCYRRhÍzA, L. 173i Licorice. Papilionacene. The Greek name, meaning "sweet root". Syn. Liquiritia, Medic, 1787. Perennial herbs with sweet roots. About 20 species, north temperate zone, $S$. America and Australia; 1 in U. S.

a. G. echináta L. Southern Europe. Sicilian Licorice, C'alabrian Licorice. Properties of (b).

b. (*. glábra L. (G. officinalis Lepech. L. officinalis Moench., G. vulgaris Gueld.). Southern Europe to central Asia. Licorice (Liquorice, Lickorice, Lickerice. Licourize). Root and underground stem; Glycyrrhiza, L. S. P., Glycyrrhiza radix Br. R. liquiritiæ, P. G.; K. glycyrrhizæ hispanicæ; Licorice-root, Sweet-root, Sweet-wood, Spanish Juice-root or Juice-wood; Ger. Süssholz, Süssholzwurzel, Lakritzenholz; Fr. Réglisse (Codex), Bois de réglisse, Bois doux, Racine douce; Sp. Orozuz, Regaliz, Palo dulce; demulcent, has the property of masking bitterness of quinine.

c. G. glandulífera Wald. \& Kitt. (G. glabra, var. glandulifera Regel \& Herder). Hungary, Turkey, west to Turkestan. Probably only a variety of (b). The source especially of Russian licorice-root.

d. G. lepidóta Pursh. British America, south to Iowa and California. Wild Licorice, American Licorice.

903. GLYPTOPLEÚRA, Eaton. Glyptopleura. Cichoriaceae. From Greek, "carved rib". Dwarf winter annuals with flowers disproportionately large. Two species, deserts of "thah and Nevada.

904. GNAPHÁLICM, L. Cudweed, Everlasting, etc. Compositae. Old Greek name of a plant, meaning "woolly". Woolly herbs with small flower heads. About 120 species, widely distributed; 18 in U. S. Sxnonyms are Chaff-weed, Petty ('otton; Ger. Katzenpfötchen, Immerschön: Fr. Pied de chat, Immortelle; Sp. (iordolobo. 
a. G. obtusifólium L. (G. polycephalum Michx.). Canada to Florida and west to Texas and Manitoba. Life-everlasting, Sweet Balsam, Field or White Balsam, Old-field Balsam, Balsam-weed, Chafe-weed, Everlasting, Sweet-scented or Fragrant Life-everlasting, Feather-weed, Fuzzy-guzzy, Indian-posy Moonshine, Poverty-weed, Rabbit Tobacco. Herb aromatic, anodyne, antiseptic.

b. G. sylváticum L. Europe, northern Asia and N. America, where it is perhaps only naturalized. Wood Cudweed, Golden Motherwort, Chafeweed, Owl's-crown. Flowering tops diaphoretic (in hot infusion.)

c. G. uliginósum L. Europe and northern Asia, nat. (or perhaps indigenous) in northern U. S. Low Cudweed, Mouse-ear, Dysentery-weed, Marsh Cudweed, Wartwort, Small Life Everlasting. Herb demulcent, stomachic.

905. GNAPHALÓDES, A. Gray. Gnaphalodes. Compositae. Fron Greek, "resembling Gnaphalium". Syn. Micropus, Rhyncolepis, in part. Low floccose-woolly annuals. Three species in California.

906. GOCHNÁTIA, H. B. K. Gochnatia. Compositae. Named for F. C. Gochnat of Strasburg. Syn. Moquinia, in part. Shrubby plants with coriaceous leaves. About 10 species, New World; 1 in Texas.

907. G0DÉTIA, Spach. - Godetia. - Onagraceae. Syn. Oenothera, in part. Annuals resembling Oenothera, but with purple or pink, instead of yellow flowers. About 20 species, New World; 16 in U. S. (Pacific border.)

908. GOMPHOCÍ RPUS, R. Br. Gomphocarpus.Asclepiadaceae. From Greek, "club-fruit". Syn. Acerates, in part. Shrubs or herbs. About 50 species, mostly of Africa and Arabia; 2 in California.

909. GOMPHRÉXA, L. (Gomphraena). A maranthaceae. Herbs or sub-shrubs. About $9($ species, tropical America, a few in Asia and Australia; 5 in U. S.

910. (GONóLOBUS, Michx. (Gonolobium). Asclepiadacere. From Greek, "angle pod". Shrubs and shrubby climbers. About 85 species, New World. See Vincetoxicum and Mesadenia.

a. G. tetrágonus DC. Cundurango de paloma of Malacatos. See Echites hirsuta. Bark reputed alterative.

911. (GORDÓNIA, Ellis. Loblolly Bay. Theaceae. Named for James Gordon, London nurseryman, 18th Century. Syn. Hypericumt, in part. Evergreen trees or shrubs. A bout 16 species, $\mathrm{N}$. America and eastern Asia, 1 in U. S.

a. (x. Lasiánthus (L.) Ellis (Hypericum Lasianthus L.). Virginia to Florida. Loblolly Bay, Tan Bay, Holly Bay, Bay Holly, Black Laurel, Swamp Laurel. Bark astringent, used for tanning. 
912. GOSSÝPIUN, L: - Cotton.

Ancient Latin name, of eastern origin. Shrubs or small trees. About 15 species, warmer regions of Old and New World; 2 cult. in U. S.

a. Gr. arbóreum L. India to Arabia. Cotton tree, New Orleans Cotton. (G. sanguineum Hassk. of Java is referred by Mueller to this species, which does not in fact form a real tree.)

b. G. Barbadénse L. (Includes according to Bentley and Trimen G. vitifolium Lam., G. Peruvianum Car., G. punctatum Schum. \& Thou., G. acuminatum Roxb. and G. religiosum Parlatore, not L. ). Tropical America, cult. in southern U. S. Yields the Sea Island cotton.

c. G. herbáceum L. India, much cult. in tropical Asia and southern Europe. Regarded by Seeman as a variety of (a). Common Cotton of the Old World. Nankin Cotton is a variety with tawny fibre. Bark of the root of this and of other species; Cossypii radicis cortex, U. S. P., Cotton-root bark; Ger. Baumwollwurzelrinde; Fr. Écorce de la racine de cotonier; emmenagogue, parturifacient. Seeds of the various species, Semina gossypii, Sem. bombacis, source of cotton-seed oil, Oleum goss ypii semin's, U. S. P. Hairs investing the seeds constitute Cotton; Gossypium Br. (Gossypium puriticatum, U. S. P.), Bombyx, Pili (Lana s. Lanugo) gossypii, Lana gossypina; Fr. Coton (Codex); used for dressing wounds, etc., as well as for textile fabrics.

d. G. hirsútum L. [G. herbaceum L. (Kew)]. Tropical America, cult. in U. S. Yields the Upland or Short-staple cotton.

e. G. religiósum L. (G. herbaceum L. (Kew), G. Peruvianum Cav.). Trupical S. America. Source of the Peruvian and Brazilian long-staple cotton, called also Kidney cotton. The plant forms a small tree.

913. GOUÁNIA. Jacq. (Gouana). Chew-stick. Rhamnaceae. Climbing or diffuse shrubs. About 50 species, tropical regions, especially of New World; 1 in U. S.

a. G. Domingénsis L. West Indies and Brazil. Chew-stick, Chaw-stick. Wood stomachic, tonic, used for cleansing the teeth. Bark aromatic, tonic.

914. GRATÍOLA, L. Hedge Hyssop. Scrophulariaceae. From ancient name gratia Dei of (a). Hairy perennial herbs. About 25 species, temperate and warm regions; 13 in U. S.

a. G. officinális L. Europe. Hedge Hyssop, Herb-of-grace (Gratia Dei); Ger. Gnadenkraut, Gottesgnadenkraut, Wildaurin; Fr. Gratiole (Codex); Sp. Graciola. Flowering herb, H. gratiolw, also root, drastic cathartic, anthelmintic. The closely related (b) G. Virginiána L. (G. officinalis Michx. not L., G. Carolinensis Pers. ), of British America and U. S., is called Water Jes amine; (c) G. aúrea Muhl., of Canada and eastern U. S., Golden Hedge-Hyssop, is called also Goldenpert. 
815. GRÁYIA, H. \& Arn. (Graya). Grayia. Chenopodiaceae. Named for Asa Gray, the distinguished American botanist. Undershrubs. Two species, Colorado to California.

916. GREENÉLLA, Gray. Greenella. Compositae. Named for Rev. Edward Lee Greene, the discoverer. Slender low winter-annuals. 'Two species, Arizona.

917. GREVÍLLEA, R. Br. Silk Oak, etc. Proteaceae. Named for R. K. Greville, English botanist, d. 1866. Includes the older genera Lysanthe and Stylurus of Salisbury. Trees and shrubs. About 160 species, Australia and New Caledonia.

a. G. robúsła Cunningham. East Australia. Silk Oak, Silk-bark Oak, Silky Oak.

918. GRINDÉLIA, Willd. Gum-plant, Tar-weed. Compositae. Named for Prof. H. Grindel of Riga, d. 1836. Syn. Donia, in part. Herbacesus or suffruticose perennials with rather large flower heads (yellow). About 35 species, western N. and S. America; 25 in U. S.

a. G. robústa Nutt. California. Grindelia, Gum-plant. Flowering tops of this and of (b); Grindelia. U. S. P.; balsamic, antispasmodic, used for relief of dyspnøeia.

b. G. squarrósa (Pursh) Dunal (D. squarrosa Pursh). Central U. S. to Mexico. Broad leaved Gum-plant; (c) G. glutinósa Dunal, Mexico, nat. in California, Calancapatle de pueblo (Mexico) and (d) G. hirsútula H. \& Arn., Pacific coast of U. S., have properties of $(\mathbf{a})$.

919. GUÁJACUM, L. (Guaiacum). Guaiac. Zygophyllaceae. From vernacular, West Indies. Trees with pinnate leaves and blue flowers. About 10 species, tropical America; 1 in Florida. See Porliera.

a. G. officinále L. (G. bijugum Stnkes). West Indies and northern S. America. Guallacan tree and (b) G. sánetum L. (G. multijugum Stokes). West Indies, southern Florida and northern S. America. Heart wood; Gualac! Iignum. U. S. P., Br., Lignum guajaci v. benedictum v. sanctum, Lignum vitæ, Guaiacum-wood, Guaiac- or Gaiac-wood, Pock-wood; Ger. Guajakholz, Pockholz, Franzosenholz; Fr. Bois de gayac (Codex); Sp. Guayaco, Palo Santo; alterative, antiarthritic, emmenagogue.

920. GUARDIOLA, L. Guardiola. Compositae. Named for a Spanish botanist. Perennial herbs with white flowers. Four species, Mexico and bordering territory; 1 in U. S.

921. GUÁREA, Allem. 1771. Cocillaña. Meliaceae. Vernacular name. Cuba. Syn. Syncarpus, in part. Trees or shrubs with pinnate leaves. About 70 species, tropical America and Africa.

a. G. Rúsbyi (Brit.) Rusby (S. Rusbyi Brit.). Cocillaña. Root has properties of Ipecac. 
922. GUETTÁRDA, L.

Velvet-seed.

Rubiaceae.

Shrubs or small trees. About 50 species, tropical America, one of wide distribution; 2 in U. S. (a) G. ellíptica Sw., West Indies to Florida, is called Velvet-seed.

923. GUILÁNIINA, L. (Guilandia). Bonduc. Caesalpinaceae. Syn. Cæsalpinia, in part, some botanists referring all the species to that genus. Prickly trailing shrubs. Abcut 5 species, tropical regions.

a. G. Bónduc L. (C. Bonduc Roxb., G. glabra Mill.). Florida and most tropical coasts. Seeds, Yellow Nicker-nuts or Nickarnuts, Bonduc-nuts (from Arabic, bondog, a necklace), Beazornuts, Mulucca Bean. Properties of (b).

b. G. Bonducélla, L. (C. Bonducella Roxb., G. aculeata Salisb.). Tropical shores generally. Seeds, Gray Nicker-nuts, Nickerseeds, Gray Bonduc-nuts or Beazor-nuts; bitter, tonic, febrifuge. Source of Nicker-seed oil, used for embrocations. Bark tonic.

924. GUILLEMÍNEA, H. B. K. (Guilleminia). Amaranthaceae. Herbs. Three species, perhaps reducible to one; 1 in Texas.

925. GUIZótIA, Cass. 1827. Til-seed, etc. Compositae. Named for the French historian, F. P. G. Guizot, d. 1874. Syn. Werrinuwa, Heyne 1814; Verbesina, in part. Herbs related to Heliopsis. About 5 species, tropical Africa and Asia.

a. G. Abyssínica Cass. (G. oleifera DC., V. sativa Roxb.). India and eastern Africa. Ramtil, Niger-seed, Black Til-seed, Oilseed. Seeds yield a bland fixed oil.

926. GUTIERRÉZIA, Lag. Brown-weed. Compositae. Named for Gutierrez, a noble family of Spain. Syn. Solidago, in part. Herbs or sub-shrubs resembling Golden-rod. About 20 species, New World; 6 in western U. S.

927. GYMÍNDA, Sarg. - Gyminda. Celastraceae. Anagram of Myginda, an allied genus. Shrub. One species in southeastern U. S.

928. GYMNÁNTHES, Swz. Gymnanthes. Euphorbiaceae. From Greek, "naked flowered". Syn. Excœecaria, in part. Shrubs. About 10 species, tropical America, chiefly in West Indies; 1 in U. S.

929. GYMNÉMA, R. Br., not Endl. Gymnema. Asclepiadaceae. Syn. Asclepias, in part. Erect or climbing shrubs. About 30 species, warmer regions of Africa, Asia and Australia.

a. G. sylvéstre R. Br. (A. geminata Roxb.). Africa and Australia. Root a reputed antidote to snake poison. Leaves when chewed destroy for a time the sense of taste.

930. GYMYÓCLADUS, Lam.

Caesalpinaceae.

From Greek, "naked branched", i, e. not thorny. Syn. Guilandina, in part. Trees with showy white flowers. Two species, one of China, one of U. S. 
a. G. dioíca (L.) Koch (G. Canadensis Lam. (Kew), G. dioica L.). Ontario to Temnessee, west to Indian Territory and Nebraska. Kentucky Coffee tree, American Coffee tree, Chicot (Canada), Kentucky Mahogany, Nicker or Nickar tree. Seeds, Coffee-nuts, American Coffee-beans, formerly used as a substitute for coffee.

931. GYMvográmia, Desv. Gold Fern, etc. Polypodiaceae. From Greek, "naked sori". The genus includes the ornamental Gold and Silver Ferns. About 30 species, especially of New World; 2 in U. S.

932. GYMNOLÓMIA, H. B. K. (Gymnoloma). Compositae. From Greek, "naked border", alluding to absence of pappus. Perennial herbs, some shrubby, resembling Helianthus. About 25 species, warmer regions of New World; 4 in U. S.

933. GYMNOSPÉRMA, Less. Gymnosperma. Compositae. From Greek, "naked seed", pappus being absent. Glutinous shrubby plants. Two species, central N. America; 1 in U. S.

934. GYYOCÁRDIA, R. Br. 1819. Chaulmugra. Bixaceae. From Greek, "woman heart". Syn. Chalmoogra, Roxb. 1814, Hydnocarpus, Chilmoria, in part. An ornamental dioecious tree. One species.

a. G. odoráta R. Br. (Chal. odorata Roxb. (apparently the older name), H. odoratus Lindl., Chil. dodecandra Buch Ham.). India to Malacca. Chaulmugra (Chalmoogra). Seeds yield Chaulmugra oil, used in cutaneous diseases.

935. GYPSÓPHILA, L. Gypsophyll. Caryophyllaceae. From Greek, "chalk loving". Herbs. About 60 species, Old World; 2 nat. in U. S.

a. G. paniculáta L. Europe and Asia, adv. in U. S. Tall Gypsophyll, Babies'-breath, Mist.

b. G. Strúthium L. Mediterranean region. Levant Soap-root, Spanish Soapwort. Root, R. saponariæ levanticæ v. hispanicae v. ægypticæ, R. lanariæ; Ger. Spanische Seifenwurzel; detergent, containing saponin.

936. GYRósTaCHYS, Pers. 1807. Ladies'-tresses. Orchidaceae. From Greek, "twisted spiize". Syn. Spiranthes, L. C. Rich. 1818; Neottia, Limodorum, Ophrys, in part. Terrestrial orchids with flowers (often fragrant) more or less spirally arranged on the spikes. About 80 species, tropical or temperate regions; 13 in U. S.

a. G. cérnua (L.) Kze. (S. cernua L. C. Rich. (Kew), O. cernua L.). Canada and eastern U. S. Nodding or Drooping Ladies'-tresses, Wild Tuberose, Screw- auger, names not confined to this species.

b. G. grácilis (Bigel.) Kze. (S. gracilis Beck. (Kew), N. gracilis Bigel.). Canada and eastern U. S. Slender Ladies'-tresses, Corkscrew plant, Twisted-stalk. 
937. GYROTHÉCA, Salisb. 1812. Red-root. Haemodoraceae. From Greek, "round fruit". Syn. Lachnanthus, Ell. 1816. Perennial herb with red fibrous roots. One species, U. S. and West Indies.

a. G. capitáta (Walt.) Morong (Anonymos capitata Walt., L. tinctoria Ell (Kew), G. tinctoria Salisb.). Swamps. Massachusetts to Florida and Cuba. Red-root, Indian or Carolina Red-root, Indian Paint-root, Spirit-weed, Wool-flower.

938. HABENíRIA, Willd. Orchis*. Orehidaceae. From Latin habena, a"rein" or"strap". Syn. Gymnadenia, Platanthera, Orchis, in part. Terrestrial orchids. About 400 species; 37 in U. S.

a. H. conópsea Benth. (G. conopsea R. Br.), and (b) H. bifólia R. Br. (P. bifolia Reich.) of Europe are among the orchids yielding salep, the palmately divided tubers of (a) called Rad. palmæ-Christi; demulcent, nutrient. See Orchis.

Showy indigenous species are (c) H. ciliáris (L.) R. Br., Yellow Fringed-orchis; (d) H. grandiflóra (Bigel.) Torr. (H. fimbriata (Wild.) A. Gray), Purple Fringed-orchis, Large or Early Purple Fringed-orchis, Tattered-fringe, Meadow Pink; (e) H. lencophaéa (Nutt.) A. Gray, Prairie White or Greenish Fringed-orchis; (f) H. peramoéna A. Gray, Fringeless or Great Yurple-orchis; (g) H. psychódes (L.) A. Gray (O. fimbriata Ait. not Willd.), Smaller Purple Fringed-orchis, Pink Fringed-orchis, Flaming Orchis, Soldier's-plume. Inconspicuous species are $(h)$ H. orbiculáta (Pursh) Torr., called Heal-all* and (i) H. bracteáta (Willd.) R. Br., Long-bracted Orchis or Vegetable Satyr.

939. HAEиÁNTHUS, L. Blood-flower. Amaryllidaceae. From Greek, "blood flower". Scapose bulbous plants. About 30 species, Africa; called also African Tulip.

a. H. coccíneus L. (H. coarctatus Jacq., H. latifolius Salisb.). Southern Africa. Cape Tulip, Salmon-leaved Blood-flower. Bulb diuretic, antispasmodic.

940. HAEMATÓXYLON, L. (Haematoxylum). Caesalpinaceae. From Greek, "blood wood". Trees of medium size. One or two species, tropical America.

a. H. Campechiánum L. Central America, nat. in West Indies. Logwood tree. Heart-wood; Logwond, Block-wood, Campeachy-wood: Ha:omatxylon, U. S. P., Hæmatoxyli lignum,Br., Lignum campechianum v. cœruleum; Ger. Campescheholz, Campecheholz; Blauholz; Fr. Bois de Campêche, Bois d'Inde (Codex), Buis de sang; Sp. Palo de Campeche; astringent, antiseptic; a valuable dyeing material.

941. HAGÉNIA, J. F. Gmel. 1791. Named for K. Gottfried Hagen. Syn. Bankesia, Bruce,1790, Cusso. Rosaceae. not Banksia, Forst. 1776; Brayera, Kunth 1824. A diœcious tree with pinnate leaves. 
a. H. Abyssínica (Bruce) Gmelin (Brayera anthelmintica Kunth (Kew), Bankesia Abyssinica Bruce). Abyssinia. Kousso tree. The female inflorescence; Cusso (Cosso, Kusso, Kooso): Cusso, U. S. P., Br.; Flores Koso, P. G., Flores brayeræ (anthelminticæ); Ger. Kosso, Kusso, Cousso; Fr. Cousso (Codex); anthelmintic, tænicide.

942. H^LóPHILA, Thou. Halophila. Valisneriaceae. From Greek, "sea loving". Inconspicuous annuals growing in salt marshes. About 5 species, widely distributed; 1 in U. S.

943. HALYMÉNIA, Agardb. Dulse. Rhodymeniaceae. From Greek, "sea" and "moon" or "month". Syn. Fucus, Rhodymenia, Sphærococcus, in part. Seaweeds. About 20 species, warmer seas.

a. H. édulis (L.) Agardh (F. edulis L., R. edulis Grev., S. edulis Kütz) and (b) H. palmátıs (L.) Agardh (F. palmatus L.). Shores of Atlantic and Mediterranean. Dulse, Dallish. Used for food in Shetland and elsewhere.

944. HAMAMÉLIS, L. Witch Hazel. Hamamelidaceae. Greek name of a kind of "medlar", flower and fruit being "borne together". Shrubs, blossoming in autumn. Three known species, 2 of Japan; 1 in U. S.

a. H. Virginiána L. (including many synonyms that are mere varieties.) Nova Scotia to Florida and west to Texas and Minnesota. Witch Hazel, Wych-hazel, Snapping Hazel, Striped Alder, Spotted Alder, Winter-bloom, Tobacco-wood; Ger. Zauberhasel; Fr. Hamamélis. Leares; Hamamelis, U. S. P., Hamamelidis folia Br.; Bark, Hamamelidis cortex, Br.; astringent, emollient, vulnerary. A distilled extract is popularly known as Pond's Extract.

945. HAMÉLIA, Jacq. - Hamelia - Rubiaceac. Named for M. du Hamel, French botanist. Shrubs of tropical America. About 12 species; 1 in U. S.

946. HANCÓRNIA, Gomez. Mangaba. Apocynaceae. Small tree or shrub. One species, Brazil; (a) H. speciósa Gomez (H. Gardneri Miers, H. pubescens Nees \& Mart.). Yields the Mangabeira rubber. Fruit (when fully ripe) edible, called mangaba or mangava. See Hevea.

947. HAPLOÉSTHES, Gray. Haploesthes. Compositae. From Greek, "simple garment"' the involucre of few bracts. Somewhat shrubby plant of saline regions. One species, Texas to Colorado.

948. HAPLóPHYTON, DC. Haplophyton. Apocynaceae. From Greek, "simple plant", alluding to absence of calycine glands. Perennial herb. One species, Arizona to Guatemala and Cuba.

949. HARBOÚRIA, C. \& R. Harbouria. Umbelliferae. Syn. Cicuta, Thaspium, in part. Herb with yellow flowers. One species, Colorado. 
950. HARDENBÉRGIA, Benth. Victorian Lilac. Papilionaceae. Named for Countess Hardenberg, sister of Baron Hugel. Woody climbers. Three known species, Australia.

a. H. monoplílla Benth. Australia. Victorian Lilac, Australian Sarsaparilla, Spurious or Native Sarsaparilla. Root, a substitute for Sarsaparilla.

951. HARPAElí RPUS, Nutt. Harpæcarpus. Composi iae. Syn. Madia, Hemizonella, in part. Herbs, closely related to Madia. Three species, western U. S.

952. HARPAGONÉLLA, Gray. Harpagonella. Boraginaceae. Dim. of Latin harpago, a "grappling hook". Insignificant annual. One species, California to Arizona.

953. HARPAGóPHYTUM, DC. Grapple-plant. Pedaliacene. From Greek, "grapple plant", the fruits furnished with sharp hooks. Syn. Uncaria, in part. Hoary procumbent herbs. Four species, Africa; (a) H. procúmbens DC. (U. procumbens Burch.) is the (Grapple plant, Grapnel plant or Wait-a-bit Thorn of South Africa.

954. HARTMÁNIA, Spach. Primrose. Onagraceae. Named for Emanuel Hartman of Louisiana. Syn. Oenothera, in part. Herbs with diurnal flowers, red, white or purple. About 10 species, New World; 3 in U. S.

955. HARTWRí(łHTIA, Gray. Hartwrightia. Compositae. Herb. One species in southern U. S.

956. HaSTÍNGSIA, S. Wats. Hastingsia. Liliaceae. Herbs closely related to Schœnolirion. Two species, California.

957. HAZÁRDIA, Greene. Hazardia. Compositae. Syn. Aplopappus, in part. Herbs. Six species in southwestern U. S.

958. HeCístocLeIs, Gray. Hecastocleis. Compositae. From Gretk, "each shut in", each flower having an involucre of its own. Low shrub with prickly leaves. One species, Nevada.

959. HÉCHTIA, Klotsch. Hechtia. Bromeliaceae. Herus with spiny-toothed leaves. About 6 species, mostly of Mexico; 1 in Texas.

960. HEDEÓMA, Pers. Pennyroyal, etc. Labiatae. Frorn Greek, "sweet smelling". Syn. Melissa, Cunila, Ziziphora, in part. Aromatic herbs. About 15 species, New World; 12 in U. S.

a. H. pulegeoídes (L.) Pers. (M. pulegeoides L. 1753, C. pulegeoides L. $1762, Z$. pulegeoides Desf.). ('anada to Florida and west to Nebraska. Pennyroyal, American or Mock Pennyroyal, Squaw Mint, Tick-weed, Stinking Balm; Ger. Amerikanischer Polei; Fr. Pouliot Americain. Leares and tops, Hedeoma, U. S. P.; aromatic, carminative, emmenagogue; source of oil of Pennyroyal; also used to drive away mosquitoes. 
b. H. thymoídes Gray. (H. piperita Gray, not Benth.) of Texas has properties of (a) but is less disagreeable; (c) H. piperíta Benth., not A. Gray, of Mexico resembles peppermint and is used in the same manner.

961. HÉDERA, L. - Ivy. - Araliaceae. The classical Latin name, "clinging". Evergreen climbers. Two species, one of Euro-Asia, one of Australia.

a. H. Hélix L. (H. poetica Salisb.). Europe and Asia, widely cult. Ivy (Ivory, Hyven), English Ivy; Barren, Black, Creeping or Small Ivy, Woodbind, Bindwood (Scotland); Ger. Epheu (gemeiner), Mauerepheu. Exudate, Ivy gum, Gumini resina hederæ, Gummi hederæ (arboreæ), emmenagogue, astringent. Berries emeto-cathartic, narcotic. Wood formerly used for issue peas.

962. HEDÝSARUM, L. Hedysarum. Papilionaceae. The Greek name of a Vetch, "sweet Broom". Perennial herbs, some shrubby. About 60 species, north temperate zone and northern Africa; 6 in U. S. (a) H. Gangéticum Auct. India. Root used like ipecac in dysentery.

963. HÉ́MIA, Link. \& Otto. Heimia. Lythraceae. Named for Dr. Heim, physician, of Berlin. Syn. Nes-æa, in part. Shrubs with yellow flowers. Two species, New World; 1 in southern U.S.

a. H. salicifólia. (H. B. K. , L. \& O. (N. salicifolia H. B. K.). Texas, Mexico and Argentina. Hanchinol, Abro sol. Leaves diaphoretic, anti-syphilitic, insecticide.

964. HELENIÁSTRUM, Vaill. Heleniastrum. Compositae. From Greek, "star Helenium". Syn. Helenium, in part. Herbs with resinous-dotted leaves. Five species, western U.S.

965. HELÉNIUM, L. Sneeze-weed. Compositae. Greek name of Elecampane. Bitter herbs with large flower heads. About 25 species, northern and central America; 16 in U. S.

a. H. autumnále L. Canada to Florida and west to Arizona and British Columbia. Sneeze-weed, Sneezewort, Swamp or False Sunflower, Oxeye, Yellow-star. In Mexico called Rosilla de puebla. Leaves and flowers errhine, having probably some narcotic properties. Other species possess similar properties.

b. H. tenuifólium Nutt. Virginia to Florida, Texas and Missouri. Fine-leaved Sneeze-weed. Plant actively poisonous.

966. HELIANTHÉLLA, Torr. \& Gr. Helianthella. Compositae. Latin, diminutive of Helianthus. Syn. Encelia, Gerœa, Leighia, Lithonia, in part. Perennial herbs with yellow flowers. About 15 species, N. America; 12 in U. S.

a. H. tenuifólia Torr. \& Gr. Florida. Helianthella. Root, expectorant, anti-spasmodic, emetic. 
967. HELIÁNTHEMUM,Pers. Rock-rose, etc. Cistaceae. From Greek, "sun flower", the flowers opening only in sunshine. Syn. Cistus, in part. Woody herbs or low shrubs. About 125 species, mostiy in warmer regions; 10 in U. S.

a. H. Canadénse (L.) Michx. (C. Canadensis L.). Maine to N. Carolina and Kentucky and west to Wisconsin. Frostwort, Frost-weed, Frost plant, Long-branched Frost-weed, Canadian Rock-rose, Sun-rose, Scrofula plant; Ger. Canadisches Sonnenröschen; Fr. Hélianthème du Canada. Herb, astringent, alterative.

b. H. Heliánthemum (L.) Karst. (C. Helianthemum L., H. vulgare Gaert.). Europe. European Rock-rose, Sol-flower, Sun Daisy, Sun-rose. Properties of (a).

968. HELIÁNTHUS, L.

Sunflower.

Compositae. From Greek, "sun flower", appropriately so named. Annual or perennial robust herbs with showy yellow flowers. Abouı 60 species, New World; 48 in U. S.

a. H. ánmuus L. Mexico, Texas and northward to the Saskatchewan, also cult. in gardens and for its seeds. Sunflower, Common or Garden Suntlower, Comb-flower, Gloden, Gold, Larrabell, Wallflower*. Seeds yield a bland fixed oil and are used for feeding poultry and stock. Pith for moxas. G'rowing plant anti-malarial.

b. H. tuberósus L. British America, south to Georgia and Arkansas, also commonly cult. Jerusalem Artichoke ("Jerusalem" is a corruption of Italian girasole meaning sun-flower), Earthapple, Canada Potato; Ger. Erdapfel, Erdartischocke; Fr. Topinambour. Tubers esculent. Less cultivated in Europe than since the introduction of the potato. Several other species have tuberous root-stocks that might be developed by cultivation. Those of (c) H. gigánteus tuberósus (Bourg.) Brit. are sonetimes used for food.

969. HELICHRÝSUM, Vaill. Immortelle. Compositae. - From Greek, "sun gold". Syn. Elichrysum. Herbaceous or shrubby plants, the flower heads having scariose colored bracts and so "everlasting". About 275 species, Old World, mostly of S. Africa.

a. H. orientále Gaertn. Crete. Everlasting; Fr. Immortelle (the most familiar name); Ger. Strohblume. More common in our gardens is the Australian (b) H. lícidnm Henckel ( $\mathrm{H}$. bracteatum Willd. ). Other Immortelles of the gardens are (c) Helípterum Manglésii F. Muell. (Rhodanthe Manglesii Lindl.) and (d) Ammóbium alátum R. Br., both from Australia.

970. HELICTÉRES, L. Screw-tree. Sterculiaceae. From Greek, "twisted", of the carpels. Trees or shrubs., About 40 species, warmer regions of both hemispheres. 
a. H. Isóra L. Southern India. Screw tree. Fruit, called Twisted-stick, Twisted-horn or Twisty, believed to relieve colic; (b) H. Jamaicénsis Jacq., in the West Indies, has the same synonyms and uses.

971. HELIÉTTA, Tul. - Helietta. - Rutaceae. Named for Louis T. Hélie, French physician. Trees or shrubs. Aboat 4 species, warmer regions of New Wirld; 1 in $\mathrm{U}$. S.

972. HELIóPSis, Pers. False ${ }^{7}$ Sunflower, etc. Compositae. From Greek, "sun like". Robust herbs with aspect of Helianthus. About 10 species, New World; 4 in U. S.; called also Ox-eye.

973. HELIOTRÓPIUM, L. Heliotrope,Turnsole.Boraginaceae. Ancient Greek name of a plant, meaning "sun turning" or "sun dial". Herbs or sub-shrubs. About 115 species, warmer regions of the globe; 14 in U. S., including some naturalized. The fragrant Heliotrope of the gardens is (a) H. Peruviánum $\mathrm{L}$., one popular name of which is Cherry-pie.

974. HELLÉBORUS, L. Hellebore. Ranunculaceae. The ancient Greek name. Perennial herbs with palmately divided leaves. About 12 species, Europe and western Asia.

a. H. foétilus L. Europe. Bear's-foot, Bastard Bear's-foot, Barefoot, Fetid or Stinking Hellebore, Garget-root. Helleboraster, Ox-heal, Setter-grass, Setterwort, Settiswort. Properties of (b).

b. H. níger L. (H. granditlorus Salisb.). Enrope and cult. in gardens. Black Hellebore, Christmas-flower, Christmas Rose, Christ's-herb, Clove-tongue, Felon-grass, New-years Rose; Ger. Schwarze Nieswurz, Winterrose, Weinachtswurz, Christwurz; Fr. Hellébore noir (Codex); Sp. Eléboro negro. Rhizome and rootlets, Rad. hellebori nigri, Rad. melampodii, gastro-intestinal irritant, hydragogue, emmenagogue, powerful depressant.

c. H. víridis L. Europe, nat. in eastern U. S. Green or Bastard Hellebore, Chris-root, Christmas Rose, Peg-root, not to be confounded with Veratrum viride q. v.; Ger. Grüne Nieswurz, Chriswurz. Properties of (b) but more active:

975. HELóxIAS, L. Swamp Pink, Stud-flower. Melanthaceae. From Greek, "marsh loving". Perennial bog herb with showy purple flowers. One species, New York to Virginia. See Chamælirium.

976. HEMEROCÁLLIS, L. (Hemerocalis). Day Lily.Liliaceae. From Greek, "beautiful for a day". Perennial herbs with large lily-like flowers. About 5 species, Europe and Asia; 2 cult. and adv. in U. S.; (a) H. fláva L, Yellow Day Lily and (b) H. fúlva $L$. the more common Orange Day Lily, Lemon Lily, Ere's-thread.

97. HEMIIÉSMUS, R. Br. Hemidesmus. Asclepiadaceae. From Greek, "half" and "bond". Syn. Asclepias, Periploca, in part. 'Twining plants. Three species, India and Moluccas. 
a. H. Índicus (L. ) R Br. (P. Indica L., A. Pseudo-Sarsa Roxb.). India. Indian Sarsaparilla, Hemidesmus, Nunnari. Root, Hemidesmi radix, Br., used like Sarsaparilla.

978. HEMIÉVA, Raf. $1836 . \quad H e m i e v a . \quad$ Saxifragaceae. Syn. Suksdorfia, Gray 1880; Saxifraga, in part. Two species in U.S.

979. HeMítonIUS, Gray 1855. Hemitomus. Monotropaceae. Syn. Newberrya, Torr. 1867, this name adopted later by ('iray himself. Brownish scaly plants with flowers in crowded spikes. Four species, Yacific coast of U. S.

950.- HEMIZÓNIA, DC. Tar-weed. Compositae. From Greek, "half girdled", alluding to the ray akenes. Heavy-scented, generally viscid herbs, related to Madia. About 25 species, 12 in California.

981. HEPÁTICA, Scop. Lirer-leaf. Ranunculacea . Ancient Greek name, "liver" plant, from form of leavis. Syn. Anemone (Kew), in part. Scapose erergreen perennials. About 4 species, north temperate zone; 2 in U.S.

a. H. acúta (Pursh) Brit. (H. triloba var. acuta Pursh, A. acutiloba Laws. (Kew), H. acutiloba DC.). ('anada to Gerrgia, west to Minnesota. Acute-lobed Liver-leaf, Sharp-lobed Liverleaf, Heart Lirer-leaf, with many of the synonyms and with properties of (b).

b. H. Hepática (L.) Karst. (A. Hepatica L. (Kew), H. triloba Chaix, H. nobilis Moench). Northern Europe, Asia and N. America. south to Florida and Missouri. Kidney Liver-leaf, Common Liver-leaf, Liv rwort* (a name belınging rather to Marchantia), Noble Liverwort, Three-leared or Heart Liverwort, Liver-weed, Golden Trefuil, Herb Trinity, Iry-fluwer, Mouse-ears, Spring-beautr* ${ }^{*}$ Squirrel-cup; Ger. Leberblume, Leberkraut, Edel-Leberkiraut; Fr. Hépatique. Leares; Folia hepatici (nobilis, ) H. hepaticæ, H. trifolii aurei; tonic, deobstruent.

982. HeracléUy, L. Cow Parsnip. Umbelliferae. Greek name of a plant, from the Hercults of myth. Perennial herbs. About 60 species, northern hemisphere; 1 in U. S.

a. H. lanátum Michx. British America south to N. Carolina, Utah and California. Cow Parsnip, Masterwort, Madness, Madnep, Youlhwort. Root and seed acrid, used in epilepsy, in dyspepsia, etc.

b. H. sphondylium L. (H. Branca-ursina All.). Europe and northern Asia. European Cow-parsnip, Bear's-breach*, Hogweed; Ger. Bürenklaue, Heilkraut; Fr. Berce, Fausse Acanthe. Properties of (a).

983. HERMÁXYA, L. Hermannia. Sterculiaceae. Named for Yaul Hermann, Professor of botany at Leyden. Undershrubs. About 90 species, tropical regions of both hemispheres; 2 in U. S. 
984. HERMíDIUM, S. Wats. Hermidium. Nyctaginaceae. Herb. A single species, Nevada.

985. HERRÁNIA, Goudot. Herrania. Sterculiaceae. Trees related to Theobroma. About 4 species, warmer regions of New World. The seeds of (a) H. albiflóra Goudit and some other species are used in S. America as substitutes for Cacao, Cacao Cimarrona.

986. HESPERÁLCEA, Greene. Hesperalcea. Malvaceae. From Greek, "western Mallow". Syn. Sidalcea, in part. Robust annual. One species, California.

987. HESPERÁLOE, Engelm. Hesperaloe. Liliaceae. From Greek, "western Alne". Plant resembling Yucca. Two species, southwestern U. S.

988. HESPERELAÉA, Gray. Hesperelæa. Oleaceae. * From Greek, "western Olive". A small tree. One speeies, Guadalupe Island.

989. HesPERÉVAX. Gray. Hesperevax. Compositae. From Greek, "western Evax". Syn. Evax, Psilocarphus, Stylocline, in part. Floccose-woolly herbs. About 5 species, California.

990. HÉSPERIS, L。 - Rocket. Cruciferae. Ancient Greek name of (a), flower of the "evening". Biennial or perennial herbs. About 30 species, Europe and Asia.

a. H. matronális L. Europe and Asia, cult. and adv. in U. S. Dame's Rocket, Dame 's Violet, Garden Rocket, Sweet Rocket, Damask Violet, Summer Lilac, Dame's or Queen's Gilliflower; Night-scented, Rogue's or Winter Gilliflower. Plant reputed diuretic.

991. HESPEROCÁLLIS, Gray. Hesperocallis. Liliaceae. From Greek, "evening beauty". Scapo:e herb with large flowers in a simple raceme. One species, California.

992. HESPERÓCNIDE, Torr. Hesperocnide. Urticaceae. From Greek, "western nettle". Perennial herbs, related to Urtica. Two'species, one in Hawaiian Islands one in California.

993. HETERANTHÉRA, R. \& Pav. 1794. Pontederiaceae. From Greek, "with diverse anthers". Syn. Schollera, Schreb. 1789, not Roth. 1788; also Leptanthus, Pontederia, Commelinat, in part. Marsh or aquatic herbs. About 10 species, 2 of Africa, the rest of America, 4 in U.S. The best known is (a) H. dúbia (Jacq.) MacM. (C. dubia Jacq., L. gramineus Michx., H. graminea Vahl. (Kew), S. graminea A. Gray). Water Star-grass. (b) H. renifórmis R. \& P. and (c) H. limósa (Sw.) Willd. are called Mud Plantain.

994. HETEROCódon, Nutt. Heterocodon. Campanulaceae. From Greek, "different bells", alluding to dimorphism of corollas. Syn. Campanula, in part. Annual herb. One species, Pacific coast of U. S. 
995. HETEROJRÁBA, Greene. Heterodraba. Cruciferae. From Greek, a "different Draba". Slender diffure annual. One species, Pacific coast of U. S.

996. HETEROGAÚRA, Rothr. Heterogaura. Onagraceae. From Greek, a "different Gaura". Annual herb with habit of Clarkia. One species, California.

997. HeleronéLes, Roemer. California Holly. Pomaceae. From Greek, a "different Medlar". Syn. Photinia, Crataegus, Mespilus, in part. A small evergreen tree, bearing ample clusters of red berries. One species; (a) H. arbutifólia (H. Ait. f. )Roem. (C. arbutifolia Ait. not Poir., P. arbutifolia Lind. (Kew), M. arbutifolia Link., H. Fremontiana Decne.). California Holly, California Christmas-berry, Laurel Hawthorn, Toyon, Tollon.

998. heterospérnui, Cav. (Heterosperma). Compositae. From Greek, with "dissimilar seeds". Annual herbs with small heads of yellow flowers. About 7 species, Mexico to S. America; 1 in southern U. S.

999. HETEROTHÉCA, Cass. Heterotheca. Compositae. From Greek, with "dissimilar cases", alluding to achenes. Herbs with rather large flower heads (yellow). About 6 species, Mexico and northward; 2 in U. S.

1000. HEÚCHERA, L. Alum-root, etc. Saxifragaceae. Named for Prof. J. H. von Heucher, German botanist, d. 1747. Perennial herbs, leaves mostly basal. About 20 species, N. America; 17 in U. S. mostly southwestern.

a. H. Americána L. Ontario to Alabama, west to Louisiana and Minnesota. Alum-root, Common Alum-root, American Sanicle Split-rock, Cliff-weed. Root of this and other species astringent. The names American Sanicle and Ground Maple apply especially to (b) H. villósa Michx., Virginia to Tennessee.

1001. HEVÉA, Aubl. Brasilian Rubber tree. Euphorbiaceae. From vernacular, hevé, S. America. Syn. Siphonia, Rich., also Jatropha, in part. Trees. About 12 species, tropical S. America.

a. H. Guianénsis Aublet. (S. Guyanensis Juss., S. elastica Pers., J. elastica L. f.). Source of Para rubber. Prepared milk-juice ( of this and other species); > lastica. U. S. P., India-rubber, Caoutchnuc (Caut-chuc), Resina elastica, Gummi elasti ·um; Ger. Kautschuk, Federharz; Fr. Caoutchouc (Codex); Sp. Cahuchu. Gioma elastica. Brasilian rubber is obtained also. from (b) H. Brasiliéusis Muell. (S. Brasiliensis Kunth.) and from (c) H. díscolor Muell. From the seeds of (b) is obtained Siringa oil, used for making soap.

1002. HEXALÉCTRIS, Raf. Crested Coral-root. Orchidaceae. From Greek, "six "rested". Syn. Bletia, in part. Terestrial orchid with coralloid roots. One species, N. Carolina to. Florida and Mexico. 
1003. HIBÍSCUs, L. Hibiscus, Rose Mallow, etc. Malvaceae. Ancient Greek name of mallow. Syn. Abelmoschus, in part. Herbs, shrubs or small trees with showy flowers. About 180 species, warm and temperate regions; 17 in U. S. (including naturalized species).

a. H. Abelmóschus L. (H. moschatus Moench). India and Egypt, nat. tropical America. Musk Mallow. Seeds Muskseed, Amber-seed, Ambrette; Semen abelmosihi, Grana moschata, Semen alceæ æg! ptıacæ; Ger. Bisankörner; Fr. Ambre ta, Grains d' ambrette; used in perfumery for their musk-like odor.

b. H. canuábinus L. (H. radiatus Cavan.). Tropical Asia, Africa and Australia. Ambaree, Bastard Jute, Brown Indiau Hemp. Leaves used as a pot herb. Plant cultivated for its jute-like fibre.

c. H. esculéntus L. (A. esculentus Guil. et. Per.). Tropical Africa and widely cult. Okra, Ochro, Gumbo, Okra bandakai. Unripe capsules mucilaginous, esculent.

d. H. militáris Cav. (H. Virginicus Walt.). Pennsylvania to Florida, west to Louisiana and Minnesota. Halberd-leaved Rose-Mallow, Sweating-weed.

e. H. Moscheútos L. Brackish marshes, Massachusetts to Florida and Louisiana. Swamp Rose-Mallow, Mallow Rose, Sea Hullyhock, Swamp or Water Mallow.

f. H. Rósa Sinénsis L. Tropical Asia and cult. for ornament. China Rose, Chinese Rose, Shoe-black plant, Shoe-flower. Root mucilaginous, used like Althæa. Bark reputed emmenagogue. Flowers yield a black dye.

g. H. Sabdaríffa L. Tropical Asia and Africa and widely cult. Red or Guinea Sorrel, Rosella, Rozelle. In Mexico and Texas called Jamaica; Fr. Useille de Guinée, Ketmie acide. Calyx acidulous, mucilaginous, refrigerant, used in jellies, etc. Plant yields the rosella fiber.

h. H. Syríacus, L. Western Asia, cult. and adv. in U. S. Shrubby Althrea, Rose of Sharon.

i. H. Triónum L. Southern Europe, nat. in eastern U. S. Bladder Ketmia, Flower-of-an-hour, Black-eyed Susan, Devil'shead-in-a-bush, Modesty, Venice Mallow.

1004. HICóRIA, Raf. 1808 (Hicorius). Hickory. Juglandaceae. From vernacular hicori of aborigines, Syn. Carya, Nutt. 1818; Juglans, in part. Trees, mostly with tough hard woud and oily seeds. About 12 species, N. America; 11 in U. S. 'Jld American name Kiskatom, whence Kiskitomas-nut (KiskyThomas nutł), no longer in use.

a. H. álba (L.) Brit. (J. alba L., J. tomentosa Lam., C. tomentosa Nutt., H. maxima Raf.). Ontario and eastern U. S., west to Nebraska. White-heart Hickory (Hiccory, Pohickery, ) White or Fragrant Hickory, Bull-nut, King-nut, MIocker-nut, Hardbark, Red or Black Hickory. Kernel esculent. 
b. H. aquática (Michx. f.) Raf. (J. aquatica Michx. f., C. aquatica Nutt. ). Southeastern U. S., west to Texas. Water Hickory, Swamp Hickory, Bitter Pecan, Water Bitter-nut. Kernel bitter. Wood soft.

c. H. glábra (Miill.) Brit. (J. glabra Mill., C. porcina Nutt., H. porciua Raf.). Canada and eastern U. S., west to Minnesota. Pig-nut, Pig-nut Hickory, Bitter-nut, Hog-nut, Broom Hickory; Black, Brown, Red or White Hickory. Kernel astringent and bitter.

d. H. laciniósa (Michx. f.) Sarg. (J. laciniosa Michx. f., C. sulcata Nutt., H. sulcata Raf.). New York to Tennessee, west to Indian Territory. Big Shag-bark, Shell-bark Hickory, King-nut; Big, Thick or Western Hickory. Nut thick-shelled. Kernel esculent.

e. H. microcárpa (Nutt.) Raf. (J. alba var. odorata Marsh., C. microcarpa Nutt., H. glabra var. odorata Sarg. ). Massachusetts to Virginia, west to Mlissouri. Small-fruited Hickory, Balsam Hickory, Little Shag-bark, Small or Little Pig-nut. Nut thin shelled. Kernel esculent.

f. H. mínima (Marsh) Brit. (J. alba var. minima Marsh, J. sulcata Willd., C. amara Nutt., H. amara Raf.). Bitter-nut, Bitter Pig-nut, Swamp or Bitter Hickory. Kernel very bitter.

g. H. ováta (Mill.) Brit. (J. ovata Mill., C. alba Nutt., not J. alba L.). Canada and eastern U. S., west to Minnesota. Shag-bark, Shag-bark Hickory, Shell-bark or Scale-bark Hickory, White Hick ory, Redheart or Upland Hickory, Kingnut, White or Sweet Walnut. Nut thin shelled. Kernel esculent.

h. H. Pecán (Marsh.) Britton (J. Pecan Marsh., H. olivæformis Raf., C. olivæformis Nutt.). Indiana and Kentucky, west to Texas and Iowa. Pecan, Peccan, Illinois-nut, Illinois Pecan, Soft-shell Hickory. Seed very sweet, yields a bland, pleasant-flavored fixed oil.

1005. HIERÁCIUM, L. Hawkweed, Speer-hawk. Cichoriaceae. Ancient Greek name of a different plant, meaning "hawkweed". Syn. Pilosella, in part. Perennial herbs. About 300 species, north temperate zone and Andes mountains; 37 in U.S. (including some naturalized); Ger. Habichtskraut; Fr. Eperviére.

a. H. aurantíacum L. Europe, nat. in U. S. Orange or Tawny Hawkweed or Hawkbit, Golden Mouse-ear Hawkweed, Grim-the-collier, Devil's Paint-brush, Flora's Paint-brush.

b. H. Canadénse Michx. British America, south to New Jersey and Michigan. Canada Hawkweed, High Dandelion.

c. H. Gronóvii L., Hairy Hawkweed and (d) H. scábrum (Michx.), Rough Hawkweed, both of eastern U. S. to Canada, are used for relief of toothache. 
e. H. murórum L. Europe, adv. in U. S. Wall Hawkweed, French Lungwort, (xolden Lungwort; Ger. Gelbes . Lungenkraut; Fr. Pulmonaire des Francais. Plant bitter, vulnerary.

f. H. Pilosélla L. Europe, adv. in U. S. Mouse-ear Hawkweed, Mouse Bloodwort, Ling Gowans, Felon-herb; Ger. Mäuseöhrchen; Fr. Piloselle, Oreille de souris. Plant bitter, astringent.

g. H. praeáltum Vill. Europe, adv. in U. S. King-devil, a. troublesome weed.

h. H. umbellátum L. Europe. Ger. Lungenhabichtskraut. Plant used in asthma.

i. H. venósum L. Canada to Genrgia, west to Nebraska and Manitoba. Rattlesnake-weed, Poor Robin's Plantain, Vein-leaf or Veiny-leaved Hawkweed or Hawkbit, Snake Plantain, Striped Blondwort, Bloodwort, Early Hawkweed. Plant reputed an antidote to snake bites.

1006. HIPPOCRATÉA, L. Hippocratea. Celastraceae. Named in honor of Hippocrates, the father of medicine. Climbing shrubs. About 30 species, tropical regions especially of New World; 1 in U. S.

1007. HIPPÓMANE, I. Manchineel. Euphorbiaceae. Ancient Greek plant name, from "horse" and "madness". Syn. Mancinella, Tuss. 1824, Mançanilla Adans. 176:3. Tree with poisonous milk sap. One species, tropical America.

a. H. Mancinélla L. (M. venenata Tussac, H. Mançanilla Jacq.). West Indies, Florida, Panama, Venezuela, etc., Manchineel, Manzanillo. Sap a powerful irritaut, a skin poison, emetocathartic, etc.

1008. HIPPÚRIS, L. Mare's-tail, etc. Haloragidaceae. From Greek, "horse's tail". Aquatic herbs with whorled leaves. Three species, temperate and frigid zones; 3 in U. S.

a. H. vulgáris L. Northern Europe, Asia and N. America, south to Maine, N. Mexico and California. Mare's-tail (originally Female Horse-tail), Bottle-brush, Cat's-tail, Joint-weed, Knotgrass*, Female Knot-grass, Paddock-pipes, Witches'-milk; Ger. Schafthalm; Fr. Pesse d'eau.

1009. HOFFMANSÉGGLA, Cav.Hoffmanseggia.Caesalpinaceae. Named for J. Centurius, Graf. Hoffmansegge. Syn. Pomaria, Caesalpinia, in part. Herbs or low shrubs. About 20 species, western America and south Africa; 10 in southwestern U. S.

1010. HOFMEISTÉRIA, Walp. Hofmeisteria. Compositae. Named for W. Hofmeister, vegetable histologist. Syn. Helogyne, Benth. 1844, not Nutt. 1841. Low suffrutescent plants. Three species, Arizona to lower California; 1 in southwestern U. S.

1011. HOLARRHÉNA, R. Br. Conessi Bark. Apocynaceae. Trees or shrubs. About 10 species, tropical Asia and Africa.. 
a. H. antidysentérica Wall. (Wrightia antidysenterica R. Br.). India. Burk, Conessi bark, Tellicherry bark; bitter, tonic, febrifuge, antidysenteric.

1012. HoLlistérIA, S. Wats. Hollisteria. Polygonaceae. White-woolly herbs with stems dichotomously branched. One species, California.

1013. HOLOCÁRPHA, Greene. Holocarpha. Compositae. From Greek, "entire chaff". Syn. Hemizonia, in part. Herb. One species, western U. S.

1014. HOLODÍSCUS, Maxim. Holodiscus. Rosaceae. Syn. Spiræa, in part. Shrubs with panicles of small white flowers. About 3 species, southwestern U. S.

1015. HOLÓSTEUM, L. Jagged Chickweed. Caryophyllaceae. From Greek, "wholly bone," appropriateness not obvious. Insignificant herbs. Three species, Old World; 1 nat. in U.S.

1016. HOLOZÓNIA, Greene. Holozonia.. Compositae. Syn. Lagophylla, in part. Perennial herb with small flowerheads. One species, California.

1017. HOMálOBUS, Nutt. Milk Veteh. Papilionacaae. Syn. Astragalus, Kentrophyta, Ervum, in part. Perennial herbs. About 6 species, Mexico and adjacent regions; 3 in U.S.

1018. HOÓKERA, Salisb. Hookera. Liliaceae. Named for Wm. Jackson Hooker, English botanist, d. 1865. Syn. Brodiæa, in part. Scapose herbs. About 15 species, New World; 8 in U.S.

1019. HÓRDEUM, L. - Barley. - Gramineae. The ancient Latin name, meaning perhaps" "bristly". (irasses with flowers in close spikes. About 12 species. Synonyms Bear, Bigg, Haules, Hoils, Pillards.

a. H. vulgáre L. Orient, now widely cultivated in cooler climates. To this species may be referred the numerous varieties of Barley; Ger. Gerste; Fr. Orge; 1 . Two-rowed Barley, H. dístichon L., including the Common English Barley, the Golden, Italian and Siberian varieties; 2. the Six-rowed Barley, $\mathbf{H}$. hexástichon L., including Scotch, Bear, Red and Square Barley; 3. the so.called Four-rowed Barley, H. vulgáre L., in the restricted application of that name, including Russian and French, Spring, Winter, Black. Naked and Wheat Barley; 4. the Dinkel and related Barleys, H. zencriton L., including Turkish, Rice, Sprat, Battledore, Fulham and Putney Barley. Seeds esculent. Husked seeds, Pearl Barley, Hordeum decorticatum, Br., Hordeum perlatum; Ger. Perlgerste, Perlgraupen; Fr. Orge perlé (Codex); nutrient. Seeds, sprouted and then dried constitute malt, used in brewing and in preparation of easily digested foods for infants or invalids.

1020. HORKÉLIA, Cham. \& Sch. Horkelia. Rosareae. Syn. Potentilla (Kew), in part. Perennial herbs resembling Potentilla. About 23 species, Pacific Border of U. S. 
1021. HOTTóxIA, L. Featherfoil, etc. Primulaceae. Named for Prof. Peter Hotton of Leyden, d. 1709. Pretty aquatic herbs with whorled leaves. Two species, one of EuroAsia, one of eastern U. S. Synonyms, Water-feather, Water Gilliflower, Water Violet, Water Yarrow; Ger. Wasserviole; Fr. Plume d' eau.

1022. HOUSTóxíA, L. Bluets, Venus'-pride. Rubiaceae. Named for Dr. William Houston, English botanist, d. 1733. Syn. Oldenlandia, Hedyotis, in part. Low herbs with suall blue, purple or white flowers. About 25 species, N. America; 18 in U. S.

a. H. coerúlea L. (Hed. cœrulea Hook., O. cœrulea A. Gray). Nova Scotia to Alabama, west to Michigan. Bluets, Innocence, Angel's-eyes, Blue-eyed grass, Bright-eyes, Eye-bright*, Littlewasherwoman, Nuns, Quaker-bonnets, Quaker-ladies, Star-ofBethlehem*, Venus'-pride, Wild Forget-me-not. (b) H. angustifólia Michx. and (c) H. mínor (Michx.) Brit. are called Star Violet.

1023. HOUTTUÝNIA, Thunb. 1784 (Houtouynia). Piperaceae. Named for M. Houttuyn, Dutch botanical writer, 18th century. Syn. Anemopsis, Hook. 1838, Anemonopsis Pritz., not S. \& Z. Marsh plants. Two species, one of eastern Asia, one of California.

a. H. Califórnica B. \& H. (A. Californica H. \& A., A. Berlanderi C. DC.). California to Mexico. Yerba Mansa. Root pungent.

1024. HOWÉLLIA, A. Gray. Howellia. Lobeliaceae. Named for the discoverers, Joseph and Thomas T. Howell. Delicate aquatic or marsh herbs. Two species, Pacific coast of U. S.

1025. HóY A, R. Br. Wax plant. Asclepiadaceae. Named for Thomas Hoy, English gardener. Herbaceous climbers. About 50 species, tropical Asia to Australia; (a) H. carnósa $\mathrm{R}$. Br. from India is the well known Wax plant, cult. for ornament.

1026. HUDSÓNIA, I. False Heather, etc. Cistaceae. Named for William Hudson, English botanist, d. 1793. Heath-like plants, very showy in bloom. Three species, eastern U.S.

a. H. ericoídes L. Nova Scotia to Virginia. Heath-like Hudsonią, Field Pine, Poverty-grass.

b. H. tomentósa Nutt. Canada and northeastern U. S. Woolly Hudsonia, False Heather, Beach Heather, Heath, Bear-grass, Dog's-dinner, Ground Cedar, Ground Moss, Poverty-grass.

1027. HÚLSEA, T. \& Gr. - Hulsea. - Compositae. Named for Dr. G. W. Hulse, U. S. Army. Viscid-pubescent balsamic herbs. Six species, California to Washington. 
1028. HÚMULUS, L.

Hop.

Moraceae. The Latin name, probably of 'Teutonic origin. Twining perennials. Two species, north temperate zone; 1 in U.S.

a. H. Lúpulus L. Europe, Asia and $\mathrm{N}$. America, south to Georgı and Arizona, also widely cult. Hop vine, Bine, Bur, Seeder, anciently known as Lupus salictarius (Pliny). Among the varieties are "White Bine", "Golding" and "Grape". Strobiles, Hops; Humulus, U. S. P., Lupulus, Br., Strobili humuli v. lupuli, Coni lupuli; Ger. Hopfen, Hopfenzapfen, Hopfenkätzchen; Fr. Cône de houblon (Codex). Glandular pouder from strobiles, Lupulin, Lupulite; Lupulinum. U.S.P. Br., Glandula lupuli, Lupulina; Ger. Hopfenmehl; Fr. Lupuline (Codex). Bitter, tonic, sedative.

1029. HÚRA, L. Sand-box tree. Euphorbiaceae. From the veruacular name, S. America. Trees. Two species, tropical America.

a. H. crépitans L. (H. Brasiliensis Willd). West Indies and tropical America. Sand-box tree. In S. America called Ajuapar or Acupa, in Brazil, Assacu or Ussacu, in Panama, Javilla. Fruit when ripe bursts with a loud report, scattering the seeds, hence called the Devil's Sand-box and the Monkey's Dinnerbell. Seeds, known in Mexico as Habilla (Pepita) de San Ignacio, drastic cathartic. The acrid bark (casca de assacu) is used medicinally.

1030. HUTCHÍNSIA, R. Br. 1812. Hutchinsia. Cruciferae. Named for Miss Hutchins, botanist of Bantry, Ireland. Syn. Hymenolobus, Nutt. 1838; Lepidium, Capsella, in part. Low herbs. About 8 species, northern hemisphere; 1 in U.S.

1031. HYDRÁNGEA, L. Hydrangea. Saxifragaceae. From Greek, a "water vessel", alluding to shape of capsule. Shrubs or small trees with flowers in corymbs. About 35 species, New World and eastern Asia; 5 in U.S.

a. H. arboréscens L. (H. vulgaris Michx.). New York and eastern U. S. Hydrangea (Hydrangia), Wild Hydrangea, Seven-bark, Bissum. Ront diuretic, lithontriptic.

b. H. Thunbérgi Siebold. Japan. Leaves used for tea, called "Tea of Heaven".

1032. HYDRÁSTIS, Ellis 1759. Golden-seal. Ranunculaceae. From Greek, "water compelling", i. e. hydragogue. Syn. Warnera, Mill. 1768. Perennial herbs from a thickened yellow rootstock. Two known species, one of Japan; 1 in U.S.

a. H. Canadénsis L. (W. Canadensis Miller). Ontario to Georgia, west to Missouri and Minnesota. Golden-seal, Orange-root, Yellow-root, Yellow Puccoon, Yellow Indian-paint, Turmericroot, Ohio Curcuma, Indian Turmeric, Ground Raspberry, Eyeroot, Eye-balm, Yellow-eye, Jaundice-root, Indian dye; Ger. Kanadisches Gelbwurz, Kanadisches Wasserkraut, Gelbes Blutkraut; Fr. Racine orange, Sceau d'or; Sp. Raiz amarilla, 
Sella de oro. Rhizome and rootlets; Hydrastis, U S. P., Hydrastis rhizoma, Br.; bitter, tonic, alterative. Contains berberine and hydrastine, which latter by oxidation yields Hydrastinine U. S. P.

1033. HYDROCótYLE, L. Marsh Pennywort. Umbelliferae. From Greek, "water cup". Perennial herbs, commonly with peltate leaves. About 75 species, widely distributed; 7 in U. S. Synonyms, Fairy-table, Shilling-grass; Ger. Wassernabel.

Of our indigenous species, the more important are (a) H. Americána L., American Marsh Pennywort, Penny-post; (b) H. ramunculoídes L. f. (H. natans T. \& Gr.), Floating Marsh Pennywort,; (c) H. umbelláta L., Umbellate or Manyflowered Marsh Pennywort, Navelwort, Sheepsbane. Watergrass, in Mexico Ombligo de Venus, and (d) H. verticilláta I'hunb. (H. vulgaris L. (Kew), H. interrupta Muhl.), Whorled Marsh or Water Pennywort, Penny-grass, Penny-rot. Properties of 424 (a), q. v.

1034. HYJROPHÝLLUM, Water-leaf. Hydrophyllaceae. From Greek, "water leaf". Herbs with coarse foliage and rather showy flowers. About 7 species, all of U. S.

a. H. Virgínicum L. is sometimes called Bur flower or Brookflower.

1035. HYGRóPHILA, R. Br. Hygrophila. Acantlaceae. From Greek, "moisture loving". Herbs. About 25 species, tropical and sub-tropical; 1 in U. S.

1036. HYMEYAÉA, L. 1752, Courbaril. Caesalpinaceae. Dedicated to Hymen, the leaves having each a single pair of leaflets. Syn. Courbari, Adans. 1763. Trees. About 12 species, tropical America.

a. H. Coúrbaril L. Tropical America. South American Locust tree, Courbaril, Varuish tree, Algarroba (of Panama). Wood exceedingly heavy and strong. Seeds surrounded by a saccharine edible pulp. Tree source of West Indian Coyal or Coapinule (Mueller). South American Anime has been wrongly referred to this source (Nat. Dispensatory).

1037. HYMENOCÁLLIS, Salisb. Spider Lily. Amaryllidaceae. From Greek, "beautifui membrane", alluding to the crown. Syn. Pancratiumt, in part. Ornamental bulbous herbs; flowers white, fragrant, the filaments connected by a web-like crown. About 30 species, New World; 11 in U. S.

1038. HYMEYOCLÉA, Torr. \& Gr. Hymenoclea. Compositae. From Greek, "enclosed membrane". Low shrubby plants. with numerous small flower-heads. Two species, southwestern U. S.

1039. HYYENOPÁPPUS, L'Her. Hymenopappus. Compositae. From Greek, "membrane pappus." Herbs with rather small discoid flower-heads (white or yellow). About 10 species, all of southern U. S. and Mexico. 
1040. HYMeNóthrYX, Gray. Hymenothryx. Compositae. From Greek, "membrane bristle", alluding to the pappus. Herbs. Two known species, southwestern U.S.

1041. HYOSCÝAMUS, L. Henbane. Solanaceae. The ancient Greek name, meaning "hog bean". Coarse, viscid-pubescent herbs. About 15 species, Mediterranean region; 1 nat. in U. S.

a. H. álbus L. Southern Europe. White Henbane. Properties of (b). Seeds are official in French Codex.

b. H. níger L. Southern Europe, sparingly nat. in U. S. Black Henbane, Henbane (Henbell, Henkam), Fetid or Stinking Nightshade, Hog's-bean, Insane-root, Belene. Chenile, Loavesof-bread, Poison Tobacco; Ger. Bilsenkraut (schwarzes), Teufelsaugenkraut; Fr. Jusquiame nuir (Codex); Sp. Beleño negro, Leaves of second year's growth; Hyoscyamus U. S. P., Hyoscyami folia, Br., Herba hyoscyami, P. G. [The seeds also were formerly official. still so in the Codex]. Sedative, deliriant narcotic. Contains the alkaloids atropine and hycscine.

1042. HYPÉLATE, P. Br. White Ironwood. Sapindaceae. The ancient Greek name of Butcher's Broom. Syn. Amyrist, Melicocca, in part. A small tree, West Indies to Florida.

1043. HYPÉRICUM, L. St. John's-wort. Hypericaceae. The ancient Greek name, "under heather". Syn. Sarothra, Androsæmum, in part. Herbs with punctate or black-dotted leaves and yellow flowers. About 210 species, widely distributed; 34 in U. S.

a. H. Androsaémum L. (A. vulgare Gaertn., A. officinale All.). Asia Minor. Tutsan (Tipsen, Titson, Titsy, Stitson; Fr. toutesaine), Park-leaves, Touch-leaves, Touch-and-heal, Sweet-amber, Sweet-leaf, White-amber. Plant vulnerary.

b. H. perforátum L. ( $H$. vulgare Lam., H. officinale Gates, $H$. officinarum Crantz). Europe and northern Asia, nat. in U.S. Common St. John's-wort, John's-wort, St. John, Herb John, Penny-John, Amber, Balm-of-warrior's-wound, Cammock, Hyssop*, Rosin-rose, Touch-and-heal; Ger. Johanniskraut, Johannisblut, Hartheu, Hexenkraut, Hasenkraut, Teufelsflucht; Fr. Millepertuis (Codex), Casse-diable; Sp. Hypericon. Flowering tops; Herba v. Summitates hyperici; bitter, terebinthinate, vulnerary. Used in preparation of Oleum hyperici, Red Oil. Some other species may be equally effective. The more noteworthy (indigenous) are (c) H. Áscyron L. (H. pyramidatum Ait. ), Great or Giant St. John's-wort; (d) H. gravéolens Buckley, Mountain St. John's-wort; (e) H. maculátum Walt. (H. corymbosum Muhl.), Spotted or Corymbed St. John'swort and (f) H. prolíficum L., Shrubby St. John's-wort, Broom-brush, Paint-brush. See Sarothra.

1044. HYPHAÉNE, Gaertn. Doum Palm. Sabalaceae. From a Greek word meaning to "weave". Branching fanpalms. About 10 species, Africa, Arabia and Madagascar. 
a. H. criníta Gaertn. (H. Thebaica Mart.). Northeastern Africa and Arabia. Doum Palm, Doom Palm, Gingerbread tree, Mealy husk of fruit edible, resembling gingerbread in taste.

1045. HYPOCHOÉRIS, L. (Hypochaeris). Cichoriaceae. From Greek, "for pigs", these animals being fond of its ronts. Perennial herbs with basal leaves and large flower-heads (yellow). About 50 species, Europe, Asia and S. America; 2 nat. U. S. Synonyms, Cat's-ear, Gosmore; Ger. Saukraut; Fr. Porcelle. Roots of some S. American species used like Salsify.

1046. HYPóPITYS, Adans. Pine-sap, etc. Monotropaceae. From Greek, "under fir trees". Syn. Monotropa, in part. Scapose saprophyte, with flowers in a one-sided raceme. One species, north temperate zone (U. S.).

a. H. Hypópitys (L.) Small (M. Hypopitys L., H. multiflora Scop.(Kew),H. lanuginosa Raf.,H. Monotropa Crantz). Northern Europe, Asia and N. America, south to Florida and Arizona. False Beech-drops, Pine-sap, Fir-rape, Bird's-nest, Yellow Bird's-nest. Plant bitter, nauseant, diuretic.

1047. HYPÓXIS, L. Star-grass. Amaryllidaceae. From Greek, "acute below", perhaps descriptive of the capsule. Syn. Ornithogalum, in part. Perennial herbs from a corm, with grass-like leaves. About 50 species, warmer regions of Old and New World; 3 in U. S.

a. H. hirsúta (L.) Coville (O. hirsutum L. 1753, H. erecta L. 1759). British America and eastern U.S. Star-grass, Yellow Star-grass. Root detergent, vulnerary.

1048. HYSSÓPUS, L. Hyssop. Labiatae. Ancient Greek nanie of some aromatic herb. Perennial aromatic herb. One species, southern Europe, nat. in U. S.

a. H. officinális $L$. ( $H$. canescens DC., $H$. orientalis Adam, etc.). Hyssop (Ezob, Isop), Garden Hyssop; Ger. Ysop, Eiserig; Fr. Hysope (Codex); Sp. Hissopo. Flowering herb, aromatic, bitter, vulnerary.

1049. IBÉRIS, L.

Candy-tuft, etc.

Cruciferae. Name from Iberia, i. e. Spain. Herbs, some ornamental. About 20 species, Mediterranean region. The Candy-tuft of gardens is (a) I. umbelláta L. of southern Europe; the white variety is $I$. Coronaria Don, not a distinct species.

1050. IBERVÍLLEA, Greene. Ibervillea. Cucurbitaceae. Syn. Maximowiczia Cogn., not Rupr. Perenuial herbaceous climbers. Two species, Texas.

1051. ICACóREA, Aubl. Marlberry Cherry. Myrsinaceae. From vernacular (Carib) name. Syn. Ardisia, Bladhia, Cyrilla, Pickeringia, in part. Shrubs. About 200 species, warmer regions of both hemispheres; 1 in Florida, viz. (a) $\mathbf{I}$. paniculáta (Nutt.) Sudw. (C. paniculata Nutt.). Marlberry Uherry. 
1052. ICHTHY0MÉTHIA, Jamaica Dogwood. Papilionaceae. From Greek, "fish intoxicant". Syn. Piscidia, L. 1759; Erythrina, in part. A West Indian tree. One species; extends to Florida.

a. I. Piscípula (L. ) Kze. (E. Piscipula L., P. Piscipula Sarg; P. Erythrina Jacq., P. toxicaria Salisb., P. inebrians Medic.) Wist Indies to Florida. Jamaica Dogwood, White Dogwood, Manaca*: Ger. Piscidie; Fr. Bois enivrant; Sp. Colorin de peces. Bark of root, narcotic, analgesic, sedative. Used to stupefy fish. See Cracca (b) and (c).

1053. ÍLEX, L. Holly, Winterberry. Ilicaceae. Ancient name of Holly Oak. Syn. Prinos, in part. Shrubs or trees with berry-like fruit, some evergreen. About:160 species, most numerous in New World; 14 in U. S.

a. I. Aquifólium L. Europe. European Holly; Aunt Mary's tree, Christmas, Crocodile, He-Holly (also She-Holly), Hulver (Helver, Holiverd, Hollin, Hollen. Hollond, Holyn), Holm, Sparked Holm, Prick-Hollin, Poison-berry; Ger. Stechpalme, Stecheiche, Christdorn; Fr. Houx. Leaves anti-arthritic. Fruit emeto-cathartic. Bark yields bird lime. Wood very white aud close-grained.

b. I. Cassíne L. (I. Dahoon Walt. (Kew); includes I. myrtifolia Walt.). Southeastern U. S. Dahoon Holly, Yaupon.

c. I. decídua Walt. Sontheastern U. S. Swamp or Meadow Holly, Bear-berry, Possum Haw. Properties and uses of (k).

d. I. opáca Ait. [I. quercifolia Meerb. (Kew)]. Maine to Flurida, west to Texas and Missouri. American Holly, White Holly. Properties of (a), but leaves are said to be sedative and expectorant.

e. I. P’araguénsis St. Hil. (I. Paraguariensis Don., I. Paraguayensis Hook., I. thæezans Bonpl. not Mart. ). Brazil and Argentina. Paraguay 'Tea, Jesuit's or St. Bartholomew's Tea, Yerba Maté; Ger. Jesuitenthée, St. Bartholomykraut; Fr. Maté (Codex). Leaves contain Caffeine. Used like Chinese tea. (f) I. Gongonlıa Lamb., (g) I. théezans Mart. and some other species are used also as yerba maté.

h. I. verticilláta (L.) A. Gray (P. verticillatus L.). Canada and eastern U. S. Black or False Alder, Striped or White Alder, Virginia or Common Winterberry, Feverbush. Bark astringent, tonic, febrifuge. Similar properties are ascribed to (i) I. glábra (L) A. Gray (P. glaber L.), Massachusetts to Florida, west to Louisiana; Ink-berry, Dye-leaves, Gall-berry, Evergreen Winterberry and (j) I. licerigáta (Pursh.) A. Grav (P. lævigatus Pursh), Maine to Virginia. Smooth Winterberry, Hoop-wood, Can-hoop.

k. I. romitória Ait. (I. Cassine Walt. (Kew), not L., I. religiosa Barth. ). Southeastern U. S., west to Texas, also in Bermuda. Cassena, Yaupon (Youpon), Emetic Holly, Indian Black-drink; 
Appalachian, Indian, Carolina or South-sea Tea; Ger. Apalachenther, Carolinathee, Indischer Thee. Leaves, Folia apala.hinis, Fol. paragur, contain caffeine and were formerly used by Indians to make their "black drink".

1054. ILICIOÍDES, Dumont 1802. Mountain Holly. Ilicaceae. From Greek. "resembling Holly". Syn. Nemopanthus (Nemopanthes), Raf. 1819 (Kew); Vacciniumt, in part. A deciduous shrub. One species, U. S.

a. I. mucronáta (L.) Britton (V. mucronatum L., N. fascicularis Raf. (Kew); N. Canadensis DC). Canada, south to Virginia and Wisconsin. Mountain Holly, Canadian or Wild Holly, Brick-timber, Cat-berry.

1055. ILLÍCIUM, L. _ Star-Anise. Magnoliaceae. From Latin, "enticing', alluding to the odor. Evergreen shrubs. About 6 species, eastern Asia, Japan and eastern $\mathrm{N}$. America; 2 in U. S.

a. I. Floridánum Ell. Florida to Louisiana, Poi-on Bay, Stinkbush ( of Louisiana), Sweet Laurel, Florida Anise tree, Florida Star-anise. Bark aromatic, tonic. Leaves and fruit have poisonous properties.

b. J. parviflórum Vent. (I. anisatum Bartr., not L.). Georgia to Florida. Properties of (a). Root said to resemble sassafras.

c. I. religiósum Siebold (I. anisatum L. not Gaertn., I. San-ki Pers.). Eastern Asia and Japan. Sacred Anise tree. Bark. Lavola bark, used for incense. Leaves and fruit aromatic but poisonous.

d. I. vérum Hook. f. (I. anisatum Gaertn., not L. ). Southeastern China, cult. in China and Japan. Chinese Anise tree. Fruit, Star-anise, Chinese Anise; Illicıum U. S. P.; Fructus (Semen) anisi stellati, Sem. badiani: Ger. Indischer Anis, Sternanis, Badian; Fr. Anis étoilé, Badiane; aromatic, carminative, with flavor of true Anise.

1056. ILYSÁNTHES, Raf. False Pimpernel. Scrophulariaceae. From Greek, "mud flower". Syn. Capraria, Lindernia. in part. Small herbs. About 10 species, 6 in U.S.

1057. IMPÁTIENS, L. Touch-me-not. Balsaminaceae. Name Latin, alluding to sensitiveness of capsules. Succulent herbs with irregular, often ornamental flowers. About 220 pecies, mostly of tropical Asia; 2 in U. S.

a. I. aúrea Muhl. (I. pallida, Nutt.). Quebec to Oregon, south to Georgia and Kansas. Pale Jewelweed, Pale Touch-me-not, Yellow or Golden Jewelweed, Wild C'elandine, Ceroline, Wild Balsam, Pale Balsam-weed, Quick in-the-hand, Silver-weed, Slipper-weed, Slippers, Wild Ladies'-slipper, Snap-weed, Weathercock. Herb aperient, diuretıc.

b. I. Balsámina L., from tropical Asia is the Common Garden Balsam; (c) I. Noli-tángere L. (1. Noli-me-tangere Crantz) is the European Touch-me-not or Wild Balsam, called also Codded Arsmart. 
d. I. biflóra Walt. (I. fulva Nutt.). British America, south to Florida and Missouri. Spotted Touch-me-not, Cowslip*, Earjewel, Spotted or Orange Jewelweed, Speckeled Jewels or Jewel-weed, Balsam-weed, Wild Balsam, Brook Celandine (Solentine), Wild Celandine, Ceroline, Kicking-colt, Kickinghorses, Ladies'-eardrop, Ladies'-pocket, Silver-leaf, Silver plant, Shining-grass, Slipper-weed, Wild Ladies'-slipper, Snapdragon*, Snap-weed, Weathercock. Properties of $(\mathrm{a})$.

1058. IMPERATÓRIA. L. Masterwort. Umbelliferae. From Latin, "imperial". Peucedanum, Oreoselinu n, in part. Robust perennial herbs. About 10 species, Old World.

a. I. Ostrúthium L. (P. Ostruthium Koch. (Kew), O. officinale Link.). Central and southern Europe adv. in U. S. Masterwort, Felon-grass, Felonwort, Imperial Masterwort, Broadleaved Hog's-fennel, Pellitory of Spain*; Ger. Meisterwurz, Kaiserwurz, Ostritzwurz, Ostranz; Fr. Impératoire (Codex). Rhizome; Rhizoma (Radix) imperatoriæ v. ostruthii, R. astrantiæ; aromatic, acrid, masticatory, etc., sometimes mixed by accident or design with aconite root. Leaves used as a pot herb, and in manufacture of some kinds of Swiss cheese.

1059. INDIGÓFERA, L. Indigo.

Papilionaceae. From Latiu, "indigo yielding". Herbs or shrubs. About 250 species, warm and temperate regions; 6 in U. S. including introduced species.

a. I. Ánil L. (I. tinctoria Blanco not L.). West Indies and tropical America; Carolina and southward in eastern U. S., also cult. West Indian Indigo plant, Devil's-eye, Anil (vernacular name whence our word aniline). Leaves source of the dye-stuff Indigo; Indicum, Pigmentum indicum; Ger. Indigo, Indig; Sp. Añil; formerly used in epilepsy, also reputed emmenagogue. Indigo is obtained also from (b) I. argéntea L. (I. cuerulea Roxb., I. glauca Lam, I. tinctoria Forst., not L.), North Africa, east to India, also cult., and from (c) I. tinctória L. (I. Indica Lam. not Mill.), tropical Asia, Africa and Australia and widely cult. in tropical countries, East Indian Indigo plant.

1060. ÍNGA, Scop. Inga tree. Vernacular name, S. America. Trees or large shrubs. About 150 species, tropical America. The pods of several species contain a saccharine pulp which in some is edible, in some is cathartic.

1061. INGENHOÚZIA, DC. not Bert. (Ingenhoussia.) Malvaceae. Shrub resembling Gossypium. One species, Mexico and southern U. S.

1062. ÍNULA, L. (Enula). Elecampane, etc. Compositae. Ancient Latin name of Elecampane, probably corrupted from Helenium, the Greek name. Syn. Astert, Conyza, Corvisartia, in part. Perennial herbs with large flower heads (yellow). About 90 species, Old World; 1 nat. in U. S. 
a. I. Helénium L. (Cor. Helenium Merat, A. Helenium Scop.). Central Asia and Europe, nat. in U. S. Elecampane (Allicampane, Alicompane, Aligopane), Elf Dock, Elfwort, Horseheal, Horse-elder, Inul, Scabwort, Yellow Starwort, Velvet Dock, Wild Sunflower; Ger. Alant, Glockenwurzel, Ottwurz; Fr. Aunée officinale, Grande aunée (Codex). Root; Inula, U. S. P., Radix helenii v. inulæ v. enulæ; diuretic, expectorant, reputed bactericide. Candied root a popular cough remedy.

b. I. squariósa (L.) Bernh. (Con. squarrosa L., I. Conyza DC.). Europe. Plowmau's Spikenard, Cinnamon-root, Fleawort*, Lady's-glove; Ger. Dürrwurz; Fr. Conyze. Herb diuretic, emmenavogue, insecticide. (c) I. crithmoídes L. of southern Europe is called Golden Samphire; (d) I. Oculus-Chrísti L. (I. Oculus Schr.), Europe, is called Christ's-eye.

1063. IODÁNTHUS,T.\&Gr. Purple or False Rocket.Cruciferae. From Greek, "violet"' colored "flower". Syn. Hesperis, Thelypodium, in part. Herb with violet or white flowers in panicled racemes. One species, easternU. S.

1064. I01ÍNA, Hook. \& Arn. Iodina. Aquifoliacene. Shrubs. Two species, South America; (a) I. rhombifólia H. \& A. is Quebracho flojo. Wood and bark rich in tannin.

1065. I0NÁ('TIS, Greene. Pine Starwort, etc. Compositae. From Greek, "violet rayed". Syn. Aster, Diplopappus, in part. Aster-like perennial herbs. Three known species, all of U. S.

a. I. linariifólius (L.) Greene (A. linariifolius L. (Kew), D. linariifolius Hook.) Canada to Florida, west to Texas and Minnesota. Stiff Aster, Savory-leaved Aster, Sandpaper Starwort, Pine Starwort.

1066. IPOMOÉA, L. (Ipımæa, Ipomea). Convolvulacene. From Greek, "worm like", alluding to twining stems. Syn. Batatas, Calonyction, Convolvulus, Pharbitis, in part. Herbs, usually twining or trailing. About 300 species, widely distributed; 33 in U. S. See also Exogonium.

a. I. Batátas Poiret (B. edulis Choisy, Conv. tuberosa). Tropical America, now widely cult. Sweet Potato, Camote. Tuber's esculent. The following species among others yield also edible tubers; (b) I. Batatílla G. Don., Venezuela; (c) I. Calobra Hill \& Muell., Australia; (d) I. costáta F. Muell., Australia; (e) I. gramínea R. Br., Australia (Mallamak of the natives); (f) I. mammósa Choisy, Amboina; (g) I. platanifólia R. \& S., Central America.

h. I. Bóna-nox L. (Cal. speciosum Choisy (Engler \& Prantl), Cal. Bona-nox (L.) Boj.). Tropical America to Florida, widely nat. [in tropical countries, also cult. Moon-Hower, Moon Creeper. 
i. I. hederácea (L.) Jacq. (Conv. hederaceus L., C. Nil L., P. Nil Choisy, I. Nil Roth, I. triloba Thunb.). Tropical America, nat. in southern U.S. and widely elsewhere. Blue Morning-glory. Roasted seeds, in India called Kaladana, in Japan Kengashi, used as a purgative. Varieties of this and of ( $i)$ I. purpúrea Lam. are the garden Morning-glories.

k. I. leptophýlla To'r. Nebrasiza to New Mexico and Texas. Bush Morning-glory, Man-root.

1. I. Orizabénsis (Pel.) Ledan. (Conv. Orizabensis Pelletan). Mexico. Tuberous roots; Male Jalap, Fusiform or Woody Jalap, Jalap-stalks; Ger. Falsche Jalape, Jalapenstengel; purgative. (m) I. símulans Hanbury. Mexico. Source of Tampico Jalap or Sierra Gordo Jalap. See Exogonium, to which possibly these species belong.

n. I. panduráta (L.) Meyer (Conv. panduratus L.). Ontario and eastern U. S. Man-root, Man-of-the-earth, Hog Potato, Wild Potato, Wild Sweet-potato, Wild Jalap, Mechoacanna, Mechamech (of the aborigines), Scammony-root, Wild Scammony. 'Iubers feebly cathartic.

1067. IRESÍNE, P. Br. Blood-leaf, etc. Amaranthaceae. From Greek, alluding to "woolly" calyx. Herbs, aunual or perennial. About 20 species, warm and temperate regions; 2 in U. S. (a) I. paniculáta (L.) Kze, southern U. S. and southward, is called Blood-leaf, Juba's-bush and Juba's-brush.

1068. ÍRIs, L. Fleur de lis, Blue Flag, etc. Iridareae. From Greek, "rainbow". Herbs from creeping root stocks. About 100 species, mostly of north temperate zone; 22 in U. S.

a. I. Florentína L. Southern Europe, Florentine Orris (i. e. Iris), White Flag, Florence or Sweet Flower-de-luce. Rhizome of this and two following species; Orris-root; Rhizoma iridis, Kadix iridis florentinæ, R. ireos; Ger. Irisrhizom, Vielchenwurzel, Violenwurzel, Scliwertelwurz; Fr. Iris de Florence (Codex); Sp. Liria de Florencia; acrid, sternutatory, but chiefly used in dentifr ces, cosmetic powders, etc. Sometimes used for issue peas (Pois d'iris de Paris)

b. I. Germánica L. Southern Europe, northern Africa to India, cult. and adv. in U. S. European Blue Flag, German Iris or Orris; Ger. Blauer Schwertel, Schwertlilie; Fr. Flambe, Fleur de lis (corrupted in English to Flower de luce). This species, also (c) I. pállida Lam., Southern Europe to Syria, Pale Blue Flag, have properties and uses of (a).

d. I. prismática Pursh. (I. Virginica Muhl. not L., I. gracilis Bigel.) New Brunswick to N. Carolina. Slender Blue Flag, Poison Flag. Properties of $(\mathrm{g})$.

e. I. Psendácorus L. Europe, adv. in U. S. Yellow Flag, False Sweet-flag, Daggers, Corn Flag, Yellow Water-flag, Sword Flag, Jacob's-sword, Flagons, Yelluw Water-skegs, Water-seg. Seeds used for coffee. 
f. I. vérna L. Pennsylvania to Georgia. Dwarf Iris, Slender Blue Flag. Root stock "pungently spicy".

g. I. versícolor L. (I. Virginica L. not Muhl.). Canada, south to Florida and west to Arkansas and Manitoba. Blue Flag, Flag Lily, Liver Lily, Snake Lily, Poison Flag, Water Flag, American Fleur-de-lis or Flower-de-luce; Ger. Verschiedenfarbige Schwertlilie, Amerikanischer Schwertel; Fr. lris varié, Flambe variée, Glaieul bleu; Sp. Liria Americana. Rhizome, Blue Flag, Iris U.S. P., cathartic, cholagogue.

1069. IRvívGIA, Hook. Dika Bread. Simarubaceae. Named for Dr. Irving, R. N. Trees with curious annulated branches. Three species, tropical west Africa. (a.) I. Bárteri Hook. f. is called Bread-tree, Dika Bread, Mango*. Seeds edible.

1070. ISÁNTHUS, Michx. False Pennyroyal, etc. Labiatae. From Greek, "equal" (i. e. regular) "flowered". Syn. Trichostema, in part. Annual herb. One species, Canada and eastern U. S., False Pennyroyal, Fluxweed, Blue Gentian*.

1071. Iś́́TIS, L. - Woad. - Cruciferae. Ancient Greek plant name. Herbs, annual or biennial. About 30 specie:, southern Europe and western Asia.

a. I. tinctória L. Europe. Dyer's Woad (Wad, Ode, Goud), Ash-uf-Jerusalem. This species as well as (b) I. indigótiea Fortune, of China yields indigo.

1072. IsNÁRDIA, L. Marsh Purslane. Onagraceae. Named for A. D. Isnard, French botanist, d. 1724. Syn. Ludwigia, in part. Suc ulent herbs. About 4 species, N. America; 3 in U. S.

a. I. palústris L. (L. palustris Ell.) . Europe, Asia and N. America; U. S. throughout. Marsh Purslane, Water Purslane, False Loose-strife, Phthisic-weed. Plant has been used in asthma.

1073. ISOCÁRPHA, R. Br. 1816. Isocarpha. Compositae. From Greek, "equal chaff", the bracts of involucre and receptable being similar. Syn. Dunantia, DC. 1836; Calea, in part. Herbs related to Ageratum. About 5 species, tropical America; 1 in U. S.

1074. IsócoMa, Nutt. Isocoma, Damiana*. Compositae. From Greek, 'equal hair". Syn. Aplopappus, Baccharis, Bigelovis, Linoseris, in part. Suffrutescent plants with succulent leaves and small rayless heads (yellow). Ten species in southwestern U. S.

a. I. venéta (H. B. K.) Greene (Bac. veneta H. B. K., Big. veneta Gray, L. Mexicana Schlecht., A. discoideus DC.). California to Mexico. One of the plants called Damiana. Plant reputed aphrodisiac.

1075. ISÓMERIS, Nutt. Isomeris. Capparidaceae. From Greek, "equal parts". A shrub of unpleasant odor, with yellow flowers. One species, California. 
1076. IS0PÁPPUS, F. \& Gr.

Isopappus.

Compositae. From Greek, with "equal pappus". Syn. Aplopappus, in part. Herbs with small heads of yellow flowers. Two species, southern U. S.

107 7. ISOPÝRUM, L.1752. False Rue Anemone.Ranunculaceae. Ancient Greek plant name. Syn. Enemion, Raf. 1820. Herbs with ternately decompound leaves. About 15 species, north temperate zone; 4 in U. S.

1078. ÍTEA, L. Virginia Willow. Saxifragaceae. From Greek name of "willow", the foliage being willow-like. Shrubs with racemed white flowers. About 5 species, 4 of eastern Asia; 1 in U. S.

1079. ÍVA, L. - Marsh Elder. - Ambrosiaceae. Old Greek name of Ground-pine (Ajuga) which has a similar odor. Syn Cyclachæna, in part. Rough herbs resembling Amhrosia. About 14 species, all American; 11 in U. S. (a.) I. frutéscens L. is called also High-water shrub and Jesuit's. bark*.

10S0. IVÉSIA, Torr. \& Gr. Ivesia. Rosaceae. Perennial herbs related to Potentilla. Syn. Potentilla, in part. Fourteen species belong to southwestern U. S.

1081. ÍXORA, L. Wild Jasmin, etc. Rubiaceae. Dedicated to Iswara, a Malabar deity in whose worship the flowers were used. Shrubs or small trees. About 135 species, tropical regions especially of Old World.

a. I. coccínea L. (I. Bandhuca Roxb.). Tropical Asia. A remedy in India for dysentery.

1082. JACARÁNDA, Juss. Rosewood, etc. Bignoniareae. From vernacular, Brazil. Syn. Bignonia, in part. Trees. About 30 species, tropical America.

a. J. prócera (Willd.) Spreng. (B. procera Willd.); (b) J. Copáia (Aubl.) D. Don. (B. Copaia Aubl. ); (c) J. Caróba (Vel.) DC. (B. Caroba Velloso); perhaps all three a single species. Guiana to Brazil. Caruba. Leaves alterative, anti-syphilitic. Other Brazilian species also called Caroba and having similar properties are (d) J. oxyphylla Cham. and (e) J. subrhómbea DC. See also Bignonia, Cybistax and Sparattosperma.

f. J. ovalifólia R. Br. (J. mimosæfolia Don.). Brazil. Wood of this and some other species is the fragrant Palixander or Palissandre wood, also called Rosewood.

1083. JACOBíNIA, Moric. Jacobinia. Acanthaceae. Shrubs. About 30 species, warmer regions of America; 1 in U. S.

1084. JACQUEMÓNTIA, Choisy.Jacquemontia.Couvolvulaceae. Named for Victor Jacquemont who traveled in the $W_{\text {est }}$ Indies, 19th century. Twining herbs. About 36 species, tropical America, 1 in Asia; 4 in U. S. 
1085. JACQUínIA, L. Bracelet-wood. Myrsinaceae. Named tor Prof. N. I. de Jacquin, botanist of Leyden, d. 1818. Evergreen shrubs. About 18 species, tropical America; 2 in U. S.; (a) J. armilláris Jacq., West Indies to Florida, is called Bracelet-wood or Joe-wood.

1086. JÁMBOS, Adans. (Jambosa DC., Jambus). Myrtaceae. Vernacular, Hindustan. Syn. Eugenia, in part. Trees bearing large edible fruits.

a. J. Jámbus (L.) Lyons (E. Jambos L. (Kew), E. jambosa Crantz, E. Jamboo Roxb., J. vulgaris DC., Jambus rosatus Noronha). East Indies, cult. in all tropical countries. Rose Apple, Malabar Plum, Jambosade, Jambu. Fruit esculent, with flavor of rose-leaves.

b. J. Malaccénsis (L.) DC. (E. Malaccensis L. (Kew), J. purpurea W. \& A., J. domestica Rumph. ). India, East Indies and Oceanica. Malay Apple, the Mountain Apple or Ohia of Hawaiian Islands. Fruit esculent.

1087. JANÚSIA, Juss. Janusia. Malpighiaceae. Climbing shrubs. About 8 species, mostly of $\mathrm{S}$. America; 1 in U. S.

1088. JASIÓNE, L. Sheep's-bit. Campanulaceae. Ancient (ireek name of this or a kindred plant. Dwarf herbs with clustered flowers. About 12 species, temperate Europe; 1 adv. in U. S., viz. (a) J. montána L., Sheep's-bit, Sheep's Scabious.

1089. JÁSMINUM, L. Jasmine, Jessamine. Jasminaceae. From the Arabic name, yasmin. Shrubs or climbers. About 125 species, warmer regions especially of Old World. The fragrant flowers of several species are largely used in perfumery, notably of (a) J. grandiflórum L., India to Japan, cult. in France, Large-flowered White Jasmine or Jessanine (Jasmin, Jessamin, Jessamy, Jeshamy); (b) J. odoratíssimum L., Madeira, Sweet-scented Yellow Jasmine; (c) J. officinále L., China and southern Asia, cult. in southern Europe, Common White Jasmine; (d) J. Sámbac, India to China, Arabian Jasmine, Bela (Hindustan).

1090. JATEORRHíza, Miers. Calumba. Menispermaceae. From Greek, "healing root". Syn. Cocculus, Menispermum, in part. Woody climbers. Three species, tropical Africa.

a. J. palmáta (Lam.) Miers (M. palmatum Lam., C. palmatus DC., not Hook., M. Columba Roxb. This last is possibly a distinct species; if so we must adopt for the name of the plant producing Calumba J. Colúmba (Roxb. ) Miers.). Eastern Africa. Root; Calumba, U. S. P., Calumbæ radix Br., Calumba or Columbo (from vernacular Kalumb); Radix Colombo, P. G., Calumbo; Ger. Kolombowurzel; Fr. Racine de Colombo (Codex), Colombe; Bitter tonic. 
1091. JÁTroPHA, L. Spurge Nettle, etc. Euphorbiacrae. From Greek, "healing nutriment". Prickly herbs or shrubs. A bout 70 species, warmer regions especially of New World; 8 in U: S. (a) J. stimulósa Michx. (J. urens, var. stimulosa Muell. ), Virginia to Florida and Texas, is called Spurge Nettle, Sand Nettle, Stinging-bush, Tread-softly.

1092. JAÚMEA, Pers. 1807. Jaumea. Compositae. Named for 1. H. Jaume St. Hilaire, French botanist. Syn. Kleinia, Juss. 1803, not L.; Coinogyne, in part. Herbs or subshrubs. A bout 5 species, chiefly of S. America; 1 in California.

1093. JEFFERSÓNIA, Bart. Twin-leaf. Berberidaceae. Named in honor of Thomas Jefferson, the statesinan. Syn. Poduphyllum, in part. Perennial herbs with solitary white flowers. Two species, one in Mantchuria; 1 in U. S.

a. J. diphýlla (L.) Pers. (P. diphyllum L., J. binata Bart. (Kew), J. Bartonis Michx.). (Intario to Virginia and west to Wisconsin. Twin-leaf, Rheumatism root, Helm t-pod, Ground-scuirrel Pea, Yellow-root. Root diuretic, alterative, anti-arthritic.

1094. JEPSóxIA, Small. Jepsonia. Saxifragaceae. Two species in U. S.

1095. JOANyÉSIA, Vell. Anda Assu. Euphorbiaceae. Syn. Anda, Juss., Andicus, Vell. Tree. One species, Brazil.

a. J. prínceps Vell. (Anda Braziliensis Raddi, A. Gornesii Juss., Andicus pentaphyllus Vell.). Brazil. Anda Assu. Seeds, Semina (Nuces) andæ; Ger. Ararafrüchte, Andanüsse; actively cathartic; yield an vil resembling castor oil.

1096. JÚGLANS, L. - Walnut - Juglandaceae. Latin name, the "nut of Jove". Trees with pinnate leaves and edible nuts. About 10 species, north temperate zone and $\mathrm{S}$. America; 5 in U. S.

a. J. cinérea L. (J. cathartica Michx., J. oblonga Mill.). Canada to Georgia, west to Arkansas and N. Dakota. Butternut, White or Lemon Walnut, Oil-nut. Bark of root; Juglans, U. S. P., Butternut bark; Ger. Graue Wallnussrinde; Fr. Écorce de noyer gris; Sp. Nogal; cathartic, cholagogue. Seeds rich in oil.

b. J. nígra L. Ontario and eastern U. S. Black Walnut. Seeds yield oil; wood valuable; (c) J. Califórnica Wats., California, is the California Black Walnut.

d. J. régia L. Europe and Asia, cult. in U.S. English Walnut, European or French Walnut, Bennut, Welsh-nut, French-nut, Madeira-nut (a thin shelled variety); Nux regia, Nux persica, Nux enbøa; Fr. Noyer commun (Codex). Rind of fruit, alterative, anthelmintic. Leaves, Folia juglandis, P. G., astringent, alterative. Kernels yield walnut oil. Immature fruit pickled. 
1097. JUyCoÍDES, Adans. 1763. Wood Rush. Juncaceae. From Greek, "rush-like". Syn. Luzula, DC. 1805. Pushlike perennials. About 40 species; 11 in U. S.

1098. JÚNCUS, L. Rush, Bog Rush, etc. Juncaceae. Ancient Latin name, referring to use of rushes for "binding". Grass-like plants, mostly paludal or aquatic. About 175 species, especially of north temperate zone; 78 in U.S.

1099. JUNíPERUS, L. Juniper. Pinaceae. Ancient Latin name, meaning "renewing its youth". Syn. Sabina, in part. Evergreen trees and shrubs with berry-likefruit. About 30 species, northern hemisphere; 9 in U. S.

a. J. Bermudiána L. Bermuda and Barbados. Pencil Cedar. The fragrant wood used for pencils, etc.

b. J. commúnis L. Northern Europe, Asia and N. America, south to New Jersey, Michigan and New Mexico. Juniper tree, Aiten (Aitnach, Etnach), Fairy-circle, Gorst, Hackmatack, Horse Savin; Ger. Wachholder, Kaddig, Kranewett, Jachandel, Johandel; Fr. Genévrier comnun; Sp. Enebro. Fruit, Juniper berries, Melmot berries; Baccæ juniperi; Ger. Wachholderbeeren; Fr. Baie de genievre (Codex); diuretic, carminative, emmenagogue; source of oil of Juniper. Oleum juniperi, U. S. P. The wood also yields by distillation a volatile oil, oleum ligni juniperi. From the fruit is distilled the spirit called gin (originally genera).

c. J. Oxycédrus L. Southern Europe and northern Africa. Prickly Cedar, Spanish Cedar, Large brown-fruited Juniper, Berry-bearing Cedar. Wood rields by dry distillation Oil of Cade; Oleum cadinum, U. S. P.; Ol. juniperi empyreumaticum, Ol. cadi, Ol. juniperi nigrum; Ger. Kadeöl, Kaddigöl, Takinöl; Fr. Huile de cade (Codex), anthelmintic; used in skin diseases; a constituent of Haarlem oil.

d. J. Sabína L. (S. officinalis Garcke.). Europe, northern Asia and N. America, south to New York and Montana. Savin (Savine), Saving tree, Cover-shame; Ger. Sadebaum; Fr. Sabine (Codex). The tops; Sabina, U. S. P., Sabinæ cacumina Br., Summitates sabinie, Herba sabinæ; Ger. Sadebaumspitzen, Sadekraut; emmenagogue, irritant, anthelmintic. Also source of oil of savin (U. S. P.)

e. J. Virginiána L. British America and U. S., east of Rocky Mountains. Red Cedar, Carolina Cedar, Virginian Cedar, Pencil Cedar, Savin*, Red Savin, Red Juniper, Pencil-wood. Properties resemble those of $(d)$.

1100. JUSSIAÉA, L. Primrose-Willow. Onagraceae. Named for Bernard de Jussieu, d. 1777. Syn. Ludwigia, in part, Jussieua (the older form). Perennial herbs with white or yellow solitary flowers. About 35 species, warm and temperate regions, especially of New World; 8 in U. S.; (a) J. diffúsa Forsk., Creeping or Floating Primrose-willow, is called also Clove-strip. 
1101. JUSTÍCLA, L.

Justicia.

A canthaceae.

Named for J. Justice, Scotch horticulturalist. Syn. Dianthera, Diapedium, Dicliptera, in part. Herbs, rarely shrubs. About 110 species, warmer regions; 1 in U. S. See Adhatoda.

1102. KALLSTROÉMIA, Scop. Caltrops. Zygophyllaceae. Named for Kallstroem. Syn. Tribulus, in part. Herbs, often prostrate, with yellow flowers. About 10 species, warm and tropical regions; 4 in U.S.

1103. KÁLMIA, L.

Sheep Laurel, etc.

Named for Peter Kalm a pupil of Linneus, d 1779 . green shrubs with showy flowers the rest of eastern U. S.

a. K. angustifólia L. Canada, south to Georgia. Sheep Laurel, Calf-Kill, Lamb-kill, Kill-kid, Narrow-leaved Laurel or Sheep-laurel, Dwarf Laurel or Sheep-laurel, Sheep-poison, Spoonwood Ivy, Wicky. Properties of (d), as have (b) K. glaúca Ait., British America, south to NewJersey, Michigan, Colorado and California., Swamp Laurel, Pale Laurel; and (c) K. hirsúta Walt., Virginia to Florida, Hairy Laurel, Wicky.

d. K. latifólia L. Canada and eastern U. S. Mountain Laurel, Calico-bush, American Laurel, Small or Wood Laurel, Broadleaved Laurel or Kalmia, Rose Laurel, Sheep Laurel, Spurge Laurel, Clamoun, Kalmia, Ivy-bush, Big-leaved Ivy, Spuonhunt, Spoonwood, Wicky. Leares alterative, narcotic, sedative, errhine, astringent. Fruit poisonous.

1104. KARWÍNSKIA, Zucc. Karwinskia. Rhamnaceae. Shrubs. About 5 species, tropical and sub-tropical N. America; 1 in U. S.

1105. KELLÓGGA, Torr. Kelloggia. Slender herb. One species, California.

Rubiaceae.

1106. KHÁYA, Juss. - Juribali.

Cedrelaceae. The vernacular name. Syn. Swietenia, in part. Large trees. Two species, tropical Africa; (a) K. Senegalénsis (Desv.) Juss. (S. Senegalensis Desv.). Western Africa. Juribali. Bark astringent, febrifuge.

1107. KNEÍFFIA, Spach. Sundrops, etc. Onagraceae. Named for Prof. C. Kneiff of Strassburg. Syn. Oenothera, in part. Suffrutescent herbs with yellow diurnal flowers. About 10 species, temperate N. America; 9 in U. S.

a. K. pumila (L.) Spach. (Oe. pumila L., Oe. chrysantha Michx.). Canada and northeastern U.S. Small Sundrops, Dwarf Evening Primrose, Golden-flowered Erening Primrose. (b) K. Pruticósa (L.) Raimann, and (c) K. glaúea (Michx.) Spach are called also Scabish. 
1108. KNOWLTÓXIA, Salisb.1796. Knowltonia. Ranunculaceae. Named for Thomas Knowlton, curator botanical garden at Eltham. Syn. Thebesia, Neck. 1790. Acrid herbs. About 6 species, So ith Africa; (a) K. resicatória Sims. South African Buttercup. Plant acrid, vesicant.

1109. KÓCHIA, Roth. White Sage, etc. Chenopodiaceae. Named for W. D. J. Koch, curator botanical garden Erlangen, d. 1849. Syn. Chenopodium, in part. Perennial herbs or low shrubs. About 35 species, mostly of Old World; 2 in U. S.

a. K. Americana Wats. (K.prostrata Auct., not Schrad.). Nevada. White Sage. A valuable salt bush, as is (b) K. villósa Lindl. of Australian deserts, called Cotton-bush. (c) K. Scopária (L) Roth. (C. Scoparia L.), Europe and Asia, adv. in U. S., is called Brown Cypress, Belvidere or Summer Cypress.

1110. KOEBERLÍNIA, Zucc. Koeberlinia. Simarubaceae. Shrub, almost leafless. One species, Texas and Mexico.

1111. KOÉLLIA, Moench 1794. Mountain Mint. Labiatae. Named for J. L. C. Koelle, German botanist, 18th Century Syn. Brachystemum and Pycnanthemum, Michx. 1803; Clinopodium, Origanum, Satureja and Tullia, in part. Mint-like perennials. About 15 species, all of U. S. Properties of Mentha.

a. K. incána (L.) Kze. (C. incanum L., P. incanum Michx. ). Ontario to Florida. Hoary Mountain Mint, Mountain Mint, Calamint, Wild Basil, locally known as Horsemint.

b. K. Virginiána (L.) MacM. (S. Virginiana L., P. lanceolatum Pursh). Canada to Georgia, west to Nebraska. Virginia Thyme, Virginia Mountain Mint, Basil*, Mountain Thyme, Pennyroyal*, Prairie Hyssop. The name Virginia Thyme is given also to the much less aromatic, (c) K. flexuósa (Walt.) MacM. ( O. flexuosum Walt., S. Thymus-Virginicus L., P. linifolium Pursh), Ontario and eastern U. S., Narrow-leaved Mountain Mint?

1112. KóNIGA, Adans. 1763. Sweet Alyssuin, etc. Cruciferae. Named for Charles Konig: curator in British Museum. Syn. Konig (older form), Lobularia, Desv. 1813; Glyce, Alyssum and Clypeola, in part. [Not to be confounded with Koenigia L., Polygonaceae.] Perennial herbs or shrubs. About 4 species, Mediterranean region. The Sweet Alyssum of the gardens is (a) K. marítima (L.) R. Br. (C. maritima L., G. maritimum Lind., A. maritimum Lam.). Seaside Koniga? s, Sweet Allison, Anise*, Madwort, Snow-drift, Seedling.

1113. KOSTELÉTZKYA, Presl. Kosteletzkya. Malvaceae. Named for V. F. Kosteletzky, botanist of Bohemia. Syn. Hisbicus, in Part. Perennial herbs or shrubs. About 8 species, New World; 3 in U. S.

1114. KRANÉRIA, Loefl. Krameria. Krameriacene. Named for Dr. J. G. H. Kramer, Austria, 18th Century. Herbs or low shrubs. About 20 species, warmer regions of America; 4 in U. S. 
a. K. argéntea Mart. Brazil. Source of Para, Brazilian or Ceara Rhatany, Ratanhia da terra.

b. K. cistoídea Hook. Chili. Root resembles Payta Rhatany.

c. K. Ixina L. Brazil to Mexico and West Indies. Source of Savanilla or New Granada Rhatany. See (e)

d. K. secundiflóra DC. (K. lanceolata Tor.). Florida to New Mexico and Mexico, Linear-leaved Krameria. Source of Texas Rhatany.

e. K. triándra R. \& Pav. (K. tomentosa St. Hil.). Peru and Bolivia. Source of Peruvian or Payta Rhatany. Root of this and of (c), Rhatany, Rliatany root; Krameria. U. S. P., Krameriæ radix, Br., Radix ratanhiæ (ratanhæ); Ger. Ratanhawurzel, Ratanhiawurzel; Fr. Ratanhia (Codex); Sp. Ratania, Crameria. [Varieties are Short or Stumpy Rhatany (the main root) and Long Rhatany (the branches) ]. A powerful astringent.

1115. KRAÚNHIA, Raf. 1808. Wisteria. Papilionaceae. Syn. Wisteria, Nutt. 1818, also Glycine, in part. Woody climbers with showy blue or purple flowers. Four known species, three of Asia; 1 in U. S.

a. K. frutéscens (L.) Raf. (G. frutescens L., W. speciosa Nutt. (Kew), W. frutescens Poir. ). Southeastern U. S. American Wisteria, Kidney-bean tree, Virgin's-bower*.

1116. KRYNítzKIA, Fisch. \& Mey. 1841. Boraginaceae. Syn. Krynitzia, Piptocalyx, Torr. 18i4, not Oliver, 1870 (but Heller catalogues two species under this name). Herbs. Perhaps 20 species, N. America. See Allocarya, Cryptanthe, Eremocarya and Oreocarya.

1117. KÚHNLA, L. False Boneset. Compositae. Named for Dr. Adam Kuhn of Philadelphia, pupil of Linnæus. Syn. Eupatorium, in part. Perennial herbs with small flower heads in corymbs. About 8 species, N. America; 4 in U. S.

1118. KUHXíSTERA, Lam.1789. Prairie ('lover. Papilionaceae. Named from resemblance to Kuhnia. Syn. Petalostemon, Michx. 1803, also Dalea, in part. Perennial herbs with spicate or capitate flowers (purple or white). About 35 species, N. America; 27 in U. S. (a) K. cándida (Willd.) Kze. is White Prairie Clover or Tassel-flower; (b) K. purpúrea (Vent.) MacM. is Violet Prairie Clover, Red Tassel-flower, Red Thimble weed.

1119. KUMLIÉNIA, Greene. Kumlienia. Ranunculaceae. Herb. One species in western U. S.

1120. KÚNZIA, Spreng. 1818, not Kunzea, Reichb. Rosaceae. Syn. Purshia, DC. 1817, not Spreng 1817. Shrubs. 'Two species, Pacific slope U. S. 
1121. LÁBLAB, Adans. 1763. Egyptian Bean. Papilionaceae. From vernacular name, Africa. Syn. Lablavia, Don 1834; Dolichos, in part. Herbaceous climbers. One species, Africa.

a. L. Láblab (L.) Lyons (D. Lablab L., L. vulgaris Savi, L. niger Medic. and L. rufus Medic., L. cultratus DC., Lablavia vulgaris D. Don). Africa, widely cult. in tropical countries. Egyptian Bean, Black or Hyacinth Bean. Seeds and pods esculent.

1122. LACHNOCAÚLON, Kunth. Lachnocaulon. Eriocaulaceae. From Greek, "woolly stemmed". Syn. Eriocaulon, in part. Scapose herbs resembling Eriocaulon. Four known species, southern U. S.

1123. LACHNó STOMA,H. B. K. Lachnostoma. Asclepiadaceae. From Greek, "woolly mouth", of the corolla. Herbaceous climbers. About 5 species, warmer regions of New World; 1.in U. S.

1124. LACINIÁRIA, Hill. 1762. Blazing-star. Compositae. From Latin, "fringed", from appearance of flower heads. Syn. Liatris, Schreb. 1791; also Serratula, Stœepelina, in part. Perennial herbs mostly from tuberous roots, the showy flowerheads in racemes or spikes. About 15 species, all of U. S.

a. L. scariósa (L.) Hill (Ser. scariosa L., Liatris scariosa Willd. ). Maine to Florida, west to Texas, Nebraska and Manitoba. Large Button-Snakeroot, Gay-feather, Rattlesnake'smaster, Blue Blazing-star, Devil's-bit. Root of this and following species reputed diuretic, diaphoretic, carminative.

b. L. spicáta (L.) Kze. (Ser. spicata L., Liatris spicata Willd.). Massachusetts to Florida, west to Louisiana and Wisconsin. Button Snakeroot, Dense Button-Snakeroot, Gay-feather, Devil'sbit, Rough-root, Sawwort, Throatwort*, Colic-root*, Rattlesnake's-master, Corn Snakeroot, Prairie-pıne, Backache-root.

c. L. squarrósa (L.) Hill (Ser. squarrosa L., Liatris squarrosa Willd.). Scaly Blazing-star, Colic-root, Rattlesnake's-master.

1125. LACTÚCA, L. - Lettuce. - Cichoriaceae. Ancient Latin name, "milky", whence our word lettuce. Syn. MIulgedium, Sonchus, in part. Herbs with small flower heads (yellow, white or blue). About 85 species, northern hemisphere; 10 in U. S.

a. L. Canadénsis L. (L. elongata Muhl.). British America, south to Georgia and Louisiana. Wild Lettuce, American or Canada Wild Lettuce, Tall Lettuce, Butter-weed, Devil's-weed, Devil's Ironweed, Fireweed*, Horseweed, Snake-bite, Snakeweed, Trumpet-weed, Trumpet Milkweed, Trumpets, Wild Opium. Juice mildly narcotic as also in the indigenous (b) L. hirsúta Muhl. (L. sanguinea Bigel., L. elongati, var. sanguinea T. \& Gr.), Hairy or Red Wood-lettuce and (c) L. sagittifólia Ell. (L. integrifolia Bigel, not Nutt., L. elongata, var. integrifolia T. \& Gr.), Arrow-leaved Lettuce, Devil's Ircn-weed. 
d. L. satíra L. Southern Asia, now widely cult. Garden Lettuce, Common Lettuce, Sallet, Sheepwort. Varieties are Cabbage Lettuce, forming heads (L. capitata DC.) and Cos Lettuce. Ger. Gartenlattich, Gartensalad; Fr. Laitue officinale (Codex): Sp. Lechuga. . Leaves used as salad. Inspissated juice is French lactucarium; Fr. Thridace (Codex).

e. L. Scarióla L. Europe, nat. in eastern U. S. Prickly Lettuce, Wild Lettuce, Horse Thistle, Compass-plant.

f. L. virósa L. Europe. Wild Lettuce (of Europe), Acrid Lettuce, Strong-scented Lettuce, Green Endive; Ger. Gift-Lattich, Stink-Lattich; Fr. Laitue vireuse (Codex). The flowering herb; Lactuca Br., Herba lactucæ (virosæ), H. intybi angusti." The concrete milk juice (of this and other species); Iactucarium, IT. S. F., Lettuce Opium; sedative, mildly narcotic, hypnotic. This species and (g) L. sagittáta Waldst. \& Kit. (L. altissima Bibers.), perhaps only a variety, are cult. in Europe as a source of lactucarium.

1126. LAGENÁriA, Séringe. Gourd. Cucurbitaceae. From Latin lagena, a "flask". Syn. Cucurbita, in part. Vine, climbing by tendrils. One species, Old World.

a. L. Lagenária (L.) Lyons (C. Lagenaria L., L. vulgaris Séringe). Europe and Asia, cult. in many varieties. Gourd, Calahash Gourd, Bottle Gourd, Sugar-trough Gourd; Ger. Kürbis; Fr. Calebasse d'Europe, Gourde, Cougourde (Codex). Root pulp reputed cathartic. Seeds (cold seeds), emollient. See $614(d)$.

1127. LAGERSTROÉMi L, L. Crape Myrtle, etc. Lythraceae. Trees or shrubs. About 20 species, warmer regions of eastern Asia. (a) L. lanceoláta Wall. (L. microcarpa Wight), East Indies, is Ben Teak, an inferior kind of teak; (b) L. Flosregínae Retz. (L. reginæ Roxb. ), India to Burmah, is Jaroul, Blood-wood; (c) L. Indica L., China, is Crape Myrtle, Indian Lilac.

1128. LAGÉTTA, A. L. Juss. Lace-bark tree. Thymeliaceae. From vernacular, lagetto. Trees. Two known species, West Indies. (a) L. linteária Lam. is the Jamaica Lace-bark tree. The name Lace-bark is applied in Australia to Stercúlia acerifólia Cunningham, Flame tree, and in New Zealand to the malvaceous Plagiánthus betulínus Cunn.

1129. LAGÓTIS, J Gaertn. 1770. Lagotis. Selaginaceae. From Greek, "hare's ear". Syn. Gymnandra, Yall. 1776. Perennial herbs. About 8 species, central and northern Asia; 1 in U. S.

1130. LAGUNCULÁRIA, Gaertn. f. $1805 . \quad$ Combretaceae. Latin, diminutive of lagena, a "flask". Syn. Horan, Adans. 1763 ; Conocarpus, in part. A small tree with habit of Mangrove. One species, tropical coasts in Atlantic Ocean, extending to Florida. (a) L. racemósa (L.) Gaertn. f. (C. racemosa L. ). White Mangrove, White Buttonwood. 
1131. LAMINÁRIA, Lam. Hanger, Tangle, etc. Laminariaceae. From Latin, lamina a thin plate. Leathery seaweeds of cold northern seas.

a. L. Cloústoni Edmonston (L. digitata Lam. The Linnæan name Fucus digitatus, has been applied to two different species.) Tangle, Hanger, Sea-girdle, Sea-staff, Sea-wand; Ger. Riementang; Fr. Laminaire digitée. Stems used for "tents" and dilating bougies.

b. L. saccharína Lam. Devil's-apron, Sweet Tangle, Sea-belt. Fronds contain mannite and are sometimes eaten.

1132. - LÁMIUM, L. - Dead-Nettle. - Cabiatae. From Greek, "throat", alluding to ringent corolla. Herbs. About 40 species, Old World; 5 nat. in U. S.

a. L. álbum L. Europe, adv. in U. S. White Dead-nettle, Bee Nettle, Blind Nettle, Day Nettle, Dumb Nettle, Dunny Nettle, Flowering Nettle, Stingless Nettle, White Nettle, Snake-flower, Suck-bottle, Suckie-Sue, White Archangel; Ger. Taubnessel, Weisser Bienensaug; Fr. Ortie blanche, Lamier (Codex). Flowers alterative, mildly astringent.

b. L. amplexicaúle L. Europe and Asia, nat. in eastern U. S. Henbit, Henbit Dead-nettle, Greater Henbit.

c. L. purpúreum L. Europe and Asia, adv. in U. S. Red Dead-nettle, Deaf Nettle, Day Nettle, Dog Nettle, French Nettle, Red Archangel, Sweet Archangel, Rabbit-meat.

1133. LANDÓLPHIA, Beauv. (Landolfia). Apocynaceae. Named for Capt. Landolph, explorer. Shrubs or small trees. About 17 species, mostly of tropical Africa. (a) L. flórida Benth. and (b) L. gummífera Lam., of southeastern Africa yield Caoutchouc, known as African or Mlungu rubber. The fruit of (a), Abo or Aboli fruit, is edible.

1134. LANGLoÍsIA, Greene. Langloisia. Polemoniaceae. Syn. Gilia, in part. Herbs. Three species in U. S.

1135. LANTÁNA, L. - Lantana. - Verbenacene. Shrubs, rarely herbs. About 60 species, tropical and subtropical America; 4 in U. S.

a. L. Cámara L. (L. Antillana Raf,, L. mutabilis Salisb.). Georgia, West Indies and cult. as a garden flower. Bahama Tea, Wild Sage (Jamaica), Sage-tree, Cailleau. Leares febrifuge, containing an alkaloid resembling quinine; substitute for Chinese tea.

1136. LAPHÁMIA, Gray 1852. Laphamia. Compositae. Na "ed for Dr. J. A. Lapham of Wisconsin, d. 1875. Syn. Monothrix, Tor. 1852. Herbs or under shrubs. About 15 species, all of southwestern U. S. and Mexico.

1137. LÁPPULA, Moench 1794. Stickseed. Boraginaceae. Latin, dim. of Lappa, "Burdock". Syn. Echinospermum, Sw. 1818; Cynoglossum, Myosotis, in part. Rough-pubescent herbs with bur-like fruit. About 40 species, north temperate zone; 12 in U. S. 
a. L. Láppula (L.) Karst. (M. Lappula L., E. Lappula Lehm. $($ Kew $)$ ), L.Myosotis Moench). Europe and Asia, nat. in U. S. European Stickseed, Bur-seed, Small Sheep-bur, Sticktight.

b. I. Virginiána (L. ) Greene (M. Virginiana L., E. Virginicum Lehm., (.. Morrisoni DC.). Canada and eastern U. S Virginia Stickseed, stick-tight, Beggar's-lice, Beggar's-ticks, Dysentery-weed, Dysentery-root, Small Sheep-bur, Soldiers, Virginia Mouse-ear. Root astringent, demulcent.

1135. LARIX, Adans. Larch. - Pinaceae. Ancient Latin name, probably from Celtic. Syn. Yinust, Abies, in part. Trees with deciduous needle-like leaves. About 9 species, north temperate zone and northward; 3 in U. S.

a. L. Americána (Muench) Michx. (P. Larix Americana nigra Muench 1770, L. Iariciua (DuRoi) Koch. (Brit. \& Brown), P. laricina Dukoi 1771 , P. pendula Ait., L. pendula Salisb., P. microcarpa Lamb:). British America, south to New Jersey, Indiana and Minuesota. l'amarack, American Larch, Hackmatack (Hackmetack, Hacmatac, Hacmack), Black or Red Larch, Cypress*, Juniper*. Bark used like that of (b).

b. L. Lárix (L.) Karst. (P. Larix L., L. Europæa DC. (Kew), A. Larix Lam., L. decidua Mill.). Europe. European Larch. Bark, Laricis cortex Br.; Ger. Lärchenrinde; Fr. Écorce de mélèze; astringent, terebinthinate. Oleoresinous exudate, Venice Turpentine; Terebinthina laricina v. laricis v. veneta; Ger. Lärchen-terpenthin; Fr. Térébenthine de Venise (Codex); balsamic, antiseptic. Saccharine exudate, Briançon Manna.

c. L. occidentális Nutt. (P. Nuttallii Parl.). Northeastern U.S. Western Larch or Tamarack. Exudate from wounds in trunk sweetish, eaten by the Indians.

d. L. Sibírica Ledeb. Northern Europe. Siberian Larch. Source of much of the European tar. See Pinus palustris.

1139. LASERPÍTIUM, L. Laserwort. Umbelliferae. Latin name of L. latifolium, the "Laser" plant. Perennial herbs. About 20 species, chietly of southern Europe.

a. L. latifólium L. Europe. White Gentian, Herb-frankincense, Broad-leaved Laserpitium or Laserwort. Root; Radix gentianæ albæ, K. cervariæ albæ; Ger. Weisser Enzian, Laserkrautwurzel; bitter tonic. Gum resin, called Laser, acrid, bitter, reputed purgative.

1140. LASTHÉNIA, Cass. Lasthenia. Compositae. Named for Lasthenia, a pupil of Plato. Syn. Bæria, Crockeria, Orobus, in part. Herbs; mostly annual. About 7 species, south western U. S.

1141. LÁTHYRUS, L. Vetchling, Marsh Pea, etc. Papilionaceae. Ancient Greek name of a Vetch. Syn. Pisum, Orobus, in part. Herbs, mostly climbing by tendrils. About 110 species, northern hemisphere and S. America; 36 in U. S. 
a. L. marítimus (L.) Bigel. (P. maritimum L.). Northern Europe, Asia and N. America, south to New Jersey and Michigan. Beach Pea, Sea or Seaside Pea, Seaside Everlasting-pea. Another circumpolar species is (b) L. palústris L., Marsh Pea, Marsh Vetchling, Wild Pea. Closely allied to this is the Myrtle-leaved Marsh Pea, (c) L. myrtifólius Muhl., of Canada and eastern U. S.

d. L. praténsis L. Europe and northern Asia, nat. in New England. Neadow Pea, Craw Pea, Mouse Pea, Angleberry, Lady'sfingers, Yellow Vetchling. Other species of interest are $(e) \mathbf{L}$. odorátus L., the Sweet Yea of gardens; (f) L. latifól.us L., the Everlasting Pea of gardens; (g) L. decapliyllus Pursh, Prairie Tetchling also called Everlasting Pea; (h) L. Cícera L. of Europe, the Lesser Chick-pea (Jarosse pois-carrés); (i) L. satívus L. of southern Europe, Jarosse or Gesse, a valuable fodder plant, the seeds esculent, and (j) L. montánus Bern. (O. tuberosus I.) of Europe, Dutch-mice, Tine-tare; producing edible tubers.

1142. LAURÉLIA, Juss. P'eruvian Nutmeg. Monimiaceae. Latin, "Laurel like". Syn. Pavonia, R. \& P. 1794, not Lav. 1787; Atherosperma, in part. Aromatic trees. Two species, S. America and New Zealand.

a. L. sempérvirens (R. \& P.) Tulasne (L. aromatica Juss. (Kew), P. sempervirens R. \& P.). Peru. Peruvian Nutmeg, Chilian Sassafras. Bark and fruit aromatic, used as condiments, the latter resembling nutmegs in flavor.

1143. LAURÉXTId, Adans. Laurentia. Lobeliaceae. Annual herbs. About 12 species, mostly of Mediterranean region and $\mathrm{S}$. Africa; 1 in $\mathrm{U}$. $\mathrm{S}$.

1144. LAÚRUS, L. - Bay Laurel. - Lauraceae. The ancient Latin name. Shrubs or trees. Two known species, Europe and western Asia. The genus has been made formerly to include species now referred to a dozen different genera.

a. L. nóbilis. L. Mediterranean region, cult. in Mexico. Bay Laurel, Bay tree, Sweet Bay, Noble Laurel; Ger. Lorbeer; Fr. Laurier commun (Codex); Sp. Laurel. Leaves aromatic, condiment; fruit, Bay-berries, Fructus lauri, Baccæ lauri; aromatic, bitter, carminative. By expression from these is obtained Laurel butter or Oil of Bays, Oleum lauri unguinosum s. expressum; by distillation is procured the ethereal Oil of Bay Laurel, not to be confounded with the oil of Myrcia.

1145. LAVÁNDULA, L. - Lavender. - Labiatae. The Latin name of (a). Perennial herbs or shrubs. About 20 species, chiefly of the Mediterranean region.

a. L. angustifólia (L.) Mill. (L. Spica var. angustifolia L., L. vulgaris Lam. 1778, L. officinalis Chaix., L. vera DC. 1805) Mediterranean region. Lavender, Garden Lavender, True Lavender; Ger. Lavandel; Fr. Lavande officinale (Codex), Sp. Alhucema, Spliego. Flowers, Flores lavandulæ, stimulant, aromatic, perfume; source of the official Oil of Lavender flowers. 
b. L. Spíca Cav. (L. latifolia Villars). Mediterranean region. Spike Lavender, French Lavender, Great or Male Lavender, Aspic; Fr. Lavande commune, Spic (Codex). F'lowers richer in vil but of less delicate aroma than those of (a); source of oil of Spike (essence d'aspic).

c. L. Stoéchas L. Mediterranean region. Arabian Lavender, French Lavender*, Gentle or Topped Lavender, Cast-me-down, Cassadong $\ddagger$, Stickadore. Properties of (b); an important honey plant.

1146. LAVATÉRA, L. Tree Mallow, etc. Malvaceae. Named in honor of the two Lavaters, naturalists of Zurich. Herbs or small trees. thout 40 species, widely distributed; 2 in U. S. (a) L. arbórea L. Mliddle and southern Europe. Tree Mallow, Sea Mallow, Velret-leaf.

114. LAVAÚXIA, Spach. Primrose. Onagraceae. Named for Francois Delavaux of Nismes. Syn. Oenothera (Kew), in part. Perennial herbs with white, pink or pale yellow flowers. About 6 species, N. America; 4 in U. S.

1148. LAWSÓNIA, L. Henna plant. Lythraceae. Named for Dr. John Lawson, early in 18th Century. Shrub with fragrant white flowers. One species. (a)L. inérmisL. (L. alba Lam. (Kew), including L. spinosa L. ). Northern Africa, southern Asia and Ausuralia. Henna plant, Egyptian Privet, Jamaica Mignonette, Flower-of-paradise, Alkhanna, Alcanna; Fr. Henué. [See Alkanna]. Leaves yield an orange dye.

1149. LEA VENWóRTHIA, Torr. Leavenworthia. Cruciferae. Named for Dr. M. C. Leavenworth, U. S. A. Syn. Cardamine, in part. Annual sub-scapose herbs. About 4 species, southeastern U. S.

1150. LECANóra, Ach. Archil Lichen. Parmeliaceae. From Greek word for a "dish".

a. L. esculénta Ach. Algiers to Tartary. Manna Lichen. Used for food in time of scarcity.

b. L. Tartárea Achar. Northern Asia. Tartarean Moss, Canary Moss, Canary-weed, Cudweed*. From this and other lichens is prepared litmus; Lacmus, Lacca musica; Ger. Lakmus; Fr. Tournesol, Laque bleu. Also from these lichens is made Archil or Orchil; Fr. Urseille, and Cudbear; Ger. Persio; Fr. Orseille de terre, all used for coluring.

1151. LÉCHEA, L. - Pin-weed. - Cistaceae. Named for Johann Leche, Swedish botanist, d. 1764. Perennial herbs, often suffirutescent, with small leaves and flowers. About 14 species, N. America and West Indies; 13 in U. S. (a) L. villósa Ell. (L. major Michx., not Lin.). Ontario and eastern U. S., west to Nebraska. Greater Pin-weed, Hairy Pin-weed. Herb tonic, antiperiodic, febrifuge.

1152. LÉCYTHIS, Loefl. Monkey-pot tree. Lecythidaceae. From Greek. "oil vase", alluding to the fruit. Large trees. About 65 species, tropical S. America. 
a. L. ollária L. Tropical America. Monkey-pot tree. Inner bark, called Kakarali or Tauaré, used for wrappers for cigarettes.

b. L, Zabucájo Aublet. Brazil. Sapucaya-nut. Seeds esculent, superior to the allied Brazil nut; source of sapucaya oil. Other species yielding esculent nuts are (c) L. Pisónis Camb., (d) L. lanceoláta Poir. (Sapueaja branca of Guiana), (e) L. urnígera Mart., (f) L. A mazónum Mart. and (g) L. Póhlii Berg.

1153. LÉDUM, .L Labrador Tea, etc.

Ericaceae. Ancient Geeek name of Cistus Ledon. Shrubs with leaves of firm texture. Three species, north temperate zone and northwards; 3 in U. S.

a. L. Groenlándicum Oeder (L. latifolium Ait.). Greenland and British America, south to New Jersey and Wisconsin. Labrador Tea, Continental Tea, Labrador Continental Tea, James' Tea. Leares expectorant, tonic; applied to insect-stings. Formerly a substitute for Chinese tea.

b. L. palústre L. Northern Europe, Asia and N. America. Wild Rosemary, Marsh Rosemary, Marsh Tea. Swamp Tea, Narrowleaved Labrador Tea, Marsh Cistus; Ger. Wilder Rosmarin, Porsch, Sumpfporsch, Porst, Mattenkraut; Fr. Lédon, Romarin sauvage. Leares and twigs, Herba ledi palustris, Herba rosmarini silvestris; reputed narcotic, sedative, insecticide; used in cutaneous eruptions, etc.

1154. LEGOÚZIA, Durand, 1782.

Campanulaceae.

Name unexplained. Syn. Specularia, Heist, 1830. Annual herbs. About 10 species, mostly of northern hemisphere; 4 in U. S. Synonym, Venus' Looking-glass.

1155. LEIBÉRGIA, Coult. \& R. Leibergia. Umbelliferae. Herb. One species in western U.S.

1156. LEITNÉRIA, Chapman. Cork-wood. Leitneriaceae. Nrmed for Dr. E. F. Leitner, German naturalist. Shrub or small tree. One species. (a) L. Floridána Chapm., Florida to Texas; Corkwood. The wood lighter eren than cork.'

1157. LembérTia, Greene. Lembertia. Compositae. Syn. Eatonella, in part. Herb. One species in western U. S.

1158. LEMMóNIA, Gray 187\%. Lemmonia. Hydrophyllaceae. Named for John Gill Lemmon the discoverer. Canescent winter-annual. One species, California.

1159. LÉMNA, L. - Duckweed. _ Lemnaceae. A ncient Greek name of a water plant. Minute floating plants. Seven known species; 5 in U. S. Synonyms, Duck's-meat, Water-lentil, Mardling, Toadspit.

1160. LÉxS, Grev. \& Godron. Lentil. Papilionaceae The ancient Latin name, whence our word lens. Syn.Ervum, Vicia, in part. Herbs. About 5 species, Mediterranean region. 
a. L. Léus (L.) Lyons (Ervum Lens L., L. esculenta Moench (Kew), L. vulgaris Delarb., L. sativa Hill, Vicia Lens Coss.). Southern Europe and the Orient. Lentil, Common Lentil, Till-seed*. Seeds an important esculent in the East. From them is prepared "Revalenta Arabica".

1161. LEONóTIS, R. Br. Leonotis. Labiatae. From Greek, "lion's ear". Herbs or shiubs with showy orange flowers, natives of southern hemisphere; 1 in U. S.

1162. LEÓNTICE, L. Lion's-leaf Berberidaceae. An ancient Greek plant name. Herbaceous perennials from tuberous roots. Eastern Europe and western Asia.

a. L. Leontopétalum L. Europe. Lion's-leaf, Lion's Turnip, Black Turnip. Tubers detergent, used in Turkey as antidote to opium.

1163. LEÓNTOD0Y, L, 1737. Hawkbit. Cichoriaceae. From Greek, "lion's tooth". Syn. Apargia, Scop. 1772, Thrincia, Roth 1796; Crepis, in part. Scapose perennials with dandelion-like flower-heads. About 45 species, Old World; 2 nat. in U. S.

a. L. autumnális L. (A. autumnalis Hoffm.). Europe and Asia, nat. in U. S. Fall Dandelion, Autumnal Hawkbit, Lion'stooth, Dog Dandelion, Arnica-bud,

1164. LEONTOPÓDIUM, R. Br. Edelweiss. Compositae. From Greek, "lion's foot". Syn. Antennaria, Gnaphalium, in part. White-woolly or silky low perennials. About 5 species, Alpine regions of Europe, Asia and S. America.

a. L. Leontopódium (L.) Lyons (L. Alpinum Cass. (Kew), not Colm., G. Leontopodium L., A. Leontopodium Gaertn.). Alps to the Himalayas. Lion's-foot, better known by its German name, Edelweiss.

1165. LEONÚRUS, L. Motherwort, Lion's-tail. Labiatae. From Greek, "lion's-tail". Syn. Ballota, Cardiaca, Panzeria, in part. Biennial or perennial herbs. About 10 species, Europe and Asia; 3 nat. in U. S.

a. L. Cardíaca L. (Cardiaca vulgaris Moench). Europe and northern Asia, nat. in U. S. Motherwort, Cowthwort, Lion'stail, Lion's-ear, Throwwort; Ger. Herzgespann, Wolfstrapp; Fr. Agripaume, Cardiaire. Herb stomachic, diaphoretic.

b. L. lanátus (L. ) Spreng. (B. lanata L., P. lanata Pors.). Northern Asia. Woolly Motherwort; Ger. Wolliger Wolfstrapp, Wolliges Ballotenkraut. Herb, Herba ballotæ lanatæ, vascular stimulant, diuretic.

c. L. Marrubiástrum L. (C. Marrubiastrum Medic.). Europe and northern Asia, nat. in U. S. Hoarhound Motherwort or Lion's-tail. 
1166. LEPARGYRÉA, Raf. 1817. Buffalo-berry. Elaeagnaceae. From Greek, "silvery scaly". Syn. Lepargyræa, Lepargyreia, Shepherdia, Nutt. 1818, also Elæeagnus, in part. Shrubs with scurfy foliage. Three known species, all of U. S.

2. L. argéntea (Nutt.) Greene (E. argentea Nutt. 1813, S. argentea Nutt. 1818.) Kansas to Nevada and northward. Buffaloberry, Rabbit-berry, Beef-suet tree, Bull-berry, Silver-leaf, Wild Oleaster-tree, Wild Olive-tree. Fruit edible.

b. L. Canadénsis (L.) Greene (E. Canadensis L., S. Canadensis Nutt.). British America, south to New York and Utah. Canadian Buffalo-berry, Wild Oleaster- or Olive-tree. Fruit insipid.

1167. LEPEUROPÉT LION, Ell.Lepeuropetalon.Saxifragaceae. A very small annual herb. One species, Georgia and S. Carolina.

1168. LEPÍDIUM, L. Peppergrass. Cruciferae. Greek name of a Cress, meaning a "little scale". Syn. Thlaspi, in part. Herbs with more or less pungent foliage. About 65 species; 29 in U. S.

a. L. apétalum Willd (L. intermedium A. Gray) and (b) L. Virgínicum L. are common weeds throughout the U. S., known as Wild Peppergrass, Tongue-grass, Bird's Pepper*. Plants pungent, antiscorbutic.

c. L. campéstre (L.) R Br. (T. campestre L.). Europe, nat. in U. S. Field Cress, Cow Cress, Mithridate Mustard, Mithridate Pepperwort, Poor-man's Pepper, Yellow-seed, English Peppergrass, Glenn Pepper; Glenn-weed, Bastard Cress, Crowdweed, False Flax. Properties of (e).

d. L. Íberis L. Europe and northern Asia. Peppergrass (of Europe); Ger. Iberiskresse, Pfefferkraut; Fr. Passerage iberide. Properties of $(\mathrm{e})$.

e. I. satívum L. Garden Peppergrass, Garden Garth or Cress (Karse), Town or Golden Peppergrass or Cress, Tongue grass, Sauce-alone, Garden Pepper-cress, Poor man's Pepper. Herb pungent, antiscorbutic, used as salad. [The New Zealand (f) L. oleráceum Forst. is cultivated as a pot herb. In the Society Islands $(\mathrm{g})$ L. piscídium Forst. (L. oleraceum Ait. not Forst. ) is used for stupefying fish].

1169. LEPIDOSPÁRTUM, Gray. Lepidospartum. Compositae. From Greek, "Scale-Broou". Syn. Linosyris, Tetradymia, Carphephorust, in part. Shrubby plants. Three known species, southwestern U.S.

1170. LEPTÁMNIUM, Raf. 1818. Beech-drops. Orobanchaceae. Syn. Epifagus (Kew), Nutt. 1818 (Epiphegus); Orobanche, in part. A purplish or brownish leafless parasite. One species, N. America. 
a. L. Virginiánum (L.) Raf. (O. Virginiana L., Epifagus Americana Nutt., Epiphegus Virginiana Bart.). Canada and eastern U. S. Beech-drops, Beech-drop, Cancer-drops, Cancer-root, Broom-rape, Fir-rape; Ger. Krebswurz; Fr. Orobanche de Virginie. Root astringent, vulnerary.

1171. LEPTÁNDRA, Nutt. Culver's-root. Sorophulariaceae. From Greek, "slender stemmed". Syn. Veronica, in part. Robust perennial herbs. Two species, one of Asia, one of N. America (U. S.).

a. L. Virgínica (L.) Nutt. (V. Virginica L., V. Sibirica L., L. purpurea Raf.). British America, south to Alabama, Missouri and Nebraska. Culver's-root, Culver's-physic, Black-root, Bealmont-root, Bownan's-root, Brinton-root, Hini, Oxadoddy, Quital, Tall Speedwell or Veronica, Whorly-wort. Rhizome and rootlets; Leptandra, U. S. P.; Ger. Leptandrawurzel; Fr. Véronıque de Virginie, Leptandra; emeto-cathartic, reputed cholagogue, alterative.

1172. LEPTARRHÉNA, R. Br. Leptarrhena. Saxifragaceae. Perennial evergreen scapose herb. One species, northeastern Asia and northwestern America (U. S.).

1173. LEPTíXIS, Raf. 1836. Leptaxis. Saxifragaceae. Syn. Tolmiza (Kew), Torr. \& Gr. 1840; Tiarella, in part. Herb related to Tiarella. One species; western U.S.

1174. LÉPTILON, Raf. 1818. Horseweed. Compositae. Syn. Cienotus Raf. 1836; Conyzella, Erigeron (Kew), in part. Herbs with very small heads of white or greenish flowers. About 20 species, America and Asia; 4 or 5 in U. S.

a. L. Canadénse (L.) Britton (E. Canadensis L., C. Canadensis (L. ) Rupr.) Widely distributed in Old as well as New World. Canada Fleabane, Horseweed, Mare's-tail, Canada Erigeron, Butter-weed, Bitter-weed, Cow's-tail, Colt's-tail, Fireweed, Blood-staunch, Hngweed, Pride-weed, Scabious; Ger. Canadisches Berufkraut, Beschreikraut. Source of oil of Canada Erigeron, Oleum Erigerontis Canadensis, U. S. P., which is reputed to control hemorrhage.

1175. LEPTOGLóSSIS, Benth. Leptoglossis. Solanaceae. From Greek, "slender throated". Syn. Nierembergia (Kew), in part. Herbs. Three known species, temperate regions of America; 1 in U. S.

1176. LEPTónCHIs, Thouars 1808. Twayblade. Orchidaceae. From Greek, "slender Orchis". Syn. Liparis, L. C. Richard, 1818; Ophrys, in part. Perennial, scapose, twoleaved herbs. About 100 species, most abundant in East Indies; 2 in U. S.

1177. LEPTÓSYNE, DC. Leptosyne. Compositae. From Greek, "slender", applicable to original species. Small scapose annuals with showy flower heads (yellow). About 7 species, California to Arizona. 
1178. LEPTOTÁ́NiA, Nutt. Leptotænia. Umbelliferae. From Greek, "slender fiilleted". Syn. Ferula (Kew), in part. Perennial herbs from fleshy roots. About 7 species, western U. S.

1179. LESPEDÉZA, Michx. Bush Clover. Papilionaceae. Named for D. Lespedez, Spanish governor of Florida, about 1800. Syn. Hedysarum, in part. Herbs, often suffrutescent, with trifoliate leaves. About 35 species, Asia, Australia and eastern N. America; 11 in U. S.

a. L. capitáta Michx. (L. frutescens Ell.). Ontario and eastern U. S. Round-headed Bush Clover, Dusty Clover.

b. L. striáta (Thunb.) H. \& A. (H. striatum Thunb.). Eastern Asia, nat. in U. S., especially in southern states. Japan Clover, Wild Clover, Hoopkoop plant. A valuable fodder plant.

1180. LEsQUERÉLLA, S. Wats. Bladder-pod. Cruciferae. Named for Leo Lesquereux, Swiss botanist, d. 1889. Syn. Vesicaria and Myagrum, in part. Low herbs with inflated globose silicles. About 35 species, N. America; 32 in U. S., mostly in the west.

1181. LESSÍNGIA, Chamisso. Lessingia. Compositae. Named for Christian F. Lessing, German botanical author. Floccose-wonlly annuals with small flower heads. About 14 species, California.

1182. LEUCAÉNA, Benth. Mimosa. Mimosaceae. From Greek, "white". Shrubs or trees with white flowers in globular heads. About 10 species, tropical America; 3 in U. S.

1183. LEUCÁMPYX, Gray. Leucampyx. Compositae. From Greek, "white bordered" (of the bracts). Perennial herb resembling Hymenopappus. One species, Colorado.

1184. LEUCELÉNE, Greene. Heath Aster. Compositae. From Greek, "white aster". Syn. Aster, in part. Perennial leafy herbs with white flowers. About two species, southwestern U. S. and Mexico.

1185. LEU ‘óCRINUM, Nutt. Soaproot*. Liliaceae. From Greek, "white lily". Perennial acaulescent herb with crocus-like, white, fragrant flowers. One species, Nebraska to California.

1186. LEUCOPHÝ LLUM, Humb. \& Bonpl. Scrophulariaceae. From Greek, "white leaf". Tomentose shrubs. Three species, Mexico and adjacent territory; 2 in U. S.

1187. LEUCOPIÝSALIS, Rydberg. Ground Cherry. Solanaceae. From Greek, "white Physalis". Syn. Physalis, in part. A viscid, hairy annual, British America and northern U. S.

1188. LEUCósYrIS, Greene. Leucosyris. Compositae. Syn. Aster, in part. Perennial herbs resembling Aster. Two species, both of U. S. 
1189. LEUCóthoE, D. Don. Leucothoë. . Ericaceae. Name from Greek mythology. Syn. Andromeda, in part. Shrubs with flowers in dense racemes. About 35 species, America and eastern $A$ sia; 6 in U. S.

a. L. Catesbaéi (Walt.) Gray (A. Catesbaei Walt., A. spinulosa Pursh.), Virginia to Georgia, is called Dog Laurel; (b) L. racemósa (L.) Gray (A. racemosa L., L. spicata G. Don.), near Atlantic and Gulf sea-board, Swamp Leucothoë, is also called White Osier, White Pepper.

1190. LEVÍSTICUM, Koch. Lovage. Umbelliferae. Robust herb, with yellow flowers. One species only, Old World. See Ligusticum.

a. L. Levísticum (L. ) Lyons (Lig. Levisticum L., Lev. officinale Koch., Lev. vulgare Reichb.). Southern Europe. Lovage, European Lovage, Italian or Garden Lovage, Lavose, Levose, Sea Parsley, Smellage; (rer. Liebstöckel, Badekraut, Bärmutterwurz; Fr. livèche (Codex), Ache des montagnes. Root, Radix levistici P. G., R. ligustici, R. laserpitii germanici, also fruit, carminative, stomachic, diuretic, emmenagogue.

1191. LEWÍSIA, Pursh. Lewisia. Portulacaceae. Named for Capt. II. Lewis, explorer. Fleshy perennial herbs, with showy rose-colored flowers. Two species, western U. S.

a. L. redíviva Pursh. Arizona to Montana and westward. Bitterroot (whence the name of the Bitter-root Mountains), Tobaccoroot. Starchy roots, called Spatlum by Oregon Indians, esculent.

1192. LIBOcÉDRUS, Endl. Incense Cedar. Pinaceae. From Greek, "balsam cedar". Evergreen trees with fragrant wood. Syn. Thuya, in part. About 8 species, America and New Zealand; 1 in California.

a. L. decúrrens Torr. Pacific coast of U. S. Post Cedar; White, Bastard or Incense Cedar. Tree attains $200 \mathrm{ft}$. in height, vielding valuable timber.

b. L. tetrágona Endl. Chili. Alerse. The most important timber tree of that country.

1193. LIGÚSTICUM, L.

Lovage.

Umbelliferae.

Named from the country Liguria, where the plant abounded. Syn. Ferula, in part. Perennial herbs with aromatic roots, About 25 species, northern hemisphere; 12 in U. S.

a. L. Canadénse (L.) Britton (L. actæifolium Michx. (Kew), F. Canadensis L.). American Lovage, Nondo, Angelico. Root aromatic, carminative, stomachic.

b. L. filícinum Wats. (L. apiifolium of Bot. King's Exp., not of Gray). Utah to Wyoming. Colorado Cough-root, Osha. Properties of (a).

c. L. Scóticum L. Europe, Asia and northern N. America. Scotch Lovage, Sea Parsley, Shunas. Used as a pot herb. 
1194. LIGÚSTRUM, L. - Privet. The ancient Latin name. Shrubs or small trees. About 35 species, Old World; 1 nat. in U. S., viz: (a) L. vulgáre L., Europe and Asia; Privet, Prie, Prim, Primwort, Print, Privy Saugh (i. e. Willow), Skedge, Skedgwith, Skerrish; Ger. Rainweide.

1195. LILAÉA, Humb. \& Bonp. Lilæa. Naiadaceae. Aquatic or marsh herbs. One or two species, warmer regions of New World; 1 in U. S.

1196. LÍLIUM, L. - - Lily. - - Liliaceae. Latin, from ancient Greek name of a Lily. Leafy herbs from scaly bulbs, with large showy flowers. About 45 species, north temperate zone; 18 in U. S.

a. L. Canadénse L. Canada to Georgia, west to Missouri and Minnesota. Canada Lily, Wild Yellow Lily; Field, Meadow or Nodding Lily.

b. L. cándidum L. Europe and western Asia. White Lily, Madonna or Annuciation Lily, Juno's Rose.

c. L. Mártagon L. Europe and north-central Asia. Martagon Lily, Turk's-cap Lily. Bulbs eaten by Cossacks.

d. L. Philadélphicum L. Ontario to west Virginia. Red Lily Wood Lily; Flame, Glade, Philadelphia or Huckleberry Lily, Wild Orange Lily, American Tiger Lily.

e. L. supérbum L. (L. Martagon Walt. not L.). Canada to N. Carolina, west to Minnesota. Turk's-cap Lily (of America), Turk's-head Lily, Nodding or Wild Lily.

f. L. tigríumm Andr. China and Japan, cult. in gardens and adv. in U. S. Tiger Lily, Crumple Lily. Bulbs esculent.

Additional indigenous species, worthy of note, are, $(\mathrm{g}) \mathbf{L}$. Caroliniánum Michx., Carolina Lily; (h) L. Catesbaéi Walt., Southern Red Lily; (i) L. Humbóldtii R. \& L., Pacific Coast, Humboldt's Lily; (j) L. pardalínum Kellogg, Pacitic Coast, California Tiger Lily, Panther Lily; (k) L. umbellátum Pursh (L. Andinum Nutt. ), Uhio and north westward, Western Red Lily, often confounded with (d) and known by the same popular names; (1) L. Washingtoniáuum Kellogg, Pacific Coast, Washington Lily.

Noteworthy exotic Lilies are $(\mathrm{m})$ L. aurátum Lindl., Golden-banded Lily; (n) L. speciósum Thunb., and (o) L. longiflórum Thunb., Long-flowered White Lily, all three from Japan. Var. eximium of the last, L. Harrisii of the florists, is known as Easter Lily. The European (p.) L. álbum L. is official in the Codex as Lis blanc.

1197. LIMNÁNTHEMUM, S. P. Gmel. 1770. Menyanthaceae. From Greek, "pool blossom". Syn. Limnanthes, Stokes, not R. Br., Limnanthus, Neck. 1790, Nymphoides, Medic. 1789; Villarsia, Menyanthes, in part. Aquatic perennials with floating heart-shaped leares. About 20 species; 3 in U.S. 
a. L. nymphaéoides (L.) Hoffm. \& Link. (L. nymphoides H. \& L. (Kew), M. nymphæoides L., Limnanthes nymphoides Stokes). Europe and Asia, cult. for ornament in U. S. Water-lily*, Floating-heart, Fringed or Dwarf Water-lily, Fringed Bog-bean.

1198. LIMNÁNTHES, Limnanthes. Limnanthacene. From Greek, "pool flower". Herbs with pungency of Tropœolum. About 7 species, southwestern U. S.

1199. LMNóBIUM, L. C. Rich. Frog's-bit. Valisneriacene. From Greek, "marsh loving". Aquatic herbs. About 4 species, all American; 1 in U. S.

1200. LIMODÓRUM, L. 175̄3. Swamp Pink. Orchidacene. From Greek, "meadow gift'. Syn. Cathea, Salisb. 1812, Calopogon R. Br. 1813; Cymbidium, in part. Scapose herbs from round tubers. Two or three species, north temperate zone; 1 in U. S.

a. L. tuberósum L. (Calthea pulchella Salisb., Calop. pulchellus R. Br., Cym. pulchellum Willd.). Canada and eastern U. S. Swamp Pink, Grass Pink*, Bearded Yink, Calopogon.

1201. LIMórIA, L. Persian Lemon. Aurantiacene. From Latin limon, a "lemon". Trees or shrubs, generally thorny. About 24 species, tropical regions.

a. L. acidíssima L. East Indies. Musk-deer plant, Persian Lemon. Fruit acid, detergent. The related Atalántia monopliylla (L.) Correa (L. monophylla L.), East Indies, is called Wild Lime.

1202. LIḾ́NIUM, Adans. 1763. Statice. Plumbaginaceae. An ancient plant name. Syn. Statice (Kew), Willd. 1798 (L. 1737). Scapose herbs with numerous panicled small flowers. About 120 species, mostly of Old World; 5 in U. S. [The name Statice is really older than Limonium and preferable to avoid confusion with Limonia, above.]

a. L. Caroliniánum (Walt.) Brit. (S. Caroliniana Walt., S. Limonium var. Carolinianum A. Gr.). Atlantic and Gulf coast of $\mathbf{N}$. America, in salt meadows. Marsh Rosemary (of America), Sea Lavender, Canker-root, Sea-thrift, Lavenderthrift, Marsh-root, Ink-root, Meadow-root.

b. L. Brasiliénsis (Bois.) Lyons (S. Brasiliensis Boiss.). Brazil. Gnaycuru, Baycuru, or Biacuru. Root astringent, styptic, as also in (c) L. Limónium (L.) Lyons (S. Limonjum L., L. vulgare Mill.). Europe. Sea Lavender, Marsh Beet, Red Behen; Ger. Strandnelke; Fr. Romarin des marais, Lavande: triste.

1203. LIMOSÉLLA, L. Mudweed, Mudwort. Scrophulariaceae. From Greek, "mud-seated". Small, tufted aquatic heıbs. About 6 species; 2 in U. S.

1201. LIXÍNTHUS, Benth. Linanthus. Polemoniaceae. From Greek, "Hax flowered"'. Syn. Gilia (Kew), in part. Annual herbs, mostly with showy white flowers, natives of $\mathrm{N}$. America; 28 in U. S. 
1205. LINíRIA, Juss. Toad-flax. Scrophulariaceae. From Latin, "flax like". Syn. Antirrhinum, in part. Herbs, some shrubby, many with showy flowers. About 150 species, mostly of Old World; 4 in U. S., including 3 naturalized. See Cymbalaria.

a. L. Liuária (L.) Karst. (A. Linaria L., L. vulgaris Mill.). Europe, nat. in U. S. Common Toad-flax, Yellow Toad-flax, Butter-and-eggs, Chopped-eggs, Bread-and-butter, Bride-weed, Dead-men's-bones, Devil's Flax, Flax-weed, Wild Flax, Gallwort, Haycocks, Impudent-lawyer, Jacob's-ladder*, Larkspur*; Ramsted, Ranstead, Rancidf, Snapdragon*, Wild Tobacco, Yellow-rod; Ger. Leinkraut, Flachskraut, Löwenmaul; Fr. Linaire commune. Herb, H. linariæ, $\mathrm{H}$. antirrbini, discutient, diuretic, alterative.

1206. LINDHEÍMERA, Gray \& Engelm.

Compositae. Named for the discoverer, F. Lindheimer. Annual herb with a tive-rayed flower head (yellow). One species; Texas.

\section{LIYGOUM, SE PTEROCARPUS.}

1207. LINNAÉA, Gronov. Twin-flower. Caprifoliaceae. Named in honor of the botanist Linné. A creeping herb, the pink flowers borne in pairs. One species, viz. (a) L. boreális L. Circumpolar, south to Long Island, Michigan and California. Twin-flower, Ground-vine, Deer-vine, Twinsisters, 'Two-eyed berries.

1208. LÍYUM, L. - $\quad$ - Flax. - - $\quad$ Linaceae. The ancient Latin name. Annual or perennial herbs. About 100 species, temperate or warm regions; 28 in U. S.

a. L. cathárticum L. Europe and Asia. Dwarf Flax, Cathartic or Purging Flax, Fairy or Mountain Flax, Fairy Lint, Laverock's Lint, Mill-mountain. Plant cathartic.

b. L. usitatíssimum L. Europe and Asia, cult. and nat. in U. S. Flax (Flix, Vlix) Lin, Lint, Lint-bells. Fiber is linen. Seeds; Linum. U. S. P., Lini semina Br., Semen lini P. G., Flaxseed, Linseed; Ger. Leinsamen, Flachssamen; Fr. Semence de lin (Codex); emollient, demulcent; source of linseed oil.

1209. LíPPIA, L. Fog-fruit, etc. Verbenaceae. Named for Auguste Lippi, French naturalist, d. 1703 . Syn. Aloysia, Lantana, Verbena, Zapania, in part. Perennial herbs or shrubs. About 100 species, mostly of tropical America; 7 in U. S.

a. L. dúleis Trev. Mexico and West Indies. Commonly known as Lippia Mexicana. Plant aromatic, stimulant, expectorant.

b. L. origanoídes Kunth. Mexico, known there as Origano. Plant aromatic.

c. L. Pseudo-Théa (St. Hil.) DC. (Lantana Pseudo-Thea St. Hil. ). Tropical America. Leaves a substitute for Chinese tea. 
d. L. triphýlla (L.'Her.) Lyons (V. triphylla L'Her., A. citriodora Urtega, L. citriodora Kunth). Chile, cult. in gardens or as a house plant. Lemon Verbena, Lemon-scented Verbena, Sweet Verbena, Herb Louisa; Fr. Verveine odorante (Codex). Leaves yield oil of Verbena.

1210. LIQUIDÁMBAR, L. Sweet-Gum, etc. Hamamelidaceae. Name Latin-Arabic. Large trees with resinous sap. About 4 species, Asia Minor, Java and N. America; 1 in U. S.

a. L. orientális Mill. (L. imberbe Ait.). Asia Minor. Storax tree, Oriental Sweet-gum tree. Balsam prepared from the inner bark, storax; -tyrax, U. S. P., Styrax præparatus, Br., Styrax liquidu $\rightarrow$ P. G., Storax liquidus; Ger. Flussiger Storax; Storaxbal sam; Fr. Styrax liquide (Codex): balsamic, stimulant, vulnerary; used in manufacture of chewing-gum.

b. L. Styraciflua L. Connecticut to Florida, west to Missouri and IIexico. Siveet-gum tree, Star-leared Gum-tree, Red Gumtree, Alligator tree, Bilsted, Copalm tree, Liquidambar tree, Opossum tree, Satin Walnut. Balsamic exudate, Sweet Gum, White Gum, Red Gum*, Amber, Copalm, Copal-balsam, Gumwax; Liquidambar, Ambra liquida; properties of sturax. Bark astringent, reputed nervine.

1211. LIRIODÉNIRUN, L. Tulip-tree. Magnoliaceae. From Greek. "lily tree". A large tree bearing tulip-like blossoms. One (perhaps two) species (U. S.).

a. L. Tulipífera L. Eastern U. S., west to Wisconsin; also in China. Tulip-tree, Whitewood, Yellow Poplar, Blue or Hickory Poplar, Tulip Poplar, White Poplar*, Canoe-wood, Cucumber-tree*, Lyre-tree, Saddle-leaf, Saddle-tres; Ger. Tulpenbaum; Fr. Tulıpier. Bark bitter, tonic, febrifuge.

1212. LÍSTERA, R. Br. Twayblade. Orchidaceae. Named for Martin Lister, botanist, d. 1712. Small herbs with a single pair of leaves. About 10 species, north temperate and Arctic zones; 3 in U. S.

1213. LITHOPHRÁGMA, Tor. \& Gr.

Saxifragaceae. Greek equivalent of "Saxifrage". Syn. Lithıfragma Nutt.; Tellina, in part. Herbs. About 10 species, western U. S.

1214. LITHOSPÉRMUM, L. Gromwell, etc. Boraginaceae. From Greek, "stone s sed". Syn. Batschia, in part. Annual or perennial hirsute herbs. About 40 species, mostly of northern hemisphere; 14 in U. S.

a. L. arvénse L. Europe and Asia, nat. in U. S. Bastard Alkanet, Corn Gromwell, Lichwale, Painting-plant, Pearl-plant, Salfern (i. e. Saffron), Stone-seed. Root of this and the following species yields a red dye.

b. L. canéscens (Michx.) Lehm. (B. canescens Michx.). British America, south to Alabama and Arizona. Hoary Puccoon, Indian Puccoon, Indian-paint, American Anchusa or Alkanet. 
c. L. officinále L. Europe and Asia, nat. in U. S. Gromwell (Graymile + ), Lichwale, Lithywale, Littlewale, Pearl-plant, Stony-hard. Seeds, Fructus lithospermi, Sem. milii solis; Ger. Steinsamen, Meerlinsen, Perlhirse, Sonnenhirse, formerly reputed lithontriptic.

1215. LITTORÉLLA, Berg. (Littanella). Plantasinaceae. From Latiu, a "littoral" plant. Insignificant grass-like herb. One specits, Europe and N. America, south to Vermont; called Shoreweed or Shore-grass.

1216. LLOÝDIA, Salisb. - Lloydia. - Liliaceae. Small herbs. Two species, one of Himalayas, one in U. S.

1217. LOBÉLIA, L. - Lobelia. - Lobeliaceae. Named for Matthias de L'Obel, Flemish botanist, d. 1616. Herbs, occasionally shrubs, often acrid, generally with brightcolored flowers. About 225 species; 25 in U. S.

a. L. cardinális L. British America, south to Florida and Texas. Cardinal-flower, Red Lobelia, Red-Betty, Red Cardinal, Slinkweed, Hog-physic. Herb used by Indians as anthelmintic. Properties of (c).

b. L. infláta L. British America, south to Georgia and Arkansas. Indian Tobacco, Lobelia, Bladder-pod, Lobelia, Wild Tobacco, Asthma-weed, Gay-root, Puke-weed, Vomitwort, Low Beliaf, Eyebright. Leaves and tops, Lobelia, U. S. P., Br., Herba lobeliæ, P. G., Ger. Lobelienkraut; Fr. Lobélie enflée (Codex). Emetic, nauseant, expectorant, anti-spasmodic. Seeds (Brown Lobelıa) also sometimes used.

c. L. syphilítica L. Ontario to Georgia, west to Louisiana and Dakota. Great Lobelia, Blue Cardinal-Hower, Blue Lobelia, High Beliał. Herb diaphoretic, alterative, reputed antisyphilitic.

1218. LOEFLínGIA, L. Lneflingia. Caryophyllacene. Named for Peter Loefling, Swedish brtanist, d. 1756. Low herbs. About 5 species, both hemispheres; 3 in southwestern U.S.

1219. LOESÉLIA, L. Loselia. Polemoniaceae. Named for John Lösel, Prussian botanist. Herbs or undershrubs with red or purple flowers. About 10 species, Mexico to New Granada; 1 in U. S.

1220. LOLLUM, L. Rye-grass, Darnel.

Gramineae. The Latin name of (a). Grasses with spiked inflorescence. About 6 species, Old World; 2 nat. in U. S.

a. L. temuléntum L. (L. arvense Withering). Europe and Asia, nat. in U. S. Darnel, Bearded Darnel, Bragge, Oheat, Dragge, Drake, Drank, Dravick, Drunk, Droke, Irray (Eaver), Lover'ssteps, Neele, Ray-grass (i. e. Rye-grass), Ray, Riely, Sturdy; Ger. Lolch, Taumelkorn, Fr. Ivraie. Fruit narcotic, intoxicant, reputed anodyne. 


\section{LOMÁRIA, Willd. Lomaria.}

Polypodiaceae.

From Greek, "fringe", alluding to the sori. A large genus of ferns allied to Blechnum; 1 in U. S.

1222. LOXÍCERA, L. Honeysuckle. Caprifoliaceae. Nained for Adam Lonitzer, German botanist, d. 1586 . Syn. Caprifolium, Periclymenum, Mill. 1752. 'Erect or climbing shrubs, often with showy flowers. About 100 species, mostly of north temperate zone; 22 in U. S.

a. L. Caprifólium L. (L. grata Ait., C. gratum Pursh, P. Italicum Mill., P. Americanum Mill., C. vulgare Mill. ). Europe, cult, and nat. in U. S. Italian Honeysuckle, Perfoliate Honeysuckle. American or Fragrant Woodbine, Goat-leaf; Ger. Geisblatt; Fr. Chèvrefeuille (Codex).

b. L. Periclýmenum L. (P. vulgare Mill.). Europe. Woodbine (of Shake-pere), Widbin (Scotland), Oodbinell, Common Honeysuckle (of England), Twisted Eglantine (Milton), Milsilvestre, Serville, Suckling, Sycamine*.

c. L. sempérvirens L. Eastern U. S., west to Nebraska. Trumpet or Coral Honersuckle, Scarlet Trumpet Honeysuckle, Woodhine. Other indigenous species are (d) L. ciliáta Muhl., Canada and northeastern U. S., American Fly-honeysuckle Medauldy bush; (e) L. dioíca L. (L. glauca Hill ( $\mathrm{Kew}$ ), L. parviflora Lam. ), Glaucous or Yellow Honeysuckle, Small or Northern Yellow Honeysuckle, Small Woodbine; (f) L. fláva Sims, (Southern) Yellow Honeysuckle; $(\mathrm{g})$ L. glaucéscens Rydb. (L. Douglasii Hook.). Douglas Honeysuckle; (h) L. hirsúta Eaton, Hairy Honeysuckle, Rough Woodbine.

\section{LOPHIÓLA, Ker. Lophiola.}

From Greek "crested", of the perianth Amaryllidaceae. in sea-board.

\section{LOPHÓPHORA, Coult. Mescale.}

Amaryllidaceae. One species, U. S., near Atlantic

From Greek, "crest bearing". Syn. Anhalonium, Mammillaria, Echinocactus, in part. One or two species, Mexico and southern U. S.

a. L. Lewínii (Henn.) Coult. (A Lewinii, Henn, M. Lewinii Auct., hy some referred to (b) L. Williámsii Lem. Coult. (A. Villiamsii Lem.), which is, howerer, probably distinct). Mexico. Source of Mescale buttons, which have remarkable narcotic and intoxicating properties.

1225. LOPHOTuCí RPUS, T. Durand. Arrow-head. Alismaceae. From Greek, "crested truit". Syn. Lophiocarpus, Miq. not Turez; Sagittaria, in part. Paludal or aquatic herbs. A bout 3 species, New World; 1 in U. S. About 330 species, warm regions except of $\mathbf{N}$. America. 
a. L. Europaéus Jacq. Eastern and southern Europe. Oak Mistletoe, Wood-of-the-holy-cross, Viscum quernum of old writers. Plant yields bird-lime. See Viscum.

1227. LóTUS, L. 1753. Bird's-foot Trefoil, Papilionaceae. An ancient Greek plant name. Syn. Hosackia, Dougl. 1829. Herbs or shrubs. About 120 species; 60 in U. S.

a. L. corniculátus L. Europe and Asia, adv. in U. S. Bird'sfoot Trefoil, Ground Honeysuckle, Bloom-fell, Crow-toe (Milton). Crosstoes, Claver, Cat-in-clover, Bird's-eye, Butter-jags, Devil's-fingers, Eggs-and-bacon, Jack-jump-about, Lady'sfingers, Lady's-glove, Lady's-slipper*, Lady's-shoes-andstockings, Sheep-foot. Valuable as a fodder plant.

1228. LUCÚMA, Mol. Marmalade tree. Guttiferae. From vernacular, Peru. Syn. Vitellaria, Gaertn.; Achras, Chrysophyllum, in part. Trees or shrubs with milky juice. About 50 species, tropical America and Australia. [The species excepting two are now referred by some botanists to Vitellaria.]

a. L. mammósa (L.) Juss. (A. mammosa L., V. mammosa (L.) Radlk.). West Indies. Marmalade tree, Marmalade Apple or Plum, Mammee, Manmee Sapota, in Jamaica called Bully tree (Bulletrie, Bolletrie). Fruit, vegetable egg, esculent.

b. L. salicifólia Kunth. Mexico. Zapote borracho, Zapote amarillo. Fruit soporific.

c. L. glycyphloéa Mart. \& Eichl. (C. glycyphloeum Casaretti). Brazil. Bark, Monesia bark, Buranham or Guranham bark; Cort. monesiæ; Ger. Monesiarinde; astringent with some stimulant action. The aqueous extract, Extractum nonesiæ, as well as the bark is called Monesia, leading to confusion.

1229. LUDWÍGIA, L. False Loosestrife. Onagraceae. Named for Prof. C. G. Ludwig of Leipsic, d. 1773. Herbs, mostly with inconspicuous tlowers. About 25 species, warm and temperate regions; 14 in U. S.; ia) L. alternifólia :L., eastern U. S., is called Seed-box, Rattle-box, Bowman's-root*. See Isnardia.

1230. LUDWIGIÁNTHA, Small. Ludwigiantha. Onagraceae. From Greek, "Ludwigia-flowered". Syn. Ludwigia, in part. Fleshy aquatic herb. One species, southeastern U. S.

1231. LUÉTKEA, Bong. $1833 . \quad$ Luetkea. Rosaceae. Syn. Lutkea, Steud. 1841, Eriogynia, Hook. 1833; Spiræa (Kew), in part. Suffrutescent plants with palmately cleft leaves. About 4 species, Pacific border of U. S.

1232. LÚFFA, Tourn. 1791. Towel Gourd. Cucurbitaceae. From the Arabic name. Syn. Turia, Forsk. 1775, Poppya, Neck. 1790; Cucumis, Momordica, in part. Prostrate herbs. About 7 species, tropical Asia and Africa, one in America. 
a. L. Lúffa (L.) Lyons (M. Luffa L., L. Aegyptiaca Mill. (Kew), Turia sativa Forsk., P. Fabiana C. Koch.). North Africa and tropical Asia. Towel Gourd, Dish-cloth Gourd, Washing Gourd, Strainer vine, Luffa (Loofa, Louff, Lief, Liff). The fibrous network of the fruit is the familiar vegetable sponge or gourd towel. Other species, as (b) L. acutáugula (L.) Roxb. (C. acutangula L. ), yield similar products.

c. L. opereuláta (L.) Cogn. (M. operculata L., L. purgans Mart. (Kew), P. operculata Roem.). Tropical America. Fruit of this and some other species violently cathartic.

1233. LÚINA, Benth. Luina. Compositae. Anagram of Inula, an allied genus. Perennial herb with small tlower heads (yellow). One species, Pacific coast of U. S.

1234. LUNÁRIA, L. Satin-pod, etc.

Cruciferae. From Latin, "moon wort". Herbs, the silicle with a membranous shining dissepiment. Two species, Europe and Asia.

a. L. ánnua L. (L. biennis Moench, L. inodora Lam.). Europe, cult. in gardens and adv. in U. S. Honesty, Penny-flower, Satin-flower, Money plant, Balbonac, Gold-and-Silver plant, Lunary, Matrimony.

1235. LUPÍxUS, L. Lupine, Sun-dial. Papilionaceae. Ancient Latin name of a Leguminous plant, from lupus a "wolf". Herbs or sub-shrubs, with digitate (rarely simple) leaves and racemes of showy flowers. About 125 species,temperate and warm regions; 99 in U. S. Many of the species are planted in gardens; some are useful fodder plants; some have pronounced poisonous properties. The names Sun-dial, Old-maid'sbonnets, Quaker's-bonnets and Wild Lupine or Lupin are almost indiscriminately applied to the various species.

1236. LÝCHNIS, L. Lychnis, Campion, etc. Caryophyllaceae. From Greek word for "lamp", alluding to bright color of flowers. Syn. Agrostemma, Coronaria, in part. Herbs. About 35 species, north temperate and Arctic zones; 16 in U. S., including nat. species.

a. L. álba Mill. (L. vespertina Sibth.). Europe, nat. in U. S. White Campion, Evening-blooming Lychniss, Bull-rattle, Cow-rattle, Snake-flower, Thunder-flower, White or Wild Cuckoo-flower, White Bachelor's-buttons, White-Robin, Ragged-Robin (a double variety).

b. L. Chalcedónica L. Japan, cult. in gardens. Scarlet Lychnis, Cross-of-Jerusalem, Jerusalem- or Knight-cross, Maltese- or Scarlet-cross, Fire-balls, None-such, Scarlet-lightning, SweetWilliam*, Mock Sweet-William.

c. L. Coronária (L.) Desr. (A. Coronaria L., C. tomentosa A. Br.). Europe, adv. in U. S. Mullen (Mullein) Pink, Mullen Lychnis?, Dusty-miller, Gardener's-eye, Rose Campion. 
d. L. Flos-cúculi L. (C. Flos-cuculi d. Br.). Europe, nat. in U. S. Cuckoo-flower, Cuckoo Gilliflower or Lychnis, Crowflower, Indian Pink, Marsh Gilliflower, Meadow Campion, Meadow Pink, Ragged-Jack, Ragged-Robin.

1237. LÝCIUM, L. Matrimnny-vine, etc. Solanaceae. Named from Lycia in Asia Minor. Syn. Iochroma, in part. Shrubs or climbers. About 75 species, temperate and warm regions; 17 in $\mathrm{U}$. S.

a. L. Áfrum L. Africa and western Asia. Kafir Thorn. Planted for hedges. Leaves discutient, alterative. Similar properties are ascribed to (b) L. umbrósum Humb. \& Bonp. [I. umbrosa Miers (Kew)], of South America.

c. L. vulgáre (Ait. f.) Dunal (L. Barbarum var. vulgare Ait. f.). Europe, nat. in U. S. Matrimony vine, Box Thorn, Bastard Jasmine, Jessamine*, Jackson vinè, Duke of Argyll's Tea-tree. Root diuretic.

1238. LYCOPÉRDON, L. Puff ball, Bunt. Gasteromycetes. From Greek, "wolf flatus": Syn. Bovista, Pachyma, in part. Globular or ovoid fungi, the innumerable spores furming when ripe a dust-like powder.

a. L. Bovísta L. (L. giganteum Batsch., B. giganteum Nees, I. cælatum Fries). Giant Puff ball, Puff ball, Blind-buff, Blindhairy, Blind-mans'-ball, Bullifer, Bullfeist, Devil's-snuff-box, Feist, Fizbo, Foist, Furze-ball, Fuss-ball, Fuzz-ball, Mollipuff, Paddock-cheese, Pluff, Puckfist, Smut-ball, Wolf's-fist; Ger. Bovist; Fr. Lycoperde des bouviers, Vesseloup. The ripe fungus; Fungus chirurgorum, Crepitus lupi, Bovista; formerly used as a styptic. Unripe fungus esculent. Spores of this and other species anesthetic.

b. L. sólidum Gronov. (P. Cocos Fries). Southern ' E. S., also in China, on roots of fir trees. Tuckahoe, (Tuckahoo), Tuckahoe Truffle, Indian Bread, Indian-head, Fuh-ling. Fungus contains much pectic acid; esculent, and used in jellies.

1239. LYCOPÉRSICON, Hill. Tomato. Solanaceae. From Greek, "wolf peach". Syn. Lycopersicum, Solanum, in part. Diffuse herbs. About 4 species, S. America.

a. L. Lycopersicon (L.) Karst. (L. esculentum Mill. (Kew), S. Lycopersicon L., L. Solanum-Lycopersicum Hill). South America, now every where cult. Tomato (from Spanish American, Tamate), Love Apple (a translation of the French Pomme d'amour, but the original Italian, Pomo dei Mori, meant Morocco Apple), Jew's-ear*, Paradise Apple. Fruit esculent, diuretic.

1240. LYCOPÓDIUM, L. Club-moss. Lycopodiaceae. Ancient Greek name, meaning "wolf's foot". [The aboriginal name in Oceanica means mouse-foot]. Perennial evergreen plants. About 100 species; 12 in U.S. 
a. L. clavátum L. Europe, Asia, N. America, south to N. Carolina, Michigan and Washington. Ground or Running Pine, Club-moss, Clubfoot Moss, Running Moss, Snake Moss, Staghorn (Stag's-horn) Moss, Buck-grass, Buck's-horn, Coral Evergreen, Creeping-bur, Creeping-Jennie, Forks-and-knives, Foxtail, Lamb's-tails, Toad's-tail, Traveler's-joy*, Wolf's-claws; Ger. Schlangenmoos, Bärlappkraut, Sautanne. Spores, vegetable sulphur; Iycopodium, U. S. P., P. G., Sem. v. Pulvis lycopodii, Sulphur vegetabile; Ger. Bärlappsamen, Streupulver, Hexenmehl, Blitzpulver, Erdschwefel, Wurmmehl; Fr. Lycopode (Codex), Soufre végétal; Sp. Licopodia. Absorbent, lenitive, diuretic.

b. L. complanátum L. Europe, Asia, N. America, south to $\mathbf{N}$. Carolina and Michigan. Trailing Christmas-green, Ground Cedar, Ground Pine, Ground-festoon, Crow-foot*, Hog-bed, Creeping-Jennie. Spores used as in (a).

c. I. obscúrum L. (L. dendroideum Michx.). Asia and N. America, south to N. Carolina and Indiana. Ground Pine, Tree-like Club-moss, Bunch Evergreen, Spiral Pine, Crowfoot*. Plant much used in Christmas decorations.

Other indigenous species are; (d) L. Alpínum L., Alpine Club-moss, Heath Cypress, Cypress Moss; (e) L. Iucídulum Michx., Shining Club-moss, Moon-fruit Pinez, Trailing Evergreen; (f) L. sabinaefólium Willd., Cedar-like Club-moss, Ground Fir; (g) L. Selágo L., Fir Club-moss, Fir Moss, Tree Moss, Fox-feet. From an allied Brazilian species, (h) L. saurúrus (?), called Piligan, has been obtained a powerfully cathartic alkaloid, piliganine. Cathartic properties are attributed also to other species.

1241. LYCÓPSIS, L. Bugloss. Boraginaceae. From Greek, "wolf face". Syn. Buglossa. Bristly hispid herbs. About 6 species, Old World; 1 nat. in U. S., viz. (a) L. arvénsis L. (B. arvensis S. F.Gray). Small or Wild Bugloss.

1242. LÝCOPUS, L. Bugleweed, Gypsywort, etc. Labiatae. From Greek, "wolf"s foot". Stoloniferous herbs. About 10 species, north temperate zone; 6 in U. S.

a. L. Americánus Muhl. (L. sinuatus Ell. (Kew), E. Europæus var. sinuatus A. Gray). British America and U. S., throughout. Cut-leaved Water-hoarhound, Bitter Bugle, Paul's Betony, Gypsywort.

b. L. Europaéus L. (L. aquaticus Moench, L. riparius Salisb., L. vulgaris Pers.). Europe, adv. in U. S., Water Hoarhound, Marsh Hoarhound, Gipsywort?, Gipsy-herb, Green Archangel, Bitter Bugle, European Bugleweed; Ger. Wasserandorn; Fr. Lycope d' Europe. Herb, Herba marrubii aquatici, astringent, hemostatic, anti-periodic.

c. L. Virgínicus L. British America, south to Elorida and Missouri. Bugleweed, Buglewort, Sweet Bugleweed, American Water-hoarhound, Carpenter's-herb, Green Archangel, Gypsie- 
weed, Paul's Betony, Wood Betony, Wolf-foot; (ier. Virginisches Wolfsfuss; Fr. Lycope de Yirginie. Herb sedative, hemostatic; antidote to snake bites.

1243. LYGODÉSMIA, D. Don. Lygodesmia. Cichoriaceae. From Greek, "twig bundle". "Syn. Prenanthes, in part. Herbs with linear leaves and pink or purple flowers. About 6 species, all of U. S. and Mexico.

1244. LYGÓDIUM, Swz. Climbing Feru. Schizaeaceae. From Greek, "pliant". Syn. Gisopteris, in part. 'Twining or climbing ferns, 16 species, mostly tropical; 1 in $\mathrm{U}$. S.

a. L. palmátum (Bernh. ) Swz. (G. palmata Bernh.). Massachusetts to Florida. Climbing Fern, Hartford Fern, Creeping or Windsor Fern.

1245. LYONOTHÁMIUS, Gray. Ironwood*. Saxifragaceae. Named for William S. Lyon, botanist of California. A tree or shrub. One species, islands off' coast of California.

1246. LYROCÁRPA, Harv.
From Greek, "lyre fruit". Perennial herbs. Two species, Pacific border of U. S.

1247. LYSICHÍTON, Schott. 1857. (Lysichitum). Alacene. From Greek, "loose mantle". Syn. Arctiodracon, Gray 1858. Robust marsh herb. One species, northern Asia and N. America (U. S.).

1248. LYSILÓMA, Benth. Wild Tamarind, etc. Mimosaeene. From Greek, "loose border". Syn. Mimosa, in part. 'Trees or shrubs. About 10 species, tropical America; 1 in U. S., viz. (a) latisíliqua (L.) Benth. (M. latisiliqua L.), West Indies to Florida; Wild Tamarind.

b. L. Sabicú Benth. Cuba. Sabicu (Savacu, Savico). Wood, Sabicu-wood, Horseflesh Mahogany, very hard and durable.

1249. LYSIMÁCHIA, L. Loosestrife. Primulaceae. Ancient Greek name, meaning "loose strife". Syn. Yiscumt, in part. Herbs with yellow flowers, axillary, racemose or paniculate. About 70 species, mostly of northern hemisphere; 7 in U. S.; Ger. Weiderich; Fr. Lysimaque.

a. I. Nummulária L. Europe, nat. in U. S. Moneywort, Creeping Loosestrife, Creeping-Jenny, Down-hill-of-life, Herb Twopence (Tuppence), Two-penny grass, Meadow-runagates, Stringsof-sovereigns, Wandering-Jenny, Wandering-sailor; Ger. Pfennigkraut; Fr. Monnayère. Herb astringent, vulnerary.

b. L. quadrifólia L. Canada and eastern U. S. Crosswort, Whorled Loosestrife, Five-sisters, Yellow Balm. IIerb astringent, stomachic, expectorant.

c. L. terréstris (L.) B. S. P. (L. stricta Ait. (Kew), V. terrestre L.). Canada and eastern U.S. Bulb-bearing Loosestrife, Swamp-candles. 
d. L. vulgáris L. Europe and Asia, adv. in U. S. Common Loosestrife, Golden or Yellow IVillow-herb, Yellow Rocket*. Properties of (b).

1250. LÝTHRUM, L.

Loosestrife.

Lythraceae From Greek, "gore''. Syn. Hyssopifolia, Opiz., Salicaria, Mill., in part. Herbs or shrubs. About 25 species, widely distributed; 12 in U. S.

a. L. Salicária L. (S. vulgaris Moench). Europe and Asia, nat in U. S. Loosestrife, Spiked or Purple Loosestrife, Spiked or Purple Willow-herb, Milk Willow-herb, Willow-weed, Willowwort, Sage Willow, Purple-grass, Long-purples, Red-Sally, Rainbow-weed, Soldiers+; Ger. Rother Weiderich; Fr. Salicaire. Herb astringent, demulcent, alterative. (b) L. alátum Pursh, Ontario and northeastern U. S., Wing-angled Loosestrife?, is called also Milk Willow; (c) L. Hyssopifólia L. (H. parviflora Opiz. ), Europe and Asia, adv. in U. S., is Hyssop Loosestrife or Grass Poly.

1251. MACBRÍDEA, Ell. Macbridea. Labiatae. Named for Dr. James Macbride. Syn. Thymbra, Prasium, Melittis, in part. Perennial herbs with showy flowers. Two species, southeastern U. S.

1252. MACHAERANTHÉRA, Nees. Aster. Compositae. From Greek, "sickle Aster". Syn. Aster (Kew), Dieteria, in part. Herbs resembling Aster. About 15 species, all of U. S. and Mexico.

1253. MACHAÉRIUM, Pers. Tiger-wood, etc. Papilionaceae. From Greek, "saber", alluding to the fruit. 'Trees, shrubs or tall climbers. About 60 species, S. America.

a. M. fértile Griseb. Argentina. Tipa. Wood and bark astringent, used in tanning; (b) M. Schombúrgkii Benth. of British Guiana is called Itaka and Tiger-wood. Some species yield varieties of Rosewood.

1254. MACOUNÁSTRUM, Small.Macounastrum.Polygonaceae. Syn. Kœnigia, L. 1764, not Konig, Adans. 1763. Insignificant herbs. Two or three species, boreal or alpine; 1 in U. S.

1255. MACRANTHÉRA, Torr. Macranthera. Scrophulariaceae. From Greek, "long stamened". Syn. Conradia, Dasystoma, in part. Tall biennial with orange-colored flowers. One species, southeastern U. S.

1256. MACROCÁLYX,'Jrew.1761.Nyctelea,etc. Hydrophyllaceae. From Greek, "large calyx". Syn. Ellisia, L. 1763 (not L. 1759 ); Ipomœa $\dagger$, Polemonium $\dagger$, in part. Annual hairy herbs. About 3 species, N. America; 2 in U. S.

1257. MACRONÉMA, Gray. Macronema. Compositae. From Greek, "long thread": Syn. Aplopappus, in part. Perennial herbs; rays few (conspicuous) or wanting. About 6 species, western U. S. 
1258. MACROSIPHÓNIA, Muell. Apocynaceae. From Greek, "long tubed". Shrubs with showy flowers, white, yellow or red. About 12 species, warmer regions of New World; 3 in southwestern U. S.

1259. MADÁRIA, DC. Mignonette-vine. Compositae. Name Latin, "Madia-like". Syn. Anisocarpus, Madia, in part. Herbs with hirsute leaves. About 4 species, Pacific border of U. S. (a) M. élegans (Don) DC. (Madia elegans D. Don). California. Mignonette-vine.

1260. MÁDIA, Mol. 1782. Tar-weed, etc. Compositae. From vernacular madi, Chili. Herbs, commonly viscid and heary-scented. About 12 species, New World; 9 in U.S.

a. M. satíva Mol. Chili, cult. in Europe, Africa and Asia. Seeds source of Madia oil.

1261. MAÉSA, Forsk. - Saoria. - Myrsinaceae. Shrubs. About 40 species. warmer regions of Old World. (a) M. lanceoláta Forst. (M. picta Hochstetter). Abyssinia. Saoria. Fruit anthelmintic.

1262. MAGXÓLIA. L. Magnolia. Named for Prof Pierre Magnol French botanistiace. Trees or shrubs with large fragrant flowers. About 15 species, $\mathrm{N}$. America and eastern Asia; 7 in U. S.

a. M. acumináta L. (M. Virginiana, var. acuminata L.). New York to Alabama, west to Arkansas. Cucumber tree, Mountain Magnolia, Black or Yellow Linn. Bark of this and other species, tonic, bitter, febrifuge.

b. M. Poétida (L.) Sarg. (M. Virginiana var. fœtida L. Ed. 1., M. grandiflora L. Ed. 2 (Kew), the preferable name as Linné himself decided). Southeastern U. S. Southern Magnolia, Large-flowered Magnolia, Laurel-leaved Tulip-tree, Bull Bay.

c. M. Fráseri Walt. (M. auriculata Lam.). Virginia to Florida and Mississippi. Fraser's Magnolia, Long-or Ear-leaved Umbrella-tree, Fraser's Umbrella-tree, North Carolina Bay, Indian-physic*, Water-lily tree, Cucumber-tree.

d. M. macrophýlla Michx. Kentucky southward, west to Arkansas. Large-leaved Umbrella-tree or Cucumber-tree, Big-bloom, Elk-bark, Elk-wood, Silver-leaf, Silver-leaf Umbrella-tree.

e. M. tripétala L. (M. Umbrella Lam.). Pennsylvania to Alabama, west to Arkansas. Umbrella-tree, Cucumber-tree.

f. M. Virginiána L. 1753 (M. glauca L. 1762). Massachusetts, south to Florida and Texas, near Atlantic and Gulf sea-board. Laurel Magnolia, Small or Sweet Magnolia, Swamp Magnolia, Beaver tree, Elk-bark, Holly Bay, Sweet or White Bay, Red Bayt, Indian-bark, Small or White Laurel, Swamp Laurel, Swamp Sassafras. 
1263. MAIRÁNIA, Neck. 1790. Alpine Bearberry. Ericaceae. Syn. Arctous, Niedenzu 1890; Arctostaphylos (Kew), Arbutus, in part. A low deciduous shrub. One species, north polar zone to $\mathrm{U}$. S.

1264. MALÁCHRA, L. Wild Okra, etc. Malvacene. Hairy herbs. About 20 species, warmer regions of ()ld World; 2 nat. in U.S.

1265. MALACóthrix, DC. Malacothrix. Cichoriaceae. From Greek, "soft hair", alluding to the pappus. Syn. Leptoseris, in part. Herbs with yellow, rarely white, flowers. About 15 species, southwestern U. S.

1266. MALAPOÉNNA, Adans. 1763. Pond-spice, etc. Lauraceae. From vernacular, Malabar. Syn. Litsea (Kew), Lam. 1789, Sebifera, Lour. 1790, Tetranthera, Jacq. 1797; Laurus, in part. Trees or shrubs. About 100 species, warmer regions, especially of Old World; 1 in U. S.

a. M. geniculáta (Walt.) Coult. (Laurus geniculata Walt., Litsea geniculata Mez. (Kew), T. geniculata Nees.). Virginia to Florida. Pond-spice.

1267. MALLótUS, Lour. 1790. Kamila, etc. Euphorbiaceae. From Greek, "woolly". Syn. Rottlera, Roxb. 1798; Echinus, Croton, in part. Trees or shrubs. About 70 species, warmer regions of Old World.

a. M. Philippinénsis (Lam.) Muell. Arg. (C. Philippinense Lam., E. Philippinensis Baill., R. tinctoria Roxb.). Abyssinia to India and Australia. Kamila tree, Monkey-face tree, Spoonwood. Glands and hairs from the capsules, Kamila, Kamala (Kamela, Kameela, Kaimaile, Kanbil), Wurrus (Wurus, Waras); Kamala, U. S. P., Rottlera, U. S. P. 1870; Glandulæ rottleræ; tenicide, used also as an orange dye.

1268. MALPíGHIA, L. Barbados Cherry, etc. Malpighiaceae. Named for Marcello Malpighi, Italian physiologist, d.1694. Trees or shrubs, some with stinging hairs. About 20 species, tropical America; 1 in U. S. Several species produce edible fruits, notably (a) M. glábra L., Surinam Cherry; (b) M. punicifólia L., Barbados Cherry; (c) M. úrens L., Cowhage Cherry.

1269. MALUS, Juss.

Apple, Crab-tree.

Pomaceae. The classical name. Syn. Pyrus, (Pirus) in part. Trees with showy white or pink blossoms. About 15 species, north temperate zone; 6 in U. S.

a. M. Málus (L.) Britton (P. Malus L., M. communis Poir., M. paradisaica Medic., M. domestica Baumg.). Western Asia, now widely cult. in numerous named varieties. Probably derived from several wild species. Apple tree. Seedling trees are known as Crab-stock, Scarb-tree, Wilding tree or Nurse-garden. Bark tonic, febrifuge. Fruit esculent. The cultivated Crabapple is (b) M. baccáta (L.) Lyons (P. baccata L.) or some hybrid of this with (a). 
Indigenous species are; (c) M. angustifólia (Ait.) Michx., southeastern U. S., Southern Crab-apple or Crab tree; (d) M. corouária (L.) Mill., Ontario and northeastern U. S., American or Garland Crab-apple, Fragrant Crab-apple, Sweetscented Crab tree; (e) M. rivuláris (Doug.) Roem., the Oregon Crab-apple.

1270. MÁLVA, L. - Mallow. - Malvaceae. The ancient Greek name. Mucilaginous herbs, the shape of the fruit suggesting the popular name "Cheeses". About 30 species, Oid World; 8 nat. in U. S.

a. M. rotundifólia L. Europe and western Asia, nat. in U. S. Low or Common Mallow (Maul, Maws), Mallows (Malice + ); Blue, Country, Dwarf or Running Mallow, Dutch-cheese, Dollcheeses, Fairy-cheeses, Pellas; Ger. Käsekraut; Fr. Petite Mauve (Codex). Flowers and leaves mucilaginous, demulcent.

b. M. sylvéstris L. Europe and Asia, nat. in U. S. High Mallow, Common or Country Mallow, Cheese-flower, Cheese-cake plant, Chock-cheese, Pick-cheese, Pancake plant, Round Dock; Ger. Käsepappel, Waldmalve; Fr. Mauve (Codex), Mauve sauvage, Grande Mauve. Flowers, Flores Malvæ P. G., Flores malvæ vulgaris s. silvestris; Ger. Malvenblüthen; mucilaginous, denulcent.

c. M. vulgáris Fries (M. rotundifolia L. $\dagger$ (Kew), M. neglecta Wallr.). Europe. Common Mallow of Europe. Leaves, Folia Malvæ, P. G., Herba malvæ; Ger. Malvenblätter, Pappelkraut, Hasenpappelkraut; Fr. Feuilles de Mauve (Codex); mucilaginous, demulcent. (d) M. Alcea L. is European or Vervain Mallow; (e) M. Moscliáta L., with faint odor of musk, is Musk Mallow or Musk plant.

1271. MALVÁSTRUM, A.Gray 1848. False Mallow. Malvaceae. Name altered from Malva. Syn. Malveopsis, Presl. 1847; Cristaria, Malva, Sida, in part. Herbs allied to Malva. About 75 species, America and S. Africa; 25 in U. S. (a) M. coccíneum (Pursh) A. Gray of western prairies is called Red False Mallow, also Moss Rose*.

1272. MALVAVÍSCUS, Adans. Malvaviscus. Malvaceae. Shrubs with crimson flowers. About 20 species, tropical America; 1 in Florida.

1273. MAMMÉA, L. Mammee Apple. Clusiaceae. From vernacular, West Indies. Trees. About 5 species, tropical regions of Old and New World. (a) M. Americána L. West Indies, cult. in most tropical countries. Mammee Apple, Mamey tree, South American Apricot. Fruit esculent. Seeds anthelmintic.

1274. MANDRÁGORA, Juss. Mandrake. Solanaceae. From the ancient Greek name, whence also our word Mandrake. Syn. Atropa, in part. Herbs. About 4 species, Mediterranean region. 
a. M. officinárum L. (M. officinalis Mill., M. vernalis Bertol., A. Mandragora L., Ed. 10). Mandrake (of Scripture), European Mandrake, Mandrake Apple, Mandragora, Devil's Apple; Ger. Alraunwurzel, Schlafapfel; Fr. Mandragora. Ront narcotic.

1275. MANGí'seRA, L. Mango. Anacarliaceae. From Latin, "Mango bearing". Syn. Mangas, Adans., Manga, Noronha. Trees. About 30 species, tropical Asia. (a) M. Indica L. Southern Asia, cult. in all tropical countries. Mango tree. Bark astringent. Fruit esculent.

1276. MáNIHOT, Adans. Cassava, etc. Euphorbiaceae. Vernacular name, S. America. Syn. Jatropha L., Janipha, H.B.K., Mandioca, Link. Herbs or shrubs. About 80 species, warmer regions of New World; 2 in U. S.

a. M. Glazióvii J. Muell. Ceara, Brazil. Source of Ceara rubber. See Hevea.

b. M. Mánihot (L.) Lyons (Jat. Manihot L., Jan. Manihot Kunth, M. utilissima Pohl). Brazil, now cult. in all tropical countries. Manioc (Mandioc, Maniocca), Cassava, Bitter Cassava, Tapioca plant. Starch obtained from the fleshy roots is Tapioca, Brazilian Arrowroot, Cassava meal, Amylum manihot; Ger. Cassarastärke, Tapiocca; Fr. Tapioka (Codex). Tapioca is obtained also from (c) M. Carthaginénsis J. Muell. (Jat. Janipha L.).

d. Y. palmáta (Vell.) J. Muell. (Jat. palmata Vell., M. Aipi Pohl, Jat. dulcis Gmel.). Tropical S. America. Aipi, Sweet Cassava. Root farinaceous, comparatively free from poisonous properties.

127. MARÁNTA, L. Arrowroot plant. Marantaceae. Named for B. Maranta, Venetian botanist, 16th century. Herbs from fleshy rhizomes. About 15 species, tropical America.

a. M. arundinácea L. Tropical America and West Indies. [The species probably includes (b) M. Indica Tussac., source of the Natal and East Indian arrowroot]. Arrowroot plant (properly aru-root, aruaru being a Brazilian word for flour). Starch from the rhizomes is Bermuda or True Arrowroot; Amylum marantæ; Ger. Pfeilwurzelmehl, Marantastärke; Fr. Arrowroot de la Jamaique (Codex)). Arrowroot is also procured from some other species, as also from the allied Canna and Curcuma.

1278. MARÁSMIUs, Fries. Champignon. Hymenomycetes. From Greek, "withering". Syn. Agaricus, in part. Fungi with a tough leathery pileus, some edible. About 300 species.

a. M. Oréades, (Bolt.) Fries (A. Oreades Bolt.). Champignon, Fairy-ring Mushroom (Champignon is the French word for Mushroom). Fungus esculent.

1279. MARGARÁNTHUS, Schlecht. From Greek, "pearl flower". Syn. Physalis, in part. Herbs resembling Physalis. About 3 species, Texas to Arizona. 
1280. MARIÁNA, Hill 1762. Milk Thistle. Compositae. Syn Silybum. Adans. 1763; Carduus, in part. A coarse prickly herb. One species, Mediterranean region.

2. M. Mariána (L.) Hill (S. Marianum Gærtn. (Kew), C. Marianus L. ). Mediterranean region, adv. in U. S. Milk Thistle, Virgin Mary's Thistle, Our Lady's Thistle, Lady's or Holy Thistle, Lady's-milk; Ger. Steckkörner, Frauendistel; Fr. Chardon Marie. Fruit, Fructus silybi, Sem. cardui mariæ; expectorant, tonic.

1281. MAKRÚBIUM, L. Hoarhound. Labiatae. Name middle Latin, of uncertain origin. Perennial herbs. About 40 species, temperate regions of Old World.

a. M. vulgáre L. Europe and Asia, nat. in U. S. Hoarhound, Horehound (Herehoune, Horhowne, Horone), Common Hoarhound, Houndbene, Marvelł, Mawroll ; Ger. Weisser Andorn, Andornkraut; Fr. Marrube blanc (Codex); Sp. Marrubia. Leaves and tops; Marrubium, U. S. P., Herba marrubii (albi); expectorant, laxative, deobstruent, carminative.

1282. MARSDÉNIA, R. Br. Condurango. Asclepiadaceae. Syn. Gonolobus, in part. Shrubs or shrubby climbers. About 60 species, tropical regions.

a. M. Cundurángo Nichols, not Reich. (G. Cundurango Triana). S. America. This species is cited by the German Pharmacopoeia as the source of Condurango. That name, meaning Eaglevine, is applied in South America to at least ten different plants. Dr. Ruschenberger names the plant yielding the white ('ondurango of Peru, Pseusmagennetus Equatoriensis, locally known as Cundurango blanco or Mata perro (i. e. dog killer). Bark, Cortex Condurango, P. G., reputed alterative.

1283. MARSHÁLLIA, Schreb. Marshallia. Compositae. Named for Humphrey Marshall of Pennsylvania. Syn. Athanasia, in part. Perennial smooth herbs with discoid flowerheads. Four known species, central and southern U. S.

1284. MARTYNIA, L.

Martyniaceae (Pedaliaceae). Named for Prof. John Martyn, English botanist, d. 1768 . Coarse, viscid herbs, with beaked capsule. About 10 species, warmer regions of New World; 3 in U. S.

a. M. Louisiána Mill. [M. proboscidea Glox. $\{$ Kew $)]$. Iowa and Illinois, southward, adv. in northern states. Elephant'strunk, Unicorn-plant, Devil's-claw, Double-claw, Martinoe, Mouse-bur, Toe-nails. [In Mexico a name meaning "Devil'sclaw" is given to the clinging hooked fruits of some species. ]

1285. MATRICÁRIA, L. Camomile. Compositae. From Latin matrix, "womb", alluding to supposed medicinal properties. Syn. Chrysanthemum, Chamomilla, Pyrethrum, Santolina, in part. Herbs with dissected leaves; flower heads commonly with white rays. About 20 species, northern hemisphere and Africa; 3 native in U. S. 
a. M. Chamomílla L. (Chrys. Chamomilla Bern., Cham. vulgaris S. F. Gray, Cham. officinalis Koch). Europe and Asia, nat. in U. S. and widely elsewhere. German Camomile (Chamomile), Wild Camomile, Dog's Camovyne, Apple-riennie, Corn Feverfew, Horse-Gowan, Mayweed*; Ger. Feldkamille; Fr. Camomille commune ou d'Allemagne (Codex); Sp. Manzanilla comun. Flowers (flower-heads), German Chamomile; Matricaria, U. S. P., Flores Chamomillae P. G.; Ger. Kamillen, Gemeine Kamillen; bitter tonic, diaphoretic, etc. Source of oil of Camomile. In South Africa the flowers of (b) M. glabráta DC. are used as a substitute for German Camomile.

1286. MaÚCHIA, Kze.

Bradburya.

Compositae. Syn. Bradburya, Tor. \& Gr., not Raf. A tall annual. One species, southern U. S.

1287. MAURÁNDIA, Ortega. Maurandia. Scrophulariaceae. Named for Prof. Maurandy of Cartagena, Spain. Syn. Antirrhinum, in part. Herbaceous climbers, often ornamenial. About 6 species, Mexico and Texas; 2 in U. S. The common Maurandia of gardens is (a) M. antirrhiniflóra (Poir.) Willd. (A. maurandioides Gray), native of Texas and Mexico.

1285. MAYÁCA, Aubl. - Mayaca. - Mayacaceae. The vernacular name, Guiana. Moss-like aquatic herbs with white flowers. About 8 species, warmer regions of New World; 1 in U. S.

1289. MAYTENUS, Mol. Maytenus. Celastraceae. Evergreen shrubs or trees. About 50 species, New World, mostly of S. America; 1 in U. S.

1290. MEDÉOLA, L. Indian Cucumber. Convallariaceae. Named after the sorceress Medea. Syn. Gyromia, Nutt. Herb with two whorls of leaves from a fleshy rhizome. One species, viz. (a) M. Virginiána L. (G. Virginica Nutt., M. Virginica Auct. Nova Scotia to Florida. Indian Cucumber, Indian Cucumber-root, Medeola. Rhizome diuretic, hydragogue.

1291. MEDICÁG0,L. (Medica).Snail Clover, etc. Papilionaceae. Ancient Greek name of Lucerne, which was brought from "Media". Mostly herbs resembling Trifolium. About 50 species, Old World; 7 nat. in U. S. The species all furnish excellent pasturage, particularly the last.

a. M. Arábica All. [M. maculata Sibth. (Kew)]. Europe, adv. in U. S. Spotted Medic (Medick), Spotted Clover, Bur or Heart Clover, California Clover, Heart Trefoil, Heart-leaf, Purple-grass.

b. M. arbórea L. Europe. Tree-Medic (Medick), Yellow Lucerne, Moon Trefoil. Plant reputed galactagogue.

c. M. lupulína L. Europe and Asia, nat. in U. S. Black Medic, Hop Medic, Black-grass, Black-seed, Hop Clover, Black Nonesuch, Nonesuch, Black or Melilot Trefoil, Hop Trefoil, Hornedi Clover, Natural-grass, Shamrock*. 
d. M. sativa L. Central Asia, now widely naturalized. Lucerne, Alialfa (applied particularly to the Peruvian rariety), Brazilian or Burgundr Clover, Chilian or Spanish Clorer. Dutch Clover, Snail Clover, Burgundr-hay, Great or Spanish Trefoil; Holrhar. Lucifer:. Purple Medic (England).

1392. MEEHÁIIA, Britton. Meehania. Labiatae. Named for Thomas Meehan, botanist, Philadelphia. Syn. Dracocephalum. Cedronella, in part. Herb with large blue flowers in secund spikes. One species, southeastern $\mathrm{L}$. S.

1293. MEGAPTÉRIUM. Spach. Prinurose*. Onagraceae. From Greek, "large winged", alluding to the orars. Spn. Oenothera, in part. Perennial herbs with large sellow Howers. Three known species, all of southwestern L. S. and Mexico.

1394. MEIBóXIA. Adans, 1763. Tick-Trefoil. Papilionaceae. Named for Dr. Brandus Meibom, d. 17t0. Syn. Desmodium, Desv. 1813; Hedrsarum, in part. Herbs, some suffrutescent; fruit a loment, the segments of which adhere to clothing. Abuut 160 species, America, Africa and Australia; 33 in $L$. S.

a. M. Canadénsis (L) Kze. (Hedrsarum Canadense L., Desmodium Canadense DC.) Canada and eastern U. S., Canadian or Showy Tick-trefoil, Beggar's-lice, Beggar-ticks; these names applied to other species also. I few of the numerous species are useful fodder plants, pepularly called Clorer or Lucerne.

b. U. girans (L. f.) Lrons (D. grrans DC., H. grrans L. f.). India and cult. for curiosity. Telegraph plant, Semaphore plant. Moring plant. Remarkable for actire spontaneous morements of the leatlets.

\section{MELALECCA, see CAJUPUTI.}

1295. MELAMPÓDICM. L. Melampodium. Compositae. The Greek name of Black Hellebore, "black foot", in no way applicable to these plants. Herbs, some shrubby. About 25 species, warmer regions of America; 4 in $\mathrm{C}$. S.

1296. IELAYPÝRLY. L. Cow-Wheat. Scrophulariaceae. The Greek name, meaning "black wheat". Annual herbs. About 10 species, northern hemisphere; 2 in U. S.; Ger. Wachtelweizen; Fr. Mélampsre.

a. M. arrénse L. Europe. Cow-wheat, Horse-flower, Motherof-wheat, Porerty-weed. Seeds reputed aphrodisiac. Similar properties are ascribed to (b) M. sylráticum L. of Europe, Horse-flower. Root of the latter reputed diuretic.

1297. MELANTHÉRA, Rohr. (Melananthera). Compositae. From Greek, "black anthered". Suffrutescent herbs with discoid flower heads. About 9 species, warmer regions of America, some African; 3 in U. S.

1295. MELÍXTIUM. L. Melanthium. Melanthaceae. From Greek, "black flower." Perennial herbs from thick rhizomes. Three known species, all in eastern $\mathrm{U}$. $\$$. 
a. M. Virginicum L. Phode Island to Florida, west to Texas and Minnesota. Bunch-flower, Black-flower, Quafodil. Punt used as a $\mathrm{Hy}$ poison.

1299. MÉLIA, L.

Pride of India, etc.

Meliaceae.

From Greek name of Ash tree, which this somewhat resembles in foliage. Srn. Azedarach, Azadirachta. Trees with panicled white or lilac flowers; 12 species, India, Australia and Oceanica.

a. M. Azadiráchta L. (Azadirachta Indica Juss., Azedarach deleteria Medic.). Fast Indies. Nim tree, Neem tree, Margosa. Bark tonic, febrifuge.

b. M. Azédarach L. (Azedarach Commelini Medic., Azed. odoratum Noronha). (China to India and widely cult. and nat. in tropical countries. Pride-of-India, Pride-of-China, Azedarach, African or Indian Lilac, Lilac tree, Bead-tree, False Sycamore, China tree, Holy tree, Hoop-tree (W. Indies), White Cedar (Australia). Wood is called Bastard Cedar. Barl: of root narcotic, cathartic, anthelmintic.

1300. MELILÓTCS, Juss. (Mellilota).

Papilionaceae.

From Greek, "honey Lotus'. Syn. Trifoliumt, in part. Annual or perennial herbs with racemed white or yellow flowers. About 20 species, Old World; 2 nat. in $U . S$.

a. M. álba Desv. (M. rulgaris Willd.). Europe and Asia, nat. in U. S. White Melilot. White Millet:, White Sweet Clorer, Honey Lotus, Cabul Clorer, Tree or Bokhara Clorer, Sweet Melilot, Sweet Lucerne. Properties of (b).

b. M. officinális (L. ) Lam. (T. Melilotus officinalis L., M. arrensis Wallr., M. diffusa Koch). Enrope and Asia, sparingly nat. in U. S. Yellow Melilot, Yellow Millet ${ }_{+}^{+}$Yellow Sweet Clover, Hart's Clover, King's Clover, Plaster Clorer, Hart's Trefoil, Heartwort, King s-crown, Whattle-grass, Wild Laburnurn (England); Ger. Steinklıe, Melilotenklee; Fr. Mélilot officinal (Codex): Sp. Meliloto, Trebol oloro-o. Florering tops, Herba Meliloti P. G., H. meliloti citrini, Balsam flowers, emollient, local anodyne; rich in coumarin. (c) M. altíssimus Thuill. of Europe resembles this -pecies and is used in its place.

1301. MELÍIA. Decne. Melinia.

Asclepiadaceae. Shrubby climbers. About 6 specie, New World, 1 in Arizona.

1302. MELÍSSA, L. - Balm. - Labiatae. From Greek, "bee". Mint-like herbs. About $\$$ species, Europe and Western Asia.

a. M. officinális L. Enrope and Asia, widely cult., nat. in $\mathrm{C}$. S. Balm (Barm, Bawme), Lemon Balm, Bee or Garden Balm, Blue or Sweet Balm, Balm Mint, Balm-leaf, Cure-all. Dropsrplant, Gnose-tongue, Honer-plant, Lemon Lobelia, Pimentary, Sweet-Mary; Ger. Citronenmelisse, Citronenkraut; Fr. Mélisse officinale, Citronelle (Codex), Celine, Herbe au citron; Sp. Toronjil. Herb, Folia Melisse P. G., H. melisse citratæ; in hot infusion, diaphoretic, emmenagogue. 
1303. MELÍTTIS, L. 1753. Bastard Balm. Labiatae. From Greek, "honey". Syn. Melissophyllon, Adans. 1763. Herb with showy flowers. One species, Europe. (a) M. Melissophyllum L. (M. melissæfolium Salisb. ). Bastard Balm; formerly reputed diuretic and lithontriptic.

1304. MELóCHIA, L. Melochia. Sterculiaceae. Tomentose herbs or sub-shrubs. About 50 species, tropical regions of both hemispheres; 2 in U. S.

1305. MELóthria, L. Creeping Cucumber. Cucurbitaceae. Old Greek plant name. Vines with small monœecious flowers. About 65 species, chiefly of Old World; 1 in U. S. (a) M. péndula L., of southeastern U.S. to Mexico, is called Creeping Cucumber.

1306. MENISPÉRMUM, L. Moonseed. Menispermaceae. From Greek, "moon seed", alluding to crescentic shape of seeds. Diocious vines. About 4 species, 3 of eastern Asia; 1 in U. S.

a. M. Canadénse L. Canada to Georgia, west to Arkansas. Canada Moonseed, Yellow Parilla, Texas or Yellow Sarsaparilla, Vine Maple; Ger. Canadisches Mondkorn; Fr. Ménisperme du Canada. Rhizome and roots; Menispermum, U.S. P., bitter tonic, alterative, diuretic.

1307. MEYODóRA, Humb. \& Bonp. Menodora. Oleaceae. From Greek, "gift of power". Syn. Bolivaria, in part. Sub-shrubs. About 15 species, mostly of Mexico and adjacent region; 6 in U. S.

1308. MÉNTHA, L. - Mint. - Labiatae. The Latin name of Mint. Syn. Pulegium, in part. Herbs with odorous foliage. About 30 species, north temperate zone; 12 in U. S.; Ger. Minze; Fr. Menthe.

a. M. arrénsis L. Europe, nat. in U. S. Corn Mint, Field Mint, Lamb's-tongue, Wild Pennyroyal, Water Calamint; Ger. Feldminze. Var. piperáscens Malinvaud is the source in part of Japanese oil of peppermint, and of menthol.

b. M. Canadénsis L. (M. borealis Michx.). British America, south to Virginia and N. Mexico. American Wild Mint. Var. glabráta Benth. is also a source of Japanese or Chinese oil of peppermint and of menthol.

e. M. eitráta Erhr. [M. aquatica L. (Kew)]. Europe, adv. in U. S. Bergamot Mint, Bishop's-weed*, Fish Mint.

d. M. críspa L. (M. aquatica var. crispa Benth.). Europe; adv. in U. S. Crisped-leaved Mint, Curled or Cross Mint, Balm Mint; Ger. Krauseminze. Leaves of this and of (e) M. crispáta Schrad., perhaps a variety of $(\mathrm{j})$, are the Folia menthæ crispre of the P. G.

f. M. longifólia (L.) Huds. (M. sylvestris L. 1763 (Kew), M. spicata var. longifolia L. 1753). Europe, nat. in U. S. European Horsemint, Brook Mint, Fish Mint, Water Mint. 
g. M. piperíta L. Europe, nat. in U. S. and widely elsewhere. Peppermint, Brandy Mint, Lamb Mint, Lammint; Ger. Pfefferminze; Fr. Menthe poivrée (Codex); Sp. Yerba beuna piperita. Leaves and tops, Nentha Piperita, U. S. P., Folia Menthae piperitae P. G., Herba menthæ; carminative, anodyne, stimulant. Plant yields oil of Peppermint, which consists partly of menthol.

h. M. Pulégium L. (P. vulgare Mill.). Europe. European Pennyroyal, Brotherwort, Churchwort, Flea Mint, Hillwort, Lillie-riallf, Lurkey-dish, Organy, Origan, Pudding-grass, Puliall, Puliolroyal; Ger. Polei; Fr. Menthe pouliot, Pouliot commun (Codex), Tolilolo; Sp. Poleo. Properties of Hedeoma pulegeoides, q. v.

i. M. rotundifólia (L.) Huds. (M. spicata var. rotundifolia L.). Eastern U. S. to Mexico. Round-leaved Mint, Patagonia Mint, Apple Mint, Horsemint*, Wild Mint, Yerba buena piperita.

j. M. spicáta L. M. spicata var. viridis L. 1753, M. viridis L. 1763 (Kew), M. sylvestris var. glabra Koch). Europe, nat. in U. S. and widely elsewhere. Spearmint, Mint, Brown or Garden Mint, Lamb Mint, Lammint, Mackerel Mint, Our Lady's Mint, Sage-of-Bethlehem; Ger. Grüne Minze, Römische Minze; Fr. Menthe verte (Codex), Menthe romaine, Baume vert; Sp. Yerba buend. Leaves and tops; D.entha Viridis, U. S. P., Herba menthae acutæ 5 . romanæ; properties of (f).

1309. MENTZÉLIA, L.

Prairie Lily.

Loasaceae. Named for C. Mentzel, German botanist, d. 1701. Syn. Bartoniat, in part. Coarse herbs or suffrutescent plants with showy white or yellow flowers. About 40 species, warmer regions of New World; 27 in U. S.

a. M. decapétala (Pursh) Urb. \& Gilg. 'B. decapetala Pursh 1812, B. ornata Pursh 1814, M. ornata T. \& Gr.). Dakota and Montana to Texas. Gunebo Lily, Prairie Lily.

1310. MENYÁNTHES, L. Buckbean. Menyanthaceae. Greek plant name. Marsh herb with trifoliate leaves. One species, northern hemisphere (U.S.)

a. M. trifoliáta L. Europe, Asia and north America south to Pennsylvania, Minnesota and California. Buckbean, Bogbean, Brook-bean, Bitter-worm, Bog Hop, Bog Mrrtle, Bognut, Bean or Bitter Trefoil, Marsh or Water Trefoil. Marsh Clover, Moon-flower*, Water Shamrock; Ger. Dreiblatt, Fieberklee, Bitterklee, Bieberkiee, Wasserklee; Fr. Ményanthe, 'Tréfle d'eau, (Codex): Sp. Trébal acuatico. Leares, Folia Trifolii fibrini P. G., bitter tonic, alterative, antiscorbutic, emmenagogue.

1311. MENZIÉSIA, J. E. Smith. Menziesia. Ericaceae. Named for Dr. A. Menzies, naturalist of Vancouver's exploring expedition. Shrubs. About 7 species, N. America and Japan; 3 in U. S. (a) M. pilósa (Michx.) Pers. (M. globularis Salisb. ) is called Minnie-bush. 
1312. MERCURIÁLIS, L. Dog's Mercury, etc. Euphorbiaceae. From Latın, "mercurial plant". Herbs. About 6 species, Mediterranean region and eastern Asia; 1 nat. in U. S.; Ger. Bingelkraut; Fr. Mercuriale.

a. M. ámmua L. Europe, adv. in U. S. Mercury herb, French Mercury. Leaves cathartic, alterative.

b. M. perénnis L. Europe. Dog's Mercury, Kentish Balsam, Bazzard-flower, Bristol-weed, Cheadle, Sapwort. The male plant is called Baron's (i. e. barren) Mercury, also Girl's Mercury, Maiden Mercury, the female plant is Buy's Mercury. Properties of (a).

1313. MERÍOLIX, Raf. Primrose*. Onagraceae. Syn. Uenothera, in part. Suffrutescent herb with yellow flowers. One species, southwestern U. S. and Mexico.

1314. MERTÉNSIA, Roth. Lungwort. Boraginaceae. Named for Prof. F. C. Mertens, German botanist. Syn. Pulmonaria, in part. Perennial herbs. About 15 species, northern hemisphere; 10 in U. S.

a. M. Virgínica (L.) DC. (M. pulmonarioides Roth. (Kew), P. Virginica L. ). Ontario to S. Carolina, west to Kansas and Nebraska. Virginia or American Lungwort, Smooth or Tree Lungwort, Virginia cowslip, Amerıcan Cowslip*, Roauoke Bell, Blue-bells*. Herb lenitive, expectorant.

1315. MESADÉYIA, Raf. Indian Plantain. Compositae. From Greek, "central gland". Syn. Cacalia, Senecio, in part. Perennial herbs with small discoid flower-heads. Abrut 12 species, N. America, 8 in U. S.

a. M. atriplicifólia (L.) Raf. (C. atroplicifolia L., S. atroplicifolius Hook.). Ontarlo to Florida, west to Kansas and Minnesota. Pale Indian Plantain, Wild Caraway. Plant emollient.

b. M. renifórmis (Muhl.) Raf. (S. Muhlenbergii Sch. (Kew), C. reniformis Muhl.). New Jersey to Minnesota and southward. Great Indian Plantain, Wild cullard.

1316. MESEMBRYÁNTHEMUM, L.

Aizoidaceae.

From Greek, "midday flower". Syn. Mesembryum, Adans. Fleshy-leaved plants, some cactus-like. About 300 species, warmer regions mostly of Old World, especially Africa; 3 nat. in $\mathrm{U}$. S.

a. M. crystállinum L. South Africa, nat. in southern Europe and in California. Ice-plant, Diamond Fig, Diamond-plant; Ger. Eiskraut; Fr. Glaciale, Ćristalline. Plant diuretic, emollient.

b. M. édule L. S. Africa. Hottentot's Fig. Fruit edible.

1317. MESOSPHAÉRUM,P. Br. 1756. Mesosphærum. Labiatae. Syn. Hyptis, Jacq. 1786. Herbs or shrubs. About 250 species, warmer regions of New World, especially in Brazil; 4 in U.S. 
1318. MÉSPILUS, L.

Medlar.

Pomaceae.

From ancient Greek name of (a). Syn. Pyrus, in part. Shrubs or small trees. One or two species, Europe and Asia.

i. M. Germánica L. [P. Germanica J. Hook. (Kew)]. Europe and western Asia. Medlar, English or Dutch Medlar, Medle tree, Hosedoup, Howdoup, Marle. Fruit edible.

1319. METASTÉLMA, R. Br. Metastelna. Asclepiadaceae. Shrubby climbers with small or minute white flowers. About 40 species, warmer regions of New World; 6 in L. S.

1320. METHÝstICUM, Raf. 1.738. Kavakava. Piperaceae. From Greek, "intoxicating". Syn. Macropiper, Miq. 1739; Piper (Kew), in part. Succulent shrubs with ample foliage. About 6 species, Polynesia.

a. M. excélsum (Forst.) Lyous (P. excelsum Forst., P. nethysticum L., not Forst., Mac. excelsum Miq.). New Zealand to Australia. New Zealand Toothache-tree, Kawakawa tree. Root analgesic.

b. II. methýstieum (Forst.) Lyons (P. methysticum Forst., Mac. metbysticum Miq., Mac. latifolium Miq. fide Hillebr., Meth. esculentum Raf.). Polynesian Islands. Kavakava, Awa, Ava, Kawa. Root intaxicant, analgesic, local anesthetic.

1321. METROSIDÉROS, Banks 1788. Lehua, etc. Myrtaceae. From Gireek, "irun womb". Syn. Nani, Adans. 1763, Nania, Miq. 185.5. Trees or shrubs, some climbers, with showy flowers. About 10 species, Oceanica to Australia.

a. M. polymórpha Gaud. (M. lutea Gray, M. spectabilis Gaertn., etc.). Polynesian Islands, Hawaii to Viti. The Lehua of Hawaiian song. The similar (b) M. tomentósa Cunn. of New Zealand is known as Fire-tree. Both are large trees with crimson (sometimes yellow) tassel-like flowers and very hard durable timber. (c) M. Véra Lind. (Nania vera Miq.) is the Iron-tree of Java.

1322. METRÓXYLON, Rottb. 1783. Sago Palm. Sabalaceae. From Greek, "womb wood", meaning probably pith wood. Syn. Sagus, Kumph. 1788. Large palms. About 8 species, Mialay archepelago to Fiji islands.

i. M. Rúmphii (Willd.) Mart. (S. Rumphii Willd., S. genuina Blume). East Indies. Prickly Sago Palm. Starch from interior of trunk is Sago, U. S. P. 1870; Fr. Sagou (Codex); Sp. Sagú.

b. M. Ságu Rottb. (M. Sago Koen., M. Sagus Spreng., M. læve Mart., S. lævis Blume). East Indies. Spineless Sago Palm. Chief source of the sago of commerce. (Sago or sagu is the Papuan word for "bread").

1323. MÉUM, Adans. Spignel, ctc. Umbelliferae. The ancient Greek name. Herbs. One, possibly 2 or 3 , species, Mediterranean region. 
a. M. Athamánticum Jacq. Europe. Spignel (Spicknel, Spikenel, Speknel, Spıke-nail), Spignet, Baldmoney (Badmoney), Bawdmoney, Bearwort, Honka, Mew, Micken. Root, Radix mei (athanıantici), Rad. anethi ursini; Ger. Bärwurzel, Herzwurzel, Mutterwurzel, Bärendillwurzel; carminative, stomachic, emmenagogue.

1324. MICHÉLIA, L. Champaca. Magnoliaceae. Named for Micheli, Florentine botanist early in 18th Century. Syn. Cha paca, Adans. Trees. About 15 species, tropical and mountainous Asia.

a. M. Chámpaca L. (C. Michelia Noronha, M. suaveolens Pers., M. Blumei Steud.). India. Chumpaka or Champak tree, sacred to Vishnu. Root bitter, tonic. Flowers exceedingly fragrant.

1325. MICRÁMPELIS, Raf. Wild Balsam-apple. Cucurbitaceae. From Greek, "small grapevine". Syn. Echinocystis, T. \& Gr.; Megarrhiza, Momordica, Sicyos, in part. Herbaceous vines. About 25 species, New World; 9 in U. S.

a. M. fabácea ( $\$ aud.) G'reene (Meg. Californica Tor.) and (b) M. Márah (Wats.) Greene (Meg. Marah Wats.), both of California, are called Big-root, Bitter-root, and Yerba marra. Seeds called chilli coyote.

c. M. Iobáta (Michx.) Greene (S. lobata Michx., E. lobata Tor. \& Gr., Mom. echinata Muhl., Mic. echinata Raf.). Ontario to Texas. Wild Balsam-apple, Mock Orange*, Creeper, Creeping-Jenny.

1326. MICRÁNTHEMUM, Michx. Scrophulariaceae. From Greek, "small flowered". Small glabrous annuals. About 16 species, New World; 2 in U. S.

1327. MICRÓCALA, Link. Microcala. Gentianaceae. From Greek, "little beauties". Slender herbs. 'Two species, one of Europe, one of N. and S. America (U. S.)

1328. MICROMÉRIA, Benth. 1829. Yerba Buena. Labiatae. From Greek, "small parts". Syn. Piperella, Presl. 1826. Low herbs, some shrubby. About 75 species, mostly of Old World, a few in America; 3 in U. S.

a. M. Chamissónis (Benth.) Greene (M. Douglassii Bentl. (Kew), M. barbata, Fisch. \& Meyer). Pacific Coast of U. S. Yerba buena (Spanish name for Mint). Plant diaphoretic, febrifuge. Siniilar properties are ascribed to (b) M. obováta Benth., West Indian Islands, called All-heal.

1329. MICRORHÁMNUS, Gray. Microrhamnus. Rhamnacene. From Greek, "small Buckthorn". Shrub. One species, Texas to New Mexico.

1330. MICRÓSERIS, Don. Microseris. Cichoriacene. From Greek, "little Endive". Herbs with scape-like peduncles, flowers yellow. About 20 species, mostly of N. America; 15 in California. 
a. M. Yórsteri J. Hook. Australia and New Zealand. Native Scorzonera. Root esculent.

1331. MíLLA, Cav. (Millea). Milla. Liliaceae. Herbs with cylindrical hollow leaves. About 20 species, New World; 1 in U. S.

1332. MIMósA, L. Mimosa, etc.

Mimosaceae. From Greek, "mimic". Herbs, shrubs or trees. Abnut 280 species, warmer parts of America, Africa and Asia; 16 in U. S.

a. M. púdica L. South America, now widely naturalized in subtropical countries. Sensitive-plant, Humble-plant, Touchweed. The Wild Sensitive-plant of Texas is (b) M. strigillósa T. \& Gr.

1333. MÍMULUS, L. Monkey-flower. . Scrophulariaceae. Latin, diminutive of mimus, an "actor". Herbs with pink, violet or yellow flowers, commonly showy. About 50 species, New World; 41 in U. S.

a. M. moschátus Dougl. Pacific coast of U. S. Musk-flower, Musk plant, Vegetable Musk. Plant has a musk-like odor.

1334. MímUSOPS, L. Balata, etc. Sapotaceae. From Greek, "ape's face". Syn. Achras, Sapota, in part. Trees or shrubs with milky juice. About 30 species, tropical regions of Old and New World.

a. M. eláta Allem. Para. Cow tree. MFilk sap resembles cow's milk. (b) M. Eléngi L. of India yields an edible fruit and a bark which is tonic and astringent. (c) M. Siéberi DC. (A. Zapotilla var. parviflora Nutt.), West Indies to Key West, is called Wild Dilly; fruit eaten by birds.

d. M. globósa Gaertn. (M. Balata Crueg., A. Balata Aublet, S. Muelleri Belkrode). Oronoco and Amazon valleys. Balata or Bully tree (Bulletrie, Bolletrie, Bullet tree). Exudate is Chicle, Balata or Tuno gum; Leche de popa, now largely used in the manufacture of chewing gum.

1330. MIRÁBILIS,L. (originally Admirabilis). Nyctaginaceae. Latin, "wonderful". Ornamental herbs, from fleshy tuhers. About 15 species, warmer regions of America; 9 in L. S.; Ger. Wunderblume; Fr. Belle de nuit.

a. M. Jalápa L. (M. Jalappa Thunb.). S. America, commonly cult. in gardens. Marvel-of-Peru, Four-o' clock, World'swonder, Afternoon-ladies, Beauty-of-the-night. Roots, known as Metalista root or False.Jalap, reputed cathartic.

1336. MITCHÉLLA, L. Partridge-berry. Rubiaceae. Named for Dr. John Mitchell, botanist of Virginia, 18th Century. Creeping. evergreen herbs with flowers in pairs. 'Two species, one of S. America, one in U. S.

a. M. répens $L$. Canada to Florida, west to Texas and Minnesota, also in Japan. Partridge-berry, Squaw-vine, Twin-berry, Checker-berry, Chicken-berry, Cow-berry, Deer-berry, Box- 
berry, Fox-berry, Hive-vine, Partridge-vine, Winter Clover, Wild Running Box, One-berry, l'igeon-berry, Snake-berry, Two-eyed berries, Squaw Plum. Plant tonic, astringent, parturifacient, etc.

1337. MITÉLLA, L. Mitrewort, Bishop's-cap. Saxifragaceae. Latin, dim. of mitra, "a cap". Perennial herbs, with slender racemes of small flowers. About 10 species, N. America and eastern Asia; 9 in U. S.

a. M. diphýlla L. Canada to N. Carolina, west to Missouri. Mitrewort, Common or Two-leaved Mitrewort, Bishop's-cap, Currant-leaf, False Sanicle, Fairy-cup, Fringe-cup. Leaves astringent, diuretic.

1338. MITRACÁRPCMI, Zucc. (Mithracarpus). Rubiaceae. From Greek, "turban fruit". Herbs. About 30 species, mostly of tropical America, a few African; 1 in U. S.

1339. NODÍOLA, Moench. Modiola.

Malvaceae. From Latin modiolus, an ancient Roman measure. A small mallow-like herb. One variable species, warmer regions of America and S. Africa (U. S.)

1340. MOEHRÍxGIA, L. Sandwort. Caryophyllaceae. Named for P. H. G. Moehring, naturalist of Danzig. Syn. Arenaria (Kew), in part. Low herbs. About 20 species, northern hemisphere; 2 in $U$. S.

1341. MoÉNCHIA, Ehrh. Pearlwort. Caryophyllaceae. Named for Prof. Konrad Moench of Marburg. Syn. Cerastium (Kew), in part. Low herbs. About 3 species, Mediterranean region; 1 adv. in U. S.

1342. MOGíPHANES, Mart. Mogiphanes. Amaranthaceae. From Greek, "hard to see". Herbs. About 12 species, warmer regions New World; 2 in U. S.

1348. MOHÁVEA, Gray. Mohavea. Scrophulariaceae. Named from the river near which the plant was discovered. Viscid-pubescent herb. One species, Arizona to southern California.

1344. MOHRODÉNDRON, Brit. Snowdrop tree. Styracaceae. Named for Dr. Charles Mohr, botanist of Alabama. Syn. Halesia, in part. Shrubs or small trees with drooping bellshaped flowers. About 4 species, southeastern U. S.

a. M. Carolínum (L.) Brit. (H. tetraptera L. 1762 (Kew), H. Carolina L. 1759). Virginia to Florida, west to Illinois. Silver-bell, Snowdrop tree, Bell tree, Wild Olive tree, Calico-wood, Shittim-wood, Tiss-wood. Some of these names apply also to (b) M. dípterum (Ell.). Brit. (H. dipterum Ell. ).

1345. MOLLÚG0, L. Carpet-weed. Aizuaceae. Low herbs, usually with whorled leaves. About 12 species, mostly tropical; 22 in U. S.

a. M. verticilláta L. Eastern U. S. and widely distributed as a weed. Carpet-weed, Indian Chıckweed, Devil's-grip. 
1346. MOLUCCÉLLA, L. (Molucca). Shell-flower. Labiatae. Named (in error) from Molucca Islands, Herbs with large bell-shaped calyx. About 2 species, Mediterranean region. (a) M. laévis L., western Asia, often cult. in gardens, is called Shell-flower or Molucca Balm.

1347. MOMóRDICA, L. Balsam Apple. Cucurbitaceae. From Latin, "chewed", alluding to appearance of the seeds. Climbing herbs. About 25 species, tropical regions of Old World; 2 adv. in U. S. (a) M. Balsámina L. (II. Charantia Desc. ). Tropical countries generally. Balsam Apple, Balsam vine, Balsamina. Root and fruit cathartic, emetic. Seeds vulnerary. (b) M. Charántia L. (M. Balsamina Desc.) is the similar Balsam Pear; East Indies and widely cult.

1348. MONíRDA, L. Horsemint, Wild Bergamot, etc. Labiatae. Named for N. Monardés, Spanish botanist, 16th Century. Aromatic herbs with rather large flowers in capitate clusters. About 12 species, N. America; 11 in U. S.

a. M. dílyma L. (M. coccinea Michx.). Canada to Georgia and Michigan. Oswego Tea, American Bee Balm, Rose Balm, Low Balm, Red or Scarlet Balm, Mountain Mint, Horsernint*, Indian's-plume; Sweet-Mary, Square-stalk.

b. M. punctáta L. New York to Florida, west to Texas and Wisconsin. Horsemint, American Origanum, Rignum‡, Monarda; Ger. Pferdeminze; Fr. Menthe de cheval. Herb, as in other species, diaphoretic, diuretic, carminative, emmenagogue. Source of oil of Monarda. (c) M. citriodóra Cerv. (M. aristata Nutt.), Nebraska to Texas and Arizona, is called Lemon Monarda or Prairie Bergamot; (d) M. fistulósa L. (M. mollis L.), Ontario and eastern U. S., is Wild Bergamot; called also () Swego Tea and Horsenint.

1349. MONÉSES, Salisb. One-flowered Pyrola. Pyrolaceae. From Greek, "single delight", alluding to the solitary flower. Syn. Pyrola, in part. Perenuial evergreen herb. One species, (a) M. uniflóra (L.) Gray (M. grandiflora S. F. Gray (Kew), P. uniflora L.). Europe, Asia and N. America. One-flowered Wintergreen, One-flowered Pyrola.

1350. MONYIÉRA,P.Br.1755.Hedge-Hyssop.Scrophulariaceae. Named for Prof. L. Guillaume le Monnier, French botanist, d. 1799. Syn. Herpestis, Gaertn. 1805, also Limosella, Gratiola, Matourea, Obolaria, in part. Herbs. About 60 species, warmer regions of both hemispheres; 7 in U. S.

1351. MonNiNA, R. \& P: Monnina. Polygalaceae. Herbs or shrubs. About 50 species, South America. (a) M. polystáchya R. \& P. Peru. South American Polygala. Root bark astringent and detergent, containing saponin.

1352. HIONODóRA, Dunal. Calabash Nutmeg. Anonaceae. From Greek, "single gift". Syn. Anona, in part. Trees with large woody fruit and aromatic seeds About 6 species, natives of Africa. 
a. M. Myrística (Gaertn.) Dunal (A.Myristica Gaertn.). Jamaica, probably introduced from Africa. Calabash Nutmeg; American, Mexican, Guinea or Jawaica Nutmeg. Sceds having flavor and use of Nutmegs.

13ō3. MONólEPIS, Schrad. Monolepis. Chenopodiaceae. From Greek, "one scale", alluding to the single scale-like sepal. Syn. Blitum, in part. Low herbs resembling Chenopodium. About 4 species, northern Asia and western N. America; 3 in U. S.

1354. MOYOLÓPIA, DC. ' Monolopia. Compositae. From Greek, "single husk", alluding to uniserial involucre. White-woolly annuals with yellow flowers. Three species, Pacific border of U. S.

135. MONóPTILON, Tor. \& Gr. Monoptilon. Compositae. From Greek, "single feather", alluding to pappus. A small desert annual. One species, California to Utah.

1356. MOYóTROPA, L. Indian-Pipe. Monotropaceae. From Greek, "singly nodding", descriptive of the flower. Syn. Monotropion. Low saprophytes, bearing a single nodding flower at the summit of a scaly scape. Two species, widely distributed; 1 in U. S.

a. M. uniflóra L. British America, U. S. throughout, Mexico, Japan and southeastern Asia. Indian-pipe, American Iceplant, Corpse-plant, Ghost-flower, Pipe-plant, Dutchman'spipe*, Fairy-smoke, Eye-bright*, Nest-root, Bird's-nest plant, Fit-root, Convulsion-root, Convulsior-weed, Ova-ova.

1357. MOYOTRóPSIS, Schwein. $1817 . \quad$ Monotropaceae. From Greek, "Monotropa-like". Syn. Schweinitzia, Nutt, 1818. Saprophytes. Two species, southeastern U.S. (a) M. odoráta Ell. (S. odorata DC. (Kew), S. Caroliniana Don.) of Maryland and N. Carolina is the rare Sweet Pine-sap, called also Carolina Beech-drops.

13.j8. MóNTIA, L. Water Chickweed, etc. Portulacaceae. Named for G. Monti, Italian botanist, 18th Century. Low annual herbs. About 5 species, colder regions of both hemispheres; 2 in U. S. (Heller includes in this genus many species referred by others to Claytonia.)

a. M. Pontána L. Northern U. S. and widely distributed. Water Chickweed, Blinking Chickweed, Blinks, Water-blinks.

1359. MORÍYDA, L. Indian Mulberry. Rubiaceae. From Latin, "Indian mulberry". Trees or shrubs, some climbers. About 40 species, warmer regions, particularly of Old World.

a. M. tinctória Roxb. (M. citrifolia Hunt., not L.). India to Australia. Indian Mulberry, Al tree. Bark and roots (Achroot, Al-root) yield a red dye, as do those of (b) M. Róyoc L. (M. umbellata L. (Kew), M. Rojoc Lour.), West Indies and Florida, called Yaw-weed. (c) M. citrifólia L. is the Noni of the Polynesian Islands: pulp of fruit used as a hairdressing. 
1360. MORÍNGd, Juss.

Ben nut.

Moringaceae. From vernacular name, Malabar. Syn. Guilandinat, in part. Trees. Three known species, N. Africa, western Asia and East Indies.

a. M. áptera Gaertı. (M. Arabica Pers.). Arabia to Abyssinia. Behen. Seeds source of true oil of Ben.

b. M. pterygospérma Gaertn. (M. oleifera Lam., G. Moringa L.). Horseradish tree. Root has pungency of horseradish. Seeds, Ben nuts, Behen nuts, yield oil of Ben which is bitter, acrid and purgative. Wood, Lignum nephriticum, formerly used in kidney complaints.

1361. MoRóNGIA, Brit. 1894. Sensitive Brier. Mimosaceae. Named for the late Rev. Thomas Morong, American botanist. Syn. Schrankia, Willd., not Medic.; Leptoglottis, Mimosa, in part. Prickly herbs or shrubs. About 10 species, warmer regions of America, 1 in Africa; 6 in U. S.

a. M. uncináta (Willd.) Brit. (S. uncinata Willd., Mimosa Intsia Walt. ) Virginia to Nebraska and southward. Sensitive Brier, Sensitive Rose, Shame-vine. (b) M. angustáta (T. \& G.) Brit., southeastern U. S., Narrow-leaved Sensitive Brier, is also called Sensitive-plant*.

1362. MoRoNóBEA, Aubl. Hog-gum tree. Guttiferae. From vernacular, Guiana. Trees. Two known species, S. America and the West Indies.

a. M. coccínea Aublet. Brazil and West Indian Islands. Hoggum tree. Resinous exudate, Hog gum, Doctor gum, Mani, Onani; terebinthinate, vulnerary. See Cochlospermum and Rhus.

1363. MORTóxiA, Gray. Mortonia. Celastraceae. Shrubs. About 5 species, Mexico and borders; 3 in U. S.

1364. MóRUS, L. - Mulberry.

Moraceae. Ancient Latin name of Mulberry. Trees or shrubs with succulent aggregate fruits. About 10 species, northern hemisphere; 2 in U. S.

a. M. álba L. China, now widely cult. and nat. White Mulberry, Sycamine, Silkworm tree. Leares the chief food of the silkworm.

b. M. nígra L. Southern Russia and Persia, widely cult. Black Mulberry; Ger. Maulbeerbaum; Fr. MIûrier; Sp. Moras. Fruit esculent: juice, Succus mororum, refrigerant. Bark of root tænicide.

c. M. rúbra L. Ontario to S. Dakota, south to Florida and Texas. Red Mulberry, American Mulberry. Properties of (b.)

1365. MUCÚNA, Adans. 1763. Cowhage. Papilionaceae. From vernacular, Brazil. Syn. Carpopagon, Dolichos, Stizolobium, P. Br. 1756, in part. Climbers with thick leathery pods. About 25 species, tropical regions of Old and New Worlds. 
a. M. prúriens (L.) DC. (D. pruriens, L., S. pruriens Medic., C. pruriens Roxb., M. prurita Hook.). East and West Indies. Seeds are called Sea-beans, Asses'-eyes, Donkey's-eyes. Hairs from the pods, Cowhage (Cowage, Cowetch); Setae v. Lanugo siliquae hirsutae; Ger. Kratzbohnen, Kuhkrätze; Fr. Pois velus, Pois à gratter; Sp. Pica-pica; formerly reputed anthelmintic. (b) II. úrens Medic. (S. urens Pers.) of S. America has the same properties.

1366. MUÍLLA, S. Wats. Muilla. Liliaceae. Anagram of Allium. Syn. Alliumt, in part. Perennial herbs resembling Allium but without the characteristic odor of that genus. Three species, Pacific coast of U. S.

1367. MÚNA, L. - Banana. - Musaceae. Syn. Ensete, in part. Gigantic herbs, the leafstalks forming a trunk often more than a fuot in diameter. About 25 species, tropical regions.

a. M. Chinénsis Sweet (M. Cavendishii Lamb., M. regia Rumph., M. nana Lour.), Chinese Banana; (b) M. paradisáica L., Plantain, Adam's Apple; (c) M. sapiéntum L., Common Banana (many varieties), Adam's Fig, (d) M. Simiárum Rumph. (M. corniculata Lour., M. acuminata Coll.), Pisang. These closely related species yield valuable esculent fruits.

e. M. textílis Nee. Philippine Islands. Abaca, Ahaka. Fibre from leaf stalks is Manila Hemp. (f) M. Eıséte.J. F. Gmel. (E. edule Bruce) of northeastern Africa, Bruce's Banana, is often planted for ornament in California and the southern States. Fruit in these species not edible.

1368. MUSCÁRI, Mill. Grape Hyacinth. Liliaceae. Late Latin, said to mean "musky". Syn. Hyacinthust, in part. Bulbous scapose herbs. About 40 species, Old World; $2 \mathrm{adv}$. in U. S. (a) M. botryoídes (L.) Mill. (H. botryoides L. ). Europe and Asia, adv. in U. S., is the Common Globe Hyacinth, Pearls-of-Spain, Blue-bell*. (b) M. comósum Mill. Europe. A cultivated variety is called Feather Hyacinth, Purple-tassels, Purse-tassels, Tuzzimuzzy.

1369. MUSENIÓPSIS, C. \& R. Museniopsis. Umbelliferae. From Greek, "resembling Musenium". Herbs. One species in Texas.

1370. MUSÍNE0N, Raf. 1820. Musineon. Umbelliferae. Greek name of "Fennel". Syn. Adorium Raf. 1825, Musenium, Nutt. 1840; Seseli, in part. Resiniferous perennials. Three species, northeastern U. S.

1371. MU'TÍSIA, L. f. - Mutisia. - Compositae. Named for José Celestino Mutis, South American botanist, d. 1808. Erect or climbing shrubs, many highly ornamental. About 36 species, South America.

a. M. viciaefólia Cavan. Chili. Flowers anti-spasmodic, sedative, cardiac, tonic. 
1372. MYGÍNDA, Jacq. 1760. Myginda. Celastraceae. Syn. Crossopetalum, P. Br. 1756, Rhacoma, L. 1759. Shrubs. About 8 species, warmer regions, New World; 4 in U. S.

1373. MYOSÓTIS, L. Forget-me-not, etc. Boraginaceae. From Greek, "muuse-ear". Low herbs with flowers in onesided racemes. About $3 \overline{5}$ species; 4 in U. S. Syn. Scorpiongrass, Mouse-ear.

a. M. palústris (L.) Lam. (M. scorpioides, var. palustris L.). Europe and Asia, cult. and nat. in U. S. Forget-me-not, Mouse-ear, Scorpion-grass, Marsh Scorpion-grass, Snake-grass, Caterpillars, Love-me.

1374. MYOSÚRUS, L. Mouse-tail. Ranunculaceae. From Greek, "Mouse-tail", alluding to form of receptacle. Low annual herbs. About 6 species, America and Australia; 5 in U. S. (a) M. mínimus L., Small Mouse-tail, is called also Blood-strange.

1375. MYRÍCA, L. Wax Myrtle, etc. Myrtaceae. Ancient Greek name of Tamarisk. Syn. Gale, Adans. Shrubs or small trees. About $3 \overline{5}$ species; 7 in U. S.

a. M. Carolinénsis Mill. Canada to Florida. Waxberry, Bayberry, with other synonyms of (b). Fruit abounds in wax, formerly used for candles, etc.

b. M. cerifera L. Maryland to Florida, west to $T+x a s$ and Arkansas. Wax Myrtle, Bayberry, Tallow Bayberry, Candleberry, Candle-berry Myrtle, Waxberry, Tallow shrub; Ger. Wachsmyrtel, Wachsbaum, Wachsgagel; Fr. Arbre à suif; Sp. Arbol del la cera. Fruit source of American vegetable wax or tallow (myrtle wax, bayberry tallow), which is said to have astringent and mildly narcotic properties.

c. M. Gále L. (G. Belgica Dum.). Europe, Asia and N. America, south to Virginia, Michigan and Wahington. Sweet Gale, Burren Myrtle, Bog or Devonshire Myrtle, Dutch or Moor Myrtle, Bay-bush, Fern Galet, Meadow Fern*, Gall-bush, Golden Osier, Golden Withy, Goule, Goyle, Meadow-burs, Moss Wythan, Sweet Willow, Wild sumact; Ger. (Gagel, Brabanter Myrte; Fr. Piment royal, Galé odorant. Leaves and buds alterative, tonic, vulnerary.

13 76. MYRIOPÝLLUM, L. Water Milfoil. Haloragidaceae. From Greek, "myriad leaved". Aquatic herbs. About 20 species; 11 in U. S. (a) M. spicátum L. may serve as a type of the genus. Spiked Water-Milfoil, Meakin, Navelwort, Water Navelwort.

1377. MYRÍSTICA, L.1742. Nutmeg. Myristicaceae. From Greek, "fit for anything". Syn. Palala, Kumph. 1741. Aromatic trees. About 90 species, tropical Asia and America.

a. M. Bicuhyba Schott. (M. officinalis Mart.).] Brazil. Seeds source of Becuiba Tallow. 
b. M. frágrans Houtt. (P. fragrans (Houtt.) O. Kze., M. moschata Thunb., M. aromatica Swz., M. officinalis L. fils.). Molucca Islands, now cult. in many tropical countries. Nutmeg tree. Seeds, Nutmegs; Myristica. U. S. P., Br. Semen myristicæ P. G., Nux moschata, Nuces nuciste; Ger. Muskatnuss, Moschatenuss, Myristicasamen; Fr. Muscade (Codex), Noix muscade; Sp. Nuez mosedda. Arilloid of fruit, Mace; Macis, U. S.P.; Arillus myristicae, Flores macidis; Ger. Muskatblüthe, Muskatblumen; Fr. Macis (Codex), Fleur de Muscade; Sp. Macias. Aromatic, carminative, narcotic. From nutmegs is obtained the volatile oil of Nutmeg and the expressed oil, Nutmeg butter. Mace also yields volatile oil.

c. M. fátua Houtt. Molucca Islands. The seeds are the Long, Wild or Male Nutmegs of commerce.

d. M. Otóba Humb. \& Bonp. Northwestern S. America. Seeds source of Otoba butter.

1378. MÝRRHIS, Scop. 1772. Sweet Chervil. Umbelliferae. The ancient Greek name. Syn. Lindera, Adans. 1763. Aromatic herbs. Perhaps only one species. See Glycosma.

a. M. odoráta Scop. Europe and Asia Minor. Sweet Chervil, Sweet Angelica, Sweet Bracken, Sweet Cicely (of Europe), Sweet Cess or Cisley, Sweet Fern†, Sweet Humlock, Myrrh†, Spanish Chervil; Ger. Körbelkraut. Root aromatic, carminative; used also in salads, etc.

1379. MÝRSINE, L. - Myrsine. - Myrsinaceae. Ancient Greek name of Myrtle. Trees or shrubs. About 80 species, warmer regions of Old and New World; 1 in U. S.

1380. MÝRTUS, L.

Myrtle.

Myrtaceae. The ancient Greek name of (a). Shrubs. About 100 species, mostly of S. America, some of Australia and Asia.

a. M. commúmis L. Western Asia, nat. in southern Europe. Myrtle, Common Myrtle (Mirtle, Mirtil), Bridal Myrtle, Dutch Myrtle, Jew's Mrrtle; Ge.; Fr. Myrte. Leaves aromatic, astringent, antiseptic. (b) M. Arragon Kunth of Mexico is there used as a substitute for the European Myrtle. [Several species of Myrtus yield edible fruits, e. g. (c) M. nummulária Poiret of Chili and Falkland Islands, Cranberry Myrtle; (d) M. tomentósa Ait. of India and China, and (e) M. Úgni Mol., the Chilian Guava.]:

1381. NÁBALUS, Cass. Rattlesnake-root, etc. Cichoriaceae. From vernacular Indian name. Syn. Prenanthes, Harpalyce, in part. Perennial herbs with heads consisting of a few ligulate Howers. About 20 species, America and Asia; 11 in U. S.

a. N. álbus (L.) Hook. (P. alba L. (Kew), H. album Don). Canada to Georgia and Kentucky. Rattlesnake-root, White Lettuce, Cancer-weed, White Canker-weed, Lion's-foot. Root bitter, tonic, reputed antidote to snake poison. 
b. N. altísimus (L.) Hook. [P. altissima L. (Kew)]. Tall White Iettuce, Lion's-foot, Rattlesrake-root, Bird-bell. Properties of (a).

c. N. serpentárius (Pursh) Hook. (P. serpentaria Pursh (Kew), N. Fraseri DC. ). Ontario to Florida. Gall-of-the-earth, Rattlesnake-root, Lion's-foot, Snake Gentian, White Lettuce, Canker-weed. Properties of (a).

1352. NíIAS, L. Water-Nymph. Naiadaceae. From Greek, "water-nymph". "Submerged aquatic plants. About 10 species; 5 in U. S.

13S3. NÁMA, L. $1753 . \quad$ Nama. Hydroplyyllaceae. From Greek, a "stream", alluding to the habitat. Syn. Hydrolea L. 1762. Perennial herbs, some shrubby, with blue flowers. About 15 species, warmer regions, both hemispheres; 4 in U. S.

\section{NANI, see METROSIDEROS.}

1384. NAPAÉA, L. Glade Mallow.

From Greek, a "wooded vale", alluding to the habitaceae. perennial herb with small white diocious flowers. One species, eastern U. S.

1385. NARCíSSUS, L. Narcissus. Amaryllidaceae. The ancient Greek name, "narcotic". Syn. Jonquilla, Scapose herbs from coated bulbs. About 20 species, mostly Furopean.

a. N. Pseudo-Narcíssus L. (J. bicolor Raf.). Europe. Daffodil (Dilly, Daffodilly, Averil), Trumpet Daffodil, Bell-flower, Chalice-flower, Cowslip, Yellow Crowbells, Easter or Yellow Lily, Lide-Lily, Queen Anne's flower; Ger. Gelbe Narcisse, Aftodil; Fr. Narcisse des prés, Porillon. Bulb and flower emetic, antispasmodic.

Common in cultivation are also (b) N. Jonquílla L., southern Europe, Jonquil, Yellow Jack; (c) N. Bulbocódium L., Mediterranean region, Hoop-petticoat Daffodil; (d) N. incomparábilis Mill. (N. aurantius Sclult.), Europe, sometimes called in England Butter-and-eggs or Eggs-and-bacon; (e) N. poéticus L. (J. poetarum Haw.), Europe, Poet's Narcissus, Asphodel, White-dillies, Laus-tibi, Sweet-Nancy, WhiteNancy; (f) N. Tazétta L. (N. polyanthos Loisel., J.' Tazetta Raf.), Europe, Polyantbus Narcissus. Var. orientális ( $N$. orientalis L. ) is tl.e ('hinese Sacred Lily or New-year's Lily.

1386. MARDóSTACHYs, DC. Spikenard. Valerianaceae. The ancient Greek name. Syn. Valeriana, in part. A fragrant herb. One species.

a. N. Jatamánsi (Roxb.) DC. (V. Jatamansi Roxb.; includes N. grandiflora DC.). Himalaya mountains. Spikenard (of the ancients), East Indian or True Spikenard, Nard, Jatamansi. Root, Nardus indica, Spica nardi; aromatic, bitter, antispasmodic. 
1357. NAREGÁMIA, W. \& Arn. Goanese Ipecac. Meliaceae. Shrub. One species; (a) N. aláta W. \& A. ( $\mathrm{N}$. dentata Miq.). West Indies. Goanese Ipecacuanha. Root and stalk emetic, nauseant, expectorant.

13S3. NAUMBÉRGIA, Moench.TuftedLoosestrife.Primulacere. Syn. Lysimachia, in part. Marsh herb with yellow flowers in axillary spikes. One species, circumpolar; northern U. S.

1389. NA YARRÉTLA, R \& Pav. (Navarettia).Polemoniacene. Named for Dr. Navarrete, Spanish physician. Syn. Gilia, in part. Annual herbs with small flowers in dense clusters. About 24 species, all of western U. S. (a) N. squarrósa (Esch.) Hook. \& Arn., is called Skunk-weed in California.

1390. TECTÁNDR A, Roland. Bebeeru, etc. Lauraceae. From Greek, "nectar stamen". Syn. Ocotea, in part. Trees. About 70 species, warmer regions of New World.

a. N. Puchury-májor Nees (O. Puchury major Mart.) and (b) N. Puchury-mínor Nees (O. Puchury-minor Mart.). Brazil. Brazilian Sassafras. Seeds (Cotyledons), Pichury beans, Sassafras nuts, Brazilian beans, Fichurim, Puchurim; Semen v. Fabæ v. Cotylæ pichurim; Ger. Pichurimbohne, Sassafrasnüsse; Fr. Fève pichurim, Noix de sassafras; aromatic, stimulant. Bark aromatic, astringent, febrifuge.

c. N. Rodioéi Hook. ( $N$. Rodiei Schomb.). British Gniana. Greenheart tree, Bebeeru tree. Bark, Bebeeru or Bibiru bark; Cortex nectandra, Cort. beberu $\mathbf{v}$. bibiru; Ger. Bibirurinde; Fr. Écorce de bébéeru; antiperiodic, tonic; source of alizaloid bebeerine. Starchy seeds, although bitter, used for food. Timber used in ship-building.

d. N. Sp. indet. Coto bark and Para-coto bark are derived from trees, natives of Bolivia, that have been referred doubtfully to this genus. Both are aromatic and astringent, used in bowel troubles. See Drymis.

1391. NELÚMBO, Adans.Lotus Lily, Water-bean.Nymphaeaceae. From vernacular, Ceylon. Syn. Nelumbium. Willd; Nymsphæa, in part. Aquatic plants with large peltate leaves and showy fragrant flowers. Two species, one of Old World, the other American (U. S.).

a. N. lútea (Willd.) Pers. (Nelumbium luteum Willd.). New England to Michigan; south to Florida and Indian Territory. American Lotus Lily, Great Water-lily, Water Lotus, Great Yellow Lily, American Nelumbo, Water Chinkapin, Wankapin, Yoncopin. Seeds, Duck Acorn, Water-nut, Rattle-nut, esculent.

b. N. Nelúmbo (L.) Karst. (Nym. Nelumbo L., Nym. nucifera Gaertn., Nelumbium speciosum Willd.). Egypt to Japan, E. Indies and Australia, adv. in southern U. S. Sacred Lotus, Indian or Egyptian Lotus, Egyptian Bean, Sacred Bean, Pythagorean Bean, Jamaica Water-lily. Rhizome and seeds esculent, the former, source of Chinese arrowroot. 
1392. NEMACAĆLIS, Nutt. Nemacaulis. Polygonaceae. From Greek, "thread stem". Annual herb. One species, California.

1393. NEMÁCLADUS, Nutt. Nemacladus. Lobeliaceae. From Greek, "thread branch". Annual herbs. Three known species, California to N. Mexico.

1394. NEMÁSTYLIS, Nutt. Nemastylis. Iridaceae. From Greek, "thread style". Syn. Eustylis, Engelm. \& Gr.; Iria, in part. Bulbous herbs with nearly regular perianth. About 10 species, New World; 4 in U. S.

1395. NEYóPHILA, Nutt. Nemophila. Hydrophyllaceae. From Greek, "grove loving". Syn. Ellisia, in part. Fragile annuals. About 12 species, all of U. S., mostly in California. (a) N. insígnis Dougl. is called Baby-eyes; (b) N. auríta Lindl. is called Love-grove.

1396. NEMÓSERIS, Greene. Nemoseris. Cichoriaceae. From Greek, "thread Endire". Syn. Rafinesquia, Nutt. Stout annuals with white flowers. Two known species, California to New Mexico.

1397. NEOWASHINGTÓNIA, Sudw.

Sabalaceae. From Greek, "new Washingtonia". Syn. Washingtonia, Wendl. 1879 , not Raf. 1818, Pritchardia, Drude 1889. Large fan-palms. Two species, southern California and southward. (a) X. filamentósa (Wendl.) Sudw., Washington Palm, is our largest native Palm. Seeds used for food by aborigines.

1398. NEPÉNTHES, L. Pitcher-plant. Nepenthaceae. (rreek name of a narcotic drug, "sorrow removing". Syn. Phyllamphora, Lour. Climbers, the leaves having pitcher-like appendages. Abuut 40 species, tropical regions of Old World.

1399. XÉPETA, L. - Catnep. - Labiatae. The ancient Latin name of Catnep. Herbs. About 130 species, Europe and Asia; 1 nat. in U. S.

a. N. Catária L. Europe and Asia, nat. in U. S. Catnep (Catnip), Catmint, Catrup, Cat's-wort, Field Mint; Ger. Katzenminze, Katzenkraut; Fr. Cataire, Chataire, Herbe aux chats, Menthe des chats. Herb antispasmodic, carminative, emmenagogue.

1400. NEPHÉLIUM, L. 1767. Litchi, etc. Sapindaceae. Ancient Latin plant name, from the Greek. Syn. Dipherocarpus, Llanos 1759, Litchi. Small trees producing edible fruits. About 20 species, southern Asia, East Indies and Fiji Islands.

a. N. lappácenm L. India. Rambutan (i. e. "hairy"), Rampostan. Fruit esculent, highly esteemed.

b. N. Lítchi Cambess. (N. Lichi Steud., L. Chinensis Sonner.). South China, Cochin China and Philippine Islands. Litchi, Litschi, Leechee, Li'tchi, La'tji. A favorite fruit in China. 
c. N. Lóngan Cambess. India to southern China. Longan. Fruit, called by the Chinese lung-yen, i. e. dragon's-eye, esculent.

1401. NEPHRÓLEPIS, Schott.

Polypodiaceae. From Greek, "kidney scale", from form of indusium. Stoloniferous ferns. About 12 species; 2 in southern. U. S.

1402. NEPTÚNIA, Lour. Neptunia. Mimosaceae. Named from the aquatic habitat of one species. Herbs or under shrubs. About 12 species, tropical regions; 4 in U. S.

1403. NÉRIUM, L. Oleander. Apocynaceae. The ancient Greek name. Syn. Oleander. Shrubs. Two or three species, Asia.

a. N. Oleánder L. (O. vulgaris Medic.). Mediterranean region and cult. as an ornamental shrub in sub-tropical regions. Oleander, Rose Laurel, Rose Bay, South Sea Rose, probably the "Willow" of Scripture; Ger. Rosenlorbeer; Fr. Laurier rose, Laurose; Sp. Adelfo. Plant has poisonous properties. The Sweet Oleander of India is (b) N. odórum Ait. (N. odoratum Lam., O. Indica Medic. ).

1404. NESAÉA, Comm. (Nessea.) Nesæa. Lythraceae. From name of a sea nymph. Herbs or shrubs. About 25. species, mostly of Africa; 1 in U. S.

1405. NÉSLIA, Desv. Ball Mustard. Cruciferae. Named for J. A. N. de Nesle, French botanist. Hispid herb with small globose silicles. One species, Europe and eastern Asia, adv. in U. S.

1406. NESOIRÁBA, Greene. Nesodraba. Cruciferae. From Greek, "island Draba". Syn. Uraba, in part. Herbs. Three species in western U.S.

1407. NESTRónIA, Raf. 1836. Nestronia. Santalaceae. From the Greek name of Daphne. Syn. Darbya, A. Gray 1846. Low diœcious shrub. One species, southeastern U. S.

1408. NEVIÚSIA, A. Gray (Neviusa). Neviusia. Rosaceae. Shrub with large white flowers. One species, southeastern U. S.

1409. NICOLLÉTIA, A. Gray. (Nicollettia). Compositae. Named for J. N. Nicollet, astronomer and explorer. Perennial herbs with large heads of purple or flesh-colored flowers. Two species, southwestern U. S.

1410. Nicotíñ , L. - Tobacco. _ Solanaceae. Named for Jean Nicot, French ambassador to Portugal about 1560. Narcotic herbs, some shrubby, one a tree. About 50 species, mostly American; 11 in U. S.

a. N. rústica L. Canada and eastern U. S., cult. in Turkey, India and elsewhere. Wild Tobacco, Indian Tobacco, Real Tobacco, Syrian Toluacco, Wit. Furnishes most of the tobacco of Turkey, the Philippine Islands and India. Projerties of (b). 
b. N. Talácum L. Tropical America, now widely cultivated. Tobacco, Virginia Tobacco, Drunkwort. The dried leaves, Leaf Tobacco; Tabacum. U. S. P., Tabaci folia Br., Folia Nicotianæ P. G.; Ger. Tabak; Fr. Nicotiane, Tabac (Codex), sedative, nauseant, sternutatory. The Shiraz tobacco of Persia is derived from (c) N. Péısica Lind. Some of the Havana tobacco is obtained from (d) N. repánda Willd. In the northwest (e) $\mathbf{~}$. multiválvis Lind. is used, in Missouri (f) $\mathbf{N}$. quadriválvis Pursh.

1411. NIGÉLLA, L. Fennel-flower. Ranunculaceae. Annuals with dissected leares. About 25 species, Mediterranean region and western Asia.

a. N. Damascéna L. Levant to southern Europe. Fennel-flower, Bishop's-wort, Devil-in-a-bush, Love-in-a-mist, Love-in-a-puzzle, Ragged-lady. Seeds used like those of (b).

b. N. satíva L. Mediterranean region. Black Cumin, Black Caraway, Fitch (of Scripture), Roman Coriander, Nutmegflower, Fennel-flower, Gith, Git; Ger. Schwartzkïmmel; Fr. Quatre épices. Seeds, semen nigelli v. melanthii v. c umini nigri, pungent, aromatic, carminative, used like Caraway seed.

1412. NISSÓLIA, Jacq.

Trees or shrubby climbers. About 8 species; warmer regions of New World; 2 in U. S.

1413. NITRóPhILA, Wats. Nitrophila. Chenopodiaceae. From Greek, "alkali loving". Low, somewhat succulent, herb. One species, western U. S.

1414. NOLÍNA, Michx. Nolina. Liliaceae. Herbs with small flowers in terminal panicles. About 15 species, Mexico and adjacent region; 9 in U. S.

1415. NOPÁLEA, Salm-Dyck. Nopalea. Cactaceae. Syn. Cactus, Opuntia, in part. Succulent thorny plants. About 3 species, tropical America.

a. N. cocheníllifer (L.) Lyons (C. cochenillifer L., O. coccinellifera Mill., N. coccinellifera (Mill.) Salm-Dyck.). Mexico and West Indies. Cochineal Cactus. See Opuntia.

1416. NothocílaIs, Greene. False Calais. Cichoriaceae. From Greek, "spurious Calais". Syn. Troximon, in part. Scapose herbs with solitary large flower heads (yellow). Three known species, central and western U. S. Called also False Dandelion.

1417. NOTHOLAÉxA, R. Br. Notholaena. Polypodiaceae. (Written also Nothochlaena). Sinall rock-ferns. About 40 species; 14 in U. S.

1418. NoTHOSCóRDUM, Kunth. Nothoscordum. Liliaceae. From Greek, "false garlic". Scapose herbs resembling Allium, but without the odor. About 10 species, mostly of tropical America; 1 in U. S. 
1419. NYCTAGíNEA, Choisy. Nyctaginea. Nyctaginaceae. Named from resemblance to Nyctago of Jussieu, now called Mirabilis. Prostrate hairy annual with rose-colored flowers. One species, Texas.

1420. NY HPHAÉA,L.1753. Yellow Pond Lily. Nymphaeaceae. From Greek, "nymph" plant. Syn. Nuphar (Kew), Sibth. \& Sm. 1806, Nyphar, Nymphozanthus. Aquatic plants with cordate floaring leaves and yellow flowers. About 8 species, north temperate zone; 6 in U. S.

a. N. ádrena Soland. (Nuphar advena R. Br. (Kew), Nuphar lutea Walt., not. L. ). Canada to Florida, west to Rocky Mountains. Yellow Pond Lily, Common or Large Yellow Pond Lily, Spatter-dock, Beaver Itily, Beaver-root, Cow Lily, Dog Lily, Frog Lily, Horse Lily, Bull-head Lily, Bonnets, Kelp*. Rhizome astringent, emollient; abounds in starch.

b. N. lútea L. (Nuphar luteum Sibth. \& Sm. (Kew), Nymphozanthus vulgaris Rich.). Europe. European Yellow Pond Lily, Cambric-leaf, Can Dock, Clote-leaf, Flatter Dock, Water-blob, Water-can, Water Coltsfoot, Nenuphar, Brandy-bottles (the fruit), also most of the synonyms of (a); Fr. Nénuphar jaune (Codex). Rhizome astringent, demulcent.

c. N. polysépala (Engelm.) Greene [Nuphar polysepalum Engelm. (Kew)]. Northwestern U. S. Western Yellow Pond Lily, Giant or Larger Yellow Pond Lily, Wankapin*. Seeds esculent. (d) N. rubrodísca (Morong) Greene of northeastern U. S., Red-disked Pond Lily is called Can Dock; (e) N. sagittrefólia Walt., southeastern U. S., Arrow-leaved Pond-lily, is called also Alligator-bonnets.

1421. NÝSSA, L. Tupelo, Ogeechee Lime, etc. Cornaceae. The name of a water nymph, nurse of Bacchus. Trees or shrubs. About 7 species, eastern N. America and eastern and central Asia; 4 in U. S.

a. N. aquática L. [N. uniflora Wang. (Kew)]. Virginia to Florida, west to Missouri. Large Tupelo, Swamp Tupelo, Cotton Gum-tree, Tupelo, Black or Sour Gum.

b. N. Ogéche Marsh. (N. capitata Walt., N. Oye-chee Steud.). Gulf states. Ogeechee Lime, Gopher Plum.

c. N. sylvática Marsh. [N. multiflora Wang. (Kew)]. Ontario to Florida, west to Texas and Michigan. Pepperidge, Sour Gum, Tupelo, Swamp Hornbeam, Black Gum, Yellow Gum, Beetlebung, Hornbine, Hornpine, Hornpipe. Fruit acid.

1422. OBOLÁRIA, L.

Pennywort.

Gentianaceae.

From Greek, obolus, a coin, the leaves being round. A perennial herb with scanty foliage. One species, southern U. S.

1423. óCIMUM, L. (Ocymum). Basil. Labiatae. The classical name. Herbs. About 35 species, warmer regions especially in Africa and Brazil; 1 in $C . S$. 
a. 0. Basílieum L. (including O. majus Hort. ,O. medium Mill. and O. minimum L.). Asia and Africa, cult. in gardens. Sweet Basil [Basil, from the Greek, means royal], Basil, Common Basil; Ger. Basilienkraut; Fr. Basilic (Codex); Sp. Albahaca. Herb has ordinary properties of mints; used as a pot herb, for seasoning, etc. Several other species have similar properties, e. g.: (b) 0. sánctum L., southern Asia and Australia, (c) 0. viride Willd. of tropical Africa, perhaps a variety of the following, in Sierra Leone called Fever-plant, and (d) 0. gratíssimum L., Southern Asia.

1424. OCÚTEA, Aublet. - Ocotea. - Lauraceae. From vernacular, Guiana. Syn. Oreodaphne, Nees; Laurus, Nectandra, Persea, in part. Aromatic trees or shrubs. About 200 species, mostly of tropical America, some African; 1 in Florida. See Nectandra.

a. O. Guianénsis, Aublet. (O. opifera Mart., Oreodaphue opifera Nees). Brazil. Canella de cheiro. Bark employed in treating abscesses. Fruit yields a fragrant volatile oil.

1425. ODONTÍTES, Gmel. Red Bartsia, etc. Serophulariaceae. From Greek, "toothache" remedy. Syn. Euphrasia; Bartsia, in part. Annual herbs. About 20 species, Mediterranean region; 1 nat. in $\mathrm{U}$. S.

a. O. Odontítes (L.) Wettst. (E. Odontites L., B. Odontites Huds.). Europe and Asia, adv. in U. S. Red Bartsia, Red Eye-bright.

1426. ODONTÓSTOMUM, Tor. Odontostomum.Haemodoraceae. From Greek, "tooth mouth". Bulbous herb with white flowers in panicled racemes. One species, Pacific coast (U.S.).

1427. 0ENÁNTHE, L. Water Hemlock, etc. Umbelliferae. Ancient Greek plant name, "wine flower". Syn. Phellandrium, in part. Herbs, mostly of marshes. About 40 species, widely distributed; 2 in U. S.

a. Oe. crocáta L. Europe. Hemlock Water-dropwort, Belderroot, Bendock, Biller, Dead-tongue, Five-fingered root, Meadow Saffron*, Hemlock Dropwort, Hemlock Water-drop, Water Hemlock, Water Lovage. Plant an active poison. The European (b) 0e. fistulósa L., Common Water Hemlock; Ger. Rebendoldenkraut, is less poisonous.

c. Oe. Phellándrium Lam. (P. aquaticum (L.). Europe and northern Asia. Fine-leaved Water Hemlock, Death-in, Edgeweed, Horsebane, Phellandrium, Water Dropwort, Water Fennel; Ger. Wasserfenchel, Rossfenchel, Pferdienchel: Fr. Phellandrie aquatique (Codex), Fenouil d'eau. Fruit, Fructus Phellandrii, P. G., Sem. fœniculi aquatici; diaphoretic, diuretic, expectorant.

1428. OENOTHÉRA, L. Evening Primrose. Onagraceae. From Greek, "wine scent" (?), the root said to have a vinous odor. Herbs with yellow nocturnal flowers. About 20 species, New World; 5 in U. S. See Anogra, Galpinsia, Gaurella, Hartmannia, Kneiftia, Lavauxia, Megapterum, Meriolix, Onagra, Pachylophus, all formerly referred to this genus. 
1429. OLDENLÁNIIA, L.

Bluets.

Rubiaceae.

Named for H. B. Oldenland, Danish botanist. Syn. Hedyotes, in part. Small herbs. About 175 species, warmer regions, especially of Asia; 4 in U. S.

a. 0. umbelláta L. (H. umbellata Lam.). India. Shaya, Chaya, Indian Madder plant. Leares expectorant. Root, Shaya root, Chay or Choy root, Indian Madder; yields a valuable red dye.

1430. ÓLEA, L. - - Olive. - Oleaceae. The classical name, whence our word "oil". Trees or shrubs. About 36 species, ()ld World and Oceanica.

a. O. Europaéa L. (O. Oleaster Hoffm., O. communis Steud., O. officinarum Cranz., O. lancifolia Moench) Southwestern Asia, now widely cultivated in sub-tropical countries. Olive. The wild tree is called Oleaster; numerous varieties are distinguished, the names being Spanish, Italian or French. Leares and bark febrifuge. Fruit esculent, surce of Olive oil (sweet oil); Oleum Olivae, U. S. P.

1431. OLEÁRIA, Moench 1802. Daisy tree, etc. Compositae. Syn. Eurybia, Cass. 1820. Shrubs, some trees or herbs. About 85 species, Australia and New Zealand.

a. O. argophýlla F. Muell. (E. argophylla Cass.). Tasmania. Silver-leaved Musk tree. Foliage has a musky odor. (b.) 0. stelluláta DC. (E. lirata DC. ), Tasmania, is called Daisy tree.

1432. OLIGÓMERIS, Cambess. Oligomeris. Resedaceae. From Greek, "few parts". Herbs or sub-shrubs. About $\overline{5}$ species, mostly of S. Africa; 1 in U. S.

1433. ǴLNEYA, Gray. Tesota, etc. Papilionaceae. Named for Stephen T. Olney, botanist of Rhode Island. A small tree, one species, O. Tesota Gray, southwestern U. S., called Ironwood (Arbol de hierro) and Tesota.

1434. OMPHÁLEA, L. Ouabe, etc. Euphorbiaceae. From Greek, "navel" plant, alluding to form of anthers. Climbing shrubs or small trees. About 12 species, tropical America, one in Madagascar.

a. O. diándra L. West Indies. Ouabe, West Indian Cob-nut; Fr. Noisettier. Seeds edible, source of Ouabe oil.

b. 0. oleífera Hemsley. Central America. Seeds source of Tambor oil which is purgative like Castor oil.

1435. OMPHALÓDES, Moench. Venus'Navelwort.Boraginaceae. From Greek, "navel like", alluding to shape of seeds. Syn. Omphalium. Herbs. About 20 species, northern hemisphere; 2 in U. S.

1436. OxAGRA, Adans. Evening Primrose Onagraceae. From Greek, "wild ass". Syn. Oenothera (Kew), in part. Herbs with yellow nocturnal flowers. About 12 species, chiefly North America; 8 in U.S. 
a. 0. biénnis (L.) Scop. (Oe. biennis L.). Labrador to Florida, west to Rocky Mountains. Common Evening Primrose, Wild or Field Evening Primrose, Night Willow-herh, Fever-plant, Four-o' clock*, King's Cure-all, 'Tree Primrose, Large Rampion, Scabish*, Scurvish; Ger. Nachtkerze; Fr. Onagre. Plant mucilaginous, alterative. Var. grandiflóra Lindl. is the Common Eveuing Primrose of gardens.

1437. ONóBRYCHIS, Gaertn. Sanfoin. Papilionaceae. Herbs or shrubs. About 70 species, Europe and southern Asia.

a. O. vicixfólia Scop. (O. sativa Lam.). Europe to Central Asia. Sanfoin, Cinquefoil, Cockscomb*, Cock's-head plant, Everlasting-grass, Hen 's-bill, Lucerne*, Medick Fitch; Fr. Esparcette. A valuable fodder plant.

1438. OxochÉA, L. Sensitive Fern, etc. Polypodiaceae, Ancient Greek plant-name, "close vessel". Syn. Struthiopteris, in part. Ferns with segments of the fertile fronds enclosing the sori. Three species, 2 in U. S. (a) 0 . sensíbilis L. is called Sensitive Fern; (b) 0. Struthiopteris (L.) Swz. (Osmunda Struthropteris L., S. Germanica Willd.) is called Ostrich Fern.

1439. oxóxIs, L. (Anonis). Rest-harrow. Papilionaceae. Ancient Greek plant-name, "ass" weed. Herbs. About 60 species, Europe and Mediterranean region.

a. 0. arvénsis L. Europe. Rest-harrow, Bomariskie, Cammock Whin, Cat Whin, Lady Whin (Scotland), Land Whin, Ground Furze, Hen Gorse, Horse's-breath, Lewte, Wild Licorice*, Sit-fast, Steadfast, Rashburn, Ramsey, Rassels, Stainch.

b. 0. spinósa L. Europe. Rest-harrow, Stay-plow, Cammock*, Petty Whin; Ger. Hauhechel, Ochsenbrechkraut; Fr. Bugrane, Bougrane. Root, Radix Ononidis, F. G., Rad. restis bovis; diuretic, lithontriptic, alterative.

1440. ONOPÓRDON, L. "Cotton Thistle. Compositae. The ancient Greek name, "asses' flatus". Thistle-like plants with decurrent leaves. About 12 species, Old World.

a. 0. acánthium L. Europe and Asia, cult. in U. S. Cotton Thistle, Argentine Thistle; Crab-, Down-, Musk-, Oat- or Queen Mary's Thistle, known in England as Scotch Thistle, see 381 (b); Ger. Eseldistel, Krebsdistel.

1441. ONÓSMA, L. Onosma.

Boraginaceae. From Greek, "ass smell". Syn. Maharanga DC. Bristly or hoary herbs. Adout 70 species. Mediterranean region to India. The roots of (a) 0. echioídes L., Europe (Ger. Lotwurz) and of (b) 0. Emodi Wall (M. Emodi DC.), India, yield a red dye.

1442. ONOSMÓDIUM, Michx. False Gromwell. Borayinaceae. From Greek, "resembling Onosma". Syn. Lithospermum, in part. Hispid or hirsute herbs. About 6 species, N. America; 5 in U. S. 
a. 0. Virginiánum (L.) DC. (L. Virginianum L.) Eastern U. S. False Gromwell, Viryinia False Gromwell, Wild Job's-tears, Necklace-weed, Pearl-plant, Gravel-weed. Root and sceds reputed diuretic, lithontriptic.

1443. O0NóPSIS, Greene. Oonopsis. Compositae. From Greek, "egg like", alluding to the involucre. Syn. Aplopappus, Bigelovia, in part. Perennial herbs with sniall flower heads. Four known species, central U. S.

1444. OPERCULÍNA, S. Manso. Turpeth root. Convolvulaceae. Syn. Convolvulus, Ipomoea, in part. Herbaceous vin€s. About 10 species, tropical Asia and East Indies.

a. 0. Túrpethum (L.) Peter (I. Turpethum R. Br. (Kew), C. Turpethum, L.). India and East Indian islands. Root, Turpeth-root, Vegetable Turpeth ('Turbith), Indian Jalap; Fr. Turbith vegétal (Codex); purgative.

1445. OPHIOGLóssUM, L. Adder's-tongue. Oplioglossaceae. From Greek, "serpent's tongue", alluding to the fructification. Somewhat fleshy plants with a single sterile frond, the sporangia in a spike. Ábout 12 species; 8 in U. $\mathrm{S}$. (Other names are Adder's-spear, Adder's Fern, Adder's-grass, Edder's-tongue, Serpent's-tongue, Snake's-tongue.)

1446. OPHIORHÍzA, L. (Ophiorrhiza).

Rubiaceae.

From Greek, "snake-root". Syn. Mungos, Adans. Perennial herbs or shrubs. About 50 species, tropical Asia, Australia and Fiji Islands. (a) 0. múngos L. East Indies. Mungo, Indian Snakeroot, Earth-gall. Root bitter, reputed antidote to snake-poison.

1447. OPÓPANAX, Koch. Opopanax. Umbelliferae. Greek name of the exudate, "all-healing juice". Syn. Ferula, Pastinaca, in part. Perennial herbs. About three species, Europe and Asia.

a. 0. Opópanax (L.) Lyons (P. Opopanax L., O. Chironium Koch, not Guss., F. Opopanax L., not Spreng.). Southern Europe. Gum-resinous exudate, Opopanax, Hercules' All-heal; Fr. Opopanax (Codex); Sp. Opoponaso; resembles Ammoniac. See Dorema.

1448. OPULÁSTER, Medic. 1799. Nine-bark, etc. Rosaceae. From Greek, "star Opulus", the fruit being star-shaped. Syn. Phys ocarpa, Raf. 1836, also Spiræea and Neillia, in part. Shrubs with palmately lobed leaves and white flowers in corymbs. About 5 species, 1 of Mantchuria; 4 in U. S.

1449. OPÚNTIA, Mill. Opuntia, Prickly Pear, etc, Cactaceae. Ancient Greek name, from that of a town. Syn. Cactus, in part. Succulent thorny plants with jointed branching stems. About 150 species, New World; 52 in U. S.

a. 0. Opúntia (L.) Coult. (C. Opuntia L., O. vulgaris Mill.). Massachusetts to Florida and Mexico. Eastern Prickly Pear, Prickly-pear Cactus, Indian Fig*, Barbary Fig, Devil's-tongue, Hedgehog Thistle. Fleshy stems discutient. Fruit edible. 
b. 0. Túna (L.) Mill. (C. Tuna L.). West Indies and tropical America. Prickly Pear. (It is the fruit of this species more particularly that is known as Prickly Pear or Indian Fig; Ger. Indische Feige, Spanierfeige; Fr. Figue de Barbarie). Fruit esculent, yields a red dye. This species is more particularly the food plant of the cochineal insect, which also thrives, however, on Nopalea cochenillifer (q. v.) as also on (c) O. FicusIndica Mill. of Central America; (d) O. Hernandézii DC: of Mexico and less commonly on (a).

1450. 6́RCHIS, L. - Orchis. - Orchidaceae. Ancient Greek name. Terrestrial orchids, some highly ornamental. About 80 species, north temperate zone; 2 in U. S.

a. 0. latifólia L. Europe. Marsh Orchis. The branching tubers of this species, of (b) 0. maculáta L. and of (c) N. sambulcína L., constitute the variety of salep formerly known as Radix palmae-Christi. See Habenaria and Cunopsea.

d. 0. máscula L. Europe. Male Orchis, Adam-and-Eve, Bloodybutcher, Dead-men's-fingers (Shakespere), Crake-feet, Cuckoo Orchis, Drake's-feet, Gandergoose, (iethsemane, Red-granfergregors, Gramfer-greygles, Greycles, Kettle-case, Man-Orchis, Long-purples, Red-butcher, Skeatlegs, Soldier's-jacket, Spreespinkle, Standerwort. Tubers constitute the official Silep, Tubera Salep P. G., Radix salep; Fr. Salep (Codex); demulcent. nutrient. Salep (simple tubers) is obtained also from (e) 0. Mórı L., and (f) 0. ustuláta L. See also Anacamptis, Eulophia and Platanthera.

g. O. spectábilis L. Canada to Georgia, west to Nebraska. Showy Orchis; Gay, Purple or Spring Orchis, Preacher-in-thepulpit.

1451. OREÁSTRUM, Greene. Mountain Aster. Compositae. From Greek, "Mountain Aster". Syn. Aster, in part. Herbs resembling Aster. Three species in U. S.

1452. OREOBRÓMA, Howell. Oreobroma. Portulacaceae. From Greek, "mountain food". Syn. Calandrina, Lewisia, Talinum, in part. Herbs. Ten species in western U. S.

1453. OREOCÁ RYA, Greene. White Forget-me-not. Boraginaceae. From Greek, "mountain nut". Syn. Eritrichium, Krynitzkia, in part. Hairy herbs. About 16 species, all of U. S., mostly southern, extending into Mexico

1454. ORÉODAX, Willd.(Oreodoxa)RoyalPalm,etc. Sabalaceae. From Greek, "mountain glory", Syn. Areca, Oenocarpus, in part. Tall palms with smooth trunk. About 6 species, tropical America; 1 in Florida.

a. O. olerácea (Jacq.) Mart. (A. oleracea Jacq.). West Indies. Cabbage Palm. Bud (cabbage) esculent. Pithy wood yields Sago.

b. 0. régia H. B. K. (Oe. regius Spreng.). Tropical America to Florida. Royal Palm. The foregoing are among the most stately and ornamental of all palms. 


\section{5็. OREÓXIS, Raf. Oreoxis. Umbelliferae.} U. S. Syn. Cymopterus, in part. Herb. A single species, western

1456. ORÍGANUM, L. Marjoram, etc. Labiatae. From Greek, "mountain joy". Syn. Majorana, in part; Perennial herbs, some shrubby. About 30 species, Old World. $1 \mathrm{adv}$. in U. S.

a. 0. Créticum Sieber (?). Southern Europe. Spanish Hop: Ger. Spanischer Hopfen, Kretischer Dosten, Kandischer Mairan. $H \epsilon \cdot b$ of this and some allied species yields Cretan oil of Origanum or Spanish Hop oil, used to relieve tooth-ache.

b. O. Dictámmis L. Levant. Dittany of Crete; Ger. Kretischer Diptam, Diptamdosten; Fr. Dictame de Crète (Codex).

๔. O. Majorána L. (M. hortensis Moench). Southern Europe and western Asia, widely cult. Sweet Marjoram, Knotted Marjoram; Ger. Meiran, Mayran, Majoran, Wurstkraut; Fr. Marjolaine (Codex); Sp. Almoraduz, Mejorana. Herb, Herba majoranæ, H. amaraci, H. sampsuchi; stomachic, carminative, used as a condiment.

d. 0. vulgáre L. Europe, nat. in U.S. Common or Wild Marjoram (Marjerim, Margerome, Majoran; from ancient Greek name), Pot Marjoram, Winter Marjoram, Mountain Mint, Origanum (Argans, Organ, Organy, Orgament), Winter-sweet; Ger. Dosten, Brauner Dosten, Wilder Majoran, Gemeiner Wohlgemuth; Fr. Origan vulgaire (Codex). Herb source of oil of Origanum; carminative, anodyne, emmenagogue.

1457. ORMÓSIA, Jacks. Bread-tree. Papilionaceae. Trees. About 20 species, tropical regions, Old and New World. (a) 0 . dasyeárpa Jacks. West Indies. Jamaica Bread-tree, Necklace-tree, Large Coral-bean (Jamaica).

14n8. ORNITHÓGALUM, L. Star-of-Bethlehem. Liliaceae. From Greek, "bird milk". Scapose herbs from coated bulbs. About 75 species, Old World; 2 nat. in U. S.

a. O. umbellátum L. Mediterranean region, nat. in eastern U. S. Star-of-Bethlehem, Star-flower, Summer-snowflake, Eleven-o'clock-lady, Ten-o' clock, Sleepy-Dick, Nap-at-noon, John-go-tobed-at-noon. Bulbs of this and allied species, esculent, probably the "dove's dung" of Scripture.

1459. OROBÁNCHE, L. Broom-rape. Orobanchaceae. From Greek, "choke vetch". Syn. Aphyllon, in part. Parasitic, nearly leafless plants. About 90 species. Old World and western America; 8 in U. S. See Conopholis and Leptamnium.

a. 0. mínor Sutt. Europe, nat. in eastern U. S., parasitic on roots of clover. Lesser Broom-rape, Clover Broom-rape, Devil'sroot, Hell-root, Herb-bane, Shepherd's-pouch*, Strangle-tare. 
1460. OROCHAENíCTIS, Coville. Orochaenactis. Compositae. From Greek, "mountain Chaenactis". Syn. Chaenactis, in part. Viscid low annual. One species, California.

1461. OROGENíA, Wats. Orogenia. Umbelliferae. From Greek, "mountain born". Herbs, related to Erigenia. Two or three species, western U.S.

1462. ORÓNIA, Greene. Oso-berry. Drupacene. Syn. Nuttallia, Tor. \& Gr. Small tree, foliage yielding much hydrocyanic acid. One species, California.

1463. ORÓNTIUM, L. Golden-club. Araceae. Greek name of a water plant from the river "Orontes". Aquatic herb. A single species, eastern U. S.

a. 0. aquáticum L. Massachusetts to Lovisiana, mostly near the coast. Golden-club, Tawkin, Water Dock, Tuckahoe. Seeds and rhizomes formerly eaten by aborigines.

1464. ORÓPHACA, Britton. Milk Vetch. Papilionaceae. From Greek, "mountain Vetch". Syn. Phaca, Astragalus, in part. Canescent or villous herbs. Three known species, northwestern U. S.

1465. ORTHOCÁRPUS, Nutt. Orthocarpus. Scrophulariaceae. From Greek, "erect fruited". Herbs. About 30 species, New World; 27 in U. S.

1466. ORTHOSÍPHOx, Benth. Java Tea. Labiatae. From Greek, "straight tube". Herbs or undershrubs. About 30 species, India and tropical America. (a) 0. stamíneus Benth. East Indies. Java Tea. Leaves diuretic, demulcent.

1467. ORÝCTES, Wats. , Oryctes., Solanaceae. From Greek, "plowshare" or "furrow". Low annual. One species, Nevada.

1468. ORÝYA, L. - - Rice. - - Gramineae. The Greek name of (a). Coarse grasses. About 10 species, southern Asia.

a. 0. satíra T. (O. officinalis Wall., O. communissima Lour., O. paulstris Salisb.). Southern Asia, widely cult. in sub-tropical regions. Rice; Ger. Reis; Fr. Riz (Codex); Sp. Aroz. The unhusked rice is called paddy. One of the most important of all food plants; source of rice starch.

1469. OSBÉRTIA, Greene. Osbertia. Compositae. Herb. One species, western U. S.

1470. OSMÁxTHUS, Lour. Fragrant Olive, etc. Oleaceae. From Greek, "fragrant flower". Syn. Olea, in part. Shrubs or trees. About 10 species, N. America, western Asia and Polynesia; 1 in U. S. 
a. 0. Prágrans (Thunb.) Lour. (Olea fragrans Thunb.). China. Fragrant Olive. Flowers used to perfume tea. The American Olive of southeastern U. S., (b) 0. Americánus (L.) B. \& H. (Olea Americana L.), is called also Devil-wood, the wood hard to split.

1471. OSMÚNDA, L. Flowering Fern. Osmundaceae. Dedicated to Osmunder, a Scandinavian deity. Marsh ferns, fertile fronds or portions of frond greatly modified, justifying the popular name. About 6 species, north temperate zone; 3 in U. S.

a. 0. cinnamómea L. Canada and eastern U. S. Cinnamon Fern, Swamp Brake, Fiddle-heads, Bread-root.

b. 0. regális L. Europe, Asia, Canada, U. S. east of Rocky Mountains, Mexico. Royal Fern, Buckhorn Brake, Royal Brake, Royal Osmund, Regal Fern, King Fern, Flowering Fern, Royal Flowering Fern, Snake or Ditch Fern, Tree Fern*, Buckhorn Male-fern, Hartshorn bush, Lady Brake, Flowering Brake, Herb Christopher*, St. Christopher's herb, Bog Onion*, Osmund-the-waterman; Ger. Köniysfarrn, Traubenfarrn. Rhizome tonic, astringent, demulcent.

1472. ÓSTRYA, Scop. Hop-Hornbeam. Betulaceae. The classical name. Syn. Carpinus, in part. Trees with heavy hard wood. Four known species, N. temperate zone; 2 in U. S.

a. 0. Virginíana (Mill.) Willd. (C. Virginiana Mill., O. Virginica Willd.). Canada and eastern U. S. Hop-hornbeam, Ironwood, Deer-wood, Lever-wood, Hardhack*, Black Hazel, Indian Cedar. Bark bitter tonic.

1473. OUROUPÁRIA, Aubl. 1775. Gambir. Rubiaceae. Syn. Uncaria, Sichreb. 1789, Uncinaria, Reichb. 1841; Nauclea, in part. Shrubby climbers with hooked spines. About 35 species mostly of India, one of S. America.

a. 0. Gambier (Roxb.) Baill. (U.Gambier Roxb., N. Gambier Hunter). East Indies. An extract of the leaves and young shoots constitutes the tanning material gambir (gambier), called also terra japonica and pale catechu, Catechu pallidun, Catechu, Br. and P. G.; Ger. Gambir Catechu, Gutta Gambir: Fr. Gambir cubique; astringent. See Acacia Catechu. Gambir is prepared also from (b) 0. ácida (Roxb.) Lyons (U. acida Roxb.) of Pulo Penang and neighboring islands.

1474. OWÉNLA, F. Muell. Plum*, Wild Apple. Meliaceae. Named for Richard Owen, naturalist. Trees. About 6 species, Australia. (a) 0. cerasífera F. Muell. is called Sweet Plum, Rancooran; (b) 0. venósa F. Muell. is called Sour Plum, Pyddharr, Tulip-wood.

1475. OXÁLIS, L. Wood Sorrel.

Oxalidaceae.

"From Greek, "sour". Syu. Oxys, Adans. Herbs, often bulbous, with digitate (commonly trifoliate) leaves. About 250 species, chiefly of warmer regions; 20 in U. S., including some naturalized. 
a. 0. Acetosélia L. (Oxys Acetosella Scop.). Europe, Asia, northern Africa, N. America, south to N. Carolina and Michigan. Wood Sorrel, White or True Wood-sorrel, Wood-sour, Wood-sowert, Alleluia (Allolida, Lujula), Cuckoo-bread, Cuckoo-flower, Cuckoo's-meat, Cuckoo-sour, Cuckoo's or Gowk's Clover, Hearts, Ladies' Clover, Laverocks, Sour or Sleeping Clover, Sleeping-beauty, Sheep Sorrel, Sour Trefoil or Trifoly, Shamrock, Stubwort, Green-sauce; Ger. Sauerklee, Hasenkleє; Fr. Alléluia, Surelle, Pain de coucou; Sp. Acederilla, Socoyol. [Many of above synonyms apply equally to other species]. Plant, as in other species, acidulous, diuretic, antiscorbutic; contains oxalic acid, and so may be poisonous.

b. 0. strícta L. (O. corniculata var. stricta Sav., Oxys stricta All.). Canada aud Eastern U. S., nat. in Eurnpe. Ladies' Sorrel, Upright Yellow Wood-sorrel, Sheep Sorrel, Sheep-poison. (c) 0. corniculáta L., Procumbent Yellow Wood-sorrel, is not distinguished popularly from this species. The Index Kewensis includes both under the latter name.

1476. OXYCóCCUS, Hill. 1756. Cranberry. Vacciniaceae. From Greek, "sour berry", Syn. Schollera, Roth. not Schreb.; Vaccinium, in part. Trailing or erect shrubs. Four speoies, northern hemisphere; 3 in U. S.

a. 0. macrocárpus (Ait.) Pers. V. macrocarpor Ait., but Index Kew. makes this a synonym of (b), as also $O$. macrocarpus Turcz.). British America south to N. Carolina, Michigan and Minnesota. American Cranberry, Large Crauberry, Bearberry, with other synonyms of (b).

b. 0. Oxycóceus (L.) MacM. ( $\mathrm{r}$. Oxycoccus L., O. palustris Pers. (Kew), S. Oxycoccus Roth.). Northern Europe, Asia and N. America, south to New Jersey and Michigan. European or Small Cranberry, Cranberry, Cramberry, Crane's-berry, Marsh Cranberry, Crowberry, Marshberry, Moss-berry, Moor-berry, Bog-berry, Fen-berry, Sourberry, Sow-berry $\uparrow$, Swamp Redberry, Bogwort, Marshwort, Moonog, Moss-milion (i. e. Moss-melon); Ger. Moosbeere, Kesselbeere, Sauerbeere, Kranichbeere. Fruit, Fructus oxycoccos, Baccæ oxycocci, acidulous, refrigerant, esculent.

1477. OXYDÉNDRUM, DC.

Sour-wood.

Ericaceae. From Greek, "sour tree". Syn. Andromeda, in part. A tree with deciduous sour leaves. One species, eastern U.S.

a. 0. arbóreum (L.) DC. (A. arborea L.). Pennsylvania to Florida. Sourwood, Sorrel-tree, Elk-tree. Leaves refrigerant, diuretic.

1478. OXÝGRAPHIS, Bunge. Crowfoot*. Ranunculaceae. From Greek, "sharp style". Syn. Cyrtorhyncha, Ranunculus, in part. Perennial herbs resembling Ranunculus. About 10 species, mostly Ariatic; 1 in U. S., viz. (a) $\mathbf{0}$. Cymbalária (Pursh) Prantl. (R. Cymbalaria Pursh.).

1479. OXÝPOL1S, Raf. 1825. Pig Potato, etc. Umbelliferae. Syn. Tiedemannia, DC. 18\%9, Archemora, DC. 1829; Oenanthe, Peucedanum, Sium, in part. Perennial marsh herbs from tuberous roots. Four species, all of U. S. 
a. 0. filifórmis (Walt.) Brit. (Oe. filiformis Walt., Ox. teretifolia Raf.). Southeastern U. S. False Dropwort, Uxypolis\%.

b. 0. rígida (L.) Raf. (S. rigidum L., A. rigida DC., P. ternatum Nutt. (Kew), A. ternata Nutt.). Eastern U. S. Cowbane, Hemlock Dropwort, Water Dropwort, Pig Potato.

14S0. OXÝRIA, Hill. Mountain Sorrel. Polygonaceae. From Greek, "sour". Syn. Acetosa, Rumex, in part. Fleshy herbs with acid foliage. Two known species, north temperate zone; 1 in U. S.

a. 0. dígyna (L.) Hill (R. digynus L., A. digyna Mill., O. reniformis Hook.). Northern Europe, Asia and N. America, south to New Hampshire and Colorado. Mountain Sorrel, Round-leaved Sorrel, Sour Dock, Boreal Sour Dock.

1481. OXÝSTYLIS, Tor. \& Frem. Oxystylis. Capparidaceae. From Greek, "sharp style". Herb with small yellow flowers. A single species, California.

1482. OXYTÉxIA, Nutt. Oxytenia. Compositae. From Greek, "pointed", alluding to the leaves. Shrubby plant resembling Artemisia. One species, California to Colorado.

1483. OXYTHÉCA, Nutt. Oxytheca. Polygonaceae. From Greek, "pointed case". Annuals resernbling Eriogonum. About 10 species, $\mathrm{N}$. America; 8 in western U. S.

1484. OXY̌TRIA, Raf. $1836 . \quad$ Oxytria. Syn. Schœenolirion, Tor. 1855. Scapose herbs. About 3 species, southwestern U.S.

1485. PACHÍLOPHUS, Spach. Scapose Primrose. Onagraceae. From Greek, "thick crest". Syn. Oenothera (Kew), in part. Scapose herb with white or pink flowers. One species, central U.S.

1486. PACHYSÁNIRA, Michx. Pachysandra. Buxaceae. From Greek, "thick stamen". Monœecious perennial herbs. Two species, one of Japan, one of southeastern U. S.; (a) P. procúmbens Michx. Alleghany Mountain Spurge.

1487. PACHÝS'TIMA, Raf. (Pachystima). Celastraceae. Syn. Oreophila, Nutt. Evergreen shrubs. Two species, both of U. S.

1488. PAEÓNIA, L. - Peony. - Ranunculaceae. The ancient Greek name, from Pron, the physician of the gods. Herbs, some shrubby. Abont 10 species, north temperate zone; 1 in $\mathrm{U}$. S.

a. P. Moútan Simson. Japan and China. Tree Prony, Botan (Japan), Moutan (China-meu-tang, King of flowers), 
b. P. officinális L. Southern Europe, cult. in gardens. Peony (Piany, Pianet, Piney), Chessest, Naupie, Sheep-shearing Rose; Ger. Gichtrose, Pfingstrose; Fr. Pivoine officinale (Codex); Sp. Peonia. Root antispasmodic. The Chinese Peony of gardens (White or Fragrant Peony) is (c) P. albiflóra Pall.

1489. PALAFóxiA, Lag. Palafoxia. Compositae. Named for Jose Palafox, noted Spanish general. Herbs, some shrubby, with purple or white flowers. About 4 species, N. America; 2 in southwestern U. S.

1490. PALÁQUIUM, Blanco 1837.Gutta-percha tree.Sapotaceae. Syn. Dichopsis, Thw. 1864; Isonandra, in part. Trees with milky sap. About 30 species, East Indies.

a. P. Gútta (Hook f.) Burck. (I. Gutta Hook. f., D. Gutta B. \& H.). East Indies. Taban or Gutta-taban tree. Concrete exudate, Gutta percha, Gummi plasticum, Gummi gettania; Ger. Fr. Gutta-percha (Codex); used for splints, etc.

1491. PALIÚRUS, Juss. Christ's Thorn. Rhamnaceae. The ancient Greek name. Syn. Zizyphus, in part. Thorny shrubs. Two species, Mediterranean region and Asia.

a. P. aculeátus Lamb. (P. Spina-Christi Mill., P. vulgaris Steud., Z. Spina-Christi Georgi, Z. Paliurus Willd.). Southern Europe to India. Christ's Thorn, Christ-thorn; Fr. Portechapeau. Seeds yield a dye. Perhaps the plant from which the "crown of thorns" was plaited.

1492. PALMERÉLLA, Gray. Palmerella. Lobeliaceae. Named for the discoverer, Dr. Edward Palmer. Herbs. Two species, southwestern U. S.

1493. PÁNAX, L.( Panacea). Ginseng. Araliaceae. Ancient Greek plant-name, "all healing". Syn. Aralia, Ginseng, in part. Perennial herbs from thickened roots. About 10 species, North America and Asia; 2 in U. S.

a. P. Gínseng Nees. [A. Ginseng Dec. \& Planch. (Kew).] China, Chinese or Genuine Ginseng (Jin-tian or Jin-Shen), Asiatic Ginseng, Schinseng; Ger. Chinesische Kraftwurzel. Root aromatic, esteemed by the Chinese almost a panacea, especially as an aphrodisiac.

b. P. quinquefólius L. (G. quinquefolium Wond, A. quinquefolia Dec. \& Planch. (Kew), P. Ginseng C. A. Meyer, not Nees., P. Ninsi Thunb. not L.). Quebec to Alabama, west to Nebraska. Ginseng, American Ginseng, Jinshang (U. S.), Ninsin*, Sang, Red-berry, Five-fingers, Garentoquen (Iroquois), Grantogen; Ger. Amerikanische Kraftwurzel, Schinseng, Fr. Ginseng. Root aromatic, stimulant.

c. P. trifólius L. (A. trifolia Dec. \& Planch. (Kew), G. trifolium Wood.). Canada and eastern U.S. Dwarf Ginseng, Dwarf Ground-nut.

1494. PANCRÁTIUM, L. Sea Daffodil, etc. Amaryllidaceae. From Greek, all powerful". Bulbous herbs. About 12 species, Mediterranean region. 
a. P. marítimum L. Europe. Pancratic Squill, Sea Daffodil. Bulb diuretic, emetic, expectorant.

1495. PáNID NUS, Rumph. 1781. Screw Pine. Pandanaceae. Syn. Keura, Forsk. 1775, Athrodactylis, Forst. 1776. Shruhby or arboreous plants. About 50 species, tropical regions of eastern hemisphere and Oceanica.

a. P. odorífera (Forsk.) Lyons ( K. odorifera, Forsk. 1775, K. odora Thunb. P. odoratissima L. f., 1781 (Kew), P. verus Rumph., P. fascicularis Lam., A. spinosa Furst.). India, Australia and Oceanica. Fragrant-flowered Screw-pine or Pandanus, Screw Pine, Umbrella-tree*, Hala (Pacitic islands). Flowers yield Keora or Ketgee oil. Fruit, called breadfruit*, edible, the chief food of natives of some of the Micronesian islands. Leaves (Lauhala) uned for plaiting mats, fans, sugarsacks, etc., as are those of (b) P. útilis Bory. in the Mauritius Islands.

1496. PÁNICUM, L. Panic-grass, etc. Gramineae. Ancient Latin name of a grass, probably Sorghum. Annual or perennial grasses. About 300 species; about 100 in U. S.

a. P. miláceum L. (P. Miliare Lam.). Asia, now widely cult. Millet, Broom-corn Millet, Hirse, Warree (Hindustan). (b) P. frumentáceum Roxb., the Shamalo or Shamoola of India, also yields a kind of millet.

1497. PAPÁVER, L. - Poppy. - Papaveraceae. The classical name. Herbs with milky sap; Howers showy. About 25 species, mostly of Old World; 10 indigenous and nat. in U. S.

a. P. Argemóne L. (P. clavigerum Lam.). Europe, adv. in U. S. Pale Rough-fruited Poppy, Long Rough-fruited Poppy, Wind Rose, Headache.

b. P. dúbium L. Europe, adv. in U. S. Long Smooth-fruited Poppy, Blaver, Headache.

c. P. Rhoéas L. Europe, cult. and adv. in U. S. Corn Poppy (Puppy, Popple, Pope), Field or Red Poppy, Corn Rose, Copper Rose (Cuprose), Cockeno, Canker, (anker Rose, African Rose, Blind-eyes, Cheesehowl,Chasbow $\neq$, Headache, Headwark $\neq$, Thunder-Hower; Ger. Klatschrose, Klapperrose, Feldrose: Fr. Coquelicot (Codex), Pavot rouge; Sp. Ampola. Petals, Redpoppy petals, Rhoeados Petala, Br., Flores rhœados, Fl. papaveris erratici; anodyne.

d. P. somníferum L. (P. officinale C. C. Gmel., P. album Mill.). Mediterranean region, cult: in India and commnnly in gardens. Opium Poppy, Cheesebowl (Chashow), Pushpole, Joan Silverpin, Marble-flower, Ger. Mohn; Fr. Pavot blanc, Pavot officinal (Codex). Capsules ' of the white variety, B. somniferum var. album DC., P. officinale Gmel.); Papaveris Capsulae, Br., Fructus Papaveris immaturi P. G., Papaver. U. S. P., 1870, 
Codia; mildly narcotic. Seeds, Maw-seed, yield Poppy oil. Concrete exudation from unripe capsules, Opium. U. S. P., Mecnnium, Succus thebaicus; narcotic, anodyne, soporific. Source of Morphine, Codeine and other alkaloids.

1498. PARAMÉRIA, Benth. Parameria. Apocynaceae. Shrubby climbers. About 5 species, East Indies. (a) P. vulnerária Radlk., Philippine Islands, is the source of Cebu balsam.

1499. PARIETÁRIA, L.

Pellitory.

Urticaceae. The ancient Latin name, whence the English word Pellitory. Herbs. About 7 species; 3 in U. S.

a. P. officinális L. Europe. Wall Pellitory, Wall Paritory $\ddagger$, Pellitory-of-the-wall, Wallwort, Lichwort; Ger. Glaskraut; Fr. Pariétaire (Codex). Perce-muraille; Sp. Parietaria. Herb astringent, diuretic, lithontriptic. (b) P. Pennsylvánica Muhl., American Pellitory, is called also Hammerwort and Helxine.

1500. PARINáRIUM, Aubl. Gingerbread-tree. Rosaceae. Syn. Parinari, Nonda. Trees, some having edible fruits. About 40 species, tropical regions. (a.) P. macrophyllum Sabine. West Africa. Gingerbread Plum. (b.) P. Nónda F. Muell. Australia. Nonda tree. Fruit edible. Gingerbread-tree.

1501. PáRIS, L. Herb Paris. Convallariaceae. From Latin par "equal", all parts of the plant being in fours. Herbs with the leaves in a single whorl. About 6 species, Europe and Asia.

a. P. quadrifólia L. Europe. Herb-Paris, Herb of Paris, Herbtruelove, Devil-in-a-bush, Fox-grape*, Leopard's-bane*, Fourleaved-grass, One-berry; Ger. Einbeere; Fr. Parisette. Plant reputed narcotic.

1502. PARISHÉLLA, Gray. · Parishella. Lobeliaceae. Herb. One species in California.

1503. PÁkKIA, R. Br. African Locust. Mimosaceae. Trees. About 25 species, tropical regions of Old and $\mathrm{New}$ World.

a. P. biglandulósa W. \& A. Africa, originally from India. African Locust, Nitta or Nutta tree, Doura (of Soudan), Soudan Coffee. Seeds and saccharine pulp surrounding them, esculent; a substitute for coffee.

1504. PaRKinsóxia, L. Horse-Bean, etc. Caesalpinaceae. Named for John Parkinson, herbalist to James I. Trees. Abont 7 species, tropical America, 1 of Africa; 1 in U. S. (a) P. aculeáta L. West Indies, Mexico and southern U. S. Retama, Horse-bean, Jerusalem Thorn (Jamaica). Bark febrifuge. 
1505. PARNíSSIA, L. Grass of Parnassus. Saxifragaceae. The ancient Greek name, plant of "Parnassus". Scapose herbs with white or yellowish flowers. A bout 12 species, north temperate and arctic zones; 8 in U. S. Synonyms are White Buttercup, White Liverwort.

1506. PARONÝCHId, Adans. Whitlowwort. Caryophyllaceae. Greek plant name, "whitlow plant". Syn. Anychia, in part. Tufted perennials. About 40 species; 15 in U. S. Synonyms are Nailwort and Knot-grass*.

a. P. argyrócoma (Michx.) Nutt. (A. argyrocoma Michx.). Maine to Georgia. Silver Whitlowwort, Silver Chickweed, Silver-head.

1507. PAROSÉlA, Cav. 1802. Parosela. Papilionaceae. Anagram of Psoralea. Syn. Dalea, Willd. 1803, not P. Br., 1756. Herbs or shrubs with small purple, white or yellow flowers in spikes. About 110 species, New World; 46 in U. S.

1508. PARRÁsIA, Greene. Parrasia. Cruciferae. Syn. Greggia, Gray 1852, not Engelm. 1848. Sub-shrubs. Two species, southwestern U. S.

1509. PÁRRYA, R. Br. Parrya. Cruciferae. Low alpine herbs from thick perennial rootstocks. About 15 species, northern hemisphere; 4 in U. S.

1510. PARRYÉLLA, Tor. \& Grr. Parryella. Papilionaceae. One species in U. S.

1511. PA RSÓNSlA, P. Br. 1756, (not of R.Br.1S09).Lythraceae. Named for Dr. James Parsons, Scotch botanist. Syn., Cuphea, P. Br. 1756, also Lythrum, in part. Herbs or shrubs. About 180 species, New World; 5 in U.S.

a. P. petioláta (L.) Rusby (L. petiolatum L., C. viscosissima Jacq.). Rhode Island to Georgia, west to Kansas. Blue Wax-weed, Clawmy Cuphea, Tar-weed, Wax-bush, Wax-weed.

1512. PARTHÉxice, Gray. Parthenice. Compositae. Cinereous annual. One species, Colorado and Arizona.

1513. PaRThéNiUM, L. Feverfew, etc. Compositae. Greek plant name, "maidenly" or "pure". Syn. Hysterophorus, Adans. Perennial herbs or shrubs. About 10 species, New World.

a. P. Hysteróphorus L. (P. pinnatifidum Stokes). West Indies to southeastern U. S. Bastard Feverfew, Indian Mugwort, Wild Wormwood, White-head (W. Indies), Brown-bush. Plant tonic, febrifuge, emmenagogue.

b. P. integrifólium L. (P. amplectens Raf.). Maryland to Georgia, west to Texas and Minnesota. American Feverfew, Prairie Dock*, Cutting Almond, Nephritic plant, Wild Quinine. Plant bitter, diuretic, febrifuge. 
1514. PARTHENOCÍSSUS, Planch. 1887.

Vitaceae.

From Greek, "virgin's Cissus". Syn. Quinaria, Raf. 1830, not Lour. 1790; Ampelopsis, Cissus, Hederat, Vitis (Kew), in part. Climbing or trailing woody rines. About 10 species, Asia; one in N. America.

a. P. quinquefólia (L.) Planch, (H. quinquefolia L., V. hederacea Willd. (Kew), A. quinquefolia Michx., C. quinquefolia Pers.). Canada, eastern U. S. and Mexico, also in Cuba. Virginia Creeper, American Ivy, American-joy, False Grape, Five-finger, Five-leaved Ivy, Five-fingered Ivy, American Woodbine, Woodbine*, Wild Woodbine, Wild Wood-vine, Woody Climber; Ger. Wilder Wein, Amerikanischer Epheu; Fr. Vigne vierge. Bark and twigs alterative, tonic, expectorant, diuretic.

b. P. tricuspidáta (Sieb. \& Zucc.) Planch. (A. tricuspidata S. \& Z., V. inconstans Miq. (Kew), A. Veitchii of gardeners). Japan, widely cult. as an ornamental vine, Japanese Ivy.

1515. PASSIFLÓRA, L. Passion-flower. Passifloraceae. Latin, "flower" of our Savior's "passion". Herbaceous or woody climbers. About 250 species, tropical regions mostly of the New World; 9 in U. S.

a. P. foétida L. Southeastern U. S., West Indies, etc. West Indian Love-in-a-mist, Wild Water-lemon. Plant expectorant, antispasmodic.

b. P. híspida DC. (P. Marigouja Per.). Jamaica. Bull-hoof, Dutchman's-laudanum. Flowers narcotic.

c. P. incarnáta L. Southeastern U. S. Wild Passion-flower or Passion-vine. Plant antispasmodic. Extract of root used in treatment of ulcers, hemorrhoids, etc. Fruit edible, called May-pops. Similar medicinal properties belong to the Yellow Passion-flower, (d) P. lítea L., of southeastern U. S.

e. P. laurifólia L. (P. tinifolia Juss.). West Indies to Brazil. Water Lemon, Jamaica Honeysuckle, Bay-leaved Passion-flower. Fruit edible. Leaves astringent, anthelmintic.

f. P. quadranguláris L. Brazil, cult. in all tropical countries. Granadilla (Diminutive of Granada, Spanish name of Pomegranate), Grenadilla. Fruit (i. e. pulp surrounding the seeds) esculent. Root narcotic. Many other species yield similar edible fruits, commonly known as granadilla, or in some cases, as water-lemon. The most notable are (g) P. édulis Sims, Brazil; (h) P. liguláris Juss., Mexico to Bolivia, of delicious flavor; (i) P. macrocárpa Masters, Brazil to Peru; fruit reaching eight pounds in weight; (j) P. malifórmis L., West Indies to Brazil, Sweet Calabash, Sweet Water-lemon, Culupa, Curubał.

1516. PaStiNáCA, L. Parsnip. Umbelliferae. Latin name of Parsnip or Carrot, from pastus, "food". Syn. Peucedanum, in part. Herbs with fleshy roots and yellow flowers. About 7 species, Europe and Asia. 
a. P. satíva L. (Peucedanum sativum S. Benth.). Europe and Asia, everywhere cult., nat. in U. S. Parsnep (Parsnip, Parsenep, Pastnip, Pasnet); The wild plant is known as Mad-nep, Mypes, Tank, Hart's-eye, Queen-weed. Root esculent. Seeds diuretic.

1517. PATRÍNIA, Juss. Patrinia. Valerianacene. Named for M. Patrini, French botanist. Herbs with corymbed yellow flowers. About 8 species, Asia. (a) P. scabiosaefólia Link. Japan. Kesso. Root antispasmodic.

1518. PAULLÍNIA, L. Guarana, etc. Sapindaceae. Named for C. F. Paullini, German botanist, d. 1712. Shrubby twining plants. About 125 species, mostly of tropical America, one African.

a. P. Cupána Kunth (P. sorbilis "Mart.). Brazil. Crushed seeds moulded into cylindrical masses and dried constitute Guarana, U. S. P., Brazilian Cocoa; Pasta guarana, Pasta seminum panlliniæ; very rich in caffeine, used as a beverage and as a nerve stimulant.

1519. PAULóWNIA, Sieb. \& Zucc. : Scrophulariaceae. Named for Anna Paulowna, daughter of the Czar, Paul I. Syn. Bignoniat, in part. A large tree resembling Catalpa. One species, Japan, nat. in southeastern U. S. Paulownia.

1520. PaVónIa, Cav.

Pavonia.

Malvaceae. Named for Don Josef Pavon, botanical traveler in Peru. Herbs or small shrubs. About 70 species, warmer regions of America, a few in Asia; 4 in U. S.

1521. PÉCTIS, L. - Pectis. - Compositae. From Latin pecten, "comb", alluding to the pappus. Sirongscented herbs with small flower heads (yellow). About 50 species, warmer regions of New World, 12 in U. S.

1522. PECTOCÁRYA, DC. 1840. Pectocarya. Boraginaceae. From Greek, "comb nut". Syn. Ktenospermum, Lehm. 1837. Low annuals with minute white flowers. About 6 species, $\mathrm{New}$ World; 4 in U. S.

1523. PEDICULÁRIS, L. Lousewort. Scrophulariaceae. Latin, "lousewort", the plants formerly believed to breed lice in sheep. Herbs. About 125 species, mostly of northern hemisphere; 33 in U. S.; Ger. Läusekraut; Fr. Pediculaire.

a. P. Canadéusis L. Canada to Florida, west to Colorado and south into Mexico. Wood Betony, Lousewort, High Heal-all, Beefsteak plant, Head Betony, Snaffles, Lousewort Foxglove

b. P. palústris L. Europe, Asia and northern N. America. Redrattle, Cow's-wort, Marsh Lousewort. Similar to this species, but with smaller flowers, is (c) P. parvifióra J. E. Smith of Oregon and British America.

1524. PEDILÁNTHUS, Neck. Slipper Plant. Euphorbiaceae. From Greek, "sandal flower". Shrubs. About 15 species, tropical America. 
a. P. tithymaló́des Poit. West Indies and S. America. Jewbush, Slipper-plant, Slipper Spurge. Plant emetic, antisyphilitic.

1525. PÉGANUM, L. Zeganum. Źgophyllareae. The Greek name of Rue, "solid", alluding to the fleshy leaves. Odorous berbs. About 5 species, warmer regions of New and Uld World; 1 in U. S.

1526. PELARGóNIUM, L'Her. Geranium. Geraniaceae. From (ireek, "sıork plant", the beaked capsules resembling a stork's bill. Herbs or shrubs with umbellate Howers. About 400 species, Old World, mostly African.

a. P. odoratíssimm Ait. South Africa. Nutmeg-scented Pelargonium or (ieranium. Leuvts yield a fragrant volatile oil of ten substituted tor oil of rose. From (b) P. rádula (Cav.) Ait., Rough Rose Geranium, and (c) P. capitátım (L. ) Ait., Rosescenied P'elargonium or Geranium, similar oils are obtained, known as oil of Rose Geranium or oil of Pelargonım. See Andropogon.

d. P. tríste Ait. S. Africa. Night-scented Pelargonium. Tubers edible. Anıong the numerous ،ulcivated Pelargoniums may be especially noted (e) P.grandıflórum IVilld., the large-flowered Lady Washingion Gerauium, (f) P. peltatum Ait., Ivy-leaved Geranium and (g) P. zonále L'Her., the Common Horseshoe Geranium.

1527. PELLAÉ, Link. Cliff-Brake. Polypodiaceae. From Gireek, "dark", alluding to the stipes. Syn. Pteris, in part. Rock-loving ferns. About 55 speries; 15 in U. S. (a) P. atropurpúrea (L.) Link. (I'ter. atropurpurea L.). British America, south to Georgia and Arizona. Purple-stemmed Cliff-brake, Clayton's Cliff-brake, Indıan's-dream.

1529. PELTÁNDRA, Raf. Arrow-Arum. Araceae. From Greek, "shield stamen". Syn. Calla, Arum, Xanthosoma, in part. Bog herbs with arrow-shaped leaves. Two species, both of eastern U.S.

a P. sagittaefólia (Michx.) Morong (C. sagittaefolia Michx., P. alba Kaf., X. sagiı taefolia (hapm., not Sichott. ). Virginia to Hlorida. White Arrow-arum, Arrow-leaved Spoon-flower.

b. P. Virgínica (L.) Kunth (A. Virginicum L.). Arrow Arum, Green Arrow-arum, Virginia Wake-robin, Tuckahoe*. Rhi zomes acrid, abounding in starch, formerly used as food by the Indians.

1529. PELTIPHÝLLCM, Engelm. From Greek, "shield leaf". One species in U. S.

1530. PENAÉA, L Penæa. Penaeaceae. Named for Pierre Pena, French botanist, 16th Century. Undershrubs. About 20 species, Africa. 
я. P. Pucáta L. (P. furcata Mur., P. fuscata Auct., not Poir., P. Sarcocalla L.) and (b) P. mucronáta L. of central and souther'n Africa, are the reputed although improbable source of the exudate, Sarcocolla, Sarcocol, Anzeroot (Arabia), Gujara (Hindustau); Ger. Fleischleingummi, Fischleimgunmi; Fr. Sarcocolle; reputed detergent, discutient, depilatory.

1531. PExisétuM, Pers. Egyptian Millet. Gramincue. From Latin, "feather bristle". Syn. Panicum, Penicillaria, in part. About 40 species, warmer regions.

a. P. thyphoídeum Rich. (Pan. ceruleum Mill., Penic. spicata Willd.). Egypt to India, cult. in southem U.S. Egyptian or East Indian Millet, Cat-tail or Pearl Millet, Bajree (India), Egyptian Wheat. One of the principal cereals of India. In China (b) P. cereále Trin. is cultivated likewise.

1532. PEXTACAENA, Bartling. Pentacena. Caryophyllaceae. From Greek, "Five thorus". 'Tufted perennials with pungent subulate leares. About 4 species, New World; 1 in southwestern U.S.

1533. PENTACHÁ́TA, Nutt. Pentachaeta. Compositac. From Greek, "Five awned". Low vernal amuals. About 6 species, southwestern U. S.

1534. PÉNTHORUM, I. Ditch Stonecrop. Crassulaceae. From Greek, "fire" and "rule", the parts of the flower being all in fives. Peremial herbs with flowers in secund cymes. Three known species, Asia and $\mathrm{N}$. America; 1 in U.S.

a. P. sedoídes L. Canada and eastern U. S. Virginia Stonecrop, Ditch Stonecrop. Herb astringent.

153ว. PÉNTODON, Hochst. Pentodon. Rubiaceae. From Greek, "five toothed". Syn. Oldenlandia, in part. Tender annuals. Two species, one in Africa, one in southeastern U. S. to C'uba.

1536. PENTSTÉMON, Soland. Beard-tongue. Seropluulariaceac. From Greek, "five stamens", the flowers having a fifth rudimentary stamen. Syn. Penstemon, Pentastemon. Perennial herbs with showy flowers. About 110 species, North America; 107 in U. S., mostly southwestern.

1537. PEPERóMIA, Ruiz. \& Pav. Peperomia. Piperaceae. From Greek, "pepper like". Fleshy herbs, some shrubby. About 400 species, warmer regions especially of New World; 2 in U. S.

1538. PERÁMIUM, Salisb. 1812. Goodyera. Orchidncene. Syn. Goodyera (Kew), R. Br. 1813, also Satyrium and Neottia, in part. Herbs with tufted basal leaves, the inconspicuous flowers in bracted spikes. About 25 species; 3 in U. S.

a. P. pubéscens (Willd.) MacM. (N. pubescens Willd., G. pubescens R. Br.). Canada and eastern (T. S. Downy Rattlesnake Plantain, Net-leaf Plantain, Spotted Plantain, Rattlesnakeweed, Networt, Adder's Violet*, Ratsbane, Scrofula-weed. 
Plant reputed alterative. The smaller (b) P. répens (L.) Salisb. (S. repens $\mathrm{L}_{\text {., }}$ G. repens $\mathrm{R}$. Br.), Creeping or Leswer Rattlesnake Plantain, is called also White Ilantain, Smaller Net-leaf Plantain and Squirrel-ear.

1539. PERAPHÝLLUM, Nutt. Peraphyllum. Pomaceae. Shrubs, allied to Amelanchier. One species, central U. S.

1540. PER ÉSKIA, L., not Vell. 1825. Bleo, ete. Cactaceae. Syn. Pierescia, Peireskia. Leafy as well as thorny shrubs. About 15 species, tropical America.

a. P. aculeáta Mill. West Indies. Barbados or West Indian Gooseberry, Gooseberry shrub. Fruit edible. In New Granada the leaves of the Bleo, (b) P. Bléo DC., are used for salad.

1541. PERÉZIA, Lag. Perezia. Compositae. Syn. Dumerelia, Less., not Lag.; 'Trixis, in part. Herbs or sub-shrubs. About 50 species, warmer regions of America; 5 in $\mathrm{U}$. S.

a. P. adnáta Gray ('T. Pipitzahoac Schaffner., D. Alamani DC.). Central Mexico. Rhizome laxative. From this and other species is obtained pipitzahoic acid, called vegetable gold, which has purgative properties.

1542. PERICÓME, Gray Pericome. Compositae. From Greek, "hair all around", referring to the akenes. A strong-scented herb with yellow flowers. Arizona to $\mathrm{New}$ Mexico. A second species is found in Mexico.

1543. PERÍLLA, I. Perilla. Labiatae. From vernacular, Hindustan. Syn. Ocimum, in part. Annual herbs with colored leaves. Two species, natives of Asia.

a. P. Prutéscens (L.) Brit. (O. frutescens L. 1753, P. ocimoides L. 1764). India, cult. in gardens and adv. in U. S. Perilla. A variety with crisped leaves, P. frutescens Nankinensis (Lour.) Brit., is called Beefsteak plant.

1544. PERÍPLOCA, L. Climbing Dogsbane. Asclepiadaceae. From Greek, "twining". Twining vines. About 12 species, warmer regions of Old World. (a) P. Graéca L. Southern Europe. Milk-vine, Silk-vine, Climbing Dog's-bane. Plant used as a wolf poison.

1545. PERÍTYLE. Benth. Perityle. Compositae. From Greek, "callous all around", of the akenes. Herbs with rather small flower-heads, white or yellow. About 12 species, Mexican border of U. S.

1546. P'́́RSEA, Gaertn. Avocado, etc. Lauraceae. Greek name of some fruit-bearing tree. Syn. Laurus, Notaphœbe, in part. Trees or shrubs. About 50 species, New World; 3 in U. S.

a. P. Borbónia (L.) Spreng. (D. Borbonia L., P. Carolinensis Nees (Kew), L. Carolinensis Michx., L. Caroliniana Poir., N. Borbonia P'ax.). Southeastern U. S. Red Bay, White Bay, Isabella-wood, False Mahogany, Tiss-wood. (b) P. pubéscens (Pursh) Sarg. of southeastem U. S. is called Swamp Bay. 
c. P. Pérsea (L. ) Cockerell (L. Persea L., P. gratissima Gaertn., L, Indica Sieb., not L.). Mexico to Brazil and Peru, cult. in all tropical countries. Avocado Pear, Avocado (Avicato, Avigato, A vocat, corrupted from A huaca or Aquacata, vernacular names), Alligator $\ddagger$ Pear, Holy-ghost Pear; Fr. Avocatier. Fruit Vegetable butter, Midshipman's butter, Vegetable marrow*; esculent. Seeds anthelmintic, anodyne.

1547. PETALÓNYX, Gray. Petalonyx. Loasaceae. Herbs. Two species, Mexican border of U. S.

1548. PETASÍTES, Gaertn. Sweet Coltsfoot, etc. Compositae. Ancient Greek plant name, meaning a 'hat', from resemblance of the leaves. Syn. Tussilago, Nardosmia, in part. Scapose herbs from thick rootstocks. About 12 species, north temperate zone and north ward; 4 in U. S.

a. P. Petasites (L.) Karst. (T. Petasites L., P. officinalis Moench, P. vulgaris Desf.). Europe and northern Asia, adv, in U. S. Butter-bur, Butterfly Dock, Butter Dock, Kettle Dock, Batter Dock, Flea Dock, Bog Rhubarb, Poison Rhubarb, Pestilenceweed, Pestilencewort, Umbrella-leaf, Cleat, EIdin, Gallon, Oxwort. Root anthelmintic. Flowers diaphoretic.

1549. PETÉRIA, Gray. Peteria. Papilionaceae. Shrubs with pinnate leaves. Two species, Mexican border of U.S.

1550. PETIVÉRIA, L. Guinea-hen weed. Phytolaceaceae. Named for J. Petiver F. R. S., London apothecary, d. 1718. Undershrubs having a garlic-like odor. About 5 species, warmer regions of America; 1 in U. S.

a. P. alliácea L. Southeastern U. S., West Indies to Brazil. Guinea-hen weed (Jumaica), Strong-man's weed. Plant acrid, used as a counter-irritant for relief of toothache, etc.

1551. PETRA DóRIa, Greene. Petradoria. Compositae. Syn. Solidago, in part. Herb. One species, western U. S.

1552. PETROSELÍNUM, Hoffm. Parsley. Umbelliferae. Ancient Greek plant name, "rock parsley", whence the English word parsley. Syn. Carum, Apium, in part. Herbs. About 3 species, Mediterranean region.

a. P. Petroselínum (L.) Lyons (A. Petroselinum L., C. Petroselinum Benth. (Kew), P, sativum Hoffm. ). Southern Europe to Asia Minor, and widely cult. Passley (Perceley, Persel, Parsil, Parcel), Apyum, March, Garden or Common Parsley, Rock Parsley; (ier. Petersilie, Petersilge; Fr. Persil; Sp. Pel egil. Fruit, Fructus petroselini, Fruct. (Semen) apii hortensis; source of apiol, an efficient emmenagogue. Root diuretic.

1553. PETUNIA, Juss. Petunia. Solanaceae. From petun, a Brazilian name of "tobacco". Viscid pubescent herbs. About 12 species, South America. Two species are commonly cult. in gardens, (a) 1'. axilláris ( $\mathrm{Lam}$.) B. S. P. $[P$, nyctaginitlora Juss. (Kew) $]$. White Petunia, and (b) P. violácea Lindl., Purple (or otten Variegated) Petunia. 
1554. PEUCÉDANUM, L. Hog-Fennel, etc. Umbelliferae. The Greek name of an Umbelliferous plant. Syn. Athamanta, Ferula, Oreoselinum, Selinum, smyrnium, Thysselinum, in part. Perennial herbs, nearly acaulencent, from tuberous roots. About 125 species; 55 in U. S. See Anethum, Imperatoria and Selinum.

a. P. ambígum Nutt, Montana to Washington. Cowish. Tuber 8 used for food by Indians.

b. P. officinále L. Europe. Hog-fennel, Sow-fennel, Brimstonewort, Sulphurwort, Sulphur-ront, Sulphur-weed, Horestrang, Horestrong, Hairstrong, Spreusidanył; Ger. Haarstrangkraut, Schwefelwurz. Root and juice diuretic, antispasmodic, expectorant.

c. P. Oreoselínum (L.) Moench (A. Oreoselinum L.,O. legitimum Bieb., (). nigrum Delarb.). Europe. Mountain Parsley, Speedwell, Fluellin; Ger. Bergpetersilie. Seed and root aromatic, aperient, deobstruent.

d. P. palústre (L.) Michx. (Sel. palustre L., T. palustre Hoffin.). Europe. Marsh Par-ley, Marsh Smallage, Swamp Sow-fennel or Hug-fennel, Swamp Hairstrong; Grr. Sumpfsilge, Elsenich; Fr. Sélin des marais, Persil des marais: Root, Rad, olsnitii, pungent, acrid, formerly used in epilepsy.

1555. PEUCEPHÝLLUM, Gray. Peucephyllum. Compositae. From Greek, "Five-l-aved". Syn. Psathyrotes, in part. Balsamic shrub. One species, Arizona to Calıfornia.

\section{PEUMUS, see BOLDU.}

1556. PHÁCA, L, :Milk Vetch*.

Papilionacene.

Ancient Greek name of Lentil. Syn. Astragalus (Kew), in part. Perennial herbs with inflated pods. About 250 species, north temperate zone; 3 in U.S. (Heller). (a) P. longifólia (Pursh) Nutt. (A. pictus var. tilifolius A. Gray) is called Bird-egg Pea.

1557. PHACÉLIA, Juss. Phacelia. Hydrophyllaceae.

From Greek, "fascicle", descriptive of inflorescence in some species. Syn. Eutoca, in part. Mostly annual herbs. About 100 species, New World; 90 in U. S.

1558. PHALACRósERIS, Gray. Phalacroseris. Cichoriacene. From Greek, "balı-headed Endive". Acaulescent perennial. One species, California.

1559. PHÁLARIS, L." Canary grass, etc. Gramineae. Greek name of a kind of grass, "shining". Robust grasses. About 10 species; 5 in U. S.

a. P. arundinácea L. Europe, Asia and N. America. Reed Canary-grass, Daggers. Variety pieta, with variegated leaves, is called Ribbon-grass, Painted-grass, Ladies'-laces, Bride's-laces, London-lace. 
b. P. Canariénsis L. Europe and Canary Islands, where it is called Alpist, Canary-grass. Seeds, Bird-seed, much used as food for cage birds.

1560. PHASÉoluS, L. (Phasellus). Bean. Papilionaceae. Ancient Greek name of a kind of Bean. Annual or perennial herbs, generally twining. About 70 species, warm and temperate climates; 10 in U. S.

The following are important food plants. (a) P. derásus Schranck, Brazil, Brazilian Bean; (b) P. lunátus L., Tropical America, now widely cult., Lima Bean, Carolina Bean, Sugar Bean, Butter Bean; (c) P. Máx L. (P. Mungo L. (Kew), P. radicatus L. ), South Asia and tropical Australia; Green Gram (highly esteemed in India); (d) P.nánus L. [P. vulgaris L. var. (Kew)], Dwarf Field-bean; varieties are Dwarf Bush, Pea, Navy and Six-weeks Bean; (e) P. vulgáris L., India, early imported into Europe and now widely cult., Kidney-bean, Haricot, French String or Pole Bean; Ger. Gartenbohne; Fr. Haricot; Sp. Frigol.

1561. PHEGóPteris, Fée. Beech Fern. Polypodiaceae. The Greek name, signifying "Beech fern". Syn. Polypodium, in part. Small or medium sized ferns. About 100 species; $b$ in U. S. The Common Beech Fern is (a) P. Phegópteris (L.) Underw. (P. polypodioides Fée). (b) P. Dryópteris (L.) Fée (Polypodium Dryopteris L.) is called Uak Fern or Pale Mountain Polypody.

1562. PHELLÓPTERUS, Benth.1867.Phellopterus.Umbelliferae. From Greek, "cork wing". Syn. Glehnia, F. Schmidt, 1867. Littoral herb. One species, Corea to Pacific coast U. S.

1563. PHERótRICHIS, Decne. Pherotrichis. Asclepiadaceae. One species, Mexico extending to U. S.

1564. PHILADÉLPHUS, L.Syringa, MockOrange. Saxifragaceae Greek name of a sweet-flowering shrub, in honor of Ptolemy "Philadelphus". Shrubs with white fragrant flowers. About 15 species, northern hemisphere; 6 in U. S. (Ger. Pfeifenstrauch; Fr. Séringat).

a. P. coronárius L. Europe, cult. and adv. in U. S. Garden Syringa, Mock Orange, Orange-flower tree. Not more ornamental than our indigenous species.

1565. PHILIBERTÉLLA, Vail. Philibertella. Asclepiadaceae. Diminutive from Philibertia. Syn. Philibertia, in part. Shrubby climbers. Six species in U. S.

1566. PHILótrIA, Raf. 1818. Water-weed. Vallisneriacene. From Greek, "three loving", the leaves being cften in whorls of three. Syn. Elodea, Michx. 1803, not Elodes, Adans. 1763, Udora, Nutt. 1818; Anacharis, in part. Water weeds. About 8 species; 1 (or more) in U. S. 
a. P. Canadénsis (Michx.) Brit. (E. Canadensis Michx. A. Canadensis Planch.). N. America, except extreme north, nat. in Europe. Water-weed, American Water-weed (England), Ditch-moss, Water Thyme, Thyme-weed, Cat's-tails, Raave, Babington's-curse (so called in Fingland, because introduced by a botanist of that name.)

1567. PHLÓXERUS, R. Br. Philoxerus. Amaranthaceá. From Greek, "drought loving'. Herbs. About 6 species, mostly South American; 1 in U. S.

1568. PHLóMIS, L. Jerusalem Sage, etc. Labiatae. The Greek name of "Mullen", from resemblance of foliage. Herbs or shrubs, often with rugose puckered leaves. About j0 species, Old World. (a) P. fruticósa L., southern Europe, is called Jerusalem Sage or Sage-leaf Mullen; (b) P. Herbavénti L., Mediterranean region, is Wind-herb; (c) P. Lychnites L., Europe, is Lampwick or Jupiter's-distaff.

1569. PHLÓx, L. Phlox, Wild S'weet-William. Polemoniaceae. The Greek name of a plant with "flame" colored flowers. Ornamental herbs, with blue, purple, red or white flowers in terminal cymes. About 40 species, N. America and Russian Asia; 34 in U. S. (a) P. bryoídes Nutt., Nebraska to Wyoming, is called Moss Phlox; (b) P. maculáta L., New Jersey to Minnesota and southward, is Wild Sweet-William, a name, however, applied to other species; (c) P. paniculáta L., is the common perennial Phlox of gardens; (d) P. speciósa Pursh, is the Pride-of-Columbia; (e) P. subuláta L., New York to Michigan and southward, is Ground or Moss Pink, Wild Pink, Flowering Moss. The annual Phlox of gardens is derived from (f) P. Drummóndii Hook. of Texas.

1570. PHOÉNIX, L. Date Palm. Sabalaceae. The Greek name of (a). Palms with trunks covered with persistent leaf-bases. About 12 species, tropical Asia and Africa.

a. P. dactylifera L. (P. excelsior Cav.). North Africa to Persia and widely cult. Date Palm. Unripe fruit astringent. Ripe fruit esculent. (b) P. farinifera Roxb. of Singapore yields sago. (c) P. sylvéstris Roxb. is the Wild Date of India, which yields date sugar (jaggery) and palm wine (toddy).

1571. PHOLÍSMA, Nutt. Pholisma. Lennoaceae. A leafless, succulent parasitic herb. One species, California.

1572. PHORADÉXDRON, Nutt. Mistletoe. Lorantlaceae. From Greek, "thief tree". Syn. Viscum, in part. Leafy parasitic shrubs. About 80 species, New World; 4 in U. S.

a. P. flavéscens (Pursh) Nutt. (V. flavescens Pursh.). New Jersey to Missouri and southward. American Mistletoe, Goldenbough. Plant ecbolic, antispasmodic, cardiac tonic. See Viscum.

1573. PHóRMIUM, Forst.

Flax Lily.

Liliacene.

Greek word for a "little basket". A shrubby plant. One or more species, New Zealand and Norfolk Islands. 
a. P. ténax Forst. New Zealand and neighboring islands. Flax Lily, New Zealand Flax, New Zealand Hemp; Ger. Flachslilie; Fr. Lin (Chanvre) de la Nouvelle Zélande. Leaves yield a very strong fibre. Root and leaf-bases vulnerary.

1574. PHRÝMA, L. Lopseed. Phrymaceae. An erect perennial shrub. One species, Canada and eastern U. S.

1575. PHYLLÁNTHUS, L. Phyllanthus. Euphorbiaceae. From Greek, "leaf flower". Syn. Cicca, Emblica, in part. Herbs, shrubs or trees. About 450 species, warmer regions of both hemispheres; 4 in U. S.

a. P. dístichus (L.) J. Muell. (C. disticha L.). India. Tahiti Gooseberry, Star G'ooseberry. Fruit esculent. Leaves diaphoretic. Root violently emetic.

b. P. Émblica L. (E. officinalis Gaertn., C. Emblica Kurz). India. Unripe fruit, Emblic Myrob^lans, White Galls; Myrobalani emblicæ; Ger. Graue Myrobalanen; astringent. See Terminalia.

c. P. Niuri L. and (d) P. Urinária L., of India, are efficient diuretics.

1576. PHYLLÓD0CE, Salisb. Mountain Heath. Ericaceae. The nanie of a sea nymph. Syn. Andromeda, Menziesia, Bryanthus (Kew), in part. Low shrubs. Three species, arctic and alpine regions of northern hemisphere; 1 in $U$. $S$.

15 77. PHYLLOSPíDIX, Hook. Phyllospadix. Naidaceae. Water weeds. 'Two species, Pacific coast, U. S.

1578. PHÝSALIS, L. Ground Cherry. Solanaceae. Ancient Greek name of (a), "bladdery". Syn. Alkekengi, Tourn. Herbs with fruit enclosed in inflated calyx. About 50 species, mostly American; 34 in U. S.

a. P. Alkekéngi L. (A. officinarum Moench). Mediterranean region eastward to Japan. Strawberry Tomato, Winter Cherry, Alkekengi, Bladder-herb. Fruit, Fructus v. Baccæ alkekengi, Baccæ halicacahi; Ger. Judenkirschen, Blasenkirschen, Schlutten; Fr. Alkékenge coqueret (Codex); diuretic, refrigeraut.

b. P. Perıviána L. (A. pubescens Moench). South America, cult. in all sub-tropical countries. ('ape Gooseberry, Peruvian Ground Cherry, Peruvian Strawberry Tomato, Husk Tomato, Poha or Paina of Hawaiian Islands. Fruit esculent, as also in (c) P. ixocárpa Brot. ( $\mathrm{P}$. aequata Jacq.) of Mexico, Tomatillo, Mexican Ground Cherry or Strawberry Tomato; (d; P. Philadélphica Lam., eastern U. S., Philadelphia Ground Cherry; (e) P. pubéscens L., not Dunal, southern U. S. to California and S. America (also in India), Dwart Cape Gooseberry, Low Hairy Ground Cherry?., Dwarf Strawberry Tomato; (f) P. viscósa L. 17.53, not Pursh (P. Pennsylvanica L. 1763, not A. Gray), southeastern U. S. to S. America, Stellate Ground Cherry?, Yellow Henbane. 
1579. PHYSALÓDES, Boehm. Apple of Peru. Solanaceae. From Greek, "resembling Physalis". Syn. Nicandra, Adans. 1763; Atropa, in part. Kobust herb with nodding blue flowers. One species, (a) P. physalódes (L.) Brit. (A. physalodes L., N. physaloides Gaert., P. Peruvianum Kze. ). Peru, cult. and adv. in U. S. Apple of Peru, Peruvian Bluebell.

1580. PHYSÁRIA, A. Gray. Bladder-pod. Cruciferae. From Greek, "bladdery", alluding to the inflated fruit. Perennial herbs with yellow flowers. About 4 species, all of western U. S.

1581. PHYSOSTÉGIA, Benth. Lion's-heart, etc. Labiatae. From Greek, "bladder covering", alluding to inflated fruiting calyx. Syn. Dracocephalum, Prasium, in part. Perennial herbs with racemes of showy flowers. About 5 species, N. America; 4 in U. S.

a. P. Virginiána (L.) Benth. (D. Virginianum L., D. speciosum Sweet). Canada and Eastern U. S. False Dragon-head, Obedient-plant, Lion's-heart.

1582. PHYsostíGMA, Balfour. Calabar Bean. Papilionaceae. From Greek, "bladder stigma". Woody climbers. Two species, tropical Africa.

a. P. venenósum Balf. Western Africa. Calabar Bean, Ordeal Bean, Chop-nut; Ger. Calabarbohne, Ordealbohne; Fr. Fève de Calabar. Seed, Physostig na. U. S. P., Physostigmatis Semen Br.. Faba calabarica, a powerful poison, antagonizing atropine, anti-spasmodic, sedative.

1эS3. PHYSÚRUS, Rich. Physurus. Orchidaceae. Terrestrial Orchids. About 40 species, warmer regions especially of New World; 1 in U. S.

1584. PHYTÉLEPHAS, Ruiz. \& Pav. Ivory Palm.Sabalaceae. From Greek, "ivory plant". Low palms with ample pinnate leaves. About 5 species, S. America.

a. P. macrocárpa R. \& P. Eastern slope of Andes. Ivory Palm. Seeds of 1 his and of some other species constitute vegetable ivory, from which buttons, etc. are made. The fruit is called Negrohead, the seeds, Ivory-nuts, Corozo- or Taqua-nuts.

1585. PHYTOLÁCCA, L. Poke-berry. Phytolaccaceae. From Greek and French, "Lacca nlant", alluding to the crimson juice of the fruit. Perennial herbs or shrubs. About 10 species, mostly tropical; 1 in U. S.

a. P. dioíca L. Southern Europe to India. (A shade tree). Tree Poke, Bellasombra tree, Umbra tree.

b. P. decánilra L. Ontario and eastern U. S., west to Minnesota. Poke, Pocan, Scoke, Coakum, Garget, Pigeon-berry, Pokeweed, Virginian Poke, American Nightshare, Red ink plant, Redweed, Cancer Jalap, Foxglove*; Ger. Kermesbeere, Scharlachbeere, Fr. Agouman, Morelle à grappes; Sp. Mazorquilla, 
Namoll, Jabonera. Root, Phytolaccae Radix, U. S. P., Poke root. Fruit; Phytolaccae Fructus, U. S. P., Baccae solani racemosi; Fr. Raisin d' Amerique; alterative, emetic, discutient. Young shoots used like asparagus.

c. P. octándra L. (?) Mexico and West Indies. West Indian Foxglove, Calulu. Fruit in Mexico a substitute for soap.

1586. PIÁR0PUS, Raf. 1836. Water Hyacinth.Pontederiaceae. From Greek, "fat foot". Syn. Eichhornia (Kew), Kunth. 1843, Eichornia A. Rich.; Pontederia, in part. Aquatic herbs. Une or two species; 1 in U. S.

a. P. crássipes (Mart.) Raf. (Pont. crassipes Mart., E. speciosa Kunth (Kew), E. crassipes Solms., Pont. azurea Hook.). Tropical America, nat. in Florida, where it impedes navigation of rivers. Water Hyacinth, Pitcher-plant*.

1587. P'ÍCEA, Link. - Spruce. - Pinaceae. Latin name of a conifer. Syn. Pinus, Abies, in part. Evergreen conical trees with pendulous cones. About 15 species, north temperate zone and northward; 8 in U. S.

a. P. Canadénsis (Mill.) B. S. P. (A. Canadensis Mill., Pinus alba Ait., A. alba Michx., not Mill., Picea alba Link). British America, south to New York, Michigan and Montana. White Spruce, Cat Pine, Cat Spruce, Pine Spruce, Sirgle or Skunk Spruce, Black Spruce*.

b. P. Mariána (Mill.) B. S. P. (A. Mariana Mill., Pinus nigra Ait., A. nigra Desf., Picea nigra Link). Black Spruce, Spruce Pine, Blue or Double Spruce, White Spruce*, Spruce-gum tree, He-Balsam*, Juniper*. Resinous exudate, Spruce gum, masticatory.

Other indigenous species are (c) P. Breweriána S. Wats., the highly ornamental Weeping Spruce of Oregon; (d) $\mathbf{P}$. púngens Engelm. (P. Parryana Sarg.), Blue or Colorado Spruce; (e) P. rúbra (Lamb.) Link (P. rubens Sarg.), Red Spruce of Canada and northeastern U. S. and (f) P. Sitchénsis (Bong.) T. \& M., Sitka or Tideland Spruce, the largest of the Spruces.

1588. PICKERÍfGIA, Nutt. Pickeringia. Papilionaceae. Spiny shrub. One species, California.

1589. PICRADÉNIA, Hook. 1833. Picradenia. Compositae. From Greek, "bitter gland". Syn. Actinella (Kew), Nutt. 1818, not Fers. 1807; Hymenoxys, Cephalophora, in part. Bitter aromatic herbs with yellow flowers. Abont 20 species, N. America; 16 in U. S., mostly in southwest.

a. P. odoráta (DC.) Brit. (H. odorata DC., A. odorata A. Gray.). Kansas to southern California and Mexico. Limonilla, Fragrant Picradenia.

1590. PICRÁSMA, Blume 1815. Quassia. Simarubaceae. Syn. Aeschrion, Vell. 1827, Picræna, Lindl. 1838; Quassia, Simaruba, in part. Trees. About 8 species, warmer regions, Old and New World. See Quassia and Simaruba. 
a. P. excélsa (Swz.) Planch. ( . excelsa Swz., Q. polygama Linds., Picræena excelsa Lindl. (Kew), S. excelsa DC.). West Indies. Quassia, Bitter Ash, Bitterwood tree, Lofty Quassia?. Wood, Quassia wood, Jamaica Bitterwood; Quassia, U. S. P., Quassia lignum, Br., Lignum muscarum v. muscicidum; Ger. Jamaika-Quassia; Jamaikanische Quassienholz, Fliegenholz; Fr. Quassie de la Jamaïque; Bitter tonic, insecticide. (b) P. quassióides (Ham.) Benn. of northern India has the same properties.

\section{PICRAMNLA, see TARIRI.}

1591. PÍCRIS, L. Picris, Oxtongue.

Compositae. From Greek, "bitter". Syn. Helmintha, in part. Herbs with rather large heads of yellow flowers. About 35 species, Old World; 4 nat. in U. S. (a) P. echioídes L., Europe, adv. in U. S., is called Bristly Oxtongue, Bugloss*, Bugloss Picris; (b) P. hieracióiles L., Europe, nat. in U. S., is Hawkweed Picris, Langdebeef + ; Ger. Bitterkraut; Fr. Picride, Langue de boeuf. Plant very bitter.

1592. PÍERIS, D. Don. Fetter-bush, etc. Ericaceae. Dedicated to the Muse, Pieris. Syn. Andromeda, Portuna, in part. Shrubs or small trees. About 12 species, northern hemisphere; 4 in U. S.

a. P. Mariána (L.) Benth. \& Hook. (A. Mariana L.). Rhode Island to Florida. Stagger-bush, Wicke, Sorrel tree*. Plant poisonous to animals. (b) P. nítida (Bartr.) B. \& H. (A. nitida Bartr.) of southeastern U. S. and Cuba is called Fetterbush and Pipe-stem.

\section{PILOCÁRPUS, Vahl.}

From Greek, "cap fruit". Shrubs with pellucid-dotted leaves. About 12 species, warmer regions of $\mathrm{New}$ World.

a. P. Jaborándi Holmes. Brazil. Jaborandi, Pernambuco Jaborandi. Leaflets; Pilocarpus, U. S. P., Jaborandi Folia, Br., Folia Jaborandi P. G., Jaborandi (Codex). [U. S. P. recognises also (b), Codex, (b) "and allied species"]. Sialagogue, mydriatic; more rich than the other species in pilocarpine. Other species also gathered as jaborandi are (b) $\mathbf{P}$. pennatifólius Lam., (P. Selloanus Eng.), Rio Janeiro Jaborandi; (c) P. microphyllus Stapf.; (d) P. spicátus St. Hil.; (e) P. trachylophus Holmes, commercial jaborandi being a mixture of two or more of these. Leaves of the worthless Swártzia decípiens Holmes are said to be now often substituted for (c).

1594. PIMÉNTA, Lindl. Allspice, Bay tree, etc. Myrtaceae. From the Spanish name. Syn. Pimentus; Amomis, Eugenia, Myrcia, Myrtus, in part. Aromatic trees. About 5 species, tropical America.

a. P. ácris (Swz.) Wight (Myrtus acris Swz., Myrcia acris, DC., E. acris W. \& Arn., P. citrifolia Kostel., A. acris, Berg. ). West Indies and Venezuela. Wild Clove, Bayberry, Jamaica Bayberry, Black or Wild Cinnamon. Leaves, source of oil $\mathrm{of}_{\mathrm{f}}$ 
Bay, Oleum Myrciae, U. S. P., Oil of Myrcia;Ger. Myrcienöl Bayöl; Fr. Essence de Myrcie Geuuine Bay rum is distilled from the leaves.

b. P. Piménta (L.) Lyons (Myrtus Pimenta L., P. Pimento Griseb., P. officinalis Lindl. (Kew), E. Pimenta DC., P. vulgaris W. \& A.). West Indies and tropical America, cult. elsewhere in tropical countries. Allspice tree, Jamaica Pepper. The nearly ripe fruit Allspice, Pimento; Pimenta, U. S. P., Br., Semen v. Fructus amomi, Piper jamaicense; Ger. Nelkenpfeffer, Englisches Gewürz, Neugewürz; Fr. Piment de la Jamaïque, Toute-épice; Sp. Pimienta gorda, Malaguecta; aromatic, stimulant, condiment; source of oil of Pimenta.

1595. PIMIPINÉLLA, L. Pimpernel, etc. Umbelliferae. The Latin name of (b). Syn. Anisum, Sium, in part. Perennial herbs. About 75 species, northern hemisphere and S. Africa; 2 in U. S.

a. P. Ánisum L. (A. vulgare Moench). Southern Europe to the Levant, also cult. Anise plant, Common Anise (Aneys, Anny, Aunyle), Sweet Cumin. Fruit, Anise, Aniseed; s nisum U.S.P. Anisi Fructus, Br., Fructus v. Semen anisi vulgaris; Ger. Anis, Anissamen; Fr. Anis, Anis vert (Codex); carminative, stomachic; source of oil of Anise.

b. P. Saxífraga L. Europe, adv. in U. S. Pimpernel (Pimpinel ), Bennet, Burnet Saxifrage, Small Burnet Saxifrage, Small Saxifrage, Small Pimpernel, Break-stone, Old-man's-plaything; Ger. Pimpernell, Bibernell; Fr. Grand Bocage. Root, Radix Pimpinellæ, P. G., aromatic, pungent, nauseant.

c. P. Sisárum (L.) Benth. (S. Sisarum L., perhaps also S. Ninsi L.). Corea. Skirret, Selı-heal*, Ninsin. Root a culinary vegetable (celery-like), also a substitute for ginseng.

1596. PINAROPÍPPUs, Less. Pinaropappus. Cichoriaceae. From Greek, "dirty pappus". Syn. Troximont, in part. Perennial herb. One species, Texas to Mexico.

1597. PINCKNÉYA, Richard. Ferer-tree. Rubiaceae. Named for Gen. C. C. Pinckney, S. Carolina statesman. Syn. Cinchona, in part. Tree. One species, U. S.

a. P. púbens Michx. (P. pubescens Lam., C. Caroliniana Poir.). S. Carolina to Florida. Fever-tree. Bark, Georgia bark, Carolina bark, Florida bark, Pinckney bark, Bitter bark; tonic, febrifuge.

1598. PINÉLLIA, Tenore. Pinellia. Araceae. Herbs. About 4 species, western Asia. (a) P. tuberifera Ten. Japan. Han-ge. Herb has properties of colchicum.

1599. PINGUícULA, L, Butterwort. Lentibulaceae. Latin dim. from pinguis "fat", the leaves unctious to the touch. Scapose herbs. A bout 30 species, cooler regions of both hemispheres; 6 in U. S. 
a. P. rulgáris L. Northern Europe, Asia and $\mathbf{X}$. America, south to New York and Minnesota. Butterwort, Bog Violet, Marsh Violet, Earning-grass (i. e. Curdling-grass), Bean-weed, Rotgrass, Sheep-rot, Sheep-weed, Sheep-root, Steep-grass, Yorkshire Sanicle.

1600. PINíTES, Goep. Pinites. Pinaceae. A genus of extinct plants known only by their fossil remains. (a) P. succínifer Goeppert (Pitoxylum succiniferum Kraus). The principal source of the Baltic Amber, a fossil resin; Succinum, Ambra flava; Ger. Bernstein, Agstein; Fr. Succin, Ambre jaune.

1601. PÍNUS, L. - - Pine. - - Pinaceae. The Latin name, of Celtic origin. Evergreen trees with needle-like leaves. About 70 species, northern hemisphere; 39 in U. S.

a. P. Cémbra L. European Alps and northern Asia. Siberian Stone-pine, Swiss Scone-pine, Siberian Cedar. Seeds, Cembra nuts, Pine nuts, Zibel nuts; edible and rich in oil. Exudate is Riga balsam or Carpathian balsam. The Stone Pine of southern Europe, (b) P. Pínea L., yields also edible nuts, Pine nuts; Fr. Pignons, Ital. Pinocchi.

American species yielding edible seeds are (c) P. édulis Engelm., Texas to Arizona, New Mexico Pinyon (Sp. piñon); (d) P. cembroídes Zucc., Arizona to Mexico, Stone-seed Pinyon; (e) P. monophylla Torr. \& Frem., Nevada Nutpine, Soft-shelled Pinyon; (f) P. Parryána Engelm., southern and lower California, and (g) P. Sabiniána Dougl., Grayleaf Pine, Digger Pine, Nut Pine, the last formerly supplying the chief food of some of the aborigines.

h. P. Lambertiána Dougl. Mountains of California and northward. Great Sugar-pine, Sugar Pine, Giant Pine, Shake Pine. The king of Pines, only surpassed in size by the giant Sequoia. Tree yields a saccharine exudate.

i. P. palústris Mill. (P. australis Michx.). Virginia to Florida and Texas. Long-leaved Pine, Georgia Pine, Soutliern or Swamp Pine, Broom Pine, Fat Pine, Florida or Virginia Pine, Georgia or Texas Yellow Pine, Southern or Yellow Pitch-pine, Southern Hard Pine, Long-straw Pine, Turpentine Pine, Yellow Pine, White-rosin tree. Resinous exudate is White Turpentine, Turpentine gum or American Thus, from which is obtained oil of turpentine and resin (Resina, U. S. P., Rosin, Colophony). 'Timber hard, compact and durable.

j. P. Pináster Solander (P. maritima Poir.). Southern Europe. Cluster Pine, Pinaster. Source of most of the French turpentine. The crude product, Bordeaux turpentine, is known in commerce as gallipot. From (k) P. Halepénsis Mill. ( $\mathrm{P}$. maritima Lamb.), the Aleppo Pine, is obtained in P'rovence the Aleppo turpentine. From the resinous (1) P. Larício Poir. of southern Europe, the Corsican Pine, is obtained the Austrian turpentine. From (m) P. Pumílio Haenke of central Europe is obtained Hungarian turpentine, Balsamum hungaricum, also a volatile oil called Oleum templinum; Ger. Krummholzöl, Latschenöl. 
n. P. ponderósa Dougl. British Columbia and Montana, south to I'exas and Mexico. Western Yellow Pine, Western Pitch Pine, Bull Pine, Gambier Parry's Pine, Long-leaved Pine (of the West), Red Pine (western), Trucker Pine. Timber light, strong and very durable.

o. P. resinósa Ait. Canada and northeastern U.S. Canadian Pine, Red Pine (eastern), Norway Pine*.

p. P. rígida Mill. Canada to Georgia and Kentucky. P'itch Pine, Torch Pine, Sap Pine, Candlewood or Lightwood Pine, Hard or Yellow Pine, Black Norway Pine. Largely used for manufacture of tar.

q. P. Stróbus L. Canada, south to Georgia and Iowa. White Pine, American White Pine, American Deal Pine, Soft Deal Pine, Northern Pine, Spruce Pine, Weymouth Pine. Timber light, strong, easily worked and durable.

r. P. sylvéstris L. Europe and northern Asia. Scotch Pine, Red Pine (European), Baltic or Norway Pine, Riga Pine, Scotch Fir, Foehre, Vippe, European or Red Deal. An important timber tree. Resinous exudate, Common Turpentine (of Europe), in England known as Common Frankincense; source of the Russian and German oil of turpentine. Leaves yield oil of Pinus Sylvestris, of agreeable fragrance.

s. P. Taéda L. Delaware to Florida, west to Texas and Arkansas. Loblolly Pine, Old-field Pine, Frankincense Pine, called also Longshucks and Bastard, Foxtail, Indian, Longstraw, Prairie, Rosemary, Sap, Slash, Swamp, Torch and Virginia Pine. Largely used for manufacture of tar. Resinous exudate American Thus.

t. P. Teocótl Ch. \& Schlecht. Mexico. Ocote Pin€, Torch Yine; Source of Mexican 'Turpentine, Brea turpentine.

1602. PÍPER, L. - - Pepper. - - Piperaceae. The Latin name. Syn. Artanthe, Ottonia, Serronia, Steffensia. Mostly shrubby climbers, a few trees or tall herbs. About 6.50 species, tropical regions. See Chavica, Cubeba and Methysticum.

a. P. angustifólium R. \& P. (A. elongata Miq., P. elongatum Vahl., Stef. elongata Kunth.). Mexico to Brazil and Peru. Matico. Leaves, Matico. U. S. P., Maticae folia; Ger. Maticoblätter; Fr. Matico (Codex); Sp. Yerba ;Palo) de soldado; astringent, terebinthinate, stimulant.

b. P. Carpúnya R. \& Pav. Chili and Peru. Leares aromatic; stomachic. (c) P. Jaborándi Vell. (Ser. Jaborandi Guill., O. Jaborandi Kunth). Brazil. Jaborandi (See Pilocarpus), according to Peckolt the true Jaborandi of Brazil, Yaguarundi (Paraguay). Root pungent, sialagogue. The following species are also known locally in Brazil as Jaborandi; (d) P. reticulátum L.; íe). P. unguiculátum R. \& P. (P. nodosum Link.) and probably (f) P. citrifólium Lam. 
g. P. nígrum L. India, cult. in many tropical countries. Black Pepper plant. Unripe fruit, Black Pepper, Conmon Pepper; Piper. U. S. P., Piper Nigrum, Br.; Ger. Schwarzer Pfeffer; Fr. Poivre noir (Codex); Sp. Pimienta negra. White Pepper, Piper album, is the fruit deprived of epicarp and sarcocarp. Antiperiodic, counter-irritant, chiefly used as a stomachic stimulant and condiment; source of piperine.

h. P. Novae-Hollándae Miq. Australia. Australian Pepper. Fruit a powerful stimulant of the mucous membrane.

i. P. peltátum L. and (j) P. umbellátum L. Tropical America. Both plants called Caapeba and Periparabo, in the West Indies Lizard's-tail and Ass'-foot. Rhizomes diuretic. Leares discutient.

1603. PIRIQUÉTA, Aubl. Piriqueta. Turneracene. Syn. Turnera, in part. Herbs or shrubs. About 20 species, mostly of S. America, a few in Africa; 1 in $\mathrm{C}$. S.

1604. PISÓNIA, L. Cock-spur, etc. Nyctaginaceae. Named for Dr. William Piso, traveler in Brazil, 17th Century. Trees or shrubs with corky wood. About 60 species, mainly of tropical America and Pacific Islands; 3 in U. S.

a. P. aculeáta L. Tropical America to southern Florida. Cockspur, Fingrigo, used for hedges.

b. P. obtusáta Jacq. Tropical America to southern Florida. Beef-wood, Corkwood*, Loblolly tree.

1605. PISTÁCIA, L. Pistachio, Turpentine tree. Anacardiaceae. From the aucient Greek name. Trees. About 8 species, north temperate zone.

a. P. Lentíscus $I_{1}$. Mediterranean basin. Mastic tree, Balsam tree, Lentisk, Lentiscus. Resinous exudate, Mastic (Mastich), Scio Mastic; Mastiche, U. S. P., Br., Mastix, Resina masticbe; Ger. Mastix; Fr. Mastic; masticatory (hence the name), used for map-varnish, etc. The Algerine or Barbary Mastic is derived from (b) P. Atlántica Desf., Bombay Mastic from (c) P. mútica F. \& M. (P. Cabulica Stokes) and (d) P. Khínjuk Stocks, northeastern India to Persia and Egypt.

e. P. Terebínthus L. (P. terebinthina St. Lag. ). Mediterranean basin and eastward. Turpentine tree. Resinous exudate, Chian Turpentine, Cyprian or Scio Turpentine, Alk, Alk gum, Terebinthina chia $v$. cypria. Has been recommended in cancer.

f. P. véra $\mathrm{L}$. (P. terebinthus Mill., not $\mathrm{L}$. ). Southern Europe to Persia. Pistachio-nut tree. Seeds, Pistachio-nut, Bladder-nut; Ger. Pimpernüsse, Pistacien; esculent.

1606. PÍSTIA, L. - Water-Lettuce. From Greek, liquid, alluding to habitat. A floating water plant. One species, widely distributed in tropical regions (U. S.). (a) P. stratiótes L. (with numerous synonyms), West Indian Water-lettuce, Tropical Duckmeat or Duckweed. 
1607. PÍSUM, L. Pea. Papilionaceae. The classical name. Herbs climbing by tendrils. Two species, natives of Asia.

a. P. satírum L. Mediterranean region, now universally cult. Garden Pea, Common Pea, Field Pea. Varieties are Sugar Pea, String Pea, etc. Seeds esculent.

1608. PITHECOLÓBIUM, Mart. 1837.

Mimosaceae. From Greek, "ape's ear", from fancied resemblance of pods. Syn, Zygia, P. Br. 1756; Inga, Mimosa, in part. Trees with white flowers in globose heads. More than 100 species, tropical America and Asia; 4 in U. S.

a P. dúlce Benth. Mexico, nat. in India, etc. Guamuchil, Manila Tamarind (India). Seeds surrounded by an edible sweet pulp.

b. P. Saman Benth. Brazil and Venezuela. Samang (Saman, Zamang), Genisaro, Rain tree. Saccharine pods fed to stock. (c) P. brevifólium Benth., Texas to Mexico, is called Huajillo; (d) P. flexicaúle Coult., Texas to California and Mexico, is called locally Ebony; (e) P. Unguis-cáti (L.) Benth. (M. Unguis-cati L., M. rosea Vahl.), Cal's-claw.

1609. PLAGIOBóTHRYS, Fisch. \& Mey. Boraginaceae. From Greek, "oblique pit". Syn. Eritrichium, Echidiocarya, Myosotis, in part. Annual herbs. About 15 species, western N. Anerica; 13 in U. S.

1610. PLÁNERA, J. F. Gmel. Planer tree. Ulmaceae. Named for Prof. J. J. Planer of Erfurt, d. 1.789. An Elmlike tree. One species, southeastern L. S. Syn. Water Elm.

1611. PLantág0, L. Plantain.

Plantaginaceae. The Latin name. Herbs, mostly acaulescent, a few shrubby. Over 200 species; 20 in U. $\mathrm{S}$.

a. P. Corónopus, Lam. Europe. Hartshorn Plantain, Buck'shorn Plantain, Buck Plantain, Herb Ivy, Star-of-the-earth.

b. P. lanceoláta L. Europe and Asia, nat. in U. S. and widely elsewhere. Rib-grass, Ripple-grass, Ribwort, English Plantair, Snake Plantain, Black-jacks, Chimney-sweep, Clock, Cocks, Dog's-rib, Headsman, Hen-plant, Jack-straws, Kemp, Kempseed, Leechwort, Long Plantain, Ram's-tongue, Rat-tail, Waybread, Windles; Ger. Spitzer Wegerich o. Wegetritt, Fr. Plantain [Codex, the name including also (c) and (d)]; Sp. Lauten. Herb, Herba plantaginis, haemostatic, vulnerary. Secds mucilaginous.

c. P. májor L. Europe and Asia, nat. in U. S. where it is said to have been known to the Indians as "White-man s-foot". Common Plantain, Plantain, Bird-seed Plantain, Round-leaved or Greater Plantain, Broad-leaf, Iour-yard Plantain. Henplant, Healing-blade, Kenp*, Lanıb's-foot, Way-bread; Ger. Grosser Wegerich, Sauohr. Properties and uses of (b). 
d. P. méllia L. Europe, adv. in U. S., Hoary Plantain, Lamb'stongue, Lamb's-lettuce, Fire-leaves, Fire-weed (England), Healing-herb, etc.; Ger. Mittler Wegerich. Properties and uses of $(b)$.

e. P. oráta Forsk. (P. decumbens Forsk.). Northern Africa. The $\mathbf{P}$. Ispaglúla Roxb. cult. in India, is believed to be a variety of this species. Seeds (of the variety), Spogel-seed, Ispaghul, Aspaghul seed; mucilaginous, demulcent.

f. P. Psíllium L. Mediterranean basin. Fleawort, Flea-seed or Branching Plantain. Sceds, Flea-seed; Ger. Flohsamen; Fr. Graines de puces; mucilaginous, demulcent.

1612. PIÁTANUS, L. Plane-tree.

Latin from Platanaceas. palmately lobed leaves and north temperate zone; 3 in U. S.

a. P. occidentális L. Ontario to Florida, west to Texas and Minnesota. The largest tree of eastern America. Buttonwood tree, Button-ball, Sycamore*, False Sycamore, American Planetree, Water Beecht. The Californian Plane-tree is (b) $\mathbf{P}$. racemósa Nutt. The Plane-tree of Europe and Asia is (c) P. orientális L., called also Chinar Tree.

1613. PLATYSPÉRMUM, Hook. (not Hoffm.) Crueiferae. From Greek, "flat seed". Low annual herb. One species, Pacific coast of U. S.

1614. PLATYSTÉMON, Benth. 1834. Cream-cups. Papaveraceae. From Greek, "flat stamen". Syn. Boothia, Dougl. 1834. Anuual herb. One species, California.

1615. PLECTRÍTES, $D C$ : Plectrites. Valerianaceae. Syn. Valerianella, in part. Herbs. Abont $S$ species, western U.S.

1616. PLÉEA, Michx. - Plee:ı. - Liliaceae. Herb. A single species, southern U. S.

161\%. PLEURICÓSPORA, Gray. A small scaly herb. One species, Califurnia.

161S. PLEUROGÝYIA, Eschol. (Pleurogyne.) Gentianaceae. From Greek, "rib stigma". Syn. Swertia, in part. Annuals with rather large blue flowers. About 7 species, higher north latitudes, 2 in U. S.

1619. PLÚCHEA, Cass. Marsh Fleabane. Compositae. Named for the Abbé N. A. Pluche of Paris, 18th Century. Syn. Baccharis, Erigeron, in part. Herbs, some shrubby, with small flower-heads. About 30 species, widely distributed; 6 in U. S.

a. P. camphoráta (L.) DC. (E. camphoratum L.). Atlantic and Gulf coast of U. S., also in West Indies. Spicy Fleabane, Salt-marsh Fleabane, Plowman's-wort, Camphor plant. (b) P. odoráta Cass., West Indies, is called Riverside Tobacco. 
1620. PluMbígo, L. Leadwort. Plumbaginaceae. Perennial herbs or shrubby climbers. About 15 species, northern hemisphere, 1 in $\mathrm{U}$. S.

a. P. Europaéa L. Europe. Conmon Leadwort, Toothwort, Dentellaria; Ger. Bleiwurz. Juice epispastic, emetic. (b) P. rósea L., India, and (c) P. scéndens L., San Domingo, called Herbe au diable, have the same properties.

1621. PLUMÉRIA, L. (Plumieria, Plumiera). Apocynaceae. Named for M. Plunier, French traveler and botanist. d. 1706. Ornamental shrubs, about 45 species, tropical America.

a. P. rúbra L. Tropical America. Jasmine tree, Red Jasmine, Frangipane, Frangipanni, Nosegay-tree, Red Nosegay-tree, Snake-wood*. (b) P. acutifólia Poir is called in India Pagoda tree, in Burmah Kambodja; (c) P. álba L. in West Indies is called Pagoda-tree, White Nosegay-tree.

1622. PLÚMMERA, Gray. Plummera. Compositae. Named for its discoverer Miss Plummer (Mrs. J. G. Lemmon). Strong-scented robust herb with yellow flowers. One species, Arizona.

1623. PNEUMáRIA, Hill. Sea Lungwort. Boraginaceae. From Greek, "lungwort". Syn. Mertensia (Kew), Pulmonaria, Steenhammera, in part. A fleshy perennial herb, one species, north temperate zone (U.S.).

a. P. marítima (L.) Hill. Pulm. maritima L., M. maritima S. F. Gray (Kew), S. maritima Reichb.). Coasts of Europe, Asia and N. America. Sea Lungwort, Sea Bugloss, Oysterplant*.

1624. PODÍSTERA, Wats. Podistera. Umbelliferae, Herb. One species, Nevada.

1625. PODOPHÝLLUM, L. Mandrake, etc. Berberidaceae. From Greek, "foot leaf". Herbs from perennial rootstocks. About 4 species, N. America and Asia; 1 in U. S.

a. P. peltátum L. Ontario to Florida, west to Texas and Minnesota. May Apple, Wild Mandrake, American Mandrake, Mandrake, Wild Lemon, Ground Lemon, Hog Apple, Devil's Apple, Indian Apple, Raccoon-berry, Duck's-foot, Umbrellaplant, Vegetable Calomel. Rhizome, Mandrake-root; Podophyllum, U. S. P., Podophylli Rhizoma Br.; Ger. Fussblattwurzel; Fr. Rhizome de podophyllum (Codex); cathartic, laxative, cholagogue. Active constituent, podophyllotoxin. Fruit edible. (b) P. Emodi Wallish of southern Asia has similar properties.

1626. PoDostémMa, Greene. Podostemma. Asclepiadaceae. From Greek, "font garland". Syn. Asclepias, in part. Herbs. Five species in U. S. 
1627. PODOSTÉMON, Michx. River-weed. Podostemaceae. From Greek, "foot stamen", the ovary being borne on a slender stalk. Aquatic or paludal plants. About 20 species, one in eastern U. S., viz. (a) P. Ceratophyllum Michx., River-weed,-Thread-foot.

1628. PODOSTÍGMA, Ell. 1817. Podostigma. Asclepiadaceae. From Greek, "stalked stigma". Syn. Stylandra, Nutt. 1818. Perennial herb. One species, southeastern U. S.

1629. POGÓGYNE, Benth. Pogogyne. Labiatae. From Greek, "beard pistil". Aromatic low annuals. Five species, all of California.

1630. POGóNIA, Juss. Snake-mouth, etc. Orchidaceae. From Greek, "bearded". Syn. Arethusa, in part. Terrestrial orchids. About 30 species; 5 in U. S.

a. P. ophioglossoídes (L.) Ker. Eastern U. S. to Canada. Rose Pogonia, Adder's Pogonia, Snake-mouth, Adder's-mouth Pogonia or Orchis. (b) P.trianthóphora (Sw.) B. S.P. (P. pendula Lindl.). Eastern U. S. Nodding Pogonia, Three-birds. c. P. vertıcilláta (Willd.) Nutt. Eastern U. S. and Ontario. Whorled Pogonia, Whorled Snake-mouth.

1631. Pogostéron, Desf. Patchouli, etc. Labiatae. From Greek, "bearded stamen". Herbs, some shrubby. About 35 species, East Indies to Japan.

a. P. Heyneánus Benth. (P. Patchouly Pelletier, P. suavis Tenore). East Indies. Patchouli plant. Patchouli Balm. Volatile oil distilled from the plant is Patchouli (Patchouly) or Putcha-pat, much used in perfumery,

1632. POINCIÁNA, L. (Poincea, Neck.). Caesalpinaceae. Highly ornamental trees. About 6 species, tropical regions, (a) P. régia Boj. Madagascar, planted for ornament in all tropical countries. Royal Poinciana.

1633. POLANÍSIA, Raf. Clammy-weed. Capparidaceae. From Greek, "very unequal", referring to the stamens. Syn. Cleome, Jacksonia, in part. Strongly scented herbs. About 15 species, temperate and tropical regions; 4 in $\mathrm{U}$. S.

a. P. gravéolens Raf. (C. graveolens Raf. (Kew.), not L., C. dodecandra Michx.). British America, south to New York, Kansas and Colorado. Clammy-weed, Worm-weed, False Mustard. Plant acrid, counter-irritant, vermifuge.

1634. POLENóniUM, L. Greek Valerian, etc. Polemoniaceae. Latin name of Valerian, of Greek origin. Herbs, mostly perennial. About 20 species, north temperate zone; 16 in U.S., mostly western.

a. P. caerúleum L. Europe. Greek Valerian, Jacob's-ladder, Ladder-to-heaven, Charity, Makebale; Ger. Speerkraut; Fr. Valériane grecque. Properties of (c). (b) P. Vau Brúutia Brit. of northeastern U. S., American Jacob's-ladder, closely resembles this species. 
c. P. réptaus L. Eastern U.S. Abscess-root, American Abscessroot, American Greek Valerian, Creeping Greek Valerian, Jacob's-ladder*, Bluebell*, Forget-me-not*, Sweet-root; Ger. Geschwürwurzel. Root alterative, astringeut, diaphoretic.

1635. POLIÁN'THES, L. Tuberose. Amaryllidaceae. From Greek, "white flowered". Syn. Polyanthus, Tuberosa, Heist. Herbs from tuberous rootstocks. About 3 species, tropical America.

a. P. tuberósa L. (T. amica Medic.). Mexico and widely cult. Tuberose, Mistress-of-the-night. Flowers fragrant, much used in perfumery.

1636. POLIONÍNTHA, Gray. Poliumintha. Labiatae. From Greek, "hoary Mint". Syn. Hedeomat, in part. Hoary suftrutescent plants. Three sjecies, Mexican border of U. S.

1637. POLYCÁRPOY, Loèfl. All-seed. Caryophyllaceae. From Greek, "many fruited". Slender annuals. About 6 species, widely distributed; 1 nat. in California, viz. (a) $\mathbf{P}$. tetraphyllum L. from Europe, called All-seed.

1638. POLÝYALA, L. Milkwort. Polygalaceae. From Greek, "abounding in milk". Herbs, rarely shrubs. About 260 species; 44 in $\mathrm{U}$. S.

a. P. amára L. Europe. Bitter Milkwort, European Bitter Polygala; Ger. Kreuzblume, K reuzwurz. Herb, Herba polygalæ, bitter tonic, stomachic. See $(d)$.

b. P. májor Jacq. Southeastern Europe. Hungarian Milkwort. . Root, Radix polygalæ hungaricæ.

c. P. paucifólia Willd. (P. unitlora Mchx.). British America, south to Georgia and 1 linois. Fringed Milkwort or Polygala, Flowering Wintergreen, Gay-wings, May-wings, Babies'-feet, Babies'toes, Babies'slippers, Bird-on-the-wing, Dwarf Milkwort, Indiau Pink, Ladies'slipper*, Little Pollom, Evergreen Snakeruot.

d. P. polýgama Walt. (P. rubella Muhl.). Canada and eastern U. S. Bitter Milkwort, Pink Milkwort or Polygala, Racemed Milkwort, Centaury. Properties of (a), as have also: (e) $\mathbf{P}$. Scopária Kunth., Southeru U. S. and Mexico; (f) P. Nuttállii T. \& Gr., eastern U. S., Nuttall's Milkwort, Ground Centaury, and (g) $\mathbf{P}$. viridéscens L. ( $P$. sanguinea L., not Nutt.). Canada and eastern U. S. Field or Purple Milkwort, Strawberry-tassel.

h. P. Sénega L. Canada to N. Carolina, west to Minnesota. Senega Snakeroot, Seneca Snakeroot, Seneca root, Rattlesnake root, Mountain Flax; Ger. Senegawurzel; Fr. Polygala de Virginie (Codex). Root, Senega, U. S. P., Senegre Radix, Br., Rad. polygalæ virginianæ; acrid, stimulanı, expectorant. A robust variety, Maryland to Tennessee and Michigan, is $\mathrm{P}$. Senega latifolia T. \& Gr. The White or False Senega root, having similar properties is from (j) P. Boykínii Nutt., southern and southwestern U. S. 
Other species of interest are ( $k$ ) P. cruciáta, eastern U.S., Cross-leaved Milkwort, Marsh Milkwort or Polygala, Drumheads; (1) P. incarnáta L., eastern U. S. to Mexico, Pink Milkwort, (American) Rogation-flower, Procession-flower; (m) P. lútea L., eastern $\mathcal{U}$. S., Orange Milkwort, Wild Bachelor's-buttons, Yellow Milkwort or Polygala; (n) P. Serpentária Eck. \& Zey., South Africa, root regarded an alexipharmic; (o) P. renenósa Juss., Jara, acrid and poisonous, and (p) P. vulgáris L., Europe, European Milkwort, Crossflower, Four-sisters, Gang-flower, Procession-flower, Rogationflower, Robin's-eye.

1639. POLYGOXÁTUM, Adans. Solomon's-seal.Convallariaceae. The Greek name, "many jointed". Syn. Convallaria. in part. Herbs with scarred rootstocks. About 20 species, nurth temperate zone; 2 in $U$. S.

a. P. biflórum (Walt.) Ell. (C. hiflora Walt.). Ontario and eastern U. S. Hairy or Twin-Howered Solomon's-seal, Dwarf Solomon's-seal or Sealwort, Conquer-John. Rhizome of this and of (b) collected in America as Solomon's-seal.

b. P. commutátum (R. \& S. ) Dietr. (P.giganteum Dietr. (Kew), C. commutata K. \& S.). ('anada to Georgia, west to Louisiana and Utah. Great Solomon's-seal, Giant or smooth solomon's seal, Sealwort, Drop-berry.

c. P. multiflórum (L.) All. (C. multiflora L.). Europe and Asia. Many-flowered Solomon's-seal\%, David's-harp, Jacob'sladder, Ladder-to-heaven, Scala cœii, Lily-of-the mountain, Fraxinelle, Drop-berry, Whitewort. Rhizome of this and of (d), Solomon's-seal (of Europe), Our-Lady's-seal, Lady' s-seal, Seal-of-hearen, White-root; Ger. Weisswurzel, Salomon'ssiegel; Fr. Sceau de Salomon; formerly reputed to posses. marvelous healing virtues.

d. P. officinále (L.) All. (C. officinalis L., C. Polygonatum L., P. vulgare Desf.). Europe and Asia. True Solomon's-seal, Sealwort, with synonyms of (c); Fr. Sceau de Salomon (Codex).

1640. POLYGONÉLLA, Michx. Jointweed. Polygonaceae. Latin, dim. of "Polygonum". Syn. I'olygonum, Gonopyrum, in part. Herbs with jointed stems. About $\$$ species, all of U. S. (a) P. articuláta (L.) Meisn., Coast Jointweed, is called also Sand-grass.

1641. POLÝGONUM, L. Knotweed, etc. Polygunaceac. The Greek name, meaning "many jointed". Syn. Bistorta, in part. Herbs, some shrubby, with spiked, racemt or capitate inflorescence. About 200 species, 66 in L. S.

a. P. amphíbium L. Europe and British America, south to Kentucky, Colorado and California. Water Persicaria, Willowweed, Willow-grass, Ground Willow, Red-shanks, Hearts-ease*.

b. P. arifólium L. Canada and northeastern L. S. Halberdleaved Tear-thumb, Scratch-grass, Sickle-grass. The latter names apply also to (c) P. sagitátum I.., Arrow-leaved Tear-thumb, a more common species. 
d. P. aviculáre L. Europe, Asia and N. America. Knot-grass, Door-weed, Door-grass, All-seed, Armstrong, Beggar-weed, Bird's-tongue, Bird-grass, Bird-weed, Centinode, Cow-grass, Crab-weed, Finzach, Goose-grass, Hog-weed, Iron-grass, Knotwort, Male Knot-grass, Ninety-knot, Mantil, Pink-weed, Sparrow-tongue, Stone-weed, Swine's-grass, Tacker-grass, Waygrass, Wire-grass*, Wire-weed.

e. P. Bistórta L. (B. officinalis Raf., B. major S. F. Gray). Europe and northern Asia. Bistort (i. e. twice bent), Snakeweed, Adderswort, Dragonwort, Easter-ledges, Easter-magients, Astrology Red-legs, Sweet Dock, Twice-writhen; Ger. Wiesenknöterich, Natterwurz, Knöterich; Fr. Bistorte (Codex), Couleuvrine. Rhizome, Bistnrta, Rad. bistortæ, Rad. columbinæ; astringent. similar properties belong to the indigenous (f) P. Virginiánum L., Virginia Knotweed, Virginia Bistort; also to the circumpolar $(\mathrm{g})$ P. vivíparum L. (B. vivipara S. F. Gray), Alpine Bistort, Serpent-grass.

h. P. Convólvulus L. Asia, nat. in Europe and U. S. Black Bindweed, Blackbird Bindweed, Climbing or Corn Bindweed, Ivy or Knot Bindweed, Bear-bind, Corn-bind, Devil's-tether, With-wind, Climbing Buckwheat*. The name False Buckwheat is given to the similnr (i) P. cristátum Engelm. \& Gr.; (j) P. dumetórum L. and $(k) P$. scándens $L$.

1. P. Hydrópiper L. Europe, nat. in U. S. Water-pepper, Smartweed, Biting Knotweed; Biting Persicaria, Bite-tongue, Lake-weed, Pepper-plant, Red-knees, Red-shanks, Sickleweed*, Culrage, Ciderage, Arse-smart, Arsenick $\ddagger$. Plant acrid, diuretic.

m. P. orientále L. India, nat. in U. S. Prince's-feather, Gentleman's-cane, Garden Persicary, Ragged-sailor.

n. P. Persicária L. Europe, nat. in U. S. Spotted Knotweed, Black-heart, Crab' s-claws, Heart-weed, Heart's-ease* (U. S.), Heart's-ear, Lover's-pride, Peachwort, Persicaria, Persicary, Pink-weed, Red-shanks, Red-weed, Willow-weed, Plumbago*'

o. P. punctátum Ell. ( P. acre H. B. K., P. Hydropiper Michx., not L.). British America, U. S. throughout, and southward. American Smartweed, Dotted or Water Smartweed, Arsesmart, Arsmart, Hydropiper, Water-pepper, Turkey-troop. Herb acrid, diuretic, diaphoretic, emmenagogue.

p. P. tinctórium Ait. Japan and China. Japanese Indigo plant. A source of indigo.

1642. POLÝMNIA, L.

Leaf-cup.

Compositae. Dedicated to the Muse Polhymnia. Perennial herbs, some shrubby. About 10 species, New World; 2 in U. S.

a. P. Credália L. Eastern U. S. Yellow Leaf-cup, Bear's-foot, Yellow Bear's-foot, Large-flowering Leaf-cup, Uvedalia. Root tonic, stimulant. 
1643. POLYPónIUM, L. Polypody. Polypodiaceae. Greek name of a kind of Fern, "many footed". Ferns from creeping rootstocks. About 350 species; 11 in U. S.

a. P. vulgáre L. Northern Asia, Europe and N. America. Common Polypody (Polypod, Polypode, Polypoddy), Rock Brake*, Adder's Fern*, Ever-fern, Golden Maidenhair*, Golden Polypody, Golden-locks, Moss Fern, Wall Fern, Wood Fern, Polypody of the Oak, Polypody of the Wall; Ger. Gemeiner Tüpfelfarn, Siissfarn, Engelsüss; Fr. Polypode Commun (Codex). Rhizome, Radix polypodii, R. filiculæ dulcis; expectorant, diuretic.

1644. POLÍPORUS, Fries. Agaric, etc. Hymenomycetes. From Greek, having "many pores". Syn. Boletus, in part. Fungi (toadstools), mostly of corky or woody texture. A few are edible.

a. P. fomentárius (L.) Fries (B. fomentarius L.). Southern and middle Europe. Oak Agaric, Surgeon's Agaric, Spunk, Punk, Touchwood; Ger. Wundschwamm, Feuerschwamm, Zunder; Fr. Agaric de chêne (Codex). Fungus absorbent, hemostatic. (b) P. ignárius (L.) Fries (B. ignarius L.) and (c) P. marginátus Fries, yield a similar Agaric, but harder.

d. P. officinális Fries (B. laricis Jacq., B. purgans Pers. ). Europe and northern Asia. White Agaric, Larch Agaric, Male Agaric, Purging Agaric, Amadou, German Tinder; Ger. Lärchenschwamm; Fr. Agaric blanc officinal, Polypore du Mélèze (Co. dex); hemostatic, purgative in large, astringent in small doses.

1645. POLYPRÉMUM, L. Polypremum. Loganiaceae. From Greek, "many stemmed". Obscure annual herb. One species, southern U. S. and Mexico.

1646. POLÝP'TERIS, Nutt. Polypteris. Compositae. From Greek, "many winged". Syn. Stevia, Palafoxia, in part. Rough herbs with pink or purple flowers. About 6 species, North America; 4 in U. S.

1647. POLYSTÁCHYA, Hook. Polystachya. Orchidaceae. From Greek, "many offshoots". Small epiphytes, mostly natives of Africa, a few in tropical America and Asia; 1 in U.S.

1648. POLYTÁ́xIA, DC. Polytænia. Umbelliferae. From Greek, with "many fillets" (i. e. oil-tubes). Herb with yellow flowers. One species, east-central U.S.

1649. POLÝTRICHUM, L. Hair-cap Moss. Musei. From Greek, "very hairy". Tall showy mosses, north tenperate and arctic zones. About 10 in U. S.

2. P. commúne L. Europe and U. S. Golden Maidenhair, Bear Moss, Besom Muss, Golden Moss, Goldilocks, Silver Heather, Silver Ling; Ger. Goldner Widerthon. Plant, Herba adianti anrei, H. polytrichi; diuretic, as is (b) P. juniperímum Hedw., Europe and U. S., Hair-cap Moss, Bear's-bed, Ground Moss, May-queen Moss, Robin's Rye. 
16อ̃. PONTEDÉRLA, L. Pickerel-weed. Pontederiaceae. Named for Prof. G. Pontedera of Padua, d. 1757. Aquatic herbs with spikes of blue flowers. About 8 species, New World; 1 in U. S.

1651. PONTHIÉVA, R. Br. Ponthieva. Orchidaceae. Terrestrial orchids. About 15 species, New World; 1 in U. S.

1652. PóPULUS, L. Poplar, Aspen, etc. Salicaceae. The classical Latin name, whence our word "poplar". Trees with soft wood. About 25 species, northern hemisphere, especially in higher latitudes; 11 in U. S.

a. P. álba L. Europe and Asia, nat. in U. S. Abele (Abel, Arbell, Awbel, Abbey), Silver Poplar (Popple), Silver-leaf or White Poplar, Aspen Poplar, Great Aspen, White Asp, Dutch Beech, Rattler tree, White-bark.

b. P. balsamífera L. British America and northern part of U. S. Balsam Poplar, Tacamahac. A variety, P. balsamifera candicans (Ait.) A. Gray, is known as Balm-of-Gilead. Leaf-buds resinous, aromatic, expectorant.

c. P. deltoídes Marsh (P. Carolinensis Moench, P. monilefera Ait., P. angulata Ait., P. (anadensis Desf.). Canada, south to Florida and New Mexico. Cottonwood, Necklace Puplar, Carolina Poplar, Yellow Cottonwood, Big Cottonwood, Cottontree, Italian Black Poplar, Carolina Poplar, River or Water Poplar, Berrv-bearing Poplar. (d) P. lieterophylla L. in the eastern States and (e) P. acumináta Rydb. also (f) $\mathbf{P}$. augustifólia James, in the west are also called Cottonwood. (g) P. trichocárpha T. \& G., California to Alaska, is called Black Cottonwood or Balsam Cottonwood.

h. P. Euphrática Olivier. Northern Africa, east to Thibet and southern Siberia. Garab tree of the Arabs. The "willow" of Scripture (Ps. 137).

i. P. tremuloídes Michx. British America, south to Kentucky, New Mexico and California. American Aspen (Asp, Aps, Espen, Haspen), Mountain Asp, Quaking Asp, Auld-wive'stongues, Trembling Poplar, Quiver-leaf, White or American Poplar. The Aspen of Europe, to which most of the above names were originally applied, is (j) P. trémula L. The Great Aspen or Large-toothed Aspen of the eastern U. S. is ( $(k)$ P. grandidentáta Michx.

1. P. nígra L. (including P. dilatata Ait.). Europe. Black Poplar (Pipple, Popillary, Pepillary), Cat-foot Poplar, Old English or Willow Poplar, Cotton-tree. The variety Italica Du Roi (P. fastigiata Desf.) is the well-known Lombardy Poplar, called also Black-lady or Water Poplar.

16.̌3. PORLIÉRIA, R. \& Pav. (Porliera). Zygophyllaceae. Named in honor of a Spanish botanist. Syn. Guaiacium, in part. Shrubs or trees with pinnate leaves. Two species, tropical America; 1 in U. S., viz. (a) P. angustifólia (Engelm.). Texas to Mexico. Wood has properties of Guaiacum q. v. 
16.5. POROPhÝlLUM, Vaill. Porophyllum. Compositae. From Greek, "pore leaved", the leaves having pellucid dots. Herbs or sub-shrubs. About 30 species, New World; 3 in U. S.

16อ๊. PORTERÁNTHUS, Britton, 1894.

Rosaceae.

Named for Prof. T. C. Porter of Lafayette College. Syn. Gillenia, Moench 1802, not Gillena, Adans. 1763; Spiræa, in part. Perennial herbs with rather large white or pinkish flowers. Two species, both in U. S.

a. P. stipulátus (Muhl.) Brit. (S. stipulata Muhl., G. stipulacea Nutt.). New York to Lonisiana and Indian Territory. American Ipecac, Indian Physic, with other synonyms of (b).

b. P. trifoliátus (L.) Brit. (S. trifoliata L., G. trifoliata Moench). New York to Georgia, west to Missouri. Indian Physic, Bowman's-root, Indian Hippo, False Ipecac, Western Dropwort, Meadow-sweet*. Root emetic, expectorant.

1656. PORTuláCA, L. Portulaca, Purslane. Portulacaceae. The Latin name, Fleshy herbs, blossoming in bright sunshine. About 30 species, mostly of New World; 9 in U. S.

a. P. grandiflóra Hook. South America, cult. in gardens and adv. in U. S. Garden Portulaca, Sun plant, Showy Portulaca, French or Garden Purslane, Wax Pink, Mexican Rose, Rose Moss, Kentucky Moss.

b. P. olerácea L. Tropical America, nat. in U. S. and widely elsewhere. Purslane, Purslain, (Pursley, Pussley). Used as a pot herb. Reputed vulnerary and antiscorbutic.

1657. POTAMOGÉTON, L. Pondweed. Naidaceae. The Grek name of a pond weed, "river inhabitant". Aquatic plants with leaves either floating or submerged. About 60 well-defined species, temperate regions; 38 in U. S. The species are called also Water-spike and Pickerel-weed*

a. P. nátans L. Europe, Asia and N. America. Common Floating Pondweed, Deil's-spoons, Batter-dock, Flatter-dock, Fishleaves, Tench-weed. (b) P. críspus L. is called Curly-leaved Pondweed, Water Caltropst. Muckweed; (c) P. lúcens L., Cornstalk-weed, Shiniıg Pondweed; (d) P. pectinátus L., Fennel-leaved Pond-weed, Pond-grass.

1658. PotentílLA, L. Barren Strawberry, etc. Rosaceae. Latın, diminutive of potens, "powerful" (medicinally). Syn. Tormentilla, in part. Herbs or shrubs. About 150 species, nearly all of north temperate zone; 90 in U.S.

a. P. Anserína L. Europe, Asia and N. America. Silverweed, Silver-feather, Wild Agrimony†, Buttercup*, Camoroche, Wild Tansy, Goose Tansy, Gonse-grass, Dog's Tansy (Scotland). Argentina; Ger. Gänserich, Silberkraut; Fr. Argentine (Codex) Anserine. Plant astringent, tonic.

b. P. argéntea L. Europe, Asia, Canada and northeastern U. S. Silvery Linquefoil, Hoary Cinquefoil. Included in the Argentine of the French Codex. 
c. P. Canadénsis L. (includes P. simplex Michx.). Canada and eastern U. S. Five-finger, Common Cinquefoil (of America), Sinkfield†, Star-flower, Running Buttercup. Resembles (f) and used in its place.

d. P. Pruticósa L. British America, south to New Jersey, Minnesota, Arizona and California. Shrubby Cinquefoil, Hardhack, Prairie-weed.

e. P. Monspeliénsis L. (P. Norregica L. (Kew), P. hirsuta Michx.). Europe, Asia and N. America. Rough Cinquefoil, Barren Strawberry.

f. P. réptans L. (T. reptans Stokes, not L.). Enrope and Asia. Creeping Cinquefoil (Sinkfield), European Five-finger, Golden-blossom; Ger. Fünffingerkraut; Fr. Potentille rampante, Quintefeuille. Plant astringent, febrifuge.

s. P. Tormentílla Neck. iT. erecta L., T. officinalis Curt., P. officinalis S. F. Gray). Europe and northern Asia. Tormentilla (Tormentil, Thormantle), Septfoil (Setfoil), Bloodroot*, Ewe Daisy, Shepherd's-knot, Sheep's-knapperty (Ireland). Rhizome, Rad. Tormentille; Ger. Tormentillwurzel, Ruhrwurzel, Heideckerwurzel, Blutwurzel; Fr. Tormentille; astringent, febrifuge.

1659. PRÉMNA, L. Premna. Verbenaceae. From Greek, "stump". Shrubs and trees. About 45 species, warmer regions of Old World.

a. P. Taiténsis DC. Tahiti to Fiji. Yaro. Bark one of the constituents of Tonga, a Fiji remedy for neuralgia, etc.

1660. PRÍMULA, L.

Primrose.

Primulaceae. The Latin name, "early" blooming. Perennial scapose herbs. About 150 species, mostly of northern hemisphere; 14 in U. S.

a. P. Aurícula L. Southern Europe, cult. in gardens. Auricula (i. e. ursi auricula), Yellow Auricula (of Alps), Bear's-ear, (Bezor), French or Mountain Cowslip, Dusty-miller, Primmilył, Tanner's-apron.

b. P. elátior Hill. (P. veris L. in part). Europe. Oxlip, Great Cowslip, Cow-sinkin, Pagle (Paigle, Peagle).

c. P. farinósa L. (P. Auricula Hill., not L.). Europe, Asia and northern N. America, south to Michigan. Mealy Primrose, Bird's-eye Primrose, Scotch Primrose, Bonny-bird-een, Powdered-beau.

d. P. officinális Jacq. (P. vulgaris Hill, not Huds., P. veris L., in part). Europe. Cowslip, English Cowslip, Cowslip Primrose, Culverkeys, Lady's-keys, Herb Peter, St. Peter's-wort*, Pagle (Paigle, Pagil), Pretty Mullen (Mullein), Palsywort, Polyanthus (Polander ${ }_{+}^{+}$), the last a cultivated variety; Ger. Primel, Peterschlüssel, Himmolschlüssel; Fr. Primavère Root Rad. paralyseos, Rad. arthritica, expectorant, antispasmodic. Flowers nervine. 
1661. PRIONÓPSIS, Nutt.

Prionopsis.

Compositae. From Greek, "saw like", alluding to leaf margins. Syn. Donia, Aplopappus (Kew), in part. Herb with large heads of yellow flowers. One species, Kansas to Texas.

1662. PRíVA, Adans.

Priva.

Verbenaceate. Perennial herbss. About 10 species, warmer regions of both hemispheres; 1 in U. S., viz. (a) P. echináta Juss., Brazil to Florida, Styptic-bur, Velvet-bur.

1663. PROSERPIXíCA, L. Mermaid-weed. Haloragidaceae. From Latin, "forward creeping". Aquatic herbs. Two species, both of eastern U. S. to West Indies.

1664. PROSÓPIS, L. Mesquit. Mimosaceae. Ancient Greek plant name, meaning a "face". Syn. Algarobia, Benth.; Acacia, Mimosa, in part. Trees or shrubs, usually thorny. About 20 species, warm or tropical regions; 3 in U. S.

a. P. juliflóra (Swz.) DC. (M. juliflora Swz., Acacia julıflora Willd. Alg. juliflora Heyne; includes P. glandulosa Tor.). Southern U. S. to Mexico and West Indies. Mesquit (Mesquite, Mezquite, Meskit), Honey Mesquit, Honey-pod, Honey Locust*, Locust Mesquit, Cashaw, July-flower (Jamaica), Algaroba (Algarroba). Succharine pods (algarobo, i. e. carob) used for fodder. See Ceratonia. Flowers yield abundant honey. Gummy exudate, Texas Mesquit gum. The bark of the South American Algaroba, (b) P. dúlcis Kunth (Alg. dulcis Benth.), Algarobilla bark, is used for tanning.

c. P. odorata Tor. \& Frem. (P. pubescens Benth.). Mexico to California. Screw Bean, Screw-pod Mesquit, Tornillo.

1665. PRóteA, L. Cape Honeysuckle, etc. Proteaceae. Named from Proteus of ancient mythology. Shrubs with flowers in dense cone-like heads. About 80 species, mostly of S. Africa. (a.) P. mellífera Thunb. Cape Honeysuckle, Honey-flower, Sugar-bush. The nectar used for coughs.

1666. PRótIUM, Burm. 1768. Caranna, etc. Burseraceae. Syn. Icica, Aubl. 1775, Dammara, Gaertn. 1791, not Lam. 1786; Anyri in part. Balsamic trees. About 50 species, tropical regions of Old and New World.

a. P. Carána (H. B. K.) March (I. Carana H. B. K., I. Caranna Auct. ). Brazil. Caranna tree. Oleoresin from this and other species is called Caranna.

b. P. heptaphýllum (Aubl.) March (I. heptaphylla Aubl., I. Tacamahaca H. B. K.). Northern S. America. Hyawa tree, Incense-wood. Resinous exudate, Tacanahac; Fr. Tacamahaca (Résine), Tacamaque terreuse (Codex). Used like Burgundy pitch.

c. P. Icicariba (DC.) March (I. IcicaribaDC.). Brazil. Source of Brazilian Elemi.

1667. PRUNÉLLA, L. (Brunella). From Latin, "quinsywort". widely distributed; 2 in U. S. 
at. P. vulgáris L. (P. Canadensis Mill., P. officinalis Cranz). Europe, Asia and N. America. Heal-all, Self-heal, Sloughheal, All-heal, Hook-heal, Carpenter's-herb. Hook-weed, Sickleheal, Sickle-weed, Sicklewort, Blue-curl, Brownwort, Heart-ofthe-earth, Pimpernel*, Thimble-Hower; Ger. Braunelle, Braunheil; Fr. Paquerette. Herb astringent, vulnerary.

166S. PRÚNUS, L. Plum, Cherry, etc. Irupaceae. The ancient Latin name. Syn. Armeniaca, Cerasus, is part. Shrubs or trees, mostly with $\mathrm{ed}$ ble fruit. About 90 species, north temperate zone, also tropical Anerica and Asia; 35 in U. S.

a. P. Americána Marsh. New York to Flnrida, west to Coloradu and Mortana; varieties culc. Wild Yellow or Red Plum, Goose Plum, Horse Plum, Hog Plum, Native Plum, Hlumgranitef. Fruit esculent.

b. P. angustifólia Marsh. (P. Chicaca Michx.). New Jersey to Fluridd, west to the Rocky Mountains; varieties cult. Chickasaw Plum. Fruit edible, but small.

c. P. Armeníaca L. (A. vulgaris Lam.). Eastern Asia, now wively cult. Apricot; Ger. Apricose: Fr. Abricotier. Fruit esculent. Nearly allied to this is (d) P. Sibírica L. (A. Sibirica Pers.), the Siberian Apricot.

e. P. Ávium L. (C. Avium Mnench). Europe, sparingly nat. in U. S. Crab Cherry, Gaskins, Gean, Hawk-berry, Mazard, Merry, Black Merry, Marasca (a variety), Sweet Cherry; (Ker. Susskirsche; Fr. Cerisier. Fruit esculent. Cultivated varieties are Black-heart, Bigareau, etc. From the fruit are prepared Kirschwasser, also Maraschino, Ratatia and other liqueurs.

f. 1. Caroliniána (Mill.) 4it. (L. Caroliniana Roem.). Southeastern U. S. Carolina or Ainerican Cherry-laurel, Mock Orange, Wild Orange*, Wild Peach, Winter Laurel. Properties of (i.)

g. P. Cérasus L. (C. vulgaris Mill.). Western Asia; early introduced into Enrope, now widely cult. Cherry, Agriot, Egriot, Griotte, Sour Cherry, Pie Cherry. Frut esculent. Cultivated varieties are May Duke, Morello, etc.

h. P. doméstica L. Asia, nnw widely cult. Plım, Horse Plum, Hor:e-gogs, Horse-jag, Horse-jug, Green Gage (brought to England hy a Mr. Gage). Var. Damascena is the Damson (i. e. Damascene or Damascus Plım), Dansasin (Iamas, Damsel + ); Ger. Pflaume, Zwetsche; Fr. Prunier commun ( Codex): Sp. Ciruela. Dried fruit, Prune; Prunum U. S. P., Br.; esculent, acidulous, laxative.

i. P. Lauro-cérasus L. (C. Lanrocerasus Lois., L. vulgaris Car., L. officinalis M. Rnem.). Western Asia to sonthern Europe. Cherry Laurel, Cherrv Bay; Ger. Kirschlorbeer; Fr. Lauriercerise (Codex); Sp. Laurel-cerezo. Lenves, Laurncerasi Folia, $\mathrm{Br}$, bitter, sedative, containing potentially hydrocyanic acid. 
j. P. Maháleb L. (C. Mahaleb Mill.). Southern Europe. Mahaleb Cherry; Ger. Weichselkirsche. Used as a stock for grafting.

k. P. marítima Wang. (P. sphærocarpa Michx.). Atlantic coast, Virginia and northward. Beach Plum, Sand Plum. Fruit esculent.

1. P. nígra Ait. ( $P$. mollis Tor., C. nigra Loisel, P. Americana $\Gamma$. \& Gr., not MLarsh.). Canada and northeastern U. S.; varieties cult. Canada Plum, Horse Plum, Red Plum, Wild l'lum, Pomegranate*. Fruit esculent.

m. P. Pádus L. (C. Pałus Delarb.). Europe. Bird Cherry, Hag Cherry, Hag-berry, (Egg-berry, Eck-berry, Hack-herry, Heckberry, Hic-berry), Fowl Cherry, Cluster Cherry, Cherry Bay; Ger. Faulbaum. Fruit scarcely edible.

1. P. Pennsylvánica L. f. (C. Pennsylvanica Lois., P. lanceolata Willd., C. borealis Michx., P. persicifolia Desf.). Canada aud eastern U.S. Pin Cherry, Bird Cherry, Fire Cherry, Pigeon Cherry, Red Cheıry. Fruit small and sour.

o. P. púmila L. (C. pumila Michx.). New Jersey and northward on Atlantic coast, also near the great lakes. Dwarf Cherry, Sand Cherry, Beach Plum*. Fruit acid.

p. P. serótina Erhr. (C. serotina Lois., P. Virginiana Mill., not L.). Ontario to Florida, west to Texas and Dakota. Wild Black Cherry, Cabinet Cherry, Choke Cherry*, Black•choke, Rum Cherry, Whiskey Cherry, Wild Cherry; Ger. Amerikanischer Ziersı rauch; Fr. Lerisier de Virginie. Bark, Wild Cherry bark; Prunus Virginia za, U. S. P. (a misnomer that ought to be corrected); Ger. Wildkirschen rinde; tonic, sedative. Fruit small, edible but harsh.

q. P. spinósa L. Europe, sparingly nat. in U. S. Sloe (Slea, Sloo, Slon), Sloe-thorn, Black-thorn, Buck-thorn*, Black-

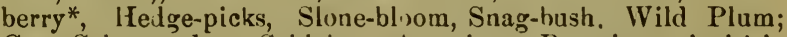
Ger. Schwarizdorn, Schlehe. A variety, P. spinosi insititia (L.) A. Gray, is the Bullace; Ger. Haferschlehe, Kriechenplaume, perhaps the original of $(h)$.

r. P. Virginiána L. (C. Virginiana Lois.). Britich America, south to Georgia and Colorado. Choke Cherry, Wild Cherry. Fruit very asıringent. (s) P. ilicifólia (Nutt.) Walp. (U. ilicifolia Nutt.) of California is called Islay, Holly Laurel and Evergreen Cherry; (t) P. subcordáta Benth., Oregon to California, is the Wild Plum of the Pacific cuast; (u) P. umbelláta Ell., southeastern U. S., is the American Black Sloe.

1669. PSICÁLIUM, Greene. Pacalium. Compositae. From (rreek, a minute "drop", or "grain". Syn. Luina, in part. Herb. One species, western U. S.

1670. PSATHYRótes, Gray (Psathyrotus). Composita.. From Greek, "brittle", of the bran hes. Syn. Tetradymia, Polydymia, Bulbostylis, in part. Low winter annuals. Four specie, Arizona to Nebraska. 
1671. PSEUDOCYIOPTERUS, Coult. \& Rose. Umbelliferae. From Greek, "false' ('ymupterus". Herbs, Three species, of western U. S.

1672. PSEUDOMAGÉNETUS, Rusch. Isclepiadacese. Shrubby climber, perhaps referable to some other genus. (a) P. Equatoriénsis, Rusch. Peru to Ecquador. Cundurango blanco, Mata perro, Bark alterative.

1673. PSEUDOPHOÉNIX, Wendl.

Sabalaceae.

From Greek, "false Date". A small palm with pinnate leaves. One species, West Indies to Florida.

1674. PSEUDOTSÚGA, Carr. False Hemlock-Spruce. Pinaceae. From Greek, "false 'Tsuga". Syn. Pinus, in part. 'Trees resembling Hemlock Sprnce. Two species, both of western U. S.

a. P. taxifólia (Lamb.) Brit. (Pin. taxifolia Lamb., Ps. Douglasii Car. (Kew), B. mucronata (Raf.) Sudw,). Puget Sound to California. Douglas Spruce, Douglas Fir, Yellow or Red Fır, Oregon Pinet. Timber valuable, especially for ship's masts. (b) P. macrocárpa (Torr.) Lemmon, Big-cone Spruce, is the Hemlock tree of southern California.

1675. PSÍIIUM, L.

Guava.

Myrtaceac.

From Greek, "pulpy", the name originally of the pomegranate. Syn. Guaiava, Adans. Trees or shrubs. About 100 species, tropical America; 2 nat. in U. S.

a. P. Cattleiánum Sabine. Brazil, cult. in all tropical countries. Purple Guava, Strawberry Guava. Fruit esculent, agreeably acid.

b. P. Guajára L. (G. pyriformis Gaertn., including P. pomiferum L. and P. pyriferum L. ). Tropical America, widely cult. and nat. in tropical countries. Guava, Common Guava, Bay Plum; Sp. Guayaba. Fruit esculent, yielding a delicious jelly. Other species also produce esculent fruits.

1676. PSILÁCTIS, Gray. Psilactis. Compositae. From Greek, "naked ray", the ray Horets having no pappus. Annual herbs. Two species, Texas to C'alifornia.

1677. PSILOCÁRPHUS, Nutt. Psilocarphus. Compositae. From Greek, "bare chaff". Syn. Benzanilla, Micropus, in part. Woolly annuals. About $\mathbf{S}$ species, all $\Lambda$ merican; $\overline{5}$ in U. S. (Pacitic border).

1678. PSILÓSTROPHE, DC. 1838. Psilostrophe. Compositae. Syn. Riddellia, Nutt. 1841 . Perennial herbs with rather small flower-heads (yellow). Three species, southwestern U. S. and Mexico.

1679. PSORÁLEA, L. Psoralca. Papilionaceae. From Greek. "scurfy". Syn. Hedysarum, in part. Herbs or shrubs with flowers in racemes, spikes or heads. About 110 species; 37 in U. S. 
a. P. corylifólia L. Arabia to India. Bauchee seed, Bawchang seed, Malay Tea. Herb and seeds tonic, alterative.

b. P. esculénta Pursh. Manitoba to Texas. Indian or Missouri Bread-root, Prairie Apple, Cree Potato, Cree Turnip, Dakota 'Turnip, Tipsin, Tipsinua; Fr. Pomme blanche, Pomme de prairie. Tubers esculent, as are the smaller ones of (c) $\mathbf{P}$. liypogaéa Nutt., Nebraska to New Mexico, Smaller Indian IBread-root.

d. P. glandulósa L. (I'. lutea Mol.). Chili. Jesuit's Tea*, Mexican Tea. Leaces used to prepare a beverage.

e. P. pedunenláta (Mill.) Vail. (P. melilotoides Michx. (Kew), H. pedunculatum Mill.). Southeastern U. S. Samson's Snakeroot, Bab's-root, Congo-root. Plant aromatic, bitter, tonic.

Other indigenous species are (f) P. floribunda Nutt. and (g) P. tenuiflóra Pursh, both called Scurfy Pea; (h) P. lanceoláta Pursh, Tumble-weed; (i) P. Onobrychis Nutt, Sanfoin Psoralea?, French-grass.

1680. PSYCHÓTRIA, L. 1759. Striated Ipecac. Rubiaceae. From Greek, "vivifying"'. Syn. Psychotrophum, P. Br.1756; Ronabea, in part. Shrubs or small trees. About 4:5 species, tropical America; 2 in U. S.

a. F. emética Mutis (R. emetica Rich.). New Granada and Peru. Root, Striated Ipecac, Peruvian or Black Ipecac; emetic. See Uragoga.

16S1. PTÉLEd, L. - Hop-tree. - Ruticeae. The Greek name of the Elm. Shrubs or small trees, fruit a nearly orbicular samara. About 6 species, $N$. America; 4 in U. S.

a. P. trifoliáta L. Ontario to northern Mexico, through eastern U. S. Three-leaved Hop-tree, Wafer Ash, Shrubby Trefoil, Ague-bark, Pickaway Anise, Prairie-grub, Quinine-tree, Sangtree, Stinking Ash, Stinking Prairie-bush, Swamp Dogwood, Wing-seed; Ger. Hopfenbaum, Kleebaum; Fr. Orme à trois feuilles. Leaves anthelmintic; Bark of root tonic, febrifuge, stomachic; fruit a substitute tor hops.

16s2. P'TEROCÁRPUS, L. 1763, not L. 1747. Papilionaceae. From Greek, "wing fruit". Syn. Lingoum, Adans. 1763. Trees. About 20 species, Asia, Africa and America.

a. P. Dráco L. West Indies. Yields a variety of Dragon'sblood.

b. P. erináceus Poir. Western Africa. Molompi, Cornwood, African Rosewood. Inspissated sap is African or Gambia Kino.

c. P. Marsúpium Roxb. (L. Marsupium (Koxb.) O. Kze.). India. Kino tree, Amboyna Kino tree, Bastard Teak, Bija. Inspissated sap, Eino, U. S. P., Br., Gummi Kino; Fr. Kino de I'Inde; Sp. Goma quino; rernacular V'engay; A powerful astringent. 
d. P. santalínus L. f. (L. santalinum (L. f.) O. Kze.). India. The wood is Red Sandalwood, Red Saunders, Red Santal, Redwood*, Ruby-wond; ¿antalum rubrum, U. S. P., Pterocarpi Lignum Br., Lignum santalinum rubrum; Ger. Rothes Sandelholz; Fr. Santal rouge (Codex); Sp. Sandalo rojo. Yields a red dye.

1683. P'TEROCAÚLON, Ell. Indian Black-root. Compositae. From Greek, "wing stem". Syn. Conyza, Chænobolus, Gnaphalium, in part. Perennial herbs. About 10 species, America and Australia; 3 in southeastern U. S.

a. P. pychnostáchyum Ell. (C. pychnostachya Michx., G. undulatum Walt.). Southeastern U. S. Indian Black-root. Root alterative, narcotic. (b) P. virgátum DC. Texas, Mexico and Wext Indies. Jamaica Golden-locks, Golden-tuft, Golden Cudweed.

1684. PTERóSPORA, Nutt. Pine Drons, etc. Monotropaceae. From Greek, "wing seeded". Syn. Monotropa, in part. Leafless saprophyte. One species, U. S.

a. P. Andromedéa Nutt. 1818. (M. procera Torr. 1818). British America, south to Pennsylvania, Arizona and Caliornia. Pinedrops, Albany Beech-drops, Giant Bird's-nest, False Crawley, Gall-of-the-earth.

1685. PTEROSTÉGIA, Fisch \& Mey.Pterostegia.Pulygonaceae. From Greek, "wing" and "covering". Herb. A single species, California.

1686. PTILÍMNIUM, Raf.1825.MockBishop-weed.Umbelliferae. Syn. Discopleura, DC. 1829; Ammi, Peucedanum, in part. Annual herbs. About 4 species, America and East Indies; 3 in U. S.

. P. capilláceum (Michx.) Hollick (A. capillaceum Michx., D. capillacea DC.). Atlantic and Fulf border of U. S.' Mock Bishop-weed, Bolewort, Bullwort, Herb William, Woodnep.

1687. PTILOCALAIS, Freene. Ptilocalais. Cichoriaceae. U. S. Syn. Microseris, in part. Herbs. Three species, western

1688. PTILONÉLLA, Nutt. Ptilonella. Compositae. Syn. Blepharipappus, in part. Herbs. Two species, western U. S.

1689. PTILÓRIA, Raf. $1832 . \quad$ Ptiloria. Cichoriaceat. Syn. Stephanomeria, Nutt. 1841, also Lygodesmia, in part. Herbs with small heads of pink flowers. About 20 species, western and central N. America; 18 in U. S.

1690. P'TYCHÓTIS, Kóch. Bishop's-weed. Umbelliferae. Syn. Carum (Kew), Ammi, in part. Herbs related to Carum. A few species, Mediterranean region to India. 
a. P. Cóptica (L.) Lyons (A. Copticum L., C. Copticum Benth. (Kew), U. Ajowaı Brniley, P. Ajowan DC.). Hindustan. Ajowan, Ajouan, Ajava, Javanee; Fr. Ammi ofticinal (Codex). Fruit aromatic, antispasmudic, used like caraway seed; contains thymol.

1691. PULICÁRIA, Gaertn. Fleawort. Compositae. Latın, "fleawort". Syn. Inula, in part. Herbs. About 30 species, mostly of Mediterranean region.

a. P. dysentériıa (L.) Gaerın. (I. dysenterica L.). Southern Europe. Fleawort, Fleabane, Fleabane-mullet, Cammock*, Herb Christopher*; Ger. Flohkraut; Fr, Pulicaire. Herb insecticide.

1692. PULMONíRIA, L. Lungwort. Boraginaceae. Latin, "lungwort". Hispid perennial herbs. About 6 species, Eurupe and Asia.

a. Y. officinális L. Europe. Lungwort, Jerusalem Cowslip, Bunloss or Bedlam Cowslip, Spotted Lungwort Suotted Comfrey, Spotted-Mary, Beggar's-basket, Joseph-and-Mary, Sage of Bethlem, Save if Jerusalem; Ger. Lungenkraut; Fr. Pulmonare ufticinale (Codex). Herb demulcent.

1693. PULSATÍLLA, Adans. Pasque-flower. Ranunculaceae. Name unexplained. Syn. Anemone (Kew), Clematis, in part. Perennial scapose herbs. About 18 species, noith temperate zone and north ward; 2 in $\mathrm{U}$. S.

a. P. hirsutíssima (Pursh) Brit. (C. hirsutissima Pursh., A. jatens (Kew I, var Nuttalliani A. Gray, A. Nuttalliana DC.). Texar to Nebraska and British I olumbia. American Pulsatilla, American or Nutıall's Pasque-flower, April-fool, Badger-weed, Easter-flower, Gosling, llartshorn plant, Headache plant, May-Hower, Prairie Anemone, Prairie or Wild Crocus. Properties of (b).

b. P. pratéusis (L.) Mill. (A. pratensis L.) and (c) P. Pulsatílla (L. ) Lyons (A. Pulsatilla L., P. vulgaris Mill.). Europe and northern Asia. Pulsatilla, European Pulsatilla or Pa:que-flower, Dane's-blood. liaster-flower; Ger. Kücheıschelle, Pulsatille; Fr. Anemone Pulsatille, Coquelourd (Codex), Sp. Pulsatila. The Howering herb of both species, Pulsatilla. U. S. P.; alterative, antispasmodic.

1694. PÚNICA, L. $1753 . \quad$ Pomegranate. Punicaceae. The Latin name, "Carthagenian" fruit. Syn. Granatum, St. Lag. 1S80. Shrub. One species, northern Africa and western Asia.

a. P. Granátum L. (G. Punicum St. Lag.). Pomegranate, Carthaegnian or Punic Apple, Garnet Apple, Bala:ısta, Balaustine; Ger. Granatbaum; Fr. Grénadier (Codex), Balustier; Sp. Granado. Bark of stem anil root, Granatum, U. S. P., Granati Radicis Cortex, Br., Cortex Granati P. G., Tænicide, containing the alkaluid pelletierine. Rind of fruit Cortex psidii, Cort. malıcorium; astringent used in tanning morocco leather. Flowers, Flores balaustii, Balaustia, astringep̣t. Fruit acidulous, esculent. 
1695. PÚYA, Mol. (Puja).

From vernacular (Chili). Shrubby or arborescent plants. Peru.
Puya. Bromeliaceae. Syn. Pourretia, R. \& Pav. About 5 species, Chili and

a. P. lanuginósa Schult. (Pourretia lanuginosa R. \& P.). Chili. Source of Chagual gum.

1696. PÝROLA, L. Wintergreen, Shin-leaf, etc. Pyrolaceae. Latin from pyrus (Pear), from similarity of leaves. Perennial scapose herbs. About 15 species, northern hemisphere; 11 in $\mathrm{J} . \mathrm{s}$.

a. P. ellíptica Nutt. British America, south to Maryland, Illinois and New Mexico. Shin-leaf, Wild Lily of-the-valley. (b) $\mathbf{P}$. chlorántha Swz. and (c) P. mínor L. are also called Shinleaf.

d. P. rotundifólia L. Europe, Asia and northern N. America, south to Georgia, west to Minnesota. Round-leaved Wintergreen, False Wintergreen, Laryer Wintergreen, Pear leaved Wintergreen, Canker Lettuce, Wild* or Indian Lettuce, Consumption-weed, ('opper-leaf, Dollar-leaf, Liverwort Lettuce; Ger. Waldmangold; Fr. Pyrule. Leares astringent, diuretic. The other species have similar properties.

1697. PYRócoMA, Hook. Pyrocoma. Compositae. Syn. Aplopappus (Kew), in part. Rigid perennial berbs; 26 species in U. S., Pacific border.

1698. PYRULíRIA, Michx. Buffalo-nut, etc. Santalaceae. Latin, "pear like". Syn. Hamiltonia, in part. Shrubs or small trees. Two species, one in Asia, one in U. S.

a. P. púbera Michx. (P. oleifera A. Gray, H. oleifera Muhl.). Pennsylvania to Georgia. Oil-nut, Buffalo-nut, Elk-nut. Seeds rich in oil.

1699. PÝRUS, L. (Pirus). - Pear. . Pomaceae. Latin name of the Pear. Trees or shrubs. About 12 species, Old World. See Cydonia, Malus, Mespilus and Sorbus.

a. P. commúnis L. Europe and central Asia, and widely cult. Pear. In the wild state called Choke Pear; Ger. Birnbaum; Fr. Poirier.• Firuit esculent.

1700. PYXIDANTHÉkA, Michx. Pyxie, etc. Iiapensiaceae. From Greek, "box anther". Syn. Diapensia, in part. Dwarf evergreen shrub. One species; (d) P. barbuláta Michx. (D. barbulata Ell.). New Jersey to N. Carolina. Flowering Moss, Pyxie, Pyxie Moss, Pine-barren Beauty.

1701. QUAMíSLA, Raf. 1818. (Quamassia). Liliaceae. From vernacular Indian name. Syn. Camassia (Kew), Lindl. 1832; Lemotrys, Scilla, in part. Scapose herbs from meinbranous-coated bulbs. About 5 species, all of U. S. 
a. Q. esculénta (Ker.) Coville (C. esculenta Lind. (Kew), L. hyacintha Raf., S. Fraseri Gray, C. Fraseri Torr. ). Pennsylvania to Minnesota, south to Texas. Eastern Quamash or camass, Wild Hyacinth. Bulb esculent.

1702. QUÁMOCLIT. Moench. Cypress vine. Convolvulaceae. Syn. Quamoclita; I pomoea, in part. Herbaceous twiners. About 10 species, warm and tropical regions; 2 nat. in U. S. viz. (a) Q. cuccínca (L.) Moench, Small Red Morningglory, American Jasmıne; (b) Q. Quamolit (L.) Brit. (Q. vulgaris Choisy), (ypress vine, American hed Bell-flower. Indian Pink, Red Jasmine, Sweet-William (Barbados).

1703. QUÁSSIA, L. - Quassia. - Simarubaceae. Named for Quassi (or Choisi), a negro of Surinam. Trees with bitter bark and wood. Two species, one in Africa, one in tropical America.

a. Q. amára L. Surinam. Surinam Quassia. Wood, Lignum Quassiæ P. G., in part (See Picrasma excel+a), Lig. quassiæe surinamensis; Ger. Quassienholz, Bitterholz, Fliegenholz; Fr. Quassie amère, Bois amer de Surinam (Codex); bitter, tonic.

1704. QUÉRCUS, L.

Oak.

Fagareae. The ancient Latin name, of Celtic origin. Trees or shrubs, fruit an acorn. About 200 species, northern hemisphere; 66 in U. S.; Ger. Eiche; Fr. C'hêne; Sp. Encina.

a. Q. acumináta (Michx) Sarg. (Q. Muhlenbergii Engelm.). Untario and eastern U. S. Chestnut Oak. Chinkapin (Chinquapin) Oak, Yellow Chestnut Oak; Yellow, Pin, Scrub or Shrub Oak. Acorns edible, as are those of (b) Q. Michaúxii Nutt., Cow Oak, Basket Oak and (c) Q. prinoídes Willd., Scrub Chestnut Oak, also called Chinkapin Oak. See (m), (o) and $(p)$.

d. Q. aégilops L. South Europe to Syria. Acorn cups, Valonia (Vallonea); Fr. Vallone, Gallon, also unripe acorns, Camata, Camatena, used in dyeing and tanning.

e. Q. agrifólia Nee. California and Mexico. Encino, Live Oak (of California), this name applying also to (f) Q. chrysólepis Liebm., a smaller tree, Maul Oak, Valparaiso Oak, and to (g) Q. oblongifólia Torr., of southern California. See (v).

h. Q. álba L. Canada and eastern U. S. White Oak, Stone Oak. Bark; Quercus Alba, U.S. P., Cortex quercus, a powerful astringent. Timber strong and durable. Closely allied to this are (i) Q. minor (Marsh.) Sarg. (Q. albus minor Marsh., Q. obtusiloba, Michx.), eastern U. S., Post Oak, Iron Oak, Brash Oak, Box White Oak, Rough White Oak, Turkey Oak, White Oak, and (i) Q. macrucárpa Michx. 1810 (Q. olivæformis Michx. 1812), Canada to Texas, Mossy-cup Oak, Bur Oak, Blue Oak, Over-cup Oak, Scrub Oak. The Over-cup Oak or Post Oak of the southeastern U. S. is (k) Q. Iyráta Walt., called also Water White Oak and Swamp Post Oak. 
1. Q. coccífera L. Mediterranean region. Kermes Oak, Cochineal Oak. The food plant of the European cochineal or kermes insect. [The historic oak of David or Abraham's uak is of this species].

m. Q. Ílex L. Southern Europe. Holly Oak, Evergreen Oak; Fr. Chêne vert (C'odex). Acorns, Chestnut acorns, Balluta, edible.

1. Q. Lusitánica Lam. (Q. infectoria Oliv.). Mediterranean region. Gall Oak. Exerescences cansed by an insect, Nutgalls, Galla, Oak-apples, Oak-warts; Galla, U. S P., Br., Galla halepense, Galla turcica v. levantica v. tinctoria v. quercina; Ger. Galläpfel, Gallen; Fr. Galle de chêne d'Alep, Noix de galle d'Alep (Codex); Sp. Agallas de levante; varieties are Aleppo, Smyrna and Sorian galls; astringent, source of tannin. See $(0)$ and $(w)$.

o. Q. lobáta Nee. California. Sacramento White Oak. Excrescences, Oak-balls, are California Nutgalls. Acoıns once the chief food of the aborigines.

p. Q. Prínus L. Canada and northeastern U. S. Rock Cliesinut Oak, Swamp or White Chestnut Uak, Mountain or Rock Oak, Tan-bark Oak. Bark much used in tanuing. Acorns edible.

q. Q. Róbur L. (Q.pedunculata Erhr.). Europe and western Asia. European White Oak (Wuke, Wuk, Yak), British Oak, Enylish Uak; Ger. Steineiche, Somwereiche; Fr. Chêno Ilanc (Codex). Bark official iu British, Gernan and Frtnch pharmacopoeias. See (h). Acorns (Yackrons) of this and other species, Jove's Nuts, Glandes quercus (tostae), a suhstiute for Coffee (Eichelkatfee). Timber used for ship-building, etc. Allied to this is (r) Q. sessiliflóra Martyn (Q. Robur Willd.). Durmast Uak, Bay or Marden Oak.

8. Q. Súber L. Southern Europe and northern Africa. Cork Oak, Cork-tree, European Alcornoque. Outer bark, corkwood, is common cork. Cork is procured also from $(t)$ Q. occidentális Gay and from (u) Q. Pseudo-súber Santi ( $Q$. suber Kotschy).

v. Q. Virginiána Mill. (Q. virens Ait.). Sontheastern U. S. to Mexico and Cuba. Live Oak. T'imber used in ship building.

w. Q. velutína Lam. 1783 (Q. tinctoria Bartr. 1791, Q. coccinea var. linctoria A. Gray). Canada and eastern U. S. Black Oak, Dyer's Oak, Quercitron Oak, Female or Spotted Oak, Yellow-bark Oak. Bark yields the yellow dye quercitron (i. e. oak yellow). Galls called Oak-plums.

Other notable species of eastern U. S. are $(x)$ Q. coccínea Wang., Scarlet Oak; Red, Black or Spanish Oak; (y) $\mathbf{Q}$. Marılántica Moench (Q. nigra var. b, L.), Black-Jack, Jack Oak, Barren or Iron Oak; (z) Q. nána (Marsh.) Sarg. (Q. ilicifolia Wang.), Bear Oak, Scrub Oak, Bitter or Barren Oak, Bitter-bush, Holly Oak, Dwarf Black Uak; (aa) Q. nigra L. 
(Q. aquatica Walt.), Water Oak, Black-Jack*; Barren, Duck, Pus-um. Punk or Spotted Oak; (bb) Q. Phéllos L., Willıw Oak, Peach Oak, Sand Jack Oak, and (cc) (Q. rúlora L., Red Uak, Black Uak*, Champion or Spanish Oak.

1705. QUILLÁJA, Mol. (Quillaia). Soap bark. Rosaceae. From vernacular Quillıi, Chilı. Evelgreen trees with thick veiny leaves. About 4 species, South Anerica.

a. Q. Saponária Mol. (Q. Molina DC.). Chili to Peru. Soapbark tree, Soap tree, Quillaya (Quillai, Cullay). Bark, Snapbark, Quillaja, I.. S. I'.; Ger. Si-ienrinde, Panamarinde; detergent, an emulsitier; cuntans saponin. (b) (2. smegmadérmos UC: also yielıls Suap-bark.

1706. QUíNCLLA, Raf. Quincula. Solanaceae. Syn. Physalis (Kew), in part. Perennial scurfy herb. One species, southwestern U. S. and Mexico.

1707. RAFFLÉSIA, R. Br. Raflesia. Rafflesiaceae. Nimled fir Sir Stamford Raffles, its discoverer. Leafless and stemless parasiter, the priant consisting practically of a single flower. Abum 8 species, Sumatra and Java The flower of (a) R. Arnóldi R. Br. (R. 'litan Jack.) is a meter in dianeter.

1708. RAILARDÉLLA, Gray. Railardella. Compositae. Dimuntive of Railardia. Stemless perennial herbs. About 4 species, C'alifurnia.

1709. RAMóXı, Greene. - Ramona. - Labiatae. Syn. Aulibertia, lienth., in part. Shrubs or undershrubs, clisely allied to Salvia. About 10 species, all of California.

1710. RÁNIIA, L. - Randia. - Rubiaceae. Named for Isaac Rand, botanist of London, 18th Century. Trees or shrub. About 100 species, tropical regions, especially of Asiu and Airica; 1 in U. S.

a. R. aculeáta L. West Indies to Florida. Indigo-berry, Inkberry. Fruil yields a blue dye.

b. R. dumetórum Lam. Africa to'Java. Malabar Ipecac. Fruit emetic, user to stupefy fish.

1711. RaNúxCULUS L. Crowfont, etc. Ranunculaceae. Latin diminutive, "froglet", some species being paludal. Acrid herbs. About 200 speries, temperate and cooler regions of both hemispheres; 41 in U. S. Synonyms are Buttercup, Creesy, Gildeups, Golland.

a. R. abortívus L. Canada and eastern U. S. to Colorado. Chicken Pepper, Kidney-leuved Crowfoot\%.

b. R. aconitifólius L. Europe, cult. in gardens. Garden Buttercup. 'The double white variety is called White Bachelor'sbuttuns (Fr. Boutons d'argent), Fair-maids-of-France, Fairmaids-of-Kent. 
c. R. ácris L. Europe, nat. in U. S. Tall or Meadow Buttercup, Field Buttercup, Buttercup, Goldicup, Gold-knops, Golden-knops, Guilty-cup, King-cun, Blister-flower, Blister-weed, Butter Cress, Butter Daisy, Crazy, Cuckoo-buds, Horse-gold, Mary-buds (Shakespere), Paigle*, Yellow-caul, Yellow C'res3, Jellow (towan (Scotland); the double variety, Yellow Bachelor's-buttons; Ger. Hahnenfuss; Fr. Renoncule. Plant, as in most species, acrid, rubefacient, counter-irritant.

d. R. arvénsis L. Europe, adv. in U. S. Corn Crowfoot, Hunger-weed, Devil's-claws, Grold-weed, Hell-weed, Horse-gold. This species and (e) R. aurícomus L., the European Goldilocks, are but slightly acrid.

f. R. bulbósus L. Europe, sparingly nat. in U. S. Bulbous Buttercup, Frogwort, Frostwort, Gill-cup, Meadow-bloom. Palewort, Pissabed, St. Anthony's Rape, St. Anthony's Turnip (i. e. Hog's 'Turnip), with most of the synonyms of (c).

g. R. delphinifólius Torr. (R. lacustris Beck. \& Tracy, R. multitidus Pursh, not Forsk. ). Ontario and eastern U. S. Yellow Water-crowfoot, Water Buttercup.

h. R. répens L. Europe, nat., perhaps also indigenous, in U. S. Creeping Buttercup\%, Meadow or Spotted-leaf Buttercup, Devil's-guts, Granny-threads, Hod-the-rake, Lantern-leaves, Meg-many-feet, Rarn's-çlaws, Sitfast, Setsicker, Tether-toad, with most of the synonyms of (c). Indigenous Buttercups are (i) R. Pasciculáris Miuhl., Canada and northern U. S., Early, Dwarf, Low or Fusted Buttercup, Cowslip* and (j) R. septentrionális Poir., Marsh, Swamp or Early Buttercup.

k. R. scelerátus L. Eurnpe, Asia and N. America, in swamps and ditches. Cursed Crowfont; Celery-leaved, Marsh or Ditch Crowfoot, Water Celery $\ddagger$, Blisterwort, Biting Crowfoot, Ache*

1712. RÍPHANUS, L. - Radish. - Cruciferae. From Greek. Herbs, mostly bieunial with showy Howers. About 6 speries, Europe and temperate $A$ sia; 2 nat. in U. S.

a. R. Raphanístrum L. Europe and northern Asia, nat. in U. S. Wild Radish, Jointed Charlock, White Charlock, Cadlock, Skedlock, Curlock, Warlock, Krautweed, Black Mustard*, Rape*. Seeds pungent like those of mustard.

b. R. satívus L. Asia, widely cult. Radish, Common or Garden - Radish (Rabone, Rawbone, Reefort). Root antiscorbutic, esculent. Pods of some varieties used as salad.

1713. RATÍBIDA, Raf. 1818. Cone-flower. Compositae. Name unexplained. Syn. Lepachys (Kew), Raf. 1819;. Rudbeckia, in part. Perennial herbs with large flower-heads, rays yellow. About 4 species, all of U. S. (a) R. columnáris (Sims) D. Don, Long-headed or Prairie Cone-flower, is also called Brush.

1714. RA VENÁLA, Adans. 1763. (Ravanella). Musaceae. Syn. Urania, Schreb. 1789. Arborescent plants with huge 
leaves of firm texture. 'T'wo species, S. America and Madagascar. (a) R. Madagascariénsis conner. (U. speciosa Willd, U. Ravenalia Rich.), is the 'Traveler's tree of Madagascar.

1715. RAZOUMÓFSKY., Hoffm. 1808.

Loranthaceae.

Named for Alexis Razoumofski, Russian botanist. Syn. Arceuthobium, Bieb. 1S19. Simall or minute parasites on coniferous trees. About 12 species, all but two of $\mathrm{N}$. America; 9 in U.S.

1716. REMIGIA, DC. . Cuprea bark. Rubiaceae. Named for Dr. Remijo who first used the bark in place of Cinchona. Syn. Cinchona, in part. Trees. About 15 species, S. America.

a. R. pedunculáta Flueck (C. pedunculata Karst.) and (b) R. Purdieána Wedd. Colombia. Bark of both called Cuprea bark; contains quinine.

1717. RESÉDI, L. Mignonette. Resedaceae. The ancient Latin name, "avaunt", a word used in incantations. Herbs. About 55 species, Old World; 3 nat. in U. S.

a. R. Lutéola L. Eurnpe, adv. in U. S. Dyer's Rocket, Ash-ofJerusalem, Dyer's-weed, Dyer's Mignonette, Italian or Yellow Rocket, Yellow-weed, Weld, Wild Woad, Wild-wood; Ger. Gelbkraut, Wau, Waid. Plant diaphoretic, diuretic. Yields a yellow dye, gaude, also a pigment called Dutch pink.

b. R. odoráta L. North Africa to Srria, cult. in gardens. Mignonette, Garden or Common Mignonette.

1718. REVERCHÓNIA, Gray. Reverchonia. Euphorbiaceae. Annual herb. One species, Texas.

1719. REYYósIA, Griseb. Darling Plum, etc. Rhamnaceae. Named for Prof. Alvaro Reynoso, chemist of Havana. A shrub producing an edible fruit. One species. (a) R. latifólia Griseb., Florida and West Indies, Darling Plum, Red Ironwood, Bullet tree.

1720. RHAMNÍDIUM, Reiss. Black Ironwood. Rhamnaceae. From Greek, "Rhamnus-like". Syn. Condalia, Rhamnus, Scutia, in part. Shrubs or small trees. About 7 species; warmer regions of Ameríca; 1 in southern Florida, viz. (a) R. férreum (Vahl.) Sarg. (C. ferrea Griseb.), Black Ironwood.

1721. RHÁMNUS, L. Buckthorn. Rhamuaceae. From the ancient Greek name. Rhamnus is now made uniformly feminiue by botanists. Syn. Alaternus, Cervispina, Frangula, in part. Shrubs. About 75 species, temperate and warm regions; 15 in U. S.

a. R. Alatérnus L. (A. Phyllica Mill.). Europe, cult. in U. S. Evergreen Privet, Alaternus. Lecices suppress secretion of milk. 
b. R. Caroliniána Walt. (F. Caroliniana A. Gray, F. fragilis Kaf.). Southeastern U. S. Southern or Carolina Buckthurn, Alder Buckthorn, Bog Birch, Indian Cherry. Bark laxative. (c) R. alnifólia L'Her., northern U. S. and northward, Alderleaved Buckıhorn, is called Dwarf Alder.

d. R. cathártica L. (C. cathartica Moench). Europe, northern Africa tn middle Asia. Buckthorn, Purging Buckthorn, Hart'sthorn, Rhineberrv, Rain-berry Thorn, Way-thorn; (ier. Kreuzdorn, Hirschdorn; Fr. Neprun purgatif (Codex); Sp. Ramno calartico, Espina cerval. Fruit, Fructus rhamıni cathartici, Baccæ spinæ cervinæ, Baccae domesticæ, hydragngue cathartic; source of sup green and bladder green, used in dyeing. (Lokao or Chinese green iniligo is a similar product obtained from (e) R. tinctória Waldst. \& Kit. (R. chiorophora Decne.) and (f) R. Dahúrica Pal. (R. utilis Decne.).

g. R. Frángula L. (F. vulgaris Reich., F. Alnus Mill. ). Europe, northern Africa to middle Asia, sparingly nat. in U. S. Alder Buckthorn, Black Alder*, European Black Alder, Berry Alder, Arrow-wood, Butcher's-prick । ree, Alder Dogwond, Black Dogwood; Ger. Faulbaum, Glatter Wegedorn, Pulverholz; Fr. Bourdaine, Bourgène. Bark (at least one year uld); Frangula, U. S. P., Rhamni Frangulæ Uortex, Br.; laxative. Charcoal from the woud is used for gunpowider.

h. R. infectória L. (R. tinctoria Mutel.). Mediterranean region. Fruit French berries, Yellow berries; Ger. Gelbbeeren; Fr. Graines d'Avignon; yield a green dye. The similar Persian berrie: and Turkish berries are from (i) R. oleoídes L. (R. amygdalina Desf.), and (j) R. saxalílis L., also perhaps other species.

k. R. Purshiána DC. Northern California, northward. Bearberry tree, Bearwond, Shittim-wond, Cascara Sagrada tree. Burk, Chittam or Chiltim bark, Cascara Sagrada, Sacred bark, Purshiana bark, Persian $\ddagger$ bark, Wahor*: h hamnus Purshiana, U. S. P.; laxative. The bark of (1) R. Californica Esch., the Califurnia Coffee-tree, is also gathered as Cascara Sagrada. Berries of this have heen uved as a substitute for Coffee. (m) R. Wíghtıi W. \& A. of the East Indi+'s yields also a laxative bark.

1722. RHA PHIDOPHÝLLA, Wend. \& Drude. Sabalacere. From Greek, "Rhaphis-leaved". Syn. Chamærops, in part. A low tan-palm. One species, (a) R. hystrix (Fraser) W. \& D., Florida to S. Carolina; Blue Palmetto.

1723. RHÉUM, L. Rhubarb. Polygonaceae. The Greek name, perhaps from Rha the ancient name of the Volga. Stout herbs from thick rootstocks. Abnut 20 species, Asia.

a. R. austrále D. Don (R. Emodi Wall., R. Webbianum Royle). Himalayan region. Yields medicinal rhuharb.

b. R. hýbridum Murray. Central Asia. This species may be one of those yielding commercial rhubarb. 
e. R. officinále Baill. Central Asia. Chinese Rhubarb plant. Believed to be the source of the best Chinese rhubarb. Root Rhubarh; Rheum, U. S. P., Rhei Radix, Br.; Ger. Rhabarher, Echte Rhabarber; Fr. Rhubarbe de Chine (Codex); Sp. Ruibarbo. Laxative, cathartic, but also astringent.

d. R. palmátum L. Central Asia, cult. in Europe. Rhubarb plant. Source of the Rusvian rhubarb formerly highly valued and of some of the European rhubarb; Fr. Rhubarbe de Moscovie (Codex). Properties of (c).

e. R. Rhapónticum L. Eastern Europe and central Asia. Rhapontic Rhubarb, Pie-plant, Wine Rhubarb; Ger. Rhapontikrhabarber, Inländische Rhabarber, Fr. Rhamontic (Codex, employed only in veterinary medicine). Ront. Radix rhei indigeni v. nost ratis. Roots cunstitute French, English and Hungarian rhubarh which are inferior to Chineve rhubarb. Leaf stulls esculent. Srime other species, as (f) R. undulátum L. and $(\mathrm{g})$ K. Tatáricum L. fil. are used in a similar manner.

1724. RHÉXIA, K. Meadow-Beauty. Melastomaceae. A Greek plant name, meaning "brittle". l'erennial herbs with showy Howers. About 10 species, all in U. S.

a. R. virgínica L. Eastern U. S. Meadow-beauty, Deer-grass, Handsome-Harry.

1725. RHINACáxthus, Nees. Rhinacanthus. Acanthaceae. From Greek, "nose Acanthus", alluding to shape of flower. Shrubs. About 6 species, natives of India.

a. R. commúnis Nees. (Justicia nasuta L.). India to China. Ringworm-root. Leaves and root, containing rhinacanthin, used for cure of ringworm.

1726. RHINÁNTHUS, L. Rattle-box, etc. Scrophulariaceae. From Greek, "nose flower". Herbs. About 3 species, northern hemisphere; 1 in U. S.

a. R. Crista-Gálli L. [R. minor Erhr. (Kew)]. Northern Europe, Asia and N. America. Rattle, Rattle-box, Yellow or Penny Raitle, Penny-grass, Rattle-bags, Money-grass, Yellow Cockscomb. Plant insecticide.

1727. RHIZÓPHORA, L. Mangrove. Rhizophoraceae. From Greek, "root bearing". Trees with aerial roots. About 3 species, tropical coasts and river margins; 1 in U. $\mathrm{S}$.

a. R. Mángle L. (R. racemoza Merer, R. Americana Nutt.). Florida, and on tropical shores generally. Mangrove, Mangue, Red Mangrove (a variety); Fr. Manglier. Bark astringent, febrifuge, used in dyeing and tanning.

1728. RHODOIÉNDRUN, L. Rose-Bay, etc. Ericaceae. From Grek, "rose tree", name nriginally applied to the Oleander. Evergreen shrubs, with showy flowers. About 100 species, northern hernisphere, especially in Asia; 10 in U. S.

a. R. Catawbiénse Michx. Virginia to Georgia. Mountain Rose-bay, Catawba or Caroliua Rhododendron. Highly ornamental. 
b. R. chrysánthemm Pall. Siberia. Yellow Rhododendron, Siberian Rose, Snow Rose; (ier. Sibirische Alpenrose. Leaves diuretic, narcotic. (c) R. ferrugíneum L., Europe, Dwarf Rose-bay, has similar properties.

d. R. máximum L. Canada to Georgia. Great Laurel, Rosebay, IVild Rose-bay, Rose Laurel, IBig Laurel, Big-leaf Laurel, Deer Laurel, Horse or Mountain Laurel, Cow-plant, Spoonhutch. Properties of (b). Wood used for engraving.

1729. RHODÓRA, L. Rhodora, Lamb-kill. Ericaceae. From Greek rhodon, a "rose". Syn. Rhododendron, in part. A shrub with deciduous leaves. One species. (a) R. Canadénsis L. (Rhododendron Rhodora J. F. Gmel.). Canada and northeastern U. S.

1730. RHÚS, L. 1753. Sumac (Sumach), etc. Anacardiaceae. The ancient Greek name. Syn. Toxicodendron, Mill. 1759; Metopium, Styphonia, in part. Shrubs or trees with odd-pinnate or trifoliate leaves, many poisonous. About 120 species, warmer regions, especially of S. Africa; 19 in U.S.

a. R. aromática Ait. ( T. crenatum Mill., R. Canadensis Marsh, not Mill.). Canada and eastern U. S. Fragrant Sumac, Sweet-srented Sumar: Root bark astringent, a remedy in eneuresis.

b. R. Coriária L. Europe. European Sumac, Tanner's Sumac; Ger. Sumach, Schmack.

c. R. glábra L. (T. glabra Mill.). British America, south to Florida and Arizona. Smooth Sumac, Mountain or Upland Sumac, Scarlet or Sleek Sumac, Yennsvlvania or White Sumac, Senhalanac, Sumach, Shue-makeł, Vinegar tree. Fruit; Rhus glabra, U. S. P., astringent, acidulous.

1. R. hírta (L.) Sudw. (Datisca hirta L. 1753, R. typhina L. 1760). Cauada and eastern U.S. Staghorn Sumac, Staghorn, American or Hairy Sumac, Virginia or Velvet Sumac, Vinegar tree. Properties of (c). The smalier (e) R. copallína L. of the eastern U. S. is called Dwarf, Black, Upland or Mountain Sumac. The Califoruian (f) R. integrifólia B. \& H. (S. integrifolia Nutt. ) is called Mahogany*. Leaves and bark of most species of Rhus are used in tanning.

g. R. Metópium L. (M. Linnea Engelm., R. oxymetopium Griseb. ). Florida to IVest Indies and S. America. Mountain Manchineel, Coral Sumac, Bum-wood. Poison-wood. Properties of (h). Gummy exudate, hog gum, doctor's gum, emeto-catharic.

h. R. rádicans L. (R. Toxicodendron Auct. (Kew), not L., T. vulgare Mill.). British America south to Florida, Arkansas. and Utah. Poison Ivy, Climbing or Three-leaved Ivy, Climath, Climbing or Trailing Sumac, Black Mercury, Markerył, Markweed. Picry, Poison Oak, Poison-vine; Ger. Giftsumac, Giftbaum; Fr. Sumach rénéneux; Sp. Zumaque venenoso. Fresh leaves; Rhus Toxicodendron, U. S. P., Folia toxicodendri; diaphoretic, diuretic, stimulant to nervous system. The Poison 
Oak of California, called also Yeara, is (i) R. diversíloba $T$. \& Gr. (R. lobata Hook., not Poir.). The Poison Oak of the southern States is the more shrubby (j) R. Toxicodéndron I. (T. magnum Snend.), the three species active skin poisons.

k. R. semialáta Murr. China, Japan, nat. in Hawaiian Islands Chinese Sumac. Excrescences on the leaves are the Chinese Nut-galls. The Japanese nutgalls are a' similar product from (1) R. Japónica Sieb.

m. R. succedínea L. Japan. Japanese Wax-tree. Fruit, source of Japan vegetable wax. (n) R. Chinénsis Mill. in China furnishes a similar wax.

o. R. vernicifera DC: (R. Vernix Thunb. not L.). Japan. Japanese Varnish tree, Lacquer tree. Exudate constitutes. Japanese lacquer.

p. R. Véruix L. (R. venenata DC. (Kew), T. pinnatum Mill.). Ontario and eastern U. S. Poison Sumac, Swamp Sumac, Poison tree, Poison Elder, Poison Ash, Poison Dogwood, Swamp. Dogwood. ' Properties of (h).

1731. RHXNCHÓSIA, Lour. 1790: Red-bead vine.Papilionaceae. From Greek, "snout", alluding to keel of corolla. Syn. Dolicholus, Medic. 1787; Glycine, Trifolium, in part. Perennial herbs. About 100 species, warmer regions; 14 in U. S. (a) R. phaseoloíles DC. (R. precatoria DC.) of tropical America is the Mexican Rosary plant or Red-bead vine.

1732. RÍBES, L. (Ribesium). Currant. etc. Grossulariaceae. Name of uncertain origin. Syn. Grossularia, Adans. Shrubs producing berries generally edible. About 60 species, north temperate zone, especially of New World and S. America; 47 in U. S.

a. R. aúreum Pursh. U. S. west of the Mississippi. Buffulo Currant, Flowering Currant, ('love Currant, Golden or Missouri Currant.

b. R. Cynósbati L. (G. Cynosbati Mill.). Canada to N. Carolina, west to Missouri and Manitoba. Wild Gooseberry, Prickly Wild Goostberry, Dogberry. Fruit esculent. The Northern Gooseberry is (c.) R. oxyacanthoídes L. (R. hirtellum Micbx.), British America, south to ()hio and Colorado; Smooth.. Wild Gooseberry, Hawthorn Gooseberry. The Eastern Wild Gooseberry or Smooth Gooseberry is (d) R. rotundifólium Michx., Massacbusetts to N. Carolina.

e. R. nígrum L. (G. nigra Mill.). Europe. European Black Currant, Blackberry*, Quinsv-berry; Ger. Gichtbeere, Aldbeere; Fr. Cassis (Codex). Leaves diuretic. Fruit antiscorbutic. The American Wild Black Currant is (f) R. flóridum L'Her. (R. Pennsylvanicum Lam.), Canada to Kentucky, west to Nebraska. The Northern Wild Black Currant is. (g) R. Hudsoniánum Richards, British America to Colorado. 
h. R. rúbrum L. (R. albinervum Michx.). Europe, Asin aud N. America, south to New Jersey, Indiana and Minnesota. Red Currant, Garnet-berry, Raspberryt, Wine-berry, Raisin tree, Rizzles, Rizzer-berry, Giarden Currant; a cultivated variety is White Currant [The name Currant (i. e. Corinthian) was first applied to the seedless grape. See Vitis]; Ger. Johannisbeere; Fr. Groseillier rouge (Codex). Fruit, Ribia rubra, Ribesia rubra, acidulous, refrigerant, esculent.

i. R. Uva-críspa L. (R. Grossularia L. (Kew), G. Uva-crispa Mill. ). Europe and Asia, cult. and nat. in U. S. Garden Goose berry, Feaberry (i. e. Feverberry), Fayberry, Feabes, Fabes, Fapes, Grozet or Groserts (Scotland) Gozelle, (roggles, Gaskins, Goose gog8, Carberry, Cat-herry, Day-berry, Eat-berry, Wineberry, Honey-blob, Tea-berry, Berry tree; Ger. Krauselbeere, Stachelbeere; Fr. Groseille. Fruit esculent.

1733. RICHÁRDIA, L. not Kunth. (Ricardia). Rubiaceae. Syn. Richardsonia (Kew), Kunth 1818. Herbs. About 8 species, warmer regions of New Wurld; 2 in U. S. See Zantedeschia.

a. R. scábra L. (R. pilosa R. \& P., Richardsonia pilosa H. B. K. (Kew), Richardsonia scabra St Hil.). Brazil, nat. in southern U'S. Mexican Clover, Spanish or Florida Clover, Water Paroley*. Root, Undulated or Farinaceous I pecacuanha, emetic. Plant valued for pasiure and fodder. Another Ipecacuanha (small striated) is helieved to be derived from a Richardia.

1734. RICINÉLLA, C. \& F Ricinella. Euphorbiaceae. Latin, diminutive from "Ricinus". Oue species in western U. S.

1735. RÍCINUS, L. Castor Beın Euphorbiaceae. Latin, from ancient Greek name of the plant, the name being applied also to an insect (tick) which resembles the seeds of this plant. Syn. Cataputia, Ludw. 1760. Herbaceous shrub, in warm climates even arbore-cent. One exceedingly variable species, Africa and Asia.

a. R. commúnis L. (R. vulgaris Mill., R. medicus Forsk., C. minır Ludw.). Southern Asia, nat. in all tropical countries, as in the southern U. S. Castor-oil plant, Palma Christi, Mexico seed, Man's-mother-wort, Oil-seet, Oil-nut, S edfast; Ger. Wunderbaum; Fr. Ririn (Corlex); Oil from the seeds, Castor oil; Oleum ricini, U. S. P., Oleurn palmæ Christi, Oleum castoris; cathartic. Leaves galactagogue.

1736. RIGIOPÁPPUS, Gray. Rigiopappus. Compositae. From Greek, "stiff pappus". Slender annual with yellow flowers. One species, Pacific border of U. S.

1337. RIVÍNA, L. (Rivinia). Hoop-withe. Phytolaccaceae. Named for A. Q. Rivinus, German botanist d. 1723 . Herbs, somewhat shrubby. About 10 species, warmer regions New World; 2 in U. S.

a. R. húmilis L. W. Indies and snutheartern U. S. Bloo 1-berry, Rouge-berry, Rouge plant. 
1738. ROBÍMIA, L.

Locust tree.

Papilionaceae.

Named for Jean and Vespasien Robin, royal gardeners, Paris, 17th Century. Syn. Pseudu-Acacia, Medic. Trees or shrubs with showy flowers in racemes. About 6 species, N. America; 4 in U. S.

a. R. Pseudacácia L. (P. vulgaris Medic., P. odorata Moench.). Southeasiern U.S. and much plauted as a shade and timber tree. Locust tree, Yellow Locust, Black or Common Locust, Post or White Locust, Honey Locust*, North American Locust tree, Pea-flower Locust, Bastard or False Acacia, Silver-chainz, White Laburnum, Whya tree; Ger. Falsche Acazie; Fr. Robinier. Bark of root tonic, enetic, narcotic. Timber strong and durable.

Other indigenous species are (b) R. híspida L. (P. hispida Moench). Rose Acacia, Moss Locust, Bristly Locust, and (c) R. viscósa Vent., Clammy Locust, Red-flowering or Roseflowering Locust, Rose Acacia*.

1739. ROCCÉLLA, DC. Archil, etc. Parmeliaceae. Probably from the Italian, Orcella. Lichens.

a. R. tinctória Ach. Mediterrauean region, Canary Islands, Azores, etc. Archil Lichen, Orchil, Orchella, Canary Moss, Dyer's Moss, Cape-weed. From this and (b) R. Pusifórmis Ach., Angola-weed, Mauritius-weed, Flat Archil or Urchil, is obtained litmıs. See Lecanora.

1740. ROMANZÓFFIA, Cham. ( Romanzovia). Hydrophyllaceae. Named for Count Nicholas Romanzıff. Delicate pale herbs. Two known species, Alaska to California.

1741. ROMNÉYA, Harv. Romneya. Papareraceae. Glaucius herb. One species, California.

1742. RORÍPA, Scop. 1760 (originally Rorippa). Cruciferae. Syn. Nasturtium, R. Br. 1812; Armoracia Sinymbrium, Cochlearia, Neobeckia, in part Herbs, more or less pungent. About 25 species, mostly of north temperate zone; 22 in U. S.

a. R. Armorácia (L.) A. S. Hitchenck (C. Armoracia L. (Kew), N. Armoracia Fries., A. sat va Bernh.). Eurupe, cult. and nat. in U. S. Horseradish; Ger. Meerrettig; Fr. Raifurt. Cran de Bretagne, Moutarde des inoines; Sp. Raban') ruscicano. Fresh root pungent, diuretir, condiment.

b. R. Nastúrtium (L.) Rusbv (S. Nasturtium L., N. offi:inale R. Br.). Eurupe, northern Asia. nat. in U. S. and widely elsewhere. Warer-crese, Commo I or True Water-cress (Crashes, Carsous, Kars, Karee), Brown Cress, Water-grass (Ireland), Water-kers, Well-grass, Bronk-lime, Eker. Tengtongues; Ger. Brunnenkresse; Fr. Cresson de fontaine (Codex); Sp. Berro. Fresh plant antiscorbutic, used for salad.

c. R. palústris (L.) Bess. IS. amphibium var. palustre L., N. palustre DC. (Kew), N. terrestre R. Br. ). Europe, Asia and N. America. Marsh or Yellow Water-cress, Yellow Woodcress, Bell-ragges. This and other species have properties of (b). 
1743. RÓSA, L.

Rose.

Rosaceae.

The ancient Latin name from the Greek. Erect or climbing shrubs. A large gentis. Northern hemisphere, 23 in U. S.

a. R. canína L. Europe, northern Asia, nat. in U.S. Dog Rose, Canker Rose, Canker blooms (Shakespere), Wild Brier, Bird Brier, Cat-whin, Hip Brier, Brere Rose, Bramble Rose, Horse Bramble, Hip-tree, Hedge-peak, Lawyers, Soldiers, Bedeguar Rose; Ger. Hundsrose; Fr. Rnsier sauvage, Églantier sauvage (Codex). Fruit (of this and allied species), Hips, Rose-hips; Rosæ Canin: Fructus Br., Cynosbata, Fructus cynosbati, Cynorrhoda; Ger. Hagebutten, Hahnebutten, Hainbutten; Fr. Cynorrhodon (Codex); astringent, refrigerant. Excrescence from puncture of insect, Rose-gall, Bedeguar, Gallæ rosa, Fungus cynosbati, astringent.

b. R. contifólia L. Western Asia, widely cult. Hundred-leaved Rose, Cabbage Rose, Provence Rose, etc. ; Ger. Centifolienrose; Fr. Rose à cent feuilles, Rose pâle (Codex). Petals, Rose-leaves; Rosa Centifolia, U. S. P., Rosae Centifoliae Petala, Br., Flores rosæ P. G., Flores rosæ pallidæ v. incarnatæ. Source of oil of rose, which is prepared also from petals of (c) and (e).

c. R. Damascéna Mill. [Perhaps not distinct from (b)]. Orient. Damascus or Damask Rose; Fr. Rose de Danias, Rose des quatre saisons, Rose de Puteaux (Codex).

d. R. Gallica L. Southern Europe and the Levant, also cult. in gardens. French Rose, Dutch Rose, Red Rose; Ger. Essigrose, Sammtrose, Zuckerrose; Fr. Rose rouge, Rose de Provins (Codex). Petals ( or unexpanded flower buds), Red-rose leaves; Rosa Gallica, U. S. P., Rosæ Gallicæ Petala, Br., Flores rosæ rubræ $\mathrm{v}$. domesticæ; astringent.

e. R. moscháta Mill. North Africa and south Asia, largely grown at Kesanlik. Musk Rose, sourree of the Kesanlik (Kisanlik) attar of rose.

f. R. rubiginósa I. (R. micrantha Bor., R. Eglanteria Mill. not L.). Europe to central Asia, nat. locally in U. S. Sweet Brier (Breer), Eglantine (Shakespere and Spenser), Eglantine Rose, Eglantere, Hip Brier, Kitchen Rose. Foliage fragrant.

The more important of our indigenous species (Wild Rose) are, (g) R. Carolína L., Swamp Rose, Hip tree; (h) R. húmilis Marsh (R. parviflora Erhr), Pasture Rose, Dwarf or Low Wild Rose, the common Wild Rose of eastern U. S.; (i) R. blánda Ait., Pale, Smooth or Meadow Rose; (j) R. nítida Willd., Shining or Northeastern Rose; (k) R. setígera Michx., Prairie Rose, Michigan Rose (although rare in Michigan), Climbing Wild Rose. Naturalized from China in southeastern U. S. is (1) R. laevigáta Michx (R. Sinica Ait.), Clierokee Rose, Jamaica Buckthoru.

1744. RONMARÍNUS, L.

Rosemary.

Labiatre. The Latin name, meaning "sea dew". Shrub. One species, Mediterranean region. 
a. R. offleinális L. Mediterranean region, cult. in gardens. Rosemary, Garden Rosemary, Old-man; Ger. Kosmarin, Meerthau; Fr. Romarin (Codex); Sp. Romero. Leaves; b.csmarinus, U. S P., Folia rosmarini, Fol. roris marini, Fol. anthos; diaphoretic, carminative, emmenagogue. Source of oil of Rosemary.

1745. ROTÁLA, L. - Rotala. - Iythraceae. From Latin, "wheel", alluding to whorled leaves of some species. Syn. A urmannia, Boykinia, in part. Low annuals. About 30 species, warmer regions; 1 in $U$. S.

1746. RotThróCKIA, Gray. Rothrockia. Asclepiadaceae One species in western U. S.

1747. ROUBIÉVA, Moq.Cut-leared Goose-foot.Chenopodiaceae. Named for G. J. Robieu, French botanist. Syn. Chenopodium, in part. A strong-scented herb. One species, tropical America, adv. in U. S.

1748. ROULÍN1A, Decne.,not Brogn. Roulinia. Asclepiadacere. Twining herbs. About 12 species, tropical America; 1 in U. S.

1749. RÚBIA, L. Madder plant. Rubiaceae. The Latin name, from muber, "red". Perennial herbs from thick ened roots. About 40 species, temperate and warm regions, both hemispheres.

a. R. tinctórum L. Mediterranean region. Madder plant, Warence; Ger. Krapp, Färberröthe; Fr. Garance (Codex); Sp. Granza. Root, Dyer's Madder, yields a red dye, as does that of (b) R. cordifólia L. (R. Mungista Roxb.), of eastern Asia and Japan, Munjeet.

1750. RÚBUS, I. Blackberry, etc.

Rosaceac. The ancient Latin name, from ruber, "red". Herbs, shrubs or trailing vines, generally prickly. About 250 species, widely distributed; 31 in $\mathrm{U}$. S.

a. R. Amcricánus (Pers.) Brit. (R. saxatilis var. Canadensis Michx., R. triflorug Rich.). Canada and northeastern U. S. Dwarf Raspberry, Dewberry, Mulberry*, Pigeon-berry, Running Raspberry, Swamp-berry.

b. R. Canadénsis I. Canada to Virginia, Louisiana and Indian Territory. Low Running Blackberry, Dewberry (of eastern U. S. ), Creeping Blackberry. See (p). The Dewberry of the southern U. S. is (c) R. triviális Michx., called also Lowbush Blackberry. Similar to these is (d) R. cuniefólius Pursh, Southeastern U. S., Sand Blackberry, Low or Kneehigh Blackberry. The Dewberry of Europe is (e) R. caésius L., called also Blackberry-token and Blue Bramble.

f. R. Chamaemórus L. Northern Europe, Asia and N. America, south to New Hampshire, Cloud-berry, Averin, Knot-berry, Knout-berry, Dwarf Mulberry, Mountain Bramble, Mountain Raspberry, Baked-apple-berry. 
g. R. Pruticósus L. Europe, north A frica to central and northern Asia. Cornmon Bramble (Brammle, Brimble, Brumble, Brummel) or Blackberry of the Old W'orld, Black.boyd or Blackbide (Scutland), Bumble-berry, Ever-bramble, Gait-berry, Ladv's garters, Mulberry Bramble, Scald-berry, Theve Thorn, Theif; (Ger. Brombeere; Fr. Ronce sauvage (Codex), Ronce noir; Sp. Zarzauora. See $(p)$.

h. R. Idaéus L. Europe, west to Japan. European Raspherry, A ruberry, Hainberry, Hindberry, Sivven; Ger. Himbeere; Fr. Fr.mboise (Lidex); Sp. Frambuena, Sanguesa. Fruit; Rubus Id eus. U. S. P. Allied to this is the American (i) R. occidentális L. (R. Idaeus var. Aınericanus Torr.), Black Ra-pberry, Blark-cap, Wild Purple Raspberry, Blackberry*, the origmal of the cultiva ed Gregy and Hilborn raspberries. The Calif.rnia Raspberry is (j) R. lencolérmis Doug'. See ( $n)$.

k. R. odorátus L. Canala to Georgia and Tennessee. Flowering Raspb-rry, Purple or Ruse Flowering-raspherry, Thimbleterry, Mullierry*, in England called Virginia Raspberry. Similar to this are (1) R. parviflorus Nutt. (R. Nutkanus Mucinu), British America and nurthern U. S.. Salmon-berry, Thimble-berry, White Floweringr-raspberry, and (m) R. spectábilis Pursh, the Salmon-berry of californa.

n. R. strigósus Michx. (R. Idaeus var, strigosus Maxim.). British Aner'ea, sıuth to N. Carolina and New Mexico. Wild Red Raspberry American Red Raspberry, the uriginal of the cultivated Cuibbert and Hansall raspb rries. The Purple W'ilil Ra-pberry of northeastem U. S. is (o. R. negléctus l'rek, whence the cultivated Carulina and (iladstome raspber ries.

p. R. villósus Ait. Eastern U. S. American Blackberry or Brauble II gh-bush Blarkberry, Finger-berry, Ihimble-herry*, Clend-berry*, Sow-tit. Fruit esculent. Burk of root of this, aloo, b) and (c), Blackherry root; nubus I . S. P.. astringent. The Munntain Blackberry of the northeastern U. S., witn latger fruit, is $(q)$ R. Alleghaniénsis Porter ( $R$. villosus var. m.ontanus Porter, not $R$. montanus Ort.). The (alifornia Blawkherry is (r) R. ursínus Cham. \& Sch. See (b), (c), (d), $(t)$ and $(\mathrm{g})$.

1751. RUDBÉCKIA, L. Cone-flower. Compositae. Nanied firr ()lans kudbeck, founder of botanic garden at Up cala d. 1702. Coarse herus with showy yellow-rayed fluwers. About $2 i$ species, N. America; 22 in U. S.., especially southwes'ern.

a. R. hírth L. Western prairies, nat. in eastern U. S. Blackeyed-Su-an, Brown-eyed Susan, Yellow Laisy, Brown-1 aaisy, Nigger Drisy, Ox-eye Daisy*, Golden-Jerusalem, Nigger-head, Brown-Betty, English Bull's-eye.

b. R. laciniátr L. Canala and eastern U. S. Thimble-weed, Till or Green-headed Cone-tlower, Cone-disk Suntlower; Double variety in cultivation, úolden-glow. Plant diuretic, tonic.

c. R. tríloba L. New Jersev to Georgia, west to Missouri. Thinleaved cone-flower, Brown-eyed Susan. 
1752. RUÉLLIA, L.

Ruellia.

Acanthaceae.

Named for Jean Ruel, French herbalist, d. 1537. Syn. Dipteracanthus, in part. Herbs or shrubs with showy Howers. A bout 200 species, tropical, mainly of New World; 9 in U. S.

\section{RÚMEX, L.}

Dock, etc.

Polygonacrae. The ancienı Latin name, "lance", from form of leaf. Syn. Acetosella, Acetosa, in part. Rolu-t herbs, some shrubby. About 130 species; 28 in U. S., including naturalized species.

ג. R. Acetósa I. (Acetosa magna Gililb., A. ofticinalis Gueld., A. pratensis Mill.). Europe, Asia, Bi itish America, nat. In U. S. Sorrel, Cock Surrel. English 1 ock Surrel, (ireen or Meadow S rrel, Bread-and-l heese, Donkey s-nats, Kitchen Sorrel. Ginger-sance, Ginger Sorrel, Redshank, Shaıp Dock, Frelch Suruck (Sourack, Sarock, Sinoracks, Sorruw), Sour-grass, Sour-saluce (Sour-sabs, Sour-suds); Ger. Sanerampler; Fr. Oseille commune (colex); Sip. Acerlera. Rrot astringent. Leures acidnluus, refrigerant, used as a pot lierb, as are llose of (b) R. luxúrians L. in Atrica.

c. R. Acrtosélla L- ( cet tesella vulgaris Four., Acetosa Acetosella Mill. !. Europe, Asta and N. America. Shrep Sorrel, lïrld Surrel, Horse or Cow sorrel. ( ommun or Gentieman's Sorrel, Momntain or Red-top Sorrel, Tuad's Surrel, Ramb-tanty, s'ur lock, Sour grals, sour l.tek, (ireli-sauce, Red-weed. I'roperties of (a). French surrel is the allied (d) R. scutatus L. (Acet.ea scutata Mill.).

e. R. críspus L. British America and U. S. throughou'. Yellow Duck, (urled Duck, Narrow Dock, Sunir J)enk". Loot "of this and o her species, nutahly $(\mathrm{g})$ and ( $\mathrm{h}$ )"; Rumex, L. S. P.,

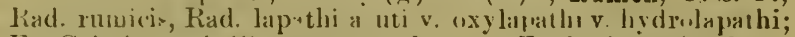
Fr. Grindwurzel, II amermangoldwurzel; Fr. i'atience (Codex); antringent, alteranive, laxative, rese bling rhubarb.

f. R. hymenosépalus Torr. Texas to Arizona and M.xicn, now extennively cult. Canaigre, Wild l'ie-plant. Roots used for tanning, astrmgent.

g. R. obtusifólius L. Enrope and Asia, nat. in U. S. Bitter Dock, Conmon Duck (of England) Broad-leaved or Bluntleaved Dock, Butter Docn ('eavis formerly useol for wraljing butter), (elery-seedt. Propertirs of $(t)$, the speries n.ost used iı kin ope. (h) R. sanguíneus L. Einroper adv. in U.S. Bloudy Dock. Blor dwort, Red-veined Lock. Olcott-ron, is also ust d, and in Europe ii) R. aquáticus L. and (i) R. Ilydrolápathum Huds.

k. R. Patiéntia L. Europe, nat. locally in U.S. Patience Dock, Passionst, Garden Patience, Monk' \& Khubarb. The latter name is given in Scotland to (1) R. alpinus L., called also Mountain Rhubarb.

1754. RÚPPIA, L.

Ditch-grass, etc.

Naindaceae. $\backslash$ amed for H. B. Rupp, German botanist, 18th C'entury. Slender-stemmed aquatic plants. About 4 species, widely distributed; 2 in U. S. 
a. R. marítima L. (R. spiralis L., R. rostellata K. B.). Brackish and salt water, widely distributed. Ditch-grass, Tasselgrass, Tassel Pond-grass, Tassel Pondweed, Sea-grass. Plant reputed vulnerary.

1755. RÚSCUS, L.

Butcher's Broom.

Liliaceae.

The ancient Latin name of (a). Evergreen plants, but without true leaves. About 5 species, Europe and northern Africa.

a. R. aculeátus L. (R. Hexuosus MPll.). Mediterranean region to middle Europe. Butcher's Broom, Sweet Broom, Box Holly, Knee Holly, Knee Holm or Hulver, Bruscus, Horse-tongue, Pettigree, Prickly Box, Shepherd's Myrtle, Wild or Jew's Myrile; Ger. Mausdorn; Fr. Petit Houx, Fragon Épineux (Codex). Root diuretic. Shoots eaten like asparagus.

1756. RÚTA, L. - - Rue. - - Rutaceae. Latin, from Greek name of (a). Heary-scented perennial herbs. About 50 species, Mediterranean region to central Asia.

a. R. gravéolens L. Southern Europe to the Orient. Rue, Garden Rue, Herb-of-grace (Shakespere), Ave-grace, Hêrb-of-repentance, Countryman's Treacle; Ger. Raute, Gartenraute; Fr. Rue (Codex); Sp. Ruda, Lreares antispasmodic, emmenagogue, anthelmintic.

1757. SÁBAL, Adans. Palmetto. Sabalaceae. From vernacular, Mexico or S. America. Syu. Chamaerops, Corypha, in part. Fan Palms. About 7 species, New World; 4 in U. S.

x. S. Palmétto (Walt.) R. \& S. (Cor. Palmetto Walt., Cham. Palmetto Michx.). N. Carolina to Florida and Bermuda Islands. Cabbage Palmetto, Palmetto.

b. S. Mexicánium Mart. (S. umbraculiferum Hort., not Mart.). Texas to Mexico and West Indies. Texas Palmetto, Royal Palmetto, Big-thatch, Bull-thatch. Our largest species.

1758. SABBÁTIA, Adans. Marsh Pink, etc. Gentianaceae. Named for L. Sabbati, Italian botanist. Svn. Chironia, Gentiana, Swertia, in part. Annual or biennial herbs with pink, red or white flowers, some highly ornamental. About 14 species, all in southern U. S. and Mexico.

a. S. anguláris (L.) Pursh (C. angularis L.). Eastern U. 8. American Centaury, American Red Centaury, Bitter-blonm, Bitter (lover, Rose Pink, Pink-bloom, Square-stemmed Sabbatia?; Ger. Sabbatie; Fr. Centaurée americaine. Herb bitter tonic. Similar properties belong to other species, notably (b). S. Elliottii Steud. (Swertia difformis L., Sab. paniculata Ell., not Pursh). Quinine-flower, Quinine-plant, Quinine-herb.

1759. SÁCCHARUM, L. (Saccharifera).

Gramineae.

Latin word for sugar, from the Sanskrit. Compare jaggery, the palm sugar of Hindustan. Robust grasses with solid culms. About 12 species, Old World. 
a. S. officinárum L. (S. officinale Salisb., Saccharifera officinalis Stokes). Southern Asia, now cult. in all tropical countries. Sngar Cane. The most important of sugar-yielding plants.

\section{SAGERÉTIA, Brong. Tia. Khamnaceae.} Named for Augustin Sageret, d. 1852. Shrubs. About 15 species, warmer regions of $A$ sia and N. America; 2 in U. S.

a. S. théezans Brongn. China. Tia. Leaves used by poorer classes for toa.

1761. SAfínA, L. Pearlwort, Pearl-weed. Caryophyllaceac. The ancient name of Spurry. Syn. Spergula, in part. Iow herbs. About 10 species, northern hemisphere; 8 in U. S.; Ger. Vierling; Fr. Sagine.

a. S. procúmbens L. Europe, Asia and N. America. Procumbent Pearlwort, Bird's-eye, Break-stone, Make-beggar, Poverty.

1762. SAGITTÁRIA, L. Arrow-head. "Alismaceae. From Latin, "arrow" leaf. Syn. Alisma, in part. Scapose aquatic or paludal herbs. About 80 species, warm and temperate regions; 25 in U.S. Typical species are, in America, (a) S. latifólia Willd. (S. variabilis Engelm.) and in Europe, (b) S. sagittaefólia L. The names Water-archer and Adder's-tongue are applied to some species. In California the tubers of (a) or a kindred species were formerly used as food by the aborigines under the name of Wappate or Wapatoo, called also Tule root.

1763. SAliCóryia, L. Glasswort, Saltwort. Chenopoliaceac. From Latin, "salt horn", the plant growing in a saline habitat and having horn-like branches. Fleshy plants, practically leafless. About 10 species; 3 in U. S.; Ger. Glasschmalz; Fr. Salicorne.

a. S. herbácea L. Saline soil throughout U.S. as in Europe and Asia. Common Glasswort (the ash, barilla, formerly used in the manufacture of glass), Marsh samphire (Sampion), Slender or Jointed Glasswort, Chicken's-toes, Crab-grass, Frng-grass, Marsh Tea, Pickle-plant, Saltwort, Sea-griss, English Seagrape, Swy. Stems used for pickles.

1764. SÁLIX, L'. - Willow. - Salicaceae.

The ancient Latin name. Trees or shrubs, mostly with narrow leaves. About 160 species, mostly of north temperate and arctic regions; 75 in U. S. Synonyms are Sally (i. e. Salix), Sallow, Salghe, Selly, Seel, Saugh, Soafs, Saff, Willey, Wilf, Wiffs, Widdy, Withy, Wythy; Ger. Weide; Fr. Saule; Sp. Sauce, Sanz.

3. S. alba L. Europe to middle Asia, nat. in U. S. White Willow, Common European Willow, Duck Willow, Huntington Willow. Varietr vitelina (L.) Koch is Golden Osier, Cane Withy, Yellow Willow. Bark, Salix, U. S. P., Cortex salicis; Ger. Weidenrinde; Fr. Saule blanc (Codex). Medicinal willow bark is obtained also from $(\mathrm{g})$ and (1), likewise from (b) s. pentándra L., (c) S. rúlura L., and from other species; bitter, tonic; active constitutent Salicin. 
d. 8. Babylóníca L. Asia, nat. in Europe and U. S. Weeping Willuw, Drooping or Ring Willow, Garb.

e. S. díscolor Muhl. Canada and northeastern U. S. Glaucous Willow, Pusiy Willow, Bug, Swamp or Silver Willow. Catkins of this and some oiher species called Pussy-cats, in Eugland Geslings, Lamb's-tails, Pawms (i. e. palms), etc.

f. S. fluviatílis Nutt. (S. longifolia Muhl.). British America to. Kentucky and New Mexico. Saud-bar Willow, River-bank Willıw, L'ng-leaf or Narrow-leaved Willow, Osier or Red Willow, shrub or White Willuw.

g. S. frágilis L. Southwestern Asia, Europe, nat. in U.S. Crack Willow, Brittle Willow, Snap or Redwood Willow, Varnished Willow. Bark very rich in salicin.

h. S. nígra Marsh. (S. Purshiana Spreng). Canarla to Florida and Califurnia. Black Willow, Pnssy Willow, swarnp Willow. Bark and "buds" bitter tonic, anaphrodisiac. Other indigenous species called Black Willow are (i) S. laevigáta Bebb. (i) S. lasiándra Benth. and (k) S. Wardii Bebo.

l. S. purpúrea L. Euripe and As a, nat. in U. S. Biter Willow, Bashet Willow, Purple Willow, Re or Whipeord Willow, Osier. See (a).

m. S. riminális L. Europe and Asia, cult. and nat. in U. S. ()sier Willıw, ()sier (Ausier. Auger), Common or Velvet ()sier, Basket IVillow, l'wig-withy, Withy-tuig, Wilgers. Twigs (usiers) used for baskets, etc. Other ()sier Wilcows are (a), (h), (1), also (n) S. amygdalína $L$. and (o) S. ríbra Hudson.

1765. S.ILAzÁRIA, Tor. (Salizaria).

Labiatae. Nan.el for I)on José Salazar y Larrequi, Mexican Commissioner of Brumfary Survey. Shrubby plant. ()ne species, Mexican bırd r of U. S.

1766. SALPICHRÓA, Miers 1845. (Salpichroma). Solanaceae. From Grrek, "colored trumpet", alluding in the corolla. Syn. Busheckia, Mart. 1824. Herbs. About 10 species, mostly of S. America; 1 in Arizona.

1767. SÁlSOLA, L. Saltwort, Glasswort. Chenopodiaceae. The Latın name, "salc soil". Syn. Kali, Adıns., Soda, in part. Herbs with aculeate-pointed leaves. About 50 species, saline districts; 2 in U. S.

a. S. Káli I. (K. Snda Moench, K. Tragus Scop.). Europe, Asia and Atlantic cuast of U. S. Prickly Saltwirt, Salıwirt (Sıwdwort), Salt-grape, Sea-grape, Sra-thrift, Eestrige, Kelpwirt, Prickly Glasswort. Sparrow's dung. Ash of the plant (harilla), as also that of ( b) s. Sóda L. (K. Soda Scop., Soda inermis Fonr.), Glasswori, of Mediterranean region, tormerly a source of soda.

c. S. Trágus L. (S. Kali var. Tragus Moq.). Europe and Asia, nat. in U. S. Russian Thistle, Russian Cacius. 
1768. SALVADÓRA, L.

Salvadora.

Salvadoraceae.

Named for J. Salvador, Spanish botanist. Shrubs or trees. About 3 species, southern Asia and northern Africa.

a. S. Pérsica L. Asia. Tooth-brush tree. Beliered to be the Mustard-tree of Scripture. Seeds yield Kikuel oil.

1769. SÁLVIA, L.

Salvia, Sage.

Labiatae.

The Latin name, "healing". Mlerbs, some shrubs, with flowers often showy. About 500 species, temperate and tropical regions; 33 in U. S.

a. S. axilláris Sesse. Mexico. Mexican Hyssop.

b. S. officinális L. Europe, widely cult. and nat. Garden Sage, Sage, Save; Ger. Salbei; Fr. Sange otticinale (Codex); Sp. Salvia. Leares; Salvia, U. s. l’., Folia salviæ: stimula t, tonic, a-tringent. The Meadıw sage of Eurıpe, (c) S. pratéusis L.; (ier. Wiesensalbei, has similar properties.

d. S. Sclárea I. Europe, cult. and adv in U. S. ('lary, ('leareye, Godrs-eie, ()culus Chrinti, See-bright, Scallewort; Ger, Nuscatellersalbei. 'The mucilaginous serds used to clear the eye of foreign particles. ()ther species having mucilaginuth-sreds are, (e) S. Columbáriae Betith., soulliwestern U. S.; (f) S. polystáchya Ortega (s. Chian LaLlive), Mexico; (g) s. Horminum L.; (h) S. verbenáca L., and (i) S. verticilláta L., the three latter of Europe. The seeds of (e) and (f) are called Chia setd, u-ed for their demulcent action.

1770. SAMÍNDURA, L. 1747. Samandera. Simarubaceae. From vernacular, Last Indies. Syn. Samadera (Kew), Gaertn. 1791, Ninta, Lam., not Aorns. Tres wih showy flowers. Two species, kast Indies and Madagarscar.

a. S. Índica (Gatertn.) Lyuns (Samadera Indica Gaertn., S. pertapetala ('. Don, N. pentapelala Lam., N. Commeronni Pers.). Hindustan. Burk, Niepa bark, Ni. la bark, Samadera bark; bitter, tonic. Seeds yield tixed oil used in rheumatism.

1771. S.AMBÚC'CS, L.

Elder.

Caprifoliaceae.

The classical name. Srn. Ehulum, Garcke. Shrubs or trees, some herbs. A buut 20 species; 8 in U. $S$.

a. S. Canadénsis L. Canada to Florida, west to Arizona and Manitoba. American Elder, Elder, Sweet Eldes. Flovers, Elder-blows, Elder-flowers; Sambicus, U. S. P., diurelic, diaphoretic, emollient. Burk cathartic, emetic. The Ilexican (b) S. Mexicána Presl has similar properties.

c. S. Ébulus L. (E. humile (iarcke). Europ . Dwarf Elder, European Dwarf Elder, Bloud Elder (Hilder), Bloodwort, Danewort, Deadwort, Lithewort, "Ialewort, Wallwort; Ger. Attich; Fr. Hièble (Codex) Yéble; Sp. Yezgo. Fruit laxative.

d. S. glaúca Nutt. (S. cœrulea Raf., S. Californica Koch.). Califoruia. California Elder. Fruit blue. 
e. S. nígra L. Europe, northern Africa to middle Asia. Europaran Elder (Ellar, Ellen, Ellarne, Alderne, Ellet, Elnorne, Elren, Hilder, Hillerne, Hylder), Common Elder (of Europe), German or Parsley Elder, Black-berried Elder, Boor-tree, Boretree, Bur-tree, Bone-tree, Bountry, Boutry), Ellanwood, Ellhorn, Judas tree*, Skaw, Winlin-berry, Whist-aller; Ger. Flieder, Hollunder; Fr. Sureau (Codex); Sp. Sahuco. Flowers, diaphoretic, diuretic, emollient. Fruit, Fructus v. Baccae sambuci, Grana actes: Ger. Fliederbeeren, Hütscheln; aperient, diuretic. Juice of fruit, Elder-roob, Elder-rob, Succus sambuci inspissatus, Rob sambuci; Ger. Fliedermus; Fr. Rob de sureau; aperient, diuretic, deobstruent.

f. S. púbens Michx. British America south to Georgia, Colorado and California. Red-berried Elder, Mountain Elder, Red Elder, Poison Elder.

1772. SÁMOLUS, L. Water Pimpernel, Brook weed.Primulaceae. Name of Celtic origin. Small marsh plants. About 10 species. most common in S. Africa and Australasia; 4 in U. S. (a) S. floribundus H. B. K. is the common species of the eastern U. S.; (b) S. valerandi L. that of Europe.

173. SANGUINÁRIA, L. Bloodroot. Papaveraceae. From Latin, "bloody", alluding to the red juice. Perennial herb from a fleshy rhizome. One species only, N. America (U. S.).

a. S. Canadénsis L. Canada to Florida, west to Arkansas and Nebraska. Blood-root, Red Puccoon, Red Indian Paint, Redroot, Puccoon-ro st, Coon-root. White Puccoon, Pauson, Snakebite, Sweet-slumber, Tetterwort. Turmeric*; Ger. Blutkraut, Blutwurzel; Fr. Sanguinaire. Rhizome; Sanguinaria, U. S. P., emetic, expectorant, sialdgogue, emmenagogue.

1774. SANGUISÓRBA, L.

Burnet.

Rosaceae.

From Latin, "blood staunching". Syn. Poterium (Kew), in part. Herbs with pinnate leaves. About 20 species, north temperate zone; 4 in U. S.

2. S. Canadénsis L. (P. Canadense A. Gray). Canada to Georgia and Michigan. American Great Burnet, Canada Burnet.

b. \$. officinális L. (P. officinale A. Gray). Europe. Garden Burnet, Italian Burnet, Burnet Blood-wort, Italian Pimpernel, Bipennula, Pimpinall, Sol begrella. Plant astringent, tonic.

c. S. Sanguisórba (L.) Brit. (P. Sanguinorba L. (Kew), S. Poterium Wigg., S. minor Scop. S., media L.). Europe and northern Africa, adv. in U. S. Salad Burnet, Burnet, Common or Garden Burnet, Bloodwort, Pimprenelle, Toper's plant Small Bibernel; Ger. Bibernell. Plant used as salad.

1775. SANÍCULA, L. Snake-root, Sanicle. Unbelliferae. From Latin, "healing". Biennial or perennial herbs, the umbellets capitate. About 20 species, temperate regions; 15 in U. S. 
a. S. Europaéa I. Europe. European Sanicle (Sinicle), Wood Sanicle, Wood March, Self-heal; Ger. Sanikel,Scherneckelkraut, Brachkraut, Heil-aller-Schaden; Fr. Sanicle (Codex). Plant, Herba saniculae, Ierba diapensiae; astringent, vulnerary.

b. S. Marylándica L. Canada to Georgia. Black Snake-root, Sanicle, American Sanicle, Black Sanicle, .Pool-root. Root astringent, antispasmodic, antiperiodic. (c) S. Canadéusis L. (S. Marylandica var. ('anadensis Torr.), Short-styled Snake-root, is also called Black Snake-root, and used indiscrininately with the foregoing as are probably other species.

17 76. SÁNTALUM, L. Samdal-wood.

Santalaceae. Trees with fragrant wood. About 16 species, East Indies, Australia and Oceanica.

a. S. album L. India. Sandalwood, White Sandal-wood, Yellow Sandal-wood, White Saunders; Probably the Almug of Scripture; Ger. Gelber Sandel; Fr. Santal citrin (Codex). Wood Lignum santali album $\nabla$. citrinum, fragrant. Source of oil of Sandal-wood. Other species yielding fragrant Sandalwood are (b) S. Cyunórum Miq. (Fusanus spicatus P. Br.), Australia; (c) S. Freycenetiámum Gaud., Hawaiian Islands; (d) S. Austro-Caledónicum Vieil., New Caledonia, and (d) S. Yási Seem., Fiji.

177\%. SANTOLÍXA, L. Lavender Cotton. Compositae. From Latin, "sacred flax". Aromatic under-shrubs. About 8 species, Mediterranean region. (a) S. Chamaecyparíssus L. (C. villosa Mill. ) is Lavender Cotton, reputed anthelmintic, insecticide.

1778. SANVITÁLIA, Lam. Thirst-plant. Compositae. Named for the Sanvitali family of Parma. Ilerbs. About 8 species, Texas and Mexico; 2 in U. S.

1779. SAPÍNDUS, L. Soap-berry. Sapindaceae. From Latin, "Indian soap". Trees or shrubs. About 10 species, warmer regions of Asia and America; 3 in U. S.

a. S. marginátus Willd. (S. acuminatus Raf.). Florida to Arizona and Mexico. Soap-berry, Wild China-tree. Fruit detergent, containing saponin. (b) S. Saponária L. of Mexico and southwestern U. S. has the same synonyms and uses. (c) S. trifoliátus L. (S. laurifolius Vahl.) of India, Indian Filbert, yields a similar fruit.

1780. SÁPIL̀, P. Br. Tallow-tree. Euphorbiaceate. Syn. Excæcaria, Croton, Stillingia, in part. Trees or shrubs. About 20 xpecies, warmer regions of both hemispheres.

a. S. sebíferum (L.) Roxb. (C. sebiferus L., E. sebifera Muell. Arg., Stillingia sebifera Michx.). China to India and Japan. Chinese Tallow-tree. Fruit, source of vegetable tallow, used for candles, etc. Wood used for engraving.

1781. SAPONÁRIA, L. Soapwort. Caryophyllacene. From Latin, "Soapwort". Herbs with showy flowers. About 35 species, Old World. 
a. S. officinális, L. Europe to middle Asia, nat. in U. S. Bouncing-Bet, Common Soapwort, Soaproot, Bruisewort, Buryt, Boston Pink, Chimney Pink, Crow-soap, Hedge Pink, Oldmaid's Pink, Fuller's-h^rb, Lady-by-the-gate, London-pride, Latherwort, Mock Gilliflower, Saponary, Scourwort, Sheepweed, Sweet-Betıy Wild Sweet William, Woods Phlox, World'swonver; Ger. Seifen wurzel, Waschwurzel; Fr. Savonnière; Sp. Saponaria. Root, Radix saponarix rubra, detergent, discutient, alterative.

1782. SíRACA, L. 1767 (not Saracha R. \& P.).Caesalpinaceae. Syn. Jonesia, Roxb. 1795. Trees or shrubs. About 6 species, tropical Asia. (a) S. Indica L. (J. Asoca Ruxb., J. pinnata Willd., S. arborescens Burm ) of Hindustan yields a bark which is astringent and a uterine tonic.

1783. SARCÓB ATUS, Nees. Grease-wood. Chenopodiaceae. From Greek, "flesh" and "thorn". Syn. Batis, in part. Thurny shrub with fleshy leaves. One species, Nebraska to Nevada.

1784. SA RCOCÉPHALCS, Afz. Guinea Peach, etc. Rubiaceae. From (ireek, "fleshy head". Syn. Cephalina. Shrubs or trees with fleshy fruit. About 10 spucies, tropical regions, Old World.

a. S. esculéntus Afzel. (C. esculenta Schum. \& Thonn.). West Africa. (iuinea Peach, Country Fig, Negro or Sierra Lene Peach. Bark, Domndake bark, African Cinchona; astringent, febrifuge. Fruit has emetic properties.

1785. SARCÓDES, Torr. Snow-plant. Munotropaceae. From Greek, "flesh like", alluding to succulent red stem. A leafless sxprophyte with red stem and flowers. One species, (a) S. sanguínr Torr., the Snow-plant of mountains of California.

1786. SARÓTHRA, L. , Orange-grass: Hypericacere. From Gireek, 'broom'. Syn. llypericum, in part. Low annual herb. One species, ea-tern U.S.

a. S. gentianoides L. (H. Sarothra Michx., H. nudicaule Walt., S. hypericoides Nutt.). Eastern U. S. Orange-grass, Pineweed, Ground Pine*, Nit-weed, False Johnswort. Plant aperient, alterative.

1787. SARRACÉNIA, L. (Sarracena). Sarraceniacrae. Named for Dr. J. A. Sarrazin of Quebec. Pereunial marsh or bog herbs with trumpet shaped leave.. About 8 species, $N$. America; 7 in U. S. Syn. Pitcher-plant, Trumpet-leaf, Indiancup.

a. S. fláva L. Southeastern U. S., Trumpet-plant, Yellow Trumpet leaf, 'Irumpets, Yellow Trumpets, Huntsman's-horn, Biscuits, Dumb watches, Water-cup, Fve's-cup, Fly-trap, Yellowflowered Water-cup or Side-saddle plant. Plant astringent, tonic, stomachic. 
b. S. purpúrea L. Cana la and eastern U. S. Pitcher-plant, Side-saddle Flower, Fly-trap, Fox-glove*, Eve's-cup, Forefather's-cup, Huntsman's-cup, Indiun-pitcher, Indian-cup, Dumb-watches, Saddle plant, Purple-flowered Pitcher-plant (although in one variety the flowers are yellow), Small-pox plant*, Whippoorwill-bouts, Whippoorwill-shoe*, Skunk Cabbage*; Ger. Wasserkrug, Jägermüıze, Trompetenblatt; Fr. Sarracénie. Plant tonic, anoḍ̣ne, astringent.

c. S. varioláris Michx. Southeastern U. S. Small-pox plant, Spotted Pitcher-plant or Trumpet-leaf, with muny of the synonyms of the foregoing. Properties of (a).

1788. SÁSSAFRAS, Nees \& Eberm. Sassafras. Lauraceae. The Spanish popular name. Syn. Laurus, in part. Au aromatic tree. One species, eastern N. America.

a. S. Sásvafras (L.) Karst. (L. Sassafras L., S. officinale Nees, not Sieb., S. variifolia (Salisb.) O. Kze., L. variif lius Salisb.). Ontario and eastern U. S. Sasbafras, Saxilrax, Ague-tree, Cinnamon-wood, Saloop, Smelling-stick; Fer. Fenchelholz, Panamehılz, Fr. Sasvafras (Codex): Sp. Sasafras. Burk of root; sassafras, U. S. P., Cortex sašafras; stimulant, aromatic, alterative, owing its virues to the volatile oil. Root, Sassafras Radix Br., Lignum Sas:afras P G. Lignumpavanum. Pith; sassafras medu. Ia. U. S. P., mucilaginous, demulcent.

1789. SATURÉLA, L.

Savory.

Labiatae. The Latin name, whence is derived the English. Syn. Micromeria, in part. Aromatic herbs or shrubs. About 18 species, mostly of Mediterranean region, 1 native in U.S.

a. S. horténsis L. Europe, widely cult. and nat. Summer Savory; Ger. Saturei, Hfefferkraut, Bohnenkraut, Wurstkraut; Fr. Sarrietle (Codex). Herb diaphoretic, carminative; uned chiefly as a condiment.

b. S. montána L. (M. montana Peich.). Southern Europe. Winter Savory. Pruperties of (a).

1790. SAURÚRUS, L. Lizard's-tail. Saururaceae. From Greek, "Lizard's tail", alluding to the inflorescence. Marsh herbs. Two known specie;, one of Asia, one of eastern U. S.

a. S. cérnuus L. Ontario and eastern U. S. Lizard's-tail, Breast-weed. Root emollient, divcutient.

1791. SAUSSÚREA, DC. Saw-wort, etc. Compositae. Named for H. B. and Theodora de Sasure, Swiss botanists, 18 th and 19th Centuries. Syn. Aplotaxis, Aucklandia, in jart. Perennial herbs with unrple ur blue flowers. About 70 species, north temperate zone; 2 or 3 in U.S.

a. S. Lappa C. B. ('arke (Ap. Lappa Decaisne, Auck. Costus Falconer). Cashmere. Cinstus root, Koot (Cashmere), Putchuk (Bengal), Knost (Arabic). Rrot, believed to be the costus of the ancients; pungent, aphrodisiac. 
1792. SAXÍFRAGA, L. Saxifrage. Saxifragaceae. The Latin name, "stone breaking". Perennial herbs, generally with tufted basal leaves. About 210 species, north temperate zone; 59 in U. S.

a. s. sarmentósa L. China and Japan, cult. as a house plant. Beefsteak or Strawberry Geranium, Aaron s-beard, Chinese Saxifrage, Creeping-sailor, Humility, Mother-of-thousands, Old-man's-beard, Pedlar's-basket, Poor-man's Geranium, Roving-Jenny, Spider plant, Strawberry plant, Thread-of-life, Wandering Jew.

b. S. Virginiénsis Michx. Canada to Genrgia and Tennessee. Early Saxifrage, Spring Saxifrage, Everlasting, Sweet-Wilson.

1793. SAXIFRAGÓPSIS, G. Small. Saxifragaceae. Greek, "Saxifrage like". Perennial with woody caudex. One species, California.

1794. SCABIÓSA, L. Scabious, Pincushion-flower. Dipsacaceae. The Latin name, the plant reputed to cure "scaly" eruptions. Syn. Knautia, Succisa, in part. Unarmed herbs, the flowerheads resembling those of a Composite plant. About 100 species, Old World; 3 nat in U. S.

a. S. arrénsis L. (K. arvensis Coult.) Europe, nat. in eastern U. S. Field Scabious, Blue-buttons, Blue-caps, Easteningwort, Gipsy Rose, Egyptian Rose, Pin-cushion. Leaves expectorant, demulcent.

b. S. atropurpúrea L. Europe and Asia, nat. in U. S. Mourning-bride, Mourning-widow, Sweet Scabious or Scabish, Egyptian Rose*.

c. S. succísa L. (Succisa pratensis Moc.). Europe. Devil's-bit, Devil's-root, Blue Scabious, Wood Scabious.

1795. SCAÉvOLA, L. Scaevola. Goodeniaceae. Named for M. Scaevola, in allusion to the one-sided flowers. Herbs or shrubs. About 70 species, Australia and Oceanica, 1 cosmopolitan species in U. S.

1796. SCÁNIIX, L. Venus' Comb, etc. Umbelliferae. The Greek name of a salad plant. Syn. Pecten. Annual herbs, with dissected leaves. About 10 species, Old World.

a. S. Pécten-Véneris L. (Pecten Veneris Lam.). Europe and Asia, nat. in eastern U. S. Venus'-comb, Lady's-comb; Shepherd's-needle. Adam's-needles, Beggar's needles, Crake-needles, Crow-needles, Devil's-darningneedle, Needle Chervil, Pinkneedles, Pucker-needle, Puck-needle (Poukenel), Shepherd'sneedles, Hedge-hog. Shoots eaten as salad.

1797. SCILAEFÉRIA, Jacq. (Scheffera,Schaefera).('elastraceae.

Named for J. C. Schaeffer, German naturalist, d. 1790. Shrubs with small coriaceous leaves. About 6 species, warmer regions of $\mathbf{N}$. America, 2 in U. S. (a) S. Prutéscens Jacq. (S. buxifolia Nutt., S. completa Swz.). Florida to Mexico and West Indies. Yellow-wood, Box-wood. 
1798. SCHEUCHZÉRIA, L. Scheuchzeria. Scheuchzeriaceae. Named for the brothers Scheuchzer, Swiss naturalists, 18th Century. Rush-like bog perennial herb. One species, north temperate zone (U. S.).

1799. SCHíNUS, L.

Pepper-tree. TheHiNUS, L. of the meptic tree, from it " Syn. Molle, Adans. Trees or shrubs with pinnate leaves. About 12 species, warmer S. America and Australia.

a. S. Mólle L. South America, cult. in California and elsewhere as an ornamental tree. Pepper-tree, Chili Pepper* (California), Peruvian Mastic-tree, Pepper shrub. Fruit pungent, used in Chili to prepare a wine.

1500. SCHIZAÉA, J. E. Smith. Curly-grass. Schizaeaceae. From Greek, "cleft". Ferns, with slender linear fronds, the fertile ones in our species terminating in a tuft-like expansion. About 16 species, mostly tropical; 1 in U. S. Sometimes called Curly-grass.

1801. SCHIZÁNDRA, Michx. 1803. Schizandra. Magnoliaceae. Syn. Stellandria, Brickell 1803. Climbing shrubs with red, white or yellowish flowers. About 10 species, mostly of warmer Asia and East Indies; 1 in U. S.

1802. SCHIZONOTUS, Gray1876 (not Lind.1830).A sclepiadaceae. Syn. Solanoa, Greene; Gomphocarpus, in part. Small perennial herb. One species, California.

1803. SCHKÚHRIA, Roth. Schkuhria. Compositae. Named for Ch. Schkuhr, German botanist. Syn. Achyropappus, Hopkirkia. Annual herbs. About 10 species, warmer regions of New World; 2 in southern U.S.

1804. SCHLEÍCHERA, Willd. Lac tree, etc. Sapindaceae. Named for J. G. Schleicher, Swiss botanist, early in 19th Century. Syn. Cussambium, Rumph. Trees. Three species, Tropical Asia.

a. S. trijuga Willd. (C. spinosum Buch Ham.). India to Burma. Lac tree, Koosumbia. Yields lac. See Croton (a).

1805. SCHOENOCRÁMBE, Greene. Schœnocrambe. Cruciferae. From Greek, "rush Crambe". Syn. Sisymbrium, in part. Herbs. Three species in U.S.

1806. SCHOÉPFIA, Schreber. Schœpfia. Olacaceae. Named for J. D. Schœepf, botanical explorer, d.1800. Shrubs or small trees. About 16 species, tropical Asia and America; 1 in U. S.

1807. SCHWÁLBEA, L. Chaff-seed. Scrophulariaceae. Named for C. G. Schwalbe of Holland, 18th Century. Perennial herb with yellowish-purple flowers. One species, eastern U. S.

1808. SCÍLLA, L. Squill, Cape Hyacinth.

Liliaceae.

The ancient Greek name of the medicinal squill. See Urginea. Scapose herbs from a coated bulb. About 80 species, Old World, a single species in Chili. 
a. S. festális Salisb. (S. nutans Sm.). Europe. Bluebell (England), Harebell (Scotland), Bell-bottle, Crow-bells, Crow Leek. See Campanula (b).

1809. SCÍRPUS, L. Rush. Cyperaceae. Latin name of Bulrush, of Celtic origin. Syn. Elytrospermum, in part. Annual or perennial sedges, soine almost leafless, others leafy. About 200 species; 35 in U. S.

a. S. lacústris L. (Includes the American S. validus Vahl.). Widely distributed. Great Bulrush, Bulrush, Bass, Bent, Black Rush, Bolder, Bumble, Club Rush, Frail Rush, Mat Rush, Panier Rush, Pole Rush, Spurt-grass. Probably a distinct species is (b) S. Califórnicus (C. A. Meyer) Brit. (E. Californicum C. A. Meyer, S. riparius J. \& C. Presl. (Kew), S. Tatora Kunth, S. lacustris var. occidentalis S. Wats.). Florida to California. California Bulrush, Tule, Tule Rush.

1810. SCLERÁNTHUS, L. Knawel, etc. Caryophyllaceae. From Greek, "hard flower". Low herbs. About 10 species, Old World. (a) S. ánnuus L. Europe, nat. in eastern U. S. Knawel, German Knotgrass, Gravel Chickweed; Ger. Wilde Knauel; Fr. Gnavelle.

1811. SCLEROCÁRPUS, Jacq. Sclerocarpus. Compositae. From Greek, "hard fruit", alluding to indurated enclosing bracts. Syn. Aldama, Gymnopsis, in part. Herbs with yellow flowers. About 8 species, Africa and Mexico; 1 in Texas.

1812. SCLERÓLEPIS, Cass. Sclerolepis. Compositae. From Greek, "hard scale", descriptive of pappus. Syn. Aethulia, Sparganophorus, in part. A slender aquatic herb with whorled leaves. One species, eastern U. S.

1813. SCOLÍOPUS, Tor. Scoliopus. Liliaceae. Herbs related to Clintonia. Two species, western U. S.

1814. SCOLOPÉNDRIUM, Adans. Polypodiaceae. From Greek, "centipede", alluding to sori. Syn Asplenium, Phyllitis, in part. Ferns with entire fronds. About 5 species; 1 in U. S.

a. S. Scolopéndrium (L.) Karst. (A. Scolopendrium L., S. vulgare J. E. Sm., P. Scolopendrium (L.) Greene, S. officinarum :Ŝwz., S. officinale DC. ). Widely distributed in Old World, rare in U.S. Hart's-tongue, Sea weed Fern, Snake Fern, Snakeleaves, Caterpillar Fern, Adder's-tongue*, Fox-tongue, Buttonhole, La mb's-tongue, Finger Fern; Ger. Hirschzunge. Fronds, Folia scolopendrii, Fol. linguæ cervinæ, Fol. phyllitidis; diuretic, expectorant.

1815. SCóLYMUS, L. Spanish Oyster-plant. Compositae. Thistle-like plants. About 4 species, Mediterranean region; 1 nat. in U. S. (a) S. Hispánicus L., Spanish Oyster-plant, Golden Thistle.

1816. SCOPÁRIA, L. Broom-weed. Scrophulariaceae. From Latin scopa, a "broom". Herbs or shrubs. About 6 species, warmer regions of New World; 1 in U. S. (a) S. 
dúlcis L. (S. procumbens Jacq., S. ternata Forsk.). Southern U. S. and southward. Sweet Broom-weed, Licorice-weed (West Indies).

1817. SCOPÓLA, Jacq. (Scopolia). Scopola. Solanaceae. Named for Scopoli, Austrian naturalist, 18th C'entury. Syn. Hyoscyamus, in part. Narcotic herbs. About 5 species, mostly of eastern Asia.

a. S. Japonica Maximowicz. Japan. Japanese Belladonna. Properties of Belladonna, as in the European (b) S. Carniólica Jacq. (H. Scopolia L.).

1818. SCORZ0NÉLLA, Nutt. Scorzonella. Cichoriaceae. Diminutive from Scorzonera. Syn. Anacalais, Calais, Microseris, in part. Biennial or perennial herbs. About 12 species, Pacific border of U. S.

1819. SCORZONÉRA, L. Winter Asparagus. Compositae. Latin from the Spanish name, meaning "snake weed". Herbs, mostly perennial with large heads of yellow flowers. About 120 species, Mediterranean region to central Asia.

2. S. Hispánica L. Europe and western Asia, extensively cult. Viper's-grass, Winter Asparagus, Black Salsify. Root esculent, with alleged medicinal properties like those of dandelion. Other species have esculent roots, rotably (b) S. deliciósa Guasson, of Sicily and (c) S. tuberósa Pallas, Turkestan.

1820. SCROPHULÁRIA, L. Figwort. Scrophulariaceae. From Latin, "serofula plant". Perennial ill-smelling herbs, some shrubby. About 120 species, northern hemisphere, especially in Europe; 4 in U. S.

a. S. aquática L. Europe. Water Figwort, Water Betony, Bullwort, Bishop's-leaves, Brownwort; Fr. Scrophulaire (Codex), in part. See (b).

b. S. nodósa L. Europe. Figwort, Common or Water Figwort, Knotty-rooted Figwort?, Brownwort, Carpenter's-square. Squarestalk, Heal-all, Kernelwort, Pilewort, Scrofula-plant, Throatwort; Ger. Kropfwurzkraut, Knotenwurz; Fr. Scrophulaire (Codex), in part; Sp. Escrofularia. Herb vulnerary, alterative, emmenagogue. The same synonyms and properties belong to the indigenous (c) S. Marylándica L. (S. nodosa, var. Marylandica Gray). American or Maryland Figwort, Holmes' weed.

1821. SCUTELLÁRIA, L. Skullcap, Helmet flower. Labiatae. From Latin, "dish", in allusion to calyx. Bitter herbs, some shrubby, flowers blue or violet, rarely white. About 100 species; 26 in U. S.; Ger. Helmkraut, Schildkraut; Fr. Scutellaire.

a. S. galericuláta L. Europe, Asia and northern America, south to $\mathrm{N}$. Carolina and Arizona. European Skullcap, Marsh Skullcap, Hooded Willow-herb.

b. S. integrifólia (S. hyssopifolia L.). Eastern U. S. Hyssop Skullcap, Larger Skullcap. 
c. S. lateriflóra L. British America, south to Florida, New Mexico and Washington. Mad-dog Skullcap, (Scullcap), Hoodwort, Mad-weed, Side-tlowering Skullcapł, American Skullcap, Blue Pimpernel, Hooded Willow-herb. Herb bitter, tonic, nervine, the same properties being attributed to the foregoing and other species.

1822. SEBASTIÁNIA, Sprengel. (Sebastiana). Euphorbiaceae. Named for Antonio Sebastiani, early part of 19th Century. Shrubs, allied to Stillingia. About 40 species, mostly of Brazil, two in Old World; 1 in West Indies and Florida.

1823. SECÁLE, L. Rye. Gramineae. Latin name, a grain which is "reaped". Grasses related to Triticum. Five species (perhaps only two) are known, of western and central Asia.

a. S. cereále L. Central Asia, much cult. in colder climates. Rye; Ger. Roggen; Fr. Seigle (Codex); Sp. Centeno. Crain esculent. See Claviceps.

1824. SÉDUM, I. Stonecrop, etc. Crassulaceae. Latin name, alluding to the lowly habit of the plants. Rhodiola, in part. Fleshy herbs. About 150 species, cooler regions, mostly of northern hemisphere; 28 in $\mathrm{U}$. S., including some naturalized.

a. S. ácre L. Europe and northern Asia, locally nat. in U. S. Wall-pepper, Mossy or Biting Stonecrop, Bird's-bread, Creeping-Charlie, Creeping-Jack, Crowdy, Ginger*, Gold-chain, Golden Moss, Jack-of-the-buttery, Kit-of-the-wall, Love-entangle, Mountain Moss, Pepper-crop, Poor-man's-pepper, Prick-madam, Pricket, Rock-plant, Stonnard, Tangle-tail, Treasure-oflove, Trip-madam, Wall Moss, Wallwort; Ger. Mauerpfeffer, Steinkraut, Katzentraublein; Fr. Joubarbe acre, Poivre des murailles; Sp. Siempreviva menor. Herb; Herba sedi minoris, H. illecebræ vermicularis; acrid, vesicant, emeto-cathartic, alterative.

b. S. refléxum L. Europe, cult. and adv. in U. S. Reflexed Stonecrop?, Dwarf House-leek, Creeping-Jenny, Indian-fog, Love-in-a-chain, Prick-madam, Trick-madam, Trip-madam.

c. S. Teléphium L. Europe and Asia, nat. in U. S. Orpine, Garden Orpine, Orpiesł, Orphan-Johnł, Live-forever, Livelong, Aaron's-rod, Arpent-weed, Bag-leaves, Everlasting, Evergreen, Frog's-bladder, Frog's-mouth, Frog-plant, Life-of-man, Midsummer-men, Witches'-moneybags, Solomon's-puzzles; Ger. Fetthenne, Fette Henne; Fr. Joubarbe des vignes, Grasette. Herb; Herba telephii, H. crassulæ majoris, H. fabariæ; refrigerant, febrifuge, antispasmodic.

d. S. telephióldes Michx. Pennsylvania to Georgia. American Orpine, Wild Live-forever, Sweet-heart. Other notable species are (e) S. álbum L., Europe, White Stonecrop, Prickmadam, Worm-grass; (f) S. Anacámpseros L., Europe, Herb-of-friendship; (g) S. pulchéllum Michx., southeastern U. S., Widow's-cross, Flowering Moss, Rock Moss; (h) S. róseum (L.) Scop. (S. Rhodiola DC., R. rosea L.)., North 
circumpolar region, Rosewort, Rose-root, Snowdon Rose, Heal-all*; (i) S. rupéstre Lo, Europe, Jealousy, (j) S. Siebóldii Auct., Japan, Constancy; (k) S. ternátum Michx, New York to Georgia, Wild Stonecrop, Three-leaved Stonecrop

1825. SELAGINÉLLA, Beauv. Selaginella. Selaginellaceae. Diminutive of Selago, an ancient name of a Ground-pine. Plants resembling Lycopodium, generally small. About 335 species, widely distributed; 9 in U. S.

a. S. lepidophýlla Spring. Arizona to southern California. Resurrection-plant, Rock-lily, Rock-rose, Hollyhock-rose. Plant when dry curls up and remains dormant indefinitely, reviring again when water is supplied.

b. S. rupéstris (L.) Spring. Throughout northern hemisphere and in Africa. Rock Selaginella, Christmas Evergreen*, Festoon Pine; Dwarf Club-moss.

c. S. selaginóides (L.) Link. (Lycopodium selaginoides L., S. spinosa Beauv.). Europe, Asia and N. America, south to Michigan and Colorado. Low Selaginella, Prickly Club-moss, Mountain Moss.

1826. SELÉNIA, Nutt. Selenia. Cruciferae. From Greek, "Moonwort", the species resembling Lunaria. Tufted herbs. Two or three species, northern Mexico and southern U. S.

1827. SELINOCÁ RPUS. Gray. Selinocarpus. Nyctaginaceae. From Greek, "parsley fruited". Herbs. Three species, Mexican border.

1828. SELÍNUM, L. Selinum. Umbelliferae. The Greek name of Parsley, whence our word celery. Tall perennial herbs. About 25 species, mostly of northern hemisphere; 8 in western U. S. See Peucedanum.

1829. SEMECÁRPUS, L. fils. Cashew-nut. Anacardiaceae. From Greek, "marking fruit". Syn. Anacardium, in part. Trees with coriaceous leaves. About 40 species, East Indies. See Anacardium.

a. S. Anacárdinm L. fils. (A. officinarum Gaertn., A. orientale Auct., A. latifolium Lam., A. solitarium Stokes). India. Oriental Cashew-nut (Cachew), Malacca-nut, Marany-nut, Marking-nut, Marsh-nut, Malacca Bean, Acajou-nut, Mangle; Ger. Elephantenlaüse. Nuts edible, but the husk is acrid and almost caustic. Juice produces an indelible stain.

1830. SEMPERVÍVUM, L. House-leek. Crassulaceae. From Latin, "ever living". Fleshy perennial herbs. About 10 species, Old World.

a. S. tectórum L. Europe, cult. and adv. in U. S. House-leek, Homewort, Bullock's-eye, Fon, Fone (Scotland), Healingblade, Hen-and-chickens, Hockerie-topner, Imbreke, Jupiter's- 
beard, Jobarbe $\ddagger$ Jubard $\ddagger$, Sengreen, Thunder-plant (formerly believed to ward off lightning); Ger. Hauslauch, Hauswurzel, Dachlauch, Donnerkraut, Fr. Grande joubarbe; Sp. Siempreviva major. Herb, Herba sedi majoris, H. sempervivi; refrigerant, astringent, antispasmodic, detergent. See Sedum.

1831. SENÉCI0, L. Groundsel, Squaw-weed, etc. Compositae. From Latin senex, "old man". Syn. Cineraria, in part. Herbs or occasionally shrubs, many with rather large showy flower-heads. About 1000 species, widely distributed; 109 in U. S.

a. S. aúreus L. (including S. gracilis Pursh, now called S. aureus gracilis (Pursh) Britton). Canada and eastern U. S. Liferoot, Golden Ragwort, Swamp Squaw-weed, Cocash-weed, Cough-weed, Female-regulator, Fireweed*, Golden Senecio, Grundy-swallowł. Mequot, Nunqua, Nutqua, Uncum, Unkum, Ragwort, Snakeroot*, Squaw-weed, False Valerian. Herb emollient, anodyne, reputed emmenagogue. (b) S. oborátus Muhl. (S. Elliottii T. \& Gr.), and some other indigenous species are also employed, and similar properties are attributed to (c) S. Balsámitae Muhl. (S. aureus (Kew.), var. Balsamitae T. \& G.), British America and northern U. S. Balsam Groundsel, Groundsel Balsam.

d. S. Cinerária DC. (C. maritima L.). Mediterranean region, cult. in gardens. Dusty-miller. The name Cineraria among florists is applied to hybrid varieties of (e) S. cruéntus DC. and other species from the Canary Islands.

f. S. Jacobaéa L. Europe, adv. in eastern U. S. Tansy Ragwort, Staggerwort, Ban-weed, Cammock, Cheadle Dock, Cushag, Fairies'-horse, Felon-weed, Kettle Dock, Kadle Dock. Ragweed*, Saracen's Comfrey, St. James'-wort, Staverwort, Stinking-Älexander (Elshinder), Stinking-Willie, Tansy*, Weeby. Properties of (a).

g. S. vulgáris L. Europe, locally nat. in U. S. Groundsel, (Grinsel), Common Groundsel, Birdseed, Chicken-weed, Chincone, Fleawort, Groundie-swallow $\ddagger$,Sencion, Simson $\ddagger$, Swichenł; Ger. Kreuzkraut, Jacobskraut; Fr. Seneçon (Codex). Plant mildly astringent, vulnerary, discutient.

h. S. lobátus Pers. (S. lyratus Michx., not L.), of southeastern U. S. and Mexico, is Butter-weed or Cress-leaved Groundsel; (i) S. mikanoídes Otto (S. scandens DC. ), of southern Africa, cult. in gardens and greenhouses, is German Ivy or Cape Ivy; (j) S. palústris (L.) Hook. (C. palustris L.), circumpolar (northern U. S.), is Marsh Fleawort, Marsh Groundsel, Pale Ragwort; (k) S. tomentósus Michx., southeastern U. S., is Woolly Rag-weed, Rag-woolwort, Ash-wort.

1832. SEQUOÍA, Endl.

Redwood, etc.

Named for Se-quo Yah (George Guess), d. 1843. Syn. Condylocarpus, Salisb. 1823, not Hoffm. 1816, Gigantabies, Sen., Washingtonia, Winslow 1854, Wellingtonia, Lindl. 1853, not Miers 1840; Taxodium, in part. The noblest of conifers. Two species, western U. S. 
a. S. sempérvirens (Lamb.) Endl. (T. sempervirens Lamb., T. giganteum Kell. \& Behr., C. sempervirens Salisb., S. gigantea Endl., G. taxifolia. Sen.). California and northward. Redwood, Bastard Cedar, Oregon Red Cedar. The most valuable timber tree of the West Coast.

b. S. Wellingtónia (Winsl.) Seem. (Wash. Wellingtonia Winsl., G. Wellingtoniana (Nelson) Sen., Wash. Californica Winsl., Wash. Americana Hort., Well. gigantea Lindl., S. gigantea Lindl. \& Gord. (Kew), not Endl.). C'alifornia. Washington Cedar, California Big-tree, Mammoth tree, Giant tree of California. The largest of trees.

1833. SERENÓA, Hook. f. Saw Palmetto, etc. Sabalaceae. Named for Prof. Sereno Watson of Harvard University. Syn. Serenæa, Brahea; Chamærops, Sabal, in part. A dwarf fan-palm. One species, southern U. S.

a. S. serruláta (K. \& S.) Honk. f. (Sabal serrulatum R. \& S., B. serrulata H. Wendl. (Kew), C. serrulata Pursh). S. Carolina to Florida and West Indies. Saw Palmetto. Fruit tonic, alterative, expectorant, reputed aphrodisiac.

1834. SERICOCÁ RPUS, Nees. White-topped Aster.Compositae. From Greek, "silky fruit". Syn. Conyza, Aster, in part. Perennial herbs with rather small flower-heads (rays white). About 5 species, all in U. S.

1835. SERÍNIA, Raf. 1817. Serinia. Cichoriaceae. From Greek name of Chicory. Syn. Apogon, Ell. 1824, also Krigia, in part. Small annuals with yellow flowers. Three species, all in U. S.

1836. SERJÁNIA, Plum. L. (Seriania). _ Sapindaceae. Named for Paul Serjeant, French botanist. Climbing shrubs. A bout 155 species, S. America, chiefly tropical; 3 in U. S. The plants are narcotic poisons. In Brazil; (a) $\mathbf{S}$. lethális $\mathbf{A}$. St. Hil. is used as a fish poiscn under the name of Timboe. Honey collected by wasps from the flowers is violently intoxicating.

1837. SÉSAMUM, L.

Sesame.

Pedaliaceae. Latin from ancient Greek name, whence also the English sesame. Herbs. About 10 species, nearly all of Africa.

a. S. Índicum L. Southern Asia, cult. in all tropical countries, nat. in southern U. S. Benne, Sesame, Oily-grain, Oily Bean, Oil plant, Gingili, Teel, Til; Ger. Sesam; Fr. Sésame; Sp. Ajonjoli. Leaves demulcent, emollient. Seeds esculent; source of Benne oil, Gingili or Teel oil; Oleum Sesami, U. S. Y., having properties of olive oil.

1838. SÉSBAN, Adans. 1763 (Sesbana).

Papilionaceae. The ancient name, of Arabic or Persian origin. Syn. Sesbania, Scop. 1777; Agati, Adans 1763, in part. Herbs or shrubs. About 15 species, warmer regions; 4 in U. S.

a. S. macrocárpa Muhl. Florida to Colorado and Central America. Long-podded Sesbanz, Pra-tree, Colorado Hemp. One of several species which yield a strong fibre for cordage. 
1839. SESÚVIUM, L. Sea Purslane. Syn. Pharnaceum, in part. Low fleshy herbs. About 4 species, sea coasts and saline regions; 2 in U. S.

1840. SHERÁRDIA, L. Herb Sherard, etc. Rubiaceae. Named for Dr. Wm. Sherard, English botanist, d. 1728. Herb with whorled, spiny-pointed leaves. One species, Old World.

a. S. arrénsis L. Europe, adv. in eastern U. S. Field Madder, Blue Field Madder, Spurwort, Herb Sherard.

1841. SHÓREA. Roxb.

Sâl tree.

Dipteraceae. Named for John Shore, Baron Teignmouth, Governor general of India, d. 1834. Large resinous trees. About 25 species, tropical Asia.

a. S. robústa Gaertn. India. Sâl-tree, Saul-tree, Indian Sal. Timber exceedingly heavy, hard and durable. Leaves the food of the Tussa silkworm. Exudate a kind of dammar.

b. S. Tálura Roxb. (S. laccifera Heyne). East Indies. The tree yields a kind of dammar, also lac.

1842. SHÓR'TIA, Tor. \&Gr: Shortia. Diapensiaceą. Named for Charles W. Short, American botanist, d. 1863. Perennial stemless plants. Two species, one in Japan, the other (rare) in N. Carolina.

1843. SIBARA, Greene. Sibara. Herb. One species, western U.S.

1844. SIBBáLDIA, L.

Sibhaldia.

Rosaceae. Named for Robert Sibbald, Scotch physician, d. 1712. Syn. Potentilla (Kew), in part. Small shrubby plants of alpine regions. About 5 species, north temperate zone; 1 in U. S.

1845. SÍCYOS,L. (Sycios). One-seeded Cucumber. Cucurbitaceae. Greek name of a Cucumber or Gourd. Syn. Sicyoides, in part. Annual vines, climbing by tendrils. A bout 35 species, America and Australasia; 3 in U. S.

a. S. angulátus L. (Sicyoides angulata Medic.). Canada and eastern U. S., nat. in Europe. Star-cucurnber, Bur-cucumber, One-seeded Bur-cucumber, Wild Cucumber, Nimble-Kate. Root and seeds bitter, diuretic.

1846. SICYOSPÉRMA, Gray. Sicyosperma. Cucurbitacene. From Greek, "Sicyos-seeded". A herbaceous vine closely related to Sicyos. One species, New Mexico.

1847. SÍDA, L. Sida, Indian Mallow. Malvaceae. An ancient Greek plant name. Herbs. About 75 species, warmer regions of both hemispheres; 22 in U.S. See Abutilon. (a.) S. rhombifólia Canariensis(Willd.) Griseb. (S. Canariensis Willd.). Canary Islands, nat. in southern U.S. Canary-island Tea-plant, Queensland Hemp. Leaves demulcent. Inner bark yields a strong tibre. 
1848. SIDÁLCEA, Gray.

Globe Mallow.

Malvaceae.

Name combined from "Sida" and "Alcea". Herbs. 27 species, California and Mexican border.

\section{SIDERÓXYLON, L.}

Sideroxylon.

Sapotaceae.

From Greek, "iron wood". Syn. Bumelia, Sapota, in part. 'Trees or shrubs. About 70 species, mostly tropical regions of southern hemisphere; 1 in U.S., viz. (a) S. mastichodén. dron Jacq., not Balb. (B. mastichodendron R. \& S., B. pallida Swz. ). Florida to West Indies. Mastic tree.

b. S. dulcífleum A. DC. of western Africa is called Miraculousberry (fruit exceedıngly sweet); (c) S. obovátum Gaertn. (B. cuneata Sw.), West Indies, is called Downward Plum, Saffron Plum, Ant's-wood; (d) S. rugósum R. \& S (Sap. rugosa Griseb.), Brazil and West Indies, is called in Jamaica Beef Apple, or Bull Apple.

1850. SÍLAUS, Bernh. Meadow Saxilrage. Umbelliferae. Greek name of some umbelliferous plant. Perennial herbs, natives of Eurone and Asia. (a) S. flavéscens Bernh. (S. pratensis Bess., Sium Silaus Roth.). Europe. Meadow Saxifrage.

1851. SILÉNE, L. Catchfly, etc. Caryophyllaceae. From Greek, "saliva", alluding to the sticky secretion. Syn. Cucubalus, Behen, in part. Annual or perennial herbs. About 250 species, widely distributed; 62 in U. S., including nat. species.

a. S. Arméria L. Europe, cult in gardens and nat. in U. S. Sweet William Catchfly, Garden or Lobel's Catchfly, Dwarf French Pink, Mice Pink, Limewort Catchfly, None-so-pretty, Old-maid's Pink, Pretty-Nancy, Sweet-Susan, Wax-plant.

b. S. vulgáris (Moench) Garcke (C. Behen L. not S. Behen L., B. vulgaris Moench, S. Cucubalus Wibel, S. inflata J. E. Sm.). Europe and Asia, nat. in eastern U. S. Bladder Campion, Behen, Bull-rattle, Cow-bell, Devil's-rattlebox, Knap-bottle*, Maiden's-tears, Rattle-bags, Sea Pink, Snappers, Spatling Poppy, Frothy Poppy, White Ben.

Other notable species are (c) S. acaúlis L., Arctic and Alpine Europe, Asia and N. America; Moss Campion, Moss Pink, Cushion Pink; (d) S. álba Muhl. (C. niveus Nutt., S. nivea Otth.), Pennsylvania to Iowa, Western White Campion, Snowy Campion; (e) S. nútans L., Europe, adv. in U.S. Nodding Catchfly, Dover or Nottingham Catchfly; (f) S. régia Sims., southeastern U. S., Royal Catchfly, Pixie, Piskits, Wild Pink.

1852. SÍLPHIUM, L. (Silphion). Rosin-weed, etc. Compositae. Greek name of some resinous plant. Robust herbs with coarse foliage. About 13 species, all of U. S.

s. S. laciniátum L. (S. gummiferum Ell.). Ohio to Alabama, west to 'Teras and S. Dakota. Rosin-weed, Compass-plant. Pilot-weed, Polar-plant. Herb resinous, somewhat aromatic. 
b. S. perfoliátum L. Ontario and eastern U. S., west to Nebraska. Cup-plant, Indian-cup, Ragged-cup.

c. S. terebinthináceum Jacq. Ohio to Georgia, west to Louisiana and Minnesota. Prairie Dock, Prairie Burdock, Rosin-plant, Rosin-weed, Turpentine Sunflower. Properties of (a).

1853. SIMÁBA, Aublet. Cedron. Simaroubaceae. From vernacular, Guiana. Syn. Quassia, in part. Trees and shrubs. About 15 species, tropical South America.

a. S. Cédron ( $\dot{R}$. Br.) Planch. (Q. Cedron R. Br.), Columbia and (b) S. ferrugínea St. Hil., Brazil. Cedron. Seeds, Cedron seed, Rattlesnake's-beans, Semen simabæ s. cedronis; Ger. Cedronbohne, Cedronsamen; Fr. Cotylédon de cédron (Codex). Bitter, antidote to venom of serpents.

1854. SIMA RÚBA, Aubl. (Simarouba).

Simarubaceae. From vernacular name of (a), Guiana. Trees with bitter bark and wood. About 4 species, tropical America; 1 in U. S. See Picrasma.

a. S. amára Aubl. (S. officinalis DC., Q. Simaruba L. f. ). Guiana to Brazil. Mountain Damson, Bitter Damson, Paradise tree, Paraiba; in Guiana called Simaruba, in Martinique, Bois blanc. Bark of the root, Simaruba bark; Ger. Simarubarinde, Ruhrrinde; bitter, tonic.

b. S. glaúca DC. (Q. glauca Spreng, S. officinalis Macf. not DC., S. medicinalis Endl.). West Indies and Central America. Paradise tree; Fr. Simarouba (Codex). Properties of (a).

1855. SLMMÓNDSIA. Nutt. 1844. Simmondsia. Buxaceae. Named for T. W. Simmonds, English naturalist. Syn. Brocchia, Mauri 1845. Evergreen shrub with acorn-like nuts. One species, California.

1856. SINÁPIS, L. (originally Sinapi). Mustard. Cruciferae. The Greek name, from Celtic. Syn. Brassica, Leucosinapis, in part. Herbs of rank growth. About 5 species, southern Europe.

a. S. álba L. (I. alba Spach., B. alba Boiss.). Europe and western Asia, adv. in U. S. White Mustard, Charlock, Kedlock, Senvre; Ger. Weisser Senf, Gelber Senf; Fr. Moutarde blanche (Codex); Sp. Mostaza blanco. Seeds, White or Yellow Mustard-seed; Sinapis Alba, U. S. P., Sem. erucæ; laxative. Seedleaves used as salad.

1857. SIPHONOGIÓSSA, Oersted. Siphonoglossa. Acanthaceae. From Greek, "tube tongue". Suffrutescent plants. About 4 species, Mexico and adjacent territory; 1 in U. S.

1858. SIPHONÝCHIA, T. \& Gr. Siphonychia.Caryophyllaceae. Annual herbs. About 4 species, western N. America; 3 in U. S. 
1859. SísON, $\mathrm{L}$.

Honewort.

Umbelliferae.

Ancient Greek name. A slender herb. One species, (a) S.

Amómum L., Europe to Asia Minor; Honewort, Bastard Stone-parsley. Seeds aromatic, used as a condiment.

1860. SISÝMBRIUM, L. (Sysimbrium).

Cruciferae.

Ancient Greek name of an allied plant. . Syn. Erysimum, Adans.; Arabis, Braya, in part. Annual or perennial herbs. About 50 species, widely distributed; 6 in:U. S.

๙. S. officinále (L.) Scop. (E. officinale L.). Europe and northern Asia, nat. in U. S. Hedge Mustard, Bank Cress, Hedgeweed, California Mustard (locally), Lucifer-matches, Scrambling Rocket; Ger. Wilder Senf, Hederich; Fr. Erysimum, Vélar, Tortelle, Herbe aux chantres (Codex); Sp. Erésimo. Plant antiscorbutic, lithontriptic. Seeds pungent.

1861. SISYRÍNCHIUM, L. 1753. Blue-eyed Grass. Iridaceae. Ancient Greek plant name. Syn Bermudiana, Adans. 1763. Perennial scapose herbs with grass-like leaves. About 70 species, New World; 10 in U. S.

a. S. angustifólium Mill. (S. anceps Cav., S. mucronatum Michx. B. graminifolia Medic. This with sorne other species has been erroneously referred to S. Bermudiana L. ). British America, south to Virginia, Kansas and Colorado. Common Blue-eyed Grass, Pointed Blue-eyed Grass, Blue-grass*, Blue-eyed Lily, Blue-eyed Mary, Grass-flower, Pig-root, Rush Lily, Star-eyed Grass. Root acrid, cathartic.

1862. SITÍLIAS, Raf. 1836. False Dandelion. Cichoriaceae. Name unexplained. Syn. Pyrrhopappus (Kew), DC. 1838; Leontodon, Barkhausia, in part. Herbs with rather large heads of yellow flowers. Six known species, North America; 4 in U. S.

1863. SÍUM, L. Water Parsnip. Umbelliferae. The Greek name of a marsh plant, perhaps of Celtic origin. Perennial marsh herbs. About 8 species, north temperate zone and Africa; 3 in U.S. See Berula and Oxypolis.

2. S. cicutaefólium Gmel. (S. lineare Michx.,S. latifolium of American authors, not of Lin.). British America, south to Florida, Louisiana and California. American Water Parsnip, Wild Parsnip. The plant is said to have poisonous properties.

b. S. Iatifólium. L. Europe. European Water Parsnip, Root, Radix sii palustris, R. pastinacæ aquaticæ; poisonous.

c. S. Sisárum L. Japan, China and Siberia, also cult. Skirret (Skeryth, Skyryth, Skyrwort), Crummock; Ger. Zuckerwurzel; Fr. Sucrerot. Root esculent.

1864. SMELÓWSKIA, C. A. Meyer. Smelowskia. Cruciferae. White-woolly alpine perennials. About 6 species, northern Asia and N. America; 3 in western U. S. 
1865. SMÍLAX, L. Sarsaparilla, etc.

Smilaceae.

Greek name of Yew, also of an Oak. Syn. Coprosmanthus, in part. Perennial climbers, commonly shrubby. About 195 species, most abundant in tropical America and Asia; 18 in U. S.

a. S. áspera L. Mediterranean region to India. Italian Sarsapar lla, Rough Bindweed. Properties of (e).

b. S. Chína L. Japan and eastern Asia. Rhizome, China-root, Radix (Khizoma s. Tuber) Chinae; Ger. Chinawurzel, Pockenwurzel, Chinaknolle; Fr. Squine (Codex); alterative.

c. S. glycyphýlla Smith. Australia. Botany Bay Tea, Sweet Tea. Leaves used instead of tea. Root alterative.

d. S. herbácea L. (C. herbaceus Kunth, S. pulverulenta Michx.). Canada and eastern U. S. Carrion-flower, American Jacob'sladder.

e. S. médica Sch. \& Cham. Mexico. Mexican Sarsaparilla. Source of the Vera Cruz and Tampico Sarsaparilla. The word Sarsaparilla is from the Spanish, meaning "bramble-vine". Root [of this and (f)]; Sarsaparilla, U. S. P., Sarsæ Radix Br., Radix sarsaparillae s. sarsae; Ger. Sarsaparille, Sassaparille, Stechwindenwurzel, Sarsa; Fr. Salsepareille du Mexique (Codex); Sp. Zarzaparilla; alterative.

f. S. officinális Humb. \& Kunth. New Granada. Source of Jamaica Sarsaparilla (the only variety recognized in the British Pharmacopoeia), Red Sarsaparilla, Bearded Sarsaparilla. See (e).

g. S. papyrácen Duham. Guiana to Brazil. This species yielda a portion of the Brazilian Sarsaparilla (Rio Negro, Para or Lisbon Sarsaparilla), the exact botanical source of the several varieties being not yet ascertained. Other species which furnish medicinal sarsaparilla are (h) S. cordato-ováta Richard, (i) S. ellealyptifólia Kunth.; (j) S. ornáta Hook. f.; (k) S. scabriúscula Kunth, and (1) S. syphilítica Kunth.

m. S. Pseudo-Chína L. Southeastern U. S. Bamboo Brier, American China-root, False or Bastard China-root, Long-stalked Green-brier, Bull-brier. R/izome alterative. The rhizome of (n) S. Bóna-nóx L. (S. hastata Willd., S. tamnoides A. Gray, not L. ), Bristly or Fiddle-shaped Green-brier, is also used.

0. S. rotundifólia L. (S. caduca L., S. quadrangularis Willd.). Ontario and eastern U. S. Green-brier, Cat-brier, Horse-brier, Bamboo-brier, Biscuit-leaves, Bread-and-butter, Devil's Hopvine, Hungry-vine, Nigger-head, Wait-a-bit. Rhizome alterative; largely used for making brier-wood pipes.

1866. SMÝRNIUM, L. Alexanders. Umbelliferae. From Greek name of Myrrh. Herbs. About 8 species, middle and eastern Europe. (a) S. Olúsatrum L. Alexanders, Alisander (Alshinder, Elshinder), Horse Parsley, Wild Celery, Wild or Macedonian Parsley, Meg-weed, Stan-march. Leafstalks used like celery. 
1867. SOLÁNUM, L.

Potato, etc.

Solanaceae.

Latin name of Nightshade from solamen, "quieting". Syn. Cyphomandra, Dulcamara, in part. Herbs or shrubs. About 900 species, most abundant in tropical America; 23 in U. S.

a. S. aculeatíssimum Jacq. Asia and tropical America, nat. in southern U. S. Apple-of-Sodom, a name given also to other species having bright colored dry fruits.

b. S. Aethiópicum L. Tropical Africa, cult. in China and elsewhere. Fruit esculent, as is that of (c) S. betáceum Cav. [C. betacea Sendt (Kew)]; (d) S. édule Schum. \& Thou. [Index Kew. makes this a syn. of (k)], Guinea; (e) S. Gílo Raddi, tropical America; (f) S. torvum Swz., tropical Anıerica; (g) S. Upóru Dunal, Oceanica; (h) S. réscum F. Muell., the Gunyang of Australia. See also (k), ( 1$),(\mathrm{m})$.

i. S. Carolinénse L. Ontario and eastern U. S. Horse-nettle, Apple-of-Sodom, Bull-nettle, Radical-weed. Berries and root, anodyne, antispasmodic, diuretic.

j. S. Dulcamára L. (D. flexuosa Moench). Europe, western Asia and northern Africa, nat. or possibly indigenous in U. S. Bittersweet, Nightshade, Climbing or Woody Nightshade, Amaradulcis, Blue Bindweed, Dwale, Felonwort, Fever-twig, Morrel, Poison-berry, Pushion-berry $\ddagger$, Poison-flower,Scarlet-berry, Skawcoo, Snake-berry, Tether-devil, Terrididdleł, Violet-bloom, Wolf-grape; Ger. Bittersüss, Hindischkraut; Fr. Morelle grimpante; Sp. Dulcamara, Gloria. Young branches; Dulcamara, U. S. P., Stipites dulcamare, mildly narcotic, sedative.

k. S. Melóngens L., not Wall. (including S. esculentum Dun, the commonly cultivated variety). Tropical Asia, now widely cult. Egg-plant. Fruit, Egg Apple, Jew's Apple, Mad Apple, Vegetable Egg, Brinjal (East indies), Aubergine (France), Begoon, Guinea Squash; esculent. The Peruvian (1) S. muricátum Ait., Pepino, Melon shrub, is also cultivated for its melon-like fruit. The fruit of (m) S. Quıtoénse Lam., Quito Orange, resembles an orange in size, color and taste.

n. S. tuberósum L. South America, now widely cult. in many varieties. Potato, Common or Irish Potato; Ger. Kartoffle; Fr. Pomme de terre; Sp. Patata. Tubers, locally called spuds, esculent, source of potato starch. Some other species produce similar starchy tubers.

o. S. nígrum L. A cosmopolitan weed, with numerous botanical synonyms. Black Nightshade, Common or Garden Nightshade, Duscle, Hound's-berry, Petty-morel; Ger. Schwartzer Nachtschatten; Fr. Morelle (Codex). Herb vulnerary, perhaps feebly narcotic, but used as a pot herb. Berries edible.

Other species of interest are (p) S. elaeagnifólium Cav., Kansas to Arizona, Silver-leaved Nightshade, Trompillo; (q) $\mathbf{S}$ indigóferum St. Hil., Brazil, a source of indigo; $(r)$ S. panicylátum L., Brazil, Jerubeba, used as a tonic; (s) S. Pseudo-Cápsicum L., Maderia, Jerusalem Cherry, Winter 
Cherry, cult. for ornament, as is the Brazilian ( $t$ ) S. capsicástrum Link., Star Capsicum, Dwarf Cherry; (u) S. Pseudoquíma St. Hil., Brazil, Quina, which is bitter and febrifuge; (v) S. rostrátum Dun. (S. heterandrum Pursh), Nebraska to Mexico, Sand-bur, Buffalo-bur, Beaked Nightshade, the original food-plant of the Colorado beetle.

1868. SOLENOSTÉMMA, Hayne. Arghel. Asclepiadaceae. From Greek, "tube garland" , Syn. Cynanchum, Gomphocarpus, in part. A hoary undershrub. One species, northern Africa. (a) S. Árgel (Delile) Hayne (C. Argel Del., C. oleæfolium Nect., C. fruticosa R. Br.). Egypt to Syria. Arghel, Argel. Leaves found as an adulterant of Alexandria senna.

1869. SOLIDÁG0, L. Golden-rod. Compositae. From ('Treek, "healing". Syn. Doria, Adans. Perennial herbs with small heads of yellow (or yellowish) flowers, generally in a terminal panicle or thyrsus. About 90 species, mostly of N. America; 83 in U. S. Flower-of-gold, Yellowtop. Proposed as the national flower of our country.

a. S. odóra Ait. Canada and eastern U. S. Sweet Golden-rod, Anise-scented or True Golden-rod, Blue Mountain Tea. Leaves anise-scented; astringent, diaphoretic, carminative.

b. S. Virgaúrea L. (D. Virgaurea Scop.). Europe, also northeastern U. S. European Golden-rod, Aaron's-rod, Woundwort; Ger. Goldruthe, Heidnisch-Wundkraut, Gulden-Wundkraut; Fr. Verge d'or; Sp. Vara de oro. Herb, H. virgaureæ, H. consolidæ saracenicæ; diuretic, lithontriptic, vulnerary.

Note-worthy indigenous species are (c) S. bícolor L., White or Pale Golden-rod, Silver-rod, Silver-weed, Bellyacheweed; (d) S. Canadensis L. (S. altissima L.), one of the most common species, Canada Golden-rod, High or Double Golden-rod, Yellow-weed; (e) S. Júncea Ait. (S. arguta T. \& Gr. ), Eurly. Golden-rod, Sharp-toothed or Pyramid Goldenrod, Plume Golden-rod; (f) S. nemorális Ait., Gray or Field Golden-rod, Dwarf Golden-rod, Dyer's-weed; (g) S. rugósa Mill. (S. altissima Ait., not L.), Wrinkle-leaved Golden-rod Tall Hairy Ĝlden-rod, Dyer's-weed, Bitter-weed, Pyramid Golden-rod, a name applied to several of the more shuwy species.

1870. SOLIVA, Ruiz. \& Pav. Soliva. Compositae. Perhaps a play on "Salvia". Low herbs. About 15 species, mostly in warmer regions of New World; 2 in U. S.

1871. SÓNCHUS, L.

Sow Thistle.

Cichoriaceae.

The ancient Greek name. Succulent herbs with rather small heads of yellow flowers. About 45 species, Old World; 4 nat. in U. S.

a. S. arrénsis $L$, Europe and Asia, adv. in U. S. Corn Sowthistle, Milk Thistle, Swine Thistle, Tree Sow-thistle, Dindle, Gut-weed, Rose-inay. 
b. S. oleráceus L. Europe and Asia, nat. in U. S. and widely elsewhere. Sow Thistle, Annual or Common Sow-thistle, Hare's Lettuce, Hare's Colewort, Hare's-palace, Hare's Thistle, Milk Thistle (Dashel), Milkweed*, Milky-dickles, Milky-tassels, Sow-dindle, Sow-dingle, St. Mary's-seed, Swinies; Ger. Gänsedistel, Saudistel; Fr. Laiteron. Leaves bitter, used as a pot herb. The similar (c) S. áspera L. is popularly known by the same names.

1872. SÓNNEA, Greene. Sonnea. Boraginaceae. Syn. Plagiobothrys, in part. Herbs. Six species in western U. S.

1873. SÓPHIA, Adans. 1763. Tansy-mustard. Cruciferae. From Greek, "wise". Syn. Descurainia, Webb \& Barth. 1836; Erysimum and Sisymbrium (Kew), in part. Hoarypubescent herbs, some shrubby. About 12 species, mostly of north temperate zone; 6 in U. S.

2. S. Sóphia (L.) Brit. (Sis. Sophia L., Sophia vulgaris Fourr., D. Sophia Webb.). Europe and Asia, adv. in U. S. Flixweed, Herb Sophia, Fine-leaved Hedge-mustard. Plant astringent, vulnerary.

1874. SOPHóRA, L. Sophora. Papalionaceae. From Arabic, sofara, a yellow plant; whence our word safron. Syn. Astragalus, in part. Perennial herbs, shrubs or even trees. About 25 species, warmer regions; 6 in U. S.

a. S. Japónica L. Japan and China. Pagoda-tree, Yen-ju. Buds, called Waifa or Chinese-berries, yield a yellow dye. Bark, flowers, etc. purgative.

b. S. secundiflóra (Cav.) DC. (S. speciosa Benth.). Texas. Coral-bean, Frigolito. Seeds narcotic, containing an alkaloid, sophorine. Similar properties belong to (c) S. serícea Nutt. (A. carnosus Pursh), Prairies, Nebraska to Arizona; Silky Sophora.

1875. SórbUS, L. Mountain Ash. Pomaceae. The ancient Latin name of (e), whence English sorb and service. Syn. Aria, Pyrus (Kew); Mespilus, in part. Trees or shrubs with pinnate leaves and berry-like fruit. About 7 species, north temperate zone; 3 in U. S.

a. S. Americána Marsh. (S. microcarpa Pursh, P. Americana DC. ). Canada and northeastern U. S. American MountainAsh, Dogberry, American Service-tree, Indian Mozemize, Missey-moosey, Moose-misse, Life-of-man, American Rowan-tree, Round-tree, Round-wood, Mountain Sumac, Quick-beam, Wild Ash, Wine-tree, Witch-wood. In the West this is replaced by the very similar (b) S. sambuçifólia (C. \& S.) Roem.

c. S. Aria Cranz. (A. Graeca Roem., M. Aria Scop., P. Aria (L.) Ehrh.). Europe and northern Asia. White-beam, Chess Apple, Hen Apple, Hoar Withy, Lot-tree, Mulberry*, Sea Ouler, Service-berry (Scotland), Whip-beam, Widbin Pear-tree; Ger. Mehlbeerbaum; Fr. Alisier. 
d. S. Aucupária L. (M. Aucuparia Scop., P. Aucuparia Gaertn.). Europe and western Asia. European Mountain-Ash, Rowan tree (Poan, Royne, Rawn, Roddin), Round-tree, Service-tree*, Quick-beam, Whistle-wood, Wicky, Wicken tree (Wiggen, Wiggin), Wild Ash, Witchen, Wychen, Witch-wood, Witch Hazel*, Witty tree; Ger. Eberesche, Vogelbeere; Fr. Sorbes. Unripe fruit and burk astringent.

e, S. doméstica I. (P. domestica Sm. (Kew), P. Sorbus Gaertn.). Europe. Sorb Apple, Sorb, Service-berry, Corme, Checker (i. e. choker) tree, Whitty Pear, Whitten Pear. Fruit astringent, antiscorbutic.

1876. SóRGHUM, Pers. Sorghum, etc. Gramineae. From vernacular, East Indies. Syn. Andropogon, Holcus, in part. Robust grasses. About 13 species, warmer regions.

a. S. Halepénse (L.) Pers. (H. Halepensis L., A. Halepense Brot. ). Europe and Asia, nat. in U. S. and widely elsewhere. Possibly the original of (b). Johnson Grass, Means Grass (Southern States), Egyptian Grass, Egyptian Millet, Cuba or Guinea Grass, Australian or Moroccu Millet, Maiden Cane.

b. S. vulgare Pers. (A. Sorghum Brot., A. sativus Hack.). Africa or India, now cult. widely in numerous varieties. Indian, Pearl or Black Millet. Var. cérnuum (Willd.)Gray(A. cernuus Roxb., S. cernuum Willd. ) is Guinea Corn; var. Dúrra is the prolific Durra or Doura of India, and perhaps includes the African Millet or Kafir Corn, in U. S. called Guinea Corn, Coffee Corn, Chocolate Corn (used as substitute for coffee); var. téchnicum is Broom Corn; var. saccharátum (L.) Gray (H. saccharatus L., A. saccharatus Roxb.) is Chinese Sugar-cane, Sorghum, Imphee, cult. for fodder and formerly as a source of sugar.

1877. SORINDÉIA, Thou. Sorindeia. Anacardiaceae. Trees or shrubs. About 6 species, tropical Africa and Madagascar. (a) S. Madagascarénsis DC., Madagascar, cult. in India, produces in profusion a delicious fruit.

1878. SOULÁMEA, Lam. Bitter-king. Simarubaceae. From vernacular, Moluccas, "king of bitters". Shrubs. About 8 species, East Indies. (a) S. amára Lam. (Cardiocarpus amarus Reinw., Cardiophora Hindsii Benth.). Molucca Islands. Bitter-king. Bitter tonic, febrifuge.

1879. SÓYMIDA, Juss. Bastard Cedar. Meliaceae. From vernacular, Telugu. Syn. Swietenia, in part. Tree with bitter bark and hard wood. Two species, tropical Africa and East Indies.

a. S. febrífuga (Willd. ) Juss. (S. febrifuga Willd.). Fast Indies. Rohan, Rohun, Rohuna, Bastard ('edar, Indian Red-wood, Red Cedar*, East Indian Mahogany, Juribali*. Bark astringent, tonic.

1880. SPARATTOSPÉRMA, Mart. Caroba*. Bignoniaceae. Syn. Jacaranda, Tecoma, in part. 'Trees. 'T'wo species, Brazil. (a) S. lithontrípticum Mart., is one of the plants known in Brazil as Caroba, called also Jacaranda branca. 
1881. SPARGÁNIUM, L. Bur-reed, Levers. Sparganiaceae. Ancient Greek name, from ribbon-like leaves. Aquatic or paludal plants with globose flower-heads. About 12 species, cooler regions; 6 in U. S. Synonyms are Bur-flag, Bede-sedge (-segg, -seggin), Knop-sedge, Reed-grass.

1882. SPÁRTIUM, L. Spanish Broom. Papilionaceae. Latin from the Greek name, signifying "cordage". Syn. Genista, Spartianthus, in part. Shrub, nearly leafless, with fragrant yellow blossoms. One species, Mediterranean region.

a. S. júnceum L. (S. junceus Link, G. Hispanica Lam.). Mediterranean region and Canary Islands. Spanish Broom. Twigs and seeds bitter, diuretic, emeto-cathartic.

1853. SPATHYÉMA, Raf. 1808. Skunk Cabbage. Araceae. From Greek, referring to the spathe. Syn. Symplocarpus, Salisb. 1818, Ictodes, Bigel. 1819; Pothos, Dracontium, in part. Perennial herb. One species, northern Asia and North America (U. S.).

a. S. foétida (L.) Raf. (D. fotidum L., I. fœtidus Bigel., Symplocarpus fotidus Nutt., P. fœida Michx.). Canada and eastern U. S. Skunk Cabbage, Skunk-weed, Polecat-weed, Meadow Cabbage, Swamp Cabbage, Collard, Fetid Hellebore, Stinking Poke, Pock-weed; Ger. Stinkende Drachenwurz; Fr. Pothos fétide. Rhizome and roots, Dracontium, U. S. P. 1870; acrid, expectorant, antispasmodic.

1884. SPÉRGULA, L. Spurry. Caryophyllaceae. From Latin, "scattering" its seeds. Obscure annuals. Two or three species, weeds of (Old World.

a. S. arrénsis L. Europe and Asia, adv. in U. S. Spurry, Corn Spurry, Beggar-weed, Cow-quake, Devil's-guts, Farmer'sruin, Pick-purse, Pine-cheat, Sand-weed, Yarr; Ger. Ackerspergel; Fr. Spergule. Plant occasionally grown for fodder.

1885. SPERMACÓCE, L. Button-weed. Rubiaceae. From Greek, "seed" and "point". Herbs with small clustered flowers. About 175 species, tropical regions of Old and New World; 4 in U. S. Several species furnish substitutes for Ipecac.

1886. SPERMÓLEPIS, Raf.1825, not Brongn.1863.Umbelliferae. From Greek "seed" and "scale". Syn. Leptocaulis, Nutt. 1829; Daucus, Apium (Kew), in part. Slender annuals with dissected leaves. Two species, southern U. S.

1887. SPHÁCELE, Benth. Sphacele. Labiatae. From Greek, "sage like". Strong-scented shrubs, warmer regions of New World; 2 in western U.S.

1888. SPHAERÁLCEA, St. Hil.1825. Globe Mallow.Malvaceae. From Greek, "globe Mallow". Syn. Phymosia, Desv. 1825. Herbs or shrubs. About 35 species, America and S. Africa; 23 in southwestern U. S. (a) S. Cisplátina St. Hil. of Brazil is used like marsh-mallow. 
1889. SPHAEROCÓCCUS, Stackh. Worm Moss. Gigartineae. From Greek, "spherical berry". Syn. Alsidium, Ceramium, Fucus, Gigartina, Helminthochortus, in part. Sea-weeds.

a. S. Helminthochórton (L.) Agardh. (F. Helminthochorton L., H. officinarum Link. In commerce always mixed with other seaweeds). Mediterranean Sea. Helminthochorton, Corsican Moss, Corsican Worm-weed, Worm Moss, Crow-silk; Ger. Wurmmoos, Wurmtang, Seebusch; Fr. Mousse de Corse (Codex). Plant anthelmintic, resolvent.

b. S. compréssus Agardh. One of the seaweeds furnishing Agaragar. See Eucheuma.

1890. SPHAEROSTÍGMA, Small. Primrose*. Onagraceae. From Greek, "globe stigma". Syn. Oenothera (Kew), in part. Herbs. About 17 species in western U. S.

1891. SPHENOCLÉA, Gaertn.1788. Sphenoclea.Campanulaceae. From Greek, "wedge pressed". Syn. Pongatium, Juss. 1789. Annual herb. One species, widely distributed (U. S.).

1892. SPIGÉLIA, L.

Pink-ront.

Loganiaceae. Named for Adrian von der Spigel, Belgian physician, d. 1825. Herbs with red, yellow or purple flowers. About 35 species, New World; 6 in U. S.

a. S. Anthélmia L. Tropical America. Demerara Pink-root, West India Pink-root. Brazilian Spigelia; Fr. Spigélie anthelminthique (Codex). Properties of (b).

b. S. Marylándica L. New Jersey to Florida, west to Texas and Wisconsin. Indian Pink, Carulina Pınk, Maryland Pink, Loricerall, Starbloom. Worm-grass, Worm-weed; Ger. Marylandische Spigelie; Fr. Spigélie du Maryland. Root, Pink-root; Spigelia, U. S. P., narcotic, used only as an anthelmintic.

1893. SPILÁNTHES, Jacq. (Spilanthus).

Compositae. From Greek, "spot-Huwer". Syn. Acmella. Annual or perennial herbs with rather small flower-heads. About 30 species, mostly tropical; 1 in U.S.

a. S. olerácea L. South America (?), cult. in all tropical countries. Para Cress; Ger. Farakresse; Fr. Cresson de Para (Codex). Plant pungent, used chiefly as an adjuvant to pellitnry in the compound tincture called Paraguay roux. (b) 5 . Acmélla Murr. (A. Mauritiana Richard), the East Indian Alphabet-plant, has the same properties.

1894. SPINÁCEA, L. Spinach. Chenopodiaceae. From Latin, "spinose", whence the English name. Unat tractive annuals, resembling Chenopodium. One or two species, old World.

a. S. olerácea L. Prohahly from Asia, now widely cult. as a pot herb. Spinach (Spinage); Fr. Epinard; Sp. Espinaca. The Schamum of central Asia may be a distinct species. 
1895. SPIRAÉA, L. Spiraea, Meadow-Sweet, etc. Rosaceae. Latin from the Greek name, "twisted" alluding to the follicles. Syn. Filipendula, Tourn. Low or tall shrubs, many ornamental. About 60 species, north temperate zone; 11 in U. S.

a. S. Filipéndula L. (F. vulgaris Moench). Europe. Dropwort, Droopwort.

b. S. hypericifólia L. Europe and Siberia and cult. in gardens. Bridal-wreath, May-wreath, Italian May, St. Peter's-wreath. Flower's astringent.

c. S. salicifólia L. Northern Asia, Europe and N. America, south to Genrgia and Missouri. Common Meadow-sweet (of America), Willow-leaved Meadow-sweet, Bride-wort, Quakerlady, Queen-of-the-meadow*, Queen's-needlework, Mock Willow, Spice Hardhack.

d. S. tomentósa L. Canada, south to Georgia and Kansas. Hard hack, Steeple-bush, Purple Hardhack, Spice Hardhack, Horseweed*, Pink Meadow-sweet, Meadow-queen, Poor-man's-soap, Rosy-bush, Silver-leaf, Silver-weed, White-cap, White-leaf, Spiræa. Bark and leaves astringent.

1896. SPIR0DÉLA, Schleid. Duckweed. Lemnaceae. From Greek. Syn. Lemna, in part. Minute floating plants. Two species; 1 in U. S., viz. (a) S. polyrhíza (L.) Schleid. (L. polyrhiza L. ), Gireater Duckweed.

1897. SPIRÓSTACHYS, Wats. Spirostachys. Chenopodiaceae. Fleshy, nearly leafless plants. About 3 species, two of South America, one of western U. S.

1898. SPÓNDIAS, L. Hog Plum, etc. Anacardiaceae. From Greek name of a kind of Plum. Trees, some producing edible fruit. About 5 species, tropical regions of both hemispheres.

a. S. dúlcis G. Forst. (S. lutea Royen, S. acida Blume, S. fragrans Pav.). Fiji and Society Islands and commonly cult. in tropical countries. Vi tree, Rewa. Fruit, Vi-fruit, Vi-apple, Tahiti Apple, acidulous, esculent.

b. S. lútea L. (S. myrobalans L., S. Mombin Jacq., not L.). Tropical America. Jamaica Plum, Hing Plum, Golden Apple. Flower buds used for a sweetmeat. Fruit laxative, esculent.

1899. SPRÁGUEA, Tor. Spraguea. Portulacaceae. Herbs closely related to Claytonia. Four species in western U. S.

1900. STÁCIIYs, L. Hedge-Nettle, Woundwort. Labiatae. Ancient G reek uame of a species having "spiked" intlorescence. Annual or perennial herbs. About 150 species, mostly of north temperate zone; 24 in U. S., including some naturalized species; Ger. Ziest; Fr. Épiaire; Sp. Yerba de la feridura. 
a. S. palústris L. Europe, Asia, northern N. America, south to New York and New Mexico. Hedge-nettle, Marsh Woundwort, Clown's Woundwort, Clown-heal, Clown's All-heal, Cockhead, Dead-nettle, Rough-weed, Runch, Swine Arnut; Ger. Stinknessel, Sumpfziest; Fr. Ortie rouge. Plant reputed vulnerary, antispasmodic, nauseant, emmenagogue. Some other species have been also used.

1901. STANFÓRDIA, Wats. Stanfordia. Cruciferae. Herb. One species, California.

1902. STAPHYLÉA, L. Bladder-nut. Staphyleaceae. From Gireek, "cluster" (of grapes). Shıubs. About 6 species, north temperate zone; 2 in U. S.

1903. STÁTICE, L. 1753 . Thrift, etc. Plumbaginaceac. Greek name of an astringent herb, blood "staunching". Syn. Armeria, Willd. 1809; Limonium, Adans. 1763 , in part. Scapose fleshy herbs. About 20 species, widely distributed; 1 in U. S.

a. S. Arméria L. (A. vulgaris Willd.). Europe, northern Asia and N. America, south to California. Thrift, European Thrift, Cliff Rose, Cushion Pink, Ladies'-cushion, Sea-cushion, Marsh or Sea Daisy, French or Scawfall Pink, Sea Pink, Red-root*, Rock Rose*, Sea Gilliflower, Sea-grass, Sea Thrift. Root astringent. See Limonium.

b. S. mucronáta L. Morocco. Safrifa. Root nervine.

1904. STEIRONÉMA, Raf. Loosestrife, etc. Primulacene. From Greek, "sterile filaments". Syn. Lysimachia, in part. Perennial herbs with axillary yellow flowers. About 5 species, all of U. S. (a) S. quadriflórum (Sims) Hitchc. (L. quadriflora Sims, L. longifolia Pursh), Canada and eastern U.S., Linear-leaved Loosestrife?

1905. STEMÓDIA, Goatweed.

Goatweed. Scrophulariaceae. Shortened from Stemodiacia, Greek, "two tipped stamen". Herbs, some shrubby. About 30 species, mostly tropical; 2 in U. S. (a) S. durantifólia Swz., Arizona to Brazil, is called Goat-weed.

1206. STENíNDRIUM, Nees. Stenandrium. Acanthaceae. From Greek, "slender stemmed". Herbs. About 20 species, warmer regions of New World; 2 in southwestern U. S.

1907. STENÁNTHIUM, Kunth, Stenanthium. Melanthaceae. From Greek, "narrow petaled". Syn. Helonias, V'eratrum, in part. Bulbous herbs with linear leaves, the flowers in an ample terminal panicle. Five species, Mexico and adjacent region; 3 in $\mathrm{U}$. $\mathrm{S}$.

1908. STENOPHRÁGMA, Celak. Mouse-earCress,etc. Cruciferae. From Greek, with "narrow septum". Syn. Arabis, Sisymbrium, in part. Herb. One species only. (a) S. Thaliána (L.) Celak (A. Thaliana L., Sis. Thalianum Gray). Europe and northern Asia, nat. in U. S. Mouse-ear Cresa, Thale Cress, Wall Cress, Rock Cress, Turkey-pod. Plant antiscorbutic. 
1909. STENORHÝNCHUS, Rich. Stenorhynchus. Orchidaceae. From Greek, "narrow beaked'. Syn. Spiranıhes (Kew), in part. Terrestrial orchids, with showy flowers. About 10 species, warmer regions of New World; 1 in U. S.

1910. STENOSÍPHON, Spach. Stenosiphon. Onagraceae. From Greek, with "slender" calyx "tube". Syn, Gaura, in part. A perennial herb, the white flowers in slender terminal spikes. One species, Kansas to Color ado and southward.

1911. STENótUS, Nutt. Stenotus. Compusitae. From Greek, "narrow" leaved. Syn. Aplopappus (Kew), in part. Low undershrubs with evergieen leaves, and rather large heads of yellow flowers. About 18 species, western $\mathrm{N}$. America; 7 in U. S.

1912. STERCÚLIA, L. Chica, etc. Sterculiaceae. From Latin, alluding to disgusting odor of some species. Trees with fibrous inner bark. About 85 species, mostly of tropical Asia.

a. S. Chíca St. Hil. (S. Carthagenensis R. Br.). Brazil. Panama tree, China tree. Seeds eaten as nuts. The Australian Calool tree, (b) S. quadrifida R. Br., and some other species yield also edible seeds.

c. S. Tragacántha Lindl. Northwestern Africa. Source of African or Senegal Tragacanth. (d) S. úrens Roxb., India, is the reputed source of Kuteera (Kutera) or Bassora gum, called also Indian tragacanth. Seeds edible.

1913. STÉvIA, Cav. - Stevia. - Compositae. Named for Prof. Esteve of Valencia. Herbs or suhshrubs. About 100 species, warmer regions of New World; 6 in U. S.

1914. STILLÍNGIA, L. Stillingia. Euphorbiaceae. Named for Dr. B. Stillingfleet. English botanist, 18th Century. Syn. Sapium, in part. Herbs or shrubs. About 15 species, tropical America and Oceanica; 7 in U. S.

a. S. sylvática L. (Sapium sylvaticum Torr.). Southeastern U. s. Queen's-delight, Cock-up-hat, Marcory+, Nettle-polato, Queen-root, Silver-leaf, Yaw-root; Ger., Fr. Stillingie. Root; Stillingia, U. S. P., sialagogue, alterative, expectorant.

1915. STIPULÍCIDA, Michx. Stipulicida. Caryophyllaceae. Herbs. Two species, both of U. S.

1916. STOKÉSIA, L'Her. (not Stocksia, Benth.). Compositae. Named for Dr. Jonathan Stokes, English botanist, d. 1831. Shrubs with spinose leaves and large heads of purple-blue flowers resembling the China Aster. Une species, (a) S. laévis\ (Hill) Greene, Gulf States, a rare plant, called Stokes' Aster.

1917. STREPTÁNTHUS, Nutt. Streptanthus. Cruciferae. From Greek, "twisted flower", the petals borne on a twisted claw. Annual or perennial herbs. About 38 species, southwestern U. S. (a) S. maculátus Nutt. (S. obtusifolius Hook.) is called Arkansas Cabbage. 
1918. STRÉPTOPUS, Michx. Twisted-stalk. Convallariaceae. From Greek, "twisted foot", the peduncle being bent or twisted in the middle. Syn. Uvularia, in part. Perennial herbs re-embling Silomon's-seal. About 5 speries, north temperate zone; 3 in U.S. Called also Liver-berry.

1919. STROPHÁNTHUS, DC. Strophanthus. A pocynaceae. From Groek, "twisted flower", alluding to the twisted and tailed lobes of the corolla. Trees, shrubs or climbers. About 20 species, tropical Africa and Asia.

a. S. híspidus DC. var. Kombé Oliver. [S. Kombe Oliv. (Kew)]. Tropical Africa. Source of the African arrow-poisons, Kombe, Inée (Ineh, Onage, Onaye, Wanika). Seeds, deprived of the awn, Strophanthus, U. S. P., Semen Strophunthi P. G.; cardiac tonic, resembling digitalis in action.

1920. STROPHOLÍRION, Tor. Stropholirion. Liliacene. „2:- From Greek, "twisted lily". Syn. Brodizea, in part. Scapose herb. One species, California.

1921. STROPhOSTÝLES, Ell. Wild-bean. Papilionaceae. From Greek, "twi-ted style". Syn. Phaseolus (Kew), in part. Mostly herbaceous vines. About 6 species, New World; 3 in U. S.

1922. STRÚMPFIA, Jacq. 1760. Strumpfia. Rubiaceae. Named for (:. C. Strumpf. Syn. Patsjotti, Adans. 1763. Low shrub. One species, Florida.

1923. STRÝCHNOs, L. (Strychnus). Greek name of a poisonous plant. in part. Trees, sbrubs or climbers. About 65 species, tropical regions of Asia and America.

a. S. colubrína L. Malabar. Snake-wond tree. Wood of this and some other species (containing strychnine), is regarded in India an antidote to the venom of serpents. See (d).

b. S. Ignátii Lindl. (Ignatia amara L. fils., the oldest name, but with false description, S. Philippinensis Blanco, Ignatiana Philippica Lour. According to Eng and Prantl, S. multiflóra Benth.). Philippine Islands, nat. in Cochin China. Bean of St. Ignatius, Ignatius Bean, Ignatia Bean. Seeds; Ignatia, U. S. P. 1880, Semen Ignatix, Faba ignatii, Faba febrifuga; Ger. Ignatiusbohne, Ignazbohne; Fr. Fève de Saint-Ignace (Codex), Féve igasurique; Sp. Haba de San Ignacio; bitter tonic, tetanizing poison, containing strychnine and brucine.

c. S. Malaccénsis Benth. (S. Gaultheriana Pierre). Southeastern Asia. Bark, the chief active constituent of the Chinese Hoang-nan, a reputed cure for leprosy.

d. S. Nux-vómica L. India to Australia. Nux-vomica tree. Seeds Nux-vomica, Dog-buttons, Quaker-buttons, Crnw-fig Bachelor's-buttons*,Poison-nut, Vomit-nut, Nuz vomica U.S P. Br., Semen strychni, Nuces vomicæ, Nux metella; Ger 
Strychnossamen, Brechnuss, Krahenaugen; Fr. Noix vomique (Codex); Sp. Nuez vomica; bitter tonic, tetanizing poison, containing strychnine and bı ucine. Bark, False Angostura bark. Wood sold as snake-wood. See (a).

e. S. potatórum L. India. Clearing-nut tree. Seeds, Clearingnuts, Indian-gum nuts, used to clarify drinking water. Pulp of fruit edible, as in (f) and some other species.

f. S. Tiente Leschenault. Java. Chettik. An extract of the roothatk is ll-ed in preparation of the arrow-poison, Upas tieute or Upas radja. See Antiaris.

g. S. toxifera Schomb. Amazon basin. An extract of the bark constitutes one of the principal cinstituents of the South American arrow-poison, Urari. Several other species of Strychnos are also used. 'T he compr und extract is known as Curare, Wourari, Wourali, Woorara, etc., and is official in the French Codex as Curare. A sedatire poison, antagonizing strychnine.

h. S. sp. indet. A shrub of western Africa, probablv of this genur, is locally known as Akarga, M'boundou, Boundou, Ikaju or Quai. An infusion of the bark is used as an ordeal. It contains strychnine or a related alkaloid.

1924. STUÁRTIA, L. (originally Stewartia).

Theaceae. Named fir Juhn Stuart, Marquis of Bute. Syn. Malachodendron, in part. Shrub, with large showy flowers. About 6 species, nouth America and Japan; 2 in U.S.

1925. STRYPHNODÉNDRON, Mart.

Fr.m Greek, "astringent tree". Trees related to Inga. Abrut 10 species, S. America.

8. S. polyphýllum Martius. Brazil. Barhatimao, Barbimao. Bark, Cortex adstringens brasiliensis, astringent. See Acacia Jurema.

1926. STYLóCliNe, Nutt. Stylocline. Compositae. From Greek, 'columın ber,", i. e. columnar receptacle. Syn. Ancistrocarphus, Micropus, in part. Floccose-woolly annuals. A bout 4 species, Pacitic border of U. S.

1927. STYLóPHORUM, Nutt. Stylophorum. Papareraceae. From Greek, "style bearing". Syn. Chelidonium, Meconopsis, in part. Herbs with yellow sap. About 4 species, eastern Asia and N. America; 1 in U. S.

a. S. diphýllum (Michx.) Nutt. (C. diphyllum Michx., M. diphylla DC: ). Ohio to Wisconsin and Missouri. Yellow Poppy, Celandine Poppy.

1928. STYLosáxThES, Swz. Pencil-flower, etc. Papilionaceae. From Greek, "pillar flower", alluding to stalk-like calyxtube. Syn. Trifoliunt, in part. Perennial herbs or undershrubs. About 25 species, warmer regions of Old and New World; 2 in U. S. 
a. S. biflóra (L). B. S. P. (T. biflorum L., S. elatior Swz.). New York to Florida, west to Indian Territory. Pencil-flower, Afterbirth-weed. Plant reputed a uterine sedative.

1929. STÝRAX, L. Storax.

Styracaceae.

The Greek name of S. officinalis. Syn. Benzuin, in part. Shrubs or trees. About 70 specie;, America, Asia and southern Europe; 5 in U. S. [Index Kewensis makes this of neuter grnder.]

a. S. Benzóin Dryander (B. odoriferum Nees, B. officinale Iayne). East Indies, cult. in Sunatra. Benznin tree, (Benjamin tree), Resinous exudate, Gum Benzoin, (ium Benjamin, Benzoin; Benzoinum, U. S. P., Br., Benzoë P. G., Resina benzoё, Asa dulcis; Ger. Benzoëharz; Fr. Benjoin de Sumatra (Codex); Sp. Benjui. [From young trees is ubtained the "head benzin" of the natives, from older ones the "helly benzoin" with fewer "tears", finally from the wood of spent trees is obtained "foot benzoin"]. Stimulant, balsamic, vulnerary, expectorant. A source of benzoic acid. Siam benzoin; Fr. Benjoin de Siam (Codex), is obtained probably from another, as yet undetermined, species of Styrax.

b. S. grandifólia Ait. Southeastern U.S. Mock Orange, Largeleaved Storax. The name Spring Orange is given sometimes to (c) S. smericána Lam.

d. S. officinális L. Southern Europe and western Asia. The original Storax tree. Source of genuine hard Storax, Styrax calamitus v. solidus, Scohs styracina; uved for incense, no longer cullected for medicinal use. From (e) s. punctíta DC. of central America is also obtained a kind of frankincense.

1930. SUBULÁRIA, L. Water Awlwort. Cruciferae. From Latin, "awlwort", alluding to subulate leaves. Small aquatic annuals. Two species, ne in Africa, the other in higher latitudes of northern hemisphere (U. S.).

1931. SUCKLÉYA, Gray. Suckleya. Chenopodiaceae. Herb. One species, western U. S. Syn. Atriplex, in part.

1932. SULLIVÁNTIA, Tor. \& Gr. Sullivantia. Saxifragaceae. Named for Wm. S arling Sullivant, American botanist, d. 1873. Perennial herbs, clovely related to Therofon. Two known species, both of western U. S.

1933. SWÉRTIA, L.

Chiretta.

Gentianaceae. Named for Emanuel Sweert, herbalist of 17th Century. Syn. Agathotes, Ophelia, also Gentiana, in part. Annual or perennial herbs. About 55 species, mostly of Old World.

a. S. Chiráyita (Roxb.) Lyons (G. Chirayita Roxb., O. Chirata Griseb., S. Chirata Ham., A. Chirayta Don ). Northern India. Chiretta, Chirata, Chirayta, East Indian Balmony; Ger. Ostindischer Enzian; Fr. Chirette. Plant; Chirata, U. S. P., Br., Chiretta, U. S. P. 1870; bitter tonic. Other species also are used in India under the same name. 
1934. SWIETÉNIA, Jacq. 1760. Mahogany tree. Meliaceae. Named for Dr. Gerard von Swieten, Australian physician, d. 1772. Syn. Mahogani, Adans. 1763, Cedrust, Cedrela, in part. Trees. Three species, Central America and West Indies; 1 in U. s.

a. S. Mahágoni Jacq. (S. Mahogani I)C., S. Mahogoni Lam., Cedrela Mahagoni L., Cedrus Mahogani Mill. ). West Indies to Florida and Mexico. Mahogany, Madeira-wood. Bark bitter, astringent, febrifuge. Wood valued for furniture, etc.

1935. SYMPETALÉIA, Gray. Sympetaleia. Loasaceae. From Greek, with "united petals". One species in U. S.

1936. SYMPHORICÁRPOS, Juss. Snow-berry,etc.Caprifoliaceae. From Greek, "clustered fruit". Syn. Symphoricarpa, Neck., Symphoricarpus, Dill., Synuphoria Pers.; Lonicera, in part. Shrubs, somewhat ornamental in fruit. About 10 species, N. America; 8 in U. S.

a. S. occidentális Hook. Michigan to Colorado and northwestward. Wolf-berry, Buck-bush; (b) S. racemósus Michx., British America, south to Kentucky, Minnesota and California. Snow-berry, Snow-drop*, Snow-drop-berry, Egg-plant*, Waxberry*; (c) S. Symphoricárpos (L. ) MacM. (L. Symphoricarpos L., S. orbiculatus Moench (Kew), s. vulgaris Michx.). New Jersey to Texas and Dakota. Coral-berry, Indian Currant, Buck-bush, Snap-berry, 'Turkey-berry.

1937. SÝnPHYTUM, L. Comfrey. Boraginaceae. The Greek name, from supposed healing virtues. Coarse perennial herbs. About 15 species, Old World.

a. S. officinále L. Europe and Asia, nat. in U. S. Comfrey, Healing-herb, Knit-back, Ass-ear, Backwort Blackwort, Bruisewort (Briswort), Boneset*, Consound (i. e. Consolida), Galloc, Gum-plant, Slippery-root; Ger. Schwarzwur, Beinwell; Fr. Grande Consoude (Codex). Root, Radix consolidae majoris, R. symphiti, mucilaginous, demulcent.

1938. SÝMPLOCUS, Jacq. 1760. Symplocaceae (Styracaceae). From Greek, "interwoven', alluding to the stamens. Syn. Hopea, L. 1767. Trees or shrubs. About 175 species, America, Asia and Australia; 1 in U. S.

2. S. tinctória (L.) L'Her. (H. tinctoria L.). Delaware to Florida and Louisiana. Sweet-leaf. Horse-sugar, Dye-leaves, Florida Laurel, Yellow-wood. Leaves yield a yellow dye.

1939. SYNÁNDRA, Nutt. Synandra. Labiatae. From Greek, with "stamens together". Syn. Lamium, Torreya, in part. Herb with showy white flowers. One species, southeastern U. S.

1940. SYNDÉSYION, Hoffing. Rue-Anemone. Ranunculaceae. From Greek, "bound together", the plant having flowers of Anemone and foliage of Thalictrum. Syn. Anemone (Kew), Anemonella, Thalictrum, in part. Perennial herb. One species, U. S. 
a. S. thalictroídes (L.) Hoffmg. (Anemone thalictroides L., T. anemonoides Michx., Anemonella thalictroides Spach). Ontario and eastern U. S. Rue-anemone, Meaduw-rue Anemone, May-flower, Wind-flower*, Meadow-lue.

1941. SYNEDRÉLLA, Gaertn. Synedrella. Compositae. From Gieek, "seated together", of the flower-heads Syn. Oligogyne, Calyptrocarpus, in part. Annual herbs with suiall heads of yellow flowers. Two species, tropiı al America; 1 in Texas.

1942. SYYóSMA, Raf. Wild Caraway, etc. Compositae. From Greek, seeming to mean a "fragrant Comprisitr". Srn. Cacalia, Selecio, in part. Perennial herb with small dircuid flıwer heads. One species; (a) S. suavéolens (L.) Rat. (C. suavenlens L. . Sen. suaveolens Ell.), Eastern U. S., Sweetscented Indian Plantain, Wild Caraway.

1943. SYNTHLÍPSIS, Gray. Synthlipsis. Cruciferae. Herbs. About three species, Mexico and adjacent regions; 2 in U. S.

1944. SYNTRICHOPÁPPUS, Grav. Compusitae. From Gretk, "united pappus-bristles". Flnccose-woolly winter-annuals. Two species, Arizona to Calitornia.

1845. SYRÍTGA, L. - Lilac. - Oleaceae. From Greek, a "pipe", the Lilac being formerly ralled Pipe-tree. Shruhs with showy flowers. Ábuut 12 species, Asia and eastern Europe.

a. S. vulgáris L. Eastern Europe, cult. in gardens and nał. in U. S. Lilac (Laylnck, Lily-oak), Commun or Scotch Lilac, Blue Asht, Blue pipe, Pipe-tree, Pipe Privet, Prince's-feather*, Roman Willowt, Spanish Asht, White Asht. The Persian Lilac is (b) S. Pérsica L.

1946. TABERNAEMONTÁNA, L. Cow-tree, etc. Apocynacere. Named for J. T. Tabernænontanus, Geiman buinnist, d. 1590. Shrubs or trees. About 150 species, tropieal regions.

a. T. útilis Arn. British Guiana. Cow-tree, Milk-tree, Hya-hya. Milky sap used like cow's-milk. (b) T. coronária Willd., East Indies, is Adam's Apple or East Indian Rose Bay; (c) T. dichótoma Roxb., Ceylon, is Forbidden-fruit, Diviladner.

1947. TÁCCA, Forst. Arrowroot*. Taceaceae. The Malay name. Perennial herbs from a tuberou- or creeping rootstor.k. About 10 species, warmer regions of Old and New World.

a. T. pinnatífida Forst. (T. oceanica Nutt., T. littnrea Rumph.). Fiji, Hawaiian and otter islands of the Pacifie. Pia plant, Tahiti Salep. Tubers yield a variety of arrowroot called by the natives Pia.

1948. TACSÓNIA, Juss. Tacsonia. Passifloraceae. From vernacular, Tacso, Peru. Climbers resembling Passiflora. About 25 species. Central America and West Indies. 
The fruit of several species is edible, notably of (a) T. mollíssima Kunth, New Granada and of (b) T. tripartíta Juss., Ecuador.

1949. TA ENIOPLEÚRUM, C.\&R.Taeniopleurum. Umbelliferae. From Greek, "fillet rib". Herb. One species, western U. s.

1950. TAENíTIS, Willd. Taenitis. Polypodiaceae. From Girek, "ribbon-like", of the fronds. A small genus of fern:; 1 in U.S.

1951. TA(xÉTES, L. Marignld*. Compositae. Latin name of Marigold, from 'Tages, an Etruscan divinity. Strung-reented herbs with large flower-heads. About 20 species, warmer regions of New World; 2 in Arizona.

a. T. erécta L. Mexico and tropical Amırica, cult. in gardens. African Marigold, Large African Marigold, Turkey Gilliflower, African Tansy or Flos africanus of old herbalists.

b. T. pátula L. Mexico to S. America, cult. in gardens. French Narigold, Velvet-flower*. Florets of this and the preceding some times sold as Calendula, but without medicinal virtue.

1952. TalivóPSIS, Gray. Talinopsis. Portulacaceae. From Gireek, "resenibling Talinum". An undershrub. One species, New Mexico.

1953. TALínUM, Adans. Rork Pink, etc. Portulacaceae. From vernacular name, Senegal. Fleshy herbs or undershiuls. Warmer ri gions especially of $N_{t} w$ World; 8 in U. S. (a) T. calycinum Engelm., Kansas to Texas, is called Rock l'ink; (b) 'I'. teretifolium P'ursh., Eastern U. S., is Fameflower; (c) T. pátens Willd. IT. praniculatum (iaertn.), Brazil to souchern U. S., is called Puchero and esteemed as a pot herb.

1954. TAMARíNDUS, L. Tamarind. Carsalpinaceae. The Latin name, "Indian Date". A large tree. Une species, Old World.

a. T. Índica L. ( T. occidentalis Gaertn., T. umbrosa Salisb., T. officinalis Hook.). Trupical Asia and Africa, cult. in West Indits, etc. Tamarind tree; Fr. Tamarindier (Codex). The -preserved fruit or the pulp surrounding the seeds; Tamarindus, U. S. P., Br., Pulpa T'amarindorum cruda, P. G., Fructus tamarindi; Ger. Ruhes Tamarindemnus, Tamarinden; Fr. Tamarin; Sp. Tamarindo; acidulous, laxative, refrigerant, much used in oriental cookery.

1955. TÁMARIX, L. Tamarisk. Tamaricaceae. From the Latin name. Sin. Tamariscus, Tourn. Shrubs or trees. About 60 species, Mediterranean region to Central Asia, a few in S. Africa. 
a. T. articuláta Vahl. (T. orientali Forsk.). Southern Asia to northern and middle Africa. Oriental Tamarisk. From this and some other species are obtuined Tamarisk galls or Atlee galls; Ger. Tamarisken-Gallen, Takuts, used like nutgalls of the Oak.

b. T. Gállica L. (Tamariscus Crallicus All.). Mediterranean region to central Asia. Tamarisk (Tamaric, Tamaricke), French 'Tamarisk, Common Tamarisk (of Europe), Flowering Cypress, Cypress*, Heath*, Ling*. The Manna Tamarisk of Arabia, (c) T. mannifera Ehrenb., is perhaps a variety of this species. Exudate caused by puncture of an ir sect is the Manna collected near Mount Sinui, Tamarisk Manna, Jew's Manna.

19506. TÁMUS, L. Black Bryony. Dioscoreaceae. Altered from Thamnus, Latin name of a grape-like vine. Herbaceous climbers from tuberous roots. Twospecies, Europe.

a. T. commúnis L. Europe. Black Brinny (Broyant), Black Bind 'reed, Adder's-meat, Isle-of-Wight vine, Lady's-sealMandrake*, Tamus, Wild-vine. Root acrid, vulnerary, diuretic. Fruit called Murrain-berries, Roll-berries or Ox-berries, Shoots eaten in Greece like asparagus.

1957. TANaCÉTUM, L. Tansy. Compositae. From the French name, derive I from Greek, "immorial". Syn. Chrysanthemum, Pyrethrum, in part. Strong-scented herbs, the numerous flower-heads generally rayless. About 35 species, northern hemisphere; 8 in U. S.

a. T. vulgáre L. (C. Tanacetum, Karsch, P. Tanacetum DC.). Europe and northern Asia, cult. and nat. in U. S. Tansy, Bitter-buttons, English Cost, Ginger-plant, Hind-heal, Parsley Fern, Scented Fern; Ger. Rainfarn, Wurmkraut; Fr. Tanaisie (Corex), Herbe anx vers; Sp. Tanaceto. A variety, Críspum, is called DoubleTansy; Leaves and tops; Tanasetum, U. S. P., Summitates tanaceti, Herba athanaviæ; stimulant, emmenagogue, vulnesary. Source of oil of Tansy.

1958. TANGHínIA, Thou. Tanghin. Apocynaceae. From vernacular name, Madagascar. Syn. Cerbera, in part. At tree. One species, Madagascar.

a. T. venenífera Poir. ( $T$. veneneflua C. Don, Cerbera Tanquin Steud. (Kew), C. Tanghin Hook.). Madagascar. Tanghin, Tanguen. Seeds emetic and poisonous, used as an ordeal. Contain a poisonous alkaloid, tanghine.

1959. TARÁXACUM, Hall (Taraxacon).

Cichoriaceae. Greek name of an allied plant. Syn. Dens-lennis, Tourn., Leontodon, in part. Scapose herbs with large heads of yellow flowers. About 20 species, northern hemisphere and S. Amorica; 2 or 3 in U. S.

a. T. Taráxacum (L.) Karst. (L. Taraxacum L., T. officinale Weber, T. Dens-leonis Desf., T. vulgare Schrank). Europe, northern Asia and N. Amprica, now widely dispersed. Dandelion, Dindle, Arnica*, Blow-ball, Cankerwort, Doon-head-clock, 
Fortune-teller, Grunsel*, Horse Gowan, Irish Daisy, Milk Gowan, Witch Gowan, Yellow Gowan, Lion's-tooth?, Monk'shead, One-o'clock, Priest's-crown, Puff-ball*; Ger. Löwenzahn, Pfaffenröhrchen; Fr. Pissenlit, Dent de lion (Codex), Couronne de moine; Sp. Diente de leon. Root; Taraxacum, U. S. P., Taraxaci Radix Br.; tonic, aperient, hepatic stimulant, diuretic, (whence the Freuch name with the vulgar English, Pissabed and the equivalent Latin, Lectiminga).

1960. TAKÁXIA, Simall.

Taraxia.

Onagraceae. Syn. Oenothera, in part. Herbs. Six species in U. S.

1961. TARÍRI, Aubl. 1775. Cascara Amarga,etc. Simarubaceae. From vernacular S. Amer. Syn. Picramnia. Swz. 1788. Shrubs and trees. About 30 species, tropical America; 1 in Florida.

a. T. Antidésma (Swz.) Lyons (P. Antidesma Swz.). Jamaica to Central and South Anierica. Macary-bitter, Majoe-bitter, Oldwoman's bitter, Tom Bontrin's-bush. Bark tonic, febrifuge, alterative.

b. T. sp. indet. Central America. Cascara Amarga (i. e. bitter bark), Honduras bark. Bark bitter, tonic, alterative; contains an alkaloid.

1962. TAXÓDIUM, L. C. Rich. Crpress. Pinaceae. From Greek, "Yew-like', of the foliage. Syn. Schubertia, Mirb., not Mart., Cupressus, in part. Tall trees with horizontal or drooping branches. Three known species, two American, one of China; 1 in U.S.

a. T. dístichum (L.) L. C. Rich. (C. disticha L., S. disticha Mirbel). Southeastern U. S. Bald Cypress, Virginia Swamp Cypress, Deciduous Cypress, Red Cypress (of southern States), Southern or Virginia Cypress, Swamp Cypress, Sabino-tree. Varieties are Black and White Cypress, from color of wood. The famous Montezeuma Cypress of Chapultepec is of the Mexican species (b) T. mucronátum Tenore.

1963. TÁXUS, L. - - Yew. - - Taxaceae. The classical name. Evergreen trees or shrubs with berrylike fruit. About 6 species, north temperate zone; 3 in U.S.

a. T. baccíta L. Europe, northern Africa and westward to the Himalayas. Yew tree, Yew (Ewe, Vew, View), Chinwood, Globe-berry, If Palm† (Ireland), Shoter, Snottle-berry, Wire Thorn; Ger. Eibe; Fr. If commun; Sp. Tejo. Leaves poisonons to stock, reputed emmenagogue. Wood tough and elastic. The Western or Oregon Yew, (b) T. brevifólia Nutt. (T. Lindleyana Laws.) of the Pacific coast, is porhaps a variety of this species.

c. T. mínor (Michx.) Brit. (T. baccata var. minor Michx., T. Canadensis Willd.). Canada, south to Virginia and Iowa. American Yew, Dwarf Yew, Ground or Creeping Hemlock, Creeping Junipert, Chinwood, Shinwood. 
1964. TECóMA, Juss. Trumpet-flower, etc. Bignoniaceae. From vernacular Aztec name. Syn. Bignonia, Tecomaria, in part. Trees, shrubs or woody climbers with showy red or orange flowers. About 25 species, warmer regions, Old and New World; 2 in U. S.

2. T. rádirans (L.) DC. (B. radicans L.). Southeastern U. S. and cult. for ornament. Trumpet-flower, Virginia Trumpetflower, Trumpet Creeper, Trumpet-vine, Trumpet Ash†, Crossvine*, Foxglove*, Bignonia.

1965. TELANTHÉRA, R. Br. Telanthera. Amaranthaceae. Herbs, some shrubby, warmer regions of New World (one in Africa); 2 in U. S.

1966. TELLIMA, R. Br. Tellima. Saxifragaceae. Syn. Lithophragma, in part. Perennial herbs. Two species, western U. S.

1967. TETRACLÉA, Gray. Tetraclea. Labiatae. From Greek, "four closed (nutlets)". Low herb. One species, Mexican border of U. S.

1868. TETRA JÝMIA, DC. Tetradymia. Compositae. From Greek, "four together", the original species having only four florets. Syn. Lagothamnus, in part. Low rigid shrubs, sometimes spinescent. Six species, plateau region of U.S.

1969. TETRAGONÁNTHUS, S. G. Gmel. 1769. Gentianaceae. From Greek, "four-angled flower". Syn. Halenia, Borck 1796; Swertia, in part. Herbs with spurred flowers. A bout 30 species, mountains of New World and of Asia; 3 in U. S. (a) T. defléxus (J. E. Sm. ) Kze. IS. deflexa J. E. Sm., H. deflexa Griseb. ). Canada and eastern U. S., Spurred Gentian.

1970. TETRAgóNIA, L. New Zealand Spinach. Ficoideae. From Greek, four angled", ancient name of the Spindle-tree. Fleshy perennials. About 20 species, southern hemisphere, especially Africa.

a. T. expánsa Murray 1783, not Thunb. 1794. S. America to New Zealand, Australia and Japan, nat. in California. New Zealand Spinach. Leares used as a pot herb, as are those of (b) T. implexicóma J. Hook., Australia to New Zealand, Victorian Bower Spinach, Australian Spinach.

1971. TETRagovothéC.1, L. Tetragonotheca. Compositae. From Greek, "four-angled case" (i. e. involucre). Perennial herbs with large heads of yellow flowers. Three species, southern U. S. and Mexico.

1972. TETRAMÉRIUM. Nees, not Graertn. From Greek, "four parted". Herbs. warmer regions of New World; 2 in U. S. About 10 species, 
1975. TEÚCRIUM, L.

Germander.

Labiatae.

Named for Teucer, King of Troy. Syn. Scordonia, in part. Herbs or shrubs. About 100 species, temperate and tropical regions; 5 in $\mathrm{U}$. S.

a. T. Canádense L. (T. Virginicum L.). Canada and teastern U. S. to Mexico. American Germander, American Woodsage, Ground-pine* (See Ajuga).

b. T. Chamaédrys L. Europe. Common Germander (of Europe), Chamædrys, Herteclowre, Horse-chire, Ground Oak, Wall Germander; Ger. Edler Gamander, Frauenbiss, Gamanderlein; Fr. Germandrée Chamædrys, Petit-chêne (Condex). Herb; H. chamædryos, $\mathrm{H}$. trixaginis; alterative, febrifuge, antiarthritic.

c. T. Márum L. Mediterranean region. Cat Thyme, Herb-mastich, Germander; Ger. Amberkraut, Katzengamander, Moschuskraut, Theriak kraut; Fr. Germandrée maritime; Sp. Maro cortesso. Leaves and tops; Herba (Summitates) mari veri, $\mathrm{H}$. thymi catariæ, aromatic, sternutatory, antispasmodic, diaphoretic, emmenagogue, etc. The other species have a similar action.

d. T. Pólium L. Europe. Poly-mountain, Yellow Poly-mountain (Puliall-mountain, Pellamountain); Ger. Bergpolei; Sp. Zamarilla.

e. T. Scórdium L. Eurnpe. Water Germander, English Treacle, Garlic*, Wood Garlic;Ger. Lachenknoblauch, Wasser-Bathengel; Fr. Germandrée aquarique; Sp. Escordio. Herb, Herba scordii; diaphoretic, anthelmıntic, etc.

f. T. Scordónia L. (S. sylvestris Link.). Europe. Wuod or Wild Germander, Ambrose, Ambroise, Garlic Sage, Mountain Sage, Rock Mint. Plant bitter, a substitute for hops.

1974. THALÉSIA, Raf. 1818. Cancer-root, etc. Orobanchaceae. Dedicated to "Thales". Syn. Anoplanthus, Endl. 1838, Aphyllon, A. Gray 1848; Orobanche, Phelipæa, in part. Rootparasites, with a few scales in place of, leaves. Three species, all in U. S.

a. T. uniflóra (L.) Raf. (O. uniflora L., An. uniflorus Endl., Aph. uniflorum Tor. \& Gr.). British America, south to Virginia, Texas and California. Naked Broom-rape, One-flowered or Pale Broom-ripe, Cancer-root. Plan/ astringent. The Yellow Cancer-root of the central and norihwestern U. S., Clustered Cancer-root \&, $_{\text {, }}$ is (b) T. fasciculátum (Nutt.) Brit. (O. fasciculata Nutt.).

1975. THÁLIA, L. Thalia. Marantaceae. Named for Johann Thalius, German naturalist, 16th Century. Scapose herbs. About 7 species, all of America; 2 in U.S.

1976. THaLÍCTRUM, L. Meadow-Rue. Ranunculaceae. Ancient Greek plant name, probably signifying "luxuriant". Perennial herbs with Maidenhair-like foliage. About 75 species, chiefly of north temperate zone; 17 in U. S. 
a. T. dioícum L. British America, south to Alabama and Missouri. Early Meadow-rue, Feathered Columbine, Shining. grass, Quicksilver-weed, Poor-man's Rhubarb*.

b. T. flárum L. Europe. Fen Rue, Maidenhair Rue, False Rhubarb, Meadow or Monks' Rhubarb, Poor-man's Rhubarb.

c. T. glaúcum Desf. Spain, cult. in gardens. Spanish-tuft, Tufted Columbine, Feathered Columbine, the latter name applied also generically.

d. T. polýgamum Muhl. (T. Cornuti Tor. \& Gr.). Canada and eastern U. S. Tall Meadow-rue, Fall Meadow-rue, Celandine*, Muskrat-weed, Musquash-weed, Rattlesnake-bite, Silver-weed.

1977. THAMNóSMA, Tor. \& Frem. 1845.

Rutaceae. From Greek, “odorous plant”. Syn. Rutosma, Gray 1819. Strong-scented desert herbs. Two species, western U. S.

1978. THÁPSIA, L. Ueadly Carrot. Umbelliferae. The ancient Greek name of T. Garganica, originally brought from Thapsus. Yerennial herbs. Four known species, Mediterranean region to Madeira.

a. T. Gargánica L. Mediterranean region. Deadly Carrot, Drias; Fr. Thapsie (Codex), Faux fenouil; Sp. Tapsia. Root irritant, emeto-cathartic. Resin counter-irritant, producing an eruption. (b) T. Sylphium Viviani of northern Africa is perhaps only a variety of (a), the Sylphium cyreniacum of the aucients, yielding the gum resin called Laser, Laser cyreniacum, Asa dulcis.

1979. THÁSPIUM, Nutt. Meadow-Parsnip. Umbelliferae. By transposition from Thapsia, an allied genus. Syn. 'Thapsia, Smyrnium $†$, Ziziat, in part. Perennial herbs. Three known species, all of eastern U. S.

a. T. trifoliátum (L.) A. Gray (Thapsia trifoliata L., S. atropurpureum Desr, T. atropurpureum Nutt.). Rhode 1sland to Tennessee and Illinois. Purple Meadow-parsnip, Purple Alexanders, Round heart. The variety aureum ('T'. sureum Nutt.) with yellow flowers is called Golden Alexanders, being coufounded popularly with Zizia aurea, q. v.

1980 THÉA, L. Tea. Theaceae (Ternstroemiaceae). Syn. Camellia. Evergreen shrubs or small trees. About 6 species, southeastern Asia.

a. T. Chinénsis L. (also T. Sinensis; C. Thea Link., C. theifera Griffith). Japan and China, cult. in India and other tropical countries. Tea plant. It was formerly supposed that black and green tea were derived from two distinct species, T. Bohen and T. viridis, but this is an error, these varieties being produced by different modes of curing. Numerous varieties are distinguished, such as Bohea, Congou, Souchong and Pekoe of black teas and Hyson Skin, 'Twankay Hyson, Young Hyson, Imperial and Gunpowder of the green varieties. Besides these there are now in market, Japan and Ceylon teas in endless variety; Ger. Thee; Fr. Thé; Sp. Te, Te de China. Active constituent theine or caffeine. 
1981. THÉKA, Adans. 1763. Teak, Indian Oak. Verbenaceae. From vernacular name of (a). Syn. Tectona, L. f., 1781, - Nautea, Noronha 1790, Theca, Juss. Large timber trees. Three species, East Indies. (a) T. grándis Lam. (Tectona grandis L. f.,Tect. Theca Lour.). India and Malaysia. Teak tree, True Teak, Indian Oak. Timber invaluable to shipbuilders.

1982. THELESPÉRMA, Less. Thelesperma. Compositae. From Greek, "nipple seed". Syn. Bidens, Coreıpsis, in part. Herbs closely related to Bidens. About 7 species, New World; 6 in U. S.

1983. THELYPÓdIUM, Endl. 1839. Thelypodium. Cruciferae. From Greek, with "stalked ovary". Syn. Pachypodium, Nutt. 1838, not Lindl. 1830. Herbs. About 26 species, all in U. S., nearly all of Pacific coast.

1984. THEOBRÓMA, L. 1737. Cacao. Sterculiaceae. From Greek, "food of the gods". Syn. Cacao, Tourn, 1752 Trees with large undivided leaves. About 15 species, warmer regions of New World.

a. T. Cacao L. (C. sativa Aubl., C. minor Gaertn., C. Theobroma Tuss. ). Brazil to Mexico. Cacao tree, Chocolate tree. Seeds, Cacao; Semen v. Fabæ Cacao; Ger. Kakaobohnen; Fr, Cacao (Codex), Fèves du Mexique. Source of Cacao, also of Cacao butter or oil of Theobroma; Oleum Theobromat1s, U.S. P. Crushed and mixed with sugar they constitute Chocolate or prepared Cocoa. The separated "Cocoa shells" are used also to prepare an inferior beverage. The cotyledons, deprived of the shells are known as "Cocoa-nibs". Characteristic alkaloid, theobromine.

1985. THERMÓPSIS, R. Br. False Lupine. Papilionaceae. From Greek, "Lupine-like". Syn Podalyria, Baptisia, Cvisus, Xylothermia, in part. Herbs with large yellow or purple flowers in racemes. About 20 species, N. America and Asia; 11 in U. S.

1986. THÉROFON, Raf. 1836. Saxifrage. Saxifragaceae. From Greek, "beast killing". Syn. Boykinia, Nutt. 1834, not Raf., also Saxifraga, in part. Perennial herbs with small white flowers in branching panicles. About 7. species, all of U. S.

1987. THESPÉSIA. Corr.

Milo.

Malvaceae. Trees or robust herbs. Syn. Hibiscus, in part. About 6 . species, tropical Asia to Madagascar. (a) T. popúlnea (L.). Correa ( $H$. populnea L., H. bacciferus Forst.). Asia, Madagascar and Uceanica. Milo (Hawaii and Tahiti), Mulo (Fiji). Tree held sacred in Tahiti.

1988. THEVÉTIA, L. Exile-tree. Apocynaceae. Named for André Thevet, French traveler, d. 1590. Syn. Cerbera. Shrubs or small trees with large yellow flowers. About 10 species, tropical America. 
a. T. Thévetia (L.) Lyons (C. Theretia L., T. nereifolia Juss.). Tropical America. Yellow Oleander, Exile-tree, Quashyquasher. Bark febrifuge.

1989. THLÁSPI, L.

Penny-Cress.

Cruciferae. Greek name of a kind of Cress, perhaps from the "flat" pod. Annual or perennial herbs. Alout 30 species, north temperate and arctic regions; 5 in U. S.

a. T. arrénse L. Europe and northern Asia, adv. in U. S. Field Penny-cress, Bastard Cress, Dish Mustard, Mithridate Mustard, Treaclewort.

1990. THRínaX, L. fils. Thatch Palm. Sabalaceae. From Greek, "three pointed". Low or medium sized fanpalms. About 12 species, mostly of West Indies; 3 in U. S.

a. T. argéntea (Jacq.) Lodd. (T. microcarpa Sarg.). Florida to Panama. Silver-top Palmetto (Florida), Chip-hat Paln, Broom Palm (Panama), Silver Thatch-palm (Jamaica), Brickley, Brittle-thatch. Leaves used for plaiing hats, baskets, etc. (b) T. parviflóra Swz. is called in Florida Sılk-top Palmetto, in the West Indies, Royal Palmetto.

1991. THRYÁLLIS, Mart. Thryallis. Malpighiacene. Syn. Galphimia, in part. Climbing shrubs. About 5 spo cies, mostly of Brazil; 2 in U. S.

1992. THÚJd, L. (Thuya). Arbor Vitae, Cedar. Pinaceae. The Greek name of an African tree with fragrant wood. Evergreen trees with scaly foliage. About 15 species, N. America and eastern Asia; 2 in U. S.

2. T. gigántea Nutt. ( $T$. plicata Lambert not Donn. Has been confounded with Libocedrus decurrens Tor.). Oregon and northward. Canoe Cedar, Pacific Red Cedar, Oregon Ked Cedar or White Cedar, Yellow Cypress. Timber used for canoes, shingles, etc. Barl fibre for mats, baskets, etc.

b. T. occidentális L. Canada, south to N. Carolina and Minnesota. Arbor Vitæ, White Cedar, Northern White Cedar, False White Cedar, Feather-leaf Cedar, Indian Feather-leal; Ger. Lebensbaum; Fr. Thuya, Arbre de vie. Branchlets and volatile oil therefrom, balsamic, stimulant, emmenagogue, etc.

1993. THYMOPHÝLLA, Lag. 1816. Thymophylla. Compositae. From Greek, "thyme leaved", a name not well chosen. Syn. Hyrnenatherum, Cass. 1817, Lowellia, Gray 1849. Herbs or under-shrubs with rather small flower-heads, rays generally yellow. About 20 species; 14 in U. S., mostly western.

1994. THÝMUS, L. Thyme. Labiatae. Ancient Greek name, signifying "fragrant". Herbs or low sub-shrubs with small leaves. About 50 species, Old World, chiefly European.

a. T. Serpýllum L. (T. Chamædrys Fries). Europe and northern Asia, adv. in U. S. Wild Thyme, Creeping or Horse Thyme, Bank or Running Thyme, Shepherd's Thyme, Mother of Thyme, 
Brotherwort, Hillwort, Pellamountain, Puliall-mountain, Penny-mountain, Serpolet; Ger. Quendel, Feldthymian, Wilder Thymian, Feldkümmelkraut, Gundelkraut, Gundling, Hühnerkraut; Fr.. Serpolet (Codex); Sp. Serpol. Herb, H. Serpylli, P. G., carmina ive, antispasmodic, emmenagogue. Var. citriodórus ( $T$. citriodorus s'chreb.) is Lemon Thyme, Lemonscented Thyme.

b. T. vulgáris L. Southern Europe and cult. in gardens. Garden Thyme, Common Thyme; Ger. Gartenthymian, Thymian, Römischer Quendel; Fr. Thym (Codex); Sp. Tomillo. Herb H. Thymi, Y. G., properties of (a). Other species with like properties are (c) T. capitátus Hoff. and Link., Mediterranean region and (d) T. mastichína L., Spain and Algeria, Herb. Mastich.

1995. THYRSÁNTHEMA, Neck. 1790.

Compositae. Syn. Chaptalia (Kew), Vent. 1800. Perennial herbs, mostly acaulescent. About 18 species, New World; 3 in western U. S.

1996. THYSANOCÁRPUS. Hook. Lace-pod. Cruciferae. From Greek, "tassel fruit". Slender annuals. About 12 species, Pacific coast of U. S.

1997. TIARÉLLA, L. False Mitrewort. Saxifragaceae. Latin diminutive of tiara, from form of capsule. Perennial herbs with leaves mostly basal. About 6 species, north temperate zone; 3 in U. S.

a. T. cordifólia L. Coolwort, White Coolwort, False Mitrewort, Foam-flower, Gem-fruit. Herb reputed diuretic.

1998. TIGRIDIA, Ker. Tigridia, Tiger-flower. Iridaceae. From Latin, "tiger" flower, alluding to spotted perianth. Bulbous herbs with showy flowers. About 7 species, tropical America; 1 in U. S.

1999. TÍLIA, I.

Linden, Lime-tree.

Tiliaceae. The Latin name, whence English Teil and Til. Trees with cordate inequilateral leaves. About 16 species, north temperate zone; 3 in U. S.

a. T. Americána L. (T. glabra Vent., T. Canadensis Michx.). Canada to Georgia, west to Texas and Nebraska. Basswood, American Linden, White-wood, Black Lime-tree, American Lin-tree or Lime-tree, Bast-tree, Bee-tree, Daddy-nut tree, Monkey-nut tree, White Lind, Whistle-wood. Wickup, Red Basswood, Yellow Basswood. Flowers antispasmodic, allodyne.

b. T. Europaéa L. [Including T. platyphyllos Scopoli (T. grandifolia Ërhr., T. pauciflora Hayne), T. ulmifolia Scop. (T. parvifolia Erhr., T. microphylla Vent.) and T. vulgaris Heyne]. Europe and Asia, cult. in U.S. European Linden, (Lin, Line, Linn, Linde), (whence was derived the name of the distinguished botanist Linnaeus), Lime-tree, Til-tree, (Teil, Tilet, Tillet), Locust-bloom, Bast-tree, Bass-tree. Flowers, Flores Tiliæ P. G., Ger. Lindenblüthen; Fr. Fleur de tilleul (Codex), antispasmodic, anodyne, demulcent. Tough inner bark (bast) used for coarse mats, ropes, etc. 
c. T. heterophyĺa Vent. (T. alba Michx.). Southeastern U. S. White Basswood, White Linden (Lin, Linn), Bee-tree, Cottonwood†, Silver-leat Poplart, Wahoo*, Lynn Wahoo. Resembles the European Silver Lime-tree, (d) T. argéntea Desf.

e. T. pubéscens Ait. (T. Americana var. pubescens Loud., T. Americana var. Walteri Wood). Southeastern U. S. Southern Basswood, Southern Linden (Lin, Linn), Southern Whitewood.

2000. TILLAÉA, L. Pigmy-weed. Crassulaceae. Named for Michael Angelo Tilli, Italian botanist, d. 1740. Syn. Bulliarda, in part. Di uinutive aquatic or paludal plants. About 25 species, widely distributed; 6 in U. S.

2001. TILLÁNDSIA, L. Long Moss, etc. Bromeliaceae. Named for Elias Tillands, Swedish botanist, 17th Century. Syn. Reanalmia, in part. Epiphytes, varying greatly in habit. About 350 species, warmer regions of New World; 14 in U. S.

a. T. usneoídes L. 1762 (R. usneoides L. 1753). Southeastern U. S., south to Uruguay and Chili. Long Moss, Florida or New Orleans Moss, Black Moss, Hanging Moss, Spanish Moss, Long-beard, Old-man's-beard, Tree-beard, Barba hispanica. The black tiliform stems constitute vegetable horsehair, used for stuffing mattresses, etc. The names Air-plant and Barren Pine-apple are given to such species as (b) T. utrieuláta LeConte.

2002. TINÁNTIA, Schiedw. Tinantia. Commelinaceae. Herbs. About 3 species, tropical America; 1 in U. S.

2003. TINÓSPORA, Miers. Tinospora. Menispermaceae. Climbing shrubs. About 12 species, tropical Asia and East Indies. (a) T. cordifólia Miers, and (b) T. críspa Miers. An extract, called Galuncha or Gulancha is reputed a cure for snake bites. Plants bitter, tonic, alterative.

2004. TIPULÁRIA, Nutt. Crane-fly Orchis. 0rchidaceae. From Latin Tipula, an insect which the flowers resemble. Syn. Limodorum, in part. Scapose herbs from tuberous rhizomes. Two known species, one of Asia, one in U. S.

a. T. unifólia (Muhl.) B. S. P. (L. unifolium Muhl., T. discolor Nutt.). Eastern U. S. (rare). Tallow-root, Crane-fly Orchis.

2005. TÍSSA, Adans. 1763. Sand Spurry. Caryophyllaceae. Name unexplained. Syn. Buda, Adans. 1763, Spergularia (Kew ), Pers. 1805, Lepigonum, Fries. 1817; Arenaria, in part. Low herbs with fleshy linear or setaceous leaves. About 20 species, mostly of salt marshes; 14 in U. S.

a. T. rúbra (L.) Brit. (A. rubra L., B. rubra Dumort, S. rubra Presl.). Europe and Asia, nat. in U. S. Sand Spurry, Purple Sandwort. Red Sandwort. Plant; A renaria rubra (Codex), diaphoretic, alterative. Other species are also used.

2006. TITHONIA, Desf.

Tithonia.

Compositae. Named for Tithonus of Greek myth. Robust annuals. About 8 species, Mexico; 1 possibly in U. S. 
2007. TOFIÉLDIA, Huds. False Asphodel. Melanthaceae. Named for Mr. Tofield, English botanist of 18th Century. Syn. Melanthium, Narthecium, in part. Perennial herbs with small flowers in a terminal spike. About 15 species, north temperate zone and S. America; 6 in U.S.

a. T. palústris Huds. Europe, northern Asia and British America, south to Lake Superior. Scottish Asphodel, False Asphodel, Lamb-lily.

2008. TOLÚ́fERA, L. 1742, not Lour. 1790. Papilionaceae. From Latin, "tolu-bearing". Syn. Myroxylon (Kew), L. f. 1781; Myrospermum Jacq., in part. Trees or shrubs, natives of tropical America.

a. T. Pereírae (Royle) Baill. (Myrospermum Pareiræ Royle, M. Sonsonatense Pereira, Myroxylon Pereiræ Klotsch (Kew), T. Balsamum var. Pereiræ H. Br.). San Salvador. Perubalsam tree. Balsamic exudate Balsam of Peru, Peru-balsam; Balsamum Peruvianum, U. S. P., Br., P. G., Balsamum indicum, Balsamum peruvianum nigrum; Ger. Perubalsam, Indischer Balsam; Fr. Baume de Peru noir, Baume San Salvador, Baume de Sansonate (Codex); Sp. Balsamo negro; stimulant, antiseptic, vulnerary.

b. T. Peruifera (L. fils.) Baill. (Myrox. Peruiferum L. fils (Kew), Myrosp. Peruiferum DC., Myrox. pedicellatum Klotzsch). Brazil. Yields a balsam similar to balsam of Peru.

c. T. Bálsamum L. (Myrox. toluiferum Kunth (Kew), Myrosp. toluiferum A. Rich., Myrox. punctatum Klotzsch). Venezuela and New Granada. Tolu-balsam tree (Prof. Baillon believes that both Peru-balsam and Tolu-balsàm are products of this species, obtained by different processes). Balsamic exudate, Balsamum Tolutanum, U. S. P., Br., Balsamum indicum siccum, Balsamum americanum; Ger. Tolubalsam; Fr. Baume de Tolu (Codex) Baume de Carthagène; Sp. Balsame de Tolu, Balsame blanco. Properties of balsam of Peru, but less active. Chiefly used in cough syrups and in pastilles for burning.

d. T. punctáta Baill. (Myrox. punctatum Klotzsch, Myrosp. balsamiferum R. \& Pav.). Peru. Quino-quino tree. Probably the same as (c).

2008 $\frac{1}{2}$. TONÉLLA, Nutt. Tonella. Scrophulariaceae. Annual herbs.' 'Two species, in western U.S.

2009. TOURNEFÓRTIA, L.False Heliotrope, etc. Boraginaceae. Named for Joseph Pitton de Tournefort, French botanist, d. 1708. Trees or shrubs, related to Heliotropium. About 100 species, warmer regions; 21 in U.S.

2009를. TOWNSÉNDIA, Hook. Townsendia. Compositae. Named for David Townsend, botanist of Philadelphia. Tufted herbs with large radiate flower-heads. About 17 species, N. America; 16 in southwestern U. S. 
2010. TOXICODÉNDRUM, Thunb.

Euphorbiaceae. From Greek, "poison tree". Syn. Hyaenanche Lamb. 1797 (Hyænachne). Poisonous shrubs. Two species, South Africa. (a) T. Capénse Thunb. ( $H$. Capensis Pers.). S. Africa. Fruit used to poison hyenas.

2011. TóXYLON, Raf. Osage Orange. Moraceae. From Greek, "bow-wood". Syn. Maclura (Kew), in part. A thorny tree with foliage like the orange. One species, southcentral U. S.

a. T. pomíferum Raf. (T. Maclura Raf. Maclura aurantiaca Nutt.). Missouri to lexas and cult. as a hedge plant. Osage Orange, Osage, Osage Apple, Nurth American Bow-wood, Bois d'arc, Bowdark $\neq$, Bodark $\neq$, Hedge plant, Yellow-wood. Leaves, food of silkworm. Root yields a yellow dye.

2012. TRACHELOSPÉRMUM, Lem.

A pocynaceae. From Greek, "neck seed", but the name seems not appropriate. Syn. Echites, Forsteronia, in part. Twining woody vines or shrubs. About 6 species, Asia and N. America; 1 in U. S.

2013. TRACHYLÓBIUM, Hayne.ChacazeCopal.Caesalpinaceae. From Greek, "rough pod". Syn. Hymenæa, in part. Tree. One species, tropical Africa. (a) T. Hornemanniánum Hayne. Eastern Africa. Zanzibar Copal tree. Yields a Copal called Chacaze Copal or Jackass $\ddagger$ Copal.

2014. TRADESCÁNTIA, L. Spiderwort. Commelinaceae. Named for John 'Tradescant, gardener to Charles I. Perennial herbs generally with linear leaves and rather showy flowers. About 35 species, New World; 16 in U. S. (a) 'T. Virginiána L. New York to Kentucky, west to Arkansas and S. Dakota. Common Spiderwort, Spider Lily*, Trinity Violet.

2015. TRÁGIA, L. Tragia. Tragia. Euphorbiaceae. Named for $\mathrm{H}$. Bock, called also Tragus, German botanist, d. 1553. Monoecious herbs, shrubs or clımbers with stinging hairs. About 50 species, mostly tropical, 5 in U. S.

2016. TRAG0PÓGON, L. Salsify, etc. Cichoriaceae. From Greek, "goat's beard", alluding to the pappus. Herbs with fleshy tap-root and large heads of yellow or purple flowers. About 35 species, Old World.

a. T. porrifólius L. Europe, widely cult., adv. in U. S. Oyster plant, Oyster-root, Vegetable-oyster, Salsify (Salsafy), Jerusalem-star, Nap-at-noon, Purple Goat's-beard. Root esculent.

b. T. praténsis L. Europe, nat. in U. S. Meadow Salsify, Buck's-beard, Go-to-bed-at-noon, Noon-tlower, Noon-tide, Noonday-Hower, Jack-by-the-hedge, Joseph's-llower, Shepherd'sclock, Star-of-Jerusalem, Yellow Goat's-beard. Root esculent.

2017. TRÁPA, L. Water-caltrop. Trapaceae. Ahbreviated from Latin Calcitrapa, a "caltrop". Aquatic herbs producing farinaceous seeds (nuts). Three species, Old World. 
a. T. nátans L. (including T. quadrispinosa Roxb.). Europe to central Asia, nat. locally in U. S. Water Chestnut, Water-nut, Jesuit's-nut (Venice), Water-caltrop, Sanghara-nut*; Fr. Châtaigne d'eau. Seeds esculent. The Chinese (b) T. bicórnis L. fils, with fruit resembling a buffalo's head, is called Leng, Ling or Links. Singhara nuts, a staple food in Cashmere, are the fruit of (c) T. bispinósa L. ('T. Cochin-Chinensis Lour., T. incisa, Sieb. \& Zucc.), southern Asia and northern Africa.

2018. TRAUVETTÉRIA, F. \& M.

Ranunculaceae. Named for Prof. 'Trauvetter, Russian botanist. Syn. Cimicifuga, Hydrastis, in part. A stout perennial herb. Une species, eastern Asia and eastern U. S. (a) T. Carolinénsis (Walt.) Vail (H. Carolinensis Walt., C. palmata Michx.). Eastern U. S. and Japan. False Bugbane.

2019. TRÉMA, Lour.

Nettle-tree. From Greek, "hole", alluding to pits in endocarp. Syn. Sponia, Celtis, in part. 'Trees or shrubs. About 25 species, warner regions; 1 in U. S. (a) T. micrántha B. \& H. Florida to West Indies and Brazil. Nettle-tree.

2020. TREPOCÁRPUS, Nutt. Trepocarpus. Umbelliferae. Smooth annual. One species, south-central U. S.

2021. TRIANOSPÉRMA, Mart. Tayuya. Cucurbitaceae. Herbaceous climbers, from fleshy roots. Syn. Dermophylla, Bryonia, in part. Cayaponia, (No. 414 q. v.) is the older and preferable name. (a) T. ficifólia Mart. (perbaps the same as C. ficifolia (Lam.) Cogn. (414 c.) but also identified by some authorities with B. 'Tayuya Velloso, C. Tayuya (Vell.) Cogn. and with D. pendulina S. Manso). Brazil. Tayuya. Root, Rad. dermophyllæ, Rad. tayuyæ; hydragogue, antisyphilitic. The synonyomy is confused. Probably several species are called 'Tayuya. See Cayaponia.

2022. TRIAJÉNUM, Raf. 1808. Triadenum. Hypericaceae. From Greek, "three glands". Syn. Elodea, Pursh 1814, not Michx. 1803 nor Elodes, Adans 1763; Hypericum (Kew), in part. Perennial marsh herbs with pink or purplish flowers. Two species, both of U. S.

2023. TRIANTHÉMA, L. Horse Purslane. Aizoaceae. From Greek, "three flowering". Herbs, generally fleshy and prostrate. About 12 species, warmer regions, mostly of Old World; 1 in U.S. (a) 'T. monógynum L. Florida to West Indies and Venezuela. Horse Purslane (Jamaica).

2024. TRÍBULUS, L. Caltrop. _ Zygophyllaceae. Greek plant name, signifying "caltrop" (i. e. three pointed). Herbs or sub-shrubs, mostly prostrate, with spinose fruit. About 12 species, warmer regions; 2 in $\mathrm{U}$. $\mathrm{S}$.

a. T. cistoídes L. Florida and widely distributed along tropical shores. Turkey-blossom (Jamaica), Nohu, Mahukona Violet (Hawaii, with allusion to the fragrance). L. Europe, adv. in U. S. Land Caltrop.

(b) T. terréstris 
2025. TRICÁ RDIA, Torr. Tricardia. Hydrophyllaceae. From Greek, "three-hearts", alluding to shape of sepals. Perennial herb. One species, Nevada.

2026. TRICHÍLIA, P. Br. Incense tree, etc. Meliaceae. From Greek, "three-lipped", alluding to the stigma. Syn. Mafureira, Moschoxylon, in part. Trees or shrubs. About 112 species, tropical Africa and America.

a. T. emética Vahl. (Maf. oleifera Bertol.). East Africa to Arabia. Mafura (Mafurra) tree. Seeds source of Mafura Tallow, resembling cacao butter.

b. T. moscháta Swz. (Mos. Schwartzii Juss.). Jamaica. Incense tree, Musk-wood, Pameroon-bark tree, Juribali, Jurubali. Bark astringent, febrifuge.

2027. TRICHOCORÓNIS, A. Gray. Trichocoronis. Compositze. From Greek, "hair crown".' Syn. Micrageratum, Margacola. Aquatic or marsh herbs with pink or purple flowers. Three species, Mexican border of U. S.

2028. TRICHómanES, L. Filmy Ferns. Hymenophyllaceae. Ancient Greek name of a kind of Fern. Ferns with pellucid fronds. About 100 species, mostly tropical; 2 in U. S. (a) T. rádicans Sw. Southeastern U. S. and widely distributed. Common Bristle Fern, Hare's-foot Fern, Cup-goldilocks.

2029. TRICHOPTÍLIUM, Gray. Trichoptilium. Compusitae. From Greek, "hair-feather". Syn. Psathyrotes. Small winter annual. One species, Arizona to California.

2030. TRICHOSTÉMA, L. Blue-Curls, etc. Labiatae. From Greek, "hair stamen", alluding to the capillary filaments, which suggest also the English name. Herbs, some shrubby. About 9 species, all of U.S., mostly southwestern.

a. T. dichótomum L., eastern U. S., is called Blue-curls, Bastard Pennyroyal; (b) T. lanceolátum Benth., California, is called Blue Tar-weed; (c) T. lanátum Benth., California, is called Black Sage.

2031. TRIENTALIS, L. Chickweed Wintergreen. Primulaceae. From Latin, "span"-high. Low perennials, the leaves forming a whorl at the summit of the stem. About 3 species, all of U. S., one also European.

a. T. Americána Pursh. Canada, south to Virginia and Illinois. Chickweed Wintergreen, May-star, Star-Hower, Star-flowered Chickweed, Star-of-Bethlehem*, Snake-flower.

2032. TRIFólIUM, L. Clover, Trefoil. Papilionaceae. The ancient Latin name, "three leaved". Syn. Chrysaspis, Chronosemium, Melilotus, in part. Herbs, leaves generally trifoliate, flowers in heads or spikes. About $25(1$ species, mostly of north temperate zone; 108 in U.S., including some naturalized. 
a. T. agrárium L. (Chrys. agraria (L.) Greene). Europe, nat. in U.S. Yellow Clover, Hop Clover, Hop 'Trefoil*. More common in U. S. is the smaller (b) T. procúmbens $\mathrm{L}$. (Chrys. procumbens (L.) Desv.), also from Europe, Low or Smaller Hop-clover.

c. T. arvénse L. Europe and Asia, nat. in U. S. Rabbit-foot Clover, Hare's-foot, Bottle-grass, Calf Clover, Dogs-and-cats, Field Clover, Old-field Clover, Poverty-grass. Pussy Clover, Pussy-cats, Pussies, Stone Clover, Watch Clover.

d. T. coerúleum Willd. (Mel. cærulea Desr.). North Africa, cult. in Europe. Blue Melilot, Garden Balsam*, Old-sow; Ger. Blauer Steinklee, Schabziegerklee, Siebenzeit, Mottenkraut. Leaves and tops, Herba meliloti cærulei, H. ægyptiaca, H. loti odorati; reputed diuretic, diaphoretic, emollient. Used in Switzerland for flavoring cheese.

e. T. dúbium Sibth. (Chrys. dubia (Sibth.) Greene, T. minus Sm., T. procumbens var. minus, Koch). Europe, nat. locally in U. S. Shamrock (Shamrug, Shambrogue, Scamrog), True Shamrock, Least Hop-trefoil, Yellow Clover or Trefoil, Wild Trefoil.

f. T. praténse L. Europe, Asia, northern Africa, nat. in U. S. Red Clover, Meadow or Purple Clover, Broad-leaved or Cow Clover, Honeysuckle Clover (England), Bee-bread, Cowgrass*, Knap, Marl-grass, Plyvens, Soukie Clover (Claver), Suckles; Ger. Rother Wiesenklee, Rother Futterklee. Flowers alterative, sedative.

g. T. répens L. Europe, Asia, sub-arctic N. America, nat. in U. S. White Clover, Dutch or Honeysuckle Clover, Honeystalks, Lamb-sucklings, Purple-grass, Purplewort, Quillet, Sheep's Gowan, Suckling, White Honeysucklet, White Shamrock, White Trefoil.

Other pasture Clovers are (h) T. hýbridum L., Alsike, Alsatian Clover, Swedish Clover; (i) T. incarnátum L., Carnation or Crimson Clover, French or Italian Clover, Napoleons; (j) T. médium L., Zigzag Clover, Cow-grass, Giant or Mammoth Clover, Mail-grass, Pea-vine Clover, the foregoing nat. from Europe. Indigenous species are $(\mathrm{k}) \mathrm{T}$. refléxum L., Buffalo Clover and (1) T. stoloníferum Muhl., Running Buffalo Clover.

2033. TRIGLÓCHIY, L. Arrow-grass. Scheuchzeriaceae. From Greek, "three pointed", alluding to the capsule. Marsh herbs, the small flowers in slender spikes. About ten species, higher latitudes in both hemispheres; 4 in U. S.

2034. TRIGONÉLLA, L. Fenugreek. Papilionaceae. From Greek, "three angled", alluding to the flower. Syn. Buceras, Fœnum-Gracum, in part. Strong-smelling herbs. About 60 species, Old World.

a. T. Foénum-Graécum L. (B. Fœnum-Græcum All., Fœn. officinale Moench). Western Asia, cult. in tropical Africa and Asia. Fenugreek (Fenugreck, Fenigreek, the word meaning 
Greek hay). Seeds, Sem. fœnugreci, Sem. feni greci; Ger. Bockshornsamen, Fenugrek, Kuhkornsamen, Griechischer Heusamen; Fr. Fenugrec (Codex); demulcent, mucilaginous.

2035. TRÍLISA, Cass. Vanilla-leaf. Compositae. Anagram of Liatris. Syn. Liatris, in part. Perennial herbs with small discoid heads. Two known species, southeastern U. S.

a. T. odoratíssimus (Walt.) Cass. (Anonymos odoratiseimus Walt., L. odoratissimus Michx.). Pine.harrens, Virginia to Florida and Louisiana. Vanilla-leaf, Vanilla plant, Carulina Vanilla, Dog's-tongue, Deer's-tongue, Hound's-tongue. Leuves have an agreeable vanilla-like odor.

2036. TRÍLLIUM, L. Wake-robin, Birthroot,etc. Couvallariaceae. Name Latin, alluding to the trimerous symmetry of the species (with an echo perhaps of Lilium.). Three-leaved herbs from a perennial rhizome. About 20 species, North America and Asia; 16 in U. S.

a. T. cérnuum L. Canada, south to Georgia and Missouri. Nodding Wake-robin, White Benjamin, Crugh-root, Ground Lily, Jew's-harp plant, Lamb's-quarters*, Rattlesnake-rout, Suakebite.

b. T. eréctum L. Canada, south to Tennessee and Missouri, also in Japan. Birthroot, Bethrootł, Red or "Purple" Trillium, Red Benjamin, Red or Purple Wake-robin, Birthwort*, Bathwort $\neq$, Bath-flower $\neq$, Bumble-bee-root, Daffy-down-dilly*, Dishclnth, Indian Balm, Indian Shamrock, Ill-scented Trillium or Wake-robin, Nose-bleed, Orange-blossom (the white variety), Squaw-flower, Squaw-root, True-love, Red' Wood-lily. Many of these names are applied also to other species. Rhizome astringent, alterative, uterine antispasmodic, in large doses emetic.

c. T. grandiflórum (Michx.) Salisb. (T. rhomboideum var. grandiflorum Michx.). Canada and eastern U. S. Largeflowered White Wake-robin, Wake-robin, White Benjamin, Trinity Lily, White Birth-root, Bath-flower, White Bath, White Wood-lily. Other indigenous species worthy of note are (d) T. séssile L., Sessile-flowered Red Wake-robin, flowers agreeably fragrant; (e) T. nivále Ridd., the Early or Dwarf White Wake-robin and (f) T. undulátum Willd. ('T. erythrocarpum Michx.), Painted Wake-robin, Sarah, Wild Pepper.

2037. TRIÓSTEUM, L. Fever-root, etc. Caprifoliaceae. From Greek, "three boned", alluding to the three $(2-5)$ bony seeds. Perennial herbs with berry-like fruit. About 6 species, north America and western Asia; 2 in U. S.

a. T. perfoliátum $\mathrm{I}$. Canada, south to Alabama and Kansas. Fever-root, Horse Gentian, Horse Ginseng, White Ginseng, White Gentian, Genson, Feverwort, Bastard Ipecac, Wild or Wood Ipecac, Tinker's-weed, Tinkar's-rootf, Wild Coffee. Root febrifuge, cathartic, deobstruent. 
2038. TRIPHÁSIA, Lour. Lime Myrtle. Aurantiaceae. From Greek, "three-fold", i. e. trimerous. A thorny shrub with fragrant white flowers. Une species, China, widely cult. in tropical countries. (a) T. Aurantíola Lour. ('T. Javanica M. Roem.). Lime Myrtle, Lime-berry, Bergamot*. Fruit esculent.

2039. TRITELÉIA, Lindl. (Tritelia).

Liliaceae.

Syn. Brodiæa, Calliprora, in part. Scapose herbs with blue or violet flowers. Thirteen species in western U.S.

2040. TRÍTICUM, L.

Wheat.

Gramineae. The Latin name of Wheat, "threshed" or "ground". Robust grasses. About 15 species, Mediterranean region to central Asia.

a. T. aestívum L. ( $T$ vulgare Vill., T. sativum Lam. The Linnæan name originally applied to a variety). The most universally cultivated of all cereals. Wheat. The very numerous varieties form three principal groups; 1 . Bearded or Summer Wheat, 'T. aestivum L., proper; 2 . Unbearded or Winter Wheat, T. hybérnum L., and 3. Spelt or Dinkel Wheat, with adherent grain, T. Spélta L.; a remarkable variety is the Egyptian Wheat with compound spikes. Seeds, ground and sifted, Wheat flour: Farina Tritici Br., used as an application for burns, etc.; esculent. Starch, Amylum tritici, is also largely prepared from the grain.

Other species worthy of note are (b) T. dicóccum Schrank, Emmer Wheat, Arras Wheat of Abyssinia; (c) T. monocóccum L., One-grained or Single-grained Wheat, St. Peter' Corn; (d) T. tricóccum Schuebl. [Index Kewensis makes this a synonym of (b)], Amel Corn, cult. in Switzerland as a source of starch.

2041. TRIUMFTÉTA, L.

Burweed.

Tiliaceae. Named for G. B. Trionfetti, Italian botanist, d. 1708. Herbs and shrubs. About 50 species, warmer regions; 1 in U. S.

(a) T. semitríloba Jacq. Florida to West Indies and tropical regions generally. Burweed, Paraquet-bur. Bark, Bur-bark, yields a tibre resembling jute.

2042. TRÍXIS, P. Br.

Trixis.

Compositae. From Greek, "three-fold", the corolla being trifid. Syn. Perdicium, in part. Herbaceous or shrubby perennials. A bout 30 species, tropical America; one or two, Mexican border of U.S.

2043. TRÓLLIUS, L. Globe-flower. Ranunculaceae. From (ierman, signilying probably "round". Perennial herbs mostly paludal with showy flowers. About 10 species, north temperate zone; 1 in U. S.

a. T. Europaéus L. Europe. Globe flower, Globe Ranunculus, Trollflower, Butter-basket, Cabhage Daisy; Golden-ball, Lockin-gowan, Lapper-gowan. 
b. T. láxus Salisb. (T. Americanus Muhl.). New Hampshire to Michigan, also in Washington. American Globe-flower, Spreading or Swamp Globe-flower, Troll-flower, with other synonyms of (a).

2044. TROPAÉOLUM, L. (Trophæum). Geraniaceae. From Greek, "trophy", alluding to the shield-like leaves. Syn. Cardamindum, Adans. Climbing or diffuse succulent herbs. About 40 species, warmer regions of New World.

в. T. május L. (C, majus Moench). Peru, cult. in gardens. Common Nasturtium (Nasturtion, Stortioner, Sturtion!, this name applying originally to Roripa; Indian Cress, Lark's-heel*. Flowers used as salad; unripe fruit a substitute for capers.

b. T. peregrínum L., South America, cult. in gardens, is Canarybird flower; (c) T. sessilifólium Poeppig, of Chili and(d) T. tuberósum R. \& P., of Peru, produce esculent tubers.

2045. TROPIDOCÁRPUM, Hook. Tropidocarpum. Cruciferae. From Greek, "keel fruited". Annual herbs. Three species, California.

2046. TSƯGA, Carr. Hemlock Spruce. Pinaceae. From vernacular, Japan, Syn. Hesperopeuce, Abies, Pinus, in part. Large evergreen trees with leaves apparently tworanked. About 7 species, North America and Asia; 4 in U.S.

a. T. Canadénsis (L.) Carr. (P. Canadensia L., A. Canadensis Michx.). Canada, south to Alabama and Wisconsin. Hemlock, Hemlock Spruce, Weeping Spruce, Spruce Pine, Tanbark tree, Palmt. Bark extensively used for tauning, medicinally under the name of Pinus Canadensis as an astringent.

b. T. Mertensiána (Bong.) Car. (P. Mertensiana Bong., A. Pattoniana A. Murr., T. Hookeriana (ar.). Oregon to Alaska, east to Montana. Western Hemlock, Mountain Hemlock, Patton's Spruce. Supplies most of the tan-bark of the Northwest.

2047. TÚBER, Mich. Truftle, Earth-ball. Tuberaceae. The ancient Latin name, a "swelling". Subterranean fungi, some of the species highly esteemed for food. The English word truffle, is from French, tartoufle, from Latin terræ tubera, whence also the German Kartoffel (potato).

a. T aestívum Micheli is the common Truffle of England; (b) T. melanósporum Vitt. is the common Truffle of France; (c) T. cibírium Sibth., the Black Truffle, Perigord and Quercy Truffle; (d) T. magnátum Pico, the garlic-flavored Gray Truffle of Italy. [The following also are known as truftles; (e) Chairómyces meandrifórmis Vitt., the White British Truffle; (f) Mylítta austrális Berk., the Australia Truffle; (g) Melanogáster variegátus Tulasne. the Red Truftle of southern Europe; (h) Terfézia leónis of Italy; (i) Sclerodérma rulgáris Fr., False Truffe, allied to the Puff-balls]. 
2048. TUBIFLÓRA, J. F. Grmel.1791. Tubiflora. Acanthaceae. From Latin, "trumpet flower". Syn. Elytraria (Kew), Michx. 1803. Low herbs. About 5 species, mostly American; 2 in U. S.

2049. TÚLIPA, L. - Tulip (Culip). - Liliaceae. From late Latin, "turban". Bulbous plants with showy flowers. About 50 species, Europe and Asia. (a) T. Gesneriána L. Asia Minor and cult. in gardens. Common Tulip, with innumerable varieties. Several other species and many hybrids are cultivated.

2050. TÚMION, Raf.

False Nutmeg.

Pinaceae. From Greek name of the Yew tree. Syn. Torreya, Arn. 1833, Caryotaxus, Zucc. 1817, Fœtotaxus. Evergreen trees with yew-like foliage; fruit a drupe. Four known species, N. America and eastern Asia; 2 in U. S.

a. T. Califórnicum (Torr.) Greene (Tor. Californica Torr. (Kew), Tor. myristica Hook., C. myristica Henk. \& Hoch.. F. myristica Sen.). California Nutmeg tree. Fruit resembles the nutmeg in appearance, not at all in taste or properties.

b. T. taxifólium (Arn.) Greene (Tor. taxifolia Arn, F. montana (Nelson) Sen. Southeastern U. S. Torrey tree, Torreya, Savin*, Stinking Cedar.

2051. TÚNICA, Adans. Saxifrage Pink, etc. Caryophyllaceae. From Latin "cloak", alluding to bracts at base of ealyx. Syn. Dianthus, in part. Slender herbs with small Howers. About 20 species, southern Europe and western Asia; 1 adv. in U. S.

2052. TÚRNERA, L. Damiana, etc. Turneraceae. Named for W, Turner, author of an English herbal, 1551 . Herbs or shrubs with yellow flowers. About 54 species, tropical America; 1 in southwestern U. S.

a. T. diffísa aphrodisíaca Urb. ( $T$. aphrodisiaca Ward, T. nicrophylla Desv.). Texas to Lower California. Damiana. Leaves aromatic, tonic, reputed aphrodisiac.

b. T. ulmifólia L. West Indies. Holly-tree*, Sage-rose. Plant tonic, expectorant.

2053. TUSSILÁGO, L. Colt's-foot.

Compositae. The Latin name, meaning "congh cure". Scapose perennial herb with yellow Howers. One species, Europe and Asia.

a. T. Fárfara L. Northern Europe and Asia, nat. in northeastern U. S. Colt's-foot (Coutfit), Coughwort, Ass-foot, Bull's-foot, Foal-foot, Horse-foot, Horse-hoof, Butter-bur*, Clay-weed, Cleats, Colt-herb, Dove-dock, Dummy-weed, Ginger, Gingerroot, Gowan, Hoofs, Sow-foot, British Tobacco. Tushylucky Dishalagał; Ger. Huflattig, Rosshuf; Fr. Tussilage, Pas d'ane ( 'odex). Leares, Folia farfaræ, Herba tussilaginis, demulcent, alterative, a cough remedy. 
פ054. TYLóPHORA. R. Br. Indian Ipecac. Asclepiadaceae. From Greck, "knob bearing". Syn. Asclepias, Cynanchum, in part. Shrubby or herbaceous twiners. About 40 species, warmer regions, Uld World. (a) T. asthmática (L.) W. \& A. (A. asthmatica L., C. Ipecacuanha Willd.). India. Indian Ipecac. Poot emetic.

2055. TÝPHA, L. Cat-tail Flag, Reed-naace, etc. Typhaceae. The ancient Greek name. Fieed-like plants. About 13 species, widely distributed; 3 in U. S.

a T. latifúlia L. North America, except extreme northern part. Cat-tail Flag, Common or Broad-leaved Cat-tail, Great Reedaace, Blackamoor, Black-cap, Bulrush**, Bull-rush, Bull-segg, Marsh-beetle, Marish-beetle, Marsh-pistle, Candle-wick, Cat-ofnine-tails, Dunche-down, Flax-tail, Heree, Water-torch.

2056. ĆLEX, L. Furze, Gorse, etc. Papilionaceae. The ancient Latin name. Spiny shrubs, practically without foliage; flowers yellow, showy. About 20 species, mostly of eastern Europe.

2 U. Europaéus L. Europe, adv. in U.S. Furze (Firsun, Furzen, Furrys, Frez, Fuzz, Fir*, Vuss, Vuz), French or Great Furze, Gorse (Gorst, Goss, Gost), Ling*, Prickly Broom, Thorn Broom, Ruffet, Turr, Ulim, Whin, Whuns; Ger. Stechginster; Fr. A jonc.

2057. CLMíRIA, Hill. Meadow-sweet, etc. Rosaceae. From Latin, "Elm-like". Syn. Filipendula, Spirza, in part. Perennial herbs with flowers in large cymose panicles. About 9 species, north temperate zone; 1 in $\mathrm{U}$. S.

*. U. Ulmária (L.) Barnh. (S. Ulmaria L., U. palustris Moench, F. Ulmaria Maxim). Europe and western Asia, cult. and adv. in U. S. Meadow-sweet, Mesdow-queen, Mead-sweet, (Mesdow-soot), Meadowwort, Bride-sweet, Bridewort, Courtshipand-matrimony, Herb Christopher*, Harif, Honey-sweet, Maidsweet, Maid-of-the-meadow, My-lady's-belt, Pride-of-the-meadow, Queen-of-the-meadow, Spirea, Sweet-hay, Sweet-meadow; Ger. Ulmenspiräe, Geissbart, Krampf, Medesüss; Fr. Ulmaire, Reine des prés (Codex). Herb astringent; floners (Codex) antispasmodic, diaphoretic, diufretic. The indigenons (b) $\mathbf{U}$. rúbra Hill (S. lobata Gronor., S. rubra Brit.) is called Queenof-the-prairie.

205S. ÚLYCS, L. - Elm. - Clmaceae. The Latin name, from Celtic, whence our word Elm. Trees. About 16 species; northern hemisphere; $\delta$ in $\mathrm{U}$. S.

2. C. Americána L. Canada and eastern U. S. American Elm, White or Common Elm, Pock Elm*, Swamp or Water Elm. Other indigenous species are (b) C. aláta Michx., Southeastern U. S., Winged Elm, Wahoo*, Cork Elm. Water Elm and (c) U. racemósa Thomas., Canada and northeastern U. S., Cork Elm, Cork White Elm, Cliff or Hickory Elm, Rock Elm, Racemed? or Swamp Elm, Wahoo*. 
d. U. campéstris L. 'Europe and western Asia. European Elm, English Elm (Ellem, Allom, Allme, Aum, Elmen, Helm, Elven, Owm), Horse-may, May; Fr. Orme champêtre, Orme pyramidal (Codex). Inner bark used like that of (f).

e. U. montána With. Europe. Scotch Elm, Broad-leaved or Mountain Elm, Chew-bark, Halse, Wych Elm, Witch Elm, Witch, Wychwood, Witch-wood, Wych-hazel*, Witch Hazel*. $^{*}$.

f. U. fúlra Michx. (U. pubescens Walt.). Canada and eastern U. S., west to N. Dakota. Slippery Elm, Moose or Red Elm, Indian Elm, Rock or Sweet Elm; Fr. Orme fauve (Codex). Inner bark, Elm-bark, Slippery Elm; Ulmus, U. S. P., Cortex ulmi; Ger. Ulmenrinde, Rüsterrinde; mucilaginous, demulcent.

2059. UMBELLULÁRIA, Nutt. 1842.

From Latin, "umbelled". Syn. Sciadiodaphne Rtichb. $18+1$ (name only); Litsea, Tetranthera, Ureodaphne, in part. Evergreen tree with aromatic foliage. One species, Pacific border of U. S.

a. U. Califórnica (Arnott) Nutt. (T. Californica H. \& Arn., O. Californica Nees, L. Californica B. \& H. ). California to Puget Sound, California Bay-laurel, California Bay tree, California Laurel, Spice tree, Mountain Laurel (of the IVest), Balm-ofheaven. Sassafras Laurel, Cajeput tree, California Wild Olive. Leaves stimulant, anodyne, used as a condiment.

2060. UNGNÁDIA, Endl. Spanish Buckeye. Sapindaceae. Named for Baron Ferdinand von Ungnad of Austria. A tree related to Aesculus. One species; (a) U. speciosa Endl. (U. heterophylla Scheele). Texas and Mexico. Seeds emetic, reputed poisunous.

2061. UNIFÓLIUM, Adans.1763,Solomon's-seal.Convallariaceae. Froin Latin, "one leaf"', sterile plants often producing but a single leaf. Syn. Maianthemum Wigg. 1780, Smilacina, in part. Low herbs resembling Smilacina. Two known species, one of Euro-Asia; 1 in U. S.

a. U. Canadénse (Desf.) Greene (M. Canadense Desf., S. bifolia, var. Canadensis A. Grap). British America, south to N. Carolina and S. Dakota. 'Two-leaved Solomon's-seal, False or Wild Lily-of-the-valley, Bead-ruby, Cowslip*, One-blade, Oneleaf.

2062. URAGÓ(XA, L. Ipecacuanha, etc. Rubiaceae. Syn. Cephaelis, Swz., 17S8, I pecacuanlia, Arruda 1810, Psychotria, Muell. Arg. 1759; Callicocca, in part. Trees or shrubs.

a. U. Ipecacuánha (Brot.) Baill. (P. Ipecacuanha Stokes (Kew), Ceph. I pecacuanha C. Rich., Call. Ipecacuanha Brot., Ceph. emetica Pers. 1805, I. officinalis Arr.). Brazil and New Granada. Ipecac, Ipecacuanha, Hippo, Poaya (vernacular); Ger. Brechwurzel, Ruhrwurzel, Graue Ipekakuanhe; Fr. Ipécacuanha aunelé ou ofticinal (Codex ,, Racine brasilienne. Root; Ipecacanaha, U. S. P., I pecacuanhr radix Br.; emetic, expectorant. 
2063. URCÉOLA, Roxb. Caoutchouc vine. Apocynaceae. From Latin, "a little urn". Syn. Chavannesia, DC. Shrubby climbers. About 8 species, East Indies.

a. U. elástica Roxb. Sumatra and Borneo. Caoutchouc vine. From this and other species, notably (a) U. esculénta Benth. (C. esculenta DC.), is obtained Penang and Borneo Caoutchouc, Jintawan. Fruit edible.

2064. URECHÍTES, Muell. Arg. Urechites. Apocynaceae. Prostrate or climbing shrubs with showy flowers. About 4 species, Mexico and West Indies. (a) U. suberécta Muell. Arg. San Domingo. Savannah flower, Yellow-flowered Nightshade. Leaves arterial sedative, alterative.

206. URÉXA, L. Indian Mallow. Malvaceae. From vernacular uren, Malabar. Herbs or shrubs. About 5 species, tropical regions; 1 in U. S.

a. U. lobáta L. Southern U. S., a common weed in nearly all tropical countries. Indian Mallow, Perpulut (Penang), Guaxima (Brazil). A fibre plant. Flowers in Brazil used for coughs.

2066. URGíNEA, Steinh. Squill, etc. Liliaceae. From Latin, "compressed", of the seeds. Syn. Scilla, in part. Scapose herbs from a coated bulb. About 24 species, Mediterranean region to India.

a. U. marítima (L. ) Baker (Scilla maritima L., U. Scilla Steinh.). Mediterranean basin. Squill, Sea Onion; Ger. Meerzwiebel; Fr. Scille (Codex) Squille; Sp. Eschila, Cebolla albarrana. The bulb, Squill, Squills; Scilla. U. S. P., Br., Bulbus Scillae P. G.; expectorant, nauseant, diuretic. Varieties of the drug are distinguished as White Squill and Red Squill.

2067. URTÍCA, L. Nettle.

Urticaceae. The ancient Latin name, "burning". Herbs with stinging hairs. About 30 species, widely distributed; 7 in U. S.

a. U. dioíca L. Europe and Asia, nat. in U. S. Stinging Nettle, Common Nettle (of Europe), Greater Nettle, Tenging Nettle, Naughty-man's-plaything, Scaddie; Ger. Brennessel; Fr. Ortie brulante; Sp. Ortigo. Fresh plant diuretic, alterative, discutient. Fiber used to make nettle-cloth. The Common Nettle of the eastern U. S. is (b) U. grácilis Ait., Tall Wild Nettle.

c. U. pilulífera L. India to southern Europe. Burning, Greek, Roman or Wild Nettle, Spanish Marjoramt. Seeds galactagogue; root diuretic.

d. U. spatuláta Sm. (U. urentissima Blume). India. Devil's Stinging-leaf, Devil's-leaf.

e. U. úrens L. Europe, nat. in U. S. Small Nettle, Dwarf Nettle, Burning or Stinging Nettle, Dwarf Stinging Nettle, Ettle.

2068. URTICÁSTRUM, Fabr. 1759, Wood-nettle. Urticaceae. From Latin, "star nettle". Syn. Laportea, Gaud, 1826, Urtica, in part. Herbs with stinging hairs. About 2.5 species, mostly tropical; 1 in U. S. 
a. U. divarieátum (L.) Kze. (Urtica divaricata L., L. Canadensis Gaud.). Canada and eastern U. S. Wood Nettle, Canada Nettle, Albany Hemp. Seeds and leaves alterative, expectorant, counter-irritant. In India are found (b) U. crenuláta (Roxb.) Lyons (Urtica crenulata Roxb.) and (c) U. stímulans (L. f.) Lyons (Urtica stimulans L. f.), both violently irritating nettles, as is (d) U. férox (Blanco) Lyons (L. Gaudichaudiana Wedd. ), Philippine Islands.

2069. URVÍLLEA, H. B. K. Urvillea. Sapindaceae. U. S. Climbing shrubs. About 15 species, tropical America; 1 in

2070. ÚSNEA, (Dill.) Ach. Beard Moss, etc. Usneaceae. Lichens with terete, often pendulous thallus, on rocks or trees. About 20 species; 6 in U. S. (a) U. barbáta Ach. Beard Moss, Tree-hair, Hanging Moss, Idle Moss, Maple Moss, Necklace Moss, Tree Moss. Plant demulcent, expectorant.

2071. USTILÁG0, Pers. Smut, Bunt, \&c. Ustilagineae. From Latin, "scorched" or "charred". Syn. Uredo, in part. Fungi, parasitic on the tissues of living plants. (a) U. máydis Leveillé (Uredo maydis DC.). Parasitic on maize. Corn-smut, Maize-smut, Corn Ergot; Ger. Maisbrand, Beulenbrand; Fr. Ergot de Mais; Sp. Kizon de Maiz. Fungus has properties of Ergot.

2072. UTRICULARIA, L. Bladderwort. Lentibulariacea. From Latin; a little "bag" or "bladder". Aquatic herbs, the leaves bearing vescicles. About 150 species, widely distributed; 20 in. U. S.

a. U. vulgáris L. (U. macrorliziza LeConte). Europe, Asia and North America. Greater Bladderwort, Common Bladderwort, Bladder-snout, Hooded Water-milfoil, Yop-weed. The synonyms applied also to other species.

2073. UVULÁRIA, L. Bellwort, Wild Oat, etc. Melanthaceae. From Latin uvula, alluding to pendulous Howers. Syn. Oakesia, in part. Herbs from perennial root-stocks. Abont 6 species, N. America; 4 in U. S. (a) U. perfoliáta L., Canada and eastern U. S., Perfoliate or Mealy Bellwort, is called Mohawk-weed; (b) U. sessilifólia L. (O. sessilifolia'S Wats.), Canada and northeastern U. S., Small or Sessile-leaved BellHower, is called Straw Lily.

2074. VACCÁRIA, Medic. Cow-herb, etc. Caryophyllaceae. From Latin, "cow" plant. Syn. Saponaria, in part. Annual with small red or pink flowers. About 3 species, Europe and Asia.

a. V. Vaccária (L.) Britton (S. Vaccaria L., V. vulgaris Host.). Europe and northern Asia, nat. in U.S. Cow-herb, Cow Basil, Cockle, Field Soapwort.

2075. VACCÍNIUM,L.Whortleberry,Huckleberry,etc. Ericaceae. The Latin vame. Syn. Metagonia, in part. Shrubs, some arborescent, many producing edible berries. About 125 species, widely distributed; 30 in U. S. 
a. V. arbóreum Marsh. Southeastern U.S. Farkleberry, Sparkleberry, Tree Huckleberry, Gooseberry*.

b. V. Aretostáphylos L. Greece to the Caucasus. The dried leaves constilut $\epsilon$ Broussa tea, used for a beverage.

c. V. corymbósum L. ( $V$. amœenum Ait.). Canada to Virginia and Louisiana, west to Minnesota. Swamp, High-bush or'Tall Blueberry, Giant Whortleberry or Huckleberry, Seedy Deerberry. The late market blueberry. Fruit esculent. The Pale or Mountain Blue-berry of Virginia to S. Carolina is (d) V. pállidum Ait. ( $V$. corymbosum var. pallidum Gray), the finest of our blueberries.

e. V. Myrtíllus L. Europe, central and northern Asia, northern N. America. Whortleberry (of Europe), Bilberry, European Huckleberry (Hockleberry, Hurtleberry, Hurtberry, Hartberry), Whinberry, Wimberry, Winberry, Wine-berrv, Whortle (the plant), Whort (the fruit, also the plant), Whurt, Wort, Blaeberry (Scotland), Blackberry*. Black-heart; Ger. Heidelbeere, Besinge, Blaubeere, Bickbeere, Gandlebeere (Schwarze); Fr. Airelle myrtille (Codex). Fruit, Fructus myrtilli, Baccæ myrtillorum, Myrtilla, astringent, antispasmodic, esculent. :

f. V. penduliflórum Gaud. (M. penduliflora Nutt.) and (g) V. reticulátum Sm. Hawaiian Islands. Ohelo. Fr•uit acidulous and somewhat astringent, esculent.

h. V. Pennsylvánicum Lam. British America, south to New Jersey and Illinois. Dwarf, Low-bush or Sugar Blueberry, Whortleberry, Huckleberry, Strawberry Huckleberry, the early market blueberry. Other Low Blueberries are (i) V. Canadénse Rich. and (j) V. racíllans Kalm. (k) V. atrocóccum (Gray) Heller and (1) V. nígrum (Wood) Brit., with black fruit, are called Black Blueberry. The California Whortleberry is $(\mathrm{m})$ V. orátum Pursh.

11. V. stamíneum L. Ontario and eastern U. S. Deerberry, Dangle-berry, Buck-berry, Goose-berry*, Squaw-berry, Squaw Huckleberry or Whortleberry. Fruit astringent, not edible. Root diuretic.

o. V. uliginósum L. Northern Europe, Asia and N. America. Bog Bilberry, Great Bilberry, Bog Whortleberry, Bog Blueberry, Bleaberry. Fruit edible.

p. V. Vitis-Idaéa L. Europe, Asia, northern N. America. Mountain Cranberry, Rock Cranberry, Cow-berry, Cluster-berry, Flowering Box, Ling-berry, Red Bilberry, Red Whortleberry, Wine-berry, Wind-berry; Ger. Preisselbeere, Kronsbeere, Steinbeere, Rothbernitzbeere. Fruit acid, edible. Leaves astringent diuretic, expectorant.

5076. VÁGNERA, Adans. 1763. Smilacina. Conrallariaceae. Named for IVagner. Syn. Smilacina (Kew), Desf. 1807, also Convallaria, in part. Perennial herbs with aspect of Solomon's-seal. About 25 species, Asia and north to central America; 5 in U. S. 
a. V. racemósa (L.) Morong (S. racemosa Desf. (Kew), C. racemosa L.). British America, south to Georgia, Missouri and A rizona. False Solomon's-seal, Wild Spikenard, False Spikenard, Small or Zigzag Solomon's-seal, Golden-seal*, Job's-tears*.

2077. VALERIÁNA, L. Valerian. Valerianaceae. From Latin valere, to be "strong". Syn. Phu, Rupp. Strong-scented perennial herbs. About 175 species, north temperate zone and S. America; 10 in U. S.

a. V. Céltica L. Alps of Europe. Celtic Nard or Spikenard. Root, Nardus, Spica celtica, valued in the Orient for its perfume. See Nardostachys.

b. V. édulis Nutt. British America, south to Ohio and Arizona. Edible Valerian, Tubacco-root, Oregon Tobacco. Root used by aborigines as food.

c. V. officinális L. (V. angustifolia Tausch, V. sambucifolia Mikan.). Europe and Asia, adv. in U. S. Valerian, called in America Garden Valerian, in Europe Great Wild Valerian; Cat's Valerian, Common Valerian, All-heal, Cut-heal, Setwall (originally applied to Zedoary, and only another form of the saıue name), Hardy or Summer Heliotrope, Herb bennet, Vandal root; Ger. Baldrian; Fr. Valériane officinale. The root Valeriana, U.S. P., Valerianæ Rhizoma Br., Radix Valerianæ, P. G., Radix valerianæ minoris; antispasmodic, nervine. (d) V. Mexicána DC. and (e) V. Toluccána DC. of Mexico, also (f) V. Sitclıénsis Bong. of Alaska and several other species have like properties.

g. V. Phú L. Western Asia and Southern Europe. Large Garden Valerian, Spikenard of Crete. Root, Radix valerianæe majoris, inferior to that of $(\mathrm{c})$.

h. V. sylvática Banks (V. dioica Pursh, not L.). British America, south to New York, Michigan and Arizona. Wood Valerian, Swamp or Marsh Valeriau (these names in Europe applied to (i) V. dioíca L.), American Wild Valerian.

2078. VALERIANÉLLA, Poll. Corn-Salad, etc. Valerianaceae. Latin, diminutive of "Valerian". Syn. Fedia, Locusta, Riv., Valeriana, in part. Dichotomously branched annuals. About 50 species, northern hemisphere, especially Mediterranean region; 7 in $\mathrm{U}$. S.

a. V. Locústa (L.) Bettke (Valerianella olitoria Poll. (Kew), L. comnunis Delarb., V.Locusta and var. olitoria L.). Europe to middle Asia and northern Africa, nat. in U. S. European Corn-Salad, I.amb's Lettuce, Milk-grass, White Pot-herb; Ger. Ackersalat; Fr. Mâche. Leares, called Fetticus. used for salad. The American (b) V. radiáta (I..) Dufr. (F. radiata Miclıx.), Beaked Corn-salad?, is also called Lamb's Lettuce.

2079. VALERI NoÍUES, Medic. 1789.

Verbenaceae.

From (ireek, "Valerian-like". Syn. Stachytarpheta. Vuhl. 1805 (Sıachytarpha), Abena, Neck. 1790, Vermicularia, Moench 1802. Herbs or shrubs resembling Vervain. A bout 45 species, warmer regions, especially of New World. 
a. V. Índica Medic. (S. Indica Vahl., V. Jamaicensis Medic.). Common to tropical countries. Gervao, Brazilian Tea. Leaves used in Europe as a substitute for Chinese tea.

2080. VALLÉSIA, R. \& P.

Vallesia.

Apocynaceae. U. S.

Shrubs or trees. About 5 species, tropical America; 1 in

2081. VALISNÉRIA, L. Tape-grass, Eel-grass. Valisueriaceae. Named for Antonio Vallisueri, Italian naturalist, d. 1730 . Aquatic perennials with grass-like leaves. One species, widely distributed (U. S.).

a. V. spirális L. Temperate and warm regions of both hemispheres. Tape-grass, Eel-grass, Wild (elery or Water Celery (Chesapeake Bay), Spring-plant (Australia).

2082. VAYCOUVÉRIA, Morr. \& Desne. Berberidaceae. Named for Capt. V'ancouver, English navigator, 18th Century. Scapose perennials. Three species, Pacific coast of U.S.

2083. VANíLLA, Plum. Greenwithe, Purple-lip. Orchidaceae. From Latin (?), diminutive meaning "little pod". Robust climbers. About 20 species, tropical regions of Old and New World; 1 in U. S.

a. V. planifólia Andrews. Mexico and Central America. Vanilla. The unripe fruit; Vanilla, U. S. P., Fructus Vanillae, P. G., Siliqua vanillæ; Ger., Fr. Vanille (Codex); Sp. Vainilla; Mex. Baynilla. Used as a flavoring agent. Vanilla is obtained from several other species, notably trom (b) V. micrucárpa Karst. of Venezuela; (c) V. Pompóna Schiede, Brazil and Peru and prohably (d) V. Guianén is Splitberger; not from (e) V. aromática Swz., as is usually believed.

2084. VARÍLLA, Gray. Varilla. From vernacular name Mexico. Shrubby compsitae. thickened leaves and yellow flowers. Truby plants with Mexico, one of Texas.

2085. VARRóNIA, P. Br. 1756. Sebesten, etc. Boraginaceae. Syn. Cordia, L. 1763, Sebesten, Adans. 1753; Myxa, Pilicordia, in part. The name Cordia is the older and has been adopted below. Trees or shrubs. About 200 species, warmer regions; 4 in U. S. In West Indies the species are called "Elm".

2. C. Mýxa L. (C. Sebestena Forsk. not L., C. officinalis Lam.. S. officinalis Gaertn., probably includes V. Abyssinica DC. and C. Africana Lam.). India to Australia and western Africa. Sebestan (Sebesten, Sapistan), Sebestan Plum, Assyrian Plum; Ger. Schwarze Brustbeere. Bark a mild astringent. Fruit mucilaginoux, emollient. The following have similar properties and uses; (b) C. Boissíeri DC., Texas to Mexico, Anacahuita (a jelly made from the fruits used in cougbs), and (c) C. oblíqua Willd. (C. latifolia Roxb.) of India.

d. C. Sebesténa L. Florida to West Indies and northern S. America. Geiger tree. 
2086. VATÉRIA, L. Piney-varnish tree. Dipterocarpaceae. Named for Abraham Vater, German botanist, 18th Century. Syn. Elæocarpus, in part. Resiniferous tree. About 30 species, tropical Asia.

a. V. Índica L. (E. copaliferus Retz.). Ceylon and Malabar. Pinne tree, Piney-varnish tree, Copal-tree, Tallow-tree. Resinous exudate, Malabar or Indian Copal, Gum Anime, White Dammer, Dammer Pitch; used as incense as well as for varnishes, and cut into "amber" ornaments. Seeds source of Piney Tallow, used for candles.

2087. VAUQUELÍNIA, Correa. Vauquelinia. Rosaceae. Named for Louis Nicolas Vauquelin, French chemist, d. 1829. Syn. Spirea, in part. Tree with corymbs of white flowers. Three species, Mexico and adjacent territory; 1 in U. S.

2088. VENFGÁSIA, DC. 1837. Venegasia. Compositae. Named for Michael Venegas, Jesuit missionary. Syn. Parthenopsis, Kellogg 1875 . Perennial herb with large flowerheads (yellow). One species, California.

2089. VERÁTRUM, L. White or False Hellebore.Melanthaceae. Ancient Latin name of Hellebore. Syn. Melanıbium, Helonias, in part. Robust herbs with acrid poisonous rhizome. About 10 species, north temperate zone; 5 in U. S.

a. V. álbum L. (including var. viridiflorum Mert. \& Koch., V. Lobelianum Bernh.). Europe and northern Asia. White Hellebore, White Veratrum, Lingwort, Sneezewort, Neezewort; Ger. Weisse Niesswurz, Weis er Germer, Krätzwurzel, Frengelwurz, Franzwurz, Sauwurz, Schampanierwurz; Fr. Hellébore blanc (Codex), Vératre blanc; Sp. Vedegambre blanco. Rhizome and rootlets, Rhizoma Veratri, P. G., Rad. hellebori albi; counter-irritant, parasiticide, sternutatory.

b. V. víride Ait. (V. album var. viride Baker, M. virens Thunb., H. viridis Ker.). British America, south to Georgia and Minnesota. American Hellebore. Green Hellebore, Green or American Veratrum, American White Hellebore?, Big or Ealse Hellebore, Swamp Hellebore, Bear-corn, Bugbane, Bugwort, Devil's-bite, Duck-retter, Earth-gall, Indian Poke, Itch-weed, Poke-root*, Poor-Anne, Tickle-weed; Ger. Grüner Germer; Fr. Vératre vert; Sp. Vedegambre verdu. Rhizome and roots; Veratrum viride, U. S. P., Veratri viridis Rhizoma, Br., Rad. veratri americani; arterial sedative, irritant, enetic, sternutatory.

2090. VERBÁSCUM, L. Mullen, etc. Scrophulariaceae. Ancient Latin name of (b). Syn. Blattaria, Thapsus, in part. Biennial, rarely perennial herbs. About 125 species, Old World; 5 nat. in U. S.

a. Y. Blattária L. (T. Blattaria Raf., B. vulgaris Four.). Europe and northern Asia, nat. in U. S. Moth Mullen (Mullein).

b. V. Thápsus L. (T. Schraderi Opiz., V. Schraderi G. Meyer.). Europe and Asia, nat. in U. S. and widely elsewhere. Common Mullen (Mullein), Great Mullen, Velvet or Mullen Dock, 
Aaron's-rod, Adan's-flannel, Blanket-leaf, Bullock's-Lungwort, Cow's or Clown's Lungwort, (andlewick. Feltwort, Flannel-leaf, Old-man's flannel, Hare's-beard, Hedge-taper (Hog-taper, High-taper, Hig-taper), Ice-leaf, Jacob's-staff, Jupiter's-staff, Lady's Foxglove, Peter's-staff, Shepherd's-club, Torches, Torchwort, Velvet-rlant, Woollen; Ger. Wollkraut, Königskerze, Himmelbrand; Fr. Bouillon blanc, Molene; Sp. Gordoloba. Leaves, Fol. verbasci, mucilaginous, demulcent. Flowers vulnerary, anodyne. In Germany the flowers of (c) V. Phlomoídes L. and of V. thapsifórme Schrad. (V. Thapsus G. Meyer, 'not L. ) are used also.

2091. VERBÉNA, L. Verbena, Vervain. Verbenaceae. Latin name, applied first to green boughs used in certain sacred ceremonies. Syn. Buchnerat, (ilandularia; in part. Herbs, some shrubby, a few highly ornamental. About 100 species, nearly all American; 24 in U. S.

a. V. Canalénsis (L.) Brit. (B. Canadensis L. 1767, V. Aubletia Jacq. 1772 (Kew), G. Carolinensis J. G. Gmel.). Southeastern U. S. to Mexicu. Large-flowered Verbena. This and (b) V. bipinnatífida Nutt., south-central U. S., are the originals of most of our garden Verbenas.

b. V. officinális L. Europe and Asia, nat. in U. S. European Vervain (Vervein, Vervine, Vervin, Berbine), Blue Vervain (of Europe), Enchanter's herb, Enchanter's plant, Herb-ofgrace, Herb-of-the-cross, Holy-herb, Juno's-tears, Pigeon-grass, Simp!er's-joy; Ger. Eisenkraut, Eisenhart, Stahlkraut, Isenkraut, Venusblut; Fr. Verveine officinale (C'odex). Herb, H. verbenæ v. columbariæ $v$. sanguınalıs; astringent, vulnerary. Leaves a substitute for Chinese tea.

c. V. hastáta L. (V. paniculata Lam.). Canada and eastern to central U.S. Blue Vervain, American Blue Vervain, Common Vervain, American or Falie Vervain, Wild Hrssop, lron-weed*, Purvain, Simpler's-joy. Flowering herb, nauseant, expectorant, sudinific. (d) V. strícta Vent. (V. rigens Michx.), Ohio to New Mexico, Hoary or Mullen-leaved Vervain, is called also Fever-weed; (e) V. urticifólia L., Canada and eastern U. S., is White Vervain, Nettle-leaved Vervain, the plant used in Rhus poisoning.

2092. VERBESÍNA, L. Crown-beard. Compositae. Name altered from Verbera, q. v. Syn. Actinomeris, Nutt, recognized by Benth. \& Hook. as a distinct genus; Siege-beckia, Ximenesia, Coreopsis, in part. Rough herbs, often with decurrent leaves. About 60 species, mostly of New World; 12 in U. S.

a. V. alternifólia (L.) Brit. (C. alternifolia L., A. squarrosa Nutt. (Kew), A. alternifolia DC. ). Southeastern U. S. Actinomeris, Wing-stem, Stick-weed. (b) V. helianthoídes Michx. Iowa to 'Texas and Georgia. Sunflower Crown-beard. Plant reputed diuretic. 
2093. VERNóNLA, Schreb. 1771. Iron-weed. Compositae. Named for William Vernon, English botanist, 17th Century. Syn. Behen, Hill 1762 not Moench 1794, Suprago, Gaertn. 1791; Chrysocoma, Serratula, Cacalia, in part. Perennial herbs, some shrubby, with small discoid flower-heads. About 475 species, warmer regions especially in S. America; 11 in U. S.

a. V. Noveboracénsis (L.) Willd, Ser. Noveboracensis L., B. Noveboracense Hill). Eastern U. S. New York or Common Iron-weed, Flat-top.

2094. VERÓNICA,L.Speedwell,Brooklime,etc.Scrophulariaceae. Dedicated to St. Veronica. Herbs, shrubs or even trees, many ornamental. About 200 species, widely distributed; 15 in U. S.

a. V. Americána Schwein. British America, south to Pennsylvania, Nebraska and California. American Brooklime, Bluebell*. Resembles (b) V. Auagállis-aquática L. Europe, Asia and northern N. America. Water Speedwell, Water Pimpernel.

c. V. Beccahúnga L. Europe and Asia. Brooklime, Horse Well-grass, Well-ink (Ireland), Wall-ink (Scotland), Waterpurpie (Scotland); Ger. Bachbungen; Fr. Beccabunga (Codex), Cressonée. Fresh plant antiscorbutic, diuretic.

d. V. Clamaédrys L. Europe, nat. in U. S. Germander Speedwell, Angel's-eyes, Bird's-eye, Blue-eye, Cat's-eye, God's-eye, Eye-bright, Forget-me-not (Scotland), Base Vervain; Fr. Véronique femelle, Petit chêne. The names Bird's-eye and Cat's-eye are given also to (e) V. Byzantíià (Sibth. \& Sm.) B. S. P. ( V. agrestis var Byzantina S. \& S., V. Buxbaumii Tenore), Europe and Asia, adv. in U. S., Buxbaum's or Byzantine Speedwell?.

f. V. officinális L. Europe and Asia, nat. in U. S. Common Speedwell, Fluellin (Llewellyn), Ground-hele, Paul's Betony* (a name given also to $(\mathrm{g}) \mathrm{V}$. serpylifólia $\mathrm{L}$., another naturalized species), Upland Speedwell; Ger. Ehrenpreis, Wundkraut, Heil-aller-Schaden, Grundheil, Veroniken, Stah-up-unga-weg; Fr. Véronique mâle. Herb, H. veronicæ, H. betonica' albæ, astringent, alterative, diuretic.

Other notable species are (h) V. agréstis L., Europe, nat. in U. S., Field or Garden Speedwell, Procumbent Speedwell, Germander Chickweed, Winterweed; (i) V. hederaefólia L., Europe and Asia, nat. in U. S., Ivy-leaved Speedwell, Ivy Chickweed, Morgeline, Mother-of-wheat, Small Henbit, Winterweed and (j) V. peregrína L., widely distributed in Old and New World, Purslane Speedweell, Neckweed.

2095. VIBÚRNUM,L. Black Haw, Viburnum, etc. Caprifoliaceae. The ancient Latin name. Shrubs or trees. About 100 species, widely distributed; 17 in $\mathrm{U}$. S.

a. V. alnifólium Marsh. (V. lantanoides Michx.). Canada to N. Carolina and Michigan. Hobble-bush, American Wayfaring- 
tree, Dogwood*, Moose-berry, Moose-bush, Tangle-foot, Tanglelegs, Trip-toe, Witch-hobble, Witch-hopple. Bark diuretic. antiperiodic.

b. V. cassinoídes L. (V. nudum var. cassinoides T. \& Grr.). Canada and northeastern U. S. Withe-rod (Wythe-rod), Appalachian Tea*, False Paraguay Tea. Leaves used as tea.

c. V. Lentágo L. Canada to Georgia and Missouri. Nannyberry, Nanny-bush, Nanny Plum, Black Haw*, Black Thorn*, Sheep-berry, Sweet-berry, Sweet Viburnum, Tea-plant*, Wild Raisin. Fruit edible.

d. V. Ópulus L. (V. trilobum Marsh.). Europe, Asia, northern N. America, south to New Jersey, Michigan and Oregon. Cranberry tree, High-bush Cranberry, Wild Guelder-rose, 'Gneldres-rose, Cherry-wood, Cramp-bark tree, Dog Rowan-tree, White Dogwood (England), Whitten-tree, Red or Rose Elder, Marsh or Water Elder, White Elder, Gadrise, Gaiter-tree, Gatten, Love Rose, May Rose, Pincushion-tree, Squaw-bush, Witch-hobble, Witch-hopple; in cultivation Snowball-bush; Ger. Wasserholder, Wasserschwelike; Fr. Obier. Burk; Viburnum Opulus, U. S. P.; uterine sedative, antispasmodic. Fruit acid.

e.' V. prunifólium L. Connecticut to Michigan, south to Florida and Texas. Black Haw, Boots, Nanny-berry*, Sheep-berry, Sloe*, Stag-bush. Bark; Viburnum Prunifolium. U. S. P., uterine sedative, antispasmodic. Fruit edible. The name Black Haw is given also to (f) V. obovátum Walt. and (g) V. rufo-tomentósum Small ( $V$. prunifolium var. ferrugineum T. \& Gr.), both of southeastern U. S.

Other species worthy of note are (h) V. acerifólium L., Canada and northeastern U. S., Maple-leaved Arrow-wood, Dockmakie, Maple Guelder-rose; (i) V. dentátum L., Canada and northeastern U. S., Arrow-wood, Mealy-tree, Withe-rod, Withe-wood; (j) V. Lantána L., Europe, Wayfaring-tree, Lithy-tree; leaves and berries astringent; $(\mathrm{k})$ V. mólle Mich $\mathbf{x}$., eastern U. S., Soft-leaved Arrow-wood?, Black Alder*; (1) V. núdum L. (V. nudum var. Claytoni T. \& Gr.), Southeastern U. S., Larger Withe-rod ( Wythe-rod) or Withe-wood, Naked Viburnum?, Nanny-berry, Possum Haw, Possum Thorn, Shawnee Haw; $(m)$ V. pauciflórum Pylaie ( $V$. Opulus var. eradiatum Oakes), British America and northern U. S., Fewfowered Cranberry-tree, Squash-berry; (n) V. Tínus L., Southern Europe, cult. for ornament in U. S., Laurestine.

2096. VÍCIA, L. Vetch, Tare. Papilionaceae. The ancient Latin name. Syn. Ervum, in part. Pea-like vines. About 120 species, north temperate zone and S. America; 24 in U. S., including nat. species.

a. V. satíva I. Europe, adr. in U. S. Common Vetch or Tare, Pebble Vetch, Spring Vetch. An important fodder plant. 
b. V. Americána Muhl. Northern U. S. and northward. American or Purple Vetch, Pea-vine, Buffalo Pea. (c) V. Crácca L. Europe, Asia and northern N. America, south to Kentucky and Iowa, Tufted or Blue Vetch, Cow Vetch, Canada Pea, Catpea, Tine-grass; (d) V. hirsúta (L.) Koch (E. hirsutum L., V. Mitchelli Raf.), Europe and northern Asia, nat. in U. S., Hairy Vetch or Tare, Strangle-tare, Tine-tare, Tine-weed; (e) V. Sépium L., Europe and Asia, adv. in U. S., Bush Vetch, Wild Iare, Crow Pea.

2097. VICTóKIA, Lindl. Victoria Regia. Nymphaeaceae. Named in honor of queen Victoria. A gigantic water lily. One species, Amazon and tributaries. (a) V. régia Lind̆l. (V. Reginæ Hook., V. Regina J. E Gray). Victoria or Royal Water-lilv, Water Maize, Irupe or Water-platter (Guiana). Seeds esculent.

2098. VÍGNA, Savi. Cow Pea. Papilionaceae. Named for Dominico Vigna, Italian botanist, 17th Centùry. Syn. Dolichos, in part. Herbs, mostly climbing or trailing. A bout 30 species, tropical and sub-ropical regions; 1 in U. S.

a. V. Sinénsis (L.) Endl. (D. Sinensis L. 1756, D. Catjang L. 1767, V. Catjang Walp.). Tropical Asia and Afriea and widely cult., adv. in U. S. Cow Pea, China Bean, Black-eyed Bean, Chowlee, Tow-cok (Tow-cock). Seeds and pods esculent.

2099. VIQUIÉRA, H. B. K. Viquiera. Compositae. Named for Dr. A. Viquier, French botanist. Herbs, some shrubby. A bout 70 species, warmer regions of America; 7 in U. S. (Mexican border).

2100. VÍNCA, L.

Periwinkle.

Apocynaceae.

The Latin name, originally Pervinca, whence the English periwinkle. Erect or trailing herbs with blue, pink or whiteflowers. About 12 species, all but one of Old World; 1 nat. in U. S.

a. V. májor L. Europe. Larger Periwinkle, Band plant, Cutfinger, Hundred-eyes; Ger. Grosses Sinngrün; Fr. Pervenche grande (Codex). Leaves astringent, hemostatic.

b. V. mínor L. Europe, nat. in U. S. Periwinkle (Pennywinkle Penny-winkler), Small Periwinkle, Hundred-eyes, Myrtle†, Running Myrtle; Ger. Kleines Sinngrün; Fr. Pervenche petite (Codex). Leaves astringent, hemostatic.

2101. VINCETÓXICUM, Walt. 1788.

Asclepiadaceae. From Greek, "subduing poison". Syn. Gonolobus, Michx. 1803, Cynanchum, in part. Perennial vines with flowers in umbel-like cymes. About 75 species, New World; 6 in U. S.

a. V. hirsútum (Michx.) Brit. (G. hirsutus Michx.). Southeastern U. S. Hairy Vincetoxicum?, Running Milk-weed, Negro-vine.

2102. VíoLA, L.

Violet.

Violacene.

The Latin name. Herbs, a few shrubby. About 150 species, widely'distributed; 57 in U. S. 
a. V. blánda Willd. British America, south to $\mathrm{N}$. Carolina and California. Sweet White Violet, American Sweet Violet.

b. T. Cauadénsis L. Canada, south to $\mathrm{N}$. Carolina, Nebrassa and Arizona. Canada Violet, American Sweet Violet, Juseflower, Hens.

c. V. cucnlláta Ait. Canada and eastern U. S. Common Blıe Violet, Meadow or Hooded Blue Violet. In common wib other species, called also Johnny-jump-up*, and the flowers (ky children) Chicken-fighters and Roosters.

d. V. odoráta L. Europe and northern Asia, cult. and adv. in U. S. English Violet, Marsh or Sweet Violet; Ger. Märzvielchen; Fr. Violette odorante (Codex); Sp. Violeta. Flowers fragrant, reputed refrigerant and lenitive.

e. Y. pedáta L. Ontario and eastern U. S. Bird's-foot Violet; Crow-foot, Horse, Horseshoe, Sand, Snake or IVood Violet, American Pansy, Johnny-jump-up, Velvets (applied particularly to var. bicolor). Fresh plant (formerly official U. S. P.) reputed emollient, laxative, etc.

f. V. trícolor L. Europe and northern Asia; cult. and adv. in U.S. Pansy, Heart's-ease, Lady's-delight, Garden or Trinity Violet, Battle-field flower, Biddy's-eyes, Cat's-faces, Cupid's-delight, Fancy, Flamy, Garden-gate, Heart's-pansy, Herb-trinity, Johnny-jump-up, Johnny-jumper, Kisses, Kiss-me, Love-inidleness (Shakespere), Monkey's-face, None-so-pretty,. Stepmother; Ger. Stiefmütterchen, Freisamkraut, Dreifaltigkeitskraut, Ie-länger-ie-lieber; Fr. Yensée sauvage (Codex); Sp. Trinitaria. The wild-grown tlowering herb (ofticial in U. S. P. 1880); Herba violæ tricoloris, P. G., jaceæ, H. trinitatis, alterative, discutient.

2103. VíroLA, Aubl. Virola. Myristicaceae. Trees, the species referred by many botanists to Myristica. A bout 10 species, tropical S. America.

a. V. sebífera Aubl. (M. sebifera Swz.). Guiana. Malagueto de montana (Panama). Seeds source of Virola tallow, called also Ocuba wax, used for candles, etc.

2104. VISCÁ RIA, Roehl. Campion. Caryophyllaceae. From Latin, "glutinous". Syn. Lychnis, in part. Herbs. About 5 species, north temperate and arctic zones; 1 in $U$. S. (a) V. Alpína (L.) Roehl. (L. Alpina L.). Northern Europe, Asia and N. America. Red Alpine Campion.

2105. VÍSCUM, L. - Mistletoe. - Loranthaceae. The ancient Latin name, from Greek. Shrubby parasites. About 30 species, warm and temperate regions, Old World.

a. V. álbum L. Europe, growing often on apple, pear or plum trees. Mistletoe (Misseltoe, Miseltoe, Miselto), European Mistletoe; Ger. Mistel, Eichenmistel*; Fr. Gui de chêne, Gillon; Sp. Visco, Muérdago. Branches, Stipites visci, Lignum visci, antispasmodic, uterine stimulant; source of bird-lime. 
2106. VísMLA, Vandelli.

Wax-tree.

Hypericaceae. Named for Visme, botanist of Lisbon. Shrubs or trees. About 30 species, tropical Africa and America. (a) V. Guianénsis. Mexico to Brazil. Gutta-gum tree, Wax-tree. Gum. resin, American Gamboge, (Gummi gutta), a drastic cathartic. Other species yield similar products.

2107. VÍTEX, L. Vitex, etc.

Verbenaceae. The Latin name of (a). Aromatic slirubs or trees, some yielding hard and durable timber (Teak of New Zealand, Lignum vitae of Queensland). About 75 species, warmer regions of Old and New World; 1 in U. S.

a. V. Ágnus-cástus L. Mediterranean region. Chaste-tree, Abraham's-balm, Hemp-tree, Monk's Pepper-tree; Ger. Abrahamstrauch, Keuschlamm, Mönchspfeffer. Seeds aromatic. (b) V. lignum-vítae A. Cunn. is Queensland Lignum vitae.

\section{VíTIS, L.}

Grape.

Vitaceae. The ancient Latin name. Climbing woody vines, mostly with tendrils. About 40 species, warm and temperate regions; 25 in U. S.

a. V. aestivális Michx. Eastern U. S. Summer Grape, Small Grape. Original among others of Jacques, Cynthiana and Norton's Virginia varieties of cultivated grapes.

b. V. cordifólia Michx. Eastern U. S., west to Nebraska. Frost Grape, Fox Grape, Chicken Grape, Possum Grape, Winter Grape.

c. V. Labrísca L. New England to Georgia, west to Minnesota, also in Japan. Northern Fox Grape, Northern Plum Grape, Wild Grape, Wild Vine. The original of the Isabella, Concord, Catawba and many other varieties. The Delaware Grape is a cross with this and $\mathrm{V}$. vinifera $\mathrm{L}$.

d. V. rotundifólia Michx. (V. vulpina Torr. \& Gr. not. L.). Maryland to Texas and Mexico, also in eastern Asia. Southern Fox Grape, Bullace Grape, Muscadine Grape. The original of the Scuppernong. Less hardy than other American Grapes, but resists phylloxera perfectly.

e. V. vinífera L. Southern Europe to central Asia, widely cult. Wine Grape; European Hot-house or California (irape, including numerous varieties such as Tokay, Muscatel, etc. fromı which European wines are produced; Ger. Weinrebe, Weinstock; Fr. Vigne. Fruit esculent. Fermented juice of the ripe fruit, Grape Wine; Vinum Album, U. S. P., Vinum Xericum Br., Vinum, P. G.; Ger. Wein; Fr. Vin. Dried fruit, Raisins, Passulæ, Uvæ passæ; Ger. Rosinen, Zibeben; Fr. Raisins secs. From the seedless variety V. (minuta Risso, V. apyrena Auct.), the black Corinth or Zante grape, are prepared the "currants" (i. e. Corinthian grapes) of commerce.

f. V. vulpína L. (V. riparia Michx., V. cordifolia var. riparia Gr.). Canada, south to Maryland and Arkansas. River-side Grape, Sweet-scented Grape, Bull Grape, Frost or Winter G rape, Aroyo Grape, Muscadine Grape. Source of the Clinton and Franklin varieties. 
2109. VITTÁRIA, Sm. Vittaria. Polypodiaceae. From Latin, a "band" or "fillet". Ferns with simple linear fronds. About 5 species, tropical regions; 1 in U. S.

2110. VOUACAPOÚA, Aubl. 1775 (Vuacapua).Papilionaceae. Syn. Andira, Lam. 1783 (Kew); Geoffrra (Geoffroya), in part. Ornamental trees. About 25 species, mostly of Brazil.

a. V. Araróba (Aguiar) Lyons (A. Araroba Ag.). Brazil. Araroba or Arariba tree, Angelim Amargoso, Angelin amarzogo. The source of Goa powder, called also Bahia powder, Brazil powder, Ringworm powder; Pulvis goa, Po de Araroba, Po de Bahia; Ger. Goapulver, Bahiapulver. From this is prepared Chrysarobin, Chrysarobinum, U. S. P., antiseptic, discutient.

b. Y. inérmis (Swz.) Lyons (G. inermis Swz., A. inermis Kunth. ). West Indies. Jamaica Cabbage-tree, Partridge-wood. Bark, Yellow Cabbage-tree bark, properties of (c).

c. Y. retúsa (Poir.) Lyons (G. retusa Poir., A. retusa Kunth). Surinam and Cayenne. Surinam Cabbage-tree. Bark, Surinam bark, Brown Cabbage-tree bark, Bark of (b) and (c) is called Worm bark, Andira; Ger. Kohlbaumrinde, Wurmrinde; Fr. Écorce de geoffrée; emeto-cathartic, anthelmintic.

d. V. vermífuga $O$. Kze. (G. vermifuga St. Hil., A. vermifuga Mart., A. anthelmintica Benth. ). Brazil. Seeds of this and other species, as (e) V. Aublétii (Benth.) Lyons (A. Aubletii Benth.) and (f) V. spinulósa (Mart.) Lyons (A. spinulosa Mart. identitied with (d) by Index Kew.), Angelim seeds, Angelim dolce; anthelmintic.

2111. VOÝRIA, Aubl.

Voyria.

Gentianaceac. Herbs, parasitical on old tree-trunks. About 25 species, tropical America; 1 in U. S.

2112. WALISTEIINLA, Willd. Waldsteinia. Rosaceae. Named for Franz Adam von Waldstein, Wartenburg, German botanist, d. 1823. Herbs with aspect of Fragaria. Four known species, north temperate zone; 2 in U, S.

2113. WALTHÉRIA, L. Waltheria. Sterculiaceae. Named for Prof. Walther of Leipsic. Herbs or shrubs. About 30 species, tropical regions; 2 in U. S. (a) W. Indica L. (W. Americana Lindl.), is widely distributed in tropical countries, extending to southern U. S., and has been used medicinally; (b) W. glomeráta Presl. of tropical America, is called Matico* and Yerba del soldado; 'hemostatic.

2114. WÁREA, Nutt. (not Waria, L. ) Warea. Cruciferae. Annual herbs. Three species in southern U.S.

2115. WashINGTónIA, Raf. 1818. Sweet Cicely. Cmbelliferae. Named in honor of George Washington. Syn. Osmorrhiza, Raf. 1818, Myrrhis. Perennial herbs with aromatic, somewhat fleshy clustered roots. About 15 species, eastern Asia and America; 5 in U. S. 
a. W. Cláytoni (Michx.) Brit. (M. Claytoni Michx., O. brevistylis DC.). Canada to $\mathrm{N}$. Carolina and Nebraska. Woolly Sweet Cicely, Hairy Sweet Cicely, Sweet Chervil or Jarvil. See Myrrhis.

b. W. longístylis (Torr.) Brit. (M. longistylis Torr., O. longistylis DC:). Canada to Alabama and Texas. Smoother Sweet Cicely, Anise-root, Sweet Anise, Sweet Chervil or Jarvil, Cicelyroot. Root aromatic, carminative, stomachic.

2116. WEDÉLIA, Jacq. 1760. Niebuhria. Coimpositae. Named for Prof. G. W. Wedel of Jena, 17th Century. Syn. Niebuhria, Neck. 1790, not DC. 1824 (Kew) nor Scop. 1777. Herbs and undershrubs, mostly littoral. About 50 species, warmer regions of Old and New World; 1 in U. S. [Wedelia, Loefl. 1758 is a genus of Nyctaginaceae, in Index Kewensis united with Allionia, Loefl. 1758. Heller catalogues one species, and one also of the foregoing.]

2117. WhíPPLEA, Torr. Whipplea. Saxifragaceae. Suffrutescent plants. Two species, Pacific border of U. S.

2118. WHITNÉYA, Gray. Whitneya. Compositac. Named for Josiah D. Whitney of Cal. Geological Survey. Low perennial herb with aspect of Arnica. One species, California.

2119. WILlUGHBAÉA, Neck. 1790. Mikania. Compositae. Named for Francis Willoughby, English naturalist, d. 1672. Syn. Mikania, Willd. 1801; Eupatorium, in part. Herbaceous vines, some shrubs, with swall discoid Hower-heads. About 150 species, New World; 2 in U. S.

a. W. scándens (L.) Kze. (E. scandens L., M. scandens Willd.). Ontario and eastern U. S. Climbing Hemp-weed, Climbing Boneset.

2120. WISLIZÉxIA, Engelm. Wislizenia. Capparidaceae. Aunual herbs. Two species, Mexican border of U. S.

2121. WISSÁDULA, Medic. Wissadula. MaIvaceae. Hoary shrubs. About 8 species, tropical, all but one of New World; 2 in U. S.

2122. WITHÁXIA, Pauquy 1824 . Withania. Solanaceae. Syn. Physaloides, Moench 1794, not Physalodes, Boehm. 1760. Hoary or woolly shrubs. Four species, Mediterranean region and southern Asia.

a. W. coágulans Dun. India. Fruit used as a substitute for rennet in making cheese.

2123. WóLFFIA, Horkel. Wolffia, Duckmeat. Lemuaceac. Named for N. M. von Wolff; Polish naturalist, d. 1784 . Plant consisting of a minute floating thallus. About 12 species; 3 in U. S. The smallest of flowering plants, except the following. 
2124. WOLFFIÉLLA, Hegelm. Wolffiella. Lemnaceae. Latin, diminutive of "Wolffia. Syn. Wolffia, in part. Minute ffoating plants. About 7 species; 3 in U. S.

2125. WOÓDSIA, R.Br. Woodsia,Flower-cupFern.Polypodiaceae. Named for Joseph Woods, English botanist, d. 1864. Syn. Hypopeltis, in part. Small or medium-sized ferns. About 15 species; 7 in U. $\mathrm{S}$.

2126. WoodWá RDIA, J.E. Smith. Chain-fern. Polypodiaceae. Named for Thomas J. Woodward, English botanist, d. 1820. Robust ferns. Six species; 3 in U. S.

2127. WRÍGHTIA, R. Br. Wrightia. Apocynaceae. Named for Dr. William Wright, botanist of Jamaica. Syn. Nerium, in part. Shrubs or trees. About 12 species, tropical Asia, Africa and Australia. See Holarrhena. (a) W. tinctória R. Br. (N. tinctorium Roxb.). India. Palay. Ivorytree. One of the plants yielding indigo.

2128. W ULFÉNIA, Jacq. 1781. Wulfenia. Scrophulariaceae. Named for Rev. F. X. Wulfen, botanical author, d. 1804. Syn. Synthyris, Benth. 1846, also Gymnandra, in part. Herbs with dense spikes of pink or purple flowers. About 12 species, mostly of New World; 9 in U. S.

2129. WYÉTHIA, Nutt. Wyethia. Compositae. Named for Nathaniel J. Wyeth, American botanist. Stout low herbs with large heads of mostly yellow flowers. Twelve species, Pacific slope, U. S.

2130. XanThísma, DC. 1836 . Xanthisma. Compositae. From Greek, "dyed yellow". Syn. Centauridium, Tor. \& Gr. 1840. Annual or biennial herb with showy yellow flowers. One species, Texas.

2131. XÁNTHIUM, L. Clotbur, Cocklebur. Ambrosiaceae. Ancient Greek name of $X$. strumarium, the plants yielding a "yellow" dye. Coarse, rough or spiny monœecious annuals. About 5 species widely distributed; 4 in U. S. (only one indigenous).

a. X. spinósum L. S. America (?) now widely nat. in U. S. and in Old World. Spiny Clotbur, Thorny Clotbur or Cocklebur, Spring Clotbur, Thorny Clotweed or Bur-weed. Leaves antiperiodic, reputed a prophylatic against hydrophobia.

b. X. strumárium L. Europe and Asia, widely nat. in U. S. and elsewhere. Common or Broad Cocklebur, Bur-weed, Buttonbur, Bur Thistle, Small or Lesser Burdock*, Sea Burdock, Clotbur (Clote-bur), Ditch-bur, Dike-bur, Louse-bur, Sheep-bur; Ger. Spitzklette, Kropfklette; Fr. Lampourde, Petit glouteron. Plant antisyphilitic, alterative. Seeds yield a bland fixed oil. Similar to this is (c) X. Canadénse Mill., Canada to N. Carolina, Nevada and Mexico, American Cocklebur, Sea Cocklebur (Cucklebur), Hedge-hog Bur-weed, Canadian Bur. 
2132. XANTHOCÉPHALUM, Will.

Compositae.

From Greek, "yellow head". Syn. Gutierrezia, in part. Herbs, some shrubby, with small flower-heads (yellow). About 10 species, mostly of Mexico; 3 in southern U.S.

2133. XANTHORRHóEA, Smith. Black-boy tree. Liliaceae. From Greek, "yellow exudate". Robust plants, somewhat resembling Yucca, with the small flowers in a dense cylindrical spike. About 12 species, Australia.

a. X. arbórea $\mathrm{R}$. Br. Australia. Black-boy tree. Resinous exudate, Black-boy gum, red, like dragon's blood.

b. X. hastilis R. Br. Australia, Grass Gum-tree, Grass-tree, Yellow-gum tree. Fragrant yellow resinous exudate, Botany-bay resin, Acaroid resin or gum, antispasmodic, carminative.

2134. XANTHORRHíZA, L.Her.(Zanthorrhiza).Ranunculaceae. From Greek, "yellow root". Low shrubby perennial with yellow wood. One species, viz. (a) X. apiifólia L'Her. (X. simplicissima Marsh.). New York to Florida. Shrub Yellowroot, Parsley-leaved Yellowwort, Yellow-wood. Rhizome and root, bitter, tonic.

2135. XANTHOSÓMA, Schott. Blue Eddoes. Araceae. From Greek, yellow body". Herbs from a tuberous or thickened root-stock. About 20 species, tropical America; 1 in U.S. (a) X. sagittifólium Schott. West Indies to southern Florida. Tannier (Tanier), Blue or Nut Eddoes. Tubers farinaceous, esculent, resembling Taro.

2136 XaNTHÓXYLUM, L.1753. (Zanthoxylum). Rutaceae. From Greek, "yellow wood". Syn. Zanthoxylon, Walt., Fagara, L. 1759., Pterota, P. Br. 1756; Fagarastrum, in part. Trees or shrubs with odd-pinnate leaves. About 110 species, temperate and warm regions; 6 in U.S.

a. X. alátum Roxb, of India, and (b) X. piperítum DC. of Japan (Japanese Pepper), produce pungently arornatic fruits used as condiments.

c. X. Americánum Mill. (X. fraxineum Willd.). Canada, south to Virginia and Missouri. Prickly Ash, Northern Prickly Ash, Angelica-tree, Pellitory bark, Suter-berry, Toothachetree, Tonthache-bush, Yellow-wood; Ger. Zahnwehrinde, Zahnwehholz; Fr. Clavalier, Frêne epineux. Bark of this and of (e); Xanthoxylum, U. S. P., pungent, sialagogue, alterative, emmenagogue. Berries used to flavor beer, etc.

d. X. Capénse Harv. (Fagarastrum Capense G. Don). South Africa. Wild Cardamom. Fruit aromatic, carminative.

e. X. Cláva-Hérculis L. (X. Carolinianum Lam.). Southeastern U. S. Southern Prickly Ash, Sea Ash, Hercules'-club, YellowHercules, Pepper-wood, Wild Orange*, Yellow Prickly Ash, Yellow-wood, Prickly or West Indian Yellow-wood, German and French synonyms and properties of $(c)$. This plant has been popularly confounded with 170 (f) q. v. 
f. X. Fagara (I.) Sarg. (X. Pterota H. B. K., X. Pterotum St. Lag., P. Fayara Crantz). Tropical America to southern U. S. Bastard Ironwood, Wild Lime, Savin*. The South American (g) X. Narangílo Griseb. is said to be sudorific, sialagogue and diuretic, like Jaburandi.

2137. XEROPHÝLLUM, Michx. Turkey-beard. Melanthaceae. From Greek, "dry leaf"'. Tall perennial herbs with ample terminal racemes of white flowers. Three species, all of U. S.

2138. XIMÉNIA, L. Tallow-nut, etc.

Olacacene. Named for Francisco Ximenes, Spanish naturalist, 17th C'entury. Shrubs or trees. About 5 species, tropical regions; 1 in U. S.

a. X. Americána L. (X. inermis L., X. spinosa Salisb.). West Indies, Florida and Mexico. Tallow-nut, Wild Olive, called in Florida Hog Plum and Wild Lime, in West Indies Mountain or Seaside Plum, False Sandalwood, in Mexico Alvarillo del campo. Fruit edible. Flowers and wood fragrant.

2139. XOLÍSMA, Raf. 1819. Privet Andromeda. Ericaceae. Syn. Lyonia, Nutt. 1818, not Raf. 1808, nor Ell. 1817; Andromeda, Vaccinium, in part. Shrubs or small trees. About 10 species, N. America; 3 in U. S.

a. X. ligustrína (L.) Brit. (V. ligustrinum L., A. ligustrina Muhl., L. ligustrina DC. ). Canada and eastern U. S. Privet Andromeda, Lyon's Andromeda? , Seedy Buck-berry, White Alder, White-bush, White Pepper.

2140. XYLOPÍCRUM, P. Br. 1756. Bitter-wood. Anonaceae. From Greek, "bitter wood". Syn. Xylopia, L. 1759; Habzelia, Unona, Uvaria, in part. Trees or shrubs. About 35 species, tropical regions, mostly of New World.

a. X. Aethiópicum (Rich.) Lyons (Xylopia Aethiopica Rich., H. Aethiopica A. DC.). Western Africa. Fruit, African, Guinea or Negro Pepper, Piper aethiopicum of old writers. Several South American species also yield aromatic fruits used as condiments. (b) X. glábra L. is the Bitter-wood of the West Indies.

2141. XYLORRHÍZA, Nutt. Xylorrhiza. Compositae. From Greek, "wood root". Syn. Aster, in part. Herbs resembling Aster. Seven species in western U. S.

2142. XÝRIS, L. Yellow-eyed Grass, etc. Xyridaceae. Grtek name of a species of lris, "sharp". Scapose plants mostly with two-ranked equitant leaves and yellow flowers. A bout 40 species; 19 in U. S.

a. X. Caroliniána Walt. (X. Jupicai Michx., P. elata Chapm.). Atlantic and Gulf States. Carolina Yellow-eyed Grass. Leaves and roots used in cutaneous diseases, as are those of $(b) \mathbf{X}$. ndica L., in India; (c) X. Americána Aubl., in Guiana and the related (d) Abolboda Brasiliénsis Kunth (X. vaginata Spreng.), in Brazil. 
2143. YEATÉSIA, Gray. (Gatesia). Yeatesia. Acanthaceae. One species in western U. S.

2144. YÚCCA, L. Adam's-needle, etc.

Liliaceac. The vernacular name (San Domingo). Robust, even arborescent plants, the showy white flowers in an ample panicle. About 16 species, N. America; 15 in southern U. S. Leares of several species yield a fiber called dagger-fiber. The stems of some species are used by the Mexicans as a substitute for soap, called by them Amole.

a. Y. aloifólia L. Southeastern U. S. Spanish-dagger, Daggerplant, Spanish-bayonet, Adam's-needle-and-thread, Eve'sthread. Fruit succulent, edible, locally called banana.

b. Y. arboréscens (Torr.) Trelease. Mohave desert. A tree sometimes 40 feet high. Joshua tree. Seeds used for food by aborigines.

c. Y. baccáta Torr. Texas to California and Mexico. Spanishbayonet, Mexican Banana, Soap-plant. Fruit edible. Leaves yield Tambigo fiber.

d. Y. gloriósa L. (Y. integerrima Stokes). Southeastern U. S. Glorious Yucca冬, Dwarf Palmetto*, Mound Lily. Still more ornamental is (e) Y. macrocárpa Coville, Texas to New Mexico and Mexico.

f. Y. filamentósa L. Southeastern U. S. and cult. in gardens. Adam's-needle, Adam's-needle-and-thread, Eve's-thread, Threadand-needle, Eve's-darning-needle, Bear's-thread, Bear-grass, Silk-grass.

2145. ZÁ MIIA, L. Florida Arrow-root. Cycadaceae. From Latin, "fir cone". Plants with palm-like foliage and a short thick caudex, often wholly subterranean. About 30 species, tropical N. America; 2 in U. S.

a. Z. integrifólia Jacq. Florida and West Indies, called in Florida Coontee (Coontie, Koontee), in Jamaica Wild Sago. Starch from the tuber-like caudex, Florida Arrowroot. A similar product is obtained in the West Indies from other species.

2146. ZANNICHÉLLIA, L. Zannichellia. Naidaceae. Named for J. H. Zannichelli, Italian botanist, d. 1729 . Obscure water-weeds. About 3 species, widely distributed; 1 in U. S.

2147. ZANTEDÉSCHIA, Spreng. 1826, not Koch 1854. Araceae. Named for Francesco Zantedeschi, Italian botanist, 19th Century. Syn. Richardia, Kunth. not L.; Calla, in part. Marsh herbs from thickened rhizomes. About 5 species, southern Africa.

a. Z. Aethiópica (L.) Spreng. (C. Aethiopica L., R. Africana Kunth (Kew), C. ambigua Salisb.). South Africa, cult. as a house plant. Calla, Calla Lilyt, Trumpet Lily, African Lily, Ethiopian Lily, Lily-of-the-Nile. Plant acrid, like Indian Turnip. 
2148. ZÉA, L. Maize, Indian Corn. Greek name of a grain used for fodder. One species, New World (U. S.)

Gramineae.

A robust grass.

a. Z. Máys L. Probably originated in S. America, now universally cult. Maize, Indian Corn, Mealies (Australia, S. Africa), Guinea Wheat\|, Turkey Corn*, Turkey Wheat\|; Ger. Mais; Fr. Mais. The numerous varieties are arranged by Dr. Sturtevant under six sub-species, viz: 1 Z. tunicáta, Pod Corns, in which each kernel is enclosed in an individual husk; 2 . Z. erérta, Pop Corns, including 25 varieties; 3 . Z. induráta, Flint Corns, 69 varieties; 4. Z. indentáta, Dent Corns, 323 varieties; 5. Z. amylácea, Soft Corns, 27 varieties and 6 . Z. Zacearáta, Sweet Corns, with shriveled kernels, 63 varieties. Styles and stigmas Corn-silk; Zea, U. S. P., Stigmata mayidis; Ger. Maispistille; Fr. Filament de mais, diuretic. Unripe grain, source of Corn Starch, Amylum mayidis. Ripe grain supplies food for man and animals. Stalks used as fodder and formerly as a source of sugar.

2149. ZENóBIA, D. Don. Zenobia. Syn. Andromeda, in part. Two species in U. S.

2150. ZEPHYRÁNTHES, Herb. Swamp Lily. Amaryllidaceae. From Greek, "wind flower". Syn. Amaryllis, Atamasco, Habranthus, in part. Lily-lıke bulbous plants with one-flowered scapes. About 30 species, New World; 5 in U. S.

a. Z. Atamásco (L.) Herb. (Am. Atamasco L., At. Atamasco Greene). Southeastern U. S. Atamasco Lily, Daffodil Lily, Easter Lily*, Fairy Lily, Swamp Lily, Stagger-grass.

2151. ZEXMÉvIA, Llave \& Lex. Zexmenia. Compositae. Transliteration of Ximenesia (Ximenezia). Shrubs. About 35 species, mostly Mexican; 3 in U. S. (Mexican border).

2152. ZÍN(IIBER, Adans. (Zinziber). Ginger. Zingiberaceae. Latin, from ancient Greek name. Syn. Amomum, Cassumunar, in part. Canna-like plants from tuberous rootstocks. About 25 species, India to Oceanica.

a. Z. Cassumúnar Roxb. (C. Roxburghii Colla). India. Souroe of Cassumunar Ginger or Bengal root.

b. Z. Zíngiber (L.) Rusby. (Z. officinale Rosc. (Kew), A. Zingiber L.). Tropical Asia, now cult. in all tropical countries. Ginger plant. Rhizome, Giiger; Zingıber, U. S. P., Br., Rhizoma Zingiberis, P. G.; Ger. Ingwer, Ingber; Fr. Gingembre (Codex); Sp. Zengibre. Commercial varieties are Jamaica and African ginger, black or "coated" and white or "scraped" ginger. The branched rhizomes are known as "hands" or "races". Stimulant, carminative, anodyne, derivative; largely used as a condiment. Young rhizomes used for preserves in China and West Indies.

c. Z. Zerúmbet (L.) Roscoe (A. Zerumbet L.). Java. Source of Zerumbet root. 
2153. ZIZÁNIA, L. Indian Rice, Wild Rice. Gramineae. Ancient Greek name of Darnel. An aquatic grass. One species, N. America (U. S.). (a) Z. aquática L. Canada and eastern U. S. Wild Rice, Indian Rice, Canada Rice, water Rice, Water Oats, Reed. Seeds a favorite food of water-fowl, formerly collected for food by Indians.

2154. ZÍZIA, Koch. Zizia, Alexanders, etc. Umbelliferae. Named for I. B. Ziz, Rhenish botanist. Syn. Smyrnium, Thaspium, in part. Perennial herbs with yellow flowers. Three species, all of U. S.

a. Z. aúrea (L.) Koch (S. aureum L., T. aureum var. apterum Gray). Canada and eastern U. S., west to Dakota. Early or Golden Meadow-parsnip, Golden Alexanders, Wild Parsley.

2155. ZÍZYPHUS, L. Jujube, Lotus-tree. Rhamnaceae. The ancient Greek name of (c). Syn. Jujuba, Burm. Thorny shrubs or trees. About 65 species, mostly of tropical Asia and America; 3 in U. S.

a. Z. Jujúba Lam. China to Australia and tropical Africa. Chinese Date. Fruit esculent. Leares food for the Tussa silkworm.

b. Z. Lótus Lam. Mediterranean region. Lotus-tree, Lote-tree, Lote-bush. Fruit, Italian Jujubes; esculent, but inferior to that of (c); believed by some to be the food of the Lotophagi.

c. Z. satíva Gaertn. (Z. vulgaris Lam.). Mediterranean region Jujube tree; Ger. Judendorn; Fr. Jujubier (Codex). Fruit, French Jujubes, Fructus v. Baceæ jujubæ, Jujubæ gallicæ v. magnæ; Ger. Jujuben, Brustbeeren; Sp. Azufaylas; esculent, demulcent, used in coughs. Other species also yield edible fruits as (d) Z. Joazeíro Mart. and (e) Z. Místal Griseb., of S. America; (f) Z. rugósa Lam., of India and (g) Z. Sinénsis? Lam., of China and Japan.

b. Z. Spina-Chrísti Willd. (Z. Africana Mill.). Northern Africa and southwest Asia. Christ's Thorn, Nebbuk tree. A hedge plant. Possibly the thorn from which our Savior's "crown". was plaited. See Paliurus.

21ə6. ZONÁNTHEMIS, Greene. Zonanthemis. Compositae. Syn. Hemizonia, in part. Two species in U. S.

2157. ZóRNIA, Gmel.

Zornia.

Papilionaceae. Named for Johann Zorn, German apothecary. Herbs with digitately bifoliate or quadrifoliate leaves. About 12 species, New World; 1 in U. S.

2158. ZOSTÉRA, L.

Eel-grass, etc.

Naidaceae. From Greek, girdle, alluding to the ribbon-like leaves. Syn. Alga, in part. Marine herbs with grass-like leaves. About 6 species, widely distributed; 3 in U. S. 
a. Z. marína L. (A. marina Lam., Z. maritima Gaertn.). Coasts of Europe, Asia and N. America. Eel-grass, Grass-weed, Grass-wrack, Sea-grass, Sea-wrack* Barnacle-grass, Bellware, Sweet-grass, Tiresome-weed, Turtle-grass, Widgeon-grass, Wrack-grass. The dried plant, Sea-hay, Sea Sedge, Alva marina, used as bedding for horses, etc.

2159. ZYGADÉNUS, Michx. Soap-plant, etc. Melanthaceae. From Greek, "yoke gland". Syn. Amianthium, Melanthium, in part. Perennial herbs, the numerous white or whitish flowers in a terminal panicle. About 10 species, one in Siberia, the rest in $\mathrm{N}$. America; 9 in U. S.

a. Z. élegans Pursh (Z. glaucus Nutt.). British America, south to New York and N. Mexico. Glaucous Zygadenus?, called also Alkali-grass; (b) Z. Fremónti Torr, California, is called Soap-plant.

c. Z. reuenósus S. Wats. British Columbia to S. Dakota and California. Poisonous Zygadenus?, Death Camass, Hog Potato.

2160. ZYGOPHÝLLUM, Bean Caper, etc. Zygophyllaceae. From Greek, "yoke leaf". Low shrubs, often spinescent. About 60 species, Old World and Australia. (a) Z. Fabágo L. Levant. Bean Caper. Flower buds used as capers.

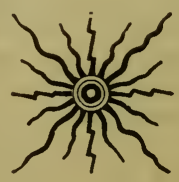




\section{NATIONAL FLOWERS.}

Athens..................... Violet.

Canada.................. Sugar Maple.

Egypt................... Lotus.

England.................. Rose.

France................... Fleur de lis.

Germany.................... Corn-flower.

Ireland.................... Shamrock.

Italy $\ldots \ldots \ldots \ldots \ldots \ldots \ldots$. Lily.

Prussia.................... Linden.

Saxony...................Mignonette.

Scotland................ Thistle.

Spain....................Pomegranate.

Wales.................... Leek.

For the United States Golden-rod is proposed, although some favor the Trailing Arbutus.

\section{STATE FLOWERS.}

California.................. Eschscholtzia.

Colorado................... Columbine.

Delaware.. ................Peach Rose.

Hawaiian Islands............ Ilima.

Maine.................. Pine (cone and tassel).

Michigan.................. Apple-blossom.

Montana.................. Bitter-root.

Minnesota................... Cypripedium.

Nebraska.................Golden-rod.

Nevada.................. Sunflower.

New York................. Rose.

N. Dakota................ Golden-rod.

Oklahoma Ter................ Mistletoe.

Rhode Island.............. Violet.

Utah..................... Sego Lily.

Vermont...................Red Clover.

Washington................Rhododendron. 


\section{ERRATA AND ADDENDA.}

\section{(NUMBERS REFER TO PARAGRAPH, NOT TO PAGE.)}

2. a. Insert synonym Mast tree.

2. f. For A. Picea (L.) Lyons, read A. Picea (L.) Lind.

45. For Cichoreaceae, read Cichoriaceae.

75. Insert, see Wedelia.

81. For Alophila, read Alophia (bis) and insert, From Greek, "without crest".

82. a. For A. Galangal, read A. Galanga.

34. a. For Balantium, read Dicksonia.

101. b. For A. Cardamomum I., read A. Cardamom L. (A. Cardamomum Koen., not White.)

223. a. For New Zeland, read New Zealand.

263. f. For Bar-marigold, read Bur Marigold.

321. a. Insert as synonym C. floripendia Comm., probably an older name.

330. a. For B. gummifera L., read B. Simaruba (L.) Sarg. (Pistacia Simaruba L.).

374. c. Read 374. d

414. b. Read C. ficifolia (Lam.) Cogn. (B. ficifolia Lam.). Insert also, See Trianosperma.

500. d., also 500 g. Read Properties of (a).

534. a. line 2. Omit the second "Autumn"

565. a. Read C. Langsdorffii.

629. a. For H. Cymbalaria, read A. Cymbalaria.

712. d. Read Fr. Fougère mâle.

713. d. Read Whitewood.

802. k. Strike out Spotted Eyebright as synonym.

918. a. line 3. Read dyspnoea.

1140. Strike out Orobus as synonym.

1723. e. Read 1723. c.

2001. b. Read T. utriculata.

2063. After notably, read (b) instead of (a). 


\section{GENERAL INDEX.}

\section{NUMBERS REFER TO PARAGRAPH, NOT TO PAGE.}

Botanical names must be looked for in their alphabetical place in the body of the work. If not found there, look in the index for the genus name which will be marked with an Asterisk (*) and see whether the name does not occur elsewhere as a synonym. Thus failing to find Atropa physalodes L. under Atropa, No. 219, look for Atropa in the index, where there will be found references to 1274 and 1579. Under the latter you will find the name sought given as a synonym of Physalodes physalodes (L.) Brit., known popularly as Apple of Peru or Peruvian Bluebell.

Where the common name consists of a noun and adjective look always for the noun, if that is properly a plant name, as Lily or Rose. Otherwise you will find the name treated as a compound word, e. g. Meadow-sweet, Old-man, to be looked for in their alphabetical place in the index.

Remember in this connection that all such names as Calisaya bark, Spruce gum, Persian berries are treated as compound words; do not look for Bark, Gum, Berries, but for Calisaya, Spruce, Persian.

Where the same popular name is applied to several species, that which it most commonly designates is placed first, and where the application of the name is unusual, the fact is indicated by affixing to the reference a dagger $(t)$.

In the case of common genera such as Oak, Maple, Ash, a general reference only is given to the genus in question, under which the species sought can then be readily found. Thus, to find Sugar Maple, look for Maple (species). The reference is to 16, under which you will find that the name is applied especially to Acer Saccharum Marsh., but also to A. Negundo L. and to A. nigrum Michx., the last distinguished, however, as Black Sugar Maple. If you fail to find a name in the index, turn always to the body of the work, and see whether the name is not given there in its alphabetical place as a genus name.

German, French and Latin names are to be looked for in the index, the noun usually standing first. Pharmacopoeial names are not given in the index when they coincide with the botanical 
(generic) name, as there will be no difficulty in finding them. The aim has been to include in the index all that is necessary to its practical completeness, without extending it to inordinate proportions.

* Generic name used as a synonym.

$\dagger$ Name more properly applied to some other plant, or else a misnomer.

Names in Italics are synonyms not included in the body of the work. Names in small capitals are English equivalents of generic names.

Aarou (Aron) 189 , a

Aaron's-beard 583. b, 629. a, 1792. a

Aaron's-rod 1824, c, 1869. b, 2090. b

Abaca (Abaka) 1367. e

Abdalavi 613 , a

*Abies 419, 1138, 1587, 2046

A bele (Abel, Abbey) 1652. a

*Abelmoschus 1603. a, c

*Abeua 2079

* Aberia 701

Abilla 829, under ia)

A bo (Aboli) 1133. a

Abolboda 2142. d

Atraham's-balm 2107, a

Abrahamstrauch 210\%. a

Abricotier 1668. c

Abro sol 963. a

Abrotanum 187. a

Abscess-root 1634. c

Absinthe, grande 187. b

Absinthe petite 187. 0

*Absinthium 187.

Absinthium Alpinum 187. h

Absinthium, U. S. P. 187. b

Abutua 475. a

Absus 396. a

Acacia 7, 64, 1664

Acacia, Bastard 1738. a

Acacia, False 1738. a

Acacia, Ruse 1738. b, c

Acacia, Three-thorned 895 . b

Acacia U. S. P. $\%$. k, etc.

Acajou à pommes 114. a

Acajou-riut 1829 . a

Acanthe fausse 982 . b

Acantho-mastich 215. a

Acaroid resin 2133. b.

Acazie, Falsche 1738 . a

*Acerates 120,908

*Acetosa 1480, 1758

*Acetosella 1753

Ach-root 1359. a

Ache 158. a, b

tAche 1711. k

Ache céleri 158. a

Ache des chiens 51. a

Ache des montagnes 1190, a

Achiras 369. a

*Achyranthes 508

+Achyranthes 86

*Ach yropanpus 1803

*Achras 682

*Achras 1228, 1334

Ackelei 166. b

Ackersalat 2078. a

Ackerspergel 1884. a

*Acmella 1893

Aconit féroce 25. e

Aconit Napel 25. i

Aconite 25 . esp. i

Aconite, Winter 759. a
Aconitum U. S. P. 25. i

Acore odorant, ou rrai 26. a

Acorn 1704. q

Acorn, Duck 1391. a

*Acrocomia 529 . a

*Aırostichum 712

* Actaea 497

Actaea radix 497. a

Actée à grappes 497 . a

*Actinella 1589

*Actinocarpus 643

*Actinomeris 2092

Acupa 1029. a

Adam-and-Eve 159. a

Adam's-flannel 2090. b

Adam's-ueedle 2144. f

Adam's-needle-and-thread 2144. $\mathrm{a}, \mathrm{f}$

Adam's-needles 1796. a

Adder's-grass 1445

Adder's-leaf 785. b

Adder's-meat 83. b, 1956. a

Adder's-luouth 21

Adder's-root 189. a

Adder's-spear 1445

Adder's-tongue $785,1+45$

†Adder's-tongue 1762 1814. a

Adder's-wort 731. a, 1641. e

Adiantum aureum 1649. a

*Adnaria 873

Adonis-flower $44, \mathrm{~b}$

*Adorium 1370

Adrue 635. a

*derobion 136

Aeschenwurzel 673. a

*Aeschrion 1590

*Aethulia 1812

Affenbrod 32 . a

Affudil 1385. a

Afterbirth-weed 1928. a

Afternoon-ladies 1335. a

Agalloclia 813. a

*Agallochum 165

Agal-wood 165. a

Agar-agar $793,877,1889$. b

Agaric blanc officinal 1644. d

Agaric, Bug or Fly 90 . a

Agaric, Larch 16+4. d

Agaric, Male 1644. d.

Agaric, mouche 90 . a

Agaric, Oak 1644. a

Agaric, Purging 1644. d

Agaric, Surgeon's 1644. a

Agaric, White 1644. d

*Agaricus 90, 1278

*A gassizia 855,865

*Agathotes 1933

*A gati 1838

Agave, Virginian 56. d

Ageratum 57. a

Aggur 165. a

Agnus scythicus 492. a

Agouman 1585 . b
AGRIMOXY 59

Agrimony, Bastard 802 . c

Agrimony, Durch 802 . c

Agrimony, Hemp 802. c.

Agrimony, Water 263. f, i, 802. c

†Agrimony, Wild 1658. a

Agriot 1668. $g$

Agripaume 1165. a

*Agrostemma 1236

Agstein 1600. a

Ague bark 1681.a

Ague-grass 68. a

Ague-root 68. a

Ague-tree 1788. a

Ague-weed 802. i, 882. f

Ahuaca 1546. c

Aigrimoine 59. a

Ail 76. $e$

Ailantus 62

Aipi 1276.

Air-plant 321. a

Airelle myrtille 2075. a

Airif 863

Aise-weed 48. a

Ait-skeiters 135 . a

Aiten (Aitnach) 1099. b

Aits 221. a

Ajava 1690 . a

Ajenjos 187. b

djouc 2056 . a

Ajowan (Ajouan) 1690 . a

Ajuapar 1029. a

Ak 354 a

Akazga 1923. h

* Akea (Akeesia) 272

Akee tree $2 \tau 2$. a

Al tree 1359. a

Alamo (Texas) 1652 . c

Alant 1062. a

*Alaternus 1721. a

Alcanna (Alkhanna) 1148. a

*Alcea 87

Alcea aegyptiaca 1003. a

Alchemille 65 . b

Alcornoco 296. a

Alcornoque 66. a, 296. a,334.a

Alcornoque, Europeau 1704.s

*Aldama 1811

Aldbecre 1732. e

ArDER (Aller) 79

Alder, Berry 1721. g

Alder, Black 1053. h

+Alder, Black 1721. g, 2095.k

Alder, Dwarf 840. a, 1721. c

Alder, False 1053. hi

Alder, Spiked 518. a

Flder, Spotted 944. a

Alder, Striped 1053. h

†Alder, Striped 944. a

Alder Tag. 79. b

+Alder, Tag 261. h

Alder, White 2139. a, 1053. h 
Alder, Wild 48, a

Alder, Witch 840 . a

Alderne 1771. e

Alecost (A lecoast) $48 \%$

Alehoof 894 . a

Alerce 349 . a

Alerse 1192. a

Alétris farineux 68 . a

*Aleurites 606

Alexander, Stinking 1831. f

Alexander's-foot 115 , b

Alexanders 1866. a

Alexanders, Golden 1979. a, 2154. a

Alexanders, Purple 1979. a

Alfalfa 1291, d

Alfilaria 777. a

* Alga 2158

Algaroba 1664. a

*Algarobia 1664

Algarobilla bark 1664 . b

†A]garroba 1036 . a

Algarroba de Valencia 432. a

Aligopane (Alicompane) 1162. a

Alisander(Alshinder )1866, a

Alisier 1875. c

*Alisma 727, 1762

Alison, White 167, a

Alk 1605. e

Alkali-grass 2159. a

ALKANET 124

Alkauet, American 1214 b

Alkanet, Bastard 1214. a

Alkanet, Dyer's 73. a

Alkanna (spuria) 73. a

Alkannawurzel 73. a

AlkCkenge coqueret 1578. a

*Alkekengi 1578

All-bone 83 . b

All-good 464, d

All-heal 1328. b, 2077. c

All-heal, Clown's 1900 \&

All-seed 1637. a, 1641. d

Alleghany-fringe (vine) 42. $a$

Alleluia 881. a, 1475. a

Allermannsharnisch 76 . i, 891. b

Allerman's-root 76 . i.

Alliaire commune 74 . a

Allicampane 1062. a

Alligator-Apple 140. c

Alligator-bonnets 1420 e

Alligator-tree 1210 . b

*Allionia 2116

Allison, Sweet 1112. 2

*Allium 1366

Allium, U. S. P. 76. e

Allolida 1475. a

Allom (Alme, Aum) 2058. d

Allspice 1594. b

Allspice, Carolina 332. b

†Allspice, Florida 332. b

Allspice, Wild 250. a

*Almond 111. a

Almond, Earth 635. b

Almond, Country 322 . c

Almond, Cutting 1513. b

Almond, Ground 645. b

Almond, Java 365 . a

Almond, Malabar 322 . c

Almond, Wild 298. a

Almug 1776. a

Aloe, American 56. a

Aloe Barbadense 80. in

Aloe Capeuse 80.b
Aloe, False 56, esp. d

Aloe Sucotrin 80. j

Aloe-root 68. a

Aloe-wood 165. a

Aloks, varieties 80

Aloès du Cap, etc. 80 . b, etc

Aloes, of Seripture 165. a

*Aloexylum 165

Alophia (not Alophila) 81

* Aloysia 1209

Alpenrose, Sibirische 1728. b

Alphabet-plant 1893. b

*Alpinia 742

Alpist 1559. b

Aıraunwirzel 1274. a

Alsei 187.

*Alsidium 1889

Alsike 2032. h

Alstonia bark 85 . \&

Althaea, Shrubby 100:3. I

Althée 87. a

Alum-bloon1 883. a

Alum-root 1000, 883. a

Aluyne 187 . b

Alva marina 2158. a

Alvarillo del campo 21:38. a

Alveloz milk 803. $\theta$

* Alyssum 1112

Alyssum, Sweet 1112, a

Alyssum, Yellow 89. a

Amadou 1644. d

Anıandes amères 111. a

Amandes de terre 635. b

Amandes douces 111. a

Amandier 111. a

Amara-dulcis 1867. j

Amaraci herba 1456. c

Amaranth 91

* Amaranthus 24

* A maryllis 2150

Ambaree 1003. b

Amber 1043. b, 1210. h

Amber (Ambra) 1600. a

Amberkraut 1973. c

Ainber-seed 1003. \&

*Amblogyne 91

Ambra liquida 1210. b.

Ambre jaune 1600 . a

Ambretie (Ambretta) 1003. a

Ambroise de Mexique 464 . b

*Ambrosia 854

Ambrosia 464. b

Ambrose 464. e

Ambrose (Ambroise) 197\%. f

*Amellus 488, 770

American-joy 1514. a

*Amianthium 479, 215!

*Ammannia 1745

*Ammi 1686, 1690

Ammi officinal 1690. a

*Ammobium 968. d

Ammoniac, African 828. i

Ammoniac plant 697 . a

Ammoniak-gummi 697. a

Amogeton 164

Amole 471. a, 2144. c, etc

Amome en grappes 101. b

Amomi semen (fructus) $1594, \mathrm{~b}$

*Amomis 1594

*Amomum $619,742,2152$

*Ampelopsis 1514

*Ampelosy cios 106

* Amphicarpa 82:3

Amy-root 160. b

Amygdala 111. a

Amylum Manihot 1276. b
Amylum marantae 1277. a

*Amyris 550, 1042, 1666

Anucahuita 2085. b

*Anacalais 1818

Anacardien, Westindische 114. a

*Anacardium 1829

*Anacharis 1566

Ananas 119. a

* Ananassa 119

*Anantherix 196

Anagua 734

* Anchusa 73

Anchusa, American 1214. b

*Ancistrocarphus 1926

*Ancistruin 8

Anda (Andicus) 1095

Anda Assu 1095. a

* Andira 827, 2110

Andira (bark) 2110. b, c

Andiroba tree 378. a

Andorn, Schwarzer 230. a

Andorn, Weisser 1281. a

Andornkraut 1281. a

*Andromeda 397, 454, 1189, $1477,1576,1592,2139$ 2149

Andromeda, Lyons' 2139. a

Andromeda, Privet 2139. a

*Andropogon 1876

*Androsaemum 1043

Andurion 802. c

*Anelasma 5

ANEMONE, species 133

*Anemone 981, 1693, 1940

Anemone des bois 133. g

Anemone, Meadow-rue 1940. a

Anemone, Prairie 1693. a

Anemone pulsatille 1693 . b

Anemone sylvie 133. g.

* Anemonella 1940

*Anemonopsis 1023

*Anemopsis 1023

Anet 134. a

Anethi fructus 134 a

* Anethum 839

Anethum ursinum 1323. a

Anette 134. a

Aneys (Anny) 1595. a

ANGELICA, species 135

*Angelica 530, 828

Angelica, Sweet 1378, a

Angelica tree 170 . f, 2136. c

Angelico 1193. a

Angélique officinale 135. a

Angelim amargoso 2110. a

Angelim dolce 2110. d, e, f

Angelim seeds 2110. d, e, f

Angelin amarzogo 2110 . a

Angel's-eyes 1022. a, 2094. d

Angleberry 1141. d

Angle-pod 2101

Angola-weed 1739. b

*Angostura 621

Angostura, Brazilian 789. a

Angostura, False 1923.d

Angustura 621. a

Angusture vraie 621 . a

*Anhalonium 1224

Anil 1059. a

Anime, Gum 2086. a

Anis (Anis vert) 1595. a

Anis 6́toile 1055. d

Anis, Indischer 1055. d

+Anise 1112. \&

Anise, Chinese 1055. d 
Anice, Common 1595. a Anise, of Scripture 134. a Anise, Pickaway 1681. a Anise, Sacred 1053. c

Anise, Star 1055

Anise, Sweet 2115. b

Anise-root 539 a, 2115. b

Anise-tree 1055

Aniseed $15+5$. a

Anisi fructus (semen) 15y5. a

*Anisocarpus 1259

Anissamen 1595. a

*Anisun 1595

Anisum stellatum 1055. d

Ankerwurzel 73. a

Annatto (Anuota) 266. a

*Anneslia 34

Annyle 15 15. a

*Anona (Annona) 198, 1352

*Anoplanthus 1974

Ansérine 1658. a

Ansérime puante 464 . i

Ansérine sauvage 464, a

Ansérine vermiluge 464.c

*Antennaria 121, 1164

*Authemis 115. b

Anthos, folia 1744. a

Anthophylli 7y6. a

*Anthrostylidium 232 i

Anti-gopher plant 813 . $g$

Antimony, Vegetable 812 , i

Antirrhiui herba 1205. a

*Antirs hinum 62f, 740, 1205. 1287

Antiscorbuticus cortex 706. a

Ant's-wood 1819. c

Ant's-wood 326

*Anychia 1506

Anzeroot 15:30. a

Apalachenthee 1053. k

Apalachinis folia 1053 . k

* Apargia 1163

* Aphalus 268

*Aphanes 65 . a

*Aphora $6+2$

*Aphyllon 1459, 1974

Apii fructus 158. a

Apii hortensis semen 1552.a

Apio silvestro 158. a

Apiol 15x. b

*Apium 156, 1552. 1886

Apium hortense $15 \%$. b

*Aplopappus $10,48 i, 489,766$, 7 i0, 957, 1074, 1076, 125\%, $14+3,1661,1697,1911$

*Aplotaxis 1:91

APPLE, species 1269

Apple, Adam's 130́\%. b, 194i. b

Apple, Balsam 13 17. a

Apple, Beef 1819 . d

Apple, Bitter 505. b

Apple, Buffalo 208. b

Apple, Bull 1849. d

Apple, Carthagenian 1694. a

Apple, Chess 1875. c

Apule, Devil's 1:74. a, 1625. a

Apple, Earth 968. b

Apple, Egg. 18.77. k

Apple, Elephant 826 . a

Apple, Garnet 1644. a

Apple. Golden 47. a, 1898. b

Apple, Hen 1875. c

Apple, Hog 1625 . a

Apple, Honeysuckle 225. a
Apple, Indian 1625. a

Apple, Jews 1867. k

Apple, Kei (Kai) 701. a

Apple, Love 1239. a

Apple, Mad 1867. k

Apple, Malay 1086. b

Apple, Mammee 1273. a

Apple, Mandrake, 3274. a

Apple, Marmalade 1228. a

Apple, May 2.5. a, 1625. a

Apple, Monkey 523 a

Apple, Mountain 108i. b

Apple, Osage 2011. a

Apple, Paradise 123y. a

Apple, Prairie 208. 0, 16r9. b

Apple, Punic $16+t$. a

Apple, Rose 108i. a

Apple, Seven-year $\div 80$. b

Apple, Sorb 18\%5. e

Apple, Swamp 22 i. a

Apple, Tahiti 1898. a

Apple, Thorn 59:2. $\mathrm{g}$

Apple, Vegetable 613. a

Apple, Vi 18:8. a

Apple, Vine 614 . b

Apple. White 15i. a

Apple, Wild $1+74$

Apple, Wood 826. a

Apple-of-Cain 17\%. b

Apple-of-Peru 619. b, c, 1579. a

Apple-of-Sodom 1867. a, i

Apple-pie 187 8, 755. a

Apple-rienuie 18\%. a, 1285. a

Apple-root 8us. a

Apples of Hesperides 628. a

Apogetion 1 it

*Apogon 1835

April-fuol 16!3. a

Apricose 1668. c

Apricot 1ti68. c, d

Apricot, South American 1273 , a

Apyum 1552. a

Aquacata +546 . c

Ar-nut 559. a

Ar-nut, Swine 1900. a

*Arabis $37 \% 4,1860,1908$

Arabisches Gummi 7. k, ete

Arach (Areche) 218. f

*Aralia $1+93$

Aralie à tige nue $1.0 \mathrm{c}$

Aralie, dornige 1\%0. f

Aralie' épiueuse 170. f

Aralie, nackte 170. c

Arar tree 34:. a

Ararafrüchte 1095. a

Araroba (Arariba) 2110, a

Araucaria 171

Arbell 1652. a

Arbol de hierro 1433. a

Arbol de léche 315 . b

Arbor vitae 1992 . b

Arbousier 172. b

Arbre à pain 385. a

Arbre à suif $1375 \mathrm{~b}$

Arbre de Judée 436 . b

Arbre de vie 1992. b

Arbute tree 172. b

*Arbutus 1263

Arbutas, Trailing 754. a

* Arceuthobium 1215

Archangel 135. a

Archangel, Black 230. a

Archangel, Green 1242. b, c

Archangel, Red 1132. c

Archangel, Sweet 1132. c
A rchangel. White 1132. a

*Archangelica 135, 530

*Archeniora 1479

Archil 1150. b, 1739. a. b

*Arctiodracon 124i

Arctostaphyli folia 176. b

*Ar ctostaphy los $12 j 3$

*Arctous 1263

* Ardisia 1051

Areca-nut Palm 17\%. a

*Areca 1454

Arekanuss 177. a

*Arenaria 99, 1340, 2005

Arenaria rubra 2005. a

Areng Palm 178. a

*Arethusa 1630

Argans 145 \%. d

Argentill 65. a

Argentina (Argentine) 1658. $a, b$

Arghel (Argel) 1858. a

*A rgorothamnia 692

*Aria 1875

Arillus myristicae 1377 . b

* Aristolochia 5. a

Aristolochia cara 372 . c

Aristolochia fabacea $37 \%$. c

Aristolochia poly rrhiza 182.c

Aristolochia solida 372 . a

*Armeniaca 1668. c

*Armeria 1903

Armoise 187. 8

*Arinoracia 1742

Armstrong 1641. d

Arnberry 1750. b

tArnica 19 i9. a

Arnica-bud 1163. a

Arnicae flores, etc 18.3. a

Arnika 18.3. a

Arnique 183. a

Arnouta 266. a

Aro 181 . b

*Aromia 9 t

Aron 18\%. a

Aron, dreiblättriger 181. b

*Aronia 96

Aronstab (Aronwurz) 189. a

Aronswurz, Indianische 181. b

Arpent-weed 1824. c

Arroche 218. f

Arrow-beam 801.c

Arrow-grass 2033

Arrow-head 1762

Arrow-wood 1721. g, 2095.1, k

Arrow-wood, Indian 576. $\mathrm{f}$, $8111 . \mathrm{b}$

Arrow-wood, Maple-leaved 2095. h

Arrowroot 194\%. a

Arrow root, Brazilian 1276. b

Arrowroot, Burmuda 1277. a

Arrow root, Canna 369. a, b

Arrowioot, Chinese 1391. b

Arrowroot, East Iudian 619. a

Arrowroot, Florida 21 15. a

Arrowroot, Portland 189. a

Arsenic, Wild 406. a, 1041. 1

Arse-smart 1041. 1, o

Arsmart, Codded 1057. c

*Artanthe $1 * 2$

Artemisa 187. 8

*Artemisia 802

Artemisiae herba 187.s

Arthanite 625. a 
Arthritica radix 1660, d

Artichoke, Bur 631. b

Artichoke, Jer usalem 968. b

Arum 189, a

*Arum 181, 541, 1528

Arum, Arrow 1528

Arum (indicum) 181. b

Arum, spotted 18!. a

Arum, Three-leaved 181. b

Arum, Water $\mathbf{3 4 5}$

Arundinaria 232. j, k

Asa dulcis 1929. a, 1y78. b

Asa Graya 1 t:

Asafetida 828, a, b, f

Asafoetida U.'S'P. 828 . b

Assai Pulm 808, a

Asarabacea 194. esp. f

Asaret 19t. a

Asaı um U. S. P. 194. a

Asclépiade 195, 630. b

Asclepiadis radix 630 . b

*Asclepias 17, 196, 354, 630 , $92+, 977,1626,2054$

Asclepias, U. S P. 195. d

AsH, species 815

Ash. Biiter 1590. a

tAsh, Bitte1 801. b

†Ash, Black 16. b

Ash, Blue 1445. a

Ash, Flowering 469, a

Ash, Ground 4x. a, 135. a, c

Ash, Hoop 4:2. a

Ash, Maple 16. b

Ash, Mountain 1875. a, d

Ash, Muuntain of Australia 790 a, u, bb

Ash, Poison 17:30.p

*Ash, Poison 469. a

*Ash, Prickly Southern 170. f

Ash, Prickly, species 2136

Ash, Rim t22. a

Ash, Sea, 1\%U. f, 2136. c

Ash, Spanisb 1945. a

Ash. S'tinking 16s1. a

Ash, Sweet 148 c

Ash, Trumpet 1964 a

Ash, Wafer 1681. a

Ash, Water 16. b

Ash, White (herb) 48. a

fAsh, White 469 a, 19 th. a

Ash, Wild 1875 a, $d$

Ash, Yellow 509. a

Ash-of-Jerusa'em 1071, a, 171\%. a

Ash-weed 48. a

Ashwort $18: 1$. $\mathrm{k}$

Asiminier 198. a

Askulasquash 614. b

Asp, Quaking 1652. i, j

Asp, White 165\%. a

Aspaghul seed 1611. e

Asparagus 199

Aspara zus, Winter 1819. a

Aspen, species 16:2. a, i, j, k Asperge 199. a

Aspérule $2 \cdot 1$. b

Asphodel 1385. e

Asphodel, Bastard 1. a

A sphodel, Bog 1

Asphodel, False 2007. a

Asphodel, Lancashire 1. a

Asphodel, Scottish 2107. a

Aspic 114). b

*Aspidium 712

Aspidium, U S. P. 712. b, c

Aspidosperma, U. S. P.203.a
*Asplenium 181

Ass-ear 1937. a

Ass'-foot 1602. i, j, 2053. a

Assacu 10,4. a

Asses' eyes 1365. 8

Asthma-weed 1217. D

*Aster $299,695,768,791,1062$, $1065,1184,1188,1252$, $1451,18.54,2141$

Aster, Golden 488

Aster, Heath 118!

Aster, Mountain 1451

Aster, Rayless 299

Aster, Silver 488. a

Aster, Stiff 1065. a

Aster, Stokes' 1916. a

Aster, White 695

Aster, White-topped 1854

*Astragalus $169,1017,1464$. $15 \% 6,1874$

Astrantiæ radix 1058. a

Astrology 16 1. e

Atalantia monophylla 1201.a

* A tamasco 21.0

*Athamanta 155

*Athanasia 1283

Athanasiæ her ba 195\%. a

*Atherosperma 1142

*Athrodactylis 1 t95

Atis 2.). $\mathrm{f}$

Atocire $1 \mathrm{tn}$. e

*Atrema 26 t

* Atriplex 1931

*Atrupa 127 t, 1579

Atte 140. e

Atticis radix 199. a

Attich 1771. c

Attsappe-mouche 679. a

Aubépine 592. a

Aubergine 186\%. k

*Aubletia 780

Aucklanoia 17:1

*Audibertia $1 \% 09$

Augentrost 804. a

Auhubu 590. b

Auld-wive's-tongues 1652. i

Aulmoneys 133. $\mathrm{g}$

A une $7 y$

Aunée officinale 1c62. a

Aunt-Jtrichos 1 135. esp. a

Aunt-Mary's tree 105s. a

Aurantii cortex 206 . c, d

Auricula 1660. a

Auricula Judae 81 t, a

Aurin, Rother 783. a

Aurone mâle 187. a

Ausier (Auger) 1\%64. m, n, o

Ave-_race 1756 . a

Avers, species 885

Avens, Mlountain 708

Averil 1:385. a

Averin 1750. $f$

A veroyne 187. a

Avigato (Avicato) 1546. c

Avocado (Avocato) 1546. c

A vocatier $15+6$.

Avoine 221. a

Awa (Ava) 1320. b

Awbel 1652. a

Awlwort, Water 1930

A wts 221. a

Ax-seed :77. c .

Ax-weed 48. a

Axwort 577. c

Aya-pana 802. m

*Azadirachta 1299

Azalea 22 , 452
Azalea, Alpine 462. a

Azalea, Trailing 452, a

Azaı 0 194. a

*Azedarach 1299

Babies'-breath 131, a, 863, f, 935. a

Babies'-feet (Babies'-toes) 1638. $\mathrm{c}$

Babies'-slippers 1638. c

Babington's-curse 1566. a

Baboot 7. a

Bab's-root $16 \overline{9}$.

Babul (Babulah) 7. a

Babur 7. a

Baby-eyes 1395. a

Baccae domesticae 1721. d

*Baccharis 11174, 1619

Bar hbungen 2094. c

Bachelor's-buttons 423. c, $d$. 1711. b, $c$,

†Bachelor's-buttons 174. a, b, 444. b, 1923. d

Bachelor's-burtons, White $1: 36$. $a$

Bachelor's-buttons, Wild 1638. $\mathrm{m}$

Baclin 26s, f

Backache-root 1121. b

Backwort 1937. a

Bacon-weed 464. a

*Bacty rilobium 409

Badekraut 1196, a

Badyer's-bane 25. g

Badger-weed 1693. a

Badiane 1u55. d

Badiani semen 1055, d

Bael (Bhel, Bel), Indian 47. 2

*Bæria 1140

Bag-leaves 1824. c

Baguenaudier โ545. a

Bahama-grass 376. a

Bahia powder 211u. a

Bahia-pulver 2110. a

Bai.mo 847. d

Bairnwort 218. a

Bajree 1531. a

Baked-apple berry 1750. f

*Balantium 669

Balata, Bastard 321 . c

Balata tree 133 t. d

Balausta(Balaustine) 1694.a

Balaustii Hores 16y4. B

Balbonac 1234. a

Bald-eyebrow 145. b

Balder-nerb 91. d

Balierbrae 14 i. b

Balders 145. b

Baldrian 20\%7. c

Baldmony (Badmoney) 1323. a

Baldmoney (Bawdmoney) 882. $\mathrm{h}$

*Baldwina (Baldwinia) 30

Bal!oon-vine 380 . a

*Ballota 1165

Ballota lanata 1165. b

Ballote, Gemeine 230. a

Ballotenkruut, Wolliges 1165. b

Balm 1342. a

Balm, Abraham's 2107. a

Balm, American Bee 1348. a

Balm, Basil 520. a

Balm, Bastaıd 1303. a

Balm, Bee or Blue 1302. a

Balm, Calamint 520. b 
Balm, Field 520. c, 894. a

Balm, Garden 1302. a Balm, Indian 2036. b Balm, Lemon 1302. a Balm, Low 1348, 1348. a Balm, Molucea 1346. a Balm, Mountain $\%$ 2. a Balm, Patchouli 1631. a Balm, Red 1348. a Balm, Rose 1348. a Balm, Scarlet 1318 . a Balm, Stiuking 960. a Balm, Sweet 418. c, 1302, a Balm, Yellow 1249. b Balm-of-Gilead 1652. b

tBalm-of-Gilead 418.e,1302.c Balm-of-Gilead (Fir) 2. b

Balm-of-Gilead (true) 550.e

Balm-of-heaven 2059. a

Balm-of-warrior's-wound 1013. b

Balmony 463. a

Balsam, Canada 2. b

Balsam, Field (Old-tield) 904. a

Balsam, Garden 1057.b

+Balsam, Garden 2032. d

Balsam, Groundsel 18.11. c

Balsam, Indischer 2008. a

Balsam Kentish 1312. b

Balsam, Peru 2008. a

Balsam, She- 2. c

Balsam, Sweet 904. a

Balsam, Tolu 2008. c

Balsam, White 904. a

Balsam. Wild 10.57. a, c, d

Balsani-apple, Wild 1325. c, 724. a

Balsam-flowers 1300. b

Balsam of Fir 2. b

Balsam-root 231

Balsam-tree 2, b, c, 1605. a

Balsan-vine 1347. a

Balsam-weed 904, a,1057. a,d

*Balsamea 550

Balsamina 1347. a

*Balsamita $4>2$. a

Balsamite odorante 482. a

Balsamkraut 4\$2. a

*Balsamodendron 550

Balsamum americanum 2008. c.

Balsamum canadense 2. b

Balsamum gileadense 550. e

Balsamum indicum 2008. a

Balsamum judiacum 550 . e

Balsamum meceae 550 . e

Balsamum peruvianum 2008. a

Balsamum tolutanum 2008. c

Balustier 1694. a

Bamboo 232

Bamboo-brier 1865. o

*Bambos (Bambus) 232

Bambuk butter $2+0$. d

BANANA 1367

+Banana 214t. a

Banana, False 198. a

Banana, Mexican 2141. c

Band-plant 2100 , a

BANEBERRY, species 27

Banewort 219. a

*Bankesia 491

Bannal 641. b

Ban-weed 183L. f

Banwort (Bennert) 248. a
Banyan 831. c, d

*Baobab 32

Baobab 32. esp. a

*Bautisia 1985

Baptisie 234. b

Baranham bark 1228. c

Barba hispanica 2001. a

Barbados-nut 618. a

+Barbados-pride 35. a

Barbaraune 251. e

Barbatimao (Barbimao) 1925. a

Barbeau 423. c

BARBERRY 251. esp. e

Barbotine 187. n

Barcelona nut 579 .

Bardana (Bardane) 174. a,b

Bardanae radix 174, a, b

Bare-foot 974. a

Bärendillwurzel 1323. a

Bärenklaue 982 . b

Bärentraube $176, \mathrm{f}$

*Barkhausia 1862

Bärlappkraut 1240. a

BARLEY, varieties 1019

Barley-caustic, Indian 193.a

Bärmutterwurz 1190. a

Barnacle-grass 2158. a

Barrenwort, American 2082

*Bartonia $130 y$

*Bartsia 403, 1425

Bartsia, Red 1425, a

Barwood 233. a

Bärwurzel 1323. a

*Baryosma 236

+Basil 1111. b

Basil, Common 1423. a

Basil, Cow 2074. a

Basil, Field, 520. d

Basil, Stone 520. d

Basil, Wild E20. d, 616. a, 1111. a

Basilic 1423, a

Basilienkraut 1423. a

Basket Palm 580. a

Bass 1809. a

Bassora gum 1912. d

Bass-tree 1999. b

Basswood 1999. a, c, e

Bast-tree 1999. a, b'

*Batatas $1066^{\circ}$

Bath, White 2036. c

Bathwort (Bath-Hower) $2(36 . \mathrm{b}, \mathrm{c}$

*Batis 1783

*Batschia 1214

Batter-dock 1548. a, 16.57. a

Battle-field flower 2102. f

Bauchee seed 1679. a

Baume blanc 550 . e

Baume de Canada 2. b

Baume de Carthagéne 2008, c

Baume de cheval 539 . b

Baume de la Mecque 550. e

Baume de Perou noir 2008. a

Baume de Sansonate 2008. a

Baume de Tolu 2008, c

Baume vert 1308. j

Baume San Salvador 2008. a

Baume-coq 482. a

Bawchang seed 1679. a

Bawdmoney 1323. s

Bay, Bull 1262. b

Bay, Cherry 1668. i. n1

Bay, Dwarf 644. b. c

Bay, Holly 911. a, 1262. f

Bay, Loblolly 911 . a
Bay, North Carolina 1262. c

Bay, Red 1546. a, 1262. f

Bay, Rose 1403. a

Bay, Rose (East Indian) 1946 b

Bay, Swamp 1546. b

Bay, Sweet 1144. a, 1262. f

Bay, Tan 911. a

Bay, White 1262. f, 1546. a

Bay-berry 1375. a,b, 1144. a

Bay-berry, Jamaica 1594, a

Bay-berry, Tallow 1375. b

Bay-bush 1375.

Bay-laurel, California 2059. a

Bay rum 1594. a

Bay-tree, California 2059. a

Baycuru (Biacuru) 1202. b

Bayöl 1594. a

Bays, oil of 1144. a

Bazzard flower 1312. b

Bazzies 174. a, b

Bdellium, East Indian 550. $b, c$

Bdellium, African 550. a

Bead-ruby 2061. a

Bead-tree 1299. b

Bean, Black, 1121. a

Bean, Black-eyed 2098. a

Bean, Brazilian 1560. a

Bean, Buffalo 208. b

Bean, Butter 1560. b

Bean, Calabar 1582, a

Bean. Carolina 1560. b

Bean, Castor 1735. a

Bean, China 2098. a

Bean, Common 1560. e

Bean, Dwarf 1560. d

Bean, Egyptian 1121. a, 1391. b

Bean, Ignatius 1923. b

Bean, Indian 406

Bean, Hyacinth 1121. a

Bean, Kidney 1560 , e

Bean, Lima 1560. b

Bean, Locust 432 . a

Bean, Malacca 1829. a

Bean, Molucca 923. a

Bean, Oily 1837. a

Bean, Ordeal 1582, a

Bean, Pale, 1560. e

Bean, Pythagorean 1391. b

Bean, Rattlesnake's 1853.a,b

Bean, Red 4. a

Bean, Sacred 1391. b

Bean, Screw 1664. c

Bean, Sea 751. a

Bean, Soy (Sahuca) 900. a

Bean, Sugar 1560. b

Bean-tree 406

Bean-weed 1599. a

Bear 1019

BEARBERRY 176. esp. $f$

Bearberry 1053. c, 1476. a

Bearberry, Alpine 1263

Bearberry tree 1721. k

Bear-bind 563. a, c, 1641. h

Bear-corn 2089. b

Bear-grass 2144. f, 1026. b

Bear's-bane 25. $\mathrm{g}$

Bear's-bed 1649 . b

Bear's-breech 15. a

†Bear's-breech 982. b

Bear's-ear 1660. a

Bear's-foot 65 . b, 974. a

Bear's-foot, Yellow 1642. a

Bear's-paw root 712 . b 
Bear's-thread 2144. f

Bear's-weed 772. a

Bear-tongue 521. a

Bear-wood 1721. k

Bearwort 1323. a

Beard-grass 129

Beard-tree 579 . c

Beast-bane 25. $\mathrm{g}$

Beaumont-root 1171. a

Beauty-of-the-night 1335. a

Beaver-poison 495 . b

Beaver-root 1420 . a

Beaver-tree 1262. f

Beaver-wood 422, a

Beazor-nut 923 . a, b

Bebeeru (Beberu) 1390. c

Bébéeru 1390. c

Bec-de-grue tacheté 883. a

Beccabunga 2094. c

Bed-flower 863.

Bedgery 714. a

Bede-sedge (-segg) 1881

Bedeguar 1743. a

Bed's-foot 520. d

BED-STRAW, species 863

Bedstraw, Shepherd's 201, a

Bee-bread 284. a, 2032. f

Bee-tree 1999. a, c

Bee-weed 206. a, e

Bee's-nest 651. a

BEECH, species 822 . a

Beech. Blue 390 . a

Beech, Dutch 1652. a

Beech, Horse(Horst, Hurst) 390. a

Beech, Seaside 816. \&

Beech, Water 390. a

rBeech, Water 1612, a

Beech-drops 558. a, 1170. a

Beech-drops, Albany 1684.a

Beech-drops, Carolina 1357.a

Reech-drops, False 1046. a

Beef-suet tree 1166. a

Beefsteak plant 1523. a 1543. a

Beefwood 405, 1604. b

Beet 259 .

Beet, Marsh 1202. c

Beet-radish 259. a

+Beet-root 91 . e

Beetle-bung 1421. c

Beetle-weed 858

Beetrave (Beetraw) 259. a

Beetrie 259. a

Beewort 26. a

Befaria 246

Beggar-lice (Beggar's-lice) 863. a, 1137 . b, 1294 a

BEGGA R-TICKS 263

Beggar ticks(Beggar's-ticks) 59. b, 1137. b, 1294. a

Beggar-weed 620, 1641. d, 1884. a

Beggar's basket 1692. a

Beggar's-buttons 174. a, b

Beggar's-needles 1796. a

Beggary 850. a

Begoon 1867, k

*Beben 1851. b, 2098

Behen, Red 1202. c

Beifuss 187. $\mathrm{s}$

Bein well 1937.

Bela 1089. d

Belae fructus 47 . a

*Belamcanda 879

Belder-root 1427. a

Bell, Roanoke 1314. a
Bell-bind 563. a. c

Bell-bottle 1808 . a

BELL-FLOWER 36?

Bell-flower 1385. a

Bell-Hower, Red 1702. b

Bell-ragges 1742 . c

Bell-tree 1344, a

Bells 166. a

Belene 1041, b

Belladone 219. a

*Belladonna 92

Belladonna 219. a

Belladonna, Japanese 1817.a

Bellasombra tree 1585. a

*Belle de nuit 1335

Belleric Myrobalans 322. d

Bellware 2158. a

+Bellwort 362 . b

BELLwORT, species 2073

Bellyache-root 135 . a

Bellyache-weed 1869. c

Ben, White 1851. b

Ben-nut (Behen) 1360

Bencdictae sylvestris, Rad 885. b

Benedictenwurz 88.5. d

Bengal-root 2152. a

Benjamin, Gum 1929. a

Benjamin, Red 2036. b

Benjamiu, White 2036. a, c

Benjamin-bush 250. a

Benjoin 1929. a

Benne 1537. a

Bennet 1595 . b

Bennet, American 85.5. e, f

Bennet, Yellow 855. e

Pennut 1096. d

Benoite 885. d

Benoite aquatique 88.5. W

Bent 350. a, 1809. a

Bent-grass, Sea 382 . a

*Benthamia 109

* Benzanilla 1677

Benzoë (Benzoinum) 1929.a

Benzoelorber 250, a

*Benzoin 1929

Benzoin, False 322. a

Benzoin tree 1929, a

Berberitze 251. e

Berbine 2091. f

Berce 982 . b

Bergamot 506. e.

+Bergamot 2038. a

Beryamot, Prairie 1348. c

Bergamot, Wild 1:48. d

*Bergera 449

Bergpetersilie 1554. c

Bergpolei 1973. d

Bergthee 870 . b

Bermuda-grass 376 . a

*Bermudiana 1861

Bernhardinerkraut 525. a

Bernstein 1600. a

Berries, French 1721. h

Berries, Persian 1721. i, j

Berries, Turkish 1721. i, j

Berries, Yellow 1721. h

Berry tree 1732. i

*Bertholetia 257

Bertram 115. b. 452 . f

Bertramblüthen, persische 482. b, c

Bertramgarbe 18 , d

Pertramskraut 18. d

Bertramwurzel, deutsche

115. a
Bertramwurzel römische 115. b

Berufkraut, canadisches 1174. a

Beschreikraut 1174, a

Besenkraut (Besenginster) 641. b

*Besenna 64

Besom (Busam) 350. a

Besom 641. b

Bessinge 2075. a

Betel-leaves 460 . a

Betel-nut 177. a

Betelnuss 177. a

Bethroot 2036. b

Betoine 260. a

Betonie 260. a

Betonica alba,2094. f

Betony, Head 152\%, a

Betony, Paul's 1242. a, c, 2094. f, $\mathrm{g}$.

Betony, Water 1820, a

Betony, Wood 260. a, 708. a, 1242. c, 1523. a

Bettarave 259 . a

Beulenbrand 2071, a

Bevilacqua 424. a

Bezoarwurzel 698. a, b

Bezor 1660. a

Bhang 370 . a

Bibernell 1595. b, 1774. c

Bibernell, small 1774. c

Bibiru 1390. c

*Bichea 533

Bichy 533. a

Bick beere 2075. a

Biddy's-eyes 2102 . f

*Bidens 1982

Bienensaug, Weisser 1132. a

Big-bloom 1262. d

Big-root 1325. a, b

Big-thatch 1757. b

Big-tree, California 1832. b

Bigaradier 506. c

*Bigelovia 476, 485, 4S9, 1074, 1443

Bigg 1019

*Bınonia 406, 465, 875, 1082, 1519,1964

Bija 1682. c

Bikh-root 25 . e

Bilberry 2075. e

+Bilberry 96

Bilberry, Bear's 176.

Bilberry, Bog 2075. 0

Bilberry, Red 2075. p

Bilimbi (Bilimbing) 22:2, a

Biller 1427. a

Billy-Buttons 174. a, b

Bilsenkraut 1041 . b

Bilsted 1210. b

Bind 620

BIND-WEED, species 563

Bindweed, Black 1641. h, 1956. a

Bindweed, Blackbird 1641. h

Bindweed, Blue 1867. j

Bind wecd, Climbing or Corn 1641. $\mathrm{h}$

Bindweed, Ivy 1641. h

Bindweed, Knot 1641 . h

Bindweed, Rough 1865. a

Bind-with 514 d

Bindwood 961. a

Bine 1028, a

Bingelkraut 1312 
Bipennula 1774. b

BrRCH, species 261

Birch, Bog 1721. b

Birch, Jamaica 330. a

Birch, Running 468. a

Birch, West Indian 330. 2

Bird-bell 1381. b

Bird-grass (Bird-weed) 1641. d

Bird-in-the-bush 180 . b

Bird-lime 1226. a, 2105. a

Bird-on-the-wing 1638 . c

Bird-seed 1559. b, 303. b, 1831. $\mathrm{g}$

Bird-seed Plantain 1611. c

Bird's-bread 1824, a

Bird's-eye 44, b, c, 116. a, 1227. a, 1761. a, 2094. d,e

Bird's nest, Edible 877. a

Bird's-nest, Giant 1684. a

Bird's-nest plant 651. a, 1356. a

Bird's-nest, (Yellow) 1046. a Bird's-tongue 116. a, 1641. d

Birke 261. a

Birnbaum 1699. a

*Birnbaumia 137

Birsthee 627

Birthroot (Birthwort) $2036 \mathrm{~b}, \mathrm{c}$.

Birthwort 182. a, c, e

Birthwort, Round 372. e

Birthwort, Solid 372. a

Bisamgünsel 63. b

Bisamkörner 1103 . a

Biscuit-leaves 1865. o

Biscuits 1787. a

Bish (Bishma) 25. e

Bishma (Bikhma) 25. h

Bishop's-cap 1337. a

Bishop's-leaves 1820. a

Bishop's-weed 98, 48 a

+Bishop's-weed 1308. c

Bishop-weed, Mock 1686. a

Bishop's-wig 167. a

Bishop's-wort 260. a, 1411. a

Bisinna 64. a

Bismalva 87 . a

Bissum 1031, a

Bistort (Bistorte) 1641. e

Bistort, Alpine 1641.g

Bistort, Virginia 1641. f

*Bistorta 1641

Bissy-bissy 533. a

Bite-tongue 1641. h

Bitter-bark 85. a, 1597. a

Bitter-bloom 1758. a

Bitter-bush $1704, z$

Bitter-buttons 1957. a

Bitter-herb 463. a, 783. a

Bitter-king 1878. a

Bitter-nut 1004, c, f

Bitter-nut, Water 1004. b

Bitter-root 160 . a, b, 882 . b 1191. a, 1325. a, b

Bitter-weed 95. a, 1174. a, 1869. $\mathrm{g}$

Bitter-wood 2140. b

Bitter-wood, Jamaica 1590.a

Bitter-wood tree 1590. a

Bitter-worm 1310. a

Bitterdistel 525. a

Bitterholz 1703, a

Bitterkraut 1591. b

Bittersuiss 1867. j

Bittersweet 1867 . j

+Bittersweet 466 . b
Bittersweet, Climbing 421. a Blite 696, 464. d

Bittersweet, False 421. a

Bittersweet, Shrubby 421. a Blite, Strawberry 273

Bitterwort 882. b

Biwa (Bywa) 769. a

Black-bide (Black-boyd) 1750. $\mathrm{g}$

Black-boy tree 2133. a

Black-bur 885. c

Black-cap 1750. i, 2055. a

Black-choke 1668. p

Black-drink, Indian 1053. k

Black-eyed Susan 4. a, 1003. i, 1751. a

Black-flower 1298, a

Black-grass 1291. c

Black-heart 1641. n, 2075. e

Black-Jack 1704. y, aa

Black-jacks 1611. b

Black-lady 1652. 1

Black-root 1171. a

Black-root, Indian 1683. a

Black-seed 1291. c

Black-soap 423 . d

Black-tang 849 . b

Black-thorn 1668.

Black-wood 7. i, 95. a, 223. a

Blackamoor 2055, a

BLACKBERRY, species 1750

†Blackberry 1668. q, 173\%. e, 2075. a

Blackberry-token 1750 . e

Blacksnaps 873 . d

Blackwort 1937. a

Bladder-herb 1578. a

BLADDER-NUT, species 1902

Bladder-nut 1605 , f

Bladder-pod 1180, 1217. b, 1580

Bladder-snout 207\%. a, etc

Bladder-wrack 849 . b

BLADDERWORT, species 2072

*Bladhia 1051

Blaeberry 2075. a

Blaew ort 362 . b

Blankenheimer Thee 861, b

Blanket-flower 855

Blanket-leaf 2090. b

Rlasenkirschen 1578. a

Blasentang 849 . b

*Blattaria 2090

Blaubeere 2075. a

Blauholz 940, a

Blaver 362. b, 423. c, 1497. b

Blawort 423 .

BLAZING-STAR, species 1124

Blazing-star 68. a, 45i

Blé cornu 512, a

Blé noir 8:1. a

Bleaberry 2075. o

Bleeding-heart 262. c, d

Bleeding-nun 625. a

Bleiwury 1620. a

Bleo 1540. b

*Blepharipappus 1688

Blessed herb 885. d

*Bletia 1002

Blimbing 222. a

Blind-buff (Blind-hairy) 1238. a

Blind-eyes 1497. c

Blind-man's-ball 1238 . a

Blind-weed 329. a

Blinks 1358. a

Blister-flower 1711. c

Blister-weed 1711. c

Blisterwort 1711. k
Blitz-pulver 1240. a

Block-wood 940. a

Blood-berry 1737.a

Blood-flower 939, 195. a

Blood-leaf 1067. a

Blood-staunch 1174. a

Blood-strange 1374. a

Blood-weed 195. a

Blood-wood 790. f, dd,1127.b

Bloodroot 1773 . a

†Blood-root $1658 . \mathrm{g}$

Bloodwort 18 . a, 783 . a, 1753. h, 1771. c, 1774. c

Blood wort, Burnet 1774. b

Bloodwort, Mouse 1005. f

Bloodwort, (Striped) 1005. i

Bloody-butcher 1450. d

Bloody-man's-finger 189. a

Bloody-warrior 4 3 . a, etc

Bloom-fell 1227. a

Blooming-down 664. b

Blooming-Sally 456, a

Blow-ball 1959. a

Blue-blauers 362 . b

Blue-blow 423. c

Blue-bonnets (Blue-caps) 493. $\mathrm{c}$

Blue-bottle 423,362 . b

Blue-buttons 1794. a

Blue-caps 1794, a

Blue-curl 1667. a

Blue-curls 2030. a

Blue-devil 206. e

Blue-devils 731. a

Blue-eye 2094. d

Blue-eyed grass 1022 . a

Blue-eyed Mary 538. a,1861.a

+Blue-grass 1861. a

Blue-hearts 323

Blue-pipe 1945. a

Blue-sailors 494. b

Blue-starry 166. b

Blue-stem 731. a

Blue-tangle 873. c

Blue-tops 423. d

Blue-weed 731. a

Bluebell 362. b, 1808. a

†Bluebell 166. b, 1314. $a_{1}$ 1368. a, 1634. c, 2094. a

Bluebell vine 514, a

Blueberry 2075. c, d, h, i, j

Blueberry, Black 2075 . k, 1

Blueberry, Bog 2075, a

Blueberry-root 413. a

Bluet 423. c

Bluets 102: 1429

Blutblume 183. a

Blutkraut 1773. a

Blutkraut, Gelbes 1032. a

Blutwurzel 1658. $g, 1773$. a

Bo-tree 831. e

Bobbins 189. a

Bocage, Grand 1595. b

Bockshornsamen 2034, a

Bockstorchschnabel 883 . b

Bodark (Bowdark) 2011. a

* Boebera 720

Bog-bean 1310, a

Bog-berry 1476. b

Bog-nut 1310. a

Bogwort 1476. b

Bohnenbaum 641, a

Bohnenkraut 1789. a

Bois amer de Surinam 1703.a 
Bois blanc 185t. a

Bois d'arc 2011. a

Bois de Campêche 940 . a

Bois de gayac 919 . a, b

Bois de sang 740. a

Bois d' Inde 940. a

Bois doux 902 . b

Bois enirrant 1052. a

Bois gentil 644. c

*Boldea (Boldoa) 280

Bolder 1809. a

Boldo (Boldu) 280.a

*Boldus 280

Bole-weed 423. d

*Boletus 1644

Boletus cervinus 737. a

Bolewort 1686 . a

*Bolivaria 1307

Bolle 76. c

Bolletrie 1228. a, 1334. d

*Boltonia 667

Bomariskie 1439. a

*Bombax 420

Bombyx 912. c

Bon Henri 464. d

*Bonamia 308

Bonaparte's-crown 803. b

Bonduc nuts 923 . a

Bone-flower (Bonewort) 248. a

Bone-tree 1771. e

BONESET, species 802

+Boneset 1937. a

Boneset, Climbing 2119. a

Boneset, False 1117

Bongay 50 . b

Bonnet de prêtre 801 . c

Bonnets 1420. a

Bonny-bird-een 379. c, 1660. c

Bonny-dame 218. $f$

*Bonplandia 621

Boor-tree (Bore-tree) 1771.e

*Boothia 1614

Boots 2095. e

Boots-and-shoes 166 . b

Borecole 303. e

Borage (Burrage) 284. a

Borasch (Boretsch) 284. a

Botan 1488. a

Botany-bay resin 2133. b

*Botraphis 497

*Botryopsis 475

Bottle-brush 758. a, 1008. a

Bottle-grass 2032. c

Bottle-tree 655

Bouillon blanc 2090. b

Bouleau 261 a

Bouncing-Bet 1781. a

Boundou 1923. h

Bountry (Boutry) 1771. e

Bourdaine 1721. $\mathrm{g}$

Bourgène 1721. $\mathrm{g}$

Bourrache 281. \&

Bourse à pasteur 329. a

Boussena 64, a

Bouton rouge 436 . a

Boutons d'argent 1711. b

Bovist 1238. a

*Bovista 1238

Bow-bells 133. $\mathrm{g}$

Bow-wood, North American 2011. a

Bowel-hive 65. \&

Bowkail 303. e

Bowman's-root 1171. a, 1655. a, b, 803 . a
†Bowman's root 160 . b, 1229 , a

+ Box 428. a

Box, Flowering 2075. p

Box, Mountain 176. f

Box, Prickly 1755. a

Box, Wild Running 1366. a

Box-berry 870. b, 1336. a

Box-tree 333. a

Box-tree, Red 790. v

Boxwood 333 a, 96. c, 576. f

+Box-wood 1797. a

*Boykinia 1745, 1986

Boys-and-girls 262. b

Boy's-love 187. a

*Brabyla 298

Bracelet wood 1085. a

Brachdistel 781. b

Brachkraut 1775. a

*Brachyris 107

*Brachystemum 1111

Brackeu, Sweet 1378. a

* Bradburya 1286

Bragge 1220. a

*Brahea 1833

Brake, Backache 204. b

Brake, Buckhorn 1471. b

Brake, Cliff 1527. a

Brake, Flowering 1471. b

Brake, Knotty 712 . b

Brake, Lady 1471. D

Brake, Rock 610

+Brake, Rock 1643. a

Brake, Royal 1471. b

Brake, Swamp 1471. a

Brake, Sweet 712. b

Bramble, Blue 1750. e

Bramble, Common 1750. $\mathrm{g}$

Bramble, Horse 1743. a

Bramble, Mountain 1750. f

Brammle 1750. $\mathrm{g}$

Branc-ursine 15, a

Brandy-bottles 1420 . b

Brank 821. a

*Brassica 561, 685, 1856

Braunelle 1667. a

Braunheil 1667. a

Brawlins 176. f

*Braya 1860

*Brayera 941

Brayerae flores 911. a

Brazil nut 257.

Brazil powder 2110. a

Brazilian beans 1390 . a, b

Brazilwood 338. b

Bread, Indian 1238, b

Bread-and-butter 1205. a, 1865. 0

Bread-and-cheese 1758. a

Bread-nut 32. a, 315. a

Bread-root 1471. a

Bread-root, Indian 1679. b,c

Bread-root, Missouri 1679. b

Bread-tree 188. a, 1069. a

Bread-tree, Jamaica 1457. a

Bread fruit 188, a

Breadfruit, Australian 868.b

Breadfruit, Hottentot 749 . a

Breakstone 65. a, 1595. b, 1761. a

Break-your-spectades 423.c

Bream 350. a

Breast-weed 1790. a

Brechnuss 1923. d

Brechnüsse, schwarze 618. a

Brechwurzel 2062. a

Breeches-flower 262. b
Breer, Sweet 1743. f

Brennessel 2067. a

Brick-timber 1054 a

*Brickellia 557

Brickley 1990. a

Bridal-wreath 1895 . b

Bride-sweet 2057. a

Bride-weed 1205. a

Bride's-laces 1559. a

Bridewort 1895. c, 2057. a

Brier, Bird 1743. a

Brier, Hip 1743, a, f

Brier, Sensitive 1361. a, b

Brier, Sweet 1743. f

Brier, Wild 1743. a

Brierwood 1865. o

Bright-eyes 1022. a

Brimble 1750. g

Brimstonew ort 1554. b

*Brindonia. 867

Brinjal 1867. k

Brinton-root 1171. a

Briony, Black 1956. a

Bristol-weed 1312. b

Briswort 1937. a

Brittle-thatch 1990. a

Brittlestem 170. b

*Brocchia 1855

Broccoli 303. e

*Brodiæa 1018, 1920, 2039

Brombeere 1750. $g$

Brome-grass 313

*Bromelia 119

Brook-bean 1310. a

Brook-flower 1034. a

Brook-tongue 495. c

Brooklime 2094. c, 1742. b

Brooklime, American 2094. a

Brookweed 1772

Broom 641

†Broom 350. a

Broom, Base 881. a

Broom, Butcher's 1755. a

Broom, Clover 234. b

Broom, Dyer's 881. a

Broom, Green 881. a, 641. b

Broom, Indigo 234. b

Broom, Irish 641. b

Broom, Prickly 2056. a

Broom, Scotch 641. b

Broom, Yellow 234. b

Broom, Spanish 1882. a

Broom, Sweet 1755. a

Broom, Thorn 2056. a

Broom-brush 1043. f

Broom-rape 1170 . a

Broom-rape, American 558. a

Broom-rape, Clover 1459. a

Broom-rape Lesser 1459. a

Broom-rape, Naked 1974. a

Broom-rape, One-flowered 1974. a

Broom-rape, Pale 1974. a

Broom-weed, Sweet 1816. a

*Brossaea 870

Brotherwort 1308. h, 1994. a

Broussa tea 2075. b

Brown-Betty 1751. a

Brown-bush 1513. a

Brown-eyed-Susan 1751. a,c Brown-weed 926

Brownwort 1667. a, 1820.a,b

Broyant 1956. a

*Brugmansia 649

Brumble (Brummel) 1750.g

Brunnenkresse 1742, b 
Bruise-root 892 . a

Bruisew ort 248. a, 892. a, 1781. a, 1937. a

Brum 863. i

Bruscus 1755. a

Brush 1713. a

Brushes 423. c

Brussels Sprouts 303. e

Brustbeere 2155. c

Brustbeere, Sch warze 2085. a

*Bryanthus 1576

Bryone blanche 320 . b

*Bryonia 414, 613. d

Bryony 320

Bryony, Black 320. a

Bubby-bush 332, a

*Bucco 236

* Buceras 2034

*Buchnera 2091

BucHU, species 236

Buchweizen 821. a

*Bucida 322

Buck-berry 2075. n

Buck-berry, Seedy 2139. a

Buck-bush 1936. a, c

Buck-grass 1240. a

Buckbean 1310. a

BUCKEYE, species 50

Buckeye, Spanish 2060. a

Buckrams 76. h

Buck's-beard 2016. b

Buck's-horn 5078, a, 1240, a

BUCKTHORN, species 1721

+Buck-thorn 1668. q

Buckthorn, Carolina 324. b

Buckthorn, Jamaica 1743. I

Buckthorn, Southern 324. b

Buckthorn, Woolly 324. a

BuckWHEAT, varieties 821

Buck wheat, Climbing 1641.h

Buckwheat, False 1641. i,j,k

Buckwheat tree 519. a

Buckwheat, Wild 773

*Buda 2005

*Buettneria 332

Buffalo-berry 1166

Buffalo-bur 1867. v

Buffalo-nut 1698. a

Buffalo-weed 95. b

Bug-seed (Bug-weed) 575

Bugbane (Bugwort) 497. a, 2089. b

Bugbane, False 2018. a

Bugle 63

Bugle, Bitter 1242. a, b

Bugle (Codex) 63. c

Bugle, Sweet 1242. c

BUGLEWEED, species 1242

Buglew ort 1242

Bugloss 124. a

†Bugloss 1591. a

Bugloss, Italian 124. b

Bugloss, Sea 1623. a

Bugloss, Small 124. b,1241.a

Bugloss, Small Wild 200. a

Bugloss, Spanish 73. a

Bugloss, upright 63. d

Bugloss, Viper's 731

Buglos8, Wild 1241. a

*Buglossa 1241

Buglosse 124. a, b

Buhach 482. b, c

*Buinalis 152

Bukko (Bucco) 236

Bukkum 338. c

*Bulbocastanum 392, 559

*Bulbostylis 1670
Bull-berry 1166. a

Bull-brier 1865. m

Bull-flower 355, a

Bull-hoof 1515. b

Bull-nettle 1867. i

Bull-nut 1004. a

Bull-rattle 1236. a, 1851. b

Bull-segg 2055. a

Bull-thatch 1757. b

Bull-weed 423. d

Bullage 1668. qf

Bulldog 151. a

Bullet tree 1334. d, 1719. a

Bulletrie 1228. a, 1334. d

Bullfeist 1238. a

* Bulliarda 2000

Bullifer 1238. a

Bullock's-eye 1830. a

Bullock's-heart 140. d

Bull's-eye, English 1751. a

Bull's-foot 2053. a

+Bulrush 2055. a

Bulrush, California 1809. b

Bulrush, Egyptian 635. f

Bulrush, Great 1809. a

Bulwand 187. 8

Bullwort 1686, a, 1820. a

Bully tree 682,1228 . a,1334.d

+Bully tree 20. a

Bully tree, Bastard 324.c

Bumble 1809, a

Bumblebee-root 2036. b

Bumble-berry 1750. $\mathrm{g}$

*Bumelia 682, 1849

Bum-wood 1730 . g

Bunch-berry 576. c

Bunch-flower 1298, a

Bunchelory 482. f

Bund-weed 423. d

*Bunias 340

*Bunium 392, 559

Bunk 494. b, 555. a

Bunny-mouth 151. a

Bunny-rabbit 151. a

Bunt 2071

*Buphthalmum 231, 287

Buplever 327. a

Bur 1028. a

Bur (Bur-nut) 400. c

Bur-bark 2041. a

Bur, Canadian 633. a,2131. c

Bur-chervil 148. a

Bur-cucumber 1845. a

Bur-flag 1881

Bur-flower 1034. a

Bur-head 727, 863. a

Bur-Marigold 263. f, g, h

Bur-reed 1881

Bur-seed 1137. a

Bur-tree 1771. e

BURDOCK, species 174

+Burdock, Lesser 2131. b

Burdock, Prairie 1852. c

Burdock, Sea 2131. b

Burgundy-bay 1291. d

Burn-wood 637. a

BURNET, species 1774

Burning-bush 801. a, b

Burnt-weed 456. a

* Burrielia 227

Bursa pastoris 329. a

*Bursera 738

Bursting-heart 801. b

Burweed 2041. a, 2131. b

Burweed, Thorny 2131. a

Burweed Hedge-hog 2131. c

Buryt 1781. a
*Busbeckia 1766

Busch thee 627

Busenna 64. \&

Bush-tree 333. a

Busserole 176. i

Bustic 682

Butcher's-prick tree 801. c, 1721.

Butter, Midshipman's 1546.c

Butter, Vegetable 1546. c

Butter-and-egg8 1205. a, 1385. d

Butter-basket 2043. a, b

Butter-bur 1548. a

+Butter-bur 2053. a

Butter-flower, Great 355. a

Butter-jags 1227. \&

Butter-leaves 218. f

Butter-print 6. a

Butter-tree 548. a

Butter-tree, Afriean 240. d

Butter-tree, Indian 240. a

Butter-weed 6. a, 1125. a, 1174. a, 1831, h

BUTTERCUP, species 1711, 639

†Buttercup 1658. a

-Buttercup, Meadow 355. a

Buttercup, Pilewort 830. a

Buttercup, Running 1658. c

Buttercup, South African 1108. a

Buttercup, White 1505. a

Butterfly-pea 301

Butterfly-weed 195. d

Butternut 1096. a

Butternut, Guiana 393

Butterwort 1599. a

Button-ball 1612. \&

Button-bur 2131. b

Button-bush 428. a

Button-hole 1814. \&

Button-tree 557. a

Button-weed 6. a, 423. d

Buttonwood 557, a

Button wood shrub 428. a

Buttonwood tree 1612 . a

Buttonwood, White 1130. a

Butua 5.b, 475. a

*Byttnera 332

* Butyrospermum 240

Caapeba 1602. i, j

Cabaret 194. f

Cabbage 303, e

Cabbage, Arkansas 1917. a

Cabbage, Bargeman's 303. b

Cabbage, Meadow 1883. a

Cabbage, Skunk 1883. a

tCabbage, Skunk 1787. b

Cabbage, Swamp 1883. a

Cabbage, Water 399. b. c

Cabbage-tree 2110. b, c

Cabbage-wood 420. a

*Cacalia 1315, 1942, 2093

*Cacao 1984

Cacao cimarrona 985. a =

Cachibou (Chibou) 330. a

Cachiman 140 . b, e

Cachou de Pégu 7. b

Cacoon antidote 829 . a

*Cactus 1415, 1449

Cactus, Cochineal 1415. a

Cactus, Russian 1767. c

Cacur 613. b

Cade, Oil of 1099. c

Cadinum (Cadi) oleum

1099. c 
Cadlock 1712. a

*Cænotus 1174

*Caesalpinia 923, 1009

Cafo 531. a

Caf6 chilen 396. i

Café du Soudan 533. a

Cafta 408. a

Cahoun Palm 220. a

Caille-lait blanc 863 . f

Caille-lait jaune 863 . i

Cailleau 1135, a

Cainana 467. b

Cainca (Cahinca) 467 a

Cainca brasiliensis 467 . b

*Cainito 486

Cajannepfeffer 377. b

Cajeput tree 2059. a

Cajuput (Cajeput) 339. esp.b

Calabar-bean 1582. a

Calabarbohne 1582. a

Calabash 1126. a

Calabash, Sweet 1515. j

Calabash tree 32 . a, $59 \overline{5}$. a

Calabazilla 614. a

*Caladium 541

*Calais 1818

Calais, False 1416

Calambac 165. a

Calamint 520. b, c

tCalamint 1111. a

Calamint, Water 1308. a

* Calamintha 520

Calamus (Calmus) 26. a

Calamus aromaticus 26. a

†Calamus, Sweet 129. a

Calancapatle de pueblo 918.c

*Calandrina 1452

*Calcitrapa 423, 525

Calcitrippa 656. c

*Calea 1073

Calebasse 1126. a

†Calendula 1951. b

Calf-kill 1103. a

Calf-snout 151. a

Calico-wood 1344. a

Calisaya bark 498. a

*Calla 1528, 2147

Calla, Wild 345 , a

* Callarocarpa 401

*Callicocca 2062

Callicoonab oil 378. b

*Calligonum 218

*Calliopsis 571

*Calliurora 2039

Calomel, Vegetable 1625. a

*Calonyction 1066

Calool tree 1912. b

*Calopogon 1200

Caltha sativa 344 . a

Caltrop, Land 2024. b

Caltrops 1102.423 . h

fCaltrops, Water 1657. b

Calulu 1585 .

Calumba 1091. a

Calumba, American 844. a

Calumba, False 581. a

*Calycanthus 332

*Caly ptranthes 491, 796

*Calyptrocarpus 1941

*Calystegia 563

Camass, Death 2159. c

Camass, Eastern 1701. a

*Camassia 1701

Camata (Camatena) 1704. d

Cambogia, U. S. P 867. a

Cambric-leaf 1420. b
*Camellia 1980

Camel's-foot 636. a

Camel's-hay 129. d

Camganiba 317. a

Camil 18. a

Camline 361. a

*Cammarum 759

Cammock 1043. b, 1831. f

†Cammock 18. a, 1439. b, 1691. a

CaMomile, species 145

Camomile, Blue 206. i

Camomile, German 1285

Camomile, Purple or Red 44. b

Camomile, Rounan 145. c

Camomile, Spanish 115. b

Camomile, Wild 482. f, 1285. a

Camomille commune 1285. a

Camomille d'Allemagne 1285. a

Camomille romaine 145 . c

Camomine 145

Camoroche 1658. a

Camote 1066. a

Camovyne, species 145

Camoryne, Dog's 1285. a

* Campanula 994

Campanule 362 . b

Campeachy-wood 940. a

Campescheholz 940. a

Camphire 599. a

Camphor 500 . b

Camphor, Borneo 710. a

Camphor, Ngai 275. a

Camphor plant 1619. a

Camphor, Sumatra 710, a

*Camphora 500. b

Camphre 500. b

CAMPION, species 1236

Campion, Bladder 1851. b

Campion, Corn 61. a

Campion, Moss 1851. c

Campion, Red Alpine 2104.a

Campion, Snowy 1851. d

Campion, Western White 1851 . $\mathrm{d}$

Camwood 233, a

Can-hoop 1053. j

Canada-pest 807 . a

Canada-root 195. d

Canaigre 1753. $\mathrm{f}$

Canary-bird flower 2044. b

Canary-grass 1559. a, b

Canary-Vine 42 . a

Canary-weed 1150 . b

Cancer-dreps 1170. a

Cancer-root 558. a, 117c. a 19\%4. $a$

Cancer-root,Clustered1974,b Cancer-root, Yellow 1974. b Cancer-weed 1381. a

Cancerillo 195. a

Cancerwort 740. a, b

Canchalagua 783. b, "c, d

Candle-berry 1375. b

Candle-tree 406. a

Candle-wick 2055. a, 2090. b

Candle-wood 112, 841

Candlenut 69 , a

CANDY-TUFT 1049

Cane, Maiden 1876. a

Cane, Spanish 192. a

Cane, Sugar 1759. a

Cane, Sweet 26. a

Cane-apple 172. b
Canebrake 191. a

*Canella 499

Canella de Cheiro 1424. a

Canella, False 499

Canella, Jamaica 499. b

Canella, Magellan 706. a

Canella, substitute 89 . b

Canella, White or Wild

368. a

Canelle blanche 368 . a

Canelle de Ceylan 500. a

Canella de China 500. a

Canelle de Saigon 500, h

Caninana 467 . b

Canker 1497, c

Cankerblooms 1743. a

Canker-root 567. b, 740. a 1202. a

Canker-weed 1381. c

Canker-weed, White 1381, a

Cankerwort 1959. a

Canna-down 774. a

Cannabis, Indian 370. a

Cannabis Indica 370. a

Cannastärke 369. a

Canne de Provence 192. a

Canne-wood 1211. a

Cantaloupe (Cantaleup) : 613. a

Canterbury bells 362 . c, e, $\mathbf{e}$

*Cantua 888

Caoutchoue (Cautschuc) 1001, 1133. a, 2063. a, b

Caoutchouc viue 2063. a

Cap-mint 520. b

Cape-weed 1739. a

Caper, Bean 2160. a

Caper bush 374. c, 803. g.

Caper, Wild 803. $\mathrm{g}$

tCapers 355.

Capillaire de Montpelier 40. a

Capillaire du Canada 40. b

Capivi 5ñ5. a

Capon'3-feather 166. b

Capon's-tail 166. b

*Capraria 556, 10̄̃

Câprier $3 \% 4$. c

*Caprifolium 1222

*Capsella 329, 1030

Capsellae herba 329 . a

Capsicum, Star 1867. t

Capsique $37 \%$. a

Capthee 627

Caramba (Carambola) 222. b

Caranna tree 1666. a

Carapa (Carap or Crab) oil 378. a

Caraway 392. b

Caraway, Black 1411. b

Caraway, Wild 148. c, 1315. a, 1942. a

Carberry 1732. i

* Cardamindum 2044

*Cardamine $167,660,1149$

CARDAMOM (Cardamome) 101,742

fCardamom 101

*Cardamomum 742

Cardamomum majus 101.

Cardamoinum, U. S. P 742.a

Cardamom, Wild 2136, d

Cardenbenedict 525. a

*Cardiaca 1165

Cardiacke 74. 8

Cardiaire 1165. a

Cardinal, Blue 1217. c 
Cardinal, Red 1217. a

Cardinal-flower 1217. a

*Cardiocarpus 1878

*Cardiophora 1878

Cardoon 631. a

Cardopatia 384. a

Cardui mariæ semen 1280. a

Cardus, Blessed, etc, 525. a

*Carduus 1280

Carduus benedictus 525. a

Careless 91. d

Caribbee (Caribaean) bark 816. a, c

Caricae fructus 831. a

Caricis rbizoma 382 ,

Carlin Heather 765. c

Carline (Carlina) 384. a

Carlock (Carlick) 303. a

Carmendik 391. under a

Carnation 664. a

Carnauba wax 566. a

Carob tree 432 . a

Caroba 265. c, 1082. a, b, c

tCaroba 1880

Carolina bark 1587. a

Carony bark 621 . a

Carotte 651. a

Caroube (Carouge) 432. a

Carpenter-herb 63. c

Carpenter's-grass 18. a

Carpenter's-square 1820 . b, c

Carpet-weed 1345. a

*Carphephorus 244, 1169

*Carpinus 147:

* Carpopagon 1365

Carragaheen 477. a

Carrageen (Carigeen) 477. a

Carrion-flower 1865. d

Carrot 651. a

Carrot, Candia 212. a

Carrot, Cretan 212. a

Carrot, Deadly 1978. a

Carrot-weed 95. a

Carsons 1742. b

Carthagena bark 498. b

Carthama 391. a

*Carum 158, 211, 559, 1552. 1690

Carum, U. S. P. 392. b

Carvies 392. b

* Carya 1004

Caryophyllatae aquosae rad. 885 . b

Caryophyllatae rad. 885. il

Caryophyllati cortex $67 \mathrm{i}$. a

*Caryophyllus 796

Caryophyllus, U. S. P 796 . a

* Caryotaxus 2050

Cascara amarga 1961. h

Cascara Sagrada 1721. k, 1

Cascarilla (Cascarille) 606. b

Case-weed (Casse-weed) 329. a

Cashaw 1664. a

Cashcuttie 7. b

Cashes 555. a

Cashew, West Indian 114. a

Cashew-nut, Oriental 18:29.a

Cashoo 7. b

Cashunuss 114. a

Cassabully 235. a

Cassada 682

Cassadong 1145. c

*Cassandra 454

Cassava 1276. b,

Cassarastärke 1276. b

Casse en batons 409 . b
Casse officinale 409 . b

Casse-diable 1043. b

Casse-lunette 423. c

Cassena 1053. k

Cassia 500. a, c, g. h

*Cassia 409

Cassia caryophyllata $674 . a$

Cassia, Horse 409. a

Cassia buds 500 . f

Cassia leaves $500 . \mathrm{g}$

Cassia lignea 500. a

Cassia, Purging 409 b

Cassia, Stinking 396, i

Cassia-flower 7. d

Cassis 1732.e

Cassie 7. d

* Cassumunar 2152

*Cassu vium 114

Castana equina 50 . b

Castana-nut 257. a

*Castanea 401

Castanhiero de Para 25\%. a

Cast-me-down 1145 . c

Castor-oil plant 1735 . a

Cat 408. a

Cat tree 801. c

Cat-berry 1054. a, 1732. i

Cat-brier 1865. o

Cat-gut 590. d

Cat-in-clover 1227. a

Cat-locks 774. a

Cat-0-nine-tails 2055. a

Cat-pea 2096. c

Cat-posy 248. a

Cat-tail 2055

Cat-whin 1743 .

Cat-whistles 758. c

Cataire (Chataire) 1399. a

Catalpa tree 406

*Catappa 322

Catapuce 803. g

Catarrh-root, East India $82 . \mathrm{b}$

Catawba tree 406

CATChFly, species 1851

†Catchfly 151. a, 16r. a

Catchweed 200. a, 863. a, b

Catechu 7. b, 1

Catechu, Pale 14r3. a

Catechu nigrum 7. b

Catechu 177. a

Cateputia minor 803. g

Caterpillars 1373. a

*Catha 1200

Catmint 1399. a

Catnep (Catnip) 1399. a

Catrup (Cat's-wort) 1399, a

Cats-claw 7. f, 1608, e

Cat's-claws 149. a

Cat's-ear 144. a, 1045

Cat's-eye 2094. d, e

Cat's-faces 2102. f

Cat's-foot (Cat's-paws) 144.a, 194. a, 894, a

Cat's-milk 803. d

Cat's-tail 91. a, "708. a, 1008.a

Cat's-tail, Blus 731 a

Cat's-tail 774. a, 1566. a

Cauliflower 303. e

Cranothe 415

*Ceanothus $43,5+1$

Cebadilla 193. a

Cebu balsam 1498. a

Cedar, Alaska 453

Cedar, Australian Red 417.b

Cedar, Barbadoes 417. a
Cedar, Bastard 1192. a,

1299. b, 1832. a , 1879. a

Cedar, Berry-bearing 109y.c

Cedar, Canoe 1992. a

Cedar, Carolina 1099. e

Cedar, Feather-leaf 1992. b

Cedar, Ground 1026. b, 1240. b

Cedar, Havana 417. a

Cedar, Incense 1192. a

Cedar, Indian 1472. a

Cedar, Jamaica Red 417. a

Cedar of Lebanon 419

Cedar, Oregon Red 1832. a

Cedar, Oregon White 1992.a

Cedar, Pencil 1099. a

+Cedar, Yencil 1099. e

Cedar, Pacific Red 19 2. a

Cedar, Port Oxford 453

Cedar, Post 453. a, 1192. a

Cedar, Prickly 1099. c

Cedar, Red 1099. e

+Cedar, Red 1879. a

Cedar, Singapore 417. b

Cedar, Spanish 417. a, 1u99.c

Cedar, Stinking 2050. b

Cedar, Swamp 453. a

Cedar, Sweet-scented 41\%. a

Cedar, Virginian 1099. e

Cedar, Washington 1832. b

Cedar, West Indian 417. a

Cedar, White 453,1192 . a, 1992. b

†Cedar, White 1299. b

Cedar-wood oil 417. a

Cedra (Cedrat, Cedrate) 506. I

*Cedrela, 1934

Cedron 1853. a, b

Cédron, Cotylédon de 1853. $\mathrm{a}, \mathrm{b}$

Cedronbohne 1853. a, b

*Cedronella 1292

*Cedrus 417, 1934

tCelandine 1976. d

Celandine, Brook 1057. d

Ceiandine, Garden 462

Celandine, Greater 46.2, a

Celandine, Lesser 830. a

Celandine, Sea 892. a

Celandine, Wild 1057, a, d

Celaster (Celastre) 421. a

*Celastrus 408

Celeriac 158, a

Celery 158. a

Celery, Water 1711. $\mathrm{k}, 2081$. a

Celery, Wild 1866. a, 2081. a

tCelery-seed 1753. $\mathrm{g}$

Celine 1302. a

Celtis 2019

Cembra nut 1501. a

Cenizo 218. a

*Centaurea 525

Centaurée Americaine 1758. a

Centaurée, Petite 783. a

*Centaurella 238

*Centauridium 2130

Centaurium minus 783 . a

Centaury 423. d, 783, 1638. d

Centaury, American 1758. a

Centaury, Corn 423. c

Centaury, Ground 814. a. 1638. ff

Centifolienrose $1743 . \mathrm{b}$

Centinode 1641 . d

*Centrosema 301 
*Centrospermum 14 Century plant 56 . a *Cephäelis 2062

*Cephalina 1784

*Cephalophora 1589

*Cephalostachyum 232. I

*Ceramium 1889

*Cerastium 83, 1341

*Cerasus 1668

*Cerbera 1958, 1988

Cerefolii herba 148. b

*Cerefolium 148

Cereus, Night-blooming 438. $a$

Cerfeuil 148. b

Cérisier 1668, e, g, p

Ceroline 1057. a, d

Cervaria alba 1139. a

*Cervispina 1721

Cess, Sweet 1378. a

Cevadilla 193. a

Cévadille 193. a

Chadlock 303. a

*Chænactis 1460

*Chænobolus 1683

*Chaerophyllum 148

*Chaetopappa 691

Chafe-weed 886. a, 904. a, b

Chaff-seed 1807

Chaff-weed 426. a, 904

Chagual gum 1695. a

Chain-fern 2126

* Chairomyces 2047. e

Chalice-flower 1385. a

*Chalmoogra 937

Chamædryos herba 1973. b

Chamædrys 1973, b

Chamæpitys 63. a

*Chamærops 1722, 17 i7, 1833

Chaméléon blanc 215 . a

Chamomile, species 145

Chamomile de Perse 482, b.c

Chamomile, see Camomile 1265. $a$

*Chamomilla 145, 1285

Chamomilla romana 14 ;. c

Champaca (Champak) 1324. a

* Champaca 1324

Chaurpignon 1278. a

Chanvre 370. a

Chanvre aquatique 263. i

Chanvre bâtard 861 . a

Chanvre du Canada 160. b

*Chaptalia 1995

Chardon 781. b

Charúon bénit 525. a

Chardon doré 384. a

Chardon étoilé 423. b

Chardon Marie 1280. a

Charity 1634. a

Charlock 303. a, 1856. a

Charlock, Jointed 1712. a

Charlock, White 1712. a

Charus (Charrus) 370. a

Chasbow 1497. c. d

Chaste-tree 2107. a

Chastey 400 . c

Châtaigne d'eau 2017. a

Chatigne du Brésil 257. a

Châtaignier 400

Chataignier d'Inde 50. b

Chaulmugra (Chalmoogra) 934. $a$

* Chavannesia 2063

Chavicae spadices 460, a

Chaw-stick 913, a

Chaya (Chay-root) 1429. a
Cheadle 1312. b

Cheat 313. a, 361. a, 1220. a

Chebula 322. d

Checkerberry 870 . b, 133\%. a

Checker tree 1875. e

Cheese-bowl 1497. c. d

Cheese-cake plant 1270 . b

Cheese-rennet 863. i

Cheeses 1270,225 , a

*Cheiranthodendron 846

* Cheiranthus 782

Cheken (Chekan) 796. b

Chelem 56. b

Chélidoine 462. a

Chélidoine, Petite 830. a

*Chelidonium 892, 1927

Chêne 1704

Chènevis 370 . a

Chenile 1041."b

Chénopode \&̀ grappes 464 . e

*Chenopodium 273, 696, 1109,1747

Chenopodium, U. S. P. $464 . \mathrm{c}$

Chequen 796. b

Cherimolia 140. a

Cherimoyer 140. a

CherRY, species 1668

Cherry, Barbados 1268. b

Cherry, Cornelian 576. h

Cherry, Cowhage 1268. c

Cherry, Dwarf 1867. t

Cherry, Ground, species $1578^{2}$

Cherry, Ground 1187

Cherry, Indian 96. c, 1721.b

Cherry, Jamaica 831. h

Cherry, Jerusalem 1867. s

Cherry, Marlberry 1051. a

Cherry, May 96. c

Cherry, Poison Black 219.a

tCherry, Sand 96. c

Cherry, Surinam 1268. a

Cherry, Winter 1867. s

f'herry, Winter 380 . a

Cherry-laurel 1668. f, i

Cherry-pie 755. a, 973. a

Cherry-wood 2095. d

CHERVIL, species 148

Chervil 445

Chervil, Hemlock 411. a

Chervil, Needle 1796. a

Chervil, Rough 411. a

Chervil, Spanish 13r8. a

Chervil, Sweet 1378. a, 2115. a, b

Chess 313, a

Chesses 1488. b

Chestnut, species 400

Chestnut, Earth 559. a

Chestnut, Golden-leaved 401. 2

Chestnut, Horse- 50

Chestnut, Kafir 298. a

Chestnut, Oak 401

Chestnut, Water 2017. a

Chestnut, IVild 298. a

Chettik 1923. f

Chew-bark 2058. e

Chew-stick 913. a

Chevorell 148. b.

Chévrefeuille 1222. a

Chia seed 1769 . e, f

Chick-pea, Lesser 1141. h

Chicken-berry 8\%0. b, 1336.a

Chicken-fighters 2102 . c

Chicken-weed 83. c, 1831. g

Chicken's-meat 494. a
Chicken's-toes 568. a 1763. a

Chickweed 83. esp. c, 430

Chickweed, Blinking 1358.a

Chickweed (Chickenweed) Red 116. a

Chickweed, Forked 152

Chickweed, Germander 2094. b

Chickweed, Gravel 1810. a

Chidkweed, Indian 1345. a

Chickweed, Ivy 2094. i

Chickweed, Mouse-ear 83. a

Chickweed, Sea 99. a

Cnickweed, Silver 1506. a

Chickweed, Star-flowered 2031. a

Chick weed, Water 83. a, 1358

Chicle 20. a, 1334. d

Chicorée sauvage 494 . b

Chicory 494. b

Chicot 930. a

Chiendent des Indes 129. f

Chiendent officinal 60. a

Chiendent, Petit 60. a

Chigger-weed 145. b

Children's-bane 495 b

Chilli coyote 1325 , a, b

Chillies 377. a, b

*Chilmoria 934

Chimney-sweep 1611. b

China (Chinae cortex) 498. a, e, f

China-root 1865 . b, m

China-root, False 1865 . m

China-shot 369

China tree 1299. b, 1912. a

China-tree, Wild 1779. a, b

Chinae radix (tuber) 1865. b

Chinar tree 1612. a

Chinarinde 498 . a, e, f

Chinawurzel 1865. b

Chincone 1831. g

Chinese-berries 1874, a

Chinkapin. (chinquapin) 400. b

Chinkapin, California. 401.2

Chinkapin, Water, 1391. a

Chinks, 870. b

Chinquapin, (Chincapin) 400. b

Chinwood, 1963. a, c

Chiquito, 548. a

Chiretta, (Chirata. Chirayta, 1933. a)

Chirette, 1933. a

*Chironia, 1758.

Chittam (Chittim) bark, 1721. $\mathrm{k}$

Chittam-wood, 583, a

Chittim-wood, 324. b

Chines, 76. $f$

Chocolate flower, 883. a

Chocolate, Indian 885 . b

Chocolate root, 885. b, e, f, etc.

Chocolate tree, 1984. a

Chock-cheese, 1270. b

Choke-berry, 185

Choke-pear, 185.

Chop-nut, 1582, a

Chopped-eggs, 1205. a

Chou, 303. e

Chris-root, 974. c

Christ-thorn, 1491. a

Christdorn, 1053. a

Christmas, 105:3 a 
Christmas-berry, California 997. a

Christmas-flower, 759. a, 974 . b

Christmas-green, 1240. b.

Christopher, Herb, see Herb Christopher.

Christophs wurz, 28. c

Christophorinae radix, 49\%. a

Christ's-eye 1062. d

Christ's herb, 974, b

Christ's-ladder, 783. a

Christwurz, 974. b, c.

*Chronosemium, 2032

Chowlee, 2058. a

*Chrysanthemum,1285.1957

Chrysanthemum, Garden, 482. $\mathrm{h}, \mathrm{i}$

Chrysarobin, 2110. a

*Chrysaspis, 2032.

*Chi ysocoma, 476, 809, 2093.

*Chrysudium, 27.

*Chrysophylla, 566.

*Chrysophyllum, 1228.

Chuckies, 166. a

Chufa, 635. b.

Chumpaka, 1324. a

Church-brooms, 686. b

Churchwort, 1308. h

Churn-staff, 803. d

Churrus, (Cherrus) 3r0. a

*Chusquea, 232. m

Cibol, 76. a

*Cicca, 1575.

Cicely, Fool's 51. a

Cicely, Rough 411. a

CICELY, SwEET species 2115.

Cicely ('Cisley), Sweet 1378.a

Cicely, Wild 148. c

*Cicendia, 783 .

*Cicuta, 949.

Cicuta major, 555. a

*Cicutaria, 495.

Ciderage 1641. i

*Cienfuegia, 496.

Cierge à grandes fleurs, 438.a

Cigar Tree, 406.

Ciguë officinale, 555. a

Ciguë petite, 51 . a

Cigü̈ vireuse, 495. c

*Cimicifuga, 2018

Cinablüthen, 187. n

Cinae flores, 187 . n

*Cinchona, 816, 1597, 1716 .

Cinchona, African 1784. a

*Ciueraria, 1831.

Cineraria, 1831. e

Cinnamon, var.s 500. a, c, g

Cinnamon, Black 1594. a

Cinnamon, Clove 6r4. a

Cinnamon, White or Wild 368. $a$

Cinnamon, Wild 1594. a

Cinnamon, Winter's 706. a

Cinnamon-root, 1062. b

Cinnamon-wood, 1788. a

Cinquefoil, 1437. a, 1658. b, c, d, e, f

Cinquefoil, Marsh 547, a

Cinquefoil, Purple 547. a

Cinquefoil, Silvery 1658. b

*Cirsium, 381.

*Cissus, 105, 1514.

*Cistus, 967.

Cistus, Marsh 1153. b

Citri, flavedo etc. 506 . i
Citron, (Citrone) 506. f, i, k Citron-wood, 349. a

Citronella, 539. b

Citronella Oil, 129. c

Citronelle, 187 a, 1302. a

Citronenkraut, 1302. a

Citronenmelisse, 1302. a

Cives (Civet) $\% 6 . \mathbf{f}$

Civette, 76. $\mathrm{f}$

Clammy-weed, 1633.

Clamoun, 1103. d

Clappedepouch, 329. a

Clapwort, 558, a

Clary, 1769. d

Clavalier, 2136. c, e

Clavelli Cassiae,(Cinnamomi) 500. $\mathrm{f}$

Claver, 1227. a

Claver-grass, 863. a,b

Clavus secalinus, 512. a

Clay-weed, 2053. a

Clear-eye, 1769. d

Clearing-nut 1923.

Clearweed, 41. a

Cleat, 1548, a

Cleats, 2053. a

Cleavers, (Clivers) 863

Cleaverwort, 863. a, b

*Clematis, 216. 1693 .

Clematis, Mountain 216. a

*Cleome, 1633

*Cliff-brake, 1527. a

Cliff-weed, 1000. a

Climath, ir30. h

Climber, Woody, 1514. a

Climbing-sailor, 629 . a

Cling-rascal, 863. a, b

*Clinopodium, 1111

Clit-bur, 174, a, b

*Clitoria, 301

Clive, 59. a, 174. a, b

Clock, 1611. b

Cloistered-heart, 882.1

Clothier's-brush, 686. a

Clove bark, 500. e

Clove tree, 796. a

Clove, Wild 1594. a

Clove-bark Tree, 674, a

Ciove-root, 885. d

Clove-strip, 1100. a

Clove-tongue, 974. b

Cloves, 796. a

Clover, species 2032.

tClover 1294. under a

Clover, Bitter 1758. a

Clover, Bokhara 1300. a

Clover, Brazilian 1291. d

Clover, Bur 1291. a

Clover, Burgundy 1291. d

Clover, Bush 1179.

Clover, Cabul 1300. a

Clover, California 1291. a

Clover, Chilian 1291, d

Clover, Cuckoo's 1475. a

Clover, Dusty 1179. a

Clover, Dutch 1291. d

Clover, Florida 1733. a

Clover, Gawk's 1475, a

Clover, Hart's 1300. b

Clover, Heart 1291. a

Clover, Hop 2032. a, b

tClover, Hop 1291. c

Clover, Horned 1291. c

Clover, Japan 1179 b

Clover, King's 1300. b

Clover, Ladies' 1475. a

Clover, Marsh 1310. a
Clover, Mexican 1733. a

Clover, Pin 777. a

Clover, Plaster 1300. b

Clover, Prairie 1118, a, b.

Clover, Sleeping 1475. a

Clover, Snail 1291

Clover, Sour, 1475. a

Clover, Spanish 1291. d, 1733. a

Clover, Spotted 1291. a

Clover, Sweet 1300. a, b

Clover,Thousand-leaver18.a:

Clover, Tree 1300. a

Clover, Wild 1179, b

Clover, Winter 1366. a

Clotbur, species 2131

+Clotbur, 174. a, b

Clotebur, 2131, 174. a, b

Clote-leaf, 1420. b

Clotweed, 2131

Clous aromatiques 796. a

Cloud-berry, 1750. f

tCloud-berry, 1750. p

Club-Moss, species 1240

Club-moss, Dwarf 1825. b

Club-moss, Prickly 1825. c

Club-weed, 423. d

Cluster-berry, 2075. p

*Clutia, 606

*Clypeola, 88, 1112

*Cnicus, 381 .

Coakum, 1585. b

Cob-nut 579. c

Cob-uut, West Indian 1434.a.

Coca (Cuca) 787. a

Cocablätter 787. a

Cocash 206. h

Cocash-weed 1831. a

Cocco (Cocoe) 541. a

Coccognidii cortex 644

*Coccoloba 526

*Cocculus 117, 416, 475, 1090

Cocculus Indicus 117

Cocellaña 921. a

Cochineal Cactus 1449. b.

Cochineal Oak 1704. I

*Cochlearia 578, 1742

Cocoa, Brazilian 1518. a

Cocowort 329 . \&

Cock-foot 462 . a

Cock-head 1900. a

Cock-up-hat 1914. a

Cockeno 1497. c

Cock-spur 1604. a

Cockiloorie 248. a

Cockle 2074. a

Cockle, Corn 61. a

Cockle, Indian, 117. a

tCockle-bur 59, 174. a, b

Cocklebur, Common 2131. b

Cocklebur, Thorny 2131. is

Cockly bur 174, a. b

Cocks 1611. b

Cock's-head plant 1437 . a

Cock's-foot 166. b

tCockscomb 1437. a

Cockscomb, Yellow 1726 a

Cock-weed 61. a

Cocky-baby 189. a

Cocoa 1984. a

Cocoanut 529. b

Coeotier 529. b

Cod-head 463. a

Codia 1497. d

Codlins-and-cream 755. a

*Coelestina 57

Coffee 531. a 
Coffee, Mogdad 396. i

Coffee, Negro 396. i

Coffee nut 930 . a

Coffee, Soudan 533. a, 1503. a

Coffee, Swedish 208, a

Coffee tree, American 930.a

Coffee tree, California 1721.k

Coffee, Wild 2037. a

Coffee-bean, Kentucky 930.a

Cognassier 628, a

Cohosh, Black 497. a

Cohosh, Blue 413. a

Cohosh, Red 27. b

Cohosb, White 27. a

Cohune Palm 220. a

Coing 628. a

Coing du Bengale 47. a

*Coinogy ne 1092

Cojote, Chili 614. a

* Colaria 533

Colchique 534. a

Cold seeds 505. a, 613. a, c, 614. $d, 1126$. a

Cole-rape 303 . b

Colework 303 . e

Colewort, Hare's 1871, b, c

Coliander 573. a

Colic-root 680 . f, 194, a

tColic-root 160. a, 1124 b, c

Colic-weed 262. a

tColic-weed 262. b, 372. b

Colicwort 65 , a

Collard (Collet) 303. e

Collard 1883. a

Collard, Wild 1315. b

Collinsonie 5:39. b

Collmarkraut 116. :

* Collomia 888

Colocynth 505 . b

*Colocynthis 505

Colocynthis, U. S. P. 505. b

Colombo Americana 844, a

Colombo de Mariette 844. a

Colombowurzel 844. a

Colophony 1601. i

Coloquinte 505. b

Colt-herb 2053. a

Colt's-tail 117t. a

Colt's-foot 2053. a

+Coltsfoot 355. a, 858 a

Coltsfoot, False 194. a

Coltsfoot, Sweet 1548

Coltsfoot, Water 1420. b

*Colubrina 43

Colubrina radix 182. f

Columbariæ herba 2091. f

Columbinae radix 1641 . e

() () LMBINE 166

(')liumbine, Feathered 1976. a, etc

Columbine, Tufted 1976. c

Columbo (Colombe) 1090 . a

Columbo, American 814. a

Colum bo-wood 581, a

Colza 303. b

Coma 324. b

Comb 304. a

Comb-flower 968. a, 304. b

Comfrey 1937. a

Comfrey, Middle 63. c

Comfrey, Saracens' 1831 f

Comfrey, Spotted 1692. a

Comfrey, Wild 633. b

*Commelina 993

Compass-plant 1125. A 1852. a

Concombre 613. c
Concombre purgatif d'âne 724. a

Concombre sauvage 724 . a

*Condalia 1720

Condiar 178. a

Condurango 1282. a

*Condylocarpus 1832

CoNe-Flower, species 1751

Cone-flower, Long-header $1713, \mathrm{a}$

Cone-flower, Prairie 1713. a

Cone-flower, Purple 304

Conessi bark 1011

Congo-root 1679. $\theta$

*Coniot hele 268

*Conocarpus 1130

*Couoclinium 802

Conomon 613. a

*Conostylis 1223

Conquer-Jobn 1639. a

*Conradia 1255

Consolida major 1937. a

Consolida regalis 656 . c

Consolida Saracenica 1869. b

Consoude grande 193\%. a

Consound 248. a, 19:37. a

Consound, King's 6.̄6. c

Consound, Middle 63. c

Constancy 1824. j

Consumption-weed 1696. d

Consumptive's-weed 772. a

Contrayerva 698. a, b

Contrayerva, German 630.b

Conval-lily 562. a

*Convallaria 1639, 2076

*Convolvulus 308, 815, 1066, 1444

Convulsion-root 1356. a

Convulsion-weed 1356. a

*Conyza 1062, 1683, 1834

Conyze 1062. b

*Conyzella 1174

Cooch-(Cutch-) grass 60, a

Cool-tankard 284. a

Coolstock 303. e

Coolweed 41. a

Coolwort (White) 1997. a

Coon-root 1773. a

Coontee (Coontie) 2115. a

*Copaiba 565

Copaiba (Copaiva) 565

*Copaifera 565

Copal, Chacaze 2013. a

Capal, Indian 2086. a

Copal, Jackass 2013. a

Copal, Kauri 55. a

Copal, Malabar 2085. a

Copal, Mexican 73\%. a

Copal, West Indian 1u36. a

Copal, Zanzibar 2013. a

Copal-balsam 121C. b

Copal-tree 2086. a

Copalchi bark 6l6. f

Copalm 565. a

Copalm tree 1210. b

Copper-leaf 1696. d

*Coprosmanthus 1865

Coptida 567. b

Coq des jardins 482. a

Coque du Levant 11i. a

Coquelicot 1497. c

Coquelourde 169.3. b

Coquilla-nut $220 \mathrm{~b}$

Coral-and-pearl 27. b

Coral-bean 1874. b

Coral-heau, Ları́e 1457. a

Coral-berry 1936. c
Coral-evergreen 1240. a

Coral-root 568

Coral-root, Crested 1002

Coral-tree 784

*Carallocarpus 320. d

Corassol 140. b, d, e

Corazo Palm 220. a

*Cordia 2085

*Cordiceps 512]

Cordylanthus 37

*Coreopsis 263, 1982, 2092

Coriander (Coriandre)573, a

Coriander, Roman 1411. b

Coriariae fructus 338 . a

Corme 1875. e

Cork-tree 1704. s, t, u

Corkscrew plant 936 . b

Cork-wood 1156. a

tCork-wood 1604. b

Cork-wood tree 140. c

Corn, Amel 2040. d

Corn, Broom 1876. b

Corn, Chocolate 1876. b

Corn Cockle 61

Corn, Coffee 1876. b

Corn, Guinea 1876. b

Corn, Heath 821. a

Corn, Indian 2149. a

Corn, Kafir 1876. b

Corn, Parrot's 391. a

Corn, St. Peter's 2040.c

('orn, Saracen's 821. a

fCorn, 'Turkey-2148. a

Corn-bind 56 \% a, 1641. h

Corn-binks $42 \%$. c

fCorn-bottle $423 \mathrm{c}$

Corn-tlower 423. c

Corn-salad, Beaked 2078. b

Corn-salad, European 2u78.a

Corn-smut 2u71. a

*Cornea 877

CoRNel, species 576

Cornelian tree 576. $\mathrm{t}$, h

Coronilla 577 a

Cornouiller 676 . b, f, h

Cornstalk-weed 1657. c

Cornwood 1682. b

*Coronaria 1236

Corozo nut 1є84. a

Corpse-plant 1356 . a

Cortex adstringens brasiliensis 1925. a

*Corvisartia 1062

* Corydalls 202

Corydales 262. a

*Corydalis 372

Corydalis cava 372 . c

Corydalis solida 372 . a

*Corypha $566,17.77$

*Cosmea (Cosmus) 582

Cosso 941. a

Cost (Costus) 482 a

Cost, English 195i. a

Costmary 482. a

Costus dulcis 363 . a

Costus root 1791

Coto bark 1390 . d

tCoto bark 7u6. a

Coton 912. c

Cottagers 677 . a

CotTun 912

Cotton, Lavender 1777. a

Cotton, Petty 901

Cotton, Wild 160. b, 195. c

Cotton-bush 1109 . b

Cotton-grass 774

Cotton-seed tree 226. a 
Cotton-tree 420. a, 1652. c, 1

Cotton-weed 144. a, 121. a, 6. a

Cotton wood 1652. c, d, e, f

+Cottonwood 1999. c

Cotylet 586. a

Couch-grass 60 . a

Couch-grass, Indian 376 . a

Couch-grass, Red 382. a

Coundi oil 378 . b

Cough-root 2036. a

Cough-root, California1193. b

Cough-weed 1831. a

Coughwort 2053. a

Cougourde 1126. a

Couleuvrée 320 . b

Coumarin 147. a, 201. b, 688. a, b, 863 . h

Conmarouma bean 688. a, b

*Coumarouna 688

*Courbari 1036

Courbaril 1036. a

Courge potiron 614 . b

Courida 223. a

Couronne de moine 1959. a

Couronne deSaint-jeans187.s

Courtship-and-matrimon y 2057. a

Coutfit 2053, a

Coventry-bells 362. d, f

Cover-shame 1099. d

Covey (sweet) 777. b

Cow-bell 1851. b

Cow-berry 547. a, 1336. a, 1851. b, 2075. p

Cow-grass 2032. f, j, 1641. d

Cow-herb 2074. a

Cow's-lick 320. b

Cow-lily 355. a

Cow-mumble 148. c

Cow-medles 1796. a

Cow-plant 1728. $d$

Cow-poison 656. e

Cow-quake 1884. a

Cow-rattle 12:36. a

Cow-sinkin 1660. b

Cow-tongue b21. a

Cow-tree 315 . b, 523, 1334. a, 19.16. a

Cow-weed 148. c

Cow-wheat 1296. a

Cowbane 495 . c, 1479 . b

Cowbane, Spotted 555. a

Cowbind 320 . b

Coudie gum 55. a

Cowhage (Cowage) 1365

Cowish 1554. a

Cowitch 1365. a

Cow's-tail 1174. a

Cow's-wort 1523. b

Cowslip 1385. a

†Cowslip 133. g, 355.a,1057.d, 1711. i, 206i. a

Cowslip, American 693. a

†Cowslip, American 1314. a

Cowslip, Bedlam 1692. a

Cowslip, Bugloss 1692. a

Cowslip, English 1660. d

Cowslip, French -660. a

Cowslip, Great 1660 . b

Cowslip, Jerusalem 1692. \&

Cowslip, Mountain 1660, a

Cowslip, Virginia 1314. a

Cowslop 355. a

Cowthwort, 1165. a

Coxcomb, Red 91. d

CrAB-A P PLE, species 1269
Crab-grass 1763. a

Crab-stock 1269. a

Crab-tree 1269, 378. a

Crab-weed 1641. d

Crab's-claws 1641. n

Crab's-eyes 4. a

Crabwood tree 378. a

*Cracca 310

Cracker berry 576. c

Crackers 873. d

Crain 830 . a

Crake-berry 570. a, 747. a

Crake-feet 1450. d

Crake-needles 1796. a

Cranberry 1476. b

Cramp-bark 2095. d

Cran de Bretagne 1742. a

CRANBERRY, species 1476

Cranberry, High-bush 2095. d'

Cranberry, Mountain 2075. p, 176. f

Cranberry, Rock 2075. p

Cranberry, Upland 176. f

Cranberry tree 2095. d. II

Cranberry, White 468. a

Crane-willow 428. a

Crane's-berry 1476. a

Cranesbill 883

Crap 821. a

Crashes 1742. b

Crassula major 1824. c

*Crassuvium 321

*Crataegus 96, 584, 997

*Crataeva 47

Cravobaum 674. a

Crawley, False 1684. a

Crawley-root 568. a, b

Crawnels 149. a

Crazy 1711. c

Crazy-Bet 355. a

Crazy-weed 208. c, p

Cream-cups 1614

Cream-nut 257. a

Cream-of-tartar tree 32

Creashak 176. $f$

Creeper 563. c, 1325. c

Creeper, Trumpet 1964. a

Creeper, Virginia 1514. a

Creeping-bur 1240. a

Creeping-Charlie 894. a, 1824. a

Creeping-Jack 1824. a

Creeping-Jenny 1325 . c 1240. a, b, 1149. a, 1824. b

Creeping-sailor 1792. a

Creesy, species 1711

*Crematomia 294

Creosote bush 588. a

*Crepis 1163

Crepitus lupi 1238. a

Cress, Bank 1860. a

Cress, Bastard 1989. a, 1168. c

Cress, Belle-isle 235. b

Cress, Bitter 379. esp.a,235.a

Cress, Butter 1711. e

Cress, Cow 1168. c

Cress, Field 1168. c

Cress, French 235. a

Cress, Garden 1168. e

Cress, Indian 2044. a

Cress, Lamb's 379. b

Cress, Land 235. a, b, 379. b

Cress, Leek 74. a

Cress, Mouse-ear 1908 a

Cress, Normandy 235 . a
Cress, Para 1893. a

Cress, Penny 1989. a

Cress, Peter's 599. a

Cress, Purple 379. d

Cress, Rock 167, 1908. a

†Cress, Rock 487. a

Cress, Rocket 235. a

Cress, St. Barbara's 23j. a

Cress, Spring 379. d

Cress, Swine's 578. a

Cress, Thale 1908. a

Cress, Tower 167. c

Cress, Wall 167, 1908. a

Cress, Wart 578

Cress, Winter 235

Cress, Yellow 1711. c

Cresson de fontaine, 1742. b

Cresson de Para, 1893. a

Cresson de roches, 487. a

Cresson des prés, 379. c

Cressonée :094. c

Crest-marine 599. a

Creyat 127. a

Crinkle-root 660 . a

Cristalline 1316. a

*Cristaria 1271

*Crockeria 1140

Crocklety-bur 174, a, b

Crocodile 514. d, 1053. a

†Crocus 754. a

Crocus, Autumn 534. a

Crocus, Autumnal 601. a

Crocus, Meadow 534. a

Crocus, Michaelmas 534. a

Crocus, Prairie 1693. a

Crocus, Purple 534. a

Crocus, U. S. P. 6u1. a

Crocus, Wild 1693. a

Cropweed 423. d

Cross-flower 1638. p

Cross-of-Jerusalem 1236. b

Cross-vine 265. b

+Crossvine 1964. a

*Crossopetalum 1372

Crosstoes 12:27. a

Crossweed 685. a

Crosewort 1249. b, 802. i

Crosswort, Golden 863. e

* Crotalaria 234.

*Crotou 1267, 1780

Croton oil 606. h

Crouper-bush 428. a

Crow-bells 1808. a

Crowbells, Yellow 1385. a

Crow-corn 68. a

Crow-fig 1923. d

Crow-flower 1236. d

Crow-Pea 747. a

Crow-poison 479. a

Crow-silk 1889. a

Crow-soap 1781. a

Crow-toe 660. b, 12:7. a

Crow-victuals 894. a

Crow-berry 747, 1;6. f, 1476. a

Crow-berry, Broom 570

Crowberry, Plymouth 570. a

Crowd-weed 303. a, 1168. c

Crowdy 1824. a

CrowFoot, species 1711.

†Crow foot $35 \%$. a, 660 . b, 833. a, 1240. b, c, 1478

Crow foot, Musk 46. a

Crow foot, Water 242

Crow foot, White-flowered

133. a

Crow foot, Wood 133. $\mathrm{g}$

Crown bark 498. e 
Crown-beard, Sunflower, 209:. b

Crown-imperial 847 . b

Crowu-0f-the-field 61. a

Crow's-foot 149. a

*Cruciata 863. e

Crunmock 1863. c

*Cryptanthus 154

*Cryptotalnia 661 .

Cuba-wood 472. a

Cubeb, (Cubébe) 611. a

Cubeb, African (Guinea) 611. $f$

Cucklebur, Sea 2131. c

Cucklemoors 174. a, b

Cuckold-dock 174, a, b

Cuckoo-babies 189. a

Cuckoo-bread 1475. a

Cuckoo-buds 1711. c

Cuckoo-button 174. a, b

Cuckoo-flower 379. c, 1236. $d, 1475$. a

tCuckoo-flower 133. g

Cuckoo-flower, White 1236 a

Cuckoo-Hower, Wild 1236. a

Cuckoo-pint 189, a

Cuckoo-sour 1475. a

Cuckoo-spit 379. c

+Cuckoo-spit 133. g

Circkoo's-cap 25. i

Cuckoo's-meat 1475, a

*Cucubalus 1851

Cucuuber 613.

Cucumber, Bitter 505. b

Cucumber, Creeping 1305. a

Cucumber, Indian 1290. a

Cucumber, One-seeded 1845

Cucumber, Snake 613, a

Cucumber, Squirtıng 724. a

Cucumber, Wild 1845.a,724.a

Cucumber-root, Indian 1290. a

Cucumber-tree 1262. a,c,d,e, 222. a

†Cucumber-tree 1211. a

*Cucumis 505, 614, 1232

Cucumis agrestis 724 . a

Cucumis asininus 724, a

*Cucurbita 505

Cucurbitae semina 614. d

Cudbear 1150. f

CUDWEED, species 144

Cudweed 904, 886. a

+Cudweed 1150 . b

Cudweed, Childing 886. a

Cudweed, Golden 1683. b

Cukukskraut 379 . c

Culberdill 15. a

Culilawan bark 500. $\theta$

Culip 2049

Cullavine 166 . b

Culıay 1705. a

*Culletia 43

Culrage 1641. 1

Culupa (Curuba) 1515. J

Culverkeys 1660 . d

Culver's-physic 1171. a

Culver's-root 1171, a

Culverwort $166 . \mathrm{b}$

Cumin (Cummin) 615. a

Cumin, Black 1411. b

Cumin de prés 392 . b

Cumiu, Sweet 1595. a

Cuminum nigrum 1411. b

Cundurango 1282. a

Cundurango blanco $16 \sim$ ? a
Cundurango de plàtano 730. a

Cundurango de paloma 730. b, 910. a

*Cunila 960

Cup-plant 1852. b

*Cupameni 9

*Cupania 272

*Cuphea 1511

Cuphea, Clammy 1511. a

Cup-guldilocks 2028. a

Cups-and-saucers 586. a

Cupid's-delight 2102. f

Cuprea bark 1716. a, b

*Cupressus 453,1962

Cuprose 1497. c

Curacao 506. c, d

Curaie 1923. g

Curcuma, Ohio 1032. a

Curuwort 863 . i

Cure-all 885 . b, 1302 . a

Cure-all, King's 1436. a

Curlew-berry 747. a

Curleck 303. a, 1712. a

Curly-grass 1800

Curly-head 514. e

Curranbine $166 \mathrm{~b}$.

CURRANT, species 1732

+Currant 2108. e

Currant, Indian 1936. c

Currant-leaf 1337. a

Curry-leaf 449. a

Cushag 1831. f

*Cussambium 1804

Cusso (Cousso) 941

Custard-apple 140. esp. d \& e

+Custard-apple 198. a, 383. a

Cut-tinger 2100. a

Cut-heal 2077. c

Cut-paper 316 . a

Cut-weed 849. b

Cutch 7. b, j

*Cyanus 423

*Cyclachæna 10\%9

*Cycloptera 3

*Cymbidium 568, 1200

Cyminum (Cuminum) 615.2

*Cymopterus 1455

*Cy nanchum 1868, 2051, 2101

*Cynodon 376

Cynoglosse 633. a

*Cynoglossum 1137

Cynorrhoda (Cynorrhodon) 1743. a

Cynosbata 1743, a

Cynosbati fungus 1743. a

*Cynthia 45

Cyperus, Sweet 635. d

*Cyphomandra 1867

Cypripède 636

CYPRESS, species 1962, 617

tCypress 63. a, 803. b, 1138. a, 1955 . b

Cypress, Belvidere 1109, c

Cypress, Brown 1109. c

Cypress, Field 63. a

Cypress, Flowering 1955. b

Cypress, Heath 1240. d

Cypress, Summer 1109. c

Cypress, Yellow 1992. \&

Cypress-root $635, \mathrm{~d}$

('vpress-vine 1702. b

( vpress-vine 42. a

*Cypripedium 359

y rilla 1051

*'vrtorhyncha 1478

* (ystoseira 849
Cytise 641. a

Cytosogenistae, herba 881. a

*Cytisus 1985

Dachlauch 1830. a

Daddy-nut tree 1999. a

Daffadowndilly 644. c

Daffodil, Checkered 847 . c

Daffodil, Hoop-petticoat 1385. c

Daffodil, Sea 1494. a

Daffodil (Trumpet) 1385 a

+Daffy-down-dilly 20:3. b

Dagyer-plant 2144. a

Daggers 1068. e, 1559. a

Daggett 261. a

Dahoon Holly 1053. b

DAISY, species 248,482

+Daisy 206, 768. b, d

Daisy, Blue 206. i, 494. b

Daisy, Brown 1751. a

Daisy, Butter 1711. c

Daisy, Cabbage 2043, a, b

Daisy, Dog 18. a, 14.5. b

Daisy, English, etc. 248. a

Daisy, Ewe 1658. g

Daisy, Horse 145. b

Daisy, Irish 1959. a

Daisy, Marsh 1903. a

Daisy, Michaelmas 206. c, g, i

Daisy, Nigger 1751, a

Daisy, Ox-eye 482. e

+Daisy, Ox-eye 1751. a

Daisy, Paris 482. d

Daisy, Pigsty 145. b

Daisy, Poison 145. b

Daisy, Sea 1903. a

Daisy, Sun 967 . b

Daisy, Yellow 1751. a

Vaisy-fleabane 768, a, b, $\odot$

Daisy-tree 1431. b

*Dalbergia 859

* Dalea 1118, 1507

Dallish 943. a, b

Damasin (Damas) 1668. h

Damiana 2052. a

tDamiana 1074. a

Dammar (Damar) 55. b, c, d, 1841. $a, b$

Dammar, Agath 55, b

Dammar resin, Black 365 . b

* Dammara 55, 1666

Dammer, White 2086. a

I) amsel 1668. h

!)amson 1668. h

Damson, Bitter 1854. a

Damson, Mountain 1854. a

Dandelion 1959. a

)andelion, Dog's 1163. a

Dandelion, Dwarf 45

Dandelion, Fall 1163. a

Dandelion, False 58, 1416. 1862.

Dandelion, High 1005. b

l)ane's-blood 362. c, 1693. b

Danewort 1771. c

bangleberry 873. c, 2075. n

*Daphne 645

*Darbya 324, 1407

*Darlingtonia 31,481 .

Darn-grass 133, $\mathrm{g}$

Darnel 1220. a

Dashel 381. a

Dashel, Milk 1871. E. le

Dasystoma 1255

Date, Chinese 2155, a

Date Palm 1570 a. 
Date, Plum 681. c. etc Date, Trebizonde 735. b

Date, Wilá 1570. c

Vattelpflaume 681

Daturae herba (semina) $649 \mathrm{~b}, \mathrm{c}$

*Daucus 1886

Daucus de Crète 212.

*Davernoya 39

David's-harp 1639. c

David's-root 46\%? a

Davy-whiteyeads 774, a Dawke 651.

Day-berry 1732. i

*Dayenia 2:24

Dead-men's-bellows 63. c

Dead-men's-bones 1245. a

Dead-men's-tingers 1450. d

DEAD-NETTLE, species 1132

Dead-nettle 1900 a

Dead-nettle, Hemp 861. a

Dead-tongue 142i. a

Deadwort 1771. c

Deal, American ,601. q

Deal, European 1601. $\mathrm{r}$

Death-come-quickly 883 . b

Death cup yo. b

Deathin 495. c, 1427. c

Death's-herb 219. a

Death-of-man 495 . o

Deer-balls 737. a

Deer-berry 1336. a, 870. b, 2075. $n$

Deer-foot 302 . a

Deer-grass 1724. a

Deer-vine 1207, a

Deer-wood 1472. a

Deer's-tongue 2035. a, 785. b

Deil's-spoons 72. a, 1657. a

*Dendrocalamus 232. n

*Dens-leonis 1959

Dentariae radix 115 . a

Dent de lion 1959. a

Dentellar a 1620 . a

Deodar 419. a

*Dermophylla 414, 2021

Dermophyllae radix 2021. a

*Descurainia 1873

*Desmanthus 31

*Desmodium 1294

Devil-in-a-busb 1411. a. 1501 a

Devil's-apple 649. b, c

Devil's-apron 1131. h

Devil's-bit 455. a, 1124. a, b. 1794. c

+Devil's-bit 68. a

Devil's-bite 2089. b

Devil's-bones 680 i

Devil's-claw 1284. a

Devil's-claws 1711. d

Devil's-club :28

Devil's-darningneedle 1796. a, 514. c

Devil's-ear 181. b

Devil's-eye 1059. \&

Devil's-fingers 1227. a

Devil's-grandmother 741, a

Devil's-grass 474. a

Devil's-grip 1345. a

Devil's-hair 514. c

Devil's-guts $620,1711, \mathrm{~h}$, 1884. a

Devil's-bead-in-a-bush 1003. $\mathrm{j}$

Devil's-leat 2067. d

Devil's-milk 803 . ỏ
†Devil's-milk 462. a

Devil's-plague 6 il. a

Devil's-posy $76 . \mathrm{b}$

Devil's-rattlebox 1851. k

Devil's-root 1794. c, 1459. a

Devil's-shoestrings 590 . d

Devil's-snufl box 1238.

Devil's-tether 1641 . h

Devil's-tongue 1449 , a

Devil's-tree 85 . b

Devil's-trumpet 649 . b, c

Devil's-walkingstick 62 . b

Devil's-weed 1125 , a

Devil-wod 1470. i

Dew-cup 65. b

tDew-planf 707. a

Dewberry 1750 . $a, b, c$

Dewtry 649. b, c

Dhak tree 331 .

Diagrydium 563 . $r$.

Diamond plant 1316, 9

*Dianthera 1101

*Dianthus 2051

*Diapedium 1101

*Diapensia 1700

Diapensiæ herba 17\%5. ค

* Diaperia 832

*Dicentra $: 6 \%$

*Dichaeta 227

*Dichetostemima 311

*Dichopsis 1490

*Dicliptera 665, 1101

*Diclytra (Dielytra) 26\%

*Dieteria 1252

Digitale pourprée 677 . \&

Dika Bread 1069, a

Dill 134

†Dill 51. a, 839. a

Dill-weed 145. b

Dillidillweeç 145. 1

Dilly 134. a, 1385.

Diliy, Wild 1334. c

*Dimeresia 762

Dindle 1959. a, 1871. 8

*Diodonta 263

*Diosma 236

*Diotis 805

*Dipherocarpus 1400

*Diplopappus 1065

Diptam (Diptame) 1456. I

Diptamwurzel 673, a

*Dipteracanthus 1752

*Diplogon 488

*Diplopappus 488, 695

Dirty-Dick 464.a

Dirty-John 464. i

Dishalaga 2053. a

Dishcloth 2036. b

*Discopleura 1686

*Distasis 448

Dita bark 85 . b

Ditarinde 85 . b

Ditch-bur (Dike-bur)2131.b

Ditch-grass 1754 . a

Ditch-moss 1566 , a

Dittander 673. a

Dittany 673

Dittany, American 616. a

Dittany, Mountain 616. a

Dittany of Crete 1456. I

Divi-divi 338. a

Diviladner 1946 . c

Dock, species 1753

Dock, Batter 1548. a

Dock, Butter (Butterfly) 1548 . 2

Dock. Can 1420. b, d
Dnck, Cheadle 1851. f

Dock, Eif 1062, a

Dock, Flatter 1420. b,

Dock, Flea 1548, a

Dock, Kadle 18.31. f

Dock, Kettle 1548. a, 1831 f

Dock, Múllen 209i. b

Dock, Prairie 1852. c

+Dock, Prairie 1513. b

Dock, Kound 127 1 , b;

Dock, Sour 1753. a, t, d, 1480 .

Dock, spatter 1420, a

Dock, Sweet 1641.

Dock, Velvet 2090.b.1062, a

Dock, Water 1463. \&

Dockmackie 2095. h

Doctor-gum 1730. $\mathrm{g}$

DODDER, species 620

Dodder-seed 361. a

Dodger 381. a

Dog-banner (Dog-binder) 145. b

Dogberry 1875. a. 1732. b, 521. a

Dog-berry tre€ 5;6. j. 185. :

Dog-blow 482. $\odot$

Dog-bur 633. a, b

Dog-buttons 1923. d

Dog-daisy 18. a, 248. a

Dog-feunel (Dog-finkel) 145. b

fDog-fennel 206, c

Dog-fenuel, False 720. a

Dog-mint 520. $d$

Dog-poison 51. a

Dogs-and-cats 2032. c

Dog's-bane, Climbing 1544.

Dog's-dinner 1026. b

Dog's-finger 677. a

Dog's-mouth 151. a

Dog's-rib 1611, b

Dog-toes 144. b

Dog's-tongue 633. a, 2035. a

Dog's-tco h grass s76. a

Dog-tree 79. a

Dogbane (Dog's-bane) 160

DoGwooD, species 576

tDogwood 96. c, 801. c, 2095. a

Dogwood, Alder 1:21. g

Dogwood, Black 1721. g

Dogwood, False 16. c

Dogwood, Flowering 576.f,g

Dogwood, Jamaica 1052. a

Dogwood, Poison 1730. p

Dogwood, Pond 428. 3

Dogwood, Striped 16. c

Dogwood, Swanp 4:8. a 3681. a, 1730. p

Dogwood, White 1052. a, 2095. d

Doft-berry 219. a

*Dolicholus 1731

*Dolichos 900, 1121, 2365 2098

Doll-cheeses 1270 . a

Dollar-leaf 1696. d

Domba oil 353. a

Dompte-verin 630 . k

*Donia 918, 1661

Donkey's-eyes 1265. a

Donkey's-oats 1753. a

Donnerkraut 1830, a

Donnerwurzel 372. c

Donn-bead-clock 1959. a 
Door-weed (Door-grass) 1641. d

Doorn-boom 7. h

*Doratophora 699

*Doria 1869

Dornapfel 649. b, c

*Doronicum 183, 768

Doronicum germanicum 183. a

Dosten (brauner) 1456. d

Dosten, kretischer 1456. a

Dother 620

Double-claw 1284 a

Double-tooth 263. f

Doum (Doom) Palm 1044, a

Doundake bark 1784. a

Doura 1503.a

Dove's-dung 1458. a

Dore's-foot 166 . b

Down-hill-of-life 1249. a

Down-weed 886. a

*Downingia 281

*Draba 778, 1406

*Dracaena 521

Drachenwurz, stinkende 1883. a

*Draco 703.

*Dracocephalum 418, 1292. 1581

*Dracontium 1883

Dracontium minus 189. a

Dragge (Drake) 1220. a

Dragon, Biting 187. e

Dragon, Brown 181. b

Dragon, Great 189. \&

Dragon's-blood 703.a, 1682.a

†Dragon's-blood 883. b

Dragon's-claws 568. a

'Dragon's-mouth 151. a, 179 a

Dragon's-tongue 466. a

Dragon-head 704

Dragon-head, False 1581. a

Dragon-root 181. a, 189. a

Dragon-tree 703. a

Dragonwort 1641. e

Dragunbeifuss 187. e

* Drakaina 703

Drake's-feet 1450. d

Drank (Dravick) 1220. a

*Drawk 61. a

Dreiblatt 1310 . a

Dreifaltigkeitskraut 2102 . f

*Drejera 137

Drias 1978. a

Droke 1220 . a

Droopwort 1895. a

Drop-berry 1639. b, c

Drops-of-snow 133. g

Dropsy plant 1302. a

Dropwort 1895. a

Dropwort, False 1479. a

Dropwort, Hemlock 1427. a. 1479. b

Dropwort, Water 1427. c, 1479. b

Dropwort, Western 1655. a.b

Drumheads 1638 . k

Drumstick 423 , d

Drumstick tree 409 . b

Drunk 1220. a

Drunkards 355. a, 870. b

Drunkwort 1410 . b

Dubock 758. a

Duck-retter 2089. b

Ducks 636. a, etc

Duck's-foot 65 . h, 1625 . a

Duck's-meat 1159
tDuckmeat 2123, 2114

Duckmeat, 'Tropical 1606. a

Duckweed 1159

*Echinospermum 1137

Duckweed, Greater 1896. a

Duckweed, Tropical 1606. a

Dudder-grass 40. a

Dudgeon 333. a

*Dulcamara 1867

Dulcamara 1867.j

Dulse 943 . a, b

Dumb-watches 1787. a, b

*Dumerelia 1541

*Dunantia 1073

Dunche-down 2055. a

Duqwat 769. a

Dur-bottle 423. d

Durchwachsdost 802 . i

Durchwachskraut 327. a

Durian 719. a

Dürlitze 576. 1

Durra (Doura) 1876. b

Dürrwurz 1062. b

Duscle 1867. o

Dusty-husband 167. a

Dusty-miller 1831. d, 1660.a. 12'36. $\mathrm{c}$

Dutch-cheese 1270 a

Dutch-mice 1141. j

Dutchman's-breeches 262. b

Dutchman's-laudanum 1515. b

Dutchman's-pipe 182. b

†Dutchman's-pipe 1356. a

Dwale 219. a, 1867. j

Dway berry 219. a

Dye-leaves 1938. a, 1053. i

Dye-weed 881. a

Dyer's-weed 1717. a, 1869.f.g

*Dyschoriste 352

Dysentery-root 1137. b

Dysentery-weed 113\%, b. 904. c

Eagle-wood 165. a

Ear-drops 262

Ear-jewel 1057. a, d

Earning-grass 1599. a

Earth-apple 968. b

Earth-ball 204\%.

Earth-club 558. a

Earth-gall 783. a, 1446. a 2089. b

Earth-nut 559. a, 635. b, 168.a

Earth-smoke 850. a

Easteningwort 1794. a

Easter-bell 83. b

Easter-flower 1693. a, b

Easter-ledges 1641. e

Easter-magients 1641.

Eat-berry 1732.

*Eatonella 1157

Eaver 1220, a

Ebénier 681. a, c

Ebénicr, Faux 641, a

Eberesche 1875. d

Eberraute 187. a

Eberwurz 384. a

Fbony 681. a, e

†Ebony 1608. d

Ebony, False 641. a

Ebony, Mountain 243. b

*Ebulum 1771

Eberreiskraut 187. a

Echalote 76 . a

*Echidiocarya 1609

* Echinacea 304.

*Echinocactus 1224

*Echinocystis 729, 1325
Ecorce de Geoffrée 2110, b,c

Eader's-tongue 1445

Eddoes, (Eddos, Edders) 541. a

Eddoes, Blue 2135. a

Eddoes, Nut 2135. a

Edgeweed 1427. c

Edelgarbe 18.

Edelschafgarbe 18. c

Edeltanne 2, f

Edelweiss 1164. a

Eel-grass 2158. a, 2081. a

Eel-grass, Green 242. a

Efstridge 1767. a

Egg, Vegetable 186\%. k

Egg-berry, (Eck-berry) $16+8 . \mathrm{m}$

Egg-plant 186\%. k

†Egg-plant 1936. b

Eggs-and-bacon 1385.d,1227.a

Eglantier, sauvage 1743. a

Eglantine (Eglantere) $174 x, f$

Eglantine, Twisted 1222, b

Egrimoine, (Egrawounde) 59. $a$

Egriot 1668. $\mathrm{g}$

Ehrenpreis 2094. f

*Ehretia 294

Ehuawa 635. j

Eibe 1963. a

Eibisch $87^{a}$ a

Eiche 1704.

Eichelkaffee 1704. q

Eichenmistel 2105, a

*Eichhornia, (Eichornia) 1586

Eihhornwurzel 68. a

Eisenhut 25, i

Eisenkraut, (Eisenhart) 2091. $f$

Eiserig 1048. a

Eiskraut 1316. a

Einbeere 1501. a

Eker 1742. b

El Kellah 98. a

*Elæagnus 1166

*Elæocarpus 2086

*Elæodendron 895

*Elaphrium 330

*Elatine 740

*Elbocarpus 434

ELDER, species 1771

Elder, Bishop's 48, a

Elder, Box 16. b

Elder, Dog 48. a

Elder, Dwarf 170. b, 48. a

Elder, Ground 135. a

Elder, Marsh 1079, 2095. d

Elder, Poison 1730. p,1771.t

Elder, Red or Rose 2095. d

Elder, Southern Prickly 170. $f$

Elder, Water 2095. d

Elder, White 209i, d

Elder, Wild 170. b

Elder-roob (Elder-rob) 1771. e

Eldin 1548. a

Elecampane 1062, a

Election-posies 403, a, etc.

Élémi 365. a

Elemi, African 289. b

Elemi, Brazilian 1666. c

Elemi, Manila 365 . a 
Elemi, Mexican 738. a

Elemi, Oriental 289. b

Elephantenlaüse 1829. a

Elephant's-ear 245

Elephant's-foot 741

Elephant's-trunk 1\%84. a

Eleven-o' clock-lady 1458. a

Ellhorn 1771. e

Elfwort 1062. a

*Elichrysum 969

Elk-bark 1262. d, f

Elk-nut 1698. a

Elk-tree 1477. a

Elk-wood 1262. d

Ellanwood 1771. e

Ellar (Ellarne) 1771. e

Ellem (Elmen, Elven) 2058. d

Ellen (Ellet) 1771. e

Eller 79

*Ellisia 795, 1256, 1395

Elloopa 240. c

ELM, species 2058

+Elm 2085

Elm, Bastard or False 422 a

Elm, Californıa Slippery 846. a

Elm, Corkwood 714. b

Elm, Water 1610

Elm-bark 2058. e, f

*Elodea 1566, 2022

Elsenich 1554. d

Elshinder 1866. a

Elshinder, Stinking 1831. f

Eluteriae cortex 606. b

* Elytraria 2048

*Elytrospermum 1809

*Emblica 1575

*Emerus 577

Emetic-root 803 . a

* Eimpetrum 570

*Encelia 966

Encens 289. a

Enchanter's herb 2091. f

Encino 1704. e

Endive 494. a

Endive, Green 1125. f

Endivie 494. b

*Endodeca 182

*Enemion $107 \%$

Enemy 1:33. g

Engelsüss 1643 . a

Engelwurz 135. a

*Ensete 1367

*Enslenia 104

Enulae radix 1062. a

Enzian 882

Enzian, ostindischer 193:3.

Enzian, weisser 1139. a

Epheu, annerikanischer 1514. a

Epheu (gemeiner) 961. a

Epiaire 1900

Epicéa 2. a

*Epifagus 1170

*Epilobium 456

Epine vinette 251. e

*Epiphegus 1170

Eppich 158. a

Epurge 803, g

Equisteum majus 758. b

Equisetum minus 758. a

Erdapfel 968. b

Erdartischocke 968 . b

Erdbeerbaum 172, b

Erdbeere 842
Erdbrod 625. a

Erdnuss 168, a

Erdrauch 850 . a

Erdscheibe 625. a

Erdschwefel 1240, a

Ergot 512. a

Ergot, Corn 2071. a

Ergot de mais 2071. a

*Erica 350

*Erigeron 1174, 1619

Erigeron, Canada 1174. a

*Eriocaulon 1122

*Eriodendron 420

*Eriogynia 1231

*Eriophyllum 29

*Eritrichium 7\%, 1453, 16:9

Erlenbaum 79

Erucae semen 1856. a

*Ervum 1017, 1160, 2096

Eryngo 781

*Erysimum 74, 235, 561, $1860,18 \% 3$

*Erythrina 1052

Erythroxyli folia $78 \%$. a

Esche 815

Escherwurzel $6 \% 3$. a

Eseldistel 1440. a

Eselsgurke (Eselskürbiss) 724. a

Esparcette 1437. a

Esparraguera 199. a

*Espeletia 231

Espen 1652 i

Essigrose 1743. d

Estragon 18\%. e

Ethuse 51. a

Etnach 1099. b

Ettle 2067. e

Eucaly ptus, U. S. P. 790. c

Eucalyptusblätter 790 . c

*Eugeuła 118, 491, 1086, 1594

Euonymus, U. S. P. 801 . b

*Euosmus 250

Eupatoire des Grecs 59. a

Eupatoire perfoliée 802 . i

Eupatorium, U. S. P. 802. i

*Eupatorium 537, 1117, 2119

Euphorbium, P. G. 803. n

Euphraise 804. a

*Euphrasia 1425

Euphrasy 804. a

*Euryangium 828

*Euryanthe 102

*Eurybia 1431

*Eustylis 1394

*Eutoca 1557

*Euxolus 91

Evans-root 885 . b

*Evax 832, 989

Ever-bramble 1750. $\mathrm{g}$

Ever-fern 1643. a

Ever-green 1824. c

Ever-white 121. a

Evergreen, Bunch 1240. c

Evergreen, Christmas 1825. b

Evergreen, Trailing 1240, e

Everlasting, species 144

Everlasting 832, 904, 969. a, 1792. b, 1824. ?

Everlasting, Pearly 121. a

Everlastiug-grass 1437. a

Eve's-cup 1787. a, b

Eve's-darning-needle 2144.f

Eve's-thread 2144, a, f, 976.b

*Evodia 789

Ewe 1963. a
*Excecearia 92\$, 1780

Exile-tree 1988. a

*Exogonium 1066. l, m

Eye-bright 116. a, 80 t. a, 1217. b, 1356. a, 2094. d

†Eye-bright 70\%. a, 1022. a

Eye-bright, Red 1425. a

Eyeloright, spotted 803. h, j.

Eye-root (Eye-balm) 1032. a

Eyewort no4. a

Ezob 1048. a

Faba calabarica 1582. a

Faba febrifuga 1923. b

Faba marina 7.51. a

Fabariae herba 1824 . c

Fabes (Feabes, Fapes) 1732. i

Face-in-hood 25. i

*Fagara 2136.

*Fagarastrum 2136

* Fagus 400. b

Fair-maid-of-France 18. d, 1711. b

Fair-maids(-of-February) 857. a

Fair-maids-of-Kerit 1711, b.

Fairies'-horse 1831 i $\mathrm{f}^{\prime}$

Fairies'-table 53. a

Fairy-bells 677. a

Fairy-cap 677. a

Fairy-cheeses 1270, a

Fairy-circle 1099. b

Fairy-creeper 42. a

Fairy-cup 1337. a

Fairy-fingers 677 . a

Fairy-smoke 1350. a

Fairy-table 1033

Fairy-thimbles 677. a

Faham (Faam) 136. a

Faitour's-grass 803 . e

Fall-flower 206. f

Fall-poison 479. a

Fallkraut 183. a

Fame-flower 1953, b

Fancy 2102.

Färberginster 881. a

Färberröthe 1749. a

Färbersafior 391. a

Farfarae folia 2053. a

Farkle berry 2075. a

Farmer's-ruin 1884. a

*Farnesia 7. d

Farnhaar 492. a, b

Fat-hen 218. e, 464, a, d, g

fFat-hen 18\% s, 329. a

Father-of-heath 765 . c

*Fatsia 170. d, 728

Faulbaum 1668. m, 1721. g

Faverel 778, a

Faverole 345 . a

Fayberry 1732. i

Eeaberry 1732. i

Feather-leaf, Indian 1992.

Feather-tree 583. b

Feather-weed 904 . a

Featherfew 482. f

Featherfoil 1021

Febrifuge plant 482 , f

Federharz 1001. a

*Fedia 2078

Feige, indische 1449. b

Feigenbaum 831. a

Feigenranunkel 830 . a

Feist (Folst) 1238. a

Feldcupresse 63 . a

Feldgarbe 18 , a

Feldkamille 1285 . a

Feldkümmelkraut 1994. a. 
Feldminze 1308, a

Feldraute 850 , a

Feldrose 1497. e

Feldthymian 1994. a

Felon-yrass 1058, a, 974. b

Felon-herb 187. s, 1005. f

Felon-weed 18:31. f

Felonwort 1058. a, 1867. j, 462. a

Feltrike 783. a

Feltwort 2090. b

Felwort 882 , b

Female-dragon 345 . a

Female-regulator 1831. a

Femble (Fimble) Hemp 370 . $a$

Fen-berry 1476. b

Fen-rue 1976. b

Fenchel 839. a

Fenchelholz 1788. a

Feni greci semen 2034, a

Fenigreek 2034. a

Fennel 839. a

Fennel, Dog 802, d

Fennel, Sea 599. a

Fennel, Water 1427. c

Fennel-flower 1411. a, b

Fenouil 839. a.

Fenouil d'eau $1 \$ 2 \%$, c

Fenouil faux 1978. a

Fenouil puant 134. a

Fenugrec (Fenugrek) 2034.a

Fenugreek (Fenugreck) 2034, a

Fern, Adder's 1445

†Fern, Adder's 1643. a

Fern, Basket 712. b

Fern, Beech 1561. a

Fern, Black-oak 204, a

Fern, Bottle 640. a

Fern, Bristle 20:28

Fern, Brittle 640. a

Fern, Caterpillar 1814. a

Fern, Chain 2126

Fern, Christmas 712, a

Fern, Cinnamon 1471. a

Fern, Climbing 1244, a

Fern, Ditch 1471. b

Fern, Female 204. b, 712. e

Fern, Filmy 2028

Fern, Finger 1814, a

Fern, Flower-cup 2125

Fern, Flowering 1471

Fern, Fragrant 712, e

Fern, Gold 931

Fern, Hare's-foot 2028. a

Fern, Hartford 1244. a

Fern, Holly 712. a

Fern, King 1471. b

Fern, Lace 461, a

Fern, Lady 204. b

Fern, Male 712. b

Fern, Marsh 712. e

Fern, Meadow 712, e

†Fern, Meadow 551. a, 1375. c

Fern, Moss 1643. a

Fern, Oak 1561, b

Fern, Ostrich 1438. b

Fern, Passley 1957. a

Fern, Petty 204. a

Fern, Quill 712. e

Fern, Regal 147ı. b

Fern, Royal 1471. b

Fern, Rue 204. c

Fern, Scale (Scaly) 441. a

Fern, Scented 1957. a
Fern, Seaweed 1814, a

Fern, Sensitive 1438. a

Fern, Shield 712

Fern, Shruby (Fern bush) 551. a

Fern, Silver 931

Fern, Snake 1471. b, 1814. a

Fern, Swamp 712. e

Fern, Sweet 551. a

$\dagger$ Fern, Sweet 1378, a

Fern, Tree 492, 622

tFern, Tree 1471. b

Fern, Wall 1643. a

Fern, Water 434

Fern, White-oak 640. a

Fern, Windsor 1244 . a

Fern, Wood 712. c, d, 164: a

Fern-gale 551. a

*Feronia 47

Feronia gum 826. a

Ferry, Sweet 551, a

*Ferula $1178,1193,1447,15: 4$

Fetid-shrub 198, a

Fetter-bush 1592. b

Fetter-foe 482. f

Fetthenne (Fette Henne) 1824. c

Fetticus 2078. a

Feuerschwamm 1644. a

Fève de Calabar 1582, a

Fève de Ste. Ignace 1923, b

Fève igasurique 1923. b

Fève pichurim 1390. a, b

Fever-bark, Australian 85.a

Fever-bush 1053. h, 250. a

Fever-bush, California 869.a

Fever-plant 1436. a, 1423.c

Fever-root 568, a

Fever-root (Feverwort) 2037. a

Fever-tree 1597, a

Fever-twig 421. a, 1867. j

Fever-weed 647. a, 781. b, 2091. d

Feverfew 482. f

†Feverfew 59. a, 783. a

Feverfew, American 1513. b

Feverfew, Bastard 151:3. a

Feverfew, Corn 1285. a

Feverwort 802 . i

Fòves du Mexique 19»4. a

Fichte 2. a

Ficus infernalis 618 . a

Ficus passa 831 . a

Fiddle 651. a

Fiddle-grase 755. a

Fiddle-heads 14;1. a

Fiddle-wood 504

Fieberklee 1310. a

Field-madder, Blue 1840, a

Fieldwort 145. b

Fig 831

Fig, Adam's 1367. c

Fig, Barbary 1449. a

Fig, Country 1784. a

Fig, Devil's 180. b

Fig, Diamond 1316. a

Fig, Hottentot's 1316. b

Fig, Indian 1449. a, b

Fig, Wild 523. a

Figue de Barbarie 1449. b

Figuier 831. a

FIGwort, species 1820

*Filago 886

Filaree 777 a

Filberd (Filbeard) 579. c

Filbert 579 . c
Filbert, Indian 1779. c

Filicula dulcis 1643, a

*Filipendula 1895, 2057

*Fillaea 786

Filly findillan 833

Filix-mas 712 . b

Finger-berry 1750. p

Finger-flower 677. a

Fingerhut 677 . a

Fingrigo 16u4. a

Finkel (Fingel) 839. a

Finzach 1641. d

FIR, species 2 :

tFir 20,6. a

Fir, Douglas 1674. a

Fir, Ground 1240. f

Fir, Joint 752

Fir, Red 16\%4, a

Fir, Scotch 1601, r

Fir, Yellow 1674. a

Fir-rape 1046. a, 1170. a

Fire-balls 1236. b

Fire-cracker, Vegetable 307. a

Fire-grass 65. a

Fire-leaves 1611. d

Fire-top 456. a

Fire-tree 1321. b

Fire-reed 760. a, 1174. a, 1611. $d$

†Fire-weed 649. b, c, 1125. a, 1831. a

Fire-weed, Purple 456. a

Firnissbaum 69. a

Fischkörner 117. a

Fischleim gummi 1530. a

Fish-berries 117. a

Fish-leaves $165 \%$. a

Fish-mouth 463. a

Fish-poison 590 . b, c, 50 . d

Fish-wood 801. a

* Fistula 409

Fitch, Medick 1437, a

Fitch, of Seripture i11, b

Fit-root 1356 . a

Five-finger 1658. c, f, 1514.8

Five-tinger, Marsh 547. a

Five-fingered root 1427 . a

Five-finyers 1443. b

Five-sisters 1249. b

Fizbo 1238 a

Flachskraut 1205. a

Flachslilie 1573. a

Flachssamen 1208. b

Flag, Blue 106s. esp. g

Flag, Cat-tail 2055. a

Flag, Corn 1068. e, 891. b

Flag, Myrtle 26. a

Flag, Poison 1068. d, g

Flag, Rattlesnake 781. a

Flag, Sweet 26

Flag, Sword 1068. e

Flag, Water 1068. g

Flag, White 1068. a

Flag, Yellow 1068. e

Flagons 1068. e

Flambe 1068 , b, g

Flannel-leaf $2090^{\circ}$. b

Flamy 210\%. f

Flap-dook (Flop-dock)677.a

Flatter-dock 1657, a

Flat-top 2093. a

Flax, species 1208

Flax, Devil's 1205. a

Flax, Dutch 361. a

Flax, False 361,1168 . c 
Flax, Mountain 783. a, 1638. h

Flax, New Zealand 1573. a

Flax, Spurge 644. a, c

Flax, Wild 1205. a. 361. a

tFlax, Wild 571. a

Flax-drop 620. a

Flax-tail 2055. a

Flax-vine 620 . a

Flaxweed 1205. a

Fleabane 1691, a

Fleabane. Canada 1174. a

Fleabane, Daisy - 768

Fleabane, Salt-marsh 1619.a

Fleabane, Spicy 1619, a

Fleabane-mullet 1691. a

Flea-seed 1611. f.

Fleawort 1691. a, 1611. f, 1831. $\mathrm{g}$

†Fleawort 863. i, 1062. b

Fleawort, Marsh 1831. j

Fleckstorchschnabel 883 . a

Fleischleim gummi 1530. a

Fleur-de-lis 1068. b, g

Flieder 1771. e

Fliegenholz 1590. a, 1703. a

Fliegenpilz 90 , a

Fliegenschwamm 90 , a

Flirtwort 482. f

Flix 1208. b

Flix-weed 685. a, 1873. a

Floating-heart 1197. a

Flohkraut 1691. a

Flohsamen 1611. f

Floramor 91 a, d

Flores anthelminticae 941 a

Floribunda (Floriponda) 649. a

Florida bark 1597. a

Flors-8eave 774

Flos africanus 1951. a

Flos cuculi 379 . c

Flowan 145 b

Flower de luce 1068

Flower-gentle 91. a, d

Flower-of-an-hour 1003 . i

Flower-of-gold 1869

Flower-of-paradise 1148. a

Fluellin 740,1554 . c, 2094. f

Fluxweed 1070

Fly-poison 479 . a

Fly-trap 1787. a, b, 160. a

Flybane 90 a

Foal-foot 2053. a, 194. f

Foam-flower 1997. a

Foehre 1601 r

Fœeniculum, U. S. P. 839. a

Fœniculum aquaticum 1427. $\mathrm{c}$

*Fœnum-Græcum 2034

*Fœtotaxus 2050

Fog-fruit 1209

Fon (Fone) 1830, a

Forbidden-fruit 506 . $\mathrm{g}$, 1946. $\mathrm{c}$

Fordboh 620

Forefather's-cup 1787. b

*Forestiera 34

Forget-me-not 1373, 2094. d

Forget-me-not 63. a, 1634.c

Forget-me-not, White 1453

Forget-me-not, White 77

Forget-me-not, Wild 1022. a

Forks-and-knives 1240. a

*Forsteronla 2012

Fortune-teller 1959, a

Fougère mâle 712 . b
*Fourcroya 852

*Fouquiera 841

Four-leaved grass 15)1, a

Four-0'clock 1335. a

†Four-o'clock 1436. a

Four-toes 144. b

Fox-berry 1336. a

Fox-feet 1240 . g

Fox-grape 1501. a

Fox-poision 644. b

Fox-tail 1240. a

Fox-tongue 1814, a

FoXglove 677

+Foxglove 1585. b, 1787. b, $1964, a$

Foxglove, American 647. a

Foxglove, Blue 362 . f

Foxglove, False 647

Foxglove, Lousewort 1523.a

Foxglove, Mullen 52. a

Foxglove, West Indian 1585. c

Foxglove, White 302 . d

*Fragaria 715

Fragon épineux 1755. a

Fraisier 842. d

Fr mboise 1750. h

*Franciscea 317

Frangipane (Frangipanni) 1621. a

*Frangula 1721

Frangula, U. S. P. 1721. g

*Franka 843

Frankincense 289. a, d, 2. a, 1601. r, 1929. e

*Franseria 854 ,

Franzosenholz 919. a, b

Frasier en arbre $1 \% 2$. b

Frauenbiss 1973. b

Frauendistel 1280. a

Frauenhaar 40

Frauenmantel 65. b

Frauenminze 482. a

Frauenshuhwurz 636. d, etc

Fraxinella, White 673. a

Fraxinellae radix 673 . a

Fraxinelle 1639. c

Freisamkraut 2102. f

*Fremontia 846

French berries 1721. h

French-grass 1679 , i

French-nut 1096. d, 400. c

Frêne 845

Erêne épineux 2136. c, e

Frez 2056. a

Friar's-cap 25, esp. i

Friar's-cowl 25 esp. i, 189. a

Frigolito 1874. b

Fringe, American 469. a

Fringe, Mountain or Wood 42. $a$

Fringe, Purple 583. b

Friuge, White 409 . a

Fringe-cup 1337. a

Fringe-tree 469

Fringe-tree, False 583. b

Fringed Orchis 938. c, d, e,g

Frog-grass 1763. a

Frog-leaf 302 , a

Frog-plant 1824. c

Frog's-bladder 1824. c

Frog's-mouth 1824. c

Frogwort 1711. f

Fröschlöffel 72 a

Frost-blite 464. a

Frost-flower 206

Frost-plant 967. a
Frost-weed 967. a

Frostwort 967. a, 1711. f

*Fucus 477, 943, 1889

Fucus irlandicus 477, a

*Fugosia 496

Fub-ling 1238. b

Fuller's herb 1781. a

Fuller's-weed 686. a

Fulwa butter 240. a

*Fumaria 262

Fumeterre 8i0. a

Fumitory 8.50. a

+Fumitory 262. a

Fumitory, Bulbous 372. c, $46 \mathrm{a}$

Fumitory, Climbing 42. a

Fumeterre bulbeuse 372 . c

Fünffingerkraut 1658. f

Fungus cervinus 737. a

Fungus chirurgorum 1238. \&

Fungus, Elder 814. a

Fungus, Fly 90. a

Fungus sambuci 814, a

Furze (Furzen, Furrys) 2056 a

Furze. Dyer's 881. a

Fuze, French 2056. a

Furze, Great 2056. a

Furze, Ground 1439. a

Furze-ball 1238. a

Fusain 801. c

*Eusanus 1776

Fuss-ball (Fuzz-ball)1238. a

Fussblattwurzel 1625. a

Fustic, American 509. a

Fustic, Old 472. a

Fustic, Young 583. b

Futterklee 2032. f

Fuzz 2056. a

Fuzzy-guzzy 904. a

Gachelkraut 18. a

Gadrise 2095. d

Gag-root 1217. b

Gage, Green 1668. h

Gagel 1375. c

Gaglee 189. a

Gaiac wood 919. a, b

Gainier 436. a

Gait-berry 1750. g

Gaiter tree 801. c, 2095. d

*Galactodendron 315

Galam butter 240 . d

*Galanga 82

Galanga minor 82 . b

Galanga officinal 82 . b

Galangal (Galangale) 82

Galaxy 858. a

Galban 828. c

Galbanum 828. c, d, e

Gale, Fern 1375. c

Galé odorant 1375 . c

Gale, Sweet 1375. c

*Galega 590

Galeopside 861

Galeopsidis herba 861 . b

Galingale (Galangal) 635, d

Galipot tree 2. a

*Galipea 621

Gall-berry 1053. i

Gall bush 1375. c

Gall-of-the-earth 1381.c, 1684. a

Gall-weed;882, f

Galla (quercina) 1704. n

Gallæ rosæ 1743 , a

Gallant 133. $\mathrm{g}$

Galläpfel 1704. n 
Galle de chêne 1704. n

Gallindrinera 803. 11

Gallion 863. a

Galliput 1601.j

Galloc 19:37. a

Gallon 1548. a

Gallow-grass 370 . a

Galls 1704. n

Galls, Atlee 1955. a

Galls, Tamarisk 1955. a

Galls, White 1575. b

Gallwort 1205. a

Galphimia 1991

Galuncha 2003. a

Gamander, Edler 1973. b

Gamanderlein 1973. b

Gambir (Gambier) 1473. a

tGambir 7. b, 1

Gamboge 867. a

Gamboge, American 2106. a

Gambogia 867. a

Gandelbeere 2075. e

Gandergoose 1450. d

Gandoo 751. a

Gang-flower 1638. p

Ganjah 370. a

*Gansblum 778

Gänsedistel 1871. b

Gänsefuss, weisser 464. a

Gänsekresse 329. a

Gänserich 1658. a

Garab tree 1652 , h

Garance 1749. a

Garb 1764. d

Garbe 392. b

Garclive 59. a

Garden-gate 2102. f

Garden-plague 48, a

Gardener's-eye 1236. c

Garentoquen 1493. b

Garget 1585 . b

Garget root 974 , a

Garlic (Garlete) 76. e

tGarlic 1973. e

Garlic, Bear's 76. h

Garlic, Clive 76. f.

Garlic, Crow 76. j

Garlic, Cow 76. $\mathrm{j}$

Garlic, Field $76 . \mathrm{j}$

Garlic, Hedge 74

Garlic, Hog's 76. h

Garlic, Meadow 76 . b

Garlic, Rush 76. f

Garlic shrub 265. a

Garlic, Wild 76. b, j

Garlic, Wood 1973. e

Garlicwort 74, a

Garnet-berry 1732. h

Garou 644. a

Garrobo 432. a

Gartenkerbel 148. b

Gartenlattich 1125 . d

Gartenlauch 76. e

Gartenraute 1756. a

Gartensalad 1125. d

Gartenschierling 51. a

Gartenthymian 1994. l,

Garth, Garden 1168 e

Gaskins 1668. e, 1732. i

*Gasteria 80. g

*Gatesia 2143

Gatten 801. c, 2095. d

Gatteridge 801. c

Gauchheil 116. a

Gaude 1717. a

Gaultbérie 870 . b

* Giaura 1910
Gay-feather 1124. a, b

Gay-wings 1638. c

Gayuba 176. i

Gean 1668, e

Gebärmutterswurzel 182. e

Geckdor 863

Geiger tree 2085. d

Geisblatt 1222 . a

Geisraute 860 . a

Geissbart 2057. a

Gelbbeereu 1721. h

Gelbkraut 1717. a

Gelbsuchtwurzel 619. c

Gilbwurz, kanadisches 103: a

Gelsemie 878. a

Gem-fruit 1997. a

Gemsblume 183. a

Génépi blanc 18. b

Genêt à balais 641 . b

Genévrier commun 1099. b)

Genip tree 880 . a

Genipap (Genipapo) 880. a

Genipi vrai 187 . h

Genipp, weisser 187. h

Genippkraüter 18 . b

*Genista 641, 1882

Genistae flores 641 . b

Genson 2037. a

GENTIAN, species 882

†Gentian, Blue 1070

Gentian, Fringed 8s2. a, j

Gentian, Horse 2037. a

Gentian, Snake 1381. c

Gentian, Spurred 1969. a

Gentian, White 1139. a, 2037. a

Gentian, Yellow 844. a

*Gentiana 783, 1758, 1933

Gentiana alba 1139. a

Gentiana lutea 882 . b

Gentiana major 882 . b

Gentiana rubra 882 . b

Gentiane jaune 882 . b

Gentleman:s-cane 1641. m

*Geoffræa (Geoffroya) 2110

Georgia bark 1597. a

GERANIUM, species 1526,883

*Geranium 777

Geranium, Beefsteak 1792. a

Geranium, Feather 464, e

Geranium, Fox 883. b

Geranium, Indian 1\%9. d

Geranium, Mint 482. a

Geranium, Mountain 883. b

Geranium, Poor-man's 1792. a

Geranjum, Rose 1526. b, c

Geranium, Spotted 883. a

Geranium, Strawberry 1792. a

Geranium, Turnpike 464. e

Gerard, Herb 48. a

*Gerardia 52, 647

Gerardia, Bushy 647. a

Geratacáca 317 a

Gerberstrauch 574. a

GERMANDER, species 1973

Germander, W all 1973. b

Germander, Wild 1973. f

Germandrée aquatique 1973. $\mathrm{e}$

Germandrée Chamsedrys $1973 \mathrm{~b}$

Germandrée naritime1973.c

(iermer, grüner 2089. b:

Germer, weisser 2089. a
*Geroe 966

Gerste 1019

Gertwurz 187. a

Gervao 2079. a

Geschwürwurzel 1634. c

Geslings 1764. e

Gesse 1141. i

Gesundheitskräuter 861. b

Gethsemane 1450. d

Gewürz, englisches 1594. b

Gew ürzuelken $\% 96$. a

(Gherkin (Gerkin) 613. c

Ghost-flower 1356. a

Giant tree 1832. b

Gichtbeere 1732. e

Gichtrose 1488. b

Gichtrübe 320 , b

Giftbaum 1730. h

Giftheil 619 , e

Gift-Jasmin 8\%8. a

Gift-Lattich 1125 . \&

Gift-Sumac 1730. h

Giftwende 630 . b

Giftwurz 630. b

Giftwurzel 698. a, b

Giftw ütherich 495. c

*Gigalobium 751

*Gugantabies 1832

* Gigantochloa 232. o

*Gigartina 1889

Gilbkraut 881. a

Gilb wurzel 619. c, d

GILDCUPS, species 1711

*Gilea 540, 1134, 1204, 1389

Gill-ale 894 a

Gill-cup 1711. f

Gill-over-the-ground 894, a

Gill-run 894. a

*Gillenia 1655

Gilliflower, varnation 664.a

Gilliflower, Clove 664. a

Gilliflower, Cuciroo 1236. d

Gilliflower, Dame's 990. a

Gilliflower, Marsh 1236. d

Gilliflower, Mock 1781. a

Gilliflower, Night-scented 990. a

Gilliflower, Queen's 990. a

Gilliflower, Rogue's 990. a

Gilliflower, Sea 1903. a

Gilliflower, Turkey 1951. a

Gilliflower, Water 10'21

Gilliflower, Winter 990. a

Gillon 2105. a

Gimlet-wood 790. aa

Gingembre 2152. a

*Gisopteris 1244

Gixger, varieties 2152. a, b

tGinger 1824. a

Giuger, Chinese 82. b

Ginger, Garden 673. a

Ginger, Green 167. 8

Ginger, Indian 194. a

Ginger, Wild 194. a, e

tGinger, Wild 182. b

Ginger-grass 129. a, d

Ginger-leaf 763 . a

Ginger-plant 1957. a

Ginger-sauce 1753. a

Gingerbread tree 1044. a, 1500. a

Gingili 1837. a

Gingko tree 889. a

Ginseug 1493. a, b

*Ginseng 1493

Ginseng, Blue 413. a

Ginseng, Horse 2037. a 
(jinseng, White 2037 a Ginseng, Yellow 413. a Girotlier 796. a

*Gisopteris 1244

Gith (Git) 1411. b

Gith (Gye) 61. a

Glaciale 1316. a

Glaieul bleu 1068. g

Glauce 893. a

Glandes quercus 1704, q

*Grandularia 2091

Glaskraut 1499. a

Glasschmalz 176:3

Glasswort 1767. b

Glasswort, Common 1763. a

Glasswort, Jointed 1763 a

Glasswort, Prickly 1767. a

Glidewort 861 . a

*Gleditschia 895

*Glehnia 1.562

Glenn-weed 1168. c

Globe-berry 1963. a

Globe-Hower 2043. a, b

Globe-flower, Mountain 428. a

Glockenblume 166. b, 362. b

Glockenwurzel 1062. a

Gloden 968. a

* Gloiopeltis 877 . b

Gloryless 46. a

Glösen 881. a

Glouteron 174. a, b

Glouteron, Petit 2131. b

*Glyce 1112

*Glycine 4. a, 157, 823, 1115 , 1731

Glycyrrhiza hispanica $902 . b$

Gnadenkraut 914. a

Gnaphalii flores 144. a

*Gnaphalium 121, 144, 886 , $1164,168:$

Gnavelle 1810. a

Go-to-bed-at-noon 2016. b

Goa powder 2110. a

Goapulver 2110. a

Goat-leaf 1222, a

Goat's-beard 45, 190

Goat's-beard, False 207. a

Goat's-beard, Purple za16.a

Goat's-beard, Yellow 2016.b

Goat's-rue 590. d

Goatweed 1905. a, 48. a

God-tree 420. a

Godes-eie 1769. d

God's-eye 2094. d

Goggles 1732. i

Gogo 751. a

Golandrina 803. $\mathrm{m}$

Gold 968. a

Gold, Vegetable 1541. a

Gold-and-silver plant 1234.a

Gold-bloom 341. a

Gold-chain 1824. a

Gold-knops 1711. c

Gold-thread 567

Gold-weed 1711, d

Golden-ball 2043. a, b

Golden-blossom 1658. f

Golden-bough 15i2. a

Golden-chain 641. a

Golden-club 1453 . a

Golden-cup 830 . a

Golden-Hower 482. $\mathrm{g}$

Golden-glow 1751. b

Golden-guineas 830. a

Golden-Jerusalenı 1751. a

Golden-locks 1643. a
Golden-locks,Jamaica 168;3.b

GOLDEN-ROD, species 1869

Golden-rod, Bushy 809. b

Golden-rod, False 300

Golden-rod, Fragrant 809

Golden-rod, Rayless 476, 489

Golden-rod, Flap-top 80\%. b

Golden-seal 1032. a

†Golden-seal 2076. a

Golden-shower 6\$1. a, 409. b

Golden-star 488. a

Golden-tuft $1683 \mathrm{~b}$

Goldenpert 914. c

Goldicup 1711. c

Goldilocks 1649. a, 1711. e

Golding 344. a

Goldmilz 48\%, a

Goldregen 611. a

(ioldruthe 1869 . b

Goldy-harefoot 885. d !

Gomine adragante 208 , f,etc

Gomme ammoniaque 697. a

Gomme arabique vraie 7 . k

Gomme-gutte 867. a

Gommart 330. a

*Gomphocarpus 1802, 1868

*Gonolobus 1282, 2101

*Gonopyrum 1640

Good-bye-summer 206

Good King Henry 464, d

Good-moruing Spring 513. a, b

*Goodyera 1538

Gools 355 . a

Goose-gogs 1732. i

Goose-grass 863. a, 1641. d, 1658. a

Goose-grass, Great 200. a

Goose-tongue 18. d, 1302. a

GOOSEFOOT, species 464

GoOSEBERRY, species 1732

tGooseberny 2075. a, n

Gooseberry, Barbados 1540.a

Gooseberry, Cape 1578. b, e

Gooseberry, Star 1575. a

Gooseberry, Tahiti 1575. a

Gooseberry, West Indian 1540. a

Gooseberry-pie 755. a

Gooseberry-shrub 1540. a

Goosechite 59. a

Gopher-plant $803 . \mathbf{g}$

Gopher-root 483 . b

Gopher-wood 509. a

Gordolobo 18. a

*Gorinkia 561

Gorse 2056. a

Gorse, Hen 1439. a

Gorst 1099. b, 2056. a

Gosling 1693. a

Gosling-grass $86:$. a

Gosmore 1045

Goss (Gost) 2056. a

Götterbaum 62. b

Gottesgabwurz 630. b

Gottesgnadenkraut 914 . a

Goud 1071. a

Gouet 189. a

Gouet a trois feuilles 181 . b

Goule (Goyle) 1375. c

GounD, varieties 1126. a

tGourd 614. b, d

Gourd, Bitter 505. b

Gourd, Dish-cloth 1232. a

Gourd, Missouri 614, a

Gourd, Towel 1232

Gourd, Washing 1232. a
Gout-weed (Goutwort) 48. esp. a

tGout-weed 135. c

Gouty-stem tree 32. b

Gowan 2053. a

Gowan, Ewe or May 248. a

Gowan, Horse 1959. a, 48\%.e

Gowan, Meadow or Open 355. a

Gowan, Milk 1959. a

Gowan, Sheep's 2032. g

Gowan, Witch 1959. a

Gowan, Yellow 1711.c, 1959. a

Gowan, Water 355. a

Gowans, Ling 1005. f

Gowk's-thumbs 362 . b

Gowlan 248. a, 314 . a

Gozelle 1732. i

Graine de Tilly 606. h

Graines d'ambrette 1003, a

Graines d'avignon 1721. b

Graines de puces 1n11. f

Grains, Guinea 101. g

Gram 493, a

Gram, Green 1560. c

Gram, White 900 . a

Grama 60. a

Gramfer-greygles 1450 . d

Graıninis dactyli radix 376.a

Graminis rbizoma (radix)

$$
\text { 60. a }
$$

Graumontsamen 614. d

Grana actes 17î. e

Grana moschata 1003 . a

Grana paradisi 101. d, g

Grana regia majora $803 . \mathrm{g}$

Granadilla (Grenadilla)

1515. $\mathrm{f}$, etc

Granatbaum 1694. a

Grauati cortex 1694. a

Granatill 606. h

*Granatuu 1694

Granny-threads 1711. h

Granny's-nightcap 133. g, 166. b

Grantogen 1493. b

GrAPE, species 2108

Grape, Bear's 176. b

Grape, False 1514. a

Grape, Hedge 320 . b

Grape, Oregon 25l. d

Grape, Rocky Mountain 251. d

Grape, Sea-(or Salt-) 1767.a

Grape, Sea-side 526 . b

Grape-fern 290

Grape-fruit 506.

Grape-root 251. d

Grape-tree 526. b

Grapewort 27. a, c

Grapnel plant 953 . a

Grapple plant 953 . a:

Grasette 1824. c

Grass 199. a

Grass, Blue-eyed 1861

Grass, Cuba 1876. a

Grass, Egyptiau 1876. a

Grass, Guinea 1876. a

Grass, Johnson 1876. a

Grass, Means' 1876. a

Grass, Sıar-eyed $18 \mathrm{r}^{*}$. a

Grass, Sweet-scented 147. a

Grass, Sweet 2 i. a

Grass-flower 1861. a, 513 . a, b 
Grass-tree 2133. b

Grass-weed 2158. a

Grass-wrack 2158. a

Grasswurzel 60. a

Grateron 863. a

Gratia Dei 914. a

*Gratiola 1350

Gratiole 914. a

Gravel-grass 863 . a

Gravel plant 754. a

Gravel-root (Indian) 802 . j

Gravel-weed 1442. a, 676. a

Graveyard-weed 803 . b

Gray-beard 514. d

Gray-beard tree 469. a

Green, Kendall \$81. a

Green, Sap 1721. d

Green-arrow 18. a

GREEN-HRIER, species 1865. $\mathrm{m}, \mathbf{n}, \mathbf{0}$

Green-Dragon 181. a

Green-sauce 1475. a, 1753. b

Green-weed 881. a

Greenheart tree 1390. c

Greenwithe 2083

Grease-wood 1783

*Greggia 1508

Grénadier 1694. a

Grenadine 664 . a

Greycles 1450 . d

Grieswurzel 4\%5. a

Grig 350, a

Grim-the-collier 1005. a

Grindelia, U. S. P. 918. a, b

Grindwurzel 1753. e

Grinsel 1831. g

Griotte 1668. g

Grip, Grip-grass 863. a, b

Gromwell, Corn 1214. a

Gromwell, Galse 1442. a

Groober (Grouber) 168. a

Groon wood 881. a

Groseille 1732. i

Grosellier 1ouge 1732. h

*Grossularia 1732

Ground-apple 14.5. c

tGround-ash 135. a, c

Ground-berry 870 . b

Ground-bread 625. a

GROUND-CHERRY, species 1578

†Ground-elder 135. a

Ground-festoon 1240, b

Ground-hele 2094. f

Ground-needle 77\%. b

Ground-nut 157. a, 1t:8. a

Ground-nut, Dwarf 1493 . c

Ground-pine 1240 . a, b

+ Ground-pine 63,1973 . a

Fround-vine 1207 a

Groundie-swallow 1s:s1. g

G 3OUNDSEL, species 1831. esp. g

Groundsel tree 226. a

Groundsel, Balsam 1831. c

Grouse-berry 870 . b

Grozet (Grosserts) 1732.i

Grundheil 2094. f

Grundy-swallow 1831. a

Grunnut 559. \&

tGrunsel 1959. a

* Guadua 232, p

Guaiac 919. a, b

*Guaiacum 1653

Guajacholz 4.19. a, b

Guallacan tree 919 . a

*Gualtheria 870
Guamuchil 1e0s, a

Guarana 1518. a

GUAVA, species 1675

Guava, Chilian 1380. e

Guaycusu 1202. b

Gujara 1530. a

Guelder-rose, Maple 2095. h

Guelder-rose, Wild 2095. (l

Guelder-rose'2095. d

Guérit-tout 539. b

Gueule de lion 151. a

Gueule de loup 151. a

Guaxima 2065. a

Gui de chêne 2105. a

*Guilandina 338. 930, 1360

Guild tree 251. e

Guilty-cup 1711. c

Guimauve 87,8

Guinea grains 101 .

Guinea-hen flower 817. c

Guinea-hen weed 1550 . a

Gulancha 2003. a

Gulf-weed 849. a

Gull-grass 863

Gumbo 1003. c

Gum, Alk 160.5. e

Gum Anime 2086. a

Gum Arabic 7. a, etc

Gum Arabic, East Indiau 826. a

Gum Arabic tree, Egyptian 7. a

Gum, Australian 7. c

Gum, Balata 1334. d

Gum, Barbary 7. a

Gum, Black-boy 2133. a

Gum, Bassora 1912. d

Gum, Butea 331. a

Guiv, Cape $7 . \mathrm{h}$

Gum, redar 417. b

Gum Chagual 1695. a

Gum Chicle 1334 d

Gum, Doctor 362. a

Gum elastic 324 a

Gum, Gedda(Jidda) 7. See (o)

Gum, Hashabi 7. under (o)

Gum Hog 1362. a

fGum, Hog 208. f

Gum, Kordofan 7.under (o)

Gum, Kuteera 1912. d

Gum, Mesquit 1664. a

fum, Mogador 7. a

Gum, Morocco 7 . a

Gum, Red 1210, b

Gum, Savakln 7. e

Gum, Sennaar (Sennari) 7 : under (o)

Gum, Suakin (Suak) $\%$ e

Gum, Sweet 1210. b

Gum Talha (Talca) 7.e

Gum, Tor 7. under (0)

Gum tragacanth 208. f. etc

Gum Tuno 1334. d

Gum, Turic 7. under (o)

Gun, Turkey 7. under (o)

Gum, Wattle 7. c

Gum, White 1210 . b

Gum plant 918,772 . a, 1937.a

Gum-top tree $790, \mathrm{bb}$

Gum-tree 790

Gum (tree), Black 1421. a, c

Gum-tree, Cotton 142t. a

Gum-tree, Grass 2133. b

Gum-tree, Red 1210. b

Gum (tree), Sour 1421. a, c

Gum (tree), Tupelo 1421. a

Gum (tree), Yellow 1421. c
Gum-wax 1210. b

Gumbo limbo 330. a

Gummi arabicum $7 . \mathrm{k}$, elc

Gummi elasticum 1001. a

Gummi-gutt 867. a

Gummi gettania 1490. a

Gummi gutta 2106. a

Gummi plasticum 1490. a

Sun-bright 758 . b

Gundelkraut (Gundling) 1994. a

Gundelreben 894. a

Gunjah (Guaza) 3\%0. a

Günsel 63. a

Günsel, goldner 63. c

Gunyang 1867. h

Guraji spice 101. e

Guranham bark 1228. c

Gurjun balsam 687. a, etc

Gurke 613. c

Guru (Gourou, Gooroo) 533. a

Gut-weed 1871. a

*Gutierrezia 2132

Gutta gamba 867. a

Gutta Garubir 1473. a

Gutta-gum tree 2106. a

Gutta percha 1490. a

Gutta-taban 1490. a

Gutter tree 576. i

Gutti 867. a

Gye 863

*Gy mnadenia 938

*Gymnopsis $1 \times 11$

*Gyninandra 1129, 2128

Gypsie-weed 1242:

Gypsophyll 955

Gypsy-combs 686 . b

Gypsy-flower 633. a

Gypsy-herb 1242. b

Gypsy wort 1242

*Gyromia 1290

Haarstrangkraut 1554. b

*Habranthus 2150

*Habzelia 2140

Hackberry 422. a

Hack-berry 16ö8. m

Hackmatac (Hackmack) 1138. a

Hackmatack 1138. a, 1099. b

Hafer-corn 221. a

Haferkümmel 615. a

Haferschlehe 1668. q

Hag-beıry 1668. m

Hag-weed 646 . b

Hagebutten 1743. a

Hagedorn 592 . a

Habnenfuss 1711. c

Hail-weed (Hair-weed) 620

Hainberry 1750. h

Hair-fern 40 . b

Hairhoof, Sweet 201. b

Hairhound 230. a

Hairif 863 . a

Hairstrong 1554. b, d

Hairy-bind 620

IIala 1495 a

Halacacabi baccae 1578 . a

Hale-bind 620

Hale-nut (Halse, Haul) 579. $c$

*Halesia 1344, 1969

*Halidrys 819

Halish 370 . a

Ha!se 2058. e

Hamamelidis folia 944 .

Hamamelis 944. a 
*Hamamelis 840

*Hamiltonia 1698

Hammerwort. 1499. b

Hanchinol 963. a

Handsome Harry 1724, a

Hanf 370 . a

Hant, canadischer 160 . b

Hanf indianischer 160 . b

Hanfnessel 861. a

Han-ye 1598. a

Hanger 1131. a

*Haplopappus 10, etc

Harbinger-of-spring 767 . a

Hard-iron 218. e

Hard-hack 539. b

Hardhack 1895. d, 1658. d

tHardhack 1472. a

Hardhack, Purple 1895. d

Hardhack, Spice 1895. c, d

Hardock 174. a, b

Hare's-bane 25. g

Hare's-beard 2090. b

Hare's-ear 327. a, 561. a

Hare's-foot 2032. c

Hare's-palace 1871. b, c

Hare's-tail 774. a

Harebell 1808. a

Harebell (Hair-bell) 362. I,

Harebur 174. a, b

Haricot 1560. e

Harif 2057. a

Harnkraut 466. b

*Harpalyce 1381

Harra (Harr nuts) 322. d

Hartberry 2075. a

Harthen 1043. b

Hart's-balls 737. a

Hart's-eye 1516. a

Hart's-thorn 17:21. d

Hart's-tongue 1814. a

Hartshorn bush 1471. b

Hartshorn-plant 1693. a

Harvest-bells 882 . g

Harvest-lice 59. a

Harz, burgunder 2. a

Haselwurz $194 \mathrm{f}$

Hasenklee 1475. a

Hasenohr 327. a

Hasenpappelkraut 1270 . c

Hasel 579

Hashish 370. a

Haskwort 362 . f

Haspen 165̄2. i

Hathorn (Haythorn) 592

Haugh-nut 168. a

Haules (Hoils) 1019

Hauslauch 1830. a

Hauswurzel 1830, a

Haver 221. a

HAw, species 592

Haw, Apple or May 592. b

Haw, Black 2095. e

†Haw, Black 324. a, 2095. c, f, g

Haw, Possum 2095. 1, 1053.c

Haw, Shawnee 2095. 1

Hawk-berry 1668. e

Hawk-feet 166. b

Hawk-nut 559. a

Hawkbit 1005

†Hawkbit 1163

Hawk's-beard 594

Hawkweed 1005

Haws 221. a

HaWTHORN, species 592

Hawthorn, Laurel 997. a

Hay-hove 894 . a
Hay-maids 804 . a

Hay-plant 201. b

Hay cocks 1205 . a

Hayo 787. a

Hazel, Black 1472. a

Hazel, Snapping 944. a

Hazel, Witch 944. a

†Hazel, Witch 1875. d, 2058, e

Hazel nut 579

Hazelwort 194. f

+He-Balsam 1587. b

He-Broom 641. a

He-Holly 1053. a

He-Huckleberry 637. a

He-Oak 405

Headache 1497. a, b, c

tHeadache 379 , c

Headache-plaot 1693. a

Headsman 1611. b

Headwark 1497. c

Heal-all 1667. a, 1820. b, c

†Heal-all 521. a, 539. b, 938 . h, 1824. h

Heal-all, High 1523. a

Heal-bite 88 . a

Heal-dog 88. a

Healing-blade 1611. c, 1830. a

Healing-herb 1937. a, 1611 d

Heart-leaf 194. c, d, e

tHeart-leaf 1291. a

Heart-of-the-earth 1667 . a

Heart-seed 380. a

Heart-weed 1641. n

Hearts 1475 . a

+Heart's-ease 1641. a, n

Heart's-ear 1641 . $n$

Heart's-pansy 2102. f

Heartsease $2102 \mathrm{f}$

Heartwort 182, 1300. b

HЕАтH (Heather) $\tau 65,350$

*Heath 1026. b, 1955. b

Heath, Black-berried 747. a

Heath, Mountain 1576

Heath-aster, White 206. c

Heath-bell 362 . b

Heaht-berry 747. a

Heather, Beach 1026. b

Heat her, False 1026. b

Heather, Monox 747. a

Heather, Silver 1649. a

Heaven ward tree 62 . b

*Hebradendron 867

Heck-berry 1668. m

Heck-how 555 a

*Hedeoma 1636

*Hedera 1514

Hederæ gummi 961. a

Hederich 1860. a

Hedge-bedstraw 863. f

Hedge-bells 56:3. a, c

Hedge-burs, Wild 863 . a

Hedge-hog 1796. a

Hedge-hyssop 1350

Hedge-maids 894. a

+Hedge-mustard 1873. 2

Hedge-nettle 1900. a

Hedge-peak 174:3. a

Hedge-picks 1668. q

Hedge-plant 2011. a

Hedge-taper 204(! b

Hedge-thorn 592. a, d

Hedge-weed 1860. a

*Hedyosmos 616

*Hedyotes 1429

*Hedyotis 1022
*Hedysarum 49, 1179, 1294 , 1679

Heideckerwurzel 1658. g

Heidelbeere 2075 . a

Heil 101. e

Heil-aller-Schaden 1775. a, 2094. $\mathrm{f}$

Heil-aller-Welt 59. a

Heiligegeistwurzel 135. a

Heilkraut 982. b

Heinrich, guter 464 . d

Helenii radix 1062 . a

*Helenium 964

Helft 65 . b

Helfringwort 63. c

*Helianthus 231, 263

*Heliosciadium 158

HELIOTROPE 973. esp. a

Heliotrope, Hardy 2077. c

Heliotrope, Summer 2077. $\mathrm{c}$

*Helipterum 968. c

Hell-bind 620

Hell-root 1459. a

Hell-weed 620,1711 . d

Helleboraster 974, a

HELLEBORE, species 974

Hellebore, American 2089. b

Hellebore, Bastard 756 . a, b, 209. a

Hellebore, Black 974 . b

tHellebore, Black 204. a

Hellebore, Big 2089. b

Hellébore blanc 2089. a

Hellebore, False 44. c

tHellebore, False 2089

Hellebore, Fetid 1883. a

Hellebore, Green 2089. b

Helléboce, noir 974 b

Hellebore, Swamp 2089. b

Hellebore, IW hite 2189. a

Hellebore, Winter 759. a

Helleborine 756. a, b

*Helleborus 567, 759

Felleborus albus 2089. a

Helm 2058. d

Helmet-flower 1821. 25

Helmet-pod 1093. a

*Helmintha 1591

Helminthochorton 1889. a

*Helminthochortus 1889

*Helogyne 1010

*Helonias 193, 455, 1907, 2089

Helxine 1499. b

Hemidesmi radix 977 a

*Hemizonia $35 t^{\circ}, 425,654$, 1013

*Hemizonella 951

HemLock, species 2046

+Hemlock 135. a

Hemlock, Creeping 1963. c

Hemlock, Dwarf 1963. c

Hemlock, Lesser 51. a

Hemlock, Mountain 2046. bo

Hemlock, Poisou 555. a

tHemlock, Poison 495. b

Hemlock, Small 51. a

HEMLOCK, WATER 495

Hemlock, Water 1427

Hemlock, Wild 495. b

Hemlock-chervil 148. a

Hemlock-spruce, False 1674

Hewlock-tree 2046 a, 1674. b

Hemlock tree, Western 2046. b

Hemony 59. a

Hemp 370. a 
Hemp, Albany 2068. a Hemp, Anerican 160. b tHemp, American 6. a tHemp, Bastard 802.c, 861.a Hemp, Bengal or Bumbay 605 . a

Hemp, Bowstring 33

+Hemp, Bowstring 354. a

Hemp, Canadian 16n. b

Hemp, Colorado 1838. a

Hemp, Indian 370. a

+Hemp, Indian 6. a

Hemp, Indian, Black 160. b

Hemp, Madras 60.5 a

Hemp, Manlla 1367. e

Hemp, New Zealand 1573. a

Hemp, Queenslaud 1847. a

Hemp, Sisal 56 . b

Hemp, Sunn 605. a

Hemp, Water 24

Hemp, Wild 95. b, 861. a

HEMP-NETTLE, species 861

Hemp-tree 2107. a

Hempwred 802. c

Hempweed, Climbing 2119.

Hen-and-chickens 248. a tHen-and-chickens 166 . b

Hen-plant 1611 . b, c

Henbane 1041

Henbane, Yellow 1578. f

Henbell 1041, b

Henbit 2:30 a

Henbit (Greater) 1132. b

Henbit, Small 2094. i

Henequen (Henequin) 56. h

Henkam 1041. b

Henna 1148. a

Hens 2102. b

Hen's-bill 1437. a

Hepatica nobilis 981 . b

Hepatica stellata 201. b

Hépatique 981. b

Herb Barbara 235. a

Heib Bennet 885. d, 2077. c

Herb Christopher 27

†Herb Christopher 260. a 886. a, 1471. b, 1691. a, 2057. a

Herb Eve 63. b

Herb frankincense 1139. a

Herb Gerard 48. a

Herb Ivy 63 . b

†Herb Ivy 578. a, 1611. a

Herb John 1043. b

Herb Louisa 1209. d

Herb mastich 1994. d, 1973. c

Herb Paris 1501. a

Herb Peter 1660, d

Herb Robert 883 . b

Herb Sherard 1940. a

Herb Sophia 1873. a

Herb Trinity 2102. f, 981. b

Herb truelove 1501. a

Herb two-pence 1249. a

Herb William 1686. a

Herb-bane 1459. a

Herb-of-friendship 1824 . f

Herb-of-grace 1756. a, 830. a, 914. a, 2091. f

Herb-of-repentance 1756 . a

Herb-of-the-cross 2091. f

Herb-of-vine 201. a

Herb-wickopy 456. a

Herba aegy ptiaca 2032. d

Herba cordialis 201. b
Herba impia 886. a

Herbe à éternuer 18. d

Herbe à fièvre 802.1

Herbe à la ouate 195. c

Herbe a l'hiroudelle 462. a

Herbe au citron 1302 . a

Herbe au diable 16:20. b, c

Herbe aux chantres 1860. a

Herbe aux charpentiers 18.a

Hex be aux gueux 514. d

Ilerbe au scorbut :27. a

Herbe aux vers 1957 . a

Herbe de Str. Barbe 235. a

Herbe parfaite 802 . i

* Herbertia 81

Herbstzeitlose 534. a

Hercules' All-heal 1447. a

Hercules'-club 170. f, 2136. e

Herehoune 2181. a

Herlitze 576 . h

Hermodactyls 534, b

Herou's-bill 777

*Herpestis 1350.

Herzfreude 201. b

Herzgespann 1165. a

Herteclow re 19:3. b

Herzwurzel 1323. a

*Hesperis 1063

*Hesperochiron 373

*Hesperopeuce 2046

* Heudelotia 550

Heusamen, griechischer 2034. a

Hexenkraut 1043. b

Hibisci radix 87 , a

*Hibiscus 1113, 1987

IIICKORY, species 1004

Hickory, Eucalyptus 790, x

Hièble 1771.

High Belia 1217. c

High-taper (Hig-taper) 2090 , b

High-water shrub 10;9. a

Hill-berry 870 . b

Hill-trot 651 , a

Hilder 1771. c, e

Hillerne 1771. e

Hillwort 1308. h, 1994. a

Himbeere 1750 . h

Himmelbrand 2090. b

Himmelschlüssel 1660. d

Hind-heal 464. e, 1957. a

Hindberry 1750. h

Hindischkraut 1867. j

Hini 1171. a

Hip tree 1743. a,g

Hippo 2062. a

Hippo, Iudian 1655. a, b

Hippo (Hipp), Wild 8 (3. a,f

*Hippocastanum 50

Hippocastani cortex 50. b

Hips 1743 a

Hipwort 586. a

* Hirneola 814

Hirschbrunsi 737. a

Hirschdorn 1721. d

Hirschklee 802 . c

Hirschtrutfle 737. a

Hilschzunge 1814. a

Hirse 1496. a

Hirtentäs shlein 329 . a

Hirundinaire 630 . b

Htrundinariae radix 630 . b

Hive-vine 1336. a, 577. c

Hoang-nan 1923.

Hoar-dock 174. a, b

Hoarhound 1281. a
Hoarhound, Bastard 230. a

Hoarhound, Black 230. a

Hoarhound, Fetid 230. a

Hoarhound Lion's-tail

1165. c

Hoarbound, Marsh 1242. b

Hnarhound, Water 1242

Hoarhound, wild 802 , b, 1,n

Hoarwort 886 , a

Hobble-bur h 2095. a

Hock (Hockboller) 87. b

Hockerie-topner 1830, a

Höckertang 849. b

Hockleberry 2075. a

Hod-the-rake 1711, h

Hog-bed 1240. b

Hog-bite 474. a

Hog-fennel 1554. b

†Hog-fennel 145. b, 1058. a

Hog-gum 1730. g

Hog-gum tree 1362 . a

Hog-nut 100 \%. c

Hog-physic 1217. a

Hog-taper 2090. b

Hogg-gum 5:8, a

Hog's-bane 464. f

Hog's-bean 1041. b

Hogweed 982. b, 411. a, 95. a, 802. d, 1174. a, 1641. d

Hohlwurzel 182. a, c, e, 372. c

Hohlzahn 861. a

Hola 590. b

*Holcus 1876

Holewort $37 \%$. c

Holigold 344. a

Holiverd 1053. a

Hollard 79

Hollicocke, (Hollek) 87. b

Hollin (Hollen, Holland) 1053. a

Hollow-root 46. a

Hollunder 1771. e

Hollunderschwanım 814, a

HoLLY, species 1053

Holly. Bay 911. a

Holly, Box 1755. a

Holly, California 997. a

Holly, Canadian 1054. a

Holly, Ground 466. b

Hully, Knee 1755. a

Holly, Mountain 1054, a

tHolly Oak 87. b

Holly, Sea 781. c

Holly, Wild 1054. a

Holly-tree 2052. b

Holly hock 87 . b

Hollyhock-rose 1825. a

Hollybock, Sea 1003 . e

Holm (Holyn) 1053. a

Holm, Knee 1755. a

Holmes'-weed 1820. c

Holy Ghost 135. a

Holy Hoke 87. b

Holy tree 1299 . b

Holy-hay 1291. d

Holy-herb 2091. f

Holy-rope 861. a

Holy-rose, Marsh 128. a

Homewort 1830. a

Honduras bark 1961. b

Honesty 1234. a

Honewort 661 f, 1859 . a

Honey (Honey-shucks) $895 . \mathrm{b}$

Honey-ball 428. a

Honey-blub 1732. i 
Honey-bloom 160, a Honey-bottle 765. c Honey-bread 432, a Honey-flower 1665. a Honey-plant 1302. a Honey-pod 1664. a Honey-stalks 2032. g Honey-sweet 2057. a HoNEYSUCKLI, species 1222 Honeysuckle 166. a, 225 Honeysuckle, Bush 676 Honeysuckle, Cape 1665. a Honeysuckle, Dwarf 576. d Honeysuckle, Ground1227.a Honeysuckle, Jamaica 1515. e

tHoneysuckle, White 2032.g Houeysuckle, Wild 871

Honey wort 863 . e

Honigthee 627

Honka 1323. a

*Honkenya 99

Hoodwort 1821. c

Hoofs 2053. a

Hoop tree 1299. b

Hoop-wood 1053. Hoopkoop plant 1179 . b

Hop 1028

Hop, Bog 1310. a

Hop, Spanish 1456. a

Hop substitute 544 b, c

Hop, Wild 260. a, 320. b

Hop-clover 2032. a, b

Hop-Hornbeam 1472

Hop-tree, 3-leaved 1681, a

Hop-vine, Devil's 1865. o

*Hopea 1938

Hopfen (Hopfenzapfen) 1028. a

Hopfen, Spanischer 1456. a

Hopfenbaum 1681. a

Hopfenkätzchen 1028. a

* Hopkirkia 1803

*Horan 1130

Horehound 1281. a

Horestrang (Horestrong) 1554. b

Horhowne 1281. a

Hornbaum 576. f

Hornbeam 390

Hornbeam, Hop- 1472

Hornbeam, Swamp 1421. c

Hornbine 1421. c

Hornmohn 892. a

Hornpine (Hornpipe) 1421.c

Hornseed 512. a

Horn-weed 433. a

Hornwort 433

Horone 1281. a

Horse-balm 539. b

Horse-bean 1504, a

Horse-blob 355. a

Horse-brier 1865 . 0

Horse-cane 95 . b.

Horse-chestnut 50. esp. b

Horse-chire 1973. b

Horse-elder 1062, a

Horse-flower 1296, a, b

Horse-foot (Horse-hoof) 2052. a

Horse-gogs 1668. b

Horse-gold 1711. c, d

Horse-gow an 482. e, 1285. a

Horse-fly weed 234. b

Horse-heal 1062. a

Horse-jag (Horse-jug)1668.h

Horse-knobs 423. d
Horse-may 2058. d

Horse-nettle 1867. i

Horse-pipe 758. a, b

Horse-sugar 1938. a

Horse-tongue 1755. a

Horse's-breath 1439. a

Horsebane 1427. c

HoRSEMINT, species 1348

tHorsemint 1111. a, 1308. i

Horsemint, European 1308.f

Horsemint, Ohio 270

Horsemint, Sweet 616. a

Horseradish 1742. a

Horseradish tree 1360, a

Horse tail 758

Horsetail, Shrubby 752

Horseweed 11\%4. a, 1125. a

Horse-weed 95 . b, 539. b

tHorsc-weed 1895. d

Hosedoup 1318, a

*Hosta 851

Houblon 1028. a

Hound's-berry 1867. o

Hound's-tongue 633. a, 2035. a

House-leek, Dwarf 1824. b

Houx 1053. a

Houx petit 1755. a

Hove 894, a

How-weed 423. d

How doup 1318. a

Howler 79

Huajilo 1608. c

Huanuco bark 498. c, d

HuCkLeberRy, species 873,2075

Huflattig 2053 a

Hühnerkraut 1994. a

Huisache 7. d

Huldee 619.

Hulver (Helver) 1053. a

Hulver, Knee 1755. a

Hulver, Sea 781. c

Humble-plant 1332. b

Humlock 1378. a

Humility 1792. a

Hundred-eyes 2100, a, b

Hundskohl 160. b

Hundskurbis 320 . b

Hundspetersilie 51. a

Hundsrose 1743, a

Hundszunge 633. a

Hungarian-grass 447. a

Hungerkorn 512. a

Hunger-weed 1711. d

Hungry-vine 1865. o

Huntsman's-cup 1787. b

Huntsman's-horn 1787. a

Hurr-bur 174, a, b

Hurt-sickle 423. d

Hurtleberry (Hurtberry) 2075. a

Husks 432, a

Husk wort 68 . a

Hütscheln 1771. e

Hutton-weed 686. b

Hyacinth, California 311

Hyacinth, Cape 1808

Hyacinth, Feather 1368.b

Hyacinth, Globe 1368. a

Hyacinth, Grape 1368

Hyacinth, Water 1586, a

Hyacinth, Wild 1701. a

tHyacinth. Wild 262. a

*Hyacinthis 1368

*Hyænachne 2010

*Hyænanche 2010
Hya-hya 1946. a

Hyawa tree 1666. b

*Hyduocarpus 934

Hydrangea, Wild 1031. a

*Hydrastis 2018

*Hydrocotyle 424

Hydrocotyle asiatica 424 . a

Hydrolapathi radix 1753.

*Hydrolea 1383

*Hydropeltis 302

Hydropiper 1641 . 0

Hylder 1771. e

*Hymenæa 2013

*Hymenatherum 1993

*Hymenolobus 1030

*Hymenoxys 1589

*Hyoseyamus 1817

*Hypelate 817

*Hypericum 911, 1786, 20:22

Hyperulc-wood 338 . b

*Ȟypogon 539

*Hypopeltis 2125

*Hyposeris 45, 184

*Hyptis 1317

Hysope 1048. a

Hyssop 1048

+Hyssop 1043. b

Hyssop, Anise 54. a

Hyssop, Giant 54

Hyssop, Hedge 914. a, c, 1350

*Hyssop, Mexican 1769. a

Hyssop of Scripture $374 \mathrm{c}$

Hyssop, Prairie 1111. b

*Hyssup, Wild 2091. c

*Hyseopifolia 1250

*Hysterophorus 1513. a

Iberiskresse 1168. d

Ice-leaf 2090 b

Ice-plant 1316. a

Ico-plant, American 1356. a

*Icica 330, 1666

*Ictodes 1883

Ie-länger-ie-lieber 2102, f

If commun 1963. a

*Ignatia (Ignatiana) 1923

Ignatia Bean 1923. b

Ignatii faba 1923. b

Ignatiusbohne 1923. b

Ignazbohne 1923. b

Ikaju 1923. h

Illecebra vermicularis 1824. a

Illinois-nut $1004 . \mathrm{h}$

*Illipe 240.

Illupi 240 . c

Imbreke 1830. a

Immerschön 904

Immortelle 96y, 904

Immortellen 144. a

Impératoire 1058. a

Imperatoria nigra 209. a

Imphee 1976. b

Impudent-law yer 1205 . a

Incense 62. c, 289. a, d. 1053 . c, 1929. d, 2086. a

Incense tree 822 . a, 2026. b

Incense-wood 1666. b

India-berries 127. a

India-rubber 404.a, b, 831 b, $946,1001,1276$. a

India-rubber African 1133. a, b

Indian bark 1262 . f

Indian dye 1032. a

Indian Hemp 370. a

†Indian Hemp 160. a 
Indian Hemp, Black 160. b

Indian Hemp, Brown 1003. b Indian Hemp, White 195. b

Indian-chief 693 . a

Indian-cigar 406

INDIA I-CUP, species 1787

Indian-cup 1852. b

Indian-guin nut 1923. $\theta$

Indian-fog 1824. b

Indian-head 380 . a

Indian-heart 1238 . b

Indian-moccasin 636. a, etc

Indian-paint 1214. b, 273. a

Indian-paint, Red 1773. a

Indian-paint, Yellow 1032.a

Indian-physic 1262. c

Indian-pipe 1356. a

Indian-pitcher 1787 . b

Indian-posy 121, a. 904, a

Indian-root 170 . e

Indian-shoe 636. $a$, etc

Indian-shot 369

Indian's-dream 1527. a

Indian's-plume 1348. a

Indicator 290 . b

Indicum (Pigmentum) 1059. a

Indig 1059. a

IND1GO, species 1059

Indigo $1071 . b, 2127$. $a$, etc

Indigo, American 23t. b

Indigo, Bastard 103, b

Indigo, Blue 234. a

Indigo, Egyptian 590. a

Indigo, False 103, 234. a

Indigo, Green. 1721. e, f

Indigo sauvage 234. b

Inciigo, Yellow 234. b

Indigo, Wild 233. esp. b

Indigo-berry 1710. a

Indigo-plaut, Japanese 1611. $p$

Indigo-weed 234. b

*Infantea 94

Infant's-breath 863 . f

*Inga 1608

Ingwer 2152. a

Ingwer gelber 619. c, d

Ingwer, indischer 194. \&

Ink-berry 1053. i, 1710. a

Ink-nut 322 . d

Ink-root 1202, a

Inkwood $81 \%$. a

Inée (Ineh) 1919. a

Innocence 538, a, 1022, a

Insane root, 1041 . b

Insect-pow der, Dalmatian 482

Insect-powder, Persian 482 . b. c

'Inty bi angusti herba 1125 . f

Inul 1062,

*Inula 488, 1691

*Iochroma 1287

*Ionidium 343

Ipado 787. a

Ipecac (Ipecacuanha) 2062.a

Ipecac, American 1655. a, 803. f

Ipecac, Bastard 196, a, 2037. a

Ipecac, Black 1680 . a Ipecac, Carolina 803, f

Ipecac, False 1655. a, b

Ipecac, Goanese 1387. a

Ipecac, Indian 2054. a

Ipecac, Malabar 1710 . b
Ipecac, Milk 803. a, f, 160. a Ipecac, Peruvian 1680. a

Ipecac, Spurge 803. f

Ipecac, Striated 1680, a

Ipecac, White 803. f, 343. a

Ipecac, Wild 160. a, 803. f, 2037. a

Ipecac, Wood 2037. a

*Ipecacuanha 2062

Ipécacuanha annelé 2062. a

Ipecacuanha, Farinaceous 1733. a

Ipecacuanba, Striated 1733

Ipecacuanha, Undulated 1733. a

Ipekakuanhe 2062. a

*Ipo 1.50

*Ipomoea 815, 1256, 1444, 1702

*Iridaps 188

Iridis (Ireos) radix 1058. a, b, c

Iris de Florence 1068, a, b,

Irisrhizom 1068, a, b, c

Iron-bark 790. d, b

Iron-grass 1641. $d$

Iron-head 423. d

Iron-tree 1321. c

IRONWEED, species 2093

tIron-weed 423. d, 2091. c

Ironweed, Deril's 1125. a,

Ironwood 390 . a, 1472. a, 324. b, 405. a, 637. a, 817. a, 1433. a

+Ironwood 519. a. 1245

Ironurood 326

Ironwood, Bastard 2136. f

Ironwood, Black 553, 1720.a

Ironwood, Red 1719. a

Iron wood, White 1042

Iron wort 861. a

Irupe 2097. a

Isabella-wood 1546, a

Isenkraut 2091. f

Islay 1668. s

Isle-of-Wight vine 1956. a

*Isonandra 1490

Isop 1048. a

*Isopy rum 567

Ispaghul 1611. e

It-brings-the-frost 206

Itaka 1253. a

Itch-weed 2089. b

Iva $18, \mathrm{~b}, \mathrm{f}, \mathrm{g}$

Irette 63 . a

Irette musquée 63 . b

Ivory, Vegetable 1584. a

Ivory-nut 1584. a

Ivory-tree 2127. a

Ivy (Irory) 961. a

Ivy, American 1514, a

Ivy, Big-leaved 1103. d

I $\mathbf{y}$, Cape 1831. i

Iry, Climbing 1730. h

Iry, Coliseum 629. a

Ivy, English, etc. 961. a

Ivy, Five-fingered 1514. a

Ivy, Five-leaved 1514. a

Ivy, German 1331. i

Ivy, Gout 63. b

Ivy, Grouud 894, 63. a, b

Ivy, Herb 63. b

Iry, Japanese 1514. b

Ivy, Keuilworlh 629. a

Ivy, Poison 1 $130 . \mathrm{h}$

Ivy, Spoonwood 1103. a

Ivy, Three-leaved $1730 . \mathrm{h}$
Ivy-berry $870 . \mathrm{b}$

Ivy-bush 1103 . d

Ivy-flower 981. b

Ivy-weed 629 . a

Ivray (Ivraie) 1220. a

*Ixia 879,1394

*Ixophorus 447

JABORANDI, species 1593

†Jaboraudi 780 . a, 1602. d.e.f

Jahorandi, True 1602. c

Jaceae herba 2102. f

*Jacaranda 1880

Jacaranda branca 1880. a

Jachandel 1099. b

Jack (Jaca, Jak) tree 188. b

Jack-by-the-hedge 74 . a, 2016. b

Jack-in-the-pulpit 181. b

Jack-in-trouser's 166. a

Jack-jump-about 48, a, 135. a, 1227. a

Jack-of-the-buttery 1824. a

Jack-straws 1611 . b

Jackanapes-on-horseback 341. a

Jackson vine 1237. e

*Jacksonia 1633

Jacob's-chariot 25.1

Jacob's-ladder 1634. a, b, c, 1639. c

fJacob's-ladder 219. a,421.a, 462. a, 1205. a

Jacob's-ladder, American 1865. d

Jacob's-staff 2090. b

Jacob's-sw ord 1068. e

*Jacobinia 249

Jacobskraut 1831.g

Jägermütze $1787 . b$

Jaggery 178. a, 285. a, 394. a, 1570 . c

Jalap 815 . a

Jalap, Cancer 1585 b

Jalap, False 1335, a

Jalap, Fusiform 1066.

Jalap, Indian 1441. a

Jalap, Male 1066. 1

Jalap, Sierra Gordo 1066. m

Jalap, Tampico 1(66. m

Jalap, tubéreux 815. a

Jalap, Wild 1066. n

Jalap, Woody 1066. I

Jalap-stalks 1066.1

Jalapa, U. S. P. 815 . a

Jalape, Falsche 1066. I

Jalapenkuollen 815 . a

Jalapenstengel 1066. 1

Jamaica 1003. g

Jamaica bark 816 . b, 20. \&

Ja nıajka-Quassia 1590. a

Jambosade (Jambu) 1086. a

*Jamesia 733

Jamestown-weed 619. b, c

*Janipha 1:76

Jarosse $1141 . \mathrm{h}, 1$

Jaroul $1127 . \mathrm{b}$

Jarrah 790.

Tarvil, Sweet 2115. a; b

Jasmin, gelber 878. a

Jasminbignonic 878. a

JASMrNE, species 1089

Jasmine, Aunerican 1702. \&

Jasmine, Bastard 123\%. c

Jasmiue, Blue 514. a

Jasmine, Cape 868. c

Jasmine, Carolina 878, a

Jasmine, Frencb 354 . b 
Jasmine, Red 1621. a

Jasmine, Wild 1081

Jasmine, Yellow 878. a

Jasmine tree 1621. a

Jatamansi 1386. a

*Jatropha 69. a, 618, 1001, 1276

Jaundice-berry 251. $\theta$

Jaundice root 1032 . a

Javanee 1690, a

Javilla 1029. a

Jay-weed 145. b

Jealousy 1824. i

Jeelico 135. esp. a

Jelly plant 793 . a

Jenny-wren 883. b

Jequiriti 4. a

Jérose hygrometrique 122 .a Jerubeba 1867. r

Jerusalem-cross 1236. b

Jerusalem-star 2016. a

Jeshamy 1089. a

Jessamin (Jessamy) 1089. a

Jessamin, see Jasmine

†Jessamine 1237. c

Jessamine, Cape 868 . c

Jessamine, Water 914. b

†Jessamine, Wild 133. g

Jestuitenthee 1053. e

†Jesuit's bark 1079. a

Jesuit's-nut 2017. a

Jew bush 1524. a

Jew's-ear 814. a

†Jew's-ear 1239. a

Jewelweed 1057. a, d

Jewsharp-plant 2036, a

Jimson-weed 649. b, c

Jinshang 1493 . b

Jintawan 2063. a, b

Joan Silver-pin 1497. d

Jobarbe (Jubard) 1830. a

Job's-tears 532. a

tJob's-tears $20 \% 6$. a

Job's-tears, Wild 1442. a

Joe wood 1085. a

Joe-Pye weed 802. j, k

Johandel 1099. b

Johannisbeere 1732. k

Johannisblut 1043 . b

Johannisbrod 432. a

Johanniskraut 1043 . b

Johanniswurzel 712. b

John-Crow beans 4. a

John-go-to-bed-at-noon 116. a, 1458. a

Johnny-jump 693. a

Johnny-jump-up 2102. c, $\theta$

Johnny-jumper 2102. f

Johuny-smoker 885 . a

JoHNswoRT, species 1043

Johnswort, fialse 1786. a

Joint-vetch 49

Joint-weed 1008. a

Joint-weed, Coast 1640, a

*Joliffia 106

*Jonesia 1782

Jonquil 1385. b

*Jonquilla 1385

Joseph-and-Mary 169. a

Jose $\rho$ 's-coat 91 . b

Joseph's-flower 2016, b

Joshua-tree.2144. b

Joubarbe acre 1824. a

Joubarbe des vignes 1824. c

Joubarbe grande 1830 . a

Jove's fruit $681 . \theta, 250$. b

Jove's nuts 1704. q
Juba's-bush (Juba's-brush) 1067. a

Judas tree 436

$+J u d a s$ tree 1771. e

Judasbaum 436. b

Judasohr 814. a

Judendorn 2155. c

Judenkirschen 1578. a

Juglandis folia 1096 . d

*Juglans 1004, 69. at

Juice-root (Juicewood) 902. b

*Jujuba 2155

Jujubae gallicae (Magnae) 2155. $\mathrm{c}$

Jujube, French 2155. c Jujube, Italian 2155. b

Jujube tree 2155 . c

Jujubier 2155 . c

July-flower 1664. a

Jumble-beads 4, a

June-berry 96

June-flower 2102. b

Jungfernkraut $18 \%$, s

Juniper 1099

†Juniper 453. a, 1138. a, 1587. b

Juniper, Creeping 1963. c

Juniper resin 349 . a

†Juniper tree 422 . a

Juno's-tears 2091. f

Jupiter's-beard 1830. a,149.a

Jupiter's-distaff 1568. c

Jur-nut 559. a

Juribali 1106, a

Juribali (Jurubali) 2026. b

tJuribali 1879. a

Jusquiame noir 1041. b

*Jussieua 1100

Justice-weed 802 . g, h

*Justicia 39, 127, 665

Jute 569. a, b

Jute, American 6, a

Jute, Bastard 1003. b

Juvia tree 25i. a

Kaddi 1099 b

Kadeöl (Kaddigöl) 1099. c

Kaffee 531. a

Kafir-bread 749. a

Kainkawurzel 467. a

Kaisersalat 187. e

Kaiserwurz 1058. a

Kakaobohnen 1984, a

Kakarali 1152, a

Kaladana 1066. i

Kalkas 541. a

Kale, Coru 303. a

Kale, Field 303. a

Kale, Sea 303. $\theta$

*Kali 1767

Kalisay achina 498. a

*Kalliactis 231

Kalmus 26. a

Kalo 541. a

Kala 7. d

Kamala 1267. a

Kamani 322. c, 853. a

Kambodja 1621. b

Kamela (Kameela) 1267. a

Kamila 1267. a

Kamille, römische 145 . c

Kamillen 1285, a

Kampfer 500. b

Kanbil 1267. a

Kaneel 500 . a

Kaneel, weisser 368. a

Kapa 316. a
Kapper 374.

Kardamom 742, a

Kariyat 127. a

Karobe 432. a

Karra-doorn 7 . h

Karri tree 790 . m

Kars i Karse) 1742 . b

Karse, Garden 1168. $\theta$

Kartoffle 1867. n

Käsekraut 1270. a

Käsepappel 1270 , b

Kaskarill rinde 606 . b

Kastanienbaum 400

Katchung oil 168. a

Katechu 7. b

Kathira gum 528, a

Katir 703. b

Katzengamander 1973. 乞

Katzenkraut 1399. a

Katzenminze 1399. a

Katzenpfotchen 144. a, 904

Katzentraublein 1824. a

Kauri Pine 55. a

Kautschuk 1001. a

Kavakava (Kava) 1320. a, b

Kedlock 1856.

Kedlock (Kellock, Kilk) 303. a

* Kedrostis 320 . c

*Keerlia 155, 293

Keeslip 863. i

Kei (Kai) Apple 701. a

Kekune oil 69 . a

Kellerhals 644 . c.

Kellup-weed 482. $\theta$

†Kelp 1420. a

Kelpware 849

Kelpwort 1767. a

Kemp (Kempseed) 1611.b,o

*Kentrophyta 1017

Keora oil 1495. a

Kerbel 148. b

Kerlock 303. a, d

Kermesbeere 1585. b

Kernelwort 1820 . b, c

Kerzennussbaum 69. a

Kesselbeere 1476. b

Ketgee oil 1495. a

Ketmia, Bladder 1003. i

Ketmie acide 1003 . g

Kettle-case 1450. d

Kettle-dock 148. c

*Keura 1495

Keuschlamm 2107. a

Khat (Kât) 408. a

Khuskhus 129 . $f$

Kicking-colt 1057. d

Kicking-horses 1057. d

Kidney-bean tree 1115 . a

Kiduey-root 226. b

Kidney Vetch 149

Kidney wort 686 . a

Kikar 7.8

Kikuel oil 1768. a

Kill-kid 1103. a

Kill-wart 462 , a

Killeen 477. a

Killikinic 576, b, i, 176. \&

King-cup 1711. c

†King-cups 355. \&

Kiug-devil 1005. $g$

King-nut 1004. a, d,

King-of-the-meadow $802 . j$

Kings-aud-queens 189. a

King's-crown 1300 . b

King's-cure 466 b

*Kinkina 498 
Kinnikinic 576. b. i, 176. f

Kino, African $1682 \mathrm{~b}$

Kino, Amboyna 1682. c

Kino, Australian 790. e, f. $\mathrm{g}, \mathrm{h}$

Kino, Bengal 331 . a

Kino, Botany Bay 790. e, $\mathrm{f}, \mathrm{g}, \mathrm{h}$

Kino, Brazilian 827. a

Kino, Caracas 526. b

Kino de l'Inde 1682. c

Kino, Gambia 1682. b

Kino, Jamaica 526. b

Kino, Palas 331. a

Kino tree 1682. e

Kino, West Indian 526. b

Kipper-nut 559. a

Kiroche 1668. c

Kirschlorbeer 1668. i

Kiskatom 1004

Kisky-Thomas nut 1004

Kiss-me-quick $803 \mathrm{~b}$

Kiss-me-quick-and-go 187. a

Kisses (Kiss-me, 2102 f

Kit-of-the-wall $182 t$, a

Kitten's-breeches 262 . b

Klapperrose 1497. c

Klapperschlangenwurzel 497. $a$

Klatschrose 1497. c

Klebkraut 863. a

Kleebaum 1681. \&

*Kleinia 1092

Kletten wurzel 174. a

Knackaway 734

Knap 2032. f

tKnap-bottle 1851. b

Knapweed 423. b

tKnapweed 423.c

Knauel, wilde is10. a

*Knautia $17 y 4$

Knawel 1810. a

Knight-cross 1296 . b

Knight's-spur 656. c

Knit-bac:k 1937. a

Knob.grass 539. b

Knob-root 539. b

Knoblauch 76 . $\Theta$

Knoblauchkraut 74 .

Knobweed 423. d, 539. b

Knop-sedge 1881

Knorpeltaug 4 47 . a

Knot-berry (Knout-berry) $1750 \mathrm{f}$

Knot-grass 1541. d

tKnot-grass 1506

Knot-grass, Female 1008. a

Knot-grass, Germau 1810. a

Kuot-gra+s, Male 1641. d

Knot-root $539 . \mathrm{b}$

Knoten wurz 1820. b

Kuöterich 1641. e

KNOTWEED, species 1641

Knotweed, Bitiug 1641. I

Knotwort 1641. d

Kockelskörner 117. a

*Koenigia 1254

Kohl 303. -

Kohl rabi 303 e

Kohlbaumrinde 2110. b, c

Kublsaatsöl 313. b

Kokuspalm 52y. b

Kokum butter 867 . b

Kola 533. a

Kolikwurzel 160 .

Kol', mbowurzel 1090. a

Kolequinten 50.5. b
Kombé 1919. a

Königschina 498. a

Königen der Nacht 438. a

Königsfarrn 1471. b

Königukerze 2090. b

Kouker tree 50 . b

Koontee 2145. a

Koosumbia 1804. a

Koot (Koost) 1791. a

Körbelkraut 1378. a

Koriandersamen 573, a

Kornblume 423 , c

Kornel 576. b, 1

Kornelkirsche 576 . h

Kousso (Kooso, Kusso) 941. 8

Kraftwurzel 1493. a, b

Kiahenaugen 19.23, d

Kranieria, U. S. P. 1114. c, $\theta$

Kramperlthee 442 . a

Krampf 2057. a

Kianewett 1099. b

Kranichbeere 1476. b

Krapp 1749. a

Kratzbohnen 1365. a

Krätzwurzel 2089. a

Krausdistel 781. b

Krauselbeere 1732. 1

Krauseminze 1308 d

Kraut-weed 303. a, 1712. a

Krebsdistel 1440. a

Krebswurz 1170. 2

Kreuzblume 1638. a

Kreuzdorn 1721. d

Kreuzkraut 1831. $\mathrm{g}$

Kreuzwurz 1638. \&

Kriechenpflaume 1668. q

* Krigia 1835

Kronanauas 119. a

Kronchina 498. $\boldsymbol{i}$

Kronsbeere 2075 . p

Kropfklette 2131. b

K ropf wurzkraut 1820 . b

Krummholzöl 1601. m

*Krynitzkia 77, 608, 764, 1453

* Ḱtenospermum 1522

Kubeben 611. a

Kuchenschelle 1693 . b

Kubhornsamen 2034. a

Kuhkrätze 1365. a

Kukui 69. a

Kümmel, Romischer 615. a

Kümmelsanen 392 . b

Kundah 378. b

Kürbis 1126. a

Kürbissamen 614. d

Kurkuma 619. c, d

Kurung (Kurunj) 859. a

Kuskus 129. f

Kuteera gum 1912. d

Kutera gum 528. a

Labdanum (Ladanum) 503

Labkraut 863.1

*Lablaria 1121

Laburnum 641. a

* Laburnum $6 \$ 1$

Laburnum, White 1738. a

Laburnum, Wild 1300. b

Lac (Lacca, Lack) 7. a, f, 331. a, 606. a, 831. c, e, f, $\mathrm{g}, 1841 . \mathrm{b}$

Lac tree 1804 . a

Lacea musica 1150 . b

Iace-bark tree 1128.

Lace-bution 768. a

Lace-Fern 461 . 2
Lace-flower 651. a

Lace-leaf 164. a

Lace-pod 1996

Lachenknoblauch 1973. e

*Lachnanthus 937

Lacuius 1150 . b

Lacquer tree 1730. o

Lactucarium 1125. d, f, g

Lad-savour 187. \&

Ladder-to-heaven 1634, a, 1639. c

Ladies'-bower 514. d

Ladies'-cushion 1903. a

Ladies'-eardrop 1057. d

Ladies'-glove 677. a:

Ladies'-laces 1559.

Ladies' mantle 65

Ladies'-nlghteap 563. c

Ladies'-pocket 1057. d

LADIKS-SLIPPER, species 636

†Ladies'-slipper 1638 . c

Ladies'slipper, Wild 1057. a, d

Ladies' thimble 677. a

Ladies'-tresses 936

Lady-fingers $67 \%$. a

Lady-by-the-gate 1781. a

Lady-never-fade 121. a

Lady-wrack 849. b

Lady's-comb 1796. a

Lady's-cushion 423. d

Lady's-delight $210 \%$. f

Lady's-fingers 149. a,1141.d, 1227. a

Lady's-garters $1750 . \mathrm{g}$

Lady's-glove 1062. b, 1227. a

Lady's-hair 40. a

Lady's-keys 1660, d

Lady's-liut 83. b

Lady's-mantle 65

Lady's-milk 1280, a

Lady's-needlework 411. a

Lady's-purse 329 . a

Lady's-ruffles 833

Lady's-seal 1639. c,d, 1956.8

Lady's-shoes 166. b

Lady's-shoes-and stockings 1227.

Lady's-slipper 122\%. "

tLady's-slippers 166. b

Lady's-smock 379. c

Lady's-thimble 36\%. b

*Lagophylla 1016

*Lagotbamnus 1968

Laiche 382 . a

Laiteron 1871 . b

Laitue officinal 1125. d

Laitue vireuse 1125. f

Lake-weed 16 11. b

Lakmos 1150. b

Lakritzenholz 902. b

Lamb-lakins 189. \&

Lawb-lily 2007. a

Lamb-succory 184

Lamb-sucklings 2032 . g

Lamb's-foot 1611 . c, 65 . b

Lamb's-lettuce 161i. d

Lamb's-quarters 464.a,218.e

tLamb's-quarters 2035. a

tamb's-tail 1240. a, 1764. e

Lamb's-tongue 785. b, 1308. a, 1611. d, 1814.a

Lamb's-toes 149 . a

Lamier 1132. a

Laminaire digitee 1131. a

- Lamium 1939 
Lammint 1308. g, j

Lampourde 2131. b

Lampwick 1568. c

Lana gossy pii 912. c

Lanariæ radix 1935 . b

Lang-de-beef 284. a

Langue de boeuf (Langdebeef) 1591. b

Langue de chien 633. a Lantar (Lontar) Palm 1\%8.a Lantern-leaves 1711. h Lanugo gossypii 912. c Lap-love 563. a

Lapathi radix 1753 . $\theta$

*Laportea 2068

*Lappa 174

Lappa, U. S. P. 174. a, b

Lappula hepatica 59 . a

Lapper-gowan 2043. a

Laque 606. a

Laque bleu 1150 . b

LARCH, species 1138

tLarch 2 e

Lärcheurinde 1138. b

Lärchenschwamm 1644. d

Laricis cortex 1138. b

Lark-heel 656 . c

Lark's-claw 656. c

†Lark's-heel 2044. a

LARKSPUR, species 656

tLarkspur 1205. a

Larrabell 968. a

*Larrea 588

Laser 1139. a

Laser (cyreniacum) 1978. b

Laserkraut 1139. a

Laserpitium germanicum 1190. a

Laserwort 1139

Latherwort 1781. a

Lathyris major $803 . \mathrm{g}$

Latschenöl 1601. m

Lattice-leaf 164. \&

Lauch 76. d

Laurel, Alexandrian 353. a

Laurel, American 1103. d

Laurel, Bay 1144. a

Laurel, Big 1728. d

Laurel, Big-leaf 1728. d

Laurel, Black 911. a

Laurel, Califoruia 2059. a

Laurel, Camphor 500 . b

Laurel, Cherry- 1668. f, i

Laurel, Copse 644. b

Laurel, Deer 1728. d

Laurel, Dog 1189. a

Laurel, Dwarf 1103. a

Laurel, Florida 1938. a

Laurel, Great 1728. d

Laurel, Ground 754. a

Laurel, Hairy 1103. c

Laurel, Horse 1728. d

Laurel, Lady 644. b

Laurel, Mountain 1103. d 1728. d

tLaurel, Mountain 2059. a

Laurel, Noble 1144. a

Laurel, Pale 11(3. b

Laurel, Rose 1728. d, 1103.d, 1403. a

Laurel, Sasıafras 2059. a

Laurel, Sheep 1103. a, b

Laurel, Small 1103. d, 1262.f

Laurel, Spurge 644. b, 1103.d

Laurel, Swamp 911.a, 1103.b, 1262. b

Laurel, Sweet 1055. a
Laurel, White 1262. f

Laure', Winter 1668. f

Laurel, Wood 644. b, 1103. d

Laurestine 2095. n

Laurier commun 1144. a

Laurier rose 1403. a

Laurier-benzoin 250. a

Laurier-cerise 1668. i

Laurocerasus 1668. i

Laurose 1403. a

*Laurus 250, 500, 1266, 1424 , 1546,1788

Laus-tibi 1385 . $\theta$

Laüsekörneı 193. a,656. d

Läusekraut 1523

Laüsepfeffer 656. d

Laüsesamen 193, a

Lavande cominune 1145. a

Lavande officinale 1145. a

Lavande triste 1202 . c

Lavandel 1145. a

LAVENDER, species 1145

†Lavender 482. \&

Lavender, Sea 1202. a, c

Laveuder-thrift 1202 . a

Laverocks 1475, a

Lavola bark 1055. c

Lavose 1190.8

Lawyers 1743.

*Layia 269

Laylock 1945

Lead plant 103. a

LEADWORT, species 1620

LEAF-CUP, species 1642

Leather-bush 689. a

Leather-flower $514 . \mathrm{g}, \mathrm{h}$

Leather-jacket $790 . \mathrm{x}$

Leather-leaf 454 . \&

Leatherwood 689,637

Lebensbaum 1992. b

Leberblume 981. b

Leberklette 59 .

Leberkraut 981. b

Leche de popa 1334, d

Lectiminga 1959. \&

Lechee 1400 . b

Leechwort 1611. b

Leek 76. d

Leek, Crow 1808. a

Leek, french 76. d

Leek, Sour 1753. b

Leek, Threo-seeded 76. $\mathrm{g}$

Leek, Wild 76. g, h

Lédon 1153. b

Lehua 1321. a

*Leighia 966

Leindotter 361 . \&

Leinkraut 1205. a

Leiusamen 1208. b

*Leiophyllum 657

*Lemna 1896

Lemou 506. e, i, h

Lemon, Ground 1625. a

Lemon Monarda 1348. c

Lemon, Persian 1201. a

Lemon, Vegetable 613. a

Lemon, Wild 1625. a

Lemon-grass 129 . b, d

*Lemotrys 1701

Leng 2017. b

Lentil 1160. a

Lentisk (Lentiscus) 1605. a

*Leontice 413

*Leontodon $153,1862,1959$

Leopard tree 835 . a

Leopard's-bane 183

tLeopards'-bane 1501. a
Leopard-flower 879. a

*Lepachys 1713

*Lepidanthus 126

*Lepidium 1030

*Lepigonum 2005

Leptandra, U. S. P. 1171. a

*Leptanthus 993

*Leptocaulis 156,1886

*Leptoclinium 866

*Leptoglottis 1361

*Leptoseris 1265

*Lepuraudra 150

Lerchenklaue 656. c

LETTUCE, species 1120

Lettuce, Canker 1696. d

Lettuce, Hare's 1871. b, c

Lettuce, Iudian 1696. d, 844, a, 513. e

Lettuce, Lamb's 2078. a, b, 1611. d

Lettuce, Liverwort 1696. d

Lettuce, Spanish 513. e

Lettuce, Water 1606. a

Lettuce, White 1381. a, b, c

Lettuce, Wild 1125. a, f

tLettuce, Wild 1696. d

*Leucanthemur 482

*Leucopsidium 155

*Leucosinapis 1856

Levant-nut 117. a

Lever-wood (Leaver-wood) 689. a, 1472. $a_{4}^{\mathrm{a}}$

Levers 1881

Levose 1190. a

*Lewisia 1452

Iewte 1439. a

Liane à l'ail 265. a

*Liatris 388, 866, 1124, 2035

*Libanotis 212

Libi-dibi (Libi-divi) 338. a

*Libidibia 338

*Licaria 674

*Licheu 442

Lichen, Archil 1150, 1739. a, b

Lichen I' Islande 442 a

Lichen, Manna, 1150. a

Lichwale 1214. a, c

Lichwort 1499. a

Lickorice (Lickerice) y02. b

LICORICE, species 902

Licorice Indiau 4. a

Licorice, Wild 863. c, d, 4. a, 208. e

thicorice, Wild 170.c, 1439. a

Licorice-weed 1816. a

Lide-lily 138.5. a

Lieber'sche Kräuter 861. b

Liebfrauenstroh 863 . i

Liebstöckel $11 \subseteq 0$. a

Lief (Liff) 1232. a

Lierre terrestre 894. a

Life-everlasting 904 . a

*Life-everlasting 121. a

Life-of-man 170. e, 676. a, 1824. c

Life-plant 321 . a

Life-root 1831. a

†Light-wood 7 . i

Lign-aloes 165. a, 674. a

tLign-aloes 813. a

Ligu-aloes, Mexican 330 . b

Lignum benedictum 919.a, b

Lignum campechianum 940. a

Lignum coeruleum 940. a 
Lignum mascarum 1590. a

Lignum muscicidum 1590.a Lignum nephriticum 1360.a Lignum pavanum 1788. a Lignum savetum $919, a, b$ Lignum vitae 919 . a, b +Lignum vitae 2107 . b Liguum vitae, Australiau 790. $\mathrm{v}$

Ligustici radix 1190. a

LrLAC, species 1945

Lilac, African 1299. b

Lilac, California 415 . c

Lilac, Indian 1127. c, 1299. b

Lilac, Summer 990. a

Lilac tree 1299. b

Lilac, Victorian 950, a

Lillie-riall 1308. h

LrLY, species 1196

tLily 597

Lily, African 2147, a

Lily, Atamasco 2150. a

Lily, Beaver 1420. a

Lily, Belladonna 92. a

Lily, Blackberry 879. a

Lily, Bull-head 1420. a

Lily, Butterfly 351. c

Lily, Calla 2i47. a

Lily, Chinese Sacred 1385. f

Lily, clinton's 5:1. a

Lily, Corn- 563. a

Lily, Cow 1420. a

Lily, Daffodel 2150. a

LILY, DAY, species 851

Lily, Day 976

Lily, Dog 1420. a

tLily, Easter 1385. a, 2150, a

Lily, Ethiopian 2147. a

Lily, Fairy 2150. a

Lily, Flag 1068. g

Lily, Flax 1573. a

Lily, Frog 1420, a

Lily, Great Yellow 1391. a

Lily, Green 817. a

Lily, Ground 2036. a

Lily, Gunebo 1309. a

Lily, Hedge- 563. c

Lily, Horse 1420. a

Lily, Jamestown 649. b, c

Lily, Lamb 2007. a

Lily, Lemon 976. b

Lily, Liver 1068. $\mathrm{g}$

Lily, Lotus 1391

Lily, Mariposa 351. c

Lily, May ธ62. a

Lily, Mound 2144. d

Lily, Newyears 1s 85 . f

Lily, Nortbern 521. a

Lily, Park 562. a

Lily, Plantain 851. b

LILY, POND, species 399.1420

Lily, Prairie 564, 1309. a

Lily, Rush 1861. a

Lily, Snake 1068. g

Lily, Spider 1037

tilly, Spider 2014. a

Lily, Spring 785. a

Lily, Straw 2073. b

Lily, Swamp 2150. a

Lily, Toad 399 b, c, 513. d

Lily, Trinity 2036. c

Lily, Trout 785 . b

Lily, Trumpet 214: a

Lily, Water 399

Lily, Water (yellow) 1420

Lily, Wild 189. a

Lily, Woud 562 . a, 2036 . b,c
Lily, Yellow 785. b, 1385. a

Lily-bell 351. a, b

Lily-bind 563 . c

Lily-grass 189. a

Lily-oak 1945 .

Lily-of-the-mountains 1639. $\mathrm{c}$

Lily-of-the-Nile 2147. a

Lily-of-the-valley 562 . a

Lily-of-the-valley, False 2061. a

Lily-of-the-valley, wild 521. a, 1696. a, 2061. a

Lily-pod, Little 302 . a

Lily-thorn 407

Lima bark 498. c

Lima-wood 338. b

Lime, Ogeechee 1421. b

Lime, Sour 506. a, b, h

Lime, Sweet $506 . \mathrm{h}$

Lime, Wild 21:36. f, 1201. b

Lime-berry 2038 a

LIME-TREE, species 1999

Limewort Catchfly 1851. a

*Limnanthes 1197

*Limodorum 936, 2004

Limonie 506. i

Limonilla 1589. a

*Limonium 1903

* Limosella 1350

Lin ( $\operatorname{Lin} n$, Line, Linde) 1999

Lin, Semence de 1208. b

Lin de la Nouvelle Zélande 1573. a

Linaire commune 1205. a

*Linaria 629, 740

Lind, White 1999. a, c

LrNDEN, specles 1999

Lindenblüthen 1999. b

*Lindera 250, 1378

*Lindernia 1056

Ling (Links) 2017. b

tling 1955. b, 2056. a

Ling, Bell 765. b

Ling, Black 350. a

Ling, Crow 350. a, 765. b

Ling, Draw- 774

Ling, Pull- 774

Ling, Silver 1649. a

Ling, Wire 747. a

Ling-berry 2075. p

*Lingoum 1682

Lingua cervina 1814, a

Lingwort 2089. a

Linn, Black 1262, a

Linn, Yellow 1262. a

*Linoseris 1074

*Iinosyris 489,1169

Linseed 1208, b

Lint (Lin) 1208. b

Lint, Fairy 1208. a

Lint, Laverock's 1208. a

Lint-bells 1208. b

Lion's-ear 1165. a

Lion's-foot 65. b, 1164. a, 1381. a, b

Lion's-heart 1581. a

Lion's-leaf 1162 . a

Lion's-mouth 151. a, 677. a

Lion's-8nap 151. a

Lion's-tail 1165

Lion's-tooth 1163. a, 1959. a

Lip-fern 461

*Iiparis 1176

Lippia Mexicana 1209. a

*Liquidambar 551
*Liquiritia 902

Liquorice, See Licorice

Liriconfancy 562. a

*Liriosma 716

Lis blanc 1196. p

*Lisianthus 807,878

*Lithag rostis 532

Lithewort 1771. c

*Lithonia 966

*Lithophragma 1906

*Lithospermum 109, 1442

Lithy-tree 2095. $\mathbf{j}$

Lithywale (Littlewale) 1214. $\mathrm{c}$

*Litchi 1400

Litmus 1160. b

Litschi (Li'tchi) 1400. b

*Litsea 1266, 2059

*Littanella 1215

Little-boy's-breeches 26\%. b

Little-guod 803. d

Little-washerwoman 1022. a

Live-forever 1824, c, d

Live-long 1824, c, 121. a

Livéche 1190. a

Liver-berry 1918

LIVER-LEAF, species 981

Liver-weed 981 . b

tLiverwort 59. a, 981. b

Liverwort, Heart 981 . b

Liverwort, Noble 981. b

Liverwort, Three-leaved 981. b

Liverwort, Water 242. a

Liverwort, White 1505. a

Lizard's-tail 1790 . a, 160'.i,j

Llewellyn 2094. f

Loaves-of-bread 1041. b

Lobe-berry 526. b

LOBELIA, species 1217

Lobelia, Lemon 1302, a

Lobélie enflée 1217. b

*Lobelienkraut 1217. b

Loblolly tree 1604. b

*Lobularia 1112

Lockin-gow an 2043. a

Loco-weed 208. c, p

tLoco-weed 605. d.

LocusT, species 1738

Locust, African 1503. a

Locust, Black 895 . b

Locust, Honey 895 . b

fLocust, Honey 1664. a, 1738. a

Locust, River 103. b

Locust, South Americau 1036. a

Locust, Swamp 89o. a

Locust, Sweet 895 . b

Locust, Thorn 895. b

Locust, Water 895. a

Locust, Yellow 509. a

Locust-berry 334. a

Locust-bloom 1999. b

Locust-plant 396 . e

Locust-tree 432. a, 1738

*Locusta 2078

Löffelkraut 527. a

Loggerheads_423. d

Logwood 940 . a

*Loiseleuria 452

Lokao 1721. e, f

Lolch 1220. 2

London-basket 885. d

*London-lace 1559. a

London-pride 669. b, 1781. a

London-tuft 664. b 
Long-beard 2001. a

Long-purples 1250 . a, 1450.d Longan 1400. c

Longshucks 1601.s

Longwort 115 . b

*Lonicera 676, 1936

Loofa (Louff) 1232. a

Loosestrife 1219,1250

tLoosestrife 1904

Loosestrife, False 10\%2. a, 1229

Loosestrife, Swamp 652. a

Loosestrife, Tufted 1388

* Lophanthus 54

*Lophiocarpus 1225

Lopseed 1574

Loquat 769. a

Lorbeer 1144. a

Lords-and-ladies 181. b, 189. a

Lot-tree 187\%. c

Lote tree 2155. b

Lotus 422 , b

Lotus, Egyptian 1391. b

Lotus, Honey 1300. a

Lotus, Indian 1391. b

Lotus odoratus 2032. d

Lotus, Sacred 1391. b

Lotus tree 2155. b, 681. c, e

Lotus, Water 1391. \&

Lotwurz 1441. a

Louse-berry tree 801. e

Louse-bur 2131. b

LOUSEWORT, species 1523

Lousewort 260. a, 647. a, 656. d

Lovage 1190

Lovape, American 1163. a

Lovage. Scotch 1193.

Lovage. Water 1427, a

Love-bind 514, d

Lore-entangle 1824. a

Love-entangled 514. d

Love-grove 1395 . b

Love-in-a-chain 1824 . b

Love-in-a-mist 1411. a, 1515. a

Love-1n-a-puzzle 1411. a

Love-in-idleness 2102. f

Love-in-winter 466. b

Love-lies-bleeding 91 . a, b, d

*Love-lies-bleeding 44 . b

Love-man 863. a

Love-me 13\%3. a

Love-peas 4. a

Love-t ree 436 . b

Love-rine 620

Love's-test 144. b

Lovely-bleeding 91. a, b, d

Lover's-pride 1641. n

Lover's-steps 1220. a

Low Belia 1217. b

*Lowellia 1993

Löwenmaul 1205, a

Löwenmaul, grosses 151, a

Löwenzahn 1959. a

Lowries, Sturdy 644 . b

Loxa bark 498, d, e

Lucerne 1291. d

tLucerne 1294. a, 1437. a

Lucerne, Sweet 1300. a

Lucerne, Yellow 1291. b

Lucifer 1291, d

Lucif r-matches 186n. a

*Ludwigia 1072, 1100, 1230

*Luina 1669

Lukwati 769 .
*Luma 118

Lumbang nut 69 . a

*Lunanaea 533

Lunary 290. a, 1231. a

Lung-yen 1400. c

Lungenhabichtkraut 1005 . h

Lungenkraut 1692 a

Lungenkraut, gelbes 1005 .e

Lungwort 1692

Lungwort, American 1314.a

Lung wort, Bullock's 2090. b

Lungwort Cow's or Clown's 2090. b

Lungwort, French 1005 . e

Lun $\_$wort, Golden 1005. e

Lungwort, Sea 1623. a

Lungwort. Smooth 1314. a

Lungwort, Tree 1314. a

Lungwort, Virginia 1314. a

LUPINE (Lupin) 1235

Lupine, False 1985

Lupuline (Lupulite) 1028. a

Lupulinum (Lupulina) 1028. a

Lupulus 1028. a

Lupus salictarius 1028. a

Lurkey-dish 1308. h

Lustwort 707 . a

*Luzula 1097

* Lychnis 61. a, $210 t$

Lycope 1242

Lycoperde des bouviers 1238. a

*Lycoperdon 737

Lycoperdon-nuts 737. a

Lycopode 1240. a

*Lycopodium 1825

*Ly godesmia 1689

*Lyonia 2139

Lyre-tree 1211. a

*Lysanthe 917

*Lysimachia 1388, 1901

Lysimaque 1219

*Lythrum 652, 1511

Macaja burter 529 . a

Macary-bitter 1961. a

Mace (Macis) 1377. b

Mâche 2078. a

*Maclura 472, 2011

*Macropiper 1320

*Macrotys 497

Mad 219. a

Mad-apple 649. b. c

Mad-dog weed 72. a

Mad-nep 1.16. a

Mad-weed 1821. c

Iad-Toman's-milk 803. d

Madar 854. a

Madder 1749 . a

t MI adder 145. b

Madder, Field 1840. a

Madder, Indian 1429. a

Madder, Wild $863 \mathrm{f}$. g

Madeira-nut 1096. d

Madeira-wood 1934, a

Maden-weed 145 . b

Maderwort 187 . b

*Madia 138, 9i1, $12 \cdot 9$

Madness (Madnep) 982. a

Madroño (Madroña) 172

Madu-nut 623, a

Madwort 361. a, 1112. a

Madwort, German 210

Mafura (Mafurra) tree 2026. a

*Mafureira 2026

Magell 644 . c
Magellanicus cortex 706. a

Maghet 482 . f

MaGxolia, species 1262

Maguey plant F.6. c

* Maharanga 1441

*Mahogani 1931

Tahogauy 1730. f

Mahogany, Australian 790.p

Mahogany, Bastard 790. p

Mahogany, East Indian

417. b, 1879. a

Mahogany, False 1546. a

Mahogany, Forest 790. y

Maho any, Horseflesh $12 \pm 8$. b

Mahogany, Indian 417. $\mathrm{b}$

Mahogany, Irish 79, a

Mahogany. Kentucky 930.a

Mahogany, Mountain 26เ. b, 437

Mahogany, Red 790. y

Mahogauy, Swamp 790. $z$

Mahogany tree 1934. a

Maho zany, White 790. z

* Mahonia 251. d

Mahwa (Mahwah) 240. b

*Maianthemum 2061

Maiblume 562, a

Maid-of-the-meadow 2057. a

Maid-sweet 2057. a

MAIDENHAIR, species 40

tMaidenhair 468. a, 885. b

Maidenhair, Black 204. a

Maidenhair, English 20\%. d

Maidenhair, Golden $16 \pm 9$. a

tMaidenhair, Golden 1643 . a

Maidenhair, White 204. c

Maidenhair tree 889 . a

Maid+n's-hones!y 514. d

Maiden's-tears 18.51. b

Maiden's-rumn 187. a

Maid's-hair 863. a, i

Maid's-love 187. a

Maiglocken 562. a

Maile (Maire) 89. a

Mairan 145i. a, c

Mais, Filament de 2148. a

Maisbrand 2071, a

Maise 145. b

Maispistille 2148. a

Maize 2148. a

Maize, Water 2097.

Maize-smut 207t.

Maize-I horn 423. b

Majoe-bitter 1961. a

Majoran 1456 . c, d

*IIajorana 1456

Make-beggar 1761. 8

Make-peace 2f1. a

Makebale 1634. a

Malabar-nut 39. a

Malabathri folia (cortex) 500.8

Malacca nut 1829. a

* Malachodendron 1924

Malagueto de montana $2103 \mathrm{a}$

Malambo bark 606. $\mathrm{d}$

Male Fern 712. d

Male-fern, Buckhorn 1471.b

Malice 1270 . a

Malicorium cortex 1694. a

Mallamak 1066. 8

Mallee tree 790 . $t$

Mallow, species 1270

Tallow 87

Mallow, False 1271. a 
Mallow, Glade 1384

Mallow, Globe 1888, 1818

Mallow. Indian 6. a, 1847 , 2065. a

Mallow, Jew's 569 . b

Mallow, Marsh- 87. a

Mallow, Musk 1003. a

Mallow, Poppy 348

Mallow, Rose 1003. d, e

Mallow, Sca 1146. a

Mallow, Swamp 1003. e

Mallow, Water 1003. $\theta$

Mallow, Tree 1146. a

Mallow, Venice 1003. i

Mallow, White 87. a

Iallygowl 344. a

Maltese-cross $1236, \mathrm{~b}$

* Malra 348, 1271

Malva arborea 87 . b

Malva vulgaris 1270 . b

Malvaviscus 87 . a

* Malveopsis 1271

Mamaeiro 383 . a

Mamey tree 1273 .

Mamilier 140 . d

Mammee 1228, a

Mamuee Apple 1273. a

* Mammillaria 337, 1224

Mawu moth tree 1832 . b

Man-of-the-earth 1066. n

Man-root $1066 . \mathbf{k}, \mathbf{n}$

Manaca (Manacán) 317. a

†Manaca 1052. a

Manawa 223, b

Mauchineel 1007. a

Manchineel, Mountain 1730. $\mathrm{g}$

* Mancivella 1007

Mancona bark 786. a

Manconarinde $\% 86$. a

Mandelbaum 111. 2

Mandeln 111. a

* Mandioca 1276

Mandrake, (American) 16.25. a

tMandrake 189, a, 1956. a

Mandrake, European 1274.a

Mandrake, False 320 . b

Mandrake, Round 891. b

Mandrake, Wild 1625. a, 501. a

Mangaba (Mangava) 946. a

Man rabeira rubber 946 , a

* 1/ angas (Manga) 1275

Mangel-wurzel 259. a

Mangle 1829. a

Manglier 17:27. a

Mango 1275 . a

tMango 867. c, 1069. a

Mango, Mountain 523. a

Mangostan (Mangostine) 867 c.

* Mangostana 867

Mangosteen 867 .

Mangrove 1727. a

tMangrove 526. b

Mangrove, Black 223, a

Mangrove, Olive 223. a

Mancruve, White 1130. a, 223. b

Mangrove, Zaragoza 557. a

Mangue 1727. a

Mani 13 i2. a

Manicou 219 . a

Manila-nut 168. a

Manioc (Mandioc) 1276. b

Mauna 845 . b, d
Manna, Australian 790.i,j,k

Manna, Briançon 1138. b

Manna, Jew's 1955. b

Manna, Lebanon 419. a

† Manna of Sinai 70 . a

Manna, Persian 70. a

Manna, Tamarisk 1955. b

Mannstreu 781. b

Man's-mother-wort 1735. a

Mantil 1641. d

Manzauilla romana 145 . c

Manzanillo 1007. a

Manzanita 176

MAPLE, species 16

Maple, Ground 1000. b

Muple, Sugar 16. g, also 16. $a, b$

Maple, Vine 1306. a

Maple-flower 248. a

Marany-nut 1829. a

Marasca 1668. e

Maraschino 1668. $\theta$

Marble-flower 1497. d

March (Merch) 158. a, b

March, Wood 1775. a

March-and-May 167. a

Marcory 1914. a

Mardling 1159

Mare's-tail 1008. a, 1174. a, 206. c

Marg 14.5. b

* Margacola 2027

Margaret 248. a

Margerome 1456. d

Margosa 1299. a

Marguerite 248. a, 482. d, e

Mari veri herba $1973 \mathrm{c}$

Marian 362 , e

Marienblatt 482 . a

Marigold (Marygold) 344

Marigold, Bur- 263. f, g. h

Marigold, Corn 482. g

Marigold, Fetiu 720

Marigold, Field 482 .

Marigold, French 1951. b

Marignld, Marsh 355

Marigoid, Rayless 263. g

Marigold, Water 26:3. d

Marigold, Wild 482 . g

Marigold, African 1951. a

Marjerin 145. d

Marjolaine 1456. c

Ma joram, Knotted 1456. c

Marjoram, Pot 1456. d.

† Marjoram, Spanish 2067. c

Marjoram, Sweet 1456. c

Marjoram, Wiuter 1456. d

Mark-weed 1730 . h

Markerry 464. d, 1730 h

Marking-nut 1829. a

Marle 1318. a

Marl-grass 2032. f,

Itarmalade-box 880. a

Marnalade tree 12:8. a

$M$ arool 33. a

Marronier $\$ 00$

Ma. row, Vegetable 614. b, 1546. $c$

Marrube blanc 1281. a

Marube noir (fétide) 2311. a

Marrubiastrum 1165 . c

Marrubii aquatici Herba $12+2$. b

Marrubium foetidum 230, a

Marrubium nigrum 230, a

Marsh-beetle 2055. a

Marsh-berry 14;6. b
Marsh-locks, Purple 547. a

Marsh-mallow 87. a

Marsh-nut 1829. a

Marsh-pestle 2055. a

Marshwort 1476. b

Martinoe 1284. a

*Maruta 145

Marvel 1281. a

Marvel-of-Peru 1335. a

Mary-bud 344, a

Mary-buds 1711. c

Märzvielchen 2102. d

Masliebenblume 248, a

Mast tree 2. a

Masterwort 982. a

tMasterwort 135. b

Masterwort, English 48. a

Masterwort, Imperial 1058. a, 209. a

Masterwort, Wild 48. a

Mastic, Algerine $160 \overline{5}$. b

Mastic, Barbary 1605. b

Mastic, Bombay 1605 . c, d

Mastic tree 1605 . a, 1819. a

Mastic-tree, Peruvian 1799. a

Mastich, Herb 1994. d

Mastich, False 215. a

Mastix 1605. a

*Mastocarpus 887

Mata perro 1282. a, 1672 . a

Maté 105 s. e

Mater secalis 512 . a

Mathas, Red 44. b

Mathes 145. b

Matfelon (Mater-filun) 423. $d$

Matico 1602 , a

Matico 8U2. f, 2113. b

Maticoblätter 1602, a

Matitas $7 . d$

* Matonia 712

* Matourea 1350

Matricaire 482 . f

*Matricaria 115. b, 482

Matrimony 1234. a

Matrimony vine 1237, c

Matrisilva 201. b

Mattenkraut 1153. f

Maudlin 482. a

Maudlin, Water 802 . c

Maudlinwort 482 . e

Mauerepheu 961. a

Mauerpfefter 1824, a

Maul (Maws) 1270 . a

Maulbeerbaum 1364. b

Mauritius-weed 1739. b

Mausdotn 1755 , a

Mauneöhrcheu 1005. f

Iauve 1270 . a, b, c

Maw-seed 1497. d

Mawroll 1281, a

* Maximowiczia 1050

May 167. a, $2058 \mathrm{~d}$

May, Italian 1895. b

May-apple 1625

May-blub $3 \div 5$. a

May-blossom 562 . a

May-bush 592. a

May-Hower 7 - a. a, 513. a, b, 13:3, b, j, 379. c, 1699. a 1940, a

May-pops 1515. c

Muy-eıar 2031. a

May-wings 1638. 。

May-wreath 1895 . b

Mayeti, Lubân 289, b 
May-weed 145. b

+May-weed 1285. a

Mayweed, Fetid 145. b

Maywort 863 . e

Mazzard 1668. e

M'boundon 1923. h

Mead-sweet 2057. a

Meadow-beauty 1724 . a

Meadow-bloom 1711. f

Meadow-bouts 355. a

Meadow-burs 1375. c

Meadow-parsnip, Eally 2154. a

Meadow-parsnip, Golden 2154. a

Meadow-parsnip, Purple 1979. a

Meadow-pride 844. a

Meadow-queen 2057. a,1895.d

Meadow-root 1202. a

MEADOW-RUE, species 1976

Meadow-rue 1940. a

Meadow-runagates 1249 . a

Meadow-sweet 2057. a

†Meadow-sweet 1655. a, b

Meadow-sweet, Commion 1895. c

Meadow-sweet, Pink 1895. d

Meadowwort 2057. a

Meakin 1376

Meal-berry 176. f

Meals (Mails, Miles) 464. a

Mealy-tree 2095. i

Meat-nut 400 . c

Mecca Balsam 550. e

Mechamech 1066 , n

Mechoacan 815 , under b

Mechoaeanna 1066. n

Meconium 1497. d

*Meconopsis 1927

Meddow-soot 2057. a

Medesïss 2057, a

MEDIC, species 1291

Nedick 1291

*Medica 1291

Medlar 1318. a

Medlar, Dutch 1318. a

Medlar, English 1318. a

Medlar, Japanese 769. a

Medle tree 1318. a

Meerlinsen 1214. c

Meer rettig 1742. a

Neerthau 1744 , a

Meerzwiebel 2066. a

Meetiug-houses 166. a

Neetru 240. c

Meg-Many-feet 1711. b

Meg-weed 1866. a

* Megarrhiza 1:325

Megerkraut 863. i

Mehlbeerbaum 1875. c

Meirau, (Mayran) 1456. c

Meisterwurz 10€8, a

Mekilwort 219 . a

* Melalcuca 339

Melampodium 974. b

Mélampyre 1296

* Melanogaster 2047. g

Melanthii semen $1+11$. b

*Melanthium 479, 2007 , 2089,2159

Melde, stinkender 464 . 1

Mélèze 1138. b

Melge 464. a

*Melicocca 817, 1042

*Melilobus 895

MELILOT, species 1300
Melilot, Blue 2032.d

Mélilot officinal $13 \mathrm{co}, \mathrm{b}$

Melilotenklee 1300 . b

*Melilotus 2032

Melilotus citrinus 1300 . b

Melilotus coeruleus 2032. d

*Melissa 520, 960

Melissa citrata 1302. a

Mélisse officinale 1302. a

*Melissophyllon 1303

*Melittis 1251

Melmot berries 1099. b

*Melo 613. a

MELON,varieties 613. a

Melon shrub 1867 .

Melon tree 383 . a

Melonenbaum 383. a

Ménisperme du Canada 1306. a

*Menispermum 117, 357, $416,581,1090$

Mentha acuta 1308. j

Mentha romana 482. a, 1308. j

Mentha saracenica 482, a

Menthe de chats 1399 , a

Menthe de cheval 1348, b

Menthe poivrée 1308 . $\mathrm{g}$

Menthe pouliot 1308 . h

Menthe verte 1308. j

Menthe-coq 482, a

Menthol 1308. a, b, s

*Mentzelia 794

Ményanthe 1310. a

*Menyanthes 302,1197

*Menziesia 319, 1576

Mequot 1831. a

Mercuriale 1312

Mercurio-vegetal 317. a

Mercury, Baron's 1312.b

Mercury, Black 1730 . h

Mercury, Boy's 1312. b

Mercury, Dog's 1312. b

Mercury, English or False 464. d

Mercury, French 1312. a

Mercury, Girls 1312. b

Mercury, Maiden 1312. b

Mercury, Scotch 677. a

Mercury, Three-seeded 9

Mercury, Vegetable 317. a

Mercury, Wild 464. d

Mercury-dockan 464. d

Mercury-weed 9. a

Mermaid, False 836

Mermaid-weed 1663

*Merostachys 232. q

Merry (Black) 1668. e

*Mertensia 1623

Mescale buttons 1224, a

* Mesembryum 1316

Mesenna 64 . a

*Mespilus 96, 185, 584, 592, $769,997,1875$

Mesquit (Mésquite) 1664. a, c

Messuate tree 790

*Metagonia $20 \% 5$

Metalista root 1335 . a

*Metopium 1730

* Neum 839

Mew 1323, a

Mexico-seed 1735. a

Nezeal 56. c

Mézéréon 644 . c

Mezereon, American 689, a

Mezereon, U. S. P. $644, a, b, c$
Mezquite (Meskit) 1664,

Micken 1323. a

*Micrageratum 202

*Micromeria 1789

*Micropus 905, 1677, 1926

*Microseris 1687,1818

*Microstylis 21

Midsunmer-men 1824 . c

Miere, roth 116 , a

MigNONETTE, species 1717

Mignonette, Jamaica 1148.a

Mignonette- $\vee$ ine 1259. a

*Mikania 2119

Milchkraut 893. a

Milfoil 18

Milfoil, Water 1376

tMilfoil, Water 242. a

Milium solis 1214 . c

Milk-grass 2078. a

Milk-the-cows 586. a

Milk-tree 315 . b, 1946, a

Milk-vetch 208

Milk-vine 1544. a

Milkmaids 379. c

MILKWEED, species 195

†Milkweed 17, 160. a, b, 196, 803. a, h, 1871. b, c

Mtlkweed, Marsh 802 . j

Milkweed, Running 2101. a

Milkweed, Trumpet 1125. a

Milkweed, Wandering 160.a

MILKWORT, speeies 1638

Milkwort, Sea 893. a

Milky-dickles 1871. b, c

Milky-tassels 1871 . b, c

Mill-mountain 1208. a

* Milla 131

Millefeuille 18. a

Millefolium 18. a

Millepertuis 1043. b

*Milleria 834

Millet 1496. a

Millet, African 1876. b

Millet, Australian 1876. a

Millet, Black 1876. b

Millet, Broom corn 1496. a

Millet, Cat-tail 1531. a

Millet, East Indian 1531. a

Millet, Egyptian 1531. a, 1876. a

Millet, German 447. a

Millet, Golden 447. a

Millet, Hungarian 447. a

Millet, Indian 1876 . b

Millet, Italiau 447. a

Millet, Morocco 1876. a

Millet, Pearl 1531. a, 1876. b

Millet, White 1300 . a

Millet, Yellow 1300. b

Milo 1987. 1

Milsilvestre 1222. b

Milt-waste 441 , a

Mimosa 31,1182

*Mimosa 7, 751, 1248, 1361, 1608,1664

Mimosae gummi 7. k, etc

Mimosen-gummi 7. k, etc

*Mimulus 684,800

Mingwort 187. b

Minnie-bush 1311. a

Mint, 8pecies 1308

Mint, Balm 1302. a

Mint, Bergamot 1308. o

Mint, Cock 48: a

Mint, Field 1399. a

Mint, MountaIN, spectes 1111 
Mint, Mountain 520. b, 1348. a, 1456. d

Mint, Rock 1973. f

Mint, Squaw 960. a

Mint, Stoue 616. a

Mint, Wild 63. c

Minze, grüne 1308. j

Miraculous-berry 1849, b

Mire-blob 355. a

Mirrot 651. a

Mirtle (Mirtil) 1380. a

Mishmee bitter 567. a

Misseltoe (Miseltoe) 2105. a

Missey-moosey 1875. a

Mist 935. a

Mist-flower 802. e

Mistel 2105. a

Mistletoe $1220^{\circ}$

Mistletoe, American 1572

Mistletoe, European 2105. a

Mistress-of-the-pight 1635. a

*Mitreola $6: 32$

Mitrewort, Common 1337. a

Mitrewort, False 1997. a

Mitrewort, Two-leaved 1337. a

Moccasin-flower 636. a, etc

Mocker-nut 1004. a

Mock-willow 1895. c

Modesty 1003. i, 327. a

Mogdad-katfee 396. i

Mogford 1s7. s

Mohawk-weed 2073. a

Mohn 1497. d

Mohre 651. a

Mohwa tree 240. b

Mole plant (Mole tree) 803.g

Molène 2050. b

Molewort, Alpine 167. a

Molette 329 . a

*Molle 1799

Iollipuff 1233. a

* Mollugo 896

Molompi 1682. b

Molucea grains 606 . h

*Momordica $724,1232,1325$

* Monarda 270

Mönchspfeffer 2107. a

Mondkorn, Candisches 1306. a

Monesia bark 1228. c

Monesiarinde 1228. c

Mnney-grass 1726 . a

Money-plant 1234. a

Money wort 1249. a

Mcneywort, Prairie 1904. a

Monkey 25. i

Monkey-bread 32. a

Monkey-face tree 1267. a

Monkey-flower 636, d, e, 1333

Monkey-grass 220. b

Monkey-nut tree 1999. a

Monkey-pot tree 1152. a

Monkey-puzzle 171. b

Monkey's dinner-bell 1029. a

Monkey's-face 2102. f

Monk's-head 1959. a

Monkshood 25. esp. i

tMonkshood 262. b

Monnayère 1249 . a

* Monnieria (Moniera) 780

*Monothrix 1136

*Monotropa 10+6, 1684.

*Monotropion 1356

*Montia 513
Moodooga oil 331. a

Moon Creeper 1066. h

Moon-berry 1476. b

Moon-feru 290 , a

Moon-flower 1066. h, 482. e 1310. a

+Moon-flower 133. g

Moon-penny 482. e

Moonog 1476. b

Moonseed, Canuda 1306

Moonseed, Carolina 416. a

Moonseed, Red-berry 416. a

Moonshiue 12i. a, 904 . a

Moonwort 290 . a, b

Moor 350 . a

Moor-grass 1. a, 707. a

Moor-pawne 774

Moorva 33. a

Moorwort $12^{2}$, a, 707. a

Moos, irländisches 477 . a

Moos, isländisches 442. \&

Moose-berry (Moose-bush) 2095. a

Moose-misse 1875, a

Moose-wood 689. a, 16. c

Moosebeere 1476. b

* Jloquinia 906

Morass-weed 43:3. a

Morel, Great 219. a

Morelle 1867. o

Morelle à grappes 1585. b

Morelle furieuse 219 . a

Morelle grimpante 1867 . j

Morgan 145. b

Morgan, Dutch 482. e

Morgeline 2094. i

Mormon-weed 6. a

Morning-glory 1066. i, j, k

Morning-glory, Dwari n63.d

Morning-glory, Red 1702. a

Morocco, Red 44. b

Morrel 1867. j

Mortification-root 87 . a

* Morus 316

Moschatel 46 . a

Moschatenuss 1377. b

*Moschoxylon 2026

Moschuskraut 1973. c

Moschuswurzel 828. h

Mosquito-bells 693. a

Moss, Bear 1649. a

Moss, Beard 2070. a

Moss, Besom 1649. a

Moss, Black 2001. a

Moss, Canary 115). b, 1739.a

Moss, Clubfoot 1240. a

Muss, Corsican 1889. a

Moss, Cypress 1240, d

Moss, Ditch 1566. a

Moss, Dyer's 1739. a

Moss, Fir 1240. $\mathrm{g}$

Muss, Florida 2u01. a

Moos, Flowering 1569 . e, 1700. a. 1824 .

Moss, Golden 492. a, b, 1649. a, 1824. a

Moss, Ground 1026. b,1649. a

Moss, Hair-cap 1649. b

Moss, Hanging 2001. a, 20\%0. a

Moss, Iceland 412, a

+Moss, Iceland 1824. k

Moss, Idle 2: 70. a

Moss, Irish 477. a, 887. a

+Moss, Irish 803 . b

Moss, Kentucky 1656. a

Moss, Long 20u1. a
Moss, Maple 2070. a

Moss, May-queen 1649. b

Moss, Mountain 1824. a, 1825. c

Moss, Necklace 2070. a

Moss, New Orleans 2001. a

Moss, Pearl 477. a

Moss, Pyxie 1700. a

Moss, Rock 1824. g

Moss, Rose 1656. a

Moss, Running 1240. a

Moss, Sea 887

Moss, Snake 1240. a

Moss, Spanish 2001. a

Moss, Staghorn 1240. a

Moss, Tartarean 1150. b

Moss, Tree 803 . b, 1240. g, 2070 . a

Mloss, WVall 1824

Moss, Worm 1889. a

Moss-berry 1476. b

Moss. bush 397

Moss-cup 774

Moss-milion 1476. b

Moss-plant 397

Mote nut 378. b

Mother cloves 796. a

Mother-die (Mother-dee) 148. a

Mother of Rye 512. a

Mother-of-thousands 629 . a, 1792, a

Mother of Thyme 520 , a, d, 1994. a

Mother of Wheat 1296. a, 2094. i

Mother's-hear't 329. a

Motherwort $1165,802 . j$

Motherwort, Golden 904. b

Motherwort, Hoarhound 1165. c

Motherwort, Stinking 464. i

Mottenkraut 2032. d

Mountain Ash, species 1875

Mountain-fringe 42 . a

Mountain-snow 803 , i

Mountain-sweet 41 . a

Mourning-bride 1794 . b

Mourning-widuw 1794. b

Mouron rouge 116. a

Mouse-bur 1284. a

Níouse-ear 1373.904. c

Mouse-ear, Virginia 1137. b

Mouse-ears 981. b

Mouse-milk 803 . d

Mouse-tail 1374

Mouse-thorn 423. b

Tousebane 25 . i

Mousse de Corse 1889. a

Mousse d' Islande 442 . a

Mousse perlée 477. a

Moussena 64, a

Moutan (Mell-tang) 1488. a

Moutarde blanche 1856 . a

Moutarde des moines 1712.a

Moutarde noire 303 . d

Mouth-root $5 ; 7$. b

Moving-plant 1294 . b

Moxa 968. a

Moxa plant $187 . \mathrm{m}$

Moxie-berry 468 a

Mozemize, Indian 1875. a

Muatta-pana 338. a

Muck-weed 464. a, 1657. b

Mudar 354. a, b

Mudweed 1203 
Mudwort 1203

Muflier 151. a

Muggert 187. s

Mugget (mugwet) 201. b

Muguet 562. a

Mugweed, Golden 863. e

Mugwort 187. k, s

Mugwort, Indian 1513. a

Muira-puama 716. a

Mulberry, species 1364

†Mulberry 1750. a, g, k, 1875. c

Mulberry, Bermuda 347. a

Mulberry Blite 273. a

Mulberry, D warf 1750. f:

Mulberry, French 347. a

Mulberry, Indian 1359

Mulberry, Paper 316. a

Mulberry, Tahiti 316. a

*Mulgedium 112j

Nullein 2090, 1660. d

MULlen, species 2090

Mullen, Pretty 1660. di

Mullen, Sage-leaf 1568. a

Mulo 1987. 1

Mungo 1446. a

*Mungos 1446

Munjeet 1749. a

Murg 145. b

Mûrier 1364. b

Murrain-berry 320. b, 19506.a

*Murraya 449

Muruxi bark 334. a

Muscade 1377. b

Muscatellersalbei 1769. d

Muscovy Musk 777. b

Musenna (Mussena) 64. a

Mushroom 53

Mushroom, Fairy-riug 1278. a

Mushroom, Poisomous 90, a

Musk 46. a, 75. a

Musk, Vegetable 1333. a

Musk-deer plant 1201. a

Musk-flower 1333. a

Musk-plant 1270 . e, 1333. a

Musk-root 828 . h, 46 . a

Musk-seed 1003, a

Musk-tree, Silver-leaved 1431. a

Musk-wood 2026. b?

Muskatnuss 1377. b!

Muskrat-weed 1976. d

Musquash-root 495. b

Musquash-weed 1976. d

MUSTARD, varieties 303. a, c, d, 1856

†Mustard, Black 1712. a

Mustard, California 1860. a

Mustard, Dish 1989. a

Mustard, False 1633

Mustard, Garlic 74. a

Mustard, Hedge 1860."a, $235, a$

Mustard, Mithridate 1989. a, 1168. c

Mustard, Orange r82. a

Mustard, Poor-man's 74. a

Mustard, Tower 167. c

Mustard, Treacle 782 . b, 561. a

Mustard, White 1856. a

Mustard, Wormseed 782 . b

Iustard-seed, Black 303. d

Mustard-seed, Yellow or White 1856. a

Mustard-shrub 374 . c
Mustard-tree 1768, a

Mutterharz 828. c

Mutterkorn 512. a

Mutterkraut 482 . f

Mutterkümmel 615. a

Mutterwurzel 1323. a

Mutton-tops 464. a

My-lady's-belt 2057. a

Myall 7.g

*M yagrum 361, 1180

* Mylitta 2047.

*Mylocaryum 519

*Myosotis 1137, 1609

Mypes 1516. a

* II yrica 551

Myrica, oil of 1594. a

Myrcienöl 1594. a

* Myrcia 1594

* Myristica 2103

Myrobalanan 322 . b, d

Myrobalanen, graue $1575 . \mathrm{b}$

Myrobalans 322 . b, d

Myrobalans, Chebulic 322. d

Myrobalans, Emblic 15i5. b

* N1 y robalauus 322

* M yrospermum 2008

*My roxylon 2008

Myrrh (Myrrha. Myrrhe) 550. $d$

tMyrrh 1378. a

*Myrrhis 901,2115

Myrte 1380 . a

Myrte, brabanter 137 . c

Myrtilli fructus (Myrtilla) 2075. a

Myrtillorum baceae 2075. a

MYrtle, species 1380

† Myrtle 2100. b

Myrtle, Bog 1310, a, 1375. e

Myrtle, Blue 415. c

Myrtle, Bridal 1380. a

Myrtle, Burren 176.f,1375.c

Myrtle, Candleberry 1375.b

Myrtle, Common 1380. a

Myrtle, Cranberry 1380. c

Myrtle, Cape 1127. c

Myrtle, Devonshire 1375. c

Myrtle, Dutch 1375. c, 1380 .a

Myrtle, Jew's 1755. a, 1380.a

Myrtle, Lime 2038. a

Myrtle, Moor 1375. c

Myrtle, Runuiug 2100 . b

Myrtle, Sand 657

Iyrtle, Shepherd's 1755. a

Myrtle, Sweet 26 . a

Myrtle, Wáx 1375. a

Mirtle, Wiid 1755. a

*Myrtoleucodendron 339

*Myrtus 118, 796, 1594

Mrsterious plant 644 . $\mathrm{c}$

* II y xa 2085

Nabelkraut 586. a

Nachtschatten, schwartzer 1867. 0

Nachtkerze 1436. a

Nailwort $702,1506,778$. a

Naked-ladies 534. a

Naked-weed 474. a

*Nama 705

*Nani (Nania) 1321

Nanny-berry (Nanny-bush) 2095. c, 1

+Nanny-berry 2095. e

Nap-at-noou 145S.a, 2016. a

Nape 303 . b

Naphae flores 506. c

Napoleons 2032. i
Naranjilo 2136. g

Narcisse des prês 1385 . a

Narcisse, gelbe 1385. a

Narcissus, Poets' 1385. e

Nard 1386. a

Nard, Américain 170. c, e

Nard, amerikanische 170. c, e

Nard, Celtic 2077. a

Nard, Wild 194. f

Nard-grass 129 . c

*Nardosmia 1548

Nardus 2077. a

Nardus americana 170 . c, e

Nardus indica 1386 . a

Nardus rustica (silvestris) 194. $f$

*Narthecium 1, 2007

*Narthex 828

Naseberry 20. a

*Nasmythia 771

Natterkopf 731. a

Natterwurz 1641. e

Natural-grass 1291. c

Nature's-mistake 576 . f

Nasturtii pratensis herba 379. c

Nasturtium (Nasturtion)

2044. a

*Nasturtium 1742

*Nastus 232. $r$

*Nauclea 1473

Naughty-man's-play thing 2067. a

Naupie 1488. b

*Nautea 1981

Navelwort 586, 1033 .

Navelwort (Water) $13 \% 6$

Navette, Wild 303. b

Navew 303. b

Nebbuk tree 2155. h

Nebneb 7. a

*Neckeria 372

Necklace-tree 145\%

Necklace-weed 1442. a, 28. a

Neckweed 2094. j

Neckweed (Nick.weed) $370 . a$

*Nectaudra 1424

Nectarine 111. b

Neele 1220 . a

Neezewort 2089. \&

Negro-head 1584. a

Negro-vine 2101. a

*Neguudo 16 . b

*Neillia 1448

Nelkeupfeffer 1594. b

Nelkenwurz 885. d

Nelkenzimmt 674. a

*Nelumbium 1391

*Nemopanthus 1054

Nénuphar blanc 399 . a

Néuuphar jaune 1420 . b

*Neobeckia 1742

*Neottia 936, 1538

*Nepeta 894

Nephritic plant 1513. b

*Nephrodium 712

Nuprun purgatif 1721 . d

*Nerium 2127

Neroll, oil B06. c

Nerve-root 636 . a, etc

Nerve-root, Water 195 . b

Nervine, Female 636. i

Nervine, Male 636. d, e

*Nessaea 652, 963

Nest-root 1356 . a

Nettle, species 2067, 2068 
Nettle, Bee 861. a, 1132. a

Nettle, Blind 1132. a

Nettle, Canada 2068. a

Nettle, Day 1132. a, c

Nettle, Deaf 1132 . c

Nettle, Dog 861. a, 1132. c

Nettle, Dumb 1132. a

Nettle, Dunny 230. a 1132.a

Nettle, Flowering 861. a, 1132. a

Nettle, French 1132 . c

Nettle, Hew P, species 861

Nettle, Sand 1091. a

Nettle, Spurge 1091

Nettle, Stingless 41. a, 1132, a

Nettle, White 1132, a

Nettle, Wood, 2068. a

Nettle-berry 422 . b

Nettle-potato 1914. a

Nettle-tree 422, 2019, a

Networt 1528. a

Neugewürz 1594. b

* Newberrya 979

Ngai 275. a

Ngmoo 714. b

* Nicandra 1579

Nicaragua wood 328 , b

Nicker-nut (Nickar-nut) 923. $a, b$

Nicker (Nickar) tree 930. a

Nicotiane 1410.b

*Niebuhria 2116

Niepa bark 1770

*Nierembərgia 1175

Niesswurz 974. b, c

Niesswurz, gelbe 567. b

Niesswurz, weisse 2089. a

Nigella, Field 61. a

Niger-seed 925 . a

Nigger-head 1751. a, 1865. o

Nigger-toes 257. a

Nigger-weed 802 .

Nightingales 189. a

+Nightshade 464. $\rho$

Nightshade, American 1585. b

Nightshade, Beaked 1867. $\nabla$

Nightshade, Bindweed 501.a

Nightshade, Black 1867. o

Nightshade (Climbing) 1867.

Nightshade, Common 1867.0

Nightshade, Deadly 219. a

Nightshade,Enchauter's 501

Nightshade, Fetid 1041. b

Nightshade, Garden 1867. 0

Nightshade, Silver-leaved 1867. $p$

Nightshade, Sleeping 219. a

Nightshade, Woody $186 \%$. j

Nightshade, Yellow-flowered 2064. a

Nim (Neem) tree 1299. a

Nimble-Kate 1845 . a

Nine-bark 1448

Ninety-knot 1641. d

Ninsin 1595. c

+Ninsin 1493. b

*Niobe 851

*Niota 1770 . a

*Niouttout 550

Nipplewort, Dwarf 183. a

Nit-weed 1786. a

Nitta tree 1503 . a

Noah's-ark 636. a, etc

Noble-pine 466 . b
*Nochetta 493

Nohu 2024, a

Noisetier 579

*Noisettia 123

Noix d'arec 177. a

Noix de galle 1704. n

Noix de Kola 533. a

Noix de sassatras 1390, a, b

Noix muscade 137\%. b

Noix vomique 1923. d

Nombril de Vénus 586 , a

Nonda tree 1500 . b

Nondo 1193. a

Nowe-so-pretty 1851. a, 2102. f

*Noue-so-pretty 121. a

None-such 1236. b

None-such (Black) 1291. c

Noni 1359. c

Noon-flower (Noon-tide) 2016. b

Noonday-flower 2016. b

Nosebleed 18. a, 2036. b

Nosegay tree 1621. a, b

*Notaphoebe 1546

Notchweed 464. i

Noyer gris 1096. a

Noyer commun 1096. d

Nuces catharticae 618 . a

Nuces nucistae 1377. b

Nuces vomicae 1923. d

Nunnari 977 . a

Nunqua (Nutqua) 1831. a

Nun's whipping post 91 . b

Nuns 1022. a

*Nuphar (Nyphar) 1420

Nurse-garden 1269. a

Nut-grass 635 . b

Nut-pine 1601 . e, g, etc

Nutgalls 1704. n, o

Nutmeg 1377. a

Nutmeg, American 1352. a

Nutmeg, Calabash 1352 . a

Nutmeg, False 2050. a

Nutmeg, Guinea 1352. a

Nutmeg, Jamaica 1:352. a

Nutmeg, Mexican 1352. a

Nutmeg, Peruvian 1142. a

Nutmeg-flower 1411. b

Nutmeg tree, Brazilian 609. a

Nutmeg tree, California 2050, a

Nutmegs, Long 1377. c .

Nutmegs, Male 1377. c

Nutmegs, Wild 1377. c

Nutta tree 1503 . a

Nuttal tree 579. c

Nuttall's-weed 571. a

*Nuttallia 348, 1462

Nuttre 579. c

Nux euboea 1096 . d

Nux metella 1923. d

Nux moschata 1377. b

Nux persica 1096. d

Nux regia 1096 . d

Nux romica 1923. d

Nyapana 802 . $\mathrm{m}$

* Nyctago 1335, see 1419

Nyctelea 1256

*Nymphaea 399, 1391

*Nymphoides 1197

*Nymphozanthus 1420

OA K, species 1704

Oak, Australian 405

Oak, Golden 647. b

Oak, Ground 1973. b
Oak, Indian 1981. a

Oak, Jerusalem 464. c, e

Oak, Poison $1730 . \mathrm{h}, \mathrm{i}, \mathrm{j}$

Oak, Sea 849 . b

Oak, Silk (Silk-bark) 917. \&

Oak, Swamp 405. a

Oak-apples 1704. n

Oak-balls 1704.

Oak-plum 1704. w

Oak-warts 1704. n

*Oakesia 5\%0, 2073

Oats, Common 221. a

tOats, Wild 2073

Oats, Water 2153. a

Obedient-plant 1581. a

Obier 2095. d

Oblionkers 50 . b

*Obolaria 1350

Occulus Christi 1769. d

Ochsenzungenkraut 124. a

* Ocotea 1390

Ode 1071. a

Odermennig 59. a

*Oensntho 1479

* Oenncarpus 1454

*Oenothera 142, 278, 490,864, $872,907,1107,1293,1313$, $1436,1485,1890,1960$

†Oenothera 1147

Oignon commun 76. c

Oha-wai 517. a

Ohelo 2075. f, g

Ohia 1086. b

Oil, Artists' 69. a

Oil, Bay Laurel 1144. a

Oil, Ben 1360. a, b

Oil, Cade 1099. c

Oil, Haarlem ic99. c

Oil, Katchung 168, a

Oil, Kekune 69. a

Oil, Keora 1495. a

Oil, Lumbang 69. a

Oil, Madia 1260. a

Oil of Bays 1144. a

Oil, Olive 1430. a

Oil, Red 1043. b

Oil, Rose Geraniun 1526. b, c

Oil, Sapucaya 1152. b

Oil, Siringa 1001. b

Oil, Sweet 1430. a

Oil, Tambor 1434. b

Oil-nut 1096, a, 1698. a, 1735. a

Oil-plant 1837. a

Oil-seed 925. a, 1735. a

Oil-seed, Siberian 361. a

Oily-grain 183r. a

Okra (Ochro) 1003. c

Okra, Wild 1264

Olcott-root 1753 . h

Old-field Sweet 206. d

Old-goose 636. a, etc

old-maid's-bonnets 1235

Old-maid's-nightcap 883. a

Old-man 187. a, 1744. a

Old-man's-beard 469. a, 514. d, 1792. a, 2001. a

Old-man's-tlaunel 2 2.90. b

Old-man's-pepper 18. a

Old-man's-plaything 1595 . b

Old-man's-root 170 . $\theta$

Old-man's-woozard 514. d

Old-sow 121. a, 2032. d

old-wives-mutches 25 . i

Old-woman, 157.b

Old-woman's-bitter 1961. a 
*Oldenlandia 1022, 1535

*Olea 1470

OLEANDER, spccles 1403

*Oleander 1403

Oleander, Wild 6:2. a

Oleander, Yellow 1988. a

Oleaster 1430 . a

Oleaster-tree, Wild 1166.a,b

Oleum templinum 1601. m

Oliban 289. a

Olibanum 289. a

Olibanum, Indian 289. d

*Oligogrne 1941

Olive 1430

Olive, American 1470. b

Olive, Fragrant 1470. a

Olive, Spurge 644. c

Olive, Wild 1344. a

tOlive, Wild 2138. a

Olive, Wild (of California) 2059. a

Olive-tree, Wild 1166. a. b

Ollick 76 . $d$

Olonier 172 . b

Olsenitii radix 1554. d

Ombéné 533. a

Ombligo de Venus 1033. c

*Omphalium 1435

Onagre (Onaye) 1919. a

Onagre 1436. a

Onani 136\%. a

One-berry 1336. a, 1501. a, 422. a

One-blade (One-leaf) 2061. a

One-o'clock 1959. a

Onion 76. c

Onion, Bog 181. b

fOniou, Bog 1471. b

Onion, Crow 76. j

Onion, Gypsy 76. h

Onion, Sea 2066, a

Onion, Shore 76. f

Oodbine 1222. b

Oonshine 506. I

*Ophelia 1933

*Ophelus 32

*Ophiorhiza 632

*Ophrys 936, 1176

Opium 1497. d

Opium, Lettuce 1125. f

Opium, Wild 1125. a

*Oplotheca 848

Opobalsamum 550. e

Opopanax 1447. a

tOpopanax 7. d

Opossum tree 1210. b

*Opuntia 1415

Orach 128 . esp. f

Orache (Orage) 218. f

ORA.TGE, varieties 506. c, d, e, l

Orange, Mock 1564. a, 1668. f, 324. b, 1929. b

tOrange Nock 1325.

Orange, Osage 2011. a

Orange, Quito 186i. m

Orange, Spring 1929. c

Orange, Vegetable 613 . a

Orange, Wild 506. c, 170. f, 1668. $f$

†Orange, Wild 2136. e

Orange-blossom 2036. b

Orange-flower tree 1564, a

Orange-grass 1786. a

Orange-root 1032. a, 195. d

Orange-root, Climbing 421. a

Orcanet, Garden 124. a
Orcanette 73. a

Orchard weed 148. c

Orchil 1150. b

Orchil (Orchella) 1739. a

*Orchis 113, 938

Orchis, Adder's-mouth 1630. a

Orchis, Crane-fly 2004. a

Orchis, Cuckoo 1450. d

Orchis, Flaming 938. g

Orchis, Fringed 938. c, d,e,g

Orchis, Ma'e 1450. d

Orchis, Man-1450. d

Orchis, Marsh 1450. a

Orchis, Purple 1450. g

Orchis, Showy 1450. g

Orchis. Spring 1450. $\mathrm{g}$

Orchis, Tree 753

Ordealbohne 1582, a

Oreille de lièvre 327 . a

Oreille de souris 1005 . f

Orellana 26ti. a

*Oreodaphne 1424, 2059

*Oreophila 1487

*Oreoselinum 1058, 1554

Organ (Organy, Orgament) 1456. d

Organy 1308. h

Orge 1019

Oriental-berries 117. a

Origan 1308. h

Origan vulgaire 1456. d

Origano 1209. b

Origanum 1456. d

*Origanum 1111

Origanum, American 1348.b

Orl 79

Orlean 266. a

Orleana 266. a

Orme a trois feuilles 1681. a

Orme champêtre 2058. d

Orme fauve 2058 . $\mathrm{f}$

Orme nyramidal 2058. d

*Ornithogalum 1047

*Ornus 845

*Orobanche 558, 1170, 1974

Orobanche de Virginie 1170. a

*Orobus 1140

Oronge, Fausse 90. a

Orphan-John 1824. c

Orpies 1824 . c

Orpine, American 1824, d

Orpine, Garden 1824. c

Orris-root 1068. a, b, c

Orseille $1150, \mathrm{~b}$

Ortie blanche 1132, a

Ortie brulante $20 j 7$. a

Ortie rouge 1900 . a

Orungurabie 714 . b

Osage 2011. a

Oseille commune 1753, a

Ossille de Guinée 1003. g

Osha 1193. b

Osier 1764. a, $\mathrm{l}, \mathrm{m}$

Osier, Golden 1764. a, 1375. c

Osier, Green 576. a, e

Osier, Red 576. b, i

Osier, White 1189. b

*Osmorrhiza 901, 2115

Osmund, Royal 1471. b

Osmund-the-waterman 1471. b

*Osmunda 290

Oso-berry 1462

Osterich 1641.e
Osterleiwurzel, feste

(rolle) 37\%. a

Osterluzei 182. a, c, e

Ostritzwurz (Ostranz) 1058. a

Ostruthii radix 1058. a

Oto 541. a

Otoba butter 1377. d

*Ottonia 1602

Ottwurz 1062. a

Ouabe 1434. a

Ouler, Sea 1875 . c

Our-Lady's-seal 1639. c, d

Ouvirandra 164

Ova-ova 1356 . a

Owl's-crown 886. a, 904. b

Owler 79

Owm 2058. d

Ox-balm 539. b

Ox-berry 1956. a

Ox-eye 965 . a, 972,44 .

Ox-eye, Sea 287 . a

Ox-eye. White 1482. 0

Ox-eye, Ycllow 482. $\mathrm{g}$

Ox-heal 974. a

Ox-tongue 124. a, 1591

Oxadoddy 1171. a

Oxford-weed 629. a

Oxlip 1660. b

Oxwort 1548. a

*Oxybaphus 75

Oxylapathi radix 1753. e

*Oxys 1475

* Oxytenanthera 2:32. s

*Oxytropis 169

Oyster plant (Oyster root) 2016. a

fOyster-plant 1623. a

()yster-plant, Spanish 1815.a

*Pachyma 1238

*Pachypodium 1983

Paddock-cheese 199. a, 1238. a

Paddock-pipes 758 . c, 1008 .a

Yadeliou 65. b

*Paepalanthus 717

Pagle (Pagil, Pargle) 1660. b, d

Pagoda tree 1621. b, c, 1874. a

+Paigle 1711. c

Pain de coucou 1475, a

Pain de porceau 625 . a

Pain de sucre 119. a

Pain des grenouilles 72 . a

Pain des singes 32 . a

Paina 1578. b

Paint-brush 1043. f

Paint-brush, Devil's 1005. a

Paint-brush, Flora's 1005. a

Paint-brush, Indian 403. a, etc

Paint-root, Indian 937. a

Painted-cur, species 403

Painted-grass 1559. a

Painting plant 1214. a

Pa-koo 889. a

Pakoe-kidang 84. a, 669. a

Paku-kidang 84. a, 669. a

*Palala 1377

*Palafoxia 1646

Palas tree 331. a

Palay 2127. a

Palewort 1711. $\mathrm{f}$

Pali-mara 85 . b

Palixander (Palisandre) 1082. f 
Palm 2046. a

Palm, Bast 220. b

Palm, Brown 220. b, 1990.a

Palm, Cabhage 1454. a

Palm, Chip-hat 1990. a

Palm, Cohune 220. a

Palm, Corazo 220. a

Palm, Date 1570. a

Palm, Fan 285. a

Palm, Fern 623

Palm, If 1963. a

Palm, Ivory 1584. a

Palm, Oil 736. a

Palm, Palmyra 285. a

Palm, Royal 1454. b

Palm, Sago 1322

+Palm, Sago 623

Palm, Sugar 529. b

Palm, Thatch 1990

Palm, Tuddy 285. a

Palm, Washington 1397, a

Palm, WVax 4:39. a, 566.

Palma Christi 938. a, 1450. a, b, c, 1735. a

Palmetto, Blue 1722. a

Palmetto, Cabbage 1757. a

Palmetto, Dwarf 2144. d

Palmetto, Royal 1757. b, 1990 b

Palmetto, Saw 1833. a

Palmetto, Silk-top 1990. b

Palmetto, Silver-top 1990. a

Palmetto, Texas 1757. b

Palmy ra Palm 285

Palo de vaca 315 . b

Palommier 870 . b

Palsy wort 355. a, 1660. d

Pameroon bark 2026. b

Panama tree 1912 . $\mathrm{s}$

Panamarinde 1705. a

Panbotano bark 346

Pancake plant 1270 . b

Pancakes 586. a

*Pancratium 1037

Panemeholz 1788. a

Panic-grass 1496

*Panicum 376, 447, 1531

Pansy 2102. f

Pansy, American 2102. e

Panther-wood 349. a

*Panzeria 1165

Pao Pareira 875. a

Papareris erratici flores 1497. c

Papaw (Pawpaw) 383

Papaw, North American 198. a

*Papaya 383

Papaybaum 383. a

Pappelkrant 1270 . c

Papple (Pauple) 61. a

Pappoose-root 413. a

Paprica 377. a

Papyrus $635 . \mathrm{f}$

*Papyrus 635

Paquerette 1667. 8

Para-coto bark 139e. d

Para-grass 220. b

Para-nut 257. a

Paradise, Grains of 101. d,g

Paradice plant 644 .

Paradise tree 1854. a, b

Paraguae folia 1053. $\mathrm{k}$

Paraguay Tea, False 2095.b

Paraiba 1854. a

Parakresse 1893. a

Paralyseos radix 1660 . d
*Parapetalifera 236

Paraquet-bur 2041. a

*Pardanthus 879

Pareira brara 475 . a

Pareira brava, False 5

Pareira brava, White 5 . b

Pareira brava, Yellow 5. a

Pariétaire 1499. a

Parilla, Yellow 1306. a

* Parinari 1500

*Parisette 1501. a

Paritory, Wall 1499. a

Park-leaves 1043. a

*Parkeria 434

*Parkinsonia 435

*Parmelia 442

Parnassus, Grass of 1505

Parsil 1552. a

Parsimon 681. e

Parsley 158. b, 1552. a

Parsley, Ass 51. a, 148. c

Parsley, Beaked 148. b

Parsley, Coney 148. c

Parsley, Cow 148. c

Parsley, Devil's 148. c

Parsley, Dog's 51. a

Parsley, False 51, a

Parsley, Fool's 51. a

Parsley, Garden 1552. a

Parsley, Hedge 411

Parsley, Hemlock 554

Parsley, Horse 1866. a

Parsley, Macedonian 1866.a

Parsley, Marsh 158. a,1554.d

Parsley, Mountain 1554. c

Parsley, Poison 555. a

Parsley, Rock 1552. a

Parsley, Sand 100

Parsley, Sea 1190. a, 1193. c

Parsley, Sheep's 148. c

Parsley, Spotted 555. a, 495 , b

+Parsley, Water 1733. a

Parsley, Welsh 370. a

Parsley, Wild 158. a,1866.a, 2154. a

Parsley-breakstone 65. a

Parsley-piert 65. a

Parslev-vlix 65. a

Parsnip (Parsnep) 1516. a

Parsnip, Cow 982

Parsnip, Meadow 2154. 3

Parsit , WATER, species 1863

Parsnip, Water 258

Parsnip, Wild 495. b, 1863.a

Parson-and-clerk 189. a

*Parthenopsis 2088

Partridge-berry 1336.a 870 . b

Partridge-berry, Mountain 468. a

Partridge-vine 1366. \&

Partridge-wood 2110. b

Pas d'âne 2053. a

Pasper 599. a

PASQue-Flower, species 1693

Passeflower 44. b

Passerage iberide 1168. d

Passerose $87 . \mathrm{b}$

Passevelours 91. a

PASSION-FLOWER, species 1515

Passion-vine 1515

Passions 1641. e, 1753. k

Passulæ 2108.
*Pastinaca 1447

Pastinaca aquatica 1863. b

Pastnip (Pasnet) 1516. a

Patchouli (Patchouly) 1631. a

Paternostererbsen 4. a

Patience 1753. e

*Patience, Garden 1753. k

*Patsjotti 1922

Pauson 1773. a

* Paronia 1142

Pavot 1497 . c

Pavot cornu 892 . a

Pawms 1764, e

Pawpaw 198 a, 383

Pea, Beach 1141. a

Pea, Bird-egg 1556. a

Pea, Buffalo 208. b, 2096. b

Pea, Butterfly 522

Pea, Canada 2096. c

Pea, Chick 493. a

Pea, Coffee 493. a

Pea, Common 1607, a

Pea, Cow 2098. a

Pea, Craw 1141. d

Pea, Crow 2096. e

Pea, Crow- 747. a'

Pea, Egyptian 493. a

Pea, Everlasting 1141. a,f,g

Pea, Garden or Field 1607.a

Pea, Ground 157. a

Pea, Ground-squirrel 1093. a

Pea, Heart $38 €$. a

Pea, Hoary 590 . d

Pea, Marsh 1141. b, c

Pea, Meadow 1141. d

Pea, Milk 856

Pea, Mouse 1141. d

Pea, Partridge 396. $\mathrm{g}$

Pea, Potato 157. a

Pea, Rabbit 590 . d

Pea, Scurfy 16\%9.f, g

Pea, Sea or Seaside 1141. a

Pea, Sensitive 396. f, g

Per, String 1607. a

Pea, Sugar 1607. a

Pea, Sweet 1141. e

Pea, Trailing 157. a

Pea, Turkey 590. d, 767. a

Pea, Wild 605. d, 1141. b

Pea, Wild Sweet 590 . d

Pea-tree 18:38. a

Pea-vine 823. a, 2096. b

Peach 111. b

Peach, Guinea 1784. a

Peach, Native 853. a

Peach, Negro 1784. a

Peach, Sierra Leone 1784, a

Peach, Vine 613. a

Peach, wild 1668. f

Peach-Wood 338. b

Peach wort 1641. n

Peagle 1660. b

Peanut 168

Peanut, Hog 823. a

Peanut, Wild 823 . a

Pear 1699. \&

Pear, Alligator 1546. c

Pear, Arocado 1546. c

Pear, Balsam 1347. b

Pear. Choke 185. a, 16.99. a

Pear, Garlic 593. a

Pear, Grape 96. b

Pear, Holy-ghost 1546. c

Pear, Indian 96 . c

Pear, Juice 96 . c 
Pear, May 96. c

Pear, Prickly 1449. esp. b

Pear, Strawberry 438. b

Pear, Sugar 96. b, c

Pear, Whitten (Whitty) 1875. e

Pear-tree, Widbin 1875, c

Pearl-plant 1214. a, c, 1442, a

Pearl-weed 1761

Pearls-of-Spain 1368. a

Pearlwort 1341, 1\%61

Peat-weed 652. a

Pecan (Peccan) 1004. h

Pecan, Bitter 1004. b

Pech, burgunder 2. a

Pêcher 111. b

*Pecten 1796

Pedelyon 65. b

Pedery 714. a

Pediculaire 1523

Pedicularis semen 656. d

Pedis cati flores 144. a

Pedlar's-basket 629. a, 1792. a

Peen-to 111. b.

Peepul tree 831. \&

Peg-root 974. c

Peg-wood 801. c

Pegukatechu 7. b

*Pekea 393. a

Pellamountain 1973. d, 1994. a

Pellas 12\%0. a

Pellitory 115. esp. b, 482. f

Pellitory, American 1499. a

Pellitory bark 2136. c

Pellitory, Bastard 18. d

Pellitory, European 18. d

Pellitory, German 115. a

Pellitory of Spain 115. b, $10 \overline{8} 8 \mathrm{a}$

Pellitory-of-the-wall 1499. a

Pellitory, Wall 1499. a

Pellitory, Wild 18. d

Pencil-flower 1928. a

Pencil-tree 226. a

Pencil-wood 1099. e

Penghawar-djambi 492. a, b

Pen-gwyn 312. a

Penicaut 781. b

*Penicillaria 1531

Peuny-cress, Field 1989, a

Penny-flower 1234. a

Penny-grass 1033. d, 1726. a

Penny-hedge 74. a

Penny-John 1043. b

Penny-leave 586. a

Penny-mountain 1994. a

Pcnny-pies (Penny-plates) 586. a

Penny-post. 1033. a

Penny-rot 1033. d

Penny-winkle 2100. b

PPennyroyal 1111. b

Pennyroyal, Americau 960 . a

Pennyroyal, Bastard 2030.a

Pennyroyal, European 1308. h

Pennyroyal, False $10 \pi 0$

Pennyroyal, High 616 . a

Pennyroyal Mock 960 . ^

Pennyroyal, Wild 1308. a

Pennywort 586 . a, 629. a, 1422
Peuny wort, Indian, 424. a

Pennywort, Marsh 424,1033

Pennywort, Tbick-leared 424, a

*Pentaptera 522

PEONY, species 1488

Pepillary 1652. 1

Pepino 1867. 1

Peponis semen 614. d

Pensée sauvage 2102. f

Pepper, African 377. b

Pepper, African Black 611.f

Pepper, Ashantee 611. f

Pepper, Australian 706. c, 1602. h

Pepper, Betel 460. a

Pepper, Bird 377

†Pepper, Bird's 1168. a, b

Pepper, Black 1602. g

Pepper, Cayenne $377^{\circ}$ b, c

Pepper, Chicken 1711. a

Pepper, Chili 377. a

+Pepper, Chili 1799. a

Pepper, Cubeb 611. a, f

Pepper, Elephant 460. d

Pepper, Garden 377. a

Pepper, German 641. c

Pepper, Glenn 1168. c

Pepper, Goat's 377. a

Pepper, Guinea 377 . a, b, 611. f, 2140. a

Pepper, Jamaica 1594. b

Pepper, Japanese 2136. a, b

Pepper, Java 611. a

Pepper, Long 460 . b, c

Pepper, Melagueta(Melegueta) 101. $\mathrm{g}$

Pepper, Negro 2140. a

Pepper, Pod 377

Pepper, Poor-man's 1168.c,e

Pepper, Red 377

Pepper, Spanish 377. a

Pepper, Tailed 611. a

Pepper, White 1602. $\mathrm{g}$, 1189. b, 2139. a

Pepper, Wild 644, c, 2036. f

Pepper-and-salt 767. a

Pepper-and-shot 329. a

Pepper-bush, Sweet 518. a

Popper-cress, Garden 1168.e

Pepper-crop 1824. a

Pepper-plant 329. a, 1641. 1

Pepper-root 660

Pepper-shrub 1799. a

Pepper-tree 1799. a

+Pepper-tree 706. a

Pepper-tree, Monk's 2107. a

Pepper-vine 105. a

Pepper-wood 2136. e

Peppergrass 1168

Pepperidge 1421. c

Pepperidge-bush 251. $\theta$

Peppermint 1308. $\mathrm{g}$

Peppermint, Japanese 1308. a, b

Peppermint, Mexican 960.c

Pepperwort, Mithridate 1168. $c$

Peppermint tree 790. a, f, li,s

Perce-muraille 1499, a

Perce-pierre 65. a

Perceley (Persel 1552. a

*Periclymenum 1222

*Perdicium 2042

Peregil 158. b

Periparabo 1602. i, j
*Periploca 977

Peritre 115. b

PeriwixkLe, species 2100

Perlgerste 1019. a

Perlgraupen 1019. a

Perlhirse 1214. c

Perlmoos 477. a

Pernambuco-wood 338. b

Pernel, Orange-lily 116. a

Perpulut 2065. a

*Persea 674, 1424

Persian bark 1721. $\mathrm{k}$

*Persica 111. b

Persicaria (Persicary) 1641. $n$

Persicaria, Biting 1641. 1

Persicaria, Water 1641. a

Persicary, Garden 1641. m

Persil 158. b, 1552. a

PERsimmon, species 681

Persio 1150. f

Pertimugget 863 . a

Pertu-balsam 2008. a

Peruvian bark 498

Pervenche 2100. a

Pesse 2. a

Pesse d'eau 1008. a

Pestilence-weed 1548. a

Pestilencew ort 1548. a

Pestilenzkraut 860 . a

*Petalostemon 1118

Peterschlüssel 1660. d

Petersilge 158. b, 1552. a

Petersilie 158. b, 1552. a

Petit ehêne 1973. b, 2094. d

Petit nard 170. c

Petroselini fructus 158. b

*Petroselinum 158

Pettigree 1755. a

Petty-morrel i70. e, 1867. o

Petty-rice 464 . h

*Peucedanum 134, 697, 1058, $1479,1516,1686$

*Peumus 280

Pewterwort 758. b

*Peziza 814

Pfaffenhütchen 801. c

Pfafienpint 189. a

Pfaffenröhrchen 1959, a

Pfeffer, langer, 460. d

Pfeffer, spanischer 377. a

Pfeffer, schwarze 1602. g

Pfefferkraut 1168. d, 1789. a

Pfefferminze 1308. g

Pfennigkraut 1249 . a

Pferdeminze 1348. b

Pferdfenchel 1427. c

Pferdfliegenstrauch 234. b

Pferdschwanz 758

Pfeilwurzel 1277. a

Pfingstrose 1488. b

Pfirsch 111. b

Pflaume 1668, h

Pfricmenkraut 641 . b

*Phaca 1464

*Phalangium 146, 471

*Pharbitis 1066

*Pharnaceum 1839

* Phaseolus 1921

Pheasant's-eye 44

*Phelipæa 1974

Phellandrie aquatique 1427. c

*Phellandrium 1427

Phellandrium 142\%. c

*Philibertia 1565

Phlox, Garden 1569. c, f 
Phlox, Moss 1569. a

Phlox, Woods 1781. \&

Phlox, Yellow 782. a

*Photinia 769, 997

Phthisic-weed 1072. a

*Phu 207\%

Phulwara 240. a

*Phyllamphora 1398

Phyllitidis folia 1814. a

*Phyllitis 1814

*Phyllostachys 232. $t$

* Phymosia 1888

*Physalis 1187, 1279, 1706

*Physaluides 2122

Physic, Indian 1655. a, b, 160. b

Physic-nut 618. a

*Physocarpa 1448

*Physostegia 306

Physostigmatis semen 1582. a

Pia plant 1947. a

Piany (Pianet, Piney) $148 \%$. b

*Picea 2

Pichi 819 , a

Pichurimbohne 1390. a, b

Pichury beans 1390. a, b

Pick-chcese 1270. b

Pick-needle 777. b

Pick-pocket 329. a

Pick-purse 329, a, 1884, a

Pick-tree 170. f

Pickerel-weed 1650

†Pickerel-weed 242. a, 1657

*Pickerungia 1051

Pickle-plant 1763. \&

Picotee 664. a

*Picraeua 1590

*Picramnia 1961

Picride 1591. b

Picry 1730. h .

Pie-nuarker 6. a

Pie-plant 1723. $e$

Pie-plant, Wild 1753. $f$

Pic-print 6. a

Pied d'alouette 656. c

Pied de chat 144. a, 904

Pied-de-corneille 883. a

Pied-de-lion petit 65 . a

Pied-de-veau 189, a

Pig-grass 147. a

Pig-nut 1004. c, e, 559.

Pig-root 1861. a

Pig-tail 863. a

Pig-wrack 477, a

Pigeon-berry 1585. b, 96. a, 170. b, 1336. a, 1750, a

Pigeon-grass 2091. f

Pigeon-root 513. c

Pigeon tree 170. f

Pigmy-weed 2000

Pignon 1601. b

Pigweed 91. esp. d, 464

tPinweed 456. a

Pigweed, Winged 626

*Pilea 41

Pilewort 760. a, 91. d, 830.a, $1820 . \mathrm{b}, \mathrm{c}$

Pili gossy pii 912. c

*Pilicordia 2085

Piligan 1240 . h

Pillards 1019

* Pilosella 1005. f

Piloselle 1005. fi

Pilot-weed 1852, a

Piment de Cayenne 377. b
Piment de la Jamaique 1594. b

Piment des jardins 377. a

Piment rouge 377 . a

Piment royal 1375, c

Pimentary 1302. a

Pimento 1594. b

Pimpernel 2094. b

*Pimentus 1594

+Pimpernel 1667. a

Pimperuel, Blue 1821. c, 116. $a$

Pimpernel, False or Bastard 426. a

Pimpernel, Italian 1774. b

Pimpernel, Red 116. a

Pimpernel, Scarlet 116. a

Pimpernel, Sea 99. a

Pinupernel, Small 1595. b

Pimpernel, Water 1772

Pimpernüisse 1605. f

Pimpinall 1774. b

Pimprenelle 1774. c

Pin-ball 428, a

PIN-WEED, species 1151

Pin-weed (Pin-grass) 777. a

Pinang 177. a

Pinckney bark 1597.

Pincushion 144. b, 1794. a

Pincushion tree 2095. d

Pindar 168. a

Pine, species 1601

*Pine 119. a

Pine, Amboyna 55. b

Pine, Blister 2. b

Pine, Cal 1587. a

Pine, Festoon 1825. b

Pine, Field 1026. a

Pine, Fir 2. b

Pine. Ground 1240. a, b, c

tPine, Ground 63. a, b, 1786. a, 1973. a

Pine, Kauri 55 . a

Pine, Moon-fruit 1240. e

Pine, Norfolk Island 171. a

tPine, Oregon 1674. a

Pine, Prairie 1124. b

Pine, Running 1240. \&

Pine, Screw 1495. a

Pine, Silver 2. f

Pine, Spiral 1240. c

Pine, Spruce 1587. b, 2046.

Pine, Sirasshurg 2. $f$

Pine, Wax 55

Pine-apple 119. a

Pine-barren Beauty 1700. a

Pine-cheat 1884. a

Pine-drops 1684, a

Pine-needle 7r7. a

Pine-nut 1601. a

Pine-sap 1046. a

Pine-sap, Sweet 1357, a

Pine-weed 1786. a

Piney-varnish tree 2086. a

Pinguin 312 . a

PINK, species 664

Pink, Bearded 1200. a

Pink, Boston 1781. a

Pink, Carolina 1892. b

Pink, Chimney 1781. a

Pink, Clove 664. a

Pink, Corn 61. a

Piuk, Cushion 1851. c,1903. a

Pink. Dwarf French 1851. a

Pink, Election 225. a

Pink, French 423. e, 1903. a

†Pink, Grass 1200. a
Pink, Ground 1569.

Pink, Hedge 1781. a

Pink, Indian 1892. b, 1236,d. 1638. c, 1702. b

Pink, Maryland 1892. b

Pink, Meadow 225. b,938.d, 1236. d

Pink, Mice 1851. a

Pink, Moss 1569. e, 1851. c

Pink, Mountain 754, a

Pink, Mullen 1236. c, 61. a

Pink, Old-maid's 1781. 61. a, 1851. a

Pink, Rock 1953. a

Pink, Rose 1758. a

Pink, Saxifrage 2051

Pink, Sea 1851. b, 1903. a

Pink, Scaw fall 1903. a

Pink, Swamp 225. a, b, 975, 1200 . a

Pink, Wax 1656. a

Pink. Wild 179. a, 1569, e, 1851. $f$

Pink, Winter 754. a

Pink-bloom 1758. a

Pink-needle 777. a, b

Pink-needles 1796. \&

Pink-root 1892, a, b

Pink-weed 1641. d n

Pinkster-flower $225, \mathrm{a}$

Pinne tree 2086. a

-Pinus 2, 419, 1138, 1587, 1674,2046

Pinyon (Piñon) 1601. c, $d, \theta$

Pipa 769. a

Pipe-plant 1356. a

Pipe-stem 1592. b

Pipe-tree 1945. a

Pipe-vine 182. b

*Piper 460, 611, 1320

Piper æthiopicum 2140. a

Piper cajannense 377. b

Piper caudatum 611. a

Piper hispanicum 377. a

Piper jamaicense 1594. b

Piper longum 460. d

*Piperella 1328

Piperidge (Peprage) 251. $\odot$

Piperidge, Spotted 466. a

Pipple 1652 . 1

Pipul tree (Pipal) 831.0

Pipewort 717

Pipitzahoic acid 1541.

Pipsissewa 466 . a, b

*Piptocaly x 1116

Piquillin 553. a

*Piratinera 315

*Pirus 1269, 1699

Pisang 1367. d

*Piscidia 1052

Piscidio 1052. a

Pisky-stool 53.a

Pismire 482. $\Theta$

Pissaba 220. b

Pissabed 1711. f, 1959. \&

Pissenlit 1959.

Pistache de terre 168. a

Pistacien 1605. $\mathrm{f}$

Pistachio nut 1605 . f

Pistolochia 182. c

* Pisum 1141

Pitay a bark 498. b

Pitch, Burgundy 2. a

Pitch, Dammer 2086. .

Pitcher-Ptant, species 1787, 1398

+Pitcher-plant 1596, 
Pitcher-plant, California 481 a

Pitchforks 263. f, g

*P'toxylum 1600

*Pittouia 294

Pituri (Pitchuri) 714. a

Yivoine officinale 1488. b

Pix alba 2. a

Pix burgundica 2. a

Pixie (Yiskies) 1851

*Plagianthus 1128. a

*Plagiobothrys 1872

Plane-tree 1612. a, b, c

Plane-tree, Mock 16. d

Planer tree 1610

* Planotia 232. u

Plant-of-glution 576. d

Piaqueminier 681

Pla vTa1N, species 1611

Plantain d'eau 72. a

Plantain, Indian, species 1315

Plantaiu, Indian, Sweetscented 1942

Plantain, Mud 993. b, c

Plantain, Net-leaf 1538. a, b

Plantain, Poor Robin's 1005. $\mathbf{i}$

Plantain, Rattlesnake 1538

Plantain, Robert's 768. c

Plantaiu, Robin's 768.

Plantaiu, Snake 1005. i

Plantain, Spotted 1538. a

Plantain, Water- 72

Plantain, White 1538. b, 144. b

*Plaso 331

*Platanthera 938

*Plectocephalus 423

Plentage 290 . a

Pleurisy-root 195. d

Plowman's-wort 1619. a

Pluff 1238. a

Plum. species 1668

†Plum 1474

Plum, Assyrian 2085. a

Plunı, Bay 16r5. b

Plum, Bunch 576. c

Plum, ('ocoa 483. a

Plum, Darling 1719, a

Plum, Date 6rt

Plum, Downward 1849. c

Plum. Dowunarel 326

Plum, Giugerbread 1500. a

Plum, Gupher 1421. b

Plum, Ground 208. b, o

Plum, Guiana 713, a

Plum, Hog 1898. b

Plium, I vory 468, a, 870. b

Plum, Jamaica 1898 b

Plum, Japau 769. a

Plum, Malabar 1086. a

Plum, Marnalade 1228. a

Plum, Mountain 2138. a

Plum, Nanny 2095. c

Plum, Yigeon 526. a

Plum, Saffron 1849. c

Plum, Sapodilla 20. a

Plum, Seaside 2138. a

Plum, Sebesien 2085. a

Plum, Seeded 681. e

Plum, Squaw 1536. a

Plum, Sugar 96. c

Plum, Thorn- 592. (g)

Plum, Winter 681. $\theta$

+Plumbago 1641. n

Plume d'eau 1021
Plumgranite 1668. a

Plyvens 2032. $f$

Poaya 343, a, 2062. a

Fock-weed 1883. a

Pock-wood 919. a, b

Pockeuwurzel 1865. b

Pockholz 919. a, b

*Podaly ria 234, 1985

Podder 620

*Podophyllum 1093

Podophyllum, Rhizome de 1625. a

Poele bask 85. c

Poha 1578. b

Pohickery 1004

*Poincea 1632

Poirier 1699. a

Pois à gratter 1365. a

Pois d'Amériquo 4 a

Pois velus 1365. a

Poison-berry 27. b, 189. a, 1053. a, 1867 .

Poison-flower 1867. j

Poison-nut 1923. d

Poison-tree 1730. p

Poison-vine 1730 . h

Poison-wood 1730. g

Poivre à queue 611.

Poiv re de Giuinée 377. a

Poivre des murailles 1824.

Poivre long 460. d

Poivre noir 1602. g

Poix de Bourgogne 2. a

Poix des Vosges 2. a

Poix jaune 2. a

Poke, Iudian 2089. b

Poke, Stinking 1883. a

Poke, Tree 1585. a

Poke-berry 1585

Poke-root 1585 . b

+Poke-root 2089. b

Poke-weed (Pocan) 1585. b

Polander 1660. d

Polar-p!ant 1852. a

Polecat-weed 1883, \&

Polei 1308, h

Polei, amerikanischer 960. a

*Polemonium 1256

Pollom, Red 870. b

Pollum, Little 1688. c

Pollum, White 468. a

Poly, Grass 1250. c

Poly-mountain 520. a, d

Poly-mountain, (Yellow) 1973. d

Polyanthus 1660. d

†Poiyanthus 1685

*Polydymia 1670

Polygaia de Virginie 1638.h

Polygala, South American 1351. a

Polygala virginiana 1638 . b

*Polygonum 821, 1640

*Polyotus 17

*Poly phema 188

Polypod (Polypode) 1643. a

Poly pode commun 1643. a

*Polypodium 622, 712,1561

Polypody (Polypoddy) 1643. a

Polypody, Pale Mountain $1561 . b$

Polypore du Mélèze 1644. d

*Polystichum 712

*Pomaria 1409

Pomegranate 1694. a

†Pomegranate 1668. I
Pomegranate, Vegetable 613. a

Pomeranzenbaum 506.

Pomme blanche 1679 . b

Pomne canelle 140 . e

Pomme d'amour 1289. a

Pomme d'ananas 119. a

Pomme de prairie 1679 . b

Pomme de terre 1867. n

Pomme épineuse 649. b, c

Pompelmos 506. g

Pompelo 506.

Pompion 614. b, d

Ponchishuiz 19:. a

Pond-grass 1657. d

Pond-grass, Tassel 1754. a

Pond-lily, Red-disked 1420. d

Pond-lily, White 399

Pond-lily, Yellow 1420.a,b,c

Pond-spice 1266. a

PONDWEED, species 1657

*Pongamia 859

*Pongatium 1891

*Ponvederia 993, $15 \% 86$

Poolwort (Pool-root) 802. $a, b$

Poon tree 353 . a

Poona oil 859

Poor-Anne 2089. b

Poor-man's-pepper 1824. a

Poor-man's-pharmacetty 329. $a$

Poor-man's-rhubarb 1976. a, b

Poor-man's-soap 1895. d

Poor-man's-treacle 74.a,76.

Poor-man's-weat berglass 116. a

Poor-Robin 863. a

Pop-dock 67\%. a

Pop-weed 2072. a, etc

Popillary 1652.1

Popille 61. a

Poplar, species 1652

Poplar, Balsam 16:2. b

Poplar, Blue 1211. a

Poplar, Hickory 1211. a

+Poplar, Silver-leaf 1999. c

Poplar, Tulip 1211. a

+Poplar, White 1211. a

Poplar, Yellow 1211. a

Popple (Pope) 1497. c

PoPPY, species 1497

Poppy, Blie 423. c

Poppy, California 788

Poppy, Celandine 1927. a

Poppy, Frothy 1851. b

Poppy, Horn or Horned 892

Poppy, Mexican 180. b

Poppy, Prickly 180

Poppy, sca 892

Poppy, Tree 658

Poppy, Spatling 1851.

Poppy, Thorn 180

Poppy, Yellow 1927. \&

*Poppya 1232

Porcelle 1045

Porillon 1385. a

Porreau 76.d

*Porrum 76

Porsch (Porst) 1153. b

Porte-chapeau 1491. a

*Portuna 1592

Possum-wood 681. e

Posy, Indian 195. d 
Pot-herb, White 2078. a

Potato, Canada 968. b

Potato, Cree 1679. b

Potato, Dakuta 157. a

Potato, Hog 1u66. n, 2159. c

Potato, Indian 157. a

Potato, Irish 1867. n

Potatu, Nettle-1914. a

Potato, 1'ig 157. a, 1179. b

Potaco, sweet 1066. a

Potato, Wild 1066. n, b13. a, b

*Potentilla 547, 1020, 1080, 1844

*Poterium 1774

* Pothos 1883

Pochos fétide 1883. a

Potirun, Semences de 614. d

Poukeuel 1796, a

Pouliot Americain 960. a

Pouliut commun 1308. h

*Pourretia 1645

Poverty 1761. a

Poverty-grass 1026. a, b, 570. a, 2032. c

Poverty-weed 904. a, 121. a, 144. b, 482 . e, 1296. a

Powk-ueedle 777. a

Prailie-bush, Stinking 1681. a

Prairie-dug weed 720 . a

Prairie-fire 403. a, etc

Prairie-grub 1681. a

Prairie-pine 1124. b

Prairie-smoke 885.

Prairie-weed 1658. d

*Prasium 1251, 1581

Preisselbeere 2075. p

*Prenanthes 1243, 1381

*Prestouia 730

Pretty-grass 351. c

Precty-Nancy 1851. 2

Prick-Hollin 1053. a

Prick-madam 18:4. a, b, e

Prick-tiıber (Prick-wood) 801. c

Pricket 1824. a

Prickly ASH, species 2136

Prickly-bark (Pricky-bark) $686 . \mathrm{b}$

Prickly-bur 400, a

Prickly-pear 1449

tPride-oj-Barbados 35. a

Pride-of-China 1299. q

Pride-of-Columbia 1569, d

Pride-of-India 1299. b

Priae-of-Ohio 693. a

Pride-of-the-meadow 2057.

Pride-weed 1174. a

Prie 1194. a

Priest's-crown 1959, a

Priest's-piutle 181. b

Prim-grass 147. a

Primavère 1660 . d

Primel 1660. d

Primimily 1660 . a

PRIMkOSE, species 1660

†Primrose 95 t, 1147, 1293, 1313,1890

Primrose, Evening 1428, 1436. a

†Primrose, Evening 142, 1107

Primrose, Spotted 872

Primrose, Tree 1436. a

Primrose-willow 1100

Primwort (Prim) 1194, a
Priuce's-feather 1641. m

†Prince's-feather 91. a, d, 1945 a

Prince's-pine 466. b

Prince-wood 816. a

*Prinos 1053

Priut 1194. a

*Pritchardia 1397

Privet 1194. a

Privet, Egyptian 1148. a

Privet, Evergreen 1721. a

Privet, Pipe 1945. a

Processiou-Hower 1638. 1, p

*Prosartes 690

Prune 1668, h

Prune-coton 483. a

Prunier 1668. h

*Prunus 111. a

*Psathy rotes 1555,2029

* Pseudo-rcacia 1738

Pseudo-mastich 215. a

*Pseudomagennetus 1282

*Pseudostachyum 232. v

*Pscva 466

Psidii cortex 1694. a

*Psilocarphus 989

*Psychotria 2062

*Psychotrophum 1680

* Plelea 519

*Pteris 15:7

Pterocarpi balsamum 687. a, etc

*Prerostephanos 139

*Pteruta 2136

*Ptilonella 269

Public-house plant 194. f

Puccoon, Hoary 1214. b

Puccoon, Indian 1214. b

Puccoon, Red 1773. a

Puccoon, White 1773. a

Puccoon, Yellow 1032. a

Puccoon-ront 1773. a

Puchero 1953.

Puchurim (Pichurim) 1390. a

Puck-needle 1796. a

Pucker-needle 1796. a

Puckfist 1238. a

Pudding-grass 1308. h

Pudding-pipe tree 409 . b

Pudding-stick tree 409 . b

*Pulegium 1308

Puerto Rico bark 544. a

Puff-ball 1238

†Puff-ball 380. a, 737. a, 1959. a

Puke-weed 1217. b

Pulas tree 331.

Puliall 1308. h

Puliall-mountain 1973. d

Pulicaire 1691. a

Puliol-mountain 1994. a

Puliolroyal 1308. h

Pulmonaire des Francais 1005. e

Pulmonaire officinale 1692. a

*Pulmonaria 1314, 16:3

Pulque 56. c

Pulsatilla 1693. b

Pulu 492. e, f

Pulverholz 1721. g

Pulvis goa 2110. a

Pulvis insecticidus 482 . b, c

Pumpkin 614. d

Pumpkiu, Wild 614. a

Punk 1644. a

Puppy 1497. c
Purga 815. under b

Purging-nuc 618. a

Purging-root 803 . a

Purgirkassie 409. b

Purgirkörner 606. h

Purgirkörner, kleine $803 . \mathrm{g}$

Purple-grass 1250 . a, 12b1.a, 2032. $\mathrm{g}$

Purple-lip 2083

Purple-tassels 1368. b

Purplewort 547. a, 2032. g

Purse-tassels 1368. b

*Purshia 1120

Purshiana bark 1721. k

Purslaxe, species 1656

Purslane (Purslain) 1656. b

Purslane, Black 803. h, j

Purslane, French 1656, a

Purslane, Garden 1656. a

Purslane, Horse 2023. a

Purslane, Marsh 1072. a

Purslane, Milk 80.3 a, h

Purslane, Mud 739

Purslane Sea 99. a, 1839

Purclane, Spotted $803 . \mathbf{h}, \mathbf{j}$

Purslane, Water 675, 1072. a

Purslane, White 803 . a

Pursley, see Purslane

Pursley (Pussley) 1656. b

Purvain 2091. c

Pushion-berry 18â7. j

Pushpole 1497. d

Pussy-cat (Pussies) 2032. c

Pussy-cats 1764 . e, h

Pussy-toes 144. b

Putcha-pat 1631. a

Putchuk 1791. a

Putty root 159 . a

*Pycnanthemum 1111

*Pycreus 635

Pyddharr 14r4. b

Pyracauth 584. a

Py ramid plant 844. a

Pyrèthre commuu 115. \&

Pyrèthre du Caucase $482 . b, c$

Py rèthre officinal 115 . b

*Pyrethrum 482. b, c, 1285 , 1957

Pyrethrum germanicum 115. a

Pyrethrum romanum 115 . b

Pyrethrum, U. S. P. 115. b

*Py rola 466, 1349

Pyrole 1696. d

Py role ombellée 466. b

*Pyrrhopappus 1862

*Pyrus 96, 185, 628, 1269 , 1318,1875

Pyxie 1700. a

Quacksalver's Spurge 803. b

*Quaeria 152

Quafodil 1298. a

Quai 1932. h

Quakers 189. a

Quaker-bonnets 1022 . a

Quaker's-bonnets 1235

Quaker-buttons 1923. d

Quaker-ladies 102\%. *

Quaker-lady 1895. c

Quainash, Eastern 1701. a

Quandong (Quandang)

853. a

Quarter-vine 265. b

Quarre épices 14i1. b

Quashy-quasher 1988. a

*Quassia 1590, 1853

Quassia, Lofty 1590. a 
Quassia, Surinam 1703. \& Quassiae lignum 1703. * Qusssie smère 1703. a Quassie de la Jamaique 1590. 8

Quassienholz 1590. a, 1703. a Quebracho blanco 203. \& Quebracho tlojo 1064. a

Quecke, rothe 382 . \&

Quecke I wurzel 60. a

Queen Anne's flower 1385. a

Queen-of-the-meadow 2057. a, 189.5. c, 802 . j

Queen-of-the-prairie 2057. b Queen-of-the-sierras 2. d

Queen-root 1914. a

Queen-weed 1516. a

Queen's-delight 1914. a

Queen's-needle work 1595 . c

Quequiri 4.a

Quendal 1994. a, b

Quercitron 1704. พ

Quercus marinus 849 . b

Quick-beam 1875 a, d

Quick-(Quitch) grass 60. a

Quick-in-the-hand 1057. \&

Quick-set, May 59:2. a

Quickens 60.

Quicksilver-weed 1976. a

Quillaya 1705. a

Quillet 2032. $\mathrm{g}$

†Quillwort 8u2.j

Quina 1867. u

*Quinaria 1514

Quince 628, a, b

Quince, Bengal 47. a

Quinine, Native 85 .

Quinine, Wild 1513. b

Quinine-flower 1758. b

Quinıne-plant (herb) 1758.b

Quinine-tree 1681. a

Quino-quino tree 2008. c

*Quinquina 498

Quinquina gris 495. c, e,

Quinquina jaune 498. a

Quinquina rouge 498 . ?

Quinoa 464. h

Quinsy-berry 1732. e

Quinsy wort 201. a

Quintefeuille 1658. \&

Quital 1171. \&

Quitte, bengalische 47. a

Quittenbaum 628. a

Quirer-leaf 1652. i

Quobsque-weed 809. a

Raave 1566 . a

Rabbit-berry 1166. a

Rabbit-brush 489. a

Rabbit-meat 1132. c

Rabbits 151. a, 629. \&

Rabbit's-flower 677. a

Rabbit's-meat 148. c

Rabbit's-mouth 151. a

Rabbit's-root 170 . c

Rabone (Rawbone) 1712. b

Raccoon-berry 1625. a a $062 . \mathrm{b}$

Racine brasilienne 2062. b

Racine de St. Christ

Radiaire 209. a

Radical-weed 1867 .

Radish, Garden 1712. b

Radish, Wild 1712. a

*Rajuesquia 1396

Rag-jag 464. a

Rag-woolwort 1831. k

Ragged-cup 1852 b.
Ragged-Jack 303. e, 1236. d Rattlesnake-Feed 781. *

Ragged-lady 1411. a

Ragged-Robin 1236. \&, d

Ragged-sailor 1641. m

Ragweed 95

+Ragweed 1831. f

Ragweed, Woolly 1831، k

Rag wort 1831, a

Ragwort, Pale 1831.

Ragwort, Tansy 1831. \&

Raifort 1742 .

Rain-berry 1721. d

Raiubow-weed 1250. a

Rainiarn 1957. a

Rainweide 1194. a

Raisin d'Amerique 1585. b

Raisin d'ours 176. $\ell$

Raisin, Wild 2095. c

Raisin-tree 1732. h

Raisins 2108. e

*Rajania 318

Rambutan

$$
\text { 1400. a }
$$

Ramie 276.

Rampion 362. a

Rampion, Large 1436. a

Rampostan 1400. a

Raups (Ramsien), 76. h

Rams 534. a, 76. h

Ram's-claws 1711. h

Ram's-head 636. b

Ram's-tongue 1511. b

Ramsey 1439. a

Ramson, Round 891. b

Ramisons 7ti, h

Ramsted 1205 \&

Ramtil 9:25. a

Rancid (Ranstead) 1205. a

Rancooran 14i4. a

*Ranunculus 242, 830, 1478

Ranunculus, Globe 2043. a

Rantipole 651. 8

Ranty-tanty 1753. b

Rape 303. b

†Rape 1712. a

Rape, St. Anthon $\bar{y}^{\prime} 3$ 1711.

Rapper-dandies 176. $\mathrm{f}, 870 . \mathrm{b}$

Rapsöl 303. b

Rashburn 1439. a

Raspberries-and-cream802.c

PuASPBERRY, species 1750

†Raspberry 1732. h

Raspberry, Ground 1032. a

Rassols 1439. 2

Rat-tail 1611. b

Ratafia 1668. $\odot$

Ratanhawurzel 1114. $\odot$

Ratanhia 1114. e

Ratanhiae radix 1114. c, e

Rattan Palm 341

Rattenpfeffer 656. d

Rattle, Penny 1726.

Rattle, Yellow 1726. a

Rattle-bags 1726. a, 1851. b

Rattle-box 605, 1726. a,1229.a

Rattle-bush 234 . b

Rattle-bush, Blue 234. a

Rattle-nut 1391. a

Rattle-root (Rattle-top) 497. a

Rattle-weed 208. p, 497. a

Rattler tree 1652 ,

Rattlesuake-bite 1976. d

Ratclesnake Fern 290. b

Rattlesnake-berb 27

Rattlesnake-root 1381. a, b,c, 1639. h, 2036.
1005 , i, 1538, \&

Rattlesnake's-beana 1853.a,b

Rattlesnake's-master 781. a, 56. d, 1124. a, b, c

Rattlesnake's-root 497. a

Rat's-bane 148. c. 4f6, 1538 a

RatsBaxe 1928. d

Raute 1756 , a

Rawn tree 1875. d

Ray-grass 1220 . a

*Reaualmia 74:2, 2001

Rebendoldenkraut 1427 . b

Red-bean vine 3. a, 1731. a

Red berry 27. b, 1493. b

Red-berry, Swamp 1476. b

Red-Betty 1217. a

Red-bird 883 . b

Red-bird's-eye 883 . b

Red-brush 576. b, i

Red-bud 436, a

Red-g'anfergregors 1450. d

Red-gum 790. e

Red-he td 195. 8

Red-Iudıans 403. a, etc

Red-ink plant 1585 . b

Red-knees (Red-shanks) 164 , 1

Red-legs 1641 . e

Red-ràttle 15:3. b

Red-Robin \$83. b

Red-rod 576. b

Red-root 415. a, 758. c, 885. e, f, 1773. a

†Red-root 91 . e, 370. a, 1903. .

Red-root, Carolina 937. a

Red-root, Indian 937. a

Red-rot 707.

Red-Sally 1250. a

Red-seed 455. a

Red-shanks 883. b, 1641. \&, n, 1753. a

Red-weed 1585. b, 1641. $n$, 1753. b

Redoul 574. 8

Redwood 1832.

tRedwood 1682. d

Red-Trood, Indian 1879. a

Redwood (of Turkey) $576 . \mathrm{b}$

Reed 192. a, 2153. a

Reed-grass 1881

Reed-mace 2055.

Reefort 1712. b

Réglisse 902. b

Rézlisse indienne 4. a

Reine des prés 2057 a.

Reis 1468. a

Renoncule 1711. c

Reree 2055. 8

Resin 1601. i

Resina elastica 1001. a

Rest-harrow 1439. a, b

Restis bovis, radix 1439. b

Resurrection-plant 122. a, 1825. a

Rettersporn 656. c

Rewa 1898. a

Rhabarber 1723. c

*Rhacoma 1372

*Rhamnus 1720

*Rhaphidophora 757

Rhapontic 1723. e

RHATAyY, species 1114

Rhees 276. a

Rheum indigenum 1723.
Red-butcher 1450. d 
Rheum nostratis 1723. e

Rheumatisı root 1093. a, $46 j . \mathrm{a}, \mathrm{b}, 680$. f

Rheumatisw-weed 160 . a, b

* Rhinantbus $6+\tau$

Rhineberry 1721. d

* Rhodanthe 968 . c

* Rhodiula 1824

* Rhododendron 225, 1729

Rhododendron, Carolina 1728. a

Rhododendron, Catawba $17: 28$. a

Rhododendron, Yellow 1728. b

\section{* Rbodymenia 943}

Rhoeados petala 1497 . c

RHUBARB, species 1723

Rhubarb, Bog $15 \pm$. a

Rhubarb, False 1976. b

Rhubarb, Meadow 1976, b

Rhuharb, Monk's 1753. k, $19 \div 6 . \mathrm{b}$

Rbubarb, Mountain 1753.k, 1

Rhubarb, Poison 1548. a

Rhubarbe de ('hine 17:3. c

Rhubarbe de Moscovie 1723. $d$

* Rhus 583

* Rhyncolepis 905

Rib-gravs (Ribwort) 1611. b

Ribbon-grass 1559. a

Ribbon-iree 261. a

Ribesia rubra 1732. h

* Pibesoides 744

Rihia rubra 1732 , h

* Ricardia 1733

kice 1468, a

Rice. Canada 2153. a

Rice. Indian 2153. a

Rice, Water 2153. a

Rice, Wild 2153. a

Rice-paper, Chinese 170. d

Rich-leaf 539 . b

Rich-weed 539. b.41. a, 95. b, 497. a, 802 . a

*Richardia 2147

*Richardsonia 1733

Ricin 1735. a

Ricinus major 618. a

Ricinussamen, grosse 618, a

*Riddellia $1687^{\circ}$

Rièbel 863 . a

Riely 1220 . a

Riementang 1131. a

Rignum 1348. b

Rilts 251. 2

Rima 158, a

Ringelblume 344 . a

Ringworm powder 2110. a

Ringworm-root 1725, a

Ripple-grass 1611. b

River-bush 428. a

River-weed 1627 . a

Riz 1468. a

Rizzles (Rizzer-berrs) $1732 . \mathrm{h}$

Roan (Roddin) tree 15:5. a

Roanoke Bell 1314, a

Rob sambuci 1771. e

Robin-hood's-fetter 514, d

Robiu-1 un-away S94. a

Robin-run-in-the-hedge S. 4. a

Robin's-eye 16 ?

Robinier 1738. a

Rock-berry $1 \% 6 ., f$
Rock-fern 40. b

Rock-l1ly 166. a, 1825. a

Rock-plant 1824. a

Rock-ROSE, species 967

Rock-rose 1825. a

Pock-weed 201. b, 883. t

Rocket, Rastard 303 , c

Rocket, Blue 25. i

Rocket, Dame's 990. a

Rocket, Iyer's 1717. a

Rocket, False 1063

Rocket, Garden 990. a

Rocket, Italian 1717. a

Rocket, Prairie 752. a

Rocket, Purple 1063, 456. a

Pocket, Sand 685 . a

Rocket, Scrambling 1860. a

Hocket, Sea 340

Rucket, Sweet 990. a

Rocket, Winter 235. a

Rocket, Wound 23.̦. a

Rucket, Yellow 235. a, 1717. a

†Rocket, Yellow 1249. n

Pocou 266. a

Rouls-gold 344. a

Rogation-flower 163S. 1, p

Poggen 1823.

Roggenmutter 512. a

Rohan 1879. a

Rohrkassie 409. b

Rubun (Rohusa) 1879. a

Roland 781 . b

Roll-herry 1956. a

Roman plant 464 , d

Rumarin des marais 1202 . c

Romarin sauvage 1153 . b

Roms 76. h

Ronce saurage 1750. g

* Ronobea $16 \times 0$

Rooster-heads 693. a

Poosters 2102, c

Hope-bark 689. a

Rorellae herba 707. a

Roris marini folia 1744. a

Roris solis herba 707 . a

Rosa-solis ( $\mathrm{Ros}$ solis) 707. a

† Kosa-solis 1. a

Rosary plant, Mexican 1731. a

RosE, species 1743

Pose à rubie 14 b

Rose, African 149\%.c

Rose, Althea $8 \pi . \mathrm{b}$

Rose, Burnet 116. a

Rose, Canker 1497. c

Rose, Chinese(China) 1003.f

Rose, Corn 1497. c, 61. a

Rose Bay, East Indian 1946. b

Rose, Christmas 974. b, c

Rise, Cliff 19u3. a

Rose, Copper 149i. c

Rose, Cotton 886 . a

Rose, Egyptian 1794. a, b

Hose, Gipsy 1794. a

Rose. Juno's 1196. b

Rose, Love 2095. d

Pose, Mallow 1003, e

Ruse, May 2095. d

Rose, Mexican 1656. a

†Rose, Moss 1271. a

Rose of Crete 503 . c

Rose of Jericho 122. a

Rose of sharon 1003 . h

Rose, New-vears 974. b

Rose pâle 1743. b
Rose, Rock 503

TRose, Rock 1903. a

Pose rouge $1743 \mathrm{~d}$

Rose, sage 2052. b

Rose, seusitive 1361 . a

Rose, sheep-shearing 1488,b

Kose, siberian 17.2\%. b

Rose, snow 1726. b

Pose, snowdou 18:4. h

Rose, South sea 14us. a

Rose tremière $8 \%$. b

Pose, Wind 149\%, a

Rose-bay 456 , a

Rose-bay, Dwarf 1728.

liose-bay, Mountain i 728 . a

R s se-bay' (Wild) 1728 . d

ruse-Betty 768. c

Ruse-may 1871. a

Rose-noble 633, a

Roseau grande 192. a

Rosée du solell 707 . a

Rosella 1003. g

Posemary, Garden 1744. a

Rosmarin (Romarin, 1744.a

Rosmarin, wilder 1153. b

Rosmarinus silvestris 1153.b

Rosemary, Marsh 1:02. a, 1153. b, 128. a

Rosemary, White 206. c

Rosemary, Wild 1153. b, 128. a, 863. a

Rosenlorbeer 1403. a

Posewood 6i4. a, 1682. $\mathrm{f}$, 1253

Rosewood, African 1682. b

Posewort (Rose-root, 1824. h

Pushé (Rosé) oil 129. d

Yosier saurage 1743. a

Rosilla de puebla 965 . a

Rosin-plant 1852. c

Rosin-rose 1043 . b

Rosin-tree 1601. i

Rosin-weed 1852. a, o

Rosin-wood 488. b

Rossfenchel 14:7. c

Rosshuf 2053. a

Rosskastanie 50. o

Rosswurzel 384. a

Rosy-bush 1895. d

Rot-grass 1599. a

*Rotang 341

Rothbernitzbeere 2075. p

*Rottlera 126 ;

Rottlerae glandulae 1267.

Rouge-berry 173\%. a

Rouge-plant 1757. a

Rough-root 1124. b

Rough-weed 1900. a

Rouud-heart 1979. a

Round-tree 1875. a, d

Round-wood 1575, a, d

Roving-Jenny 1792. a

Roving-sailor 629. \&

Rowan-tree 1575 . a, d

Rowan tree, Ilog 2095. d

Royn tree is75. d

Rozelle 1003.

Rubber, Brasilian 1001

Rubber, Ceara 1276 a

Rubber, Para 1001. a

Rūbe, gelbe 651 . a

Rūböl 303. b

Ruby-wood 16S2, d

*Rudbeckia 304, 1713

Ruddes 34 , a

Rue de chèrre 860 . a

Rue, Garden 1756. a 
Rue, Goat's 590. d, 860 . a Rue, Maideuhair 1976. b Rue, Stone- or Wall- 204. c Rue-auemone 1940, a

Ruffet 20.6. a

Ruhrrinde 1854, a

Ruhrwurzel 1658. g, 2062. a

*Ruizzia 280

* Runiex 1480

Runch 303. a, 1900. a

Runkelrübe 259 , a

Runnet 863. i

Ruprechtskraut 883 . b

Rusa oil 129. d

Rusci oleum 261. a

RUsH, species 1098, 1809

Rush, Bog 1098

Rush, Cotton 774

Rush, Dutch 758. b

Rush, Guinea 635. a

Rush, Mountain 752

Rush, Polishiug 758. b

Rush, Scouring 758. b

Rush, sweet 26. a

Rush, Wood 1097

Rush-grass 774. a

Rush-nut 635 b

Rüsterrinde 2058. f

Ruswut (Rusat) 251. a

Rut-of-harte 737, a

Ruta capraria 860.2

Rutland-beauty 563. c

*Rutosma 1977

Rye 1823. a

Rye, Cockspur 512. a

Rye, Robin's 1649. b

Rye, Spuried 512. a

Rye-brome 313, a

Rye-grass 1220

* Sabadilla 193

Sabadillsamen 193. a

* Sabal 1833

Sabbatie 1758. a

Sabicu 1248. b

*Sabiua 1099

Sabiua, U. S. P. 1099. d

Sabine 1099. d

Sabino tree 1962. a

* Saccharifera 1759

Sacci 56 . b

Sack-tree 150. a

Säckelkraut 329 . a

Sacred bark 1721. k

Saddle-leaf 1211. a

Saddle-plant 1787. b

Saddle-tree 1211. a

Sadebaum 1099. d

Sadekraut 1099 . d

Saff (Saugh) 1764

Safflower 391

Saffron 601. a, b

Saffron, African 391. a

Saffron, American 391, a

tSaffron American 601. a

Saffron. Bastard 391. a

Saffron, Dyer's 391. a

Saffron, False 391. a

Saffron, Indian 619 . c, d

Saffron, Meadow 534

tSaffron, Meadow 1427. a

Saffiron,'Spanish 601. a

Saffron, Thistle 391. a

Safran 601. a

Safran bâtard 534 . a

Safran deutscher 391. a

Safran falscher 391. a

Safrifa 1903 , b
Sagachomi 176. f

Sagapenum 828. $\mathrm{g}$

Sage, Black 2u30. c

Sage, Garden 1769. b

Sage, Garlic 1973, f

Sage, Indian 802.1

Sage, Jerusalem 1568, a

Sage, Meadow 1769. c

Sage, Mountain 16\%. $\mathrm{g}$, 1973. f

Sage, Western 187. k

Sage, White 1169 a, 805. a

Sage, Wild 187. g. 802 . i, 1135. a

Sage, Wormwood 187. f

Sage-bush 187. g, p, q. r

Sage-of-Bethlehem 1308. j, 1692 . a

Sage-of-Jerusalem 1692. a

Sage-rose 2052. b

Sage-tree 1135. a

* sagina 238

*Sagittaria 727, 1225

Sago 178. a, 623. a, b, 1570 b

Sayo Palm, 1322

Sago Palm, Bastard 394. a

Sayo Palm, Malabar 623. a

Sago plant 189. a

Sago, IVild 2145. a

Sagou 1322. a

*Sagus 1322

Saigonzimmt 500 . h

Sailor's-knot 883 . b

St. Andrew's-lace 370. a

St. Andrew's-cross 197. a

St. Bennet's berb 555 a

St. Jame's-wort 1831. f

St. Jonn's-bread 432. a

St. Johu's-wort 1043

St. Lucia bark 816 . c

St. Mary's-beed 1871. b, c

St. Peter's-wort 197

tSi. Yeter's-wort 1660. d

St. Peter's-wreath 1895 . b

St. Thomas' tree 243. a

Sal, Indian 1841. a

Sal-tree (saul-tree) 1841. a

Salad-tree 436. a

Salarline 462 . a

Salai tree 289. d

Salal 870 . c

Salary 158. a

Salbei 1769. b

Salep 113. a, 798. a, b, y38. a. b, 1450

Salep, Tahiti 1947. a

Salfern 1214.

Salicaire 1250. a

*Salicaria 1250

Salicin 1764. a, etc

Salicorne 1763

* Salisburia 889

Salivaire 115 . b

Sallet 1125. d

Sallow 1764

Sally (Salghe) 1764

Sally-blooin 456. a

Salmon-berry $1750.1, \mathrm{~m}$

Salomou's-siegel 1639. c, d

Saluop 1788. a

*Salpingia 864

Salsepareille 1865 . e

Salsify (Salsafy) 2016. a, b

Salsify, Black 1819. a

Salsify, Mtradow 2016. b

*Salsola 696
Salt-bush 218. b, c, d, 1109. a, b

Salt-grape $176 \%$, a

Salt-rheum wced 463. a

Saltwort 1763 a

Saltwort, Black 893. a

Saltwort, Jamaica 241

Saltwort, Prickıy 1767. \&

* Samandera 17iv, a

Samang (Saman) 1608. b

*.jamara 744

Samuntrose $1743 . d$

Sampfen 338. c

Samphire 599. a

Samphire, Golden 1062. c

Samphire, Jamaica 241 287. a

Samphire, Marsh 1763, a

Sampion, Marsh 1763. a

Sampsou, Black 304. b

Sampson-root 304. a

Sampsuchi herba 1456 . c

Sanbois 644. a

Sanctuary 783. a

Saud-box, Devil's 1029. a

Sand-bur 1867. v

Sand-grass 1640 . a

Sand-star 382. a

Sand-vine 104

Sand-weed 1884. a

SANDALWOOD, species $17 \%$

Sandalwood, False 2138. a

Sandalwood, Red 1682. d

tSandal wood, Red 35

Sandarac 349. a

Sandaraca 349 , a

Sandarak 349. a

Sandaraque 349 , a

Sandel, gelber 1776. a

Sandelholz, Rothes 1682. d

Saudriedgras 182 . a

Sandsegge 382 . a

Sandwort 99,1340

Sandwort, Red 2^05. a

Sandwort, Purple 2005. a

Sanfoin $143 \%$ a

Saufoin Psoralea 1679. i

Sang 1493. b

Sang-tree 1681. a

Sanghara-nut 2017. a, c

Sanyrel (Sangree) 182. f

Sanguinaire 1773. a

Sanguinalis herba 2091. f

Sanguinary 18. a

SANICLE, species 17T5

Sanicle, American 1000 . b

Sanicle, Black 209. a

Sanicle, False 1337. a

Sanicle femelle 20\%. a

Sanicle, Great 65 . b

Sanicle, Indian. 802. a

Sanicle, White 802 . a

Sanicle, Yorkshire 1599. \&

Sanikel 1775. a

*Sansiviera 33

*Sansivieria 33

Santal citrin 1776. a

Santal, Red 1682. d

Santal rouge 1682. d

*Santalum 853

Santalum rubrum 1682, d

*Santolina 128.5

Santonica 187. n

Saoria 1261. a

Sapadillo 20. a

Sapin argenté 2. $\mathrm{f}$

Sapin faux 2. a 
Sapistan 2085. a

*sapium 1914

Sapuullia 20

*saponaria 2074

Supuuaria aegy ptiaca 935 . b

Sayollaria hispanica 930. b

Saponaria levautica 935 . b

Sapunary 1781. a

* Siapota 20. a, 1334, 1849

Sapola, Mammee 1228. a

Sappau 338. c

Sapucaya nut 1152. b

Sapwort 1312. b

Sarah 203n. f

Sarcocolla (Sarcocol) 1530, \&

Sardinian-nut 400 . a

* Sargassum 849

Sarock 17.)3. a

* Sarothamnus '641

* Sarothra 1043

Sarracéuie 1787. b

Sarrasin 821. a

Sarriette 1789. a

Sarsae radix 1865 . e, f

SA FSAPARILLA, species 1865

Sarsaparilla, U. S. P. 1805. e, f

Sarsaparilla, American 170.c

Sarsaparilla, Australian 950. a

Sarsaparilla, Big 182. b

Sarsaparilla, Bristıy 170. b

Sarsavarilla, Brittle-stem 170. b

Sarsaparilla, False 170. c

Sarsaparilla, German 382. a

Sarsaparilla germanica 382.2

Sarsaparilla, Indian 977. a

Sarsaparilla, Native 9 i0. a

Sarsaparilla, Rough 170 b

Sarsaparilla, Spurious 950 .a

Sursaparilla, Texas 1306. a

Sarsaparula, Virginian 170.c

Sarsaparilla, Wild 170. c

Sarsaparilla, Yellow 1306. a

Sarsaparille 1865. e

Sassaliras 1788. a

Sassufras. Brazilian 1390.a,b

Sassafras, Chilian 11+2. a

Sassafras, Swamp 1262. f

Sassafras, Tasmanian 213. a

Sassafras-nuts 1390 . a, b

Sassafras-tree 699. a

Sassafrasnüsse $1 \cdot 90$. a, b

Sassaparilie 1865. e

Sassy-bark 786. a

Satin-flower 83. c, 1234

Satin-flower, Crimson 307. a

Satin-pod 1234

Saturday's-pepper 803. d

Saturei 1789. a

* Satureja 616,1111

* Satyrium $15: 8$

Sauce-alone 74. a, 1168. e

Saucy bark 786. a

Saudistel 1871. b

Sauerampfer 1753 . a

Sauerbeere $1476 . \mathrm{b}$

Sauerklee 1475. a

Sauge officinale 1769. b

Saugh, Privy 1194, a

Saukraut 104.5

Saule blanc 1764. a

Saunders, Red 1682. d

Saunders. White 1776. a

Sauohr 1611.
Saurach 251.e

*saussurea 851

Sautaune 1240. a

Savauuab tlower 730, 2064。 8

Save $176 y$. b

Savicu (Savico) 1248. b

Savin (Savine) 16:9. d

tsaviu 2050. b, 21.6. $\boldsymbol{f}$

Saviu, Horse 1099. b

Savin, Red 1099. e

Saving-tree 1099. d

Savounière 1781, a

Savory, Summer 1789. a

Savury, Wiuter 1789. b

Saw wort 1124. b, 1791

*Saxifraga 978, 1986.

SAXIFRAGE, species 1792

†Saxif

Saxilraye, burnet 1595. b

Saxifrage, Golden 487. a

Saxifraye, Meaduw 1850. a

Saxilirage, small 1595. b

Saxif ax 1788. a

Scabby-head 411. a

Scabby-head 148. a

Scabish 1107. b, c

tScabish 1436 . a

Scabisd, Meadow 206. h

Scabish, sweet 1794. b

Scabious, suecies 1794

Scabiuus 1174. a

Scabious, Sheep's 1088. a

Scabious, Sweet 768. a, b

Scabwort 1062. a

Scaddie 206\%. a

Scala coeli 1639. c

Scalbeyres 28. c

Scald-berry $17,00 . \mathrm{g}$

Scald-wred 620

Scale-bark Hickory 1004. g

Scallewort 1769 . d

Scallion 7ti. a

tscalliun 76. $\mathrm{d}$

Scammonée (Scammon) $563 . \mathrm{b}$

Scammunium 563. b

SCAMMONY, varieties 563. b

Scalumony, French 630. a

* Scalumony, German 563. c

Scammouy Nuntpelier $630 . a$

Siammony, Wild 1066. n

Scammouy root 1066 . n

Scaunrog 2032. $\theta$

*Scandix 148

Scarb t.ee 1269. a

Scarlet-berry $186 \%$ j

Scarlet-cross 1236 . b

Scarlet-lightning 1236 . b

Sceau de Salowon 1639. c, d

Scegu d'or 1032. a

Schabziegerklee 2032. d

Schachtelhalm 758. a, b

Schafgarbe 18. a

Schafgriupe 18. a

Schafihalm 1008. a

Schallotte 76. a

Schanum 1894

Scharlach beere 1585 . b

Scherneckelkraut 1775. a

Scheuerkraut 758 . a

Schierling, gefleckt+r 555. a

Schinseng 1493. a, b

*Schizostachyum 232. w

Schlafapfel 1274.

Schlaugenmoos 1240 . a

Schlangenwurz, canadische 194. a
S̈chlangenwurzel, schwarzo 497. a

Schlan sen wurzel, virginische 18\%. f

Schlebe 1608 q

Schlutten 578 . a

* Schollera 993, 1476

Schöllkraut 462. a

* Schoenocaujon 193

*Schoenolirion 1 t84

Schmack 1730 . b

Schuol masters 189. a

Schottnpfeffer :77. a

Schuittauch 76. $\mathrm{f}$

*Schıankia 1361

Schwalbenwurz 630 . b

Schwalbenwurzt-1 195

Schw rnzpteffer 611. a

Schwarzdorn 16t8. q

Schwarzerle 79. a

Schwarzkümmel 1411. b

Schwarzw urz 1937. a

Schwefelwurz 554. b

Schweinbrod 625 . a

*Schweiuitzia 1357. a

Scliwertel, amerikanische 1068. $\mathrm{g}$

Schwertelwurz 1068. a, b, c

Schwertlitie 1068. b, g

S.hwiudelkörner 611 . a

*Schubertia 1962

*Schultesia 783

*Sciadiodaphne 2059

*Scilla 1701, 2066

Scilla, U. S. P. 2066. a

Scille (Squille) 2066. a

* Scleroderma 2047 i

*Scleroderma 737

Scobs styracina 1929. d

Scoke 1585 . b

Scold 620

Scoparius U. S. P. 641, b

Scordii berba 1973. e

*Scordonia 1973

* Scordosma 828

Scorpion-grass 1373

* Scorpius 577

Scurzonera, Native 1330.

Scotch-grass 376 . a

Scouring-rush 758. b

Scourwurt 1781. a

Scratch-grass 1641 . b, c

Screw-auger 9:36. a

Screw-bean 1664. c

Screw Pine 1445. a

Screw-stem 238, a

Screw-tree 970. a, b

Scrofula plant 967 . a, 1820 . b, c

Scrofula-root 785 . b

Scrofula-weed 15:28. a

Scrophulaire 1820. a, b

Scrub-brush 206, c

Scrubby-grass 527. a

SCULlCAP, species $\mathbf{1 8 2 1}$

Scurvish 1436. a

Scurvy 303. d

Scurvy-grass 527. a, 488. a

Scurvy-grass, Wild 578. \&

Scurvy-grass, Yellow 235 .

Scutch-grass $60.8,376$. a

*Scutia 1720

Sea-bean 1365. a

Sea-belt 1131. b

Sea-bent 382 . a

Sea-blite 696

Sea-cushion 1903. a 
Sea-girdle 1131, a

Sea-grape 526. b, 1767. a

Sea-grape, English 1763. a

Sea-hay 2108. a

Sea-grass 1754. a, 1763. a, 1903. a, 2158. a

Sea-staff 1131. a

Sea-thrift 1202. a, 1767. a

Sea-weed 11:31. a

Sea-wrack 849 . b

tSf a-w ack 2158. a

Sealwort 1639

Seaweed 849

Sebestan (Sebesten) 2085. a

*Sebesten 2085

*Sebifera 1266

* Sebipira 296

Secale cornutum 512. a

Seckelblume 415. a

Sedge 382

Sedye, Cinnamon 26. a

Sedum majus 18:30. a

Sedge, Myrtle 26. a

Sedge, Sea 2158. a

Sedge, sweet 26. a

Sedocke 15. a

Sedum minus 1824 . 'a

See-bright 1769 . d

Seebusch 1889. a

Seed-box 1229. a

Seeder 1028. a

Seedling 1112. a

Seeeiche 849 . b

Seidelbast 644 . $c$

Seidenpflanze 195. c

Seifenrinde 1705. a

Seifenwurzel 1781. a

Seifenwurzel, spanische 935. b

Seigle 1823. a

Seigle, Ergot de 512. a

Segg, see Sedge

Self-heal 166 a, 1775. a

tSelf-heal 1595. c

Sélin de marais 1551. d

*Selinum 1554

Sellerie 158, a

Selly (Seel) 1764'

Semaphore plant 1294

Semen contra 187 . n

Semen sanctum 187. n

Semencine 187. n

Semper, Rock- 599. a

Sencion 1831. g

Séné d'Alexandrie 396. c

Séné de Tinnerelly 396. d

Séné indigìne 545 . a

* senebiera 578

Seneca root 1638 . h

*Senecio $760,1315,1942$

Seneçon 1831. $g$

Senegawurzel i638. h

Senega-root, False 1638. j

Sene-a-rnot, White 1638 . j

Senagae radix 1638 . h

Senf, gelber 1856. a

Senf (schwarzer) 303. d

Senf, weisser 1856. 2

Senf, wilder 1860 . a

Sengreen 1830 . :

Senhalanac 1730 . e

SenNa, varleties 396

* Senna 396

Senna, Bastard 545. a

Senna, Bladder 545, a

Senna, Scorpion 577. b

Eenna, U. S. P. 396. c, d
Senna, Wild (Europeau) 897. a

Sennesblätter 396. c, d

Sensitive-plant 1332. a

tsensitive-plant 1361. b

Sensitive plant, American 49

Sensitive-plaut, Wild 396. f $1332 \mathrm{~b}$

Senvre 303. d, 1856. a

Septfoil (Setfoil) 1650. g

Sequa 829 . a

*Serapias 756

*Sereuaea 1833

* Sericographis 249

Serpent gra-s 1641.g

Serpent's tongue 1445

Serpentaire de Virgiuie 182. $\mathrm{f}$

Serpentaria 182. d, f

Serpentaria brasiliana 467 .b

Serpentary 182 . d, f

Serpentary, English 1641. e

Serpolet 1994. a

Serpyllum 1994. a

*Serratula :38, 1124, 2093

Serronia 1602

Service-berry 96,1875 . c,d,e

Service-tree 1875 . a, d, 96

Serville 122\%. b

Sesam (Sésame) 1837. a

Sesame 1837. a

Sesame, German 361. a

*Sesbania 650, 899, 1838

*Seseli 1370

*Setaria 447

Setsicker 1711. h

Setter-grass (Setterwort) 974. a

Settiswort 974. a

Setwall 2077. c

Seven-bark 1031. a

Seven-sisters 803 . d, k

Seven-year's-luve 18, d

Seyah 7. m

Seyal (Seyaleh 7.0

*Seymeria 52

Shad-bush 96 b, c

Shad-flower 754. a, 7i8. a

Shaddock 506.g

Shag-bark 1004. d, e, g

Shallon 870 .

Shallot 76 . a

Shamalo (Shamoola) 1496. b

Shambrogue 2032. e

Shame-face 883. a

Shame-vine 1361. a

Shamrock 1475. a

tShamrock 1291. c

Shamrock, Indian 2 136 . b

Shamrock, True 2032.

Shamrock, Water 1310. a

Shamrock, White 2032. g

Shamrug 2032. e

Shawnee-w0od 406. b

Shave-grass 758 . b

Shavings 469. a

Shay a 1429. a

She-Heather 765. b

She-Holly 1053. a

She-Oak 40.

Shea-tiee 210 , d

Sheep-berry 2095. c. $\theta$

Sheep-blue 563. s

Sheep-bur 21:1. b

Sheep-bur, Snall 1137, a, b

Sheep-foot 1227, a

Sheep-grass 1599. a
Sheep-lice 633. a

Sheep-nose $8+2$. d

Sheep-poison 1103. a, 1475.b

Sheep-root 1599. a

Sheep-rot 1599. a

Sheep-weed 1781. a, 6. a, 15y9. a

Sheep's-bit 1088. a

Sheep's-cheese 6u. a

Sheep's-knapperty 1658. g

Sheepsbane 1033. c

Sheepwort 1125. d

Shell-bark 100 k. d, g

Shell-flower 1346. a

tshell-dow er 463. a

Shellac 606 . a

*sheplierdia 1166

Shepherd's-caleuder 116. a

Shepherd's-clock 116. a, 2016. b

She herd's-club 2090. b

Shepherd's-delight 116. a

Sheuberd's-knot $16058 \mathrm{~g}$

Shepherd' - -needles 1796. a

tShepherd's-pouch 14,9 .

Shepherd's-purse 329 . a

Shepherd's-staff 686 . b

Shepherd's-suudial 116. a

Shepherd's-warning 116. a

Shepheıd's-watch 116. a

Sheriff-weed 482 . e

Shield-Fern 712

Shilling-grass 1033

Shinin $\leftarrow-\mu$ rass 1057 . d, 1976. $d$

Shinleaf 1696. a, b, c

Shinwood 1963. c

Shittim-wood 1721. k, 1341. a

Shoe-black plant 1003 . f

Shoe-flower 1003. f

Shoe-make 1730 . c

Shoe-strings 103 . a

Shoemaker's-heels 464 . d

Shoo-fly 234. b

Shooting-star 693. a

Shore-grass 1215

Shore-weed 1215

Shot-bush 170 . c, f

Shoter 1963. a

Shovel-weed 329. a

Shreetalum 580, a

Shunas 1193 , c

*Sibthorpia 668

Sickle-grass 1641 . b, c

Sickle-heal 1667. a

Sickle-pod 167. b

Sickle-weed 1667. a

+Sickle-weed 1641. 1

Sicklewo1t 1667. a, 63. c

*Sicy os 1325

Sicy oides 1845

*Sida 348,1271

* Sidalcea 986

Siddhi 370 . \&

tside-saddle flower 481. a

Side-sadule plant 1787. a, b

*Sideroxylon 324, 326

* Sideroxylon 682

Siebpnzeit 2032 . d

*Siegesbeckia 2092

Siegmarswurz 891. b

Sierra salvia $187 . \mathrm{g}$

Sii palustris rarlix 1863 . b

Silberkraut 1658. a

Siliqua dulcis 432 . a

Siliqua hirsuta 1365 . a

*Siliquastrum 436 
Silk, Virginian 195. c

Silk-cotton tree 420 . a

Silk-grass 488. a, 2144. f

Silk-vine 1544. a

Silkweed 195

Silkworm tree 1364. a

Silphium 828. i

Silver-bell 1344, a

Silver-berry 735 . a

Silver-button 121. a

Silver-chain 1738. a

Silver-feather 165 s. a

Silver-gra*s $4 \times 8$. a

Silver-head 1506. a

Silver-leilf 1914 , a, 121. a, 1057. d, 1166. a, 1262. d, 1895. d

Silver-rod 1869 . c

Silver-weed 1t58. a, 1057. a, 1869. c, 1895. d, 1976. d

*Sily bum 1280

Simarouba $185 \mathrm{t}$. b

*Simaruba 1590

Simarubarinde 1854. a

Simbolee oil 449. a

Simpler's-juy 209l. c, f

Simson 1831. g

* Sinupis 303

Sinapis nizra 303. d

Siniele 1775. a

Sinkti+ld 1658. c

Sinngrün 2100. a

Sinnthau 707. a

*Siphonia 1001

Siri oil 129 . d

Siringa oil 1001. b

Sisal-hemp 56 . b

*sison 158, 767

*Sisymbrium $74,167,685$, $1742,1805,1873,1908$

Sit-fast 1439. a, 1711. h

Sithes (viethes) 76 . f

*sium 258, 1479, 1595, 1850

Sivven 1750 , h

Skaw 1771. e

Skaw-coo 1867. j

Skeatlers 14.50. d

Skedge (Skedgwith) 1194. a

Skedlock 1712. a

Skeleton werd 474.

Skerrish 1194. a

Skeryth 1863. c

Skevish 768 . b

Skewer-wood 801. c

Skirret 1595. c, 1863. c

*Skoinilon 193

Skorbutkraut 527 . :

SkullcaP, species 1821

Skunk-bush 869 . a

Skunk-weed $18 \times 3$. a, 1389. a

Skyryth (Skyrwort) 1863. c

Skytes 135. a

Sleeping-beauty 1475. a

Sleepy-Dick 1458. a

Slink-weed 652. a, 1217. a

Slipuer plant 1524 . a

Slippery-root 1937. a

Slipper-weed (Slippers) 1057. a, d

Sloe (Sloo, Slon) $1678 . q$

tSloe 2095. e

Sloe, Amprican 1668. u

Sloe-thorn $1668, q$

Sloush-heal 1667. a

Sloven-wood 187. a

Slunkweed 802.j

Small-pox plant 1787 . b, c
Smallache 158. a

Smallage 158 a

Smallage, Marsh 1554. d

Smartweed 1641.1

Smartweed, [notted 1641. o

Smartweed, Water 1641. o

Smear-dock 464. d

Smeetalum 580, a

Simellage 1190. a

Sniellbuxes 133. $\mathrm{g}$

Smelling-stick 1788, a

Smelling-wood 187. a

Smelly-million 613. a

Smick-s'rock 379. c

Smiddy-leaves 464 , d

*similicina 2061, 2076

Smoke-tree 583

Sinoke-wood 514 . d

Smoking-bean 406

Snut 2071

Smut of Rye 512. a

Simut-ball 1238 . a

*Smrrnium 1554, 1979,2154

Snuffies 1523, a

Snag-bush 1668. q

Snagrel 182. f

Snake-lerry $28 . \mathrm{b}, 320$. b, 133ti. a, 1867. j

Snake-bite 2036. a, 1125. a 1773. a

Snake-flower 731. a, 83. b, 1132. a, 1236. a, 2031. a

Snake-grass 1373 . a, 83. b

Snake-head 463. a

Snake-leaf, Yellow 785. b

Snuke-leaves 1814. a

Snake-milk 803 . a

Snake-mouth 1630. a

Snake-pipes 758. c

Snake-plant 583

Snake-wood 1621. a

Snake-wood tree 1923. a, d

Snake's-head 847. c

Snake's-meat 189 a

Snake's-tongue 1445

tSnakeroot $2 \tau$ a, b. 1831. a

Snakeroot, Black 497. a, 194. a, 1775. b, c

Snakeroot, Brazilian 467. b

Snakeroot, Button 1124. a,b, 781. a

Snakeroot, Canada 194. a

Snakeroot, Corn 781. a, 1124. b

Snakeroot, Furopean 194. f

Snakeroot, Evergreen 1638. c

Snakeroot, Heart 194. a

Snakeroot, Indian 1446. a

Snakeront, Poisun 555. a

Snakernot, Sampson 882 . g, 1679 . e

Snakeroot, Senega, 1638. h

Snakeroot, Short-styled 1775. $\mathrm{e}$

Snakeroot, Vermont 194. a

Snakeroot, Virginia 182. f

Snakeroot, White 802 . a, b

Suakeweed 182. f, 1125. \&, 1611 . e

Snakeweed, Poison 495. b, 5.5. a

Snakewnrt, 1641, e

Snap-berry 19:36, c

Snap-jack 83 . b

Snap-weed 1057. a, d

Snap-wood 250.
Snapdragon 151. esp. a

tśnapd, agon 160. b, 1057. d, 1205. a

Snappers 83 . b, 1851. b

Snatch-weed 863 . a

Sneeze-weed 965

Sneezewort 965,2089 . a

Sneezewort, Tansy 18. d

Snottle-berry 1963. a

Snow-flower 469 . a

Snow-in-harvest 514 . d

Snow-on-the-mountain 167. a, 803. i

Snow-plant 1785 . a

Snow ball, Little \$28. a

Snowball, Wild 41.5. a

Snowball-bush 2095. d

Snowbeury $1936 . \mathrm{b}, 467$

Snowherry, Creeping 468. a

Snowdrift 167. a, 1112. a

Snowdrop 857

†Snow-drop 1936. b

Snowdrop tree 1344 . a

Snowdrop, Yellow 78j. b

Snow-drops 133. j

Snow-Hake 634 . b

Snuff bea a 688. a

Soafs 1764

Soap-apple 471. a

Soap-bark tree 1705. a, b

Soap-berry 1779. a, b

So +p-bulb 471. a

Soap-plant 471. a, 2144. c, $2159 . \mathrm{b}$

Soap-root 1781. a

tSosp-root 1185

Soap-root, California 471.

Soap-root, Levaut 935. b

Soap tree 1705 . a

Soapwort, Common 1781. a

Soapwort, Field 2074. a

Soapwort. Spanish 935. b

*Soccus 188

*Soda 1767

* Soja 900

Sol begrella 1774. b

Sol-Hower 967. b

* Solanoa 1802

*Solanum 12:39

Solanum racemosum 1585 . b

Soldiers 133. g, 1137. b, 1250. a, 1753. a

Soldier's-buttons 355 . a

Soldier's-cap 262. b

Soidier's pocket 1450 . b

Soldier's plume 938. g

*Solea 612

Solentine 10.57. d

*Solidayo $300,309,809, \cdot 926$, 1551

Solomun's-puzzles 1824 . c

SOLOMON'S-SEAL, species 1639

Solomon's-seal, False 2076.a

Solomon's-seal, Snall 2076. a

Solomou's-scal, Two-leaved 2061. a

Solomnn's-seal, Zigzag

2076. a

Somerwort $182 . \theta$

Somniereiche 1704. q

Son-befure-the-father 534. a

*Sonchus 1125

Sonnendistel 384, a

Sonnenhirsa 1214. c

Sonnenröschen $96{ }^{-}$

Sonnenthau 707. a 
Soodbrod 432. a

Sooja 900 . a

Soo acks (Sorrow) 1753. a

* Sophora 234

Sorb 187 : e

Sorbes 1875. d

* Sorbus 628

Sorghum 18\%6. b

SORREL, varieties 1753.a,c,d

Sorrel, Guinea 10113. g

Sorrel, Lauies' 1475. b

Sorrel, Mountain 1480, a

Sorrel, Red 1003. g

Sorrel, Ruind-leaved 1480.a

Sor rel, Sheep 1475. a, b

Sorrel, Tree 222

Sorrel, Woud 1475

Sorrel-tree 1477. a

tSorrel-tree 1592. a

Sorrel-vine 50 : a

Somari (Suwarrow) 393. b

Souchet comestible ti35. b

Sonci 344. a

Soufre végétal 1210. a

Sour-bush 347. a

Sour-dock, Boreal 1480. a

Sour-gourd tree 32

Sour-grass 1753 . a, b

Sour-sabs (Suur-suds) 1753. $a$

Sour-sauce 1753. a

Sour-sop 140. b

Sourberry 14if. b

Sourock (Suurack) 1753. \&

Sourwood 1477. a

Southernwuod 187. a, f

Sow-berry 1476. b, 251. e

Sow-bread 62. a

Sow-dindle (dingle) 187 I. b, c

Sow-fennel 1554. b

Sow-foot 2053. a

Sow-grass 578 , a

SOW THISTLE, species 1871

Sow-tit 842. d, 1750. p

Sowbane 464 . f

Sowdwort 166. b, 1767. a

Soy bean 900 a

Spadic 787. a

Spanierfeige 1449. b

Spanish-bayonet 2144. a, c

Sprnish-dayger 2144. a

Spanish-needles 263. e

Spanish-tuft 1476. c

Sparagus (Sperage) 199. a

Sparganophorus 1812

Spargel 199. a

Sparkleberry 2075. a

Sparrow-grass 199. a

Sparrow-tongue 1641. d

Sparrow's-dung 1767. a

* Spartianthus 1882

* Spartium ri4l

Spartium scoparium 641. b

Spatlum 1191. a

Spatmore 892 . a

Spatter-dock 1420. a

Spearmint 1308. j

Spechtwurzel 673 . c

* Specularia 1154

SPEEDWELL, ppecies 2094

Speedwell 1554. c

Speedwell, Tall 1171. a

Speer-hawk 1005

Speerkraut 1634. a

Speichelwurzel i15. a

Speknel 1323. a
Spelt 2040. a

Sperage 199. a

Spergule 1884. a

* Sperkula 1761

*Spergularia 2005

*Sphaerococcus 477, 887, 943

Spic 1145. a

Spica celtica 2077. a

Spica nardi 1386. a

Spice-berry 170. e, 870. b

Spice-bush 250

tspice-bush 332

Spice-tree 2059. a

Spice-wood 251). a, b

Spid.r-flower 515

Spider-p ant 1792. a

Spiderwort, ('ommon 2014.a

Spigélie anthelwintique 1892. a

Spigélie du Maryland 1892.b

Spignel (Spickuel) 1323. a

Spinnet 170. e, 1323. a

Spike, Uil of 1145. b

tSpikenard 129. c

Spikenard, Awerican 170. e

Spikenard, California $1 \% 0$. a

Spikenard, Celtic 2077. a

Spikenard, East Indiam 1386. a

Spikenard, False 20.76. a

Spikenard of ( reıe $207 \% \mathrm{~g}$

Spikenard, Plowman's 1062. b, $2: 6$. a

Spikenard, Small 170 . c

Spikenard, True I\$86. a

Spikenard, Wild 2076. a

Spikenard tree 170. f

Spikenel (Spike-1uail) 1323.a

Spullbaum 801. c

Spinach 1894. a

Spinach, Australian 1970. b

Spiuach, French 46 1. g

Spinach, Mountain 218. $f$

Spinach, New Zealand 1970. a

Spinach, Strawberry 273. a

Spinach, Victorian Bower 1970. b

Spinach, Wild 464. a, d, 2.9. a

Spinae cervinae baccae 1721. d

Spinage 1894. a

Spindle-tree 801. b, c

Spink 379 c

Spinnen distel 525 . a

*Spiraea 140, 4511, 451, 833, $1014,1231,1448,1655$, 2057,2087

Spiræa 2057. a

*Spiranthes 936, 1909

Spirit-weed 937. a

Siitzklette 2131. b

Spleenwort 204

Sple+nwort bush 55I. a

Split-rock 1000. \&

Spogel-seed 1611. $\theta$

* Suunia 2019

Sponge, Vegetable 1232. a

Spunge-tree 7. d

Spool-wood 261. c

Spoon-flower, Arrow-leaved 1528. a

Spoon-hunt 110\%. d

Spoon-hutch 1728. d

Spoonwood 1103. a
Spoonwort $52 \%$. a

Spotted tree 835 . a

Spotted-Mary 1692. a

Sprangles 415. a

Spree-spinkle 1450. d

Spreusidauy 1554. b

Spingel 839. a

Spring-b yuty 513. a, b

+Spriug-beauty 981 . b

Spring-l,loom 225. b

Spring-daisy, Rose 768. c

Spring-grass 147. a

Spring-plant 2081. a

Sprınggurke (Spritzgurke) $72+$ a

Springkörner, kleine 803. $\mathrm{g}$

Springwort 803. $\mathrm{g}$

SPRUCE, suecies 1587

Spruce, Big-come 1674. b

Spruce, Cat 1587. a

Sqruce, Duuble 1587. b

+Spruce, Double 2. c

Spruce, Douglas 1674. a

Spruce, Heılock 2046. a

Spruce, Norway '2,

Spruce, Patton's 2046. b

Spruce, Single 1.587. a

†Spruce. Single 2. b

Spruce, Wreping 2046. a

Spruce-ytum tree 1587. b

Spud 1867. n

Spunk 1644. a

SPURGE, species 803

Spurge, Alleghany Mountain 1486.

Spurge, Slipper 1524. a

Spuriy, Coru 1884. a

Spurry, Sand 2006. a

Spurt-krass 1809. a

Spurwort 1840 . a

Squanter-squash 614. b

Square-sialk 1820 . b, c, 1348. a

Squash 614. b, c, d

Squash, Crookneck 614. c,d

Squash, Guinea 1867. k

Squash-berry 2u95. m

Squatmore $89 \%$. a

Squaw-berry 2075. n

Squaw-bush 2095. d, 576. b

Squaw-drops 558. a

Squaw-fluwer 20:36. b

Squaw-root 497 . a. 413 . a, 558. a, 2036. b

Squaw-vine 1336 .

tSquaw-weed 206. h, 802. a

Squaw-weed (Swamp) 1831.2

SQUILL, species 1808

Squill 2066. a

Squill, Pancratic 1494. a

Squinancy 201. a

Squine 1865 . b

Squirrel-cup 981. b

Squirrel-corn 262. a, c

Squirrel-ear 1538. d

Squirrel-shoes 636. a, etc

Squirrel's-grandfather 288.a

Squitch-grass 60 . a

Stabwurzel 187. a

St achelbeere 1732. i

* Stachychrysum 35

* Stachys 261)

*Stachy tarpheta 2079

Staff-tree 421

Staff-vine 421. a

Stag-bush 2095 . e 
Stagger-bush 1592. a

Stagger-grass 2150. a Staggerweed 26. a, c,656. c

Staggerwort 1831. f

Staghorn (Sumac) 1730. d

Stah-up-un-ga-weg 2u94. f

Stanlkraut 21.91. I

Stainch 1439. a

Stanmerwort 95 . a

Stan-march 1866 a

Standerwort 1450. d

Staphadrıasameu 6.56. d

Staphidis agriae semen 656. d

Staphisaigre 656. d

*Staphisagria 656

Star-anise 1115.)

Star-apple 486. a

Star-bloom 1892. b

Srar-cucumber 1845. a

Star-flower 2031. a, 83. b, 14i8. a, 16.58. c

tStar-flower 284, a

Star-flower 206. h

Star-grass 68, 201.b

tStar-grass 455 . a

Star-grass, Faise 68. a

Star-gruss, Water 993. a

Stur-yrass (Yellow) 1047

Star-of-Bethlehem 1458. a

tStar-ut-Bethlehem 1022.a, 2031. a

Star-of-Jerusalem 2016. b

Star-of-the-earch 88 \%. d, 16.1. a

Star-root 68 . a

Star-thistle $4 \div 3$. a, b

Star.h-root 189 . a

Starchwort 181. b

Stare $382^{\circ}$.

Starwort, Mealy 68. a

Starwort 83

Starwort, Irooping 455. a

Starwort, Pine 1065

Starwurt, Sandıraper 1065. a

Starwort. Yellow 1062. a

*Statice 1202

Staunchwurt 149 a

Staverwort 1831. f

Stavesacre 656 . d

Stay-plow 1+39. b

Steadiast 14\%9. a

Stechapfel $649 . \mathrm{b}, \mathrm{c}$

Stecheiche 11153. a

Slechginster 2056. a

Stechkörner 1280. a

Stechpalme 1053. a

Stecbwind nwurzel 1865 . e

Sted fast 1735 . a

*Steenhammera 1623

Steeple-busi 1895 . d

Steffensia 1602

St+ inbeere 2075. p

Steineiche 1704. q

Steinklee 1300 . b

Steinklee, blauer 2032. d

Steiukraut 1824 . a

Steinsamen 1214. c

*Stellaria 83

*Stellandria 1801

* Stephanomeria 1689

Stephanskörner 656. d

Stepmother 2102 . f

*Sterculia $533,655,1128$. a

Sternanis 1055 . d

Sterndistel 423 . b

Sternleberkraut 201. b
*Stevia 8:37, 1646

Stevia 802. a

Stick-a-back (Stickleback) 863. a

Stick-button 174. a, b

Stick-pile 777. a

Stick-seed 59,1137

Stick-right 1137, 263. g

Stick-weed 59. b, etc, 95 . a, 2092 a

Stick-weed, Old Virginia 206. d

Stickadore 1145. c

Stickleback 863

Stickwort 59

Stickwurz 320 . b

Stiefunütırchen 2102. f

Stigwata maydis 2148. a

*Stillingia 1780

Stilliugie 19/4, a

Stinging-bush 1091, a

Stinging-leaf, Deviı's 2067.d

Stink 649. b, c

Stiok-weed 649 . b, c

Sriukasant 828 . b

Stinking-Roger 230, a

Stinking-Willie 1831 . f

Stinkkamillen 145 , b

Stiuklattich 1125. f

Stinknessel 1900. a

Stitchwort. Greater 83. b

Stitson 1043. a

Stockmalve 87 . b

Stockrose 87. b

*Stizolobium 1:365

*StuepHlina 1124

Stove-bloom 1668. q

Stone-paisley, Bastard 18:9. a

Stone-pine 1601. a, b

Stone-root $5.9 . \mathrm{b}$

Stone-rue 204. c

Stone-seed 1214. a

Stone-weed 1641. d

StONECROP, species 1824

Stonecrop, Ditch 1534, a

Stonecrop Virginia 1534. a

Stounard 1824. a

Stony-hard 1214. c

Stopper 796. j, k, l, m

Storax, species 1 y29

Storax 1210. a

Sioraxbalsam 1210. a

Stor hsi hnabel 883

Stork's-bill 777, 883. a

Stortioner 2044, a

Stover-nut 400 . c

Stragalkaffee 208. a

Strainer-vine 1232. a

Stramoine 649. b, c

Stramoninm 649. b, c

Strandnelke 1202. c

Strangle-tree 620 , 1459. a, 2096. d

Strangle-weed 620

STRA WBERRY, species 842

Strawberry, Barren 1658. e

Strawberry, Barren or Dry 2112

Strawberry, Rog 547. a

Strawberry, Indian 273. a, 715. a

Strawberry, Mock 715

Strawberry, Yellow 715. a

Stra wberry bush or shrub 801. a, b, 332

Straw berry-plant 1792 . a
Strawberry-tassel $1638 . \mathrm{g}$

Straw berry-tree 801 . b

Strawberry-t1ee, European 172. b

*Streptopus 690

Streupuiver 1240. a

Striu S-of-sovereigns 1249. a

Stingy-bark 790. q, r

Strobili humuli 1028. a

Strohblume 969. a

Stroug-mall's weed $15 \% 0$. a

*struthiopteris 1438 . b

Stry chnossamen 1923. d

Stubwort 1475 . a

Stud-Hower 975

Sturdy 1220 . a

Sturmhut 25. i

Sturtion 2044. a

*Stylandra 16:8

*Stylipus 885

*Stylisma 308

*stylucline J25, 989

*Sty lurus 917

* Styphunia 1730

Styptic-bur 1662. a

Styptic-weed 396. i

Styrax calamitus 1929. d.

Sty rax liquidus $1: 10$. a

Styrax solidus 1929 . d

* Suaeda 695

Suicamore 16. d

Succin 1600, a

Succinum 1600. a

*succisa 1794

Succory 494

Succory gum 474. a

Succory, Hoy's 183. a

Succory, Lamb 184. a

Succory, Swine's 183. a

Suck-buttle 1132. a

Suckie-Sue 1132. a

Suckles 2032. f

Suckling 1222. b, 2032. g

Sucrerot 1863 . c

Sugar-apple 140. d, e

Sugar-berry 422 . a, 96 . c

Sukat-buth 1665. a

Sugar-calıe 1759. a

Sugar-cane, Chinese 1876. b.

Sugar gum-tree 790 . b

Sugar-pear, Swamp 96. b

Sugar-palni $178 \mathrm{a}, 1570$. c

Sugar-pine 1601. h

*Suksdorfia 978

Sulphur-root 1554 . b

Suiphur-weed 1.54. b

Sulphurwort 1554. b

SUMAC, species 1730

Sumac, Cuinese 62 b

Sumac, Currier's 574. a

Sumac, Mountain 1875. a

Sumac, Tanner's 574. a

Sumac, Venice 583 . b

tsumuc, Wild 1376 . c

Sumach, see sumac

Sumbul 828 . h

*Suubulus 825

Sunmer-snowflake 1458. a

Sumpfoelkenwurzel 885 . b

Sumpfporseh 1153. b

Sumpfsilge 1554. d

Sumpfziest 1900 . a

Sun-dial 1235

Sun-plant 1656 . a

Sun-rose 907 . a b

Sun-weed r03. d

SUNDEW, species $70 \overline{6}$ 
Sundrops 1107, a

Suntower 968

*Sun-flower 116. a. 344. a

Suntlower, Brook 263. h

Sunflower, Cone-disk 1751.b

Sunflower, False 965. a, $9 \tau 2$

Suntlower, Tickseed 263. a. b, c, 571

Sun-flower, Red 304. b

Sunflower, Swamp 965. a

Sunflower, Turpentine 1852. c

Sunflower, WVild 1062. a

Supple-jack 2.32

*Suprago 2093

Sureau 1771. e

Surelle 1475. a

Surinam bark 2110, c

Süssfar'a 1643. a

Süs-holz 902. b

Süssholz, indisches 4. a

Suter-berry $21: 36$. c

Swallowwort 195

tSwallowwort 462. a, 803. m

Swallowwort, White 630. b

Swamp-berry 1750. :

Swamp-candles 1249 . c

Swamp-robin 345 . a. 355 . a

Swamp-wood 689. a, 428. a

Swan-weed 206. h

Swarms 74. a

Swarms 1593. under (e)

Sweat-weed 87. a

Sweating plant 802 . i

Sweating-weed 1003. d

Sweeps 423. d

Sweet-Alice 167. a

Sweet-amber 1043. a

Sweet-ash 148 .

Sweet-bean 895 . b

Sweet-Benjamin 187. a

Swert-berry 2095. c

Sareet-Betsies 332 . b

Sweet-Betty 1781. a

Sweet-bush 551. a

Sweet-flag, False 1068. e

Sweet-gale, Canada 551. a

Sweel-grass 26. a, 201. b, 2158. a

Sweet-GuM, species 1210

Sweet-hay 205\%. a

Sweet-heart 1824 , d

Sweet-hearts 863 . a

Sweet-John 664. b

Sweet-leaf 1043. a, 1938. a

Sweet-Mary 1302. a, 1348. a

Sweet-meadow 2057. a

Sweet-Nancy 135.j. e

Sweet-pod 432. a

Sweet-potato 1116f, a

Sweet-potato, Wild 1066. n

Sweet-root 902.b, 26.a,1634.c

Sweet-rush 26. a

Sweet-scented Shrub 332.a,b

Sweet-sedge 26. a

Sweet-slumber 1773. a

Sweet-sop 140. e

Sweet-Susan 1851. 2

Sweet-William $664 . \mathrm{b}, 1702 . \mathrm{b}$

Sweet-William (Mock) 1236. b

Sweet-William, Wild 1569.b, etc., 1781. a

Sweet-IWilson 1792. b

Sweet-wood 902. b

Sweet wood tree 606. b
*Swertia 1618, 1758, 1969

Sweth 76. $\mathrm{f}$

Swichen 1831.g

*Swietenia 1106, 1879

Swine-bread 625 . a

Swine's-bane 464. f. g

Swine's-grass 16t1. d

Swinies 1871. b, c

Sword-lily 891

Swy 1763. a

Sycamine 1364. a

tSycanuine 1222 . b

Sycamore 831. i, 16. d

Sycamore, False 1612. a, 1299. b

*Sycios 1845

Srlibi fructus 1280. a

Sylphium cy reniacum 1978.b

*Symphoria 1936

*Symphoricarpa 1936

*Symplocarpus 1883

*Syncarpus 921

Syndaw 65 . b

* Synthyris 2128

Syria Balsam or Balm 550.e

Syringa, Garden 1564. a

Syves 76 . $\mathrm{f}$

*Syzygium 796

Tabacum 1410. b

Tabak (Tabac) 1410, b

Taban 1491). a

Tacamahac 1666. b, 353. a,b, 1652. b

Tacamaque tcrreuse 1666 . b

Tacker-grass 1641. d

Tad-pipes 758. c

Tag-alder 79. b

*Tagetes $\% 20$

Takamahak (Takmak) 353.a

Takinöl 1099.

Takuts 19.5. a

*TAlinum 14:?

Talipot Palm 580

Tallicouna $3 / 8, \mathrm{~b}$

Tallow, Bay-berry 1375. b

Tal low, Becuiba 1377, a

Tallow, Mafura 2026. a

Tallow, Piney 2086 a

Tallow, Vegetable 1780. a

Tallow, Virola 2103. a

Tallow-nut 2138. a

Tallow-root 2004. a

Tal ow-shrub 1375. b

Tallow-tree 2086. a

Tallow-tree, Chinese 1780 , a

Tallow-wood 790 . q

Tamarack 1138. a, c

Tamaric (Tamaricke) $1955 . \mathrm{b}$

Tamarind, Manila 1608. a

Tamarind tree 1954. a

Tamariud, Wild 1248. a

Tamarindemnus 1454. a

Tamarindier 1954. a

Tamariscus 1957

TAMARISK, species 1955

Tamarisken-Ga len 1955. a

Tame-poison $63 \%$. b

Tan-bark tree 2046. a, b

*Tanacetum 482

Tanaisie 1957. a

Taugerine 506.1

Tangle 1131. a, b

Tangle-berry 873. c

Tangle-foot (Tangle-legs) 21095 . a

Tangle-tail 1824. a
Tanghin (Tanguen) 1958.

Tanhoof 894. a

Tank 1516. 8

Tanne 2.f

Tanner's-apron 1660 ,

Tannier (Tanier) 2135. a

Tansy 1557. a

tTansy 18. a, 1831. $\rho$

Tansy, African 1951. a

Tansy, Dog's 1658. a

Tausy, Doub e 195̄7. a

Tansy, Grose 16 8. a

Tansy, Maudlin 18.e

Tansy, White 59. a

tTansy. White 18. d

Tansy, wild 1658. a, 95. a

†Tansy, Wild 59. a

Tansy-mustard 1873

Tanya 541. a

Tapa 316. a

Tape-grass 2081. a

*Tapia 593

Tapioca (Tapioka) 1276. b,e

Taqua-nut 1581, a

Tar $16 ! 1 . \mathrm{p}, \mathrm{s}$

Tar, European 1138. d

Tar-bottle 423 . d

Tar-weed 588. a, 918, 980 1260,1511

tTar-weed 772. a

Tar-weed, Blue 20:30. b

Tare, Common 2096, a

Tale, Hairy 2096. d

Tare, Wild 2096. e

Taro 541. a

Taıragon 187 . e

Tarrify 782 . b

Tartarian-lamb 492. a

Tartoufle 2047

Taschenpfeffer 377. a

*Tasmannia 706

Tassel 423. d, 686. b

Tassel-bı:r 381

Tassel-flower 1118. a, b

Tassel-grass 1754. a

Tassel-weed 95. a

Tattered-fringe 938, a

Tauaré 1152. a

Taubnessel 1132. a

Taumelkurn 1220. a

Tausengu'denkraut 783. a

Tawkin 1463. a

Tayuya 414. b, 2021. a

*Taxodium 1832

Tea, Abyssinian 408. a

Tea, African 627

Tea, Appalachian 1053. k

†Tea, A ppalachian 2095. b

Tea, Arabian 408. a

Tea, Bahama 1135. a

Tea, Blue Mountain 1869. a

Tea, Botany Bay 1865. c

Tea, Brazilian 2079. a

Tea, Broussa 2075. b

Tea, Bush 627

Tea, Canadian 870 . b

Tea, Carolina 1053. $\mathrm{k}$

Tea, Chinese 198u. a

Tea, Continenral 1153. a

Tea, Faham 136. a

Tea, False Paraguay 2095, b

Tea, Isle of Bourbun 136. a

Tea, 'James' 1153.

Tea, Java 1466, a

Tea, Jersey 415 . a

Tea, Jerusalem 464. b

Tea, Jesuit's 1053. e 
tTea, Jesuit's 464. b,1679. d Tea, Labrador 1153

Tea, Malay 1679. a

Tea, Marsh 1153 b, 1763. a

Tea, Mexican 464. b, 1679.d

Tea, Mountain 870 . b

Tea, New Jersey 415 . a

Tea of Heaven 1031. b

Tea, Oswego 1348. a, d

Tea, Paraguay 1053. e

Tea, Prairie 606. e

Tea, Redberry 870. b

Tea, St. Bartholomew's 1053. e

Tea, South-sea 1053, k

Tea, Spanish 464. b

Tea, Sweet 1865. c

Tea, Teamsier's 752 . a

Tea, Walpole 415 . a

Tea, Whorehouse 752. a

Tea, Wild 103. a

Tea-berry 870 . b, 1732. i

Tea-berry, White 468. a

Tea-plant 2095. c

Tea-plant, Canary Is. 1847.a

Tea-tree, Duke of Argyll's 1237. c

Teak, Bastard 331. a, 1682.c

Teak, Ben 1127. a

Teak, New Zealand 2107

Teak, True 1981. a

Tear-thumb 1641. b, c

Teasel 686

* Tecoma 1880

*Tecomaria 1964

*Tectona 1981

Teel (Til) 1837. a

Teil 1999. b

Telegraph plant. 1294. b

Telephii he، ba 1824. c

*Telfairia 106

Tellicherry bark 1011. a

*Tellina 1213

Ten-0' clock 1458. a

Tench-weed 1657. a

Tengtongues 1742. b

Tentwort 204. c

*Tephrosia 590

Téphrosie 590. d

Térébenthine au citron $2 . \mathrm{f}$

Térébenthine d'Alsace 2. f

Térébenthine de Strasbourg 2. $f$

Térébenthine de Venise 1138. b

Térébenthin des Vosges 2.f

Térébenthine du Canada 2. b

Terebinthina 1601

Terebinchina argentoratensis 2. $\mathrm{f}$

Terebinthina canadensis $2 . b$

Terebinthina chia (cypria) 1605. $\theta$

Terebenthina veneta 1138 . b

* Terfezia 2047 . h

* lerminalia 322

*Ternatea 622

Terpentin, ranadischer 2. b

Terra de la NouvelleOrleana 266. a

Terra japonica 7. b, 1,1473. a

Terrididdle 1867.j

Tesota 1433. a

Tether-devil 1867. j

Tether-toad 1711. h

*Tetradymia 1169,1670

*Tetranthera 1266, 2059
Tetter-berry 320. a

Tetterwort 462. a, 1773. a

Teufelsaugenkraut 1041 . b

Teufelsdreck 828 . b

Teufelsflucht 1043, b

*Thalictrodes 497

*Thalictrum 1940

*Thapsia 1979

Thapsie 1978.

*Thapsus 2090

*Thaspium 949, 2154

Thatch-palm, Silver 1990. a

The du Canada 870 . b

Thebaicus succus 1497. d

*Thebesia 1108

*Theca 1981

Thee (Thé) 1980. a

Thee, canadischer 870 . b

Thee, indischer 1053. k

Theif $1750 . \mathrm{g}$

*Thelypodium 1063

Theriakkiaut 1973. c

*Thesium 546

Theve-thorn $1750 . \mathrm{g}$

Thimble-berry 1750 . k, 1

†Thimble-berry 1750 . p

Thimble-Hower 1667. a

Thimble-weed 1118. b,133.j,k

Thimbles 677. a

Thistle, species 381

tThistle 174

Thistle, Argentine 1440. a

Thistle, Bitter 525. a

Thistle, Blessed 525. a

Thistle, Blue 731. \&

Thistle, Briery 781

Thistle, Bur 2131. b

Thistle, Carline 384

Thistle, Cottun 1440, a

Thistle, Crab 1440. a

Thistle, Cursed 525. a

Thistle, Down-1440. 2

Thistle, Flowering 180

Thistle, fuller's 686 . a

Thistle, Golden 1815. a

Thistle, Ground 381. a

Thisrle, Hare's 1871. b, c

Thistle, Hedgehog 1449. a

Thistle, Holy 525. a, 1280. a

Thistle, Horse 1125. e

Thistle, Hundred-headed 781. b

Thistle, Indian 686. b

Thistle, Jamaica Yellow 180 . b

Thist e, Lady's 1280. a

Thistle, Milk 1871. b, c, 1280. a

Thistle, Musk 1440. a

Thistle, Oat 1440. a

Thistle, Our Lady's 525. a, 1280. a

Thistle, Poppy 180

Thistle, Queen Mary's 1440 , a

Thistle, Russian 176\%.c

Thistle, St. Benedict's 525.a

Thistle, Scotch 381 . b,c, 1440. a

Thistle, Sow 1871

Thistle, Spotted 525 . a

Thistle, Star- 423. a, b

Thistle, Swine 1871. a

Thistle, Virgin Mary's 1280. a

Thirst-plant 1778

*Thlaspi 329, 1168
THORN, species 592

Thorn, Black 2095. c

Thorn, Box 1237. c

Thorn, Christ's 1491. a, 2155. $\mathrm{h}$

†Thorn, Christ's 584. a

Thorn, Egyptian 7. a

†Thorn, Egyptian 584. a

Thorn, Evergreen 584. a

Thorn, Fire 584. a

Thorn, Goat's 208. f

Thorn, Jerusalem 1504, a

Thorn, Kafir 1237, a

Thorn, Karoo 7. h

Thorn, Maize (Mouse) 423. b

Thorn, May 592. a

Thorn, Possum 2095. 1

Thorn, Rain-berry 1721. d

Thorn, Theve 175u. g

Thorn, Thirsty 7. n

Thorn, Wait-a-bit 953. a

Thorn, White 592. a

Thorn, Wire 1963. a

Thorn-apple 649. b, c

†Thorn-apple 592. (g)

Thorn-plum 592. (g)

Thorough-stem $80 \%$. i

Thorough-wax (Thorowwax) 727. a, 802 . i

Thoroughwort $802 . \mathrm{g}, \mathrm{i}, \mathrm{l}, \mathrm{n}$, esp. i, 327. a

Thousand-leaf 18 . a

Th read-and-needle 2144. $f$

Thread-foot 1627. a

Thread-of-life 1792. a

Three-buds 1630 . b

Thridace 1125 . d

Thrift, European 1903. a

Thrift, Sea 1903. 2

*Thrinciá 1163

Throat-root 885 . b, e

Throatwort 362 . f, 1820 . b, c

tThroatwort 677. a, 1124. b

Through-wax 802. 1

†Throw wort 1165 . a

Thrunwort 91. a

Thrumwort, Great 72 . a

*Thuja $349,453,1192$

Thunder-flower 83. b $123 \delta^{\circ}, \mathrm{a}, 1497$. c

Thunder-plant 1830 . a

Thuris cos tex 606 . b

Thus 289. a, d

Thus, American 1601. i, s

Thuy a 1992. b

*Thıya, see Thuja

Thrm 1994. b

*Thymbra 1251

THYME, species 1994

Thyme, Basil 520. a, c

Thyme, Cat 1973. c

Thy me, Field or Horse 520.d

Thyme, Mouritain 1111. b

Thyme, Virginia 1111. b

Thyme, Water 1566. a

Thyme-weed 1566. a

Thymeleae cortex 644

Thymian 1994. b

Thymian, wilder 1994, a

Thymol 1690. a

*Thymus 520

Thymus cataria 1973 . c

*Thysselinum 1554

Tia 1760. \&

*Tiarella 20i, 1173

Tick-seed 575

Tick-trefoil 1294 
Tickle-weed 2089. b

Tickweed 960. a

* Tiedemannia 1479

Tiger-flower 1998

Tiger-lily, Dwarf 879. a

Tiger-wood 349. a, 1253. b

Tiger's-milk 813 , a

Tiger's-mouth 151. a

*Tíglium 606

Tiglium 606. h

Tika 1253. a

Tikor 619. a

Til 1837. a

Til-seed 925. a

Til-tree 1999. b

†Till-seed 1160. a

Tillet (Tilet) 1999. b

Tilleul 1999. b

Tilly seeds 608. $\mathrm{g}, \mathrm{h}$

Timboe 1836. \&

Tinder, German 1644. d

Tiue-grass 2096. c

Tine-tare 1141. j, 2096. d

Tine-weed 2096. d

Tinker's weed (Tinker'sruot) 2037. a

Tipsen 1043. a

Tipsin ('Tipsinna) 1679. b

Tiresome-weed 2158, a

Tischlerschachtelhalm 758.b

Tiss-wood 1344. a, 1546. a

Tithymal 803. c

*Tithymalus 803

Titi 519. a

Titi, Red (or White) 637. a

Titson (Titsy) 1043. a

Tivers 863

To-sai-shin 194. $\mathrm{g}$

To2 405. \&

Toad-flax 1205, 740

Toad-flax, Bastard 546. a

Tood-flax, I $v$-leaved 629. a

Toad-lily 513. d

Toad-pipes (Tad-pipes) 758. $\mathrm{c}$

Toad-root 28 . b

Toad-spit 1159

Toad's-mouth 151, a

Toad's-tail 1240. a

Toadstool 5:3

TOBACCO, specics 1410

Tobacco, British 20 i3. a

Tobacco, Indian 1217. b

tTobacco, Indian 144. b

Tobacco, Ladies' 121. a, 144, b

Tobacco, Mountain 183, a

Tobacco, Oregon 2077. b

Tobaceo, Poison 1041. b

Tohacco, Rabbit 904. a

Tcbacco, Riverside 1619. b

Tobacco, Wild 1205. a, 1217.b

Tobacco, Woman's 144 . b

Tobacco-root 1191. a, 2077. b

Tobacco-weed 741. a

Tobacco-wood 944, a

Toddy 178. a, 285. a, 394. a, 529. b, 1570. c

The-nails 1284 . a

Todtenblume 344 .

Tolemane, Fecule de 369. a

Tollkirsche, (Tollkraut) 219. a

Tollkörner 117. a

Tolmeiner 664. b

*Tolmiaea 507,1173

Tolu-balsam 2008. c
Tom Bontrin's-bush 1961. a Treaclewort 1959, a

Tom Pimpernowl 116. « Tread-softly 1091. a

Tomatillo 1578. e

Tomato 1239. a

Tomato, Husk 1578. b

Tomato, Strawberry 1578

Tonga 757. 2, 1659. a

Tonga-bean 688 . a, b

Tongue 206. a

Tongue-grass 1168. a, b, e, 83. $\mathrm{c}$

Tonka-bean 688. a, b

Tonkabohnen 688. a

Tonquin-tican 688 . a, b

Tooart 790. n

Toun true 417 . b

Tuot-poison 574 . b

Tooth-brush tree 1768. a

Tooth-cup 97. a

Tooth-pick plant 98 . a

Touth-root 660

Trothache-tree 2136. c, 170 . $\mathrm{f}$

Touchache-tree, Now Zealand 1320 . a

Toothwort 660,1620 . a

+'Toothwort 329. a

Topana 392. e

Toper's plant $1774 . \mathrm{c}$

Topinambour 968. b

Torch-wiod 112

Torches (Torchwort) 2090.b

*Tordylum 411

*Torilis 411

*Torilis 1 18. a

Tormentil (Thormantle) $1658 \mathrm{~g}$

*Tormentilla 1658

Tormentilla root $16.58 \mathrm{~g}$

Tormentillwurzel 1658. $\mathrm{g}$

Tornillo 1664. c

*Torreya 1939,2050

Torrey tree 2050 . b

Tortelle 1860 . a

Tory-wee 1633 . a

Touch-and-heal 1043. a, b

Touch-leaves 1043. a

Touch-me-not 1057

Touch-weed 1332. b

Touchwood 1641. a

Toulema 369. a

Touloucouna 378. b

Tous les mois 369 , c, 2344. a

Tournesol 1150 . b

Toute-épice 1594. b

Tow-cok ('Tow-cock) 2098. a

*Toxicodendron 1730

Tuyon (Tollon) 997. \&

Toywort :329. a

Tragacanth 208. f, etc

Tragacanth, African 1912. c

Tragacanth, Indian 1912. d

Tragacanth, Senegal 1912. c

Tragacantha 208. f, etc

Traganth 208. f, etc

Trauhenfarrn 14\%1. b

Traubenkraut 464 . b, e

tTraveler's-delight 157 .

Truveler's-joy 514. c d, †Traveler's-joy 1240. a

Traveler's tree 1714. a

Treacle, Cluwn's 76. e

Treacle, Countryman's 1756. a

Treacle, English 74. a, 1973. e

Treacle, Poorman's 74. a, 76. $\mathrm{e}$

Trefoil, Hop 1:291. c

Trip-toe 2095 . a
Treasure-of-love 1824

Tree-beard 2001. a

Tree-fern 84, 492

†Tree-fern 1471. b

Tree-hnir 2070. a

Tree-of-heaven 62

Tree-of-the-gods 62 . b

Tréfle d'eau 1310 . a

TREFOIL, species 2032

Trefoil, Bean 1310. a, 641. a

Trtfisil, Bird's-foot 12.27. a

Trefoil, Bitter 1310. a

Trefoil, Black 1291. c

Trefoil, Golden 981 b

Trefoil, Great 1291. d

Trefoil, Hart's 1300. b

Trefuil, Heart 12.41. a

Trefoil, Marsh 1310. a

Trefoil, Melilot 1:291. c

Trefuil, Moon 1291. b

Trefoil, Shrubby 1681. a

Trefoil, Sour 1475. a

Trefoil, Spanish 1291. d

Trefoil, Sweetsmelling 802.c

Trefuil, Water 1310. a

*Trianosperma 414

*Tribulus 1102

*Tricerastes 648

*Trichophyllum 228

*Trichostema 1070

Trick-madam 1824. b

'Trickle $60^{\circ} 0$.

*Tricratus 3

*Trifolium 1300, 1731, 1928

Trifolium aureum 981 . b

Trifolium fibrinum 1310. a

Trifuly, Sea 893, a

Trifoly, Sour 14;5. a

Trinitatis herba 2102, f

Trip-madam 1821. a, b

*Trupolium 299

*Tripterella 328

Tristram's-knot 370. a

*Triticum 60

Triticum U. S. P. 60 a

Trixaginis herba 1973. b

*Trixis 1541

Troll-flower 2043. a, b

Trompetenblatt 1787 . b

Troupillo 1867. p

*Troximon 58, 1416, 1596

True-love 20:36. b

Truffe de ceif 737 \&

Truffle, species 2047

+Truffle 5.59. a

Truffle, Hart's 737. a

Truffle, Tuckahie 1238. b)

Trumpet Creeper 1964, \&

Trumpet-flower 26 .

Trumpet-flower, Evening 878. a

Trumpet-flower (Virginia) 1964. a

Trumpet-leaf 1787

Trumpet-plant 1787. a

Trumpet.viue 1964. a

Trumpet-weed 802. j, 1125.a

Trumpets 1125 . a

Trumpets, (Yellow) 1787. a

Tshuking 187. c

Tuber-root 195. d

*Tuberosa 1635

Tuberose 1635. a 
Tuberose, Wild 936. a

Tuckaho (Tuckahoo) 1238.b

Tuckahoe 1238. b, 1463. a

†Tuckahoe 1528. b

Tucum oil 210. a

Tuggur 165 a

Tule (Tule Rush) 1809. a

Tule root 1762

TulIP, species 2049

Tulip, Butterfly 351. c

Tulip, Cape 939. a

Tulip, Pine 466. b

Tulip, Wild 351. c

Tulip-tree 1211. a

tTulip-tıee 1262. b

Tulip-wood 1474. b

Tulipier 1211. a

*Tuliia 1111

Tulpenbaum 1211. a

Tulucuna 378 . b

Tumbler-weed 91. e, 575. a, $626,1679 . \mathrm{h}$

Tumeric see Turmeric

*Tunica 664

TUPELO, species 1421

Tüpfelfarrn 1643. a

Turbith vegétal 1444. a

*Turia 1232

Turkey-beard 2137

Turkey-b+rry 1936. c

Turkey-blossom 2024. a

Turkey-bur 174, a

Turkey-claw :68. a

Turbey-corn 262. a

Turkey-grass 863 . a

Turkey-pea 262 . a

TTurkey-pea 767. a

Turkey-pod 1908. a

Turkey-troop 1641. 0

Turmeric 619. c, d

tTurmeric 1773. a

Turmeric, Indian 1032. a

Turmeric root 1032 . a

*Turnera 1603

Turnip 303. b

Turnip, Black 1162. a

Turnip, Cree 1679. b

Turnip, Dakota 1679. b

Turnip, Devil's 320. b

Turnip, Dragon 181. b

Turnip, Indiau 181. esp. b

Turnip, Lion's 1162. a

Turnip, Marsh or Meadow 181. b

Turnip, Pepper 181. b

Turnip, St. Anthouy's 1711.f

Turnip, Swamp 181. b

Turnip, Wild 181. b

Turnsole 973

tTurnsole 803 . d

Turpentine 1601,i,j,k,l,m,r,t

Turpeutine Chian 1605. e

Turpentine Cyprian 1605. e

Turpentine, ()il 1601. i, r

Turpentine, Scio 1605. e

Turpentine, Strassburg 2. it

Turpentine, Venice 1138. b

Turpentine tree 1605 . e

Turpeth, Vegetable 1144. a

Turpeth root 1444 . a

Turr 2056. a

*Turritis 167

Turtle-bloom 463. a

Turtle-grass 2158. a

Turtle-head 463

Tushylueky 2053. a

Tussilage 2053. a
Tussilaginis herba 2053. a

*'Tussilago 1 j48

Tutsan 1143. a

Tutu 574. b

Tuzzimuzzy 1368, b

Tway-blade 1212,1176

Twice-writhen 1641. e

Twig-withy 1764. m

Twin-berry 1:336. a

Twin-flower 1207. a

Twin-leaf 1093. a

Twin-sisters 1207. a

Twisted-horn (Twisty) 970. a, b

Twisted-sialk 936. b

Twisted-stick 970 . a, b

Twitch-grass 60 . a

Two-rved berry 1336. a, 1207. a

Two-faces-under-a-hat 166.b

Two-lips 636, a, etc

Two-penny grass 1249. a

*Udora 1566

Ulim 2056. a

Ulmaire 2057, a

Ulmen rinde 2058 , f

Ulmenspirä^ 2057. a

*Umbellula 2059

Umbil-root 636. d, e

*Umbilicus 586

Umble (Umbel) 636. d, e

Umbra tree 158.5. a

Umbrella-leaf 683,1548 , a

Umbrella-plant 1625 . a, 6 เ5. $\mathrm{g}$

Umbrella tree 1262. $\mathrm{c}, \mathrm{d}, \mathrm{e}$, 322. $c$

†Umbrella tree 576.a, 1495.a

Umbrellawort 75

*Uncarıa 953, 14i3

*Uncinaria 147.5

Uncum (Unkum) 1851.a

Unicorn (True) 68 . a

Unicorn plant 1284. a, 68. a

Unicorn-rout $6 \ltimes$. a

Unienrn-root, False 455. a

Unicorn's-horn 455. a, 68. a

Universe-vine 1;6. $\mathrm{f}$

*Unona 364,2140

Unshoe-the-horse 290. a

Upas anıiar 150 . b

Upas radja 1923. f

Upas tieute 19:3. f

Upas tree 150 . b

Upstart 534. a

* Urania 1714

Urari 19:3. g

*Uredo $20 \% 1$

*Urostigma 831

*Urtica 2068

Ussacu 1029. a

Uva anguina 320 . b

Uva ursi 176. f

Uvae passae 2108 . e

Uvalho do campo 796 . h

*Uvaria 364, 2140

Uredalia 1642 . a

*Uvularia 1918

*Vacciniım 468, 873, 1054, $14 ; 6,2139$

*Vachellia 7. d

VAlkriaN, species 2077

Valerian, Anerican 636. $a$, etc

Valerian, False 1831. a

VALERTAN, GREEK, species 1634
Valerian, Wild 636, a, ete

*Valeriana 1386, 20:8

Valeriana major 207\%. g

Valesiana minor 2077. c

Valériane americaine 636. d

Valériane greque 1634 . a

Valériane officinale 2077. c

*Valerianella 71, 1615

Valonia (Vallonea) 1704. d

Valleys 562. a

Vandal-root 2077 .

Vanilla, Carolina 2035. a

Vanilla-leaf 2035. a

Vanillae siliqua (fructus) 2083. a

Vanille 2083. a

Varech vesiculeux $849 . b, c, d$

Varnish-tree 1036. a

Vaı uish-tree False 62 . b

Varnish-tree, Japanese 17:30. 0

Vegetable-borsehair 2001. a

Vegetable-oyster 2015. a

Vegetable-satyr 938. i

*Velaea 186

Vélar 1860 . a

Velvet-bur 1662. a

Velvet-fiower 91 . a

†Velvet-flower 1951. b

Velvet-leaf 6 . a, 1146. a

V'elvet-leaf 475 . a

Velvet-plant 2090. b

Velvet-seed 9:2. a

Velvet-weed 6 . a

Velvets 2102. e

Vengay 1682. c

Venus'-bath 686 . b

Venus'-comb 1796. a

Venus'-cup 636, d, e, 686. b

Venus'-fly trap 679. a

Venus'-hair 40. a

Venus'-looking- lass 1154

Venus'-pride 1022

Venus'-shoe 636. a, etc

Venusblut 2091. f

Venusfinger 633. a

Venushaar 40. a

Vératre blane 2089. a

Vératre vert 2089. b

*Veratrum 193, 455, 1907

Veratrum americanum 2059. b

*Verbena 1219

Verhena, Garden 2091. a,b

Verbena, Lemon 1209. d

Verbena, Sweet 1209. d

Vertiena-grass 129 b

*Verbesina $7: 32,925$

Verge d'or 1869. b

*Vermicularia 2079

Vernal-grass 147

Vernis de Japon 62 . b

*Veronica 1171

Veronica purpurea 260. a

Veroniken 2094. f

Véronique de Virginia 1171 . a

Véronique femelle 2094, d

Véronique mâle 2094. $f$

Verrucariae herba 344 . a

VervaIs, species 2091

Vervain, Base 2094. d

Vervein' (Verviue, Vervin) 2091 .

Verveine odorante 1209. d

Verveine officinale 2491 . f

*Vesicaria 1150 
Vesseloup 1238. \&

VETCH, species 2096

Vetch, Joint- 49

Vetch, Kidney- 149

Vetch, Licorice 208. e

VETCH, MILK-, species 208,1464

+ Vetch, Milk- 1556

Vetchling 1141

Vetiver 129. f

* Vetiveria 129

Vettervoo 482. f

Vew (View) 1963. a

Vi-tree 1898. a

*Viborquia 818

*Vicia 1160

Victoria regia 2097. a

Victorialis bulbus 76 . $\mathrm{i}$

Victorialis rotundi bulbus 891. b

Tielchenwurzel 1068. a, b, c

Vierling 1761

Vigne 2108. e

Vigne vierge 1514. a

*Villarsia 1197

Vin 2108. e

Vincetoxici radix 630 . b

*Vincetoxicum $63 i$

Vine, Wild 320 . a

Vine, White 320

Vinegar tree 1730 . c, d

Vineıtier 251. e

*Viola 3 \$3

VIOLET, species 2102

Violet, Adder's 785. b

+Violet, Adder's 1538. a

Violet, Bog 1:99. a

Violet, Calutbian 832. g

Violet, Damask 990. a

Violet, Dame's 990. a

Violet, Dog's-tooth 785 . b

Violet, Green 612

Violet, Mahukona 2024. a

Violet, Marsh 1599. a

Violet, Mrrcury's 362 . e

Violet, Nodding 343, b

Violet, Pattlesnake's $785 . \mathrm{b}$

Violet, Star 1022. b, c

Violet, Trinity 2014. a

Violet, Water 1021

Violet, Whorl-l+aved 343. b

Violet-hloom 1867.j

Violet-wood 7. g

Violette odorante 2102 . d

Viper's-grass 731. a, 1819. \&

Viper's-herb 731. a

Vip-rina radix 182 . f

Vipérine 731. a

Vipśrine de Virginie 182. f

Vippe 1601. r

Virgaurea 1869. b

*Virgilia 509

VIRGIx's-Bower, species 514

†Virgin's.bower 1115. a

Viryin's-bower, Purple 216. a

Visci stipites (lignum) 2105. a

*Viscum 1249

Viscum quernum 1226. a

* Vitellaria 1228

*Vit is $105,502,1514$

Vitis aloa 320 . b

Vutis alba sylvestris"320. a

*Vleckia 54

Vlix 1208. b
Vogelbeere 1875. d

*Volvulus 563

Vomit-nut 1923. d

Vomitwort 1217. b

* Vuacapua 2110

Vulneraria 149. a

Vulvaire 464. i

Vuss (Vuz) 2056. a

Wachbolder 1099. b

Wachsbaum 1375. b

Wachsgagel 1375 . b

W achswy riel 1375. b

Wachtelweizen 1296

Wahoo (Wauboo) 801. b

†Wakvo 1721. k, 1999. c, 2058. b, c

Wahoo, Lynn 1999. c

Waid 1717 . a

Waifa 1874. \&

WAKE-ROBIN, species 2036

Wake-robin 181. b, 189. a

Wake-robin, Virginia 1528.b

Wait-a-bit 1865 . 0

Waldfain 712 . b

Walduahnenfuss, weisser 13.3. $\mathrm{g}$

Waldmalve 1270 . b

Waldmangold 1696. d

Waldmeister 201. b

Waldstroh 863 . $\mathrm{f}$

Walewort (Wallwort) 1771.c

Walking-feru 363

Wall-ink 2094. c

Wall-pepper 1824. a

Wall-pie 204. c

Gall-rue Fern 204. c

thVallflower $\$ 68$. a

Walltower, Western 160, a, 782, a

Wallnussrinde, graue 1096.a

Wallwort 1499. a, 1771. c, 1824. a

WALNUT, species 1096

Walnut, Belgaum 69. a

Walnut, Country 69 . a

Walnut, Indian 69. a

Wainut, Lemon 1096. a

Waluut, Satin 1210. b

Walnut. Spanish 69. a

Walnut, Sweet 1004. g

Walnut, Tahiti 69. a

Walnut, White 1004. $\mathrm{g}$

Wancopin 1391. a

Wandering-Jeun 1249 , a

Wandering-Jew 629. a, 1792. a

Wandering-sailor 1249. a

Wauika 1919. a

tWankapin 1420. c

Wappate (Wapatoo) 1762

Waras (Wars) 1267. a

Ward-seed 329. a

Warence 1749. a

Warlock 303. a, 1712. a

Warmot $18 \%$. b

*Warnera 1032

Warree 14y6. a

Wart flower 462. a

Wart-spurge 803 . d

Wart-weed 462 \&, 803. d, k

Wartwort 803. d, k, 462. a, $5 ; 8 . \mathrm{a}, 904$. c

Warzenkraut 344.8

Waschwurzel 1781. a

*Washingtouia 1397

*Washingtoniana 1832

Wasser-Bathengel 1973. e
Wasserandorn 1242. b

W asserbenedikten wurzel 885 . b

Wasserdost 802 . c, i, m

Wasserdürrwurz 263 . i

Wasserfenchel 1427. c

Wasse1 banf 263. i, 802. c, i

Wasserholder 2095. d

Wasserk raut, kanadisches 1032. a

Wasserkrug 1787. b

Wassermangold wurzel 1753. $\mathrm{e}$

W assernabel 1033

Wassernabel, asiatischer 424. a

Wasserschierling 495. c

Wasserschwelke 2095. d

Wasserviole 1021

Wasserwegerich 72 , a

Water-archer 1762

Water-bean 1391

Water-blinks 1358 . a

Water-blob 355. a, 399. a, 1420. b

Water-caltrop 2017. a

Water-can 399. a, 1420. b

Water-carpet 487 . a

Water-cress, American 379.e

Water-cress, Marsh 1742. c

Water-cress, Mountain 379. d, e

Water-cress, True 1742 b

Water-cress, Yellow 1742. c

Water-crowfoot 1711. g

Water-cup 1787. a

Water-dragon 3.55. a

Water-drop, Hemlock 1427. a

Water-dropwort, Hemlock $142 \pi$. a

Water-feather 1021

Water-fern 434

Water-goggles 3.55 . a

Water-grass 10 :33. c, 1742. b

Water-hemp 24

Water-hemp, Agrimony 263. i

Water Hoarhound 1242

Water-jelly 302. a

Water-kers 1742. b

Water-leaf 302. \&, 1034

Water-]emon 1515. a, e, j

Water-lentil 1159

Water-lettuce, W. Indian 1606. 8

W ATER-LILY, species 399 , 1420

Water-lily, Dwarf 1197 . a

Water-lily, Fringed 1197. a

Water-lily, Great 1391. a

Water-lily, Jamaica 1391. b.

Water-lily, Little 302. a

Water-lily, Tree 1262. c

Water-lily, Victoria 2097. a

Water-lily, White 399

Water-lily, Yellow 1420

Water-melon E05. a

Water-milfoil, Hooded 2072. a, etc

Water-nut 2017. a, 1891. a

Water-nymph i3s2, 399. b,c

Water-pepper 1ti41. 1, 0

Water-platter 2097. \&

Water-purpie 2094. c

Water-seg 1068. e

Water-shield 302 . \&, 335 
Water-skegs, Yellow 1068. e

Water-spike 1657

Water-target 302 . a

Water-torch 2055. a

Water-weed 1566. a

Water-yam 164, a

Waterwort 739,204 . d

Wattle 7. c, j, etc

Wau 1717, a

Wax, Ocuba 2103. \&

Wax, Vegetable 1375. b

Waxberry 1375. a, b

tWax-berry 1936. b

Wax-berry, Cornel 5i6. i

Wax-bush 1511. a

Wax-cluster $8 \% 0$. a

Wax-dolls 850. a

Wax-palm, Brazilian 566. a

Wax-plant 1025. a, 1851. \&

Wax-tree 2106. a

Wax-tree, Japanese 1730. m

Wax-weed, Blue 1511. a

Wax-work, Roxbury 421. a

Waxen-Woad 881. a

Way-bread 1611. b, c

Way-grass 1641. d

Way-thorn 1721. d

Way faring tree 2095. j

Way faring-tree, American 2095. a

Wayworl 116. a

Weandee 353. a

Weathercock 1057. a, d

Weeby 1831. f

Weeping-widow 847. c

Wegedorn, glatter 1721. $g$

Wegerich (Wegetritt) $1611, b$

Weiberkraut 187. s

Weichselkirsche 1668 . j

Weide 176t

Weiderich 1249

Weiderich, rother 1250 . a

Wein 2108. e

Wein, wilder 1514. a

Weinachtswurz 974 , b

Wein rebe 2108 . e

Weinstock 2108. e

Weirauch 289 .

WTeisstanne 2. f

Weisswurzel 1639. c, d

Welcome-to-our-house 805 .b

Weld 1717. a

Well-grass 1742. b

Well-grass, Horse 2094. c

Well-ink 2094. c

*Wellingtonis 1832

Welsh-nut 1096. d

Weremod 187. b

Wermuth 187. b, o

* Werrinuwa 925

Weyth.rnoy 482 . f

WHEAT, varieties 2040

Wheat, Couch 60. a

Wheat, Egyptian 1531. a

Wheat, Guinea 2148. a

Wheat, Indian 821. a

Wheat, Turkey 2148. a

Wheat-grass 60

Wheat-thief 109

Whig-plant 145 . c

Whin (Whuns) 2056. a

Whin, Cammock 1439. a

Whin, Cat 1439. a, 1743. a

Whin, Dyer's 8si. a

Whin, Lady 1439. a

Whin, Land 1439. a
Whin, Petty, 1439. b

Whinberry 2075. \&

Whip-beam 1875. c

Whip-tongue 863. ₹

Whippoorwill-boots 178\%. b

Whippoorwill's-shoe 636. \&, $1787 . \mathrm{b}$

Whist-aller 17i1. e

Whistle-wood 16. c, d,1875.d, 1999. a

White-amber 1043. a

White-apple 15\%, a

White-bark 1652. a

White-beam 1875. c

White-berry 27. a

White-bird 83 b, c

White-blow 778. a

White-bush 518. a, 2139. a

White-cap 1895. d, 53. a

White-devil 206. d

White-dillifs 1385 . e

White-head 1513. a

White-beads $27, a$

White-leaf 1895. d

White-Nancy 1385. e

White-Robin 1236. a

White-rock 167 . a

White-root 195. d, 1639. c, d

White-rosin tree 1601. i

Whlte-vine 514. d, 320

White-weed 452. e, 143. c

White-kood 1999. a, e, 1211. a, 713. a

White-wood, Bahama 368. a

Whitewort 1639 . c, 482. f

Whitlow-grass 702

Whitlow-grass, Yernal $7 i 8$

Whitlow wort, Silver 1506,

Whitten tree 2095. d

Whorl 5 -Wort 1171, a

Whort (Whurt) 2075. a

WhortLeberRY, species 873,2075

Whortleberry, Bear's 176. f

Whuttle-grass 1300 . b

Whya tree 1738 . a

Wick 60. a, 592. a

Wickakee 403. a, etc

Wicke 1592. a

Wicke 1103. c, d, 1S75. d

Wicken-tree 18,5 . d

Wickens 60. \&, 592. a

Wicopy 6S9. a

Wicopy. Indian 456. a

Wickup 456. a, 755. b,689. a 1999. \&

Wicky 1103. c, d, 18\%5. d

Widbiu 1222. b, c

Widdy 1764

Widertbon, edler $70 \%$. a

Widerthon, goldner 1649 . a

Widow-wail S17.

Widow-wisse 851. a

Widow's-cross 1524 g

Wiesenklee 2032. f

Wiesenknöterich 1641. e

Wiesenkressen 379 . c

Wiffs 1764

Wig-tree 583. b

*Wigandia $7: 2$

Wiggen (Wiggin) 1575. d

Wild-cherry bark 1668. p

Wild-rine 1956. a

Wild-wood 171\%. \&

Wildaurin 914.8

Wilding tree 1269. a

Wilgers 1764. m
Wildkirsche 1668 . p

Willey (Wilf) 1;64

WILLow, species 1764

Willow, Bay 456. a

Willow, Blooming 456. \&

Willow, Crane 428. a

Willow, Desert 465

Willow, Flowering 456. a

Willow, French 456. a

Willow, Ground 1641. a

Willow of Scripture 1403. a, 16j2. h

Willow, Milk 1250. b

Willow, Persian 456. a

Willow, Primrose 1100

Willow, Red 576. b

Willow, Roman 1945. a

Willow, Pose 576. b

Willow, Sage 1250. a

Willow, Sweet 1375 . c

Willow, Virginia 1078

Willow, Water - 653

Willow-grass 1641. a

Willow-herb 755

Willow-herb, French 456. a

Willow-hert, Golden 1249.d

Willow-herb, Great 456

Willow-herb, Hooded 1821. a, c

Willow-herb, Milk 1250. a,b

Willow-herb, Night 1436. a

Willow-herb, Purple 1250.a

Willow-herb, Spiked 456. a, 1250 . a

Willow-herb, Swamp 652. a

Willow-herb, Yellow 1249.d

Willow-weed 12:0. a, 1641. a, n

Willow wort 1250 . a

Wimberry 2075. a

Windles 1611. b

Winberry (Wine-berry) 20\%5. a

Wincopipe 116. \&

Wind 563. a

Wind-berry 2075. p

Wind-flower 133. esp. $g$ and j, 1940. a

+Wii d-flower 329. a, 514 f

Wind-flower, Red 133. f

Wind-herb 1568. b

Wind-root 195. d

Wine 210s. e

Wine Paln 15\%0. c

Wine-berry 1732. b, i, $2075 . p$

Wine-berry shrub 5it. b

Wine-tree $18 \% 5$. a

Wing-seed 16si. a

Wing-stem 2092. a

Wink-a-peep 116. a

Winlin-berry 17\%1. e

Winter-berry 1053. h, i, j

winter-bloom 944. a

Winter-fat 80 . . a

Winter-sweet 1456. d

Winter-weed 2094. h, i, 83. c

Winter's bark 706. a

+Winter's bark 499. b, c

Winter's-bark, False 368 . a

*Wintera 706

*Winterania 363

Winteranus spurius cortex 368. a

Wintergreen $8 ; 0 . \mathrm{b}$

Wintergreen, Bitter 466 . b 
Wintergreen, Chickweed 2031. a

Wintergreen, False 1696. d

Wintergreen, Flowering 1638. $\mathrm{c}$

Wintergreen, Large 1696

+Wintergreen oil 261. b

Wintergreen, One-flowered 1349. a

Wintergreen, Pear-leaved 1696. $d$

Wintergreen, Round-leaved 1696. $d$

Wintergreen, Spotted 466. a

Wintergreen, White 468 . a

Winterbrunnenkresse 235. a

Wintergrün 466 . b

Winterrinde, echte 706. a

Winterrose 974. b

Winterszimmt 796 . a

tWire-grass 1641. d

Wire-weed 1641. d, 206. d

*W isteria 1115

Wisteria, American 1115. a

Wit 1410. a

Witch 2058. e

Witch-hobble (-hopple) 2095. a, d

Witch-grass 60 . a

Witch-wood 801. c, 1875. a,d 2058. e

Witches'-bell 362. b

Witches'-bells 423. c

Witches'-milk 1008. a

Witches'-money bag 1824. c

Witches'-pouches 329. a

Witches'-thimble 362 . b

Witches'-thimbles 423. c

Witchen 1875. d

With-wind 563. a, 1641. b

Withe-rod 2095. b, i, l

Withe-wood 2095. i, 1

Witherspail 863

Withy, Cane 1764. a

Withy, Golden 1375. c

Withy, Hoar 1875. c

Withy-twig 1764. m

Withy-wind 514. d

Witty tree 1875 . d

Woad (Wad) 1071

Woad, Wild 1717. a

Woad-waxen 881 . a

Woats (Wocks) 221. a

Wode-whistle 555 . a

Wohlgemuth, gemeiner 1456. $d$

Wohlverleih 183. a

Woke (Wuk) 170t. q

Wolf-berry 1936. a

Wolf-foot 1242. c

Wolf-grape 1867. j

Wolf-root 25 . i

Wolf's-bane 25, esp. i, 183.a, 759. a

Wolf's-claws 1240. 2

Wolf's-fist 1238. a

Wolf's-milk 803. d, g

*Wolffia 2114

Wolfsfuss 1242 . c

Wolfskirche 219. a

Wolfstrapp 1165. a, b

Wolfswurz 28. c

Wollkraut 2090. b

Wood-aster, Blue 206. a

Wood-broomis 686. b

Wood-cress, Yellow 1742. c
Wood-fern 712. c, d

Wood-flower 133. b

Wood-fringe 42 a

Wood-lettuce 1125. b

Wood-lily, Red 2036. b

Wood-lily, White 2036. c

Wood-nut 579. c

Wood-of-the-holy-cross 1226. a

Wood-oil 687. a, etc

Wood-sage, American 1973. a

Wood-sore 251.e

Wood sour 1475 . a, 251. e

Wood-sow 251. e

Wood-sower 1475 . a

Wood-vine, Wild 1514. a

Wood-wax (Woodwaxen) 881. a

Wood-bine 563. c, 961. a

WOODBINE, species 1222

†Woodbine 514. c, 563. c

Woodbine, American 1514.a

Woodbine, Carolina Wild 878. a

Woodbine, Wild 1514. a

Wooduep 1686. a

Woodrip 201. b

Woodrowel (Woodrowe) 201. b

Woodruff 201. b

Wool-fluwer 937. a

Woolen 2090. b

Wooly-butt tree 790. o

Wordsworth's flower 830. a

World's-wonder 1335. a, 1781. a

Worm-bark 2110. b, c

Worm-grass 1892 . b, 1824. e

Worm-weed 1633, 1892. b

Worm-weed, Corsican 1889. a

Wormint 187 . b

Wormseed, Aleppo 18i. n

Wormseed, Alexandria187.n

Wormseed, American 464. c

Wormseed, Levant 187. $\mathrm{n}$.

Wormseed, Treacle 78\%. b

WORMWOOD species 187

Wormwood, Bastard 95. a

Wormwood, Romau 95. a

Wormwood, Wild 1513.a

Wort 2075. a

Wots 221. a

Woundwort 149 . a, 1869. b

Wound wort, Clown's 1900.a

Woundwort, Marsh 1900. a

IVoundwort, Soldier's 18, a

Wourari (Wourali) 1923. g

Wreath-aster, White 206. f

Wren's flower 883. b

Wret-weed 462 . a

*Wrightia 1011

Wudwise 881. a

Wuk 1704. q

Wukkum 338 . c

Wunderbaum 1735. a

Wunderblume 1335

Wundkraut 2094. f

Wundkraut, gulden 1869.b

Wundsehwamm 1644. a

Wurmfarn 712 . b

Wurmkraut 1957. a

Wurmmoss 1889. a

Wurmarinde 2110. b, c

Wurmsamen 187. n, 464. c

Wnrmtang 1889. a
Wurmtod 187. b

Wurrus (Wurus) 126i. a

Wurstkraut 1456. c, 1789. a

Wych-elm 2058. e

Wych-hazel 944. a

† WV ych-hazel 2058. e

iv y ch-wood 2058. e

Wychen 1875 . d

Wymote 87 . a

Wy than, Moss 1375. c

*Xanthosoma 1528

*Ximenesia 2092

*Xylocarpus 378

*X ylopia 2140

*Xylosma 713

*Xylothermia 1985

Yackron 1704.

Yaits (Yetts) 221. a

Yak 1704. q

YAM, species 680

Yam, Water 164, a

Yam, Wild 680. $\mathrm{f}$

Yamp 211. 2

Yantonica 187. n

Yarr 1884. a

Yarrow 18

Yarrow, Water 1021

Yate-tree 790. 1

Yaupon 1053. b, k

Yaw-root 1914. 2

Yaw-weed 1359. b

Yeara 1730. i

Yèble 1771. c

Yellow-bells 785 . b

Yellow-berries 1721. h

Yellow-caul 1711. c

Yellow-eye 1032. a

Yellow-eyed Grass, Carolina 2142. a

Yellow-flower 303. a

Yellow-gum tree 2133. b

Yellow-Hercules 2136. e

Yellow-Jack 1385. b

Yellow-rod 1205. a

Yellow-root 567. b, 1032. a, 421. a, 1093. 2

Yellow-root, Shrub 2134, a

Yellow-seed 1168. c

Yellow-star 965 . a

Yellow-top 1869

Yellow-weed 1717. a

Yellow-wood 2136. c, e, 472. a, 583. a, 1797. a 1938. a, 2011. a, 2134.

Yellow-wood, Keutucky 509. a

Yellow-wood, Prickly 2136. $\mathrm{e}$

Yellow-wood, West Indian 2136. e

Yellowwort, Parsley-leaved 2134. a

Yellows 636. d, e

Yen-ju 1874. a

Yer-nut 559. a, 168. a

Yerba buena 1328. a, 1308. j

Yerba buena piperita 1308 . i

Yerba del soldado 2113 . b

Yerba mansa 1023. a

Yerba marra 1325. a, b

Yerba maté 1053. e, f, g

Yerba reuma 843. a

Yerba santa 772. a

Yercum 354. a

Yerrow 18. a

YEW, species 1963

Yin-hing 889. a 
Ylang-ylang 364

Yoncopin 1391. a

Youpon 1053. b, k

Youthwort 707. a, 982. a

Y sop 1048. a

Yungfernblüthe 707. a

*Zaga 4

Zahnwehrinde 2136. c, e

Zahuwurzel 115. a

Zamang 1608. b

Zante-wood 583. b

*Zanthoxylon 2136

*Zapania 1209

Zapfenkorn 512. a

Zapote 395 . a

Zapote borracho 1228. b

Zapote prieto (negro) 681. d

Zarnabac 619.e
Zauberhasel 944. a

Zaunrübe 320 . b

Zédoaire 619. b, e

Zedoary (Zedoaria) 619. b,e Zehrkraut 260. a

Zebrwurz 181. b, 189. a

Zeitlosenwurzel 534. a

Zerechtit 187. c

Zerumbet root 2152 . $\mathrm{c}$

Zibel nut 1601. a

Zierstrauch, amerikanischer 1668. $p$

Ziest 1900

Zimmt 500. a, d

Zimmt, weisser 368, a

Zımmtblüthen 500 . $\mathrm{f}$

Zimmtnägelchen 500 . $\mathrm{f}$

*Zinnia 591
Zinuia, Garden 591

Zinnkraut 758. a

Zipolle 76 . c

Zittwersamen 187. n

Zittwerwurzel 619. e

*Zizia 1979

*Ziziphora 960

*Zizyphus 1491

Zuckerrübe 259. a

Zuckerrose 1743. d

Zuckerwurzel 1863. c

Zuh 6y7. b

Zunder 1644. a

Zwetsche 1668. h

Zwiebel 76. c

*Zygadenus 479

*Zygia 1608

\section{ERRATA AND ADDENDA.}

\section{SEE ALSO PAGE 406.}

455. a. Add to list of English synonyms, Grub-root, Star-grass*.

619. b. For Zedoarie, read Zedoaire.

707. a. For Wiederthon, read Widerthon.

942. For Valisneriaceae, read Vallisneriaceae.

1280. a. For Steckkörner, read Stechkörner.

2081. For Valisneria read Vallisneria and for Valisneriaceae read Vallisneriaceae.

2148. a. For mayidis (lines 12 and 13 ) read maydis.

The following corrections should be made with a pen in the index.

Page 415. Box, Wild Running 1336. a, instead of 1366. a.

Page 420. Clover, Winter 1336. a, instead of 1366. a.

Page 447. Partridge-vine 1336. a, instead of 1366. a. 


\section{ABBREVIATIONS OF AUTHORS' NAMES.}

Adans................... Michel Adanson A. DC...........Alphonse DeCandolle A. Rich ................ Richard Ait................. William Aiton Ait. f.........Wm. Townsend Aiton All................... Carlo Allioni Andr................ Henry C. Andrews Andrz................Andrzejowski Arn.............George A. W. Arnott Aubl............ Jean Baptiste Aublet Bart. \& Wend..Bartling and Wendland Baill. or Bail...... Ernest Henri Baillon Bart...........William P. C. Barton Bartl..................... Bartling Bartr...............William Bartram Beauv......Ambrose Palisot de Beauvais Beck.................. Lewis C. Beck Benth...............George Bentham B. \& H. or Benth. \& Hook..... Bentham (George) and Hooker (J. D.)

Berg...................... Bergius Bernh........ Johann Jacob Bernhardi Bieb...F. A. Marschall von Bieberstein Bigel.................. Jacob Bigelow Bl ................ Karl Ludwig Blume Boiss................Edmond Boissier Borkh................. Borkhausen Brit.......... Nathaniel Lord Britton Brong........... Adolphe T. Brongniart Brot....................... Brotero Bunge............. Alexander von Bunge Burm..................... Burman Carr................ Elie Abel Carrière Cass............... Compte de Cassini Cav...........Antonio Jose Cavanilles C. DC.............Casimir De Candolle Cerv............... Vicente Cervantes Cham...........Adalbert von Chamisso C. \& S........Chamisso \& Schlechtendal Chapm.............Alvan W. Chapman Chois............Jacques Denys Choisy Corr.................. Corréa de Serra Curt.................William Curtis Curtis.............. Moses Ashley Curtis DC............... P. DeCandolle Dec. or Decne.......... Joseph Decaisne Del....................... Delile Desf........ René Louiche Desfontaines Desr................... Desroussaux Desv.............. Augustin N. Desvaux
Don.................... George Don D. Don................. Darid Don Dougl............... David Douglas Dryand..................Jonas Dryander Duchesne.........Antoine N. Duchesne Dumort...... Barthêlemy C. Dumortier Dun................. Michel Felix Dunal Ehrh..............Friedrich Ehrhart Ell................... Stephen Elliott Engelm...........George Engelmann F. Muell.......Ferdinand von Mueller Fee................ Antoine L. A. Fée Fisch..Friedrich E. Ludwig von Fischer Forst..............Johann R. Forster (also Georg Forster, the son) Froel...........Joseph Aloys Froelich Gaertn..............Joseph Gaertner Gaud..... Charles Gaudichaud-Beaupré Gil....................... Gilibert Gmel.......... Samuel Gottlieb Gmelin Gr. or Gray................. Asa Gray Griseb........Heinrich R. A. Grisebach Hassk............ Justus Karl Hasskarl Haw.......... Adrian Hardy Haworth H. B. K.Humboldt, Bonpland \& Kunth Hedw....................... Hedwig Herb.............. William Herbert Hoffm.........Georg Franz Hoffmann Hook..........William Jackson Hooker Hook. f.......... Joseph Dalton Hooker H. \& A ........... Hooker and Arnott Hort............ Horticulturalist's name Houtt..................Houttuyn Jacq.............. Nicolaus J. Jacquin Juss........... Antoine Laurent Jussieu Kauf.................... Kauffmann Kaulf..................... Kaulfuss Koch................... Karl Koch Kunth........... Karl Sigismund Kunth L. ........... Carl von Linné (Iinnaeus) L. f........... Carl von Linne, the son Labill.......... Jacques J. Labillardière Lam..... . . . . Jean Baptiste Lamarck Lamb.......... Aylmer Bourke Lambert LeConte...........John Eaton LeConte Ledeb.... Karl Friedrich von Ledebour Lehm............Johann G. C. Lehmann Lem................. Charles Lemaire L'Her................. L. L. L'Heritier Lindl...................John Lindley 
Link.........Heinrich Friedrich Link Loisel.J. I. A. Loiseleur-Deslongchamps Lour................Juan Loureiro Marsh...........Humphrey Marshall Mart...........Karl Friedrich Martius Maxim............Karl J. Maximowicz Meisn ...... Karl F. Meisner (Meissner) Mey.............. Ernst H. F. Meyer Michx...............André Michaux Michx. P......Francois Andrê Michsux Mill............... Phillip Miller Miq..........Friedrich A. W. Miquel Moench..............Konrad Moench Mol................. Konrad Molina Moq............Alfred Moquin-Tandon Muell. Arg........J. Mueller, of Argau Mubl...........Henry L. Mublenberg Murr..............Johann A. Murray Nees...Christian G. Nees von Esenbeck Nutt.............. Thomas Nuttall O. Kze.................. Otto Kunze P. Br................ Patrick Browne Pav.....................José Pavon Pers............... Christian H. Persoon Planch..........Jules Emile Planchon Poir...........Jean Louis Marie Poiret Presl..............Karel Boriwog Presl Pursh ........... Frederick T. Pursh R. Br............... Robert Brown Raf........ Samuel Rafinesque-Schmalz R. \& P..Hipollto Ruiz Lopez \& J.Paron Reich........Heinrich G. L. Reichbach Richard........... Louis C. M. Richard Ridd............John Leonard Riddell Roem........... Johann Jacob Roemer (also M. J. Roemer) Rosc................William Roscoe Roxb............William Roxburgh Rupr............. Franz J. Ruprecht
Salisb......Richard Anthony Salisbury Sarg......... Charles Sprague Sargent Schlecht.......... D. F. Leonhard ron Schlechtenda]

Schott. \& Endl.... Schott and Endlicher Schrad....... Heinrich Adolph Schrader Schwein. ..Lewis David von Schweinitz Scop............Johann Anton Scopols Seem.................... Seeman Sieb........ Philipp Franz von Siebuld Sims....................John Sims Sm .............James Edward Smith Soland............. Daniel Solander

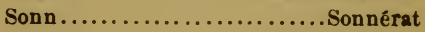
Spach.................. Eduard Spach Spreng................ Kurt Sprengel St. Hil.......Auguste de Saint Helaire Steud ....................... Steudel Sud. or Sudw .............. Sud worth Swz.................... Olof Swartz T. \& Gr........... Torrey and Gray Thunb........... Carl Peter Thunberg Torr...................John Torrey Trev.............Ludolf C. Treviranus Tul.....................Tulasne Tuckm ............Edward Tuckerman Vahl....................Martin Vahl Vent........... Etienne Pierre Ventenat Vill.............. Dominique Villars W. \& A...........Wight and Arnott Walt...............Thomas Walters Wang...F. A. Julius von Wangenheim Wats.................. Sereno Watson Wedd ................... Weddell Wendl............Jonann C. Wendland (also Hermann Wendland) Wendr..................Wenderoth Willd..........Karl Ludwig Willdenow With ..............WHlliam Withering Zucc.............Joseph G. Zuccarini 



New York Botanical Garden Library

Lyons, Albert Brown/Plant names, scienti

gen

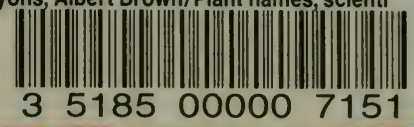


